\title{
Juridisch humanisme en costumiere acculturatie : Inhouds- en vormbepalende factoren van de Antwerpse "Consuetudines Compilatae" (1608) en het "Gelderse Land- en Stadsrecht" (1620)
}

Citation for published version (APA):

van Hofstraeten, B. (2008). Juridisch humanisme en costumiere acculturatie : Inhouds- en vormbepalende factoren van de Antwerpse "Consuetudines Compilatae" (1608) en het "Gelderse Land- en Stadsrecht" (1620). [Doctoral Thesis, Maastricht University]. Datawyse / Universitaire Pers Maastricht. https://doi.org/10.26481/dis.20080509bh

Document status and date:

Published: 01/01/2008

DOI:

$10.26481 /$ dis.20080509bh

Document Version:

Publisher's PDF, also known as Version of record

Please check the document version of this publication:

- A submitted manuscript is the version of the article upon submission and before peer-review. There can be important differences between the submitted version and the official published version of record. People interested in the research are advised to contact the author for the final version of the publication, or visit the DOI to the publisher's website.

- The final author version and the galley proof are versions of the publication after peer review.

- The final published version features the final layout of the paper including the volume, issue and page numbers.

Link to publication

\footnotetext{
General rights rights.

- You may freely distribute the URL identifying the publication in the public portal. please follow below link for the End User Agreement:

www.umlib.nl/taverne-license

Take down policy

If you believe that this document breaches copyright please contact us at:

repository@maastrichtuniversity.nl

providing details and we will investigate your claim.
}

Copyright and moral rights for the publications made accessible in the public portal are retained by the authors and/or other copyright owners and it is a condition of accessing publications that users recognise and abide by the legal requirements associated with these

- Users may download and print one copy of any publication from the public portal for the purpose of private study or research.

- You may not further distribute the material or use it for any profit-making activity or commercial gain

If the publication is distributed under the terms of Article 25fa of the Dutch Copyright Act, indicated by the "Taverne" license above,

Download date: 26 Apr. 2023 
JURIDISCH HUMANISME EN COSTUMIERE ACCULTURATIE 



\section{JURIDISCH HUMANISME EN COSTUMIERE ACCULTURATIE}

INHOUDS- EN VORMBEPALENDE FACTOREN VAN DE ANTWERPSE CONSUETUDINES COMPILATAE (1608) EN HET GELDERSE LAND- EN STADSRECHT (1620)

\section{PROEFSCHRIFT}

TER VERKRIJGING VAN DE GRAAD VAN DOCTOR

AAN DE UNIVERSITEIT MAASTRICHT

OP GEZAG VAN DE RECTOR MAGNIFICUS

PROF. MR. G.P.M.F. MOLS

VOLGENS HET BESLUIT VAN HET COLLEGE VAN DECANEN

IN HET OPENBAAR TE VERDEDIGEN OP

VRIJDAG 9 MEI 2008 OM 12.00 UUR

\section{DOOR}

BRAM VAN HOFSTRAETEN 
Promotores

Prof. dr. A.M.J.A. Berkvens

Prof. dr. F. Stevens (Katholieke Universiteit Leuven)

Beoordelingscommissie

Prof. mr. C.H. van Rhee (voorzitter)

Prof. mr. A.Fl. Gehlen

Prof. mr. G.R. de Groot

Prof. dr. R.C.H. Lesaffer (Universiteit van Tilburg en Katholieke Universiteit Leuven)

Druk: Datawyse/Universitaire Pers Maastricht, 2008 
Oppida quot spectant oculo me torva sinistra,

tot nos invidiae pallida tela petunt.

Lugdunum omnigenum est, operosa Lutetia, Roma ingens, res Venetum vasta, Tolosa potens: omnimodae merces, artes priscaeque novaeque, quorum insunt aliis singula, cuncta mibi.

Julius Caesar Scaliger (1484-1558) 



\section{VOORWOORD}

Vandaag schrijf ik 2008. Het is exact 400 jaar geleden dat te Antwerpen de laatste hand werd gelegd aan de Consuetudines compilatae. Deze costumiere compilatie was het resultaat van een vierde poging om het Antwerpse gewoonterecht te boek te stellen. Het redactieproces nam maar liefst zestien jaar in beslag en de 3646 artikels tellende compilatie mag dan ook terecht als een ware codex omschreven worden. Hoewel de vroegere gedrukte Consuetudines impressae uit 1582 een grotere verspreiding hebben gekend en tevens een sterkere invloed hebben uitgeoefend op andere costumiere redacties, zou ook deze vierde redactie, omwille van haar kwalitatief uitzonderlijk hoge niveau, als voorbeeldredactie worden aangewend. Een mooi voorbeeld hiervan kan gevonden worden in het redactieproces van het Gelderse Land- en Stadsrecht (1620). Deze compilatie van het gewoonterecht van het Overkwartier Roermond werd immers naar Antwerps voorbeeld gemodelleerd. In dit boek staat niet alleen de invloed centraal die is uitgegaan van de Antwerpse geredigeerde costume, maar tevens de invloeden die de vorm en inhoud van deze laatste zelf hebben bepaald. Meer algemeen draagt dit boek bij tot de kennis van de inhouds- en vormbepalende factoren van de costumiere redacties in de Habsburgse Nederlanden aan het begin van de zeventiende eeuw. Zulk een opzet is terecht, aangezien tot nog toe vooral de externe geschiedenis van het redactieproces in de landen van 's herwaarts over werd beschreven en hierbij weinig aandacht is uitgegaan naar een meer gedetailleerde studie van de interne ontwikkeling van deze costumiere compilaties. Welke rechtsbronnen lagen aan de basis van de redacties? Wat inspireerde de compilatores? Hoe zuiver costumier is de geredigeerde costume anno 1608 nog? In welke mate beïnvloedden compilaties van verschillende regio's of steden elkaar onderling en in hoeverre heeft dit bijgedragen tot de unificatie van het gewoonterecht binnen de Habsburgse Nederlanden? Dit zijn vragen die in deze problematiek een hoofdrol opeisen. Maar evenzeer zal ik in dit boek nagaan tot op welke hoogte men ook binnen het costumiere veld de doorwerking kan vaststellen van de verworvenheden van het juridisch humanisme. Vele van de samenstellers hadden immers hun opleiding genoten aan universiteiten, en dan de Leuvense Alma Mater in het bijzonder, welke vanaf de zestiende eeuw geleidelijk aan bevolkt werden met professoren die de verlokkingen van de mos gallicus niet hadden kunnen weerstaan. Door me in dit boek te concentreren op de redacties van Antwerpen en Roermond, ben ik in staat gebleken een antwoord te formuleren deze vragen. Een antwoord dat me is ingegeven door deze specifieke case study en het bijbehorende bronnenmateriaal. Ik wil dan ook op de noodzakelijkheid wijzen in het licht van deze thema's ook andere situaties onder de loep te nemen.

Hoezeer ik de bezigheden van een rechtshistoricus tijdens een onderzoek als dit ook als eenzaam heb mogen ervaren, toch is dit boek niet zonder de hulp van anderen tot stand gekomen. Ik wil hier dan ook van de gelegenheid gebruik maken eenieder te danken die op welke manier dan ook heeft bijgedragen tot de goede afloop van dit project. Enkelen onder hen wens ik nadrukkelijk in de verf te zetten. In de eerste 
plaats denk ik aan mijn promotores, prof. dr. Louis Berkvens en prof. dr. Fred Stevens. Beiden hebben me elk op hun eigen manier gemotiveerd. Hun aandeel binnen dit ganse verhaal moet op z'n minst als essentieel beschreven worden. Ik ben ook prof. mr. Remco van Rhee, prof. mr. Ton Gehlen, prof. mr. René de Groot en prof. dr. Randal Lesaffer dankbaar omdat zij deel wensten uit te maken van de leescommissie. Ook mijn ouders verdienen hier een prominente plaats, en dat niet alleen om de klassieke redenen. Ook zij hebben aan de hand van correctiewerk en het vormgeven van enkele bijlagen -wat niet altijd het meest vrolijke werk is- een zeer concreet steentje bijgedragen aan dit boek. Verder stel ik ook de bereidwilligheid om het manuscript na te kijken van Karin van der Ven en Christophe Andrades, collegae aan de Faculteit der Cultuur- en Maatschappijwetenschappen te Maastricht, ten zeerste op prijs. Louise Rayar wordt bedankt voor het aanleveren van de Engelse samenvatting. Onder mijn vakgenoten te Leuven wil ik Dave de Ruysscher bedanken. Als collega-vorser op het vlak van het Antwerpse recht heb ik meermaals en op vruchtbare wijze met hem van gedachten en materieel kunnen wisselen. Ook aan dr. Brigitte Meijns, postdoctoraal onderzoeker binnen de vakgroep middeleeuwse geschiedenis van de Katholieke Universiteit van Leuven en promotor van mijn licentiaatsverhandeling, ben ik veel verschuldigd. In wezen heeft zij de eerste regels geschreven van dit Maastrichtse hoofdstuk uit m'n leven. Dank daarvoor, het is een unieke ervaring gebleken. Mark Stout dank ik voor de intensiteit van vier jaar samen een kantoor delen; de andere collega's in de Bouillonstraat, nu zelfs vrienden, voor het delen van de koffiekamer. Tenslotte wil ik mijn dank betuigen aan de mensen van Clio, een huis waar ik steeds welkom was en met veel plezier vertoefd heb. Merci.

Bram Van Hofstraeten

Maastricht, maart 2008. 


\section{INHOUDSOPGAVE}

HISTORISCHE INLEIDING

De redactie van het gewoonterecht in Frankrijk

en de Bourgondisch-Habsburgse Nederlanden $\quad 2$

De vier Antwerpse compilaties

Het Gelderse Land- en Stadsrecht

Juridisch bumanisme 15

PROBLEEMSTELLING EN OPBOUW VAN HET ONDERZOEK 21

Probleemstelling 23

Opboun 24

BIBLIOGRAFIE

Onuitgegeven bronnen 29

Uitgegeven bronnen $\quad 30$

Literatuur $\quad 34$

HOOFDSTUK 1

DE RECHTSBRONNEN VAN DE INNOVATIES

BINNEN DE CONSUETUDINES COMPILATAE (1608) 57

PARAGRAAF 1

STATUS QUAESTIONIS EN METHODE 61

Status quaestionis 61

Methode 64

PARAGRAAF 2

DE JURIDISCHE OORSPRONG VAN DE

INNOVATIES BINNEN DE CONSUETUDINES COMPILATAE 84

Deel I 84

Deel II $\quad 92$

Deel III

Deel IV 109

Deel V 123

Deel VI 127

Deel VII 132

PARAGRAAF 3

DE GEVOLGEN VAN HET REDACTIE-

EN COMPILATIEPROCES VOOR HET ANTWERPSE

KARAKTER VAN HET ANTWERPSE GEWOONTERECHT 
JURIDISCH HUMANISME EN COSTUMIERE ACCUlTURATIE

Lexificatie

Derden: actief en passief

Romanisatie en humanisme

Theorie versus praktijk:

de verwetenschappelijking van bet gewoonterecht 175

Omtrent vroegere en buitensteedse compilaties

PARAGRAAF 4

HET ANTWERPSE GEWOONTERECHT NA 1608:

DE HERLEVING VAN DE CONSUETUDINES IMPRESSAE EN

HET RELATIEVE BELANG VAN DE CONSUETUDINES COMPILATAE 202

CONCLUSIE BIJ HOOFDSTUK 1

\section{HOOFDSTUK 2}

DE BEÏNVLOEDING VAN HET GELDERSE LAND-

EN STADSRECHT (1620) DOOR DE ANTWERPSE CONSUETUDINES COMPILATAE (1608): COSTUMIERE ACCULTURATIE

PARAGRAAF 1

KLEINERE INVLOEDEN OF HET ONDERZOEK TOT DUS VER...

$\checkmark$ roegere en buitensteedse redacties

Geleerd recht in strikte qin

PARAGRAAF 2

DE ANTWERPSE CONSUETUDINES COMPILATAE

ALS RATIO SCRIPTA

Methode

Deel I

Deel II

Deel III

Deel IV

Deel V

Deel VI

PARAGRAAF 3

DE ANTWERPSE CONSUETUDINES COMPILATAE ALS PAARD VAN TROJE

Methode

Deel I 
PARAGRAAF 4

STRUCTURELE ASSIMILATIE:

DE SYSTEMATISERINGSDRANG VAN HET JURIDISCH HUMANISME 275 Het empirisme te Antwerpen 277 Het bumanisme te Antwerpen 279

Het humanisme te Roermond 285

CONCLUSIE BIJ HOOFDSTUK 2

\section{HOOFDSTUK 3}

DE ALLEGATIES VAN DE ANTWERPSE MEMORIEN

PARAGRAAF 1

DE GEALLEGEERDE AUTEURS EN WERKEN

IN DE ANTWERPSE MEMORIEN OP DE COSTUMEN 297

Methode 300

Overzicht van geallegeerde rechtsgeleerden 314

PARAGRAAF 2

DE ROL VAN DE VERSCHILLENDE RECHTSGELEERDE GENRES MET BETREKKING TOT

DE REDACTIE VAN HET ANTWERPSE GEWOONTERECHT 350

Monografiën 356

Particulier recht $\quad 367$

Geleerd recht $\quad 382$

Rechtspraak $\quad 391$

$\begin{array}{ll}\text { Consilia } & 401\end{array}$

Secunda scholastica $\quad 406$

CONCLUSIE BIJ HOOFDSTUK $3 \quad 411$

ALGEMENE SLOTBESCHOUWING 
BIJLAGEN

BIJLAGE 1

REFERENTIELIJST ARTIKELCOMMENTAAR MEMORIEBOEKEN 425 Boek 28bis 425

Boek $49 \quad 430$

Boek $50 \quad 436$

Boek $51 \quad 443$

BIJLAGE 2

DE PRIMAIRE RECHTSBRONNEN

VAN DE NIEUW TOEGEVOEGDE ARTIKELS

IN DE ANTWERPSE CONSUETUDINES COMPILATAE 451

Deel I 451

Deel II $\quad 454$

Deel III 459

Deel IV $\quad 467$

Deel $V \quad 486$

Deel VI 495

Deel VII 497

BIJLAGE 3

'LETTERLIJKE' ASSIMILATIE VERSUS 'NIET-LETTERLIJKE'

ASSIMILATIE: VOORBEELDEN

BIJLAGE 4

NAAR ANTWERPS MODEL GEASSIMILEERDE ARTIKELS

IN HET GELDERSE LAND- EN STADSRECHT

BIJLAGE 5

INHOUDSOPGAVEN VAN VIER VOORONTWERPEN

VAN HET GELDERSE LAND- EN STADSRECHT

Inhoudstafel ontwerp 1564

Voorontwerp versie B (<voorjaar 1617) 529

Voorontwerp versie $C$ (<voorjaar 1617) 532

Voorontwerp versie D (voorjaar 1617-juni 1618) 534 


\section{HISTORISCHE INLEIDING}

Socrates bevindt zich met Phaedrus in de schaduw van een plataan net buiten de stad. Zij praten en wanneer Socrates is aangekomen bij de waarde van het geschreven woord vertelt hij volgende mythe:

"Goed. Men vertelde me dat er in de buurt van Naucratis, in Egypte, een god leefde, een van de oude godheden van de streek: aan hem is ook de heilige vogel gewijd, die zij, zoals je weet, Ibis noemen. De god zelf heette Teuth. Hij was de eerste die het getal en het rekenen, de geometrie en de astronomie uitvond, en bovendien ook nog het damspel en het dobbelspel en met name het schrift. Als koning over heel Egypte heerste toen Thamus, die resideerde in de grote stad van Opper-Egypte, waaraan de Grieken de naam geven van Egyptisch Thebe, zoals ze aan de god de naam Ammon geven. Teuth nu richtte zich tot hem, vertoonde al zijn kundigheden en zei hem dat deze aan de overige Egyptenaren bekendgemaakt moesten worden. De koning vroeg bem welk. nut elk, van die dingen had en, terwijl de andere het hem witlegde, drukte bij zijn goed- of afkeuring uit, al naar gelang de uiteenzetting bem bevredigde of niet. Zo zou bij volgens de mythe, aan Teuth veel opmerkingen, voor en tegen, gemaakt hebben over elk van zijn kundigheden: te lang om te vertellen. Toen ze op het schrift gekomen waren, zei Teuth: 'Hier, sire, hebben we een leervak dat de Egyptenaren verstandiger zal maken en dat hun geheugen zal verbeteren: mijn uitvinding is een toverdrank voor geheugen en verstand.' Waarop de andere antwoordde: 'Zeer kunstvaardige Teuth, de ene is het gegeven de kunsten in het leven te roepen, de andere wit te maken in boeverre ze nuttig of schadelijk zullen zijn voor hen die ze zullen gebruiken. Zo is het ook met u: u bent de vader van het schrift, en in un vaderlijke genegenheid schrijft $u$ un kind een kracht toe die het tegendeel is van wat het werkelijk vermag. Want un uitvinding zal in de ziel van hen die haar leren, vergetelheid doen ontstaan, doordat ze bun geheugen niet meer zullen oefenen. Door bun vertrounen in het schrift zullen ze immers het middel om zich iets te herinneren buiten zichzelf gaan zoeken, in vreemde lettertekens, in plaats van in zichzelf door zelf hun geheugen te gebruiken. En zo is uw uitvinding een toverdrank, niet voor het geheugen, maar voor een zich weer te binnen brengen. Van de wijsheid biedt $u$ uw leerlingen de schijn, niet de werkelijkheid: veel-belezen kunt $u$ ze maken, maar zonder onderwijs daarbij zullen ze alleen veelweters lijken, terwijl ze voor het meerendeel onwetenden zullen zijn en daarbij nog lastig in de omgang: want in plaats van wijzen, zijn ze waanwijzen geworden." "1

${ }^{1}$ PLATO, Phaedrus, X. DE WIN et alii ed. (Plato Verzameld werk. Deel IV), Kapellen-Baarn, 1999, 72-73. 
De redactie van het gewoonterecht in Frankrijk en de Bourgondisch-Habsburgse Nederlanden ${ }^{2}$

De kritiek van de koning is juist de drijfveer van keizer Karel V. Hij wil de noodzaak om te memoriseren tot een minimum beperken en wil daartoe een 'extern middel om te helpen herinneren' creëren ter vervanging van 'zelf het geheugen gebruiken', wat niet altijd even betrouwbaar wordt geacht. De turbenonderzoeken, gebaseerd op het geheugen van de 'oudsten', moeten verdwijnen ten voordele van geschreven verzamelingen van de gangbare costumen. Gerechtelijke onderzoeken waarbij men zich beroept op het geheugen van enkele 'oude wijze mannen' impliceren immers een zekere rechtsonzekerheid en hebben in het verleden al vaak tot conflicten geleid. Verschriftelijking, als 'middel om iets te herinneren' blijkt de ideale remedie te zijn voor de misbruiken die aan de grote verscheidenheid aan costumen ontsproten en de moeilijkheden verbonden aan hun bewijs. Door optekening van de costuymen en de styl ende manier van procederen eigen aan elke rechtbank zou er meer rechtszekerheid ontstaan, waardoor de processen konden worden ingekort en bijgevolg de kosten verminderd. Gilissen opperde eveneens dat de unificatie van de brede waaier aan verschillende costumen in functie van het Bourgondisch-Habsburgse staatsvormingsproces eveneens aan de basis lag van Karels besluitvorming, een ambitie die de keizer ook openlijk toegaf in een latere herinneringsbrief van $1546 .{ }^{3}$ Op 7 oktober 1531 had hij namelijk een ordonnantie uitgevaardigd, waarin hij de optekening van de lokale costumen beval. ${ }^{4}$ Het gewoonterecht van elke plaats binnen

2 Omtrent het redactieproces in de Nederlanden, cfr. J. GILISSEN, "Les phases de la codification et de l'homologation des coutumes dans les XVII Provinces des Pays-Bas", Tijdschrift voor Rechtsgeschiedenis, 18 (1950), 36-67 en 239-290. J. GILISSEN, Historische inleiding tot het recht, Antwerpen, 1989, 50-52. J. GILISSEN, "Le ressort des coutumes codifiées aux XVIe et XVIIe siècles dans les XVII Provinces des Pays-Bas, essai de géographie coutumière”, Revue $d u$ Nord, 31 (1949) 234e.v. J. GILISSEN, "La rédaction des coutumes en Belgique aux XVIe et XVIIe siècles", J. GILISSEN red., La rédaction des coutumes dans le passé et dans le présent. Colloque organisé les 16 et 17 mai 1960 par le centre d'bistoire et d'ethnologie juridiques, Brussel, 1962, 87-111. J. GILISSEN, "La rédaction des coutumes dans le passé et dans le présent. Essai de synthèse", J. GILISSEN red., La rédaction des coutumes dans le passé et dans le présent. Colloque organisé les 16 et 17 mai 1960 par le centre d'histoire et d'ethnologie juridiques, Brussel, 1962, 15-61. L. P. GACHARD, Documents sur la rédaction et l'homologation des coutumes I-II (Bulletin en Handelingen van de Koninklijke Commissie voor de uitgave der oude wetten en verordeningen. I), Brussel, 1848.

3 J. GILISSEN, "Efforts d'unification du droit coutumier belge aux XVIe et XVIIe siècles", A. ABEL red., Mèlanges Georges Smets, Brussel, 1952, 295-317. GILISSEN, "La rédaction des coutumes", 92. C. HIRSCHAUER, "La rédaction des coutumes d'Artois au XVIe siècle", Nouvelle revue historique de droit français et étranger, 42 (1918), 43-64.

4 Ordonnance sur l'heresie, les monnaies, la redaction des coutumes, les notaries, les monopoles, les banqueroutiers, vagabonds, la mendicité et la bienfaisance, les kermesses, les noces, baptêmes, la police des cabarets, les crimes dus à l'ivrognerie, les buveurs, le luxe des vêtements, le commerce et l'exportation des chevaux, las blasphémateurs, les relations entre les divers pays de par deça, etc., 7 oktober 1531, J. LAMEERE ed., (Recueil des ordonnances des Pays-Bas. 2e série. III), Brussel, 1902, 266. Deze ordonnantie veralgemeende het bevel tot optekening van de costumen tot de ganse Nederlanden. Een eerste ordonnantie van 22 augustus 1531 beperkte zich tot het graafschap Vlaanderen. (Cfr. F. STEVENS, Revolutie en notariaat. Antwerpen 1794-1814 (Brabantse Rechtshistorische Reeks. 8) Assen-Leuven, 1994, 21.) 
de landen van 's herwaarts over moest binnen de zes maanden worden geredigeerd en door de soeverein gedecreteerd. Vooral dit laatste kon op heel wat terughoudendheid en verzet van de lokale besturen rekenen, waardoor het hele proces aanzienlijk veel vertraging opliep. Uiteindelijk zou de realisatie van het project het ganse Ancien Régime in beslag nemen. ${ }^{5}$

Zulk een afwikkeling staat in schril contrast met Frankrijk alwaar het project reeds aan het einde van de zestiende eeuw werd voltooid. ${ }^{6}$ Bovendien verschenen hier reeds de eerste commentaren op de geredigeerde coutumes op het moment dat het project in de Nederlanden nog goed en wel van start moest gaan. Men mag evenwel niet vergeten dat in Frankrijk de opdracht tot de optekening van de costumen 77 jaar eerder werd gegeven dan dit in de Nederlanden het geval was. ${ }^{7}$ Het was de Franse koning Karel VII die in 1454 met de Ordonnance de Montilz-les-Tours het redigeren van het gewoonterecht beval. De taak moest worden uitgevoerd door plaatselijke praktizijnen en kenners van het lokale gewoonterecht. De ontwerptekst die uit hun samenwerking voortvloeide werd vervolgens onderzocht door het gewestelijke gerechtshof of 'parlement'. Nadien kon het ontwerp door de vorst worden bekrachtigd en afgekondigd. Ook deze gang van zaken had echter af te rekenen met heel wat weerstand van de basis omwille van de verwaarloosbare rol die in de ganse procedure was weggelegd voor de Statenvergadering. Van zodra de resultaten daadwerkelijk achterwege bleven, drong een herziening zich dan ook op. Van nu af aan was het in een eerste fase aan de plaatselijke kenners van het gewoonterecht om een ontwerptekst op te stellen, die vervolgens onderzocht werd door twee, soms drie of vier, commissarissen, welke door de koning onder de leden van het parlement werden aangesteld. Zij kwamen ter plaatse en bespraken het ontwerp met de opstellers ervan. Hun taak bestond erin de tekst duidelijker en ordelijker te maken, maar tevens het recht in het gewest te unificeren. Als koninklijke commissarissen garandeerden zij de vrijwaring van de koninklijke rechten, maar, als legisten, drongen

\footnotetext{
5 Omtrent het redactieproces van de Luikse costume, cfr. M. YANS, "La rédaction de la coutume liégeoise”, Bulletin de l'Institut archéologique liégeois, 67 (1949-1950), 379-384.

${ }^{6}$ Omtrent het redactieproces te Frankrijk: GILISSEN, Historische inleiding tot het recht, 277-279, 48-50. R. FILHOL, "La rédaction des coutumes en France aux XVe et XVIe siècles", J. GILISSEN red., La rédaction des coutumes dans le passé et dans le présent. Colloque organisé les 16 et 17 mai 1960 par le centre d'histoire et d'ethnologie juridiques, Brussel, 1962, 63-85. Omtrent de rol van koninklijke commissarissen bij het redactieproces, maar evenzeer binnen de romanisatie van het Franse gewoonterecht, cfr. J. YVER, "Le président Thibault Baillet et la rédaction des coutumes (1496-1514)”, Revue historique de droit, I (1988), 19-42. R. FILHOL, Le premier président de Thou et la réformation des coutumes, Parijs, 1937. J. VENDRAND-VOYER, "Réformation des coutumes et droit romain. Pierre Lizet et la coutume de Berry", Annales de la Faculté de droit et de sciences politiques de Clermont-Ferrand, 18 (1981), 313-381. J. POUMAREDE, "Coutumes et droit écrit", Dictionnaire de l'Ancien Régime, Parijs, 1996, 364-371.

${ }^{7}$ In het verlengde van het koninklijke bevel en in dezelfde geest als Karel VII, ordonneerde hertog René I van Anjou een gelijkaardig bevel in 1458. Vijf jaar later promulgeerde hij in 1463 de coutumes van zijn hertogdom. (J. VANDERLINDEN, Le concept de code en Europe occidentale du XIII au XIX siecle: Essai de definition (Études d'histoire et d'ethnologie juridiques), Brussel, 1967, 26.)
} 
zij eveneens het geleerde recht op. Vervolgens werd de tekst besproken door de Staten van het baljuwschap, bestaande uit de leden van de drie standen: clerus, adel en de derde stand. Eén voor één werden de artikelen al dan niet goedgekeurd (accordé versus discorde). De afgekeurde artikelen werden uiteindelijk naar het bevoegde parlement gezonden, dat mocht beslissen welke tekst zou worden aangenomen. Deze nieuwe wijze van handelen kon op heel wat meer sympathie rekenen. Tussen 1500 en 1540 werden op deze manier maar liefst 600 coutumes te boek gesteld, voornamelijk in Midden- en Noord-Frankrijk.

De compilaties bleken echter ontoereikend te zijn, aangezien zij te vluchtig en zonder voldoende voorbereiding neergeschreven waren. Ze vormden dan ook een gemakkelijke prooi voor kritische rechtsgeleerden. Hun soms vernietigende commentaar leidde tot een algemene réformation des coutumes (1555-1581) onder leiding van de eerste president van het parlement van Parijs, Christofle de Thou (15081582). ${ }^{8}$ Door onredelijke gewoonten af te schaffen en rechtsregels te doen aanvaarden, die hij putte uit zijn praktijkervaring in het parlement van Parijs, slaagde hij erin te komen tot een aanzienlijke unificatie van het Franse gewoonterecht op basis van de Parijse coutumes. De totstandkoming ervan werd gedragen door praktijkjuristen, voornamelijk advocaten. Voor Koschaker is dit de logica zelf. Enkel praktisch georiënteerde juristen, die voortdurend in verbinding stonden met de praktijk, en dus niet humanistisch, archeologisch en antiquarisch ingestelde professoren, konden zijns inziens het gemene Franse civiele recht als historische realiteit scheppen..$^{10}$ Dit neemt echter niet de mogelijkheid weg dat er via deze, vaak academische opgeleide, praktizijnen ook humanistische invloeden hun weg vonden naar de gewoonterechtelijke compilaties. In deze dissertatie zal ik laten zien dat dit te Antwerpen en Roermond niet anders is geweest.

Ook in de Bourgondisch-Habsburgse Nederlanden stootte men aanvankelijk op heel wat verzet van onderuit. Het Groot Privilegie (1477) van Maria van Bourgondië waarborgde immers de privaatrechtelijke identiteit van de gewesten, doordat Maria plechtig had verklaard de bijzondere gewoonterechten van elk van de gewesten te zullen eerbiedigen. ${ }^{11}$ Keizer Karel daarentegen behield zich uitdrukkelijk het recht de gewoonte te wijzigen indien hij dit nodig achtte. ${ }^{12}$ Net zoals in Frankrijk waren het de lokale overheden die instonden voor het ontwerp van een eerste tekstversie. Dit ontwerp werd vervolgens ter controle naar de provinciale raad gezonden, waarna het

\footnotetext{
8 J.-L. THIREAU, "Thou Christofle de", P. ARABEYRE, J.-L. HALPERIN en J. KRYNEN red., Dictionnaire historique des juristes français (XIIe-XXe siècle), Parijs, 2007, 740-741.

${ }^{9}$ FILHOL, Le premier président de Thou. M. SEONG-HAK KIM, "Christofle de Thou et la réformation des coutumes: l'esprit de réforme juridique au XVIe siècle", Tijdschrift voor Rechtsgeschiedenis, 72 (2004), 91-102.

10 P. KOSCHAKER, Europa en het Romeinse recht, Deventer, 2000, 121. Dit is de Nederlandstalige versie van het oorspronkelijke Europa und das römische Recht dat reeds in 1947 voor het eerst is verschenen.

11 J. H. A. LOKIN en W. J. ZWALVE, Hoofdstukeen nit de Europese codificatiegeschiedenis, Deventer, 2001, 272-273.

12 LOKIN en ZWALVE, Hoofdstukeen, 277.
} 
opnieuw besproken werd met de lokale overheden. In een derde fase ging deze nieuwe versie naar de Geheime Raad, die de tekst indien nodig terug naar de provinciale raad kon zenden. De uiteindelijke homologatie gebeurde door de vorst. De grote rol van de provinciale en Geheime Raad, gecombineerd met het negeren van de Statenvergaderingen, maakte dat in een eerste fase van het codificatieproces (1531-1545) slechts 22 costumen werden geredigeerd. Slechts acht van hen werden gehomologeerd, en dit ondanks meerdere herhalingen van het edict door Karel $\mathrm{V}$ in de jaren 1532, 1540 en 1546. De laatste herinneringsbrief luidde een nieuwe fase in (1545-1569), te meer de keizer ermee dreigde alle niet-ingezonden costumen af te schaffen. Ongeveer 220 ontwerpen vonden nu hun weg naar Brussel, waarvan 172 Vlaamse, twintig uit de personele unie van Brabant-Limburg en de Landen van Overmaze en nog eens twintig uit andere provincies. Desondanks verwierven niet meer dan tien compilaties officiële geldingskracht. Nadat in de jaren 1569-1570 nieuwe dreigementen werden geuit vanwege de landvoogd, Fernando Alvarez de Toledo, beter bekend als de hertog van Alva, waren het vooral de regio's Holland, Zeeland en Utrecht evenals Brabant-Limburg die hun teksten naar Brussel zonden. In totaal ging het om 92 teksten. Slechts één ervan werd in deze derde fase (1569-1579) gehomologeerd. Uiteindelijk waren het de aartshertogen Albrecht en Isabella, die de grootste successen oogsten in een vierde fase (vanaf 1579). Vooral na de afkondiging van het Eeuwig Edict op 12 juli 1611, waarin de opdracht tot het redigeren van de costumen nogmaals werd herhaald, kwamen 212 nieuwe ontwerpen binnen. ${ }^{13}$ Maar liefst 49 hiervan werden bekrachtigd en afgekondigd. Gilissen berekende dat over de ganse lijn 691 costumen werden opgetekend, waarvan er uiteindelijk slechts 88 werden gehomologeerd. Toch betekende het niet homologeren van een costume niet noodzakelijk haar verdwijning. Een twintigtal onbekrachtigde compilaties bleven in gebruik, zoals ook te Antwerpen het geval was. Tegen het einde van de zeventiende eeuw had het merendeel van de voornaamste steden en regio's haar costumier recht te boek gesteld.

In zijn Historische inleiding tot het recht duidt Gilissen een zevental belangrijke gevolgen aan van de optekening van het gewoonterecht. ${ }^{14}$ Zo verdween de rechtsonzekerheid, maar anderzijds geraakte de gewoonte gefixeerd. De gehomologeerde teksten werden immers tot aan het einde van de achttiende eeuw niet meer gewijzigd. Verder werd er een zekere unificatie bereikt, ondanks het feit dat territoriale verbrokkeling bleef bestaan. Bijna zevenhonderd costumen werden namelijk teruggebracht tot een totaal van circa honderd. Ook 'slechte' gewoonten werden verwijderd en een duidelijke invloed van het geleerde recht kan niet ontkend worden. ${ }^{15}$ Daarnaast zou de costumiere rechtsleer een ware bloeiperiode beleven met het ontstaan van talloze

13 Cfr. G. MARTYN, Het Eeuwig Edict van 12 juli 1611. Zijn genese en zijn rol in de verschriftelijking van het privaatrecht (Algemeen Rijksarchief en Rijksarchief in de provinciën. Studia. LXXXI), Brussel, 2000, 137-138. Ook hier staat te lezen dat er in deze periode onder de lokale besturen beduidend minder terughoudendheid te bespeuren was. Iedereen leek van de noodzaak van een geredigeerd gewoonterecht overtuigd te zijn.

14 GILISSEN, Historische inleiding tot het recht, 283-284.

15 GILISSEN, "Rédaction des coutumes", 92. 
commentaren. Maar het meest ingrijpende gevolg is ongetwijfeld dat het gewoonterecht zijn typische karakteristieken verloren zag gaan. Het costumiere recht was niet langer ongeschreven en het ontleende zijn geldingskracht niet meer aan het feit dat de costumen ergens lange tijd in gebruik waren, maar omdat zij nu goedgekeurd en uitgevaardigd waren door de soevereine overheid. In wezen waren zij verworden tot wetgeving. ${ }^{16}$

Hoe dan ook, ook zonder de aanwezigheid van een vorst als centrale overheid, bleek er nood aan 'codificatie' te zijn. Er bestaan voldoende voorbeelden om deze hang naar verschriftelijking van het gewoonterecht te staven. Ik denk hierbij bijvoorbeeld aan de Consuetudines impressae van Antwerpen, welke op eigen (stedelijk) initiatief tot stand kwamen, maar eveneens aan de talrijke Noord-Nederlandse steden en regio's die hun costumiere regels hebben geboekstaafd, ook nadat zij zich hadden losgemaakt van het gezag van de Spaanse koning. ${ }^{17}$ Het is duidelijk dat het homologatiebevel van keizer Karel V een belangrijke beweging op gang heeft getrokken. Te Antwerpen heeft dit zelfs geresulteerd in vier officiële redactiepogingen, waarvan de laatste twee zijn uitgegroeid tot ware codices. De vierde en laatste redactiepoging, bekend als de Consuetudines compilatae (1608), heeft bovendien een enorme invloed uitgeoefend op het redactieproces en het uiteindelijke uitzicht van het Gelderse Land-en Stadsrecht zoals dat in 1620 in het Overkwartier van Roermond tot stand kwam. Het is namelijk zo dat Hendrik Uwens, één van de leden van de commissie die verantwoordelijk was voor de Consuetudines compilatae, na eerst in de hoedanigheid van raadsheer deel uitgemaakt te hebben van de Grote Raad van Mechelen, tot kanselier van het Hof van Gelre werd gepromoveerd op het moment dat men daar bezig was met de redactie van het eigen, costumiere recht. Uwens adviseerde Tilman van Bree, die verantwoordelijk was voor de redactie, gebruik te maken van de Antwerpse compilatie en die zaken te ontlenen welke voor beide regio's golden. De persoon van Uwens is de missing link tussen Antwerpen en Roermond, de trait-d'union tussen de Consuetudines compilatae en het Gelderse Land-en Stadsrecht. ${ }^{18}$ Omdat beide compilaties de

\footnotetext{
${ }^{16}$ Meer omtrent de verhouding tussen wet en gewoonte, cfr. J. GILISSEN, "Loi et coutume. Esquisse de l'évolution des sources du droit en Belgique du XIIe au XXe siècle", Revue de droit international et de droit comparé, 39 (1962), 1-140. J. GILISSEN, "Loi et coutume. Quelques aspects de l'interpénétration des sources du droit dans l'ancien droit belge", Revue d'bistoire du droit, 21 (1953), 257-298.

${ }^{17}$ LOKIN en ZWALVE, Hoofdstuke.en, 284-285. Zie ook: F. KEVERLING BUISMAN, Mer 't is geen lantrecht' Over regionale wetboeken als bron van het oud-vaderlands recht van de Middeleeuwen tot de tijd van de Republiek. Rede nitgesproken ter aanvaarding van het ambt van bijzonder hoogleraar in het Oudvaderlands recht aan de Universiteit van Amsterdam op donderdag 30 maart 2000, Amsterdam, 2000, 15-22.

18 Deze band werd als eerste door Geradts opgemerkt in 1860. (J. L. GERADTS, Bijdrage tot de geschiedenis van den Souvereinen Raad in het Overkwartier van Gelderland te Ruremonde (1580-1794), Leiden, 1860, 53.) Hij wordt terug van onder het stof vandaan gehaald door Feenstra en Spijkerboer: R. FEENSTRA en G. SPIJKERBOER, "La coutume de Gueldre (Quartier de Ruremonde) de 1619 et la coutume d'Anvers dite 'Compilatae"', Revue du Nord, 36 (1954), 74 76.
} 
centrale as vormen van de case study waar dit proefschrift zich op concentreert, verdient ook hun genese in deze inleiding kort toegelicht te worden.

De vier Antwerpse compilaties ${ }^{19}$

De Antwerpse Consuetudines compilatae is de laatste officiële redactie in een rij van vier. Een reeks die zijn oorsprong kent in het edict van Karel V uit 1531. Voordien werden te Antwerpen geen officiële compilaties voortgebracht. Wel bestonden er reeds compilaties welke zich bevonden op het grensgebied tussen private en officieuze redacties enerzijds en publieke, officiële compilaties anderzijds. In de eerste plaats denk ik aan het Keurboeck van Antwerpen of Keurboeck metten doppen, waarvan de oudste passages dateren van de eerste helft van de veertiende eeuw. ${ }^{20}$ Naast een overvloed aan bestuurrechtelijke voorschriften bevat deze compilatie evenwel slechts hier en daar enkele regels van gewoonterechtelijke aard, 33 in totaal. Voorts is er de verzameling genaamd de Statuten der Stadt van Antwerpen genaemt bet gulden boeck ofte gulde bulle. ${ }^{21}$ Dit Guldenboeck bevat uitsluitend gewoonterecht en de overgeleverde kopijen, die in het stadsarchief van Antwerpen worden bewaard, zijn niet ouder dan de tweede helft van de zestiende eeuw. De artikels die zij bevatten gaan echter veel verder terug, in sommige gevallen tot de vijftiende eeuw. Het gaat hier om een wanordelijke mengeling van burgerlijk recht en strafrecht zonder logische samenhang en met vele herhalingen.

De eerste officiële pogingen om het Antwerpse gewoonterecht te boek te stellen waren evenmin meesterwerken. Zoals zoveel andere plaatsen reageerde ook de Antwerpse magistraat met een aanzienlijke dosis terughoudendheid op het keizerlijke edict van 1531. Ook een nieuw plakkaat vol strenge bewoordingen wist in 1540 de havenstad niet te bewegen. ${ }^{22}$ Pas na drie opeenvolgende regeringsbrieven $(1545,1546$, 1547), waarin de stad werd berispt om haar nalatigheid, werd een eerste ontwerptekst naar de kanselier van Brabant overgezonden. ${ }^{23}$ Deze eerste versie van 1547, welke

\footnotetext{
${ }^{19}$ Dit blok is in de eerste plaats gebaseerd op: M. GOTZEN, "De costumiere bronnen voor de studie van het Oud-Antwerpsch burgerlijk recht", Rechtskundig tijdschrift voor België, 39 (1949) 3-16, 105-124 en 191-208.

${ }^{20}$ De compilatie werd tevens door De Longé uitgegeven: Coerboeck de la ville d'Anvers, G. DE LONGE ed. (Coutumes de Pays et Duché de Brabant. Quartier d'Anvers. Coutumes de la ville d'Anvers), I, Brussel, 1870, 1-89.

${ }^{21}$ De compilatie werd tevens door De Longé uitgegeven: Les statuts de la ville d'Anvers appelés Het Gulde Boeck, G. DE LONGE ed. (Coutumes de Pays et Duché de Brabant. Quartier d'Anvers. Coutumes de la ville d'Anvers), I, Brussel, 1870, 379-428.

22 04/10/1540. Edit de l'Empereur, concernant les sectes et hérésies, les banqueroutiers, les monopoles, les monnaies, les contrats de mariages des commerçants, l'usure, le prêt à l'intérêt, l'homologation des coutumes, les conflits de juridiction entre juges ecclésiastiques et civils, les dons et legs des mineurs, les notaires, la prescription de certaines créances, les mariages clandestins et la nomination des magistrats locaux, J. LAMEERE en H. SIMONT ed. (Recueil des ordonnances des Pays-Bas. 2e série, IV), Brussel, 1907, 232-238.

${ }^{23}$ Deze brieven werden samen met en aan het begin van de Consuetudines antiquissimae door De Longé uitgegeven: Coutumes de la ville d'Anvers dites antiquissimae, G. DE LONGE ed. (Coutumes de Pays et Duché de Brabant. Quartier d'Anvers. Coutumes de la ville d'Anvers), I, Brussel, 1870, 92-98.
} 
men later als de Consuetudines antiquissimae is gaan aanduiden, miste echter elke logische ordening en de artikelen waren niet onderverdeeld in paragrafen en bovendien overdreven lang. Hoewel Gotzen ontkent dat er een duidelijk onderscheid werd gemaakt tussen civiel recht en strafrecht, heb ik evenwel kunnen vaststellen dat de titels gerangschikt werden over een publiekrechtelijk en een privaatrechtelijk luik. ${ }^{24}$ Toch besefte men al gauw dat men te slordig te werk gegaan was. De homologatie bleef dan ook uit.

In 1559 werd de tekst terug afgehaald te Brussel, maar men zou echter tot 1570 moeten wachten vooraleer er opnieuw schot in de zaak kwam. Alva zou immers een koninklijke ordonnantie laten verschijnen, die gebood dat de ontwerpen binnen de twee maanden te Brussel moesten aankomen. ${ }^{25}$ Het Antwerpse stadsbestuur stelde een commissie van negentien experts samen, belast met het opmaken van een nieuwe tekst. ${ }^{26}$ Het resultaat van hun werkzaamheden, de Consuetudines antiquae, werd in 1571 naar Brussel gezonden. Het aantal titels nam toe van zestien tot 39 en verscheidene onderwerpen werden meer in detail uitgewerkt, voornamelijk die betreffende procesrecht. Bovendien blijkt uit een vergelijking met de artikels van de Consuetudines antiquissimae, dat de artikels van de Consuetudines antiquae doorgaans nog omvangrijker zijn. Zo telt de tweede redactiepoging zo goed als evenveel artikels als de eerste redactiepoging, zij het verspreid over meer titels en uitvoeriger van aard. Verder is het volledig ontbreken van elke logische ordening een grote teleurstelling.

Voor Gotzen, die het Antwerpse gewoonterecht als eerste uitvoerig heeft onderzocht en beschreven, verdronken de samenstellers van deze twee eerste ontwerpen dan ook in een onderwerp dat zij onmachtig waren. Desalniettemin respecteert Gotzen het pionierswerk dat door hen verricht werd. Anderzijds ziet hij in hun ontoereikendheid de reden voor het feit dat de compilaties niet werden gehomologeerd. Dit is echter onjuist. De werkelijke reden hiervoor ligt in de weerstand die de Raad van Brabant heeft geboden aan de homologatieprocedure van de centrale overheid. Zo weigerde de Raad de ontwerpen voor te leggen aan de Geheime Raad. Men handelde als dusdanig op basis van de Blijde Inkomst (1356) welke onder meer garandeerde dat

\footnotetext{
${ }^{24}$ GOTZEN, "De costumiere bronnen", 12. Cfr. infra, hoofdstuk 2, paragraaf 4, Het empirisme te Antwerpen.

${ }^{25}$ De brief van 17 mei 1570 waarin het stadsbestuur om drie maanden uitstel vraagt, is tevens aan het begin van de Consuetudines antiquae door De Longé uitgegeven: Coutumes de la ville d'Anvers dites antiquae, G. DE LONGE ed. (Coutumes de Pays et Duché de Brabant. Quartier d'Anvers. Coutumes de la ville d'Anvers), I, Brussel, 1871, 433-438.

${ }^{26}$ Uit het college van burgemeester en schepenen werden volgende personen afgevaardigd: burgemeester Hendrik van Berchem en de schepenen Lancelot van Ursele, Jacob van der Heyden, Hendrik van Etten en Jan vander Meeren. Het ambtenarencorps werd vertegenwoordigd door de stadssecretarissen Alexander Grapheus en Jan van Asseliers, en de stadspensionaris Jan Gillis. Verder behoorde ook oud-burgemeester Rococx, de oudschepenen Jan van den Werve, Merten van Ranst en Pauwel Schuermans en de oud-klerken Lambrecht van Baerle en Seger Shertoge tot de commissie. De balie werd vertegenwoordigd door de advocaten Karel Gabri, Gillis Gerardi en Hiermenus van Hille. Tot slot maakte ook de procureurs Gillis Fabri en Reynaut van Heylweghen deel uit van deze commissie. (GOTZEN, "De costumiere bronnen", 13.)
} 
alle Brabantse aangelegenheden ook door Brabanders moeten worden behandeld. De Geheime Raad kende echter ook niet-Brabanders onder zijn leden. Dit had tot gevolg dat geen enkele van de voornaamste, Brabantse costumen werd gehomologeerd. ${ }^{27}$

Daarenboven lijkt Gotzen mijns inziens verblind door de klasse van zowel de Consuetudines impressae, maar zeker de Consuetudines compilatae. Zoals nog uitvoerig uit dit boek zal blijken, laten deze compilaties alle voorgaande pogingen in het niets verdwijnen. Anders dan Gotzen wens ik mij niet uitsluitend pejoratief uit te laten over de eerste twee redactiepogingen. Vergeleken met alle andere compilaties van omliggende regio's en andere grote Brabantse steden, moeten noch de Consuetudines antiquissimae, noch de Consuetudines antiquae voor hen onderdoen. Het zijn juist de Consuetudines impressae en de Consuetudines compilatae die de vreemde eenden in de bijt uitmaken. Zij bepalen zeker niet de standaard.

Het eerste van deze meesterwerken verschijnt in 1582. Antwerpen, dat sinds 1577 een calvinistische stad was geworden, zag in 1579 haar katholiek college van burgemeesters en schepenen vervangen worden door een protestants college, dat de Consuetudines antiquae op een meer 'hervormde' manier hervormd wilde zien worden. Vijf rechtsgeleerden werden hiertoe aangesteld en in 1580 werd een tweede commissie van dertien leden in het leven geroepen om de tekst van de eerste commissie nader te onderzoeken. ${ }^{28}$ De definitieve tekst werd uiteindelijk in 1582 in druk uitgegeven, waardoor er vanaf dat moment naar de compilatie verwezen werd als Consuetudines impressae. Hoewel de tekst gezuiverd werd van katholieke elementen, verdubbelde ook nu weer de inhoud tot 1446 artikels verspreid over 72 titels. Voor het eerst werden lacunes opgevuld met gerecipieerd Romeins recht en bovendien werd heel wat procesrecht aan het geheel toegevoegd. ${ }^{29}$ Dit alles was het werk van de twee protagonisten van de commissie, Karel Gabri en Philips van Mallery. ${ }^{30}$ Hoewel

${ }^{27}$ Cfr. GILISSEN, Historische inleiding, 282. Zij die wel de homologatie van hun costumen wisten te verwerven, moeten bij de Raad van Brabant toegevingen hebben weten af te dwingen inzake hun afkerige houding ten overstaan van de homologatieprocedure. Een vergelijkbaar probleem stelde zich overigens met betrekking tot het Gelderse Land- en Stadsrecht, alwaar de Staten van het Overkwartier, op basis van hetzelfde privilege de non evocando, getracht hebben te bekomen dat het Hof van Gelre de costume in naam van de soeverein mocht homologeren. Men beriep zich hierbij op het Tractaat van Venlo (1543). (Cfr. infra, inleiding, Het Gelderse Land- en Stadsrecht.)

${ }^{28}$ De eerste commissie van vijf bestond uit Karel Gabri, Philips van Mallery, Daniel de Kempeneer, Engelbert Masius en Hendrik de Moy. De tweede commissie telde de volgende leden: Pauwel Schuermans, Jan Gillis, Engelbert Masius, Hendrik de Moy, Jan van den Werve, Jan de Herde, Jan de Pape, Jan Isermans, Jan de Warck, Severius van Uffele, Gillis van Vlierden, Wolffart van Egmont en Roelant Pauletti. (GOTZEN, "De costumiere bronnen", 108.)

${ }^{29}$ Het is me onduidelijk gebleven of Gotzen hiermee de ordonnantie op de stijl en manier van procederen bedoelt, die in 1582 samen met en achteraan de Consuetudines impressae werd uitgegeven. (Cfr. Styl ende Maniere van procederen, G. DE LONGE ed. (Coutumes de Pays et Duché de Brabant. Quartier d'Anvers. Coutumes de la ville d'Anvers), II, Brussel, 1871, 599685.)

30 Omtrent Karel Gabri, cfr. DEKKERS, Bibliotheca Belgica Juridica, 59. 
het geheel nog niet is onderverdeeld in grotere 'delen', zoals later bij de Consuetudines compilatae en het Gelderse Land-en Stadsrecht te zien zal zijn, is de tekst toch al volgens een meer logische en systematische orde opgesteld. ${ }^{31}$

Gotzen spreekt van een klein meesterwerk, maar vergeven van een calvinistische geest. Ontvoogding is hierbij het kernwoord, en dit niet alleen ten overstaan van het kerkelijk recht, maar tevens ten overstaan van hogere rechtbanken buiten de stad en zelfs de centrale overheid. Deze redactie kwam immers tot stand op eigen initiatief en niet als antwoord op een bevel van bovenaf. Zelf meen ik overigens dat er ook al in deze derde redactiepoging sprake kan zijn van ontvoogding van het middeleeuwse gedachtegoed. De structurele opbouw van de tekst en de openheid naar vreemde, juridische invloeden, waarvoor een subsidiaire rol is weggelegd, kondigen de doorwerking van het juridisch humanisme op de costumiere redacties aan. In tegenstelling tot de Consuetudines compilatae, waar deze invloed nog manifester aanwezig is, komen de Consuetudines impressae in dit opzicht echter niet aan bod in dit onderzoek. Juist omdat ze zulk een kind van hun tijd waren zouden de Consuetudines impressae van het toneel moeten verdwijnen van zodra Alexander Farnese, de hertog van Parma en landvoogd van de Zuidelijke Nederlanden, Antwerpen in 1585 heroverde. Een jaar later werd het calvinistische stadsbestuur afgezet en een nieuwe commissie ter revisie van de Consuetudines impressae samengesteld. ${ }^{32}$ Deze geraakte echter niet gelanceerd en het plan bleef dan ook lange tijd in de koelkast. Een tweede commissie, opgericht in 1592, zou wel in haar opzet slagen. ${ }^{33} \mathrm{Zij}$ moest de Consuetudines impressae herzien en een nieuwe definitieve tekst samenstellen. Dit werk zou echter zestien jaar in beslag nemen. Pas in 1608 zagen de Consuetudines compilatae voor het eerst het Antwerpse daglicht en dit in de hoedanigheid van een waar meesterwerk. De sterke katholieke inslag die de tekst kenmerkt, van hen evenwel evenzeer een kind van hun tijd. Ter illustratie van de wijze waarop confessionele verschillen zichtbaar worden in costumiere redacties, heb ik de te zweren eden om poorter van de stad te worden

\footnotetext{
${ }^{31} \mathrm{Ik}$ kom hier later nog uitvoerig op terug. Cfr. infra, hoofdstuk 2, paragraaf 4, Het humanisme te Antwerpen.

32 De commissie van 1586 werd gevormd door binnenburgemeester Adriaan van Heylweghe, de schepenen Jan de Pape en Gillis Gerardi, de stadspensionaris Engelbert Masius en de stadssecretaris Hendrik de Moy. (GOTZEN, "De costumiere bronnen", 114.) Op het zelfde moment werden de Consuetudines impressae afgeschaft en het gebruik ervan door praktizijnen verboden. (F. H. MERTENS en K. L. TORFS, Geschiedenis van Antwerpen sedert de stichting der stad tot onze tyden, V, Antwerpen, 1849, 513.)

33 De commissie van 1592 was samengesteld uit de volgende leden: binnenburgemeester Adriaan van Heylweghe, de schepenen Jan de Pape en Gillis Gerardi, de stadssecretaris Hendrik de Moy, de pensionarissen Philips Ayala en Hendrik Schotti, en de advocaten Jan 's Hertogen en Hendrik Uwens. Aan hen kwam de algemene leiding toe van het project. Voor de grondige uitwerking in details konden zij beroep doen op externe hulp. Het betreft hier de heren Martens voor het eerste en tweede deel, De Witte en Lums voor het derde deel, Valckenisse en De Weerdt voor het vierde deel en tot slot Greyns voor het vijfde deel en Raeckt voor het zesde en zevende deel. (GOTZEN, "De costumiere bronnen”, 114.)
} 
naast elkaar gezet. ${ }^{34}$ In de Consuetudines compilatae staat het volgende te lezen: "Hier sweire ick van nu voortaene den hertoghe van Brabant, als marckgrave des Heijlijcks-Rijckx, goet ende getrouw te sijn, ende desen Borcht, metten borchgrave ende borchtlieden, te helpen hueden ende wachten naer mijn best vermogen: soo moet mij Godt helpen ende alle sijne heijligen". ${ }^{35}$ In de protestantse Consuetudines impressae is er van heiligen geen sprake: “... Hier sweer ick van nu voortaen den Hertoghe van Brabant ende Marcgrave goet ende getrouw te sijne, ende deser Borcht metten Borchgrave ende Borchlieden te helpen hueden ende wachten naer mijn beste vermoghen, soo moet my Godt belpen." 36 De Memorieboeken verklaren het als volgt: "Sunt desumpti ex art 2 in impressis et 3 in antiquis et antiquissimis, nisi quod in impressis pleraque omissa erant que tangebant religionen, ideoque merito restituta." 37 Diezelfde Memorien op de costumen laten echter ook zien dat men in sommige gevallen verkoos de confrontatie uit de weg te gaan, zoals blijkt uit de toelichting met betrekking tot artikel 1.4 .20 omtrent de gasthuizen alwaar de aalmoezeniers geen bewind over hebben: "Est ex art 97 in impressis d tit van onbejaerde kinderen, deletis plerisque qu[a]e tangebant religionem et poterant offendere." 38

Opnieuw nam de omvang enorm toe. De Consuetudines compilatae tellen in totaal 3643 artikels verspreid over 81 titels. $^{39}$ Allen zijn ze gerangschikt op een heel logische en systematische manier, waarover later meer. ${ }^{40}$ Waarom Gotzen hier terecht mag spreken van een hoogstaand meesterwerk, zal uit en in dit proefschrift meermaals blijken. Vandaar dat ik hier nu niet dieper inga op de vernieuwingen en verdiensten van deze vierde redactie van het Antwerpse gewoonterecht.

\section{Het Gelderse Land- en Stadsrecht 41}

Op het moment dat de hulp van Hendrik Uwens werd ingeroepen, had het Gelderse Land-en Stadsrecht zijn precedenten reeds gehad. In de zestiende eeuw hadden de

\footnotetext{
34 Ook in het verdwijnen van pelgrimagestraffen in de Consuetudines impressae kan deze protestanse geest herkend worden. (Cfr. W. MEEWIS, De Vierschaer. De Criminele Rechtspraak in het Oude Antwerpen, Kapellen, 1992, 127-128.)

${ }^{35}$ Het betreft hier artikel 1.14.3 uit de Consuetudines compilatae. Cfr. Coutumes de la ville d'Anvers dites Consuetudines compilatae, III, 62.

36 Het betreft hier artikel 2 van titel 37: Cfr. Coutumes de la ville d'Anvers dites Consuetudines impressae, G. DE LONGE ed. (Coutumes de Pays et Duché de Brabant. Quartier d'Anvers. Coutumes de la ville d'Anvers), II, Brussel, 1871, 212.

37 Cfr. Memorieboeken met betrekking tot artikel 1.14.3. (zie Bijlage 1: referentielijst artikelcommentaar Memorieboeken)

38 Cfr. Memorieboeken met betrekking tot artikel 1.4.20. (zie Bijlage 1: referentielijst artikelcommentaar Memorieboeken)

${ }^{39}$ Later zal ik nog laten zien dat zulk een verdubbeling van het aantal artikels niet automatisch impliceert dat de helft van de Consuetudines compilatae als nieuw kan worden beschouwd. Cfr. infra, hoofdstuk 1, paragraaf 1, Methode.

${ }^{40} \mathrm{Cfr}$. infra, hoofdstuk 2, paragraaf 4, Het bumanisme te Antwerpen.

${ }^{41}$ Dit luik is grotendeels gebaseerd op en ontleend aan A. M. J. A. BERKVENS, G. H. A. VENNER en G. SPIJKERBOER ed., Het Gelderse Land- en Stadsrecht van het Overkwartier Roermond 1620 (Werken der Stichting tot Uitgaaf der Bronnen van het Oud-Vaderlandse Recht, 25), Arnhem, 1996.
} 
landsheerlijke initiatieven tot optekening en homologatie van het aldaar geldende recht geen respons gekend in het Overkwartier van Gelre. Hetzelfde geldt voor de pogingen van de Staten van het Overkwartier in 1564 en 1596 om tot een (gedeeltelijke) redactie te komen. ${ }^{42} \mathrm{Op}$ de kwartiersdag van 4 augustus 1608 werd voor het eerst uitdrukkelijk een besluit genomen om te komen tot een geredigeerd landrecht. Desalniettemin vlotten de werkzaamheden niet, en het is het Eeuwig Edict van 1611 geweest dat een nieuwe impuls gaf. Raadsburgemeester van Roermond Matheus van Dulcken, oud-burgemeester Gerard Creyarts, de burgemeester van Venlo Peter Moeits en de licentiaat Tilman van Bree werden verzocht een nieuwe compilatie samen te stellen. Een eerste ontwerp, gebaseerd op de laatmiddeleeuwse Cleernissen, van het hoofdgerecht Roermond, werd in 1613 door Tilman van Bree afgeleverd. ${ }^{43}$ Nadat de ontwerptekst in 1614 door een andere commissie was gevisiteerd en deels aangepast werd besloten over te gaan tot het verzoeken van de homologatie ervan. De tekst werd aan het Hof van Gelre overgemaakt, waarvan Hendrik Uwens sinds 1615 kanselier was geworden.

Dat Uwens tot de belangrijkste praktijkjuristen van zijn tijd behoorde, blijkt ondermeer uit zijn nominatie voor de functie van president van de Grote Raad van Mechelen. ${ }^{44}$ Zijn overlijden in 1622 belette hem hier echter toe. Uwens, die in Nijmegen werd geboren, behaalde in 1576 de graad van licentiaat in de beide rechten aan de Oude Universiteit van Leuven. ${ }^{45}$ In 1581 werd hij poorter van Antwerpen, alwaar hij aan de slag ging als advocaat. Vanaf 1592 tot 1608 behoorde hij tot de commissie die verantwoordelijk was voor de herziening van de Antwerpse Consuetudines impressae, en speelde zo een aanzienlijke rol bij de totstandkoming van de Consuetudines compilatae. Ondertussen was hij in 1607 benoemd geworden tot raadsheer van de Grote Raad van Mechelen en promoveerde hij vervolgens tot kanselier van

42 Meer hieromtrent, cfr. BERKVENS, VENNER en SPIJKERBOER, Gelderse Land- en Stadsrecht, XVI-XIX.

${ }^{43}$ Cfr. A. J. A. FLAMENT, "Bree (Tilman van)", Nieun Nederlandsch Biografisch Woordenboek, I, Leiden, 1911, 459-460. DEKKERS, Bibliotheca Belgica Juridica, 26.

${ }^{44}$ Van Uwens is slechts één geschrift gekend. Het betreft een consilium dat hij opstelde voor de Antwerpse handelaar Christoffel Prynen en het bevindt zich in de handschriftencollectie van de Hamburgse Staats- en Universiteitsbibliotheek. Het maakt er deel uit van een konvoluut die bestaat uit een dertigtal consilia en quaestiones forenses. (Cfr. E. MATTHES, Die juristischen Handschriften der Staats- und Universtätsbibliothek Hamburg. 1. Foliobandschriften, Stuttgart, 1996, jur.2268.)

${ }^{45}$ Ik spreek van Oude Universiteit van Leuven omdat ik verwijs naar de instelling welke bestond tijdens het Ancien Régime. Officieel zou deze namelijk worden afgeschaft in 1797 onder het Franse bewind om vervolgens, als Rijksuniversiteit, opnieuw te worden opgericht in 1816 door de koning van het Verenigd Koninkrijk der Nederlanden, Willem I. Na het ontstaan van België in 1830 werd deze Rijksuniversiteit in 1835 opnieuw afgeschaft en kon de, in 1834 door de bisschoppen in Mechelen opgerichte, Katholieke Universiteit van Leuven opnieuw vanuit Mechelen naar Leuven verhuizen. Dit is de instelling zoals die vandaag de dag nog steeds bestaat. (Lovanium docet. Geschiedenis van de Leuvense Rechtsfaculteit (1425-1914), G. VAN DIEVOET, D. VAN DEN AUWEELE, F. STEVENS, M. OOSTERBOSCH, en C. COPPENS red., Leuven, 1988, 7-13.) 
het Hof van Gelre. Hoewel deze promotie reeds in 1614 plaatsvond, zou hij pas een jaar later zijn intrek nemen in Roermond, waar het conceptontwerp van Van Bree één van zijn eerste bezigheden zou worden.

Uwens raadde Van Bree aan het ontwerp verder aan te vullen en bood hem aan hierbij een beroep te doen op een kopij van de Antwerpse Consuetudines compilatae, om zo costumen over te nemen die beide streken gemeen hadden. Drie maanden van herzien en aanvullen volgden, waarna tot een homologatieverzoek overgegaan kon worden. Meningsverschillen tussen Roermond en de centrale overheid omtrent de hierbij te volgen procedure evenals het feit dat de onderheren, wiens mening eveneens was gevraagd, het conceptontwerp nog eens wensten door te nemen, maakten dat de tweede fase van het homologatieproces, namelijk de controle ervan door het provinciale gerechtshof, het Hof van Gelre, pas tegen het einde van 1615 was afgerond. ${ }^{46}$ Ondertussen had Uwens, die tijdelijk in Mechelen vertoefde, de tekst nogmaals doorgenomen en de volgorde van de titels vastgelegd, evenals een onderverdeling in paragrafen toegevoegd omdat dit naar zijn mening de overzichtelijkheid ervan ten goede zou komen. Ook typisch Brabantse woorden werden vertaald. De derde fase omvatte het onderzoek van de tekst door de Geheime Raad. Dit vond plaats vanaf het einde van de maand augustus van 1617. Uiteindelijk werd Uwens verzocht de goedkeuring en homologatie te Brussel te bewerkstelligen. De kanselier had er immers zijn connecties en het was van belang dat welgezinde raadsheren uit de Geheime Raad als rapporteurs werden aangeduid. ${ }^{47}$ Het onderzoek nam de hele maand september en half oktober in beslag, en had volgens Uwens niet geleid tot wezenlijke veranderingen, toevoegingen of schrappingen. Na zijn terugkeer naar Roermond werden de op aanvraag van de Geheime Raad vereiste wijzigingen doorgevoerd, en zou Uwens nog enkele titels aan het geheel toevoegen (1618-1619).

\footnotetext{
${ }^{46}$ De meningsverschillen tussen Roermond en de centrale overheid betroffen het feit dat men te Roermond wenste de tweede en derde fase van het homologatieproces te combineren. Bijgevolg zou het onderzoek van de tekst door de Geheime Raad overgeslagen worden. Hierbij beriep men zich op gewestelijke privileges welke waren vastgelegd in het privilege de non evocando van 1310 en later opnieuw in het vierde artikel van het Traktaat van Venlo (1543). Dit hield in dat de Gelderse ingezetenen enkel in het binnenland in rechte betrokken mochten worden. Waar de Staten van het Overkwartier ook daden van bestuur en wetgeving onder de werking van deze bepaling begrepen, stelde Brussel dat deze bepaling enkel betrekking had op de rechtspraak. Wanneer de Staten hun gelijk zouden thuishalen, dan betekende dit dat het Hof van Gelre eenzelfde competentie zou toebedeeld krijgen als de Raad van Brabant. Hier zouden zij echter niet in slagen en de homologatie van het Gelderse Land-en Stadsrecht werd aan de centrale instellingen overgelaten en niet aan het Hof van Gelre. (Cfr. BERKVENS, VENNER en SPIJKERBOER, Gelderse Land- en Stadsrecht, XXXIV-XXXIX. Zie ook: A. M. J. A. BERKVENS, “'In wesen sal het Tractaet van Venlo onderhalden worden...' Het Tractaat van Venlo als fundamentele wet van Spaans en Oostenrijks Gelre 1580-1794", F. KEVERLING BUISMAN red., Verdrag en tractaat van Venlo: herdenkingsbundel, 1543-1993 (Werken, uitgegeven door Gelre, Vereeniging tot Beoefening van Geldersche Geschiedenis, Oudheidkunde en Recht. No. 43), Hilversum, 1993, 153-170.)

${ }^{47}$ Het betreft twee oude bekenden van Hendrik Uwens, met name Willem van Steenhuis en Otto Hartius.
} 
Uiteindelijk werd deze definitieve tekst op 19 september 1619 goedgekeurd en door de Aartshertogen Albrecht en Isabella bekrachtigd.

De optekening van al deze lokale en regionale gewoonterechten maakt deel uit van twee ruimere processen. Enerzijds getuigt het van de tendens waarbij de vorst zijn wetgevende macht gaat uitbreiden ten nadele van de 'regelgeving van onderuit' zoals het ongeschreven costumiere recht dat zich in de buik van de samenleving ontwikkelt; descending power versus ascending power. 48 Anderzijds past het in het zestiende-eeuwse unificatieproces van het recht dat op zijn beurt in het teken stond van het Bourgondisch-Habsburgse staatsvormingsproces.

De redactionele activiteiten zelf werden doorgaans toevertrouwd aan legisten, veelal gevormd aan de Oude Universiteit van Leuven. De Alma Mater kon op dit ogenblik immers beschouwd worden als de rekruteringsplaats bij uitstek voor de leden van de hogere magistratuur. Het is dan ook te verwachten dat via deze, academische geschoolde legisten, het juridisch humanisme zijn weg naar het lokale recht vond. Reeds in 1917 gaf Brants aan hoe bepalend de rol van de professoren, zij het onrechtstreeks, kon zijn voor de totstandkoming van wetgeving: "Les maitres de Louvain, par la concentration de leur enseignement, et en même temps leur intervention dans la justice, préparèrent la législation civile nationale issue, tout à la fois, du droit écrit et de la coutume. Les professeurs formaient les magistrats et les avocats; souvent ils allaient eux-mêmes s'asseoir sur les sièges les plus élevés des corps législatifs et judiciaires; ils donnaient et publiaient des consultations judiciaires (consilia, responsa); on les appelait comme juges dans les procès de grande revision au Conseil suprême de Malines; leurs livres formaient l'esprit juridique; celui-ci s'unifiait ainsi que la jurisprudence dont, en cas de conflit, la Cour de Malines on le Conseil privé tranchait le différend; ainsi se prépara l'oeuvre qui aboutit, en 1611, à l'important Edit perpétuel réglant certaine matière juridique pour tous les Pays-Bas et la rédaction méthodique des contumes." 49 Eenzelfde redenering geldt met betrekking tot de samenstellers van de verschillende geredigeerde costumen. Ook nu gaat het om practici die academisch gevormd zijn en welke volop in contact gekomen zijn met de nieuwe ideeën zoals ze aan de juridische faculteiten werden onderwezen. Eenzelfde idee is terug te vinden bij Berkvens wanneer hij zich afvraagt in hoeverre de toegenomen bereidheid mee te werken aan het redactieproces, na het Eeunvig Edict van 1611, een gevolg is van 'betere intellectuele condities'. Doordat leerlingen van de Gabriel van der Muyden, de founding father van het juridisch humanisme te Leuven, professorale ambten wisten te bemachtigen, verandert het Studium generale in een broedplaats van juristen, advocaten en ambtenaren welke een zekere voeling hadden met het nieuwe gedachtegoed. Wanneer zij vervolgens op belangrijke posities terechtkwamen, zoals die van raadsheer in één van de vele provinciale raden, bespoedigde dit proces de samenwerking. Zij gaven namelijk blijk van eenzelfde 'codificatiedrang', op zoek naar het beste recht, als de

${ }^{48}$ Cfr. W. ULLMAN, Principles of Government and Politics in the Middle Ages, Londen, 1966.

${ }^{49}$ V. BRANTS, La Faculté de droit de l'Université de Louvain à travers cinq siècles: étude historique, Parijs-Brussel, 1917, (anast. herdruk Brussel, 1998), 49. 
centrale overheid. ${ }^{50}$ Op een vergelijkbare manier kan verondersteld worden dat de verworvenheden van het humanisme nu ook hun weg naar de redactie van het gewoonterecht zullen vinden. Ten aanzien van de doorwerking ervan, denkt Berkvens in de eerste plaats aan de systematische ordening van het materiaal, waarbij het Institutensysteem, of een bewerkte versie ervan, als leiddraad werd genomen. ${ }^{51}$ Aangezien de doorwerking van de humanistische novus methodus, de rode draad van dit proefschrift is, zal ik ook kort de belangrijkste feiten en verdiensten van deze beweging op een rij zetten.

\section{Juridisch humanisme ${ }^{52}$}

Het juridisch humanisme kende zijn ontstaan en bloeiperiode aan de Franse universiteit van Bourges in het midden van de zestiende eeuw. Aldaar geïntroduceerd door stamvader Andrea Alciato (1492-1553) zette het zich, als mos gallicus, in de eerste plaats af tegen de tot dan toe overheersende mos italicus van de bartolistische commentatoren. Laatstgenoemden zochten in het Corpus Iuris Civilis in de eerste plaats naar werkbare regels die konden worden toegepast op de praktische problemen van de laatmiddeleeuwse maatschappij. Het Romeinse recht werd dus in functie van de eigentijdse problemen gelezen, waarbij het respect voor het document als kenbron van een samenleving in het verleden werd genegeerd. Door de teksten meer en meer aan te passen om er oplossingen in te vinden voor contemporaine juridische problemen, raakte de tekst steeds verder verwijderd van de oorspronkelijke Justiniaanse tekst, waaraan hij zijn autoriteit ontleende. De glossen en commentaren werden door de humanisten beschouwd als een kwaadaardige kanker die weggesneden diende te worden. Vandenbergh wees er met een treffende vergelijking op dat uit het Corpus Iuris Civilis de bouwstenen werden gekapt voor de theoretische

50 A. M. J. A. BERKVENS, "Imperatoriam maiestatem non solum armis decoratam sed legibus oportet esse armatam... Notes on the influence of Justinian's Institutes on the codification of customary law in the Southern Netherlands", L. DE LIGT red., Viva Vox Iuris Romani. Essays in honour of Johannes Emil Spruit (Studia Amstelodamensia. Vol. 38), Amsterdam, 2002, 2-7.

51 BERKVENS, "Imperatoriam maiestatem", 6-7.

52 Deze paragraaf werd voornamelijk gebaseerd op volgende overzichtswerken: P. STEIN, Roman Law in European History, Cambridge-New York-Melbourne, 1996, 75-85. KOSCHAKER, Europa en het Romeinse Recht, 105-123. M. BELLOMO, The Common Legal Past of Europe 1000-1800 (Studies in Medieval and Early Modern Canon Law. IV), Washington, 1995, 203-210. G. C. J. J. VAN DEN BERGH, Geleerd recht. Een geschiedenis van de Europese rechtswetenschap in vogelvlucht, Deventer, 2000, 51-71. R. LESAFFER, Inleiding tot de Europese rechtsgeschiedenis, Leuven, 2004, 315-325. Zie ook: P. STEIN, "Legal humanism and legal science", Tijdschrift voor Rechtsgeschiedenis, 54 (1986), 297-306. H. E. TROJE, "Die Literatur des gemeinen Rechts unter dem Einfluss des Humanismus", H. COING red., Handbuch der Quellen und Literatur der Neueren europäischen Privatrechtsgeschichte, II/1, Munchen, 1977, 615-796. G. C. J. J. VAN DEN BERGH, Die Holländische elegante Schule (Ius Commune Sonderheft 148), Frankfurt am Main, 2002. Ook het oeuvre van Osler mag hier niet ontbreken en dan in het bijzonder: D. J. OSLER, “The Myth of European Legal History”, Rechtshistorisches Journal, 16 (1997), 393-410. 
opbouw van de eigen middeleeuwse maatschappij zoals de Romeinse rünes als steengroeven voor de middeleeuwse nieuwbouw dienden. ${ }^{53}$

Omwille van de band tussen de Romeinse maatschappij en haar recht enerzijds en de kloof tussen het Corpus Iuris Civilis en de zestiende-eeuwse maatschappij anderzijds, werd dit recht vanaf nu als onbruikbaar beschouwd voor de zestiende-eeuwse rechtspraktijk. De humanistische juristen zullen het Corpus Iuris Civilis dan ook bestuderen om het Corpus Iuris Civilis in se. Het wordt nu aanzien als een document dat iets leert over een beschaving van 1500 jaar geleden, en de toepassing ervan op contemporaine juridische problemen wordt afgezworen. Om tot het ware Romeinse recht door te kunnen dringen, diende de tekst echter in de eerste plaats gezuiverd te worden van alles wat er door de glossatoren en de commentatoren aan was toegevoegd. Deze restauratie gebeurde niet langer met behulp van de traditionele en tot dan toe steeds gehanteerde littera bononiensis uit de elfde eeuw. Deze tekstversie werd door de humanisten immers als te jong en bijgevolg onbetrouwbaar aanzien. Bovendien was hij opgesteld in het minderwaardige geachte, middeleeuwse Latijn. De vertegenwoordigers van de mos gallicus daarentegen beriepen zich op de littera florentina, daterend van de zesde eeuw, die mogelijk de originele tekst bevatte die keizer Justinianus naar paus Vigilus had gezonden in de jaren vijftig van de zesde eeuw. Ook het barbaarse Latijn van de commentatoren werd achterwege gelaten en de humanisten knoopten terug aan met het klassieke Latijn van Cicero en consorten. Daarenboven werden opnieuw Griekse bronnen geraadpleegd en gelezen, daar waar middeleeuwse juristen zich doorgaans behielpen met nogal gebrekkige Latijnse vertalingen.

Een eerste manifestatie van deze nieuwe wind manifesteert zich aan het begin van de zestiende eeuw te zien, wanneer uitgerekend een Italiaan, Andrea Alciato, vanuit Italië naar Frankrijk verhuisde om er uit te groeien tot de stamvader van het juridisch humanisme. Zelf te Pavia opgeleid door de laatste grote meesters van de bartolistische traditie, Giasone del Maino (1435-1519) en Filippo Decio (1454-1535), zag Alciato het als zijn taak de humanistische studies met de rechtswetenschap te verbinden. Hij was het die de ideeën van de nieuwe rechtswetenschappelijke traditie in Frankrijk introduceerde. Nadat hij eerst gedurende zes jaar te Avignon (1518-1522) had gedoceerd, kwam hij in 1529 te Bourges terecht, wat onder zijn impulsen zou uitgroeien tot het Mekka van de mos gallicus. Hier kende de stroming halverwege de zestiende eeuw zijn hoogtepunt met vooraanstaande protagonisten als Jacques Cujas (1522-1590) en François Hotman (1524-1590). ${ }^{54}$ Ik schrijf de tweede helft van de zestiende eeuw en de nadruk is nu eindelijk komen te liggen op het meer juridische aspect, daar waar de pioniers van het juridisch humanisme, zoals Andrea Alciato, Guillaume Budé (1468-1540) en Ullrich Zäsi (1461-1535) zich nog concentreerden op het voorbereidende werk, ondermeer het verwijderen van de glossen en

53 VAN DEN BERGH, Geleerd recht, 65.

54 Osler merkt terecht op dat men steeds over het hoofd heeft gezien wie de fakkel heeft doorgegeven aan deze lieden van de zogenaamde 'tweede generatie'. Zelf waren zij immers te jong op het moment dat Alciato te Bourges werkzaam was. (OSLER, "Myth of European Legal History", 395-396.) 
commentaren. Ook leken ze meer aandacht te hebben voor het historische facet van de tekst, dan het recht zelf. Juristen als Cujas en Hotman daarentegen waren meer op het juridische plan actief. Cujas was de tekstcriticus die er onder meer op wees dat een correcte lezing niet voldoende was, maar dat men deze lezing eveneens diende af te wegen tegen de ratio iuris of het principe achter de regel. François Hotman was meer de verdediger van de stelling dat het Romeinse recht onlosmakelijk verbonden is met de Romeinse maatschappij en dat het bijgevolg onmogelijk kon dienen als model voor contemporain Frankrijk. Dit is overigens een rechtstreekse aanval op de typisch middeleeuwse claim dat het Romeinse recht universeel geldend zou zijn. De autoriteit wordt aangetast. Ontvoogding wordt hoog in het vaandel gedragen. Het Romeinse recht moet aan dogmatische ambities inboeten, wat op zijn beurt -zoals ik in dit boek zal aantonen- meer ruimte laat aan andere, niet-Romeinsrechtelijke, rechtsbronnen bij het opstellen van het eigen, lokale recht.

De grote systematicus Hugo Doneau (1527-1591) is op zijn beurt dan weer de protagonist van de structuur. Het tweede-eeuwse Institutensysteem van Gaius wordt van onder het stof vandaan gehaald, maar niet zonder facelift, zoals later nog uitgebreid aan bod zal komen. ${ }^{55}$ Het laat zien hoezeer de aanhangers van de mos gallicus oog hebben voor logische orde, methode en systematiek, ten nadele van de tot dan toe traditionele ordo legum van de Justiniaanse Codex. Het casuïstische van de tekst wordt ingeruild voor een meer abstracte benadering van de tekst, welke op zoek gaat naar een systeem en onderliggende basisprincipes. Bovendien waren deze prominente protagonisten doorgaans protestants, die conform de wijze waarop hun theologische collegae de autoriteit van de Kerkvaders in twijfel trokken en wilde terugkeren naar de oorspronkelijke betekenis van de Heilige Schrift, op een vergelijkbare manier de glossatoren en commentatoren bekritiseerden, terwijl men op zoek gingen naar het authentieke Corpus Iuris Civilis. Deze confessionele geaardheid betekende echter eveneens het einde van Bourges. Na de Sint-Bartholomeusnacht (23 augustus 1572) explodeert de school als het ware en verspreiden haar aanhangers zich over de meer gastvrije protestantse buurlanden. Zo komt bijvoorbeeld Hugo Doneau, via omzwervingen in Duitsland, in Leiden terecht, alwaar hij zijn humanistische principes introduceerde in de Noord-Nederlandse rechtswetenschap. ${ }^{56}$

Het juridisch humanisme verspreidde zich echter niet alleen op een gedwongen manier. De peregrinatio academia zorgde ervoor dat het gedachtegoed reeds veel vroeger in de Zuidelijke Nederlanden voet aan de grond kreeg. In de landen van 's herwaarts over kwamen de nieuwe inzichten terecht via Gabriel Van der Muyden (1500-1560), een leerling van Alciato te Bourges, die sinds 1537 tot aan zijn dood te Leuven doceerde in het Romeinse recht. ${ }^{57}$ Hij propageerde er de nieuwe filologisch-historische

${ }_{55}$ Cfr. infra, hoofdstuk 2, paragraaf 4, Het bumanisme te Antwerpen.

${ }^{56}$ Cfr. R. FEENSTRA, "Hugues Doneau et les juristes néerlandais du XVIIe siècle: l'influence de son 'système' sur l'évolution du droit privé avant le Pandectisme", B. SCHMIDLIN et A. DUFOUR red., Jacques Godefroy (1587-1652) et l'Humanisme juridique à Genève, Basel-Frankfurt am Main, 1991, 231-248.

${ }^{57}$ Cfr. Lovanium docet, 66-69. Voor Gilissen en Van den Bergh is Wigle van Aytta de allereerste vertegenwoordiger van het juridisch humanisme in de Nederlanden. Hij heeft namelijk in 1534 
methode van het humanisme, gekenmerkt door een sobere stijl en de inlassing van uitweidingen over klassieke auteurs zoals Cicero en de geschiedenis van het oude Rome. Leerlingen van hem waren onder meer Elbrecht de Leeuw (1519/20-1598), die hem in Leuven zal opvolgen, Matthias Wesenbeeck (1531-1586), Jean Wamese (1524-1590), Joachim Hopper (1523-1576), Jean Vendeville (1527-1592), Pieter Peck (1529-1589) en Johan Tack (1535-1578). ${ }^{58}$ Hoewel in de literatuur doorgaans wordt aangenomen dat te Leuven de oude onderwijsmethoden in gebruik bleven onder druk van een dominante en conservatieve theologiefaculteit, kan ik me niet van de indruk ontdoen dat humanistische voormannen, zoals hierboven opgesomd, een moderniserende invloed moeten gehad hebben op het Leuvense onderwijs aan de rechtenfaculteit. ${ }^{59}$ Hierbij veronderstel ik, net als Berkvens, dat er een centrale rol is

de Griekse tekst van de 'Parafrasen van de Instituten' van Theophilus voor het eerst uitgegeven. (GILISSEN, Historische inleiding, 343. VAN DEN BERGH, Geleerd recht, 56.) Tevens wijst Van den Bergh erop dat het mogelijk is tegelijk humanist en bartolist te zijn, indien men enig contact met de buitenwereld wilde bewaren. Een carrière als topjurist realiseren, zoals Viglius dat gedaan heeft in het Bourgondisch-Habsburgs bestuursapparaat, is immers onmogelijk zonder een stevige portie bartolistisch realisme. (VAN DEN BERGH, Geleerd recht, 70.) Hoewel Viglius dus nooit een professorenambt in zijn bezit heeft gehad, wist hij via zijn bestuurlijke functies toch heel wat invloed uit te oefenen. (Cfr. BERKVENS, "Imperatoriam maiestatem", 6.)

Britz van zijn kant vestigt de aandacht op het belang van de Brugse advocaat Jacob de Corte (ca.1504-ca.1556): "De Corte ne doit jamais être omis dans la galerie des jurisconsultes progressifs de l'époque qui nous occupe." Curtius schrijft en zegt in zijn inleiding op zijn vertaling van Theophilius hetzelfde als wat Van der Muyden op dat moment te Frankrijk ontdekt. (BRITZ, Code de l'ancien droit Belgique, I, 118. Zie ook: BRITZ, Code de l'ancien droit Belgique, I, 84-86.)

Tot slot mag volgens Van den Auweele zelfs in de Topica van Nicolaes Everaerts (1461/14621532), welke dateert van 1516, reeds een aankondiging gezien worden van het juridisch humanisme. Het werk getuigt van een uiterst kritische houding ten aanzien van de middeleeuwse auctoritates, opteert voor meer systematiek en synthese en laat zich kenmerken door talrijke verwijzingen naar auteurs van de klassieke oudheid. (Lovanium docet, 62-63.) (Cfr. O. M. D. F. VERVAART, Studies over Nicolaas Everaerts (1462-1532) en zijn Topica, Arnhem, 1994.)

${ }^{58}$ Lovanium docet, 67-69. VAN DEN BERGH, Geleerd recht, 71.

59 Zo staat er in de geschiedenis van de Leuvense Rechtsfaculteit uit 1988, Lovanium docet, het volgende te lezen: "De middeleeuwse scholastieke werkwijze blijft ook in de 16de, 17de en 18de eeun haar volle betekenis behouden. Het is onjuist te stellen dat het humanisme daaraan iets fundamenteels zou veranderd of gewijzigd hebben." (Lovanium docet, 29.) Verder in de tekst wordt evenwel erkent dat het humanisme evenwel nieuwe accenten weet te leggen, maar Leuven is ook niet voor niets een traditionele, behoudsgezinde universiteit en biedt het juridisch bumanisme inhoudelijk weinig, formeel iets meer ruimte. (Lovanium docet, 30-31.) Vermoedelijk waren de auteurs ervan deels geïnspireerd door Dekkers: "Ten aanzien van de hervormde wetenschap waren de akademische kingen uiteraard nog steeds terughoudend. Men citeert dikwijls, in dezen zin, een typisch beshit der rechtsfaculteit te Leuven, waarbij aan een professor nitdrukkelijk bevolen werd, de gebruikelijke scholastische methode te volgen, en geen gehoor te geven aan nieuwe experimenten." (R. DEKKERS, Het bumanisme en de rechtswetenschap in de Nederlanden (Vlaamsche rechtskundige bibliotheek. XIX), Antwerpen, 1938, 103.) Omtrent de hervorming van het onderwijs in het algemeen, cfr. VAN DEN BERGH, Geleerd recht, 60-62. 
weggelegd voor de humanist Wigle van Aytta en de drie koninklijke leerstoelen die hij in 1557 in het leven weet te roepen. ${ }^{60}$ Gezien het feit dat deze bezet werden door leerlingen van Gabriel Van der Muyden, ben ik er van overtuigd dat dit alles tot gevolg had dat ook aan de Leuvense rechtsfaculteit de middeleeuwse onderwijsmethode, gekenmerkt door een exegetische benadering van het Corpus Iuris, plaats moest ruimen voor een meer systematische aanpak, waarbij het recht meer als systeem werd benaderd en uitgelegd. De ordo legum was niet langer doorslaggevend en men stapte over naar een onderwijstype dat de nadruk legt op de Instituten van Justinianus en de laatste titels van het Corpus Iuris: de verborum significatione en de diversis regulis iuris antiqui. ${ }^{61}$ Desalniettemin wordt doorgaans aangenomen dat Van der Muyden slechts een middenweg bewandelde. Deze via media kenmerkte zich door een blijvend respect voor de meningen van de middeleeuwse auteurs. Ook het Romeinse recht werd niet uitsluitend in het licht van de kennis omtrent de Romeinse beschaving bestudeerd, omdat het geen enkel nut zou kunnen hebben voor de contemporaine samenleving van de zestiende eeuw. Van der Muyden besefte maar al te goed dat hij advocaten op te leiden had, die met twee benen in de praktijk stonden. Wanneer nu ook de hulp van deze practici wordt ingeroepen bij het costumiere redactieproces, dan mag verwacht worden dat de verworvenheden van het juridisch humanisme hun stempel weten te drukken op de uiteindelijke gewoonterechtelijke compilaties. ${ }^{62}$

Het is de doorwerking van deze humanistische verworvenheden die de rode draad vormt van mijn verhaal. ${ }^{63}$ Aan de hand van de case study Antwerpen-Roermond zal ik

\footnotetext{
60 BERKVENS, "Imperatoriam maiestatem", 6.

${ }^{61}$ BERKVENS, "Imperatoriam maiestatem", 6.

62 Ook de Visscher wees er reeds in 1939 op hoe Matthias Wesenbeeck, een leerling van Van der Muyden, niet alleen als professor werkzaam was te Wittenberg, maar er tevens betrokken rakkte bij het voorbereidende werk voor de constituties van 1572 van het keurvorstendom Saksen. Cfr. F. DE VISSCHER, "Gabriel Mudaeus", Annales de droit et de sciences politiques, publiees sous les auspices de l'Association des anciens étudiants de la faculté de droit de l'Université de Louvain, 8 (1939), 6. (overdruk) Verder werkte ook de Leuvense hoogleraar, Albrecht de Leeuw (Leoninus), in de jaren 60 van de zestiende eeuw mee aan het ontwerp van het Veluwse landrecht (1564). (Cfr. F. KEVERLING BUISMAN, "Welke faktoren bepaalden de inhoud van de Gelderse landenrechten tijdens het Ancien Regime”, E. J. M. F. C. BROERS en B. C. M. JACOBS red., Interactie tussen wetgever en rechter voor de Trias Politica. Handelingen van het congres gehouden te Tilburg op 12 en 13 december 2002), Den Haag, 2003, 200-201.) Gezien zijn academische vorming te Leuven kan ook hier een zekere invloed van het juridisch humanisme op de redactie van het (Veluwse) gewoonterecht vermoed worden. Ook Leoninus wordt immers als juridisch humanist bestempeld. (Cfr. BRITZ, Code de l'ancien droit Belgique, I, 90-92.) ${ }^{63}$ Dat het juridisch humanisme als beweging in de literatuur vaak gerelativeerd werd, hoeft echter niet noodzakelijk een obstakel te vormen voor de idee dat haar invloed ook op de redactie van het gewoonterecht daadwerkelijk aantoonbaar is. (Cfr. KOSCHAKER, Europa en bet Romeinse recht, 110-123. OSLER, "Myth of European Legal History", 404-410. VAN DEN BERGH, Geleerd recht, 64-71.) Het feit dat auteurs als Van den Bergh en Osler het humanisme typeren als een elitecultuur of zelfs marginaal verschijnsel in de globale rechtsgeschiedenis
} 
trachten aan te tonen dat er met recht en rede gesproken kan worden van humanistische invloeden op het redactieproces van het gewoonterecht in de Nederlanden. Let wel, het gaat hier om de rode draad. De opzet en het traject van mijn onderzoek wordt echter bepaald door het unieke karakter van de casus Antwerpen-Roermond. Deze stelt me immers in staat een aantal fenomenen, werkzaam bij het redactieproces, aan het licht te brengen, welke tot nog toe onderbelicht zijn gebleven. Ik denk hierbij aan de rechtsbronnen van het geredigeerde gewoonterecht (hoofdstuk 1) en de mate waarin compilaties elkaar onderling, zowel inhoudelijk als vormelijk, beïnvloed hebben (hoofdstuk 2). Doorheen dit verhaal zal ik evenwel meermaals geconfronteerd worden met sporen van het humanistische gedachtegoed. Ter bevestiging van mijn centrale these, zal ik in een derde hoofdstuk het intellectuele kader trachten te reconstrueren van waaruit de commissieleden van de Antwerpse Consuetudines compilatae opereerden. De door hen gehanteerde, rechtsgeleerde literatuur geeft immers een idee van de mate waarin zij op de hoogte waren van en beïnvloed door de novus methodus van de mos gallicus.

Om tot slot terug te komen op ons openingsverhaal in verband met de koning die 'te boek stelt om beter te memoriseren omdat met het geheugen herinneren niet altijd even betrouwbaar is', wil ik er bij wijze van waarschuwing op wijzen dat ook boeken niet altijd even betrouwbaar zijn als bron voor historische kennis. Zoals ook Gilissen reeds stelde, is alleen de rechtspraak en de schriftelijke neerslag hiervan een betrouwbare spiegel van de (historische) werkelijkheid. ${ }^{64}$ Men moet dus steeds het idealistische karakter van wetboeken in het achterhoofd houden. Ze schetsen immers hoe men graag zou hebben dat de wereld eruit ziet, niet hoe hij er ook daadwerkelijk uitziet.

neemt niet weg dat haar verworvenheden wel degelijk doorwerken tot op het niveau van het lokale, costumiere recht, zoals ik met dit onderzoek zal trachten aan te tonen.

${ }^{64}$ Cfr. GILISSEN, Historische inleiding, 388. 


\section{ProbleEMSTELLING EN OPBOUW VAN HET ONDERZOEK}

“A un tribunal, après tout, l'état civil des témoins importe beaucoup plus que celui des avocats." 65

Wegens de tand des tijd zijn historici gedwongen te roeien met de riemen die ze hebben. De overgeleverde bronnen bepalen niet alleen welke vraagstellingen op een historisch-wetenschappelijke manier kunnen worden beantwoord, maar ook de wijze waarop de onderzoeker zijn 'gekozen' onderwerp benadert. De ideale weg waarbij de historicus de lijnen uitzet, is maar al te vaak een utopie gebleken. Dit dwingende karakter van de historische bron vloeit voort uit de fundamentele rol die ze speelt bij de zoektocht naar de historische waarheid. Dat haar belang hierin groter was dan de rol gespeeld door de wetenschapper wist Bloch reeds mooi te verwoorden aan de hand van de metafoor in bovenstaand citaat. De getuigen van het verleden bepalen onze mogelijkheden en beperkingen het verleden al dan niet te kennen. $\mathrm{Zij}$, en niet de historicus, schrijven geschiedenis.

Ook zij kunnen echter te lijden hebben aan sprakeloosheid en ik ben me er dan ook terdege bewust van hoe gelukkig ik me moet prijzen met het uitzonderlijke bronnenpakket waarover ik de afgelopen vier jaar heb kunnen beschikken. Dit lof komt toe aan de Memorien op de Costumen, kortweg Memorieboeken, waarvan zonder verpinken gezegd kan worden dat de rijkdom ervan haar dwingende karakter minimaliseerde tot een habbekrats. ${ }^{66}$ Met betrekking tot het Antwerpse luik sneed het

${ }^{65}$ M. BLOCH, La société féodale, Parijs, 1968 (5 de editie), 17, noot 5.

66 ANTWERPEN, Stadsarchief, Vierschaer, nrs. 48-53: Memorien op de Costumen, 1608. Meermaals zal ik in dit boek de Memorien op de costumen citeren. Bij de transcriptie van de geciteerde passages uit deze Memorieboeken heb ik volgende regels in acht genomen. Ik heb zoveel mogelijk de oorspronkelijke tekst behouden. Ook kennelijke verschrijvingen worden ongewijzigd overgenomen met er achter tussen teksthaken de bedoelde tekst voorafgegaan door sic of lees. Verder werden hoofdletters en kleine letters naar hedendaags gebruik genormaliseerd. De interpunctie van zijn kant werd behouden, net als die worden die aan elkaar werden geschreven welke vandaag doorgaans van elkaar worden gescheiden. Bij wijze van voorbeeld vermeld ik hier het woord 'vande'. Ook veelvoorkomende afkortingen heb ik niet opgelost. Voorbeelden hiervan zijn d (dicti), art (articulus), tit (titulus), tex of text (textus), fol (folio), fin (finalis), c of cap (capittel of caput), lib (liber), ... Bij onzekere lezingen van de basistekst 
mes zelfs aan de andere kant: het grenzeloze potentieel van het beschikbare bronnenmateriaal dwong me tot het maken van keuzes, tot selecteren en tot schrappen. De Memorien op de costumen bieden immers de mogelijkheid nog tal van andere vragen te beantwoorden. Zo bieden zij de onderzoeker de mogelijkheid dieper in te gaan op de inhoudelijke genese van het Antwerpse gewoonterecht, zoals dat in de Consuetudines compilatae van 1608 aan de wereld verschenen is. De Memorieboeken geven immers voor elk afzonderlijk artikel de inhoudelijke, juridische discussie weer welke ervan aan de basis ligt. Bijgevolg kan tevens het waarom en de ratio achter elk artikel achterhaald worden, wat op zijn beurt een beeld kan geven van de wijze van redeneren en de modus operandi van de commissieleden. Zelf heb ik deze mogelijkheid aan mij laten voorbijgaan, gezien ikzelf een historicus pure sang ben en geen juridische vorming genoten heb. Ook de mate waarin confessionele overwegingen de inhoud van de katholieke Consuetudines compilatae hebben bepaald en de hieruit voortvloeiende verschillen met de protestantse Consuetudines impressae kunnen mogelijk onderzocht worden met behulp van de Memorieboeken. Ook deze materie zal hier niet aan bod komen. Ik ben namelijk van mening dat het belang van dit religieuze aspect relatief beperkt van omvang is gebleven. Zo blijkt onder meer dat de verschillende commissies, welke instonden voor de derde en vierde redactiepoging, een aantal gemeenschappelijke leden kenden, ongeacht hun religieuze achtergrond. Daarenboven blijkt uit de Memorieboeken dat er onder de geciteerde auteurs geen onderscheid gemaakt wordt tussen protestantse en katholieke auteurs. Desondanks kan dit aspect nog nader onderzocht worden, zeker ten aanzien van de inhoudelijke verschillen tussen beide compilaties inzake aan religie gerelateerde materie.

De rijkdom van het Antwerpse bronnenmateriaal wordt dan weer gecompenseerd door de mogelijkheden van het archiefmateriaal aan Roermondse zijde. Zo bemoeilijkt het ontbreken van het originele ontwerp van Tilman van Bree het onderzoek naar de mate waarin de Consuetudines compilatae het Gelderse Land- en Stadsrecht wisten te beïnvloeden. Bijgevolg ben ik, zoals zal blijken uit het tweede hoofdstuk van dit boek, op een andere manier te werk gegaan ter beantwoording van deze vraagstelling. ${ }^{67}$ Tevens zorgde een initiële overschatting van de waarde van de persoonlijke notities en marginale opmerkingen van Hendrik Uwens bij de documenten betreffende het Gelderse Land-en Stadsrecht ervoor dat het onmogelijk was uit te maken in hoeverre de ratio achter de voorstellen en beslissingen van de Antwerpse advocaat onder invloed stond van een humanistisch georiënteerde grondhouding. Dit alles maakt dat het zwaartepunt van het onderzoek sterk kwam te verschuiven naar Antwerpse zijde.

wordt de meest waarschijnlijke lezing gevolgd door een vraagteken tussen teksthaken. Dezelfde regels werden ook toegepast telkens wanneer ik uit andere manuscripten citeerde. Ik denk bijvoorbeeld aan de vijfde bijlage waar een viertal inhoudsopgaven van conceptontwerpen van het Gelderse Land en Stadsrecht worden gereconstrueerd.

${ }^{67}$ Cfr. infra, hoofdstuk 2, paragraaf 2, Methode. 


\section{Probleemstelling}

Op deze manier dwong het bronnenmateriaal tot een driedelige structuur en opzet.

Gezien de specificiteit van de probleemstelling binnen elk deel van het drieluik, heb ik ervoor geopteerd de status quaestionis ervan evenals de toegepaste methode en aangewende bronnen aan het begin van elk hoofdstuk te bespreken. Bijgevolg beperk ik me hier tot de algemene probleemstellingen en een korte voorstelling van de opbouw van het onderzoek.

Een eerste deelaspect van het redactieproces dat geanalyseerd zal worden, betreft de rechtsbronnen van de Antwerpse costumen zoals ze in de Consuetudines compilatae uiteengezet worden. Welke formele en materiële rechtsbronnen liggen aan de basis van de 3643 verschillende artikels? Een overzicht hiervan geeft een idee van het belang van de wetgeving, het Romeinse recht, de rechtspraak, enzovoort voor het Antwerpse gewoonterecht. Het laat zien hoezeer de eigen, lokale gewoonte wordt gerespecteerd en in welke mate de commissieleden getuigen van een openheid naar vreemde, van origine niet-Antwerpse, invloeden. Het stelt me in staat tal van invloeden aan het licht te brengen welke voordien nauwelijks aan bod kwamen in de historiografie omtrent het costumiere redactieproces. Belangrijk hierbij is dat, van zodra er sprake kan zijn van verschillende 'buitensteedse' rechtsbronnen, zulk een openheid aangewend kan worden als criterium voor het vaststellen van humanistische invloeden. Belangrijk in dit opzicht is de rol welke is weggelegd voor de ratio et aequitas iuris als redelijkheid en billijkheid van het gekozen recht, evenals de houding welke men aannam ten overstaan van het Romeinse recht in het bijzonder. Zowel het laten primeren van het meest 'redelijke' recht als het verzet tegen het -typisch middeleeuwse- dogmatische karakter van het Romeinse recht, getuigen van een proces van ontvoogding, dat als typisch humanistisch beschouwd kan worden.

Een tweede hoofdstuk concentreert zich op de band tussen het Gelderse Land- en Stadsrecht en de Antwerpse Consuetudines compilatae. ${ }^{68}$ Hoewel in het verleden reeds meermaals filiaties tussen costumiere redacties van verschillende steden en regio's aan het licht werden gebracht, werd tot nog toe nooit eerder een gelijkaardig fenomeen beschreven zoals zich dat met betrekking tot de tandem Antwerpen-Roermond voorgedaan heeft. Dit proces, waarbij de beïnvloeding van de ene compilatie door de andere zulke proporties aangenomen heeft dat er terecht gesproken kan worden van

\footnotetext{
${ }^{68}$ Omtrent de uitwisseling van regels, zie ook A. WATSON, Legal Transplants. An Approach to Comparative Law, Edinburgh, 1974. Hierin omschrijft de auteur legal transplants als "the moving of a rule or a system of law from one country to another, or from one people to another". (WATSON, Legal Transplants, 21.) Zijn studie leidt hem onder meer tot volgende conclusies: legal transplants komen niet alleen vaak voor, het is bovendien één van de meest vruchtbare voedingsbodem ter ontwikkeling van het recht op een bepaalde plaats. Daarenboven geschiedt deze uitwisseling gemakkelijk en meestal zonder veel weerstand, en dit ondanks het feit dat de overname van een regel of een set van regels bijna altijd een wijziging of aanpassing inhoudt. Watson ziet evenmin een onderscheid tussen de verschillende gebieden van het privaatrecht inzake ontvankelijkheid ten opzichte van vreemde invloeden. (WATSON, Legal Transplants, 95-101.)
} 
een zeker identiteitsverlies, ben ik gaan aanduiden als 'costumiere acculturatie'. ${ }^{9}$ Dit tweede hoofdstuk tracht een antwoord te vinden op de vraag hoe ingrijpend dit verschijnsel is geweest en binnen welke rechtsgebieden het voornamelijk heeft huisgehouden. Dat zowel inhoud als structuur er vatbaar voor zijn, zal eveneens blijken uit dit tweede luik. Bovendien bewijst de opbouw van beide compilaties volgens de nieuwe, humanistische ordeningsprincipes de doorwerking van het juridisch humanisme op het costumiere redactieproces. Uiteindelijk is het, dankzij de resultaten van hoofdstuk 1, tevens mogelijk een idee te geven van welke rechtsbronnen, via de Consuetudines compilatae als Paard van Troje, tot in het Overkwartier terecht zijn gekomen.

Beide voornoemde luiken dragen er toe bij inzicht te verwerven in de wijze waarop het juridisch humanisme ook op gewoonterechtelijk vlak van belang is geweest. Deze probleemstelling kent zijn sluitstuk in een derde hoofdstuk, waarin de allegaties in de Memorien op de Costumen worden beschreven en geanalyseerd. Door de reconstructie van het intellectuele kader, van waaruit de commissieleden opereerden en redeneerden, kan een bevestiging gezocht worden voor de centrale hypothese dat de invloed van het juridisch humanisme op het costumiere redactieproces daadwerkelijk aantoonbaar is. Door een overzicht te maken van de talloze juridische werken waarnaar door de redacteurs van de Consuetudines compilatae in hun overleg en discussies wordt verwezen, kan een idee verkregen worden van de auteurs en genres welke hun voorkeur genieten. De rechtsgeleerde 'scholen' waartoe de geallegeerde juristen behoren, maar meer nog de mate waarin het hier gaat om humanistisch georiënteerde literatuurtypes, maken het mogelijk de invloed van het juridisch humanisme op het lokale, geredigeerde gewoonterecht al dan niet definitief vast te stellen.

Op deze manier zal ik met dit boek trachten een drietal facetten van het costumiere redactieproces te belichten, welke tot nog toe nauwelijks of geen aandacht gekregen hebben in de hedendaagse historiografie: de rechtsbronnen van de compilaties, het fenomeen van costumiere acculturatie en de invloed van het juridisch humanisme.

Opbouw

Ik heb reeds meermaals aangegeven dat het duo Antwerpen-Roermond het uitgangspunt vormt van ons onderzoek. Deze tandem is de casus van de case study, het chassis waarop de ganse studie berust. De Consuetudines compilatae fungeren als actief sturende vooras, het Gelderse Land- en Stadsrecht is de passief meegaande achteras. Uiteraard ligt het dan ook voor de hand dat in een eerste hoofdstuk het Antwerpse gewoonterecht centraal staat. Een eerste paragraaf beschrijft de stand van zake van het onderzoek tot dus ver en de wijze waarop ik tewerk zal gaan teneinde de rechtsbronnen van het Antwerpse gewoonterecht correct naar waarde in te schatten. De tweede paragraaf omvat een omschrijving van de verschillende rechtsbronnen welke ik per deel heb kunnen identificeren. Ook de mate waarin zij bepalend zijn

${ }^{69}$ De term wordt volledig omschreven en gedefinieerd in de derde paragraaf van het eerste hoofdstuk. Cfr. infra, hoofdstuk 1, paragraaf 3, Romanisatie en bumanisme. 
geweest voor de verschillende titels van elk deel komt hier descriptief aan bod. De derde paragraaf van het eerste hoofdstuk, kent een meer analytische inslag. Hierin wordt dieper ingegaan op de gevolgen welke de aanwezigheid van de verschillende bronnentypes gehad heeft voor de uiteindelijke aard van het Antwerpse gewoonterecht. Er wordt gesproken van de invloed van de vorst en zijn wetgeving (lexificatie), de subsidiaire rol van het Romeinse recht (romanisatie), de impact van de rechtsleer (verwetenschappelijking) en de rechtspraak, de rol van personen of groepen die buiten de commissie stonden (actieve en passieve derden), en tot slot het effect van vroegere redactiepogingen en buitensteedse, costumiere compilaties op de vorm en inhoud van de Antwerpse Consuetudines compilatae. Met het oog op de vraag naar de invloed van het juridisch humanisme op het costumiere redactieproces, zal ik bij elk van de verschillende bronnentypes trachten een beeld te vormen van hun positie op de autoritatieve ladder. Behoudt het Romeinse recht zijn monopolie als subsidiair recht of primeert de redelijkheid van de gerecipieerde regels, wat hun oorsprong ook moge wezen? Hierbij zal steeds ruimte gelaten worden voor de mate waarin de impact van vreemde invloeden de eigen, lokale gewoonte al dan niet respecteert. Hoe zuiver is de geredigeerde gewoonte werkelijk? De vierde en tevens laatste paragraaf van dit hoofdstuk plaatst het belang van de Consuetudines compilatae in perspectief. Meer bepaald wordt er gewezen op de herleving van de Consuetudines impressae na 1608.

Het fenomeen van costumiere acculturatie wordt in een tweede hoofdstuk uitgelegd aan de hand van een viertal paragrafen. Een eerste inleidende paragraaf beperkt zich evenwel tot een beschrijving van de invloeden waarvan het bestaan tot nu toe reeds was aangeduid. Er wordt gekeken naar de vroegere redactiepogingen binnen het Overkwartier, de impact van de vorstelijke wetgeving en het geleerde recht in strikte zin, waarbij met dit laatste het Romeinse recht wordt bedoeld. Pas vanaf paragraaf 2 komt een eerste deelaspect van de costumiere acculturatie aan bod, namelijk de mate waarin de inhoud van het Gelderse Land- en Stadsrecht aan de Antwerpse Consuetudines compilatae werd geassimileerd. Nadat ik eerst de werkwijze heb uiteengezet volgens welke ik de concordanties tussen beide compilaties vastgesteld heb, volgt per deel een uiteenzetting over de plaats waar en de mate waarin de assimilatie heeft plaatsgevonden. Het beschrijft hoe de Consuetudines compilatae als het ware gefungeerd hebben als ratio scripta voor de samenstellers van het Overkwartierlijke, costumiere recht. Opnieuw is ook deze paragraaf uiterst descriptief van aard. Hetzelfde geldt overigens voor paragraaf 3, alwaar dieper ingegaan wordt op de verschillende rechtsbronnen welke, via de Antwerpse compilatie, hun weg vinden naar het Overkwartier. De paragraaf toont de Consuetudines compilatae als Paard van Troje. Ook nu weer worden deze invloeden deel per deel beschreven. De vierde en laatste paragraaf omvat het structurele aspect van de costumiere acculturatie. Het beschouwt de wijze waarop het Gelderse Land-en Stadsrecht werd geordend naar het model van de Antwerpse Consuetudines compilatae. Centraal hierin staat de impact van de drang tot systematisering van het juridisch humanisme en hoe deze tevens blijkt uit beide gewoonterechtelijke compilaties. Deze hang naar logische ordening zal aan de hand van beide redacties worden geillustreerd. 
Het laatste hoofdstuk, omtrent de allegaties in de Memorieboeken, telt slechts twee paragrafen. De eerste omvat de methode die ik gehanteerd heb om een betrouwbaar overzicht van geallegeerde, juridische werken samen te stellen, dat een oprecht beeld geeft van de intellectuele achtergrond van waaruit de commissieleden hebben geopereerd. Ook het uiteindelijke overzicht van al deze werken heb ik in de tekst zelf opgenomen. De tweede paragraaf is meer analytisch van aard. Deze beschrijft de belangrijkste auteurs en werken aan de hand van de verschillende literatuurtypes waartoe deze werken behoren: monografieën, compilaties van en commentaren bij zowel particulier als geleerd recht, jurisprudentiële verzamelingen, consilia en de moraalfilosofische werken van Laatscholastieke auteurs. Ik zal telkens trachten na te gaan in hoeverre de vaststellingen die ik op basis van de allegaties uit de Memorieboeken heb gedaan, passen in de gangbare opvattingen omtrent de autoritaire verhoudingen van de verschillende genres. Door telkens in deze paragraaf de verschillende werken te verdelen over hetzij een middeleeuwse, hetzij een humanistische categorie, hoop ik een blauwdruk te kunnen schetsen van de intellectuele, rechtsgeleerde achtergrond van de commissie als geheel en in hoeverre deze in het verlengde ligt van het juridisch humanisme. Op die manier kan ik al dan niet een bevestiging vinden voor de hypothese dat het juridisch humanisme ook het costumiere redactieproces heeft beïnvloed.

Elk van deze drie hoofdstukken wordt afgesloten met een tussentijdse conclusie, waarbij de belangrijkste vaststellingen, welke op basis van het desbetreffende hoofdstuk kunnen gemaakt worden, op een rij worden gezet. Het ganse boek zal uiteindelijk worden afgesloten met een meer algemene slotbeschouwing waarin de nadruk zal komen te liggen op de hypothese of de invloed van het juridisch humanisme nu daadwerkelijk aantoonbaar gebleken is of niet.

Het geheel wordt aangevuld met een aantal bijlagen die hoofdzakelijk ter verantwoording dienen. Zo geeft een eerste bijlage de bibliografische referentie weer van de commentaren bij de verschillende artikels van de Consuetudines compilatae, zoals ze in de Memorieboeken neergeschreven staan. Teneinde het voetnotenapparaat van dit boek niet te overladen, heb ik er immers voor geopteerd deze referenties aan het einde te groeperen. Doorheen de tekst wordt bijgevolg simpelweg verwezen naar het artikelnummer zonder bibliografische referentie. De tweede bijlage omvat een overzicht van de belangrijkste rechtsbronnen van elk artikel uit de Consuetudines compilatae, zoals ik deze op basis van de Memorien op de Costumen heb geselecteerd. Bijlage 3 geeft aan de hand van een reeks voorbeelden het onderscheid aan tussen wat ik versta als letterlijk en niet-letterlijk geassimileerde artikels. Een vierde bijlage bevat een overzicht van alle artikels in het Gelderse Land-en Stadsrecht welke letterlijk naar Antwerps voorbeeld werden geassimileerd. Ook het artikelnummer van het Antwerpse voorbeeldartikel wordt telkens aangegeven. Bijlage 5, tot slot, geeft enkele inhoudsopgaven weer van vroegere ontwerpteksten van het Gelderse Land-Stadsrecht. Deze aanpak vergemakkelijkt het begrijpen van het wordingsproces van een aantal titels uit het Gelderse Land-en Stadsrecht, zoals daar vaak in paragraaf 2 van hoofdstuk 2 op teruggekomen zal worden. 
Omdat ik het zelf niet beter onder woorden kan brengen, wil ik deze inleiding afsluiten met een passage van Georges Duby, zoals hij deze neergeschreven heeft in zijn autobiografisch boek De geschiedenis gaat door: "Sinds een paar jaar gebruik. ik in mijn boeken steeds meer de ik-vorm. Dat doe ik om mijn lezers te waarschuven. Ik pretendeer niet bun de waarheid te vertellen, maar ik doe bun een suggestie aan de hand van wat waarschijnlijk waar is geweest, ik houd hun een beeld voor dat ik mijzelf in alle oprechtheid van de waarheid heb gevormd. Dat is voor een groot deel gebaseerd op mijn persoonlijke ideeën. Ik heb er echter voor gezorgd dat de buigzame verbeeldingskracht stevig verankerd bleef op de ijzeren steunpunten waaraan ik, uit respect voor de wetenschapsethiek, niets heb veranderd, maar die ik stuk voor stuk, zeer naungezet op bun stevigheid heb getest. Dit onderstel, dat zijn de bronnen. Mijn 'bewijzen'.'”70 Om dezelfde reden heb ook ik steeds de ik-vorm gebezigd in dit boek. We schrijven 1 maart 2008.

${ }^{70}$ G. DUBY, De geschiedenis gaat door. Het verhaal van een historicus. Amsterdam, 1992, 56-57. Het betreft hier een Nederlandse vertaling van het origineel L'bistoire continue uit 1991. 



\section{BIBLIOGRAFIE}

Onuitgegeven bronnen

ANTWERPEN, Rijksarchief, Manuscriptenverzameling, nr. 130: Annotata ad consuetudines antwerpienses.

ANTwERPEN, Stadsarchief, Privilegiekamer, nr. 552: Acte collegiale vande collectatie vande rechten ende Costumen van Antwerpen, onder t'consulaet van Heer Jan van Straelen, Heer van Merxen, Dambrugge, etc. Buyten-Borgemeester, Heer Willem de Vos, Binnen Borgemeester. 18 juli 1578, fol. 204r-204v.

ANTWERPEN, Stadsarchief, Privilegiekamer, nr. 1452: Weeskamer. Ordonnanties.

ANTWERPEN, Stadsarchief, Vierschaer, nrs. 21-23: HENDRIK DE MOY, Tractaat over de Costuymen.

ANTWERPEN, Stadsarchief, Vierschaer, nr. 28bis: Memorien op de Costumen, 1608.

ANTWERPEN, Stadsarchief, Vierschaer, nrs. 48-53: Memorien op de Costumen, 1608.

ANTWERPEN, Stadsarchief, Vierschaer, nr. 64, Adviezen betreffende de Costumen en de revisie.

ANTWERPEN, Stadsarchief, Vierschaer, nr. 64: Acte collegiale nopende de recollectie van de Rechten ende Costumen van Antwerpen. 18 juli 1580.

ANTWERPEN, Stadsarchief, Vierschaer, nr. 64: Extract uyt den Collegiael acteboeck van D'Heeren Wethouderen der Stad Antwerpen, 15 oktober 1592.

ANTWERPEN, Stadsarchief, Vierschaer, nr. 64: JACQUES VAN UFFEL, Adviezen betreffende de Costumen en de revisie, 10 augustus 1610.

ANTWERPEN, Stadsbibliotheek, ms. E2956: D. MASTELYN, Notae sive commentaria ad consuetudines Antverpienses, cum domini Biesval additionibus, 1774.

ANTWERPEN, Universiteitsbibliotheek, ANTONIO ANSELMO, Rechten ende Costuymen der Stadt Antwerpen met de annotatien en commentaren van Heer ende Mr. Antonius Anselmo Advocaet ende oudt-Schepen der selver Stadt, 1676.

BRUSSEL, Koninklijke Bibliotheek, ms. 13569: ANTONIO ANSELMO, Commentaria in leges municipales non compacta.

DENDERMONDE, Verzameling Mr. Jozef Dauwe, Observationes sue notae ad Consuetudines Antwerpen.

MAASTRICHT, Regionaal Historisch Centrum Limburg, Staten van het Overkwartier, nr. 73: Kwartierrecessen 1615-1617, 1615-1617. 
MAASTRICHT, Regionaal Historisch Centrum Limburg, Staten van het Overkwartier, nr. 573: Concepten van een landrecht van het Overkwartier, 1564

MAASTRICHT, Regionaal Historisch Centrum Limburg, Staten van het Overkwartier, nr. 581: Stukeken betreffende de adviezen van edelen en steden over een concept van het landrecht en memories aangaande de opstelling en indeling van de verschillende concepten.

MAASTRICHT, Regionaal Historisch Centrum Limburg, Staten van het Overkwartier, nr. 582: Concept van het landrecht van het Overkwartier, ca. 1614. concept $A$

MAASTRICHT, Regionaal Historisch Centrum Limburg, Staten van het Overkwartier, nr. 583: Concept van het landrecht van het Overkwartier, ca. 1614. concept B

MAASTRICHT, Regionaal Historisch Centrum Limburg, Staten van het Overkwartier, nr. 584: Concept van het landrecht van het Overkwartier, ca. 1614. concept $C$

MAASTRICHT, Regionaal Historisch Centrum Limburg, Staten van het Overkwartier, nr. 585: Concept van enige gewijzigde titels van concept $C$, ca. 1615. Concept D

MAASTRICHT, Regionaal Historisch Centrum Limburg, Staten van het Overkwartier, nr. 586: Concept van enige gewijzigde titels van concept $C$, ca. 1615. Concept $\mathrm{E}$

MAASTRICHT, Regionaal Historisch Centrum Limburg, Staten van het Overkwartier, nr. 587: Concept van enige gewijzigde titels van concept $C$, ca. 1615. Concept $F$

MAASTRICHT, Regionaal Historisch Centrum Limburg, Staten van het Overkwartier, nr. 588: Concept van enige gewijzigde titels van concept $C$, ca. 1615. Concept $G$

MAASTRICHT, Regionaal Historisch Centrum Limburg, Staten van het Overkwartier, nr. 589: Concept van het landrecht van het Overkwartier, ca. 1617. concept H

MAASTRICHT, Regionaal Historisch Centrum Limburg, Staten van het Overkwartier, nr. 590: Concept van het landrecht van het Overkwartier, ca. 1617. concept I

MAASTRICHT, Regionaal Historisch Centrum Limburg, Staten van het Overkwartier, nr. 591: Concept van het landrecht van het Overkwartier, ca. 1617. concept J

G. SPIJKERBOER, Enkele beschouwingen over de Gelrische Landt- en Stadtrechten in't Overkwartier van Ruremonde (Persoonlijke notities G. Spijkerboer).

Uitgegeven bronnen

DE Bracton, H., Bracton on the laws and customs of England, S. E. THORNE en G. E. WOODBINE ed., Cambridge, 1968-1977.

Codex Belgicus seu Ius edictale a principibus Belgarum sancitum, A. ANSELMO ed., Antwerpen, 1649 (anast. herdruk Brussel, 1998).

Blyde Incompste van Keyser Carel den V. 24 Januarii 1514, 14 januari 1515 (n.s.), A. ANSELmo ed., Codex Belgicus seu Ius edictale a principibus Belgarum sancitum, Antwerpen, 1649 (anast. herdruk Brussel, 1998), IV, 405 421.

Die eerste additien des Princen van Spaingnien, Hertoghe van Bourgoingnien, tot sijnder Blijder Incompste. 12. April 1515. tot Gendt, 12 april 1515, A. ANSElmo ed., Codex Belgicus seu Ius edictale a principibus Belgarum sancitum, Antwerpen, 1649 (anast. herdruk Brussel, 1998), I, 205-207. 
Die tweede additie vander Blijder Incompste des Princen van Spaengnien. 26 april 1515 tot Brugghe. 26 april 1515, A. ANSELMO ed., Codex Belgicus seu Ius edictale a principibus Belgarum sancitum, Antwerpen, 1649 (anast. herdruk Brussel, 1998), I, 207-210.

Die Blijde Incomste, des Hertochdomme van Brabandt, in voortijden by haren Landtsheeren verleent, ende van Keyser Carolus den V. gheconfirmeert, ende by Philippus sijne Sone Coninck van Spaingnien den II. Solemnelijck ghesworen. Anno 1549. 5. Iulii tot Leuven, 5 juli 1549, A. ANSELMO ed., Codex Belgicus seu Ius edictale a principibus Belgarum sancitum, Antwerpen, 1649 (anast. herdruk Brussel, 1998), I, 192-205.

Privilegie van Hertoch Jan den II. V an dien naeme, ghegheven aen die van Antwerpen, Anno 1306. op S. Nicolaes dach, 6 december 1306, A. ANSELMO ed., Codex Belgicus seu Ius edictale a principibus Belgarum sancitum, Antwerpen, 1649 (anast. herdruk Brussel, 1998), IV, 139-140.

Placcaert nopende de Zee-driften. 15 Maij 1574, 15 mei 1574, A. ANSELMO ed., Codex Belgicus seu Ius edictale a principibus Belgarum sancitum, Antwerpen, 1649 (anast. herdruk Brussel, 1998), III, 240-242.

Ordinancie, Styl ende Maniere van procederen vanden souverainen raede van Brabandt ende landen van Overmaeze, 13 april 1604, A. ANSELMO ed., Codex Belgicus seu Ius edictale a principibus Belgarum sancitum, Antwerpen, 1649 (anast. herdruk Brussel, 1998), I, 709-780.

Ordonnantiën vanden Keyser, nopende de Hantschriften ende Obligatien byden Cooplieden d'een den anderen ghegheven. den 7 Meert 1537, 7 maart 1537, A. ANSELMO ed., Codex Belgicus seu Ius edictale a principibus Belgarum sancitum, Antwerpen, 1649 (anast. herdruk Brussel, 1998), I, 515-516.

De concept-procesordonnantie van 1662 van de Raad van Brabant in Den Haag en de Albertine ordonnantie van 1604 voor de Raad van Brabant te Brussel, E.-J. M. F. C. B. BroERS en B. C. M. JACOBS ed. (Werken der Stichting tot Uitgaaf der Bronnen van het Oud-Vaderlandse Recht. XXIX), Amsterdam, 2003.

Coutumes du pays et duché de Brabant. G. DE LONGE ed. (Recueil des anciennes coutumes de la Belgique), 7 dln., Brussel, 1869-1878.

Coerboeck de la ville d'Anvers, G. DE LONGE ed. (Coutumes de Pays et Duché de Brabant. Quartier d'Anvers. Coutumes de la ville d'Anvers), I, Brussel, 1870, 1-89.

Les statuts de la ville d'Anvers appelés Het Gulde Boeck, G. DE LONGE ed. (Coutumes de Pays et Duché de Brabant. Quartier d'Anvers. Coutumes de la ville d'Anvers), I, Brussel, 1870, 379-428.

Coutumes de la ville d'Anvers dites antiquissimae, G. DE LONGE ed. (Coutumes de Pays et Duché de Brabant. Quartier d'Anvers. Coutumes de la ville d'Anvers), I, Brussel, 1870.

Coutumes de la ville d'Anvers dites antiquae, G. DE LONGE ed. (Coutumes de Pays et Duché de Brabant. Quartier d'Anvers. Coutumes de la ville d'Anvers), I, Brussel, 1870. 
Coutumes de la ville d'Anvers dites impressae, G. DE LONGE ed. (Coutumes de Pays et Duché de Brabant. Quartier d'Anvers. Coutumes de la ville d'Anvers), II, Brussel, 1871.

Styl ende Maniere van procederen, G. DE LONGE ed. (Coutumes de Pays et Duché de Brabant. Quartier d'Anvers. Coutumes de la ville d'Anvers), II, Brussel, 1871.

Coutumes de la ville d'Anvers dites compilatae, G. DE LONGE ed. (Coutumes de Pays et Duché de Brabant. Quartier d'Anvers. Coutumes de la ville d'Anvers), III-IV, Brussel, 1872-1874.

Coutumes du Kiel, de Deurne et de Lierre. G. DE LONGE ed. (Coutumes de Pays et Duché de Brabant. Quartier d'Anvers. 5), Brussel, 1875.

Costumen, usantien, policien ende styl van procederen, der stadt Utrecht, geapprobeert ende gedecreteert in M.C.C.C.C.C.L. W. VAN DER MEULEN ed., Utrecht, 1709.

De crimineele ordonnantien van koning Philips van Spanje ten dienste van zijne Nederlanden uitgegeeven. B. VOORDA ed., Leiden, 1792.

De DAmHOuder, J. Practycke in civile saecken, Den Haag, 1626 (anastasische herdruk Antwerpen, 1999).

Het Gelderse Land- en Stadsrecht van het Overkwartier Roermond 1620, A. M. J. A BerkVens, G. H. A. Venner en G. Spijkerboer ed. (Werken der Stichting tot Uitgaaf der Bronnen van het Oud-Vaderlandse Recht, 25), Arnhem, 1996.

Rechtsbronnen van het Gelders Overkwartier van Roermond, K. J. T. JANSSEN DE LIMPENS red. (Werken der Vereeniging tot Uitgaaf der Bronnen van het Oud Vaderlandsche Recht, 20), Utrecht, 1965.

Rechtsbronnen van de stad Bergen op Zoom, J. VAN ROMPAEY red., (Verslagen en mededeelingen der Vereeniging tot Uitgaaf der Bronnen van het Oud Vaderlandsche Recht, 13), Utrecht, 1968.

Recueil des ordonnances des Pays-Bas. Deuxième série: 1506-1700 Tome troisième: Contenant les ordonnances du 8 Janvier 1529 (1530, N.ST.) au 11 Décembre 1536. J. LAMEERE ed. (Recueil des anciennes ordonnances de la Belgique), Brussel, 1902.

Ordonnance sur l'heresie, les monnaies, la redaction des coutumes, les notaries, les monopoles, les banqueroutiers, vagabonds, la mendicité et la bienfaisance, les kermesses, les noces, baptêmes, la police des cabarets, les crimes dus à l'ivrognerie, les buveurs, le luxe des vêtements, le commerce et l'exportation des chevaux, las blasphémateurs, les relations entre les divers pays de par deça, etc., 7 oktober 1531, J. LAMEERE ed., (Recueil des ordonnances des Pays-Bas. $2^{\mathrm{e}}$ série. III), Brussel, 1902, 265-273.

Recueil des ordonnances des Pays-Bas. Deuxième série: 1506-1700 Tome quatrième: Contenant les ordonnances du 9 Janvier 1536 (1537, N.ST.) an 24 Décembre 1543. J. LAMEERE en H. SimOnT ed. (Recueil des anciennes ordonnances de la Belgique), Brussel, 1907.

Edit de l'Empereur, concernant les sectes et hérésies, les banqueroutiers, les monopoles, les monnaies, les contrats de mariages des commerçants, l'usure, le prêt à l'intérêt, l'homologation des coutumes, les conflits de juridiction entre juges ecclésiastiques et 
civils, les dons et legs des mineurs, les notaires, la prescription de certaines créances, les mariages clandestins et la nomination des magistrates locaux, 4 oktober 1540, J. LAMEERE en H. SimONT ed. (Recueil des ordonnances des Pays-Bas. 2e série, IV), Brussel, 1907, 232-238.

I Rotuli dei lettori, legisti et artisti dello Studio Bolognese dal 1384 al 1799, U. DALLARI ed., I, Bologna, 1888-1919.

Tweeden placaet-bovck inhovdende diversche ordonnancien, edicten, ende placaete vande Coninclicke Ma.ten ende haere deurluchtighe hooc-heden, grauen van Vlaendren, metsgaders van beurliederen Prouincialen Raede aldaer, ghepubliceert inden voorghenoemden lande van Vlaendren t'zedert den iaere vyfthien-hondert t'zestich, tot ende metten iaere zesthien hondert neghenen-twintich. Gent, 1629.

Ordonnantie statuyt ende eeuwich edict s'Coninghs ons gheduchts Heeren, op t'faict vander Zee-vaert: ende hoe dat alle Cooplieden, ende Schippers schuldich syn voort aen haere Schepen toe te rusten, Equiperen ende voorsiene. Oock, hoe zy hemlieden reguleren zullen, sowel int laden ende afvoeren van bueren goeden en [de] Coopmanschepen, als ooc in haerlieder reyse, wedercomste, ende lossen oft ontladen van dien. Metsgaders van de Zeerechten alsoo wel onder de Schippers als den Cooplieden. Ende de ordonnantie op t'faict vander verzekerynghe oft Asseurantie, met meer andere zaken der Zeevaert aengaende. Ghegheven te Bruessele, den lesten Octobri, XVC.LXIII, 31 oktober 1563, in Placcaert boecken van Vlaenderen (1630), II, 307-334.

Ordonnantie, statuut ende niev edict op het faict van der Zee-vaert: ende hoe dat alle Cooplieden, Schippers, Visschers en [de] Bootghesellen schuldigh rijn voordan baere Schepen toe te reeden, equipperen ende voorts hoe zij hemlieden regulen zullen, zo wel int laden ende afvoeren van haeren goeden en [de] Coopmanschepen, als ooc in haerlieder reyse, wedercomste ende lossen oft ontladen van dien. Met diveersche poinc[k]ten ende articlen den Zeerechten angaende, van nieus daertoe ghedaen. Ghegheven te Bruessele den XIX. V an Hoymaendt, int jaer M.CCCCC.LI, 19 juli 1551, in Placcaert-boecken van Vlaenderen (1629), I, 375-396.

Ordonnantie, statuyt ende policie ghemaec[k]t byden Coninck onsen alderghenaedichsten Heere, op t'feyt vande contrac[k]ten vande asseurantien ende verzekerynghen in dese Nederlanden, 20 januari 1570, in Placcaert-boecken van Vlaenderen (1630), II, 335-344.

Ordonnance, Statut \& Edict de plusieurs matieres: Premiers, Touchant les impetrans de remission. 2. Touchant l'octroy des lettres de legittimation. 3. Des lettres de Placet, sur les bulles Apostoliques. Des lettres de respit \& cession. 5. Du benefice d'inventoire. Donné à Bruges, le XX. Jour d'Octobre, l'an M.XLI, 20 oktober 1540, in Placcaert-boecken van Vlaenderen (1629), I, 776-781.

Wielant, P., Practijcke Civile, Antwerpen, 1573, (anastasische herdruk Amsterdam, 1968). 
“Acculturation”, The New Encyclopaedia Britannica, 15de uitg., I, Chicago, 1974-1991, 57.

J. VAN ACKER e.a., Antwerpen in de XVIIde eeuw, Antwerpen, 1989.

J. M. DE Aguilar, "The law of nations and the Salamanca School of Theology", The Thomist: a speculative quarterly review, 9 (1946), 186-221.

R. D’AMAT, "Philibert Bugnyon”, Dictionnaire de biographie française, VII, Parijs, 1956, 637-638.

“Anselmo, Antonius", J. VAN ROMPAEY, Nieuw Biografisch Woordenboek, I, Brussel, 1964, 27-36.

P. ARABEYRE, Les idées politiques à Toulouse à la veille de la Réforme. Recherches autour de l'cuvre de Guillaume Benoît (1455-1516), Toulouse, 2004.

P. ARABEyRe, J. L. HALPERIN, J. KRYNEN, Dictionnaire historique des juristes français, Parijs, 2007.

P. ArABEyre, "Benoît (Benedicti) Guillaume", P. ArABEYRE, J.-L. HALPÉRIN en J. KRYNEN red., Dictionnaire historique des juristes français (XIIe-XXe siècle), Parijs, 2007, 65-67.

P. ARABEYRE, "Bertrand Etienne", P. ArAbEYre, J.-L. HALPÉRIN en J. KRYNEN red., Dictionnaire historique des juristes français (XIIe-XXe siècle), Parijs, 2007, 79.

P. ARABEYre, "Duval (Du Val, Valla) Nicolas", P. ARABEYre, J.-L. HALPÉRIN en J. KRYNEN red., Dictionnaire historique des juristes français (XIle-XXe siècle), Parijs, 2007, 303.

P. Arabeyre, “Feu (Ignaeus) Jean”, P. ArABEYRE, J.-L. HALPÉRIN en J. KRYNEN red., Dictionnaire historique des juristes français (XIIe-XXe siècle), Parijs, 2007, 329.

P. ARABEYRE, "Marc (Marcus, Marchi) François", P. ArABEYRE, J.-L. HALPÉRIN en J. KRYNEN red., Dictionnaire historique des juristes français (XIIe-XXe siècle), Parijs, $2007,535$.

P. Arabeyre, "Ranchin Etienne", P. Arabeyre, J.-L. HALPÉRIN en J. KRYNEN red., Dictionnaire historique des juristes français (XIIe-XXe siècle), Parijs, 2007, 651.

M. ASCHERI, "Rechtsprechungs- und konsiliensammlungen. Italien", H. COING red., Handbuch der Quellen und Literatur der Neueren europäischen Privatrechtsgeschichte, II/2, Munchen, 1976, 1113-1222.

M. Ashmann, "Mudaeus (Van der Muyden), Gabriel", M. STOLLEIS red., Juristen: ein biographisches Lexikon von der Antike bis zum 20. Jahrbundert, Munchen, 2001, 457-458.

M. ASHMANN, "Wesenbeck, Matthaeus", M. STOLLEIS red., Juristen: ein biographisches Lexikon von der Antike bis zum 20. Jahrbundert, Munchen, 2001, 669-670.

J.-M. Augustin, "Tiraqueau André”, P. ArabeYre, J.-L. HALPÉRIN en J. KRYNEN red., Dictionnaire historique des juristes français (XIIe-XXe siècle), Parijs, 2007, 742-743.

M. AvenARIUS, "Neque is sine magna servii laude...' Historisierung der Rechtswissenschaft und Genese von System und Methode bei Donellus", Tijdschrift voor Rechtsgeschiedenis, 74 (2006), 61-93. 
J. BALtEAU, "Bertrand d'Argentré", Dictionnaire de biographie française, III, Parijs, 1939, $572-574$.

J. BARBICHe, “Antoine Favre”, Dictionnaire de biographie française, XIII, Parijs, 1975, 857-862.

J. BARBiChe, "Favre Antoine", P. Arabeyre, J.-L. HAlPERIN en J. KRYNEN red., Dictionnaire historique des juristes français (XIIe-XXe siècle), Parijs, 2007, 322-323.

J. BART, Recherches sur l'bistoire des successions ab intestat dans le droit du duché de Bourgogne de la fin du XIIIe à la fin du XVIe siècle, Parijs, 1966.

J. BART, en M. PETITJEAN, L'influence du droit romain en Bourgogne et France-Comté (Ius Romanum Medii Aevi. Pars V, 4, e), Milaan, 1975.

B. Basdevant-Gaudemet, "Pithou Pierre", P. Arabeyre, J.-L. Halperin en J. KRYNEN red., Dictionnaire historique des juristes français (XIIe-XXe siècle), Parijs, 2007, 627-629.

O. BEHRENDS, "Cicero, Marcus Tullius", M. STOLLEIS red., Juristen: ein biographisches Lexikon von der Antike bis zum 20. Jabrbundert, Munchen, 2001, 131-133.

M. Bellomo, The Common Legal Past of Europe 1000-1800 (Studies in Medieval and Early Modern Canon Law. IV), Washington, 1995.

A. BeLloni, Professori giuristi a Padova nel secolo XV, Frankfurt am Main, 1986, 283-292.

C. BergFelD, "Katholische Moraltheologie und Naturrechtslehre", H. COING red., Handbuch der Quellen und Literatur der Neueren europäischen Privatrechtsgeschichte, II/1, Munchen, 1977, 999-1033.

C. Bergfeld, "Stracca, Benvenuto", M. STOLLEIS red., Juristen: ein biographisches Lexikon von der Antike bis zum 20. Jabrbundert, Munchen, 2001, 605-606.

G. C. J. J. VAN DEN BERGH, Geleerd recht. Een geschiedenis van de Europese rechtswetenschap in vogelvlucht, Deventer, 2000.

G. C. J. J. VAN DEN BERGH, Die Holländische elegante Schule (Ius Commune Sonderheft 148), Frankfurt am Main, 2002.

G. C. J. J. VAn Den Bergh, Bibliografie van Prof. Mr. Govaert C. J. J. Van den Bergh, Nijmegen, 2005.

A. M. J. A. BerKVENS, 'In wesen sal het Tractaet van Venlo onderhalden worden...' Het Tractaat van Venlo als fundamentele wet van Spaans en Oostenrijks Gelre 1580-1794", F. KEVERLING BUISMAN red., Verdrag en tractaat van Venlo: herdenkingsbundel, 1543-1993 (Werken, uitgegeven door Gelre, Vereeniging tot Beoefening van Geldersche Geschiedenis, Oudheidkunde en Recht. No. 43), Hilversum, 1993, 153-170.

A. M. J. A. Berkvens, G. H. A. Venner en G. Spijkerboer ed., Het Gelderse Land en Stadsrecht van het Overkwartier Roermond 1620 (Werken der Stichting tot Uitgaaf der Bronnen van het Oud-Vaderlandse Recht, 25), Arnhem, 1996.

A. M. J. A. BERKVENS, "Het concept van de 'nieuwe landrechten van het hooggrafelijk stift en vorstendom Thorn"', Verslagen en mededelingen van de Stichting tot uitgaaf van de bronnen van het Oud-Vaderlandse Recht, nieuwe reeks, 9 (1997), 39-96. 
A. M. J. A. BERKVENS, "Het nieuwe Landrecht van Thorn. Verlicht absolutisme en codificatie onder het bewind van de vorstin-abdis Maria Cunegonda van Saksen (1776-1794)", Publications de la Société Historique et Archéologique dans le Limbourg - Jaarboek van Limburgs Geschied- en Oudheidkundig Genootschap, 134-135 (1998-1999), 102-104.

A. M. J. A. BERKVENS, "Imperatoriam maiestatem non solum armis decoratam sed legibus oportet esse armatam... Notes on the influence of Justinian's Institutes on the codification of customary law in the Southern Netherlands", L. DE LIGT red., Viva Vox Iuris Romani. Essays in honour of Johannes Emil Spruit (Studia Amstelodamensia. Vol. 38), Amsterdam, 2002, 1-7.

J. BERLIOZ et alii, Identifier sources et citations (L'atelier du Médiéviste. 1), Turnhout, 1994.

"Bero, Agostino", Novissimo Digesto Italiano, I, Turijn, 1974, 376.

R. BESNIER, La coutume de Normandie. Histoire externe. Parijs, 1935.

Biographie nationale de Belgique, 44 dln., Brussel, 1866-1986.

E. BLOCAILLE, Etude sur François Hotman: La Franco-Gallia, Dijon, 1902.

M. BLOCH, La société féodale, Parijs, 1968 (5 editie).

J. W. BOSCH, "Enige rechtshistorische aantekeningen over Zuid-Nederlandse juridische invloeden in het Noorden", Rechtskundig Weekblad, 32 (1948), 1009 1015.

J. W. BOSCH," "Remarques sur quelques influences, exercées en matière de droit, par les provinces méridionales sur les provinces septentrionales des Pays-Bas jusqu'en 1795", Tijdschrift voor Rechtsgeschiedenis, 13 (1951), 133-157.

"Bossi, Egidio", Novissimo Digesto Italiano, II, Turijn, 1974, 558.

R. BOUMANS, Het Antwerps stadsbestuur voor en tijdens de Franse overheersing. Bijdrage tot de ontwikkelingsgeschiedenis van de stedelijke bestuursinstellingen in de Zuidelijke Nederlanden, Brugge, 1965.

P. BOUTEILlER, "Un historien du XVIe siècle: Etienne Pasquier", Bibliothèque d'bumanisme et renaissance, 6 (1945), 357-392.

P. BOUTEILLER, Recherches sur la vie et la carrière d'Etienne Pasquier: historien et humaniste, Parijs, 1989.

A. J. BOYE, "Notes sur Jean Faure", Etudes d'histoire du droit privé offertes à Pierre Petot, Parijs, 1959, 28-38.

V. BRANTS, La Faculté de droit de l'Université de Louvain à travers cinq siècles: étude historique, Parijs-Brussel, 1917 (anast. herdruk Brussel, 1998).

J. BREJON, Un jurisconsulte de la Renaissance André Tiraqueau (1488-1558). Parijs, 1937.

J. BRITZ, Code de l'ancien droit Belgique, ou Histoire de la jurisprudence et de la législation, suivie de l'exposé du droit civil des provinces Belgiques, 2 dln., Brussel, 1847.

R. C. VAN CAENEGEM, Geschiedenis van het strafprocesrecht in Vlaanderen van de XIe tot de XIVe eeuw (Verhandelingen van de Koninklijke Academie voor Wetenschappen, Letteren en Schone Kunsten van België. Klasse der Letteren. 24), Brussel, 1956.

R. C. VAN CAENEGEM, Le droit romain en Belgique (Ius Romanum Medii Aevi. Pars V, 5, b), Milaan, 1966. 
H. P. H. CAMPS, De stadsrechten van Graaf Willem II van Holland en hun verhouding tot het recht van 's-Hertogenbosch, Utrecht, 1948.

C. A. CAnNATA, "Systématique et dogmatique dans les commentarii iuris civilis de Hugo Donellus", B. SCHMIDLIN et A. DufOUR red., Jacques Godefroy (1587 1652) et l'Humanisme juridique à Genève, Basel-Frankfurt am Main, 1991, 217-230.

A. M. M. CANOY-Olthoff en P. L. NÈVE, Holländische eleganz gegenüber deutschem Usus Modernus Pandectarum?, Nijmegen, 1990.

P. G. CARON, "Pietro d'Ancharano", Novissimo Digesto Italiano, I, Turijn, 1974, 615.

Catalogo in linea dell'Università degli Studi di Milano, 2006 (http://opac.unimi.it/).

J. M. CAUCHIES, "Coutume et législation en Hainaut du XIIe au XVIe siècle", Recueil d'études d'bistoire hainuyère offertes à Maurice-A. Arnould. Annalectes d'bistoire du Hainaut, 2 (1983), 7-33.

"Cepolla, Bartolomeo", Novissimo Digesto Italiano, III, Turijn, 1974, 116.

L. CHABRAND, Étude sur Gui Pape, (1404?-1477), Parijs, 1912.

L. Charondas le Caron, Le Code du Roy Henry III, Roy de France et de Pologne, redigé en ordre par Barnabé Brisson, depuis augmenté des édits du Roy Henry IV, avec la conférence des ordonnances, et rapporté aux ancien Code de Théodose et de Justinien, et aux Basiliques, et illustrés des Conciles de l'Eglise, Lois des Romains et autre peuples, Histoires, Antiquiez, Arrêts, Observations et Annotations, Parijs, 1587.

L. Chevalier, "Le président Faber et la jurisprudence du Sénat de Savoie de 1585 1605”, Tijdschrift voor Rechtsgeschiedenis, 20 (1952), 263-289 en 456-478.

J. B. CHRISTYN, Brabandts recht, Antwerpen, 1682.

G. Claro, Opera omnia sive practica civilis et criminalis, Genève, 1739.

P. J. A. Clavareau, "Les sources du droit maritime du Moyen Âge (essai de bibliographie raisonnée)", Tijdschrift voor Rechtsgeschiedenis, 18 (1950), 385-412.

H. COING, Handbuch der Quellen und Literatur der neueren europäischen Privatrechtsgeschichte (Max-Planck-Institut für Europäische Rechtsgeschichte), 3 dln., Munchen, 1973-1980.

F. C. J. P. Copleston, A History of Philosophy, I, New York, 1985.

F. B. Costello, The political philosophy of Luis de Molina, S. J. (1535-1600) (Bibliotheca Instituti Historici S. I. Vol. XXXVIII), Rome, 1974.

M.-Y. CRÉPIN, "Argentré Bertrand d"”, P. ARABEYRE, J.-L. HALPÉRIN en J. KRYNEN red., Dictionnaire historique des juristes français (XIIe-XXe siècle), Parijs, 2007, 17-18.

S. DAUCHY, en V. DEMARS-SION, Les recueils d'arrêts et dictionaires de jurisprudence (XVTe XVIIIe siècles) (Collection bibliographie. II), Parijs, 2005.

E. DeFACQZ, Ancien droit Belgique, 2 dln., Brussel, 1873.

R. DEKKERS, Het bumanisme en de rechtswetenschap in de Nederlanden (Vlaamsche rechtskundige bibliotheek. XIX), Antwerpen, 1938.

R. DEKKERS, Bibliotheca Belgica Juridica. Een bio-bibliografisch overzicht der rechtsgeleerdheid in de Nederlanden van de vroegste tijden af tot 1800 (Verhandelingen van de koninklijke Vlaamse academie voor wetenschappen, letteren en schone kunsten van België. Klasse der Letteren. N¹4), Brussel, 1951. 
Y. DeStAINGES, "Jean Feu”, Dictionnaire de biographie française, XIII, Parijs, 1975, 1211-1212.

Dictionnaire de biographie française, 19 dln., Parijs, 1933-2001.

Dictionnaire historique des juristes français (XIIe-XXe siècle), 5 dln., Parijs, 2006.

G. VAN DiEvOET, Het notariaat in Brabant gedurende de Nieuwe Tijd, Het notariaat in Brabant, Tentoonstelling, Huis der Notarissen te Leuven 30 september - 10 oktober 1982, Brussel, 1982, 69-73.

G. VAN DIEVOET, Les contumiers, les styles, les formulaires et les 'artes notariae' (Typologie des sources du Moyen Âge occidentale. 48), Turnhout, 1986.

R. DOUCET, Les bibliothèques parisiennes an XVIe siecle, Parijs, 1956.

G. DuBY, De geschiedenis gaat door. Het verhaal van een historicus. Amsterdam, 1992.

A. Dufour, "Godefroy (Gothofredus) Denys", P. ArABEYRE, J.-L. HALPÉRIN en J. KRYNEN red., Dictionnaire historique des juristes français (XIIe-XXe siècle), Parijs, 2007, 376-377.

C. Dugas de La Boissonny, Barthélémy de Chasseneuz (1480-1541), Grenoble, 1977.

C. Dugas De LA Boissonny, "Chasseneuz (Chasseneux) Barthélemy de", P. ARABEYRE, J.-L. HALPÉRIN en J. KRYNEN red., Dictionnaire historique des juristes français (XIIe-XXe siècle), Parijs, 2007, 183-184.

N. DuYsentDAELDERS, Observationes ad leges, statuta, consuetudinesque Amstelaedamenses, Amsterdam, 1662.

"Elegans", Van Wageningen en Muller Latijnsch Woordenboek, Groningen en Den Haag, 1929, 313.

M. H. H. ENGELS, Register van auteurs met bun werken zoals die voorkomen in de grote verzameling van het recht: Oceanus Iuris - Venetiis 1584-1584, Leeuwarden, 1999.

A. ERLER, Thomas Murner als Jurist (Frankfurter wissenschaftliche Beiträge. rechts- und wirtschaftswissenschaftliche Reihe. Band 13), Frankfurt am Main, 1956.

P. FAURE, "Jean Duret”, Dictionnaire de biographie française, XII, Parijs, 1970, 752-753.

R. FEENSTRA en G. SPIJKERBOER, "La coutume de Gueldre (Quartier de Ruremonde) de 1619 et la coutume d'Anvers dite 'Compilatae", Revue du Nord, 36 (1954), 74-76.

R. FEENSTRA, "Ouvrages de droit romain dans les catalogues des anciens Pays-Bas Septentrionaux (XIIIe-XVIe siècle)", Tijdschrift voor Rechtsgeschiedenis, 28 (1960), 439-530.

R. FEENSTRA en C. J. D. WAAL, Seventeenth-century Leyden law professors and their influence on the development of the civil law: a study of Bronchorst, Vinnius and Voet (Verhandelingen der Koninklijke Nederlandse Akademie van Wetenschappen, Afdeeling Letterkunde. dl. 90), Amsterdam, 1975, 11.

R. FEEnstra, "Johannes de Platea, Bologneser Professor aus dem Anfang des 15. Jh.: Die Überlieferung seiner Schriften, mit kurzen Beiträgen über Henricus de Piro, Arnoldus Westphal und Johannes de Gradibus," Europäisches Rechtsdenken in Geschichte und Gegenwart: Festschrift für Helmut Coing zum 70. Geburtstag. Munchen, 1982. 39-62.

R. FEENSTRA, "Hugues Doneau et les juristes néerlandais du XVIIe siècle: l'influence de son 'système' sur l'évolution du droit privé avant le Pandectisme”, B. 
SCHMIDLIN et A. DufOuR red., Jacques Godefroy (1587-1652) et l'Humanisme juridique à Genève, Basel-Frankfurt am Main, 1991, 231-243.

R. FEenstra, "Aytta, Wigle van (Viglius Zuichemus ab Aytta)", M. STOLLEIS red., Juristen: ein biographisches Lexikon von der Antike bis zum 20. Jabrhundert, Munchen, 2001, 51-52.

R. FEENSTRA, "Damhouder, Joos de", M. STOLLEIS red., Juristen: ein biographisches Lexikon von der Antike bis zum 20. Jahrbundert, Munchen, 2001, 158-159.

L. FEUGERE, Essai sur la vie et les ouvrages d'Etienne Pasquier, Parijs, 1848.

R. FILHOL, Le premier président de Thou et la réformation des coutumes, Parijs, 1937.

R. FILHOL, "La rédaction des coutumes en France aux XVe et XVIe siècles", J. GILISSEN red., La rédaction des coutumes dans le passé et dans le présent. Colloque organisé les 16 et 17 mai 1960 par le centre d'bistoire et d'ethnologie juridiques, Brussel, 1962, 63-85.

A. J. A. Flament, "Bree (Tilman van)", Nieuw Nederlandsch Biografisch Woordenboek, I, Leiden, 1911, 459-460.

S. J. FOCKEMA ANDREAE, "Recht en rechtsbedeling in Overijsel, gedurende het overgangstijdperk 150-1630", Tijdschrift voor Rechtsgeschiedenis, 17 (1941), 243-298.

P. FOURNIER, "Jean Faure, légiste", Histoire littéraire de la France, XXXV, Parijs, 1921, 556-580.

A. Frigerio, "Choppin René”, P. ArABeyre, J.-L. HALPÉRIN en J. KRYNEN red., Dictionnaire historique des juristes français (XIIe-XXe siècle), Parijs, 2007, 190-191.

K. GABRI, Rechten ende costumen van Antwerpen, Amsterdam, 1639.

L. P. GACHARD, Documents sur la rédaction et l'homologation des coutumes I-II (Bulletin en Handelingen van de Koninklijke Commissie voor de uitgave der oude wetten en verordeningen. I), Brussel, 1848.

J.-L. GAZZANIGA, "Rédaction des coutumes et codification", Droits: revue française de théorie juridique, 26 (1997), 71-80.

H. GEHRKE, "Rechtsprechungs- und Konsiliensammlungen. Deutsches Reich", H. COING red., Handbuch der Quellen und Literatur der Neueren europäischen Privatrechtsgeschichte, II/2, Munchen, 1976, 1343-1398.

"Gellius, Aulus", Grote Winkler Prins Encyclopedie, 9de uitg., IX, Amsterdam-Antwerpen, 1991, 515.

P. GÉNARD, "Jean-Baptiste Ferrufini et les assurances maritimes à Anvers au XVIe siècle”, Bulletin de la Société de géographie d'Anvers, 7 (1882) 193-268.

J. L. GERADTS, Bijdrage tot de geschiedenis van den Souvereinen Raad in het Overkwartier van Gelderland te Ruremonde (1580-1794), Leiden, 1860.

J. GILISSEN, "Romeins recht en inheems Gewoonterecht in de Zuidelijke Nederlanden", Tydskrif vir hedendaagse Romeins-Hollandse reg, I (1937), 97-139.

J. GILISSEN, "Le ressort des coutumes codifiées aux XVIe et XVIIe siècles dans les XVII Provinces des Pays-Bas, essai de géographie coutumière", Revue $d u$ Nord, 31 (1949) 234 e.v. 
J. GILISSEN, "Les phases de la codification et de l'homologation des coutumes dans les XVII Provinces des Pays-Bas", Tijdscbrift voor Rechtsgeschiedenis, 18 (1950), 36-67 en 239-290.

J. GILISSEN, "Efforts d'unification du droit coutumier belge aux XVIe et XVIIe siècles", A. ABEL red., Mèlanges Georges Smets, Brussel, 1952, 295-317.

J. GILISSEN, "Loi et coutume. Quelques aspects de l'interpénétration des sources du droit dans l'ancien droit belge", Revue d'bistoire du droit, 21 (1953), 257-298.

J. GiLissen, "A propos de la réception du droit romain", Revue du Nord, 40 (1958), 367.

J. GILISSEN, "Essai statistique de la législation en Belgique de 1507 à 1794", Revue du Nord, 40 (1958), 431-435.

J. GILISSEN, "La rédaction des coutumes dans le passé et dans le présent. Essai de synthèse", J. GILISSEN red., La rédaction des coutumes dans le passé et dans le présent. Colloque organisé les 16 et 17 mai 1960 par le centre d'histoire et d'ethnologie juridiques, Brussel, 1962, 15-61.

J. GILISSEN, "La rédaction des coutumes en Belgique aux XVIe et XVIIe siècles", J. GILISSEN red., La rédaction des coutumes dans le passé et dans le présent. Colloque organisé les 16 et 17 mai 1960 par le centre d'bistoire et d'ethnologie juridiques, Brussel, 1962, 87-111.

J. Gilissen, "Loi et coutume. Esquisse de l'évolution des sources du droit en Belgique du XIIe au XXe siècle", Revue de droit international et de droit comparé, 39 (1962), 1-140.

J. GilisSEN, "Le problème des lacunes du droit dans l'évolution du droit médiéval et moderne", C. Perelman red., Le Problème des lacunes en droit, Brussel, 1968, 197-246.

J. GILISSEN, Historische inleiding tot het recht, Antwerpen, 1989.

J. GILISSEN, "La coutume dans les 'Pays de par-deçà"', Recueils de la Société Jean Bodin pour l'bistoire comparative des institutions. La coutume, LII, Brussel, 1990, 295-309.

G. Giordanengo, "Pape (Papa ou Pape) Gui", P. Arabeyre, J.-L. Halpérin en J. KRYNEN red., Dictionnaire historique des juristes français (XIIe-XXe siècle), Parijs, 2007, 606-607.

P. GodDing, Le droit foncier à Bruxelles au moyen age (Etudes d'histoire et d'ethnologie juridiques 1), Brussel, 1960.

P. GODDING, "L'origine et l'autorité des recueils de jurisprudence dans les Pays-Bas Méridonaux (XIIIe-XVIIIe siècles)", Rapports belges an VIIe Congrès international de droit comparé, Brussel, 1970, 1-37.

P. GODDING, "Jurisprudence et motivation des sentences, du Moyen Âge à la fin du $18^{e}$ siècle", J. T. DE SMIDT red. Miscellanea Consilii Magni (Verzamelen en bewerken van de jurisprudentie van de Grote Raad. Nieuwe reeks. $\mathrm{N}^{\circ} 4$ ), Amsterdam, 1980, 121-151.

P. GODDING, "La formation des étudiants en droit à Louvain (fin 16e - début 17e siècle): fait-elle place au droit coutumier et édictal de nos régions?", Recht en instellingen in de oude Nederlanden tijdens de middeleeuwen en de nieune tijd. Liber Amicorum Jan Buntinx. (Symbolae. Vol. 10), Leuven, 1981, 435-446. 
P. GODDING, Le droit privé dans les Pays-Bas méridionaux du $12^{e}$ au $18^{e}$ siècle (Mémoires de la Classe des Lettres. Collection in quarto. XIV), Brussel, 1987.

J. A. GORIS, Etude sur les colonies marchandes méridionales (Portugais, Espagnols, Italiens) à Anvers de 1488 à 1567. Contribution à l'bistoire des débuts du capitalisme moderne, Leuven, 1925.

M. GOTZEN, "De costumiere bronnen voor de studie van het Oud-Antwerpsch burgerlijk recht”, Rechtskundig tijdschrift voor Belgie, 39 (1949) 3-16, 105-124 en 191-208.

M. GOTZEN, "Het Oud-Antwerps burgerlijk procesrecht volgens de Costumiere Redacties van de 16e-17e eeuw", Rechtskundig tijdschrift voor België, 31 (1951), 291-315 en 424-468.

A. GOURON en O. TERRIN, Bibliographie des coutumes de France. Editions antérieures à la Révolution (Travaux d'histoire éthico-politique. 28), Genève, 1975.

A. GOURON, "Coutumes et commentateurs: essai d'analyse quantitative", Droit privé et institutions régionales. Etudes historiques offertes à Jean Yver. (Publications de l'Université de Rouen. 31), Parijs, 1976, 321-332.

M. Grandgagnage, L'influence de la législation civile Française sur celle des Pays-Bas pendant le XVIe et XVIIe siècle (Mémoires couronnés par l'Académie royale des sciences et belles-lettres de Bruxelles. VIII), Brussel, 1831.

A. J. DE GROOT, "Datenverarbeitung bei der Rezeptionsgeschichte", J. T. DE SMIDT red. Miscellanea Consilii Magni (Verzamelen en bewerken van de jurisprudentie van de Grote Raad. Nieuwe reeks. N4), Amsterdam, 1980, 159-169.

H. L. V. DE Groote, De Zeeassurantie te Antwerpen en te Brugge in de zestiende eeuw, Antwerpen, 1975.

P. GUENOYS, La Conférence des ordonnances royals distribuée en XII livres à l'imitation et selon l'ordre du Code de l'empereur Justinien, avec plusieurs annotations et observations servans pour l'intelligence d'icelles, Lyon, 1593.

G. D. GUYON, "Un arrêtiste Bordelais: Nicolas Boerius (1469-1539)", Annales de la faculté de Droit, des sciences sociales et politiques et de la Faculté des Sciences Economiques, de Bordeaux I, 1 (1976), 17-44.

G. D. GUYON, "Recherches sur la méthode jurisprudentielle criminelle du Parlement de Bordeaux", J. Poumarede, en J. Thomas red., Les Parlements de Province au XVTe siècle, Toulouse, 1996, 285-309.

G. D. GUYON, "Les annotations de la coutume de Bordeaux et la romanisation du droit pénal", J. KRYNEN red., Droit romain, jus civile et droit français, Toulouse, 1999, 300-328.

G. D. GuYON, “Arrérac Jean d"', P. ArABEYRE, J.-L. HALPERIN en J. KRYNEN red., Dictionnaire historique des juristes français (XIIe-XXe siècle), Parijs, 2007, 20-21.

G. D. GUYON, "Bohier (Boyer, Boerius) Nicolas", P. ARABEYRE, J.-L. HALPERIN en J. KRYNEN red., Dictionnaire historique des juristes français (XIIe-XXe siècle), Parijs, 2007, 95-97.

P. HAMON, "Pierre Coustau”, Dictionnaire de biographie française, IX, Parijs, 1961, 1089.

W. HENTRICH, Gregor von Valencia und der Molinismus. Innsbruck, 1928. 
B. H. D. HermesDorf, "Het Landrecht van Montfort van 1605”, Maasgouw, 52 (1932), 49-52 en 63-67.

B. H. D. HermesDorf, "Het Landrecht van Montfort van 1605", Maasgoum, 53 (1933), 7-9 en 17-20,

B. H. D. HeRMESDORF, Das Römisches Recht in den Niederlanden (Ius Romanum Medii Aevi. Pars V, 5, a), Milaan, 1968.

J. Hilaire, "Coutume et droit écrit: recherche d'une limite", Mémoires de la Société pour l'histoire du Droit et des Institutions des Anciens Pays Bourguignons, Comptois et Romands, XL (1983), 153-174.

C. Hirschauer, "La rédaction des coutumes d'Artois au XVIe siècle", Nouvelle revue historique de droit français et étranger, 42 (1918), 43-64.

E. HOLTHÖFER, "Die Literatur zum gemeinen und partikularen Recht in Italien, Frankreich, Spanien und Portugal", H. COING red., Handbuch der Quellen und Literatur der Neueren europäischen Privatrechtsgeschichte, II/1, Munchen, 1977, 103-500.

E. HolthÖFER, "Brissonius (Brisson), Barnabas (Barnabé)", M. STOLLEIS red., Juristen: ein biographisches Lexikon von der Antike bis zum 20. Jahrbundert, Munchen, 2001, 104.

E. HolthÖFER, "Coquille (Conchyleus), Guy", M. STOLLEIS red., Juristen: ein biographisches Lexikon von der Antike bis zum 20. Jabrhundert, Munchen, 2001, 144-145.

E. HolthöFER, "Decio (Decius), Filippo", M. STOLLEIS red., Juristen: ein biographisches Lexikon von der Antike bis zum 20. Jahrbundert, Munchen, 2001, 172-173.

E. HOLTHÖFER, "Godefroy (Gothofredus), Jacques”, M. STOLLEIS red., Juristen: ein biographisches Lexikon von der Antike bis zum 20. Jabrbundert, Munchen, 2001, 248-250.

E. HolthÖFER, "Menocchio (Menochius), Jacopo", M. STOLLEIS red., Juristen: ein biographisches Lexikon von der Antike bis zum 20. Jabrhundert, Munchen, 2001, 436.

E. HOLTHÖFER, "Rebuffi (Rebuffus), Pierre", M. STOLLEIS red., Juristen: ein biographisches Lexikon von der Antike bis zum 20. Jahrbundert, Munchen, 2001, 528-529.

C. L. HOOGEWERF, Het Haarlemse stadsrecht (1245). Inleidende beschouningen, tekst, vertaling en artikelsgewijs commentaar, Amsterdam, 2001.

N. HORN, "Die legistische Literatur der Kommentatoren und der Ausbreitung des gelehrten Rechts", H. COING red., Handbuch der Quellen und Literatur der Neueren europäischen Privatrechtsgeschichte, I, Munchen, 1973, 261-364.

J. B. HuYGENS, Notarius Belgicus oft ampt der notarissen, zesde druk, Brussel, 1771.

G. IMMEL, "Typologie der Gesetzgbung des Privatrechts und Prozessrechts", H. COING red., Handbuch der Quellen und Literatur der Neueren europäischen Privatrechtsgeschichte, II/2, Munchen, 1976, 3-96.

Index Biographique Français, T. NAPPO red., 3de editie, 7 delen, Munchen, 2004. 
Indice Biogräfico de Espana, Portugal e Iberoamérica, V. H. MeDIAVILLA red., 3de editie, 10 delen, Munchen, 2000.

Indice Biografico Italiano, T. NAPPO red., 4de editie, 10 delen, Munchen, 2007.

A. D’InNOCEnZO, "Imbert Jean", P. ARABEYRE, J.-L. HAlPÉRIN en J. KRYNEN red., Dictionnaire historique des juristes français (XIIe-XXe siècle), Parijs, 2007, 417.

K. J. T. JANSSEN DE LIMPENS, Rechtsbronnen van het Gelders Overkwartier van Roermond (Werken der Vereeniging tot Uitgaaf der Bronnen van het Oud Vaderlandsche Recht, 20), Utrecht, 1965.

H. KANTOROWICZ, "Die Allegationen im späteren Mittelalter", Arcbiv für Urkundenforschung, 13 (1933), 15-29.

D. R. KELLEY, "Legal Humanism and the Sense of History", Studies in the Renaissance, 13 (1966), 184-199.

D. R. Kelley, François Hotman. A Revolutionary Ordeal, Princeton, 1973.

D. R. Kelley, "Louis le Caron philosopher", E. P. MAhoney red., Philosophy and Humanism: Renaissance Essays in Honor of Paul Oskar Kristeller, Leiden, 1976, 30.

K. VON KEMPIS, Andreas Gaill (1526-1587): zum Leben und Werk eines Juristen der frühen Neuzeit. (Rechtshistorische Reihe 65), Frankfurt am Main, 1988.

F. KEVERLING BUISMAN, 'Mer 't is geen lantrecht' Over regionale wetboeken als bron van het oud-vaderlands recht van de Middeleeunven tot de tijd van de Republiek. Rede nitgesproken ter aanvaarding van het ambt van bijzonder hoogleraar in het Oud-vaderlands recht aan de Universiteit van Amsterdam op donderdag 30 maart 2000, Amsterdam, 2000, 15-22.

F. KEVERLING BUISMAN, "Welke faktoren bepaalden de inhoud van de Gelderse landenrechten tijdens het Ancien Regime", E. J. M. F. C. Broers en B. C. M. JACOBS red., Interactie tussen wetgever en rechter voor de Trias Politica. Handelingen van het congres gehouden te Tilburg op 12 en 13 december 2002), Den Haag, 2003, 191-215.

G. KISCH, Studien zur bumanistischen Jurispruden₹, Berlijn, 1972.

H. F. KÖCK, Der Beitrag der Schule von Salamanca zur Entwicklung der Lehre von den Grundrechten (Schriften zur Rechtsgeschichte. Heft 39), Berlijn, 1987, 15-25.

C. DE KONINCK, Geschiedenis van het strafprocesrecht in Vlaanderen en Brabant van de XIVe eeun tot de Criminele Ordonnantiën van 5 en 9 juli 1570, nitgevaardigd door Filips II, koning van Spanje, Ongepubliceerde licentiaatsverhandeling, Rijksuniversiteit Gent, 1981.

H. KoOIKER, Lex scripta abrogata. De derde renaissance van het Romeinse recht, Nijmegen, 1996.

A. Korthals Altes, Ons oudste zeerecht (Uitgaven van het Molengraaf Instituut voor Privaatrecht te Utrecht. 5), Zwolle, 1976.

P. KOSCHAKeR, Europa en het Romeinse recht, Deventer, 2000.

J. KRYNEN, "Voluntas domini regis in suo regno facit ius. Le roi de France et la coutume", A. I. FERREIROS red., El dret comú $i$ Catalunya: actes del VII Simposi Internacional (Barcelona, 23-24 de maig de 1997), Barcelona, 1998, 59-89.

J. KRYNEN, Droit romain, jus civile et droit français (Etudes d'histoire du droit et des idées politiques. III), Toulouse, 1999. 
J. Krynen, "Cun (Cunh, Cugno, Cunho, de Cuneo) Guillaume de", P. ARABEYre, J.-L. HALPERIN en J. KRYNEN red., Dictionnaire historique des juristes français (XIIe-XXe siècle), Parijs, 2007, 223-225.

J. Krynen, "Guénois (Guénoys) Pierre", P. Arabeyre, J.-L. Halperin en J. KRYNEN red., Dictionnaire historique des juristes français (XIIe-XXe siècle), Parijs, 2007, 387.

C. LAENENS en L. LeEMANS, De geschiedenis van het Antwerpse gerecht, Antwerpen, 1953.

A. Laingui, "Bugnyon Philibert", P. ARABeyre, J.-L. Halpérin en J. KRYNen red., Dictionnaire historique des juristes français (XIIe-XXe siècle), Parijs, 2007, 145-146.

S. LAMMEL, "Die Gesetzgebung des Handelsrechts", H. CoING red., Handbuch der Quellen und Literatur der Neueren europäischen Privatrechtsgeschichte, II/2, Munchen, 1976, 571-1084.

P. LANDAU, P. en F.-C. SCHROEDER, Strafrecht, Strafprozess und Rezeption: Grundlagen, Entwicklung und Wirkung der Constitutio Criminalis Carolina (Juristische Abhandlungen. XIX), Frankfurt am Main, 1984.

P. LANDAU, "Johannes Andreae", M. STOLLEIS red., Juristen: ein biographisches Lexikon von der Antike bis zum 20. Jabrbundert, Munchen, 2001, 337-339.

P. LANDAU, "Nikolaus de Tudeschis (Panormitanus)", M. STOLLEIS red., Juristen: ein biographisches Lexikon von der Antike bis zum 20. Jabrbundert, Munchen, 2001, 470-471.

"Lapo de Castiglionchio (il vecchio), Giovanni", Novissimo Digesto Italiano, IX, Turijn, 1975, 450.

A. LeCA, "Hotman François", P. Arabeyre, J.-L. Halpérin en J. KRYNEN red., Dictionnaire historique des juristes français (XIIe-XXe siècle), Parijs, 2007, 409-411.

A. LEFEBVRE-TEILLARD, "Recherches sur la penetration du droit canonique dans le droit coutumier français", Mémoires de la Société pour l'bistoire du droit et des institutions des anciens pays bourguignons, comtois et romands, XL (1983), Dijon, 59-76.

R. LESAFFER, Inleiding tot de Europese rechtsgescbiedenis, Leuven, 2004.

M. LESCUYER, "Guillaume Ranchin (1559-1605), érudit protestant et gallican: sa bibliothèque et sa famille", Bulletin de la Société de l'bistoire du protestantisme français, 145 (1999), 323-358 en 509-571.

J. P. LEVY, "La pénétration du droit savant dans les coutumiers angevins et bretons au Moyen Age", Tijdschrift voor Rechtsgeschiedenis, 24 (1956), 1-53.

J. P. LEVY, "La pénétration du droit privé savant dans le Vieux coustumier de Poictou", Etudes d'histoire du droit privé offertes à Pierre Petot, Parijs, 1959, 371-383.

J. P. LEVY, Le droit romain en Anjou, Bretagne, Poitou (d'après les coutumiers) (Ius Romanum Medii Aevi. Pars V, 4, b), Milaan, 1970.

G. LEYTE, "Charondas et le droit français", Naissance du droit français II (Droits: revue française de théorie juridique 39), Parijs, 2004, 17-33.

G. LEYTE, "Bacquet Jean", P. ARABEYre, J.-L. HALPERIN en J. KRYNEN red., Dictionnaire historique des juristes français (XIIe-XXe siècle), Parijs, 2007, 33. 
G. LeYTE, "Le Caron Louis", P. ARABeyre, J.-L. HALPERIN en J. KRYNEN red., Dictionnaire historique des juristes français (XIIe-XXe siècle), Parijs, 2007, 479-480.

J. H. A. LOKIN en W. J. ZWALVE, Hoofdstukken nit de Europese codificatiegeschiedenis, Deventer, 2001.

Lovanium docet. Geschiedenis van de Leuvense Rechtsfaculteit (1425-1914), G. VAN DIEVOET, D. Van den Auweele, F. Stevens, M. Oosterbosch, en C. Coppens red., Leuven, 1988.

J. MAECKL, "Das Stadtrecht von Erkelenz", Bijdragen en mededelingen Gelre, 8 (1905), 319-448.

L. T. MAES, La bibliothèque du Grand Conseil à Malines, Mechelen, 1949.

L. T. MAES e.a., Juristen en rechtsleven ten tijde van Rubens, Antwerpen, 1977.

A. P. Martin, "Bibliographie der Gesetzgebung des Privatrechts und Prozessrechts. Spanien", H. COING red., Handbuch der Quellen und Literatur der Neueren europäischen Privatrechtsgeschichte, II/2, Munchen, 1976, 228-281.

R. Martinage, "Jean Papon (1507-1590), le mal aimé?", A. Deperchin, N. DERASSE en B. DuBOIS red., Figures de Justice. Etudes en l'honneur de Jean-Pierre Royer, Rijsel, 2004, 247-257.

R. MARTINAGE, "Les arrêts en matière pénale dans les ouvrages juridiques du XVIe siècle", S. DAUCHY, en V. DEMARS-SION red., Les recueils d'arrêts et dictionaires de jurisprudence (XVIe-XVIIIe siècles) (Collection bibliographie. II), Parijs, 2005, 219-251.

G. MARTYN, Het Eeuwig Edict van 12 juli 1611. Zijn genese en zijn rol in de verschriftelijking van het privaatrecht (Algemeen Rijksarchief en Rijksarchief in de provinciën. Studia. LXXXI), Brussel, 2000.

E. MATTHES, Die juristischen Handschriften der Staats- und Universtätsbibliothek Hamburg. 1. Foliohandschriften, Stuttgart, 1996.

R. MAURENBRECHER, Die rheinpreußischen Landrechte, 2 dln., Bonn, 1830.

R. J. C. MAW, Humanism and legal education during the reception of Roman law in Germany : a case study, Michigan, 1976.

Max-Planck-Institut für Europäische Rechtsgescbichte. Online-Katalog der Bibliothek, 2006 (http://sunrise.mpier.uni-frankfurt.de/webOPAC/).

L. MAYALI, "La coutume dans la doctrine romaniste au Moyen Age", Recueils de la Société Jean Bodin pour l'histoire comparative des institutions. La coutume, LII, Brussel, 1990, 11-31.

A. MazZACANe, "Farinacci, Prospero", M. STOLLEIS red., Juristen: ein biographisches Lexikon von der Antike bis zum 20. Jabrbundert, Munchen, 2001, 206-207.

"Medina, Bartholomew", The Catholic Encyclopedia, X, New York, 1911, 143-144.

W. MEEWIS, De Vierschaer. De Criminele Rechtspraak in het Oude Antwerpen, Kapellen, 1992.

F. H. MERTENS en K. L. TORFS, Geschiedenis van Antwerpen sedert de stichting der stad tot onze tyden, 8 dln., Antwerpen, 1845-1853.

P. MESNARD, "La place de Cujas dans la querelle de l'humanisme juridique", Revue historique du droit francais et étranger, 27 (1950), 521-537. 
E. MEYNIAL, "Remarques sur le rôle joué par la doctrine et la jurisprudence dans l'oeuvre d'unification du droit en France, depuis la rédaction des Coutumes jusqu'à la Révolution, en particulier dans la succession au propres", Congrès international de droit comparé tenu à Paris du 31 juillet au 4 anôt 1900: procès-verbaux des séances et documents, 1905, Parijs, 269-309.

E. VON MOELLER, Julius Clarus aus Alessandria, der Kriminalist des 16. Jabrbunderts, der Rat Pbilipps II. 1525-1575 (Strafrechtliche Abhandlungen 136), Breslau, 1977.

J. Monballyu, "Costumier strafprocesrecht in Vlaanderen voor en na de criminele ordonnantiën van 1570", Handelingen van de Koninklijke Commissie voor de witgave der Oude Wetten en Verordeningen van België, 32 (1996), 115-230.

J. Monballyu, "De hoofdlijnen van de criminele strafprocedure in het graafschap Vlaanderen (16de tot 18de eeuw)", C. H. VAN RHEe, F. STEVENS en E. PERSOONS red., Voortschrijdend procesrecht. Een bistorische verkenning, Leuven, 2001, 63-108.

J. MonbalLyU, Geschiedenis van het familierecht, Leuven, 2006.

J. MONBALlyU, Zes eeuwen strafrecht. De geschiedenis van het Belgische strafrecht (1400-2000), Leuven, 2006.

L. MontAZel, "Pithou (Pithoeus), Pierre", M. STOLLEIS red., Juristen: ein biographisches Lexikon von der Antike bis zum 20. Jabrbundert, Munchen, 2001, 499-500.

O. MOORMAN VAN KAPPEN, "De rechtskracht van de ordonnantie op de stijl van procederen in criminele zaken van 9 juli 1570 in de Oostenrijkse Nederlanden", Tijdschrift voor Rechtsgeschiedenis, 58 (1990), 327-343.

O. MOORMAN VAN KAPPEN, "Receptie van het Gelders-Overkwartierlijke land- en stadsrecht van 1619 in Nijmegen?", A. M. J. A. BERKVENS, A. F. GEHLEN en G. H. A. VENNER red., Flittich erforscht und gecolligeert..' Opstellen over Limburgse rechtsgeschiedenis, Maastricht, 1995, 173-185.

O. Moorman van Kappen, Bespreking van A. M. J. A. Berkvens, G. H. A. VenNer en G. SPIJKERBOER, Het Gelderse Land- en Stadsrecht van het Overkwartier van Roermond, Arnhem, 1996, Tijdschrift voor Rechtsgeschiedenis, 65 (1997), 536-538.

O. MOORMAN VAN KAPPEN, "Zur Lehre von der Subsidiarität der geldrischen Landrechte", P. BLICKLE, T. O. HUGLIN en D. WYDUCKEL, red., Subsidiarität als recbtliches und politisches Ordnungsprinzip in Kirche, Staat und Gesellschaft. Genese, Geltungsgrundlagen und Perspektiven an der Schwelle des dritten Jabrtausends (Beiheft 20 'Rechtstheorie'), Berlijn, 2002, 259-289.

T. DE MORembert, "Denis Godefroy", Dictionnaire de biographie française, XVI, Parijs, 1985, 437-438.

T. DE MOREMBERT, "François Hotman", Dictionnaire de biographie française, XVII, Parijs, 1989, 1309-1310.

J. MÜLLER, "Durantis, Guilelmus d. Ä. (Speculator)", M. STOLLEIS red., Juristen: ein biographisches Lexikon von der Antike bis zum 20. Jabrbundert, Munchen, 2001, 191.

Nederlandse Centrale Catalogus, 1998-2007 (http://www.picarta.nl). 
C. NESSINK, Het landt-recht van Over-Yssel met eenige aanmerkingen en aantekeningen op het selve, door Mr. Christoffer Nessink, Campen, 1747.

Neue deutsche Biographie, 22 dln., Berlijn, 1953-2005.

P. L. NEVE, "Ius commune oftewel 'gemeen recht': traduttore traditore?", O. E. Tellegen-Couperus, P. L. Neve en J. W. Tellegen red., Tertium Datur. Drie opstellen aangeboden aan Prof. mr. J. A. Ankum, Tilburg, 1995, 3-58.

P. L. NEVE, Schets van een geschiedenis van het notarisambt in het buidige België tot aan de Franse wetgeving (Rechtshistorische reeks van het Gerard Noodt Instituut. XXXIV), Nijmegen, 1995.

P. L. NEvE, en A. F. GEHLEN, Het notariaat in de Lage Landen ( \pm 1250-1842): opstellen over de geschiedenis van het notariaat in de Lage Landen vanaf de oorsprong tot in de negentiende eeun (Ars notariatus. CXVII), Amsterdam, 2005.

Nieuw Nederlandsch biografisch woordenboek, 10 dln., Leiden, 1911-1937.

J. VAN DEN NIEUWENHUIZEN, "Bestuursinstellingen van de stad Antwerpen (12 de eeuw-1795)", R. VAN UYTVEN, C. BRUNEEL, H. COPPENS en B. AUGUSTYN red., De gewvestelijke en lokale overheidsinstellingen in Brabant en Mechelen tot 1795 (Algemeen Rijksarchief en Rijksarchief in de provinciën. Studia 82), 2 dln., Brussel, 2000, 462-510.

J. P. VAN NIEKERK, The development of the principles of insurance law in the Netherlands from 1500 to 1800, Johannesburg, 1998.

G. P. VAN NIFTERIK, Vorst tussen volk en wet: over volkssoevereiniteit en rechtsstatelijkheid in het werk van Fernando Vázquez, de Menchaca (1512-1569), Deventer-Rotterdam, 1999.

W. NOLET en P. C. BOEREN, Kerkelijke instellingen in de Middeleeuwen, Amsterdam, 1951.

K. W. NÖRR, "Die kanonistische Literatur", H. COING red., Handbuch der Quellen und Literatur der Neueren europäischen Privatrechtsgeschichte, I, Munchen, 1973, 394-395.

K. W. NÖRR, Kirche und Konz̨il bei Nicolaus de Tudeschis (Panormitanus) (Forschungen zur kirchlichen Rechtsgeschichte und zum Kirchenrecht. Band 4), Keulen, 1964.

Novissimo Digesto Italiano, 27 dln., Turijn, 1957-1987.

E. NYS, Le droit des gens et les anciens jurisconsultes espagnols, Den Haag, 1914.

W. F. H. OLDEWELT, "De pogingen tot 'codificatie' van het Amsterdamse recht", Verslagen en mededeelingen Vereeniging tot Uitgaaf der Bronnen van het Oud vaderlandsche recht, 13 (1967), 66-73.

F. OlivieR-MARTIN, Les manuscrits de Simon Marion et la coutume de Paris au XVIe siècle (Travaux juridiques et économiques de la faculté de droit de l'Université de Rennes), Rennes, 1922.

M OOsterbosCH, Het openbare notariaat in Antwerpen tijdens de late Middeleeunven (1314 1531). Een institutionele en prosopografische studie in Europees perspectief, Leuven, 1992.

M. OOSTERbosch, “Van Groote abuysen ende ongeregeltheden' Overheidsbemoeiingen met het Antwerpse notariaat tijdens de XVIde eeuw", Tijdschrift voor Rechtsgeschiedenis, (1995) 63, 83-102. 
R. OPSOMMER, "Wielant, Filips", M. STOLLEIS red., Juristen: ein biographisches Lexikon von der Antike bis zum 20. Jabrbundert, Munchen, 2001, 671-672.

R. ORESTANO, "le Caron, Louis", Novissimo Digesto Italiano, IX, Turijn, 1975, 574.

D. J. OSLER, "Towards a legal-historical Bibliography: A Census of $16^{\text {th }}$ Century Legal Imprints", Ius Commune: Zeitschrift für Europäische Rechtsgescbichte, 15 (1988) 231-242.

D. J. OSLER, "The Myth of European Legal History", Rechtshistorisches Journal, 16 (1997), 393-410.

D. J. OSLER, Bibliographica Iuridica 1. Catalogue of books printed on the continent of Europe from the beginning of printing to 1600 in the library of the Max-Planck-Institut fir Europäische Rechtsgeschichte, Frankfurt am Main (Ius Commune: Veröffentlichungen des Max-Planck-Instituts für europäische Rechtsgeschichte. Sonderheft 130), Frankfurt am Main, 2000.

D. J. OsLer, Bibliographica Iuridica 2. Catalogue of books printed in Spain, Portugal and the Southern and Northern Netherlands from the beginning of printing to 1800 in the library of the Max-Planck-Institut für Europäische Rechtsgeschichte, Frankfurt am Main (Ius Commune: Veröffentlichungen des Max-Planck-Instituts für europäische Rechtsgeschichte. Sonderheft 131), Frankfurt am Main, 2000.

D. J. OsLER, Images of legal bumanism, 2001. (http://www.pum.umontreal.ca/revues/surfaces/vol9/osler.htm)

D. J. OSLER, Bibliographica Iuridica 3. Edoardo Volterra (1904-1984): a catalogue of the early printed books in his library, now in the Ecole française de Rome (Ius Commune: Veröffentlichungen des Max-Planck-Instituts für europäische Rechtsgeschichte. Sonderheft 211), Frankfurt am Main, 2006.

J. ОTTO, "Alciatus, Andreas", M. STOLLEIS red., Juristen: ein biographisches Lexikon von der Antike bis zum 20. Jabrbundert, Munchen, 2001, 27-29.

J. ОтTO, "Cujas (Cujacius), Jacques", M. STOLLEIS red., Juristen: ein biographisches Lexikon von der Antike bis zum 20. Jabrbundert, Munchen, 2001, 152-153.

J. ОтTO, "DuMoulin (Molinaeus), Charles", M. STOLLEIS red., Juristen: ein biographisches Lexikon von der Antike bis zum 20. Jabrbundert, Munchen, 2001, 188-189.

J. Отто, "Favre (Faber), Antoine", M. STOLLEIS red., Juristen: ein biographisches Lexikon von der Antike bis zum 20. Jahrbundert, Munchen, 2001, 207-208.

J. ОтTO, "Gaill, Andreas", M. STOLLEIS red., Juristen: ein biographisches Lexikon von der Antike bis zum 20. Jabrbundert, Munchen, 2001, 228-229.

J. ОтTO, "Hotman (Hotomannus), François", M. STOLLEIS red., Juristen: ein biographisches Lexikon von der Antike bis zum 20. Jahrbundert, Munchen, 2001, 303-304.

J. Отто, "Mynsinger von Frundeck, Joachim", M. STOLLEIS red., Juristen: ein biographisches Lexikon von der Antike bis zum 20. Jahrbundert, Munchen, 2001, 462.

P. OURLIAC, Etienne Bertrand: droit romain et pratique méridionale an XVe siècle, Parijs, 1937. 
P. OURLIAC, “Le Palais et l'Ecole vers 1500: témoignage de Guillaume Benoît, canoniste", Revue internationale d'bistoire de la profession d'avocat, 4 (1992), 77-92.

J. PAPON, Recueil d'arrestz notables des courts souveraines de France, ordonnez, par tiltres, en vingt-quatre livres, Lyon, 1559.

J. M. PARDESSUS, Collection de lois maritimes antérieures au XVIIIe siècle, 6 dln., Parijs, 1828-1845.

E. PASQUIER, Les oeuvres d'Estienne Pasquier : contenant ses recherces de la France; son plaidoyé pour M. le duc de Lorraine ... ; ses lettres, ses oeuvres meslées ; et les lettres de Nicolas Pasquier, fils d'Estienne, 2 dln., Amsterdam, 1723.

"Peck (Petrus)", Nieuw Nederlandsch biografisch woordenboek, IX, Leiden, 778-780.

L. Pfister, "Papon Jean", P. Arabeyre, J.-L. HALPÉRIN en J. KrYNEN red., Dictionnaire bistorique des juristes français (XIIe-XXe siècle), Parijs, 2007, 607-609.

L. PIGEAud, "Pierre Grégoire", Dictionnaire de biographie française, XVI, Parijs, 1985, 1143-1144.

Plato, De Wetten, X. DE WIN et alii ed. (Plato Verzameld werk. Deel IV), Kapellen-Baarn, 1999.

Plato, Phaedrus, X. DE WIN et alii ed. (Plato Verzameld werk. Deel IV), Kapellen-Baarn, 1999.

H. PohlmanN, "Bibliographie der Gesetzgebung des Privatrechts und Prozessrechts. Niederlande", H. COING red., Handbuch der Quellen und Literatur der Neueren europäischen Privatrechtsgeschichte, II/2, Munchen, 1976, 468-500.

M. PopOFF, Prosopographie des gens du Parlement de Paris (1266-1753), Parijs, 1996.

J.-F. POUDRET, "Rapport de synthèse. Connaissance et preuve de la coutume en Europe occidentale au moyen âge et à l'époque moderne", Recueils de la Société Jean Bodin pour l'histoire comparative des institutions. La coutume, LII, Brussel, 1990, 511-545.

J. Poumarède, "Coutumes et droit écrit", Dictionnaire de l'Ancien Régime, Parijs, 1996, 364-371.

J. Poumarède en J. Thomas, "Introduction", J. Poumarède, en J. Thomas red., Les Parlements de Province au XV Te siècle, Toulouse, 1996, 7-25.

J. POumarède, "Les arrêtistes toulousains", J. POUMARÈDE, en J. THOMAS red., Les Parlements de Province au XV Te siècle, Toulouse, 1996, 369-391.

J. POUMARÈDE, "Droit romain et rédaction des coutumes dans le ressort du Parlement de Bordeaux", J. KRYNEN red., Droit romain, jus civile et droit français, Toulouse, 1999, 329-345.

J. Poumarède, "Maynard Géraud de", P. ArABeyre, J.-L. HALPÉRIN en J. KRYNEN red., Dictionnaire historique des juristes français (XIIe-XXe siècle), Parijs, 2007, 553-554.

M. PREVOST, "Jean d'Arresrac ou d'Arrérac", Dictionnaire de biographie française, IV, Parijs, 1948, 1084-1085.

M. PRevost, “Nicolas de Bohier”, Dictionnaire de biographie française, VI, Parijs, 1954, 782. 
M. PREvOST, "Jean Chenu", Dictionnaire de biographie française, VIII, Parijs, 1959, 995-996.

M. PREvOST, "René Choppin", Dictionnaire de biographie française, VIII, Parijs, 1959, 1252-1253.

D. Quaglioni, "Bodin Jean”, P. Arabeyre, J.-L. HALPERIN en J. KRYNEN red., Dictionnaire historique des juristes français (XIIe-XXe siècle), Parijs, 2007, 92-94.

D. Quaglioni, "Grégoire Pierre", P. Arabeyre, J.-L. HALPERIN en J. KRYNEN red., Dictionnaire historique des juristes français (XIIe-XXe siècle), Parijs, 2007, 384-385.

C. M. G. VAN RAA, "Nicolaas Everaerts (1461 of 1462-1532)”, Zestig juristen. Bijdragen tot een beeld van de geschiedenis van de Nederlandse rechtswetenschap, T. J. VEEN en P. C. KOP red., Zwolle, 1987, 97-103.

F. RABELAIS, Gargantua en Pantagruel, Amsterdam, 1999.

F. RANIERI, "Bibliographie der Gesetzgebung des Privatrechts und Prozessrechts. Italien”, H. COING red., Handbuch der Quellen und Literatur der Neueren europäischen Privatrechtsgeschichte, II/2, Munchen, 1976, 97-186.

C. F. REATZ, Geschichte des europäischen Seeversicherungsrecht, Leipzig, 1870.

C. F. REATZ, "Ordonnances du duc d'Albe sur les assurances maritimes de 1569, 1570 et 1571, avec un précis de l'histoire du droit d'assurance maritime dans les Pays-Bas", Bulletin de la commission royale de l'histoire (4e série), 5 (1878) 41-118.

W. M. C. REgT, "Montanus, Paulus", Nieuw Nederlandsch biografisch Woordenboek, X, Amsterdam-Antwerpen, 1974, 645.

N. REICHARDT, "Gómez, Antonio", M. STOLLEIS red., Juristen: ein biographisches Lexikon von der Antike bis zum 20. Jahrbundert, Munchen, 2001, 252-253.

M.-F. RenOuX-Zagamé, "Marion Simon”, P. Arabeyre, J.-L. HALPÉrin en J. KRYNEN red., Dictionnaire historique des juristes français (XIIe-XXe siècle), Parijs, $2007,540$.

M.-F. RenouX-Zagamé, "Pasquier Etienne”, P. Arabeyre, J.-L. Halpérin en J. KRYNEN red., Dictionnaire historique des juristes français (XIIe-XXe siècle), Parijs, 2007, 611-613.

D. REuILlard, "Pierre Guenois", Dictionnaire de biographie française, XVI, Parijs, 1985, 1446-1447.

M. REulos, "L'importance des praticiens dans l'humanisme juridique", in Pédagogues et juristes (De Pétrarqua à Descartes. 4), Parijs, 1963, 119-133.

M. REulos, "Les juristes humanistes et la coutume de Normandie", Droit privé et institutions régionales. Etudes historiques offertes à Jean Yver. (Publications de l'Université de Rouen. 31), Parijs, 1976, 605-613.

M. REULOS, “L'influence des juristes humanistes sur l'évolution du droit en France (enseignement et pratique) au XVIe siècle et au début du XVIIe siècle", in La formazione storica del diritto moderno in Europa, Firenze , 1997, 281-288.

M. RHEINSTEIN, "Types of reception", Annales de la Faculté de droit d'Istanbul, 6 (1956), 31-40. 
S. RIALS, "Veritas iuris. La vérité du droit écrit. Critique philologique humaniste et culture juridique moderne de la forme", Droits: revue française de théorie juridique, 26 (1997), 101-181.

H. DE RIDDER-SYMOENS, De universitaire vorming van de Brabantse stadsmagistraten en stadsfunctionarissen - Leuven en Antwerpen, 1430-1580 (Studia historica Gandensia. 208), Gent, 1977.

H. RIES, "Binsfeld, Peter", Neue deutsche Biograpbie, II, Berlijn, 1971 (nadruk van 1955), 248-249.

J. ROELINK, Een honderdtal brieven uit de correspondentie van Elbertus Leoninus. Uitgegeven met inleiding en toelicbting, Nijkerk, 1946.

J. VAN RoEy, "Notarissen en schepenen te Antwerpen in de 16 de eeuw", Kroniek. Orgaan van Stabuco. Vereniging Stadspersoneel Antwerpen (1950), 49-51.

G. RoOsEBOOM, Recueil van verscheyde Keuren en Costumen, mitsgaders Maniere van procederen binnen de Stadt Amsterdam, Amsterdam, 1644.

F. Ross, "López de Tovar, Gregorio", M. STOLLEIS red., Juristen: ein biographisches Lexikon von der Antike bis zum 20. Jabrbundert, Munchen, 2001, 400-401.

F. Ross, "Molina, Luis de", M. STOLLEIS red., Juristen: ein biographisches Lexikon von der Antike bis zum 20. Jabrbundert, Munchen, 2001, 449-450.

F. W. Rudmin, "Critical history of the acculturation psychology of assimilation, separation, integration, and marginalization", Review of General Psychology, VII (2003), 3-37.

F. W. RUDMIN, "Field notes from the quest for the first use of 'acculturation", Cross-Cultural Psychology Bulletin, XXXVII (2003), 24-31.

J. SCHASSERT, Commentatio ad Reformationem Velaviae, Harderwijk, 1719.

K. O. SCHERNER, "Die Wissenschaft des Handelsrechts", H. COING red., Handbuch der Quellen und Literatur der Neueren europäischen Privatrechtsgeschicbte, II/1, Munchen, 1977, 797-998.

J.-M. SCHOLZ, "Rechtsprechungs-und Konsiliensammlungen. Spanien", H. COING red., Handbuch der Quellen und Literatur der Neueren europäischen Privatrechtsgeschichte, II/2, Munchen, 1976, 1271-1318.

O. VON SCHLIESSER, "Gail(1), Andreas", Neue deutsche Biographie, VI, Berlijn, 1971 (nadruk van 1964), 38-39.

P. P. SCHMIDT, Oude drukken in de bibliotheek van de Hoge Raad der Nederlanden: catalogus, Zwolle, 1988.

J. F. VON SCHULTE, Die Geschicbte der Quellen und Literatur des canonischen Rechts von Gratian bis auf die Gegenwart, 3 dln., Stuttgart, 1875-1880.

S. SCHUMANN, Joachim Mynsinger von Frundeck (1514-1588) (Wolfenbütteler Forschungen Band 23), Wiesbaden, 1983.

K. SeELmanN, "Covarubias (Covarruvias) y Leyva, Diego de", M. STOLLEIS red., Juristen: ein biographisches Lexikon von der Antike bis zum 20. Jabrbundert, Munchen, 2001, 148-149.

K. Seelmann, "Vazquez de Menchaca, Fernando", M. StOlleis red., Juristen: ein biographisches Lexikon von der Antike bis zum 20. Jahrbundert, Munchen, 2001, 647-648. 
W. SELLERT, "Mynsinger von Frundeck, Joachim”, Neue deutsche Biographie, XVIII, Berlijn, 1997, 671-673.

M. SEONG-HAK KIM, "Christofle de Thou et la réformation des coutumes: l'esprit de réforme juridique au XVIe siècle”, Tijdschrift voor Rechtsgeschiedenis, 72 (2004), 91-102.

L. SOLEIL, "Grimaudet François", P. ARABEYRE, J.-L. HALPÉRIN en J. KRYNEN red., Dictionnaire historique des juristes français (XIIe-XXe siècle), Parijs, 2007, 385-386.

A. SÖLLNER, "Die Literatur zum gemeinen und partikularen Recht in Deutschland, Österreich, den Niederlanden und der Schweiz", H. COING red., Handbuch der Quellen und Literatur der Neueren europäischen Privatrechtsgeschichte, II/1, Munchen, 1977, 501-614.

J. T. DE SMIDT, "Komputer und die Rezeption des gelehrten Rechts", J. T. DE SMIDT red. Miscellanea Consilii Magni (Verzamelen en bewerken van de jurisprudentie van de Grote Raad. Nieuwe reeks. N4), Amsterdam, 1980, 153-158.

U. SPECK, "Bodin, Jean”, M. STOLLEIS red., Juristen: ein biographisches Lexikon von der Antike bis zum 20. Jahrbundert, Munchen, 2001, 90-92.

P. STEIN, "Legal humanism and legal science", Tijdschrift voor Rechtsgeschiedenis, 54 (1986), 297-306.

P. STEIN, Roman Law in European History, Cambridge-New York-Melbourne, 1996.

F. STEVENS, Revolutie en notariaat. Antwerpen 1794-1814 (Brabantse Rechtshistorische Reeks. 8), Assen-Leuven, 1994.

P. STOCKMANS, Decisionum curiae Brabantiae sesque centuriae, Brussel, 1670.

M. STORME, “'Practique judiciare ès causes civiles.' Un manuel de procedure dans les Pays-Bas du XVIe siècle”, A. DePerchin, N. Derasse en B. DubOis red., Figures de Justice. Etudes en l'honneur de Jean-Pierre Royer, Rijsel, 2004, 259-260.

E. I. STRUBBE, "Die Stellung Damhouders in der Rechtswissenschaft: Wielant-De Damhouder", Revue d'bistoire du droit, 1 (1930), 219-226.

E. I. STRUBBE en E. SPILlEMAECKERS, “De 'Antwerpse Rechtsaantekenigen' van Willem de Moelnere", Bulletin en Handelingen van de Koninklijke Commissie voor de uitgave der oude wetten en verordeningen, 18 (1954), 7-148.

E. I. STRUBBE, "Joos de Damhouder als criminalist", Tijdschrift voor Rechtsgeschiedenis, 38 (1970), 1-65.

M. SUEL, "Le président Brisson et la codification", Droits: revue française de théorie juridique, 24 (1996), 31-44.

"Suetonius", Grote Winkler Prins Encyclopedie, 9de uitg., XXII, Amsterdam-Antwerpen, 1993, 131.

K. VAN SULL, Leonardus Lessius, Wetteren, 1923.

J. A. TEDESCHI, "Notes toward a genealogy of the Sozzini family", J. A. TEDESCHI red., Italian reformation studies in honor of Laelius Socinus, Firenze, 1965, 282-287.

O. E. Tellegen-Couperus, P. L. Neve en J. W. Tellegen red., Tertium Datur. Drie opstellen aangeboden aan Prof. mr. J. A. Ankum, Tilburg, 1995, 3-58.

J.-L. THIREAU, Charles de Moulin (1500-1566): étude sur les sources, la méthode, les idées politiques et économiques d'un juriste de la renaissance, Genève, 1980, 34-35. 
J.-L. Thireau, "Hugues Doneau et les fondements de la codification moderne", Droits: revue française de théorie juridique, 26 (1997), 81-100.

J.-L. THIREAU, "L'alliance des lois romaines avec le droit français", J. KRYNEN red., Droit romain, jus civile et droit français, Toulouse, 1999, 347-374.

J.-L. Thireau, "Du Moulin (Du Molin, Dumoulin, Molinaens) Charles", P. ARABEYRe, J.-L. HALPÉRIN en J. KRYNEN red., Dictionnaire historique des juristes français (XIle-XXe siècle), Parijs, 2007, 276-278.

J.-L. Thireau, "Thou Christofle de", P. ARABEYRE, J.-L. HALPERIN en J. KRYNEN red., Dictionnaire historique des juristes français (XIIe-XXe siècle), Parijs, 2007, 740-741.

H. THIEME, "Natürliches Privatrecht und Spätscholastik", Zeitschrift der Savigny-Stiftung für Rechtsgeschichte. Germanistische Abteilung, 83 (1953), 230-266.

H. Thieme, "Qu'est-ce que nous, les juristes, devons à la Seconde Scolastique espagnole", P. GROSSI red., La Seconda Scolastica nella formazione el diritto privato moderno. Incontro di studio. Firenze, 16-19 ottobre 1972, Milaan, 1973, 7-21.

B. TIERNEY, "The Idea of Natrual Rights. Studies on Natural Rights, Natural Law and Church Law 1150-1625", Atlanta, 1997, 255-315.

Tractatus universi iuris, Venetië, 1584.

H. E. Troje, "Die Literatur des gemeinen Rechts unter dem Einfluss des Humanismus", H. COING red., Handbuch der Quellen und Literatur der Neueren europäischen Privatrechtsgeschichte, II/1, Munchen, 1977, 615-796.

H. E. TROJE, Humanistische Jurispruden₹: Studien zur europä̈schen Rechtswissenschaft unter den Einfluss des Humanismus (Bibliotheca eruditorum: internationale Bibliothek der Wissenschaften. 6), Goldbach, 1993.

W. UlLman, Principles of Government and Politics in the Middle Ages, Londen, 1966.

J. VANDERLINDEN, Le concept de code en Europe occidentale du XIII an XIX siecle: Essai de definition (Études d'histoire et d'ethnologie juridiques), Brussel, 1967.

F. VANHEMELRIJCK, De criminaliteit in de ammanie van Brussel van de Late Middeleeunen tot bet einde van bet Ancien Régime (1404-1789) (Verhandelingen van de Koninklijke Academie voor Wetenschappen, Letteren en Schone Kunsten van België. Klasse der Letteren. 97), Brussel, 1981.

P. VAUCELLES, "Jehan Bacquet", Dictionnaire de biographie française, IV, Parijs, 1948, 1122.

T. J. VeEN, P. C. KOP en G. C. J. J. VAN DEN BERGH, Zestig juristen : bijdragen tot een beeld van de geschiedenis der Nederlandse rechtswetenschap, Zwolle, 1987.

T. J. VeEN, "Viglius (Zuichemius) ab Aytta (1507-1577)", T. J. VeEN en P. C. KoP red., Zestig juristen: bijdragen tot een beeld van de geschiedenis der Nederlandse rechtswetenschap, Zwolle, 1987, 104-109.

J. VENDRAND-VOYER, "Réformation des coutumes et droit romain. Pierre Lizet et la coutume de Berry", Annales de la Faculté de droit et de sciences politiques de Clermont-Ferrand, 18 (1981), 313-381.

J. Vendrand-Voyer, "Duret Jean", P. Arabeyre, J.-L. HALPÉRIN en J. KRYNeN red., Dictionnaire historique des juristes français (XIIe-XXe siècle), Parijs, 2007, 296. 
J. Vendrand-Voyer, "Labbé de Montveron Gabriel", P. ARABeYre, J.-L. HALPÉRIN en J. KRYNEN red., Dictionnaire historique des juristes français (XIIe XXe siècle), Parijs, 2007, 442.

J. Vendrand-Voyer, "Masuer (Mazuer, Masuyer) Jean", P. ArABEyre, J.-L. HALPÉRIN en J. KRYNEN red., Dictionnaire bistorique des juristes français (XIIe-XXe siècle), Parijs, 2007, 546-547.

C. VERLINDEN, Codigo de seguros maritimos segun la costumbre de Amberes, promulgado por el consulado Espanol de Brujas en 1569 (Cuadernos de Historia de Espana), Buenos Aires, 1947-1948.

C. VerLINDEN, "De zeeverzekeringen der Spaanse kooplui in de Nederlanden gedurende de XVIe eeuw", Bijdragen voor de geschiedenis der Nederlanden, 2 (1948) 191-216.

C. VERLINDEN, "Code d'assurances maritimes selon la coutume d'Anvers, promulgué par le consulat espagnol de Bruges en 1569", Bulletin de la Commission royale des anciennes lois et ordonnances de Belgique, 16 (1949) 38-142.

O. M. D. F. VervaART, Studies over Nicolaas Everaerts (1462-1532) en zijn Topica, Arnhem, 1994.

P.-E. VIARD, André Alciat, 1492-1550, Parijs, 1926.

M. VILLEY, "La promotion de la loi et du droit subjectif dans la Seconde Scholastique", P. GROSSI red., La Seconda Scolastica nella formazione el diritto privato moderno. Incontro di studio. Firenze, 16-19 ottobre 1972, Milaan, 1973, 66.

F. DE VISSCHER, "Gabriel Mudaeus", Annales de droit et de sciences politiques, publiées sous les auspices de l'Association des anciens étudiants de la faculté de droit de l'Université de Louvain, 8 (1939), 6. (overdruk)

L. VOET, De Gouden Eeuw van Antwerpen, Antwerpen, 1974.

Volumen tractatuum ex variis iuris interpretibus collectorum I-IX, Lyon, 1535.

Volumen tractatuum ex variis iuris interpretibus collectorum I-XVII, Lyon, 1549.

M. VAN DER VRUGT, De criminele ordonnantiën van 1570. Enkele beschouningen over de eerste strafrechtscodificatie in de Nederlanden, Zutphen, 1978.

U. WAGNER, "Rechtsprechungs- und konsiliensammlungen. Niederlande", H. COING red., Handbuch der Quellen und Literatur der Neueren europäischen Privatrechtsgescbichte, II/2, Munchen, 1976, 1399-1430.

G. WALTER, "Rechtsprechungs- und konsiliensammlungen. Frankreich", H. COING red., Handbuch der Quellen und Literatur der Neueren europäischen Privatrechtsgeschichte, II/2, Munchen, 1976, 1223-1270.

N. Warembourg, Guy Coquille et le droit français. Le droit commun coutumier dans la doctrine juridique du XVIe siècle, Ongepubliceerd doctoraatsproefschrift, Université de Lille II, Faculté des sciences juridiques, politiques et sociales, 2005.

A. WATSON, Legal Transplants. An Approach to Comparative Law, Edinburgh, 1974.

C. WAUTERS, Le droit commercial belge mis en rapport avec la jurisprudence ... précédé d'une introductionrenfermant le texte flamand et la traduction française de l'ancienne coutume commerciale inédite d'Anvers, promulguée dans cette ville en 1609 sous le règne des archiducs Albert et Isabelle, 2 dln., Brussel-Antwerpen, 1867. 
H. VAN DER WEE, The Growth of the Antwerp Market and the European Economy (fourteeth sixteenth centuries), 3 dln., Den Haag, 1963.

K. WEIDENVELD, "Faure (Fabri) Jean”, P. ARABEYRE, J.-L. HALPÉRIN en J. KRYNEN red., Dictionnaire historique des juristes français (XIIe-XXe siècle), Parijs, 2007, 321-322.

P. WEIMAR, "Die legistische Literatur der Glossatorenzeit", H. COING red., Handbuch der Quellen und Literatur der Neueren europäischen Privatrechtsgeschichte, I, Munchen, 1973, 129-260.

P. WeIMAR, "Martinus Gosia", Lexikon des Mittelalters, VI, Munchen, 1993, 351.

P. WEIMAR, "Baldus de Ubaldis", M. STOLLEIS red., Juristen: ein biographisches Lexikon von der Antike bis zum 20. Jahrhundert, Munchen, 2001, 58.

P. WEIMAR, "Jason de Mayno", M. STOLLEIS red., Juristen: ein biographisches Lexikon von der Antike bis zum 20. Jahrhundert, Munchen, 2001, 330-331.

P. WEIMAR, "Paulus de Castro", M. STOLLEIS red., Juristen: ein biographisches Lexikon von der Antike bis zum 20. Jahrhundert, Munchen, 2001, 489.

A. WIJFFELS, Qui millies allegatur: les allégations du droit savant dans les dossiers $d u$ Grand Conseil de Malines (causes septentrionales, ca. 1460-1580) (Rechtshistorische studies 11), Leiden, 1985.

A. WiJfFELS, "Een prince ende heere van justitie. Un avis de G. Mudaeus sur l'organisation d'une table de prêt", Tijdschrift voor Rechtgeschiedenis, 64 (1996), 113-139.

L. WinkEL, "Cujas (Cujacius) Jacques", P. ARABEYRE, J.-L. HALPÉRIN en J. KRYNEN red., Dictionnaire historique des juristes français (XIIe-XXe siècle), Parijs, 2007, 220-222.

A. WOLF, "Die gesetzgebung der entstehenden Territorialstaaten", H. COING red., Handbuch der Quellen und Literatur der Neueren europäischen Privatrechtsgeschichte, I, Munchen, 1973, 517-800.

H. VAN DE WOUW, "Opmerkingen over de aandacht voor het Romeinse recht in de Middeleeuwen”, Tijdschrift voor Rechtsgeschiedenis, 61 (1993) 335-348.

M. YANS, "La rédaction de la coutume liégeoise", Bulletin de l'Institut archéologique liégeois, 67 (1949-1950), 379-384.

J. Yver, "Les deux groupes de coutumes du Nord", Revue du Nord, 35 (1953), 197-220, en 36 (1954), 5-36.

J. Yver, Le droit romain en Normandie (avant 1500) (Ius Romanum Medii Aevi. Pars V, 4, a), Milaan, 1976.

J. Yver, "Le président Thibault Baillet et la rédaction des coutumes (1496-1514)", Revue historique de droit, I (1988), 19-42.

C. ZENDri, "Rebuffi (Rebuffe, Rebuffus) Pierre", P. ARABEYRE, J.-L. HALPÉRIN en J. KRYNEN red., Dictionnaire historique des juristes français (XIle-XXe siècle), Parijs, 2007, 656-657. 



\title{
HOOFDSTUK 1
}

\section{DE RECHTSBRONNEN VAN DE INNOVATIES BINNEN DE ANTWERPSE CONSUETUDINES COMPILATAE (1608)}

\author{
"..., dat een groot deel vande nieum te hove \\ overgesonden costumen, niet en syn costumen oft \\ oude bercommen, (hoowel soe voor sulcx benne \\ hoocheden aengedient worden), maer wel eenen \\ hoop niew geinventeerde ende imaginaire rechten, \\ diemen onder deser stadt costumen beeft \\ vermengelt." 71
}

Van zodra de Consuetudines compilatae waren voltooid, waren ook de meningen snel gevormd. Er waren pro's; er waren contra's. Maar in de eerste plaats was men verdeeld. ${ }^{72}$ Het stadsbestuur van zijn kant verdedigde het geheel -in zijn katholieke ijver- met hand en tand en wees er bij de Aartshertogen Albrecht en Isabella dan

71 ANTWERPEN, Stadsarchief, Vierschaer, nr. 64: JACQUES VAN UFFEL, Adviezen betreffende de Costumen en de revisie, 10 augustus 1610. Bij deze wil ik Dave de Ruysscher bedanken voor de transcriptie van deze documenten. Hij is als assisterend onderzoekend personeel verbonden aan de onderzoekseenheid 'Romeins recht en rechtsgeschiedenis' van de Katholieke Universiteit van Leuven. Ook de volgende keren wanneer ik citeer uit of verwijs naar documenten afkomstig van de bundels in nummer 64 van het Archief van de Vierschaer, gaat het om transcripties van de hand van Dave de Ruysscher.

Ook wil ik aan het citaat van Jacques van Uffel nog toevoegen dat het in Frankrijk aan het einde van de zestiende eeuw niet anders klonk. Ter illustratie citeer ik de Franse jurist René Choppin (1537-1606), die zich op een gelijkaardige manier uitliet over de gereformeerde, Franse costumen: "les coustumes nouvellement réformées que nous fueilletons, sont plutost des loix et des ordonnances des commissaires commis pour la réformation qu'ils ont faite de leur jugement, que non pas les anciens statuts des coutumes des provinces" (Geciteerd naar J. KRYNEN, "Voluntas domini regis in suo regno facit ius. Le roi de France et la coutume", A. I. FERREIROS red., El dret comú $i$ Catalunya: actes del VII Simposi Internacional (Barcelona, 23-24 de maig de 1997), Barcelona, 1998, 80.) Krynen laat ook andere contemporaine rechtsgeleerden, zoals Etienne Pasquier (15291615) en Guy Coquille (1523-1603) aan het woord. Ook zij laten zich ontkennend uit omtrent de gewoonterechtelijke zuiverheid van de geredigeerde, provinciale costumen binnen de grenzen van het Franse koninkrijk.

${ }^{72}$ GOTZEN, "De costumiere bronnen", 123-124. 
ook op met wat voor een speciale zorg deze compilatie tot stand was gebracht. ${ }^{73}$ Anderzijds was er het, soms vernietigende, oordeel van de tegenstanders, vaak voorstanders van de protestants georiënteerde Consuetudines impressae. Sta me toe hieromtrent te wijzen op het anonieme en niet-gedateerde schotschrift dat de compilatoren vergelijkt met cuisiniers nouveaux et apprentifs, lesquels pour faire paroistre leur capacité en ce mestier ne cessent de tellement mesler diverses saulsen, brouets, berbes et especeries, qu'à la fin tout leur cuisson ne sent que mauvais potage, ausquels cuisiniers se refere Plaute en son Mostellaria, disant: Ibidem olent, quasi cum una multa Jura confundit coquus. ${ }^{74}$ Er verschenen echter ook meer gefundeerde, kritische uitlatingen. Zo adresseerde de Antwerpenaar Jacques Van Uffel zich, als uwen dienaer, op 9 augustus 1610 tot het stadsbestuur met zijn Redenen tot handhoudinge van de costumen deser stadt, tegen alle nieuwigheden. ${ }^{75}$ Hierin verweet Van Uffel de commissie allerlei normen ingevoerd te hebben die geen oude costumen waren. Bovendien beschuldigde hij de leden ervan oude gewoonterechtelijke regels te hebben geschonden: ..., maer oock hen bebben verstont een menichte nieuwe wetten daer in te voegen, doude costumen in diverse puncten wechnemende, ende in plaetse van dien nieuwe wetten subrogerende, naer hen goetduncken ende fantasye, oft wel naer de opinie van eenige docteurs, glossisten oft commentarijsten d'onsekerheyt vande welcke ende repugnantie genuch haer selven is confonderende. ${ }^{76}$ Verder wees hij op de onmogelijkheid van autoritaire rechtsgeleerden, maar ook van de vorst, om de gangbare gewoonte te wijzigen. Bovendien zouden de novateurs te weinig rekening hebben gehouden met de Consuetudines impressae, die mits enkele wijzigingen (verminderen ende besnyden), samen met de Consuetudines antiquae als basis hadden moeten dienen voor de totstandkoming van een nieuwe definitieve tekst. Ten aanzien van het probleem van onvolledigheid dat zich eventueel op deze manier zou kunnen voordoen, verwijst Van Uffel naar de inspirerende kracht van de turbenonderzoeken, verzameld in de verschillende turbenboeken van de stad.

Gotzen van zijn kant verwijt diezelfde Jacques Van Uffel vereering van het oude om het oude en een gemis aan een doordachte en overtuigende argumentatie. Zelf wil ik in dezen wijzen op het traktaat dat de Antwerpse stadssecretaris, Hendrik de Moy, schreef over de Consuetudines impressae. ${ }^{77}$ In de proloog vertelt de auteur hoe de Consuetudines impressae werden gecompileerd op basis van de Consuetudines antiquae, Consuetudines antiquissimae, turben, stedelijke privileges of privileges van het land van Brabant. "Oft oock andersins uuyt de gescreven rechten."

73 GOTZEN, "De costumiere bronnen", 117.

${ }^{74}$ ANTWERPEN, Stadsarchief, Vierschaer, nr. 64, Adviezen betreffende de Costumen en de revisie.

75 SAA, Vierschaer, 64: VAN UFFEL.

76 SAA, Vierschaer, 64: VAN UFFEL.

77 ANTWERPEN, Stadsarchief, Vierschaer, nrs. 21-23: HENDRIK DE MOY, Tractaat over de Costuymen. Cfr. R. DEKKERS, Bibliotheca Belgica Juridica. Een bio-bibliografisch overzicht der rechtsgeleerdheid in de Nederlanden van de vroegste tijden af tot 1800 (Verhandelingen van de koninklijke Vlaamse academie voor wetenschappen, letteren en schone kunsten van België. Klasse der Letteren. Nº14), Brussel, 1951, 119.

78 SAA, Vierschaer, 21: DE MOY, Tractaat, fol. 1r. Dit ligt voor de hand wanneer men bedenkt dat het stadsbestuur expliciet heeft opgeroepen tot het aanwenden van het Romeinse recht. 
wetenschappelijke literatuur niet altijd even duidelijk is geweest wat er exact onder gescreven rechten verstaan mag worden, staat het evenwel buiten kijf dat het hier geen lokaal -in dit geval Antwerps- gewoonterecht betreft. ${ }^{79}$ Desondanks blijkt Jacques Van Uffel hier geen aanstoot aan te nemen. Men kan dus terecht de vraag stellen naar de daadwerkelijke oorzaak van Van Uffels antipathie jegens de Consuetudines compilatae, gezien zijn gebrekkige argumentatie en inconsequente houding. Werd Van Uffel misschien gedreven door wrok ten aanzien van alles wat getuigt van enig katholicisme. Of is zijn aversie gerelateerd aan de (familiale) band die er mogelijk bestaat tussen hem en Severinus Van Uffel, die in 1584 en 1607 een uitgave van de Consuetudines impressae had verzorgd? ${ }^{80}$ Bovendien behoorde laatstgenoemde, als greffier, tot de commissie die in 1580 werd samengesteld ter revisie van de Consuetudines antiquae. Bijgevolg heeft hij mee aan de wieg van de Consuetudines impressae gestaan. ${ }^{81}$ Daarenboven wordt hij tevens vermeld als secretaris van de styl ende maniere van procederen, welke samen met de Consuetudines impressae in 1582 werd uitgegeven. ${ }^{82}$ Ook deze betrokkenheid kan zijn antipathie ten overstaan van de vierde redactie verklaren. Wat de ware toedracht moge geweest zijn van Jacques Van Uffels vernietigende oordeel ten aanzien van de Consuetudines compilatae, wens ik hier in het midden te laten. Des te meer boeit me -en dit kan ik bovendien ook daadwerkelijk achterhalen- de mate waarin de geuitte kritiek gerechtvaardigd is. De vraag naar de oorsprong van het geredigeerde gewoonterecht is overigens terecht. Hebben we werkelijk te maken met zuiver costumier recht dat louter in een legislatief kleedje werd gestoken? Of gaat het daadwerkelijk om een poging zuivere wetgeving, onder het mom van costumier recht, ingang te doen vinden? ${ }^{83}$ Met andere woorden, gaat het om verdoken wetgeving of zijn de compilaties oprechte weergaven van de contemporaine costumiere werkelijkheid? Dankzij de vier boeken Memorien op de costumen ben ik in staat de

Cfr. GOTZEN, "De costumiere bronnen", 110: "De collegiale akte van 1578 gebood reeds onomwonden de inlassching van geschreven, d.i. hoofdzakelijk Romeinsch recht." Zelf heb ik in de akte enkel de opdracht de costumen deser stadt te confereren mette gheschreven rechten kunnen terugvinden. (Cfr. ANTWERPEN, Stadsarchief, Privilegiekamer, nr. 552: Acte collegiale vande collectatie vande rechten ende Costumen van Antwerpen, onder t'consulaet van Heer Jan van Straelen, Heer van Merxen, Dambrugge, etc. Buyten-Borgemeester, Heer Willem de Vos, Binnen-Borgemeester. 18 juli 1578, fol. 204r204v.)

${ }^{79}$ Omtrent de betekenis van de 'geschreven rechten': cfr. P. L. NEVE, “Ius commune oftewel 'gemeen recht': traduttore traditore?”, O. E. TELLEGEN-COUPERUS, P. L. NEVE en J. W. TELLEGEN red., Tertium Datur. Drie opstellen aangeboden aan Prof. mr. J. A. Ankum, Tilburg, 1995, 3-58.

80 Rechten ende costumen van Antwerpen, S. VAN UFFELE ed., Keulen, 1584. Recbten, ende costumen van Antwerpen, S. VAN UFFELE ed., Keulen, 1607. De Consuetudines compilatae loven en aanprijzen zou een averechts effect kunnen hebben op de verkoopcijfers van de gedrukte Consuetudines impressae.

${ }^{81}$ Cfr. ANTWERPEN, Stadsarchief, Vierschaer, nr. 64: Acte collegiale nopende de recollectie van de Rechten ende Costumen van Antwerpen. 18 juli 1580.

82 Cfr. Styl ende Maniere van procederen, II, 599-685.

83 Cfr. GOTZEN, "De costumiere bronnen", 120-121: "Op geheel de lijn zien we den Staat geleidelijk meer de plaatselijke vrijheden beperken. Ook te Antwerpen ..." 
zuiverheidsgraad te achterhalen van de Antwerpse Consuetudines compilatae. Zij kunnen een idee geven van de impact van niet-costumiere rechtsbronnen op het gewoonterecht. Inderdaad, niet alleen wetgeving speelt hier een rol. Ook andere brontypes hebben hun invloed gehad. Zo kan, op basis van de academische opleiding welke de protagonisten van de commissie hebben genoten, zowel een uitgesproken romanisatie als verwetenschappelijking van het gewoonterecht vermoed worden. De redacteurs fungeren namelijk als een gateway waarlangs nog meer geleerd recht het costumiere bekken instromen kan. Ook laten ze zien in hoeverre er gekeken werd naar vroegere voorbeelden van compilaties zowel van eigen als van vreemde bodem. Andere vooraanstaande steden uit de Zuidelijke Nederlanden, zoals Brussel, Mechelen, Gent, etcetera hadden hun homologatie immers reeds enige tijd achter de rug. Hun gebruik kon de homologatie van de eigen redactie alleen maar bevorderen. Ook Gotzens conjectuur van een grote invloed van de Franse rechtsleer zal in dit hoofdstuk aan bod komen. ${ }^{84}$

Deze Memorieboeken zijn met andere woorden het ideale instrument voor de historicus om te achterhalen in hoeverre de negatieve houding van Jacques Van Uffel aanvaard kan worden. Hoe dan ook, men mag bij dit alles niet uit het oog verliezen dat de infiltratie van costumier-vreemde elementen in het Antwerpse gewoonterecht niet noodzakelijk een schending hoeft in te houden van datzelfde ius proprium. De opgenomen wetgeving of Romeinsrechtelijke regels kunnen immers evenzeer een getrouwe weergave of bevestiging zijn van wat op dat moment op costumier vlak gebruikelijk was. In hoeverre dit ook werkelijk een afspiegeling is van de usus quotidiana kan in principe enkel onderzocht worden via een vergelijkend onderzoek tussen de bronnen van de stedelijke rechtspraak en dat wat in de Consuetudines compilatae terug te vinden is. Zelf zal ik de zuiverheid van de vierde redactiepoging niet op deze manier controleren, aangezien dit alles niet past binnen het tijdsbestek dat voor deze doctorale dissertatie vooropgesteld was. Wel zal ik aandacht hebben voor de wijze waarop deze niet-costumiere elementen in de Memorieboeken worden gepresenteerd. Worden zij als vijandig ervaren of eerder als een officiële confirmatie van de eigen dagdagelijkse gebruiken? In het eerste geval kan niet langer volhard worden in de zogenaamde costumiere zuiverheid van de Antwerpse costume. Van zodra er sprake kan zijn van een daadwerkelijke receptie van vreemde, nietgewoonterechtelijke elementen, steken fenomenen als romanisatie, verwetenschappelijking, lexificatie, technocratisering, rationalisering, etcetera de kop op. Dit alles komt in de derde paragraaf van dit hoofdstuk uitgebreid aan bod. De tweede paragraaf is louter descriptief. Hierin zal ik per deel de mate van innovatie ten opzichte van de Consuetudines impressae weergeven, aangevuld met een beschrijving van de verschillende rechtsbronnen die aan de oorsprong liggen van deze vernieuwing. De eerste paragraaf zet de methode uiteen die ik bij dit alles heb toegepast. Een vierde paragraaf tracht het belang in te schatten van de Consuetudines compilatae en dit in vergelijking met de Consuetudines impressae.

${ }^{84}$ GOTZEN, "De costumiere bronnen”, 200. 


\section{PARAGRAAF 1}

STATUS QUAESTIONIS EN METHODE

In hoeveel superlatieven er vandaag de dag ook over de Consuetudines compilatae wordt geschreven, vier eeuwen geleden liep klaarblijkelijk niet iedereen even hoog op met deze vierde Antwerpse redactie. Het verhaal van tegenstanders als Jacques Van Uffel, die de compilatie vergeleken met soepmakerij, is reeds an bod gekomen. Dit eerste hoofdstuk onderzoekt in hoeverre deze aantijgingen als gerechtvaardigd kunnen worden beschouwd. Hiertoe zal ik dieper ingaan op het innovatieve karakter van de Consuetudines compilatae ten opzichte van de Consuetudines impressae. In hoeverre kunnen de commissieleden als echte novateurs omschreven worden? In welke mate gaat het daadwerkelijk om costumier-vreemde elementen? Met andere woorden: waar, in welke mate en op welke juridische basis werden de Consuetudines impressae vernieuwd?85 Deze taak tot een goed einde brengen, veronderstelt ten eerste een duidelijk onderscheid tussen de oude artikels aanwezig in de Consuetudines compilatae maar afkomstig van de Consuetudines impressae enerzijds en de nieuw geïntroduceerde artikels in de Consuetudines compilatae anderzijds. De eerste stap hierbij is de identificatie van de nieuw toegevoegde artikels. Wat is nieuw? En wat is vernieuwd? Enkel zij -en niet de hernomen artikels uit de Consuetudines impressae- kunnen iets bijbrengen over de redacteurs van de Consuetudines compilatae. Van zodra ik deze innovaties heb weten localiseren, kan ik op zoek gaan naar de juridische oorsprong ervan. Is deze vierde Antwerpse redactie inderdaad niet meer dan een farragine of mengelmoes van normen die geen oude costuymen zijn? Zijn de artikels dan daadwerkelijk grotendeels geinventeerde ende imaginaire rechten? Of is Van Uffels kritiek onterecht en gaat het in de eerste plaats om een inhoud die hoofdzakelijk op een costumiere basis gefundeerd is? De locatie evenals de juridische basis van deze nieuw toegevoegde artikels kan ik an de hand van de overgeleverde Memorien op de Costumen achterhalen. Zij geven immers de oorspronkelijke rechtsbronnen van elk individueel artikel aan. ${ }^{86}$

\section{Status Quaestionis}

Het uiteindelijk palet aan rechtsbronnen dat ik op bovenstaande manier bekomen zal, geeft een idee van zowel de interne als de externe invloeden, welke bepalend zijn geweest voor de zeventiende-eeuwse costumiere redacties te Antwerpen. Nooit eerder werd een dergelijke detailstudie naar de juridische basis van officiële,

85 Ik beperk me hierbij tot de inhoudelijke vernieuwing. Structurele innovaties krijgen een plaats in het derde hoofdstuk, alwaar de invloed van het juridisch humanisme, en zijn systematiseringsdrang in het bijzonder, centraal komt te staan. Met andere types van vernieuwing, zoals bijvoorbeeld op taalkundig vlak, zal ik me niet inlaten. Dit neemt echter niet weg dat er geen van zulke verschillen bestaan.

${ }^{86}$ Het reeds vernoemde traktaat van Hendrik de Moy over de Consuetudines impressae doet iets gelijkaardigs, zij het dat de overgeleverde versie (SAA, Vierschaer, 21-23: DE MOY, Tractaat.) niet helemaal volledig is uitgewerkt. Deze tekortkoming gecombineerd met de tijdslimiet waarbinnen dit project voltooid moest worden, maakt dat ik me zal beperken tot een sporadische excursie naar het traktaat, zonder welke volledigheid dan ook na te streven. 
costumiere redacties ondernomen. Voor zover er in het verleden aanzetten toe werden gegeven, hebben deze zich in de eerste plaats in Frankrijk voorgedaan. Treffend hierbij is hoezeer de aandacht in dezen in de eerste plaats uitgaat naar een fenomeen als de romanisatie van het gewoonterecht. ${ }^{87}$ Dit blijkt eveneens uit het overzicht dat Krynen geeft in zijn studie omtrent de verhouding van de Franse koning tot de gewoonte. Hij verwijst er naar de studies van Besnier en Yver met betrekking tot Normandië, Lévy met betrekking tot Anjou en Bretagne, Bart met betrekking tot Bourgogne en meer recentelijk Vendrand-Voyer met betrekking tot Berry. ${ }^{88}$ Een tweetal jaren later, in 1999, verscheen in de reeks Etudes d'histoire du droit et des idées politiques en onder leiding van opnieuw Krynen de bundel Droit romain, jus civile et droit francais. ${ }^{89}$ De compilatie bevat verschillende artikels aangaande de receptiegeschiedenis. Zo is er van de hand van Gérard Guyon een studie omtrent de romanisatie van het gewoonterecht van Bordeaux, en dan het strafrecht in het bijzonder. ${ }^{90}$ In een ander artikel gaat Jean-Louis Thireau op zoek naar de alliantie tussen de Romeinse wetten en het Franse recht. ${ }^{91}$ Jacques Poumarède op zijn beurt behandelt het Romeinse recht in relatie tot de redactie van het costumiere recht binnen het ressort van het Parlement van Bordeaux.92 Eveneens kenmerkend voor deze studies is de nadruk die steeds op de middeleeuwse contumiers tot an de vijftiende en zestiende eeuw ligt. De redacties van de nieuwe tijd genieten in dit opzicht heel wat minder aandacht.

\footnotetext{
${ }^{87}$ Cfr. KRYNEN, "Voluntas domini regis", 77: “Ainsi rédigée par des gens de justice, aucune coutume d'aucun pays coutumier n'échappe à l'emprise du droit savant."

88 R. BESNIER, La coutume de Normandie. Histoire externe. Parijs, 1935. J. YVER, Le droit romain en Normandie (avant 1500) (Ius Romanum Medii Aevi. Pars V, 4, a), Milaan, 1976. J. P. LEVY, "La pénétration du droit savant dans les coutumiers angevins et bretons au Moyen Age", Tijdschrift voor Rechtsgeschiedenis, 24 (1956), 1-53. J. P. LEVY, "La pénétration du droit privé savant dans le Vieux coustumier de Poictou", Etudes d'histoire du droit privé offertes à Pierre Petot, Parijs, 1959, 371-383. J. BART, Recherches sur l'bistoire des successions ab intestat dans le droit du duché de Bourgogne de la fin du XIIIe à la fin du XVTe siècle, Parijs, 1966. J. BART, en M. PETITJEAN, L'influence du droit romain en Bourgogne et France-Comté (Ius Romanum Medii Aevi. Pars V, 4, e), Milaan, 1975. VENDRAND-VOYER, "Réformation des coutumes et droit romain", 313381. Zie ook: J. P. LEVY, Le droit romain en Anjou, Bretagne, Poitou (d'après les coutumiers) (Ius Romanum Medii Aevi. Pars V, 4, b), Milaan, 1970. J. HILAIRE, "Coutume et droit écrit: recherche d'une limite", Mémoires de la Société pour l'histoire du Droit et des Institutions des Anciens Pays Bourguignons, Comptois et Romands, XL (1983), 153-174.

89 J. KRYNEN, Droit romain, jus civile et droit français (Etudes d'histoire du droit et des idées politiques. III), Toulouse, 1999.

${ }^{90}$ G. D. GUYON, "Les annotations de la coutume de Bordeaux et la romanisation du droit pénal”, J. KRYNEN red., Droit romain, jus civile et droit francais, Toulouse, 1999, 300-328.

${ }^{91}$ J.-L. THIREAU, "L'alliance des lois romaines avec le droit français", J. KRYNEN red., Droit romain, jus civile et droit français, Toulouse, 1999, 347-374.

92 J. POUMAREDE, "Droit romain et rédaction des coutumes dans le ressort du Parlement de Bordeaux", J. KRYNEN red., Droit romain, jus civile et droit francais, Toulouse, 1999, 329-345. In de Dictionaire de l'Ancien Régime behandelt de auteur de materie op een meer algemene manier: POUMAREDE, "Coutumes et droit écrit”, 364-371.
} 
Wat de invloeden betreft, welke in Frankrijk werkzaam waren bij de officiële redacties vanaf 1454 tot aan de reformatie onder leiding van Christofle de Thou (1508-1582), wil ik verwijzen naar de studies van Jean Yver, Jacqueline Vendrand-Voyer en René Filhol.93 Hierin hebben zij vooral oog voor de invloed van de koninklijke commissarissen en andere individuen welke nauw betrokken waren bij het homologatieproces op het redactieproces. Wat al deze studies verenigt, is dat geen van hen alle mogelijke invloeden in hun geheel bespreekt. Bovendien heb ik de indruk dat men zich steeds beperkt tot een aantal vage uitspraken waarbij de materie nooit op kwantitatieve wijze werd benaderd en de conclusies op eenzelfde manier gefundeerd. Ten aanzien van de Franse coutumes, waagt enkel Filhol zich eraan: "Quant aux règles mêmes intégrées dans les textes coutumiers, elles sont d'origine variable, et ce trait ne distingue pas les coutumes rédigées des coutumes médievales: la coutume a toujours utilisé pour son développement des sources hétérogènes: conventions entre les particuliers imitées de proche en proche, usages de grandes familles généralisés, emprunts à la doctrine, au droit savant ou à la jurisprudence." ${ }^{4}$ De bronnen blijken variabel en heterogeen te zijn, maar een beeld van hoe ze zich ten opzichte van elkaar verhouden wordt niet gegeven. Enkel ten aanzien van de hervormde coutumes van de zestiende eeuw onderlijnt Filhol het belang van de rechtsleer en de rechtspraak. Enerzijds is er de invloed van de rechtsgeleerde en gewoonterechtkenner, Charles Dumoulin. Anderzijds verwijst hij naar het voorwoord van Jean Coquille bij zijn Coutume de Nivernais, alwaar deze het als volgt heeft over de in 1580 hervormde redactie van het Parijse costumiere recht: "Les dits articles de la nouvelle coutume pour la plupart contiennent les décisions de plusieurs difficultez et diversitez d'opinions qui estoient entre les jurisconsultes françois, même qui ont été décidées par arrestz solennels." ${ }^{5}$ Ten aanzien van de redacteurs van de voorgaande hervormingen looft hij l'autorité des commissaires qui étoient grands personnages et prudhommes et fort experimentez an droit francois et aux belles décisions faites par les arrestz. de la cour." 96 Hiermee beperkt ook Filhol zich wederom tot het klassieke verhaal. Nergens is er sprake van minder prominente factoren zoals het canonieke recht, vreemd gewoonterecht of de invloed van derden op het proces.

Ook ten aanzien van de costuymen van eigen bodem, zijn er nauwelijks precedenten bekend. Opnieuw beperkt men zich tot algemene uitspraken zoals die van Gilissen omtrent de redactie van de costuymen in de Zuidelijke Nederlanden. Zo wijst hij er op dat naast stedelijke en vorstelijke ordonnanties ook de jurisprudentie en vooral de turbenonderzoeken een belangrijke bron zijn geweest voor de redacteurs van de verschillende compilaties. ${ }^{97}$ Waar Gilissen zich op baseert, is me niet duidelijk. Ten

\footnotetext{
93 Omtrent de rol van koninklijke commissarissen bij het redactieproces maar evenzeer binnen de romanisatie van het Franse gewoonterecht, zie: YVER, "Le président Thibault Baillet", 1942. FILHOL, Le premier président de Thou. VENDRAND-VOYER, "Réformation des coutumes et droit romain”, 313-381. Cfr. THIREAU, “Thou Christofle de”, 740-741.

${ }^{94}$ FILHOL, "Rédaction des coutumes", 73.

${ }^{95}$ FILHOL, "Rédaction des coutumes", 73.

96 FILHOL, "Rédaction des coutumes", 73.

97 GILISSEN, "Rédaction des coutumes", 103-104. Meer omtrent de verhouding tussen wet en gewoonte, cfr. GILISSEN, "Loi et coutume. Esquisse de l'évolution des sources du droit",
} 
aanzien van Antwerpen was er dan weer Gotzen, die, op een al even algemene wijze, de aandacht vestigde op het verrassende belang van vooral de Franse rechtsleer voor de Antwerpse commissieleden. ${ }^{98}$ Op doortastend cijfermateriaal zijn uitlatingen als deze echter nooit gefundeerd geweest. Bijgevolg lijken zij eerder het resultaat van een 'indruk' die men heeft, dan van een gegronde, wetenschappelijke analyse van historisch bronnenmateriaal. Van andere 'Belgische' compilaties heb ik geen studies kunnen achterhalen. Wel wil ik hier nog wijzen op een tweetal standaardwerken omtrent de receptie van het Romeinse recht in de Nederlanden. Het gaat hier om synthesewerken als Le droit romain en Belgique (1966) van Van Caenegem en Das Römisches Recht in den Niederlanden (1968) van Hermesdorf. ${ }^{99}$ Ook hier komt de penetratie van het Romeinse recht in het costumiere landschap uitgebreid aan bod.

Met dit eerste hoofdstuk hoop ik dan ook een eerste stap te stappen in de richting van het opvullen van deze lacune. Ik zal de juridische basis van het Antwerpse gewoonterecht uit de Consuetudines compilatae tot op het fijnste niveau blootleggen, beschrijven en beoordelen. Hiermee ligt mijn onderzoek in de lijn van de zoektocht van Vanderlinden naar interne invloeden bij het redactieproces van de Vlaamse costumen, een onderzoek dat hij reeds in 1953 startte. ${ }^{100}$

\section{Methode}

Gezien het feit dat ik me -zoals reeds eerder aangegeven- zal beperken tot de oorsprong van de artikels welke nieuw in de Consuetudines compilatae werden ingevoegd, komt het er in de eerste plaats op aan te bepalen welke artikelen als nieuw kunnen worden beschouwd en welke een herhaling zijn van een gelijkaardige norm in de Consuetudines impressae. De basisvoorwaarde om dit tot een goed einde te kunnen brengen, is het opstellen van een sluitende definitie van wat verstaan moet worden onder een 'nieuw toegevoegd artikel'. Hierbij zal ik me in de eerste plaats laten leiden door de Memorieboeken, aangezien zij -in het geval van een nieuw artikel- hun analyse beginnen met de woorden Est novus ex..., gevolgd door de formele of materiële rechtsbron waaraan dit artikel werd ontleend. Een duidelijk voorbeeld hiervan is artikel 1.4.19 waar de Memorieboeken het volgende over schrijven: Est novus hic additus ex usu. ${ }^{101}$ Dit betekent eenvoudigweg dat het artikel hier nieuw is toegevoegd op basis

1-140. GILISSEN, "Loi et coutume. Quelques aspects de l'interpénétration des sources du droit", 257-298.

98 Cfr. GOTZEN, "De costumiere bronnen", 200.

99 Beide werken zijn verschenen in de reeks Ius Romanum Medii Aevi. (R. C. VAN CAENEGEM, Le droit romain en Belgique (Ius Romanum Medii Aevi. Pars V, 5, b), Milaan, 1966. B. H. D. HERMESDORF, Das Römisches Recht in den Niederlanden (Ius Romanum Medii Aevi. Pars V, 5, a), Milaan, 1968. Vergelijkbaar met het werk van Van Caenegem, maar ouder, is de studie van Gilissen uit 1937: J. GILISSEN, "Romeins recht en inheems Gewoonterecht in de Zuidelijke Nederlanden”, Tydskrif vir hedendaagse Romeins-Hollandse reg, I (1937), 97-139.

100 VANDERLINDEN, “Essai sur la structure des textes coutumiers”, 269-293.

$101 \mathrm{Om}$ het voetnotenapparaat van deze dissertatie niet onnodig te belasten, heb ik ervoor geopteerd voor de verschillende referenties naar de Memorieboeken niet elke keer opnieuw naar de desbetreffende pagina te verwijzen. Deze kan aan de hand van bijlage 1 (Referentielijst artikelcommentaar Memorieboeken) op een uiterst eenvoudige manier worden teruggevonden. 
van de gewoonte. $\mathrm{Nu}$ is het echter zo dat men, bij strikt vasthouden aan deze omschrijving, een heleboel artikels over het hoofd ziet, daar lichte variaties op de formulering mogelijk zijn. ${ }^{102}$ Het gebeurt immers dat de Memorieboeken zich bedienen van andere uitdrukkingen, zoals Est desumptus ex..., Est additus in hac revisione ex..., Est... of Ita expresse in antiquis articulo septimo. ${ }^{103}$ Dit heeft me er toe aangezet naar een nieuwe, het zij negatieve, definitie op zoek te gaan, welke als volgt luidt: "Nieuw is elk artikel waarvoor in de Memorieboeken níet naar de Consuetudines impressae als primaire rechtsbron verwezen wordt."

Dit impliceert echter niet dat het verwijzen naar de Consuetudines impressae telkens betekent dat ik met een oud artikel te maken heb. Zo moet in een aantal specifieke gevallen een artikel toch als nieuw worden beschouwd, ondanks het voorkomen van het woord Consuetudines impressae. Ik denk hierbij in de eerste plaats aan die artikels welke gedeeltelijk nieuw en gedeeltelijk oud zijn. In de Memorieboeken zijn deze te onderscheiden aan het gebruik van volgende zinsconstructies: Est partim novus, partim ex art 8 in impressis hoc tit... of Principium est ex usu et reliqua ex $d$ art 66 in impressis pro quo est art 60 int Keurboeck. ${ }^{104}$ In zulke gevallen heb ik steeds met halve waarden gerekend. Eenzelfde voorzichtigheid is geboden daar waar de Memorien op de Costumen stellen dat een artikel nieuw is ex impressis a contrario sensu, zoals bij artikel 3.2.29 te zien is: Est desumptus ex art 2 in impressis tit van handtschriften a contrario sensu nisi quod deletis verbis, oft yet anders doende cracbt van leveringe hebbende quod nimis incertum substitu [i] mus clausulam oft yet anders doende daer doere by die muyt syne handen laet gaen, ... Het artikel werd hernomen, zij het in de omgekeerde betekenis, en bijgevolg moet het als nieuw worden beschouwd. Ook de zeldzame keren dat de Consuetudines impressae als secundaire bron werden opgevoerd, blijft het om een nieuw te definiëren artikel gaan. De Consuetudines impressae worden immers niet als primaire rechtsbron vermeld en meestal concordeert de inhoud slechts met een deelaspect van het artikel uit de Consuetudines impressae, zoals ook blijkt uit artikel 3.4.71: Est desumptus ex art 35 in antiquis, accordat quoad principium d art 62 in impressis in fine et consuet [udo] Gandens[is] rubr 16 art 7 circa medium pro residius a clausula ende soo verre sy gelycke deelen syn bebbende est art 12 in antiquiss[imis] et confirmantur foer omnia etiam consuetudo Mechlin[iensis] art 6 hoc tit. Ten vierde zijn er de situaties waarbij de Consuetudines impressae worden vermeld omdat het nieuwe artikel 'in de plaats' gekomen is van een bepaald artikel uit diezelfde Consuetudines impressae. Doorgaans wordt de vervanging van dit artikel beargumenteerd aan de hand van een 'specifieke reden'. ${ }^{105}$ Ter illustratie wijs ik hier op de situatie ten aanzien van de artikels 3.8.24/25/26/27/28: Sunt novi loco articuli 14 et 36 in impressis qui ibidem etiam novi et obscuri, ideoq[ue] explicandi erant accuratius, ut fecimus in hac postrema

De tabel geeft voor elk artikel weer op welke pagina van welk boek de commentaar wordt ingezet.

102 Over de mogelijkheid van tal van verschillende formuleringen: Cfr. GUYON, "Annotations de la coutume de Bordeaux", 305. Vandaar ook dat gedetailleerd onderzoek vereist is.

103 Cfr. respectievelijk 5.11.15, 5.11.16, 5.11.8 en 3.13.73.

104 Cfr. respectievelijk 3.4.10 en 3.5.74.

${ }^{105}$ Cfr. infra, hoofdstuk 1, paragraaf 1, Methode, 11 Specifieke reden. 
revisione ex placito bic et i bibi] citato art 3. 5. 6. 12 et 13. Een vijfde situatie die de nodige voorzichtigheid veronderstelt, is die waarbij verschillende artikels gezamelijk worden besproken in de Memorieboeken. Het is immers mogelijk dat, hoewel de bespreking begint met de stelling dat de artikels uit de Consuetudines impressae afkomstig zijn, sommige onder hen desondanks toch nieuw werden toegevoegd. Zulk een situatie deed zich onder meer voor ten aanzien van de artikels 2.5.114/115/116: Sunt desumpti ex art 39 in impressis ex usu nisi quod in hac postrema revisione po[e]na qu[a]e erat $x$ florenorum sit aucta ad xx et additus sit art 116 ob ea qu[a]e d sunt i[bi] ad ar[ticu]los proxime pr[a]ecedd. De artikels 114 en 115 zijn duidelijk oud, waar artikel 116 de volle honderd procent nieuw is toegevoegd.

Alzo ben ik er uiteindelijk toe gekomen 1801.5 artikels als nieuw te bestempelen. Bijgevolg leidt een eenvoudige aftreksom tot een totaal van 1841.5 artikels afkomstig van de Consuetudines impressae, wat de verhouding tussen oud en nieuw brengt op ongeveer 50-50. Niets is echter minder waar. In tegenstelling tot wat Gotzen dacht, liggen de zaken complexer dan op het eerste zicht lijkt. ${ }^{106}$ Gotzen meende immers een verdubbeling van de inhoud te mogen veronderstellen omwille van twee foute redeneringen: ten eerste rekende hij de Ordonnantie op de styl ende maniere van procederen (1582) tot het totale aantal artikels van de Consuetudines impressae en ten tweede hield hij geen rekening met de eliminatie- en splitsingsmogelijkheden welke er bestaan. Oude artikels van de Consuetudines impressae kunnen immers niet alleen verdwijnen, zij kunnen binnen de Consuetudines compilatae evenzeer opgesplitst worden in meerdere nieuwe artikels. Zo werd bijvoorbeeld artikel 1 van titel XXXIV (Van levering) uit de Consuetudines impressae in de Consuetudines compilatae opgesplitst in vijf nieuwe artikels, namelijk 3.9.3, 3.9.4, 3.9.5, 3.9.6 en 3.9.8. In zulke gevallen kan er van innovatie echter geen sprake zijn, hoewel dit louter op basis van het aantal artikels wel zo lijkt. ${ }^{107}$ Het is bijgevolg van kapitaal belang de situatie van een andere kant te benaderen. In concreto moet men op zoek naar de hoeveelheid verschillende artikels, afkomstig van de Consuetudines impressae, welke worden hernomen. Op basis van de Memorieboeken ben ik zo tot de vaststelling gekomen dat slechts 1255 verschillende artikels uit de Consuetudines impressae op een totaal van 1446 -de styl ende maniere van procederen van 1582 niet meegerekend- in de Consuetudines compilatae werden hernomen. Met andere woorden, 191 artikels uit de Consuetudines impressae werden niet langer weerhouden en dus uit de redactie geëlimineerd. Dit zijn 191 artikels welke Gotzen

106 GOTZEN, “De costumiere bronnen”, 117-118.

107 Een ander voorbeeld is terug te vinden bij de artikels 3.8.41/42/43/44/45/46/47/48. Allen werden zij onttrokken aan eenzelfde artikel uit de Consuetudines impressae, met name artikel 35 van titel LVII (Van contracten ...): Sunt desumpti ex articulo 35 in impressis et 27 in antiquis $d$ tit van contracten, et accordat 65 in antiquissimis d tit van schepenebrieven nisi quod in hac postrema revisione, pleraq[ue] q[uae] intricata et obscura videbantur, accuratius et distinctius sint explicata ex usu. Met betrekking tot de artikels 5.17.47/48/49, die teruggaan op eenzelfde artikel uit de Consuetudines impressae, stellen de Memorieboeken dit expliciet: Sunt desumpti ex articul[o] xlii in impressis $d$ tit van vonnissen amputatis superfluis en [de] onder andere vande teeckeninge vanden borgem [eeste]re ob ea qua[e] diximus art 17 et 18 boc tit et divisimus totam materiam in plures articulos ut melius intelligeretur. 
over het hoofd heeft gezien. Dat ik nu -volgens onze eerste berekening- toch met maar liefst 1841.5 artikels word geconfronteerd die volgens de Memorieboeken hun oorsprong in de Consuetudines impressae kennen, is louter het gevolg van de splitsingsmogelijkheden. De 1255 weerhouden artikels uit de Consuetudines impressae werden in de Consuetudines compilatae opgesplitst in 1841.5 nieuwe artikels. Methodologische herzieningen als deze hebben tot gevolg dat de innovatieve waarde van de Consuetudines compilatae groter is dan tot nog toe werd aangenomen. De verhouding oud-nieuw is niet langer 1841.5-1801.5, of circa fifty-fifty zoals Gotzen eertijds aangaf, maar wel 1255-1801.5 of procentueel ongeveer 40-60.

Het innovatieve karakter wordt echter nog groter van zodra ik rekening houd met die artikels welke in de Memorieboeken als ex impressis werden omschreven, maar welke bij hun overgang naar de Consuetudines compilatae lichte tot meer ingrijpende, inhoudelijke en/of vormelijke mutaties zijn ondergaan. In de Memorieboeken bedient men zich meestal van de uitdrukking nisi quod ter aanduiding van zulke bescheiden metamorfoses. ${ }^{108}$ Hierbij kan nisi quod vertaald worden als 'behalve dat', zoals duidelijk wordt in het volgende voorbeeld met betrekking tot de artikels 1.12.17/18 waar men zich van de Nederlandse variant heeft bediend: Ex art 20 in impressis tit van opdrachten et 3 inde voorschreven ordonnantien vanden jaere 1593 behalvens datmen ten aengeven vande secretarisen, ende stoelclercken, de straeten die te voorens waeren gestelt bij wijcken als nu geordonneert heeft te stellen ordinel litterarum als gereeder ende min ondersueck hebbende. Een nog sprekender voorbeeld is te vinden ten aanzien van de artikels 1.14.2/3/4/5 waar overigens ook het confessionele aspect van de redactie aan bod komt: Sunt desumpti ex art 2 in impressis et 3 in antiquis et antiquissimis, nisi quod in impressis pleraque omissa erant que tangebant religionem, ideoque merito restituta. Het is echter ook mogelijk dat andere termen worden gehanteerd. Ik denk bijvoorbeeld an sed cum ('maar waar/terwijl') zoals in de artikels 2.5.23/24: Sunt ex art 81 in impressis 6 in antiquiss[imis] hoc tit, et tit van successien art 32, quibus consentit jus scriptum in $L$ inter $17 C$ de pr[a]ed[iis] et alijs rebus min [orum] sed cum in impressis requirantur o[omnin] o commissarij, et in antiquiss [imis] $d$ art 32 amici vel commissarij nobis visum utrumque coniungere, ita tamen ut amici a magistratu authorisati pr[a]eferantur, et commissarij veniant in subsidum deficientibus amicis ut $d$ art 6 in antiquissimus hoc tit et cum eo consentit turba d[icti] Henrici van Berchem int turbboeck. fol 28 verso, et sane amici et consanguinei sunt plerunque commodiores ad bunc effectum quam commissarij qui omnum rerum sunt ignari; of het middelnederlandse muytgenomen dat zoals bij de artikels 4.11.286/287: Sunt desumpti ex art 8 int placcaet vanden jaere 1563 hoc tit et 20 in dat vanden jaere 1570 uuytgenomen dat men goet gevonden heeft de versekeringe vande schepen toe te laeten totte twvee

108 De aanwezigheid van de woorden nisi quod impliceert echter niet altijd het bestaan van een gewijzigd artikel dat reeds deel uitmaakte van de Consuetudines impressae. Het gebeurt ook, weliswaar uiterst zelden, dat men met dezelfde woorden nisi quod wijst op verschillen welke zich voordoen in een nog oudere redactiepoging. Dit is bijvoorbeeld het geval ten aanzien van artikel 2.1.167, alwaar het artikel aan zijn variant in het Guldenboeck wordt vergeleken: Est ex art 93 in impressis cum quo accordat 49 in antiquis hoc tit 38 in antiquissimis tit van successien 34 et 77 int guldeboeck, nisi quod ibi desint verba, oft binnen cortten tyt daer naer, qu[a]e minus considerate addita sunt in impressis, et propterea bic quoque omissa ut allegata i[n] art 161 adde i[n] art 169 ubi hac plenius applicantur. 
derdendeelen vande weerde in plaetse vande hellicht byde voors[creven] placcaeten geordonneert et ita expresse habet ordinatio Amstelredamensis art 10 babentque equissimam rationem ut dictum $i[n]$ tit van schipuracht art 45 et seqq.

Ook de mutatie in se kan verschillende gedaanten aannemen. Zo zijn er enerzijds de vormelijke vernieuwingen, waarbij de modificatie in de eerste plaats linguïstiekgrammaticaal van aard is, welke staat tegenover de inhoudelijke wijzigingen waar de mutatie eerder van juridisch-technische aard is. Een voorbeeld van de eerste soort is te vinden bij artikel 2.5.31: Est 14 in impressis ex usu, et consequentia art $1 d$ ordina[tio] pupillaris, ubi dicitur quod parentes cogantur liberis procurare tutores, quod pr [a] esupponit ipsos met [?] tutelam non habere, sed videtur quod stijlus posset leviter mutari deleta linea i[n] verbo waere et restituendo $i[n]$ linea final hoc modo momboir oft momboiresse over de selve kinderen waere gestelt. Ook nadere verklaringen behoren in wezen tot deze categorie: Sunt etiam ex..., id suppletum sub obscure in impressis et nos apertius declaravimus art 140 ad c[lausu]lam, sonder daer toe, ... ${ }^{109}$ Inhoudelijke wijzigingen daarentegen tasten de inhoud aan: Est ex art 91 in impressis ..., sed mutavimus in impressis principium ut conveniret pr [a]ecedd. .. ${ }^{110}$ Hier kan het verder ook gaan om toevoegingen: Est 41 in impressis, 13 in antiquis 49 in antiquissimis, 39 int guldeboeck addita bic clausula ten waere bij voorgaende authorisatie vande[n] weth ex ijs qu[a]e dicuntur i[n] art 39 et 61111, weglatingen: Sunt desumpti ex articul[o] 3 in impressis ... et ex eo nos delevimus verba oft aen syn huys gesin, nam ... ${ }^{112}$, en 'restituties': Est 7 in impressis ..., nisi quod in impressis desint verba, als sy kinders van priesters, religieusen, oft geordende persoonen, qu[a]e nos restituimus ex antiquis et antiquissimis, et... ${ }^{113}$ Soms betreft het louter een aanpassing van de strafmaat zoals in artikel 2.5.62: Est clausula fin art 17 in impressis et 1 ordinat[io] pupillaris de anno 1495 nisi quod auximus pa[e]nam van sesse Bourgoensche guldens tot twintich guldens, nam illa hoc tempore nimis exilis pr[a]esertim apud ditiores, qui s[a]epissime ta[men] in ijs peccant. Een derde type van modificaties is van structurele aard. Zo werd bijvoorbeeld het elfde artikel van de titel omtrent de executie van civielrechtelijke vonnissen uit de Consuetudines impressae behouden in de Consuetudines compilatae, het zij opgesplitst in twee afzonderlijke artikels, namelijk 2.17.93/94. De Memorieboeken formuleren dit als volgt: Sunt desumpti ex articulo 11 in impressis d tit van vonnissen nisi quod eum diviserimus in duos ut res esset clarior. Opnieuw is dit een geval dat het innovatieve karakter van de nisi quod-gevallen sterk relativeert.

Tot slot zijn er nog de schijnbare mutaties, waarbij de Memorieboeken spreken van clausules die zouden toegevoegd kunnen worden, maar daarom niet daadwerkelijk werden toegevoegd. Dit was onder meer het geval bij artikel 2.5.76: Est 65 in impressis ex usu et ex eodem usu, et jure scripto posset addi exceptio ad finem, ten waere dat bij de momboirije maer voor seeckeren tyt, oft tot seeckeren gevalle hadde aenveert, met consent van de weth oft weesmeesters, ende dat den selven tyt, oft geval oock gecommen waere et articulus erit plenior, et pertinebit etiam ad utilitatem pupillorum, ut saltem pro certo tantopere commidium, securum, et sibi utilem tutorem inveniant. Vergelijkbaar is de situatie waarbij men aangeeft wat een

$1092.1 .139 / 140$.

110 2.1.169.

1112.1 .64

$1124.2 .13 / 14$

1132.4 .23 . 
bepaalde instantie graag veranderd had gezien, maar wat desondanks niet veranderd werd. Ik denk aan artikel 1.1.3: Est 3 et 4 in impressis, et iuris, vide text in L 2 Alphenus 87 et $L$ aedificia 139 et ibi Alciat[us] Rebuff[us], Cepolla et alii ff duverb [lees, de verborum] signif[icatione] sed nota dat de heeren commissarissen eenige swaericheyt schenen te vinden in verbis ende d'ingesetenen aldaer zijn vrij van alle beden ende meynden datmen in plaetse van dyen behoorden te stellen, ende d'ingesetenen aldaer en geven intbesunder egeene beden, et illa videtur mens nan [lees: $\mathrm{nam}$ ] recto civitate contribuente, etiam illi contribuunt, et in genero et cum corpore, non separatim, quaro ita mutetur.

Door deze mogelijkheid van schijnbare mutaties, de grote verscheidenheid aan modificaties, de verschillende maten waarin zij zich kunnen voordien en de beperkte inhoudelijke consequenties van vele onder hen, is het uiterst moeilijk gebleken zulke innovaties kwantitatief voor te stellen en te 'verrekenen'. ${ }^{114}$ Soms gaat het immers louter om een eerder oppervlakkige, vormelijke aanpassing waarbij het slechts één woord betreft, zoals bijvoorbeeld met betrekking tot de artikels 2.1.1/2: Ex art 1 in impressis ... cogita tamen an $d$ art 2 in fine loco verbi, onbehoorlijcke non possit et debeat poni onredelijck bespreeck nam rem melius explicat. Men beperkt zich tot een betere uitleg van het artikel. Een andere keer gaat het om halve of volledige zinnen waarbij er bovendien ook iets substantieels aan het artikel werd gewijzigd of toegevoegd: Pars altera $d$ art 90 in impressis 47 in antiquis hoc tit et 27 in antiquissimis tit van successien, nisi quod nos art 62 ex jure scripto et consuet[udine] Mechlin[iae] art 42 hoc tit addiderimus die den staet contradiceren wilt hem ierst verclaeren moet voor erffgenaam binnen den tyt daer toe te stellen,...115 Omdat het nu juist zo moeilijk is deze wijzigingen aan de hand van een kwantitatieve waarde te taxeren, en hen zo, naar gelang hun relatieve impact op innovatief vlak, in rekening te brengen, heb ik ervoor geopteerd hen buiten beschouwing te laten. Hoezeer sommige oude artikels uit de Consuetudines impressae op het eerste gezicht ook mogen gewijzigd zijn, ik beperk me tot die artikels welke geheel nieuw zijn toegevoegd aan de Consuetudines compilatae.

De taak van de novateurs moet dus nog ingrijpender zijn geweest als men in eerste instantie meent te mogen geloven. De verhouding tussen oud en nieuw neigt immers

114 Omtrent de beperkte inhoudelijke consequenties van deze wijzigingen wil ik ter illustratie verwijzen naar artikels als 3.9.11/12/13 (Sunt desumpti ex articulo $6^{\circ}$ tam in impressis quam antiquis hoc tit et 17 in antiquissimis tit van schepenebrieven, accordat de voers[chreven] ordonnancien vande leveringe articulo $2^{\circ}$ et $3^{\circ}$ preterquam quod in impressis et bic articulo 13 addita sint verba, als die hem verbuert oft geleent syn om buys te bouden quae suppleta ex articulo 15 in antiquis et 48 in antiquissimis in fine tit van schepenebrieven.), 5.6.23/24 (Sunt desumpti ex articulo 7 in impressis et fundator in tractatu cum Bredaniis facto 20 aprilis 1437 geconfirmeert by hertoch Philips van Bourgoignien a[nno] 1461 sed videtur quod ad finem articul[em] 23 loco verbi tuygen posset poni overtuygen et $i[n]$ art 24 mutari leviter principum hoc modo en [de] oft alsulcke poorters alhier warden overtuycht en [de] verwonnen vant gene bun opgeleght oft geheyscht wordt, soo moeten die ut textus sit paulo clarior et verba significatiora.), 5.11 .15 (Est desumptus ex art 20 vande ordonnantie vanden 24 octob[er] 1592 nisi quod in hac revisione restrinxerimus ar[ticu]lum ad causam pra[e]cedentis nam alioqui nulla estratio quare admitti debeat tum ne partes scripturis et sumptibus onerentur tum ne causa detur de allegatis aliquid mutandi ut $\int$ art 13.), 6.2.19/20 (Sunt etiam novi in hac revisione ex allegatis $\int$ art 17 et reliqua desumpta unyte voors[creven] ordonnantie van Hollandt art 16 nisi quod magis temperavimus et acommodavimus nostris moribus.)

115 2.1.161/162. 
meer naar 30-70 dan 50-50. Slechts één factor zou als compenserend effect kunnen optreden, met name de zogenaamde Ordonnantie op de Styl ofte Maniere van procederen die als bijlage achteraan de Consuetudines impressae aan de compilatie werd toegevoegd. Van zodra men de artikelen in de Consuetudines compilatae afkomstig van deze ordonnantie ook als oud zou beschouwen, dan neemt het innovatieve karakter plots spectaculair af. De ordonnantie bevat immers maar liefst 276 artikels in totaal. Ik heb echter mijn redenen om dat niet te doen. Ten eerste wil ik enkel appels met appels vergelijken. Bijgevolg vergelijk ik enkel op zich staande redactiepogingen als afgerond geheel. Ten tweede hanteren de Memorieboeken zelf het incipium Est novus ex... wanneer ze het hebben over artikels afkomstig van de styl ofte maniere van procederen, wat aantoont dat ook de redacteurs hen als nieuw in de compilatie beschouwen.

Mijn definitie, inclusief de vele uitzonderingen die haar regel bevestigen, heeft het mogelijk gemaakt alle artikels uit de Consuetudines compilatae te polariseren over een oud en nieuw kamp. Het is te verwachten dat het aandeel van elk kamp zal variëren van deel tot deel, titel tot titel en zelfs paragraaf tot paragraaf. Zo wordt ook door tabel 1.1 bevestigd.

Tabel 1.1 Het innovatieve karakter van de Consuetudines compilatae per deel

\begin{tabular}{|l|c|c|c|}
\hline Deel & Artikels & Nieuwe artikels & $\mathbf{\%}$ \\
\hline I & 244 & 77.5 & 30.4 \\
\hline II & 505 & 197 & 36.0 \\
\hline III & 779 & 266 & 32.7 \\
\hline IV $^{116}$ & 1124 & 823 & 73.0 \\
\hline V & 691 & 310 & 44.4 \\
\hline VI & 118 & 82 & 68.6 \\
\hline VII & 182 & 46 & 25.3 \\
\hline Totaal & $\mathbf{3 6 4 3}$ & $\mathbf{1 8 0 1 . 5}$ & $\mathbf{4 9 . 5}$ \\
\hline
\end{tabular}

Ten eerste laat de tabel zien dat elk deel op zijn minst voor een derde werd vernieuwd. Rekening houdend met de licht gewijzigde artikels neemt dit percentage in werkelijkheid wellicht nog toe. Bovendien wordt ook duidelijk dat het ene deel een pak forser werd uitgebreid dan het andere. Het meest opvallende in dit opzicht is ongetwijfeld het vierde deel dat massaal werd aangedikt met zee- en verzekeringsrechtelijke materie evenals andere commerciële titels. Ook de portie burgerlijk procesrecht werd serieus uitgebreid. Dat dit grotendeels te wijten is aan de integratie van de Ordonnantie op de Styl ende Maniere van procederen (1582) heb ik reeds aangestipt. Interessanter lijkt me dan ook het deel omtrent het strafrecht dat ten opzichte van de Consuetudines impressae bijna werd verdubbeld. Het beeld dat deze tabel laat zien, blijft evenwel voldoende vaag. Het is dan ook aangewezen verder in te zoomen tot op het niveau van de verschillende titels en hun paragrafen. Enkel hier is te zien waar de Consuetudines impressae nu exact werden geïnnoveerd.

${ }^{116}$ Inclusief het zee- en assurantierecht. Het gaat om 506.5 nieuw toegevoegde artikels. 
$\mathrm{Nu}$ er geen verwarring meer bestaat omtrent het onderscheid tussen enerzijds nieuw toegevoegde en anderzijds uit de Consuetudines impressae hernomen artikels, wordt ook duidelijk waar het innovatieve ingrijpen van de 'novateurs' voornamelijk heeft plaatsgevonden. Een volgende vraag naar de oorsprong van deze nieuwe artikels dringt zich dan ook op.

Ook nu weer kan het antwoord hierop worden gevonden aan de hand van de Memorieboeken. Zij geven immers weer waar de compilatoren de mosterd hebben gehaald. Dit ligt echter niet altijd voor de hand. Tijdens de transcriptie van de Memorien op de Costumen viel het me immers op dat niet aan elke rechtsbron eenzelfde waarde kon gehecht worden. Dit blijkt onder meer uit artikel 4.7.45: Est novus etiam ex usu et iure scripto, et accordat consuet[udo] Mecblin[iae] art fin hoc tit. Gevallen als deze hebben me ertoe aangezet een onderscheid te maken tussen wat ik enerzijds primaire en anderzijds secundaire rechtsbronnen ben gaan noemen. Primaire rechtsbronnen geven de eigenlijke oorsprong van het artikel aan. Meestal volgen zij onmiddellijk op de woorden Est novus ex..., Est desumptus ex..., etcetera. ${ }^{117}$ Secundaire bronnen daarentegen moeten de primaire argumentatie extra kracht bijzetten, mogelijk in functie van de verlangde homologatie. Zij volgen nooit op ex, maar wel steeds op woorden die op semantisch vlak aanleunen bij 'bevestigen', 'confirmeren' of 'overeenkomen'.'118 Voorbeelden hiervan zijn er bij de vleet: confirmare, accordere, observare, conformus esse, pro id esse, pro id facere, consentire, affirmare. ${ }^{119}$ Ook constructies in de lijn van 'zoals te vinden is bij', 'zoals vermeld staat bij', 'zoals wordt gehandhaafd door', 'volgens', 'zoals duidelijk wordt gemaakt door' getuigen van een eerder secundair belang: tradere, testare, explicare, ostendere, sequiri, servare, cavere, praeter, propter, ut videlicet manerent, faciunt clariorem, et ita statutum quoque in, vide en adde.

$\mathrm{Nu}$ is het echter zo dat de redacteurs van de Memorieboeken zelf zulk een sluitend systeem niet altijd even consequent hebben toegepast tijdens hun redactionele activiteiten. Bovenstaand onderscheid straalt dan ook in zekere zin iets 'idealiters' uit en de werkelijkheid blijkt helemaal niet zo eenvoudig en ongenuanceerd te zijn dan ik zou willen geloven. In sommige gevallen -gelukkig minimaal in aantal- heb ik me dan ook enkel kunnen laten leiden door een persoonlijk subjectief aanvoelen. Dit impliceert dat uitzonderingen onvermijdelijk zijn geworden. ${ }^{120}$ Desalniettemin heeft

117 Een enkele keer ontbreekt het voorvoegel 'ex'. Toch heb ik de weergegeven bronnen als primair beschouwd. Dit is onder meer het geval ten aanzien van artikel 4.9.1: Est novus usu et iure fundatus.

118 Deze terminologie wordt niet exclusief in het Latijn in de Memorieboeken aangewend. Ook hun Nederlandse varianten komen aan bod, zoals onder meer artikel 5.1.22 laat zien: Est primus inde ordonn [antie] achter de gedructe costuymen tit van policye en [de] in die vanden jaere 1564 eodem tit geconfirmeert byde nieuwe ordonnantie vanden xxiiii octob [er] 1592.

119 Een enkele keer heb ik in het geval van 'observare' toch voor een primair karakter geopteerd, aangezien het in dit geval voorafgegaan werd door het verklarende voornaamwoord nam. Dit was zo ten aanzien van het artikel 5.17.23: Est etiam novus in bac revisione ex diversis statutis, et ex iis deleto verbo belieft linea 5 debet poni precise als partye hun die terstont wilt overlaeten nam usus ita observat.

120 Zo heb ik, in het geval dat er alleen maar sprake is van secundaire bronnen, deze als primair verrekend. Een voorbeeld hiervan is te vinden bij artikel 3.11.15: Est novus additus in hac 
de toepassing van deze methode op de Memorieboeken bijlage 2 (De primaire rechtsbronnen van de nieuw toegevoegde artikels in de Antwerpse Consuetudines compilatae) opgeleverd, waarin een overzicht wordt gegeven van de verschillende primaire rechtsbronnen per rechtsartikel. Dat ik in de toekomst enkel rekening zal houden met de primaire rechtsbronnen, lijkt me gerechtvaardigd. Het hierboven beschreven voorbeeld betreffende artikel 4.7.45 toont het waardeverschil aan dat er tussen verschillende bronnen bestaan kan. Het lijkt me dan ook correct de meeste aandacht te besteden aan de primaire bronnen. Dat deze overigens meervoudig kunnen zijn met betrekking tot eenzelfde artikel blijkt uit artikel 4.3.47: Est etiam novus ex iure et statutis Genuensium d tit de compensat[ione] art 2 incipit verum si litteris cambii. Het spreekt voor zich dat in zulke gevallen de verschillende rechtsbronnen op een gelijkwaardige manier in rekening werden gebracht.

Een belangrijke opmerking bij dit alles betreft opnieuw de zogenaamde nisi quodgevallen, zij het dat het hier nu gaat om modificaties bij nieuwe in plaats van oude artikels, zoals dat eerder het geval was. Het komt namelijk voor dat een bepaald artikel ontleend werd aan rechtsbron $\mathrm{x}$, maar dat het gedeeltelijk werd aangepast aan wat men in een andere rechtsbron y kon terugvinden. Deze aanpassing werd doorgaans na de woorden nisi quod aangegeven, zoals te zien is ten aanzien van de artikels 4.11.80/81/82/83/84/85: Sunt omnes etiam novi ex usu et convenit d ordinatio Brugens[is] tit 7 art 5 et seqq et Rothomag[ensis] cap 9 art 14 nisi quod nos accuratius distincxerimus casus ex suggestione peritorum. Alle artikels werden nieuw toegevoegd op basis van de Usus en stemmen overeen met zowel de Ordonnantie van Rouen als de Ordonnantie van Brugge uit 1569, beter bekend als de Hordenanzas van het consulaat van de Spaanse Natie te Brugge. De casus werd echter accurater onderscheiden op aangeven van de periti of experts. Het spreekt voor zich dat de primaire bronnen volgend op nisi quod eveneens in rekening werden gebracht.

Een tweede en tevens laatste opmerking -ook van methodologische aard- betreft de collectieve bespreking van de artikels in de Consuetudines compilatae. In vele gevallen werden in de Memorieboeken namelijk meerdere artikels gezamelijk besproken, zoals ook te zien was in het zojuist vernoemde voorbeeld. Omdat het ook voorkomt dat men binnen deze bespreking opnieuw een onderscheid maakte tussen de verschillende artikels en hun oorsprong, ben ik genoodzaakt geweest in die gevallen de artikels terug te ontkoppelen. Dit was onder meer het geval bij de artikelengroep 4.8.26/27/28: Sunt desumpti ex d ar[ticu]lo 5 int placcaet vanden jaere 1563 et d art 34 int oudt recht nisi quod visum sit exigere protestum ut videlicet mercator in mora ponatur et constet saltem vere similiter, nautam ad instantiam eius profectionem distulisse, ut aut pra[e]ced. addidimus quoque van dat den schipper alsoo goeden ter schepe syn, gehouden is daermede voorts te varen sonder te

revisione sed usu et iure communi approbatus tex in L sequitur $4^{a} \int f$ [inalis] $f f$ de [usurpationibus et] usucap[ionibus] Wesenbec[ius] in paratit[]] is ad tit de servitutibus, accordant consuetudines Galliae Paris[ii] art 186 Aurelian [um] articulo 122 et similes. Vergelijkbaar is de situatie met betrekking tot artikel 4.11.111: Est novus continens generalem declarationem eius cuius periculum in so suscipit assecurator et ita usus tam hic quam alibi observat et habes nominatim in hac fere formam in ordinatione Rhot [o]mag[ensis]. cap 5 art $1^{\circ}$. 
verbeyden, cur enim id non faciat cum integrum nautum illi solvatur et ita usus observat postremo addidimus ar[ticu]lum 28 ex iudicio tam peritorum quam mercatorum bona ut nobis videtur ratione nam ut equum est nautam extradamnum poni cum negligentur mercatoris navis non oneratur ita iniquum foret illi actionem dari in subsidium ad interesse cum parum aut nichil illi abest invento intra tempus constitutum novo locatore qui damnum pro parte aut in totum supplet. Omwille van de toevoeging ex iudicio tam peritorum quam mercatorum hebben we artikel 28 terug losgekoppeld van de groep.

Tot capita, tot sententiae. Wegens de enorme diversiteit aan rechtsbronnen, is het onbegonnen werk gebleken elk van hen zelfstandig te laten participeren in de mathematische verwerking van onze vaststellingen. Het ligt bijgevolg voor de hand te werken met meer abstracte, algemene categorieën. Uiteindelijk volstonden een veertiental verschillende types opdat elke individuele rechtsbron kon worden ingepast in een groter geheel. ${ }^{121}$ Hieronder volgt een korte toelichting van de veertien verschillende categorieën van rechtsbronnen.

1 De Usus of het dagdagelijkse gebruik (Usus)

Onder Usus is te verstaan 'het (langdurig) gebruik' als causa consuetudinis of oorsprong van een gewoonterechtelijke regel of consuetudo. De Usus slaat op het gebruik als feit; de consuetudo verwijst naar een gewoonte als vorm van recht. Dit gewoonterecht vloeit voort uit het meermaals herhalen van een welbepaald feit, met andere woorden een gebruik. ${ }^{122}$ De categorie verwijst dus in wezen naar een herhaaldelijke gang van zaken welke aan de oorsprong van een bepaalde gewoonterechtelijke regel ligt. Wanneer dit herhaaldelijk gebruik ervan gedurende een betrekkelijk lange tijd plaatsvindt in een bepaalde socio-politieke groep welke deze gewoonte als bindend beschouwt, kan er gesproken worden van de gewoonte als formele rechtsbron. ${ }^{123}$

Deze categorie omvat bijgevolg die artikels wier aanwezigheid wordt gerechtvaardigd aan de hand van deze Usus. Ter illustratie verwijs ik in dezen naar artikel 1.4.19: Est novus bic additus ex usu. Ook andere formuleringen zijn echter mogelijk, doch ook schaarser: ... ita quotidie practicatur, of ... ut quotidiana experentia docet. ${ }^{124}$ De nadruk ligt op het dagdagelijks gebruik van een bepaalde regel, net als bij artikel 1.14.32: Est novus ad interpretationem precedentis ex notorio et quotidiano usu.

121 Onder deze verschillende types bevinden zich zowel formele als materiële rechtsbronnen. De bronnen van formele aard verwijzen naar het klassieke vierspan (wet, gewoonte, rechtsleer en rechtspraak). De materiële rechtsbronnen omvatten de externe factoren welke de inhoud van het recht bepalen. (Cfr. MARTYN, Eeuwig Edict, 493. Wat de Antwerpse Consuetudines compilatae betreft, denk ik in dit opzicht onder meer aan de magistraat van de stad, het billijkheidsgevoel, de handelaars, enz.

122 Cfr. L. MAYALI, "La coutume dans la doctrine romaniste au Moyen Age", Recueils de la Société Jean Bodin pour l'histoire comparative des institutions. La coutume, LII, Brussel, 1990, 20.

123 Cfr. GILISSEN, Historische inleiding, 251-256.

${ }^{124}$ Cfr. 2.5.99/100 en 2.1.98/99/100. 
2 Interne en externe wetgeving (iWG, eWG)

Een tweede categorie groepeert de bronnen van legislatieve aard. Conform Gilissen, gaat het hier om een zeer algemene vorm van wetgeving, met name de wet als 'een rechtsregel of geheel van rechtsregels, van betrekkelijk algemene en permanente aard, meestal in schrift gesteld, door hij of zij die het gezag in een min of meer zelfstandige socio-politieke groep uitoefenen'. ${ }^{125}$

Zelf zal ik binnen dit onderzoek steeds een onderscheid maken tussen wettenrecht afkomstig van de centrale overheid enerzijds en dat wat uitgaat van de stedelijke magistratuur anderzijds. Zo werd bijvoorbeeld de organisatie van de Weeskamer officieel geboekstaafd en uitgevaardigd met de ordonnantie op de weeskamer van 26 maart 1496, waarvan een aantal bepalingen ook in de Consuetudines compilatae opgenomen zouden worden. Ter illustratie verwijs ik naar de artikels 2.5.14: Est novus in hac postrema revisione additus ex $\mathrm{d}$ art 36 ordinationis pupillaris in fine juncta L 2 et qu[a]e ibi notantur $C$ de his qui ven[iam] a [e]tatis impetr[averunt] confirmanturque ijs qu[a]e diximus $i[n]$ tit van gehoude persoonen. Tot de centrale overheid reken ik de souverein en de bestuursraden uit zijn onmiddellijke omgeving (Geheime Raad, Raad van State, Raad der Financiën, ...). Hun wil uit zich in ordonnanties, plakkaten, privileges, blijde inkomsten, ... Een voorbeeld hiervan is te vinden bij de artikels 1.13.3: Est ex altera ordinatione seu placito Imp[eratoris] Caroli de 4 octobris 1540 cap beginnende dat alle notarisen, et cum eo accordant constit[utiones] Galli[a]e in Cod[ice] Henric[iano] d lib 3 tit 22 des notaires art 16. Het gaat om de ordonnantie van Karel van 4 oktober 1540, ook wel het Eeuwig Edict van Karel V genaamd. Ook documenten afkomstig van provinciale raden, zoals de Raad van Brabant, behoren tot deze subcategorie. Voorbeelden hiervan doen zich voor daar waar regels vanuit de Albertine Ordonnantie (1604) in het Antwerpse procesrecht worden gerecipieerd, zoals onder meer het geval is bij artikel 5.15.21: Est novus in hac revisione ex art 600 vande voors [creven] nieuwe ordonnantie vanden Raedt.

Niet alleen overheden van eigen bodem hebben echter hun invloed laten gelden op het Antwerpse gewoonterecht. Ook de wetgeving van andere landen, zoals bijvoorbeeld Frankrijk en Spanje, vond haar weg naar de handelsmetropool aan de Schelde. Eén van de vele voorbeelden is terug te vinden ten aanzien van de artikels 1.13.9/10/11: Ex constitut[ionibus] Galli[a]e in Cod[ice] Henricia[no] ad tit 22 lib 3 art 16 et ijs qu[a]e diximus $i[n]$ tit van secretarisen art bic citatis. In dit concreet geval gaat het om het wettenrecht van de Franse koning Hendrik III. Artikel 2.1.3 laat de invloed vanuit Spaanse zijde zien: Est novus ex LL Hispani [a]e nominatum in L regia de las cortes de Madrid de anno 1534 cap 101 rolata in $L 5$ nove recopulationis tit $3 \mathrm{~L} 1$... Het spreekt voor zich dat ook zij binnen deze groep terecht zullen komen. Voor zover het van toepassing moge zijn, krijgt ook de pauselijke wetgeving onderdak binnen dit luik van de rechtsbronnen.

De enige voorwaarde waaraan voldaan moet worden is dat men expliciet naar de uitspraak in se verwijst en niet naar bijvoorbeeld de mening of commentaar van de compilerende jurist in kwestie. Een voorbeeld hiervan is te vinden bij artikel 1.13.7: Est novus in hac revisione additus ad tollendos abusus et falsitates qu[a]e po[ss]ent committi si

125 GILISSEN, Historische inleiding, 29. 
domestici testes a notarijs adbibentur, ..., reliqua sunt partim ex jure, partim ex praxi Galli [a]e de qua Charondas ad d art 8 tit 22 lib 3 Cod[icis] Henric[iani] nisi quod ibi requiratur quod testis sit $x \times v$ annorum, nobis sub beneplacito Curie visum est $x \times$ sufficere ne nunium et notarios et contrabentes. Zulke primaire bronnen zullen in de categorie van de rechtsleer worden ondergebracht.

\section{Corpus Iuris Civilis (Ciciv)}

Elk artikel dat zijn oorsprong rechtstreeks kent in een of andere lex uit het Corpus Iuris Civilis behoort tot deze groep. Dit wordt mooi geillustreerd door de Memorieboeken met betrekking tot artikel 2.5.181: Est etiam novus ex $L 1 \int$ nunc tractemus 10 cum tribus seqq. If de tut[elae] et ration[nibus] distrab[endis et utili curationis causa actione] $L$ inter fideiussores 26 et L si contendat 28 ff de fideiuss[oribus et mandatoribus]. Dit artikel werd nieuw toegevoegd op basis van een vijftal verschillende leges uit de Digesten (D.27.3.1.10, D.27.3.1.11, D.27.3.1.12, D.27.3.1.13, D.46.1.26, D.46.1.28).

Het voorkomen van zulke allegaties impliceert echter niet altijd ook een daadwerkelijke receptie van het Romeinse recht. Voorzichtigheid is immers geboden van zodra zulk een referentie vergezeld wordt van een rechtsgeleerde. In zulke gevallen gaat het immers in de eerste plaats om rechtsleer. De nadruk ligt met name op de woorden van de jurist, terwijl de inhoud van de Romeinsrechtelijke lex meer naar de achtergrond verschuift. Zo is artikel 2.2.24 enerzijds ontsproten uit de Codexregel C.4.50.2, maar anderzijds ook uit de opinie van Bartolo da Sassoferrato en andere doctores bij de Digestenregel D.10.2.20pr: Est novus additus in hac postrema revisione ex $L 2 C$ si quis sibi vel alteri [vel sibi sub alterius nomine vel aliena pecunia emerit] ex iis qu[a]e tradit Barth[olus] et $\mathrm{d}\left[\right.$ octores] ad $L$ si filia $C$ famil[iae] eriscund[ae]. ... ${ }^{126}$ In sommige gevallen wijst men er expliciet op dat beide rechtsbronnen van belang zijn: Est novus ex necessaria consequentia art precedentis, et est etiam iuris text et d[octores] in $L$ unica Cod ubi de hered[itate] agatur [et ubi scripti heredes in possessionem mitti postulare debent]. ${ }^{127}$ Zowel de tekst van het wetsartikel uit de Codex als de mening van de doctores hieromtrent is van belang.

Tot slot wil ik nog wijzen op het bestaan van artikels waaromtrent op een meer abstracte manier naar het Romeinse recht wordt verwezen. Zo beperkt men zich ten aanzien van artikel 2.5.171 tot de term ius: Est novus sed in iure et ratione fundatus... Soms hanteert men de formulering ex notorii iuris, zoals in artikel 5.11.46: Est etiam novus sed notorii iuris adiecimus antem clausulam die by bem selven oft in syn bywesen gedaen, oft oft gehandelt

126 Ten aanzien van deze referenties naar het Justiniaanse recht, heb ik meermaals kunnen vaststellen hoe slordig met de referenties werd omgesprongen. Meermaals spreekt men van een titel uit de Codex, wanneer men in wezen de Digestae bedoelt, en vice versa. Een materiële controle heeft me steeds uitsluitsel gegeven omtrent het boek waarnaar verwezen wordt.

Een tweede opmerking omtrent deze referenties betreft de afkorting $d d$. Wanneer deze aan een referentie naar het Romeinse recht voorafgaat, dan staat de afkorting doorgaans voor doctores. Voorzichtigheid blijft evenwel geboden, want $d d$ kan eveneens dicti ('vernoemd') betekenen. Cfr. 2.1.225: Est 80 in impressis ex usu, nisi quod nos addiderimus clausulam dan dat sy kinderen bebbende, ex ijs qu[a]e dd sunt $i[n]$ art 98 et seqq.

127 1.14.18. 
is quia ... Meestal spreekt men echter van ius scriptum, zoals bij artikel 5.11.21/22 gebeurt: Sunt etiam novi ex iure scripto textus in $C$ quoniam frequenter $\int$ sunt et alii et ibi d[octores] X ut lite non contest[ata] Gottofredus Minsing[er] et alii ubi $\int$. Ook andere formuleringen, zoals ius commune, ius civile en ius romanum, zijn evenwel mogelijk, maar zij komen nauwelijks tot nooit aan bod als het om het Romeinse recht als primaire rechtsbron gaat. ${ }^{128}$

Ook gevallen waarbij men verwijst naar de ratio van het Romeinse recht, komen niet alleen in de categorie 'Ratio en aequitas' maar eveneens hier terecht. Een voorbeeld is artikel 4.12.33: Est novus in hac revisione ex usu et ratione iuris nisi quod additum sit vanden eedt ad excludendas omnes fraudes.

\section{Corpus Iuris Canonici (Cican) ${ }^{129}$}

Hier geldt hetzelfde als zopas geformuleerd bij bovenvermelde categorie, met dit verschil dat het nu regels betreft welke ontleend werden aan het Corpus Iuris Canonici. Een voorbeeld van gerecipieerd kerkelijk recht is artikel 3.13.49: Est etiam novus ex iure scripto textus in capitulo Raiiuntius, et in c Rainaldus extra de testamento,... Ook nu spreekt men simpelweg van ius scriptum. Samen met de artikels 5.11.21/22 gaat het hier overigens om de enige drie artikels binnen de Consuetudines compilatae welke een canoniekrechtelijke oorsprong kennen. ${ }^{130}$ Een andere keer spreekt men van Filips Wielant die in zijn Practycke Criminele (ca. 1510) een canoniekrechtelijke regel allegeert. Het betreft de artikels 7.1.7/8/9/10/11: Sunt additi in hac revisione ex pra $[x] i$ Gallica praeside $[n] s$ Wilandii lib 2 tit de inquisition et tit de diffamation precedente ubi allegat textum in $\mathrm{C}$ qualiter et quando $\mathrm{X}$ de accusat et usus ita plane etiam observat sed conveniebat bic

\footnotetext{
128 Voorbeelden hiervan zijn te vinden respectievelijk bij de artikels 2.3.7 (Sunt omnes novi additi in hac postrema revisione ex jure communi, qu[a]e mulieribus maioribus nusquam i $[n]$ terdicta est rerum suarum administratio, vel necessariarum aut etiam utilium rerum comparatio, et usus ita observat, ...), 3.14 .5 (Est duodecimus in antiquis titulo van rechten gehoude persoonen aengaende et 71 titulo van successien, et est desumptus uuyt het Ceurboeck art 180 ubi dicitur dat d'ouders erffven in alle tgene van bun gecommen is oft weerde van dyen, ten waere daerkints kinderen waeren ut et ius civile confirmat tex. in L profectitia 12 in princ [ipe] et $\int$ si pater $11 \mathrm{ff}$ de iure dot[ium]) en 5.4 .1 (Est additus in hac revisione et continet generaelen quandam divisionem iuridica [e] citationis ut ita via sternatur non solum ad reliquam tractationem buius tituli sed etiam ad alios subsequentes titulos ubi agitur de extraordinariis citationibus quas ius Romanum ignoravit et mos aut privilegium nostrorum civius introduxit.). Wat de term ius commune betreft, wil ik hier nog aan toevoegen dat deze op geen consequente wijze werd aangewend. Soms refereert de term louter naar een Romeinse lex, waar hij in een andere situatie kan verwezen naar het geleerde recht in de zin van de rechtsgeleerde opinio doctorum. (Cfr. NEVE, "Ius commune", 3-58.) ${ }^{129}$ Omtrent de penetratie van het canonieke recht in het costumiere recht van Frankrijk, zie: A. LEFEBVRE-TEILLARD, "Recherches sur la penetration du droit canonique dans le droit coutumier français", Mémoires de la Société pour l'bistoire du droit et des institutions des anciens pays bourguignons, comtois et romands, XL (1983), Dijon, 59-76. De auteur stelt er vast dat het fenomeen traag van aard is, vaak afhankelijk van specifieke juridische problemen en sterk verbonden aan de penetratie van het Romeinse recht.

130 In een aantal gevallen werden kerkrechtelijke canons ook als secundaire rechtsbron aangewend: cfr. de artikels 3.13.50, 3.13.51, 3.13 .52 (testamentair erfrecht) en 5.11.18/19/20 (bewijsvoering in burgerlijke procesgang).
} 
exprimere ad instructionem officiariorum et etiam scabinorum qui non studuerunt. Ook nu werd deze regel als primaire bron aanzien.

5 V roegere redactiepogingen van oud Antwerps recht $(O A R)$

Deze categorie verzamelt die artikels welke werden ontleend aan vroegere compilaties van Antwerps gewoonterecht. Hierbij kan het zowel om officieuze als officiële redactiepogingen gaan. Concreet gaat het in dit opzicht om de twee eerste, officiële redacties van het Antwerpse gewoonterecht, met name de Consuetudines antiquissimae (1547) en de Consuetudines antiquae (1570), maar ook om nog oudere, officieuze compilaties zoals daar zijn het Keurboeck van Antwerpen uit de eerste helft van de veertiende eeuw en beter bekend als het Coerboeck metten doppen en de Statuten der Stadt van Antwerpen genaempt het Gulden Boeck (veertiende en vijftiende eeuw). ${ }^{131}$ Ook de minder frequente en tot nog toe ongeïdentificeerde Oude specificatie geintituleerd keuren ende breucken van Antwerpen heb ik binnen deze groep ondergebracht.

Deze oude redacties hoeven niet noodzakelijk conform het nieuw toegevoegd artikel te zijn. Zij kunnen immers ook inspireren tot een tegengestelde opvatting. Dit wil ik illustreren aan de hand van artikel 3.3.14: Est ex art 83 int Guldeboeck in verbis inde tselve goet en [de] materie in sulcken staet ende wesen waere als dat gelevert mochte syn a contrario sensu accordat consuet [udo] Paris[ii] art 177 et Aurelian[i] d art 458 etiam a contrario sensu. ${ }^{132}$

De nadruk ligt dus op verzamelingen van materieel costumier recht. Vroegere versies van de procesrechtelijke Ordonnantie op de styl ende maniere van procederen (1564, 1576 en 1582) horen hier niet thuis. Zij werden bij de groep van legislatieve bronnen ondergebracht, aangezien zij door het stadsbestuur werden uitgevaardigd en bekrachtigd.

Ook de artikels welke een plaats hadden in de Consuetudines impressae behoren niet tot deze groep. Zij werden immers als oude artikels bestempeld. Slechts een enkele keer heb ik een artikel dat ook in de Consuetudines impressae aanwezig was als nieuw beschouwd. Hierbij gaat het om situaties waarbij verwezen wordt naar de redelijkheid welke spreekt uit een bepaald artikel in de Consuetudines impressae. Een voorbeeld hiervan is te vinden ten aanzien van artikel 3.3.2: Est desumptus ex iure scripto et paritate rationis art 2 et 3 in impressis tit van erffscheydingen. Een andere uitzondering op deze regel betreft de situaties waarin een welbepaalde clausule uit een artikel van de Consuetudines impressae inspirerend werkt. Dit is onder meer het geval bij artikel 4.13.4: Est novus ex parte finali art 6 in impressis hoc tit et usu, cui consentiunt tradita a Charonda renspons[es] lib

${ }^{131}$ Beide redacties werden samen met de vier officiële redacties door de Longé uitgegeven: cfr. Coerboeck de la ville d'Anvers, I, 1-89. Les statuts de la ville d'Anvers appelés Het Gulde Boeck, I, 378426.

132 Een ander voorbeeld (artikel 3.2.29) hiervan heeft betrekking op een artikel uit de Consuetudines impressae: Est desumptus ex art 2 in impressis tit van handtschriften a contrario sensu nisi quod deletis verbis, oft yet anders doende cracht van leveringe bebbende quod nimis incertum substitu[i]mus clausulam oft yet anders doende daer doere by die unyt syne banden laet gaen, ut excludererimus constitutum et eiusmodi inaves [?] et imaginativas traditiones qu[a]e non satis efficaces sunt ad excludendas fraudes qu[a]e in eiusmodi cessionibus rerum mobilium nimis quam frequentes intervenire solent, manente actuali possessione apud enim qui rem cedit aut oppignorat, et ita usus observat tam bic quam in Galiis. 
vii resp[onse] 74 Le Guenoys ad conferentias consuetudines Gallia[e] aux additions sur le tiltre 5 des actions personnelles fol 391 ad litteram Z ubi allegat L ubicunque 6 ff de fideiuss [oribus et mandatoribus ${ }^{133}$ Ook nu worden de Consuetudines impressae als oud Antwerps recht beschouwd en verrekend.

6 Interne (Antwerpse) en externe (buitensteedse) rechtspraak (RSi en RSe)

Hier gaat het om de jurisprudentie als formele rechtsbron. Een sprekend voorbeeld is artikel 2.1.16: Ex duabus sententiis Consilii Brabanti[a]e ibi citatis de 19 februarii 1592 et 5 aprilis 1593. Het artikel vindt zijn oorsprong in twee uitspraken door de Raad van Brabant voltrokken op respectievelijk 19 februari 1592 en 5 april 1593.

Ook nu bestaat er een enorme waaier aan rechtbanken wier jurisprudentie aan de basis kan liggen van de in de Consuetudines compilatae geïntegreerde rechtsregels. Gezien deze diversiteit en het feit dat men zich soms beperkt tot zeer abstracte formuleringen als Est novus ex diversis sententiis, leek het me raadzaam geen verder onderscheid te maken tussen stedelijke, provinciale, centrale of zelfs buitenlandse rechtbanken. ${ }^{134}$

Ook uitgebreide compilaties van vonnissen, de zogenaamde rechtspraakverzamelingen of decisiones behoren in principe tot deze groep. Zo wordt er in volgend voorbeeld bij de artikels 5.10.75/76/77/78 expliciet naar de Decisiones Sacri Mantuani Senatus (1597) van de Italiaan Giovanni Pietro Sordi da Casale verwezen: Sunt desumpti ex d practica Wielandii loco i[bi] citato late Molin[aeus] ad L 1a $\int$ si quis simpliciter $n^{\circ} 97$ et seqq ff de verbor[um] oblig[atione] Menoch[ius] d[e] arbirtr[ariis] iud[icum] quest[ionibus et causis] lib 2 cent 1a casu $39 n^{\circ} 21$ et seqq latissime et optime Surdus decis[ione]s Rota[e] Mant[uani] decis[io] 258 per totum nisi quod nos art 76 explicaverimus per exempla quid sit aliquem captare quod erat satis necessarium ut res intelligeretur secuti qua [e] pra[e] dicti authores locis citatis tradunt. De enige voorwaarde waaraan voldaan moet worden is dat men expliciet naar de uitspraak in se verwijst en niet naar bijvoorbeeld de mening of commentaar van de compilerende jurist bij deze casus. Een gelijkaardige opmerking heb ik reeds ten aanzien van de categorie wettenrecht gemaakt, en zal ik ook doen met betrekking tot de compilaties van vreemd gewoonterecht. Zulke primaire bronnen zijn in een volgende categorie terechtgekomen, met name die van de rechtsleer.

\section{Rechtsleer (RL)}

Generaliter omvat deze groep regels welke zijn afgeleid van de rechtsgeleerde opinie van zowel de grote als de minder illustere figuren binnen de rechtsgeschiedenis. Hierbij denk ik in de eerste plaats aan traktaten en monografieën. Zo zijn de artikels 5.10.33/34 deels afkomstig van de Institutiones forensis (1535) van Jean Imbert en de

\footnotetext{
${ }^{133}$ Een gelijkaardige situatie is te vinden met betrekking tot de artikels 4.12.19/20: Sunt novi in hac revisione substituti in locum clausula [e] en [de] worden aenden selven pande geprefereert voorde rentieren naerde selve leveringe, oft arbeyt opden voors[chreven] pandt gehipoticeert synde quid enim miri si anterior posteriori preferatur maior questio erat alser onder renten opden pandt beset soude syn, an videlicet is quoque redemptores vel opifices preferri debeant, quod magistratui visum definire...

134 Cfr. 3.8.59.
} 
annotaties (1603) van Louis le Caron bij de Somme rural van Jean Bouteiller: Sunt desumpti partim ex $d$ art 3 inde voors[creven] twee ordonnantien partim ex iis qua[e] de garandio formali et simplici eleganter et distincte tradunt Imbert lib $1^{\circ}$ instit [utionum] forens[ium] cap 20 et Charondas in annotationib[us] ad summam ruralem tit 33 et in memora[bi] lib [us] verbo garand ou garantia $[e]$. Maar ook wanneer -zoals ik hierboven zopas heb toegelicht- expliciet verwezen wordt naar de commentaar van een welbepaalde rechtsgeleerde bij tekstuitgaven, gewoonterechtelijke redacties, rechtspraakverzamelingen of legislatieve compilaties, moet er gesproken worden van rechtsleer. Kortom, alles wat ontspringt aan de opinio van de jurist hoort thuis binnen deze categorie.

Ook wanneer men met een meer algemene en anonieme term zoals doctores wil aangeven wat de heersende opinie binnen de rechtsgeleerde wereld is, mondt dat artikel uit in deze groep. Bij wijze van voorbeeld vermeld ik hier artikel 2.2.24: Est novus additus in hac postrema revisione ex $L 2$ C si quis sibi vel alteri ex $i j$ s que tradit Barth[olus] et d[octores] ad L si filia C [lees, f] famil[iae] erciscund[ae].

\section{Buitensteeds of extern gewoonterecht (eGR)}

Onder extern gewoonterecht wordt gewoonterecht verstaan dat afkomstig is van vreemde costumiere redacties, waarbij vreemd staat voor 'alles wat niet Antwerps is'. Zo kan het gaan om compilaties van bijvoorbeeld Utrecht en/of Bretagne: Est desumptus ex consuet[udine] Ultraiect[ensis] rub 46 art $1^{\circ}$ et 2 excepta clausula finali maer alleenelyck qua[e] desumpta ex consuet[udine] Britannia[e] Minoris art 675 et sunt omnia a[e]quissima. ${ }^{135}$ Straks zal blijken dat te Antwerpen dit assortiment aan vreemde compilaties zeer uitgebreid was.

Het bestaan van deze categorie alleen al toont aan dat niet uitsluitend geleerd recht werd gerecipieerd. Ze maant de lezer aan zich niet langer blind te staren -zoals in het verleden maar al te vaak werd gedaan- op de invloed van het ius commune op het ius proprium van een bepaalde streek. Ook naburige redacties vervullen een voorbeeldfunctie. In een tweede hoofdstuk van deze dissertatie zal ik uitgebreid ingaan op dit fenomeen dat ik 'costumiere acculturatie' ben gaan noemen.

\section{Consuetudines compilatae (Comp)}

Deze negende van veertien categorieën bevat die artikelen welke hun opname in de Consuetudines compilatae te danken hebben aan een ander artikel uit de Consuetudines compilatae. Zij vloeien er noodzakelijkwijs uit voort. Het is namelijk zo dat de integratie van een bepaald artikel maar al te vaak heel wat collateral damage met zich mee brengt. Zo dankt bij wijze van voorbeeld artikel 4.11 .314 zijn bestaan aan wat er werd gezegd in de artikels 205 en 300: Est novus in hac revisione ex usu et iis qua[e] diximus $i[n]$ art 205 et 300. Artikels als deze kennen hun oorsprong dus in de Consuetudines compilatae zelf. Vaak zijn zij het logische gevolg (collateral damage) van de introductie van een ander artikel, zoals het geval is bij de artikels 3.14.124/125 die voortvloeien uit de redelijkheid van de artikel 3.14.123, dat eveneens nieuw was toegevoegd aan de Consuetudines compilatae: Sunt etiam novi ex ratione precedentium et iis qu[a]e dicta sunt i[n] tit

135 Cfr. 6.1.46. 
van testamenten art 35 et 53 et $i[n]$ tit van geselschap art 21 et seqq. Nog een vergelijkbaar voorbeeld is artikel 4.18.13: Est novus in hac revisione ex paritate rationis ar[ticu]li precedentis ex usu. In beide gevallen betreft het overigens een situatie (ex ratione precedentium of ex paritate rationis art[icu]li precedentis) waarbij de nadruk ook op de redelijkheid van de inhoud van het voorgaande artikel ligt. Vandaar dat ik zulke artikels zowel tot deze als de volgende categorie omtrent de 'Ratio en aequitas' heb gerekend.

10 Ratio en aequitas ( $\mathrm{R} A$ )

In de Memorieboeken kan de term ratio twee verschillende betekenissen hebben. Zo is er die van de 'rede' als 'redelijkheid' enerzijds tegenover die van 'reden' als oorzaak anderzijds. In tegenstelling tot wat te zien is in het traktaat van Hendrik de Moy over de Consuetudines impressae is laatstgenoemde betekenis in de Memorieboeken de minst frequente. Een voorbeed hiervan is te vinden bij artikel 3.12.11: Est novus ex usu et ratio est quod nemo coram scabinis venire soleat aut possit nisi deliberato animo, ita ut quod facit effectum habere velit non habebit autem si ab eius voluntate pendet eadem revocandi cum praeterea recognitio aut inheredatio coram scabinis facta dominium statim transferat, etiam nulla acceptatione interveniente ut dicto titulo van opdrachten ende overgevinge van goederen articulo secundo et sexto, non debet minoris effectus esse in hac caussa donationis, cum ratio ubiq[ue] par sit et usus ita observat. Waar de Moy zeer vaak de formule ...quod ratio est... hanteert in de zin van 'waarvan de reden is dat ...', wordt de ratio in de Memorieboeken eerder gebruikt in de zin van redelijkheid, vergelijkbaar met de billijkheid of aequitas.

In deze categorie beperk ik mij tot die gevallen waar de ratio in de betekenis van redelijkheid wordt gebruikt. Voorbeelden hiervan zijn te vinden bij het artikel 4.9.7: Est etiam novus sed qui summam habet a[e]quitatem ut patet ex textu, et posset multis rationibus comprobari, of ook artikel 2.1.90: Novus ex identitate rationis,... Omwille van haar kwalitatieve eigenschappen behoort het artikel tot de Consuetudines compilatae.

Het gebeurt nu evenzeer dat er wordt gerefereerd naar de redelijkheid van andere formele rechtsbronnen. Ik denk hierbij onder meer aan de ratio van het Romeinse recht, die van een ander artikel uit dezelfde Consuetudines compilatae of zelfs die uit de Consuetudines impressae, zoals ik reeds eerder heb laten zien. ${ }^{136}$ In zulke omstandigheden heb ik het artikel steeds dubbel, t.t.z. in beide categorieën, ondergebracht. Ook situaties zoals zij zich ten aanzien van artikel 5.10.6 hebben voorgedaan, komen dubbel in de statistieken terecht: Est pars finalis $d$ art 7 inde voors[creven] ordonnantie acter de gedructe costuymen, et 4 in die vanden jaere 1564 nisi quod in postrema ordinatione addatur dat den aenleggere indyen cas hem mette stucken naermaels nyet en soude mogen beholpen quod satis iniquum. Ideoque merito mutatum. Het artikel werd namelijk geïnnoveerd omdat het 'genoeg onredelijk was en dus terecht veranderd mocht worden'.137 Zulk een verantwoording hoort thuis in zowel de categorie van de 'Ratio en aequitas' als degene die hierna volgt omtrent specifieke redenen.

${ }^{136}$ Cfr. supra, hoofdstuk 1, paragraaf 1, Methode, 9 Consuetudines compilatae.

${ }_{137}$ Cfr. 5.10.6: Est pars finalis $d$ art 7 inde voors [creven] ordonnantie acter de gedructe costuymen, et 4 in die vanden jaere 1564 nisi quod in postrema ordinatione addatur dat den aenleggere indyen cas hem mette stucken naermaels nyet en soude mogen beholpen quod satis iniquum. Ideoque merito mutatum. 
11 Specifieke reden (S)

Deze categorie groepeert in zekere zin de zojuist omschreven eerste betekenis van ratio als een nog nader te verklaren reden. Vaak zijn deze zodanig specifiek en situatiegebonden, dat ik voor hen een aparte categorie in het leven heb geroepen. Het unieke karakter van elke afzonderlijke situatie komt het best tot uiting aan de hand van enkele voorbeelden: Sunt novi additi in hac revisione ad tollendos multos abusus, qui ex omissione et abbreviatione harum clausularum s[a]epe oriuntur ${ }^{338}$; Nam rem melius explicat ${ }^{33}$; Sunt novi bic additi in postrema revisione ut veteres et novas consuetudines aliquo modo reduceremus in concordiam quamquam ista nova consuetudo,... ${ }^{140}$; Sunt novi sed ex mente imo etiam verbis antiquarum consuetudinum,... ${ }^{141}$; Sunt omnes novi a nobis additi in bac postrema revisione ut desiderio multorum satisfierit via et formula constitata,... ${ }^{142}$; Est partim novus, partim ex art 8 in impress[is] hoc tit et satis necessarius, ut odiosa ista consuetudo aliquo modo reducatur ad [a]equitatem,... ${ }^{143}$; Sunt novi additi in hac postrema revisione van voor te commen veele inconvenienten ende processen dyerwijsen,... ${ }^{144}$; Est novus additus in hac ultima revisione ad excludendas fraudes... ${ }^{145}$; Sunt novi in hac revisione necessariio additi ut intelligatur wat eygentlyck charte party[e] en [de] wat cognoscement is...146; Uterque est novus continens actiones qua[e] tam assecuranti quam assecuratori ex hoc contractu dantur, ut videlicet iuniores schabini et adnocati omnia apertius intelligant ${ }^{47}$; Sunt novi additi in hac revisione ad tollendas ambiguas et anxias disputationes... ${ }^{148}$; Est quoque novus ex usu et ... qua[e] debent supplere linea 6 post verba eersten faillissemente nam textus sine iis est obscurior. ${ }^{149}$; Est novus sed satis necessarius op datmen in alsulcke saecken kort en [de] sommier recht mach doen als beyde de partyen geprepareert comen et facit ad exonerationem officiariorum ${ }^{150}$; Sunt etiam novi ex iis qua [e] dicta sunt i $[n]$ parte $4^{4}$ tit van borchtocht [en] art 33 et hac parte $5^{a}$ tit van dagementen art 3 et 4 . Sed quia stilus articuli 36 est minus perfectus videtur quod posset paulum mutari et concipi hoc modo... ${ }^{151}$; Sunt quoque novi additi in hac revisione ex usu, en [de] om ewech te nemen vele captien en [de] bedrogen die daegelyckx gebeuren door eenige lichte persoonen... ${ }^{152}$. Ook de bruikbaarheid van een bepaalde regel kan bepalend zijn voor bepaalde wijzigingen: Sunt quoque novi ex usu et communi voto mercatorum accordant statuta Genuens[ium] lib 4 cap 6 art incip[it] si creditores cum art incip[it] excludantur semper fol 102 nisi quod ibi requiratur consensus vande seven achtste gedeelten dwelck. te seer precis is en [de] qualyck practicabel en [de] daeromme is beter gevonden te blyven byde costuyme

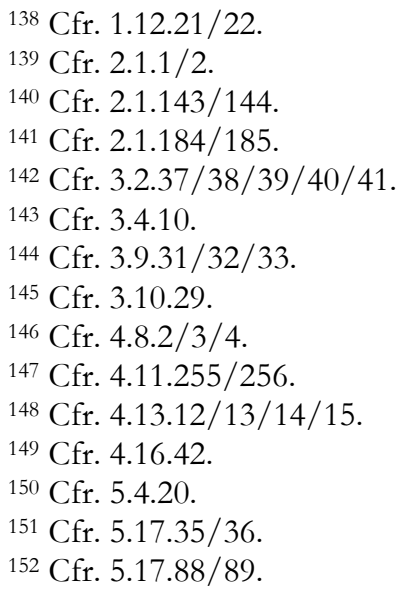


vande borse pra $[$ e] sertim cum proxime accedat ad ius commune vide text in L iuris gentium 7 If fin et in L maiorem $8 \mathrm{ff}$ de pactis et pro 37 text in L si precedente $58 \int 1^{\circ} \mathrm{ff}$ mandati [vel contra].153 Ook de noodzakelijkheid van een artikel drukt een zekere specifieke reden uit: Est novus sed satis necessarius ne sub pretextu private litis prejudicium communitati fiat,... ${ }^{154}$

Een laatste groep artikels welke eveneens binnen deze categorie onderdak hebben gevonden betreft die artikels welke in de Memorieboeken omschreven werden als artikels welke in de plaats zijn gekomen van een welbepaald artikel uit de Consuetudines impressae, waarbij dit laatste niet langer houdbaar was omwille van een specifieke reden. Een voorbeeld hiervan is te vinden bij artikel 3.9.43: Est novus loco ar[ticu]li vigesimi et vigesimi primi in impressis decimi 3 in antiquis hoc titulo 24 in antiquissimis tit van schepenebrieven et dicto articulo $1^{\circ}$ inde ordonnan [tie] op de leveringe die nyet wel onder den anderen en accorderen, usus nunc observat ut hic et confirmatur placito anni 1571.

\section{Derden (3)}

Hier gaat het om artikels die op aangeven van een derde, niet tot de commissie behorende, partij aan het geheel werden toegevoegd. Hoofdzakelijk betreft het hier ervaringsdeskundigen of 'experts' (ex suggestione peritorum) maar evenzeer belanghebbenden als erfscheiders (by aengeven vande erffscheyders), handelaars (ex suggestione mercatorum), onderhandelaars (ex suggestione negociatorum), verzekeraars (ex suggestione assecuratoribus) en schippers (ex suggestione nautarum). In een zeldzaam geval gaat het om theologen (ex suggestione theologorum) of de rechters van de Lakenhal, oudermans genaamd (ex relatione illorum qui nunc huic iudicio presunt). ${ }^{155}$

Ook wanneer het de magistraat of de amptman goed leek een aantal zaken te wijzigen, dan heb ik die wijzigingen in deze categorie ondergebracht: Sunt novi in bac revisione substituti in locum 42 in impressis ubi simpliciter dicebatur dat vonnissen van hem te mogen povideren egeen recht van preferentie en gaven, quod magistratui visum satis iniquum ideoque accuratius voluit explicari additis ex eadem ratione duobus aliis casibus cum videlicet aut appellatur aut iis [?] procrastinatur et trabitur ne alioqui sub absentia[e] appellationis vel longioris litis pretextu creditores ludificentur ut sepissime accedit. ${ }^{156}$ De reden dat ik hen niet bij het wettenrecht heb ondergebracht, schuilt in het ontbreken van het officiële element. Men beperkt zich immers tot een adviserende rol. In hoeverre het advies wordt gevolgd, is afhankelijk van de autoriteit die men uitstraalt. Een enkele keer werd het hof om advies gevraagd. Dit gebeurde slechts één maal en meer bepaald ten aanzien van de artikels 4.10.17/18 met betrekking tot de makelaars: Sunt desumpti uuyt seker advis te hove overgesonden opt stuck vande maeckelaers et ita observant passim in Galliis consuet[udo] Minerv[ois] cap 32 art 21 Dunois cap 17 art 89 Orleans tit 19 art 429 Berry tit 9

153 Cfr. $4.16 .35 / 36 / 37$

${ }^{154}$ Cfr. 1.1.13.

155 Deze laatste twee groepen komen respectievelijk slechts twee $(4.8 .78,4.1 .9 / 10)$ en één (1.5.13) maal voor. Omtrent deze oudermans, cfr. M. GOTZEN, "Het Oud-Antwerps burgerlijk procesrecht volgens de Costumiere Redacties van de 16 1 -17e eeuw", Rechtskundig tijdschrift voor België, 31 (1951), 313.

${ }^{156}$ Cfr. 4.18.64/65/66. 
art 31 Bourbon cap 13 art 131 in conferentiis fol 39 quibus adde qua [e] dicta sunt i[n] art 34 et 5 boc tit.

In één enkel geval is het me niet duidelijk geworden om welke personen het exact gaat. Zo blijft het een mysterie wie er met de cantor bedoeld wordt ten aanzien van artikel 2.5.123 omtrent het verhuren van eigendommen van de vermomboorde door de voogd: Est novus ex usu, cui consentit consuetudo Claremont[is] in Gallijs art 195 nisi quod illa requirat etiam cautionem pro mercede locationis, sed cum id insolitum sit apud nos non existimavimus convenire, immo damnosum fore pupillis si exprimatur, vix enim est ut sub tali conditione quis conductorem inveniat, addidimus autem de consensu Cantoris, ut videlicet gratificationi locus non sit et ita judicatum refert Le Guenois in conferentijs consuet[udines] Gallia[e] fol 645 ad l[itte]ram L.

13 Buitensteeds of extern zee- en assurantierecht (eZR)

Antwerpen was een handelsmetropool met een haven van formaat als kwintessens van het commerciële leven dat het ritme van de stad bepaalde. Haar leidinggevende positie binnen de Europese handel manifesteerde zich ook op juridisch vlak. Geen enkele andere stad zou in haar costume zoveel zee- en assurantierecht verzamelen als Antwerpen in zijn vierde redactiepoging. Het haalde bovendien zulk een hoog niveau dat het als enige onderdeel van de Consuetudines compilatae zou worden gehomologeerd op 14 februari 1609. Deze categorie omvat nu die artikels welke hun oorsprong kennen in vreemde en/of vroegere verzamelingen van maritiem recht. Bij wijze van voorbeeld vermeld ik hier het Wisbuyse Zeerecht, in de Memorien op de Costumen aangeduid als het Oud recht van Wisbuy: Est pars finalis d ar[ticu]li 13 int out recht van wisbuy nisi quod in hac revisione omnia distinctius explicata sint paucis etiam additis ut convenirent pra[e]cedentibus et usus ita observat. ${ }^{157}$ Maar ook vele andere zeerechtelijke compilaties zullen hier aan bod komen.

\section{$14 \operatorname{Varia}(V)$}

Een laatste groep omvat het residu of alles wat op geen enkele verantwoorde manier bij één van bovenstaande categorieën kon worden ondergebracht. Hun aandeel is, net als hun relevantie, gelukkig tot het minimum beperkt. Net zoals ik ook ten aanzien van het canonieke recht heb gedaan, beperk ik me hier tot het kort aangeven van de situaties waar het om gaat. Het betreft onder meer het certificatio schabinali zoals dit ter sprake komt met betrekking tot artikel 4.18.69: Est additus in hac revisione ex $d$ certificatione schabinali de qua art $63 \mathrm{i}[\mathrm{n}]$ hoc tit. Waar het juist om gaat, is me onduidelijk gebleven. ${ }^{158}$ Drie andere artikels verwijzen naar de usus curiae en stilus curiae. ${ }^{159}$ Het betreft hier de Raad van Brabant en zijn gebruiken.

\footnotetext{
157 Cfr. 4.8.55.

158 Enkel ten aanzien van de artikels 4.18.60/61/62 leren de Memorieboeken ons meer omtrent dit certificaat. Zo is het namelijk olim facta ad requisitionem van die van Herentals 29 decemb[er] 1542 staende int oudt register fol 61 verso. ${ }^{159}$ Cfr. 3.14.65, 5.10.69 en 5.17.87.
} 
PARAGRAAF 2

DE JURIDISCHE OORSPRONG VAN DE INNOVATIES BINNEN DE CONSUETUDINES COMPILATAE (1608)

In de vorige paragraaf ben ik kort ingegaan op de stand van zaken van het onderzoek naar de invloeden welke werkzaam zijn geweest bij de redactie van het gewoonterecht in de Nederlanden en Frankrijk. Vervolgens heb ik de methode uiteengezet welke ik zal hanteren om ten eerste de vernieuwingen in de Consuetudines compilatae te lokaliseren en vervolgens de juridische oorsprong ervan te catalogiseren. Deze tweede paragraaf geeft nu een overzicht van de resultaten welke ik bekomen kon door voornoemde methode toe te passen op het materiaal vervat in de Memorieboeken. Het is bijgevolg een uiterst descriptieve paragraaf, waarbij het niet in mijn ambities ligt alle, mogelijk verrassende, vaststellingen van een definitieve verklaring te voorzien. Mijn hoofddoel echter is louter aangeven op welke vlakken de Consuetudines compilatae in de eerste plaats vernieuwend zijn geweest en vervolgens op basis van welke rechtsbronnen dit geschied is. Zo stelt deze beschrijving me in staat tal van invloeden kenbaar te maken welke tot nog toe onzichtbaar waren gebleven in de kelders van het Antwerpse stadsarchief. Bovendien biedt ze de mogelijkheid de kritiek van Jacques Van Uffel op zijn houdbaarheid te testen. Dit zal echter grotendeels in een volgende, derde paragraaf aan bod komen.

De opbouw van deze tweede paragraaf volgt de structuur van de Consuetudines compilatae. Ik zal met andere woorden de materie deelsgewijs benaderen, waarbij ik binnen elk blok zal afdalen tot op het niveau van de afzonderlijke titels. Enkel op deze manier kan ik concrete uitspraken formuleren omtrent de plaatsen waar voornamelijk geïnnoveerd werd en kan ik zeer specifieke relaties an het licht brengen, welke er ongetwijfeld bestaan tussen de verscheidene juridische materies en de verschillende types van rechtsbronnen.

Deel I

Zoals in de meeste andere Brabantse compilaties beschrijven ook de eerste titels van de Consuetudines compilatae publiekrechtelijke aangelegenheden. Generaliter omvat dit eerste deel artikels waarin de stedelijke overheid en haar rechtelijke organisatie centraal staan. ${ }^{160}$ Ook de juridische positie van de poorters van de stad is hier aan de orde. Ook in de Consuetudines impressae was dit niet anders (titels I-IX). Enkel de titels betreffende de binnen- en buitenpoorters van de stad Antwerpen moet daar verderop in de tekst gezocht worden (titels XXXVI-XXXIX). De tiende titel van de Consuetudines impressae omtrent de seyntschepenen of syndikalen werd in de Consuetudines

160 Omtrent de Antwerpse bestuursinstellingen, zie: R. BOUMANS, Het Antwerps stadsbestuur voor en tijdens de Franse overheersing. Bijdrage tot de ontwikkelingsgeschiedenis van de stedelijke bestuursinstellingen in de Zuidelijke Nederlanden, Brugge, 1965. J. VAN DEN NIEUWENHUIZEN, "Bestuursinstellingen van de stad Antwerpen (12de eeuw-1795)", R. VAN UYTVEN, C. BRUNEEL, H. COPPENS en B. AUGUSTYN red., De gewestelijke en lokale overheidsinstellingen in Brabant en Mechelen tot 1795 (Algemeen Rijksarchief en Rijksarchief in de provinciën. Studia 82), 2 dln., Brussel, 2000, 462-510. 
compilatae niet hernomen. De reden hiervoor moet gezocht worden in het spanningsveld tussen protestanten en katholieken. Aanvankelijk resideerde te Antwerpen geen bisschop en bijgevolg waren burgers vaak verplicht naar het verre Kamerijk te reizen wanneer zij verwikkeld waren in huwelijks- en geslachtszaken (o.a. zedenmisdrijven). Deze aangelegenheden behoorden immers exclusief tot het domein van het canonieke recht en werden behandeld door het synodale gerecht of seend. Vermoedelijk is het Antwerpse bestuur er op een moment van verzwakking van het kerkelijke gezag omstreeks 1270 in geslaagd deze bevoegdheden onder te brengen in een Antwerps rechtscollege van seyntschepenen. Een belangrijk onderscheid met de bisschoppelijke, aartsdiakonale en dekenale seend is dat de Antwerpse seyntschepenen zuiver burgerlijk van aard waren. ${ }^{161}$ Wanneer echter Antwerpen in 1559 het centrum werd van een eigen bisdom, kwam de hoofdbestaansreden van de Antwerpse seyntschepenen te vervallen en vervolgens geraakte de onderbank in onbruik. In 1580 zag het protestantse stadsbestuur er een ideaal hervormingsmiddel in teneinde alles binnen de bevoegheden van een radicaal lekengerecht onder te brengen. De seyntschepenen waarvan sprake is in de Consuetudines impressae hebben dan ook weinig gemeen met hun middeleeuwse voorgangers. $\mathrm{Na}$ het verdwijnen van het protestantse bestuur en het in onbruik geraken van de oorspronkelijke seyntschepenen, hebben de compilatores van de Consuetudines compilatae het niet langer raadzaam geacht binnen de compilatie van deze onderbank melding te maken. ${ }^{162}$

Het innoverend karakter van dit eerste deel is relatief beperkt. Gezien het feit dat het merendeel van deze titels reeds in de voorgaande redacties aan bod kwam en er bovendien sterk was uitgewerkt, overstijgt het totale aandeel van de nieuw geïntroduceerde artikels nipt de dertig procent. Hiermee behoort dit 'overheidsrecht' tot de minst innovatieve rechtsdomeinen van de Consuetudines compilatae. Bijgevolg kan er, althans wat dit eerste deel betreft, niet zozeer van 'novateurs' gesproken worden. Tabel 1.2 geeft de verdeling weer van de innovaties over de verschillende titels.

Tabel 1.2 Het innovatieve karakter van deel I

\begin{tabular}{|l|l|c|c|c|}
\hline & Titel & $\begin{array}{c}\text { Aantal } \\
\text { artikels }\end{array}$ & $\begin{array}{c}\text { Aantal nieuwe } \\
\text { artikels }\end{array}$ & $\%$ \\
\hline 1.1 & Van de stadt, haere paelen ende rechten & 15 & 5 & 33.3 \\
\hline 1.2 & $\begin{array}{l}\text { Van der stadts overheijt, ende eerst van den schoutet, } \\
\text { onderschoutet ende hunne colfdraegers }\end{array}$ & 16 & 3 & 18.8 \\
\hline 1.3 & Van den amptman, sijne clercken ende dienaeren & 16 & 0 & 0.0 \\
\hline 1.4 & Van borgemeesteren ende schepenen, ende bunne dienaeren & 24 & 3 & 4.2 \\
\hline 1.5 & Van de lakenhalle & 15 & 0.5 & 3.3 \\
\hline
\end{tabular}

161 Omtrent het unieke karakter van deze burgerlijke seyntschepenen, zie: W. NOLET en P. C. BOEREN, Kerkelijke instellingen in de Middeleeunen, Amsterdam, 1951, 308, noot 1.

162 Omtrent het synodale gerecht of seend, cfr. NOLET en BOEREN, Kerkelijke instellingen in de Middeleeuwen, 209-211 en 306-308. Omtrent de ontwikkeling van de Antwerpse seyntschepenen, cfr. GOTZEN, “Oud-Antwerps burgerlijk procesrecht”, 430-434. 


\begin{tabular}{|l|l|c|c|c|}
\hline 1.6 & Van de peijsmaeckers & 8 & 5 & 62.5 \\
\hline 1.7 & Van de weesmeesters' ${ }^{163}$ & 14 & 3 & 21.4 \\
\hline 1.8 & Van de rechters van de watermeulenbrugge & 3 & 0 & 0.0 \\
\hline 1.9 & Van de heerlijckheijt van den Kiele ende de rechters aldaer & 5 & 0 & 0.0 \\
\hline 1.10 & Van verscheijde andere rechteren binnen dese stadt & 8 & 5 & 62.5 \\
\hline 1.11 & Van de greffiers ende henne clercken & 10 & 9 & 90.0 \\
\hline 1.12 & Vande secretarissen ende bunne stoel-clercken & 31 & 27 & 87.1 \\
\hline 1.13 & Van notarissen & 14 & 10 & 71.4 \\
\hline 1.14 & Van de binnen-poorters & 43 & 6 & 14.0 \\
\hline 1.15 & Van buijten-poorters, t'sij geboorne oft geëede & 7 & 0 & 0.0 \\
\hline 1.16 & Van ingesetenen ende inwoonders & 15 & 1 & 6.7 \\
\hline
\end{tabular}

Voor zover er al sprake kan zijn van noemenswaardige vernieuwingen, beperken deze zich tot een vijftal titels: titel 1.6 ( $V$ an de peijsmaeckers), titel 1.10 (Van verscheijde andere recbteren binnen dese stadt), titel 1.11 (Van de greffiers ende benne clercken), titel 1.12 (Vande secretarissen ende bunne stoel-clercken) en tot slot titel 1.13 (Van notarissen). Gezamelijk nemen ze 56 of drie kwart van alle nieuwe artikels binnen dit deel voor hun rekening. Tabel 1.3 geeft een idee waar deze nieuwe artikels vandaan komen. Er is te zien voor welk percentage van de nieuwe artikels welke rechtsbron verantwoordelijk is. ${ }^{164}$

Tabel 1.3 Percentage nieuwe artikels waarvoor elk. type rechtsbron verantwoordelijk is (deel I)

\begin{tabular}{|c|c|c|c|c|c|c|c|c|}
\hline WG & Usus & Comp & S & OAR & RL & Ciciv & RS & 3 \\
\hline 49.0 & 27.1 & 15.5 & 11.6 & 9.0 & 5.2 & 3.9 & 2.6 & 0.1 \\
\hline
\end{tabular}

Wat meteen in het oog springt is de zeer nadrukkelijke aanwezigheid van de wetgeving. Minstens de helft van de nieuw toegevoegde artikels zijn het gevolg van legislatieve inspanningen. Dat de wetgeving in dit eerste deel zulk een prominente plaats inneemt, ligt enigszins voor de hand. Het gaat immers om publiekrecht, dat per definitie in de meeste gevallen het resultaat was van legislatieve arbeid. Dat het bijgevolg ook bepalend is geweest voor bijna dertig procent van alle nieuwe artikels, verrast dan ook niemand. Concreet gaat het hier om wettenrecht dat afkomstig is van zowel de stedelijke als de vorstelijke overheid. Gezien de centrale rol die de stedelijke overheid vervult binnen dit luik, mag er mijns inziens een overwicht van stedelijke ordonnanties worden verwacht. En terecht, de verhouding stedelijk versus vorstelijk blijkt er één te zijn van 26 op negen. ${ }^{165}$

Alvorens dieper in te gaan op de verschillende legislatieve documenten waarnaar verwezen wordt, wil ik er op wijzen dat de af- of aanwezigheid van bepaalde types

${ }^{163}$ P. GODDING, Le droit privé dans les Pays-Bas méridionaux du $12^{\circ}$ au $18^{e}$ siècle (Mémoires de la Classe des Lettres. Collection in quarto. XIV), Brussel, 1987, 131.

164 Aangezien het voor één artikel onduidelijk is gebleven om welke primaire rechtsbronnen het exact gaat, bestaat er voor elke categorie binnen deze tabel een theoretische foutmarge van één artikel of -in het geval van een totaal aantal nieuwe artikels van 77.5- 1.3 procent.

165 Eén ordonnantie, die op de verzwijginge vande renten van 15 februari 1593, heb ik niet in rekening kunnen brengen omdat het onduidelijk is gebleven of het landsheerlijke dan wel stedelijke wetgeving betrof. Hetzelfde geldt voor die artikels waarvoor naar het abstracte 'diversis statutis' wordt verwezen. Samen zijn deze goed voor vier nieuwe artikels. 
van rechtsbronnen doorgaans onderwerpgebonden -lees titelgebonden- is. Vandaar dat het raadzaam is steeds te kijken naar de verhoudingen tussen de verschillende bronnentypes op titelniveau, zoals ik ten aanzien van deel $\mathrm{I}$ in tabel 1.4 heb weergegeven. ${ }^{166}$

Tabel 1.4 Aandeel van ieder type rechtsbron per titel (deel I)

\begin{tabular}{|c|c|c|c|c|c|c|c|c|c|c|c|c|}
\hline Tot & $\mathbf{1}$ & $\mathbf{. 1}$ & $\mathbf{. 2}$ & $\mathbf{. 4}$ & $\mathbf{. 5}$ & $\mathbf{. 6}$ & $\mathbf{. 7}$ & $\mathbf{. 1 0}$ & $\mathbf{. 1 1}$ & $\mathbf{. 1 2}$ & $\mathbf{. 1 3}$ & $\mathbf{. 1 4}$ \\
\hline 38 & WG & - & - & - & - & 4 & 3 & - & 8 & 15 & 8 & - \\
\hline 21 & Usus & - & - & 2 & - & - & - & 5 & 1 & 11 & 1 & 1 \\
\hline 12 & Comp & - & - & 1 & - & 1 & - & - & - & 4 & 3 & 3 \\
\hline 9 & S & 2 & 1 & 1 & - & - & - & - & - & 2 & 2 & 1 \\
\hline 7 & OAR & 3 & 1 & - & - & - & 1 & - & - & - & - & 2 \\
\hline 4 & RL & - & - & - & - & - & - & - & - & 1 & 2 & 1 \\
\hline 3 & Ciciv & - & - & - & - & - & - & - & - & - & 2 & 1 \\
\hline 2 & RS & 1 & 1 & - & - & - & - & - & - & - & - & - \\
\hline 0.5 & $\mathbf{3}$ & - & - & - & 0.5 & - & - & - & - & - & - & - \\
\hline
\end{tabular}

Meteen wordt duidelijk dat men bijvoorbeeld ten aanzien van de titel 1.6 omtrent de peysiers of schepenen van de peyse hoofdzakelijk een beroep heeft gedaan op wetgevende bronnen. De Memorieboeken laten zien dat het hier voornamelijk stedelijke wetgeving betrof, welke de organisatie ervan regelde. De peyskamer was immers een stedelijke onderbank, van wie de organisatie sinds de veertiende eeuw in stedelijke ordonnanties werd vastgelegd. ${ }^{167}$ Vandaar dat ik hier dan ook ordonnanties op de peyskamer zoals bijvoorbeeld die van 12 november 1509 ontmoet. Een andere ordonnantie die binnen deze titel tot twee maal toe vermeld wordt, is die van 24 oktober 1592.168 Ook met betrekking tot de zevende titel omtrent de weesmeesters wordt er verwezen naar een

166 Opgelet, het betreft hier absolute waarden. Tevens wil ik opmerken dat titels, welke ten opzichte van de Consuetudines impressae niet werden geïnnoveerd, ook niet in de tabel werden opgenomen. Hetzelfde geldt voor bronnencategorieën die binnen dit deel niet aan bod kwamen.

167 Sinds de veertiende eeuw hadden deze peysmaeckers een zeer nauwkeurig omschreven taak. Om private bestraffing te vermijden, daar waar het recht van weerwraak gold voor de benadeelde en zijn familie, werd sinds lang getracht een verzoening tussen beide partijen tot stand te brengen. Aanvankelijk behoorde deze taak tot het takenpakket van de schepenen, maar sinds 1357 werd bij stedelijke ordonnantie een zelfstandig rechtsorgaan in het leven geroepen. De Memorien op de Costuymen spreken in deze verkeerdelijk van een statuut dat de instantie op Sinte Gregorius dach anno 1326 in het leven riep. (Cfr. 1.6.1) Ook Hendrik de Moy houdt het in zijn traktaat op de Consuetudines impressae bij Sint-Gregoriusdag van het jaar 1356 (1357 n.s.). (SAA, Vierschaer, 21: DE MOY, Tractaat fol. 50r.) De vier peysiers, welke tot 1681 steeds oud-schepenen waren en daarna ook dienende schepenen, werden door de magistraat aangesteld. Ambtsweigering werd met een geldboete bestraft. (GOTZEN, "Oud-Antwerps burgerlijk procesrecht", 426-427.)

168 De Memorieboeken spreken, met betrekking tot de artikels 1.6.6/7, verkeerdelijk van 23 oktober 1592. Materiële controle van de inhoud heeft immers uitgewezen dat het hier om dezelfde ordonnantie van 24 oktober 1592 gaat welke meermaals aangehaald wordt in het vijfde civiele en procesrechtelijke deel. Aldaar wordt de ordonnantie omschreven als zijnde stedelijk (Cfr. 5.10.7/8), nieuw en zelfs gedrukt (Cfr. 5.10.59). 
statutaire stedelijke ordonnantie, namelijk die op de weesen van 28 maart 1495 (1496 n.s.). ${ }^{169}$ Maar ook hier grijpt men terug naar de zopas vermelde ordonnantie van 24 oktober 1592.

Eenzelfde trend is waarneembaar bij de titels 1.11 en 1.12, respectievelijk de griffiers en secretarissen evenals hun klerken aangaande. ${ }^{170}$ Stedelijke ordonnanties voeren er de rangen aan. In eerste instantie de procesrechtelijke, gedruckte ordonnantie achter de costuymen op de styl ende maniere van procederen van 1582, en haar voorgangers in het genre, meer bepaald de gelijknamige ordonnanties van 1564 en 1576.171 Voor maar liefst negentien van de 36 nieuwe artikels in beide titels wordt hier minstens naar één van voorscreven ordonnantien verwezen. Wat de twaalfde titel betreft wil ik nog wijzen op het belang van de ordonnantie op de verawijging van de renten van 15 februari 1593 en de abstracte diversis statutis waarvan sprake is met betrekking tot één artikel.

169 Deze ordonnantie is onder meer terug te vinden in het archief van de Privilegiekamer: (ANTWERPEN, Stadsarchief, Privilegiekamer, nr. 1452: Weeskamer. Ordonnanties, fol. 1.) De weeskamer kende reeds een precedent in de vorm van de drie oppermomboren, die sinds 1428 door de stad werden aangesteld. Deze instelling boven de hoofden van de voogden stond in voor het medebeheer, samen met voogden, over de goederen van de weeskinderen. In 1496 werd deze instelling omgevormd tot een eigenlijk stedelijke onderbank, bestaande uit 3 weesmeesters en een gezworen klerk als griffier. Als rechterlijke macht behandelde ze conflicten tussen de voogden en weeskinderen. (GOTZEN, "Oud-Antwerps burgerlijk procesrecht", 424-426.) Gotzen houdt evenwel geen rekening met de paas(jaar)stijl en spreekt hier verkeerdelijk van 1495 .

${ }^{170}$ In de Consuetudines impressae kenden deze titels geen precendent. Zij maakten in 1582 nog deel uit van de gedrukte styl ende maniere van procederen.

171 Van geen van beide ordonnanties heb ik in het Antwerpse stadsarchief sporen kunnen terugvinden, en dit ondanks het feit dat ook de ordonnantie van 1564 gedrukt zou zijn, althans wanneer ik de Memorieboeken ten aanzien van artikel 1.3.7 mag geloven: Est 8 in impressis hoc tit ende inde ghedruckte ordonnantie op de maeniere van procederen de anno 1564 tit, van dagemen[ten] art 16 et est etiam desumptus ex sententia i[bi] allegata ad precedent. Mijns inziens gaat het hier eerder om een misverstand waarbij men de ordonnantie van 1564 verward met de gelijkaardige ordonnantie op de stijl en manier van procederen welke samen met de Consuetudines impressae in 1582 werd gedrukt. Hier staat tegenover dat ook het aanhef van de civielrechtelijke titel XX (Der justicien ende judicature in [t] civiele aenghaende ende tgene der selver aencleeft) in de Consuetudines antiquae naar deze ordonnantie van 1564 verwijst als zijnde 'gepubliceerd'. De tekst luidt als volgt: Opde forme ende maniere van procederen ende administreren van justitien int civiel, midtsgaeders tgene daeraf dependeert, is versien by ordonnantien ende statuyten, ende besundere lestmael by ordonnantie gepubliceert inden jaere 1564, daermen hem biertoe refereerdt, alleenelyck bier naer stellende eenige costumen inde voorscreve ordonnantie nyet geruert. (Coutumes de la ville d'Anvers dites antiquae, I, 554.) Toch volstaat dit niet als argument. 'Publiceren' betekent in deze context louter 'openbaar maken', en kan in principe louter doelen op het feit dat de ordonnantie luidop aan het volk werd voorgelezen. Zij hoeft daarom niet noodzakelijk gedrukt te zijn.

Ten aanzien van de ordonnantie van 1576 ontbreekt elk verder spoor volkomen. Enkel in de Consuetudines impressae (titel 1, artikel 14) is er ten aanzien van het notarisambt sprake van een zekere Ordinantie deser stadt vanden achtsten dach van meye vanden jaere XVc ende Ixxvj. (Coutumes de la ville d'Anvers dites Impressae, II, 6.) Omtrent de vraag in hoeverre het hier om dezelfde ordonnantie gaat, heb ik echter nergens aanwijzingen of bewijsmateriaal kunnen terugvinden. 
Titel 1.13 (Van notarissen) van zijn kant is voor drie kwart nieuw en kende in tegenstelling tot voornoemde titels, noch in de Consuetudines impressae, noch in de hieraan toegevoegde styl ende maniere van procederen een precedent. Wederom ligt de nadruk op legislatieve rechtsbronnen. In tegenstelling tot de zojuist besproken titels wordt er nu hoofdzakelijk verwezen naar vorstelijk in plaats van stedelijk wettenrecht. Hierbij is een prominente rol weggelegd voor de keizerlijke ordonnantie van 4 oktober 1540, ook wel eens betiteld als het Eeunig Edict van Karel V. ${ }^{172}$ De ordonnantie bevat onder meer bepalingen omtrent de honoraria van notarissen, hun bevoegdheden bij het opstellen van de huwelijksvoorwaarden en de vorm van de notarisakten. Andere vorstelijke wetgeving, die van bepalende aard is met betrekking tot deze titel, is de keizerlijke ordonnantie van 7 oktober $1531 .{ }^{173}$ Het is het eerste plakkaat dat bepalingen bevat met betrekking tot het notariaat en wordt bovendien beschouwd als de grondslag voor de structuur van het notariaat in de Nederlanden. ${ }^{174}$

172 Edit de l'Empereur, concernant les sectes et hérésies, les banqueroutiers, les monopoles, les monnaies, les contrats de mariages des commerçants, l'usure, le prêt à l'intérêt, l'homologation des coutumes, les conflits de juridiction entre juges ecclésiastiques et civils, les dons et legs des mineurs, les notaires, la prescription de certaines créances, les mariages clandestins et la nomination des magistrats locaux, 4 oktober 1540, J. LAMEERE en H. SIMONT ed. (Recueil des ordonnances des Pays-Bas. $2^{\mathrm{e}}$ série, IV), Brussel, 1907, 232-238.

173 Ordonnance sur l'heresie, les monnaies, la redaction des coutumes, les notaries, les monopoles, les banqueroutiers, vagabonds, la mendicité et la bienfaisance, les kermesses, les noces, baptêmes, la police des cabarets, les crimes dus à l'ivrognerie, les buveurs, le luxe des vêtements, le commerce et l'exportation des chevaux, las blasphémateurs, les relations entre les divers pays de par deça, etc., 7 oktober 1531, J. LAMEERE ed., (Recueil des ordonnances des Pays-Bas. 2e série. III), Brussel, 1902, 265-273. Omtrent beide plakkaten (1531 en 1540) en het belang ervan voor het notariaat wil ik verwijzen naar de bibliografische aanwijzingen hieromtrent van Stevens. Cfr. STEVENS, Revolutie en notariaat, 32, noot 2. Voor een beknopt overzicht van de zestiende- en zeventiendeeeuwse verordeningen aangaande het notariaat, zie G. VAN DIEVOET, Het notariaat in Brabant gedurende de Nieuwe Tijd, Het notariaat in Brabant, Tentoonstelling, Huis der Notarissen te Leuven 30 september - 10 oktober 1982, Brussel, 1982, 69-73. Betreffende overheidsbemoeiingen met het Antwerpse notariaat tijdens de XVIde eeuw, zie: M. OOSTERBOSCH, "'Van Groote abuysen ende ongeregeltheden' Overheidsbemoeiingen met het Antwerpse notariaat tijdens de XVIde eeuw", Tijdschrift voor Rechtsgeschiedenis, (1995) 63, 83102. Hierin besprak Oosterbosch de invloed van de vorstelijke wetgeving evenals die van de stedelijke geboden op het notariële leven. Oosterbosch omschreef eveneens het laatmiddeleeuwse openbare notariaat van de stad Antwerpen in zijn proefschrift dat in 1992 gepubliceerd werd: M OOSTERBOSCH, Het openbare notariaat in Antwerpen tijdens de late Middeleeuwen (1314-1531). Een institutionele en prosopografische studie in Europees perspectief, Leuven, 1992.

174 Omtrent de geschiedenis van het notariaat in de Nederlanden: cfr. P. L. NEVE, Schets van een geschiedenis van het notarisambt in het huidige België tot aan de Franse wetgeving (Rechtshistorische reeks van het Gerard Noodt Instituut. XXXIV), Nijmegen, 1995. P. L. NEVE, en A. F. GEHLEN, Het notariaat in de Lage Landen ( \pm 1250-1842): opstellen over de geschiedenis van het notariaat in de Lage Landen vanaf de oorsprong tot in de negentiende eeun (Ars notariatus. CXVII), Amsterdam, 2005. STEVENS, Revolutie en notariaat. Met betrekking tot de periode vòòr de Franse tijd, zie: STEVENS, Revolutie en notariaat, 31-62. Wat de Antwerpse notarissen in de 
Te Antwerpen werden deze ordonnanties echter voorafgegaan door en aangevuld met stedelijke verorderingen. Deze stadsgeboden hadden allen tot doel de activiteit van de notarissen binnen duidelijk omlijnde grenzen te houden of zelfs terug te dringen. Hierbij werd gepoogd het instituut onder stedelijke controle te brengen. ${ }^{175}$ Van deze stadsgeboden is in de Memorieboeken echter geen sprake. De helft van de tien nieuwe artikels binnen deze titel daarentegen gaat terug op voornoemde vorstelijke plakkaten. ${ }^{176}$ Het succes van de legislatie past overigens perfect in de synthese van Nève met betrekking tot de ontwikkeling van het notarisambt in de nieuwe tijd. Waar het notariaat aanvankelijk meer een kerkelijke instelling was, ondergaat het in de zestiende eeuw een karakterverandering. Het wordt namelijk een wereldlijke aangelegendheid en dit zelfs op landsheerlijk niveau, waardoor langzaamaan zelfs de contouren van een 'nationaal' recht zichtbaar worden. Hierbij krimpt de actieradius van de notaris evenwel tot de volontaire jurisdictie. ${ }^{177}$

Des te opvallender bij dit alles is het buitenlands, vorstelijk wettenrecht dat hier een hoofdrol voor zichzelf opeist. Voor maar liefst zeven van de tien nieuwe artikels wordt namelijk verwezen naar de commentaar van de Franse jurist, Louis le Caron (1536-1614), op de Codex Henricianus, een compilatie van vorstelijk wettenrecht welke was samengesteld door Barnabé Brisson (1531-1591). Het betreft de wetgeving van de Franse koning Hendrik III (1551-1589).178 Daarenboven komt deze wettenverzameling ook met betrekking tot de titel omtrent de secretarissen een aantal keer voor als secundaire rechtsbron. Dat men zich in deze mate liet inspireren door vreemde, vorstelijke wetgeving, en dan in het bijzonder het wettenrecht van de Franse koning, verbaast me niet. Reeds in 1831 heeft Grandgagnage het belang van de Franse constitutions voor de kanselarij van de landsheer van de Nederlanden aangetoond. ${ }^{179}$

Ook de tiende titel omtrent verscheijde andere recbteren binnen dese stadt verdient extra aandacht. In de Consuetudines impressae bleef dit onderwerp namelijk beperkt tot één

zestiende eeuw betreft, zie: J. VAN ROEY, "Notarissen en schepenen te Antwerpen in de 16e eeuw", Kroniek. Orgaan van Stabuco. Vereniging Stadspersoneel Antwerpen (1950), 49-51.

175 Cfr. OOSTERBOSCH, "Van Groote abuysen ende ongeregeltheden", 88.

176 Beide plakkaten kaderden overigens volledig in het vorstelijk streven naar centralisatie. Cfr. OOSTERBOSCH, "Van Groote abuysen ende ongeregeltheden", 87.

${ }^{177} \mathrm{NEVE}$, Schets van een geschiedenis van het notarisambt, 143.

${ }^{178}$ L. CHARONDAS LE CARON, Le Code du Roy Henry III, Roy de France et de Pologne, redigé en ordre par Barnabé Brisson, depuis augmenté des édits du Roy Henry IV, avec la conférence des ordonnances, et rapporté aux ancien Code de Théodose et de Justinien, et aux Basiliques, et illustrés des Conciles de l'Eglise, Lois des Romains et autre peuples, Histoires, Antiquiez, Arrêts, Observations et Annotations, Parijs, 1587. (Cfr. E. HOLTHÖFER, "Die Literatur zum gemeinen und partikularen Recht in Italien, Frankreich, Spanien und Portugal", H. COING red., Handbuch der Quellen und Literatur der Neueren europäischen Privatrechtsgeschichte, II/1, Munchen, 1977, 269.)

179 Cfr. M. GRANDGAGNAGE, L'influence de la législation civile Française sur celle des Pays-Bas pendant le XVTe et XVIIe siècle (Mémoires couronnés par l'Académie royale des sciences et belles-lettres de Bruxelles. VIII), Brussel, 1831. MARTYN, Eeunig Edict, 97. 
titel welke enkel aan de Natie van Portugal was gewijd ${ }^{180}$. In de Consuetudines compilatae daarentegen werd deze lijst van instanties met een beperkte rechterlijke macht binnen de stad angevuld met het geestelijk hof, de feodale bank, de bank van de munte, de Tolkamer en de handelsrechtbank van de Oosterse Natie (Hanzen). Al deze aanvullingen vonden grotendeels plaats ex usu. De redactie van het gewoonterecht manifesteert zich hier in de eerste plaats als een vastleggen van de bestaande costumiere werkelijkheid en dus niet -zoals kwatongen graag beweren- als het wijzigen van de juridische werkelijkheid. Deze Usus speelt overigens over de ganse lijn van dit eerste deel een voorname rol. Als primaire rechtsbron is ze in totaal immers goed voor bijna dertig procent van de nieuw toegevoegde artikels. ${ }^{181}$

Verder springt ook de quasi volledige afwezigheid van het Romeinse recht in het oog, net als het feit dat er nauwelijks gewag gemaakt wordt van welke vorm van buitensteeds gewoonterecht dan ook. Toch is ook dit niet verwonderlijk. Elke stad of regio kent immers haar eigen geschiedenis of traditie waarin haar bestuurlijke en juridische instellingen zich langzaamaan op een zo goed als onafhankelijke manier ontwikkelden, meestal gekatalyseerd door de stedelijke overheid, lees stedelijke wetgeving. ${ }^{182}$ Deze regionale specificiteit bemoeilijkt het ontdekken van parallellen in tijd en ruimte. Het ligt dan ook voor de hand dat er noch in de Romeinse instellingen, noch in die van andere, naburige steden veel overeenkomsten te vinden waren. Dit lees ik ook bij Monballyu: "Een ander typisch institutioneel kenmerk van de late middeleeunven en de nieuwe tijd was dat de meeste overbeidsinstellingen toen niet door een ingreep van boven totstandkwamen, maar empirisch en pragmatisch groeiden wit bestaande instellingen waarin op een

\footnotetext{
${ }^{180}$ Dit was één van de gerechten welke te Antwerpen voor de (gepriviligeerde) vreemdelingen operationeel waren. Omdat dit echter zodanig in de stedelijke, rechterlijke hiërarchie was geïntegreerd, kan het veeleer als een echte onderbank worden beschouwd.. (GOTZEN, "Oud-Antwerps burgerlijk procesrecht", 429-430.)

${ }^{181}$ In dit opzicht zou ik willen opmerken dat ook keuren en stedelijke privileges tot op zekere hoogte als geredigeerd gewoonterecht kunnen worden beschouwd. Maar al te vaak waren zij immers de schriftelijke weergave van een bestaande werkelijkheid, welke door haar langdurig bestaan algemeen aanvaard was. (Cfr. GILISSEN, Historische inleiding, 296-299.)

182 Zie hieromtrent de 29 procent aan nieuwe artikels welke gebaseerd zijn op de gewoonte en vooral de 54 procent aan nieuwe artikels op basis van stedelijk wettenrecht.

Ook Hermesdorf heeft aandacht gehad voor de relatie tussen het Romeinse recht en het eigen publiekrecht. Hoewel hij zich hierbij concentreert op de juridische onderbouw van de centrale macht (Kerk en Staat), weidt hij kort uit over de rol van het Romeinse recht met betrekking tot de ambtsdragers van het lagere, lokale niveau. (Cfr. HERMESDORF, Römisches Recht in den Niederlanden, 97-99.) De auteur laat er, aan de hand van Filips van Leiden, zien hoe Romeinse termen en regelingen worden getransponeerd naar contemporaine ambten zoals bijvoorbeeld dat van de amptman en meer specifiek zijn verblijfplaats. Bovendien wijst hij erop dat de wetenschappelijke kennis in dit opzicht nog heel wat lacunes vertoont, wat bijgevolg heel wat perspectieven biedt aan de huidige generatie onderzoekers. Het probleem van Hermesdorf -en dat geeft hij ook zelf toe- is dat hij zich gebaseerd heeft op rechtsgeleerde literatuur (Filips van Leiden) en dat hieromtrent betwijfeld kan worden in hoeverre deze representatief is voor de de facto gang van zaken in de rechtspraktijk.
} 
bepaald ogenblik bepaalde taken werden toevertrouwd aan gespecialiseerde personen. achter de rug heeft. Die verenigden zich allengs in een afzonderlijke instelling, die zich dan van de moederinstelling afsplitste." "83 Desalniettemin was Hermesdorf ervan overtuigd dat ook binnen deze themata het Romeinse recht, reeds vanaf de middeleeuwen, invloed heeft uitgeoefend. Hij erkende echter even openlijk dat op dit vlak nog heel wat onderzoek gebeuren moe(s)t. ${ }^{184}$ Onze bevindingen blijken echter niet in dezelfde lijn te liggen. De invloed van het Romeinse recht is aantoonbaar doch tot een minimum beperkt. Net als ten aanzien van de jurisprudentie is er ook met betrekking tot de rechtsleer geen opvallende trend waar te nemen. Beide categorieën beperken zich tot respectievelijk drie en vijf procent van de nieuw toegevoegde artikels.

Deel II

Het tweede deel verzamelt de normen met betrekking tot het personen- en familierecht. Conform andere compilaties ligt ook hier de nadruk op het huwelijksvermogensrecht (titel 2.1) evenals de regelgeving betreffende de vermomboirde personen of weeskinderen (titel 2.5). Beide titels tellen minstens 200 artikels, waar de overige drie titels niet eens de kaap van dertig overschrijden. ${ }^{185}$ Ook de Consuetudines impressae vertoonden reeds een vergelijkbaar beeld, waar het de titels XLI en XLIII zijn die de voornoemde aspecten van het personenrecht beschrijven. Ten aanzien van diezelfde Consuetudines impressae werden deze titels gemiddeld voor 36 procent geïnnoveerd. Opnieuw is dit geen cijfer dat uit de band springt. Bovendien laat tabel 1.5 zien dat, op één uitzondering na, namelijk titel 2.4 (Van onwettige kinderen oft bastaerden), deze vernieuwing gelijkmatig over de verschillende titels is verdeeld.

Tabel 1.5 Het innovatieve karakter van deel II

\begin{tabular}{|l|l|c|c|c|}
\hline & Titel & $\begin{array}{c}\text { Aantal } \\
\text { artikels }\end{array}$ & $\begin{array}{c}\text { Aantal nieuwe } \\
\text { artikels }\end{array}$ & $\mathbf{\%}$ \\
\hline 2.1 & {$[$ Van gehoude persoonen $]$} & 228 & 76.5 & 33.6 \\
\hline 2.2 & Van de recbten tusschen de ouders ende kinderen & 29 & 7.5 & 25.9 \\
\hline 2.3 & Van ongehoude vrouwen & 17 & 6 & 35.3 \\
\hline 2.4 & Van onwettige kinderen oft bastaerden & 24 & 15 & 62.5 \\
\hline 2.5 & Van minderjaerige ende andere vermomboirde persoonen ... & 207 & 92 & 44.5 \\
\hline
\end{tabular}

183 J. MONBALLYU, Zes eeuwen strafrecht. De geschiedenis van het Belgische strafrecht (1400-2000), Leuven, 2006, 70.

184 HERMESDORF, Römisches Recht in den Niederlanden, 93-99.

185 Guyon wees onlangs nog op de laattijdige rol die het huwelijksvermogensrecht binnen de ontwikkeling van de Franse coutumiers vervulde. Aanvankelijk betekenden deze laatsten niet meer dan een verzameling stedelijke statuten, welke vervolgens werden uitgebreid met strafrechtelijke bepalingen. Een derde fase voegde hier het publiek- en feodale recht aan toe en pas in vierde instantie werd het geheel aangevuld met huwelijksvermogens- en erfrecht. ${ }^{185}$ (Cfr. GUYON, “Annotations de la coutume de Bordeaux", 300.) Zowel uit de Consuetudines compilatae als uit alle drie de voorgaande redacties, blijkt dat dit proces te Antwerpen reeds aan het begin van de zestiende eeuw zijn voltooiing had gekend. Zowel in de Consuetudines antiquissimae als in de Consuetudines antiquae en de Consuetudines impressae zijn onderwerpen als die aangaande de gehuwde en vermomboorde personen reeds sterk uitgewerkt. Vandaar ook dat zij in de vierde redactie relatief weinig wijzigingen behoefden. 
Waar de innovatieve waarde van drie van de vijf titels zich beperkt tot het gemiddelde van dertig à veertig procent, werd titel XLV uit de Consuetudines impressae (Van bastaerden) van maar liefst 62.5 procent aan nieuwe artikels voorzien. Het gaat hier hoofdzakelijk om regelgeving betreffende het legitimeren van bastaarden en de erfrechtelijke status van gelegitimeerde bastaarden. ${ }^{186}$

Ook het innovatieve karakter van de tweede titel, over de rechten tussen ouders en kinderen, is licht buitenproportioneel. Slechts 7.5 van de 29 artikels zijn nieuw toegevoegd. En dit ondanks het feit dat deze titel geen precedent heeft gekend in de vorige redactiepogingen. ${ }^{187}$ De titel is namelijk het resultaat van een symbiose van twee titels uit de Consuetudines impressae, met name titel XLIV (Van emancipatie) en titel XXXVI (Staet ende condicie van persoonen). Bijgevolg bestaan beide titels niet langer zelfstandig in de Consuetudines compilatae. Ondanks haar aanwezigheid in de Antwerpse redactiepogingen behoort deze materie tot de minst frequente thema's binnen de traditionele, costumiere redacties. ${ }^{188}$ Godding stelt dat de rechten en plichten van de ouders vont de soi dans la mesure où ils correspondent aux principes enseignés par l'Eglise et reçus par les moeurs. ${ }^{189}$ Dit verklaart uiteraard de dominante rol van de Usus binnen de innovaties van titel 2.2.190

Tabel 1.5 laat echter ook zien dat ik niet aan de innovaties binnen de titels 2.1 en 2.5 voorbij kan. Hoewel het procentuele, innovatieve karakter van geen van beiden de kaap van vijftig overstijgt, kan ik er niet omheen dat het hier absoluut gezien om maar liefst 75 en 79 nieuwe artikels gaat. Zulke waarden maken hen verantwoordelijk voor 85 procent van alle innovaties binnen deel II. Bovendien nodigen ze de onderzoeker uit dieper in te gaan op de juridische basis ervan. Hiertoe dient onderstaande tabel 1.6. ${ }^{191}$

${ }^{186}$ Het onderscheid tussen de verschillende soorten van onwettige kinderen, zoals dat bestond in het canonieke recht, werd in het gewoonterecht aanvankelijk niet gemaakt. De discriminatie van buitenechtelijke of overwonnen en incentueuze kinderen ten overstaan van simpele bastaerden vond pas als gevolg van de strenger wordende zeden onder invloed van het Concilie van Trente zijn weg naar het costumiere recht. (Cfr. GODDING, Droit privé, 115.) Te Antwerpen was dit onderscheid reeds met de Consuetudines impressae tot het costumiere recht doorgedrongen.

187 Ook in de overige Brabantse compilaties is deze titel eerder ongebruikelijk. Cfr. infra, hoofdstuk 2, paragraaf 2, Deel II.

${ }^{188}$ Cfr. infra, hoofdstuk 2, paragraaf 2, Deel II. Zie ook: GODDING, Droit privé, 121.

189 GODDING, Droit privé, 121.

190 Godding wijst er tevens op dat Antwerpen en Roermond de enige steden in de Nederlanden zijn, welke zich afzetten tegen het ouderlijk recht op het vruchtgebruik van de bezittingen van de kinderen. (GODDING, Droit privé, 123.)

191 Aangezien het voor één artikel onduidelijk is gebleven om welke primaire rechtsbronnen het exact gaat, bestaat er voor elke categorie binnen deze tabel een theoretische foutmarge van één artikel of -in het geval van een totaal aantal nieuwe artikels van 197- een halve procent. 
Tabel 1.6 Aandeel van ieder type rechtsbron per titel (deel II)

\begin{tabular}{|c|c|c|c|c|c|c|}
\hline Tot & $\mathbf{2}$ & $\mathbf{. 1}$ & $\mathbf{. 2}$ & $\mathbf{. 3}$ & $\mathbf{4}$ & $\mathbf{. 5}$ \\
\hline 64 & Ciciv & 5 & 1 & 3 & 5 & 50 \\
\hline 55.5 & S & 33.5 & - & 1 & 1 & 20 \\
\hline 44.5 & Usus & 12.5 & 5 & - & 7 & 20 \\
\hline 39 & Comp & 24.5 & 1.5 & 3 & 1 & 9 \\
\hline 25 & RL & 3 & 1 & 3 & 4 & 14 \\
\hline 13.5 & RS & 7.5 & - & - & - & 6 \\
\hline 12.5 & RA & 7.5 & - & - & 1 & 4 \\
\hline 12 & OAR & 9 & - & - & - & 3 \\
\hline 11 & eGR & 3 & - & - & 1 & 7 \\
\hline 11 & WG & 3 & - & - & - & 8 \\
\hline 9 & $\mathbf{3}$ & 1 & - & - & - & 8 \\
\hline
\end{tabular}

Wat betreft de eerste titel, aangaande de gehuwde personen, is er duidelijk een inspirerende kracht uitgegaan van andere artikels binnen de Consuetudines compilatae. Maar liefst 33.5 artikels kunnen worden verklaard als het gevolg van zaken die elders in de Consuetudines compilatae vermeld staan. Een verklaring voor deze vaststelling is mijns inziens te vinden in de inhoud van deze titel zelf. Het is immers zo dat het huwelijksvermogensrecht tal van raakvlakken vertoont met de materie van andere titels uit de Consuetudines compilatae. Een blik op de paragraaftitels zegt voldoende: 'contracten' van gehuwde personen; 'schulden' van gehuwde personen, 'giften en testamenten' van gehuwde personen, ... Telkens gaat het om zaken die ook als zelfstandig rechtsgebied in de Consuetudines compilatae aan bod komen.

Eveneens opvallend is het aandeel nieuwe artikels die het resultaat zijn van zeer specifieke redenen. In concreto gaat het om redenen als de beteugeling van roekeloosheden (...ad reprimandam audaciam ... $)^{192}$, de beëindiging van discussies tussen de doctores onderling (....sed nos addidimus verba bij maniere e [n] de titel van giste, ut tolleremus disputationem $d\left[\right.$ octores] ad L cum maritus $\int$ mulier ff de pactis dotal[ibus]...) ${ }^{193}$, het vermijden van fouten (...ut videlicet error corrigatur qui irrepserat quod non putarent necessarium... ${ }^{194}$, de bevrediging van velen hun verlangens (...ut satisfaceremus multorum desiderio... $)^{195}$, het verenigen van de oude en de nieuwe costumen (...ut veteres et novas consuetudines aliquo modo reduceremus in concordiam quamquam ista nova consuetudo... $)^{196}$ en de bestrijding van fraude (...ad excludendas omnes fraudes...) ${ }^{197}$.

Het zo goed als volledig ontbreken van het geleerde recht lato sensu verklaart zich aan de hand van het feit dat het huwelijksvermogensrecht steeds een typisch civielrechtelijk rechtsgebied -lees: costumier rechtsgebied- is geweest. ${ }^{198} \mathrm{De}$

192 2.1.18.

193 2.1.12.

$1942.1 .50 / 51 / 52 / 53$.

$1952.1 .68 / 69 / 70 / 71 / 72$.

196 2.1.143/144.

197 2.1.188/189/190.

198 Cfr. GODDING, Droit privé, 268: "L'ensemble du droit familial (régimes matrimoniaux et droit successoral) représente la partie la plus complexe du droit privé coutumier, celle qui a été le plus tributaire d'une évolution variant selon les régions et le milieu social." 
gebruikelijke Usus blijft dus ook binnen deze titel manifest aanwezig en vandaar dat er ook weinig inmenging van bovenaf waar te nemen is. Noch het stedelijk bestuur, noch de centrale overheid laten zich in met het huwelijksvermogensrecht. Dit ligt in de lijn van de idee dat de invloed van de (middeleeuwse) vorst zich beperkte tot publiekrechtelijke aangelegenheden. Van privaatrechtelijke gewoontes hield hij zich meestal op een veilige afstand. ${ }^{199}$ Ook de moderne vorst beperkte zich in zijn ordonnanties in de eerste plaats tot het staatsrecht en het administratief recht. ${ }^{200}$

Naast de titel omtrent het huwelijksvermogensrecht, kent ook die betreffende de wezen, hun voogdij en het beheer van hun goederen absoluut een sterke uitbreiding. Hoewel de momborije aanvankelijk een exclusief familiale aangelegenheid was, waarbij het weeskind werd toevertrouwd aan de goede zorgen van de meest verwante ouder aan vaders zijde, gaat deze verantwoordelijkheid stilaan ingepalmd worden door de stedelijke overheid. ${ }^{201}$ De magistraat werpt zich op als 'beschermende instelling' en eigent zich de organisatie en de controle van de voogdij toe. Vanaf de dertiende eeuw verschijnen echter de eerste 'weesmeesters'; de magistraat delegeert zijn macht inzake la tutelle geheel of slechts gedeeltelijk aan deze weeskamer. Vanaf de vijftiende eeuw verschijnen de eerste stedelijke ordonnanties hieromtrent en in de zestiende eeuw ontwikkelt het recht zich definitief. ${ }^{202}$ Ook Antwerpen zag een gelijkaardige instelling tot stand komen op initiatief van de stedelijke overheid. Vanaf 1428 verschijnen de drie zogenaamde oppermomboren ten tonele en sinds de Ordonnantie op de weeskamer de dato 28 maart 1496 krijgt Antwerpen een echte weeskamer als volwaardige stedelijke onderbank. ${ }^{203}$ Dat de invloed van het Romeinse recht hierbij zeer manifest is, heb ik, conform Godding, ook in de Memorieboeken kunnen vaststellen. ${ }^{204} \mathrm{Zij}$ tonen aan dat voor maar liefst 50 van de 79 nieuw geïntroduceerde artikels wordt verwezen naar regels uit het Corpus Iuris Civilis. Godding zegt hierover het volgende: "Dès le $15^{e}$ siècle, 'mambournie' des orphelins fait l'objet d'ordonnances prises par le Magistrat, précisant les règles à suivre par la désignation des tuteurs, leurs obligations, mes mesures de contrôle à leur égard, etc. L'influence du droit romain y est très nette, et ne fera que se renforcer au $16^{e}$ siècle, époque à laquelle le droit en matière de tutelle se fixe définitivement." ${ }^{05}$ Ook ten aanzien van titel 2.3 en 2.4, respectievelijk aangaande ongehuwde vrouwen en bastaardkinderen, neemt het Corpus Iuris Civilis een aanzienlijk deel van de nieuwe artikels voor zijn rekening. Tenminste wat betreft de bastaarden ligt dit voor de hand. Net als het huwelijk werd immers ook de afstamming aanvankelijk bijna uitsluitend door het canonieke recht

\footnotetext{
199 Cfr. GILISSEN, Historische inleiding, 302.

200 Cfr. GILISSEN, Historische inleiding, 316.

201 De vorstelijke overheid houdt zich in dezen tot de achttiende eeuw op de achtergrond, vermoedelijk omdat deze zaken zo goed waren geregeld op stedelijk niveau. (Cfr. GODDING, Droit privé, 126.)

202 Cfr. GODDING, Droit privé, 124-138.

203 Cfr. infra, hoofdstuk 1, paragraaf 2, Deel I.

${ }^{204}$ Cfr. GODDING, Droit privé, 125.

205 GODDING, Droit privé, 125.
} 
geregeld. Dit kerkelijk recht bestond op zijn beurt vaak uit regels die grotendeels aan het Romeinse recht werden ontleend. 206

Een sterke invloed van het Romeinse recht impliceert in de Consuetudines compilatae meestal een vergelijkbare invloed van de rechtsleer. Zoals in tabel 1.7 is te zien, is over de ganse lijn bijna dertien procent van de nieuwe artikels terug te brengen op rechtswetenschappelijke werken. Met betrekking tot de wezen, waar het aandeel van de rechtsleer veertien op 79 artikels bedraagt, behoort de abstracte groep van doctores tot de voornaamsten onder de geciteerde auteurs. Voor de rest beperkt men zich tot een allegaartje van namen die slechts één maal worden vernoemd. ${ }^{207}$ Wat de eerste titel omtrent het huwelijk betreft, krijgt men binnen de eerste tien artikels ervan een concentratie te zien van de Nederlandse jurist Pieter Peck (Tractatus de testamentis conjugum, in quinque libros distinctus, 1585) en de Spanjaard Antonio Ayerve de Ayora (Tractatus de partionibus de bonorum, communium inter maritum et uxorem et filios, et heredes eorum, 1586). Verder heeft de rechtsleer binnen deze titel geen noemenswaardige rol kunnen spelen. Ten aanzien van titel 2.4, omtrent bastaarden, spreekt men van Charles Dumoulin, Louis le Caron, Jean Papon en Fernando Vazquez de Menchaca. Dat deze titel in het teken staat van de Franse rechtsleer, wordt definitief bevestigd door de nadrukkelijke anwezigheid van de Franse jurist, Jean Bacquet. Hoewel zijn werk voornamelijk als secundaire rechtsbron werd aangewend en slechts één maal als primaire bron, komen Les oeuvres de Jean Bacquet des droicts du domaine de la couronne de France (1601), hetzij primair, hetzij secundair, maar liefst bij zeven van de vijftien nieuwe artikels aan bod.

De weeskamer is echter een 'levende' instelling en haar recht evolueert dan ook met de tijd. Vandaar dat ook in de Memorieboeken is te zien hoe de leden van de weeskamer gehoord zijn geweest met het oog op de uitwerking van deze titel in de Consuetudines compilatae. De introductie van een viertal nieuwe artikels wordt namelijk verantwoord ex suggestione et ad instantiam camer[a]e pupillaris... of ex suggestione iudicum pupillar [is] of ex annotatis et suggestione graphyarii camera[e] pupillaris. ${ }^{208}$ Het laat tevens zien hoe de leden van de weeskamer tot in beperkte mate in het debat werden betrokken en dat er ook daadwerkelijk rekening gehouden werd met hun visie. Of deze democratische houding van de commissieleden een noodgedwongen anpak is geweest omwille van een gebrek aan ervaring hunner zijde, wens ik hier in het midden te laten. Hoe dan ook, de weesmeesters hebben tot op zekere hoogte -lees: titel- mee het uiteindelijke uitzicht van de Consuetudines compilatae kunnen bepalen.

Wat de overige titels betreft blijven de aantallen zeer klein en de vaststellingen mankeren spektakel. Wel loont het de moeite dieper in te gaan op de ondermaatse rol vervuld door het wettenrecht, de vroegere redactiepogingen en de buitensteedse compilaties. Dit blijkt uit onderstaande tabel 1.7. Bovendien haalt de rechtspraak met een zeven procent over het algemeen in geen enkel ander deel zulk een groot aandeel

${ }^{206}$ Cfr. GODDING, Droit privé, 113.

207 Het betreft hier auteurs als Baldus de Ubaldus, Juan Garzia de Saavedra, Joost de Damhouder en Jean Papon.

${ }^{208}$ Cfr. respectievelijk 2.5.60, 2.5.106, 2.5.112/113. 
als binnen dit personenrecht. Enkel de afzonderlijke titel 3.14 omtrent het intestaat erfrecht doet met dertien procent beter. ${ }^{209}$ Binnen deel II is het de titel 2.1 omtrent de gehuwde personen die het merendeel aan jurisprudentie voor zich opeist. 7.5 nieuwe artikels of bijna tien procent vloeien voort uit de rechtspraak. Grotendeels heeft ze deze score te danken aan de hoge concentratie aan turben waarnaar verwezen wordt tussen artikel 2.1.145 en artikel 2.1.175. In globo betreft het hier paragraaf 7 (Sterffhuijs van gehoude persoonen, ende betaelinge van de scbulden) en 8 (Inventaris oft bewijs boeck ende staet van den sterffhuijse) van het huwelijksvermogensrecht.

Tabel 1.7 Percentage nieune artikels waarvoor elk type rechtsbron verantwoordelijk is (deel II)

\begin{tabular}{|c|c|c|c|c|c|c|c|c|c|c|}
\hline Ciciv & S & Usus & Comp & RL & RS & RA & OAR & eGR & WG & 3 \\
\hline 32.5 & 28.2 & 22.6 & 19.8 & 12.7 & 6.9 & 6.4 & 6.1 & 5.6 & 5.6 & 4.6 \\
\hline
\end{tabular}

Onder de vroegere redacties, die zich beperken tot de titel 2.1 omtrent het huwelijksvermogensrecht, ligt de nadruk op de Consuetudines antiquissimae en het Guldenboeck. Wat het wettenrecht betreft, heb ik moeten vaststellen dat noch de vorstelijke, noch de stedelijke wetgeving een bepalende rol heeft kunnen spelen in de totstandkoming van dit deel omtrent de personae. ${ }^{210} \mathrm{Er}$ is enkel sprake van een handvol ordonnanties: Ordonnantie op de verzwijging van de renten (1593), Ordonnantie op de weeskamer (1496), Ordonnantie van Brussel op't stuck van de weeskinderen (1445/1589) en de Ordonnantie van Brugge (1494/1507).211 De Brusselse ordonnantie van 19 juni 1445 wordt voornamelijk belangrijk geacht omwille van de Romeinsrechtelijke invloed die erin schuilgaat. ${ }^{212}$

Wel bevat dit deel, samen met de erfrechtelijke titel 3.13 uit deel III, één van de zeldzame verwijzingen naar het Spaanse wettenrecht als primaire rechtsbron. ${ }^{213}$ Artikel 2.1.3 vindt namelijk zijn oorsprong in de Cortes de Madrid van 1534 en is ook zoals de meeste wetten van de Cortes overigens- opgenomen in de latere Nueva Recopilación (1567).214 Deze compilatie verschijnt opnieuw ten aanzien van artikel 2.1.4 en dit in combinatie met de Leyes de Toro, het recht afkomstig van de Cortes de Toro van 1505. Een laatste verwijzing naar het Spaanse recht bevindt zich bij artikel 2.5.63: Est

\footnotetext{
${ }^{209}$ Cfr. infra, hoofdstuk 1, paragraaf 2, Deel III, Erfrecht.

${ }^{210} \mathrm{Ik}$ zal er later nog op terugkomen dat noch de middeleeuwse, noch de moderne vorst zich sterk heeft ingelaten met deze materie. Cfr. Supra, hoofdstuk 1, paragraaf 3, Lexificatie.

${ }^{211}$ Cfr. GODDING, Droit privé, 126.

212 Cfr. GODDING, Droit privé, 126. Deze ordonnantie werd later hernomen en herwerkt in de ordonnanties van 19 mei 1589 en 19 mei 1657.

213 Ten aanzien van de artikels 3.13.65 en 3.13.67 wordt er geciteerd uit Antonio Gomez' uitgave van deze Leyes de Toro.

${ }^{214}$ De Cortes kunnen beschouwd worden als de Spaanse versie van de 'Statenvergadering'. Hun vergaderingen werden steeds genoemd naar de plek waar ze plaatsvonden. Zo staat de vergadering van 1505 in Toro bekend als de Cortes de Toro. De legislatieve activiteiten aldaar verricht, krijgen bijgevolg de naam Leyes de Toro. (MARTYN, Eeunig edict, 99; A. P. MARTIN, "Bibliographie der Gesetzgebung des Privatrechts und Prosessrechts. Spanien", H. COING red., Handbuch der Quellen und Literatur der Neueren europäischen Privatrechtsgeschichte, II/2, Munchen, 1976, 232-233.)
} 
novus ex jure scripto in L omnem 6 C ad [senatus consultum] Tertull[ianum] et in L sciant omnes $C$ de legit[imis] hered[ibus] quas receperant etiam leges Hispania part. 6 tit $16 \mathrm{~L} 12$ in septem partitis adiecimus tamen temperamentum,... Men wijst erop dat deze Romeinsrechtelijke regel tevens door het Spaanse recht was gerecipieerd, meer bepaald in de Siete Partidas (1263), welke door koning Alfons X van Castilië-León in de dertiende eeuw werd afgekondigd als de algemene wet van het koninkrijk. ${ }^{215}$ Enkel artikel 6.1 .40 gaat rechtstreeks op deze compilatie terug. ${ }^{216}$

Zulk een ondervertegenwoordiging van de Spaanse wetgeving in het geheel van de Consuetudines compilatae is enigszins verbazend omwille van de band van de Zuidelijke Nederlanden met de Spaanse kroon. ${ }^{217}$ Deze verwaarloosbare invloed vanuit het Iberische schiereiland staat bovendien in schril contrast met het belang van verzamelingen van Franse wettenrecht, zoals bijvoorbeeld de Codex Henricianus van Barnabé Brisson, aangevuld en becommentarieerd door Louis le Caron. Vermoedelijk moet de reden hiervoor gezocht worden in het vergevorderde stadium waarin de Franse rechtsleer zich aan het begin van de zeventiende eeuw reeds bevond en waardoor deze het niveau van alle andere omringende landen oversteeg. Anderzijds liet Grandgagnage reeds in de negentiende eeuw zien dat men zich in de Nederlanden al te graag liet inspireren door Franse ordonnanties en edicten. ${ }^{218}$ Als het regent in Parijs, dan druppelt het in Brussel. Ook Martyn wees er onlangs nog op dat eenzelfde Franse invloed heeft ingewerkt op de samenstellers van het Eeuwig Edict van 12 juli 1611.219 Bovendien stelde ook hij vast dat de invloed van Spanje dan weer minimaal is gebleven. ${ }^{220}$

215 Alfons X de Wijze (1226-1284) hoopte op deze manier een einde te maken aan het (juridisch) particularisme in zijn ééngemaakt rijk dat zowel Castilië als León omvatte. De Libro de las Leyes of Siete Partidas, zo genoemd naar hun indeling in zeven delen, waren het eindpunt van een lang proces van redigeren en herzien, dat meerdere decennia in beslag nam. Het was een verzameling van traditionele costumen van Castilië en León, civiel en canoniek recht evenals regels afgeleid van het Oude en het Nieuwe testament, en de geschriften van de Kerkvaders. (BELLOMO, Common Legal Past of Europe, 100; STEIN, Roman Law in European History, 65-66. A. WOLF, "Die gesetzgebung der entstehenden Territorialstaaten", H. COING red., Handbuch der Quellen und Literatur der Neueren europäischen Privatrechtsgeschichte, I, Munchen, 1973, 669-674. VANDERLINDEN, Concept de code, 23 en 261-262.

216 Cfr. Memorieboeken ten aanzien van 6.1.40: Est etiam novus ex septem partitis Hispania parte $7^{a}$ tit $9 \mathrm{~L} 1^{a}$ ubi dicitur inde finite quod nemo teneatur de convicio vero sed id intellige si publice verum sit ne pugnet cum pra[e]cedenti et ita eleganter explicat Charondas sur la somme rurale lib 2 tit 27 ad finem aut si officiario denuncietur ut $1^{a}$ art seqq.

217 Bovendien staat bij Martyn te lezen dat, waar de Nederlanden in de tweede helft van de zestiende eeuw nog veel werk voor de boeg hadden ten aanzien van de redactie van hun costumen, Spanje in deze reeds vergevorderd was. De auteur wijst onder meer op de Nueva Recopilación van 1567. (Cfr. MARTYN, Eeunig edict, 98.)

${ }^{218}$ GRANDGAGNAGE, Influence de la législation civile française, 111.

${ }^{219}$ Cfr. MARTYN, Eemwig edict, 97-98.

220 "Behalve een zekere aanmaning om iets aan het recht of beter het staatsbestel in zijn geheel te doen, mogen we stellen dat er geen rechtsreekse Spaanse tussenkomst in de genese van het edictale privaatrecht is." (MARTYN, Eeuwig Edict, 98.) 
Rest me enkel nog te wijzen op het externe gewoonterecht dat ook hier weer in de eerste plaats fungeert als secundaire rechtsbron en dit over de ganse lijn. Voor zover er in dit deel al secundaire bronnen werden aangegeven, gaat het in negentig procent van de gevallen om gewoonterechtelijke compilaties van vreemde bodem. Opvallend is de grote verscheidenheid aan compilaties waarnaar verwezen wordt. In de eerste plaats gaat het om de costuymen van Gent (1563) en Mechelen (1535), maar ook de Conférérence des coutumes (1596) van de Franse jurist Pierre Guenoys speelt een meer dan bepalende rol.221 Verder wil ik wijzen op de coutumes van Berry, Bourbon, Bourgogne, Bretagne, Brussel, Clermont, Henegouwen, Parijs, Utrecht en Zeeland. Allen komen zij meer dan één keer aan bod.

Deel III

Deel III verzamelt het goederenrecht en de verschillende manieren om goederen te verkriigen. Bij dit laatste denk ik onder meer aan het naastingsrecht, de verjaring of prescriptie, giften, etcetera. Ook het erfrecht behelst, met het testament en de successio ab intestat of wettige versterffenisse, twee manieren waarop de eigendom van goederen van de ene op de andere persoon kan overgaan. De Consuetudines impressae zagen beide aspecten van het goederenrecht minder als één geheel. De titels verspreiden zich eerder lukraak over het geheel van het deel. Titels XXXIV, XXXV, XLVIII, LX, LXI en LXII omvatten het Antwerpse goederenrecht en het erfrecht zit vervat in de titels XLVI en XLVII. ${ }^{222}$ Respectievelijk zijn beide rechtsgebieden in de derde redactiepoging goed voor een aandeel van respectievelijk twintig en net geen vijf procent. Dat het totale aandeel van beide materies gezamelijk licht achteruit gaat ten opzichte van hun aandeel binnen de Consuetudines antiquae en de Consuetudines antiquissimae -waar hetzelfde aandeel nog respectievelijk 34.6 en 35.2 procent betrof, is louter een gevolg van de overmaat an handelsrecht welke met de Consuetudines impressae zijn intrede doet. Dit neemt echter niet weg dat de nadrukkelijke aanwezigheid van beide juridische domeinen duidelijk maakt, hoezeer zij tot het costumiere landschap zijn gaan behoren. Hun plaats aan het costumiere firmament is in de zestiende eeuw verzekerd. Op het verbintenissenrecht van het vierde deel na, betreft het hier bovendien de grootste juridische familie binnen de ganse compilatie. Dit neemt echter niet weg dat de commissie van 1586 de materie is blijven uitbreiden, wijzigen en vernieuwen. Tabel 1.1 heeft reeds laten zien dat 266 artikels nieuw zijn toegevoegd aan de Consuetudines compilatae. Dat is goed voor bijna een derde van alle artikels in deel III en vijftien procent van het totale innovatieve karakter van de compilatie. Relatief gezien correspondeert dit met een voorlaatste plaats wanneer het

${ }^{221}$ Cfr. infra, hoofdstuk 3, paragraaf 2, Particulier recht.

222 Enkel de eerste drie titels (3.1, 3.2 en 3.3), samen met de achtste (cijnzen en renten) en de twaalfde (giften) titel hebben geen afzonderlijke titel in de Consuetudines impressae. Zij gaan in eerste instantie terug op volgende titels uit de Consuetudines impressae: titel XLI omtrent de gehuwde personen (3.1), titel XLVI aangaande het testamentair erfrecht (3.1), titel LVII omtrent contracten (3.2 en 3.8), titel LVIII aangaande reivendicatie en verloren goederen (3.3) en titel LIII omtrent handschriften (3.12). De overige titels hebben een letterlijke variant in de Consuetudines impressae. 
gaat om de impact van de vernieuwing. Absoluut gezien is de uitbreiding echter de derde grootste na die van het burgerlijk procesrecht van deel V (307 artikels) en het verbintenissenrecht van deel IV (820 artikels). Waar deze innovaties zich voornamelijk hebben voorgedaan, illustreert tabel 1.8.223

Tabel 1.8 Het innovatieve karakter van deel III

\begin{tabular}{|l|l|c|c|c|}
\hline & Titel & $\begin{array}{c}\text { Aantal } \\
\text { artikels }\end{array}$ & $\begin{array}{c}\text { Aantal } \\
\text { nieuwe } \\
\text { artikels }\end{array}$ & $\%$ \\
\hline 3.1 & Van verscheijdentheijt van goeden & 19 & 14 & 73.7 \\
\hline 3.2 & Van opdracht ende overgevingen van goeden & 43 & 16 & 37.2 \\
\hline 3.3 & Van vervolgh van sijn eijgen goet & 30 & 12 & 40.0 \\
\hline 3.4 & Van vernaerderinge & 106 & 19.5 & 18.4 \\
\hline 3.5 & Van gebuerelijcke rechten ende servitueten & 106 & 16.5 & 15.6 \\
\hline 3.6 & $\begin{array}{l}\text { Van erfscheijdinge, oft maniere van vervolch tot onderbout van } \\
\text { gebuerelijcke rechten }\end{array}$ & 21 & 7 & 33.3 \\
\hline 3.7 & Van tocht ende tochtenaers & 28 & 2 & 7.1 \\
\hline 3.8 & Van chijnsen ende renten & 73 & 23 & 31.5 \\
\hline 3.9 & $\begin{array}{l}\text { Van leveringe ende ander rechtelijck vervolch tot betaelinge van } \\
\text { chijnsen ende renten }\end{array}$ & 57 & 10 & 17.5 \\
\hline 3.10 & Van affdaeginge ende suijveringe van onruerende goeden & 36 & 5 & 13.9 \\
\hline 3.11 & Van verloop van tijde oft prescriptie & 20 & 11 & 55.0 \\
\hline 3.12 & Van giften & 17 & 11 & 64.7 \\
\hline 3.13 & $\begin{array}{l}\text { Van testamenten ende andere unijtterste willen, ende van de } \\
\text { executeurs der selven }\end{array}$ & 92 & 66 & 71.7 \\
\hline 3.14 & $\begin{array}{l}\text { Van wettige versterffenissen, scheijdinge ende deijlinge, en des } \\
\text { daertoe behoort }\end{array}$ & 131 & 53 & 40.5 \\
\hline
\end{tabular}

Absoluut gezien heeft voornamelijk het erfrecht een groot aandeel in de innovatie van deel III. Beide erfrechtelijke titels zijn immers gezamelijk met 116 nieuwe artikels uitgebreid. Dit correspondeert met bijna de helft van het totale aantal nieuw toegevoegde artikels. Omwille van zulke proportionele evenals thematische verschillen, lijkt het me verstandig de bronnen van het erfrecht en die van het goederenrecht afzonderlijk te behandelen. Een keuze die meteen wordt gerechtvaardigd door wat tabel 1.9 laat zien. Het gaat duidelijk om verschillende categorieën wanneer ik de top 3 aan rechtsbronnen van beide rechtsgebieden met elkaar vergelijk. Bij het goederenrecht spannen de specifieke redenen, de gewoonte en het Romeinse recht de kroon, waar de rangschikking met betrekking tot het erfrecht wordt aangevoerd door hetzelfde Romeinse recht, maar vervolgens wordt vervolmaakt met categorieën als de rechtsleer en andere artikels uit de Consuetudines compilatae. Ook wat de overige posities betreft, bestaan er duidelijke verschillen tussen beide lijsten.

223 Over drie artikels uit de Consuetudines compilatae (3.9.55/56/57) wordt in de Memorieboeken met geen woord gerept. 
Tabel 1.9 Percentage nieuwe artikels waarvoor elk type rechtsbron verantwoordelijk is (goederen-en erfrecht)

\begin{tabular}{|c|c|c|c|c|c|c|c|c|c|c|}
\hline \multicolumn{11}{|c|}{ Goederenrecht } \\
\hline $\mathrm{S}$ & Usus & Ciciv & Comp & WG & RA & OAR & RL & 3 & eGR & RS \\
\hline 26.9 & 24.2 & 21.1 & 15.0 & 13.6 & 12.6 & 11.6 & 10.9 & 10.2 & 4.8 & 2.7 \\
\hline \multicolumn{11}{|c|}{ Erfrecht } \\
\hline Ciciv & RL & Comp & Usus & eGR & $\mathrm{S}$ & WG & RS & 3 & OAR & $\mathrm{RA}$ \\
\hline 25.2 & 22.7 & 21.9 & 21.0 & 18.5 & 10.1 & 8.4 & 7.6 & 6.7 & 6.7 & 1.7 \\
\hline
\end{tabular}

\section{Erfrecht}

Gezien hun absolute impact op het vernieuwingsproces zal ik met het erfrecht van start gaan. Onderstaande tabel 1.10 geeft de spreiding weer van de verschillende bronnentypes over de twee erfrechtelijke titels 3.13 en 3.14.224 Meteen valt op hoe deze zich verdelen over twee polaire fronten. Enerzijds zijn er de verwaarloosbare rechtsbronnen, van wie het totaal aantal artikels rond een procentuele waarde van tien en lager schommelt (S, WG, RS, 3, OAR, RA). Anderzijds kan er sprake zijn van meer decisieve rechtsbronnen. $\mathrm{Zij}$ leveren gemiddeld twintig procent of meer nieuwe artikels (Ciciv, RL, Comp, Usus, eGR).

Tabel 1.10 Aandeel van ieder type rechtsbron per titel (erfrecht)

\begin{tabular}{|c|c|c|c|}
\hline Tot & $\mathbf{3}$ & $\mathbf{1 3}$ & $\mathbf{. 1 4}$ \\
\hline 30 & Ciciv & 22 & 8 \\
\hline 27 & RL & 22 & 5 \\
\hline 26 & Comp & 15 & 11 \\
\hline 25 & Usus & 12 & 13 \\
\hline 22 & eGR & 9 & 13 \\
\hline 12 & S & 10 & 2 \\
\hline 10 & WG & 3 & 7 \\
\hline 9 & RS & 2 & 7 \\
\hline 8 & $\mathbf{3}$ & 8 & - \\
\hline 8 & OAR & 2 & 6 \\
\hline 2 & RA & 2 & - \\
\hline
\end{tabular}

Op de verwaarloosbare types zal ik hier niet dieper ingaan. Enkel de onopvallende positie van het wettenrecht en de rechtspraak binnen deze groep wil ik aan bod laten komen. Uitsluitend rond de vierde paragraaf van titel 14 (aanvaarding van de sterfhuis onder beneficie van de inventaris) kan ik namelijk een zekere concentratie vaststellen van plakkaten van keizer Karel V (8 november 1541, 14 mei 1544). Wat de jurisprudentie betreft, stel ik vast dat proporties als deze normaliter nauwelijks opvallen in vergelijking met die van andere rechtsbronnen, ware het niet dat de rechtspraak nergens zulk een groot aandeel haalt als hier. Hierbij doel ik dan voornamelijk op haar aandeel binnen titel 3.14. Verantwoordelijk voor zeven artikels, neemt ze er 13.2 procent van de nieuw toegevoegde artikels voor haar rekening. Dat is ruim boven

224 Aangezien het voor één artikel onduidelijk is gebleven om welke primaire rechtsbronnen het exact gaat, bestaat er voor elke categorie binnen deze tabel een theoretische foutmarge van één artikel of -in het geval van een totaal aantal nieuwe artikels van 77.5-1.3 procent. 
haar algemeen gemiddelde van vier procent en ook hier kijkt men, op één turbe na, naar het zuiden. Via het genre van de rechtspraakverzamelingen oefent de Franse rechtspraak evenzeer invloed uit op haar omringende territoria. Vooral het oeuvre van Louis le Caron komt aan bod en in mindere mate ook dat van Jean Papon, René Choppin en François Marc. Enkel de titel omtrent intestaat erfrecht bevat een aantal referenties naar Antwerpse turbenonderzoeken.

Anderzijds is er de doorslaggevende invloed van de decisieve bronnentypes. Nogmaals, het betreft de Usus, het buitensteedse gewoonterecht, het geleerd recht in brede zin en de dwingende kracht van andere artikels uit de Consuetudines compilatae. Laat ik beginnen bij het Corpus Iuris Civilis. Zo goed als een kwart van alle nieuw toegevoegde artikels vindt zijn oorsprong in het Romeinse recht. Dit verbaast me niet. Godding stelde immers reeds vast dat zelfs een sector aussi marqué par la coutume que le droit successoral en a été pénétré. 225 Tabel 1.10 laat zien dat de hoogste waarden voorkomen in de titel aangaande de testamenten, namelijk 22 artikels of 33.3 procent. Volkomen logisch, het betreft hier immers een typisch Romeinsrechtelijk mechanisme, en dit ondanks de totstandkoming van een typisch middeleeuwse invulling van het testament. Tot de twaalfde eeuw kon het gebruik ervan immers nergens worden vastgesteld. De Germaanse volkeren bedienden zich van de donatio. Pas na de herontdekking van het Corpus Iuris Civilis in de twaalfde eeuw, verschijnen voor het eerst titels betreffende het testament, meer bepaald in de Decretales (1234) van Gregorius IX. De Kerk spoort haar kudde aan een testament te maken in functie van hun zielenheil. Op die manier wordt het een algemeen aanvaard principe dat het niet goed is voor het heil van zijn ziel, wanneer een christen sterft zonder een testament opgesteld te hebben. Alzo verschijnt het testament in de dertiende eeuw, zij het gemarkeerd met een onuitwisbare canonieke stempel. Het blijft bovendien beperkt tot een louter religieus doel. Op deze manier raakt het testament verder verwijderd van het oorspronkelijke Romeinse model.226 Vanaf de veertiende eeuw verspreidt het zich ook buiten kerkelijke middens, alwaar het principe weinig weerstand ondervindt van de gewoonte. Deze was immers reeds vertrouwd met een gelijkaardig procédé, met name dat van de giften post mortem en pro animo. Al gauw ontdekte men ook de opportuniteiten ervan. Het testament liet immers toe meisjes te compenseren voor hun geleden verlies ten gevolge van de prioriteit van de man op de vrouw in erf- en opvolgingskwesties. Bovendien was het een manier om tegemoet te komen aan de noden van onwettige kinderen. Het kwam de populariteit en de verspreiding ervan alleen maar ten goede. 227

In de zestiende eeuw ondergaat het mechanisme van het testament geen noemenswaardige modificaties. Ook van de canonieke invloed blijft veel behouden.

225 GODDING, Droit privé, 6.

${ }^{226}$ Zo wordt bijvoorbeeld de rol van de erfgenamen, onontbeerlijk in het Romeinsrechtelijke, testamentaire erfrecht, overgedragen aan de testamentuitvoerders. Ook mondelinge testamenten, uitgesproken in het bijzijn van getuigen, worden vanaf nu geldig geacht. (Cfr. GODDING, Droit privé, 380.)

227 De historische ontwikkeling van het testament, zoals hier uiteengezet, heb ik gereconstrueerd op basis van Godding: GODDING, Droit privé, 377-383. 
Wel is op dat moment de invloed van het Corpus Iuris Civilis over het algemeen zeer sterk geworden. Dit blijkt onder meer uit de overname van een rechtsfiguur als het wettelijk erfdeel. Het gaat hier om het minimum dat de erflater van zijn erfenis moet reserveren voor bepaalde personen onder zijn meest verwante erfgenamen. Het beschermt op deze manier de nakomelingen (en voorouders) van de erflater. In de veertiende en vijftiende eeuw was er van deze juridische constructie nog geen sprake in de coutumiers. ${ }^{228}$ Ook te Antwerpen werd het pas een eerste keer grondig uitgewerkt in de Consuetudines compilatae, meer bepaald in paragraaf 3 (Institutie ende wettich deel van de kinderen) van titel 3.13. Dertien artikels zijn er aan deze legitime portie oft wettich deel gewijd, in tegenstelling tot slechts één artikel in de Consuetudines impressae (titel XLVI). Tien ervan gaan rechtstreeks terug op Romeinsrechtelijke normen uit het Corpus Iuris Civilis.229

Deze invloed van het Romeinse recht gaat zoals gewoonlijk gepaard met een massa aan rechtsgeleerde allegaties. Bovendien was dit onderwerp zeer populair onder de zestiende-eeuwse rechtsgeleerden. ${ }^{230}$ Hun werken worden dan ook meermaals als primaire rechtsbronnen in de Memorieboeken aangewend. In totaal gaat het bij titel 3.13 om negentien artikels, waarvan veertien verschillende auteurs aan de basis liggen. Ik zal me hier beperken tot hen die voor meer dan één artikel verantwoordelijk zijn. ${ }^{231}$ Antonio Padilla y Meneses is goed voor twee artikels; Giulio Claro en Michael Grass leveren drie artikels. De belangrijkste auteurs zijn echter Diego Covarubias y Leyva en meer nog Louis le Caron. Ondanks het enorme oeuvre van le Caron wordt evenwel enkel zijn Memorables observations du droit françiis uit 1601 aangewend. Vermoedelijk gaat het hier om de meest 'rechtsgeleerde' titel van de ganse Consuetudines compilatae. De rechtsleer treedt voor één derde van de nieuwe artikels op als primaire rechtsbron en bovendien is geen enkele andere titel in zulke mate vergeven van rechtsgeleerde allegaties.

Deze concentratie aan juristen en het bijbehorende rechtsgeleerde karakter stopt echter bruusk aan het begin van paragraaf 8 omtrent de testamentuitvoerders.

\footnotetext{
228 GODDING, Droit privé, 396-397.

229 Ook uit het toegenomen belang van de erfgenamen in het ganse proces blijkt de sterke invloed van het Romeinse recht op het erfrecht van de zestiende eeuw. Zo zal hen het recht verleend worden de plaats in te nemen van de testamentuitvoerders om te garanderen dat het testament binnen een tijdspanne van één jaar wordt uitgevoerd. (Cfr. GODDING, Droit privé, 399.) In de Consuetudines compilatae komt dit aan bod in artikel 3.13.75: D'erffenaemen, indijen het hun belieft, mogen selver den last van de executie aenveerden, midts doende genoechsaeme versekerheijt voor schepenen, ten seggen ende verclaeren van de weth, van dat sij die legaeten ende vuijttersten wille ten lancxsten binnen sjaers sullen voldoen ende de schulden van den sterffhuijse betaelen. (Coutumes de la ville d'Anvers dites compilatae, III, 544). Nieuw is dit echter niet. De Memorieboeken tonen dat de mogelijkheid reeds bestond in de Consuetudines antiquissimae, de Consuetudines antiquae en de Consuetudines impressae. Uit die Memorien op de Costuymen blijkt eveneens dat ook de stad Mechelen eenzelfde regel verdedigde. Toch wordt nergens de Romeinsrechtelijke oorsprong ervan expliciet erkend.

${ }^{230}$ GODDING, Droit privé, 382.

231 De volgende auteurs hebben slechts één artikel op hun conto: Baldus de Ubaldis, Denis Godefroy, Bartolo da Sassoferrato, Pierre Pithou, Andrea Alciato, Manoel da Costa, Charles Dumoulin, Wigle van Aytta, en de onidentificeerbaar gebleken picus.
} 
Hetzelfde kan gezegd worden van de verwijzingen naar het Corpus Iuris Civilis. Hier wordt de scepter immers doorgegeven aan het buitensteedse gewoonterecht, waarbij de nadruk exclusief op de Conférence des coutumes (1596) van de Fransman Pierre Guenoys komt te liggen.232 $\mathrm{Ik}$ heb hier dan ook te maken met een typisch middeleeuws aspect van het testament. ${ }^{233}$ De Romeinen van hun kant werkten immers met erfgenamen ter executie van hun laatste wilsbeschikking. De logica blijft gerespecteerd. Door deze concentratie aan extern gewoonterecht in de achtste paragraaf haalt deze categorie maar liefst 18.5 procent in totaal en komt ze in de buurt van rechtsbronnen als de andere artikels uit de Consuetudines compilatae, voornoemde rechtsleer en de alomtegenwoordige Usus. Met 24 procent van de nieuw toegevoegde artikels behaalt de categorie Comp zelfs een tweede plaats. Dit lijkt me in die zin begrijpelijk dat de raakvlakken tussen het erfrecht en andere delen van de Consuetudines compilatae relatief talrijk zijn, zoals dit ook met betrekking tot het huwelijksvermogensrecht uit titel 2.1 het geval was.

Naast het testamentair erfrecht bestaat de successio ab intestat of wettige versterffenisse. Het staat beschreven in de veertiende en tevens laatste titel van het derde deel van de Consuetudines compilatae. Wat de bronnen ervan betreft, laat tabel 1.10 een zeer gevarieerd patroon zien. In die mate dat het uitgesproken geleerde karakter, zoals ik dat bij het testamentair erfrecht heb kunnen vaststellen, in deze laatste titel volledig wordt afgevlakt. Het aandeel van de verschillende categorieën nivelleert naar elkaar toe. Zo leveren het Corpus Iuris Civilis, de rechtsleer en de andere artikels uit de Consuetudines compilatae zelf in ten voordele van bronnentypes als de vroegere redacties (Guldenboeck), de Usus, het externe gewoonterecht en voornamelijk de wetgeving van vorstelijk origine. Wat deze laatste categorie betreft, draait het hoofdzakelijk om twee plakkaten van keizer Karel V, welke dateren van de jaren veertig van de zestiende eeuw, meer bepaald van 8 november 1541 en 14 mei 1544. Beiden concentreren zich rond de artikels 64-77, wat correspondeert met het eerste deel van de vierde paragraaf omtrent de aenveerdinge van den sterffhijje onder beneficie van inventaris. Voor Gilissen is dit één van de voorbeelden waarbij de romanisatie van het gewoonterecht zich voltrekt via de penetratie van landsheerlijke wetgeving. ${ }^{234}$ Godding daarentegen stelt dat deze praktijk in de zestiende eeuw vanuit Frankrijk -waar hij sinds de eerste helft van de veertiende eeuw onder invloed van het Romeinse recht werd gepraktiseerd- is overgewaaid naar de Nederlanden. ${ }^{235}$ Ook deze opvatting wordt door de Memorieboeken bevestigd. Het externe gewoonterecht dat namelijk ook binnen deze titel zeer nadrukkelijk aanwezig is, concentreert zich eveneens binnen deze vierde paragraaf. Het betreft uitsluitend Frans gewoonterecht, waarbij men in de eerste

${ }^{232}$ Het is ook binnen deze titel dat het gewoonterecht van 's Hertogenbosch (1606) aan bod komt. Binnen het geheel van de Consuetudines compilatae is dit uiterst uitzonderlijk. Het betreft het artikel 3.8.55: Est etiam novus ex usu et consuetudine Buscoduc[ensis] hoc tit cui consentit ius commune ex receptiori et magis approbata dd sententia.

233 GODDING, Droit privé, 398-400.

234 GILISSEN, "Romeins recht en inheems Gewoonterecht”, 130.

235 GODDING, Droit privé, 405-406. 
plaats verwijst naar ook nu weer de Conférence des coutumes (1596) van Pierre Guenoys, gevolgd door de coutumes van het hertogdom Berry en het weinig frequente Artesië. Ook als secundaire bron is dit buitensteeds gewoonterecht prominent aanwezig. De Usus, het geleerde recht en de vroegere redacties van hun kant verspreiden zich dan weer eerder gelijkmatig over de titel.

Wat het Romeinse recht betreft, stel ik evenwel vast dat er Justiniaanse leges werden gerecipieerd, ondanks het typisch gewoonterechtelijk karakter van het intestaat erfrecht: "C'est un domaine aussi où le droit coutumier règne à pau près sans partage, du moins si l'on s'en tient aux successions ab intestat. L'influence du droit romain ne se fera sentir, à partir du $16^{e}$ siècle, qu'en certains lieux et sur des points précis: tempérer l'exclusion des ascendants, introduire la représentation successorale au profit des neveux et nièces. ${ }^{2} 36$

Goederenrecht

Ondanks het feit dat een aantal titels van het goederenrecht qua omvang niet moeten onderdoen voor die van de erfrechtelijke titels, blijft de vernieuwing hier eerder beperkt, althans in absolute cijfers. Relatief gezien zijn er echter onderwerpen die meer aandacht verdienen dan andere. Waar traditionele titels als 3.4 (vernaerdering), 3.5 (servituyten), 3.7 (tocht) evenals 3.9 (leveringe) en 3.10 (affdaeginge) nauwelijks werden anngepast, komt de innovatieve waarde van titels als 3.2 (opdracht), 3.3 (vervolg van eigen goed), 3.6 (erfscheydinge) en 3.8 (cijnzen en renten) net boven de grens van dertig procent uit. ${ }^{237}$

Tabel 1.11 Aandeel van ieder type rechtsbron per titel (goederenrecht)

\begin{tabular}{|c|c|c|c|c|c|c|c|c|c|c|c|c|c|}
\hline Tot & $\mathbf{3}$ & $\mathbf{. 1}$ & $\mathbf{. 2}$ & $\mathbf{. 3}$ & $\mathbf{. 4}$ & $\mathbf{. 5}$ & $\mathbf{. 6}$ & $\mathbf{. 7}$ & $\mathbf{. 8}$ & $\mathbf{. 9}$ & $\mathbf{. 1 0}$ & $\mathbf{. 1 1}$ & $\mathbf{. 1 2}$ \\
\hline 39.5 & S & 2 & 6 & 1 & 8.5 & 1 & 1 & - & 9 & 7 & 3 & 1 & - \\
\hline 35.5 & Usus & 7 & 2 & 1 & 2 & 5.5 & 2 & - & 5 & 3 & - & 4 & 4 \\
\hline 31 & Ciciv & 4 & 1 & 1 & 2 & 2 & - & 1 & 4 & - & - & 8 & 8 \\
\hline 22 & Comp & 2 & 7 & 1 & 3 & 2 & - & - & 3 & 1 & 1 & 1 & 1 \\
\hline 20 & WG & - & - & 1 & 1 & - & 3 & - & 12 & - & 1 & - & 2 \\
\hline 18.5 & RA & 3 & 1 & 2 & 4.5 & 4 & - & - & 2 & - & - & 1 & 1 \\
\hline 17 & OAR & 1 & 1 & 8 & 1 & 3 & - & 2 & - & - & 1 & - & - \\
\hline 16 & RL & 4 & 1 & - & 2 & - & - & - & - & - & - & 5 & 4 \\
\hline
\end{tabular}

236 GODDING, Droit privé, 317.

${ }^{237}$ Het mechanisme van naderschap bestond reeds vanaf de twaalfde eeuw in onze streken en kende geen equivalent in de Romeinse wereld of haar juridisch systeem. De naasting had reeds een lange traditie achter de rug en mede daardoor blijven de innovaties binnen deze titel aan het begin van de zeventiende eeuw dan ook beperkt. Het ontbreken van een Romeinsrechtelijke equivalent verklaart de minimale invloed van het Romeinse recht binnen deze materie. Op een totaal van 106 artikels wordt in de Memorieboeken slechts vijf maal naar het Corpus Iuris Civilis verwezen. Hetzelfde stel ik vast met betrekking tot titel 3.5 omtrent de gebuurlijke rechten en servituten. Ook hier wordt slechts omtrent drie van de 106 artikelen verwezen naar het Romeinse recht. Ook de rechtsbronnen van de titel omtrent het vruchtgebruik liggen in de lijn van de verwachtingen. Het is een uitgesproken Romeinsrechtelijke uitvinding en dat wordt dan ook bevestigd door het aantal referenties naar het Corpus Iuris Civilis, namelijk 26 verwijzingen op 28 artikels. (GODDING, Droit privé, 211 214.) 


\begin{tabular}{|c|c|c|c|c|c|c|c|c|c|c|c|c|c|}
\hline 15 & 3 & - & - & - & 2 & 8 & 3 & 1 & - & - & - & 1 & - \\
\hline 7 & eGR & 3 & - & - & - & - & - & - & 2 & - & - & 2 & - \\
\hline 4 & RS & - & 1 & - & - & - & - & - & 1 & - & - & - & 2 \\
\hline
\end{tabular}

Opvallende vaststellingen op basis van bovenstaande tabel 1.11 zijn de ordonnanties met betrekking tot titel 3.8 (cijnzen en renten), het hernemen van artikels uit de Consuetudines antiquissimae binnen titel 3.3 (vervolg van eigen goederen) en het aandeel van andere artikels uit de Consuetudines compilatae als rechtsbron en de specifieke redenen bij titel 3.2 (opdracht). Deze laatste rechtsbron komt ook nadrukkelijk voor bij de vierde titel omtrent het naastingsrecht. De innovaties binnen de achtste titel omtrent cijnzen en renten vloeien grotendeels voort uit wetgeving van vorstelijke aard. Deze descending power manifesteert zich aan de hand van documenten als het plakkaat van de Filips II van 5 maart $1571^{238}$ en dat van de Aartshertogen van 25 juni $1601^{239}$. Verder wordt er binnen deze titel ook gewezen op het statuyt van de leveringe de dato 19 juni 1535 en bevat de titel de enige, expliciete verwijzing naar wetgeving van pauselijk origine, namelijk de bul van paus Pius V van 14 februari 1568.240 De bul treedt er op als secundaire bron. Legislatieve inspanningen die ook elders binnen dit deel aan bod komen, zijn het statuut van 18 augustus 1592 en dat van 1518 by de stadt gemaeckt en te hove geconfirmeerd opt stuck van fugitiven. Ook hier speelt opnieuw de Franse Codex Henricianus een bescheiden rol.

Wat betreft de titels 3.5 (servituten) en 3.6 (erfscheiding) wil ik wijzen op de rol van derden, meer bepaald die van de erfscheiders. Deze gezworen experts staan in voor alles wat met het grensgebied tussen twee eigendommen (percelen, huizen, gemeenschappelijke muren, ...) te maken heeft. Zij zijn het stedelijke equivalent van de rurale deambulatio of cerquemanage, een methode om de grenzen van een gebied te bepalen. Aanvankelijk behoorde deze taak in de steden toe aan de schepenen. Zij delegeren ze echter aan de erfscheiders. Van zodra 'grensconflicten' de kop opsteken, verschilt hun rol echter van streek tot streek. In sommige gevallen beperkt deze zich tot het rapporteren van het conflict bij de schepenen, welke op hun beurt dan een oordeel vellen. In andere regio's, zoals Antwerpen, zijn de erfscheiders zelf

\footnotetext{
238 Ordonnantie ende edict ons heeren des Conincx op t'stuck van creatie van renten in graene en[de] dierghelycke contracten. Ghegheven te Bruessele, den vyfsten van Martio, M.D.LXXI, 5 maart 1571, in Placcaert-boecken van Vlaenderen (1630), II, 422.

239 Placcaert, verklarende dat de Renten, Contracten, Obligatien, Lasten ende Schulden voogaendelyck geconstituëert met Geldt-specien, mogen gelost worden in Goude ende Silvere Munte, cours bebbende binnen deze Landen ten tyde van het afquyten, 25 juni 1601, in Placcaert-boecken van Vlaenderen (1630), II, 439-442.

240 Cfr. 3.8.68: Est novus additus in hac postrema revisione, ut aliquo modo restringeretur odiosa prosecutio contra constituentes reditus q[uae] fere peripetua erat etiam contra eorum baeredes saepe omnium rerum ignares, idq[ue] in infinitum et non obstante quod venditio illis insinuata non esset, quod valde rigidum, ideoq[ue] mitigandum fuit presertim et eo magis, quod de iure pontifitio ista obligatio personalis velut annexa sit et pendeat ab hypoteca, qua diminuta, deficiente vel sublata, illa quoq[ue] minuitur [?] aut cessat, ut nominatim in bulla Papae Pii quinti 14 calendas feb. 1568.
} 
gemachtigd dit laatste te doen. ${ }^{241}$ Uit de Memorieboeken blijkt nu dat ook hun mening in acht werd genomen, althans met betrekking tot elf nieuw toegevoegde artikels. Dit is bijna de helft van de 23.5 nieuw toegevoegde artikels binnen de titels 3.5 en 3.6. Zij werden in de compilatie geïntegreerd by aengeven vande erffscheyders. ${ }^{242}$ Dat de zesde titel over erfscheiding ook sterk beïnvloed werd door de Ordonnantie van styl ende maniere van procederen is een gevolg van het feit dat de stijlordonnantie van 1582 eveneens een titel $V$ an erfscheydinghen bevatte. 243

De prominente rol van de erfscheiders binnen voornoemde titels maakt dat een categorie als 'derden' goed is voor tien procent van alle nieuwe artikels binnen het goederenrecht van deel III. Dit is gebleken uit tabel 1.9. Daarenboven toont de tabel eveneens aan dat het de Usus is die in globo de rangen aanvoert. De gewoonte verdeelt zich gelijkmatig over het geheel aan goederenrechtelijke titels. Dat het Romeinse recht ook hier nog een tweede plaats weet te bemachtigen, is een gevolg van de titels 3.11 en 3.12, respectievelijk betreffende de prescriptie of verloop van tijde en de giften. Beide titels behoren met respectievelijk vijftig en zestig procent tot de meer geïnnoveerde titels van het derde deel. ${ }^{244}$

Wat het verjaren betreft, doet er zich vanaf de vijftiende eeuw in wereldlijke milieus een infiltratie voor van de langdurige prescriptie van dertig of veertig jaar, ontleend aan het Romeinse recht. Voordien was dit enkel in kerkelijke milieus doorgedrongen, terwijl men in seculiere middens uitsluitend de prescriptie van korte duur kende, een gebruik dat in onze streken volledig onafhankelijk van het geleerde recht onstaan was. Aanvankelijk gaat het om prescripties van één jaar en één dag, zoals bij de Franken. In Brabant en Doornik werd dat drie jaar en drie dagen. Vanaf de twaalfde eeuw verscheen dan de langdurige prescriptie in de canonieke milieus van waaruit deze zou worden overgenomen door de wereldlijke rechtbanken. Het ligt dan ook voor de hand dat we hier voornamelijk met verwijzingen naar het Corpus Iuris Civilis te maken krijgen. Toch gaat het hier niet om een blindelingse overname. Het voorbeeld van Brussel, met een letterlijke receptie van Romeinse recht, is vrij uniek. ${ }^{245}$ Elke regio ontwikkelde immers een eigen variant, wat ook meteen duidelijk wordt wanneer ik de Memorieboeken opensla. Betreffende het laatste artikel van titel 3.11 stellen zij dat dit

241 GODDING, Droit privé, 206-208. Zie ook: P. GODDING, Le droit foncier à Bruxelles au moyen âge (Etudes d'histoire et d'ethnologie juridiques 1), Brussel, 1960.

${ }^{242}$ Cfr. 3.6.16.

243 Styl ende Maniere van procederen, II, 638. De titel bevat evenwel slechts drie artikels.

${ }^{244}$ De prescriptie kwam in de Consuetudines impressae aan bod in titel LXI, waar ze zeven artikels omvatte. De verjaring kent er een termijn van dertig jaar, waarop uitzonderingen worden toegestaan. In de Consuetudines antiquae telt de overeenkomstige titel XXXII slechts één artikel, waarin de termijn van de prescriptie wordt vastgelegd op dertig jaar zonder uitzonderingen. In titel XIV van de Consuetudines antiquissimae bedraagt de verloop van tijde slechts zeventien jaren, zeventien weken, zeventien dagen en zeventien uren. De Romeinse, langdurige prescriptie doet met andere woorden zijn intrede te Antwerpen met de samenstelling van de Consuetudines antiquae.

${ }^{245}$ Wat de historische achtergrond en kenmerken van de prescriptie betreft: cfr. GODDING, Droit privé, 250-253. 
contra ius scriptum is, sed quem usum approbavit tam hic quam in Galliis. ${ }^{246}$ Het bestaan van zulke eigen interpretatiemogelijkheden brengt logischerwijs een hoge score voor de Usus met zich mee. Binnen deze ontwikkeling bleef de rol van de overheid zeer beperkt. Enkel de magistraat heeft met betrekking tot de giften zijn invloed weten laten gelden.

Wat deze giften betreft, word ik geconfronteerd met een vergelijkbare verdeling. De belangrijkste overeenkomst is de invloed van het Romeinse recht op de materie, hoewel het mechanisme van de donatio van origine een zuiver Germaanse constructie was, welke het verdwijnen van het typisch Romeinsrechtelijke testament teweeg zou brengen. Het gebruik van laatstgenoemde kan nergens worden vastgesteld tussen de negende eeuw en de twaalfde eeuw. In beide gevallen gaat het immers om mechanismen waarbij goederen van de ene op de andere persoon overgaan. Het verschil zit hem in het feit dat de giften een onherroepelijk, onmiddellijk en bilateraal karakter hebben. Aangepaste versies waren de donatio post mortem (niet meer 'onmiddellijk') en die gift waarbij de begunstigde enkel het vruchtgebruik verkreeg en dus niet de nakkte eigendom. Vervolgens zullen de giften nog meer tot testamenten verworden, wanneer men in het geval van de kruisvaarders giften herroepelijk gaat maken, voor het geval zij toch levend terugkomen van het Heilige Land. Ook het bilaterale karakter geraakt aangetast. Toch zullen beide mechanismen -na de herontdekking van het Romeinse recht in de twaalfde eeuw- naast elkaar blijven bestaan. Meer zelfs, in de veertiende eeuw blijken kerkelijke instellingen zelfs de zekerheid van een onherroepelijk en onmiddellijke donatio inter vivos te prefereren boven de onzekerheid van de revocabiliteit van het testament. ${ }^{247}$ Dat giften in de zestiende eeuw sterk onder de invloed van het Romeinse recht kwamen te staan, blijkt ook uit de Memorieboeken. Voor maar liefst zeven van de elf nieuwe artikels wordt er naar het Corpus Iuris Civilis verwezen.

Wie Romeins recht zegt, zegt rechtsleer. Dat is reeds meermaals gebleken, en blijkt ook nu weer uit deze twee titels. In beide titels waar het Corpus Iuris Civilis de hoofdleverancier van nieuwe artikels is, namelijk 3.11 en 3.12, blijkt ook de rechtsleer wederom een voorname plaats als rechtsbron in te nemen. Hoofdrolspelers van het debat zijn Franse juristen als Louis le Caron en Charles Dumoulin. Als secundaire bron is ook het verzamelde Franse gewoonterecht van Pierre Guenoys hier nadrukkelijk aanwezig.

Het meest hebben de novateurs echter huis gehouden in titel 3.1 over de verschillende soorten van goederen. Het palet van rechtsbronnen mag er dan wel kleurrijk zijn; er is niets dat uit de band springt. De Usus neemt er het voortouw, gevolgd door het geleerde recht lato sensu, waarbij een noemenswaardige rol is weggelegd voor juristen als Aries Pinhel (Ad constitutiones Codicis de bonis maternis commentarii, 1557) en Pieter

\footnotetext{
${ }^{246}$ Cfr. 3.11.20.

247 Wat de historische achtergrond en kenmerken van de giften betreft: cfr. GODDING, Droit privé, 377-379.
} 
Peck (Tractatus de testamentis conjugum, 1585).248 Pinhel zal nergens anders worden aangehaald.

Deel IV

Het vierde deel verzamelt het verbintenissenrecht. Het gaat om overeenkomsten of contracten welke tot een verbintenis (obligatio) leiden. Ik denk hierbij onder meer aan huurcontracten, commerciële verbintenissen (koopovereenkomsten), crediteuren en debiteuren evenals borgstelling, maar ook zeerechtelijke aangelegenheden en het assurantiewezen behoren tot dit rechtsgebied. Dat, in tegenstelling tot de doorsnee Brabantse redactie, dit vierde deel in de Consuetudines compilatae zulk een omvang kent, is in de eerste plaats te wijten aan de voorname plaats die het zee- en verzekeringsrecht binnen deze groep krijgt toebedeeld. Gezamelijk zijn de titels omtrent de schipvracht (4.8) en het verzekeringswezen (4.11) namelijk goed voor maar liefst 533 artikels of ongeveer de helft van het ganse deel. Zulk een prominente aanwezigheid van beide materies is het logische gevolg van de uitzonderlijke commerciële positie welke de stad Antwerpen bekleedde binnen de mondiale handel. ${ }^{249}$ Waar het verbintenissenrecht normaliter eerder tot de minst ontwikkelde costumiere rechtsgebieden behoort, bestaat het binnen het Antwerpse gewoonterecht uit een totaal aantal artikels van 866, wat correspondeert met een procentueel aandeel van 23.8 ten honderd. ${ }^{250}$

Het handels-, zee- en verzekeringsrecht doen hun intrede met het verschijnen van de Consuetudines impressae, ware het niet zo dat hun aandeel aldaar eerder als zeer summier te omschrijven is. Het betreft de titels XLIX-LV, welke gezamelijk 94 artikels omvatten, wat overeenkomt met een bescheiden aandeel van 6.5 procent. De Consuetudines antiquae op hun beurt bevatten enkel één titel over het assurantiewezen (titel XXIX, twaalf artikels) en één omtrent wisselbrieven (titel XXVIII, drie artikels). Samen vertegenwoordigen ze 2.7 procent van de gehele compilatie. De Consuetudines antiquissimae zwijgen als vermoord.

In functie van de tijd neemt het belang ervan alleen maar toe. Uiteindelijk culmineert deze trend in de Consuetudines compilatae in twee monsterachtige titels omtrent respectievelijk het zeerecht (titel 4.8; 210 artikels) en het verzekeringswezen (titel 4.11;

248 Wat betreft Aries Pinhel, cfr. HOLTHÖFER, "Die Literatur zum gemeinen und partikularen Recht”, 348. Wat betreft Pieter Peck, cfr. A. SÖLLNER, "Die Literatur zum gemeinen und partikularen Recht in Deutschland, Österreich, den Niederlanden und der Schweiz", H. COING red., Handbuch der Quellen und Literatur der Neueren europä̈schen Privatrechtsgeschichte, II/1, Munchen, 1977, 603.

${ }^{249}$ Omtrent de groei van de Antwerpse handel van de veertiende tot de zestiende eeuw, zie H. VAN DER WEE, The Growth of the Antwerp Market and the European Economy (fourteeth-sixteenth centuries), 3 dln. Den Haag, 1963. Omtrent de rol van buitenlandse handelaars binnen de Antwerpse handelsmarkt, zie: J. A. GORIS, Etude sur les colonies marchandes méridionales (Portugais, Espagnols, Italiens) à Anvers de 1488 à 1567. Contribution à l'bistoire des débuts du capitalisme moderne, Leuven, 1925. Zie met betrekking tot Antwerpen in deze periode ook: L. VOET, De Gouden Eeuw van Antwerpen, Antwerpen, 1974.

250 Omtrent de rol van het verbintenissenrecht binnen het costumiere recht, cfr. GODDING, Droit privé, 7 . 
323 artikels) en verder ook acht titels aangaande handelsrechtelijke aangelegenheden (titels 4.3, 4.4, 4.5, 4.6, 4.9, 4.10, 4.16 en 4.18; 359 artikels). ${ }^{251}$ Samen gaat het met andere woorden om bijna een kwart van alle artikels welke deel uitmaken van de Consuetudines compilatae. Een ongebruikelijke omvang als deze, gecombineerd met het feit dat er steeds al te specifieke bronnen aan de basis liggen van de verschillende titels, heeft me ertoe aangezet deze titels afzonderlijk te behandelen. Tabel 1.12 geeft per titel het innovatieve karakter van alle titels uit deel IV weer.

Tabel 1.12: Het innovatieve karakter van deel IV

\begin{tabular}{|l|l|c|c|c|}
\hline & Titel & $\begin{array}{c}\text { Aantal } \\
\text { artikels }\end{array}$ & $\begin{array}{c}\text { Aantal nieuwe } \\
\text { artikels }\end{array}$ & $\mathbf{\%}$ \\
\hline 4.1 & Van geoorloffde ende ongeoorloffde contracten & 16 & 11 & 68.8 \\
\hline 4.2 & Van schepene brieven ende bantschriften & 17 & 5 & 29.4 \\
\hline 4.3 & Van wisselbrieven & 77 & 58 & 75.3 \\
\hline 4.4 & Van de vrije jaermerckten & 17 & 0 & 0.0 \\
\hline 4.5 & Van de peerdemerckten & 9 & 2 & 22.2 \\
\hline 4.6 & Van coop ende coopmanschappen & 26 & 12 & 46.2 \\
\hline 4.7 & Van buere & 45 & 16 & 35.6 \\
\hline 4.8 & Van schipvracht & 210 & 205 & 97.6 \\
\hline 4.9 & Van geselschap ende gemeijnschap van goeden & 39 & 28 & 71.8 \\
\hline 4.10 & Van bevel ende factorije & 22 & 21 & 95.5 \\
\hline 4.11 & Van versekeringe oft asseurantie & 323 & 301.5 & 93.3 \\
\hline 4.12 & Van pantschappe & 36 & 14 & 38.9 \\
\hline 4.13 & Van borcbtocbten & 40 & 13 & 32.5 \\
\hline 4.14 & Van bantvullinge oft namptisatie & 25 & 6 & 24.0 \\
\hline 4.15 & Van betaelinge, bewijsinge, compensatie, etc. & 28 & 17 & 60.7 \\
\hline 4.16 & Van gebroken schuldenaers & 91 & 54 & 59.3 \\
\hline 4.17 & $\begin{array}{l}\text { Van brieven van respijt oft unijtstel van betaelinge, ende } \\
\text { van cessie }\end{array}$ & 25 & 21 & 84.0 \\
\hline 4.18 & $\begin{array}{l}\text { Van voordeel oft preferentie onder de } \\
\text { crediteuren }\end{array}$ & 78 & 38.5 & 49.4 \\
\hline
\end{tabular}

${ }^{251}$ In tabel 1.13 werden de handels- en zeerechtelijke titels in het vet afgedrukt. Zij vormen het geheel dat met de Remonstrance van 14 februari 1609, het recht verkreeg gedrukt te worden: "t'gene raeckte coop ende coopmanschap, wissel, geselschap, oft compagnie, bevel oft factorye schipuraght, asseurantie oft versekeringe faillissementen van de schuldenaers ende de preferentie van de crediteuren". (SAA, Vierschaer, 64: Acte van den Hove waerby by provisie wordt gepermitteert te mogen drucken dese nieuwe gecompileerde coustuymen voor soo veele als raecket den coophandel.) Dit wil echter niet zeggen dat het deel ook de homologatie verwierf, zoals zo vaak aangenomen wordt. (Omtrent deze foute visie, zie STEVENS, Revolutie en notariaat, 1994.) 
Zee- en assurantierecht ${ }^{252}$

Dit luik is samengesteld uit twee titels: titel 4.8 over de schipvracht en titel 4.11 omtrent het verzekeringswezen. Met respectievelijk maar liefst 97.6 en 93.3 procent aan nieuw toegevoegde artikels en een absoluut antal nieuwe artikels dat de 500 overschrijdt, zijn deze titels in wezen de sterkst geïnnoveerde titels van de ganse Consuetudines compilatae. De percentages laten tevens zien dat er in de vroegere redacties van zee- of assurantierecht nauwelijks sprake was. Het ligt dan ook voor de hand dat, zoals overigens uit tabel 1.13 blijkt, de vroegere redacties niet als primaire rechtsbron van het zee- of verzekeringsrecht binnen de Consuetudines compilatae hebben gefungeerd. De enkele artikels die wel in de Consuetudines impressae aanwezig waren beperken zich tot het verzekeringswezen, dat er gedeeltelijk aan bod kwam in titel LIV ( $V$ an contracten van asseurantien, van weddinghe ende spel). Een andere grote afwezige is

252 Een fundamenteel werk binnen de historiografie omtrent het zeeverzekeringsrecht was van de hand van de Duitse geleerde Reatz. (C. F. REATZ, Geschichte des europäischen Seeversicherungsrecht, Leipzig, 1870. Zie ook: C. F. REATZ, "Ordonnances du duc d'Albe sur les assurances maritimes de 1569, 1570 et 1571, avec un précis de l'histoire du droit d'assurance maritime dans les Pays-Bas", Bulletin de la commission royale de l'histoire (4' série), 5 (1878) 41-118.) In navolging hiervan plaatst ook de Belgische historicus Goris in zijn studie aangaande de Zuid-Europese handelslui te Antwerpen de oorsprong van het zeeverzekeringsrecht in Portugal. (GORIS, Etude sur les colonies marchandes, 178-193.) De Gentse hoogleraar Verlinden liet echter zien dat deze opvatting volledig verkeerd is en wees op de Italiaanse en Provençaalse basis van het zeeverzekeringsrecht welke via bemiddeling van Spaanse kooplui ook te Antwerpen zijn ingang zou vinden. Bovendien wees Verlinden terecht op de belangrijke invloed die de Hordenanzas van de consuls van de Spaanse Natie te Brugge, welke in 1569 gedrukt werden en waar ik verder naar verwijzen zal als de Ordonnantie van Brugge, op het zeeverzekeringsrecht in de Nederlanden hebben uitgoefend en dat van Antwerpen in het bijzonder. (C. VERLINDEN, Codigo de seguros maritimos segun la costumbre de Amberes, promulgado por el consulado Espanol de Brujas en 1569 (Cuadernos de Historia de Espana), Buenos Aires, 1947-1948. C. VERLINDEN, "De zeeverzekeringen der Spaanse kooplui in de Nederlanden gedurende de XVIe eeuw", Bïdragen voor de geschiedenis der Nederlanden, 2 (1948) 191-216. C. VERLINDEN, "Code d'assurances maritimes selon la coutume d'Anvers, promulgué par le consulat espagnol de Bruges en 1569", Bulletin de la Commission royale des anciennes lois et ordonnances de Belgique, 16 (1949) 38-142.) Dat ook het Antwerpse zeeverzekeringsrecht in deze Brugse ordonnantie vervat zou zitten, zoals Verlinden wil laten uitschijnen, werd van zijn kant op overtuigende wijze ontkracht door de Groote. (H. L. V. DE GROOTE, De Zeeassurantie te Antwerpen en te Brugge in de zestiende eeun, Antwerpen, 1975, 52-58.) Ook de rol van de Piemontese koopman Gian-Battista Ferrufini mag, met betrekking tot de verfijning van het verzekeringswezen, niet onderschat worden. Op zijn advies zou er vanaf 1559 een einde komen aan de veel te grote vrijheid welke de verzekeraars en verzekerden gelaten werd en welke bijgevolg aanleiding gaf tot speculaties en talloze misbruiken. Génard weidde een zeer bevredigende en gedetailleerde studie aan de Italiaanse handelaar. (P. GÉNARD, "JeanBaptiste Ferrufini et les assurances maritimes à Anvers au XVIe siècle", Bulletin de la Société de géographie d'Anvers, 7 (1882) 193-268.) Tevens onontbeerlijk betreffende de historische ontwikkeling van de principes van het verzekeringsrecht in de Nederlanden in de moderne tijd is de studie van de hand van Van Niekerk: J. P. VAN NIEKERK, The development of the principles of insurance law in the Netherlands from 1500 to 1800, Johannesburg, 1998. 
het Romeinse recht. Ook dit is evident gezien het feit dat deze thema's nog niet in het Romeinse recht waren uitgewerkt. ${ }^{253}$

Tabel 1.13 Percentage nieuwe artikels waarvoor elk type rechtsbron verantwoordelijk is (zee- en assurantierecht)

\begin{tabular}{|c|c|c|c|c|c|c|c|c|}
\hline Usus & 3 & WG & Comp & eZR & S & RA & Ciciv & eGR \\
\hline 52.5 & 34.8 & 32.2 & 21.0 & 16.0 & 14.4 & 4.0 & 1.8 & 0.4 \\
\hline
\end{tabular}

De Groote betreurde in zijn studie omtrent het assurantiewezen in de zestiende eeuw te Brugge en Antwerpen het gebrek aan tijd dat hem belette alle 323 artikels aangaande de verzekering in titel 4.11 van de Consuetudines compilatae te onderzoeken. ${ }^{254}$ Zelf heb ik wel de moeite en de tijd genomen de rechtsbronnen van zowel deze titel als de titel over de schipvracht onder de loep te nemen. De resultaten ervan zijn weergegeven in tabel 1.14.

Tabel 1.14 Aandeel van ieder type rechtsbron per titel (zee-en assurantierecht)

\begin{tabular}{|c|c|c|c|}
\hline Tot & $\mathbf{4}$ & $\mathbf{8}$ & $\mathbf{1 1}$ \\
\hline 266 & Usus & 86 & 180 \\
\hline 176 & $\mathbf{3}$ & 71 & 105 \\
\hline 163 & WG & 117 & 46 \\
\hline 106.5 & Comp & 27 & 79.5 \\
\hline 81 & eZR & 49 & 32 \\
\hline 73 & S & 17 & 56 \\
\hline 20 & RA & 4 & 16 \\
\hline 9 & Ciciv & 5 & 4 \\
\hline 2 & eGR & - & 2 \\
\hline
\end{tabular}

Zoals bovenstaande tabel aangeeft, moet de oorsprong van zowel het Antwerpse zeerecht als het verzekeringsrecht van de stad overduidelijk in de Usus worden gezocht. Bij titel 4.8 wordt veertig procent van de nieuw toegevoegde artikels verantwoord op basis van de gewoonte. Bij titel 4.11 loopt dit percentage zelfs op tot 58.6 procent. Hierbij dient evenwel opgemerkt te worden dat dit niet geldt voor de paragrafen 11 ( $V$ an de schiplieden oft bootsgesellen, ende waertoe sij gehouden sijn, ende van bennen loon), 12 (Hoe ende wanneer de boetsgesellen vuyt hennen dienst mogen scheijden, oft daeraff verlaten worden) en 13 (Regel op d'eten ende drincken, ende anderen noot ende regimente van de schiplieden) van de titel omtrent de schipvracht. Hier nemen de vorstelijke zeevaartordonnanties van 1551 en 1563 het voortouw. Ik stel me hierbij echter de vraag in hoeverre de commissieleden werkelijk op de hoogte waren van wat op dat moment in de wereld van de scheepvaart en verzekeringen 'gebruikelijk' was. Men zou immers kunnen vermoeden dat hun kennis van dit toch wel even specifiek als zeldzaam rechtsgebied eerder beperkt was. Dat de Usus dan ook veelal -voornamelijk met betrekking tot titel 4.8 aangaande de schipvracht- vergezeld wordt van andere

${ }^{253}$ H. KOOIKER, Lex scripta abrogata. De derde renaissance van bet Romeinse recht, Nijmegen, 1996, 30.

${ }^{254}$ DE GROOTE, Zeeassurantie, 23-26. 
primaire rechtsbronnen, zoals de sententia peritorum en andere zeerechtelijke compilaties -waarover zodadelijk meer-, bevestigt mijn achterdochtig vermoeden enigszins. Toch blijkt men ook binnenskamers over de nodige expertise te beschikken. Bij de Groote staat immers te lezen dat, wanneer op vraag van Filips II stadsafgevaardigden, vergezeld van kooplieden, naar Brussel worden gezonden ter advisering bij het project van de ordonnantie op de zeeassurantie van 1570, hiertoe individuen behoren welke later ook deel zullen uitmaken van de commissie van 1582. ${ }^{255}$ Het bewijst het voor handen zijn van kennis en expertise binnen de stadsmuren van de metropool en meer nog binnen de commissie verantwoordelijk voor de redactie van het gewoonterecht. Het verklaart overigens ook de aanwezigheid van de periti in de Memorieboeken en de beschikbaarheid van tal van verschillende buitensteedse compilaties van zeerecht.

Waar bij het verzekeringswezen de Usus het voortouw neemt, is dit privilege bij de schipvracht weggelegd voor de wetgeving. In titel 4.8 is deze categorie goed voor 59.4 procent, waar dit percentage bij titel 4.11 slechts 17.6 bedraagt. Ditmaal is de legislatie uitsluitend van vorstelijke komaf. Met betrekking tot de titel omtrent de schipvracht ligt de nadruk op de zeevaartordonnantie van Filips II uit 1563, welke goed is voor 113 van de 205 nieuwe artikels. ${ }^{256}$ Een meer bescheiden rol is hier weggelegd voor de ordonnantie van diens voorganger van het jaar $1551 .{ }^{257}$ Het plakkaat levert 45 nieuwe artikels. De ordonnantie van 1570 (1571 n.s.) neemt dan weer het voortouw in de elfde titel. ${ }^{258}$ Dit statuut op t'feyt vande contrac[k]ten vande asseurantien ende verzekerynghen is voor minstens 41 nieuwe artikels verantwoordelijk geweest, waar de eerder genoemde ordonnantie van 1563 hier slechts zeven artikels heeft aangeleverd. ${ }^{259}$ Hoe dan ook gaat ten aanzien van titel 4.8 bijna drie vijfde terug op het vorstelijke wettenrecht.

255 DE GROOTE, Zeeassurantie, 23-26.

256 Ordonnantie statuyt ende eeunich edict s'Coninghs ons gheduchts Heeren, op t'faict vander Zee-vaert: ende hoe dat alle Cooplieden, ende Schippers schuldich syn voort aen haere Schepen toe te rusten, Equiperen ende voorsiene. Oock, hoe zy bemlieden reguleren zullen, sowel int laden ende afvoeren van bueren goeden en [de] Coopmanschepen, als ooc in haerlieder reyse, wedercomste, ende lossen oft ontladen van dien. Metsgaders van de Zeerechten alsoo wel onder de Schippers als den Cooplieden. Ende de ordonnantie op t'faict vander verzekerynghe oft Asseurantie, met meer andere zaken der Zeevaert aengaende. Ghegheven te Bruessele, den lesten Octobri, XV .LXIII, 31 oktober 1563, in Placcaert-boecken van Vlaenderen (1630), II, $307-$ 334.

257 Ordonnantie, statuut ende niev edict op het faict van der Zee-vaert: ende hoe dat alle Cooplieden, Schippers, $V$ isschers en [de] Bootghesellen schuldigh zijn voordan haere Schepen toe te reeden, equipperen ende voorts hoe zij hemlieden regulen zullen, zo wel int laden ende afvoeren van haeren goeden en[de] Coopmanschepen, als ooc in haerlieder reyse, wedercomste ende lossen oft ontladen van dien. Met diveersche poinc [k]ten ende articlen den Zeerechten angaende, van nieus daertoe ghedaen. Ghegheven te Bruessele den XIX. Van Hoymaendt, int jaer M.CCCCC.LI, 19 juli 1551, in Placcaert-boecken van Vlaenderen (1629), I, 375-396.

258 Ordonnantie, statuyt ende policie ghemaec $[k] t$ byden Coninck onsen alderghenaedichsten Heere, op t'feyt vande contrac [k]ten vande asseurantien ende verzekerynghen in dese Nederlanden, 20 januari 1571 (n.s.), in Placcaert-boecken van Vlaenderen (1630), II, 335-344.

259 Placcaert nopende de Zee-driften. 15 Maij 1574, 15 mei 1574, A. ANSELMO ed., Codex Belgicus seu Ius edictale a principibus Belgarum sancitum, Antwerpen, 1649 (anast. herdruk Brussel, 1998), III, 240-242. 
Opvallend is evenwel dat paragraaf 6, omtrent avarie grosse bij bevechtinge ende beroovinge vant schip, ende hoe men de genomen goeden ende schepen mach composeren oft lossen, volledig ontsnapt aan welke legislatieve invloed dan ook. De gewoonte neemt hier de fakkel over als voornaamste rechtsbron. Treffend bij dit alles is ook de scheiding die er blijkt te bestaan tussen legislatieve en costumiere rechtsbronnen. Daar waar sprake is van de gewoonte, zal men namelijk niet gauw een tweede primaire bron terugvinden van wetgevende aard.

Ook belangrijk binnen titel 4.11, is de categorie der derden. Het gaat om een aandeel van 34.8 procent. Ook ten aanzien van titel 4.8 is deze rechtsbron verantwoordelijk voor minstens 71 artikels of 34.6 procent. Deze groep van derden bestaat steeds uit experts of periti. In een aantal gevallen bedient men zich van meer concrete belangengroepen zoals daar zijn de mercatorum (handelaars), negociatorum (onderhandelaars), nautarum (schippers), ...qui assecuratoribus presunt of ex iudicio eorum die het stuck van versekeringhe het meest behandeld hebben en die gewoon syn te dirigeren (verzekeraars), ... en zelfs theologorum (theologen). Hun expertise verspreidt zich willekeurig over de verschillende titels. Het is namelijk niet zo dat deze deskundigheid zich rond welbepaalde paragrafen concentreert. Dat hun aanwezigheid geïnterpreteerd mag worden als een zeker democratisch idealisme, betwijfel ik ten zeerste. Enerzijds is hun expertise uiteraard onontbeerlijk, maar anderzijds zie ik hun nadrukkelijke aanwezigheid eerder als een gevolg van hun voorname positie binnen de Antwerpse maatschappij. Een positie die hen de macht geeft de Consuetudines compilatae naar hun hand te zetten. ${ }^{260}$

Het Antwerpse zeerecht is echter niet alleen onderhevig geweest aan interne invloeden. Zoals dat het geval is geweest voor bijna elke Europese haven, die zich in een commercieel web bevindt dat vaak gans Europa bestrijkt, spelen ook hier vreemde zeerechtelijke codificaties een rol. Contacten met de buitenwereld zijn er in een havenstad immers in overvloed. Zulke compilaties van buitensteeds zeerecht nemen met betrekking tot titel 4.8 maar liefst 23.9 procent of bijna een kwart van de nieuw toegevoegde artikels voor hun rekening. Ten aanzien van het verzekeringswezen is dit aandeel met een percentage van twaalf procent beduidend bescheidener. Hoewel er van de zeerechtelijke bakermatredacties zoals de Rôles d'Oléron en haar Vlaamse vertaling, het Zeerecht van Damme, geen expliciete melding wordt gemaakt in de Memorieboeken, heeft Korthals Altes laten zien hoezeer deze compilaties overal in Europa hun doorwerking hebben gekend.261 Ook de veertiendeeeuwse Ordonnantie van Amsterdam, ontbreekt in de Memorieboeken.262 Via de uitgebreide Oostzeehandel zal deze ordonnantie het voornaamste bestanddeel gaan uitmaken van

260 Cfr. GUYON, "Annotations de la coutume de Bordeaux", 300. Zie DE GROOTE, Zeeassurantie, 23-26.

261 A. KORTHALS ALTES, Ons oudste zeerecht (Uitgaven van het Molengraaf Instituut voor Privaatrecht te Utrecht. 5), Zwolle, 1976, 9.

262 De Ordonnantie van Amsterdam, waarvan sprake is in de Memorieboeken met betrekking tot het verzekeringsrecht van titel 4.11, dateert van 1598 en is specifiek op het verzekeringswezen gericht. 
de overbekende Wisbuyse Zeerecbten, welke vermoedelijk rond 1450 hun ontstaan kende. In wezen gaat het om een combinatie van de Amsterdamse ordonnantie en bepalingen uit Lübeck. Maar ook hier zijn sporen van het Vlaamse zeerecht uit Damme in te ontdekken. De Wisbuyse Zeerechten hebben op hun beurt de keizerlijke plakkaten betreffende het zeerecht beïnvloed, aldus Goudsmit. ${ }^{263}$

Tot de belangrijkste zeerechtelijke compilaties ten aanzien van titel 4.8 behoren enerzijds de zojuist genoemde Wisbuyse Zeerechten en anderzijds de zogenaamde Guidon de la Mer. Hoewel deze laatste compilatie nooit als dusdanig in de Memorieboeken wordt omschreven, maar steeds als ordinatio Rhotomagensis of ordonnantie van Rouwaenen wordt aangeduid, en hoewel de oudst bekende druk ervan pas dateert van 1607, heb ik er toch voor geopteerd deze rechtsbron als dusdanig te identificeren. ${ }^{264}$ Ook als secundaire rechtsbron zijn beide compilaties uiterst belangrijk geweest.

Een andere compilatie welke ten aanzien van deze achtste titel voornamelijk als secundaire rechtsbron van belang is geweest, zijn de Hordenanzas van de consuls der Spaanse Natie te Brugge. In de Memorieboeken wordt er naar gerefereerd als de Ordonnantie van Brugge. Zij werd voor het eerst gedrukt in 1568 en is deels gebaseerd op de ordonnantie op de zeeverzekering van de Spaanse stad Burgos. ${ }^{265}$ De stelling van Verlinden dat ook het Antwerpse zeeverzekeringsrecht in deze ordonnantie vervat zou zitten, werd door de Groote op overtuigende wijze weerlegd. 266

Tot de belangriikste primaire rechtsbronnen van de elfde titel behoort in de eerste plaats de zestiende-eeuwse Ordonnantie van Amsterdam (1598). ${ }^{267} \mathrm{Zij}$ levert maar liefst zestien artikels. Verder komen ook de Ordonnantie van Brugge en die van Rouen (Guidon de la Mer) als primaire bron aan bod, zij het, respectievelijk met vijf en elf artikels, in

${ }^{263}$ Cfr. DE GROOTE, Zeeassurantie, 32.

264 Cfr. DE GROOTE, Zeeassurantie, 32; P. J. A. CLAVAREAU, "Les sources du droit maritime du Moyen Âge (essai de bibliographie raisonnée)", Tijdschrift voor Rechtsgeschiedenis, 18 (1950), 401. Materiële controle heeft uitgewezen dat het om hetzelfde werk gaat. Het is evenwel niet in het Handbuch van Coing terug te vinden. Nog meer opvallend is het recente karakter van de compilatie. De oudst bekende uitgave dateert immers van 1607. Indien er geen vroegere geschreven versies voor handen waren, gaat het hier om een kwestie van maanden. Bijgevolg toont haar aanwezigheid hoezeer de commissieleden op de hoogte waren van de meest recente literatuur en ontwikkelingen. Dit blijkt overigens nog maar eens uit de Memorieboeken met betrekking tot artikel 4.15.18, alwaar verwezen wordt naar een turba non registrata daterend van de maand juli anno 1608: Est pars $1^{a}$ ar[ticu]li decimi tertii in impressis ex usu et turba non registrata onder den secretaris de Moy mense iulio a [nno] 1608 tusschen Ian Mendez Henricques et Zoesa Figueroa.) Anderzijds kan dit voor de sceptici een argument zijn voor het bestaan van een oudere, tot nu toe onbekende, versie van de Guidon de la Mer. Een recentere uitgave van de Guidon de la Mer is te vinden bij Pardessus: J. M. PARDESSUS, Collection de lois maritimes antérieures au XVIIIe siècle, II, Parijs, 1831, 377-432.

265 DE GROOTE, Zeeassurantie, 46.

266 VERLINDEN, "De zeeverzekeringen der Spaanse kooplui in de Nederlanden", 191-216. DE GROOTE, Zeeassurantie, 52-58.

${ }^{267}$ Cfr. S. LAMMEL, "Die Gesetzgebung des Handelsrechts", H. COING red., Handbuch der Quellen und Literatur der Neueren europäischen Privatrechtsgeschichte, II/2, Munchen, 1976, 677. 
beduidend mindere mate. ${ }^{268}$ Opgelet, hun invloed mag niet overschat worden. ${ }^{269} \mathrm{Het}$ zijn nog steeds de Usus, de periti en de wetgevende activiteiten van Filips II die hier de toon zetten. Met betrekking tot de verzekering ontbreekt evenwel elke verwijzing naar Londen, meer bepaald naar de usantien van Lombard Street, waarvan in vele Antwerpse polissen sprake is, zoals De Groote aangeeft. ${ }^{270}$

Ook wat de secundaire bronnen van titel 4.11 betreft, zijn het deels dezelfde namen als bij titel 4.8 die de lijst aanvoeren. Opnieuw zijn er de Guidon de la Mer en de Ordonnantie van Brugge. Maar ook wordt er nu opvallend meer naar voornoemde Ordonnantie van Amsterdam verwezen. Bovendien komen nu ook, het zij op eerder bescheiden manier, mediterrane invloeden aan bod. Het betreft twee bronnen van Genuese oorsprong. Ten eerste zijn er de Decisiones Rotae Genuensis de mercatura, welke voor een eerste maal door Marco Antonio Belloni werden uitgegeven in $1581 .{ }^{271} \mathrm{Als}$ burgerlijke rechtbank van een havenstad als Genua kreeg deze rota tal van handelskwesties te verwerken. Het tweede werk afkomstig van Genua zijn de statuten van deze stad. Het betreft hier de Statutorum Civilium Reipublicae Genuensis. Nuper reformatorum. Libri sex, cum duplici indice altero rubricarum, et altero materiarum (1589). ${ }^{272}$

Overigens, de persoon van Belloni als rechtsgeleerde herinnert me aan de zo goed als totale afwezigheid van de rechtsleer als primaire rechtsbron met betrekking tot dit zee- en verzekeringsrecht. Bijzonder is dit omwille van het wel degelijk bestaan van een uitgebreid oeuvre aan zeerechtelijke traktaten. Of het ook daadwerkelijk voor handen was, kan ik niet bevestigen. Wel heb ik in de Memorieboeken drie verwijzingen kunnen terugvinden naar het Tractatus de mercatura seu mercatore (1553) van de Italiaanse auteur Benvenuto Stracca. Al bij al blijft dit evenwel een magere troost. Te meer

\footnotetext{
268 Ook de meer abstracte omschrijving 'exemplum vicinorum locorum' ten aanzien van artikel 4.11.67/68 heb ik in deze categorie opgenomen.

269 Qua belang wordt deze ondervertegenwoordiging meer dan voldoende gecompenseerd door de mate waarin ze als secundaire rechtsbronnen worden aangewend. Met betrekking tot titel 4.8 blijkt dat de Ordonnantie van Rouen voor maar liefst 59 nieuwe artikels als secundaire rechtsbron optreedt. De Wisbuyse Zeerechten doen dit voor 42 gevallen. De rol van Brugge en Amsterdam daarentegen blijft hier over het geheel beperkt. Ten aanzien van titel 4.11 neemt hun impact dan weer toe, gezien het feit dat het verzekeringsrecht nu centraal komt te staan. De Ordonnantie van Brugge is goed voor minstens 88 artikels en die van Amsterdam voor minstens 26. Maar ook nu weer wordt de lijst, met 123 artikels op zijn conto, aangevoerd door de Ordonnantie van Rouen. De invloed van Wisbuy is in deze te verwaarlozen. Uit deze cijfers blijkt duidelijk dat de invloed van de verschillende, vreemde zee- en assurantierechtelijke ordonnanties beduidend groter is geweest dan op het eerste gezicht blijkt uit hun aandeel als primaire rechtsbronvan de Antwerpse Consuetudines compilatae.

${ }^{270}$ DE GROOTE, Zeeassurantie, 57-58 en 126-128. Zie ook: VAN NIEKERK, Development of the principles of insurance law, I, 255-257.

271 Cfr. M. ASCHERI, "Rechtsprechungs- und konsiliensammlungen. Italien", H. COING red., Handbuch der Quellen und Literatur der Neueren europäischen Privatrechtsgeschichte, II/2, Munchen, 1976, 1181.

272 Cfr. F. RANIERI, "Bibliographie der Gesetzgebung des Privatrechts und Prosessrechts. Italien”, H. COING red., Handbuch der Quellen und Literatur der Neueren europäischen Privatrechtsgeschichte, II/2, Munchen, 1976, 163.
} 
omdat er dus van de grote pioniers noch van de klassieke maritieme standaardwerken helemaal geen sprake is. ${ }^{273} \mathrm{Ik}$ doel hier op auteurs als de Spanjaard Pedro de Santarem (Tractatus de assecurationibus et sponsionibus mercatorum, 1553), de Italiaan Giulio Ferretti (De iure et re navali et de ipsius rei navalis et belli aquatici praeceptis legitimis liber, 1579) en voor het Britse eiland de advocaat uit Edinburgh, Alexander King (Tractatus legum et consuetudinum navalium quae apud omnes fere gentes in usu babentur, 1587-1592). Voor de Nederlanden is er Pieter Peck die in 1556 een commentaar liet verschijnen op de zeerechtelijke titels van de Digesten en de Codex (Commentaria in omnes pene iuris civilis titulos ad rem nauticam pertinentes, 1556). Een andere auteur van Nederlands origine is Quintin Weytsen (1518-1565). Zijn Tractaet van Avarien verscheen pas in 1617, maar kwam vermoedelijk veel vroeger tot stand (1554-1563). Het is duidelijk, op dit punt prefereert men de periti boven de academici. Het doet me veronderstellen dat ik periti niet met rechtsgeleerden mag vereenzelvigen.

Het is echter niet alleen de rechtsleer die ontbreekt. Ook een aantal andere belangrijke zeerechtelijke compilaties lijken niet ter beschikking gestaan te hebben van de compilatoren. Ik denk bijvoorbeeld aan de protagonist onder de Zuid-Europese compilaties, met name het Consolato del Mar (dertiende-veertiende eeuw) uit Barcelona.. ${ }^{274}$ Verder ontbreekt ook elk spoor van de beroemde statuten van Hanzesteden als Hamburg (1603) en Lübeck (1586). ${ }^{275}$ Ook van het overkoepelende Hansische Seerecht van 1591 is geen enkele invloed te traceren. ${ }^{276}$ Deze lacunes brengen me bij de idee dat bij de ontwikkeling van het maritieme recht binnen Europa een bipolariteit ontstaan is, waarin twee rechtskringen centraal staan. ${ }^{277}$ Enerzijds is er het Middellandse Zeegebied waar een centrale rol wordt ingenomen door het Consolato del Mar; anderzijds is er sprake van een Noordatlantisch Zeegebied onder invloed van de Hanze- en Nederlandse steden. ${ }^{278}$ De positie van Antwerpen hierin is echter onduidelijk. Aan de ene kant ontbreken er belangrijke compilaties uit beide rechtskringen; waar aan de andere kant Antwerpen door zeerecht afkomstig van beide regio's is beïnvloed. Antwerpen fungeert, net zoals in de handel, ook op handelsrechtelijk vlak als een overslaghaven waar twee verschillende kringen elkaar

\footnotetext{
${ }^{273}$ Het overzicht dat nu volgt, is gebaseerd op K. O. SCHERNER, "Die Wissenschaft des Handelsrechts", H. COING red., Handbuch der Quellen und Literatur der Neueren europäischen Privatrechtsgeschichte, II/1, Munchen, 1977, 848-856.

${ }^{274}$ Cfr. R. LESAFFER, Inleiding tot de Europese rechtsgeschiedenis, Leuven, 2004, 247.

${ }^{275}$ Cfr. LAMMEL, "Die Gesetzgebung des Handelsrecht", 772.

276 Cfr. LAMMEL, "Die Gesetzgebung des Handelsrecht", 677.

277 Osler bepleit ook met betrekking tot het Europees recht in het algemeen een sterker benadrukken van regionale verschillen volgens politieke en zelfs confessionele contouren. Voor Osler kijkt een Brabander in de eerste plaats naar Brabant. De auteur trekt dit zelfs zo ver door dat hij vanaf de zestiende eeuw niet langer van een Europees ius commune wil spreken, maar de voorkeur geeft aan 'nationale juridische culturen'. (OSLER, "Myth of European Legal History", 404-410.) Met dit boek zal ik echter aantonen dat deze opvatting aanzienlijk genuanceerd moet worden. Het laat immers overtuigend zien hoezeer het belang van nietAntwerpse factoren niet onderschat mag worden.

278 Cfr. LAMMEL, “Die Gesetzgebung des Handelsrecht”, 579-580.
} 
ontmoeten, met als gevolg dat haar eigen zeerecht het karakter van een ware melting pot vertoont. ${ }^{279}$

Handelsrecht en verbintenissenrecht

Het residu van deel IV valt onder de Romeinse noemer obligationes. Hiertoe worden ondermeer het verbintenissen-, contract- en handelsrecht gerekend. Zoals algemeen wordt aangenomen, mag men hier een sterke invloed van het Romeinse recht verwachten. ${ }^{280}$ Dat het verbintenissenrecht van nature geen costumier rechtsgebied was, makkt dat men gedwongen was terug te grijpen naar de Romeinsrechtelijke regelgeving. ${ }^{281}$ Onderstaande tabel 1.15 geeft een idee in hoeverre deze vooronderstellingen betrouwd kunnen worden. ${ }^{282}$

Tabel 1.15 Percentage nieuwe artikels waarvoor elk type rechtsbron verantwoordelijk is (deel IV)

\begin{tabular}{|c|c|c|c|c|c|c|c|c|c|c|}
\hline Usus & S & Comp & WG & 3 & Ciciv & RA & RL & RS & OAR & eGR \\
\hline 34.1 & 22.8 & 20.9 & 19.9 & 18.0 & 16.9 & 12.6 & 7.9 & 4.4 & 4.1 & 0.3 \\
\hline
\end{tabular}

Het is dan ook enigszins verrassend dat de Memorieboeken slechts in achttien procent van de gevallen gewag maken van het Corpus Iuris Civilis. Tegen de verwachtingen in wordt deze ondervertegenwoordiging gecompenseerd door de gewoonte. In 34.1 procent van de nieuw toegevoegde artikels ten aanzien van het verbintenissenrecht blijkt namelijk de fundamentele oorsprong ervan in de Usus te liggen. Een verklaring voor de magere prestatie van het geleerde recht in strikte zin kan gezocht worden in het feit dat de romanisatie mogelijk reeds bij een vroegere redactiepoging heeft plaatsgevonden. ${ }^{283}$ Een ander mogelijkheid bestaat erin dat het gezamelijk behandelen

279 Hierbij dien ik evenwel de kanttekening te maken dat Antwerpen niet alleen als transithaven fungeerde. Ze beschikte eveneens over een gezonde export die gevoed werd door een bloeiende, Vlaamse plattelandsindustrie enerzijds en de fijnere industrieën van naburige Vlaamse en Noord-Nederlandse steden. Cfr. GORIS, Etude sur les colonies marchandes méridionales, 270.

${ }^{280}$ GODDING, Droit privé, 6: "Quant aux obligations, la technique romaine s'est imposé d'autant plus naturellement que la pratique coutumière n'avait élaboré qu'un petit nombre de solutions, très concrètes, auxquelles elle restera fidèle dans l'ensemble." GILISSEN, "Rédaction des coutumes. Essai de synthèse", 57: "Certaines parties du droit civil y sont même peu représentées: le mariage et le divorce, régis par le droit canonique, et les obligations, matière plus profondément influencée par le droit romain."

${ }^{281}$ Cfr. FILHOL, "Rédaction des coutumes", 73.

282 Aangezien het voor één artikel onduidelijk is gebleven om welke primaire rechtsbronnen het exact gaat, bestaat er voor elke categorie binnen deze tabel een theoretische foutmarge van één artikel of -in het geval van een totaal aantal nieuwe artikels van 316.5- 0.3 procent.

283 Deze vraag kan deels beantwoord worden met behulp van het traktaat van Hendrik de Moy aangaande de Consuetudines impressae. Hierin behandelt de auteur immers de juridische oorsprong van elk afzonderlijk artikel. De tijd ontbrak me echter ook dit handschrift volledig door te nemen. Wel wil ik er in dit opzicht nog op wijzen dat De Moy aan het begin van zijn traktaat bij de Consuetudines impressae reeds aangaf dat ook het Romeinse recht een belangrijke bron voor de samenstelling ervan is geweest: "Oft oock andersins uuyt de gescreve $[n]$ rechte $[n]$. En [de] hoe verre elck costuyme $[n]$ mette $[n]$ gescreve $[n]$ rechte $[n]$ is accorderen [de] oft d[aer] aff discreperen [de]." (SAA, Vierschaer, 21: DE MOY, Tractaat, fol. 1r.) 
van meer specifiek handelsrecht enerzijds met het meer algemene verbintenissenrecht anderzijds een vertekend beeld veroorzaakt heeft. Het lijkt me dan ook raadzaam dit residu op te splitsen in een part met zuiver commerciële titels (4.3, 4.4, 4.5, 4.6, 4.9, $4.10,4.16,4.18)$ en een deel dat het contract- of verbintenissenrecht $(4.1,4.2,4.7$, $4.12,4.13,4.14,4.15,4.17)$ verzamelt. Deze ingreep levert tabel 1.16 op. $^{284}$

Tabel 1.16 Percentage nieuwe artikels waarvoor elk type rechtsbron verantwoordelijk is (handelsrecht en contract- of verbintenissenrecht)

\begin{tabular}{|c|c|c|c|c|c|c|c|c|c|c|}
\hline \multicolumn{11}{|c|}{ Handelsrecht } \\
\hline Usus & 3 & $\mathrm{~S}$ & Comp & Ciciv & WG & RA & RL & RS & OAR & eGR \\
\hline 34.7 & 24.8 & 22.0 & 19.2 & 16.2 & 14.5 & 12.2 & 7.5 & 5.2 & 4.2 & 0.5 \\
\hline \multicolumn{11}{|c|}{ Contract- of verbintenissenrecht } \\
\hline Usus & WG & Comp & $\mathrm{S}$ & Ciciv & RA & RL & 3 & OAR & RS & eGR \\
\hline 33.0 & 31.0 & 24.3 & 24.3 & 18.5 & 13.6 & 8.7 & 3.9 & 3.9 & 2.9 & 0.0 \\
\hline
\end{tabular}

Maar ook nu blijkt wederom dat het Romeinse recht in geen van beide rechtsgebieden een vuist kan maken. Bovendien bestaat er in dezen slechts een klein verschil tussen het handelsrecht en het verbintenissenrecht. De Usus blijft bijgevolg in beide gevallen de leverancier bij uitstek.

Een andere in het oog springende trend, op basis van bovenstaande tabel 1.16, is onder meer de rol van de derden bij het handelsrecht. Ook hier ligt het namelijk voor de hand dat er met betrekking tot een specifiek onderwerp als het commerciële recht een beroep wordt gedaan op ervaringsdeskundigen als de mercati zelf. Het brengt de groep op een derde plaats onder de verschillende categorieën van rechtsbronnen. Eenzelfde redenering verklaart de vaststelling dat binnen dit handelsrecht ook de ratio evenals de specifieke redenen één van hun hoogste waarden halen. Het handelsrecht is immers zo ongewoon en nieuw, dat het rationeel en origineel denken vereist, bij voorkeur mét behulp van ervaringsdeskundigen of experts. Onderstaande tabel 1.17 geeft aan waar deze verschillende bronnentypes zich binnen de handelsrechtelijke titels concentreren.

Tabel 1.17 Aandeel van ieder type rechtsbron per titel (handelsrecht)

\begin{tabular}{|c|c|c|c|c|c|c|c|c|c|}
\hline Tot & $\mathbf{4}$ & $\mathbf{. 3}$ & $\mathbf{. 4}$ & $\mathbf{. 5}$ & $\mathbf{. 6}$ & $\mathbf{. 9}$ & $\mathbf{. 1 0}$ & $\mathbf{. 1 6}$ & $\mathbf{. 1 8}$ \\
\hline 74 & Usus & 25 & - & - & 5 & 10 & 8 & 17 & 9 \\
\hline 53 & $\mathbf{3}$ & 19 & - & 1 & 1 & 7 & 2 & 19 & 4 \\
\hline 47 & $\mathbf{S}$ & 14 & - & - & 1 & 7 & 7 & 9 & 9 \\
\hline 41 & Comp & 7 & - & - & 5 & 6 & 6 & 10 & 7 \\
\hline
\end{tabular}

284 Ten aanzien van het handelsrecht geldt het volgende. Aangezien het voor één artikel onduidelijk is gebleven om welke primaire rechtsbronnen het exact gaat, bestaat er voor elke categorie binnen deze tabel een theoretische foutmarge van één artikel of -in het geval van een totaal aantal nieuwe artikels van 213.5 - 0.5 procent.

Ten aanzien van het verbintenissenrecht geldt op een gelijkaardige manier het volgende. Aangezien het voor geen enkel artikel onduidelijk is gebleven om welke primaire rechtsbronnen het exact gaat, bestaat er voor elke categorie binnen deze tabel een theoretische foutmarge van nul artikels of -in het geval van een totaal aantal nieuwe artikels van 103-0.0 procent. 


\begin{tabular}{|c|c|c|c|c|c|c|c|c|c|}
\hline 34.5 & Ciciv & 4 & - & - & 2 & 10 & 7 & 3 & 8.5 \\
\hline 31 & WG & 5 & - & 1 & - & 6 & 2 & 13 & 4 \\
\hline 26 & RA & 3 & - & - & 3 & 2 & - & 12 & 6 \\
\hline 16 & RL & 1 & - & - & 2 & 1 & 5 & 1 & 6 \\
\hline 11 & RS & 4 & - & - & - & - & 2 & 2 & 3 \\
\hline 9 & OAR & - & - & - & - & - & - & 7 & 2 \\
\hline 1 & eGR & - & - & - & - & 1 & - & - & - \\
\hline
\end{tabular}

De ambities van de redacteurs op handelsrechtelijk vlak doen hen teruggrijpen naar de bakermat ervan. Meer dan elders valt men voor het handelsrecht terug op de statuten van Genua, en dit zowel als primaire evenals secundaire rechtsbron. De statuten zijn aan te treffen in de titels omtrent de wisselbrieven (4.3; vier artikels), de gemeenschap van goederen (4.9; zes artikels), het bevel ende factorije (4.10; twee artikels), gebroken schuldenaars (4.16; zes artikels) en preferentie onder de crediteuren (4.18; twee artikels). In één enkel geval, in titel 4.3 omtrent de wisselbrieven, wordt zelfs verwezen naar Venetiaanse wetgeving. Het betreft een edictum venetorum dat dateert van 14 december 1593.285 Ondanks de baanbrekende rol van steden als Genua en Venetië op commercieel vlak, heeft ook de eigen wetgeving een rol gespeeld binnen deze materie. Dit geldt voornamelijk ten aanzien van de zestiende titel omtrent de gebroken schuldenaars, alwaar zeven nieuwe artikels vanuit interne legislatie in de Consuetudines compilatae werden geïntegreerd. In vier gevallen gaat het om de stedelijke statuten van 1515 en 1518 gemaecket op de fugitiven. Vijf keer betreft het de keizerlijke plakkaten van 7 oktober 1531 en 4 oktober 1540.286 De statuten van 1515 en 1518 komen ook nog één maal ter sprake in titel 4.18 omtrent de preferentie onder de crediteuren. Titel 4.5 aangaande de paardenmarkten verwijst voor het eerste artikel naar een privilege van hertog Jan van Brabant uit 1298 dat aan de stad werd verleend.

Meer nog dan bij het handelsrecht, speelt het wettenrecht een doorslaggevende rol bij het verbintenissenrecht. Maar liefst dertig procent van de nieuw toegevoegde artikels is namelijk afkomstig van legislatieve inspanningen. In tegenstelling tot het handelsrecht, krijg ik nu een groep wetgevende rechtsbronnen te zien welke aanzienlijk minder gevarieerd is, en waarbij de nadruk is komen te liggen op de wetgeving afkomstig van de centrale overheid. ${ }^{287}$ Veruit de belangrijkste titel in dit opzicht is titel 4.17 omtrent brieven van respijt, uitstel van betaling en cessie. Ten aanzien van de eerste paragraaf ligt de nadruk op de zogenaamde laatste ordonnantie van de Raad alias de Albertine Ordonnantie van 13 april 1604.288 Zij fungeert als primaire

\footnotetext{
285 Om welk document het exact gaat, heb ik evenwel niet kunen achterhalen.

${ }^{286}$ Cfr supra, hoofdstuk 1, paragraaf 2, Deel I.

287 Ook het wettenrecht afkomstig van het buiten de landsgrenzen, is een pak minder exotisch. Enkel ten aanzien van de titels 4.1 (geoorloofde en ongeoorloofde contracten) en 4.7 (huur) is er sprake van de Franse wetgeving vervat in de reeds vernoemde Codex Henricianus. In totaal gaat het hier om vier nieuwe artikels.

288 Ordinancie, Styl ende Maniere van procederen vanden souverainen raede van Brabandt ende landen van Overmaeze, 13 april 1604, A. ANSELMO ed., Codex Belgicus seu Ius edictale a principibus Belgarum sancitum, Antwerpen, 1649 (anast. herdruk Brussel, 1998), I, 709-780.
} 
bron voor tien nieuwe artikels. Wat de tweede paragraaf betreft staan twee keizerlijke plakkaten, respectievelijk van de jaren 1537 en 1541, centraal.289 Ze zijn goed voor zes nieuwe artikels.

Tabel 1.18 Aandeel van ieder type rechtsbron per titel (verbintenissenrecht)

\begin{tabular}{|c|c|c|c|c|c|c|c|c|c|}
\hline Tot & $\mathbf{4}$ & $\mathbf{. 1}$ & $\mathbf{. 2}$ & $\mathbf{. 7}$ & $\mathbf{. 1 2}$ & $\mathbf{. 1 3}$ & $\mathbf{. 1 4}$ & $\mathbf{. 1 5}$ & $\mathbf{. 1 7}$ \\
\hline 34 & Usus & 5 & 2 & 5 & 9 & 5 & - & 7 & 1 \\
\hline 32 & WG & 5 & 1 & 3 & - & - & 4 & 3 & 16 \\
\hline 25 & Comp & - & 3 & 2 & 5 & 3 & 6 & 5 & 1 \\
\hline 25 & S & 3 & - & 8 & 3 & 5 & 1 & 2 & 3 \\
\hline 19 & Ciciv & 1 & - & 1 & 6 & 3 & - & 4 & 4 \\
\hline 14 & RA & - & - & - & 3 & - & 3 & 8 & - \\
\hline 9 & RL & 2 & - & - & 2 & 3 & - & 2 & - \\
\hline 4 & $\mathbf{3}$ & - & - & - & 2 & - & - & - & 2 \\
\hline 4 & OAR & - & - & - & 2 & 1 & - & - & 1 \\
\hline 3 & RS & - & - & 1 & 1 & - & - & - & 1 \\
\hline
\end{tabular}

Op basis van bovenstaande tabel 1.18 blijkt dat ook de veertiende titel omtrent namptisatie, qua wetgeving, het vermelden waard is. Vier van de zes nieuwe artikels zijn namelijk afkomstig van de stedelijke Ordonnantie op de Styl ende Maniere van procederen achter de gedruckte costuymen. Titel 4.15 (Van betaeling) kenmerkt zich voornamelijk door de aanwezigheid van het reeds vernoemde plakkaat van 25 juni 1601. ${ }^{290}$ Het ligt er aan de oorsprong van drie nieuwe artikels.

Wat zowel het handelsrecht als het verbintenissenrecht gemeen hebben, is de hoge score van de categorie van specifieke reden, en in iets mindere mate ook de prominente aanwezigheid van nieuwe artikels welke het gevolg zijn van andere artikels uit de Consuetudines compilatae. De specifieke redenen verklaren zich aan de hand van het specifieke karakter van de desbetreffende rechtsmaterie; de positie van de tweede categorie (Comp) kan gezien worden als een gevolg van het feit dat het vierde deel het meest geïnnoveerde deel is. Des te groter het aantal nieuwe artikels, des te groter de zogenaamde collateral damage. Meer nieuwigheden vragen immers om veel duiding.

289 Ordonnantiën vanden Keyser, nopende de Hantschriften ende Obligatien byden Cooplieden d'een den anderen ghegheven. den 7 Meert 1537, 7 maart 1537, A. ANSELMO ed., Codex Belgicus seu Ius edictale a principibus Belgarum sancitum, Antwerpen, 1649 (anast. herdruk Brussel, 1998), I, 515-516. De Memorieboeken spreken verkeerdelijk van 5 of 6 maart 1537 (n.s.). (Cfr. 4.2.5, 4.2.13/14) Het traktaat van De Moy spreekt terecht van 7 maart 1537 (n.s.). (Cfr. SAA, Vierschaer, 22: DE MOY, Tractaat, fol. 457.)

Ordonnance, Statut \& Edict de plusieurs matieres: Premiers, Touchant les impetrans de remission. 2. Touchant l'octroy des lettres de legittimation. 3. Des lettres de Placet, sur les bulles Apostoliques. Des lettres de respit \& cession. 5. Du benefice d'inventoire. Donné à Bruges, le XX. Jour d'Octobre, l'an M.XLI, 20 oktober 1540, in Placcaert-boecken van Vlaenderen (1629), I, 776-781. Verdere uitleg en interpretatie van de ordonnantie volgt op 3 januari 1542 (Placcaert-boecken van Vlaenderen, I, 781782).

${ }^{290}$ De Memorieboeken spreken verkeerdelijk van 1605. Materiële controle heeft dit uitgewezen. 
Ook de categorieën die laag scoren zijn in beide gevallen vergelijkbaar. Het gaat om het buitensteedse gewoonterecht, de vroegere redacties, de rechtspraak, de rechtsleer evenals de categorie omtrent de redelijkheid. De afwezigheid van extern gewoonterecht als beïnvloedende factor verklaart zich ongetwijfeld door de afwezigheid van voorbeeldcompilaties op het vlak van het commerciële recht. Wat de vroegere redacties betreft, spelen deze enkel ten aanzien van titel 4.16, omtrent de gebroken scbuldenaers, een rol. Zoals ik reeds eerder heb kunnen vaststellen, beperkt men zich hier voornamelijk tot de Consuetudines antiquissimae en het Guldenboeck. Eén maal grijpt men terug naar de gebruiken van de beurs van Antwerpen (Costuymen vande Borse)..$^{291}$

Ter afronding van dit vierde deel wil ik er nog op wijzen hoezeer dit vierde deel zich manifesteert als symbiose van eigen ervaring, ambities en creativiteit enerzijds (Usus, 3 , Specifieke redenen) met het Romeinse recht anderzijds. De ambiguiteit waarvan het vierde deel op deze manier blijk geeft, past perfect in de ontwikkelingsgeschiedenis welke het verbintenissenrecht in onze streken doormaakt. Bij Godding staat namelijk duidelijk te lezen hoe de lokale gemeenschappen aanvankelijk hun eigen contractuele regels ontwierpen om vervolgens vanaf de zestiende eeuw de invloed van het geleerde recht stricto sensu te ondergaan. ${ }^{292}$ Deze invloed kon behoorlijk groot worden, gezien het feit dat de meeste costumen het verbintenissenrecht slechts zeer summier of zelfs geheel niet behandelden. Lacunes als deze werden doorgaans ingevuld aan de hand van een subsidiair geldend Romeins recht. ${ }^{293}$ Antwerpen neemt in dezen een uitzonderingspositie in. Door de exhaustieve

${ }^{291}$ Cfr. 4.16.35/36/37.

292 GODDING, Droit privé, 415-416: "Mais, à l'époque même où se produit cette évolution du droit urbain, l'étude du droit romain est remise à l'honneur dans les universités. Son influence dans nos régions se fera sentir surtout à partir du $16^{e}$ siècle, comme dans d'autres domaines du droit privé. Si le droit coutumier y a assez bien résisté dans le domaine des droits réels immobiliers, des régimes matrimoniaux, des successions, par contre, dans le domaine des obligations contractuelles, la technique romaine imposera sa supériorité. Dans les coutumes rédigées aux $16^{e}$ et $17^{\circ}$ siècles, il n'est guère questions des obligations contractuelles. ... En effet, dès le règne de Charles-Quint, c'est au droit romain que le souverain impose de recourir pour combler les lacunes des coutumes homologuées."

${ }^{293}$ Cfr. KOOIKER, Lex scripta abrogata, 9-24. Vele geredigeerde costumen verwezen expliciet naar het Romeinse recht voor die gevallen waarin het eigen, lokale recht niet voorzag. De centrale overheid zou de subsidiariteit van het Romeinse recht steeds bevorderen. Een eerste expliciete verwijzing van de overheid naar het Romeinse recht als subsidiair geldend recht dateert van het jaar 1462. In een instructie aan het Hof van Holland stelt Karel de Stoute voor een beroep te doen op de 'geschreven rechten' van zodra men met leemtes in het lokale recht wordt geconfronteerd. Een ander voorbeeld tref ik aan bij de ordonnantie van 1487 inzake de admiraliteit van Maximiliaan van Oostenrijk. (Cfr. VAN CAENEGEM, Droit romain, 47.) Ook de artikels 38 en 57 van de Criminele Ordonnantiën van Filips II kenden wettelijk een subsidiaire rol toe aan het Romeinse recht (tenminste op strafrechtelijk vlak). Voordien bestond deze aanvullende waarde van het Justinaanse recht uitsluitend gewoonterechtelijk, aldus Monballyu. (MONBALLYU, Zes eeuwen strafrecht, 38.) Cfr. J. GILISSEN, "Le problème des lacunes du 
behandeling van het handels- en verbintenissenrecht vrijwaart het de eigen gebruiken van te veel andersoortige gebruiken zoals bijvoorbeeld die uit de Romeinse tijd. Men gelooft duidelijk in de superioriteit van het eigen systeem. Via de redactie ervan, met behulp van de eigen experts, weet men dit te beschermen. Deze reactie op het feit dat Karel V als het ware een vrijgeleide gaf aan het Romeinse recht, klinkt logisch gezien het belang van de eigen gebruiken voor een handelsmetropool als Antwerpen. ${ }^{294}$

Deel V

Omtrent dit vijfde deel kan ik relatief kort zijn. Het omvat het burgerlijk procesrecht zoals Antwerpen dat in de zeventiende eeuw kende. ${ }^{295}$ Dat dit reeds in de zestiende eeuw tot wasdom was gekomen en eveneens te boek werd gesteld, blijkt uit het bestaan van de Ordonnantie op de Styl ende Maniere van procederen, daterend van 1582, welke achteraan de Consuetudines impressae werd bijgevoegd en samen met deze compilatie werd uitgegeven. Dit bracht met zich mee dat het aantal procesrechtelijke artikels in't civiel in de Consuetudines impressae zelf relatief beperkt bleef. Zij zaten immers in voornoemde ordonnantie van 1582 vervat. Uit de Memorieboeken blijkt nu dat er ook eerdere versies van deze styl ende maniere hebben bestaan. In het eerste deel ben ik reeds varianten van de jaren 1564 en 1576 tegengekomen, zoals onder andere bleek uit artikel 1.11.2/3: Ex art 1 inde gedruckte ordonnantie op de maeniere van procederen staende achter de costuymen ende in die vanden jaere 1564 et 1576 art 2 hoc tit. Ook binnen dit vijfde deel wordt meermaals verwezen naar de gelijknamige ordonnantie de anno 1564, zoals onder meer bij artikel 5.10.1: Est 7 inde gedructe ordonnan[tie] achter de costuymen 3 et 4 in die vanden jaere 1564 hoc tit. Ik ben er evenwel niet in geslaagd een exemplaar terug te vinden van één van beide ordonnanties. Ook in de beschikbare literatuur heb ik nergens verwijzingen kunnen aantreffen naar deze vroegere versies van de styl ende maniere van procederen.

Wanneer nu blijkt dat het aantal procesrechtelijke artikels in de Consuetudines compilatae ten opzichte van de vorige redactiepoging uit 1582 bijna verdubbeld werd, mag men er reeds bij voorbaat van uit gaan dat dit het gevolg is van de integratie van de ordonnantie op de styl ende maniere van procederen in de compilatie. Dat dit geen onterechte veronderstelling is, zal zodadelijk blijken. Tabel 1.19 geeft het aandeel weer van elke afzonderlijke titel in het inovatieve karakter van deel V.

droit dans l'évolution du droit médiéval et moderne", C. PERELMAN red., Le Problème des lacunes en droit, Brussel, 1968, 197-246.

294 Een interessante vraag kan zijn in hoeverre dit 'Antwerpse' verbintenissenrecht de handelsrelaties met andere -meer Romeinsrechtelijk geörienteerde- steden mogelijk bemoeilijkt heeft. Hier staat dan weer tegenover dat Antwerpen zich in belangrijke mate heeft aangepast aan wat in het zuiden (Genua) gebruikelijk was.

${ }^{295}$ Cfr. GOTZEN, “Oud-Antwerps burgerlijk procesrecht”, 291-315 en 424-468. 
Tabel 1.19 Het innovatieve karakter van deel $V$

\begin{tabular}{|l|l|c|c|c|}
\hline & Titel & $\begin{array}{c}\text { Aantal } \\
\text { artikels }\end{array}$ & $\begin{array}{c}\text { Aantal nieuwe } \\
\text { artikels }\end{array}$ & $\mathbf{\%}$ \\
\hline 5.1 & Van de rechtvoorderinge & 77 & 50 & 64.9 \\
\hline 5.2 & Van aenleggeren ende verweerderen & 4 & 3 & 75.0 \\
\hline 5.3 & Van de advocaten ende procureurs & 30 & 23 & 76.7 \\
\hline 5.4 & Van dagementen & 32 & 12 & 37.5 \\
\hline 5.5 & Van beschrijffrieven & 8 & 0 & 0.0 \\
\hline 5.6 & Van unijtscriffbrieven & 30 & 2 & 6.7 \\
\hline 5.7 & Van ammans brieven & 33 & 0 & 0.0 \\
\hline 5.8 & Van arresteringe ende aentastinge van persoonen om civile & 57 & 6 & 10.5 \\
& saecken & & & \\
\hline 5.9 & Van arresten van goeden ende vervolch der selver & 95 & 18 & 19.0 \\
\hline 5.10 & Van de maniere ende forme van procederen & 79 & 72 & 91.1 \\
\hline 5.11 & Van den thoon & 60 & 60 & 100.0 \\
\hline 5.12 & Vant veriaeren ende affgaen oft desisteren van den processe & 6 & 1 & 16.7 \\
\hline 5.13 & Van vonnissen, ende taxatie oft begroottinge van de costen & 19 & 10 & 52.6 \\
\hline 5.14 & Van provocatien oft beroepen & 20 & 5 & 25.0 \\
\hline 5.15 & Van appellation ende leeringe van vonnissen & 22 & 8 & 36.4 \\
\hline 5.16 & Van reformation & 17 & 3 & 17.6 \\
\hline 5.17 & Van executie oft pandinge & 102 & 37 & 36.3 \\
\hline
\end{tabular}

Slechts een viertal titels $(5.5,5.6,5.7,5.8)$ werden nauwelijks of niet gewijzigd. De hiermee overeenstemmende titels uit de Consuetudines impressae (respectievelijk de titels XXVI, XXX, XXXI, XXXII) werden grotendeels behouden. Bij zeven andere titels kan er wel sprake zijn van een noemenswaardig ingrijpen, doch de impact ervan blijft beperkt. Het gaat hier om de titels 5.4, 5.9, 5.12, 5.14, 5.15, 5.16 en 5.17. Tabel 1.20a geeft een overzicht van de rechtsbronnen die de innovaties voorafgaan.

Tabel 1.20a Aandeel van ieder type rechtsbron per titel (deel V)

\begin{tabular}{|c|c|c|c|c|c|c|c|c|}
\hline Tot & $\mathbf{5}$ & $\mathbf{. 4}$ & $\mathbf{. 9}$ & $\mathbf{. 1 2}$ & $\mathbf{. 1 4}$ & $\mathbf{. 1 5}$ & $\mathbf{. 1 6}$ & $\mathbf{. 1 7}$ \\
\hline 37 & WG & 8 & - & - & 5 & 6 & 3 & 15 \\
\hline 23 & S & 2 & 11 & 1 & - & - & - & 9 \\
\hline 17 & Comp & - & 5 & - & 1 & - & - & 11 \\
\hline 13 & Usus & 1 & - & - & - & - & - & 12 \\
\hline 11 & $\mathbf{3}$ & - & 6 & 1 & - & - & - & 4 \\
\hline 7 & RA & 1 & 1 & - & - & - & - & 5 \\
\hline 4 & Ciciv & - & - & - & - & 2 & - & 2 \\
\hline 3 & OAR & - & - & - & - & - & - & 3 \\
\hline 3 & RS & - & - & - & - & - & - & 3 \\
\hline 1 & RL & - & - & - & - & - & - & 1 \\
\hline
\end{tabular}

Meteen blijkt dat er voor de meeste titels weinig verrassende vaststellingen zijn waar te nemen. Enkel in het geval van titel 5.9 ( $V$ an arresten van goeden ende vervolch der selver) kan er op de uitzonderlijke positie van de specifieke reden als rechtsbron gewezen worden. Wat de overige titels betreft ligt de nadruk overduidelijk op de legislatieve rechtsbronnen. Uiteraard is dit het gevolg van de integratie van de reeds vermelde, stedelijke ordonnantie op't stuck van procederen die in 1582 uitgegeven werd achter de gedructe costuymen. Zij zal nu in het geheel van de Consuetudines compilatae worden geïntegreerd. 
Wat de vijftiende en de zestiende titel betreft liggen de zaken anders. Zij werden geheel op basis van een andere ordonnantie geïnnoveerd, met name de laatste ordonnantie van de Raad. De Memorieboeken doelen hier op de Ordinancie, Styl ende Maniere van procederen vanden souverainen raede van Brabandt ende landen van Overmaeze van 1604, beter bekend als de Albertine Ordonnantie en recentelijk uitgegeven en van een inleiding voorzien door Broers en Jacobs. ${ }^{296}$ Ook zij regelt procesrechtelijke aangelegenheden, met name die van de Raad van Brabant. Dit verklaart meteen de enorme hoeveelheid legislatieve regels binnen deze titels. Dat deze ordonnantie hier als basis wordt gehanteerd, ligt voor de hand gezien het onderwerp van beide titels: appelatien en reformatien. 297

Tabel 1.20b Aandeel van ieder type rechtsbron per titel (deel V)

\begin{tabular}{|c|c|c|c|c|c|c|c|}
\hline Tot & $\mathbf{5}$ & $\mathbf{. 1}$ & $\mathbf{. 2}$ & $\mathbf{. 3}$ & $\mathbf{. 1 0}$ & $\mathbf{. 1 1}$ & $\mathbf{. 1 3}$ \\
\hline 142 & WG & 33 & 1 & 22 & 51 & 30 & 5 \\
\hline 37 & RL & - & - & - & 16 & 21 & - \\
\hline 35 & S & 5 & 1 & 5 & 10 & 9 & - \\
\hline 32 & Comp & 12 & 1 & 2 & 6 & 10 & - \\
\hline 20 & Usus & 6 & - & - & 2 & 7 & 4 \\
\hline 15 & Ciciv & - & 1 & - & 2 & 10 & 2 \\
\hline 8 & RA & - & - & 1 & 3 & - & 3 \\
\hline 4 & $\mathbf{3}$ & 1 & - & - & 3 & - & - \\
\hline 2 & eGR & 1 & - & - & 1 & - & - \\
\hline 2 & RS & 2 & - & - & - & - & - \\
\hline 2 & Cican & - & - & - & - & 2 & - \\
\hline 1 & OAR & - & - & - & - & - & - \\
\hline
\end{tabular}

Resten nog die titels welke meer dan verdubbeld zijn ten opzichte van de vorige redactiepoging $(5.1,5.2,5.3,5.10,5.11,5.13)$. Opnieuw is het de wetgeving die het voortouw neemt, en opnieuw gaat het om de stedelijke procesrechtelijke ordonnantie van 1582. Maar liefst 103 van de 218 nieuwe artikels vinden binnen deze titels hun oorsprong in laatstgenoemde ordonnantie. ${ }^{298}$ Men verwijst echter zeer zelden naar deze ordonnantie alleen. De voorganger van 1564 vergezelt die van 1582 in het merendeel van de gevallen. De integratie ervan maakt dat het wettenrecht een ongekend aandeel vertegenwoordigt, zoals blijkt uit tabel 1.21.299 Toch wil ik er hier nogmaals op wijzen dat het innovatieve karakter ervan gerelativeerd moet worden.

296 De concept-procesordonnantie van 1662 van de Raad van Brabant in Den Haag en de Albertine ordonnantie van 1604 voor de Raad van Brabant te Brussel, E.-J. M. F. C. B. BROERS en B. C. M. JACOBS ed. (Werken der Stichting tot Uitgaaf der Bronnen van het Oud-Vaderlandse Recht. XXIX), Amsterdam, 2003.

297 Tot de overige, minder invloedrijke, ordonnanties binnen dit deel behoren het nieuw ontwerp van de ordonnantie van 1543, de reeds vermelde ordonnantie van 24 oktober 1592 en de ordonnantie van 1 oktober 1601.

${ }^{298}$ Over het ganse deel zijn de stijlordonnanties goed voor 131 nieuwe artikels.

299 Aangezien het voor twee artikels onduidelijk is gebleven om welke primaire rechtsbronnen het exact gaat, bestaat er voor elke categorie binnen deze tabel een theoretische foutmarge van twee artikels of -in het geval van een totaal aantal nieuwe artikels van 310- 0.7 procent. 
Het gaat immers om de integratie van procedures welke men gewoon was te doen. Omdat de Usus als 'feitelijk iets' reeds verworden was tot geredigeerd gewoonte'recht' en vervolgens ook tot wettenrecht aangezien het door de stedelijke overheid bekrachtigd werd, heb ik het hier als stedelijk wettenrecht verrekend.

Tabel 1.21 Percentage nieuwe artikels waarvoor elk type rechtsbron verantwoordelijk is (deel V)

\begin{tabular}{|c|c|c|c|c|c|c|c|c|c|c|}
\hline WG & S & Comp & RL & Usus & Ciciv & 3 & RA & RS & OAR & eGR \\
\hline 57.7 & 18.7 & 15.8 & 12.3 & 10.7 & 6.1 & 4.8 & 4.8 & 1.6 & 1.3 & 0.7 \\
\hline
\end{tabular}

Niet elk nieuw artikel is echter afkomstig van voornoemde ordonnanties. Zo vormen bepaalde paragrafen op zich vaak een uitzondering. Ik denk hierbij aan de zesde paragraaf van titel 5.10 over Antwoorde bij kennen ende ontkennen, alwaar een belangrijke rol is weggelegd voor de rechtsleer. Het betreft de auteurs Filips Wielant, Charles Dumoulin, Jacopo Menocchio, Giovanni Pietro Sordi da Casale en Louis le Caron. In de derde paragraaf van diezelfde tiende titel, over Uuytstel om t'antwoorden, ende waerschap ofte guarand, ligt de nadruk dan weer op de Institutiones forenses (1535) van Jean Imbert en de annotationes (1603) van Louis le Caron bij de Somme rural van Jean Bouteiller. Filips Wielant van zijn kant is ook niet weg te denken uit de elfde titel en dan in het bijzonder uit de paragrafen 3 (Maniere van getuijgen te overhooren), 4 (Schriftelijcken thoon ende bekentenisse van partijen) en 5 (Thoon bij sicht ende claerheijt vant stuck, oft eedt van partije). In totaal werd zijn Practycke civile (1508-1519) er voor maar liefst vijftien nieuwe artikels als rechtsbron geraadpleegd. 300

Hoewel er voor deze rechtsleer enigszins een unificerende taak zou kunnen zijn weggelegd, blijft ook het burgerlijk procesrecht een eerder regiogebonden aangelegenheid. 301 In die zin is het burgerlijk procesrecht sterk verwant met het publiekrecht van deel I. Iedere plaats kende immers zijn eigen ontwikkeling, zijn eigen 'stijl'. Ook deze civiele procedure, styl of maniere van procederen, stoelt namelijk op een eigen, spontaan gegroeide, traditie. In dit opzicht wil ik verwijzen naar Martyn: "De stijl, de 'gerechtelijke costume' van een, zowel hoge als lage, rechtbank, is meestal spontaan geëvolueerd en wordt op een bepaald moment vastgesteld en al dan niet gehomologeerd. Alle rechtbanken bebben hun eigen stijl, waarvan het ontstaan vaak even onbekend in het verre verleden ligt, als de geboorte van de instelling zelf. De procedureregels van hogere, regionale, provinciale of centrale, instellingen daarentegen zijn meestal, zij het vaak slechts gedeeltelijk, effectief ingevoerd op het moment dat de instelling zelf bij ordonnantie, 'reglement' of 'instructie', is gecreëerd.' 302 Dit

300 Cfr. DEKKERS, Bibliotheca Belgica Juridica, 191. Het betreft hier de Nederlandstalige uitgave, aangezien er altijd in het Nederlands naar de titels verwezen wordt en er steeds sprake is van sua praxis germanica. Later zal blijken, wanneer ik het over Wielants Practycke criminele (ca. 1510) zal hebben, dat men zich bediende van een Franstalig manuscript. Met betrekking tot deze strafrechtelijke 'instructie' wordt immers altijd naar Franse titels verwezen en men spreekt nu van sua praxis gallica. Het betreft hier de Franse vertaling welke in 1555 door Joost de Damhouder werd verzorgd. (Cfr. DEKKERS, Bibliotheca Belgica Juridica, 192.)

301 Gilissen wees er reeds op hoezeer het procesrecht een zaak van eigen gewoontes was: "Ainsi, la procédure a été presqu'exclusivement coutumière dans l'Europe médiévale". (GILISSEN, "Rédaction des coutumes. Essai de synthèse", 58.)

302 MARTYN, Eeuwig Edict, 160. Cfr. MONBALLYU, Zes eeuwen strafrecht, 350. 
verklaart vermoedelijk de afwezigheid van quasi alle andere types van rechtsbronnen, zoals vreemde costumiere redacties of het Romeinse recht. Desalniettemin herbergt deze stijl, ten gevolge van de romano-canonieke revolutie, welke plaatsvond in de dertiende eeuw, ongetwijfeld heel wat Romeinsrechtelijke invloeden. Maar omwille van de lange tijdspanne die erop volgde, is men deze elementen als Usus gaan beschouwen.

\section{Deel VT}

Het materiële strafrecht van deel VI zit vervat in drie verschillende titels. Niet minder dan zeventig procent van de inhoud is nieuw ten opzichte van wat er hieromtrent in de Consuetudines impressae terug te vinden is (titels XIII, XVI, XVII, XX). Toch moet ook dit uitgesproken innovatief karakter gerelativeerd worden. Ten eerste is het in absolute termen en in het licht van het geheel van de Consuetudines compilatae helemaal niet uitzonderlijk. De 81 nieuwe artikels waar het immers om draait, vertegenwoordigen slechts vijf procent van alle nieuwe artikels binnen de ganse vierde redactiepoging van Antwerpen. Ten tweede impliceert een percentage van zeventig procent niet noodzakelijk dat de Consuetudines impressae in vergelijking met de Consuetudines compilatae ondermaats waren uitgewerkt. Artikels kunnen namelijk vervangen worden. Desondanks omvatten de vier strafrechtelijke titels uit de Consuetudines impressae slechts 49 artikels, wat in vergelijking met de situatie welke ik in de eerste twee redactiepogingen heb aangetroffen, waar het strafrecht gelijkaardige gedaantes aanneemt, niet als omvangrijk omschreven kan worden. De vraag dringt zich dus op waarom dit strafrecht in tegenstelling tot de andere materies in de Consuetudines impressae niet sterker werd uitgewerkt. Heeft dit mogelijk iets te maken met de vaak veronderstelde, officieuze doorwerking van de officieel afgeschafte Criminele Ordonnantiën van 1570?303 Of, wachtte men een nieuw vorstelijk initiatief tot 'codificatie' af? Het is namelijk bekend dat vanaf de zestiende eeuw de vorst van het strafrecht meer en meer een landsheerlijke aangelegenheid tracht te maken. ${ }^{304}$

Wat er ook van zij, op strafrechtelijk vlak is er met de Consuetudines compilatae heel wat werk verricht. Tabel 1.22 laat zien dat dit niet meteen op het vlak van lijfstraffen is gebeurd, maar wel met betrekking tot de keuren ende breucken. Deze titel zag zijn omvang groeien van tien tot 55 artikels. Ook de tweede titel aangaande bannissementen bestaat voor bijna drie kwart procent uit nieuw toegevoegde artikels.

Tabel 1.22 Het innovatieve karakter van deel VI

\begin{tabular}{|l|l|c|c|c|}
\hline & Titel & $\begin{array}{c}\text { Aantal } \\
\text { artikels }\end{array}$ & $\begin{array}{c}\text { Aantal } \\
\text { nieuwe } \\
\text { artikels }\end{array}$ & $\%$ \\
\hline 6.1 & $\begin{array}{l}\text { Van keuren ende breucken, ende van misbruijcken daertoe } \\
\text { de keuren ende breucken staen }\end{array}$ & 55 & 48 & 87.3 \\
\hline 6.2 & Van bannissementen ende saecken daertoe den ban oft & 35 & 25 & 71.4 \\
\hline
\end{tabular}

303 Cfr. O. MOORMAN VAN KAPPEN, "De rechtskracht van de ordonnantie op de stijl van procederen in criminele zaken van 9 juli 1570 in de Oostenrijkse Nederlanden", Tijdschrift voor Rechtsgeschiedenis, 58 (1990), 327-343.

${ }^{304}$ Cfr. GILISSEN, Historische inleiding, 307. MONBALLYU, Zes eeuwen strafrecht, 37-38. 


\begin{tabular}{|l|l|c|c|c|}
\hline & arbitraele straffe staet & & & \\
\hline 6.3 & Van lijfstraffen ende tot wat misdaeden lijfstraffe staet & 28 & 9 & 32.1 \\
\hline
\end{tabular}

Wanneer ik naar de rechtsbronnen van deze nieuwe artikels kijk, word ik onmiddellijk geconfronteerd met de talrijke artikels welke uit één van de vroegere redactiepogingen werden heropgevist. ${ }^{305}$ Onderstaande tabel 1.23 laat zien dat maar liefst 56 procent van alle nieuw toegevoegde artikels reeds aanwezig was in één van de oudere, costumiere redacties van de stad.

Tabel 1.23 Percentage nieuwe artikels waarvoor elk type rechtsbron verantwoordelijk is (deel VI)

\begin{tabular}{|c|c|c|c|c|c|c|c|c|c|c|}
\hline OAR & WG & Ciciv & Comp & RL & eGR & 3 & Usus & S & R & RS \\
\hline 56.1 & 22.0 & 14.6 & 12.2 & 11.0 & 9.8 & 9.3 & 8.5 & 6.1 & 2.4 & 0.0 \\
\hline
\end{tabular}

In het merendeel van de gevallen gaat het om de Consuetudines antiquissimae (1547). Dit is enigszins verbazingwekkend gezien de jongere leeftijd van de Consuetudines antiquae (1570). Toch wordt er naar deze redactie -en dit geldt voor de ganse Consuetudines compilatae- slechts in uitzonderlijke gevallen verwezen. Ten aanzien van het strafrecht lijkt me dit een gevolg te zijn van de bijna totale afwezigheid van strafrechtelijk materiaal in de Consuetudines antiquae. Dit ontbreken is op zijn beurt hoogstwaarschijnlijk te verklaren aan de hand van de aangekondigde codificatie van het strafrecht (Criminele Ordonnantiën) door Filips II in 1570. Wat de ondervertegenwoordiging van de Consuetudines antiquae binnen het geheel van de Consuetudines compilatae betreft, blijft voor mij voorlopig een mysterie. Wanneer ik nu titel per titel bekijk, dan blijkt de verdeling van de oude, Antwerpse redacties er één van gelijkmatige aard te zijn. Het aandeel van de Consuetudines antiquissimae als rechtsbron schommelt van 44 procent voor titel 6.2 over 60.4 procent voor titel 6.1 tot 66.7 procent voor titel 6.3. Tabel 1.24 geeft dit in absolute cijfers weer. ${ }^{306}$

Tabel 1.24 Aandeel van ieder type rechtsbron per titel (deel VI)

\begin{tabular}{|c|c|c|c|c|}
\hline Tot & $\mathbf{6}$ & $\mathbf{. 1}$ & $\mathbf{. 2}$ & $\mathbf{3}$ \\
\hline 46 & OAR & 29 & 11 & 6 \\
\hline 18 & WG & 5 & 11 & 2 \\
\hline 12 & Ciciv & 3 & 6 & 3 \\
\hline 10 & Comp & 5 & 5 & - \\
\hline 9 & RL & 8 & - & 2 \\
\hline 8 & eGR & 5 & 1 & 2 \\
\hline 8 & $\mathbf{3}$ & 2 & 4 & - \\
\hline 7 & Usus & 4 & 3 & - \\
\hline 5 & S & 4 & 1 & \\
\hline 2 & R & 1 & 1 & \\
\hline
\end{tabular}

305 Omtrent de bronnen van het strafrecht, zie ook: MONBALLYU, Zes eeunen strafrecht, 37-43. 306 Aangezien het voor geen enkel artikel onduidelijk is gebleven om welke primaire rechtsbronnen het exact gaat, bestaat er voor elke categorie binnen deze tabel een theoretische foutmarge van nul artikels of -in het geval van een totaal aantal nieuwe artikels van 82- 0.0 procent. 
Naast de Consuetudines antiquissimae speelt ook de Oude specificatie geintituleerd keuren ende breucken van Antwerpen een belangrijke rol, zowel als primaire als secundaire rechtsbron, en dit voornamelijk binnen de grenzen van de eerste titel. Om welke tekst het hier exact gaat, heb ik echter niet weten te achterhalen. ${ }^{307}$

Hoe gelijkmatig het aandeel van de Consuetudines antiquissimae ook over de drie verschillende titels verdeeld moge zijn, enkel in paragraaf 3 van titel 6.1 over Breucken van lasteringe ende dreijgementen zijn geen verwijzingen naar de Consuetudines antiquissimae te bespeuren. Hier is het de rechtsleer die de toon aangeeft, waarbij opnieuw een hoofdrol is weggelegd voor de Franse jurist Louis le Caron. Binnen zijn oeuvre trekken de Memorables observations du droit françois (1601) en zijn commentaren beide de Grand Coutumier (1598) en Somme Rural (1603) van respectievelijk Jacques d'Ableiges en Jean Bouteiller de meeste aandacht. Van een echt trefpunt van strafrechtspecialisten kan ik hier niet spreken. Zoals zodadelijk zal blijken, lijkt het strafprocesrecht hen meer te interesseren dan het materiële recht in criminele zaken.

Alle overige rechtsbronnen zitten in de spreekwoordelijke buik van het peloton. Een twaalftal artikels vindt zijn oorsprong in het Romeinse recht en voor achttien artikels wordt er verwezen naar legislatieve bronnen. ${ }^{308}$ Hierbij is het de vorstelijke wetgeving

\footnotetext{
${ }^{307}$ Dat het hier niet gaat om het Keurboeck van Antwerpen, blijkt uit artikel 6.1.1: "Est etiam primus tam in impressis quam in antiquis 20 in antiquissimis hoc tit 161 int kuerboeck 48 in sekere oude specificatie geintituleert keuren en [de] breucken van Ant [werpen] geconfirmeert byde blyde incompsten en [de] byden landtcharter articul[us] 35 in nostro exemplari".

${ }^{308}$ Meermaals laat Monballyu in zijn boek omtrent de geschiedenis van het strafrecht in België zien hoe het Romeinse recht het strafrecht beïnvloedde: MONBALLYU, Zes eeuwen strafrecht. (Cfr. VAN CAENEGEM, Droit romain; HERMESDORF, Römisches Recht.) Ook uit het feit dat in de Criminele Ordonnantiën van 1570 een subsidiaire rol werd toegekend aan het Romeinse recht, blijkt dat de Romeinsrechtelijke invloed op strafrechtelijk vlak in de zestiende eeuw nooit veraf was. (Cfr. M. VAN DER VRUGT, De criminele ordonnantiën van 1570. Enkele beschouwingen over de eerste strafrechtscodificatie in de Nederlanden, Zutphen, 1978, 16.)

Wat de Franse rechtshistortici betreft, wil ik wijzen op een recentelijk artikel van Gérard Guyon, waarin de auteur de annotaties bij de costume van Bordeaux onderzocht in functie van de romanisatie van het strafrecht. (GUYON, "Annotations de la coutume de Bordeaux", 300-328.) Een interessant punt in dezen is dat Guyon ten aanzien van de Romeinsrechtelijke invloed spreekt van een verzwaring van de straffen: "...la reference au droit romain sert dans la plupart des cas à aggraver la sanction”. (GUYON, “Annotations de la coutume de Bordeaux”, 310.) Dat het Romeinse strafrecht strenger was dan het middeleeuwse costumiere strafrecht, stond reeds bij Britz te lezen: "Er is niets barbaarser als Romeins strafrecht." J. BRITZ, Code de l'ancien droit Belgique, ou Histoire de la jurisprudence et de la législation, suivie de l'exposé du droit civil des provinces Belgiques, I, Brussel, 1847, 139.) En ook Monballyu wees er op dat tegen het einde van de middeleeuwen het strafrecht, onder vorstelijke invloed, steeds harder werd: "Naarmate zich in de Middeleeunven een sterker staatsgezag ontwikkelde, nam het aantal misdaden toe waarop de doodstraf stond. ... Deze afschrikkingsgedachte maakte het strafrecht harder in de late middeleeunen en de nieuwe tijd." (MONBALLYU, Zes eeuwen strafrecht, 144.) Welke rol hierin weggelegd was voor het Romeinse recht is bij Monballyu niet aan de orde. Voor een gedetailleerde bespreking van alle straffen is er in het boek immers geen ruimte. De auteur beperkt zich tot een uitvoerige bespreking van
} 
die de kroon spant. ${ }^{309}$ Zo werd er in de eerste plaats verwezen naar de keyserlijcke statuten ende rechten en aan het einde van titel 6.2 tevens naar de Constitutio Criminalis Carolina (1532). ${ }^{310}$ In dit eerste geval doelt met op Keyserlicke statuten Ordonantien, Costumen, ende Ghewoonten, ende bysonder elcker Stadt techten, principalijck den keyserlijcken landen aengaende (1519), samengebracht door Thomas Murner (1475-1537). De Carolina van zijn kant is de welbekende ordonnantie van Karel V uit 1532 inhoudende het strafprocesrecht en het materieel strafrecht. ${ }^{311}$ Hoewel Britz ervan overtuigd is dat deze ordonnantie in onze streken nooit van kracht is geweest, wegens het bestaan van een op juridisch vlak zelfstandige Bourgondische Kreits sinds de Transactie van Augsburg in 1548, blijkt uit de Memorieboeken evenwel dat de ordonnantie desondanks invloed heeft uitgeoefend op het Antwerpse gewoonterecht aan het begin van de zeventiende eeuw. ${ }^{312}$ Meermaals trad de Constitutio op als primaire rechtsbron binnen titel 6.2.313

Vermeldenswaardig is ook het zo goed als geheel ontbreken van elke verwijzing naar de Criminele Ordonnantiën van Filips II. Dit trio van ordonnanties werd in 1570 in het leven geroepen ter bestrijding van de verscheidenheid aan criminele rechtssystemen in de Nederlanden. De nadruk lag evenwel op het strafprocesrecht en de documenten waren voornamelijk gebaseerd op Filip Wielants Practycke criminele (ca. 1510) en opnieuw de voornoemde Constitutio Criminalis Carolina van keizer Karel V uit 1532.314

de doodstraf, waarvan hij het hoogtepunt in de zes- en zeventiende eeuw plaatst. Nadien kondigt zich een tendens waarbij deze steeds minder wordt toegepast.

${ }^{309}$ Dit ligt in de lijn van wat onder meer bij Gilissen te lezen staat. Het strafrecht, dat in wezen zeer costumier van oorsprong was, verwordt vanaf de vijftiende en zestiende eeuw meer en meer tot wetgeving ten gevolge van de fixatie van de strafrechtelijke regels door de landsheer. Een proces dat in de zestiende eeuw uitmondt in de Constitutio Criminalis Carolina (1532) van Karel V en de Criminele Ordonnantiën (1570) van Filips II. (GILISSEN, "Rédaction des coutumes. Essai de synthèse", 60.)

310 Tot twee maal toe wordt er tevens naar de zogenaamde statutum ordinum hollandia $[e]$ op de policye gemaeckt en [de] gedruct inden hage a [nno] 1597 verwezen.

311 Cfr. P. LANDAU, en F.-C. SCHROEDER, Strafrecht, Strafprozess und Rezeption: Grundlagen, Entwicklung und Wirkung der Constitutio Criminalis Carolina (Juristische Abhandlungen. XIX), Frankfurt am Main, 1984.

312 BRITZ, Code de l'ancien droit Belgique, I, 138.

313 Andere bronnen van wetgevende aard welke binnen dit deel aan bod kwamen, zijn het Landcharter van Brabant van 1292, een privilege van hertog Jan I uit 1335, een stedelijke ordonnantie betreffende de Antwerpse peyskamer van 12 december 1509, het plakkaat van Karel V daterend van 7 oktober 1531 en de Spaanse Siete Partidas (1263) van Alfonso de Wijze. 314 Artikel 62 heeft het over een Receuil Generael dat in de toekomst tot stand gebracht moet worden en dat het materieel strafrecht moet verzamelen: "Ende hoewel dat die penale ordinancien placcaten edicten ende geboden cleer genoech zyn ende dat doende tdebuoir om die te visiteren zeer licht ay de zelve te verstaen: des nyetmin om deze materie vande kennisse ingemente vonnisse van criminele zaken te voirderen ende op dat eenyegelyck die penen gestelt by de voirseyde ordinancien hier voirmaels gepubliceert des te beter mach schouwen ende eviteren Onse meyninge ende intentie is ende bebben eenigen van onze raden geordineert een generael recueil te maken vande ghene die wy houden voir eeuwige wetten edicten ende gheboden als op tstuck vande Religie vagabonden straetschenders lantloopers monopoliers valsche muntslagers ende andere 
Deze strafrechtcodificatie werd in 1576 met de Pacificatie van Gent officieel afgeschaft. Dat er niet alleen in het straf(proces)rechtelijke deel van de Consuetudines compilatae, maar eveneens in de overige delen, zo goed als nooit expliciet verwezen werd naar de Criminele Ordonnantiën, is dan ook geen verrassing. In de Memorieboeken wordt slechts twee maal expliciet verwezen naar deze strafrechtcodificatie van Filips II. Een eerste keer betreft het de artikels 5.10 .2 en 5.10.3. ${ }^{315}$ Op basis van de Memorieboeken kan ik spreken van materiële receptie. Beide artikels sunt novi in hac revisione ex ordinatione criminali de anno 1570 art 54 nisi quod magistratui visum sit adiicere poenam in advocat [o]s et procuratores, si contraveniant quia ab iis principaliter dependit. De magistraat bevindt zich evenwel in een positie die hem de mogelijkheid geeft aanpassingen voor te stellen en door te voeren. Ook een andere keer opteert men ervoor een oude gewoonte aan te passen van het geleerde recht en de Criminele Ordonnantiën. Dit is zo met betrekking tot artikel 2.5.30, omtrent de vermomboorde die met een misdaad wordt belast: Est novus loco art 75 in impressis, cum quo accordat consuet[udo] Gandens[is] rubr. 22 art 13 sed cum juris dispositio in L clarum $C$ de author [itate] pr[a]estanda, et ordinatio criminalis anni 1570 art 61 contrarium disponant, idque ad maiorem securitatem et defentionem pupillorum et minorum pertineat, visum est veterem consuetudinem bac ex parte mutare et reducere ad jus commune. Ondanks hun formele afschaffing, werken de ordonnanties met andere woorden materieel wel degelijk door, het zij op een uiterst bescheiden manier. Deze vraag aangaande de mate waarin de bepalingen van 1570 na 1576 nog blijven doorwerken, al dan niet formeel en in welke regio's, heeft reeds heel wat stof doen opwaaien. Dienaangaande wil ik verwijzen naar het artikel van Moorman van Kappen omtrent de rechtskracht van de Criminele Ordonnantiën. ${ }^{316}$ Conform het besluit van Moorman van Kappen kan en mag -ook op basis van wat ik in de Memorieboeken heb kunnen lezen- niet langer volhard worden in de overtuiging dat de Criminele Ordonnantiën tot aan het einde van het oud-regime grotendeels wetskracht behouden zouden hebben, uitgezonderd in de regio Henegouwen. ${ }^{317}$ En inderdaad, men mag ook niet over het hoofd zien dat ondanks het grotendeels ontbreken van expliciete vermeldingen, de ordonnantiën mogelijk impliciet sterker hebben doorgewerkt dan de Memorieboeken op het eerste gezicht doen uitschijnen. Bijgevolg treed ik Moorman van Kappen bij en lijkt de vraag die hier van

diergelycke gestatueert voir eeunige edicten." (De crimineele ordonnantien van koning Philips van Spanje ten dienste van zijne Nederlanden nitgegeeven. B. VOORDA ed., Leiden, 1792, 31-32.)

315 5.10.2: D'aenspraecke moet innehouden claer verhael ende openinge van de gelegentheijt van de geheele saecke, ende totdijen den heijsch oft conclusie daertoe staende, met bijvueginge van clausule salutaire van recht ende justitie te doen, oft soo vele min oft meer aen te wijsen als men vuijtten bedinghde van de saecke, naer gelentheijt van dijen, soude vinden te behooren, oft andere dijergelijcke. (Coutumes de la ville d'Anvers dites compilatae, IV, 612.)

5.10.3: Ende oft d'advocaet oft procureur versuijmelijck waere geweest alsulcke clausule in de conclusie oft aenspraecke te stellen, soude t'elcke reijse verbeuren sesse guldenen tot behoeve van de busse, ende en soude desevenwel de conclusie oft aenspraecke in rechte niet ontfangen, maer terstond verworpen worden. (Coutumes de la ville d'Anvers dites compilatae, IV, 612.)

316 MOORMAN VAN KAPPEN, "De rechtskracht", 327-343.

317 MOORMAN VAN KAPPEN, "De rechtskracht”, 341-342. 
belang is eerder de materiële doorwerking van allerlei elementen uit de ordonnanties te betreffen dan de formele gelding en officiële naleving ervan. ${ }^{318}$

Tot slot wil ik nog kort stilstaan bij het externe gewoonterecht. Binnen deze categorie verschijnt namelijk voor het eerst het gewoonterecht van Utrecht, zoals het in 1550 werd geredigeerd en gehomologeerd. Ook in het zevende deel ten aanzien van het strafprocesrecht zal zij een niet te onderschatten rol spelen. Wat de overige rechtsbronnen betreft, blijft de invloed verwaarloosbaar. Ze zijn aanwezig, maar op een zwijgzame manier. Wanneer het om derden gaat, betreft het de magistraat van Antwerpen en verder lijkt het fenomeen van de 'heropgeviste artikels uit de Consuetudines antiquissimae' een historisch laag aandeel van de Usus tot gevolg te hebben.

\section{Deel VII}

Het strafprocesrecht is door de band genomen zelden zeer uitgebreid. ${ }^{319}$ Ook bij de Consuetudines compilatae is dit niet anders. Met een totaal van 182 artikels vormt dit rechtsgebied op één na het kleinste deel. Ook in de Consuetudines impressae was dit strafprocesrecht goed voor slechts 90 artikels (titels XIV, XV, XVIII, XIX, XXI, XXII, XXIII). De verhoudingen blijven dus gerespecteerd. Hierbij dient echter opgemerkt te worden dat in de Memorieboeken slechts 46 artikels als nieuw staan omschreven. Dit impliceert dat de 136 overige artikels van het zevende deel uit de Consuetudines compilatae teruggaan op slechts 90 strafprocesrechtelijke artikels uit de Consuetudines impressae. Dit houdt in dat een groot aantal van hen werd opgesplitst.

\footnotetext{
318 MOORMAN VAN KAPPEN, "De rechtskracht", 341-342. Tot slot wil ik hier nog twee opmerkingen bij maken. Ten eerste dat ook in het traktaat van Hendrik de Moy over de Consuetudines impressae zo goed als elke expliciete verwijzing naar de Criminele Ordonnantiën ontbreekt. Slechts één maal ben ik een verwijzing naar de ordonnantie tegengekomen. Het betrof artikel 8 in de titel XV omtrent de forme te procederen ter vierschaere ende vande betuygingen in criminele saecken. (SAA, Vierschaer, 21: DE MOY, fol. 96r.) De tweede opmerking betreft de vaststelling dat de commissieleden zich naast hun afkeer van de Criminele Ordonnantiën kenmerken door een sterke hang naar de (strafrechtelijke) wetgeving van keizer Karel V.

319 GILISSEN, "Rédaction des coutumes", 103-104. Cfr. MONBALLYU, Zes eeunen strafrecht. R. C. VAN CAENEGEM, Geschiedenis van het strafprocesrecht in Vlaanderen van de XIe tot de XIVe eeuw (Verhandelingen van de Koninklijke Academie voor Wetenschappen, Letteren en Schone Kunsten van België. Klasse der Letteren. 24), Brussel, 1956. C. DE KONINCK Geschiedenis van het strafprocesrecht in Vlaanderen en Brabant van de XIVe eeun tot de Criminele Ordonnantiën van 5 en 9 juli 1570, nitgevaardigd door Filips II, koning van Spanje, Ongepubliceerde licentiaatsverhandeling, Rijksuniversiteit Gent, 1981. F. VANHEMELRIJCK, De criminaliteit in de ammanie van Brussel van de Late Middeleeunen tot het einde van het Ancien Régime (1404-1789) (Verhandelingen van de Koninklijke Academie voor Wetenschappen, Letteren en Schone Kunsten van België. Klasse der Letteren. 97), Brussel, 1981. J. MONBALLYU, "Costumier strafprocesrecht in Vlaanderen voor en na de criminele ordonnantiën van 1570", Handelingen van de Koninklijke Commissie voor de uitgave der Oude Wetten en Verordeningen van België, 32 (1996), 115-230. J. MONBALLYU, "De hoofdlijnen van de criminele strafprocedure in het graafschap Vlaanderen (16de tot 18de eeuw)", C. H. VAN RHEE, F. STEVENS en E. PERSOONS red., Voortschrijdend procesrecht. Een historische verkenning, Leuven, 2001, 63-108.
} 
Tabel 1.25 Het innovatieve karakter van deel VII

\begin{tabular}{|l|l|c|c|c|}
\hline & Titel & $\begin{array}{c}\text { Aantal } \\
\text { artikels }\end{array}$ & $\begin{array}{c}\text { Aantal nieuwe } \\
\text { artikels }\end{array}$ & $\mathbf{\%}$ \\
\hline 7.1 & Van ondersoeck ende vervolch van gevluchte misdaedige & 17 & 11 & 64.7 \\
\hline 7.2 & $\begin{array}{l}\text { Van tvangen ende bewaeren der misdadige, ende } \\
\text { beschrijvinge van hunne goeden }\end{array}$ & 25 & 6 & 24.0 \\
\hline 7.3 & $\begin{array}{l}\text { Van gevangenen t'ondervraegen ende ter scherper } \\
\text { examinatien te brengen oft pijningen }\end{array}$ & 30 & 22 & 73.3 \\
\hline 7.4 & $\begin{array}{l}\text { Van betichtinge ende vervolch der gevangene ter hooger } \\
\text { vierschaeren }\end{array}$ & 43 & 4 & 9.3 \\
\hline 7.5 & Van purge oft suijveringe van misdaeden & 8 & 0 & 0.0 \\
\hline 7.6 & Van vrede & 27 & 0 & 0.0 \\
\hline 7.7 & Van oorvrede & 12 & 0 & 0.0 \\
\hline 7.8 & Van den soene & 20 & 3 & 15.0 \\
\hline
\end{tabular}

Ook ten aanzien van het innovatieve karakter van dit deel kan ik relatief kort zijn. Waar het materiële strafrecht nog sterk werd uitgebreid, breekt het strafprocesrecht op dat vlak geen noemenswaardige potten. Integendeel, het is het minst geïnnoveerde deel binnen het geheel van de Consuetudines compilatae. In totaal werd met name slechts een kwart van de aanwezige artikels nieuw ingevoerd, waarbij drie titels zelfs geheel ongewijzigd bleven (titel 7.5, 7.6 en 7.7). Drie andere werden slechts licht gewijzigd (titel 7.2, 7.4 en 7.8). Bijgevolg concentreert een kwart aan nieuwe artikels zich grotendeels in de twee resterende titels, namelijk 7.1 ( $V$ an ondersoeck ende vervolch van gevluchte misdaedige) en 7.3 (Van gevangenen t'ondervraegen ende ter scherper examinatien te brengen oft pijningen). Samen nemen ze 33 van de 46 nieuw toegevoegde artikels voor hun rekening.

Tabel 1.26 laat zien waar alle nieuwe geïntegreerde artikels hun aanwezigheid aan te danken hebben.

Tabel 1.26 Percentage nieuwe artikels waarvoor elk type rechtsbron verantwoordelijk is (deel VII)

\begin{tabular}{|c|c|c|c|c|c|c|c|c|c|c|}
\hline Usus & RL & Ciciv & WG & eGR & Comp & OAR & RA & 3 & S & RS \\
\hline 60.9 & 39.1 & 30.4 & 17.4 & 8.7 & 6.5 & 6.5 & 6.5 & 2.2 & 2.2 & 0.0 \\
\hline
\end{tabular}

Ook nu blijft het aantal verrassingen eerder beperkt. Traditionele rechtsbronnen als daar zijn het Corpus Iuris Civilis, de rechtsleer, de wetgeving en buitensteeds gewoonterecht spelen een even klassieke als vooraanstaande rol. Wat het meest in het oog springt, is de vaststelling dat bijna twee derde van de nieuw geïntroduceerde artikels teruggaat op de Usus. Nooit eerder haalde deze categorie zulk een hoge waarde. Een vaststelling die te verwachten is aangezien de criminele procesgang in onze streken tijdens het oud-regime geen uniforme, uitputtende, wettelijke regeling kende. Er bleef dus veel vertrouwen in de strafrechter en er bestond een enorm particularisme. Elke strafrechtbank had zo haar eigen, met de tijd mee evoluerende, 
styl crimineel.320 Dit verklaart het enorme aandeel van de Usus binnen deze rechtsmaterie. Tabel 1.27 geeft de spreiding van de rechtsbronnen weer per titel.321

Tabel 1.27 Aandeel van ieder type rechtsbron per titel (deel VII)

\begin{tabular}{|c|c|c|c|c|c|c|c|c|c|}
\hline Tot & $\mathbf{7}$ & $\mathbf{. 1}$ & $\mathbf{. 2}$ & $\mathbf{. 3}$ & $\mathbf{. 4}$ & $\mathbf{. 5}$ & $\mathbf{. 6}$ & $\mathbf{. 7}$ & $\mathbf{. 8}$ \\
\hline 28 & Usus & 4 & 5 & 17 & 2 & - & - & - & - \\
\hline 18 & RL & 8 & - & 10 & - & - & - & - & - \\
\hline 14 & Ciciv & 2 & 1 & 9 & 2 & - & - & - & - \\
\hline 8 & WG & - & - & 5 & 1 & - & - & - & 2 \\
\hline 5 & Cican & 5 & - & - & - & - & - & - & - \\
\hline 4 & eGR & - & - & 4 & - & - & - & - & - \\
\hline 3 & Comp & 2 & - & 1 & - & - & - & - & - \\
\hline 3 & OAR & - & 1 & - & 1 & - & - & - & 1 \\
\hline 3 & RA & - & 1 & 2 & - & - & - & - & - \\
\hline 1 & $\mathbf{3}$ & - & - & - & - & - & - & - & 1 \\
\hline 1 & S & - & - & 1 & - & - & - & - & - \\
\hline
\end{tabular}

$\mathrm{Nu}$ blijkt dat de impact van de Usus vooral gezocht moet worden in de titels 7.2 en 7.3, betreffende het arresteren en de tortuur. Met respectievelijk 83.3 en 77.3 procent is zij in beide titels veruit de belangrijkste leverancier van nieuw materiaal. Ook bij de andere titels neemt ze de meest voorname plaats is, zij het minder uitgesproken.

Ook kan ik niet om de invloed van het externe gewoonterecht heen. Ten aanzien van de eerste en de derde titel verschijnen de Costuymen van Utrecht (1550). Dit is enigszins verrassend omwille van twee redenen. Ten eerste is er de typisch eigen traditie van procesrecht die elke regio kent en ten tweede is er het feit dat het plots om een andere -binnen de Memorieboeken ongebruikelijke- compilatie van vreemd gewoonterecht gaat, dan welke ik gewoon ben tegen te komen op basis van de vorige delen. Zowel als primaire (titel 7.3) als secundaire (titels 7.1 en 7.3) rechtsbron is zij hier manifest aanwezig. Ook in het zesde deel betreffende het materiële strafrecht heb ik deze redactie al ontmoet. Wat het Utrechtse straf(proces)recht zo aantrekkelijk maakt voor de Antwerpse commissieleden blijft voorlopig een raadsel.

Anderzijds bestond eveneens de theoretische mogelijkheid dat men zou terugvallen op legislatieve inspanningen als daar onder andere zijn de Criminele Ordonnantie op de Stijl van Filips II uit 1570. Opnieuw stellen de redacteurs in dezen teleur. Ook meer algemeen gaat slechts één vijfde van het totaal aantal nieuwe artikels terug op wetgeving als formele bron van recht. Behalve het feit dat het voornamelijk om ordonnanties afkomstig van de centrale overheid gaat, is er verder binnen dit aandeel geen trend te ontwaren. Legislatieve bronnen die van invloed zijn geweest, zijn de stedelijke ordonnantie van de peyskamer daterend van 12 november 1509, de Albertine Ordonnantie van de Raad van Brabant (1604) en verder ook de Blijde Inkomsten van

320 Cfr. MONBALLYU, Zes eeuwen strafrecht, 349-350.

321 Aangezien het voor geen enkel artikel onduidelijk is gebleven om welke primaire rechtsbronnen het exact gaat, bestaat er voor elke categorie binnen deze tabel een theoretische foutmarge van nul artikels of -in het geval van een totaal aantal nieuwe artikels van 82- nul procent. 
keizer Karel V en koning Filips II. ${ }^{322}$ Als secundaire wetgevende bronnen vermeld ik het Privilegie van hertog Jan II van Brabant uit 1306.323 Ook de Keyserlijke rechten ende statuten (1519) verzameld door Thomas Murner spelen opnieuw een rol. Het ontbreken van referenties naar de ordonnantie op de styl ende maniere van procederen achter de gedruckte costuymen (1582) kan verklaard worden doordat deze zich beperkte tot het burgerlijk procesrecht.

Wat naast de gewoonte wel een noemenswaardige rol heeft gespeeld, is het geleerde recht lato sensu. In totaal zijn het Romeinse recht en haar traditionele metgezel, de rechtsleer, elk goed voor een klein derde van de nieuw toegevoegde artikels. Beiden kennen hun plaats hoofdzakelijk in de derde titel, waar het gaat om het ondervragen van gevangenen ende ter scherper examinatien te brengen oft pijningen. Hoewel bij Monballyu te lezen staat dat onder invloed van het geleerde recht de voorwaarden om tot tortuur over te gaan overal gelijkgeschakeld gaan worden, gaat het hier -bij deze 'geleerde' artikels- niet om diezelfde voorwaarden. ${ }^{324}$

Wat de rechtsleer betreft ligt wederom de nadruk op Filips Wielant en zijn Practycke criminele (ca. 1510). Zowel op primair als secundair vlak is het procesrechtelijk werk niet te verwaarlozen. Ook andere processualisten komen meermaals aan bod. Ik denk aan Prospero Farinacci (Praxis et theorica criminalis, 1581-1614) en Egidio Bossi (Tractatus varii qui omnem fere criminalem materiam excellenti doctrina complectuntur et ..., s.d.). Ten aanzien van de eerste titel gaat de aandacht vooral naar strafrechtspecialist Giulio Claro. Zijn procesrechtelijk oeuvre staat zowel primair als secundair garant voor meerdere artikels. Daarenboven spelen ook Jacopo Menocchio (De arbitriis iudicum quaestionibus et causis, 1569) en Pierre Grégoire (Syntagma iuris universi, 1582) een vooraanstaande rol binnen deze titel. Andreo Fachineo is alleen als secundaire bron present.

322 Blyde Incompste van Keyser Carel den V. 24 Januarii 1514, 14 januari 1515 (n.s.), A. ANSELMO ed., Codex Belgicus seu Ius edictale a principibus Belgarum sancitum, Antwerpen, 1649 (anast. herdruk Brussel, 1998), IV, 405-421.

Die eerste additien des Princen van Spaingnien, Hertoghe van Bourgoingnien, tot sijnder Blijder Incompste. 12. April 1515. tot Gendt, 12 april 1515, A. ANSELMO ed., Codex Belgicus seu Ius edictale a principibus Belgarum sancitum, Antwerpen, 1649 (anast. herdruk Brussel, 1998), I, 205-207.

Die tweede additie vander Blijder Incompste des Princen van Spaengnien. 26 april 1515 tot Brugghe. 26 april 1515, A. ANSELMO ed., Codex Belgicus seu Ius edictale a principibus Belgarum sancitum, Antwerpen, 1649 (anast. herdruk Brussel, 1998), I, 207-210.

Die Blijde Incomste, des Hertochdomme van Brabandt, in voortijden by haren Landtsheeren verleent, ende van Keyser Carolus den V. gheconfirmeert, ende by Philippus sijne Sone Coninck van Spaingnien den II. Solemnelijck ghesworen. Anno 1549. 5. Iulii tot Leuven, 5 juli 1549, A. ANSELMO ed., Codex Belgicus seu Ius edictale a principibus Belgarum sancitum, Antwerpen, 1649 (anast. herdruk Brussel, 1998), I, 192-205.

323 Privilegie van Hertoch Jan den II. Van dien naeme, ghegheven aen die van Antwerpen, Anno 1306. op S. Nicolaes dach, 6 december 1306,, A. ANSELMO ed., Codex Belgicus seu Ius edictale a principibus Belgarum sancitum, Antwerpen, 1649 (anast. herdruk Brussel, 1998), IV, 139-140.

324 MONBALLYU, Zes eeuwen strafrecht, 360. 


\section{PARAGRAAF 3}

DE GEVOLGEN VAN HET REDACTIE- EN COMPILATIEPROCES VOOR HET

ANTWERPSE KARAKTER VAN HET ANTWERPSE GEWOONTERECHT

Jacques Van Uffel verweet in 1610 de samenstellers van de Consuetudines compilatae 'novateurs' te zijn die zich niet uitsluitend beperkten tot het redigeren van oude costumen. Ook de commissie van 1592 zou oude costumiere regels geschonden hebben via het invoeren van nieuwe elementen vreemd aan de Antwerpse dagdagelijkse gebruiken. Dat dit bovendien naar eigen goeddunken en fantasie of naar de opinie van de doctores gebeurde, zat Van Uffel dwars. Voor hem stond immers de onmogelijkheid van zowel wereldlijke als rechtsgeleerde autoriteiten om oude gangbare gewoonten te wijzigen buiten discussie. Bovendien hadden de compilatores zijns inziens onvoldoende gebruik gemaakt van niet alleen vroegere redactiepogingen zoals daar waren de Consuetudines antiquae en de Consuetudines impressae, maar ook van de vruchtbare voedingsbodem van de talloze turbenboeken. In wezen hekelt Van Uffel de discrepantie die ontstaan was tussen le pays réel en le pays légal en waarvan de Consuetudines compilatae zijns inziens blijk gaven.

Inderdaad, uit de voorgaande paragraaf is duidelijk gebleken dat tal van vreemde elementen hun invloed op het redactieproces hebben weten uit te oefenen. Naast typisch Antwerpse rechtsbronnen, denk ik eveneens aan het Romeins recht, de vorstelijke wetgeving, de rechtsleer, 'buitensteeds' gewoonterecht, etcetera. Bovendien is hun invloed aanzienlijk gebleken. Iets wat niet gezegd kan worden van de Antwerpse rechtsbronnen zoals de eigen rechtspraak, de eerder ondernomen redactiepogingen en nog oudere compilaties van lokaal recht, ... Hoewel deze bronnencategorieën, welke Jacques Van Uffel sterk favoriseerde, wel degelijk aan bod zijn gekomen, manifesteren zij zich beduidend minder nadrukkelijk als juridische basis.

Aanvankelijk lijkt de kritiek van Jacques Van Uffel dan ook terecht, maar definitief uitsluitsel kan men hieromtrent pas bekomen met een antwoord op een meer substantiële vraag, namelijk die naar de werkelijke impact van deze bronnen. Het is namelijk zo dat niet altijd een werkelijke of materiële receptie in substantia plaatsvindt van bijvoorbeeld vreemd recht. Vaak beperkt men zich er immers toe louter de uitdrukkingsvormen over te nemen ter formulering van de eigen costumiere regels. In dat geval neigt het verhaal meer naar acculturatie dan receptie en zou men, nonconform Van Uffel, niet van een schending van het Antwerpse gewoonterecht kunnen spreken. Op die manier is de vraag naar de reële receptie van belang voor de geldigheid van de kritiek van Van Uffel. Voor zover deze vraag onbeantwoord blijft, kan ik de cijfers uit paragraaf 2 van dit hoofdstuk alleen maar interpreteren als 'potentiële' beïnvloeding. Paragraaf 3 van zijn kant graaft dieper. Ik ga er op zoek naar de reële impact van de verschillende rechtsbronnen op de Consuetudines compilatae.

In voorgaande paragraaf stonden dus plaats en oorsprong van de innovaties binnen de Consuetudines compilatae centraal. Het onderzoek stelde me in staat een mozaïek aan factoren bloot te leggen die een -tot nog toe slechts veronderstelde- vorm- en 
inhoudsbepalende rol hebben gespeeld bij de totstandkoming van de Consuetudines compilatae. Dit maakte het overigens mogelijk een aantal invloeden aan te duiden welke voordien nauwelijks aandacht verkregen in de literatuur. Ik denk hierbij bijvoorbeeld aan de categorie van de derden, met een toch wel opvallende rol die voor de magistraat was weggelegd. Maar ook de Franse rechtsleer evenals de verschillende provinciale coutumes binnen het Frane koninkrijk bleken een invloed uit te oefenen die niet langer onvermeld mag gelaten worden. Ook het belang van de redelijkheid en billijkheid springt in het oog. In deze derde en tevens laatste paragraaf wil ik nu de reële impact van deze nieuwe, maar ook oudere, traditionele invloeden verder onderzoeken. Waar ik in paragraaf 2 vertrokken ben vanuit de deel- en titelstructuur van de compilatie, zal ik nu vertrekken vanuit de verschillende categorieën van rechtsbronnen en hun respectievelijk aandeel binnen het innovatieve aspect van de Consuetudines compilatae. Het stelt me in staat dieper in te gaan op een aantal fenomenen van beïnvloeding welke reeds eerder een plaats hebben gekregen binnen het wetenschappelijk onderzoek (romanisatie, verwetenschappelijking, rationalisatie, ...). Anderzijds maakt deze aanpak het mogelijk ook nieuwe fenomenen aan het licht te brengen en hun karakteristieken te omschrijven (lexificatie, costumiere acculturatie, technocratisering, ...). Aan de hand van de Memorieboeken zal ik in staat zijn aan te tonen of dit terecht wordt aangenomen.

Belangrijk bij deze opzet is tabel $1.28 .{ }^{325} \mathrm{Zij}$ geeft per type rechtsbron het potentiële aandeel weer binnen het innovatieve karakter van elk afzonderlijk deel. Gezien mijn methode focus ik me op de kolom met de totale waarden exclusief die van het zee- en verzekeringsrecht. Omwille van de uitzonderlijke positie van het zee- en assurantierecht binnen het Antwerpse gewoonterecht, lijkt het me immers verstandig -met het oog op eventuele toekomstige comparatieve studies- de cijfers allereerst zonder voornoemde rechtsgebieden te interpreteren. Wanneer het echter wel de moeite loont hen erbij te betrekken, zal dit expliciet worden vermeld. Zoniet, zijn de weergegeven waarden steeds exclusief het zee- en verzekeringsrecht.

Tabel 1.28 Aandeel van ieder type rechtsbron per deel van de Consuetudines compilatae

\begin{tabular}{|c|c|c|c|c|c|c|c|c|c|c|c|}
\hline & I & II & III & IV & V & VI & VII & Tot & -ZR & Tot & +ZR \\
\hline WG & $49 \%$ & $6 \%$ & $11 \%$ & $20 \%$ & $58 \%$ & $20 \%$ & $17 \%$ & $\mathbf{2 7 \%}$ & $\mathbf{3 4 7}$ & $28 \%$ & 510 \\
\hline Usus & $27 \%$ & $23 \%$ & $23 \%$ & $34 \%$ & $11 \%$ & $6 \%$ & $61 \%$ & $\mathbf{2 3} \%$ & $\mathbf{3 0 2}$ & $31 \%$ & 568 \\
\hline S & $12 \%$ & $28 \%$ & $19 \%$ & $23 \%$ & $19 \%$ & $6 \%$ & $2 \%$ & $\mathbf{2 0} \%$ & $\mathbf{2 5 2}$ & $18 \%$ & 325 \\
\hline Ciciv & $4 \%$ & $33 \%$ & $23 \%$ & $17 \%$ & $6 \%$ & $15 \%$ & $30 \%$ & $\mathbf{1 8} \%$ & $\mathbf{2 3 1 . 5}$ & $14 \%$ & 240.5 \\
\hline Comp & $16 \%$ & $20 \%$ & $18 \%$ & $21 \%$ & $16 \%$ & $13 \%$ & $7 \%$ & $\mathbf{1 8 \%}$ & $\mathbf{2 2 7}$ & $19 \%$ & 333.5 \\
\hline RL & $5 \%$ & $13 \%$ & $16 \%$ & $8 \%$ & $12 \%$ & $11 \%$ & $39 \%$ & $\mathbf{1 3} \%$ & $\mathbf{1 6 2}$ & $9 \%$ & 162 \\
\hline OAR & $9 \%$ & $6 \%$ & $9 \%$ & $4 \%$ & $1 \%$ & $56 \%$ & $7 \%$ & $\mathbf{9 \%}$ & $\mathbf{1 1 0}$ & $6 \%$ & 110 \\
\hline 3 & $1 \%$ & $5 \%$ & $9 \%$ & $18 \%$ & $5 \%$ & $7 \%$ & $2 \%$ & $\mathbf{8} \%$ & $\mathbf{1 0 4 . 5}$ & $15 \%$ & 280.5 \\
\hline RA & - & $6 \%$ & $8 \%$ & $13 \%$ & $5 \%$ & - & $7 \%$ & $\mathbf{7 \%}$ & $\mathbf{9 1}$ & $6 \%$ & 111 \\
\hline eGR & - & $6 \%$ & $11 \%$ & - & $1 \%$ & $10 \%$ & $9 \%$ & $\mathbf{4} \%$ & $\mathbf{5 5}$ & $3 \%$ & 57 \\
\hline RS & $3 \%$ & $7 \%$ & $5 \%$ & $4 \%$ & $2 \%$ & - & - & $\mathbf{4} \%$ & $\mathbf{4 7 . 5}$ & $3 \%$ & 47.5 \\
\hline
\end{tabular}

325 Ik wil er nogmaals op wijzen dat deze cijfers niet pretenderen definitief te zijn. Zij beperken zich immers tot de nieuw toegevoegde artikels in de Consuetudines compilatae en zeggen bijgevolg enkel iets over de situatie anno 1608. 


\begin{tabular}{|c|c|c|c|c|c|c|c|c|c|c|c|}
\hline Cican & - & - & - & - & $1 \%$ & - & $11 \%$ & $\mathbf{1} \%$ & $\mathbf{7}$ & $0 \%$ & 7 \\
\hline V & - & - & - & - & $1 \%$ & - & - & $\mathbf{0} \%$ & $\mathbf{3}$ & $0 \%$ & 4 \\
\hline eZR & - & - & - & - & - & - & - & $\mathbf{0} \%$ & $\mathbf{0}$ & $5 \%$ & 81 \\
\hline
\end{tabular}

Op basis van wat deze tabel prijsgeeft, kan ik, conform Van Uffel, niet langer spreken van zuiver gewoonterecht. Naast de gewoonte hebben verschillende andere, voornamelijk juridische, factoren hun invloed laten gelden op de uiteindelijke vorm en inhoud van de Antwerpse costumen. Sommige onder hen doen dit zelfs zeer nadrukkelijk. Zo blijkt de wetgeving mogelijk verantwoordelijk voor maar liefst 27 procent of een groot kwart van alle nieuw geïntroduceerde artikels. Rechtsbronnen van de tweede lijn vormen, naast de voor de hand liggende Usus, de specifieke redenen, het Romeinse recht, de andere 'dwingende' artikels binnen de Consuetudines compilatae en de rechtsleer. Zij blijken goed voor meer dan tien procent van de innovaties binnen de vierde redactiepoging. De invloed van de overige bronnentypes blijft bijgevolg eerder beperkt. Met minder dan tien procent zijn ze zelden verantwoordelijk voor meer dan honderd nieuwe artikels. ${ }^{326}$ Enkel de categorie der derden en de vroege, Antwerpse redacties halen nog net deze kaap. De innovaties op basis van de ratio, het buitensteedse gewoonterecht en de rechtspraak schommelen tussen een vijftiende en een twintigste van het totaal. Op basis van deze cijfers lijkt Jacques Van Uffel het bij het rechte eind te hebben. Ik stel namelijk een teveel aan rechtsleer, wetgeving, etcetera vast en een tekort aan rechtspraak, vroegere redacties, enzovoort. Nu komt het er echter op aan deze cijfers naar waarde in te schatten. Dit zal gebeuren bij de bespreking van de verschillende bronnencategorieën en hun overeenkomstige actieradius. Concreet zal ik als volgt te werk gaan. Vooreerst komt de rol van de vorstelijke wetgeving aan bod, zowel in het licht van zijn absolutistische pretenties als zijn unificerende ambities. Aansluitend hierbij zal ik heel wat aandacht besteden aan andere mogelijke, menselijke factoren welke hun invloed hebben laten gelden en wier invloed steeds geminimaliseerd werd. Het betreft het advies ingewonnen bij derden als belangengroepen, ervaringsdeskundigen en experts. Ik spreek van technocratisering van het costumiere recht, een aspect dat perfect past binnen de volwassenwording van het geredigeerde gewoonterecht. Een ander proces omvat de traditionele romanisatie, zoals ze in het verleden reeds veelvuldig het onderwerp van studie is geweest. Een derde blok omvat de Verwissenschaftlicbung van het lokale recht en de invloed van de praxis hierop. Het plaatst de theorie tegenover de praktijk, het rechtsgeleerde traktaat tegenover de ervaring van de praktizijn. In een vierde onderdeel staan de vroegere en vreemde redacties centraal. Er is het belang van oudere redactiepogingen, maar vooral dat van vreemde, buitensteedse compilaties. Het is een amuse-bouche van het costumiere acculturatieproces, dat een climax zal bereiken in een tweede hoofdstuk, en bovendien een proces dat niet onderschat mag worden wat betreft de unificatie van het gewoonterecht binnen de Nederlanden.

326 Dat de som van de afzonderlijke percentages niet gelijk is aan honderd, is het gevolg van het feit dat deelverzamelingen mogelijk zijn. Eenzelfde artikel kan immers verschillende primaire rechtsbronnen hebben. 
Lexificatie

Alvorens een nieuwe term als lexificatie in het leven te roepen, is een definitie van het fenomeen dat er achter schuilgaat geen overbodige luxe. Lexificatie verwijst naar de penetratie van interne, vorstelijke wetgeving in de geredigeerde costumen. ${ }^{327} \mathrm{Ik}$ spreek van 'intern' wettenrecht, afkomstig van de eigen landsheer, omdat ik enkel zo het begrip ook kan inschakelen in het verdere onderzoek naar bijvoorbeeld de unificerende ambities van de landsheer. Ik spreek van 'vorstelijk' wettenrecht opdat ik later de lexificatie ook als criterium kan hanteren in het licht van de absolutistische pretenties van de monarch. Als penetratie van wetgeving overkoepelt het begrip twee verschillende zaken. Ten eerste kan het gaan om geïntegreerde wetgeving welke louter een bevestiging is van reeds in gebruik zijnde gewoonten. Het proces neigt meer naar acculturatie en omdat het niet noodzakelijk verwijst naar daadwerkelijke receptie van wettenrecht, noem ik het potentiële lexificatie. Hier staat de reële lexificatie tegenover, namelijk die gevallen waarbij daadwerkelijk materiële rechtsregels vanuit het vorstelijk wettenrecht in het costumier recht worden gerecipieerd. In beide gevallen spreek ik dus van lexificatie, maar het spreekt voor zich dat enkel de reële lexificatie van belang is met betrekking tot de vraag naar de machtspositie van de vorst binnen het costumiere homologatieproces.

De term mag dan wel nieuw zijn, met het fenomeen in se is de wetenschappelijke wereld reeds lang vertrouwd. Gilissen vestigde reeds de andacht op de primaire rol welke zowel de urbane of stedelijke als de vorstelijke wetgeving vervulde binnen het costumiere redactieproces. ${ }^{328}$ Ook Gotzen van zijn kant waarschuwde voor de toenemende vorstelijke macht. ${ }^{329}$ Beide auteurs wijzen op een toenemende centralisatie. ${ }^{330}$ In functie van wat ik versta onder lexificatie is het echter van belang het individuele aandeel van het koninklijke wettenrecht te onderzoeken en het te plaatsen tegenover dat van de stedelijke ordonnanties. Zulk een onderscheid biedt me

327 Anderzijds kan ook de statuutswijziging, welke plaatsvindt bij de homologatie van geredigeerde costumen, aanspraak maken op een vergelijkbare uitdrukking. De gewoonte wordt er immers omgezet in wetgeving. Desalniettemin ligt dit aspect semantisch meer in de lijn van een term als 'legisme', welke de heerschappij van het geschreven recht en de toepassing ervan benadrukt. Vandaar dat ik de term lexificatie voorbehouden heb voor de penetratie van interne, vorstelijke wetgeving.

328 GILISSEN, "Rédaction des coutumes", 103-104.

${ }^{329}$ GOTZEN, "De costumiere bronnen”, 120-122.

${ }^{330}$ Gilissen drukt dit als volgt uit: "La situation change au XV Te siècle: les seigneurs -en fait, alors, Charles-Quint et Philippe II- poursuivant leur politique de centralisation, diminuent considérablement le pouvoir législatif des villes. De plus, la rédaction et l'bomologation des coutumes a rendu impossible des modifications en matière civile sans intervention expresse du seigneur." (GILISSEN, "Loi et coutume. Esquisse de l'evolution des sources", 19) Bij Gotzen staat het volgende te lezen: "Op geheel den lijn zien we den Staat geleidelijk meer de plaatselijke vrijheden beperken. Ook. Antwerpen zal in de $17^{e}$ eeun den invloed daarvan ondervinden. Vanaf den tijd van Albrecht en Isabella is het verschijnsel aldaar duidelijk merkbaar: van een 'democratie' en een 'republiek' die zich beriep op zelfstandigheidsprivilegiën, op eigen wallen en eigen weermacht, op eigen rechtspraak en overleg met het Hof omtrent de Edicten, zal de Stad meer en meer worden een onderdanige, administratieve eenheid in het Hertogdom." (GOTZEN, "De costumiere bronnen", 120.) 
namelijk de mogelijkheid een idee te vormen van de penetratie van vorstelijke wetgeving en dus ook van de impact van de vorst en zijn wetgevende administratie op het hele redactieproces van het Antwerpse gewoonterecht. Enerzijds werkte zijn invloed door via de door hemzelf opgezette en uitgedachte homologatieprocedure waarbij onder meer de Geheime Raad als controleorgaan fungeerde. Maar anderzijds is er ook de integratie van de koninklijke ordonnanties in het corpus van het Antwerpse gewoonterecht. De Memorieboeken bevatten echter enkel informatie over de penetratie van de vorstelijke wetgeving. 331 De rol van de Geheime Raad komt hier dan ook niet aan bod. ${ }^{332}$ Wat de landen van 's herwaarts over betreft, werd een landsheerlijke impact in de literatuur vooralsnog geminimaliseerd, en dit zowel wat betreft de middeleeuwse ordonnantiën als die van de nieuwe tijd. Waar Gilissen eerder reeds wees op de manifeste rol van stedelijke ordonnantiën, benadrukt hij in zijn Historische inleiding tot het recht evenwel de beperkte rol van de koninklijke ordonnanties ten aanzien van het privaatrecht dat meestal costumier van aard was. Zo staat er tot twee maal toe te lezen hoe bescheiden de invloed van de vorstelijke wetgeving op het redactieproces is geweest: "In de Middeleeuwen behandelden de koninklijke ordonnantiën vooral publiek recht, zeer zelden privaatrecht. Het doel van de ordonnantiën was de orde in het rijk te handhaven en te zorgen voor een goed bestuur; de koning trad dus vooral op inzake administratie, financiën, leger, rechterlijke organisatie, etcetera. Op enkele uitzonderingen na werden burgerlijk recht en strafrecht steeds door de plaatselijke gewoonten beheerst." 333 Wat de nieuwe tijd betreft, klinkt Gilissen niet erg verschillend: "De meeste wetten betroffen wat men toen 'politie en justitie' noemde: de administratie, de financiën en bet muntwezen. Men maakte weinig wetten inzake strafrecht, nog minder in zake burgerlijk recht, dat vooral vastgelegd was in de gehomologeerde costumen." 334 Een andere aanwijzing van een bescheiden koninklijke impact op het middeleeuwse privaatrecht vind ik in de stelling dat de rol van de vorst aanvankelijk beperkt bleef tot het louter bevestigen van goede of afschaffen van slechte gewoontes, waarbij deze laatsten meestal werden aangepast

331 Bovendien ben ik me er ter dege van bewust dat een onderzoek naar de werkelijke impact van de vorstelijke wetgeving op de costumiere redactie in de eerste plaats naar de volledige redactie moet kijken. Daarenboven behoort eenzelfde onderzoek in principe te vertrekken vanuit de wetgeving, waarbij de aandacht gevestigd is op de mate waarin de ganse ordonnantie werd gerecipieerd, en dus niet vanuit de costumiere redactie, waarbij gezocht wordt naar een percentage aan artikels dat een vorstelijk origine kent. Ratione temporis heb ik me hier echter moeten beperken tot een meer bescheiden aanpak, welke vertrekt vanuit de redactie en zich bovendien limiteert tot de innovatieve artikels binnen de Consuetudines compilatae.

332 Dat de invloed van vergelijkbare instanties, zoals bijvoorbeeld de koninklijke commissarissen betrokken bij het Franse redactieproces, niet onderschat mag worden is reeds aangetoond geweest: cfr. J.-L. GAZZANIGA, "Rédaction des coutumes et codification", Droits: revue française de théorie juridique, 26 (1997), 76. YVER, "Le président Thibault Baillet", 19-42. FILHOL, Le premier président de Thou. VENDRAND-VOYER, "Réformation des coutumes et droit romain", 313-381. De vraag blijft echter in hoeverre de ideeën van deze commissarissen ook daadwerkelijk de wil van de vorst weerspiegelen.

333 GILISSEN, Historische inleiding, 302.

334 GILISSEN, Historische inleiding, 315-316. Desondanks is de invloed niet verwaarloosbaar. Cfr. GODDING, Droit privé, 7. 
aan een nieuwe, gewijzigde, doch gewoonterechtelijke, realiteit. ${ }^{335}$ Van reële lexificatie kan er in zulk opzicht geen sprake zijn. Deze monarchale onmacht wordt vanaf de zestiende eeuw evenwel gecounterd vanuit het opkomende vorstelijk absolutisme. Het maakt dat ik een sterkere inmenging vanuit koninklijke hoek mag verwachten, zelfs op privaatrechtelijk vlak, en dit ondanks de overgangsfase waarin de Nederlanden zich op dat ogenblik bevonden. De zestiende eeuw kenmerkt zich immers als een periode waarin de macht van de vorst niet altijd even stabiel en constant is gebleken. Men denke aan de opstand van de Gentenaars in 1536, de Tachtigjarige Oorlog die de Zeventien Provinciën religieus en politiek verscheurde, en wat Antwerpen in concreto betreft, het feit dat de stad in slechts één decennium tot drie maal toe van landsheer verwisselde. Het doet me vermoeden dat het gezag van de vorst er niet hetzelfde niveau bereikte als hij bijvoorbeeld in Spanje gewoon was. Desondanks handelt de vorst niet overeenkomstig deze regio-specifieke status. Integendeel, hij lijkt zijn Spaanse status (onterecht) te transponeren naar zijn Nederlandse territoria waardoor hij zich als een sterk vorst gedraagt, niettegenstaande de ongetwijfeld sterke machtspositie van de maatschappelijke onderlaag. Kortom, het is duidelijk dat het aanzien van de vorst een uiterst boeiend onderzoeksobject is geworden. Ik zal dus trachten na te gaan in hoeverre de standpunten van Gilissen, zoals zojuist omschreven, anno 1608 nog houdbaar zijn. Waar vindt de lexificatie plaats? Hoe groot is de potentielle lexificatie? En hoe groot is de reële lexificatie? Deze laatste vraag is meteen een weerspiegeling van de werkelijke vorstelijke impact op het redactieproces, en van de monarchale macht tout court. ${ }^{336}$

Wanneer ik de impact van de vorst en zijn wetgevende activiteiten op de geredigeerde Antwerpse costumen wil onderzoeken, komt het er dus in de eerste plaats op aan een onderscheid te maken tussen stedelijke wetgeving enerzijds en vorstelijke wetgeving anderzijds. 337 Op een totaal van 345 'legislatieve' artikels werden -het zee- en assurantierecht uitgezonderd- maar liefst 150 nieuwe artikels in de Consuetudines compilatae geïntegreerd vanuit wetgevende bronnen welke afkomstig waren van een

\footnotetext{
335 Cfr. GILISSEN, "Loi et coutume. Esquisse de l'evolution des sources", 8: "La loi, que ce soit sous forme de privilèges généraux ou d'ordonnances des princes, des seigneurs ou des villes, ne tend en général qu'à confirmer les règles établies par la coutume, à les abroger ou à les modifier; il est assez rare qu'elle crée de nouvelles règles juridiques, surtout en matière de droit privé."

336 De vraag naar het waarom van de lexificatie komt hier niet aan bod. In dit opzicht wil ik verwijzen naar de arenga van de plakkaten. Mogelijk bieden zij uitsluitsel.

337 Voor een aantal vernoemde ordonnanties heb ik niet kunnen uitmaken of deze van stedelijke, dan wel landsheerlijke oorsprong waren. Het betreft in de eerste plaats de abstracte omschrijvingen zoals diversis statutis en plerisque statutis. (cfr. delen I en V) Verder zijn er de ordonnantie op de verzwijging van de renten van 1593 (cfr. delen I en II), het statuut van 8 augustus 1592 (cfr. 3.4.43), de zogenaamde nieuwe ordonnantie van 1593 (cfr. 4.18.35) en het 'nieuwe beworp' van de ordonnantie van 1543 (cfr. 5.17.67/68/69). Formuleringen als ex mente placitorum (cfr. 4.16.38) en ex placitis (cfr. 3.13.2) heb ik als landsheerlijk geïnterpreteerd, aangezien er in de Memorieboeken altijd vorstelijke ordonnanties worden bedoeld, wanneer men het heeft over plakkaten.
} 
hogere overheid. 338 Dit is bijna twaalf procent. De rest is urbaan van aard. Maar ook deze 150 artikels zijn niet zuiver intern en koninklijk van oorsprong. Verder differentiëren kan dan ook niet vermeden worden. Een vereiste welke resulteert in een drietal subgroepen: ten eerste de stijlordonnanties van de Raad van Brabant zoals bijvoorbeeld de Albertine Ordonnantie van 1604, vervolgens de ordonnanties rechtstreeks afkomstig van de eigen vorst en tenslotte de legislatieve inspanningen van buitenlandse heersers. Respectievelijk staan deze verschillende categorieën garant voor 39, 72 en 42 nieuwe artikels. Wat de Albertine Ordonnantie betreft, in de Memorieboeken aangeduid als laatste ordonnantie van den Raad, gaat het om procesrechtelijke regelgeving welke in de eerste plaats die procedures binnen de Antwerpse regelgeving behandelde waar ook de Raad van Brabant als hof van beroep een rol in speelde. ${ }^{339}$ De invloed ervan ligt voor de hand. Veelzeggender is echter de aanwezigheid en impact van de wetgeving afkomstig van vreemde heersers. Maar liefst 42 nieuwe artikels vinden hun oorsprong in extern of 'buitenlands' wettenrecht. Hierbij komt de nadruk te liggen op Franse, vorstelijke wetgeving enerzijds en de statuten van de stad Genua anderzijds. Franse koninklijke ordonnantiën zoals ze door Barnabé Brisson (1531-1591) werden verzameld en vervolgens door Louis le Caron becommentarieerd (Codex Henricianus) werden in totaal maar liefst veertien maal aangewend als primaire rechtsbron. ${ }^{340}$ Bovendien heeft de compilatie ook als secundaire rechtsbron geen onaardige rol gespeeld. Naast de Franse constitutiones zijn enkel de Statutorum Civilium Reipublicae Genuensis van 1589 noemenswaardig, en dit voornamelijk met betrekking tot het handels- en verbintenissenrecht uit deel IV, waar het statutaire recht aan de basis ligt van maar liefst twintig nieuwe artikels. ${ }^{341}$ Ondanks de heerschappij van de Spaanse kroon over de Zuidelijke Nederlanden blijft de invloed van de Spaanse wetgeving, op drie artikels na, tot het minimum beperkt. ${ }^{342}$ Ook Martyn kwam met betrekking tot het Eemwig Edict van de Aartshertogen Albrecht en Isabella (1611) tot een gelijkaardige conclusie. De invloed van Spanje is er minimaal. ${ }^{343}$ Bijgevolg is deze vergelijkbaar met de impact van legislatie afkomstig van andere Nederlandse steden, zoals de ordonnanties van Brugge en Brussel

\footnotetext{
338 Het zee- en verzekeringsrecht meegerekend, stijgt het totaal aantal gelexificeerde artikels zelfs tot 509 .

${ }^{339}$ Het gaat in de eerste plaats om de titels 5.15 (Van appellatien) en 5.16 (V an reformatien). Ook in titel 5.10 (Van manier van procederen) is de ordonnantie nadrukkelijk aanwezig, en iets minder in titel 5.3 (Van advocaten en procureurs). Wanneer er sprake was van de Usus van de Raad van Brabant of de stilus van dezelfde Raad, dan heb ik dit steeds als Varia gecatalogiseerd. Ter illustratie verwijs ik hier naar artikel 5.10.69: Est additus in hac revisione ex usu et stilo curia[e] et accordat etiam in substantia art 4 inde voors[creven] ordonnantie vanden jaere 1564.

${ }^{340}$ Dat deze wetgeving zich bij titel 1.13 omtrent het notariaat concentreert, heb ik reeds in paragraaf 2 aangetoond.

341 De twintig nieuwe artikels concentreren zich voornamelijk binnen de titels omtrent de wisselbrieven (titel 4.3), factorije (titel 4.10) en gebroken schuldenaers (titel 4.16). Cfr. supra, hoofdstuk 1, paragraaf 2, Deel IV.

342 Het betreft de artikels, 2.1.3, 2.1.4 en 6.1.40. De wetgeving waar het om draait, zijn de Nueva Recopilación (1567) en de Siete Partidas (1263).

343 MARTYN, Eeunig edict, 98-99.
} 
omtrent de weeskinderen. ${ }^{344}$ Anderzijds is de invloed vanuit vreemde landen zoals Frankrijk geen nieuw gegeven. Grandgagnage wees reeds in 1832 op de idolatrie van autochtone juristen ten aanzien van de Franse wetgeving en ook Gotzen maakte de lezer attent op het toch wel uitzonderlijke belang van de Franse juridische wereld voor de landen van's herwaarts over en Antwerpen in het bijzonder. ${ }^{345}$

Desalniettemin ben ik het meest geïnteresseerd in de 72 artikels welke rechtstreeks teruggaan op de wetgevende activiteiten van de eigen vorst. ${ }^{346}$ Enkel zij dragen bij tot de beschrijving en kennis van het lexificatieverschijnsel. Een eerste vraag in dit opzicht betreft de locatie ervan. Waar situeren deze artikels zich binnen het geheel van de Consuetudines compilatae? Ook hieromtrent is het wederom Gilissen geweest die reeds een idee gegeven heeft van waar ik de penetratie wel (policie ende justitie), en waar niet (burgerlijk en strafrecht), mag verwachten. Aan de hand van tabel 1.29 zal ik laten zien in hoeverre het beeld dat door Gilissen werd geschetst ook van toepassing is op het Antwerpse gewoonterecht zoals het zich in 1608 aan de wereld presenteerde. In een eerste kolom geeft de tabel de spreiding weer van de 72 gelexificeerde artikels over de verschillende delen van de compilatie. Kolom 2 laat zien welk percentage (op een totaal van 72) hiermee correspondeert. Beide kolommen tonen de voorkeur van de vorst(elijke ordonnanties). Het laat zien waar er voornamelijk geïnfiltreerd wordt, indien er geïnfiltreerd werd. Een derde kolom bevat het procentuele aandeel van de vorstelijke wetgeving als primaire rechtsbron binnen de innovaties van elk deel afzonderlijk. Met andere woorden, het geeft een idee van het belang van de vorstelijke wetgeving voor de totstandkoming van het individuele deel. Waar de kolommen 1 en 2 de wetgeving in verhouding tot de afzonderlijke delen plaatsten, benadrukt kolom 3 de positie van de wetgeving ten opzichte van de andere bronnentypes binnen elk deel. Om de uitspraken van Gilissen te toetsen aan de Antwerpse casus, behoef ik de cijfers te analyseren zoals ze in kolom 2 zijn weergegeven, namelijk diegene die de voorkeur weerspiegelen.

Tabel 1.29 Het aandeel van lexificatie per deel

\begin{tabular}{|l|c|c|c|}
\hline & Voorkeur & Voorkeur (\%) & Belang (\%) \\
\hline I & 5 & $7.0 \%$ & $6.5 \%$ \\
\hline II & 1 & $1.4 \%$ & $0.5 \%$ \\
\hline III & 23 & $31.9 \%$ & $8.7 \%$ \\
\hline IV & 20 & $27.8 \%$ & $6.3 \%$ \\
\hline V & 3 & $4.2 \%$ & $1.0 \%$ \\
\hline VI & 14 & $19.4 \%$ & $17.1 \%$ \\
\hline VII & 6 & $8.3 \%$ & $13.0 \%$ \\
\hline
\end{tabular}

$344 \mathrm{Zij}$ leveren slechts vier verschillende artikels: 2.5.78, 2.5.83, 2.5.84 en 2.5.168.

345 GRANDGAGNAGE, Influence de la législation civile française, 111. GOTZEN, "De costumiere bronnen", 200.

346 Zeer uitzonderlijk beperkt men zich tot de 'geest' van de plakkaten, zoals bij artikel 4.16.38: Est etiam novus ex mente placitorum et accordant statuta Genuensium loco i[bi] cit[ato] art incip[it] si ullo unquam tempore fol 104. 
Wat blijkt nu? Ten eerste stel ik vast dat de vorst zijn handen afhoudt van het personenrecht, een vaststelling die grosso modo in de lijn der verwachtingen ligt. Ook het procesrecht laat hij grotendeels aan de regio's of steden zelf over. De vorst lijkt niet meteen een universele procedure te ambiëren. Integendeel, hij respecteert de verschillende stylen ende manieren van procederen en werkt in zekere zin een unificatie zelfs tegen door de redactie en homologatie ervan aan te moedigen. ${ }^{347}$ Binnen de overige publiekrechtelijke domeinen neemt de monarchale invloed wel toe. Waar de invloed van de vorstelijke wetgeving op de toegevoegde inhoud van deel I nog beperkt blijft tot 6.5 procent, neemt deze ten aanzien van de straf(proces)rechtelijke delen VI en VII toe tot respectievelijk 17.1 en 13 procent. De aanwezigheid van vorstelijk wettenrecht binnen deel I, ligt enigszins in de lijn der verwachtingen. Deel I regelt immers de policie ende administratie, rechtsmaterie waarin Gilissen een grote rol zag weggelegd voor de vorst. ${ }^{348}$ Anderzijds blijft dit, gezien de rol van stedelijke instellingen binnen dit deel, toch voornamelijk een deel waarin het stedelijk wettenrecht het voortouw neemt.

Het zesde, strafrechtelijke deel, dat voor 17.1 procent uit wettenrecht bestaat, wordt gekenmerkt door recht dat afkomstig is van keizer Karel V, wat in twee opzichten verrassend is. Ten eerste heb ik met bronnen als de Constitutio Criminalis Carolina (1530) en de Keyserlycke Rechten ende Statuten, in 1519 uitgegeven door Thomas Murner, te maken met wetgeving welke oorspronkelijk enkel van kracht was binnen het Heilige Roomse Rijk. Ondanks het feit dat de Nederlanden met de Transactie van Augsburg in 1548 een onafhankelijke Bourgondische Kreits gingen vormen los van het Heilige Roomse Rijk, blijft de wetgeving zelfs in 1608 doorwerken, het zij gewoonterechtelijk. Het tweede opzienbarende punt betreft het vermijden van Filips II als wetgever op strafrechtelijk vlak. Zijn Criminele Ordonnantiën van 1570, formeel niet langer van kracht binnen de Zuidelijke Nederlanden na de Pacificatie van Gent (1576), komen nauwelijks aan bod. Doorgaans wordt evenwel verondersteld dat de inhoud ervan, ondanks de officiële afschaffing, desondanks bleef doorwerken. ${ }^{349}$ Toch wordt ook in de Memorieboeken slechts twee maal expliciet naar het document verwezen, en grijpt men terug naar keizerlijke ordonnanties welke meer dan zeventig jaar oud waren. ${ }^{350} \mathrm{Al}$ deze wetgeving concentreert zich binnen deel VI in titel $6.2 \mathrm{en}$ het is het plakkaat van 7 oktober 1531 dat er de rangen sluit. Wederom betreft het een plakkaat afkomstig van de kanselarij van Karel V. En dit geldt overigens voor het merendeel van de in de Memorieboeken geciteerde plakkaten en ordonnantiën. De nadruk ligt steeds op ordonnanties afkomstig van de kanselarij van Karel V en nauwelijks op die van de recentere Filips II. Dat dit me enigszins verbaast, is het gevolg van het feit dat Filips II (1555-1598) gemiddeld per jaar dubbel zoveel ordonnanties uitvaardigde dan Karel V (1506-1555). Meer nog, geen enkele andere

347 Cfr. GILISSEN, Historische inleiding, 283. GILISSEN, "Rédaction des coutumes. Essai de synthèse", 33 .

348 Cfr. supra.

349 Cfr. MOORMAN VAN KAPPEN, “De rechtskracht”, 327-345.

350 Voorbeelden van receptie van elementen uit de Criminele Ordonnantiën zijn te vinden bij de artikels 2.5 .30 en 5.10.2/3. 
vorst van de Nederlanden vaardigde binnen het tijdvak van het oud-regime evenveel ordonnanties uit als Filips II.351 Ook de aartshertogen Albrecht en Isabella (15981621) beperkten hun invloed tot een minimum aan plakkaten. Dit is evenwel te verklaren door de korte duur van hun regeerperiode op het moment waar ik nu van spreek, evenals door het feit dat zij de eerste jaren van hun machtsperiode geheel ingenomen waren door militaire aangelegenheden, waardoor hen nog weinig tijd restte voor legislatieve activiteiten.

Wat echter de klassieke opvatting lijkt te tarten, is de impact van de vorst op delen als die omtrent het goederen-, het erf- en het verbintenissenrecht. Voornoemde rechtsgebieden genieten duidelijk zijn voorkeur. Op een totaal van 72 gelexificeerde artikels, nemen deel III en deel IV respectievelijk 31.9 en 27.8 procent voor hun rekening. Relativeren is in dit opzicht echter aangewezen. Met respectievelijk 23 en twintig gelexificeerde artikels behoren beide delen -conform de traditionele opvattingniet tot de meest gelexificeerde rechtsgebieden. Het aandeel van de wetgeving beperkt er zich namelijk tot respectievelijk 8.7 en 6.3 procent. ${ }^{352}$ Desalniettemin blijven beide delen goed voor meer dan de helft van de artikels op basis van interne, vorstelijke wetgeving. Kortom, hoewel beide delen absoluut het merendeel voor hun rekening nemen, zijn de meest gelexificeerde delen desalniettemin de meest voor de hand liggende, namelijk het publiekrecht in tegenstelling tot het privaatrecht. Met andere woorden: enerzijds liggen de vaststellingen na nuancering in de lijn van de uitspraken van Gilissen, anderzijds blijft het verrassend dat, wanneer wetgeving afdaalt naar het costumiere veld, deze voornamelijk terechtkomt in de delen III en IV. ${ }^{353}$ Nogmaals, dit is de situatie anno 1608. Uiteraard bestaat de mogelijkheid dat andere delen reeds bij vroegere redacties zoals de Consuetudines impressae, of zelfs de Consuetudines antiquae door wetgeving gepenetreerd waren.

Is de vorst werkelijk zijn macht aan het uitbreiden? Ik kan in ieder geval niet ontkennen dat zijn ordonnanties zich laten gelden in rechtsmaterie welke doorgaans niet tot zijn potestas wordt gerekend. Het zou dan ook om een bevestiging kunnen gaan van de toename van de vorstelijke invloedssfeer op zijn weg naar vorstelijk absolutisme evenals een confirmatie van wat Gilissen verkondigde, namelijk dat in de

${ }^{351}$ Cfr. GILISSEN, Historische inleiding, 315. J. GILISSEN, "Essai statistique de la législation en Belgique de 1507 à 1794", Revue du Nord, 40 (1958), 431-435.

${ }^{352}$ Cfr. supra, hoofdstuk 1, paragraaf 3, tabel 1.29.

353 Inclusief het maritieme recht en de integratie van de ordonnanties op het zee- en verzekeringswezen wordt dit alles nog omvangrijker. De vorstelijke impact uit zich namelijk nog nadrukkelijker op het vlak van het zee- en assurantierecht. Ik krijg namelijk een manifeste integratie van de zeerechtelijke ordonnanties van Karel V (1551) en Filips II (1563) te zien, zoals reeds in paragraaf 2 uitvoerig aan bod is gekomen. Enkel paragraaf 6 van titel 4.10 omtrent de schipvracht blijft ervan gevrijwaard. In tegenstelling tot wat ik zojuist hebt geopperd, ligt hier de nadruk wel op de meer recente ordonnanties van Filips II (45 versus 120 nieuwe artikels). Ook de ordonnantie omtrent het verzekeringswezen van 1570 vindt zijn weg naar Antwerpen. Met 41 nieuwe artikels brengt ze het totaal op 162, wat op zijn minst aanzienlijk genoemd kan worden. Van stedelijke wetgeving is binnen de titels 4.8 en 4.11 evenwel geen sprake. 
zestiende eeuw steden wetgevende bevoegdheden moeten inleveren ten voordele van de vorst. ${ }^{354}$ Tabel 1.30 geeft aan dat in het Antwerpen van 1608 een gelijkaardig proces aan de gang is. De tabel plaatst het aandeel van de stedelijke wetgeving tegenover dat van de vorstelijke, en dit voor elk deel afzonderlijk. ${ }^{355}$

Tabel 1.30 Stedelijk aandeel versus vorstelijk aandeel inzake lexificatie per deel

\begin{tabular}{|c|c|c|}
\hline Stedelijk aandeel per deel & Deel & Intern, vorstelijk aandeel per deel \\
\hline $9.0 \%$ & I & $6.5 \%$ \\
\hline $1.5 \%$ & II & $0.5 \%$ \\
\hline $0.8 \%$ & III & $8.7 \%$ \\
\hline $1.6 \%$ & IV & $6.3 \%$ \\
\hline $6.5 \%$ & V & $1.0 \%$ \\
\hline $1.2 \%$ & VI & $17.1 \%$ \\
\hline $2.2 \%$ & VII & $13.0 \%$ \\
\hline
\end{tabular}

Zoals aangekondigd, ligt ook bij de innovaties binnen de Consuetudines compilatae het aandeel van de stedelijke wetgeving lager dan dat van het vorstelijk wettenrecht. Enkel daar waar de invloed van de vorst tout court te verwaarlozen was, zoals bij het personenrecht, stel ik het omgekeerde vast. De 6.5 procent met betrekking tot het vijfde burgerlijk procesrechtelijke deel, toont nog maar eens hoe weinig de vorst zich hiermee wil inlaten. Het procesrecht blijft een uiterst lokale angelegenheid. ${ }^{356} \mathrm{De}$ overgrote meerderheid van deze 6.5 procent vindt zijn oorsprong overigens ex ordinatione seu statuto civitatibus van 24 oktober 1592. Ik heb echter niet kunnen achterhalen om welk statuut het hier exact gaat. ${ }^{357}$ Desondanks komt het binnen deel $\mathrm{V}$ bij maar liefst 29 verschillende artikels als primaire rechtsbron aan bod.

Wat het aandeel van de vorstelijke wetgeving binnen de innovaties van de Consuetudines compilatae betreft, kan ik alleen maar toegeven dat de monarchale macht zich nadrukkelijk laat voelen. Er is een uitbreiding van de actieradius en er is de

354 GILISSEN, Historische inleiding, 307. GILISSEN, "Loi et coutume. Esquisse de l'evolution des sources", 19. Ook Krynen wijst er op dat recente studies hebben aangetoond, dat de vorstelijke invloed op de gewoonte niet langer onderschat mag worden: "Du seul point de vue la royauté dans ses rapports avec la coutume, il en résulte: -que la non-intervention du pouvoir central dans la sphère du droit privé relève du mythe; -que la maîtrise royale de la coutume a été originelle et constante; -que celle-ci a toujours été encouragé par une doctrine de l'omnipotence normative du souverain." (KRYNEN, "Voluntas domini regis", 63.) Eenzelfde primaire rol voor de vorstelijke wetgeving weerklinkt uit het verhaal van Seong-Hak Kim met betrekking tot Christofle de Thou en de hervorming van de Franse costumen: "La primauté de la législation royale est également prowvée par les modifications des contumes jugées injustes on inéquitables." (SEONG-HAK KIM, "Christophe de Thou et la réforme des coutumes, 97.”)

${ }^{355}$ De stedelijke stijlordonnanties van 1564, 1576 en 1582 zijn hierin niet verrekend. Omwille van het bijzondere statuut van deze Ordonnanties op de styl ende maniere van procederen heb ik hen een aparte plaats toeggekend.

356 Cfr. MONBALLYU, Zes eeuwen strafrecht, 349-350.

${ }^{357}$ Cfr. supra, hoofdstuk 1, paragraaf 2, Deel I. 
dominantie van het vorstelijke over het stedelijke wettenrecht. ${ }^{358} \mathrm{Nu}$ is het echter zo dat voorgaande conclusies pas naar werkelijke waarde kunnen worden ingeschat, van zodra zij ook onderbouwd worden door een positief antwoord op de vraag in hoeverre ik hier te maken heb met een daadwerkelijke receptie van de regels voorgeschreven in de verschillende ordonnanties. Gaat het immers louter om acculturatie, waarbij -zoals Gilissen ooit opperde ${ }^{359}$ - het wettenrecht niet meer behelst dan een bevestiging van reeds bestaande en in gebruik zijnde gewoonten, dan spreekt dit niet in het voordeel van een absolutistische vorst. Het ligt dan ook voor de hand dat wanneer men de werkelijke impact van de monarch wil inschatten, men in de Memorieboeken op zoek moet naar sporen van hoe men zich tegenover dit wettenrecht opstelde. Belangrijk hierbij is of deze artikels van legislatieve oorsprong al dan niet door de Usus bevestigd worden. ${ }^{360}$ In het ene geval lijkt de wetgeving dan niet meer dan een bevestiging van reeds bestaande gewoontes te zijn, waar het in het andere geval mijns inziens om een meer fundamentele en originele ingreep gaat. ${ }^{361}$ Wat blijkt? Voorbeelden van laatstgenoemde situatie blijken legio te zijn. Zeer weinig zogenaamde legislatieve artikels worden in de Memorien op de Costumen expliciet bevestigd; dit zowel ten aanzien van de externe wetgeving en meer nog ten aanzien van het interne wettenrecht. Een zuiver voorbeeld hiervan is te vinden bij artikel 1.12.13 omtrent de secretarissen en greffiers: Est art 6 vande voorscreven ordonnantien vanden 15 februarii 1593. Zelfs elke vorm van discussie of nabeschouwing blijft uit. In gans de Memorieboeken heb ik, met betrekking tot nieuwe artikels van legislatieve aard, slechts drie maal expliciet gewag horen maken van een bevestigende Usus, onder meer ten aanzien van artikel 6.2.28 in verband met meineed: Est etiam desumptus ex $d$ statutis Carolinis usu approbatis, et quod bic pena omnino sit arbitraria patet ex eo quod ut diximus i[n] $d$ art 47 tit van thoon committatur hoc casu stellionatus, L fin ff stellionat[us] cuius pena est arbitraria, vide Menoch[ius] de arbitr[ariis] iud[icium] quaest[ionibus] lib 3 centur 4 casu 319 per

\footnotetext{
358 Men kan zich hierbij de vraag stellen naar de wijze waarop dit aandeel van de vorstelijke wetgeving binnen de Consuetudines compilatae zich verhoudt tot het aandeel ervan binnen de Consuetudines impressae. Het gereformeerde bestuur erkende immers niet langer het koninklijk gezag. Welke bronnen van recht vullen dit machtsvacuüm in? Of, is er helemaal geen sprake van een vacuüm en blijven de oudere ordonnanties in de gunst van het nieuwe stadsbestuur? 359 Cfr. GILISSEN, "Loi et coutume. Esquisse de l'evolution des sources", 8. Ook Lesaffer ziet het gewoonterecht heel breed. Hij ziet de wetgeving vaak als gewoonterecht omdat het maar al te vaak een bevestiging is van wat leeft, een verzekering van de bestaande gewoontes en privileges. Uitsluitsel hieromtrent kan bekomen worden aan de hand van een onderzoek dat een vergelijking maakt van de inhoud van de ordonnanties te vergelijken met de juridische werkelijkheid zoals ze zich presenteert in de procesdossiers daterend van voor de ordonnantie. (LESAFFER, Inleiding tot de Europese rechtsgeschiedenis, 247.)

${ }^{360}$ Deze bevestiging door de Usus, kan er immers op wijzen dat het wettenrecht op zijn beurt reeds een bevestiging van bestaande gewoontes was. (Cfr. GILISSEN, "Loi et coutume. Esquisse de l'evolution des sources", 8.)

${ }^{361}$ Dat dit een aanvaardbare en verantwoorde keuze is, blijkt zodadelijk uit de situatie bij de romanisatie. Cfr. infra, hoofdstuk 1, paragraaf 3, Romanisatie en bumanisme.
} 
totum. ${ }^{362}$ Mocht er verder nog sprake zijn van legislatieve artikels met bevestiging, dan betreft het andere rechtsbronnen dan de Usus. Ik denk onder meer aan het Romeinse recht $^{363}$ en het ius commune of de rechtsleer ${ }^{364}$, maar ook aan externe costumiere compilaties $^{365}$ evenals vreemde wetgeving ${ }^{366}$ en de ratio ${ }^{367}$. Elke bevestiging door een werkelijke weerspiegeling van de Antwerpse costumiere wereld, zoals de lokale rechtspraak of eigen Usus, blijft evenwel uit. Het toont aan hoe weinig rekening de centrale overheid hoeft te houden met de basis en haar gebruiken. Zelden of nooit wordt het wettenrecht er aan afgewogen, wat een indicatie kan vormen van de sterker wordende monarchale macht.

Naast de al dan niet confirmerende Usus, levert ook een onderzoek naar de onderlinge gezagsverhoudingen van wet en gewoonte op basis van de Memorieboeken, een bijdrage tot de kennis van de werkelijke positie van de vorst. Wie primeert over wie bij conflicterende opinies? Wie past zich aan aan wie? In tegenstelling tot wat ik later nog met betrekking tot het Romeinse recht zal vaststellen, resulteert deze aanpak in een bedroevend overzicht, in die zin dat het weinig cohesie vertoont. Ten eerste is het aantal conflictsituaties te zeldzaam en de uitkomst ervan te verscheiden om er definitieve conclusies op te baseren. Toch wil ik hier een idee geven van de mogelijke relaties. Zo spreken de Memorieboeken van legislatieve artikels welke werden aangepast op basis van eigen, Antwerpse statuten: Est novus additus in hac postrema revisione ex usu et ratione placiti i bi] allegati, behalvens dat wy in cas vande leveringe eenighen tyt meer gunnen, uuyt het statuet vande selve leveringe gemaeckt 19 iunii 1535 art $1^{\circ}$ ubi expresse dat niemant syne renten

362 Het tweede voorbeeld betreft artikel 1.13.6: Ex posterioribus placitus et usu, nisi quod nos bic addiderimus, dat emners [lees: immers] den eenen getuygen moet connen schrijven ex $d$ d constit[utionibus] Galli[a]e in Cod[ice] Henric[iano] loco i[bi] citato art 8 ut 10. Een derde keer betrof het zeer oude wetgeving, namelijk een privilege van de Brabantse hertog Jan II uit 1298 met betrekking tot 4.5.1: Est novus geconfirmeert by tprivilegie van hertoch Jan van Brabandt feria quinta post dominicam qua cantatur misericordia a nno] 1298 daerby de schepenen wordt geaccordeert alle saterdagen peerdemerct te ordonneren en [de] te houden dwelck naermaels om de commoditeyt vanden coopman en [de] andersints verandert is en [de] gebrocht totten tyt albier gedesigneert et ita usus nunc observat. Het privilege verleende de Antwerpse schepenen in 1298 het voorrecht elke zaterdag een paardenmarkt te organiseren. In de Consuetudines compilatae is deze frequentie teruggebracht naar twee markten per jaar. (Cfr. Coutumes de la ville d'Anvers dites compilatae, IV, 54.)

363 3.14.77: Est novus etiam desumptus ex d placitis text in L scimus $22 \int$ et si prefatam 4 C de iure deliber [andi et de adeunda vel adquirenda hereditate].

364 3.13.2: Est novus additus in hac revisione, partim ex usu partim ex placitis et sunt foere iuris communis et nominatim quoad subsignationem testatoris et testium, et ita expresse etiam tenet consuetudo Paris[iensis] dicto art 289 in fine et reliquae consuetudines Galliae ex constitutionibus regiis quas citat et confirmat Le Guenois in conferentiis fol 680 ad l[itte] ram $N$.

365 3.14.64: Est novus additus in hac revisione ex duobus placcatis Caroli Imper[atoris] van[de] 8 novemb[er] 1541 et 14 maii 1544 accordat consuet Arthesi[a]e tit 111 art 111 Lille tit 14 art 176 et ali[a]e consuet [udines] Galli[a]e passim.

366 1.13.3: Est ex altera ordinatione seu placito Imp[eratoris] Caroli de 4 octobris 1540 cap. beginnende dat alle notarisen, et cum eo accordant constit[utiones] Galli[a]e in Cod[ice] Henric[iano] d. lib. 3 tit 22. des notaires art 16.

367 3.8.73: Est novus ex recenti ordinatione super ea re promulgata et rationem habes in textu. 
langer mach laeten loopen dan twee jaeren ende de selve overstreken synde, moet mette ierste cloecke leveringe nemen, dwelck de saecke brenght op drye jaeren 6 maenden luttel meer oft min ut i[n] tit van leveringe art 37 et... ${ }^{368}$ Maar ook het Romeinse recht kan in dit opzicht dwingend optreden: Est desumptus partim ex antiquissimis art 34 tit van keuren en[de] breucken partim muyt voors[creven] boeck geintituleert keyserlycke statuyten a fol[io] 213 art 3 paucis mutatis vel additis ut conveniret titulo vide text in L perspiciendum $11 \mathrm{~L}$ hodie 13 et L autem [lees, aut] facta 16 in fine ff de p[o]enis et adde den landtcharter art 63 ubi expresse quod novi casus oft die aldaer nyet wel unytgedruckt en syn geremitteert worden totten rechter.369 Hetzelfde geldt voor de Franse wetgeving: Ex posterioribus placitus et usu, nisi quod nos bic addiderimus, dat emners [lees: immers] den eenen getuygen moet connen schrijven ex $d d$ constit[utionibus] Galli[a]e in Cod[ice] Henric[iano] loco i[bi] citato art 8 ut 10.370 De kracht van het Franse model blijkt nog maar eens uit artikel 4.1.4 omtrent de nietigverklaring van een contract: Est etiam novus ex usu nisi quod bic addita sint verba en[de] dat binnen dan tyt qua[e] desumpta ex ordinationibus Gallia[e] quas babes in Cod[ice] Henriciano lib 6 art 22 art primo et $3^{\circ}$ et... Het betreft het enige voorbeeld waar de Usus wordt aangepast aan buitenlandse, vorstelijke wetgeving van eigen bodem. Een enkele keer betreft het interne, vorstelijke wetgeving: "Sunt desumpti ex articul[o] 3 in impressis tit van namptisa[ti] cum quo accordat placit[um] imperat[oris] d 6 martii 1536 et ex eo nos delevimus verba oft aen syn huys gesin nam placitum requirit omnia $[\mathrm{m}]$ citationem personalem et merito, additur quoque ibidem in placito van datmen de obligatie soude moeten kennen oft ontkennen, sed non observatur, nec videtur etiam necessarium cum taciturnitas hoc casu pro recognitione sit ut $i[n]$ tit van handtvullinge art 10 et 11." "371 Soms gaat het echter om niet meer dan stijlveranderingen, opdat de zaken beter en duidelijker worden verwoord, zoals ten aanzien van de artikels 4.16.47/48 omtrent facteurs ende behulpers van gefailleerde kooplieden: Sunt etiam novi ex eodem statuto et placito nisi quod in hac revisione pleraque accuratius sunt explicata et... ${ }^{372}$ Zoals zodadelijk nog uitvoerig ter sprake zal komen, beschikt ook de magistraat over verregaande bevoegdheden wat betreft het aanbrengen en doordrukken van wijzigingen. Ten aanzien van regels, welke werden geïmporteerd vanuit vorstelijke ordonnanties, is dit niet anders. Ter illustratie verwijs ik naar de artikels 5.10.2/3 omtrent de eis van de aanklager: Sunt novi in hac revisione ex ordinatione criminali de anno 1570 art 54 nisi quod magistratui visum sit adiicere poenam in advocatos et procuratores, si contraveniant quia ab iis principaliter dependit. 373 Toegegeven, gezien het feit dat deze ordonnanties sinds de Pacificatie van Gent (1576) niet langer officieel van kracht waren, staat niets hun aanpassing nog in de weg. Dat de afschaffing ervan niet noodzakelijk hoeft te betekenen dat zij ook hun aantrekkingskracht als inspiratiebron verloren hadden, blijkt uit dit voorbeeld des te meer. ${ }^{374}$ Vergelijkbaar is de situatie bij de integratie van vreemd wettenrecht, zoals bijvoorbeeld bij de Statuta (1589) van Genua. Ook hier

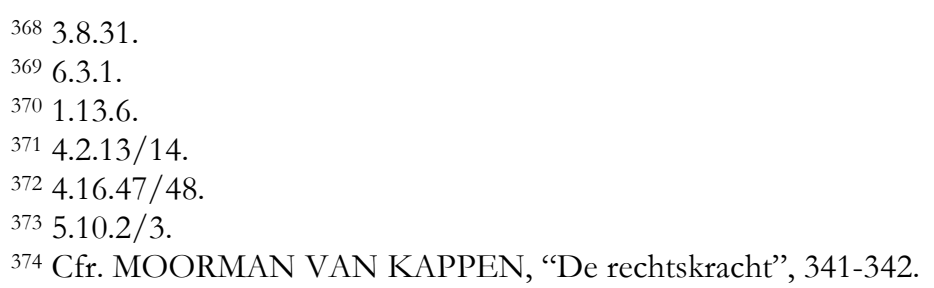


staat geen enkele gezagsdrager de aanpassing ervan in de weg. De magistraat liet zich hier dan ook van zijn meest creatieve kant zien. Bij wijze van voorbeeld beperk ik me tot de artikels 4.16.18/19 betreffende de verschillen tussen gevluchte cooplieden en enckele, gebroken cooplieden: Sunt novi in hac revisione ex statutis Genuensium lib 4 tit de decoctis et debitore non solvendo versic si debitor non constituerit fol 103 nisi quod ibi eo amplius requiratur quod decoctor etiam se constituat in foriis i [bi] in potestate magistratus et maneat domi sua [e] aut eo loco quo magistratus iusserit donec conventum sit cum creditoribus et ita observatur etiam Florentia[e] et passim alibi magistratui id visum nimis rigorosum et exorbitans tam i[bi] a placitis quam consuetudine nostra ideoque putavit sufficere si bona fide libri exbibeantur et bona manifestentur sem [?] minus ut tunc per capturam aut etiam rigorosius coerceantur ex placitis ut bic, quod si malum eo nibilominus ingruat et novo remedio opus sit poterit princeps novo placito providere. ${ }^{375}$ Hoewel geconfirmeerd door het Florentijnse gebruik evenals dat van andere plaatsen, oordeelt de magistraat het statuut van Genua te streng en afwijkend van zowel onze plakkaten als onze gewoonte. Bijgevolg stelt hij een wijziging voor. Maar ook met betrekking tot de officiële, interne wetgeving lijkt hij over een gelijkaardige bevoegdheid te beschikken, zoals blijkt uit de Memorieboeken met betrekking tot de artikels 6.2.13/14 aangaande blasfemie: Sunt novi in hac revisione ex placito imperatoris Caroli de 7 octob[ris] 1531 art 43 nisi quod ibi tempus poenitentie limitetur ad mensem magistratui visum id relinquere arbitrio iudicis qui ex qualitate delicti statuat accordat in substantia bet boeck geintituleert keyserlycke statuyten fol 219 in princip nisi quod ibi inde finite ponatur poena capitis pro quo est textus in novella constit [utionem] 77 ut non luxurientur homines contra naturam cap $1^{\circ} \int$ et quoniam $1^{\circ} \mathrm{cum}$ seqq gloss[a] in L omnes $C$ de delationibus [lees, dilationibus] lib 10 et ibi Jo[ann]es a [b] Platea, sed poenam illam in desuetudinem abesse tradit Lucas de Penna ad d L omnes col 3 versic qua [e]ritur et ubique fere factam esse arbitrariam dicit Clarus lib 5 sententiarum $\int$ blasphemia versic sed qua[e]ritur qua[e] sit pena quod magistratui visum est sequi, et sane multa genera blasphemiarum sunt qua [e] uno genere pen [a]e non possunt aut debent puniri in Galliis pro quatuor vicibus paniuntur pena pecuniaria quinta vice arbitraria et si non habent unde solvant te waeter, en [de] te broode ten goetduncken vanden rechter sexta vice traicitur et perforatur illis labrum superius, septima inferius ita ut dentes appareant, octana amputatur lingua, quod si atrox blasphemia sit pena est capitalis vide Papon, in arrest [is] lib $1^{\circ}$ tit $2^{\circ}$ art $1^{\circ}$ et Boer[ius] decis[io] 701 ubi citant duo arresta senatus Burdegalensis adde Iulium Clarum loco i[bi] cit[ato] qui et ipse citat duo arresta senatus Mediolanensis quo tales blasphematores in atrocioribus ad triremes fuerunt condemnati si ad hoc apti essent sin melius ad furcam sed ut diximus melius est relinquere arbitrio indicis qui moderetur pro qualitate delictorum et personnarum cum id casum valde mutet ut i[bi].376 Hoe dan ook, de enige voorlopige conclusie welke ik op basis van deze voorbeelden wil trekken, is dat er ondanks een groeiende monarchale macht nog steeds mogelijkheden worden gelaten voor andere rechtsbronnen evenals lagere bestuursniveaus, zij het evenwel zeer bescheiden. Dit zal des te meer blijken uit een volgende blok betreffende de 'technocratisering'.

375 Ander voorbeelden hiervan zijn te vinden bij de artikels 4.9.19/20/21 en 4.9.22.

376 6.2.13/14. 
Ik ben me er ter dege van bewust dat mijn aantallen vrij beperkt zijn, wat de argumentatie van mijn stellingen niet ten goede komt. Toch lijken mijn vaststellingen te passen in de algemene opvatting van een steeds sterker wordende vorstelijke invloed binnen een algemene Europese tendens van vorstelijk absolutisme. Een trend die zich dus ook op costumier vlak laat gevoelen. Er is met name niet alleen de penetratie van vorstelijke wetgeving in niet-traditionele rechtstakken en de afwezigheid van de Usus als secundaire bron bij legislatieve artikels, er is ook de dominantie van de vorstelijke wetgeving over de urbane equivalent. Ook op het vlak van conflicten maakt de gewoonte geen overtuigende indruk. De voorbeelden waar de gewoonte primeert boven de wetgeving zijn immers te zeldzaam. Er mag mijns inziens dus wel degelijk gesproken worden van een bewuste lexificatie. Een voorafspiegeling van deze groeiende positie heb ik bovendien aangetroffen bij de toevoeging van de woorden oft placcaet van den prince, in artikel 1.1.14: Daervan men $t^{\prime}$ Antwerpen egeene besondere costuijmen, privilegien, ordonnantien, statuijten oft placcaet van den prince en heeft, noch de redene oft fondament der selver tot beslissinge van de saecken en dient, noch $t^{\prime}$ gemeijn gebruijck des lants ter contrarie en is, ismen gewoon int wijsen t'achtervolgen de gemeijne geschreven rechten. ${ }^{377}$ In artikel 6 van titel I van de Consuetudines impressae zag dit er nog als volgt uit: Ende daermen bier t'Antwerpen egheene besondere costumen, ordonnantien oft statuyt aff en heeft, ismen ghewoonlijk int wijsen te achtervolghen de ghemeyne geschreven rechten. ... ${ }^{378}$ Een formulering welke sterk gelijkt op die van 1570 finalis totius collectionis in antiquis: Ende daer men bier tAntwerpen egeene besundere costuymen, ordonnantien oft statuyten af en heeft, is men gewoonelyck int wysen te achtervolgen ende bem te reguleren naer de gemeyn geschreven rechten. ${ }^{379}$ Teruggrijpen naar het Corpus Iuris Civilis is in 1608 dus minder gemakkelijk dan voordien. Allereerst moet nu ook de vorstelijke wetgeving uitgeput zijn. Het toont nog maar eens het toegenomen belang aan van de wetgeving als (subsidiaire) bron van recht.

Uiteraard hebben deze conclusies repercussies voor het unificatievermogen van de vorst als soeverein, namelijk dat hij bij machte is zijn wetgeving hierbij in te schakelen. De omvang van het fenomeen inschatten en achterhalen in hoeverre dit doelbewust werd nagestreefd, vereist echter een andersoortig, comparatief onderzoek, waarbij verschillende compilaties en hun vorstelijke beïnvloede artikels met elkaar

377 Coutumes de la ville d'Anvers dites compilatae, III, 6. De Memorieboeken vertellen ons het volgende omtrent dit artikel 1.1.14: Est 6 in impressis et finalis totius collectionis in antiquis, nisi quos nos addidimus verbum privilegien, et post placcaet vande prince ex usu, et iterum noch de redene noch fondament der selver, unyt den landcharter D [omini] Jo[ann] is de anno 1292 art 54 in nostro exemplari ubi dicitur dat soo verre daer yet nieuws vuerquaeme tselve gehandelt soude wordden met schepenen naer eenich punct vande ordinnantie daer bet meest gelijck mede soude sijn, accordat jus civile in $L$ de quibus ubi d.d. in verbis, tunc quod proximum est ff. de legib [us] [senatusque consultis et longa consuetudine]. Molin [aeus] ad consuet [udo] Parisiensis tit 1 art 108 Motan[us] in tractatu de feudis lib. 1 cap. 4 post remum addidimus quoque verba, noch tgemeyn landtsrecht ter contrarien en is, ne pleraque videamur excludere que notorii usus sunt per totam provinciam contra leges juris scripti, que tam hic quam in Gallijs exoleverunt vel potius nunquam recept[a]e fuerunt, ut apud Bugnon et alios, dwelck groote inconvenienten souden mogen mede brengen, nisi exprimatur, cum omnium in particulari non possit fieri mensio.

378 Coutumes de la ville d'Anvers dites impressae, II, 2.

${ }^{379}$ Coutumes de la ville d'Anvers dites antiquae, I, 704. 
worden vergeleken. Ook studies naar eventuele bewuste acties in functie van de unificatie en vanwege de Geheime Raad als controlemechanisme, verdienen hier aangespoord te worden. Ik houd het bij de vaststelling dat de vorst wel degelijk het potentieel had deze unificatie te bewerkstelligen, althans dat tonen me de Memorieboeken. Later in deze paragraaf en vooral binnen hoofdstuk 2 zal ik aantonen hoe de vorst in dit opzicht hulp krijgt vanuit onverwachte hoek, namelijk wanneer ik het zal hebben over de costumiere acculturatie. Unificatie wordt immers bewerkstelligd op twee manieren: enerzijds via een bewuste politiek en al haar mogelijke instrumenten, anderzijds via onbewuste, toevallige acties. ${ }^{380}$

\section{Derden: actief en passief}

De vorst is echter niet de enige wereldlijke gezagsdrager die invloed wist uit te oefenen op het redactieproces van de Antwerpse costumen. Ook andere ambtsdragers en hogere overheden zijn in dit opzicht succesvol geweest. Zo heb ik reeds gewezen op de rol van de Geheime Raad als controleorgaan in een laatste fase van de homologatieprocedure en de obstakels welke de zoektocht naar haar invloed bemoeilijken. Hetzelfde kan en moet gezegd worden van de Raad van Brabant. Ook deze vergadering oefende een tussentijdse controlefunctie uit, zij het in een vroeger stadium van de redactieprocedure. Nadat een eerste tekstversie was opgesteld door de lokale overheden, werd deze namelijk ter controle naar de Raad van Brabant gezonden, waarna het becommentarieerde ontwerp opnieuw besproken werd door de lokale overheid. Bij Gilissen was reeds te lezen hoe groot de impact van zulk een vergadering -in dit geval de Raad van Vlaanderen met betrekking tot de costumen van Gent- wel niet kan zijn en hoezeer de raad kan fungeren als een bron van Romeinsrechtelijke beïnvloeding van het inheemse recht. In een periode van vijf jaar (1546-1551) werd de tekst meermaals en uitvoerig gewijzigd door de leden van de Raad van Vlaanderen, en later ook door die van de Geheime Raad, die uiteindelijk de homologatie ervan toestond in 1563. ${ }^{381}$ In de Memorieboeken ontbreken echter concrete

${ }^{380}$ De unificerende kracht van rechtspraakverzamelingen is hier nog niet aan de orde. (Cfr. S. DAUCHY, en V. DEMARS-SION, Les recueils d'arrêts et dictionaires de jurisprudence (XVIeXVIIIe siècles) (Collection bibliographie. II), Parijs, 2005, 19.) De eerste verzameling met betrekking tot de rechtspraak in de Nederlanden verschijnt pas in 1626. Het betreft de Practicarum quaestionum rerumque in supremis belgarum curiis actarum et observatarum decisiones van Paul van Christynen (1553-1631). Cfr. DEKKERS, Bibliotheca Belgica Juridica, 36; P. GODDING, "L'origine et l'autorité des recueils de jurisprudence dans les Pays-Bas Méridonaux (XIIIeXVIIIe siècles)", Rapports belges au VIIe Congrès international de droit comparé, Brussel, 1970, 15-17. Met betrekking tot de invloed van de rechtsleer en de rechtspraak op de unificatie van het Franse recht sinds de redactie van de costumen tot de Franse revolutie, zie: E. MEYNIAL, "Remarques sur le rôle joué par la doctrine et la jurisprudence dans l'oeuvre d'unification du droit en France, depuis la rédaction des Coutumes jusqu’à la Révolution, en particulier dans la succession au propres", Congrès international de droit comparé tenu à Paris du 31 juillet au 4 auôt 1900: procès-verbaux des séances et documents, 1905, Parijs, 269-309.

381 GILISSEN, "Romeins recht en inheems Gewoonterecht", 135. Gilissen heeft hierbij vooral aandacht voor het Romeinse recht dat langs deze weg gerecipieerd wordt in de Gentse costumen. 
verwijzingen naar de rol van de Raad van Brabant binnen het ganse redactieproces. De invloed die is uitgegaan van deze instantie laat ik hier bijgevolg achterwege. Maar dát er ook te Antwerpen wel degelijk invloed van de vergadering is uitgegaan, heb ik reeds in paragraaf 2 kunnen vaststellen. Er zijn niet alleen de jurisprudentiële activiteiten van de Raad welke, hoe bescheiden ook, worden aangewend als primaire rechtsbron, ook de uitstraling van haar procesrechtelijke ordonnantie van 1604 (Albertine Ordonnantie) heeft sporen nagelaten in het uiteindelijke ontwerp. ${ }^{382}$

Heel anders is de situatie met betrekking tot de zogenaamde magistratus. Onder deze 'magistraat van Antwerpen' moet de burgemeester en zijn schepenen verstaan worden. De Memorieboeken tonen dat zij er zeer in geslaagd zijn de Consuetudines compilatae gevoelig naar hun hand te zetten. Vast staat wel dat hij over het geheel van de Memorieboeken meer dan honderd maal wordt vermeld als actief deelnemer aan het redactieproces. ${ }^{383}$ Telkens gaat het om duidingen van de visie van de magistraat omtrent een welbepaald artikel en of er zijns inziens al dan niet wijzigingen moeten worden doorgevoerd. Dat hij ook daadwerkelijk over de macht beschikte zijn wil door te drukken blijkt uit de Memorien op de Costumen en staat buiten kijf. Indien de magistraat het namelijk nodig achtte zaken te wijzigen, dan gebeurde dit ook. Een voorbeeld hiervan is te vinden bij artikel 3.11.7 aangaande de prescriptie van roerende goederen: Est novus additus in hac postrema revisione ex iure scripto, nisi quod cum eo iure tantum constitutum esset triennum quod passim consuetudines Galliae sequuntur Melun cap 9 art

382 Dat men ook reeds a priori rekening hield met de positie van de Raad van Brabant binnen het homologatieproces, blijkt onder meer uit de artikels 5.1.41/42: Sunt desumpti ex articulo 21 inde voors[chreven] ordonnantie achter de gedructe costuymen et usus ita observat sed queritur quid iudicandum als de gedaechde de saecke verandtwoordt en [de] de schult ontkent nec aliquid adducitur quod iudicem merito moveat in contrarium an non reus absolvendum erit si iurare paratus est $i[n]$ certe ratio id videtur exigere ex generali regula actore non probante et posset hic suppleri nisi curia putet satius esse id relinquere dispositione iuris co[mmun]is quo nos quoque inclinamus. ('en dit zou hier toegevoegd kunnen worden tenzij de raad meent dat het volstaat dit over te laten aan de beschikking vanhet geleerde recht, welke ook wij genegen zijn.') Gezien de vereiste goedkeuring wordt reeds preventief rekening gehouden met de mogelijke opstelling van de provinciale curia. Dat men de Brabantse weg echter niet blindelings wil volgen, blijkt dan weer uit een aantal andere artikels. Zo wordt artikel 5.1.4 behouden, ondanks het feit dat de Raad in deze materie onlangs a contrario heeft geoordeeld: Est additus in hac revisione ex usu et conveniebat aliquid exprimere ne res tam clara in controversiam deducatur, ut tentatum fuit nuperrime in causa curatorum bonorum Iacobi Weymans \& Loys Peres de Baron cum suis sed curia in contrarium ar[ticu]lo iudicavit. Aangaande artikel 5.10.60 wordt dan weer gesteld dat men de stijl van de Raad aan de eigen stijl heeft aangepast: Est desumptus ex art 504 inde voors[creven] nieuwe ordonnantie vanden Raedt nisi quod eum accommodaverimus ad nostrum stilum. ${ }^{383}$ Dit is evident aangezien het in principe de taak van de plaatselijke magistraat was het lokale recht op te tekenen. Te Antwerpen besteedde hij deze opdracht grotendeels uit aan een commissie van lokale notabelen en ervaringsdeskundigen. (Cfr. MARTYN, Eeuwig edict, 152-153.) 
169 Amiens titulo 9 art. 163 Perone titulo $8^{\circ}$ art 214 et similes magistratui visum est temperare constituto bic quinquennio, ne quis temere dominio rerum suarum cadat, ut expresse etiam consuet [udo] Britanniae Minoris tit 15 art 385 sed cum nullibi quidquam statutum esset in casu quo titulus deesset, quod tamen satis necessum est ut fomenta litium praescindantur statutum est decennium ex iis q[uae] dicemus $i[n]$ articulo sequenti. Volstond daarentegen het voorgelegde ontwerp, dan bleef het ook zo behouden. Artikel 2.5.64, omtrent de Romeinsrechtelijke verplichting van bloedverwanten om als voogd op te treden, illustreert dit als volgt: Est etiam novus ne quis putet hac in re locum habere jus scriptum consanguineos obligans ad ipsam tutelam ut notant Faber ad \fin. instit de capit[is] diminut[ione] [lees, minutione] Bald[us] cons[ilio] 92 vel 4 Maseur in praxi tit de tutor. nu 24 aut ut consuetudines Galli[a]e interpretantur et capiunt ad damna et interesse nisi ultro eam suscipiat tanquam a lege ad is vocatus ut apud Aurelian[um] art 183 et Britan[niae] Minor[is] art 486. Sed sane illa satis rigida, et insolita moribus nostris quare magistratus censuit nihil innovandum.

Uiteindelijk zal de magistraat op deze manier maar liefst 64 verschillende artikels blijvend van uitzicht of inhoud weten te veranderen. ${ }^{384}$ Telkenmale treedt hij hierbij op als corrigerende of aanvullende hand, en bijgevolg dus niet als rechtstreekse bron van recht waaruit de regel in eerste instantie werd geput. Dit is overigens een rol die de magistraat, gezien zijn bevoegdheden verbonden aan zijn bestuurlijke functie, niet kan claimen. Terminologisch manifesteert deze houding zich voornamelijk als visum est, letterlijk vertaald als het lijket (hem) goed: Sunt novi in hac revisione ex ordinatione criminali de anno 1570 art 54 nisi quod magistratui visum sit adiicere poenam in advocat[o]s et procuratores, si contraveniant quia ab iis principaliter dependit. ${ }^{385}$ In het Nederlands klinkt het als volgt: Est 18 et 19 in impressis, 2 et 3 d ordin [atio] behalvens dat de magistraet in de leste revisie heeft goet gevonden den ouderdom van t'seventich jaeren te brenghen op t'sestich jaeren hoewel de geschreven rechten oock uuyt druckelijck spreecken van tseventich jaeren text in L 2 in princ[ipe] ff de excus[ationibus] tut. L unic[um] C qui [a]etate midts dat de 60 jaeren albier soo veele is als in Italien, ende elders inde beete landen 70 om de momboirije eenigen tyt bequaemelijck te mogen bedienen. 386 Andere mogelijke uitdrukkingsvormen zijn censuit ('hij oordeelt') of iussit ('hij beveelt'). Voorbeelden hiervan zijn terug te vinden bij respectievelijk artikel 2.1.212 omtrent de scheiding en deling van onroerende goederen (Est novus in hac postrema revisione positus in locum art 72 in impressis, 62 in antiquis, 50 in antiquissimis hoc tit et ibidem in antiquissimis tit van successien art 9 qui plane contrarium statuebant videlicet b[a]ec talia haberi pro acquisitis quod tamen absurdum, et fraudibus abnoxium censuit magistratus mutandum, want...) en artikel 3.4.31 aangaande renten en naasting (...id qu[a]e plerisque videretur valde durum ut revera est, iussit magistratus duos istos ar[ticu]los addi bona et manifesta ratione soe om dese actie die rigoureux genoch is eenichsints te besnyden besonder wesende genoch tegens de natuere van [de] rechten,...). Kortom, de magistraat moet, ondanks de uitbesteding van het compileren aan een commissie, zeer kort bij de redactie van de Consuetudines

384 Met het zee- en verzekeringsrecht incluis, loopt dit aantal op tot 73 . De rol van de magistraat blijft er met andere woorden zeer beperkt.

$3855.10 .2 / 3$.

386 2.5.46. 
compilatae gestaan hebben. De magistraat heeft het proces op de voet gevolgd en bijgestuurd waar hij dat nodig achtte.

Tabel 1.31 laat zien in welke mate deze 64 artikels over de verschillende delen verspreid zijn. Meteen wordt duidelijk dat de magistraat zijn invloed in zo goed als elk deel heeft laten gelden. Hij is niet alleen prominent maar ook voortdurend aanwezig. De percentages tonen aan dat hij zich, naast het materiële strafrecht, voornamelijk met het verbintenissenrecht van deel IV heeft ingelaten. Maar liefst één tiende ondergaat er zijn rechtstreekse invloed, en dit vooral binnen titel 4.16 ( $V$ an gebroken schuldenaers).

Tabel 1.31 Spreiding van het aandeel van de verschillende 'derden' over de verschillende delen

\begin{tabular}{|l|c|c|c|c|c|c|c|c|}
\hline Deel & I & II & III & IV & V & VI & VII & Totaal \\
\hline Magistraat (\%) & - & $4(2.0)$ & $12(4.5)$ & $34(10.7)$ & $7(2.3)$ & $6(7.3)$ & $1(2.2)$ & $64(5.6)$ \\
\hline Handelaars & - & - & - & 24 & - & - & - & 24 \\
\hline Erfscheiders & - & - & 10 & - & - & - & - & 10 \\
\hline Amptman & - & - & - & - & 8 & - & - & 8 \\
\hline Weeskamer & - & 4 & - & - & - & - & - & 4 \\
\hline Experts & - & - & - & 1 & - & - & - & 1 \\
\hline
\end{tabular}

Maar liefst een kwart of veertien van de 54 nieuwe artikels binnen deze titel hebben de invloed van de magistraat ondergaan. Het maakt van hem dé belangrijkste derde onder alle derden, zoals ik ze in paragraaf 2 heb leren kennen.

Waar de magistraat zelf het initiatief neemt en een eerder actieve rol voor zich opeist binnen het ganse redactieproces, kenmerken de overige subgroepen binnen de categorie van derden zich eerder door een passieve houding. Tegenover de eerder dwingende acties van gezagsdragers staat namelijk het meer 'demo- en technocratische' bevragen van derden bij wijze van inwinnen van advies. Omdat het initiatief hierbij niet zozeer van deze derden zelf uitgaat, spreek ik van passieve derden. Hen werd immers enkel om advies gevraagd; advies dat overigens niet bindend bleek te zijn, zoals op te maken is uit de Memorieboeken ten aanzien van artikel 5.9.64 betreffende het arresteren buiten de stad: Sunt novi in hac revisione om eenige oordre te stellen hoe en [de] in wat manieren datmen dese wete behoort te doen, daerinne tot noch toe groote faute is gewvest, oft beeft men de wete gedaen, en heeft men naermaels daeraff nyet connen doen blycken, daeruuyt vele inconvenienten rysen en [de] syn alle gestelt met advis vanden Amman, et usus tam bic quam in curia ita fere observat... ${ }^{387}$ De amptman adviseert. Meer nog, deze

387 Andere gelijkaardige gevallen betreffen suggesties (4.8.72: Est novus ex usu, et suggestione peritorum cui consentit d ordinatio Rhotomag[ensis] cap 6 art 6 et Brugens[is] tit 12 art $1^{\circ}$.) en opinies (4.8.62/63/64: Sunt omnes novis sed maxime necessarii ne sub pretextu conformationis rei usuries nauticiis ostium aperiatur ut fierit si versura id est permutatio unius debiti in aliud admittatur et ita statutum quoque in d ordinatione Rhot [omagensis] cap 19 art 2 nisi quod nobis in iudicio peritorum visum sit prosecutioni ponere certum tempus ne videlicet quis temere actione sua cadat et tamen fraudes usuraria[e] excludantur ut i[bi]. Of ook 4.8.78: Est novus ex usu, cui consentit ordinatio Rhotomag[ensis] d cap 5 art 34 nisi quod ex sententia tam negociatorum quam eorum qui assecuratoribus presunt visum sit addere clausulam en[de] 
groep van passieve derden beschikte -in tegenstelling tot de actieve derden- niet over de macht wijzigingen of voorstellen door te drukken. Dit blijkt sprekend uit de Memorieboeken aangaande artikel 3.5.100 omtrent het graven van grachten ter afbakening van het eigen erf. Hier behoeven de landmeters of erfscheiders de goedkeuring van de magistraat: Est 74 in antiquissimis quem mensores existimanerunt omnino restituendum, et magistrati approbavit,... Het voorbeeld toont nog maar eens het essentieel verschil tussen beide types van derden.

In principe kan de groep nogmaals opgesplitst worden, aangezien dit raadplegen van passieve derden twee verschillende oorzaken kan hebben. Ex una parte vloeit het initiatief voort uit een zekere welwillendheid rekening te houden met de grieven van belanghebbenden, zoals onder meer bij artikel 5.17.7, omtrent de executie van vonnissen, het geval is ten aanzien van de amptman: Est novus in hac revisione additus ad instantiam ammanni et convenit... ${ }^{388}$ Ex altera parte vindt het initiatief zijn oorsprong in de tekortkomingen van de commissieleden. In dit geval is men, wegens het gebrek aan kennis op het vlak van al te specifieke rechtsgebieden, verplicht een beroep te doen op de expertise van externe ervaringsdeskundigen of experts. Dit is voornamelijk het geval geweest bij het nieuwe zee- en verzekeringsrecht, maar heeft zich evenzeer voorgedaan met betrekking tot de overige verbintenisrechtelijke titels, zoals onder andere blijkt uit de artikels 4.3.39/40 inzake wisselbrieven: Sunt etiam novi additi in hac revisione ex contraria turba tusschen Goosserie, en [de] Roomen de anno 1601 paucis additis vel clarius explicatis ex suggestione mercatorum ut ratio decisionis appareret qua $[e]$ alioqui satis obschura. Op aangeven van de handelaars werden beide artikels deels aangepast, opdat ze helderder uitgelegd zouden worden. Nog duidelijker spreekt hun ingrijpende invloed echter uit de artikels aangaande het zee- en verzekeringsrecht. Bij wijze van voorbeeld verwijs ik naar de artikels 4.8.70/71 aangaande 'avarie': Sunt desumpti ex art 3 int voors[chreven] placcaet vande jaere 1563 hoc i[n] tit van schipbreking 16 et 37 int voors [chreven] oudt recht nisi quod loco verborum binnen corten tyt visum sit substituere certum et definitum tempus unius mensis ex consilio peritorum ne videlicet semper disputantum sit an navis intra breve tempus reparari potuerit an non ut in simili statutum etiam i[n] tit van versekeringe art 181 et $222 \mathrm{cum}$ seqq. Men zou het als volgt kunnen stellen: de groep van derden verschijnt waar de kennis verdwijnt.

Om wie gaat het nu concreet en wat is hun afzonderlijke impact geweest? Uit voorgaande tabel 1.31 blijkt dat de grootste subgroep die van de handelaars is. Naast de zee- en assurantierechtelijke titels concentreren hun adviezen zich eveneens binnen de overige commerciële titels en meer bepaald die omtrent de wisselbrieven (titel 4.3, negentien artikels) en de gebroken schuldenaars (titel 4.16, vijf artikels). De tweede grootste groep onder hen -ook al is dat met slechts tien nieuwe artikels zeer relatief- zijn de zogenaamde erfscheiders of mensores in het Latijn. Het is evident dat de invloed van deze landmeters zich beperkt tot de titels 3.5 (Van gebuerelijcke rechten ende servitueten) en 3.6 ( $V$ an erffscheijdinge, oft maniere van vervolch tot onderhout van

dat die taemelyck, en[de] matel[yck] syn cur enim nautis permittamus in re aliena liberales, et profusus [?] esse, cum etiamsi in votis exe[r]cessissent illa moderari debeant ex consilio et arbitria theologorum).

388 5.17.7. 
gebuerelijcke recbten). ${ }^{389}$ In derde instantie is er de amptman. Dat het in wezen gaat om een hertogelijk ambtenaar binnen de stad en de rol van de magistraat indachtig, maakt dat ik hem eerder bij het actieve type verwachtte. Toch blijkt zijn macht bij het redactieproces beperkt. Op basis van de Memorieboeken kan ik zijn rol immers enkel maar als passief omschrijven. Van enige concentratie kan bovendien nergens sprake zijn. Een laatste subgroep wordt gevormd door de leden van de weeskamer. Het spreekt voor zich dat de vier nieuwe artikels welke ex suggestione van de instelling en/of haar leden werden opgenomen in de Consuetudines compilatae, zich concentreren binnen de grenzen van titel 2.5 omtrent de voogdij. Bij twee van hen wordt zelfs heel specifiek naar de graphyarii van diezelfde instelling verwezen. ${ }^{390}$ Tot slot wil ik nog wijzen op de totale afwezigheid van eender welke derde ten aanzien van zowel het materiële als het formele strafrecht. ${ }^{391}$

Het zee- en verzekeringsrecht verdient in dit opzicht een bijzondere aanpak. Omwille van de specificiteit van het onderwerp en het gebrek aan ervaring van de commissieleden dienaangaande, tref ik hier een uitzonderlijk hoog aandeel van passieve derden aan. Tabel 1.32 geeft weer om wie het exact gaat.

Tabel 1.32 Aandeel van de verschillende 'derden' in de zee- en verzekeringsrecbtelijke titels

\begin{tabular}{|l|l|l|}
\hline Derden & Titel 4.8 & Titel 4.11 \\
\hline Experts & 32 & 70 \\
\hline Handelaars & 4 & 15 \\
\hline Onderhandelaars & 4 & 14 \\
\hline Schippers & 1 & - \\
\hline Verzekeraars & 1 & 29 \\
\hline Theologen & 1 & - \\
\hline
\end{tabular}

Men blijkt in de eerste plaats periti te raadplegen. Wat exact onder deze term verstaan moet worden, is binnen de Memorieboeken niet aan de orde. Gaat het om ervaringsdeskundigen in de zin van leden van de belangengroep in kwestie -dus handelaars- of suggereert men het inroepen van advies van meer geleerde kenners in de zin van theoretici? Louter op basis van de Memorieboeken lijkt het me onmogelijk deze vraag te beantwoorden. Wel is het zo dat belangengroepen doorgaans expliciet bij naam worden genoemd. Anderzijds heb ik mijn twijfels bij de consequentie waarmee de redacteurs met deze terminologie zijn omgegaan. Ook om de externe adviseurs, waarvan sprake is in de collegiale akte van 15 oktober 1592 ter

${ }^{389}$ Een helder voorbeeld is terug te vinden in de Memorieboeken ten aanzien van artikel 3.5.19: Est novus in hac postrema revisione additus by suggestie ende aengeven vande erffscheyders et profecto [a] equissimum est dat soo wanneer daer geene gote en beeft gelegen den gebuer alsdan een deel vanden cost draege op dat den anderen nyet te seer en worde belast.

390 Cfr. 2.5.112/113: Uterque est novus ex annotatis, et suggestione graphyarij camera pupillaris, et satis necessarius,...

391 Verder wordt er binnen de titel ook gesproken over de consensu cantoris. (Cfr. 2.5.123: ..., addidimus autem de consensu Cantoris,...) Hiervan heb ik de betekenis echter niet weten te achterhalen. 
samenstelling van de commissie, lijkt het mijns inziens niet te gaan. ${ }^{392}$ Daar is namelijk enkel sprake van periti met betrekking tot deel IV, terwijl de heren, die door Gotzen als externe adviseurs worden vermeld, ook met betrekking tot de andere delen bedrijvig zijn geweest. ${ }^{393} \mathrm{Ik}$ houd het dus voorlopig bij de abstracte uitdrukking 'experts'.

De prominente aanwezigheid van andere belangengroepen als handelaars, schippers en verzekeraars is evident. Het vierde deel bevat maar liefst 500 en meer nieuwe zeeen verzekeringsrechtelijke artikels. Dat hun impact bovendien zo groot is, is vermoedelijk ook een gevolg van hun dominante, sterke maatschappelijke positie binnen de Antwerpse sociale structuur. Dit belang van de handel voor de stad uit zich niet alleen in de omvang van het vierde verbintenis- en handelsrechtelijke deel, maar eveneens in de betrokkenheid van deze sociale laag bij het redactieproces. ${ }^{394}$ Hoewel de zo goed als kritieke levensader van de Antwerpse economie sinds 1585 leek afgesneden, blijft de handel voor Antwerpen van essentieel belang. Deze kip met de gouden eieren moet verwend worden. Desalniettemin blijkt hun opstelling bij het compilatieproces eerder passief van aard te zijn. Slechts in één enkel geval is er nadrukkelijk sprake van een verzoek vanwege de handelaars. Het betreft artikel 4.3.69 omtrent wisselbrieven: Est etiam additus in hac revisione ad requisitionem mercatorum, et habet rationem cum in dubio pra[e]sumendum sit pro litteris, sed videtur quod ad maiorem energiam possit addi sub finem al waert dat den presenteerder oock maer naeckt mandataris vanden seynder vanden brieff en waere et ita usus observat. Vijf andere artikels onderscheiden zich van de overige artikels op aangeven van de handelaars, in die zin dat zij de nadrukkelijke goedkeuring hebben gekregen van alle handelaars. ${ }^{395} \mathrm{Er}$ lijkt een vorm van referendum te hebben plaatsgevonden. Bij wijze van voorbeeld verwijs ik naar de artikels 4.16.35/36/37 inzake 'gebroken' kooplieden: Sunt quoque novi ex usu et communi voto mercatorum accordant statuta Genuens[ium] lib 4 cap 6 art incip[it] si creditores cum art incip[it] excludantur semper fol 102 nisi quod ibi requiratur consensus vande seven achtste gedeelten dwelck te seer precis is en [de] qualyck practicabel en [de] daeromme is beter gevonden te blyven byde costuyme vande borse pra [e] sertim cum proxime accedat ad ius commune vide text in L iuris gentium $7 \int$ fin et in L maiorem $8 \mathrm{ff}$ de pactis et pro 37 text in L si precedente $58 \int 1^{\circ} \mathrm{ff}$ mandati [vel contra]. De 'gemeenschappelijk stem van de handelaars' ligt aan de basis van deze

392 ANTWERPEN, Stadsarchief, Vierschaer, nr. 64: Extract uyt den Collegiael acteboeck van D'Heeren Wethouderen der Stad Antwerpen, 15 oktober 1592.

393 Cfr. infra, hoofdstuk 1, paragraaf 3, Derden: actief en passief. GOTZEN, "De costumiere bronnen", 114.

394 Cfr. GUYON, "Annotations de la coutume de Bordeaux", 300. Ook te Bordeaux spreekt de auteur van een invloedrijke positie van de handelaars uit de stad: "On peut cependant souligner une autre logique dans les textes des coutumes. Elle est conduite par le groupe influent des bourgeois marchands. Ceux-ci ont intérêt à avoir un droit spécifique, plus technique, moins dépendant des règles féodales et qui lui assure davantage de sécurité dans ses transactions (par exemple des règles précises en matière commerciale) on qui lui permette une meilleure conservation des biens dans les familles (d'où les dispositions relatives au droit matrimonial et successoral) ou qui assure aux habitants de la ville une meilleure protection des personnes et des biens et aménage la rigueur nouvelle du droit pénal et de la procédure."

395 4.16.35/36/37, 4.16.67/68. 
regel. Kortom, de handelaars werden nauw betrokken bij de totstandkoming van het zee- en assurantierecht. 396

Naast de handelaars wekt vooral de groep van de onderhandelaars de aandacht. Wie waren zij? En tussen welke twee groepen werd er door hen bemiddeld? Louter op basis van de Memorieboeken ben ik niet in staat hieromtrent uitsluitsel te geven. Omdat ze enkel in de titels omtrent het zee- en verzekeringsrecht voorkomen, vermoed ik dat hun identiteit ook binnen dit milieu gezocht moet worden.

Uiteraard heeft deze invloed van derden zijn consequenties voor de algemene zuiverheidsgraad van het Antwerpse gewoonterecht zoals het in de Consuetudines compilatae te boek werd gesteld. Wat betreft de derden van het passieve type ben ik geneigd te veronderstellen dat zij naar eer en geweten hebben gehandeld en de commissieleden op de hoogte hebben gebracht van de werkelijk gangbare gewoonten. Ook in de Memorieboeken worden hun uitspraken grotendeels bevestigd door de gewoonte. Voorbeelden hiervan zijn er te over, zoals met betrekking tot artikel 3.5.68 inzake lickteeckenen van gemeijne oft eijgen mueren: Est novus in hac postrema revisione additis by suggestie ende aengeven vande erfscheyders et usus ita observat. ${ }^{397}$ De ratio die de regel in zich draagt, kan hierbij nog een aanvullende reden zijn, zoals op te maken is uit de artikels 3.5.98/99 aangaande servituten van hoven en landerijen: Sunt novi addito in bac ultima revisione ex usu et suggestione vande voers[chreven] erfscheyders et habet bonam et aequitabilem rationem.

Wat het actieve type daarentegen betreft, liggen de kaarten mijns inziens anders. Daar lijkt een grotere vrijheid te bestaan en bijgevolg ook een grotere variëteit aan redenen welke aan de basis kunnen liggen van de doorgevoerde wijzigingen. Vooral de magistraat toont zich hierin zeer creatief. Voorbeelden van zijn vindingrijkheid zijn in de Memorieboeken terug te vinden ten aanzien van artikels als 3.4.31 omtrent renten en naasting (... iussit magistratus duos istos ar[ticu]los addi bona et manifesta ratione soe om dese actie die rigoureux genoch is eenichsints te besnyden besonder wesende genoch tegens de natuere van [de] rechten, die op sekeren pant geset synde aenden selven gebonden, en [de] alsoe gerestringeert behooren te syn sonder voorder obligatie, al waert oock dat den pandt arger werdt oft oock te nyet ginck,...) en 6.1.33/34 omtrent het omhakken van iemand anders bomen (Est XXV in antiquissimis sed ibi dicitur dat den affhouner hoc casu soude verliesen syn byff en[de] goet quod magistratui visum nimis durum nec ulla ratione sustineri posse ideoque natigavimus statuta pena quadrupli als nyet en blyckt van groote moetwillicheyt et si de ea patet, den ban, en [de] arbitrale correctie, quod certe satis poenarum est pro damno reparabili.) Een andere motivatie kan zijn

396 Desalniettemin blijkt hun stem niet altijd doorslaggevend geweest te zijn. Er bestaan namelijk voorbeelden waarbij zij het onderspit moeten delven tegen andere types van rechtsbronnen zoals bijvoorbeeld de vorstelijke wetgeving omtrent het verzekeringsrecht. Ter illustratie verwijs ik naar artikel 4.11.6: Uterque est novus in hac revisione contra communem quidem usum mercatorum die de priseringe met pact expres hebben willen toelaeten ut videtur etiam statutum inde voors[chreven] ordonnan [tie] van Rouwaenen d cap 2 art 12 et seqq en [de] in die van Brugge tit 4 art $1^{\circ}$ maer alsoo t'selve d'ordonnantie vande placcaeten teenemael illusoir soude maecken midts dat nyet te twyfelen en is... 397 Andere vergelijkbare situaties doen zich voor bij onder andere de artikels 3.6.16, 5.9.64 en 5.9.94. 
dat de magistraat in de desbetreffende materie het geleerde recht wil navolgen. Dit blijkt onder andere uit artikel 3.7.11 omtrent de timmeragien die een vruchtgebuiker maakt op de desbetreffende grond: Est 66 in antiquissimis d tit[ul]i van successien, quem magistratus censuit restituendum nam licet de iure scripto proprietarius videatur obligari ad maiores restaurationes quando necessariae sunt, adeo quidem ut si usufructuarius eas fecit eas repetere po[ss] it $d$ L eum qui [lees, eum ad quem] $7^{a} C$ de usufructu [lees, usu fructu] [et habitatione et ministerio servorum], ... Op basis van 6.3.23, omtrent de lijfstraf bij doodslag, blijkt dit echter geen prioriteit te zijn: Est desumptus ex articulo 28 et 33 in antiquiss[imis] tit van administratie van iustitie int criem nisi quod magistratus iudicans necessarium illum moderari ne quis putet eum procedere in omni homicidio id enim esset contra ius quo constat... Soms blijft een verantwoording ook geheel afwezig, zoals in artikel 7.8.18 inzake de betaling van zoenpenningen: Est novus bic additus in postrema revisione ex ordinatione vande peyscamer vanden xii novemb[er] 1509 behalvens dat de pene aldaer is gestelt op 20 ... [?] en[de] inde voorgaende ordonnan[tie] vanden jaere dertienhondert sessenyyftich was die van 50 ouden tournoys ende op zoenbrake, magistratu[s] visum sufficere dat de pene gedobbleert worde. Kortom, de voorbeelden tonen aan dat de confirmatie door de Usus niet expliciet of noodzakelijk hoeft te zijn, met de nodige gevolgen voor het costumiere karakter van het geredigeerde recht.

Samenvattend wil ik concluderen dat Antwerpen zich als een mooi voorbeeld van 'technocratisering' van het geredigeerde gewoonterecht manifesteert. Er is namelijk de opvallende invloed van verschillende passieve derden, welke zijn oorsprong hoofdzakelijk kent in de behoefte an expertise of tekortkomingen van de commissieleden en deels in de welwillendheid van diezelfde commissarii. Maar van een zeker 'democratisch' idealisme vanwege de redacteurs kan, als verklaring voor de prominente rol der derden, geen sprake zijn. Zulk een aanpak bemoeilijkt immers nog meer de besluitvorming. De enige democratische sporen heb ik bij de handelaars en hun referendum teruggevonden. Deze technocratisering wordt op zijn beurt gecompenseerd door de (autoritaire) wijze waarop de magistraat zijn wil weet door te drukken.

Dat men overigens beroep doet op externe adviseurs verbaast me niet. Reeds in de collegiale akte van 15 oktober 1592 werden de 'novateurs' aangespoord de hulp van niet-commissieleden in te roepen waar zij dit nodig achtten. De akte somt de leden van de nieuwe commissie op ende met alsulke andere practiaynen als bun geraeden sal duncken tot bun te assumeren, ... 398 Gotzen stelde op basis van de verslagen van de zittingen van de commissie vast dat aldus volgende personen hebben meegewerkt: Martens (deel I en II), De Witte en Lums (deel III), Valckenisse en De Weerdt (deel IV), Greyns (deel V), Raeckt (deel VI en VII). ${ }^{399}$ Met andere woorden, het ligt voor de hand dat in de Memorieboeken ook wordt verwezen naar de opinie van belanghebbenden en ervaringsdeskundigen als daar zijn de handelaars-verzekeraars, de erfscheiders, weesmeesters, maar ook schippers en zelfs onderhandelaars. Dat men hierbij veel

398 SAA, Vierschaer, 64: Extract uyt den Collegiael acteboeck, 15 oktober 1592.

399 GOTZEN, “De costumiere bronnen”, 114. 
respect betoonde voor de Usus, spreekt in het voordeel van de zuiverheid van het Antwerpse costumiere recht. Enkel daar waar de magistraat zich in het debat mengt, is deze zuiverheid niet langer gegarandeerd.

\section{Romanisatie en humanisme}

Dat het Romeinse recht altijd een groot aanzien heeft genoten, is verre van een boude stelling. Als bron van recht kent ze in de Europese rechtsgeschiedenis nauwelijks haar gelijke. De invloed van het Romeinse recht op de vele iura propria van het Europese vasteland behoort dan ook tot één van de vroegste processen van beïnvloeding. Voordien bestond het costumiere recht daarentegen in zijn zuiverste, ongeschreven vorm en was het zowel naar inhoud als procedure nog ver van het geleerde recht verwijderd. ${ }^{400}$ Hoewel de Justiniaanse leges in middeleeuws Europa nooit de status van vigerend recht hebben verworven, zouden zij dit via de penetratie van het gewoonterecht wel weten te bewerkstelligen. Vanaf de twaalfde eeuw, nadat ook de studie van het geleerde recht weer op gang was gekomen, gaan meer en meer invloeden het geldende gewoonterecht infiltreren. Lesaffer neemt binnen dit fenomeen van bevruchting een dubbel proces waar, dat bestaat uit enerzijds receptie en anderzijds acculturatie. Onder receptie van het geleerde recht verstaat men de overname van inhoudelijke elementen uit het geleerde recht door het eigen costumiere recht. Acculturatie duidt daarentegen op het proces waarbij het eigen recht zich vormelijk aanpast in de richting van het geleerde recht. Alzo interpreteert Lesaffer acculturatie licht verschillend van Van den Auweele, die overigens als eerste dit onderscheid tussen receptie en acculturatie maakte, waarbij hij acculturatie eerder zag als het identiteitsverlies van een lagere, costumiere rechtscultuur ten aanzien van een hogere, geleerde rechtscultuur. ${ }^{401}$ Ook in Frankrijk is er sprake van acculturation juridique. Bij Poumarède gaat het echter om de romanisatie van de costumen in de zin van penetratie van Romeins recht in het gewoonterecht, wanneer hij spreekt van juridische acculturatie. ${ }^{402}$ Gezien de verscheidenheid aan interpretaties lijkt het me raadzaam een aantal terminologische herzieningen voor te stellen, welke meer duidelijkheid moeten scheppen. De weg naar eender welke wetenschappelijke waarheid is immers geplaveid met een consistente terminologie. Mijns inziens gaat het bij juridische acculturatie in wezen om het aanpassen van het recht van cultuur $\mathrm{x}$ aan het recht van cultuur y. Dit kan op twee manieren gebeuren. Ofwel 'recipieert' men materiële regels afkomstig van de andere cultuur (receptie); ofwel past men zich vormelijk aan de hogere rechtscultuur (assimilatie). Bij receptie gaat het dus om de overname van positief recht, zowel materieel als procesrecht. 403 Assimilatie daarentegen duidt op de vormelijke aanpassing van $\mathrm{x}$ aan $\mathrm{y}$. Dit kan gaan om taalkunde, terminologie, systematisering, formuleringen, etcetera. De letterlijke

\footnotetext{
${ }^{400}$ Cfr. LESAFFER, Inleiding tot de Europese rechtsgeschiedenis, 243-248.

${ }^{401}$ LESAFFER, Inleiding tot de Europese rechtsgeschiedenis, 244. Lovanium docet, 28-29.

402 POUMAREDE, "Droit romain et rédaction des coutumes", 330.

403 Omtrent de verschillen tussen impositie, transplantatie en receptie als verschijnselen waarbij recht van de ene omgeving in een andere wordt opgenomen, zie: M. RHEINSTEIN, “Types of reception", Annales de la Faculté de droit d'Istanbul, 6 (1956), 31-40.
} 
overname van de formulering van een juridische norm, of die nu ook in het eigen ressort van kracht was of niet, is bijvoorbeeld een vorm van assimilatie, net als de overname van de structuur volgens dewelke een tekst werd opgebouwd, of de overname van bepaalde termen. Wanneer een 'geassimileerde' regel voordien niet van kracht was in de 'assimilerende' cultuur y, dan is er tevens sprake van receptie. Ook inhoudelijk werd de regel overgenomen. Kortom, acculturatie bestaat uit twee hoofdfacetten, namelijk receptie en assimilatie, waarbij het ene het andere niet noodzakelijk uitsluit. Beide kunnen zich zowel afzonderlijk als gezamelijk voordoen.

Dit dubbel proces van acculturatie, dat dus zowel receptie als assimilatie inhoudt, kent bovendien twee fasen. Een eerste daarvan start in de twaalfde eeuw wanneer Romeinsrechtelijke elementen, zowel inhoudelijk als vormelijk (romano-canonieke procedure), via het kerkelijke recht de kerkelijke rechtbanken binnensijpelen. Een tweede fase omvat de beïnvloeding van de seculiere iura propria. In les pays du droit écrit (Italië, Zuid-Frankrijk en Spanje) komt deze reeds in de dertiende eeuw op gang. Les pays $d u$ droit coutumier in het noorden moeten wachten tot de veertiende, vijftiende en zelfs zestiende eeuw. Bij de optekening van het eigen recht fungeert het geleerde recht als intellectuele context waarin het eigen recht zich ontwikekelde en hielp om de tekortkomingen van dat laatste te bestrijden, aldus Lesaffer. ${ }^{404}$

Deze rol ontsproot uit het prestige dat het geleerde recht stricto sensu kende als ratio scripta. Het Romeinse recht werd namelijk door allen als de geschreven rede bij uitstek gepercipieerd. Het maakte het zeer geliefd, zowel bij de toenmalige juristen als onder hedendaagse rechtshistorici. De Romeinsrechtelijke invloed op of romanisatie van het gewoonterecht is dan ook een verschijnsel dat in het verleden reeds veel aandacht heeft genoten binnen het rechtshistorische bedrijf en dit over gans West-Europa. Gezien het belang van de Franse rechtsleer voor de landen van 's herwaarts over wil ik hier in de eerste plaats de aandacht vestigen op een aantal Franse auteurs die zich op dit thema hebben toegelegd. Jacques Krynen vatte, in zijn studie omtrent de verhouding van de koning van Frankrijk tot de gewoonte, de wetenschappelijke inzichten aan het einde van de twintigste eeuw samen in een kort inhoudelijk en bibliografisch overzicht. 405 Bovendien wijst de auteur op de mythe van de zuivere gewoonte. Klimrath toonde immers reeds in zijn standaardwerk uit 1843 aan dat de Franse coutumes doordrongen waren van zowel Romeins als canoniek recht, jurisprudentiële precedenten en legislatieve documenten. Reeds vanaf de eerste officieuze compilaties kan er dus al sprake zijn van enige rechtsgeleerde invloed op verschillende fronten. Alles wijst er op dat het op punt stellen van de lokale costumen zich in het licht van het Romeinse en canonieke recht heeft voorgedaan. En gezien de rol van universitair gevormde gerechtelijke officieren en koninklijke commissarissen binnen het (Franse) officiële redactieproces, ontsnapt dus ook hier geen enkele compilatie aan deze invloeden. 406 Ondanks het feit dat verscheidene rechtshistorici dit reeds voor tal van verschillende Franse provinciale costumen hebben aangetoond, is

${ }^{404}$ LESAFFER, Inleiding tot de Europese rechtsgeschiedenis, 247. Cfr. STEIN, Roman law in European bistory, 83.

${ }^{405}$ Cfr. supra, hoofdstuk 1, paragraaf 1, Status quaestionis.

${ }^{406}$ Cfr. supra, hoofdstuk 1, paragraaf 1, Status quaestionis. 
men -onterecht- ten aanzien van hieropvolgende redacties -dus ook de officiële redacties van de vijftiende en de zestiende eeuw- steeds blijven spreken van compilaties van lokale gewoonten, waar in werkelijkheid de zuiverheid van de gewoonte niet langer gegarandeerd kan worden, aldus Krynen. ${ }^{407}$ Ook uit mijn onderzoek bleek dit in Antwerpen niet anders geweest te zijn. De variëteit aan rechtsbronnen, welke ik in paragraaf 2 heb tentoongespreid, zegt voldoende. Desalniettemin blijft de echte hamvraag in hoeverre deze vreemde invloeden zich onderscheiden van de gangbare gewoonten. Enkel wanneer er werkelijk contradicties bestaan tussen de inhoud van beide bronnen, kan ten aanzien van de zuiverheid van de costumen terecht gesproken worden van een mythe.

Wat de Nederlanden betreft, is het de afgelopen decennia omtrent de romanisatie van het gewoonterecht betrekkelijk stil gebleven. Synthesewerken als Le droit romain en Belgique (1966) van Van Caenegem en Römisches Recht in den Niederlanden (1968) van Hermesdorf lijken eerder een afschrikwekkend dan motiverend of inspirerend effect gehad te hebben en bovenal schijnen zij de indruk gewekt te hebben dat het werk zo goed als voltooid was. ${ }^{408}$ Niets is echter minder waar. Zoals overigens ook al uit deze standaardwerken bleek, mankeren de Nederlanden detailstudies naar de bronnen van het geredigeerde gewoonterecht. ${ }^{409} \mathrm{Er}$ is mij geen enkele studie bekend waarin de juridische basis van het costumiere recht van een bepaalde Belgische of Nederlandse stad, regio of provincie onderzocht werd. In tegenstelling tot Frankrijk is er wat onze contreien betreft vooral weinig geweten over de costumen die na 1500 tot stand zijn

407 KRYNEN, "Voluntas domini regis", 76.

408 Beide werken zijn verschenen in de reeks Ius Romanum Medii Aevi. (VAN CAENEGEM, Droit romain. HERMESDORF, Römisches Recht.) Het werk van Van Caenegem sluit sterk aan bij een vroegere studie van Gilissen: GILISSEN, "Romeins recht en inheems Gewoonterecht", 97-139. Centraal in deze werken staat de penetratie van het Romeinse recht in het gewoonterecht en de verschillende wegen waarlangs deze heeft plaatsgevonden. Hierbij wordt er veel aandacht geschonken aan de rol van juristen aan alle mogelijke hoven, evenals andere administratieve en bestuurlijke instellingen. Verder is er de beschikbaarheid in de Nederlanden van rechtsgeleerde werken van zowel allochtone als autochtone juristen. Ook de rol van de vorst als propagateur van de subsidiariteit van het Romeinse recht komt aan bod. Beide auteurs hebben in globo oog voor gelijksoortige factoren. Wel betreurt Van Caenegem in zijn werk het ontbreken van studies die de interne geschiedenis van het fenomeen behandelen. Een lacune die gedeeltelijk pas in 1987 zal worden ingevuld met het verschijnen van Goddings Le droit privée dans les Pays-Bas méridionaux du $12 e$ au 18 e siècle. Hierin is steeds ruimte gelaten voor de invloed van het Romeinse recht op de verschillende privaatrechtelijke rechtsfiguren. Ook Hermesdorf botste in dit opzicht nog op een tekort aan ondersteunend onderzoeksmateriaal.

${ }^{409}$ Nergens ben ik meer dan enkele verdwaalde uitspraken over de invloed van het Romeinse recht op het lokale, costumiere recht tegengekomen. Ik denk bijvoorbeeld aan de uitspraken van Gilissen met betrekking tot de costumen van Gent, en in mindere mate ook Ieper. (GILISSEN, "Romeins recht en inheems Gewoonterecht", 135-136.) Concrete detailstudies, die zich uitsluitend met het onderwerp bezighouden, ontbreken. In vergelijking met Frankrijk doet dit pover aan. Anderzijds moet natuurlijk ook het juiste bronnenmateriaal voor handen zijn dat zulk een onderzoek mogelijk maakt. 
gekomen. Nog niet lang geleden, in 1996, verwoordde Georges Martyn in zijn proefschrift aangaande het Eeuwig Edict van 1611 zijn bezorgdheid om het ontbreken van diepgaande studies per ressort. ${ }^{410}$ En ook an Nederlandse zijde deelde Frank Keverling Buisman in 2000 dit ongenoegen. ${ }^{411}$ Hij wees er bovendien op in hoeverre de voor handen zijnde studies zich focussen op de middeleeuwse landrechten en hoe weinig aandacht ze hebben voor alles wat na 1600 tot stand was gekomen. De auteur beëindigde zijn betoog met een oproep tot meer rechtsvergelijkend onderzoek. Aan deze oproep zal ik in een tweede hoofdstuk gehoor geven.412

De andere lacune omtrent de detailstudies naar de rechtsbronnen hoop ik in dit eerste hoofdstuk reeds van antwoord gediend te hebben en meer nog hoop ik een eerste aanzet gegeven te hebben tot verder onderzoek. Onderzoek dat zich overigens niet alleen beperkt tot de identificatie van het lappendeken aan juridische bronnen welke ten grondslag hebben gelegen aan de costumiere compilaties, maar ook onderzoek dat verder durft te kijken, meer bepaald naar de wijze waarop deze verschillende bronnen zich tot de Usus als causa consuetudo verhouden. Zoals zonet aangegeven, biedt enkel zulk een aanpak, waarvan ik me ook in deze derde paragraaf zal bedienen, een oplossing aangaande het mythevraagstuk omtrent de zuiverheid van de gewoonterechtelijke redacties van de nieuwe tijd. Teneinde deze queeste tot een goed einde te brengen zal ik vooreerst ingaan op de houding van de Antwerpse commissieleden tot het Romeinse recht en hoe zij dit hanteren in relatie tot het costumiere recht van de stad. Dit zal overigens boeiende uitspraken opleveren die een bijdrage leveren tot het derde luik van onze studie, namelijk dat omtrent de sporen van juridisch humanisme. ${ }^{413}$

Op basis van de beschikbare literatuur mag men dus verwachten dat er ook te Antwerpen reeds heel wat Romeins recht zijn weg naar de costumiere compilaties had gevonden. In de Nederlanden kreeg de penetratie van het geleerde recht immers vrij spel van zodra men zich in de late middeleeuwen ook hier ontvankelijk ging opstellen. Een houding die resulteerde in een situatie waarbij tijdens het homologatieproces van de Nederlandse costumen in de zestiende en zeventiende eeuw het Romeinse recht bij tal van hen officieel een subsidiaire rol kreeg toebedeeld.414 Ook in de handelsmetropool aan de Schelde was dit het geval. In de Consuetudines compilatae ziet het Romeinse recht zijn voorname rol bevestigd met artikel 1.1.14: Daervan men $t^{\prime}$ Antwerpen egeene besondere costuijmen, privilegien, ordonnantien, statuijten oft placcaet van den prince en heeft, noch de redene oft fondament der selver tot beslissinge van de saecken en dient, noch $t^{\prime}$

\footnotetext{
410 MARTYN, Eeuwig edict, 155.

${ }^{411}$ KEVERLING BUISMAN, 'Mer 't is geen lantrecht', 8-9. Klassiek in dit opzicht is dat ook de status quaestionis van Van der Wouw zich wederom tot de middeleeuwen beperkt. (H. VAN DE WOUW, "Opmerkingen over de aandacht voor het Romeinse recht in de Middeleeuwen”, Tijdschrift voor Rechtsgeschiedenis, 61 (1993) 337-341.)

412 Keverling Buisman lijkt evenwel Goddings Droit privé over het hoofd te zien.

${ }^{413}$ Cfr. infra, hoofdstuk 3.

414 Cfr. J. GILISSEN, “A propos de la réception du droit romain”, Revue du Nord, 40 (1958), 367. KOOIKER, Lex scripta abrogata, 9-24.
} 
gemeijn gebruijck des lants ter contrarie en is, is men gewoon int wijsen t'achtervolgen de gemeijne geschreven rechten. 415 In de Consuetudines impressae zag dezelfde maatregel er nog als volgt uit: Ende daermen bier t'Antwerpen egheene besondere costumen, ordonnantien oft statuyt aff en heeft, ismen ghewoonlijk int wijsen te achtervolghen de ghemeyne geschreven rechten. 416 Een formulering welke sterk gelijkt op die van 1570 finalis totius collectionis in antiquis: Ende daer men bier tAntwerpen egeene besundere costuymen, ordonnantien oft statuyten af en heeft, is men gewoonelyck int wysen te achtervolgen ende hem te reguleren naer de gemeyn geschreven rechten. 417 Het is duidelijk. Deze subsidiaire rol voor het Romeinse recht gaat veel verder terug dan 1608.418 In 1547 daarentegen is er bij de Consuetudines antiquissimae echter nog geen sprake van een gelijkaardige clausule. Enkel artikel 19 van titel V omtrent de administratie van justitie int civile verduidelijkt iets over het recht dat geldt binnen de muren van de stad: Item, der stadt recht is geintroduceert by costumen, ende costumen soe langhe onderbouden datter, gheene memorie en is ter contrarien, maken reebt ende moeten onderhouden worden voer der stadt recht. ${ }^{419}$ Van de subsidiariteit van andere rechtsbronnen is hier nog geen sprake.

Voorgaande artikelen geven echter ook blijk van steeds strenger wordende voorwaarden vooraleer er naar het Romeinse recht teruggegrepen mag worden. Iets wat tevens blijkt uit de tekst van de Consuetudines compilatae zelf. Zo stelt het artikel 4.1.3 het geschreven recht te volgen, voor zover dit niet in tegenspraak is met de landsheerlijke wetgeving of de eigen stedelijke rechten: "Soo wanneer nocbtans de gemeijne rechten toelaten dat men eenige contracten oft onderbandelingen, die sekeren ende besonderen naem bebben, ende daeromme in de rechten geheeten worden nominati, vermach te scheijden, tselve beeft naer deser stadts recht oock plaetse, ten waere dat vijitdruckelijck bij eenige placcaten van den prince, oft

415 Coutumes de la ville d'Anvers dites compilatae, III, 6. De Memorien op de Costuymen zeggen dienaangaande het volgende: Est 6 in impressis et finalis totius collectionis in antiquis, nisi quos nos addidimus verbum privilegien, et post placcaet vande prince ex usu, et iterum noch de redene noch fondament der selver, uuyt den landcharter d[omini] Jo[ann] is de anno 1292 art 54 in nostro exemplari ubi dicitur dat soo verre daer yet nieuws vuerquaeme tselve gehandelt soude wordden met schepenen naer eenich punct vande ordinnantie daer het meest gelijck mede soude sijn, accordat jus civile in $L$ de quibus ubi d.d. in verbis, tunc quod proximum est ff. de legib [us] [senatusque consultis et longa consuetudine]. Molin[aeus] ad consuet [udo] Parisiensis tit. 1 art 108 Motan[us] in tractatu de feudis lib. 1 cap. 4 post remum addidimus quoque verba, noch tgemeyn landtsrecht ter contrarien en is, ne pleraque videamur excludere que notorii usus sunt per totam provinciam contra leges juris scripti, qu[a]e tam bic quam in Gallijs exoleverunt vel potius nunquam recepte fuerunt, ut apud Bugnon et alios dwelck groote inconvenienten souden mogen mede brengen, nisi exprimatur, cum omnium in particulari non possit fieri mensio.

416 Artikel 6, titel I (Coutumes de la ville d'Anvers dites impressae, II, 2). In het traktaat van de Moy staat hierover te lezen dat dit subsidiaire principe conform de geschreven rechten is. (SAA, Vierschaer, 21: DE MOY, Tractaat fol. 5v.) Men verwijst er naar de lex C.7.62.32.6 (Quidquid autem hac lege specialiter non videtur expressum, id veterum legum constitutionumque regulis omnes relictum intellegant). (Cfr. NEVE, "Ius commune", 3-58.)

417 Coutumes de la ville d'Anvers dites Antiquae, II, 704.

${ }^{418}$ Dat men ook werkelijk naar deze regel handelde, wordt mooi geillustreerd aan de hand van de Memorieboeken omtrent artikel 3.14.15: “...ex generali regula, quod ibi consuetudo deficit, recurrendum sit ad ius commune..."

${ }^{419}$ Coutumes de la ville d'Anvers dites antiquissimae, I, 194. 
bij de selve stadts rechten, anders waere versien." 420 Er heeft zich als het ware een autoritatieve degradatie van het Romeinse recht voorgedaan. Waar in de Consuetudines antiquae en de Consuetudines impressae onmiddellijk naar het Justiniaanse recht teruggegrepen mocht worden van zodra de eigen costumen noch de stedelijke wetgeving geen oplossing meer boden, moet vanaf 1608 ook eerst de prinselijke -lees vorstelijke- wetgeving evenals de ratio als bron van recht uitgeput zijn. De invloed van de gemeyn geschreven rechten wordt met andere woorden beknot. ${ }^{421}$

Een gelijkaardig signaal bereikt ons vanuit de collegiale akten uit deze periode. Wanneer er commissies ter redactie van de Antwerpse costumen moesten worden samengesteld, werd er immers expliciet om verzocht het eigen, lokale recht te toetsen aan of te vergelijken met de ratio scripta van het Romeinse recht. Zo staat er in de collegiale akte van 18 juli 1578 met betrekking tot de redactie van de Consuetudines impressae het volgende te lezen: “...om tomschrijven ende te revideren de costuymen des stadt ende die te confereren met den geschreven rechten ende ...". ${ }^{422}$ Een opdracht die nogmaals letterlijk herhaald werd in de akte van 18 juli 1580 met betrekking tot de samenstelling van de tweede commissie belast met de compilatie van de Consuetudines impressae. ${ }^{423}$ In de collegiale akten aangaande de commissies die instonden voor de voltooiing van de Consuetudines compilatae, verdwijnt deze passage daarentegen: "...ende costumen op den nieuws te oversien, ende te visiteren ende de selve te corrigeren, veranderen ende redresseren, daer men bevinde zal van noode te zyne, ende van alles naderhant aen Myne Heeren voors. rapport doen om't

\footnotetext{
${ }^{420}$ Coutumes de la ville d'Anvers dites compilatae, IV, 2. Zie ook artikel 3.11.11: "Item, alle actien ende gerechticheden, die naer de dispositie van rechte hebben den tijt van vijff jaeren ende daeronder, worden oock. albier geprescribeert binnen den selven tijt daertoe naer rechte geordonneert, ten waere bij placcate oft ordonnantie minderen oft meerderen tijt daertoe waere gestelt." (Coutumes de la ville d'Anvers dites compilatae, III, 504.)

${ }^{421}$ In dit opzicht wil ik hier tevens verwijzen naar zestiende-eeuwse rechtsgeleerden zoals Charles Dumoulin en Guy Coquille, die pleitten voor een subsidiaire rol van het gemene droit français, dat als geheel van regels, gemeenschappelijk aan alle regionale costumen, ideaal werd bevonden ter opvulling van lacunes binnen de lokale costumen. Beide auteurs moesten evenwel toegeven dat ook dan een beroep op het Romeinse recht onvermijdelijk was om alle lacunes opgevuld te krijgen. In hun aanzien was het Corpus Iuris evenwel verworden tot subsidiair recht van de laatste instantie. In die zin bestaan er raakvlakken tussen wat de Consuetudines compilatae ons leren en deze voorstanders van het gemene Franse recht. (STEIN, Roman law in European history, 85.) Ook het eerste hoofdstuk van Warembourgs proefschrift omtrent Guy Coquille en het Franse recht omschrijft deze émancipation du système du 'jus commune'. (N. WAREMBOURG, Guy Coquille et le droit français. Le droit commun coutumier dans la doctrine juridique du XVTe siècle, Ongepubliceerd doctoraatsproefschrift, Université de Lille II, Faculté des sciences juridiques, politiques et sociales, 2005, 34-124.)

422 SAA, Privilegiekamer, 552, fol. 204r-204v.

423 SAA, Vierschaer, 64: Acte collegiale. 18 juli 1580.
} 
selve gehoort, ..." ${ }^{424}$ Kortom, de geschreven rechten boeten aan belang en dus ook aan gezag in. ${ }^{425}$

Dit komt niet alleen de lexificatie van het gewoonterecht ten goede, zoals ik reeds eerder heb aangetoond. ${ }^{426}$ Deze vaststellingen passen tevens binnen de idee van een veronderstelde invloed van het juridisch humanisme op de redactie van het gewoonterecht. ${ }^{427}$ Uit de syntheseliteratuur blijkt hoezeer de houding ten overstaan van het Romeinse recht aangewend kan worden als criterium voor het aanwijzen van een humanistische ingesteldheid. ${ }^{428}$ Met de humanisten wijzigt immers de opstelling ten overstaan van antieke bronnen grondig: "De bumanisten verwierpen de absolute gezagswaarde, de auctoritas, van de oude teksten. De bumanisten erkenden dat de bronnen wit de Oudheid menselijke creaties waren, producten uit een afgesloten tijdvak, afkomstig van een verdwenen beschaving. Ze droegen niet de volledige, volmaakte en tijdloze waarheid in zich. ... Van dragers van een tijdloze, omvattende waarheid werden de teksten tot kenbronnen van de hoogste menselijke beschaving die ooit had bestaan." 429 Ten aanzien van de antieke, juridische bronnen, zoals het Corpus Iuris Civilis, was dit niet anders. Ook deze compilatie mocht vanaf nu haar universele pretenties opbergen. Deze nieuwe houding waarbij men niet langer het geleerde recht aanzag als een dogmatisch referentiekader of als de ultieme juridische autoriteit waaraan het eigen, lokale recht getoetst moet worden, mag gerekend worden tot een van de verdiensten van de humanistische rechtsgeleerden. Deze démarche betekende echter niet dat het Romeinse recht onverzoenbaar was geworden met het actuele recht. Het zou altijd een belangrijke bron van inspiratie voor de eigen tijd blijven, een bron waaraan ontleend kon en mocht worden. ${ }^{430}$

424 SAA, Vierschaer, 64: Extract uyt den Collegiael Acteboeck van b[ee]ren Wethouderen der Stad Antwerpen. 30 mei 1586.

425 Dit blijkt mogelijk ook nog eens uit het de prominente rol die niet-Romeinsrechtelijke thema's als het zee- en verzekeringsrecht binnen de compilatie krijgen toebedeeld. (Cfr. WATSON, Legal Transplants, 39.)

${ }^{426}$ Cfr. supra, hoofdstuk 1, paragraaf 3, Lexificatie.

${ }^{427}$ Dit fenomeen zal in het derde hoofdstuk centraal staan. (Cfr. infra, hoofdstuk 3.)

428 Cfr. STEIN, Roman law in European history, 75e.v. VAN DEN BERGH, Geleerd recht, 64-71. LESAFFER, Inleiding tot de Europese rechtsgeschiedenis, 315-325. KOSCHAKER, Europa en het Romeinse recht, 105-108.

${ }^{429}$ LESAFFER, Inleiding tot de Europese rechtsgeschiedenis, 306 en 312. Deze gezagswaarde blijkt mooi uit de wijze waarop de middeleeuwse juristen het Romeinse recht zonder voorbehoud als zuivere ratio scripta of geschreven rede beschouwden. Ter verduidelijking wil ik verwijzen naar Poumarède die ten aanzien van de redactie van de verschillende coutumes in het ressort van het Parlement van Bordeaux ook kon vaststellen dat men er nog zeer middeleeuws te werk ging. De ware doelstelling van de hele onderneming was het moderniseren van het gewoonterecht aan de hand van de rede. De juristen verantwoordelijk voor de redactie kende echter slechts één ratio en dat was die van het geschreven Romeinse recht. Bijgevolg correspondeerde een appel à la raison met een recourir au droit romain, aldus Poumarède. (POUMAREDE, "Droit romain et rédaction des coutumes", 330.)

430 Dit blijkt eveneens uit de manier waarop Christofle de Thou de hervorming van de reeds geredigeerde Franse coutumes tijdens de tweede helft van de zestiende eeuw benaderde. SeongHak Kim schrijft hieromtrent het volgende: "De Thou s'enforce ainsi d'introduire dans les coutumes 
Hierbij was het evenwel van belang dat het historisch begrip van het Romeinse recht gerespecteerd bleef. Het Romeinse recht toepassen op de eigentijdse praktijk, in die mate dat er een loopje werd genomen met de correcte interpretatie van dat recht zoals de Bartolisten steeds hadden gedaan, werd niet langer aanvaard. Ik kan het niet beter omschrijven dan Lesaffer: "Voor sommige problemen bood het Romeins recht een oplossing. Dat werd dan overgenomen in de zin dat men het eigen recht aan het Romeinse voorbeeld aanpaste. Bood het Romeins recht geen oplossing, dan zocht men een andere oplossing. Soms vond men daartoe een gedeeltelijke inspiratie in het Romeinse recht. Als men dan een Romeinsrechtelijke regel aanpaste en vervormde, deed men dat bewust. Het werd niet meer voorgesteld als een overname uit het Romeins recht, maar als een gewilde aanpassing. Op die manier hoefde men de historische werkelijkheid niet te verdraaien." 431

Zulk een omgangsvorm spreekt ook uit de Memorieboeken. Enerzijds bekleedt het Romeinse recht er een vergelijkende functie, ongeacht haar eventuele conformiteit met het lokale recht. Anderzijds blijft receptie van datzelfde recht een optie, al dan niet in licht gewijzigde vorm, aangezien gerecipieerd Romeins recht geen schending van de lokale rechten mocht impliceren. Eventuele wijzigingen worden ook openlijk toegegeven. Uit beide vaststellingen blijkt de prioriteit van de gewoonte over het geleerde recht in strikte zin. Ik zal dit alles verduidelijken aan de hand van een reeks voorbeelden uit de Memorien op de Costumen. Ik heb alle artikels onder ogen genomen waarin zowel de Usus als het Romeinse recht een bepalende rol hebben gespeeld, en in geen enkel geval moet de gewoonte als bron van recht inboeten ten voordele van het Romeinse recht. ${ }^{432}$ De Usus prevaleert steeds, zoals onder meer blijkt uit artikel 3.14.97 omtrent de scheiding en deling van de goederen van de echtgenote: Est novus, et quidem contra ius novellarum ut in Auth. quod locum, $C$ de collat [ionibus] et novella 97 de [a] equalitate dotis unde sumpta est cap 6 sed usus nunc aliter observat et merito, cum ius in eo potissimum fundetur quod mulier in potestate patris constituta dotem exigere non posset, et ita sibi

certaines innovations venant du droit romain qu'il estime apporter un complément utile au droit coutumier. [...] Il cherche effectivement à améliorer les coutumes par une romanisation partielle et prudente. Ces idées de Christophe de Thou représentent l'essentiel de l'humanisme juridique français." (SEONG-HAK KIM, "Christophe de Thou et la reforme de coutumes", 94.) Verder in de tekst verduidelijkt de auteur de Thou's fundamentele bezorgdheid te komen tot billijke oplossingen. Uiteindelijk besluit Seong-Hak Kim als volgt: "Sa réforme des coutumes a ainsi permis en France une réception sélective du droit romain, alors qu'en Allemagne cette réception a été massive. Elle révèle donc les manifestations nationales de l'bumanisme juridique au XVTe siècle." (SEONG-HAK KIM, "Christophe de Thou et la reforme de coutumes", 101.)

431 LESAFFER, Inleiding tot de Europese rechtsgeschiedenis, 321.

432 Slechts een enkele keer heb ik kunnen vaststellen dat een Romeinse lex, het zij in samenwerking met een artikel uit de Criminele Ordonnantiën van Filips II (1570), het Antwerpse recht, zoals dat eerder in de Consuetudines impressae neergeschreven stond, kon vervangen. Dit is het geval geweest bij artikel 2.5.30 uit de Consuetudines compilatae omtrent de vermomboorde die met een misdaad wordt belast: Est novus loco art 75 in impressis, cum quo accordat consuet [udo] Gandens[is] rubr. 22 art 13 sed cum juris dispositio in $L$ clarum $C$ de author[itate] pr[a]estanda, et ordinatio criminalis anni 1570 art 61 contrarium disponant, idque ad maiorem securitatem et defentionem pupillorum et minorum pertineat, visum est veterem consuetudinem hac ex parte mutare et reducere ad jus commune. 
cavere, quod nostris moribus cessat, ideoque in Galliis eandem novellam etiam abrogatum esse testatur Molin[aeus] ad Dec[io] in L ea demum $6 C$ de collat[ionibus].433 Hoewel de leges uit het Corpus Iuris Civilis tegengesteld zijn aan de heersende gewoonte, respecteert en behoudt men deze laatste. ${ }^{434}$ De voorrang blijkt nogmaals uit artikel 4.6.20 inzake het eisen van interest, welk nieuw was op basis van de Usus en slechts gedeeltelijk afweek van het Romeinse recht, maar waarbij de notoire Usus dit terecht heeft gewijzigd, zowel hier als in Frankrijk: Sunt etiam novi in hac revisione ex usu et ius non dissentit nisi in debito ex causa venditionis sed notorius usus id merito mutavit tam bic quam in Galliis cum odio usurarum tum quod... Het artikel geeft duidelijk blijk van de openheid ten aanzien van doorgevoerde wijzigingen aan het Romeinse recht. Nog een voorbeeld vind ik bij artikel 3.11.11 omtrent de prescriptie van actien en gerechtigheden: Est novus sed satis necessarius, ne videamur particulares prescriptiones a iure scripto introductas excludere, quas usus hic admittit, veluti quod interdicta annalia sint vel brevioris temporis, quod actio reddibitoria, et quanti minoris annalis vel semestris, quod restitutiones in integrum quadriennales, quod nullatis questio in rebus minorum quinquennalis post minorem aetatem et similes accordat consuetudo Gandensis rub. decima nona articulo $2^{\circ}$ nisi quod nos tempus triennii ibi statutum putavimus ad quinquennium producendum ut videlicet tempus restitutionis in integrum minorum et similes prescript [iones] comprehendantur, et ne alioqui multas prescriptiones variarum actionum quas tanquam odiosas lex arctiore tempore constringendas esse censuit, puta ad summum quinquennio ad 30 annos produxisse videamur, contra quam usus et recta ratio admittit, sed videtur quod stilus que non satis apertus possit dilucidius ita poni, item alle actien oft gerechticheden die naerdere dispositie van rechte bebben den tydt van vyff jaeren ende daeronder worden oock albier geprescribeert binnen den selven tydt. Enkel die uitzonderingen worden toegestaan, welke ook de Usus toelaat. Het primeren van de gewoonte boven het Romeinse recht blijkt evenzeer uit het feit dat laatstgenoemde steeds in overeenstemming diende gebracht te worden met de Usus, zoals ook tot uiting komt ten aanzien van artikel 2.5.183 omtrent het einde van de voogdij en de mogelijke schulden van de vermomboorde bij de voogd: Est etiam novus ex L 1 in princip[e] ff de contr[aria] tut[elae] et utili act[ione] nisi quod nos addiderimus de cautione invicem pr[a]estandae et namptisatione facienda, quando debitum non esset liquidum ex usu, et ut vicissim aliquo modo consuleretur tutori qui non facile aliquid impendet in rem pupilli nisi sciat se recepturum quod impendit ut aut text in $d L 1$. Wanneer er echter geen sprake is van

${ }^{433}$ Een ander voorbeeld vind ik bij artikel 4.9.11: Est etiam novus et quidem contra ius quo certum est societatem morte unius socii semper finiri neque adeo pacisse posse ut heredes succedant nisi respectu conductionis vestigalium L nemo potest 35 L adeo morte socii 59 ibi Mudeus ff pro socio sed usus tam hic quam alibi contrarium observat et sane qua[e] de iure scripto traduntur subtilitates fere sunt cum constet commoda et damna societatis etiam eo iure saltem continuari et transmitti posse ad heredes licet revera societas non sit $L$ actione distrabitur $65 \int$ morte 9 ff eodem.

${ }^{434}$ Een ander voorbeeld is te vinden bij artikel 2.4.11: Est etiam novus, et quidem contra jus, text in $d$ novel[lam] 74 cap 1 et 2 in princip[e] et d novel[lam] 89 cap 9 etiam in princip[e] sed qui generali consuetudine tam huius patrie quam totius fere Europa est approbatus et nominatum de Gallijs testatur Bacquet [ius] ubi i[bi] quamvis magna ratio stet pro jure scripto, ut a concubinatu tanto facilius transeatur ad matrimonia et quod extra ordinarium remedium non videatur admittendum, ubi ordinarium superest, quo idem effectus subsequatur, isque potentior, sanctior, et favorabilior tam parenti quam liberis Curia deliberet et videat, an articulus addmitti debeat, in ijs ubi est magna disparitas, et matrimonium pro dignitate et conditione alterius ignominiosum, aut parum conveniens futurum esset, in alijs autem servetur jus commune. 
conflicterende opinies en de Romeinse rechtsregels dus in hun geheel gerecipieerd werden, dan ging dit in de overgrote meerderheid van de gevallen gepaard met een bevestiging van de gerecipieerde lex door de Usus. Bij wijze van voorbeeld, citeer ik hier de Memorieboeken aangaande artikel 3.14.104 en het inbrengen van goederen in het sterfhuis: Est additus in hac revisione ex d novella 97 de equalitate dotis cap 6 et usus ita observat. Het lijkt erop dat Romeinsrechtelijke zaken -conform de humanistische principes- behouden blijven zolang de gewoonte haar goedkeuring geeft. ${ }^{435}$ Deze opstelling laat overigens eveneens aanpassingen of uitbreidingen toe op basis van het Romeinse recht, zolang deze niet strijdig zijn met de eigen gebruiken. Klaarblijkelijk is de innovatieve rol van het ius commune nog niet helemaal uitgespeeld. Dit blijkt onder andere grotendeels uit artikel 2.5.120 omtrent de situatie wanneer eenige penningen van de weesen gecommen sijn in handen van de momboors: Est desumptus ex $d$ art 42 circa finem addito tantum dat de wedth[ouders] oft weesmeesters de penninghen souden moeten laeten onder de momboirs, ut ha[e]c aliquo modo reduceremus ad jus commune, quo tutor pecuniam retinere poterat modo id aperte faceret, et palam se debitorem constitueret, et profiteretur text in L quoties 9 I non tantum 7 L non existimo 54 ff de administ[ratione et periculo] tut[orum et curatorum qui gesserint vel non et de agentibus vel conveniendis uno vel pluribus].

De voorbeelden spreken voor zich. De gezagswaarde van het Romeinse recht is aanzienlijk gedegradeerd en de prioriteit van de Usus is manifest. Het Romeinse recht wordt in alle transparantie aangepast waar nodig en verder fungeert het louter als vergelijkingsmateriaal, ongeacht het nu conform of a contrario de gewoonterechtelijke regel is. Beide rechtsbronnen worden als op zichzelf staande entiteiten beschouwd en de onderlinge verschillen worden gerespecteerd. De zuiver comparatieve taak van het Justiniaanse recht blijkt uit velerlei artikels. Bij wijze van voorbeeld verwijs ik naar artikel 4.2.16 inzake genoechsaem bewijs van ijmants hantschrift. Est etiam novus in hac revisione ex usu et ius non dissentit. De geschreven rechten wijken niet af. Hetzelfde doet zich voor ten aanzien artikel 3.11.20 inzake het breken van de prescriptie: Est etiam novus contra ius scriptum, sed quem usus approbavit tam hic quam in Galliis eleganter Argentreus ad consuetudines Britanniae Minoris articulo 266 et Le Guenois ad conferentias consuet[udines] Galliae fol. 140 versiculo ad l[itte]ram $Z$ babetque rationem,... Beide rechtsbronnen zijn

435 Slechts een uitzonderlijke keer heb ik geen confirmerende Usus aangetroffen. Artikel 6.2.18 is hier een voorbeeld van: Est additus et suppletus in hac revisione ex Aucth. sed hodie C ad l[egem] Iuliam de adult [eriis coercendis] et novella 134 cap 10 unde illa desumpta et quod id etiam hodie observetur in Galliis patet ex Papone in arrestis lib 22 tit 9 art 2 et 5 olim sub inff [?] nam antiqutas fortassis aliud fuit pena adulterii erat mors, $L$ castitati $9 L$ quamvis $30 \mathbb{\int}$ sacrilegiis $C$ ad l[egem] Iuliam de adult[eriis coercendis] quod hodie vix obtinet nisi adulterio iunctus sit incestus, $L$ si adulterium cum incestu ibi dd ff eod[em] Papon d tit 9 art 7 vide qua[e] diximus $i[n]$ art 13 et 14 hoc tit et art 127 tit van gehoude persoonen. Een ander voorbeeld betreft de artikels 6.1.41/42. Hier wordt het Romeinse recht enkel door extern gewoonterecht bevestigd: Sunt etiam desumpti ex iure scripto et pro priori est textus elegans in L eum qui nocentem 18 in princip[e] ff de iniuriis [et famosis libellis] pro altero textus in $L$ fallaciter 9 cum seqq $C$ de calvum $L$ qui crimen $3 C$ de iis qui accus[arunt] non poss[unt] $L$ fin $C$ de accusat[ionibus et inscriptionibus] late Anton [ius] Faber in suo Codice Fabriano d tit de accusat definit[ione] 2 et 3 Le Guenoys de conferentiis consuet[udines] Gallia[e] fol $153 v$ [er] so ad l[itte]ram O et ita expresse etiam cavetur consuet [udines] vicinor [um] locorum Gandens [is] rubr 41 art 10 Bourbon cap 8 art 164 et seqq Avergnia[e] cap 29 art 12 et seq La Marche art 336 et seqq. 
strijdig met elkaar, maar zoals reeds eerder aangetoond, primeert de gewoonte. Andere uitdrukkingsvormen van een vergelijkend Romeins recht vind ik bij artikel 7.3.22 omtrent het respect dat getoond moet worden voor het lichaam van een gevangene wanneer deze wordt gefolterd: Est quoque novus et additus in hac revisione ex usu et consuet[udo] Ultraiect[ensis] rub 37 art 5 et consentit ius commune text in L questionis modus [lees, quaestionis modum] $7 \mathrm{ff}$ de qu[a]estion[ibus], et in L item apud labeonem $15 \int$ sed et si iussu $42 \mathrm{ff}$ de iure iur[ando] Menoch[ius] de arbitr[ariis] iud[icium] quaest[ionibus] lib $2^{\circ}$ cent 3 casu 271. Bovendien is het zelfs mogelijk dat men aangeeft hoe het artikel met behulp van het Romeinse recht verbeterd zou kunnen worden, maar dat men hier -uit respect voor de gewoonte- van af ziet. Dit is zo ten aanzien van artikel 2.5.76, dat handelt over de 'testamentaire momboor' die niemand in zijn plaats als voogd mag aanstellen: Est 65 in impressis ex usu et ex eodem usu, et iure scripto posset addi exceptio ad finem, ten waere dat hij de momboirije maer voor seeckeren tyt, oft tot seeckeren gevalle badde aenveert, met consent van de weth oft weesmeesters, ende dat den selven tyt, oft geval oock gecommen waere et articulus erit plenior, et pertinebit etiam ad utilitatem pupillorum, ut saltem pro certo tantopere commidium, securum, et sibi utilem tutorem inveniant. Materiële controle heeft aangetoond dat de conjunctieve wijs van posse op zijn plaats is. De clausule werd immers nooit aan dit artikel toegevoegd, hoewel ze het artikel plenior of 'meer volkomen' zou maken. 436 Ik kan zelfs nog een stap verder gaan wanneer ik mij concentreer op het belang van de ratio binnen gans deze nieuwe houding. Romeinsrechtelijke leges worden gerecipieerd voor zover ze een zekere rationaliteit (ratio) en billijkheid (aequitas) in zich dragen. Een Justiniaanse lex dankt zijn receptie niet langer ex ratione auctoritatis, maar gold nu imperii rationis. ${ }^{437}$ De Memorieboeken vatten dit mooi samen in het kader van artikel 2.1.98 omtrent de giften en testamenten van gehuwde personen: Sunt omnes novi, quibus pr[a]edictae veteres et nov[a]e consutudines [lees: consuetudines] quodam modo temperantur et ad rationem reducuntur ex dispositione juris communis, in L f[o]emin [a]e ff de secund[is] nupt[iis] ne alioque nimis effusa libertate disponendi concessa, si millis limitibus subijciatur liberis prioris coningij nimium pr[a]eiudicetur dum rebus a parente suo relictis, et ad secundum matrimonium translatis plerumque fraudantur, ut quotidiana experientia docet. Met dit nieuwe artikel worden de oude en nieuwe costumen met elkaar in overeenstemming gebracht met het oog op de creatie van rationeel recht en met respect voor het dagdagelijkse gebruik. Hierbij verantwoordt de rationaliteit de receptie van geleerd recht stricto sensu. De rol van de ratio ten aanzien van het Romeinse recht blijkt des te meer uit de talloze keren dat er bij de receptie van geschreven recht verwezen wordt naar de redelijkheid van het recht (Est novus ex ratione iuris...) en uit de mate waarin de billijkheid de nieuw geïntroduceerde regel confirmeert (...enim aequissimum est). ${ }^{438} \mathrm{Ik}$ meen te mogen concluderen dat de Usus en de ratio hoger als bron van recht worden ingeschat dan Rome.

436 Hoewel dit voorbeeld betrekking had op een oud artikel uit de Consuetudines impressae, was dit even goed mogelijk ten aanzien van de nieuw toegevoegde artikels.

${ }^{437}$ Cfr. WAREMBOURG, Guy Coquille, 81-87. Ook bij Franse humanisten als Coquille wordt het Romeinse recht in de eerste plaats als ratio scripta erkend.

438 Dat deze ratio en aequitas ook bij andere bronnen aan bod komen, wijst erop dat het Romeinse recht niet langer als enige bron van redelijkheid beschouwd werd, zoals men dat in 
Het feit dat het Corpus Iuris Civilis niet langer beschouwd werd als de onaantastbare autoriteit, impliceerde dus niet dat het ook haar intrinsiek hoge waarde als bron van rationeel recht verloren had. ${ }^{439}$ Ondanks de kwalen van een handschriftelijke traditie als die van het Corpus Iuris, welke door de humanisten aan het licht werden gebracht, bleven tal van regels 'recipieerbaar', ook voor deze humanisten. Of, zoals bij Van den Bergh te lezen staat: "Ratio vincit, vetustas cessit." 440 De rede overwint, de oudheid vervalt. Bedoeld wordt dat het verleden zijn greep op het heden verliest en dit ten voordele van de rede. ${ }^{441}$ De auteur vermeldt dit in het kader van het natuurrecht en het Romeinse recht, maar dit kan even goed betrekking hebben op de manier waarop de redacteurs zich in de Memorieboeken blootgeven. Het Romeinse recht verliest haar absolute gezag, maar blijft bruikbaar voor zover het rationeel is. Bijgevolg zijn ook bij de Consuetudines compilatae -net zoals dat reeds bij de Consuetudines impressae het geval was- heel wat innovaties gestoeld op het rationele, Romeinse recht. ${ }^{42}$ Met een aandeel van achttien procent zijn de Justiniaanse leges, exclusief het te verwaarlozen canonieke recht, goed voor een totaal van 234.5 nieuwe artikels. ${ }^{443}$ Bijgevolg nemen zij een voorname plaats in onder de verschillende, primaire rechtsbronnen. Met het zee- en assurantierecht meegerekend komt hun aantal op 243.5. Tabel 1.33 laat de spreiding zien van dit geschreven recht als primaire bron over de verschillende delen van de Consuetudines compilatae.

Tabel 1.33 Aantal artikels, absoluut en relatief, op basis van het Romeins recht per deel

\begin{tabular}{|l|c|c|c|c|c|c|c|}
\hline & I & II & III & IV & V & VI & VII \\
\hline Absoluut & 3 & 64 & 66 & 55.5 & 20 & 12 & 14 \\
\hline Relatief (\%) & $4 \%$ & $33 \%$ & $25 \%$ & $17 \%$ & $7 \%$ & $15 \%$ & $30 \%$ \\
\hline
\end{tabular}

de middeleeuwen gewoon was. (POUMAREDE, "Droit romain et rédaction des coutumes", 330.)

${ }^{439}$ Cfr. STEIN, Roman law in European history, 79.

${ }^{440}$ VAN DEN BERGH, Geleerd recht, 84.

441 Humanistische rechtsgeleerden waren immers op zoek naar de best mogelijke tekst, gebruikmakend van een kritische houding waarin de ratio de meest doorslaggevende factor was. (Cfr. VAN DEN BERGH, Höllandische elegante Schule, 109-121.) Een vergelijkbare opvatting is terug te vinden in Reulos' analyse van de wijze waarop de Franse praktizijnen het juridisch humanisme vertaalden in hun bezigheden: "Car ce qu'il y a d'essentiellement humaniste, c'est que le droit forme un tout et constitue une partie intégrante de la formation bumaniste. Le droit, c'est un tout qui doit donner satisfaction à un certain nombre de préoccupations; que le problème posé soit résolu par le droit romain ou par le droit coutumier, cela n'a pas d'importance, tant qu'on s'attache aux principes." (M. REULOS, "L'importance des praticiens dans l'humanisme juridique", in Pédagogues et juristes (De Pétrarqua à Descartes. 4), Parijs, 1963, 128.)

${ }^{442}$ Cfr. SAA, Vierschaer, 21: DE MOY, Tractaat, fol. 1r. Ook Jacques van Uffel, fervent voorstander van de Consuetudines impressae, lijkt de receptie van Justiniaans recht, ondanks het vreemde karakter ervan, te aanvaarden en bewaart het stilzwijgen. De commentaren van de juris periti op dit geleerde recht verdienen zijns inziens echter geen kans. (SAA, Vierschaer, 64: VAN UFFEL.)

${ }^{443}$ Men spreekt voornamelijk van gescreven rechten en ius scriptum. Zeldzamer zijn termen als ius civile (2.5.155) en ius romano (2.5.71). 
Deze romanisatie 'rationele stijl' strekt zich voornamelijk uit over vijf verschillende delen. De over- of ondervertegenwoordiging ervan en de bijpassende verklaringen werden reeds uitvoerig besproken in paragraaf 2 van dit hoofdstuk. Het publiekrechtelijke deel I en het burgerlijk procesrecht van deel V zijn in het licht van de romanisatie nauwelijks het vermelden waard. Hun innovaties worden voornamelijk door de Usus geïnspireerd gezien de specifieke, eigen traditie die aan de basis ligt van beide rechtsgebieden. Ook het gemiddelde aandeel van het Corpus Iuris bij het verbintenissenrecht van deel IV verbaast me niet. Het is het logische gevolg van de symbiose tussen de eigen ontwikkelde contractuele regels enerzijds en de hierop volgende Romeinsrechtelijke beïnvloeding vanaf de zestiende eeuw anderzijds. Ook het zesde, strafrechtelijke deel onderging een romaniserend effect wat zich qua omvang in het midden houdt. ${ }^{444} \mathrm{Bij}$ het strafprocesrecht was deze invloed dan weer meer uitgesproken, zij het louter relatief. Het Romeinsrechtelijk aandeel van dertig procent binnen deel VII correspondeert er namelijk met niet meer dan veertien nieuwe artikels. Drie andere rechtsgebieden spannen de kroon: het personenrecht, het goederenrecht en het erfrecht. Hier liggen twee zaken aan de oorsprong van deze uitgesproken romanisatie. Hetzij betreft het de uitwerking van titels omtrent typisch Romeinsrechtelijke rechtsfiguren, hetzij vloeit deze romanisatie voort uit de beïnvloeding van oorspronkelijk costumiere aangelegenheden door het Romeinse recht. In beide gevallen kan er gesproken worden van een werkelijke, materiële receptie van Romeinse recht. ${ }^{45}$ Deze daadwerkelijke receptie past perfect in het beeld dat we erover te zien krijgen bij auteurs als Van den Bergh en Lesaffer, en waar ik reeds eerder op gewezen heb. ${ }^{446}$ Ook de humanistsiche wetenschap bleef immers een praktisch doel voor ogen hebben: "Verklaring en toepassing van het Corpus Iuris bleven het middelpunt van alle rechtsgeleerde activiteit." 447 Men kan spreken van een zeker samengaan van een humanistische, kritische grondhouding met de bartolistische bruikbaarheid van het Corpus Iuris. Uiteindelijk zou dit leiden tot bewegingen als de Usus Modernus Pandectarum. In zekere zin kondigt deze nieuwe stijl zich reeds aan in de benadering van de Antwerpse commissieleden. Een benadering die overigens getuigt van het gematigde en pragmatische humanisme dat de Universiteit van Leuven in de eerste helft van de zeventiende eeuw kenmerkte, de zogenaamde via media. ${ }^{488}$ Hierbij was

\footnotetext{
${ }_{444}$ Men kan zich hierbij evenwel de vraag stellen in hoeverre deze romanisatie een verzwaring van het strafrecht heeft teweeggebracht? Dit wordt immers door een aantal auteurs gesuggereerd: GUYON, "Annotations de la coutume de Bordeaux", 309-310. MONBALLYU, Zes eeuwen strafrecht, 144.

445 Dat de romanistaie van het Antwerpse gewoonterecht meer is geweest dan louter een formele receptie, houdt in dat de stelling van Van Caenegem in dit opzicht niet langer houdbaar is. Van Caenegem opperde namelijk dat de invloed van het Romeinse recht op het redactieproces voornamelijk van formele aard was. (VAN CAENEGEM, Droit romain, 51.)

446 VAN DEN BERGH, Geleerd recht, 69. LESAFFER, Inleiding tot de Europese rechtsgeschiedenis, 319-321.

447 VAN DEN BERGH, Geleerd recht, 69.

448 LESAFFER, Inleiding tot de Europese rechtsgeschiedenis, 320. Dit alles vindt plaats ondanks de druk van een zeer conservatieve, theologische faculteit. Cfr. Lovanium docet, 31: "Maar Leuven is
} 
nog steeds een plaats weggelegd voor het Romeinse recht als inspiratiebron. Romeins recht werd nog steeds gerecipieerd voor zover het bruikbaar en rationeel was. Zoniet, dan paste men het aan. In die zin staan de compilatores van Memorieboeken overigens ook in de traditie van de Franse praktische humanisten waar Thireau in zijn artikel omtrent de coutumes in het ressort van Bordeaux over sprak: "Les praticiens humanistes, les défenseurs du droit français, n'excluaient pas de continuer à s'inspirer des lois romaines, mais à la condition de pouvoir le faire en toute liberté, sans être constraints de faire prévaloir leurs dispositions sur celle du droit national, sans s'astreindre à suivre un système rigide, par une libre adhésion et non par obligation. En d'autres termes, ils admettaient d'utiliser le droit romain, mais pas comme un ensemble de lois impératives, seulement en qualité de doctrine, en fonction de sa valeur propre librement appréciée."449

Met dit luik onder de noemer 'romanisatie en humanisme' heb ik drie belangrijke vragen van antwoord kunnen dienen. Ten eerste was er de daadwerkelijke receptie van het Romeinse recht in het Antwerpse gewoonterecht zoals het anno 1608 werd geïnnoveerd. Naast de erkenning van de subsidiariteit van het Romeinse recht en de insijpeling van diezelfde Justiniaanse leges ten gevolge van de positie van romanistisch gevormde legisten in de ganse homologatieprocedure, werd deze receptie ook vanuit de eigen middens gevoed. Tijdens het eigenlijke redactieproces werd deze romanisatie echter enkel getolereerd voor zover er aan twee voorwaarden werd voldaan. Het gerecipieerde, Romeinse recht moest conform, of minstens non a contrario, de gangbare gewoonte zijn, of het moest van een hogere rationaliteit getuigen ter justificatie van haar integratie. Werd hier niet aan voldaan, dan kon het geleerde recht in strikte zin naar believen en in alle openheid gewijzigd worden. Van een blindelingse receptie kan bijgevolg geen sprake zijn; van een blind vertrouwen in een dogmatisch ius scriptum al evenmin. Integendeel, de Usus prevaleert in alle omstandigheden boven het geleerde recht.

Dit brengt me bij de tweede vraag, met name die omtrent de houdbaarheid van de mythe van de zuivere gewoonte. Hoewel Krynen het geloof in een zuivere costume naïef vindt, heeft ons onderzoek evenwel aangetoond dat men niet zonder meer mag oordelen, dat al wat gerecipieerd werd, de zuiverheid van het eigen lokale recht verstoorde. ${ }^{450}$ Kortom, de rol van het geleerde recht stricto sensu is in globo niet langer zo ingrijpend als wanneer het nog haar totale (middeleeuwse) gezagswaarde genoot.

ook niet voor niets een traditionele, behoudsgezinde universiteit en biedt het juridisch bumanisme inhoudelijk weinig, formeel iets meer ruimte."

449 THIREAU, "L'alliance des lois romaines avec le droit français", 361. Dit is uiteraard logisch gezien het feit dat de redacteurs van de Consuetudines compilatae ook zelf in de eerste plaats practici zijn. Vermoedelijk kwamen zij enkel aan de universiteit, tijdens hun opleiding, in contact met de verworvenheden van het juridisch humanisme. Het zijn er dus niet zelf de protagonisten, theoretici of vertegenwoordigers van de eerste lijn van. Dit verklaart de zin voor praxis en hun pragmatische houding, in tegenstelling tot de eerste, Franse humanisten die het Romeinse recht enkel een rol in de antieke maatschappij wilden toekennen.

${ }^{450}$ Cfr. KRYNEN, "Voluntas domini regis", 76. Cfr. de interpenetratie van wet en gewoonte bij Martyn: MARTYN, Eeunig edict, 49. 
Het ontvoogdende effect van het juridisch humanisme heeft met andere woorden ook bij de redactie en onder de compilatores van het (Antwerpse) gewoonterecht zijn sporen nagelaten. Zo heb ik duidelijk een autoritatieve degradatie van het Romeinse recht kunnen vaststellen, zowel in de compilatie zelf als de bijbehorende Memorieboeken en collegiale akten. Deze gewijzigde houding ging bovendien gepaard met een promotie van de ratio welke paste in een meer algemene rationaliseringstendens van het geredigeerde gewoonterecht. Wijzigingen worden doorgevoerd met rationele en billijke argumenten en de ingrijpende invloed van vreemde rechtsbronnen wordt getolereerd omwille van de rationaliteit die zij in zich droegen. Samengevat voltrekt de rationalisering van het gewoonterecht zich ofwel aan de hand van de eigen rede, ofwel met behulp van een acculturatieproces aan de redelijkheid van andere rechtsbronnen. De opkomst van de rede werd bovendien aangekondigd in het reeds geciteerde artikel 1.1.14 uit de Consuetudines compilatae. Hier werd voor het eerst de rol van de eigen rede in de verf gezet. Pas wanneer '...noch de redene oft fondament der selver tot beslissinge van de saecken en dient, mocht het Corpus Iuris zijn subsidiaire rol vervullen. ${ }^{451}$ Van zulk een renvoi, is in de vorige redactiepogingingen helemaal geen sprake. Kortom, het middeleeuwse dogma wordt door de individuele ratio van de moderne mens van de troon gestoten.

Theorie versus praktijk: de verwetenschappelijking van het gewoonterecht

Reeds in de jaren '60 sprak Van Caenegem van een Verwissenschaftlichung van het middeleeuwse, costumiere recht en dit vanaf de vijftiende eeuw. ${ }^{452}$ Hij deed deze uitspraken in zijn synthesewerk Le Droit Romain en Belgique, waarin hij de verschillende wegen besprak waarlangs het Romeinse recht het lokale recht van onze streken penetreerde. Zowel de allochtone als de autochtone rechtsgeleerde literatuur kan beschouwd worden als één van deze gateways waarlangs het Romeinse recht zijn weg vond naar de Nederlanden. Volgens Van Caenegem hebben vele van deze werken sterk bijgedragen tot de verbeterde kwaliteit die de costumiere compilaties sinds de vijftiende eeuw kenmerkte. ${ }^{453}$ Ook criticaster Jacques Van Uffel was zich bewust van de invloed van de opinio doctorum op het Antwerpse geredigeerde recht, zoals het in de Consuetudines compilatae staat geboekstaafd. Waar hij de receptie van het Justiniaanse recht nog lijkt te dulden, keert hij zich echter heftig af van de opinie van eenige docteurs, glossisten oft commentarijsten d'onsekerheyt vande welcke ende repugnantie genuch haer selven is

${ }^{451}$ Coutumes de la ville d'Anvers dites compilatae, III, 6.

452 Cfr. VAN CAENEGEM, Droit romain, 28-46. LESAFFER, Inleiding tot de Europese rechtsgeschiedenis, 322. Ook Godding concludeerde, met betrekking tot de middeleeuwse rechtspraak, dat een aanzienlijke invloed van de rechtsleer niet langer ontkend kan worden: "Sous réserve de quelques cas exceptionnels, la doctrine est donc unanimement défavorable à la motivation des jugements. Nous verrons que son influence sur la pratique a été déterminante et de longue durée." (P. GODDING, "Jurisprudence et motivation des sentences, du Moyen Âge à la fin du 18 e siècle", J. T. DE SMIDT red. Miscellanea Consilii Magni (Verzamelen en bewerken van de jurisprudentie van de Grote Raad. Nieuwe reeks. N²4), Amsterdam, 1980, 133.)

453 VAN CAENEGEM, Droit romain, 63. 
confonderende. ${ }^{454}$ Van Uffel erkent de autoriteit niet van de iuris periti, noch van de glossatoren en evenmin die van de commentatoren.

Dat de commissieleden zich al te sterk hebben laten leiden door rechtsgeleerde opinies, kan inderdaad niet ontkend worden. Uiteindelijk gaat het binnen het geheel van de Consuetudines compilatae immers om 162 nieuwe artikels, wat goed is voor een percentage van dertien ten honderd. Ongegrond is de kritiek van Jacques Van Uffel dan ook niet. Binnen welke rechtsgebieden deze 'rechtsgeleerde' artikels voornamelijk voorkomen, heb ik reeds in een vorige paragraaf laten zien. Hier wil ik me daarentegen focussen op mogelijke neveneffecten evenals enkele karakteristieken van deze rechtsgeleerde invloed. ${ }^{455} \mathrm{Zo}$ is er de band welke er blijkt te bestaan tussen het geleerde recht stricto sensu en de rechtsleer. Vervolgens zal mijn aandacht uitgaan naar de herkomst en de plaats in de tijd van de gerecipieerde auteurs, evenals de verschillende wetenschappelijke literatuurtypes welke aan bod zijn gekomen. Dit hoop ik te kunnen interpreteren in het licht van het juridisch humanisme. Tot slot zal ik -zoals elders- ook hier kijken naar de mate waarin de receptie reëel te noemen is en in hoeverre dit gevolgen heeft voor de zuiverheid van de Antwerpse costume. Een zuiverheid die -zoals algemeen aangenomen- beter gegarandeerd kan worden met een renvoi an praxis, welke als geen andere rechtsbron een weerspiegeling is van de juridische werkelijkheid, in plaats van een receptie van rechtsgeleerde ideeën. Bijgevolg zal ik aansluitend op het stuk omtrent de verwetenschappelijking de rol van de rechtspraak binnen het redactieproces van de Consuetudines compilatae onder de loep nemen. Kortom, theorie versus praktijk en in welke mate zij elkander weten te beïnvloeden.

In de eerste plaats blijkt er een band te bestaan tussen het aandeel van het Romeinse recht en dat van de rechtsleer binnen de verschillende titels van de Consuetudines compilatae. Beide bronnentypes evolueren als het ware recht evenredig met elkaar. Ze kennen op gelijke momenten een hausse en delen in de klappen. Zo blijkt uit het cijfermateriaal dat in veruit de meeste titels waar het Corpus Iuris Civilis op innovatief vlak een dominante rol heeft gespeeld, ook de rechtsleer een gelijkwaardige positie zij het in verhouding- inneemt. Slechts voor een zestal van deze achttien 'Romeinsrechtelijke' titels is dit niet van toepassing: titel 2.3 (ongehuwde vrouwen), titel 3.8 (cijnsen en renten), titel 4.9 (gemeenschap van goederen), titel 4.12 (pantschap), titel 4.13 (borchtocht) en titel 6.2 (bannissementen). ${ }^{456} \mathrm{Bij}$ al de resterende titels profileert de rechtsleer zich als trouwe metgezel van het Romeinse recht. Het betreft de titels omtrent bastaardkinderen (titel 2.4), voogdij (titel 2.5),

${ }^{454}$ SAA, Vierschaer, 64: VAN UFFEL. Van Uffel geeft evenwel niet aan om welke docteurs het hier gaat.

$455 \mathrm{Ik}$ beperk me hier tot rechtsgeleerde werken welke als primaire rechtsbron aan bod komen in de Memorieboeken. In hoofdstuk 3, waar deze rechtsleer veel uitvoeriger en uitputtender behandeld zal worden, komen alle geallegeerde auteurs centraal te staan, dus ook zij die louter als secundaire bron werden aangewend.

456 Dit gebrek wordt evenmin gecompenseerd door een nadrukkelijke aanwezigheid van het Romeinse recht als secundaire rechtsbron. 
verscheidenheid van goeden (titel 3.1), successie (titel 3.14), testamenten (titel 3.13), giften (titel 3.12), prescriptie (titel 3.11), factorije (titel 4.10) en preferentie onder crediteuren (titel 4.18). Tabel 1.34 laat zien hoe de percentages verhoudingsgewijs in dezelfde lijn liggen en hoe ze in vergelijking met het totale aandeel van zowel het Corpus Iuris Civilis (achttien procent) als de rechtsleer (dertien procent) aan de hoge kant liggen.

Tabel 1.34 De band tussen het Romeinse recht en de rechtsleer

\begin{tabular}{|l|c|c|}
\hline Titel & Corpus Iuris Civilis (\%) & Rechtsleer (\%) \\
\hline 2.4 (bastaarden) & 33.3 & 26.7 \\
\hline 2.5 (voogdii) & 54.4 & 14.1 \\
\hline 3.1 (verscheidenheid van goederen) & 28.6 & 28.6 \\
\hline 3.11 (prescriptie) & 72.7 & 45.5 \\
\hline 3.12 (giften) & 81.8 & 36.4 \\
\hline 3.13 (testamenten) & 36.4 & 33.3 \\
\hline 3.14 (successie) & 18.9 & 9.4 \\
\hline 4.10 (factorije) & 33.3 & 28.6 \\
\hline 4.18 (preferentie onder crediteuren) & 22.1 & 15.6 \\
\hline
\end{tabular}

In een aantal uitzonderlijke gevallen lijkt de rechtsleer zelfs een voornamere rol te spelen dan het Justiniaanse recht. In eerste instantie denk ik hierbij an procesrechtelijke titels als die omtrent de thoon (titel 5.10) en de maniere van procederen (titel 5.11). Zoals reeds in paragraaf 2 werd aangegeven is dit doctrinaal label te wijten aan auteurs als Jean Imbert, Louis le Caron, Charles Dumoulin en Jacopo Menocchio, maar in de eerste plaats gaat het hier om een auteur van eigen bodem, namelijk Filips Wielant en zijn Practycke civile en Practycke criminele. Het procesrechtelijke karakter van zijn oeuvre, of toch tenminste zijn hoofdwerken, ligt logischerwijs aan de grondslag van zijn prominente aanwezigheid binnen deze titels. Dit rechtsgeleerde cachet geldt echter niet voor het ganse vijfde deel. In geen enkele andere titel van burgerlijk procesrecht heeft de rechtsleer -ook Wielant niet- nog een rol van betekenis weten te spelen. Andere concentraties van rechtsgeleerde auteurs zijn evenwel te vinden met betrekking tot het strafrecht, i.c. titel 6.1 (keuren en breuken), alwaar Louis le Caron een decisieve invloed heeft uitgeoefend op de inhoud van de derde paragraaf (Breucken ter oorsaecke van eens anders beschaedigheijt). Verder is er nog titel 7.3 (tortuur) waar de rechtsleer als primaire rechtsbron zelfs een aandeel behaalt dat de 45 procent overstijgt. Overigens, binnen het ganse geheel van het zevende, strafprocesrechtelijke deel kent dit brontype een ongekende hausse. 39 procent van de nieuw toegevoegde artikels vindt er hun oorsprong in de opinio doctorum. Opnieuw ontpopt Wielant zich, als processualist, tot één van de centrale figuren bij uitstek, zowel als primaire als secundaire bron van recht van de Antwerpse Consuetudines compilatae. Andere protagonisten zijn de Italianen Prospero Farinacci en Jacopo Menocchio, en de Franse jurist Pierre Grégoire.

Titels waar enkel de rechtsleer toonaangevend is zonder dat ook de invloed van het geleerde recht stricto sensu doorslaggevend is geweest, zijn er nauwelijks tot niet. Legio zijn dan weer de titels waar het Romeinse recht zo goed als afwezig is en dus ook de 
rechtsleer nauwelijks van tel. Kortom, tot op zekere hoogte zijn het Romeinse recht en de rechtsleer met elkaar verbonden.

Globaliter manifesteert dit geheel van iuris periti, wier oeuvre als rechtsbron voor de Consuetudines compilatae heeft dienst gedaan, zich als een uiterst heterogene groep. Toch zal ik trachten enkele karakteristieken bloot te leggen, die de gerecipieerde auteurs kenmerken. Tabel 1.35 rangschikt hen naar het aantal nieuwe artikels, welke in de Memorieboeken aan hen wordt toegeschreven.

Tabel 1.35 Aantal artikels per 'gerecipieerde' auteur

\begin{tabular}{|c|c|c|}
\hline Aantal artikels & Herkomst & Auteur \\
\hline 30 & Frankrijk & Louis le Caron \\
\hline 27 & Nederlanden & Filips Wielant \\
\hline 22 & - & doctores \\
\hline 14 & Frankrijk & Charles Dumoulin \\
\hline 10 & Italië & Bartolo da Sassoferrato \\
\hline \multirow{2}{*}{9} & Frankrijk & Jean Imbert, Jean Papon \\
\hline & Italië & Baldus de Ubaldis \\
\hline 8 & Italië & Alessandro di Tartagni \\
\hline \multirow{2}{*}{7} & Spanje & Diego Covarubias y Leyva \\
\hline & Savoie & Antoine Favre \\
\hline \multirow{3}{*}{6} & Frankrijk & Denis Godefroy \\
\hline & Italië & Giulio Claro, Jacopo Menocchio \\
\hline & Heilige Roomse Rijk & Joachim Mynsinger von Frundeck \\
\hline \multirow{3}{*}{5} & Italië & Prospero Farinacci \\
\hline & Frankrijk & Jean Favre \\
\hline & Nederlanden & Matthias Wesenbeeck \\
\hline \multirow{3}{*}{4} & Frankrijk & Pierre Guenoys \\
\hline & Italië & Andreo Alciato, Angelus de Ubaldis \\
\hline & Heilige Roomse Rijk & Michael Grass \\
\hline \multirow{4}{*}{3} & Frankrijk & Pierre Cousteau, Etienne Bertrand \\
\hline & Heilige Roomse Rijk & Michael Grass \\
\hline & Italië & Henrico di Boverio \\
\hline & Portugal & Aries Pinhel \\
\hline \multirow{4}{*}{$2^{457}$} & Frankrijk & $\begin{array}{l}\text { Pierre Pithou, André Tiraqueau, Nicolas du Val, } \\
\text { Pierre Rebuffi, Jean Bacquet }\end{array}$ \\
\hline & Italië & $\begin{array}{l}\text { Paulo di Castro, Filippo Decio, Giovanni } \\
\text { Francesco Sannazari della Ripa, Benvenuto Stracca }\end{array}$ \\
\hline & Nederlanden & Pieter Peck, Wigle van Aytta \\
\hline & Spanje & $\begin{array}{l}\text { Antonio Padilla y Meneses, Antonio Ayerve de } \\
\text { Ayora }\end{array}$ \\
\hline \multirow[t]{2}{*}{1} & Frankrijk & $\begin{array}{l}\text { Jean Bodin, Bartholomé de Chasseneuz, Jacques } \\
\text { Cujas, Pierre Grégoire, François Grimaudet, } \\
\text { Bertrand d'Argentré }\end{array}$ \\
\hline & Italië & $\begin{array}{l}\text { Egidio Bossi, Borgnino Cavalcani, Aimone } \\
\text { Cravetta, Phanutio di Fanuzzi, Sebastiano }\end{array}$ \\
\hline
\end{tabular}

457 Omdat picus onbekend is gebleven, is het tevens onmogelijk zijn herkomst te achterhalen. Desalniettemin werd er twee maal naar de mening van deze mysterieuze jurist verwezen. 


\begin{tabular}{|r|l|} 
& Monticello, Bartolomeo de Saliceto \\
\cline { 2 - 3 } Nederlanden & $\begin{array}{l}\text { Joost de Damhouder, Nicolas Everaerts, Gabriel } \\
\text { Vander Muyden }\end{array}$ \\
\cline { 2 - 3 } Spanje & $\begin{array}{l}\text { Diego Rodrigo Alvarado, Manoel da Costa, Juan } \\
\text { Garzia de Saavedra, Fernando Vasquez de } \\
\text { Menchaca, Luis de Peguera }\end{array}$ \\
\hline
\end{tabular}

Twee namen springen meteen in het oog: de Franse jurist Louis le Caron alias Charondas en de Nederlandse processualist Filips Wielant. Hun waarden brengt hen op een eenzame hoogte. Wielant is goed voor 27 nieuwe artikels, le Caron neemt er 30 voor zijn rekening. De werken van eerstgenoemde situeren zich thematisch voornamelijk binnen het domein van het civiel evenals het crimineel procesrecht. Het betreft de Practycke civile (ca. 1508) en de Practycke criminele (ca. 1510). Opvallend in dezen is dat de redacteurs van de Consuetudines compilatae expliciet naar het deels onuitgegeven oeuvre -enkel de Practycke civile was reeds gepubliceerd- van Wielant verwijzen, en niet naar het gedrukte, weids verspreide en bijgevolg ook meer toegankelijke 'plagiaat' van Joost de Damhouder. ${ }^{458}$ Het gerecipieerde oeuvre van Louis le Caron is dan weer meer verscheiden en vooral ook uiterst recent. De nadruk ligt evenwel op zijn commentaren bij het Franse particuliere recht: Memorables Observations du droit françois (1601, elf artikels), zijn commentaar op de Somme rural van Jean Bouteiller (1603, twaalf artikels), zijn commentaar op de Codex Henricianus van Barnabé Brisson (1601, vijf artikels) en tot slot zijn commentaar op de Grand Coustumier de France van de hand van Jacques d'Ableiges (1598, drie artikels). Geen enkel van deze werken is ouder dan tien jaar op het moment waarop de Consuetudines compilatae werden voltooid. Sommigen onder hen verschenen zelfs slechts vijf jaar nadat de commissie haar werkzaamheden had aangevat. Andere auteurs in de voorste gelederen, doch van de tweede lijn, zijn onder meer de Franse juristen Jean Imbert, Charles Dumoulin en Jean Papon. Laatstgenoemde wordt voornamelijk gewaardeerd om zijn rechtsgeleerde beschouwingen in zijn Recueil d'arrests notables des courts souveraines de France (1556). In totaal gaat het om vijf artikels. Imbert dankt zijn manifeste aanwezigheid geheel aan zijn Institutiones forenses (1535). Het procesrechtelijk werk is goed voor negen artikels en dit binnen titel 5.10 aangaande de bewijsvoering,

458 Dit staat in schril contrast met Hendrik de Moy die in zijn traktaat over de Consuetudines impressae veelvuldig naar Joost de Damhouder verwijst en nergens spreekt van Wielant. (SAA, Vierschaer, 21-23: DE MOY, Tractaat.)

Omtrent dit plagiaat, zie: E. I. STRUBBE, "Joos de Damhouder als criminalist", Tijdschrift voor Rechtsgeschiedenis, 38 (1970), 1-65. E. I. STRUBBE, "Die Stellung Damhouders in der Rechtswissenschaft: Wielant-De Damhouder", Revue d'bistoire du droit, 1 (1930), 219-226. Zie ook de inleiding van Strubbe op zijn herdruk van Wielants Practycke Civile: WIELANT, P., Practijcke Civile, Antwerpen, 1573, (anastasische herdruk Amsterdam, 1968), V-XI. Monballyu en Dauwe van hun kant relativeren, althans met betrekking tot de Practycke Civile, de term 'plagiaat' en verkiezen te spreken van de Damhouder als co-auteur. In de inleiding van hun herdruk van Wielants Practycke Civile wijzen zij erop dat de toegevoegde waarde van de Damhouder niet langer genegeerd worden. Zie: DE DAMHOUDER, J. Practycke in civile saecken, Den Haag, 1626 (anastasische herdruk Antwerpen, 1999), 8-10. 
zoals ook zopas reeds aangestipt werd. Het geraadpleegde oeuvre van Dumoulin daarentegen valt in die zin op dat het niet die werken omvat waar de man, als expert van de Franse coutumes, doorgaans mee geassocieerd wordt, namelijk zijn commentaren op de Franse, costumiere compilaties. Neen, de commissieleden hanteren in de eerste plaats zijn andere, meer monografische werken, en dit tot elf maal toe. Met andere woorden, Dumoulin, zo blijkt, moet Louis le Caron laten voorgaan als kenner bij uitstek van het gewoonterecht. Ook in hoofdstuk 3 zal deze bijzondere perceptie van de jurist Dumoulin nogmaals aan het licht komen en ook uitvoeriger behandeld worden. ${ }^{459}$ Hoezeer voornoemde auteurs ook gekenmerkt worden door de jeugdige leeftijd van hun werk, ook de werken van oudere, middeleeuwse auteurs zijn van de partij. Als protagonisten van de commentatorentijd tref ik, binnen deze groep van vooraanstaande rechtsgeleerden, personen als Bartolo da Sassoferrato, Baldus de Ubaldis en Alessandro di Tartagni aan. De eerste twee worden voornamelijk geapprecieerd om hun commentaren bij de Justiniaanse leges. In het geval van di Tartagni, in de bronnen doorgaans aangeduid als Alexander, gaat het in zeven van de acht gevallen om zijn consilia. Naast Bartolus en Baldus tref ik ook recentere, contemporaine 'commentatoren' van het geleerde recht aan, zoals daar zijn de Spanjaard Diego Covarubias y Leyva en de Fransman Denis Godefroy. Respectievelijk zijn ze goed voor zeven en zes nieuwe artikels. Tot slot zijn ook de Italiaanse processualisten Giulio Claro en Prospero Farinacci met respectievelijk zes en vijf nieuwe artikels op hun conto het vermelden waard, evenals Jacopo Menocchio en zijn traktaat De arbitrariis iudicum quaestionibus et causis (1569), wat tot zes maal toe werd aangesproken. 460 Ook Joachim Mynsinger von Frundeck is goed voor zes artikels. Net als bij Antoine Favre, naar wier Codex Fabrianus tot zeven maal toe wordt verwezen, gaat het hier om rechtsgeleerde beschouwingen bij jurisprudentiële verzamelingen.

Kortom, Louis le Caron spant de kroon. En ook qua herkomst is die van Charondas representatief voor de meerderheid binnen de groep. Tabel 1.36 laat zien dat maar liefst 75 nieuwe artikels door Franse auteurs werden beïnvloed.

Tabel 1.36 Aantal 'verwetenschappelijkte' artikels per land van herkomst

\begin{tabular}{|l|l|}
\hline Land van herkomst & Aantal artikels \\
\hline Frankrijk & 75 \\
\hline Italië & 43 \\
\hline Nederlanden & 39 \\
\hline Spanje & 16 \\
\hline Heilige Roomse Rijk & 12 \\
\hline Savoie & 7 \\
\hline Portugal & 3 \\
\hline
\end{tabular}

De Italiaanse auteurs doen het, met 43 artikels, beduidend minder goed. De derde plaats van de autochtone rechtsgeleerden ligt dan weer voor de hand en is grotendeels

${ }^{459}$ Cfr. infra, hoofdstuk 3, paragraaf 2, Particulier recht.

460 Het enige, niet zuiver juridische werk dat hier een rol heeft gespeeld is het politiektheoretische werk Les six livres de la République (1576) van de Fransman Jean Bodin. 
te danken aan Filips Wielant en in mindere mate aan Matthias Wesenbeek, die goed is voor vijf artikels. De overigen (Pieter Peck, Gabriel Van der Muyden, Joost de Damhouder en Nicolaes Everaerts) halen met moeite de kaap van twee artikels.

Een ander element dat de moeite loont om op een meer kwantitatieve wijze geanalyseerd te worden, zijn de literatuurtypes welke als inspiratiebron fungeren voor de Antwerpse commissieleden. Onderstaande tabel 1.37 geeft een overzicht van de verschillende mogelijke genres in relatie tot het aantal nieuwe artikels waarvoor zij verantwoordelijk geacht mogen worden. ${ }^{461}$

Tabel 1.37 Aantal 'verwetenschappelijkte' artikels onder invloed van welk, rechtsgeleerd genre

\begin{tabular}{|l|l|l|l|}
\hline Genre & Subgenre \\
\hline \multirow{3}{*}{$\begin{array}{l}\text { Monografische } \\
\text { werken }\end{array}$} & 77 (47.5 procent) & Traktaten & 28 \\
\cline { 3 - 4 } & & Procesrecht & 43 \\
\cline { 3 - 4 } & & Quaestiones & 1 \\
\cline { 3 - 4 } & & Additiones & 2 \\
\cline { 3 - 4 } & & Singulariae & 7 \\
\cline { 3 - 4 } & & Farinacci/Bodin & 6 \\
\hline Particulier recht & $31(19.1$ procent $)$ & Gewoonterecht & 26 \\
\cline { 3 - 4 } & & Collatio/Censurae & 12 \\
\cline { 3 - 4 } & & Wetgeving & 7 \\
\hline Ius communet62 & $53(32.7$ procent $)$ & & \\
\hline Decisiones & $25(15.4$ procent $)$ & & \\
\hline Consilia & $12(7.4$ procent $)$ & & \\
\hline
\end{tabular}

Wat blijkt nu? Ten aanzien van de genres die het gerecipieerd oeuvre kenmerken, geldt le Caron niet langer als pars pro toto. Le Carons werk typeert zich namelijk door een sterke, zelfs exclusief, particulierrechtelijke inslag, waar in globo -zoals in tabel 1.37 is te zien- de nadruk ligt op die genres welke zich het beste lenen tot rechtsgeleerde beschouwingen. Hierbij denk ik voornamelijk aan traktaten (zowel omtrent het materiële recht als het procesrecht) en commentaren op het geleerde recht. Pas in tweede instantie gaat het ook om commentaren op particulierrechtelijke compilaties en het genre van de rechtspraakverzamelingen.

Beide aspecten (herkomst en genre) van de gerecipieerde rechtsleer doen denken aan het juridisch humanisme. Het is namelijk zo dat deze stroming haar bakermat kent in het Franse koninkrijk en zich bovendien kenmerkt door een voorkeur voor literatuurtypes welke ook hier dominant aanwezig zijn, met name de commentaren op het geleerde recht en het monografische genre. Vooral binnen deze types is het humanisme in staat geweest zijn verworvenheden te laten gelden. ${ }^{463}$ Met andere

${ }^{461}$ Deze onderverdeling vloeit voort uit hoofdstuk 3, waar ze een centrale rol speelt in de opbouw van het hoofdstuk. Voor wat de ratio achter deze indeling betreft, wil ik dan ook naar dit derde hoofdstuk verwijzen. Cfr. infra, hoofdstuk 3, paragraaf 2.

462 Deze groep omvat enkel geïdentificeerde commentaren op het ius commune. De verwijzigingen naar de meer abstracte 'doctores' werden hier niet in verrekend.

463 Cfr. LESAFFER, Inleiding tot de Europese rechtsgeschiedenis, 323; TROJE, "Die Literatur des gemeinen Rechts unter dem Einfluss des Humanismus”, 634-635. 
woorden, bovenstaande vaststellingen roepen nieuwe vragen op omtrent de juridische geaardheid van de commissieleden. Is het namelijk zo dat dit overwicht aan Franse auteurs typisch humanistische literatuurtypes correspondeert met een bewuste humanistische ingesteldheid van de redacteurs? Dit is uiteraard een uiterst complexe materie, en hoewel het vraagstuk naar de invloed van het juridisch humanisme meer uitvoerig behandeld zal worden in een derde en tevens laatste hoofdstuk, kan ik hier evenwel een eerste tip van de sluier oplichten. Aan de hand van de criteria volgens dewelke ik de verschillende geallegeerde werken in hoofdstuk 3 heb geclassificeerd naar gelang de mate waarin ze middeleeuws of modern -lees: humanistisch- behoren geacht te worden, kan ik de hier gerecipieerde werken op eenzelfde manier opdelen in twee categoriën, met name 'oude werken' en 'moderne werken'. Een derde groep verzamelt hen waarvan het onduidelijk is gebleven tot welke van beide voornoemde categorieën ze behoren. ${ }^{464}$ Dit heeft zich 57 keer voorgedaan. ${ }^{465} 107$ keer werd naar een middeleeuws werk gerefereerd als primaire bron voor de nieuwe artikels. Dit is vergelijkbaar met de honderd keer dat humanistisch geachte werken werden aangewend. Ik meen te kunnen besluiten dat de redacteurs zeer goed op de hoogte waren van het reilen en zeilen en dan vooral de nieuwe trends binnen de rechtsgeleerde wereld. Dit bleek overigens al eerder uit de dominante rol van recente auteurs als Louis le Caron. Dat niet alleen het humanistische aandeel meer dan aanzienlijk is te noemen, maar ook het bartolisme niet radicaal over boord wordt gegooid, zou geïnterpreteerd kunnen worden als het pragmatisme dat bijvoorbeeld de Leuvense Rechtenfaculteit van de zestiende eeuw kenmerkte, alwaar het merendeel van de redacteurs hun onderwijs genoten hadden. ${ }^{466}$

Ook hier blijft evenwel de hamvraag in hoeverre ik met betrekking tot deze zogenaamde verwetenschappelijking van het gewoonterecht kan spreken van een reële receptie van de opinio doctorum. Of, gaat het hier louter om de bevestiging van reeds lange tijd in gebruik zijnde gewoonten? Het antwoord op deze vraag is bepalend voor de mate waarin ik met betrekking tot de Consuetudines compilatae van 1608 nog kan spreken van een zuivere gewoonte. Opnieuw zal ik dit onderzoeken aan

\footnotetext{
${ }^{464}$ De groep omvat enerzijds werken van auteurs die als overgangsfiguren worden beschouwd en anderzijds werken waarvan ik in de literatuur geen aanwijzingen heb kunnen terugvinden omtrent de mate waarin ze al dan niet als modern moeten worden aanzien.

$465 \mathrm{Ik}$ ben als volgt tot deze cijfers gekomen. Eerst heb ik de verschillende, gerecipieerde werken opgedeeld volgens de categorieën middeleeuws, modern en die werken welke tot geen van beide behoren. Vervolgens heb ik aan elk werk het aantal artikels gekoppeld waarvoor het als primaire rechtsbron werd geciteerd. Tot slot heb ik de optelsom gemaakt van alle aantallen bij de verschillende werken, naargelang ze tot één van de drie voornoemde categorieën behoorden. Bijgevolg kunnen de sommen hoger liggen dan het aantal artikels die ermee overeenstemmen. Het is immers mogelijk dat meerdere werken bij een welbepaald artikel werden geciteerd.

${ }^{466}$ LESAFFER, Inleiding tot de Europese rechtsgeschiedenis, 320.
} 
de hand van de al dan niet bevestigende Usus. ${ }^{467}$ In hoeverre wordt de geïntegreerde rechtsleer door de gewoonte geconfirmeerd? Uit de Memorien op de Costumen blijkt in de eerste plaats dat het merendeel van de nieuwe, 'rechtsgeleerde' artikels een confirmatie door de Usus mankeert. Bijna drie kwart van de 162 nieuwe artikels wordt niet bevestigd. Het aantal keer dat de rechtsgeleerde opinie door de eigen gewoonte wordt 'geobserveerd' is op één hand te tellen. Eén van de zeldzame voorbeelden tref ik aan bij het bewijsrechtelijk artikel 5.11 .43 omtrent de bekentenis: Est quoque novus et suppletus ex traditis ab eodem Wilandio d parte 6 cap $18 n^{\circ} 2$ et 14 et usus ita observat etiam. Zeer uitzonderlijk wijst de geallegeerde auteur zelf op het dagdagelijkse gebruik van de geïntegreerde idee. Voorbeelden hiervan zijn terug te vinden bij de artikels 3.13.43 omtrent fideicommissen (Est novus itidem ex novella constitut[ione] 39 cap $1^{\circ}$ Padilla ad d Auth. res quae nu 47 ubi ostendit hanc esse communem.) en 4.18 .76 omtrent de betaling van schulden in cas van voordeel (Est etiam additus in hac revisione ex usu et utroque statuto op de fugitiven gemaeckt anno 1515 et 1518 cum quibus accordat t'Guldeboeck. art 133 sed nos addidimus clausulam finalem dyes worden de capitalen ex iis qua[e] tradit Wesenbec[ius] cons[ilio] $50 \mathrm{nu} 34$ in fine ubi dicit ita quotidie practicari et in eum finem citatur etiam arrestum Curia[e] Tholosana[e] apud Gerard[um] Meynardum quest[ionis] iur[is] lib 3 cap 3.), alwaar respectievelijk Antonio de Padilla y Meneses en Matthias Wesenbeeck erop wijzen dat men sinds lang gewoon is als dusdanig te handelen. Verder bestaat er een minderheid van artikels waarvan de anwezigheid binnen de Consuetudines compilatae zowel op basis van de gewoonte als op grond van de rechtsleer wordt beargumenteerd. Ik denk hierbij onder meer aan artikel 3.1.8 omtrent de plaats van de leengoederen binnen de algemene verscheidenheid aan goederen: Est etiam novus ex usu, et communi d[octores] opiniones ut i[n] art 6 et videtur quod sub finem post verbum vervolgen, debet addi oft oock by manniere van naerderschap daertoe te comen, nam ratio est eadem, et qui vendicare aut retrabere potest, parum abest quin [?] rem ipsam habere videatur ut proinde actiones ist[a]e vere sint reales. In dit geval blijkt er dus duidelijk een costumiere equivalent te bestaan voor de rechtsgeleerde opinie. ${ }^{468}$ Dit is uiteraard eveneens het geval wanneer de rechtsleer optreedt als secundaire rechtsbron bij een artikel dat op basis van de Usus werd geïntegreerd in het geheel van de redactie. Louter ter illustratie verwijs ik in dezen naar artikel 3.8.55 omtrent de kwijting en ontlasting van renten: Est etiam novus ex usu et consuetudine Buscoduc[ensis] boc tit cui consentit ius commune ex receptiori et magis approbata d[octores] sententia. Het in globo ontbreken van een

${ }^{467} \mathrm{Ik}$ wil er hier nog op wijzen dat deze rechtsleer ook costumier recht kan om- en bevatten. Zo bevatten de procesrechtlijke werken van Filips Wielant heel wat gewoonterechtelijke materie. (Cfr. VAN CAENEGEM, Droit romain, 44.)

${ }^{468}$ Talrijker zijn echter de situaties waarbij buitensteedse, gewoonterechtelijke compilaties, en dan voornamelijk die van Frans origine, worden aangewend ter confirmatie van de gerecipieerde rechtsleer. Kijk bijvoorbeeld naar artikel 2.5.198: Est novus ex usu et jure communi, de quo text et d[octores] in L cum agnatis ff d[e] captivis [et de] postlim [inio et] redem [ptis ab hostibus] et L ab hostibus 15 in princip [e] et 161 dd ff ex quib[us] caus[is] quibus consentiunt consuet[udo] Borbon d art 172 Aniou art 506 Maine art 501 et similes. Een enkele keer krijgt men te maken met een bevestiging door Franse (Cfr. 2.5.138) of eigen (Cfr. 4.12.5) rechtspraak, of het Romeinse recht (Cfr. 7.3.4). 
confirmerende Usus doet me evenwel besluiten dat ik wel degelijk kan spreken van een reële receptie van juridisch materiaal dat enigszins als vreemd beschouwd kan worden en dat buiten de sfeer van het Antwerpse gewoonterecht valt. Bijgevolg kan men niet langer volhouden dat het geredigeerde, Antwerpse gewoonterecht zuiver costumier van aard is. De mythe brokkelt af. Zoniet had men mijns inziens immers meer nadrukkelijk aangegeven dat de gerecipieerde ideeën conform de eigen gebruiken waren.

Vervolgens bevatten de Memorieboeken ook hier aanwijzingen omtrent de hiërarchische verhouding van de rechtsleer binnen het geheel van de overige rechtsbronnen. Wie prevaleert boven wie? Autoritair kan het gezag van de rechtsleer alleszins niet genoemd worden. De doctrine moet immers verscheidene malen voorrang verlenen aan andere bronnentypes. Hierin wil ik vooral wijzen op de magistraat, de Usus en de ratio. Meermaals hebben zij zich als een hogere autoriteit weten laten gelden. Ik beperk me tot enkele artikels bij wijze van voorbeeld. Wat de magistraat betreft is er de definitie van 'weesepenningen' in artikel 4.18.10: Est desumptus ex iis qua [e] respond[it] Alex[ander] cons[ilio] $108 \mathrm{nu} 1^{\circ}$ Cravett[a] cons[ilio] 129 lib $1^{\circ}$ Cavalcan[us] in tract [atu] de tutor [e] et curat [ore] nu 243 nisi quod cum illi satis generaliter loquantur magistratui visum sit addere duplicem limitationem ut videlicet id non obtineat nisi in subsidium et in casu quo pecunia pupillaris apud tutorem fuit tempore emptionis. ${ }^{469}$ Het overwicht van de costume wordt mooi geillustreerd door de artikels 3.13.56/57/58 omtrent legaten: Sunt desumpti ex art 45 et 46 in impressis tit van versterffenisse et usus ita observat quamvis ius commune sit in contrarium tex. in L ex his verbis $5^{a} C$ quando dies legati cedet Alexander consilio 55 et 164 vel $2^{\circ}$ et iterum cons[ilio] 209 volum[ine] $6^{\circ}$ eleganter Molin[aeus] ad eundem Alex[andrem] cons[ilio] 77 volumine quinto. ${ }^{470} \mathrm{En}$ de ratio toont zich van zijn meest dwingende kant met betrekking tot het procesrechtelijk artikel 5.10.37/38: Sunt additi in hac revisione ex iis que tradunt Imbertus et Charondas locis i[bi] citatis art 33 et seq et ratio ostendit ita deberi observari.

469 Andere voorbeelden zijn de artikels 3.13.14/15 (Sunt etiam novi additi in hac postrema revisione, ex novella constit [utione] 107 cap $1^{\circ}$ et Auth. quod sine subscriptione, ibi Baldus c. de testamentis Mynsinger obser[vationum] cam [erae] imper[ialis] lib quinto obser[vatio] vigesima octava Clarus lib $3^{\circ}$ sentent [ia] $\mathbb{I}$ testamentum quaest[ione] $14^{a}$ nisi quod cum illi alter utrum putent sufficere, vel quod testatur scripserit testamentum vel subsignaverit propria mane [?] Godefred[us] ad d Auth. quod sine ad l[itte]ram D magistratui visum ytrumq[ue] coniungere, ut videlicet de volentate testatoris eo nimus dubitetur, et confirmantur ...) en 3.13.71/72 (Sunt etiam novi ex iis quae tradit Anthon[ius] Faber in suo Codice Fabriano tit de testamentis definit[ione] 18 quamvis ipse magis inclinet ut divisio bonorum fiat, proinde acsi nullum fuisset testamentum, sed cum id nimis recedat a voluntate testatoris, magistratui visum fuit eam pro portione saltem observare, ex iis quae Faber ipse loco citato allegat sub nu $6^{\circ}$ et quod diversitas conditionis bonorum ut pote feudalium et similium magnam alioqui possent inducere inaequalitatem, presertim hac in civitate quae Flandriam et una et Mechliniam ex altera contingit, ubi ratio successionis ab intestato in plerisq[ue] diversa.)

${ }^{470}$ Een ander sprekend voorbeeld is te vinden bij de artikels 2.3.13/14: Est art 9 in impressis et 7 in antiquis tit van bastaerden 75 in antiquissimis tit van successien, nisi quod nos in uno et in alio art addidimus verba binnen den tyt dat sy ethc[etera] ut videlicet omnia redigantur ad tempus constitutum a nostra et accordat consuet [udo] Mechlin[iensis] tit van bastaerden art 4 et 5 nisi quod ibi statuatur tempus unius anni, quod nobis visum nimis exorbitans, ideoque malvimus id relinquere dispositioni juris communi. 
Anderzijds heb ik ook één enkele keer kunnen vaststellen dat een omgekeerde situatie evenzeer tot de mogelijkheden behoort. Zo wordt in verband met de artikels 3.2.17/18, aangaande de opdracht ende overgevinghe van roerende goederen, de gangbare gewoonte gewijzigd op basis van de rechtsleer: Sunt novi additi in hac postrema revisione ex usu, sed videtur ad finem art 17 addendum ende ondertusschen is en[de] blijft hem den pant daervoere verbonden, iuxta text in L fundum $17 \mathrm{ff}$ de actionib[us] empt [i venditi] ibi Barth[olus] idem Barth[olus] in L si quis legaverit ff de leg[ationibus] Bald[us] ad L 6 C si quis sibi vel alt [eri] [lees, si quis alteri vel sibi] [sub alterius nomine vel aliena pecunia emerit] Molin[aeus] in novis intellectibus ad $L$ si partem $n^{\circ} 85$ et seqq ff quem ad servit[utes] amittant[ur] [lees, quemadmodum servitutes amittuntur].

Uiteindelijk heeft dit overzicht een eerder ambigue situatie aan het licht gebracht. Enerzijds is de rechtsleer als bron van recht niet onaantastbaar; anderzijds blijft ze tot op zekere hoogte gezagswaarde behouden en is ze in staat de gewoonte te corrigeren. Een eerder onverschillige houding als deze, waarbij de autoriteiten van de rechtsleer niet langer hun gezag onvoorwaardelijk afdwingen, maar waarbij hun hulp eerder naar eigen goeddunken wordt ingeroepen, doet me opnieuw denken aan de kritische en ontvoogde grondhouding welke de juridische humanisten zo kenmerkte. Als ware 'systeembouwers' recipieert men waar, wanneer en hoe men het wil.

Het staat dus vast dat het lokale recht tijdens het redactieproces wel degelijk een 'verwetenschappelijking' ondergaat. Dit impliceert overigens dat de theorie daadwerkelijk in staat is geweest de praktijk te beïnvloeden, op voorwaarde dat de Consuetudines compilatae ook daadwerkelijk in de stedelijke rechtbanken werden aangewend. Het meest verbazingwekkend is nu dat deze rechtsleer uit de studeerkamer van de doctores anno 1608 meer impact heeft gehad op de innovaties binnen de Consuetudines compilatae dan de jurisprudentie uit de rechtbank. ${ }^{471}$ Over het algemeen is ook deze vaststelling nefast voor de zuiverheidsgraad van het costumiere recht. De rechtsleer is in vergelijking met de rechtspraktijk immers veel te subjectief. Van de objectieve waarde van de rechtspraak zou men echter pas in de moderne tijd overtuigd geraken. Pas vanaf de zeventiende eeuw zal de jurisprudentie namelijk haar inhaalbeweging op de hiërarchische ladder der autoriteiten inzetten. ${ }^{472}$ Het ligt dan ook enigszins voor de hand dat hier te Antwerpen anno 1608 nog niet veel van te merken is. Terecht wordt dit gemis ook door Jacques Van Uffel betreurd. Er is

471 Omtrent de autoriteit van de rechtspraak als bron van recht in de zestiende, zeventiende en achttiende eeuw, zie ook: GODDING, "Jurisprudence et motivation des sentences", 140-151. Godding stelt, aan het begin van de moderne tijd, een toenemende invloed van de rechtspraak van hogere hoven vast, zodanig zelfs dat hun uitspraken al gauw zullen prevaleren boven de niet-gehomologeerde costumen. Deze trend gaat gepaard met een steeds sterker beperkt wordende, rechtsvormende rol van de lagere rechtbanken.

472 Met betrekking tot de Italiaanse rechtspraakverzamelingen: cfr. ASCHERI, "Rechtsprechungs- und konsiliensammlungen", 1113e.v. Met betrekking tot de Franse rechtspraakverzamelingen, cfr. G. WALTER, "Rechtsprechungs- und konsiliensammlungen. Frankreich", H. COING red., Handbuch der Quellen und Literatur der Neueren europäischen Privatrechtsgeschichte, II/2, Munchen, 1976, 1228e.v. 
inderdaad geen betere weerspiegeling van de juridische werkelijkheid denkbaar dan de schriftelijke neerslag van de rechtspraktijk, zoals samengebracht in rechtspraakverzamelingen (decisiones) en de verzamelingen van turbenonderzoeken (turbenboeken). De eerste groep omvat de vonnissen van de verschillende voornamelijk provinciale of hogere- hoven. De stedelijke rechtbanken van Antwerpen kenden aan het einde van de zestiende eeuw nog geen officiële compilatores. 473 De belangrijkste van deze compilaties van uitspraken ben ik reeds bij het voorgaande luik aangaande de verwetenschappelijking tegengekomen. Wat deze compilaties betreft, liet men zich namelijk in de eerste plaats inspireren door de rechtsgeleerde commentaar bij een vonnis uit de compilatie, dan door de inhoud van het vonnis zelf. De turbenboeken van hun kant bevatten de inquisitiones per turbam naar de geldigheid van een bepaalde costumiere regel. Zolang deze niet notoir of openbaar was, moest het bestaan ervan immers bewezen worden. Voor de periode van de vijftiende tot en met de zeventiende eeuw worden deze turbenboeken nog steeds door en in het Antwerpse stadsarchief bewaard. ${ }^{474}$ Een tweede soort waarvan ook in de Memorieboeken sprake is, is die van de zogenaamde ongeregistreerde turben. In dit geval wordt er uitsluitend verwezen naar de secretaris gedurende wier ambtstermijn het turbenonderzoek had plaatsgevonden. Het is me echter niet duidelijk welk de vindplaats is van deze turbae non registratae. Dat het om één of ander register moet gaan, vermoed ik omdat er steeds naar een welbepaald nummer wordt verwezen. Bij wijze van voorbeeld citeer ik hier de Memorieboeken omtrent artikel 3.2.1: "Est 8 in impressis ex usu et consequentia precedentium additus bic verbis oft buercodullen et $i[n]$ eenige onverschenen renten bueren, pachten, oft staenden vrucbten etiam ex usu, et turba non registrata tusschen mr Lucas de Mera aen[legge]re ende Wouter van Hove verweerdere 27 februarii 1562 staende onder die van[de] secretaris Asseliers n ${ }^{\circ} .7$..." 475

Ondanks hun beschikbaarheid, de kritiek van Jacques Van Uffel en de intrinsieke waarde van het genre als waarheidsgetrouwe reflectie van de juridische realiteit, blijkt de rechtspraak dus nauwelijks gezag verworven te hebben onder de Antwerpse redacteurs. Met slechts vier procent of 45.5 nieuwe artikels, bevindt de jurisprudentie zich in de onderste regionen van overzichtstabel 1.28. Uiteraard dient in dit opzicht gewezen te worden op de eigen praktijkervaring en kennis van de lokale jurisprudentie die de samenstellers ongetwijfeld bezaten. De evidentie ervan heeft er vermoedelijk voor gezorgd dat er in de Memorieboeken niet altijd expliciet naar verwezen werd. Anderzijds is er, zoals zojuist reeds kort aangestipt, het gegeven dat

473 Ook de algehele afwezigheid van de Antwerpse Rechtsaantekeningen van Guillaume de Moelnere, een verzameling van Antwerpse rechtspraak de dato 1405-1407, verbaast me niet. Aangezien men nu slechts over één manuscript beschikken kan van dit document, mag verondersteld worden dat de actieradius ervan ook in de vijftiende eeuw beperkt was tot de privésfeer van Guillaume de Moelnere. (Cfr. E. I. STRUBBE en E. SPILLEMAECKERS, "De 'Antwerpse Rechtsaantekenigen' van Willem de Moelnere", Bulletin en Handelingen van de Koninklijke Commissie voor de uitgave der oude wetten en verordeningen, 18 (1954), 7-148; GODDING, "Recueils de jurisprudence", 7.

474 ANTWERPEN, Stadsarchief, Vierschaer, nrs. 68-71: Turben.

475 Zie ook 3.14.6. 
men er in de huidige literatuur van overtuigd is dat de rechtspraktijk als rechtsbron pas aan het begin van de moderne tijd aan zijn opmars begonnen is. Doorgaans wordt aangenomen dat pas vanaf de zeventiende eeuw de rechtspraakverzamelingen een hoofdrol opeisen binnen de autoritatieve hiërarchie. ${ }^{476}$ Het is evident dat hiervoor ook eerst verzamelingen daadwerkelijk voor handen moeten zijn. De Zuidelijke Nederlanden moeten zelfs tot het tweede kwart van de zeventiende eeuw wachten alvorens hun eerste rechtspraakverzameling van de drukpers rolt. ${ }^{477}$ Bijgevolg kan het genre enkel later een hoogtepunt beleven. Dit hoogtepunt kent het genre dan ook pas in de achttiende eeuw. In de Nederlanden van de zeventiende eeuw daarentegen zijn het nog steeds de consilia die de rangen aanvoeren.478 Daar jurisprudentiële verzamelingen van eigen bodem ontbreken, richt men de blik naar het zuiden. Frankrijk ervaart dit ganse proces immers veel vroeger. Langzaam maar zeker komt de bijdrage die de juridische precedenten er hebben geleverd aan de vorming van een eigen nationaal recht, op een vergelijkbare hoogte als andere rechtsbronnen zoals het Romeinse recht, de opinio van de rechtsgeleerden en de aequitas, aldus Dauchy. ${ }^{479}$ Het ligt dan ook voor de hand dat de jurisprudentie invloed zal uitoefenen op de vorming van het recht.

Bij dit alles wil ik evenwel opmerken dat, voor het verschijnen van de eerste rechtspraakverzamelingen, deze lacune van de jurisprudentie als rechtsbron mijns inziens gecompenseerd werd door een parate kennis van de eigen rechtspraktijk. Het lijkt me onvermijdbaar dat men voortdurend putte uit de eigen ervaring zonder dat hier expliciet naar verwezen werd. In die zin is de invloed van de rechtspraktijk ongetwijfeld groter geweest dan doorgaans wordt aangenomen op basis van de aanwezige rechtspraakverzamelingen.

De cijfers uit paragraaf 2 blijken de zojuist beschreven en traditionele tendensen te bevestigen. Het aandeel van de rechtspraak met betrekking tot de nieuw toegevoegde artikels in de Consuetudines compilatae blijft immers beperkt tot vier procent in totaal. Hoewel we reeds 1608 schrijven, moet de echte bloeiperiode van de rechtspraak nog aanbreken. Deze ondergeschikte rol ligt in de lijn van de vaststellingen van Vervaart met betrekking tot de allegaties in de Topica van Everaerts. ${ }^{480}$ Ook hier bevindt de rechtspraak zich nog onderaan de ladder van de hiërarchie van juridische autoriteiten. Gezien de plaats in de tijd van Everaerts zelf, namelijk het begin van de zestiende eeuw, is dit logisch. De consilia zijn aan de macht. Wat het Antwerpen van 1608 nu juist zo bijzonder maakt, is dat de voorkeur er blijkt uit te gaan naar monografische werken en commentaren bij het geleerde recht, zoals hierboven aangetoond.

476 ASCHERI, "Rechtsprechungs- und konsiliensammlungen", 1199.

477 Het is wachten tot 1626 wanneer de Practicarum quaestionum rerumque in supremis belgarum curiis actarum et observatarum decisiones van Paul van Christynen voor het eerst verschijnt. (Cfr. DEKKERS, Bibliotheca Belgica Juridica, 36; GODDING, "Recueils de jurisprudence", 15-17.)

${ }^{478}$ U. WAGNER, "Rechtsprechungs- und konsiliensammlungen. Niederlande", H. COING red., Handbuch der Quellen und Literatur der Neueren europä̈schen Privatrechtsgeschichte, II/2, Munchen, 1976, 1418.

${ }^{479}$ Cfr. DAUCHY en DEMARS-SION, Les recueils d'arrêts, 19.

${ }^{480}$ VERVAART, Studies over Nicolaas Everaerts, 120-124. 
Wat zijn nu de karakteristieken van de gerecipieerde, jurisprudentiële precedenten? Ten eerste is uit paragraaf 2 gebleken dat er geen specifieke rechtsgebieden bestaan, waar de jurisprudentie opvallend nadrukkelijk anwezig is. De ondervertegenwoordiging ervan is alomtegenwoordig. Enkel het tweede deel omtrent het personenrecht overstijgt het gemiddelde percentage van vier met een drietal punten, wat bovendien logisch is gezien het costumiere karakter van dit privaatrechtelijke deel. Wat dit tweede deel betreft, spant de Antwerpse rechtspraak de kroon. Bij het erfrecht uit deel III is de Franse jurisprudentie toonaangevend. Het is namelijk zo dat ook dit erfrecht afzonderlijk voor meer dan zeven procent bepaald werd door jurisprudentiële precedenten, zij het voornamelijk van Franse hoven. Binnen het goederenrecht blijft het aandeel van de rechtspraak beperkt tot een schamele 1.4 procent. Ook opvallend is de totale afwezigheid van jurisprudentie binnen het straf- en het strafprocesrecht. Globaliter verdeelt de rechtspraak zich zoals in tabel 1.38 wordt weergegeven.

Tabel 1.38 Aandeel van elk type rechtspraak per deel

\begin{tabular}{|c|c|c|c|c|c|c|c|c|}
\hline Type rechtspraak & I & II & III & IV & $\mathbf{V}$ & VI & VII & Totaal \\
\hline Turben & 1 & 8.5 & 1 & 7 & - & - & - & 17.5 \\
\hline Antwerpse rechtspraak & - & 3 & 1 & 7 & 5 & - & - & 16 \\
\hline Frankrijk & - & - & 9 & - & 1 & - & - & 10 \\
\hline Raad van Brabant & 1 & 1 & - & - & - & - & - & 2 \\
\hline Heilige Roomse Rijk & - & - & - & - & - & - & - & - \\
\hline Napels & - & 1 & - & - & - & - & - & 1 \\
\hline Percentage & 2.6 & 6.9 & 4.1 & 4.4 & 1.9 & 0.0 & 0.0 & 45.5 \\
\hline
\end{tabular}

Hoewel de cijfers te beperkt zijn om op basis van hun onderlinge verhoudingen conclusies te trekken, wil ik er evenwel op wijzen dat de eigen rechtspraak de voornaamste inspiratiebron vormt (turben en Antwerpse jurisprudentie). Ik heb de geïntegreerde turben onderzocht en ben op zoek gegaan naar een rode draad die hen mogelijk bindt. Buiten het feit dat allen dateren van circa het midden van de zestiende eeuw, ben ik van een kale reis teruggekomen. ${ }^{481}$ Zestien andere artikels worden louter als het gevolg van 'interne rechtspraak' angeduid. ${ }^{82}$ Hoogstwaarschijnlijk gaat het om uitspraken van stedelijke, Antwerpse rechtbanken, aangezien men met betrekking tot andere hoven deze ook expliciet vermeldt, zoals bijvoorbeeld bij de Raad van Brabant ten aanzien van artikel 1.2.16 omtrent de schout en zijn recht gevangenen te arresteren: Ex duabus sententiis Consilii Brabantie ibi citatis de 19 februarii 1592 et 5 aprilis 1593. De tien -waarvan zeven erfrechtelijke- artikels, welke teruggaan op de Franse rechtspraak, verwijzen hoofdzakelijk naar Louis le Caron. Zeven artikels gaan namelijk terug op cases beschreven in zijn Responses du droit françois (s.d.), Memorables

481 Deze plaats in de tijd evoceert de vraag naar de representativiteit ervan voor het Antwerpen van de zeventiende eeuw.

482 Ter illustratie verwijs ik hier naar artikel 2.5.108: Est novus etiam ex usu et ita nuperrime judicatum in causa Francisci Poock weerdt inde gauwbloeme tegens de momboiren van syne kinderen, die allen de meublen wilden vercocht hebben, pr[a]eter omnem rationem. 
Observations du droit françois (1601) en zijn commentaar bij geredigeerde coutumes van Parijs (1582). 483

Wat er ook van zij, een totaal van iets meer dan 45 artikels, blijft iets minder dan bedroevend. En ook als secundaire bron blijkt de rechtspraak geen noemenswaardige potten te breken. ${ }^{484}$ Misschien kan een onderzoek naar de rol van de rechtspraak binnen de Consuetudines impressae nog troost bieden.

Aan de zuiverheidsgraad valt hier, althans op het eerste gezicht, niet veel af te doen. Lokale rechtbanken werden immers verondersteld te oordelen volgens de heersende gewoonte. Bijgevolg kunnen turben en vonnissen van de eigen schepenbank geacht worden de meest getrouwe weerspiegeling van de gangbare gewoonte te zijn. ${ }^{485} \mathrm{Bij}$ hogere rechtbanken daarentegen ligt dit thema gevoeliger gezien de sterkere invloed van het geleerde recht aldaar via de subsidiaire rol toegekend aan het Romeinse recht en de universitaire achtergrond van de leden van de vergadering, hoewel ook in de lagere rechtbanken vaak een subsidiaire rol an het Romeinse recht was toegekend. Hierbij komt nog dat ik een zekere invloed heb kunnen vaststellen van jurisprudentie afkomstig van vreemde hoven, zoals de Franse rechtspraak. De vraag blijft in hoeverre deze vonnissen representatief zijn voor wat te Antwerpen als gebruikelijk werd aanzien. Omwille van deze onduidelijkheden, zal ik ook hier nagaan in hoeverre de geïntegreerde rechtspraak ook door de Usus werd bevestigd. Dit zal zeer summier gebeuren, aangezien het aantal jurisprudentiële artikels zeer beperkt is.

Hoewel ik ten aanzien van de turben geen confirmatie verwacht, is dit evenwel mogelijk, zoals te zien is bij artikel 4.3.37/38 omtrent de wisselbrieven: Est additus in hac revisione ex d turba duplici de anno 1599 citata ad ar[ticu]lum pra[e]cedentem et usus ita observat. Bij de andere, interne rechtspraak, krijg ik uiterst zelden tot nooit een bevestiging te zien. Ook oordelen van de Raad van Brabant werden nooit door de eigen gewoonte geconfirmeerd. ${ }^{486} \mathrm{Al}$ evenmin werd er ten aanzien van de

483 Andere auteurs, zelden goed voor meer dan één artikel, zijn René Choppin, Joachim Mynsinger, Guy de la Pape, Nicolas Bohier en Jean Papon.

${ }^{484}$ In dit opzicht is artikel 4.18.19 interessant. Er wordt, naast de Raad van Brabant, ook verwezen naar de Grote Raad van Mechelen en naar de Raad van Vlaanderen: Est novus etiam sed usu et multis sententiis etiam curia $[e]$ comprobatus no $[m] i[n]$ atim in causa vidue Jans Vleminckex tegens de crediteuren desselfs Jan en [de] Aertus Vleminckx in Magno Concilio 18 martii 1600 midtsgaeders inde voors[chreven] saecke vande wed[unve] Reyngoudts inden Raedt van Brabant 24. 1589 en[de] inden grooten Raedt 4 novemb[er] 1597 item van Petronella Haeck wed[uwe] wylen Romboude Huens inden Raede van Vlaenderen 28 iunii 1596 en [de] van te voren hier voor de wethouderen 2 maii 1587 geconfirmeert inden Raedt van Brabant 12 octob[er] 1588 item van heer Lenaert en [de] en [de] Ian de Fraey iure materno inden Raede van Brabant 10 octob [er] 1598 et est de iisdem certificatio scabinalis de 5 novemb[er] 1562 staende int procuratieboeck. Het roept de vraag op naar de vindplaats van deze informatie.

${ }^{485}$ Cfr. GILISSEN, "Rédaction des coutumes. Essai de synthèse", 58.

486 Twee maal heeft het zich evenwel voorgedaan dat een vonnis van de Raad van Brabant ook in de eigen gewoonte van Antwerpen een equivalente costumiere regel bevatte. Het betreft de artikels 4.16.63 (Est etiam novus ex usu, et sententia Consilii Brabantia[e] tusschen Joris Stechen en [de] wylen den amman Sterck nisi quod in hac revisione addita sit clausula oft immers vande dry virendeelen ex iis qua $[e]$ dicta sunt $i[n]$ art 36 et seqq sed in textu linea $7^{a}$ post verbum eenighe videtur addendum van bun 
gerecipieerde, Franse jurisprudentie bevestiging gezocht in de Antwerpse Usus. Een aantal keer werd evenwel verwezen naar de redelijkheid dat het vonnis in zich droeg, bijvoorbeeld bij artikel 3.14.73 omtrent de aanvaarding van een sterfhuis onder beneficie van inventaris: Est etiam ex d placitis et usu nisi quod in hac ultima revisione addita sit clausula van dat de crediteuren ter woerderinge ende priseringe mogen comen verhoopen quam sumpsimus ex consuet[udine] Arthesi[a]e tit 11 art 111 et duobus arrestis quam in eam sententiam citat Papon arrestor. lib 21 tit 10 art 6 habentque evidentissimam rationem, presertim cum nos facultatem eam restrencherimus ad tempus 3 mensium, ne videlicet heres semper in inserto sit.487 Deze rede komt eveneens terug bij één van de weinige artikels welke zowel een jurisprudentiële als gewoonterechtelijke basis blijken te hebben, namelijk artikel 2.5.108 aangaande de verkoop van goederen van weeskinderen: Est novus etiam ex usu et ita nuperrime judicatum in causa Francisci Poock weerdt inde gauwbloeme tegens de momboiren van syne kinderen, die allen de meublen wilden vercocht hebben, pr[a]eter omnem rationem.

Voorgaande vaststellingen hebben laten zien dat, ondanks de zogenaamde objectiviteit van de rechtspraak, de nodige voorzichtigheid vereist is met betrekking tot uitspraken omtrent de zuiverheid van het Antwerpse gewoonterecht. Het merendeel van de artikels op basis van vonnissen afkomstig van buitensteedse hoven werd immers niet expliciet bevestigd door de eigen gewoonte. Verder onthoud ik opnieuw de opvallende rol van de ratio. Oude vonnissen kunnen worden gewijzigd door de heersende ratio. ${ }^{488}$ Meer nog, de redelijkheid lijkt in staat te zijn de zuiverste van alle costumiere bronnen, namelijk de turbe aan te passen. Dit blijkt uit de Memorieboeken ten aanzien van de artikels 4.3.39/40 opnieuw betreffende de wisselbrieven: Sunt etiam novi additi in hac revisione ex contraria turba tusschen Goosserie, en [de] Roomen de anno 1601 paucis additis vel clarius explicatis ex suggestione mercatorum ut ratio decisionis appareret qua[e] alioqui satis obschura. ${ }^{489}$

Omtrent vroegere en buitensteedse compilaties

Aan het begin van dit eerste hoofdstuk heb ik laten zien dat ongeveer de helft van de artikels in de Consuetudines compilatae uit de Consuetudines impressae afkomstig is, zij het

quod per in curiam amanuensis ommissum.) en 4.16 .65 (Est additus in hac revisione ex usu et sententia i [bi] citata art 63 sed linea $1^{a}$ loco verborum en [de] alle videtur ponendum oft andere officier ut $1^{\circ}$ art seqq.).

${ }^{487}$ Een ander voorbeeld betreft de artikels 3.14.122/123: Sunt etiam novi in hac revisione ex arrestis Curie Paris[iensis] apud Choppin[um] de previleg[iis] rusticorum lib 3 parte $1^{a}$ cap 3 et Charond[as] lib 5 resp[ons] 11 et lib 8 resp[ons] 42 eleganter Nicolaus V ala de rebus dubiis tract[atus] $10 n^{\circ} 2$ et tract[atus] 11 etiam $n^{\circ} 2$ ubi respondet iis qu[a]e tradentur in L si consentit $\int$ tenendum ff quibus modis pign [us] vel hipoth [eca] solvatur [lees: solvitur] et similibus videlicet quod magis in subtilitate quam equitate consistant, ideoque apud populos qui moribus vimut [?] et equitatem inspiciunt non esse recepta, quod et nos observamus. ${ }^{488}$ Dit blijkt onder meer uit de volgende artikels: 2.1.159/160, 2.5.108, 3.14.73, 3.14.122/123.

${ }^{489} \mathrm{Bij}$ de artikels 5.13.18/19 is het de turbe zelf die dwingend optreedt: Sunt desumpti ex art 4 in beyde d'ordonnantien soo achter de gedructe costuymen als die vanden jaere 1564 tit van toon sed cogita an sub finem art 19 qui satis est brevis non possit et debeat addi dies moet partye oft haeren procureur daerop altyt gedaecht worden om by maniere van diminutien oft andersints op alles te bebben syn verantwoorden. Nam ita tam bic quam in curia observatur turba Lucas van Holchem staende int turboeck. fol 52 in princ[ipe] geconfirmeert byt Guldeboeck art 131 et convenit fortassis exprimere propter iuniores. De ordonnanties op de styl ende maniere van procederen van 1564 en 1582 worden aangepast op basis van de turbe. 
vaak in licht gewijzigde vorm. Een aanzienlijk aantal van hen maakte bovendien ook deel uit van zowel de Consuetudines antiquae als de Consuetudines antiquissimae. ${ }^{490}$ In dat opzicht is de kritiek van Jacques Van Uffel, die de te kleine rol van vroegere redactiepogingen betreurde, overdreven. Overigens is uit de tweede paragraaf van dit hoofdstuk gebleken dat, naast de behouden gebleven artikels uit de Consuetudines impressae, ook een noemenswaardig aantal nieuwe artikels zijn oorsprong vindt in de Consuetudines antiquae, Consuetudines antiquissimae en zelfs nog oudere, evenwel nietofficiële, redactiepogingen zoals het zogenaamde Guldenboeck en het Keurboeck. In totaal betreft het negen procent van alle innovaties, wat correspondeert met een absoluut aantal van 110 nieuw toegevoegde artikels. Eén van de meest opvallende vaststellingen hierbij is het aandeel dat de Consuetudines antiquissimae binnen deze groep voor zich opeisen. Tabel 1.39 geeft de onderlinge verhoudingen weer.

Tabel 1.39 Aandeel van de verschillende oude redactiepogingen per deel

\begin{tabular}{|l|c|c|c|c|c|}
\hline & Guldenboeck & Keurboeck & $\begin{array}{c}\text { Oude } \\
\text { specificatie }\end{array}$ & $\begin{array}{c}\text { Consuetudines } \\
\text { antiquissimae }\end{array}$ & $\begin{array}{c}\text { Consuetudines } \\
\text { antiquae }\end{array}$ \\
\hline Deel I & - & 1 & - & 7 & 2 \\
\hline Deel II & 4.5 & 1 & - & 9 & 3 \\
\hline Deel III & 6 & 3 & - & 18 & 4 \\
\hline Deel IV & 2 & - & - & 7 & 1 \\
\hline Deel V & - & - & - & 5 & - \\
\hline Deel VI & - & 5 & 12 & 46 & 1 \\
\hline Deel VII & - & - & - & 3 & - \\
\hline Totaal & $\mathbf{1 2 . 5}$ & $\mathbf{1 0}$ & $\mathbf{1 2}$ & $\mathbf{9 5}$ & $\mathbf{1 1}$ \\
\hline
\end{tabular}

Wat meteen in het oog springt, is dat deel VI van de Consuetudines compilatae met het materiële strafrecht in zekere zin een terugkeer betekent naar het strafrecht van de Consuetudines antiquissimae. ${ }^{491}$ Het jaar 1608 wordt als het ware 1547. Maar liefst 46 van de 82 nieuwe artikels worden terug opgevist uit de eerste Antwerpse redactiepoging, zoals het geval is bij de artikels 6.1.12/13 omtrent het verbod moordwapenen te dragen: Sunt desumpti ex art 18 in antiquiss[imis] et 20 int kuerboeck. Hoewel het zesde deel ook het meest geïnnoveerde deel bleek te zijn, wordt het innovatieve element van deze zogenaamde vernieuwing grotendeels gecompenseerd door een terugkeer naar oude, costumiere rechtsbronnen. Desalniettemin betreft het geen blindelingse overname. Letterlijke hernemingen zoals in bovenstaand voorbeeld vormen een minderheid. De gerecupereerde artikels worden namelijk meestal aangepast aan de noden van een veranderde samenleving. Bij wijze van voorbeeld verwijs ik naar de artikels 6.1.9/10 omtrent wat onder moordwapenen verstaan moet worden: Sunt desumpti ex articulo 4 in antiquiss[imis] en[de] 8 inde voors[creven] specificatie nisi quod nos

${ }^{490}$ Dit blijkt meermaals uit de Memorieboeken zoals bijvoorbeeld bij de artikels 3.9.35/36: Sunt desumpti ex articulo 17 et 19 in impressis 11 in antiquis hoc titulo et 22 in antiquissimis d tit van schepenebrieven cum quibus accordat clausula finalis articuli $1^{i}$ inde voors[chreven] ordonnan[tie].

491 De enige uitzondering op deze regel is paragraaf 3 van titel 6.1 (V an keuren ende breucken). Deze wordt gedomineerd door de categorie van de rechtsleer. Er is nauwelijks sprake van de Consuetudines antiquissimae. 
eum divisimus in duos ar[ticu]los amputatis superfluis et substitutis aliis quibusdam ex hodierno usu. Omdat ik hier te maken heb met strafrecht, gaat het echter in veel gevallen om een aanpassing van de strafmaat, waarin vooral de magistraat zich van zijn meest creatieve kant laat zien. Een voorbeeld van een strafmaatwijziging is terug te vinden bij onder meer artikel 6.2.21 aangaande overspel: Est desumptus ex art 22 in antiquiss[imis] tit van keuren en [de] breucken nisi quod aucta sit pena et additum dat die soude genomen worden vanden dach aff dat sy bevonden souden syn alsoo geseten te bebben ut videlicet pena qua [e] exigua est eo magis stringat et arctet. 492 De rol van de magistraat hierin blijkt onder meer uit artikel 6.3.23 inzake doodslag: Est XXV in antiquissimis sed ibi dicitur dat den affhouwer hoc casu soude verliesen syn lyff en [de] goet quod magistratui visum nimis durum nec ulla ratione sustineri posse ideoque natigavimus statuta pena quadrupli als nyet en blyckt van groote moetwillicheyt et si de ea patet, den ban, en [de] arbitrale correctie, quod certe satis poenarum est pro damno reparabili... Opvallend hierbij is hoezeer de magistraat een neus voor redelijkheid lijkt te hebben. De straf is 'te hard en kan door geen enkele redelijkheid ondersteund worden'. Hier staat tegenover dat deze aanpassing vaak niet meer impliceert dan een stilistische ingreep, zoals ten aanzien van artikel 6.1.11 omtrent het verbod moordwapenen te dragen is gebeurd. De formulering werd er aangepast opdat 'de zaken beter begrepen zouden worden': Est pars $2 d$ art 1 in antiquissimis cum quo accordat 3 inde voors [creven] specificatie sed videtur quod stilus paulum posset mutari ut res melius intelligatur deletis linea 2 verbis tselve verbodt, et post verba te kennen geven addendo datmen egeene moort waepenen binnen de stadt en mach draegen. ${ }^{493}$

Verder zal het menig aandachtig lezer opgevallen zijn dat elke referentie naar de Consuetudines antiquae binnen het strafrecht zo goed als volledig ontbreekt. In verband met slechts één artikel wordt er naar de tweede redactiepoging verwezen als primaire rechtsbron. ${ }^{494}$ De verklaring ligt voor de hand. Omwille van de 'criminele' codificatieplannen van de Spaanse koning Filips II anno 1570, bevatten de Consuetudines antiquae nauwelijks strafrechtelijke artikels. De Antwerpse commissieleden waren hier ongetwijfeld van op de hoogte. Bijgevolg telt de titel genaamd keuren ende breucken in de Consuetudines antiquae niet meer dan vijf verschillende artikels. Men lijkt de Criminele Ordonnantiën af te wachten. In de Consuetudines antiquissimae kende deze titel namelijk nog een omvang van maar liefst 52 artikels. Dit verklaart waarom het strafrecht binnen de Consuetudines compilatae in de eerste plaats gebaseerd is op dat van de Consuetudines impressae en de Consuetudines antiquissimae, welke op strafrechtelijk gebied sterker waren uitgewerkt, aangevuld met

492 Cfr. 6.1.18/19: Sunt etiam desumpti ex art 5 et 6 in antiquiss[imis] 9. 10. 11. 13 et 14 inde voors[creven] specificatie nisi quod aliquo modo aucta sit pena ut ante. 6.2.33: Est etiam 33 in antiquissimis $d$ tit van keuren en [de] breucken additis in princip [e] verbis oft die teirlingen speelt ex paritate rationis et aucta in fine poena consensu officiarii.

${ }^{493}$ Op de mogelijke aard van de aanpassingen, welke kunnen volgen op nisi quod, ben ik reeds aan het begin van dit hoofdstuk uitvoerig ingegaan. Cfr. supra, hoofdstuk 1, paragraaf 1 , Methode.

${ }^{494}$ Het betreft hier artikel 6.2.12, alwaar de Consuetudines antiquae in het gezelschap vertoeven van de Consuetudines antiquissimae. 
een niet te verwaarlozen hoeveelheid keizerlijke wetgeving afkomstig van de kanselarij van Karel V.495

Kortom, wat het materiële strafrecht betreft, geldt de kritiek van Jacques Van Uffel niet. A contrario zijn overtuiging, en hoewel hij eerder een gebruik van de Consuetudines antiquae voor ogen had, werd er mijns inziens door de commissieleden wél voldoende gebruik gemaakt van vroegere redacties zoals de Consuetudines antiquissimae en de Consuetudines impressae. Bovendien lijkt er van de Consuetudines antiquissimae meer gezag uit te gaan dan van de Consuetudines impressae, althans voor zover ik me baseer op de Memorieboeken angaande artikel 2.5.89 omtrent de taken van de voogd: Est 30 in impressis cum quo accordat pars fin d art 22 in impressis hoc tit nisi quod in impressis addita sint verbae ende den selven ter weescaemer overbrenghen $\mathrm{q}[\mathrm{a}] \mathrm{ue}$ nos omisimus, nam desunt in antiquissimis, et constat superstites, ad id non teneri cum proprie id tutoris sit, ut bic etiam expressimus additis verbis, ende daer toe moeten de momboirs ethc[etera]. Het lijkt te gaan om een bewuste keuze de Consuetudines antiquissimae voorop te stellen voor elke andere, oudere redactie. Dit is evenwel de enige expliciete uitlating van deze idee die ik heb aangetroffen. Een andere belangrijke redactie binnen dit strafrechtelijk deel is de Oude specificatie geintituleerd keuren ende breucken van Antwerpen. Zij komt enkel voor in de gelijknamige titel 6.1 en staat er garant voor twaalf artikels. Deze zijn evenwel allemaal vergezeld van een verwijzing naar de Consuetudines antiquissimae. Met betrekking tot de rest van de Consuetudines compilatae is het document van geen enkel belang. Ik ben er ook niet in geslaagd het te identificeren noch te lokaliseren.

Andere titels waar de Consuetudines antiquissimae een beslissende invloed hebben uitgeoefend, zijn minder aantrekkelijk voor nadere toelichting. 496 Binnen het burgerlijk procesrecht van deel V bereikt de categorie met slechts twee procent zelfs een absoluut dieptepunt. Dit wordt er evenwel gecompenseerd door de integratie van de ordonnantie op de styl ende maniere van procederen van 1582 binnen dit deel. In zekere zin kan deze ordonnantie ook beschouwd worden als een vroegere redactie, zij het dan van Antwerps procesrecht.

Welke implicaties hebben deze articuli restituti nu voor de zuiverheidsgraad van de Consuetudines compilatae als compilatie van Antwerps, costumier recht? Gezien de nadruk op de Consuetudines antiquissimae is het in dit opzicht van belang te kijken naar de mate waarin zij nog als een verzameling van zuiver costumier recht kunnen

495 Dat de Consuetudines impressae opnieuw een grondig uitgewerkt, strafrechtelijk deel bevatten, is vermoedelijk een gevolg van het feit dat het nieuwe, gereformeerde stadsbestuur het gezag van de Spaanse vorst niet langer erkende en zijn strafrechtcodificatie van 1570 (Criminele Ordonnantiën) officieel werd afgeschaft met de Pacificatie van Gent (1576). Omtrent de discussie in hoeverre deze bepalingen na 1576 nog zijn blijven doorwerken, cfr. supra, hoofdstuk 1, paragraaf 2, Deel VI.

496 In geen enkel ander deel zijn de vroegere redactiepogingen overigens zo nadrukkelijk aanwezig als in deel VI. Enkel het goederen- en erfrecht van deel III (titels 3.3 (vervolg van eigen goed), 3.7 (tochte) en de eerste drie paragrafen van titel 3.14 (wettige versterfenisse) zijn het vermelden waard. In het laatste geval is, naast de Consuetudines antiquissimae, ook het Guldenboeck belangrijker dan doorgaans het geval is. Ter volledigheid vermeld ik ook titel 1.1. 
worden beschouwd. Gotzen getuigt hieromtrent van een categoriek optimisme. Zijns inziens kan er pas vanaf de Consuetudines impressae gesproken worden van infiltratie van vreemde elementen als het Romeinse en het geleerde recht. ${ }^{497} \mathrm{Hij}$ meent dan ook dat de Consuetudines antiquissimae en de Consuetudines antiquae van zuiver costumiere aard zijn. Ook het Guldenboeck, ook Statuten der stadt Antwerpen genaemt bet gulden boeck ofte gulde bulle genaamd, welk dateert van vermoedelijk het einde van de vijftiende eeuw, bevat naar zijn mening uitsluitend gewoonterechtelijk materiaal en is dus vrij van elke vreemde invloed. Gotzen typeert dit Guldenboeck als een wanordelijk mengelmoes van burger-en ook strafrechtelijke voorschriften, zonder eenigen logischen samenhang achter mekaar opgeteekend, met tal van herbalingen.498 Dit is niet het geval met betrekking tot het Keurboeck, aldus dezelfde auteur. Dit Keurboeck of Coerboeck metten doppen dateert van de eerste helft van de veertiende eeuw en heeft als kern de uitwerking van de principes welke waren vastgesteld in het Brabantse Landcharter voor het Schoutambacht Antwerpen van 1292. Nadien groeide het stilaan uit tot een mengelmoes van stedelijke ordonnantiën en voorschriften. Ten midden van deze overvloed aan bestuurlijke voorschriften zijn hier en daar ook regels van costumiere aard aan te treffen. ${ }^{499}$

Zelf zou ik in dit kader meer voorzichtigheid willen prediken. Zowel aan Belgische als aan Nederlandse zijde hebben verschillende rechtshistorici (na Gotzen) aangetoond hoe reeds in de late middeleeuwen rechtsgeleerde elementen hun weg vonden naar het costumiere veld en in welke mate de Lage Landen er zich ook vanaf dan ontvankelijk voor opstelden. ${ }^{500}$ Ook recente, buitenlandse studies bevestigen deze opvattingen en betwisten de zuiverheid van de vroegste costumiere compilaties of redacties. ${ }^{501}$ Het lijkt mij dan ook meer dan plausibel dat dit te Antwerpen niet anders is geweest. Een mogelijke bevestiging hiervoor kan gezocht worden aan de hand van een analyse van de mate waarin de nieuwe artikels op basis van vroegere redactiepogingen in de Memorieboeken al dan niet expliciet door de Usus werden bevestigd. Wanneer ik de verschillende artikels op een rij zet, blijkt meteen dat men zeker niet elk nieuw artikel wenst te verantwoorden aan de hand van de gewoonte. Het minst handelt men zelfs zo ten aanzien van het strafrecht. Meer dan de helft van de verschillende artikels mist een expliciete bevestiging door de eigen Usus. Artikel 2.1.84, in verband met de schulden van gehuwde personen, is hier een voorbeeld van: Est ex art 12 in antiquis et 52 in antiquissimis hoc tit additis verbis oft gemeyne, et in al mochte de vrouwe daer inne oock gehouden sijn qu[a]e articulum faciunt clariorem ex preced. Men streeft er louter naar meer duidelijkheid. Soms ontbreekt ook elke verantwoording volledig, zoals het geval is ten aanzien van artikel 6.1.14 inzake het verbod op moordwapenen: Est 2 in antiquissimis et 4 inde voors[creven] specificatie. Minder dan de helft beschikt dan weer wel over een expliciete bevestiging door de Usus, zoals bijvoorbeeld ten aanzien

497 GOTZEN, "De costumiere bronnen”, 110.

498 GOTZEN, "De costumiere bronnen", 10.

499 Voorgaande is gebaseerd op Gotzen: GOTZEN, "De costumiere bronnen”, 7-16.

500 Cfr. VAN CAENGEM, Droit romain. HERMESDORF, Römisches Recht. GILISSEN, "Romeins recht en inheems Gewoonterecht", 97-139. GODDING, "Recueils de jurisprudence", 1-37.

501 Cfr. KRYNEN, "Voluntas domini regis", 59-89. 
van artikel 3.14.116 omtrent de scheiding en deling van het sterfhuis en andere gemeenschappelijke goederen: Est ex art 143 int Guldeboeck et est notissimi usus.502 De overige 'gerecupereerde' artikels kennen een bevestiging door andere rechtsbronnen, zoals interne wetgeving, het geleerde recht, een andere vroegere redactie ${ }^{503}$, maar meer nog extern gewoonterecht en dan voornamelijk de costumen van Mechelen ${ }^{504}$. Kortom, de kans dat er via vroegere redacties niet-costumiere elementen in de Consuetudines compilatae infiltreren, is reëel.

Wat de onderlinge machtsverhoudingen van de verschillende rechtsbronnen betreft of de autoritatieve positie van de vroegere redacties binnen het geheel van de rechtsbronnen, geven de Memorieboeken deze keer zeer weinig geheimen prijs. Een enkele keer tracht men de vroegere redacties in overeenstemming te brengen met het geleerde recht in strikte zin, zoals bijvoorbeeld gebeurt bij de artikel 2.5.179 aangaande het einde van de voogdij: Est fere ad verbum desumptus ex art 23 in antiquissimis, nisi quod ea quae ibi dicebantur de absolutione eius qui non administravit ut i[n] art 175, nos reduximus ad jus co[mmun]e juxta text in $L$ fin $C$ si tutor vel curat [or] non gess[erit] [lees, si tutor non gesserit] L 2 C de b[a]eredi[bus] tut[orum] L 1 C si tut [or] rei p[ublicae] c [au]sa aberit d L tres tutores 55 in princip[e] versic plane si pecunia numerata ff de administ [ratione et periculo] tut [orum et curatorum qui gesserint vel non et de agentibus vel conveniendis uno vel pluribus].505 Een andere keer worden ze aangepast aan de hedendaagse Usus, zoals ten aanzien van artikel 2.1.133, betreffende man en vrouw wier huwelijk door een geestelijk hof werd ontbonden: Est desumptus ex art[icul]i 45 in antiquissimis nisi quod nos addiderimus ultima verba, ten keuse vanden onnooselen ex usu, et ijs qu[a]e dicta sunt i[n] art 124 et seqq. ${ }^{506}$ Verder gebeurt het ook dat men de Consuetudines antiquissimae a contrario sensu herneemt. Artikel 2.1.78, opnieuw omtrent de schulden van gehuwde personen, is hier een voorbeeld van: Est novus ex art 15 in antiquissimis boc tit a contrario sensu, nam cum ibi dicatur dat de vrouven inde schulden voor den bouwelijck gemaeckt off andere die tot extinctie der selver sijn gecontracteert nyet gehouden en is ten waere dat sij naer haers mans doot inden sterffhuysse gebleven waere sequitur a contrario sensu

502 Andere voorbeelden zijn de artikels 3.14.62 (Est ex art 18 in antiquiss[imis] et $d$ art 3 int Guldeboeck in fine, et ita servatur non solum bic sed in tota patria cum feuda nostris moribus redacta sint ad formam patrimoniorum ut in Galliis et passim per totam Europam observarii testatur Molineus ad consuetud[inem] Borboni[a]e articulo 365) en 5.17.57/58 (Sunt desumpti ex articulo 2 vande voors[creven] ordonnantie achter de gedructe costuymen tit van executie en [de] leveringe et quoad primum accordat art 20 in impressis in clausula en [de] mach den debiteur et 3 cum seqq in antiquiss[imis] tit van administratie van iustitie int civiel in princ[ipe] ex quo nos restituimus in hac revisione verba nacht en dach cum modificatione tamen quam ammannus desideravit apponi als sy daertoe versoecht worden, et art 58 addidimus in fine cl[ausu] am en [de] oft daermede ex ratione iuris et mente consuetudinis et usu.)

${ }^{503}$ Cfr. 2.5.85, 1.1.5, 1.1.11.

${ }^{504}$ En dit ondanks lichte verschillen, zoals blijkt uit de Memorieboeken omtrent artikel 6.1.47: Principium est desumptum ex art 47 in antiquissimis et accordat consuet[udo] Mechlin[iensis] tit van criminele saecken art 4 reliqua sunt ex art 28 in antiquiss[imis] boc tit et 42 vande voors[creven] oude specificatie, et cum iis accordat etiam de costuyme van Mechelen eodem tit van criminele saecken art 22 nisi quod differat in poena die aldaer is een be [de]vaert tot Tours.

${ }^{505}$ Een ander voorbeeld is artikel 6.3.1.

${ }^{506}$ Een ander voorbeeld is artikel 6.1.9/10. 
dat als sij uuyt de gemeynschap scheydt sij van alsulcke schulden ontlast wordt, et id obtinere generaliter, cum mulier acquisitis et communitati renunciat, ut bic pr[a]eter notata ad art preced [entem] ostendemus latissime i[n] art 142. Tot slot wil ik er nog op wijzen dat het herstel ook het initiatief kan zijn van ervaringsdeskundigen zoals bijvoorbeeld de landmeters. De goedkeuring van de magistraat is in dit geval evenwel een vereiste, zoals blijkt uit het reeds vermelde artikel 3.5.100 inzake de afbakening van een terrein met grachten: Est 74 in antiquissimis quem mensores existimanerunt omnino restituendum, et magistrati approbavit, et possent usum habere nyet alleen inde nyeunstadt daer alnoch vele ledige erffven liggen, maer oock ende vele meer buyten de stadt binnen de cuype midts de menichte van speelhuysen ende hoven die aldaer plachten te syn ende alnoch souden mogen commen. Kortom, de vroegere redacties lijken niet meteen de koers te bepalen.

Van vroegere redactiepogingen naar vreemde gewoonterechtelijke compilaties is in zekere zin maar een kleine stap. In beide gevallen gaat het om particulier recht. Het fundamentele onderscheid tussen beiden schuilt ofwel in de plaats, ofwel in de tijd. Zoals de invloed van de vroegere redactiepogingen evident en enigszins voorspelbaar was, wekt ook die van gewoonterechtelijke compilaties van andere steden of regio's niet bijzonder veel verbazing. De wetenschappelijke literatuur heeft reeds eerder voldoende voorbeelden aan het licht gebracht van banden tussen verschillende compilaties, zelfs over de grenzen heen. Aangaande deze mogelijke filiaties, en het fenomeen van costumiere acculturatie in het bijzonder, wil ik verwijzen naar hoofdstuk 2, waar dit thema de kwintessens van zal uitmaken. ${ }^{507}$ In dit blok daarentegen zal ik me beperken tot een overzicht en de kentrekken van de verscheidene buitensteedse, gewoonterechtelijke compilaties, welke in verschillende mate bepalend zijn geweest voor de inhoud en het uitzicht van de Antwerpse Consuetudines compilatae.

Globaliter blijft de impact van deze vreemde compilaties op het innovatieve gedeelte van de Consuetudines compilatae evenwel beperkt tot een schamele vier procent. Bijgevolg gaat het om één van de minst doortastende invloeden, tenminste als primaire rechtsbron. Binnen de grenzen van deel I (publiekrecht), IV (verbintenissenrecht) en $\mathrm{V}$ (civiel procesrecht) is het aandeel ervan zelfs tot een absoluut minimum herleid, namelijk nihil. Ook binnen het personenrecht van deel II beperkt de groep zich tot zes procent. Slechts drie rechtsgebieden presteren licht beter: het materiële strafrecht (deel VI), het strafprocesrecht (deel VII) en het erfrecht (titels 3.13 en 3.14). ${ }^{508}$ Binnen welke materie de verschillende compilaties zich hoofdzakelijk concentreren, heb ik reeds in de tweede paragraaf van dit hoofdstuk uitvoerig beschreven. Het betrof in de eerste plaats de Franse jurist, Pierre Guenoys, en zijn Conférence des coutumes, een verzameling van Frans gewoonterecht uit 1596, welke toonaangevend is binnen de paragrafen omtrent de testamentuitvoerders (titel 3.13, paragraaf 8) en de aanvaarding van het sterfhuis onder beneficie van inventaris (titel 3.14, paragraaf 4). Naast deze Franse coutumes, bleken ook de Costuymen van

507 Cfr. supra, hoofdstuk 2.

${ }^{508}$ Het goederenrecht is in dit opzicht niet het vermelden waard. Slechts zes artikels op een totaal van 139 gaan terug op vreemde, gewoonterechtelijke compilaties. 
Utrecbt (1550) met betrekking tot het straf(proces)recht prominent aanwezig te zijn. Ik kan evenwel geen enkele reden bedenken waarom met betrekking tot deze materie plots een beroep werd gedaan op deze Noord-Nederlandse compilatie, waar men zich in alle overige delen tevreden stelde met compilaties uit het zuiden (Frankrijk, Mechelen, Gent). Utrecht is geografisch gezien helemaal niet nabij gelegen, wat de kans op gewoonterechtelijke concordanties mijns inziens bovendien nog kleiner maakt. Desondanks heeft men meermaals Utrechtse strafrechtelijke bepalingen zo goed als letterlijk overgenomen in het Antwerpse gewoonterecht. Dit is gebleken uit een steekproef die ik heb uitgevoerd waarbij ik enkele Antwerpse artikels met hun Utrechtse equivalent heb vergeleken. ${ }^{509}$ De gelijkenis bleek maar al te vaak zeer treffend. De vraag blijft echter in hoeverre het hier om materiële receptie dan wel louter formele assimilatie gaat. Aangezien in de Memorieboeken deze 'Utrechtse' artikels steeds geflankeerd worden door de eigen Usus, meen ik te mogen veronderstellen dat de regel ook een oud Antwerps gebruik was en dat het hier dus eerder om assimilatie aan dan wel receptie van vreemd gewoonterecht gaat.

Het is duidelijk: noch de rol van het Franse gewoonterecht, noch die van de Costuymen van Utrecht, mag met betrekking tot voornoemde rechtsgebieden onderschat worden. Hoe liggen de kaarten nu wanneer ik rekening houd met alle nieuwe artikels op basis van vreemde compilaties? Tabel 1.40 geeft een overzicht. Hierbij heb ik evenwel enkel rekening gehouden met Franse coutumes en Nederlandse costuymen. De invloed van overige landen of regio's is immers maximaal verwaarloosbaar. ${ }^{510}$

${ }^{509} \mathrm{Om}$ dit te bewijzen, heb ik hier twee artikels tegenover elkaar gezet. De eerste twee artikels zijn Utrechts. Het gaat om artikel 1 en 2 van rubriek 38 omtrent 'confronteren' van misdadigers: [art 1] Als twee gevangenen malkanderen belasten ende dat sy discorderen sal men eenen yegelycken apart ende bysonder interrogeren op de discordantie met alle circumstantien ende daer na beyde te samen. [art 2] Ende indien sy persisteren in eure contrarieteyt ende dat men anders die waerheyt niet geweten en kan soo werden sy ter banck geleyt. (Costumen, usantien, policien ende styl van procederen, der stadt Utrecht, geapprobeert ende gedecreteert in M.C.C.C.C.C.L. W. VAN DER MEULEN ed., Utrecht, 1709, 373.) Het derde bevindt zich in de Antwerpse redactie en werd volgens de Memorieboeken op voornoemde Utrechtse artikels gebaseerd. Het betreft artikel 7.3.12: Soo wanneer daer twee gevangen sijn, die malcanderen belasten ende in bun verclaeren niet overeen en commen, soo moet men elck besonder ondervraegen op de verscheijdentheijt vant selve verclaeren ende omstaende van dijen. ende daernaer d'een in de tegenwoordicheijt van d'andere, ende indijen die alsdan bij bunne verscheijdentheijt blijven, ende dat men anderssints de waerbeijt niet en can weten, soo worden sij ter bancken gebrocht. (Coutumes de la ville d'Anvers dites compilatae, IV, 796.) Het is duidelijk dat men zich, ondanks een verschillende terminologie, heeft laten inspireren door de Utrechtse costume.

510 Wel zijn er nog abstractere gevallen zoals bijvoorbeeld ten aanzien van artikel 2.4.11, alwaar naar het geheel van Europa wordt verwezen: Est etiam novus, et quidem contra jus, text in d novel[la] 74 cap 1 et 2 in princip [e] et d novel[la] 89 cap 9 etiam in princip[e] sed qui generali consuetudine tam huius patrie quam totius fere Europa est approbatus et nominatum de Gallijs testatur Bacquet[ius] ubi i[bi] quamvis magna ratio stet pro jure scripto, ut a concubinatu tanto facilius transeatur ad matrimonia et quod extra ordinarium remedium non videatur admittendum, ubi ordinarium superest, quo idem effectus subsequatur, isque potentior, sanctior, et favorabilior tam parenti quam liberis Curia deliberet et videat, an articulus addmitti debeat, in ijs ubi est magna disparitas, et matrimonium pro dignitate et conditione alterius ignominiosum, aut parum conveniens futurum esset, in alijs autem servetur jus commune. 
Tabel 1.40 Aantal artikels per type buitensteeds gewoonterecht

\begin{tabular}{|l|l|l|l|}
\hline Frankrijk & $\mathbf{3 6}$ & Nederlanden & $\mathbf{2 3}$ \\
\hline Conférence des coutumes (Pierre Guenoys) & 24 & Utrecht & 10 \\
\hline Berry & 8 & Gent & 8 \\
\hline Bretagne & 5 & Mechelen & 3 \\
\hline Parijs & 2 & Zeeland & 2 \\
\hline Bourbon & 1 & 's Hertogenbosch & 1 \\
\hline Chalons & 1 & & \\
\hline Artesië & 1 & & \\
\hline
\end{tabular}

Op een totaal van 54 artikels die voortvloeien uit vreemd gewoonterecht, wordt er voor 36 hiervan verwezen naar Franse coutumes.511 Maar liefst 34 van hen houden zich op in de eerste drie delen. Dat andere landen nauwelijks aan bod komen ligt voor de hand. Enkel Frankrijk kende een traditie van costumen die aan de Nederlandse voorafging en deze aan het begin van de zeventiende eeuw ook, zowel kwantitatief als kwalitatief oversteeg. Zoals reeds aangeduid situeren deze Franse costumen zich voornamelijk in het erfrecht. Het werk dat ook hierbuiten een prominente rol inneemt, is opnieuw de Conférence des coutumes van Pierre Guenoys. Twee andere voorname costumiere compilaties zijn die van de territoria Berry en Bretagne. Hoogstwaarschijnlijk kon men beschikken over de commentaren hierop, respectievelijk van de hand van Nicolas Bohier (1469-1539) en Bertrand d'Argentré (1519-1590). ${ }^{512}$

Het Franse overwicht wordt gedeeltelijk gecompenseerd door de costumen van Gent (1563) in het personenrecht van deel II, en die van Utrecht (1550) in de eerste plaats binnen de straf(proces)rechtelijke delen VI en VII. Enigszins opvallend is toch de teleurstellende invloed van naburige costumen zoals die van bijvoorbeeld Mechelen (1535). In totaal werd deze compilatie slechts drie maal als primaire rechtsbron aangewend. Desondanks is er voor de compilatie in kwestie geen onaardige rol weggelegd als secundaire rechtsbron. Dit geldt overigens voor de ganse categorie van het externe gewoonterecht. Waar deze primair slechts een invloed van vier procent vertegenwoordigt, behoort ze onder de secundaire bronnen tot de meest geciteerde. Definitief zijn de cijfers niet, maar een ruwe schatting leert ons dat de categorie voor bijna 200 van alle nieuwe artikels als secundaire rechtsbron wordt aangewend. Dit komt neer op een aandeel van circa elf procent.

Ook nu kan ik, aan de hand van het al dan niet ontbreken van een confirmerende Usus, een idee opdoen van de mate waarin vreemde rechtsregels daadwerkelijk werden gerecipieerd. Ik heb reeds eerder gewezen op het fenomeen van assimilatie aan de Utrechtse compilatie, maar ook alle overige artikels waar er gesproken wordt van extern gewoonterecht als primaire rechtsbron heb ik nader onderzocht. Gelet het schaarse aantal artikels dat hiervoor in anmerking kwam, is het evenwel moeilijk gebleken hier scherp afgelijnde trends in waar te nemen. Desalniettemin blijkt een

511 Er doen zich dus heel wat overlappingen voor.

512 Voor de bibliografische verwijzingen, cfr. infra, hoofdstuk 3, paragraaf 1, Overzicht van geallegeerde rechtsgeleerden. 
expliciete bevestiging door het eigen gebruik zich uiterst zelden voor te doen. Eén van de weinige voorbeelden is terug te vinden bij de artikels 6.1.52/53 omtrent het verhinderen van landsheerlijke officiers in de uitoefening van hun ambt: Sunt additi in hac revisione ex consuet[udine] Ultraiect[ensis] rub 15 art $1^{\circ}$ et usus ita fere observat nisi quod bactenus non sit constituta certa pena. Meer frequent zijn de artikels waar, naast een externe compilatie, ook de Usus als primaire rechtsbron wordt aangewend. Dit is het geval bij artikel 2.1.74, nogmaals omtrent de schulden van gehuwde personen: Est novus ex usu et consuet[udine] aliarum gentium et civitatum, nominatum Gandens[is] d rubr 20 et 9 Bituric[ensis] tit de l'estat des personnes eod[em] tit art 169 in conferentijs consuetud[inem] Galli[a]e fol 7 circa princip[e].513 Wat het Franse, maar evenzeer het Gentse, gewoonterecht betreft, valt het op dat deze in beduidend mindere mate door expliciete bevestigingen vergezeld worden dan dit het geval was bij het Utrechtse gewoonterecht. Men kan zich hierbij afvragen of de kans op daadwerkelijke receptie in deze gevallen reëler is dan bij de costume van Utrecht.

Ook omtrent de autoritatieve waarde van de externe compilaties binnen het geheel van formele rechtsbronnen, wil ik het kort houden. De cijfers zijn immers te beperkt in aantal. Ik beperk me er dan ook toe enkele mogelijke verhoudingen aan te geven, zonder te pretenderen op basis hiervan tot definitieve conclusies te komen. Zoals ik eerder heb gezien, gaat er van het Romeinse recht niet langer een dogmatische invloed uit. Ook externe, costumiere compilaties zijn in staat deze regels te modificeren, zoals bijvoorbeeld is gebeurd bij de artikels 2.5.86/87/88 betreffende de taken van de voogd: Sunt desumpti ex art 28 et 35 in impressis circa finem 27 et 29 in antiquissimis, 9 d ordinat [io] pupillar [is] de anno 1495, quibus consentiunt consuetudines locorum Gandens[ium] rubr 22 art 2 Mechlin[ia] art 12 hoc tit Ultraject [um] rubr 31 art 3 et Galli[a]e passim et sunt juris communis text in $L$ ultim [a] $C$ arbitr [ium] tutel[ae] $L$ tutores qui repertorium 7 in princ [ipe] ff eod[em] nos addidimus verba, soo wel testamentelijcke, als andere, quia ita expresse in antiquiss[imis] $d$ art 21 et judices pupillares existimarunt omnino necessarium id restitui ex jure civili ob multos abusus, addidimus quoque c[lausu]lam, terstondt naer dien sij totte momboirije gecommen syn, ne dilatio detrimentum adferat text in $d L$ ult [ima] et in $d L$ tutores, et sequuntur consuet[udines] Galli[a]e no[m]i[n]atum Bituric[ensis ducatus] tit 1 art 42 Bourbon[iae] c 16 art 142 Poictou tit 8 art 306 et similes, denique art 87 addidimus dat den inventaris gemaecket moet wordden ter presentie van vrienden, ex d consuet[udine] Bituric[ensis] art 44 cui consentit Sedan [um] tit 8 art 142 et sane illi plerunque aptiores quam commissarij qui omnium rerum sunt ignari ad finem tamen articuli 87 posset addi, ende ondertusschen dat men daer mede besich is vermogen de momboirs des even wel, de goeden te aenveerden, midtsgaeders de schulden, actien ende gerecbticheden te vervolgen, in rechte ende daer buyten, hoe wel naer de gemeyne geschreven rechten anders is geordonneert, nam ita observatur tam hic quam in Gallijs contra d L ult[ima] $\mathbb{1} \mathrm{C}$ arbitr[ium] tut[elae] et si hoc placet principium art[icu]li 88 erit mutandum deletis verbis ende den selven, ut art incipiat absolute, den benysboeck, ende staet etha. Verder zijn

513 Zelf heb ik de indruk dat het buitensteedse gewoonterecht in zulke gevallen eerder als secundaire rechtsbron geïnterpreteerd dient te worden dan als primaire rechtsbron. Mijns inziens gaat het hier eerder om assimilatie dan receptie. (Cfr. supra, hoofdstuk 1, paragraaf 3, Romanisatie en humanisme.) De buitensteedse compilaties fungeren eerder als sjabloon om het eigen recht vorm te geven. 
ze eveneens in staat de oude Consuetudines antiquissimae aan te passen, zoals blijkt uit artikel 6.1.36 aangaande laster en eerroof: Est pars 1 a art 47 in antiquissimis 1 us inde landtcharter 4 inde costuymen van Meckelen tit van criminele saecken addita clausula finali ende is de lasteringe qua[e] desumpta ex consuet[udine] Avergna[e] cap 29 art 7 videtur quod linea 4 post verba by gescrifte debeat addi indyen partye daerover clachtich valde ne quis putet quod officiarius in his iniuriis verbalibus poenam proprio motu et ex officio exigere possit id enim nunquam auditum immo in simili contra statutum $i[n]$ tit van minderiarige en [de] andere vermomboirde persoonen art 6 en[de] 79 idque Galliarum consuetudinibus hoc casu de quo agimus de quo diserte cautum et propibitum s'il ny a sang ou playe ouverte ou batteure out ragieuse ut ipsi loqunntur consuet[udo] Avergnia[e] cap 29 art 10 La Marche cap 29 art 335 et similes sane si aliter observes soude groote oorsaecke van afftreck en [de] verbitteringe tusschen de borgers geven daerdoore bunne reconciliatie en [de] vele accoorden van processen souden belet worden quod sane non est permittendum. Anderzijds is ook nu weer de magistraat in staat naar believen wijzigingen aan te brengen. Zo blijkt uit artikel 3.13 .86 in verband met de testamentuitvoerders: Est desumptus ex consuetudine Galliae ut i[bi] naementl[yck] Meaux cap. $6^{\circ}$ articulo 38 Troyes tit $6^{\circ}$ art 100 Minervois d cap 33 art $4^{\circ}$ Melins Bourbon cap 24 art 295 et Angoumois cap 9 articulo 113, nisi quod executores ibi mittantur etiam in possessionem immobilium nisi heres peccuniam aut mobilia offerat ut i[bi] idq[ue] intra octoduum [?], sed id magistratui visum satis rigorosum et insolens, ideoq[ue] secuti sumus mitiorem partem data executoribus tantum actione ut bic. Kortom, indrukwekkend is dit alleszins niet. Op zijn minst laat het wederom zien op welke ontvoogde manier er met het assortiment aan rechtsbronnen wordt omgesprongen. Het getuigt van een vrijgevochten, humanistische ingesteldheid.

Hoewel de invloed van de buitensteedse compilaties dus zeker niet onderschat mag worden, lijkt ook nu weer de meeste aandacht uit te moeten gaan naar het effect van de ratio als redelijkheid. Voornamelijk met betrekking tot de testamentaire artikels op basis van extern gewoonterecht uit titel 3.14 is deze zeer prominent aanwezig. Ik denk bijvoorbeeld aan artikel 3.14.85 in verband met de aanvaarding van een sterfhuis onder beneficie van inventaris: Est ex consuet[udinibus] Galli[a]e et nominatum quo ad principium Laon tit 8 art 72 Chalons tit 12 art 79 Reims tit 11 art 308 Peronne tit 8 art 208 Cambray tit 12 art 19 Orleans tit 17 art 340, et quo ad partem finalem die alsdan noch onverlet blyft consuet [udo] Meldun cap 17 art 271 Insul[a] tit 14 art 184 in fine Bituric[ensis ducatus] tit 19 art 23 nisi quod tempus quod ibi vel nimus angustum vel incertum erat, nos in hac clausula finali preduximus ad quator deum dies et habent omnia evidentem rationem. ${ }^{514}$ Maar ook elders ontbreekt de ratio niet. ${ }^{515}$ Het zuiverste voorbeeld hiervan betreft artikel 6.1.46

514 Voor andere voorbeelden, zie de artikels 3.14.80, 3.14.73, 3.14.86, 3.14.90/91.

515 Zie artikel 3.13.78: Est novus hic ex usu et consuet[udinibus] Galliae nominatim Atrebati tit $3^{\circ}$ articulo $34^{\circ}$ et seqq. Quentin tit $2^{\circ}$ articulo 26 nisi quod in plerisq[ue] addatur quod executor id non possit nisi haerede presente aut saltem ad hoc vocato, Sens tit 8 et 74 Auxerre tit 12 articulo 231 Clermont tit 11 art 135 Valois tit 13 articulo 132 Troyes articulo $114^{\circ}$ et fortassis non abs re esset illud etiam bic supplere, aliae consuetudines hanc facculatem et authoritatem executori adimunt, et volunt absente legatarus legata accipere de manu haeredis presertim si res immobiles sint, Melun cap 16 art. 250 Laon tit 7 articulo 63 Chalons tit 11 articulo 72 Rheims art 296 Amiens tit $3^{\circ}$ art 62 et similes sed postremum nobis non videtur habere magnam rationem cum id proprie ad officium executoris pertineat, et legatarius si velit etiam rei vendicatione uti possit ut diximus $i[n]$ art 60 . 
in verband met laster en eerroof: Est desumptus ex consuet [udine] Ultraiect [ensis] rub 46 art $1^{\circ}$ et 2 excepta clausula finali maer alleenelyck qua[e] desumpta ex consuet [udine] Britannia[e] Minoris art 675 et sunt omnia a[e]quissima[e].

Wat er ook van zij, het staat buiten kijf dat vreemde compilaties wel degelijk een beslissende invloed hebben uitgeoefend op de inhoud en vooral de vorm van verschillende redactieprocessen. ${ }^{516} \mathrm{Ik}$ kan me dan ook niet van de indruk ontdoen dat er afstand genomen dient te worden van de uitspraken van Gotzen omtrent de rol van deze buitensteedse redacties: "Door vergelijking met de costuymen wit andere plaatsen hebben de opstellers van 1608 eveneens nawwkeurig onderzocht welke costumiere gegevens eigen waren aan Antwerpen, en vitgaande van de redeneering dat daar, waar geen buitensteedsche documenten konden geraadpleegd worden ter inlichting, de plaatselijke rechtsschriften des te duidelijker en des te vollediger moesten zijn, bebben ze aan die onderwerpen een bizondere witbreiding en witwerking gegeven". ${ }^{517}$ De auteur ziet voor de buitensteedse compilaties in de eerste plaats een comparatieve functie weggelegd en lijkt elke vorm van acculturatie uit de weg te willen gaan. In al het voorgaande heb ik daarentegen kunnen vaststellen dat de rol van het externe gewoonterecht wel degelijk doorslaggevend van aard kan zijn. Dat dit fenomeen bovendien een buitenproportionele omvang kan aannemen zal ik zodadelijk laten zien in hoofdstuk 2, alwaar de invloed van de Antwerpse Consuetudines compilatae op het Gelderse Land- en Stadsrecht van het Overkwartier Roermond centraal staat. Wat de nieuw toegevoegde artikels in de Consuetudines compilatae betreft, onthoud ik voornamelijk de invloed van het Franse recht met betrekking tot het Antwerpse erfrecht en gelijkaardig die van de Utrechtse costumen op het strafrecht. Het personenrecht profileert zich eerder als een mélange.

516 De rol van, al dan niet vreemde, middeleeuwse coutumiers, is zo goed als tot nul herleid. Dit strookt met de uitlatingen van Van Dievoet omtrent dit rechtsgeleerde genre: "En parcourant les écrits des juristes français $d u 16^{e}$ au $18^{e}$ siècle, on a l'impression qu'ils citent quelques coutumiers du moyen âge, mais plutôt sporadiquement. Au $16^{e}$ siècle, ils invoquent encore leur autorité, tandis qu'au $17^{e}$ et $18^{e}$ siècles, ils les citent surtout comme témoins du passé." (VAN DIEVOET, Les coutumiers, 54.)

${ }^{517}$ GOTZEN, “De costumiere bronnen”, 119. 
PARAGRAAF 4

HET ANTWERPSE GEWOONTERECHT NA 1608: DE HERLEVING VAN DE CONSUETUdINES IMPRESSAE EN HET RELATIEVE BELANG VAN DE CONSUETUDINES COMPILATAE

Dit eerste hoofdstuk vond zijn oorsprong in de kritiek van Jacques Van Uffel op de Consuetudines compilatae die de compilatores ervan als 'novateurs' omschreef. Voorgaande paragrafen hebben inderdaad aangetoond dat er, ten aanzien van de innovaties binnen het Antwerpse gewoonterecht de dato 1608, wel degelijk gesproken kan worden van onder meer een reële lexificatie, evenals een werkelijke, materiële receptie van Romeins recht in combinatie met een infiltratie van rechtsgeleerde opinies (Verwissenschaftlichung). Ook van de invloed van niet-Antwerpse, gewoonterechtelijke compilaties evenals jurisprudentiële verzamelingen is het costumiere recht van de handelsmetropool aan de Schelde, zij het in mindere mate, niet gevrijwaard gebleven. Hierbij kon bovendien de concordantie met de gangbare, Antwerpse gewoonte niet altijd gegarandeerd worden. In paragraaf 3 heb ik namelijk aangetoond dat de mate waarin deze ideeën de Antwerpse gewoonte reflecteren inderdaad sterk betwijfeld kan worden. Desalniettemin lijkt het me in dezen raadzaam nader onderzoek te verrichten waarbij het geredigeerde gewoonterecht (theorie) getoetst wordt aan de contemporaine, Antwerpse rechtspraak (praktijk). De resultaten van diezelfde derde paragraaf gebieden me echter er tevens op te wijzen dat met betrekking tot een aantal andere invloeden wel een grote mate van correspondentie met de Antwerpse Usus verondersteld mag worden. Ik denk hierbij onder meer aan de interne rechtspraak op basis van turbenonderzoeken, het fenomeen van technocratisering en de rol van zowel de vroegere, Antwerpse redactiepogingen als de stedelijke wetgeving. Het spreekt voor zich dat ook de artikels op basis van de Usus als een getrouwe reflectie van de Antwerpse gewoonte beschouwd mogen worden. Doch, voorzichtigheid blijft altijd geboden. Hoe dan ook, ondanks deze overeenkomsten, kan ik niet langer het beperkte aandeel negeren dat deze groep van 'corresponderende' invloeden vertegenwoordigt binnen de innovaties van de Consuetudines compilatae. Van Uffels kritiek ten aanzien van de Consuetudines compilatae is dan ook geheel niet onterecht. De vraag in hoeverre zijn voorkeur voor de Consuetudines impressae als de enige getrouwe weerspiegeling van de Antwerpse costume gehandhaafd kan worden dringt zich evenwel op. Dit vraagt om een nieuw en nader onderzoek, waarvoor binnen dit boek evenwel geen ruimte is, en waarbij de juridische basis van deze derde redactiepoging op zijn concordantie met de Antwerpse gewoonte getoetst zal worden. De introductie van de commentaar van de Antwerpse rechtsgeleerde Antonio Anselmo (1589-1668) op de gedrukte costume doet immers vermoeden dat Van Uffels enthousiasme over de Consuetudines impressae mogelijk betwijfeld kan worden. In de versie van deze commentaar uit de verzameling van meester Jozef Dauwe staat immers het volgende te lezen: "Eerst also vele articelen in dese costumen syn conform ende gemeyn met de geschreven rechten oock met den placaerten van synen majesteyt ende ordonnantien ofte statuten deser stadt, eenige wederom syn contrarie van alle deselve, soo worden ten respecte van d'een ende d'ander de wetten ende rechten geciteert ende aengewesen de placcaerten ende de voosyden stadts statuten van 
gelycken de plaetsen daer de doctoren ende meesters in recbten deselve materien onder de anderen pro et contra tracteren, synde tusschen suiderlingen geschiet ten respecte vande gene die geduerende dese eeun in dese nederlanden geschreven bebben. Ende alsoo vele articelen in dese gedructe costumen accorderen met d'alderoutste ende oude geschrevene costumen vande jaeren respective 1543, ende 1571 eenige oock daervan diffentieren ende contrarieren soo dat daervan oock ter bequaemen plaetse mentie gemaeckt ende den leser d'aenwysingen vanden selve gedaen om hem daervan te dienen ...". 518

Doordat de Consuetudines compilatae een niet onaanzienlijke hoeveelheid nieuwigheden blijken te bevatten, kan men zich de vraag stellen in hoeverre zij de juridische werkelijkheid anno 1608 weerspiegelen? Hierin kan eveneens een gedeeltelijke verklaring herkend worden voor de beperkte rol die de vierde redactiepoging na haar totstandkoming en tot aan het einde van het oud-regime heeft gespeeld. De Consuetudines compilatae lijken eerder een vrucht te zijn afkomstig van het pays legal, waarbij de commissieleden niet geheel als representatief kunnen beschouwd worden voor de doordeweekse, Antwerpse rechtspraak van het pays réel. Hoewel mijns inziens de mate waarin dit ook van de samenstellers van de Consuetudines impressae gezegd kan worden nader onderzoek vereist, werd in het verleden er reeds op gewezen dat het aanvaardbaar is de gedrukte compilatie in de plaats te stellen van het Antwerpse gewoonterecht. ${ }^{519}$ Hierbij beroepen zij zich niet op een vergelijkend onderzoek van de inhoud van de compilatie met de Antwerpse rechtspraktijk, maar wel op het belang van deze derde redactiepoging binnen de juridische wereld na 1608 en dit in tegenstelling tot de beperkte rol die de Consuetudines compilatae toebedeeld werd.

Hoewel deze laatste compilatie op sommige gebieden wist te prevaleren boven de gedrukte compilatie van 1582, blijken de Consuetudines impressae evenwel de bovenhand te halen. ${ }^{520}$ Het belang van de gedrukte costumen blijkt uit verschillende vaststellingen. $Z o$ is er de rol die de compilatie speelde in de latere rechtspraak. Laenens en Leemans illustreerden dit aan de hand van een turbenonderzoek dat dateert van 30 december 1631 en waarin letterlijk een beroep wordt gedaan op de ghedrucbte costuymen. ${ }^{521}$ Tevens verwijzen beide auteurs naar een uitspraak van de Raad van Brabant, daterend van 18 januari 1694, waarin het college verwijst naar de

518 DENDERMONDE, Verzameling Mr. Jozef Dauwe, Observationes sue notae ad Consuetudines Antwerpen, 6.

519 Cfr. C. LAENENS en L. LEEMANS, De geschiedenis van het Antwerpse gerecht, Antwerpen, $1953,25$.

${ }^{520}$ Met betrekking tot het belang van de Consuetudines compilatae verwijst Gotzen naar de besprekingen tot herziening van het geredigeerde gewoonterecht in 1633. Hierbij moest namelijk de tekst van 1608 als uitgangspunt dienen. Bovendien werd er op dat ogenblik streng de hand gehouden aan een aantal regelingen welke in 1608 waren ingevoerd. Ter illustratie vermeldt Gotzen de formaliteiten om binnenpoorter te worden. Als tegenreactie op de geseculariseerde versie van de calvinistische procedure, zoals ze beschreven was in de Consuetudines impressae, vereiste het binnenpoorterschap opnieuw een doopcertificaat en een getuigschrift van de pastoor van de vorige residentieplaats. (GOTZEN, "De costumiere bronnen", 193.)

${ }^{521}$ LAENENS en LEEMANS, De geschiedenis van het Antwerpse gerecht, 24. STEVENS, Revolutie en notariaat, 26. 
compilatie van 1582. Het Hof voegt er aan toe dat, hoewel het desbetreffende gebruik meer dan honderd jaar oud is, dit steeds door verscheidene turbenonderzoeken en menig vonnissen bevestigd geworden is. ${ }^{522}$ Ook Stevens vermeldt in zijn studie omtrent het notariaat te Antwerpen tijdens de Franse periode een conflict aangaande de uitsluitende bevoegdheid van de stoelklerken tot openbare verkopen op de vrijdagse markt uit 1777 , waarbij de secretarissen zich beriepen op bepalingen opgenomen in de Consuetudines impressae. 523 Stevens voegt er aan toe dat ook de verwijzingen naar de redactie van 1582 in de negentiende-eeuwse jurisprudentie in dit opzicht tekenend zijn. De auteur vermeldt tal van vonnissen en arresten, zowel van het Hof van Beroep van Brussel als het Hof van Cassatie, waarin ofwel eenvoudigweg gerefereerd werd naar de costume van 1582, ofwel hun beslissing expliciet op de Consuetudines impressae gefundeerd werd. ${ }^{524}$

Naast de rechtspraak vinden Laenens en Leemans ook in de zeventiende-eeuwse wetgeving aanwijzingen terug die blijk geven van het primerende belang van de gedrukte costume. Zo maken zij melding van een plakkaat van 12 september 1735, waarin bevolen wordt dat iedereen zich dient te gedragen overeenkomstig artikel 41 van titel XLIII uit de Consuetudines impressae omtrent weeskinderen. ${ }^{525}$ Beide auteurs gaan zelfs verder en zien in deze passage een zekere homologatie van de gedrukte costume, aangezien hieruit blijkt dat de compilatie beschouwd werd als hebbende kracht van wet. Vervolgens wordt verwezen naar het Hof van Beroep te Brussel dat in 1848 de passage uit het plakkaat van 1735 omschrijft als een approbation virtuelle.526

Niet alleen de latere jurisprudentie en wetgeving geven blijk van de voorname positie die de Consuetudines impressae innemen onder de verschillende, Antwerpse optekeningen. Ook de woorden van zeventiende-eeuwse iuris periti zetten deze overtuiging kracht bij. Zo duidt het feit dat de in 1590 overleden Jan Wames of Wamesius (1524-1590) stelt dat de redactiepoging van 1570-1571 in zijn tijd geen toepassing vond erop dat, hoewel de gedrukte costume van 1582 sinds 1586 buiten werking was gesteld, deze beslissing niet geheel werd nageleefd. ${ }^{527}$ Indien de

522 LAENENS en LEEMANS, De geschiedenis van het Antwerpse gerecht, 25. Zie ook: STEVENS, Revolutie en notariaat, 25. Stevens stelt er evenwel verkeerdelijk dat het om een akte van 12 september 1735 gaat.

523 STEVENS, Revolutie en notariaat, 26.

524 STEVENS, Revolutie en notariaat, 28-30. Een opmerkelijk resultaat van Stevens' onderzoek is de vaststelling dat men aan deze instellingen klaarblijkelijk pas na het verschijnen van de historische werken van Mertens en Torfs en van Defacqz rekening gaat houden met de verschillende optekeningen van het Antwerpse gewoonterecht. (Cfr. STEVENS, Revolutie en notariaat, 29, noot 177.) Stevens besluit dat vooral de Consuetudines impressae op het einde van het oud-regime als Antwerps gewoonterecht hebben gegolden, maar waarschuwt dat men steeds ook oog zal moeten hebben voor eventuele wijzigingen zoals deze in de optekening van 1608 geuit werden. (STEVENS, Revolutie en notariaat, 30.)

${ }^{525}$ LAENENS en LEEMANS, De geschiedenis van het Antwerpse gerecht, 25. Cfr. STEVENS, Revolutie en notariaat, 25.

526 LAENENS en LEEMANS, De geschiedenis van het Antwerpse gerecht, 25-26.

${ }^{527}$ LAENENS en LEEMANS, De geschiedenis van het Antwerpse gerecht, 24. STEVENS, Revolutie en notariaat, 25. 
compilatie van 1570-1571 ten tijde van Wamesius niet werd aangewend, kan men er namelijk van uitgaan dat een beroep werd gedaan op de redactie van 1582. Ook Antonio Anselmo wees in zijn Consultationes (1671) op een gebruik dat de principiële minderwaardigheid van de optekening van 1582 een feit was, ook al bekommerde de praktijk zich hier weinig om. ${ }^{528}$ Stevens verwijst eveneens naar een passage uit de Decisionum curiae Brabantiae (1670) van Pieter Stockmans (1608-1671) waarin deze laatste de toepasselijkheid van de Consuetudines impressae vaststelt. ${ }^{529}$ Ook Johan Baptist Joseph Huygens (1657-1708) citeerde in zijn Notarius Belgicus (1704) de tekst van de derde, Antwerpse optekening. ${ }^{530}$ Tenslotte is er de anonieme commentaar van het einde van de zeventiende eeuw (Annotationes ad consuetudines antverpiensis impressas) welke het volgende besloot aangaande de gedrukte costume: "... maer allegeert men daegelyckx noch de selve costuymen, wort daer recht uyt gedaen voor sooveel de selve in gebruyck rijn, oock. alwaert sy contrarierende waeren aen gecompileerde, waeromme oock soo op d'eene als op d'andere turben geleyt worden". ${ }^{531}$

Ook het aantal commentaren dat aan de verschillende optekeningen gewijd werd, kan een indicatie geven van het relatieve belang van de Consuetudines compilatae. Wat deze laatste redactiepoging betreft, zijn enkel de Memorien op de Costuymen bekend als commentaar. ${ }^{332}$ Deze Memorieboeken werden echter door de samenstellers van de Consuetudines compilatae zelf opgesteld en dit ter argumentatie van de doorgevoerde innovaties. Zij werden dan ook samen met de costumiere optekening naar Brussel verzonden. Bijgevolg kunnen zij niet als een externe, onafhankelijke beschouwing aanzien worden, noch als een resultaat van het belang dat de Consuetudines compilatae vertegenwoordigde. ${ }^{533}$ Dit geldt wel voor de commentaren die op de Consuetudines impressae werden geschreven en het relatief grote aantal ondersteunt de veronderstelling van hun groter belang. Totdusver heb ik namelijk zes verschillende commentaren geïdentificeerd die aan deze derde redactiepoging werden gewijd. De meest bekende is ongetwijfeld het Tractaat over de Costuymen van de Antwerpse stadssecretaris Hendrik de Moy, die bovendien lid was geweest van de commissie die belast werd met het opstellen van een eerste ontwerp van de derde redactiepoging. Deze commentaar bevindt zich in het Antwerpse stadsarchief.534 Twee andere commentaren worden, aldus Gotzen, bewaard in het handschriftelijk fonds van de

528 GOTZEN, “Costumiere bronnen”, 195. STEVENS, Revolutie en notariaat, 25.

529 GOTZEN, "Costumiere bronnen", 196. STEVENS, Revolutie en notariaat, 25. P. STOCKMANS, Decisionum curiae Brabantiae sesque centuriae, Brussel, 1670.

${ }^{530}$ STEVENS, Revolutie en notariaat, 27. J. B. HUYGENS, Notarius Belgicus oft ampt der notarissen, zesde druk, Brussel, 1771.

531 Geciteerd naar STEVENS, Revolutie en notariaat, 25.

532 SAA, Vierschaer, 48-53: Memorien op de Costumen.

533 GOTZEN, "Costumiere bronnen", 198.

534 SAA, Vierschaer, 21: DE MOY, Tractaat. Bij Stevens staat te lezen hoe, volgens Prims, stadssecretaris Hendrik de Moy en stadspensionaris Engelbert Maes omwille van hun katholieke overtuiging zouden worden afgedankt in de tweede helft van 1583. (Cfr. STEVENS, Revolutie en notariaat, 23, noot 132.) 
Koninklijke Bibliotheek van België te Brussel. ${ }^{535}$ Dit is niet langer correct, althans gedeeltelijk. De eerste commentaar, de Annotata ad consuetudines antwerpienses, bevindt zich namelijk niet langer te Brussel, maar is overgebracht naar het Antwerpse Rijksarchief. ${ }^{536}$ De auteur ervan is onbekend en de tekst is afwisselend in het Nederlands en het Latijn opgesteld. ${ }^{537}$ De tweede commentaar is de Commentaria in leges municipales non compacta en werd door Gotzen aan twee verschillende, onbekende handen toegeschreven. ${ }^{538}$ Eigenhandig onderzoek heeft echter uitgewezen dat er drie verschillende handen aan het document hebben meegewerkt. Opvallend is dat deze derde hand op het toneel verschijnt bij de aanvang van titel LXVI. Dit is hetzelfde punt waar een vierde commentaar, door Van Rompaey vermeld in het Nieun Biografisch Woordenboek en toegeschreven aan Antonio Anselmo, eindigt. ${ }^{539}$ Op het moment dat Van Rompaey deze biografische notities schreef, was het manuscript in handen van professor Strubbe. Door het document toe te schrijven aan Anselmo weerlegt Van Rompaey Gotzens stelling dat de commentaar die Anselmo op de Consuetudines impressae schreef, verloren was gegaan. ${ }^{540}$ Van Rompaey concludeert dit op basis van de vaststelling dat de tweede hand naar de werken van Anselmo verwijst in ik-vorm. Volgens de auteur gaat het evenwel niet om een autograaf, maar wel om een afschrift dat nog dateert van de zeventiende eeuw. ${ }^{541}$ Andere versies van de commentaar van Anselmo bevinden zich in de verzameling van meester Jozef Dauwe en de Antwerpse universiteitsbibliotheek. ${ }^{542}$ Twee andere commentaren die in het teken staan van de Consuetudines impressae zijn van de hand van de advocaten Karel Gabri (Rechten ende costumen van Antwerpen) en D. Mastelyn (Notae sive commentaria ad consuetudines Antverpienses), respectievelijk daterend van 1639 en 1774.543

\footnotetext{
535 GOTZEN, “Costumiere bronnen”, 199.

536 ANTWERPEN, Rijksarchief, Manuscriptenverzameling, nr. 130: Annotata ad consuetudines antwerpienses. Wegens renovatiewerkzaamheden in het Antwerpse Rijksarchief ben ik evenwel niet in de mogelijkheid geweest dit handschrift nader te bestuderen.

537 De gedachte, die door anderen geopperd werd, dat het hier de commentaar van Anselmo betrof, die Gotzen verloren achtte, is voor hem onaanvaardbaar. In dit opzicht verwijst Gotzen naar de referenties die binnen het handschrift worden gemaakt naar de commentaar van Anselmo. Cfr. GOTZEN, “Costumiere bronnen”, 199.

538 BRUSSEL, Koninklijke Bibliotheek, ms. 13569: ANTONIO ANSELMO, Commentaria in leges municipales non compacta. Cfr. GOTZEN, “Costumiere bronnen”, 199.

539 “Anselmo, Antonius”, J. VAN ROMPAEY, Nieuw Biografisch Woordenboek, I, Brussel, 1964, 27-36.

${ }^{540}$ Cfr. GOTZEN, "Costumiere bronnen”, 199.

541 “Anselmo, Antonius", 35.

542 DENDERMONDE, Verzameling Mr. Jozef Dauwe, Observationes sue notae ad Consuetudines Antwerpen. ANTWERPEN, Universiteitsbibliotheek, ANTONIO ANSELMO, Rechten ende Costuymen der Stadt Antwerpen met de annotatien en commentaren van Heer ende Mr. Antonius Anselmo Advocaet ende oudt-Schepen der selver Stadt, 1676. Bij deze wil ik professor Stevens bedanken mij op het bestaan van deze handschriften attent te maken.

543 Cfr. DEKKERS, Bibliotheca Belgica Juridica, 59 en 137. K. GABRI, Rechten ende costumen van Antwerpen, Amsterdam, 1639. D. MASTELYN, Notae sive commentaria ad consuetudines Antverpienses, Antwerpen, 1774. Beiden staan eveneens vermeld in het Handbuch der Quellen und
} 
Laatstgenoemde werd in de achttiende eeuw door de rechtsgeleerde Benedictus Biesval becommentarieerd in zijn Additiones ad commentaria ad consuetudines Antwerpienses de Matselyn (1774).544 Beide commentaren berusten in de Antwerpse stadsbibliotheek.

Een laatste aanwijzing voor het primaire belang van de Consuetudines impressae is de bijval die de gedrukte costume te Amsterdam genoot. De compilatie was immers perfect aanvaardbaar in het calvinistische Noorden, aangezien zij alle katholieke kenmerken uit het Antwerpse gewoonterecht zuiverde. Zo kwamen de Consuetudines impressae model te staan voor de private compilatie van Amsterdams gewoonterecht, het Recueil van verscheyde keuren en costuymen uit 1644, van de hand van de Amsterdamse stadssecretaris Gerhard Rooseboom. ${ }^{545}$ De auteur gebruikte de Consuetudines impressae als basis voor zijn tekst en verschillende artikelen werden geheel of gedeeltelijk vrijwel letterlijk overgenomen. ${ }^{546}$ Andere Amsterdamse rechtsgeleerden dreven de adoratie zelfs zover door dat het Antwerpse recht naast het Romeinse recht ook als het gemene recht beschouwd kon worden. Zo maakt Nicolaus Duysentdaelders (+1670), de zeventiende-eeuwse expert van het Amsterdamse recht, in zijn Observationes veelvuldig gebruik van het Antwerpse recht, en erkent hij in de opdracht dat het doel van zijn werk is alles soo te voegen, dat in yder deel mochte blyken, waer in wy met 'et Roomsche Recht en de Coustumen van Antwerpen, die seer loffelyk syn, overeenkomen, ende waer in wy met deselve verscheelen. ${ }^{547}$ Ook vele andere, latere juristen verwijzen nog naar de Consuetudines impressae, en de redactie ontbreekt bovendien bijna in geen enkele Noord-Nederlandse bibliotheek. 548

Literatur der Neueren europäischen Privatrechtsgeschichte van Helmut Coing: H. POHLMANN, "Bibliographie der Gesetzgebung des Privatrechts und Prozessrechts. Niederlande", H. COING red., Handbuch der Quellen und Literatur der Neueren europäischen Privatrechtsgeschichte, II/2, Munchen, 1976, 497-498. Bij Dekkers en Coing spreekt men, met betrekking tot de commentaar van Gabri, evenwel van Notas op de costuyme van Antwerpen. Wat de commentaar van Mastelyn betreft, omschrijven beiden de auteur als 'J. B. Pothier alias Mastelyn'.

544 ANTWERPEN, Stadsbibliotheek, ms., BENEDICTUS BIESVAL, Additiones ad commentaria ad consuetudines Antwerpienses de Matselyn, 1774. Cfr. DEKKERS, Bibliotheca Belgica Juridica, 15.

545 G. ROOSEBOOM, Recueil van verscheyde Keuren en Costumen, mitsgaders Maniere van procederen binnen de Stadt Amsterdam, Amsterdam, 1644.

${ }^{546} \mathrm{~J}$. W. BOSCH," "Remarques sur quelques influences, exercées en matière de droit, par les provinces méridionales sur les provinces septentrionales des Pays-Bas jusqu'en 1795”, Tijdschrift voor Rechtsgeschiedenis, 13 (1951), 145 noot 3. Dat ook de Consuetudines compilatae model hebben gestaan voor Noord-Nederlandse redacties, zoals het Gelderse Land-en Stadsrecht, is mijns inziens eerder te wijten aan de rol die Hendrik Uwens binnen deze historie speelt, dan aan het algemene belang van de compilatie binnen de rechtsgeleerde wereld van die tijd.

547 Geciteerd naar Bosch: J. W. BOSCH, "Enige rechtshistorische aantekeningen over ZuidNederlandse juridische invloeden in het Noorden", Rechtskundig Weekblad, 32 (1948), 1012. N. DUYSENTDAELDERS, Observationes ad leges, statuta, consuetudinesque Amstelaedamenses, Amsterdam, 1662.

${ }^{548} \mathrm{BOSCH}$, "Remarques sur quelques influences", 147. 
Ook Stevens benadrukt de enorme verspreiding van de compilatie. ${ }^{549}$ Een verspreiding die uiteraard sterk bevorderd werd door het feit dat de compilatie gedrukt werd. Na een eerste druk in Antwerpen bij Plantyn in 1582 volgden bovendien nog verschillende herdrukken te Keulen (1584, 1597, 1607, 1644 en 1660) en Amsterdam (1597, 1607, 1613 en 1639). De laatste uitgave ten tijde van het oudregime dateert van 1793 en geschiedde in Antwerpen. ${ }^{550}$ Toch is het mijns inziens niet aan het drukken van de Consuetudines impressae te wijten dat de compilatie zulk een verspreiding kende. De verspreiding, evenals het drukken, is namelijk in de eerste plaats een gevolg van de bijval die de redactie van 1582 genoot binnen juridische middens. Dat het drukken van een werk overigens geen vereiste is voor succes, blijkt des te meer uit de invloed die de handschriftelijke traditie van Wielants Practycke Civile evenals zijn Practycke criminele op de Antwerpse costume van 1608 uitgeoefend heeft, en welke ik in de paragrafen 2 en 3 heb aangetoond. ${ }^{511}$ Belangrijk is dat deze massale verspreiding van de Consuetudines impressae een 'inburgering' ervan mogelijk heeft gemaakt die zich bovendien breed over het Antwerpse, juridische landschap uitstrekte. Deze inburgering heeft er bijgevolg voor gezorgd dat de Consuetudines impressae gemeengoed zijn geworden en dat de Consuetudines compilatae in zekere zin overbodig werden, ondanks een eventuele hogere kwaliteit. De situatie doet mij denken aan wat er zich vandaag de dag afspeelt op het vlak van besturingssystemen voor personal computers. Waarom Apple gebruiken als iedereen Windows installeert? Op die manier ligt het eveneens voor de hand dat wanneer iemand als Jean-Baptiste Christyn (ca.1635-1707) in 1682 zijn Brabandts recht publiceert, hij hierbij, gezien haar ingeburgerde positie binnen de rechtspraktijk, de tekst van de Consuetudines impressae verkiest boven die van de Consuetudines compilatae. ${ }^{52}$ Desondanks trachtte de magistraat van Antwerpen in 1674 bij de Geheime Raad te Brussel tevergeefs de plannen van Van Christijnen te verhinderen. 553

Tot slot spreekt het voor zich dat ook het geringe aantal handschriften dat er van de Consuetudines compilatae bewaard is gebleven, tekenend is voor het geringe belang van de redactie na haar totstandkoming. ${ }^{54}$ Het staat namelijk in schril contrast met het aantal drukken dat van de Consuetudines impressae verschenen is. Enkel deze derde redactie was overigens in druk verschenen, alvorens de Longé in de negentiende eeuw de verschillende optekeningen van het Antwerpse gewoonterecht uitgaf. ${ }^{555}$

\footnotetext{
549 STEVENS, Revolutie en notariaat, 28.

550 STEVENS, Revolutie en notariaat, 26, noot 160.

${ }^{551}$ Cfr. supra, hoofdstuk 1, paragrafen 2 en 3.

${ }^{552}$ J. B. CHRISTYN, Brabandts recht, Antwerpen, 1682. Cfr. STEVENS, Revolutie en notariaat, 27.

553 GOTZEN, “Costumiere bronnen”, 193.

${ }^{554}$ Cfr. STEVENS, Revolutie en notariaat, 26, noot 160.

555 Cfr. STEVENS, Revolutie en notariaat, 27. Hierbij dient vermeld te worden dat Wauters enkele jaren voordien een uitgave verzorgde van het vierde deel van de Consuetudines compilatae betreffende het contracten- en verbintenissenrecht: C. WAUTERS, Le droit commercial belge mis en rapport avec la jurisprudence ... précédé d'une introductionrenfermant le texte flamand et la traduction
} 
Op basis van deze verschillende aanwijzingen lijkt het me niet onvoorzichtig te concluderen dat er wel degelijk een verschil bestond qua belang tussen de derde en vierde Antwerpse redactiepoging. Dat de Consuetudines compilatae hierbij het onderspit moeten delven, neemt echter niet weg dat zij, samen met de Memorien op de Costuymen, een uiterst boeiend studieobject vormen in het licht van de geschiedenis van het costumiere recht in de Nederlanden.

française de l'ancienne coutume commerciale inédite d'Anvers, promulguée dans cette ville en 1609 sous le règne des archiducs Albert et Isabelle, 2 dln., Brussel-Antwerpen, 1867. 


\section{CONCLUSIE BIJ HOOFDSTUK 1}

Centraal in dit eerste hoofdstuk stond de juridische basis van de innovaties, welke in de vierde Antwerpse redactiepoging werden doorgevoerd. Het betreft de rechtsbronnen die aan de basis liggen van de 1801.5 nieuw toegevoegde artikels. De belangrijkste resultaten van dit onderzoek kunnen als volgt worden samengevat: ten eerste hebben de redacteurs van de Consuetudines compilatae zich, naast de derde redactiepoging (Consuetudines impressae), voor meer dan een kwart van alle nieuwe artikels laten inspireren door wetgevende rechtsbronnen. Hierbij kwam de nadruk te liggen op legislatieve documenten, welke afkomstig waren van de Antwerpse stedelijke overheid. Dit overwicht is echter in belangrijke mate te wijten aan de integratie van de Ordonnantie op de Stijl ende Maniere van Procederen welke in 1582 samen met de Consuetudines impressae werd uitgegeven. Hier staat tegenover dat bijna de helft van de artikels met een legislatieve basis zijn oorsprong kent in het wettenrecht van een hogere, zowel binnenlandse als buitenlandse, overheid. Wat het 'buitenlandse' wettenrecht betreft, is vooral de rol van de Franse koninklijke ordonnanties noemenswaardig gebleken. Onder de legislatieve documenten van binnenlandse, hogere overheden daarentegen ressorteren voornamelijk de stijlordonnanties van de Raad van Brabant, evenals de koninklijke ordonnanties van Karel V, Filips II en de aartshertogen Albrecht en Isabella. Hierbij heb ik kunnen vaststellen hoezeer de nadruk ligt op de wetgevende activiteit van de kanselarij van Karel V. Dit mag enigszins verbazen gezien de veel grotere legislatieve productiviteit van Filips II als wetgever. Hoewel rechtsgebieden als het goederen-, het erf- en het verbintenissenrecht absoluut het merendeel van de 'gelexificeerde' artikels voor hun rekening nemen, maken -relatief gezien- ook de meest voor de hand liggende rechtsgebieden tevens de meest gelexificeerde rechtsdomeinen uit. Het betreft hier het publiekrecht en dit in tegenstelling tot het privaatrecht, dat doorgaans minder tot de invloedssfeer van de vorstelijke, wetgevende activiteit gerekend wordt. Desalniettemin ziet het er op basis van de Memorien op de costumen naar uit dat ook binnen het privaatrechtelijke domein een uitbreiding van de vorstelijke invloed op het gewoonterecht kan worden vastgesteld. Uit de analyse van de juridische basis, waarop het geredigeerde Antwerpse gewoonterecht werd geïnnoveerd, blijkt namelijk dat de koninklijke ordonnanties zich eveneens laten gelden in privaatrechtelijke aangelegenheden, welke doorgaans niet tot de royale potestas werden gerekend. Een uitbreiding van de actieradius kan duidelijk worden vastgesteld en bovendien is te zien dat de vorstelijke wetgeving de bovenhand neemt over de stedelijke ordonnanties, tenminste wanneer ik -gezien hun bijzondere status- de stedelijke stijlordonnanties buiten beschouwing laat. Dat het hier niet louter gaat om een 'schijnbare lexificatie' van het gewoonterecht, waarbij de wetgeving niet meer inhoudt dan een bevestiging van reeds in gebruik zijnde gewoonten, blijkt uit het feit dat de Memorieboeken slechts zeer zelden verwijzen naar de plaatselijke Usus als bijkomende legitimatie voor de aanwezigheid van de rechtsregel in de Consuetudines compilatae. Zulk een 'reële lexificatie' past volkomen in de trend van een steeds sterker wordend vorstelijk absolutisme. 
$\mathrm{Na}$ de wetgeving als voornaamste rechtsbron van de innovaties binnen de Consuetudines compilatae volgt de gewoonte, meer bepaald de Usus in de zin van causa consuetudinis. Zij wordt in 23 procent van de gevallen als primaire rechtsbron vermeld. Dit is conform alle logica gezien het feit dat het hier een compilatie van costumier recht betreft. Wanneer ook het zee- en verzekeringsrecht in rekening gebracht worden, stijgt haar aandeel zelfs tot 31 procent en laat het hiermee het wettenrecht als voornaamste rechtsbron achter zich.

Achttien procent van de nieuw toegevoegde artikels kent een juridische oorsprong die ik als 'specifieke redenen' heb angeduid. Uit de beschrijving ervan is gebleken hoe divers deze kunnen zijn.

Naast de wetgeving en de gewoonte is het Romeinse recht als inspiratiebron terug te vinden op een verdienstelijke, vierde plaats. Met een aandeel van achttien procent fungeert dit Justiniaanse recht voor 231.5 nieuw toegevoegde artikels als justificatie. Ook deze vaststelling is volkomen logisch onder meer omdat het Romeinse recht binnen de Consuetudines compilatae officieel een subsidiaire rol toebedeeld kreeg. Wanneer haar aandeel met vier eenheden daalt tot veertien procent, van zodra ook de rechtsbronnen van het zee- en verzekeringsrecht in rekening gebracht worden, laat zien hoezeer het Antwerpse maritieme recht van elke Romeinsrechtelijke invloed gevrijwaard is gebleven. Hetzelfde geldt voor het publiekrechtelijke deel I en het burgerlijk procesrecht van deel V. Ook zij zijn in het licht van de romanisatie nauwelijks het vermelden waard. Het gemiddelde aandeel van het Corpus Iuris met betrekking tot het verbintenissenrecht van deel IV is het logische gevolg van de symbiose tussen de eigen ontwikkelde contractuele regels enerzijds en de hierop volgende Romeinsrechtelijke beïnvloeding vanaf de zestiende eeuw anderzijds. Ook het zesde, strafrechtelijke deel onderging een romaniserend effect wat zich qua omvang in het midden houdt. Bij het strafprocesrecht was deze invloed dan weer meer uitgesproken, zij het louter relatief. Het Romeinsrechtelijk aandeel van dertig procent binnen deel VII correspondeert namelijk met niet meer dan veertien nieuwe artikels. Drie andere rechtsgebieden spannen de kroon: het personenrecht, het goederenrecht en het erfrecht. Twee zaken liggen aan de oorsprong van deze uitgesproken romanisatie. Ofwel betreft het de uitwerking van titels omtrent typisch Romeinsrechtelijke rechtsfiguren, ofwel vloeit deze romanisatie voort uit de beïnvloeding van oorspronkelijk costumiere aangelegenheden door het Romeinse recht. In beide gevallen kan er gesproken worden van een werkelijke, materiële receptie van Romeins recht.

Deze daadwerkelijke receptie van Romeins recht past probleemloos binnen de idee dat ook de humanistische rechtswetenschap een praktisch doel voor ogen had. Dienaangaande kan er sprake zijn van een symbiose tussen een humanistische, kritische grondhouding en de bartolistische bruikbaarheid van het Corpus Iuris. Op lange termijn zou deze opstelling leiden tot bewegingen als de Usus Modernus Pandectarum. Voorlopig lijkt deze omgangsvorm aan te sluiten bij het gematigde en pragmatische humanisme zoals het aan de Universiteit van Leuven bedreven werd, de zogenaamde via media. De bruikbaarheid van het Romeinse recht werd, in tegenstelling tot extreme humanisten, niet ontkend noch afgezworen. 
Romeinsrechtelijke figuren en regels konden nog steeds aangewend en gerecipieerd worden voor zover zij bruikbaar en rationeel waren. Zoniet, diende zij aangepast te worden. Ook in de Memorieboeken kunnen sporen van deze 'nieuwe stijl' teruggevonden worden. Het Romeinse recht kan er zich niet langer beroepen op zijn universele pretenties. Het wordt enkel nog aanvaard wanneer het overeenkomstig de gewoonte en/of rationeel is. Zoniet moet het andere, meer rationele oplossingen dulden, vaak geïnspireerd door gans andere bronnen van recht. Te Antwerpen heeft het ooit zo onaantastbare en exclusieve Justiniaanse recht duidelijk een autoritatieve degradatie ondergaan. Enerzijds bekleedt het Romeinse recht in de Memorien op de costumen een louter vergelijkende functie, ongeacht haar eventuele conformiteit met het lokale recht. Anderzijds blijft receptie van datzelfde recht een optie, al dan niet in licht gewijzigde vorm, aangezien gerecipieerd Romeins recht geen schending van de lokale rechten mocht impliceren. Eventuele wijzigingen worden ook openlijk toegegeven. Uit beide vaststellingen blijkt de prioriteit van de gewoonte over het geleerde recht in strikte zin. Ik kan zelfs nog een stap verder gaan wanneer ik mij concentreer op het belang van de ratio binnen gans deze nieuwe houding. Romeinsrechtelijke leges worden gerecipieerd voor zover ze een zekere rationaliteit (ratio) en billijkheid (aequitas) in zich dragen. In dit opzicht wil ik tevens wijzen op de zeven procent of 91 artikels welke hun aanwezigheid te danken hebben aan de 'redelijkheid' die zij in zich dragen. Ik meen dan ook te mogen concluderen dat de Usus en de ratio hoger als bron van recht worden ingeschat dan Rome.

Waar gehakt wordt, vallen spaanders. Voor maar liefst achttien procent van de nieuw toegevoegde artikels in de Consuetudines compilatae wordt in de Memorieboeken verwezen naar andere, reeds in de compilatie aanwezige, artikels. Zij zijn er een rechtstreeks en noodzakelijk gevolg van. Men zou kunnen spreken van collateral damage. Deze categorie vormt de vijfde belangrijkste groep onder de verschillende facetten van de juridische basis van de innovaties binnen de Consuetudines compilatae. Ze gaat de rechtsleer nipt vooraf. Dertien procent van de innovaties binnen de Antwerpse compilatie staat namelijk in voor wat Van Caenegem de Verwissenschaftlichung van het gewoonterecht noemt. De opinio doctorum, die door Van Uffel zodanig gehekeld werd, is goed voor 162 nieuwe artikels. Binnen het zee- en verzekeringsrecht speelt het geen enkele rol. Wel noemenswaardig is de uitgesproken aanwezigheid van de rechtsleer binnen het strafprocesrecht, waarin een hoofdrol weggelegd is voor de Practycke criminele van Filips Wielant. Globaliter manifesteert dit geheel van iuris periti, van wie de rechtsgeleerde werken als rechtsbron voor de Consuetudines compilatae hebben dienst gedaan, zich als een uiterst heterogene groep. Slechts twee namen springen meteen in het oog: de Franse jurist Louis le Caron alias Charondas en de Nederlandse processualist Filips Wielant. Andere auteurs in de voorste gelederen, doch van de tweede lijn, zijn onder meer de Franse juristen Jean Imbert, Charles Dumoulin en Jean Papon. Met andere woorden, Dumoulin, zo blijkt, moet Louis le Caron laten voorgaan als kenner bij uitstek van het gewoonterecht. Dit is enigszins verbazingwekkend, aangezien doorgaans de Fransman Charles Dumoulin steeds als grote gewoonterechtkenner wordt geportretteerd. Hoezeer voornoemde auteurs ook gekenmerkt worden door de jeugdige leeftijd van hun werk, ook de werken van 
oudere, middeleeuwse auteurs zijn van de partij. Als protagonisten van de commentatorentijd tref ik binnen deze groep van vooraanstaande rechtsgeleerden personen als Bartolo da Sassoferrato, Baldus de Ubaldis en Alessandro di Tartagni aan. Hun aandeel reikt echter nog niet tot aan het middel van le Caron en Wielant. Bovendien geven de commissieleden binnen de Memorieboeken blijk van een voorkeur voor eigentijdse, Franse auteurs. Op noemenswaardige afstand volgen de Italianen en de Nederlanders. Wat de meest geprefereerde literatuurtypes betreft, spannen de traktaten (zowel omtrent het materiële recht als het procesrecht) en commentaren op het geleerde recht de kroon. Pas in tweede instantie gaat het ook om commentaren op particulierrechtelijke compilaties en het genre van de rechtspraakverzamelingen. $\mathrm{Al}$ deze karakteristieken van de geraadpleegde literatuur wijzen in de richting van het juridisch humanisme. Bovendien heb ik ook nu weer kunnen vaststellen dat het bij deze verwetenschappelijking tevens om een daadwerkelijke receptie van juridische opinies gaat. Opnieuw kan de zuiverheid van de Antwerpse gewoonte niet langer gegarandeerd worden.

Opvallend is dat deze rechtsleer uit de studeerkamer van de doctores anno 1608 meer impact heeft gehad op de innovaties binnen de Consuetudines compilatae dan de jurisprudentie uit de rechtbank. De rechtsleer is in vergelijking met de rechtspraktijk immers veel subjectiever van aard. Toch haalt de rechtspraak als bron van recht slechts een aandeel van vier procent. Toonaangevend binnen deze categorie blijken te zijn geweest de Antwerpse turben en interne rechtspraak, evenals de Franse jurisprudentie zoals deze verhaald werd in de verschillende rechtspraakverzamelingen. Ondanks hun beschikbaarheid, de kritiek van Jacques Van Uffel en de intrinsieke waarde van het genre als waarheidsgetrouwe reflectie van de juridische realiteit, blijkt de rechtspraak dus nauwelijks gezag te hebben verworven onder de Antwerpse redacteurs.

Naast lexificatie, romanisatie, verwetenschappelijking en rationalisering, geven de Memorieboeken blijk van een vijfde fenomeen, dat ik ben gaan aanduiden als 'technocratisering' van het gewoonterecht. Acht procent van de nieuw toegevoegde artikels kent een juridische basis die teruggaat op de actieve en passieve inmenging van derden. Tot de voornaamste 'actieve derden' behoort de magistraat van Antwerpen. Indien deze het nodig achtte zaken te wijzigen, gebeurde dit ook. Uiteindelijk zal de magistraat op deze manier maar liefst 64 verschillende artikels blijvend van uitzicht of inhoud weten te veranderen. Telkenmale treedt hij hierbij op als corrigerende of aanvullende hand, en bijgevolg dus niet als rechtstreekse bron van recht waaruit de regel in eerste instantie geput werd. Bijgevolg moet de magistraat, ondanks de uitbesteding van het compileren aan een commissie, zeer kort bij de redactie van de Consuetudines compilatae hebben gestaan. Waar de magistraat zelf het initiatief neemt en een eerder actieve rol voor zich opeist binnen het ganse redactieproces, kenmerken de overige subgroepen binnen de categorie van derden zich eerder door een passieve houding. Tegenover de eerder dwingende acties van gezagsdragers staat namelijk het meer 'demo- en technocratische' bevragen van derden bij wijze van inwinnen van advies. Deze groep van 'passieve derden' kan nogmaals worden opgesplitst in twee subcategorieën, aangezien de raadpleging twee 
verschillende oorzaken kan hebben. Enerzijds vloeit het initiatief voort uit een zekere welwillendheid rekening te houden met de grieven van belanghebbenden. Het betreft hier hoofdzakelijk de handelaars, de erfscheiders, de amptman en de leden van de weeskamer. In het andere geval vindt het initiatief zijn oorsprong in de tekortkomingen van de commissieleden. Dit is voornamelijk het geval geweest bij het nieuwe zee- en verzekeringsrecht, maar heeft zich evenzeer voorgedaan met betrekking tot de overige verbintenisrechtelijke titels. Invloedrijke derden binnen deze categorie zijn de zogenaamde 'experts' of periti, handelaars, schippers, verzekeraars en onderhandelaars. Samenvattend kan ik concluderen dat Antwerpen zich als een mooi voorbeeld van 'technocratisering' van het geredigeerde gewoonterecht manifesteert. $\mathrm{Er}$ is namelijk de opvallende invloed van verschillende passieve derden, welke zijn oorsprong hoofdzakelijk vindt in de behoefte aan expertise of tekortkomingen van de commissieleden en deels in de welwillendheid van diezelfde commissarii. Maar van een zeker 'democratisch' idealisme vanwege de redacteurs kan, als verklaring voor de prominente rol der derden, geen sprake zijn. Zulk een aanpak bemoeilijkt immers nog meer de besluitvorming. De enige democratische sporen heb ik bij de handelaars en hun referendum teruggevonden. Deze technocratisering wordt op zijn beurt gecompenseerd door de (autoritaire) wijze waarop de magistraat zijn wil weet door te drukken.

Tot slot heeft dit eerste hoofdstuk ook de invloed van twee andere, zij het minder prominente, rechtsbronnen aan het licht gebracht. Het betreft de vroegere en de buitensteedse compilaties, respectievelijk verantwoordelijk voor negen en vier procent van de innovaties binnen de Consuetudines compilatae. Wat de vroegere, Antwerpse redactiepogingen betreft, is het aandeel van de Consuetudines antiquissimae binnen het zesde strafrechtelijke deel één van de meest markante vaststellingen. Het jaar 1608 wordt als het ware 1547. Meer dan de helft van de artikels wordt opnieuw opgevist uit de eerste Antwerpse redactiepoging. Desalniettemin betreft het geen blindelingse overname. Letterlijke hernemingen vormen een minderheid. De gerecupereerde artikels worden namelijk meestal aangepast aan de noden van een veranderde samenleving. Hierin blijkt de magistraat een voorname rol te spelen. Vaak betreft het een aanpassing van de strafmaat. Kortom, wat het materiële strafrecht betreft, geldt de kritiek van Jacques Van Uffel niet. A contrario zijn overtuiging, en hoewel hij eerder een gebruik van de Consuetudines antiquae voor ogen had, werd er mijns inziens door de commissieleden wél voldoende gebruik gemaakt van vroegere redacties zoals de Consuetudines antiquissimae en de Consuetudines impressae. Wel mist een aanzienlijk deel van de gerecupereerde artikels een bevestiging door de Usus, wat mogelijk de zuiverheid van het Antwerpse gewoonterecht kan schaden.

De invloed van vreemde, niet-Antwerpse, compilaties, blijft beperkt. Voor zover buitensteedse compilaties nieuwe rechtsregels aanleveren, betreft het hoofdzakelijk normen afkomstig van Franse coutumes, waarbij de Conférence des coutumes van de Franse jurist Pierre Guenoys het voortouw neemt. Guenoys is vooral binnen de erfrechtelijke titels aan te treffen. Aan Nederlandse zijde zijn in de eerste plaats de costumen van Utrecht, met betrekking tot het straf(proces)recht, en die van Gent, met betrekking tot het personenrecht, terug te vinden. Gelet op het schaarse aantal artikels dat 
hiervoor in aanmerking kwam, is het evenwel moeilijk gebleken hier scherp afgelijnde trends in waar te nemen. Wat het Franse, maar evenzeer het Gentse, gewoonterecht betreft, valt het op dat deze in beduidend mindere mate door expliciete bevestigingen vergezeld worden dan dit het geval was bij het Utrechtse gewoonterecht. Wat er ook van zij, het staat buiten kijf dat vreemde compilaties wel degelijk een waarneembare invloed uitgeoefend hebben op de inhoud en vooral de vorm van verschillende redactieprocessen. Dit zal nogmaals blijken uit het volgende hoofdstuk omtrent het fenomeen van costumiere acculturatie. 



\title{
HOOFDSTUK 2
}

DE BEÏNVLOEDING VAN HET GELDERSE LAND- EN STADSRECHT (1620) DOOR DE ANTWERPSE CONSUETUDINES COMPILATAE (1608): COSTUMIERE ACCULTURATIE

\author{
“... Het verkeer tussen staten heeft als natuurlijk \\ gevolg een mengelmoes van allerbande zeden en \\ gebruiken, daar de ene vreemdeling bij de andere \\ een zucht naar nieuwigheden doet ontstaan. Voor \\ goed bestuurde staten met gepaste wetten zou juist \\ dat in de hoogste mate schadelijk kunnen zijn; de \\ meeste staten zijn echter allesbebalve goed geordend, \\ en trek.ken zich er dan ook helemaal niets van aan \\ dat de burgers in een smeltkroes terecbtkomen, \\ door in het eigen land vreemdelingen te ontvangen \\ of door zelf plezierreisjes naar vreemde staten te \\ ondernemen, telkens als de begeerte in hen opkomt \\ een reisje te maken waar dan ook heen of wanneer \\ ook maar, of ze nu jong zijn of oud." 556
}

Bovenstaand citaat uit De Wetten van de Griekse filosoof, Plato, behoort tot de vroegste passages waarin het fenomeen van acculturatie en zijn mogelijke implicaties beschreven wordt. Vandaag de dag omschrijft de Encylopaedia Britannica acculturatie als the processes of change in artifacts, customs, and beliefs that result from the contact of societies with different cultural traditions. ${ }^{557} \mathrm{Om}$ zich te vrijwaren van zulke inmenging van

\footnotetext{
556 PLATO, De Wetten, X. DE WIN et alii ed. (Plato Verzameld werk. Deel IV), KapellenBaarn, 1999, 516.

557 “Acculturation", The New Encyclopaedia Britannica, 15de uitg., I, Chicago, 1974-1991, 57. Gedurende de periode die de Encyclopaedia Britannica van Plato scheidt, is het fenomeen onderwerp geweest van talloze, theoretische beschouwingen. Een historisch overzicht is terug te vinden bij onder meer: I. B. BERKSON, Theories of acculturation: a critical study, New York, 1920. F. W. RUDMIN, "Field notes from the quest for the first use of 'acculturation"', CrossCultural Psycbology Bulletin, XXXVII (2003), 24-31. F. W. RUDMIN, "Critical history of the
} 
buitenaf konden wetteksten vaak als instrument aangewend worden. Toch kunnen ook zij zelf tot het subject van acculturatie verworden, zoals blijkt uit de wijze waarop de Antwerpse Consuetudines compilatae en het Gelderse Land-en Stadsrecht zich tot elkaar verhouden. Omdat het een acculturatie betreft van gewoonterechtelijke regels, zal ik dit fenomeen aanduiden met de term 'costumiere acculturatie'. Dit verschijnsel zal in dit tweede hoofdstuk uitvoerig beschreven worden.

Hoofdstuk 1 heeft tal van factoren aan het licht gebracht en beschreven welke in de periode 1592-1608 zowel actief als passief hebben ingewerkt op het redactieproces van het Antwerpse gewoonterecht. Niet alleen meer traditionele rechtsbronnen, zoals het Romeinse recht, de rechtsgeleerde opinio doctorum, de wetgeving van zowel stedelijke als vorstelijke aard en uiteraard de Usus als causa consuetudinis hebben in belangrijke mate de inhoud maar evenzeer het uitzicht van de Consuetudines compilatae bepaald. Ook andere, minder voor de hand liggende factoren hebben de totstandkoming ervan beïnvloed. Ik denk onder meer aan de precedenten uit de (Antwerpse) rechtspraak en de expertise, raad en desiderata van derden, maar ook het voorbeeld van buitensteedse, geredigeerde, en vaak reeds gehomologeerde, costumen verdient in dezen vermeld te worden. Gezien het unieke karakter van een casus als de tandem Antwerpen-Roermond, met Hendrik Uwens aan het stuur, wil ik in dit tweede hoofdstuk dieper ingaan op de zojuist vermelde, wederzijdse beïnvloeding van verschillende costumiere compilaties. Dit fenomeen heeft immers nergens zo doortastend ingegrepen als bij de redactie van het Gelderse Land-en Stadsrecht. Wanneer de beïnvloeding zowel op inhoudelijk als vormelijk vlak zulke, bijna ongeziene, proporties aanneemt, dan spreek ik van 'costumiere acculturatie'. Dit vraagt om een nadere analyse.

De term 'costumiere acculturatie' verwijst -zoals zojuist aangegeven- naar het verschijnsel waarbij een bepaalde redactie $\mathrm{x}$ niet alleen als bron van recht maar eveneens als (vormelijk) referentiekader fungeert bij de redactie van een andere compilatie y.558 Kortweg gaat het om het aanwenden van een kwalitatief hogere compilatie van vreemd gewoonterecht bij het redactieproces van het eigen, kwalitatief lagere, costumiere recht. Compilatie x treedt hierbij op als een soort van ratio scripta, waarvan zulk een inspirerende kracht kan uitgaan dat de mogelijkheid bestaat dat compilatie y zowel inhoudelijk als vormelijk gans overschaduwd wordt. ${ }^{559}$ Dit is wat er zich in het Overkwartier bij de redactie van het Gelderse Land-en Stadsrecht heeft voorgedaan. De komst van Hendrik Uwens, als kanselier van het Hof van Gelre, zal het redactieproces te Roemond een nieuwe impuls geven, maar meer nog betekent dit een andere strategie, waarin een kapitale rol is weggelegd voor de Antwerpse Consuetudines compilatae als ratio scripta en het verlies van de eigenheid van het Gelderse Land-en Stadsrecht als mogelijk neveneffect. Het sjabloon dat Uwens over het

acculturation psychology of assimilation, separation, integration, and marginalization”, Review of General Psychology, VII (2003), 3-37.

558 Cfr. supra, hoofdstuk 1, paragraaf 3, Romanisatie en humanisme.

${ }^{559}$ Voor de toelichting van de term acculturatie als dubbel proces van receptie en assimilatie, cfr. supra, hoofdstuk 1, paragraaf 3, Romanisatie en bumanisme. 
Overkwartierlijke gewoonterecht heen legt, verheft dit laatste evenwel naar een hoger niveau.

Status quaestionis

Costumiere acculturatie, als het verhaal van een 'verheffende' ratio scripta, behoort tot vandaag de dag tot het wetenschappelijk braakland. Hoewel men in het verleden steeds op de hoogte is geweest van het bestaan van het verschijnsel, werd dit tot nog toe niet aan een grondige analyse en beschrijving onderworpen. Kennis van het fenomeen heeft men te danken aan het feit dat het advies de Consuetudines compilatae als voorbeeldredactie te gebruiken zwart op wit neergeschreven stond en steeds bewaard is gebleven in de kwartierrecessen: “... ende voerts goed bevonden dat mijn heeren in geschrifte solden stellen der eheluyden gerechtichbyden int francois geheyten Les droits des maries ende was daeraen cleeft ende andere goede ende noodige puncten soe inde Reformatie niet begrepen syn, presenterende tot sulcken eynde te leenen die concepten vande Antwerpsche Reformatie om daer unyt te scheppen ende te nemen was mit deses Landts coustumen mochte accorderen, dwelck mijn beeren bebben goet gevonden ende dieselve concepten versocht ende gebeden geleent te mogen hebben." 560 Vervolgens is het Jan L. Geradts geweest die er anno 1860 in zijn proefschrift, gewijd aan de Sowvereinen raad in het Overkwartier van Gelderland te Ruremonde, opnieuw de aandacht op vestigde: "De Kanselier vond het niet doelmatig de herziening, met den spoed, die door de Commissie verlangd werd, te behandelen, maar verlangde rijpelijk te beraadslagen over een werk van zoo veel aanbelang, en nadat hij opgemerkt had, dat de reformatie van de Costumen van Antwerpen sommige bepalingen inbield van denzelfden aard als die van het ontwerp, kwam hij met de Commissie overeen die costumen te raadplegen, en in het ontwerp die bepalingen op te nemen, welke er voor geschikt geoordeeld zouden worden." 561 Desondanks heeft deze passage geen enkele onderzoeker aangespoord dit fenomeen nader te bekijken.

In het verleden beperkte men zich met name tot het aangeven van vaak zeer bescheiden filiaties, welke eerder een sporadisch dan systematisch karakter vertoonden.562 Van een systematische interpenetratie van rechtsregels tussen verschillende costumiere redacties is nergens sprake. Louter illustratief en zonder volledigheid te willen nastreven, verwijs ik in dezen naar auteurs als Vanderlinden, Bosch en Keverling Buisman. ${ }^{563}$ Dat ook de derde, gedrukte redactiepoging te

560 MAASTRICHT, Regionaal Historisch Centrum Limburg, Staten van het Overkwartier, nr. 73: Kwartierrecessen 1615-1617, 1615-1617.

${ }^{561}$ GERADTS, Sowvereinen raad, 53. Bijna een eeuw later zijn het Feenstra en Spijkerboer die de filiatie tussen beide compilaties herontdekken: FEENSTRA en SPIJKERBOER, "Coutume de Gueldre et Coutume d'Anvers", 74-76.

562 Zo kopieerden de samenstellers van de middeleeuwse coutumiers eveneens formuleringen uit coutumiers van andere (vaak naburige) regio's. (Cfr. VAN DIEVOET, Les coutumiers, 43.)

563 VANDERLINDEN, "Essai sur la structure des textes coutumiers", 269-293. (Cfr. infra, hoofdstuk 2, paragraaf 4.)

BOSCH, "Enige rechtshistorische aantekeningen", 1009-1015. BOSCH, "Remarques sur quelques influences", 133-157. Wat de periode tot 1384 betreft, wijst hij erop dat de stadsrechten van het merendeel van de Hollandse steden teruggaan op die van Brabantse steden, meer bepaald de Leuvense stadsrechten. Bovendien is er de invloed van Damme en Brugge wat betreft het zeerecht. Voor de periode 1384-1585 wijst hij vooral op de manier 
waarop lokaal, zuidelijk recht zijn intrede deed in het Noorden via de vorstelijke ordonnanties van Karel V en Filips II. De derde periode, tot 1756, staat in het teken van de derde Antwerpse redactie, de Consuetudines impressae (1582). De Antwerpse costumen in protestants jasje zijn daardoor -maar ook omwille van hun intrinsieke waarde- zeer populair in het Noorden, meer bepaald in Holland. Onder meer Hugo de Groot verwees ernaar in zijn Inleidinge tot de Hollandsche Rechtsgeleerdheid. Maar nog nauwer aansluitend bij ons onderzoek is de band die er bestaat tussen de Consuetudines impressae enerzijds en de private compilatie van Amsterdams gewoonterecht, het Recueil van verscheyde keuren en costuymen uit 1644 en door stadssecretaris Rooseboom opgesteld. Rooseboom gebruikte de Consuetudines impressae als model voor zijn tekst en verschillende artikelen zijn geheel of gedeeltelijk vrijwel letterlijk overgenomen. (Cfr. BOSCH, "Remarques sur quelques influences", 145 noot 3.) Sommigen gingen zover dat zelfs het Antwerpse recht naast het Romeinse recht ook als het gemene recht werd beschouwd. Zo makt Duysentdaelders, de zeventiende-eeuwse expert van het Amsterdamse recht, in zijn Observationes veelvuldig gebruik van het Antwerpse recht, en erkent hij in de opdracht dat het doel van zijn werk is alles soo te voegen, dat in yder deel mochte blyken, waer in wy met 'et Roomsche Recht en de Coustumen van Antwerpen, die seer loffelyk syn, overeenkomen, ende waer in wy met deselve verscheelen. (Geciteerd naar Bosch: BOSCH, "Enige rechtshistorische aantekeningen", 1012.) Ook vele andere, latere juristen verwijzen nog naar de Consuetudines impressae, en de redactie ontbreekt bijna in geen enkele Noord-Nederlandse bibliotheek. Ook van de band tussen de Consuetudines compilatae en het Gelderse Land-en Stadsrecht is Bosch reeds op de hoogte. Via Roermond zou het Antwerpse recht ook in het Land van Nijmegen zijn doorgedrongen, aldus Bosch (BOSCH, "Remarques sur quelques influences", 147. Cfr. O. MOORMAN VAN KAPPEN, "Receptie van het Gelders-Overkwartierlijke land- en stadsrecht van 1619 in Nijmegen?", A. M. J. A. BERKVENS, A. F. GEHLEN en G. H. A. VENNER red., 'Flittich erforscht und gecolligeert...' Opstellen over Limburgse rechtsgeschiedenis, Maastricht, 1995, 173-185.) Ook wat de vierde periode betreft (1756-1795) beperkt Bosch zich slechts tot een 'aanzet geven tot'. Of, om het met Bosch' eigen woorden te zeggen: 'Laten deze te hooi en te gras samengeraapte fragmentarische aantekeningen het maken van enige gevolgtrekking toe? De eerste is wel deze, dat er nog heel wat wetenschappelijk werk zal moeten verricht worden vooraleer het mogelijk zal zijn zich een duidelijke en vastomlijnde voorstelling te maken van de mate der wederzijdse invloeden, die werkzaam zijn geweest." (BOSCH, "Enige rechtshistorische aantekeningen", 1014.)

KEVERLING BUISMAN, Mer 't is geen lantrecht, 20. In het kader van het Drentse landrecht dat in 1614 herzien werd, benadrukt laatstgenoemde auteur het belang van wederzijdse beïnvloeding: "Dat de wetgevers in Drenthe wel degelijk oog hadden voor de regelingen in de nabuurprovincies blijket bieruit dat de Landdag nog op 17 februari 1614 opmerkt dat de Groningers in haere landrechten de Drenten witsluiten van het recht van het recht van naarkoop in de Ommelanden. Er werden twee vertegenwoordigers, vergezeld door een landschrijver, naar de eerstvolgende bijeenkomst van de Groninger Staten gezonden om een verandering te bepleiten. Of die bezending enig resultaat heeft gehad, is mij (nog) niet bekend, maar het geeft eens te meer aandat we meer oog moeten hebben voor de mogelijkheid van wederiijdse beïnloeding bij de totstandkoming van landrechten en ordonnanties." Ook andere filiaties worden in deze rede vermeld. Elders vermeldt Keverling Buisman eveneens de band die er bestaat tussen het Veluwse landrecht en dat van Overijsel. Omdat het gewoonterecht van Veluwe mede door een groots jurist als Leoninus werd samengesteld, ging er immers een grote aantrekkingskracht van uit. (KEVERLING BUISMAN, “Actoren”, 200.)

Omtrent de banden tussen het Haarlemse stadsrecht van 1245 en het recht van de stad 'sHertogenbosch (ca. 1185), zie: C. L. HOOGEWERF, Het Haarlemse stadsrecht (1245). Inleidende beschouwingen, tekst, vertaling en artikelsgewijs commentaar, Amsterdam, 2001. Met betrekking tot de stadsrechten van Graaf Willem II van Holland en het recht van 
Antwerpen, naast Deurne, ook voor het Amsterdamse recht belangrijk is geweest, is reeds langer bekend.564 Wat de costume van Mechelen betreft, reikt haar invloed volgens Fockema Andreae zelfs tot in Overijssel. ${ }^{565}$ Ook aan het belang van de Parijse coutumes voor de overige Franse regio's wordt sinds jaar en dag niet meer getwijfeld. Bovendien heb ik zelf, in het eerste hoofdstuk, kunnen aantonen dat het lokale recht van de Franse lichtstad tot in de metropool aan de Schelde is doorgedrongen. Meer nog, naast de Parijse coutumes, zijn ook die van andere Franse provincies samen met de costumen van steden als Gent, Utrecht en Mechelen, bepalend geweest voor het uitzicht van de Consuetudines compilatae. Het doortrekken van deze lijn brengt vaak verrassende filiaties aan het oppervlak. Zo zullen de door de Consuetudines compilatae beïnvloede rechten van het Overkwartier op hun beurt het landrecht van Thorn beïnvloeden. ${ }^{566}$ Berkvens omschrijft het Nieuwe Landrecht van Thorn (1788) zelfs als een restatement van het Gelderse Land- en Stadsrecht.567 Op deze manier is de kans reëel dat men in het achttiende-eeuwse Thorn met Frans gewoonterecht uit de zestiende eeuw te maken krijgt. Naast de kettingreactie behoort ook de cirkelbeweging tot de mogelijkheden. Zo is het eerste ontwerp van Overkwartierlijk recht uit 1564 één van de inspiratiebronnen geweest voor het Landrecht van Montfort dat omstreeks 1605 door Johan Kehrn van Fronhoven werd geredigeerd. ${ }^{568}$ Zoals ik zodadelijk nog zal zien, heeft ditzelfde landrecht dan weer in dienst gestaan van de redacteurs van het Gelderse Land-en Stadsrecht. Kortom, wederzijdse beïnvloeding kan zelden onderschat worden en verdient veel meer aandacht dan tot dusver werd verkregen.

Dit gebrek aan aandacht betekent echter niet dat er geen andere voorbeelden van costumiere acculturatie bestaan. Zij wachten echter nog op een analyse. Meer nog, de overgrote meerderheid moet vooreerst geïdentificeerd worden en aan de wetenschappelijke wereld worden geopenbaard. Zo heb ik zelf, op basis van hun sterk gelijkende inhoudstafels, het bestaan van filiaties ontdekt tussen verschillende

\footnotetext{
'sHertogenbosch, zie: H. P. H. CAMPS, De stadsrechten van Graaf Willem II van Holland en hun verhouding tot het recht van 's-Hertogenbosch, Utrecht, 1948.

${ }^{564}$ Cfr. W. F. H. OLDEWELT, "De pogingen tot 'codificatie' van het Amsterdamse recht", Verslagen en mededeelingen Vereeniging tot Uitgaaf der Bronnen van het Oud-vaderlandsche recht, 13 (1967), 66-73.

565 FOCKEMA ANDREAE, "Recht en rechtsbedeling", 283-284. Ook onderkende Fockema Andreae een relatie met het Veluwse landrecht. Cfr. KEVERLING BUISMAN, Mer 't is geen lantrecht, 17.

${ }^{566}$ Cfr. A. M. J. A. BERKVENS, "Het nieuwe Landrecht van Thorn. Verlicht absolutisme en codificatie onder het bewind van de vorstin-abdis Maria Cunegonda van Saksen (1776-1794)", Publications de la Société Historique et Archéologique dans le Limbourg - Jaarboek van Limburgs Geschieden Oudheidkundig Genootschap, 134-135 (1998-1999), 102-104. Ook van belang in deze is de mogelijke invloed van het Gelderse Land- en Stadsrecht op het Nijmeegse recht. Zie hiervoor: MOORMAN VAN KAPPEN, "Receptie van het Gelders-Overkwartierlijke land- en stadsrecht van 1619 in Nijmegen?", 173-185.

567 A. M. J. A. BERKVENS, "Het concept van de 'nieuwe landrechten van het hooggrafelijk stift en vorstendom Thorn"', Verslagen en mededelingen van de Stichting tot uitgaaf van de bronnen van het Oud-V aderlandse Recht, nieuwe reeks, 9 (1997), 39-96.

${ }_{568}$ Cfr. infra, hoofdstuk 2, paragraaf 1 , $V$ roegere en vreemde redacties.
} 
Brabantse, geredigeerde costumen. Het gaat om de redacties van Lier (1570), Kiel (1570), Deurne (1577), Bergen op Zoom (1606) en 's Hertogenbosch (1606) enerzijds en de compilatie van Mechelen (1535), als voorbeeldredactie, anderzijds. ${ }^{569}$ Laatstgenoemde kruipt hierbij in de rol van ratio scripta. Het Mechelse gewoonterecht vormt de basis van de stemma compilationis die ik op deze manier aan het licht heb gebracht. ${ }^{570}$ Dat men op deze plaatsen ervoor geopteerd heeft zich te spiegelen aan het Mechelse gewoonterecht, ligt voor de hand omwille van twee redenen. Ten eerste is de costume van Mechelen één van de eerste die geredigeerd en gehomologeerd waren (1535). Vervolgens moet het de plaatselijke overheden verstandig geleken hebben zich te laten inspireren door het recht van de stad waar de hoogste beroepsinstantie, de Grote Raad van Mechelen, gelegen was. Zoniet, was de kans om in appelzaken afgewezen te worden ongetwijfeld groter geweest.

Figuur 2.1 De aan de costume van Mechelen (1535) gerelateerde costumen

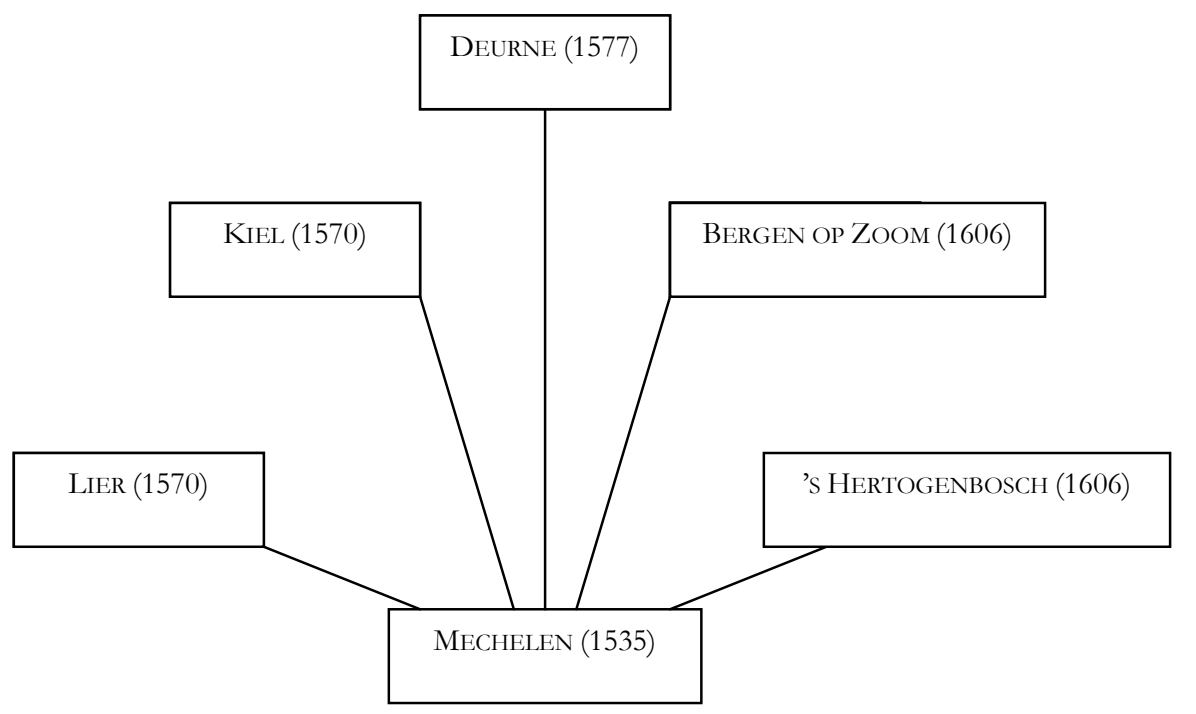

569 Deze filiatie verklaart de snelheid waarmee de compilatie tot stand kwam (zes weken) evenals het kwaliteitsniveau van deze tweede redactiepoging van 1570. Van Rompaey is hier, gezien zijn verwondering, duidelijk nog niet van op de hoogte. (Rechtsbronnen van de stad Bergen op Zoom, J. VAN ROMPAEY red., (Verslagen en mededeelingen der Vereeniging tot Uitgaaf der Bronnen van het Oud Vaderlandsche Recht, 13), Utrecht, 1968, 204.)

570 Een voorlopige, eerder vluchtige, analyse van de verschillende Brabantse costumiere compilaties, geeft me de indruk dat, binnen de grenzen van het oude hertogdom Brabant, de geredigeerde, Mechelse costume van 1535 een vergelijkbare, structuur- en inhoudsbepalende invloed heeft uitgeoefend op deze Brabantse redacties, zoals de herinneringsbrief van Karel V dat binnen het oude graafschap Vlaanderen heeft gedaan. (Cfr. VANDERLINDEN, "Essai sur la structure des textes coutumiers", 292.) 
Zoals figuur 2.1 laat zien, gaat het in dit geval meer om struikgewas, waar de filiaties verbonden aan het Antwerpse recht meer een echte (stam)boom tot stand brengen. Deze andere familie heeft de Antwerpse redactiepogingen als stamvader. Zo liggen de Consuetudines impressae niet alleen aan de basis van de Consuetudines compilatae, maar eveneens aan die van de tweede redactiepoging te Deurne (>1611). Via de Consuetudines compilatae werd ook het Gelderse Land-en Stadsrecht (1620) binnen deze familie opgenomen.

Figuur 2.2 De aan de Antwerpse costume gerelateerde costumen

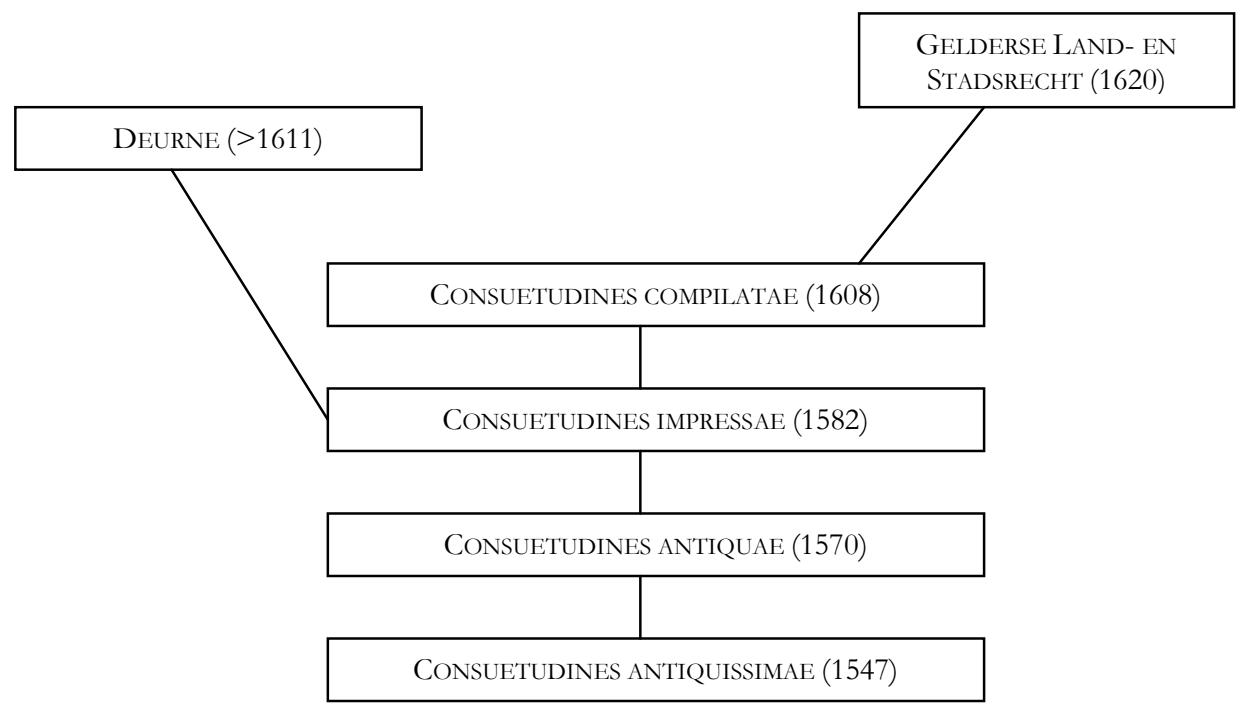

In dit hoofdstuk beoog ik vooreerst een analyse te maken van het fenomeen 'costumiere acculturatie' zoals het zich bij de redactie van het Gelderse Land en Stadsrecht heeft voorgedaan. Toch zal ik dit hoofdstuk openen met een paragraaf aangaande de overige invloeden, welke naast de Antwerpse Consuetudines compilatae, eveneens in de literatuur worden vermeld. Waar en in welke mate zij hebben ingewerkt, kan ik wegens het gebrekkige bronnenmateriaal evenwel niet beschrijven. Hoewel het Regionaal Historisch Centrum Limburg te Maastricht binnen het archief van de Staten van het Overkwartier tal van documenten bewaart, welke gerelateerd zijn aan de genese van het Gelderse Land-en Stadsrecht, is een Roermondse equivalent van de Antwerpse Memorien op de Costumen niet beschikbaar. Bijgevolg ligt het niet binnen mijn mogelijkheden de bronnen van het geredigeerde, Overkwartierlijke gewoonterecht even exhaustief en systematisch te omschrijven als ik in het eerste hoofdstuk met betrekking tot Antwerpen heb kunnen doen. Ik beperk me dan ook 
tot de opsomming ervan. ${ }^{571}$ Bovendien bestaat de mogelijkheid dat -ten gevolge van de costumiere acculturatie aan het Antwerpse model- andere, meestal oudere invloeden van buitenaf teniet werden gedaan. Toch wil ik hier niet het woord tabula rasa in de mond nemen. Dit hoofdstuk zal immers nog aantonen dat, weliswaar met betrekking tot welbepaalde materie, ook de invloed van Antwerpen tot een minimum beperkt kan blijven. ${ }^{572}$ Waar dit het geval is, komt meteen heel wat ruimte vrij voor redacties van onder andere meer nabij gelegen en bijgevolg ook zeer gelijkaardige regio's.

De twee volgende paragrafen richten hun vizier specifiek op de rol die het Antwerpse recht gespeeld heeft in het redactieproces van het Gelderse Land- en Stadsrecht. Costumiere acculturatie als fenomeen komt hier volledig tot zijn recht. Bij de omschrijving ervan heb ik een dubbel doel voor ogen. Vooreerst zal ik me concentreren op de loci van het gebeuren. Waar werd het meeste materiaal aan het Antwerpse recht geassimileerd? Onder impuls van Uwens groeit het Gelderse Land-en Stadsrecht immers uit tot een buitengewoon omvangriike compilatie van net geen tweeduizend artikels. In rechtshistorische wandelgangen werd geopperd dat vermoedelijk zestig procent ervan 'gerecipieerd' werd uit de Consuetudines compilatae. ${ }^{573}$ Aan de hand van een nauwgezette en stapsgewijze vergelijking zal ik nu laten zien waar en in welke mate Antwerps recht de Overkwartierlijke rechtskring is binnengeslopen. Welke rechtsmaterie is het meest onderhevig gebleken aan de Antwerpse invloed? Of, binnen welke domeinen heeft het Roermondse recht zijn meerdere moeten erkennen in de Antwerpse regelgeving of formulering? Dit onderzoek vereist een comparatieve annak waarbij elk artikel uit het Gelderse Land-en Stadsrecht op een letterlijke Antwerpse equivalent wordt gecontroleerd.

Een derde paragraaf besteedt aandacht aan één van de mogelijke implicaties van het acculturatiefenomeen, namelijk het Trojaans Paard in de voorbeeldredactie. Welke vreemde invloeden vinden via de Consuetudines compilatae hun weg naar het Overkwartier en tasten er mogelijk de zuiverheid van het lokale, Roermondse recht aan. De Consuetudines compilatae fungeren namelijk als Paard van Troje, volgestouwd met elementen welke in hoofdstuk 1 werden geïdentificeerd en beschreven. Van zodra er sprake zou kunnen zijn van werkelijke receptie van Antwerps recht, impliceert dit heel wat meer. Opnieuw kan ik dan gaan spreken van processen als romanisering, lexificatie, verwetenschappelijking, rationalisering, etc. Hiertoe moet echter eerst de vraag omtrent de werkelijke receptie van Antwerps recht worden

571 Ook de persoonlijke invloed van Hendrik Uwens op het proces blijft een moeilijk te achterhalen gegeven. Zijn rol binnen de externe geschiedenis van het redactieproces is reeds uitputtend beschreven door Berkvens en Venner. Zijn rol in de interne geschiedenis, of met andere woorden de ratio achter zijn handelen achterhalen, is op basis van zijn persoonlijke notities bij de verschillende tekstversies, zo goed als onmogelijk gebleken. Hoewel dit oorspronkelijk behoorde tot de centrale doelstellingen van dit project omtrent de invloed van het juridisch humanisme, is het beschikbare materiaal hiertoe te fragmentarisch en dus ook ontoereikend gebleken.

${ }^{572}$ Cfr. infra, hoofdstuk 2, paragraaf 2, Deel $V$.

573 Cfr. FEENSTRA en SPIJKERBOER, “Coutume de Gueldre et Coutume d'Anvers”, 75. 
opgelost. Dit vraagt echter om een ander, afzonderlijk onderzoek, waar me hier de tijd niet voor restte. De beschrijving van de costumiere acculturatie levert een essentiële bijdrage tot de geschiedenis van het redactieproces, waarbinnen tot nog toe maar weinig aandacht besteed werd aan dit fenomeen. ${ }^{574}$ Bovendien eist dit verschijnsel, zij het onbewust, zijn plaats op binnen het ganse verhaal omtrent de unificatie van het privaatrecht in de Zuidelijke Nederlanden.

Dat de studie ervan gerechtvaardigd is, blijkt evenzeer uit de oproepen die in dit opzicht reeds in het verleden werden gedaan. Ik denk aan Keverling Buisman die het in zijn rede 'Mer 't is geen lantrecht als volgt uitdrukte: "Naast de vraagstelling die gericht is op één specifiek landrecht -en dat is tot nu toe vrijwel witsluitend het geval geweest-is bovendien meer rechtsvergelijkend onderzoek zeer gewenst. In welke mate komen de landrechten van de verschillende gewesten overeen, en op welke terreinen doet zich dat voor? Spelen de gezaghebbende auteurs daarbij een rol? ..." 575 En meer concreet met betrekking tot de casus Antwerpen-Roermond is er Moorman van Kappen. Hij pleitte reeds in zijn recensie bij de uitgave van het Gelderse Land-en Stadsrecht door Venner en Berkvens voor een meer doortastend onderzoek naar de inhoudelijke aspecten van deze Overkwartierlijke codificatie, waarvan -aldus Moorman van Kappen- de hoofdbronnen gevormd worden door het Overkwartierlijke costumiere recht enerzijds en de Antwerpse Consuetudines compilatae anderzijds. "Daaraan zou mr. G. Spijkerboer zijn dissertatie wijden. Zijn plotselinge overlijden op 14 angustus 1995 verijdelde helaas dit door hem lang gekoesterde en na zijn pensionering met bernieuwde ijver opgevatte plan. Die taak wacht dus nog op uitvoering, een taak, die witstekend gecombineerd zou kunnen worden met een ander, door de beide witgevers zelf geuit desideratum ( $p$. LXX): de uitgave van de voorontwerpen van het onderhavige Land-en Stadrecht (waaronder dat van Tilman van Bree van 1613)."576 Deze laatste verwachtingen ga ik niet inlossen, gezien de opzet van mijn onderzoek dit niet mogelijk maakt. Meer nog, mijns inziens bestaat het ontwerp van Van Bree uit 1613 niet meer. Ik heb het ganse archief van de Staten van het Overkwartier -voor zover het te maken heeft met de totstandkoming van het Gelderse Land- en Stadsrecht- doorzocht, maar mijn inspanningen bleken tevergeefs. Ook het gemeentearchief van Roermond bleek niet meer dan een magere

574 Over het waarom van de acculturatie ga ik hier niet uitweiden. Gaat het louter om het hogere, kwalitatieve niveau van de voorbeeldcompilatie of betreft het een bewuste unificatiestrategie vanwege de lagere bestuursniveaus? Of is de assimilatie niet meer dan een gevolg van een gemakzuchtige houding, welke op haar beurt voort kan vloeien uit de terughoudendheid waardoor de lokale besturen zich aanvankelijk kenmerkten ten aanzien van het redactiegebod.

Waarom men voor een welbepaalde voorbeeldredactie kiest, verschilt van situatie tot situatie. In het geval van de tandem Antwerpen-Roermond liggen Hendrik Uwens en zijn benoeming tot kanselier van het Hof van Gelre hiervan aan de oorsprong. Wie exact de compilatores te Lier, Kiel, Deurne, Bergen op Zoom en 's Hertogenbosch heeft aangemaand zich aan het Mechelse voorbeeld te spiegelen, is vooralsnog niet bekend. Mogelijk werpen de documenten in de respectievelijke stadsarchieven meer licht op deze zaak?

${ }^{575}$ KEVERLING BUISMAN, Mer 't is geen lantrecht, 9.

576 O. MOORMAN VAN KAPPEN, Bespreking van A. M. J. A. BERKVENS, G. H. A. VENNER en G. SPIJKERBOER, Het Gelderse Land- en Stadsrecht van het Overkwartier van Roermond, Arnhem, 1996, Tijdschrift voor Rechtsgeschiedenis, 65 (1997), 536-538. 
oogst op te leveren, zijnde nihil. De verwoestende stadsbrand van 1665 zal hier ongetwijfeld een hand in hebben. Mochten er nog ontwerpen bestaan, dan moeten ze vooreerst gezocht worden in de onderhavige steden, welke het ontwerp ter becommentariëring toegestuurd kregen: "Werd bij de vroegere poging tot codificatie in 1596 gestart met het verzoek om de oude rechten en gewoonten in te zenden, nu werd een concept-landrecht ontworpen dat vervolgens aan de steden, onderheren en drosten werd toegezonden, zodat zij en de schepenen op het platteland er kennis van konden nemen en het concept van commentaar konden voorzien. Daartoe werden twaalf afschriften van het ontwerp-landrecht vervaardigd. De tekst omvatte minstens 160 folio's." 577

Hoofdstuk 2 zal afgesloten worden met een paragraaf omtrent de structurele assimilatie. Het betreft hier een ander deelaspect van de costumiere acculturatie en de assimilatie in het bijzonder. Centraal staat de mate waarin de ordening van zowel de Antwerpse Compilatae als het Gelderse Land- en Stadsrecht, door haar assimilerende houding, onder invloed is komen te staan van het juridisch humanisme. De paragraaf toont hoe belangrijk de typerende systematiseringsdrang van de humanistische auteurs is geweest voor het definitieve uitzicht van beide compilaties.

577 BERKVENS, VENNER en SPIJKERBOER, Gelderse Land- en Stadsrecht, XXIX. De archieven van deze onderhavige plaatsen heb ik evenwel niet bezocht. Enkel het gemeentearchief van Roermond, heb ik nog op mogelijke, bruikbare documentatie onderzocht. Deze inspanning heeft echter geen vruchten afgeworpen. 


\section{PARAGRAAF 1}

KLEINERE INVLOEDEN OF HET ONDERZOEK TOT DUS VER...

In deze eerste paragraaf wil ik een summier overzicht geven van enkele factoren welke, naast de Antwerpse Consuetudines compilatae, eveneens een rol hebben gespeeld bij het redactieproces van het Gelderse Land-en Stadsrecht. Dit resumé baseert zich uitsluitend op wat hieromtrent te vinden is in de beschikbare literatuur en dus niet op innovatief bronnenonderzoek. Elementen die hier aan bod zullen komen, omvatten onder meer de vroegere ontwerpen van het Overkwartierlijke gewoonterecht, de vreemde compilaties van hoofdzakelijk naburige regio's, documenten van legislatieve aard en het geleerde recht in strikte zin. Wegens het ontbreken van Roermondse Memorien op de costumen, kan en zal ik hier niet dieper ingaan op de mogelijke invloed van andere types van rechtsbronnen zoals ik ze met betrekking tot de Consuetudines compilatae ben tegengekomen (rechtsleer, rechtspraak, derden, ratio, etc.). Hoewel Maurenbrecher er nog op attendeerde dat de invloed van Zuid-Nederlandse juristen over het algemeen zeer groot was, zijn de verwijzingen naar rechtsgeleerde auteurs in de marges van de verschillende ontwerpteksten bijzonder schaars gebleken. ${ }^{578}$ Ook de rol van Tilman van Bree zal ik, net als die van Hendrik Uwens, wegens de tekortkomingen van het beschikbare bronnenmateriaal buiten beschouwing laten. ${ }^{579}$

Een eerste keer dat er in de wetenschappelijke literatuur over de bronnen van het Gelderse Land-en Stadsrecht werd gesproken, was in 1831 en is een verdienste van Mario Maurenbrecher. In zijn werk Die rheinpreußischen Landrechte beantwoordde de auteur de vraag naar de juridische basis van het Gelderse Land- en Stadsrecht, als volgt: "Die Materialen, wonach die ständischen Commissariën gearbeitet haben, sind meist unbekannt. In manchen Materiën, namentlich in den aus dem Römischen Rechte erst bekannt gewordenen, ist das ewige Edict Grundlage gewesen. Das Römische Recht selbst hat in den übrigen Materiën mehr als Muster, wie als Quelle gedient. Ausländische Rechtsquellen sind durchaus fern gehalten worden, böchstens was die Methode betrifft, mögen sie von den gründlichen Redactoren benutrt worden sein, besonders das Zutphensche Landrecht von 1604. Am meisten werden die älteren Rechtssammelungen und Privilegien der einzelnen Distrikte ausgeholfen haben. Die gewöhnlichste Quelle ist das auf der Tradition und dem Gerichtsgebrauche berubende (ungeschriebene) Recht des Landes gewesen." 580 We schrijven 1831 en van enige Antwerpse invloed is nog geheel

578 R. MAURENBRECHER, Die rheinpreußischen Landrechte, I, Bonn, 1830, 125-126.

${ }^{579}$ In deze wil ik de heer Spijkerboer bijtreden, die erop gewezen heeft dat een onderzoek naar de rol van Tilman van Bree in de eerste plaats in de richting moet gaan van een biografisch onderzoek. (Cfr. FLAMENT, "Bree (Tilman van)", 459-460. DEKKERS, Bibliotheca Belgica Juridica, 26.) Hierdoor zal mogelijk duidelijk worden, welke rechtsbronnen van Bree heeft gebruikt, evenals vanuit welke intellectuele achtergrond en door welke oorzaken hij deze heeft geraadpleegd. Hetzelfde geldt overigens voor de persoon van Hendrik Uwens.

${ }^{580}$ MAURENBRECHER, Rheinpreußischen Landrechte, II, 478. Geciteerd naar SPIJKERBOER, Enkele beschouningen, 12. (Cfr. K. J. T. JANSSEN DE LIMPENS, Rechtsbronnen van het Gelders Overkwartier van Roermond (Werken der Vereeniging tot Uitgaaf der Bronnen van het OudVaderlandsche Recht, 20), Utrecht, 1965, XVII-XVIII.) 
geen sprake. Het is immers -zoals reeds eerder aangegeven- wachten geblazen tot 1860 wanneer de band tussen Antwerpen en Roermond opnieuw onder de aandacht van de rechtshistorische middens wordt gebracht door de heer Geradts in zijn proefschrift omtrent de Souvereinen raad in het overkwartier van Gelderland te Ruremonde. ${ }^{581}$ Desondanks laat Maurenbrecher tal van andere rechtsbronnen de revue passeren (Romeins recht, Landrecht van Zutphen, de gewoonte en de rechtspraak). Zij zullen ook zodadelijk aan bod komen.

$V$ roegere en buitensteedse redacties

$\mathrm{Na}$ Maurenbrecher is het in feite wachten tot 1965 wanneer er nogmaals (uitvoerig) gesproken wordt over de mogelijke inspiratiebronnen voor de redacteurs van het Gelderse Land-en Stadsrecht. Het is Janssen de Limpens geweest die in dat jaar tal van andere rechtsbronnen, welke in het Overkwartier voor handen en van kracht waren, heeft uitgegeven en beschreven. ${ }^{582}$ In de inleiding op deze uitgave Rechtsbronnen van het Gelders Overkwartier van Roermond stelt de auteur het volgende: "De onderhavige nitgave beeft ten doel daarnaast voor gebruik toegankelijk te maken de rechtsbronnen opgetekend en in werking geweest vóor het landrecht van 1619 en [die] ten dele zeker als bron van dit landrecht kunnen gelden." 583 Bijgevolg suggereert Janssen de Limpens het gedeeltelijk aanwenden van de rechtsbronnen van alle afzonderlijke ambten, zoals daar zijn Erkelenz, Gelder, Goch, Kessel, Kriekenbeeck, Middelaer, Montfort, Straelen, Wachtendonck en de stad en heerlijkheid Gennep. Uiteraard ontbreken ook de oudere ontwerpen van het landrecht, respectievelijk daterend van de jaren 1532 en 1564, niet in deze lijst. Het eerste ontwerp (1532) bevat echter voornamelijk desiderata en wil in de eerste plaats rechtsvernieuwend werken en misverstanden uit de weg ruimen. De inhoud ervan is in die mate belangrijk dat het laat zien op welke punten van het geldend recht en van de juridische organisatie men rechtsvernieuwend wenste op te treden. Wat het ontwerp van 1564 betreft, stelt de auteur het volgende: "Al heeft de redactie van 1564 niet mogen leiden tot de tot stand koming van een algemeen landrecht voor het Overkwartier, toch is zij niet zonder invloed geweest." 584 Het werd namelijk verspreid over alle steden en ambten van het Overkwartier en werd daar, ook zonder homologatie, in acht genomen. Bovendien zou het een rol spelen bij de totstandkoming van het Landrecht van Montfort in 1605.585

\footnotetext{
581 GERADTS, Souvereinen raad, 53.

582 Wat nu volgt, is grotendeels gebaseerd op zijn bevindingen, uiteengezet in de inleiding op zijn uitgave van verschillende rechtsbronnen van het Overkwartier: JANSSEN DE LIMPENS, Rechtsbronnen.

583 JANSSEN DE LIMPENS, Rechtsbronnen, XVIII.

584 JANSSEN DE LIMPENS, Rechtsbronnen, LXXXIV.

585 Anderzijds blijkt dat dit ontwerp van Froenhoven zelf deels gebaseerd is geweest op het eerste ontwerp van het Roermondse gewoonterecht. Uit de bronnen van Montfort, die Froenhoven zelf aangeeft, blijkt immers dat een aantal artikels hun oorspong vinden in het eerste ontwerp van het landrecht van het Overkwartier, daterend van 1564 en waaraan Froenhoven ook zelf heeft meegewerkt. Van 38 artikels is de oorsprong bekend. Drie ervan zijn afkomstig van het ontwerp van 1564. Verder blijkt hieruit dat Froenhoven zich in de
} 
Dit Landrecht van Montfort zal later op zijn beurt worden aangewend door de samenstellers van het Gelderse Land-en Stadsrecht. In de Maasgouw van 1932 wees Hermesdorf reeds op de invloed die het Landrecht van Montfort mogelijk heeft gehad.: "'t Belangrijlest is wel de vermelding in de memorie, dat het landrecht van Gelderland, waarmede wel niet anders bedoeld kunnen zijn dan de Gelresche land- en stadsrechten van 1619, wit het costumierboek van Kebrn 'ten meesten deele genoemen is'. Op deze wijze wordt ons een duidelijk antwoord gegeven op iets dat voor Maurenbrecher een open vraag is gebleven. Daarmede staat wel voldoende vast, dát de samenstellers het landrecht van Montfort raadpleegden bij de beschrijving en redaktie der Gelresche land-en stadsrechten van 1619. ... Uit vergelijking van de teksten der beide landrechten blijket wel, dat een reeks artikelen voorkomen in beide werken. Daarmede is echter nog niet uitgemaakt, dat de bepalingen van het eene landrecht nu ook ontleend rijn aan die van het andere. ... Men beperkte zich derhalve uiteraard tot datgene wat voor allen gold."586 Om welke artikels het in concreto gaat, vermeldt Hermesdorf niet. Deze compilatie, welke vermoedelijk tussen 1587 en 1593 door Johan Kern van Froenhoven werd geredigeerd, trok in 1605 de aandacht van de Staten van het Overkwartier van Roermond. Op 14 april 1605 werd immers besloten een exemplaar van dit ontwerp in handen te krijgen. Uiteindelijk zou het nog tot maart 1615 duren vooraleer men dit ook wist te bewerkstelligen. 587 Het voor handen zijn van het Landrecht van Montfort, maakt haar gebruik en invloed mogelijk. Zo vermeldt Hermesdorf een memorie raeckende den landtschryvers ende landtscholtussen in den ampte van Montfort, welke luidt als volgt: "Het is te weten, vuyt een formulierboeck van de statuten van de alde gewoonten des ampts Montfort bij de eijgen handt van den scholtus Froenhoven geschreven denwelcken in desen quartier

eerste plaats op jurisprudentie heeft gebaseerd. Zowel de rechtspraak van landelijke schepenbanken als die van het hoofdgerecht te Roermond en het Hof van Gelre komen aan bod. Verder is er, naast besluiten van Kwartiersdagen en de Rechtsordnung van Gulik uit 1554, tevens sprake van landsheerlijke ordonnanties (Cancelary-Instructie van 1547, Criminele Ordonnantiën van 1570, de ordonnantie in succesionibus van 1544 en de ordonnanties van 1516 en 1532). Cfr. JANSSEN DE LIMPENS, Rechtsbronnen, XLVIII-XLIX.

586 B. H. D. HERMESDORF, "Het Landrecht van Montfort van 1605", Maasgouw, 52 (1932), 66. Zie ook: HERMESDORF, "Landrecht van Montfort", 1932, 49-52 en 63-68. B. H. D. HERMESDORF, “Het Landrecht van Montfort van 1605”, Maasgouw, 53 (1933), 7-9 en 17-20. Dit recht verzamelt het ongeschreven recht uit de eigen streek, Guliks recht en een aantal edicten en plakkaten van Karel V, maar tevens werd er geput uit de hoofdvonnissen van de Roermondse schepenbank.

${ }^{587}$ Cfr. BERKVENS, VENNER en SPIJKERBOER, Gelderse Land- en Stadsrecht, XXI-XXII. De vraag blijft evenwel waarom men de bemachtiging ervan voor ogen had? Beoogde men -in 1605- een codificatie van het eigen gewoonterecht? Men vroeg immers specifiek naar dat materiaal wat het Overkwartier betrof. Het feit dat op diezelfde kwartiersdag nog klachten over het Hof van Gelre werden behandeld en men pas in 1608 expliciet zou besluiten tot de redactie van het lokale recht over te gaan, speelt in de kaart van de veronderstelling dat het hier louter gaat om een verdedigingsreflex waarbij de vrijwaring van de eigen privileges voorop wordt gesteld. Het initiatief gaat immers uit van de Staten en niet van de centrale overheid. Een landsheerlijk centralisatiestreven is hier niet aan de orde, wat niet gezegd kan worden van de bescherming van de gewestelijke privileges. (Cfr. BERKVENS, VENNER en SPIJKERBOER, Gelderse Land-en Stadsrecht, XXI-XXII.) 
gehalden is geweest voor den besten Costumier van sijnen tijdt ende vuyt wijens Costumierboeck het landtrecht van Gelderlandt ten meesten deele genoemen is." 588 Voor Hermesdorf is dit het bewijs dat het Landrecht van Montfort werd gebruikt bij het opstellen van het Gelderse Land-en Stadsrecht.

Uit diezelfde periode dateert het Landrecht van Zutphen (1604). ${ }^{589}$ Ook deze compilatie zou voor de Roermondse redacteurs inspirerend gewerkt hebben, althans wat betreft de methode, aldus Maurenbrecher. ${ }^{590}$ Volgens Spijkerboer is het echter zeer moeilijk dit te onderschrijven. ${ }^{591}$ Spijkerboer vermoedt namelijk dat Maurenbrecher in dit opzicht moet gedacht hebben aan de opbouw van het vijfde deel van het Gelderse Land- en Stadsrecht, waarin het burgerlijk procesrecht wordt behandeld. Voor Spijkerboer staat het wel vast dat een aantal titels van het Landrecht van Zutphen overeenkomsten vertonen met titels van het Gelderse Land-en Stadsrecht. Hij verwijst in dit verband naar de titels 11 en 22 van het Zutphense landrecht, zijnde $V$ an Peyndunghe und Pandtkeerunghe en Van Schuttinge. Hun Roermonds equivalent situeert Spijkerboer in de titels 5.5 ( $V$ an Pandinge oft Peyndinge) en 2.6.5 (Clachte ende vervolgh op schade by der Naebueren ende andere Beesten gedaen). Ook het feit dat men het eedformulier van een landdrost uit de graafschap Zutphen en een schout van Lochem heeft willen gebruiken voor de compilatie van het Overkwartier, kan als argument worden gebruikt ten voordele van de hypothese dat het Zutphense recht als rechtsbron heeft gediend voor het Gelderse Land-en Stadsrecht. Spijkerboer besluit dat enkel nadere onderzoekingen de conclusie kunnen wettigen dat het ene als bron voor het andere heeft gediend. Zelf wil ik hier één bedenking aan toevoegen. Het vijfde, civielrechtelijke deel van het Gelderse Land-en Stadsrecht is -zoals ik straks nog laten zien zal- geheel gevrijwaard gebleven van elke vorm van assimilatie aan de Antwerpse Consuetudines compilatae. Dit biedt uiteraard mogelijkheden aan andere invloeden, zoals bijvoorbeeld het Landrecht van Zutphen. Deze vaststelling speelt met andere woorden in de kaart van Maurenbrechers veronderstelling.

${ }^{588}$ HERMESDORF, "Landrecht van Montfort", 66. Op basis van deze memorie beschouwt Hermesdorf de invloed die het Landrecht van Montfort heeft uitgeoefend op het Gelderse Land- en Stadsrecht als zijn belangrijkste verdienste. Janssen de Limpens merkt hierbij op dat het Landrecht van Montfort belangrijkere aspecten heeft. Zo biedt het de mogelijkheid het inheemse recht te kennen alvorens de receptie van Romeins recht onder invloed van het Hof van Gelre zijn beslag kreeg. De belangrijkste rechtsbron van het landrecht is immers de lokale jurisprudentie. Bovendien acht Janssen de Limpens het landrecht eveneens van belang als uniek document ter kennis van de oude rechtstaal. (Cfr. JANSSEN DE LIMPENS, Rechtsbronnen, XLVII.)

589 Reformatie der landtrechten, gebryycken vnd gewoontheyden der graefscahp Zvtphen, Arnhem, 1604. Cfr. POHLMANN, "Bibliographie der Gesetzgebung”, 476. Omtrent de instellingen en personen die een belangrijke rol speelden bij de totstandkoming van het Zutphense landrecht, zie: KEVERLING BUISMAN, “Actoren”, 205-210.

590 MAURENBRECHER, Rheinpreußischen Landrechte, II, 478.

${ }^{591}$ G. SPIJKERBOER, Enkele beschouningen over de Gelrische Landt- en Stadtrechten in't Overkwartier van Ruremonde (Persoonlijke notities G. Spijkerboer), 34. 
Verder wordt ook het Gulik-Bergse Landrecht van 1554 genoemd, dat zowel in 1556 als in 1564 werd gereviseerd. ${ }^{992}$ Spijkerboer stelde vast dat, wanneer men beide landrechten met elkaar vergelijkt, men kan concluderen dat er op tal van punten overeenstemming bestaat en dit onder andere op procesrechtelijk en op erfrechtelijk vlak. Vaak is de overeenkomst zelfs een letterlijke. Ter illustratie spoort Spijkerboer aan tot een vergelijking van de materie inzake de plaats en functie van getuigen en procureurs, de eenkindschap en de pacht. ${ }^{593}$ In dit verband zij opgemerkt, dat ook Maurenbrecher bij het vermelden van de tekst van het landrecht van het Overkwartier meermaals verwijst naar Gulik-Bergse Landrecht. Onder de minuten van het landrecht van Roermond bevinden zich enkele stukken die waarschijnlijk een kopie of een gedeelte van een uittreksel van het Gulik-Bergse Landrecht zijn, aldus Spijkerboer. ${ }^{594}$ Dat deze invloed voor de hand ligt, blijkt bovendien uit de aankoop van enkele boeken door het stadsbestuur. Het type boeken dat werd aangeschaft, wijst erop dat het stadsbestuur ook van enig vreemd, 'buitenkwartierlijk' recht kennis kon nemen. ${ }^{595}$ Belangrijk hierin zijn ongetwijfeld de Institutiones imperiales verdentr, welke in 1552 werden aangekocht, maar dus ook de nye reformation der Gulicher recbten. Het betreft het in 1565 gereformeerde Guliks-Bergse Landrecbt.

Ook het Stadsrecht van Erkelenz. (zestiende eeuw) verdient hier zijn plaats. Deze compilatie zou in aanmerking komen voor het label 'rechtsbron van het Gelderse Land-

592 SPIJKERBOER, Enkele beschouwingen, 35-36. Ik wil hierbij opmerken dat deze beïnvloeding niet noodzakelijk rechtstreeks hoeft te gebeuren, maar dat dit eveneens via het Landrecht van Montfort kan geschieden. Dit landrecht was immers eveneens door het Gulik-Bergse recht beïnvloed. (Cfr. JANSSEN DE LIMPENS, Rechtsbronnen, XLIX.)

Deze redenering brengt me tevens bij wat ik ben gaan noemen 'het gevaar van de bedrieglijke driehoeksverhouding'. Deze houdt in dat, wanneer bijvoorbeeld zowel het Landrecht van Montfort als dat van het Overkwartier door het Gulik-Bergse recht werden beïnvloed, de onaandachtige lezer -die geen weet heeft van het bestaan van het Gulik-Bergse Landrechtverkeerdelijk kan besluiten, dat het Landrecht van Montfort het Overkwartierlijke recht heeft beïnvloed. Dit is één van de voornaamste risico's van de 'parallelle vergelijking' als methode. Het is bijgevolg raadzaam ook steeds over andere archiefdocumenten te beschikken, waarin de filiatie tussen de desbetreffende redacties zwart op wit wordt bevestigd.

593 SPIJKERBOER, Enkele beschouwingen, 36. Omtrent de plaats en functie van getuigen verwijst Spijkerboer naar Capittel 26 van het Gulik-Bergse Landrecht en hiermee corresponderend, de Roermondse titel 5.12. Aangaande de plaats en functie van procureurs verwijst de auteur naar de Gulik-Bergse Capittels 7, 13 en 14 enerzijds en de Roermondse titel 5.8 anderzijds. Ten aanzien van de eenkindschap gaat het om Capittels 75 en 76 van het GulikBergse Landrecht en titel 3.7 van het Gelderse Land- en Stadsrecht. Voor de pacht, verwijst Spijkerboer naar de overeenkomsten tussen de Overkwartierlijke titel 4.4 en het Gulik-Bergse Capittel 106.

Cfr. FEENSTRA en SPIJKERBOER, “Coutume de Gueldre et Coutume d'Anvers”, 75: Les Etats du Quartier délibérèrent même sur un premier projet et ils firent insérer plusieurs articles, parmi lesquels se trouvent les dispositions qui d'ailleurs ont été empruntées toutes (à l'exception de la dernière) au "JülichBergisches Landrecht" (c'est-à-dire les statuts des duchés voisins de Juliers et de Berg) de 1564-1565."

594 SPIJKERBOER, Enkele beschouwingen, 36.

595 BERKVENS, VENNER en SPIJKERBOER, Gelderse Land-en Stadsrecht, XX. 
en Stadsrecbt. ${ }^{596}$ Ze werd in de eerste helft van de zestiende eeuw opgetekend door Mathias Baux en aan het begin van de vorige eeuw wijdde Josef Maeckl er een artikel aan. ${ }^{597}$ De auteur stelt: "Aus verschiedenen Akten des Stadtarchives ist denn auch ersichtlich, dasz. das Buch der Stadt wiederbolt als offirielle Rechtsquelle gedient hat, bis im Jabre 1620 das allgemeine Geldrische Landrecht an die Stelle des örtlichen Gewohnheitsrechtes trat." ${ }^{598} \mathrm{Bij}$ Janssen de Limpens staat echter klaar en duidelijk te lezen hoezeer er aan de kwaliteiten van Maeckl getwijfeld kan worden. ${ }^{599}$ Ook Spijkerboer treft nauwelijks overeenkomsten aan tussen het voornoemde stadsrecht en het Gelderse Land- en Stadsrecbt. ${ }^{600}$ Bijgevolg vermoedt Spijkerboer dat het werk niet als rechtsbron bij het eigenlijke redactieproces dienst heeft gedaan. Ook zelf heb ik in het archief van de Staten van het Overkwartier geen stukken kunnen terugvinden die op zulk een letterlijke invloed kunnen wijzen. ${ }^{601}$

Tot slot wil ik nog wijzen op een aantal documenten welke wel in het archief van de Staten van het Overkwartier terug te vinden zijn en welke kunnen wijzen op de invloed van vreemd gewoonterecht. Spijkerboer wees reeds op een aantal eedformulieren: "Tot slot dient nog vermeld te worden, dat in de minuten van het Landrecht twee merkwaardige stukken zijn; het ene vermeldt de tekst van het eedformulier van een ambtman van Bommel en Bommel- en Tielrewaarde, het andere de tekst van het eedformulier van een landdrost wit de Graafschap Zutphen en schout van Lochem; de eerste tekst is bruikbaar gemaakt voor het Overkwartier, zodat te voorschijn komt het eedformulier van de ambtman; het andere heeft men gepoogd ook bruikbaar te maken; bij tekstvergelijking blijkt echter dat dit niet doorgegaan is, zoals het vermeld wordt in bet Landrecht. Deze stukken staan alsnog geheel op zichzelf. Door welke oorzaken deze eedformulieren als voorbeeld gebruikt zijn, is vooralsnog een vraag." 002 Zelf heb ik nog een aantal andere documenten ontdekt welke het gebruik van vreemd gewoonterecht doen vermoeden. Zo zijn er fragmenten van de costumen van Utrecht, Gent en Nijmegen, de Keure van Zeelandt en het Landcharter van Brabant van

596 Janssen de Limpens zegt hierover het volgende: "Daar volgens Maeckl de auteur zijn werk zonder enig systeem zou hebben bijeengeschreven, beeft Maeckl zelf de orde aangebracht, die de auteur er z.i. in had moeten aanbrengen. Deze ordening van den text door Maeckl is echter dermate ingrijpend en willekeurig, dat het oorspronkelijk handschrift in deze nitgave absoluut onberkenbaar is geworden. Deze handelwijze is temeer onbegrijpelijk, nu het werk van Baux zeker niet ordeloos en systeemloos is en dit in vergelijking met menige andere compilatie van dien aard integendeel goed in elkaar zit." Bovendien telt de compilatie meer dan 400 artikels. Onder de bronnen vermeldt hij naast de handschriften van Goswinus Sas en Jacobus de Speculo tevens charters uit het stadsarchief, landsheerlijke ordonnanties en besluiten van kwartiersvergaderingen van het Overkwartier. (JANSSEN DE LIMPENS, Rechtsbronnen, XX-XXIII.)

597 J. MAECKL, "Das Stadtrecht von Erkelenz", Bijdragen en mededelingen Gelre, 8 (1905), 319448.

598 Geciteerd naar SPIJKERBOER, Enkele beschouningen, 13.

${ }^{599}$ JANSSEN DE LIMPENS, Rechtsbronnen, XX-XXII.

600 SPIJKERBOER, Enkele beschouningen, 36.

${ }^{601}$ De enige keer dat Erkelenz ter sprake komt, is in verband met het ingewonnen advies betreffende het voechtgeding. (MAASTRICHT, Rijksarchief Limburg, Archief van de Staten van het Overkwartier, nr. 581, f.9-12.)

602 SPIJKERBOER, Enkele beschouningen, 13. 
1292. Ik vermoed dat een aantal van deze documenten door Uwens meegebracht werden ter verantwoording van door hem voorgestelde wijzigingen.

\section{Wetgeving}

Terecht onderschat ook Janssen de Limpens de sterke invloed van de wetgeving niet. Hij gaat zelfs zo ver terug in de tijd dat hij in dezen ook een rol weggelegd ziet voor de vroegmiddeleeuwse, Frankische Lex Ribuaria. Menig bepaling is zijns inziens immers terug te brengen op of ontleend aan deze Ripuarische wet. In concreto zou het gaan om de bepalingen met betrekking tot de meerderjarigheidstermijn. ${ }^{603}$ Deze uitspraken laat ik echter voor zijn rekening. De eerste concrete aanwijzingen van de invloed van vorstelijke wetgeving verschijnen pas vanaf de zestiende eeuw. ${ }^{604}$

Ook wat deze latere periode betreft, vat de auteur de verschillende algemene, legislatieve rechtsbronnen samen welke voor het ganse Gelderse hertogdom golden en dus ook binnen het Overkwartier van kracht waren. De auteur doelt in de eerste plaats op de privileges afkomstig van de landsheer, beginnende bij het privilegium de non-evocando (1310) gaande tot de kanselarij-ordonnantie voor Gelderland van 1547.605 Later volgde nog meer wetgeving vanuit landsheerlijke hoek. Zo is er de nieuwe kanselarij-ordonnantie van 1609, een herziening van de rechten en bevoegdheden van het Hof van Gelre zoals ze waren vastgelegd in de eerste kanselarij-ordonnantie van het jaar 1547. De herziening bracht het conflict omtrent de zaak der revisie of de 'regeling van hoger beroep' opnieuw aan de oppervlakte. Dit conflict was ontstaan in het kader van het ontwerp van 1564. Hierin kwamen niet alleen het Hof en de Staten tegenover elkaar te staan, ook de Staten zouden vanaf 1610 intern verdeeld geraken. Artikel 19 van de nieuwe kanselarij-ordonnantie stelde de oplossing ervan uit naar een afzonderlijk te maken ordonnantie. Het zijn uiteindelijk de aartshertogen Albrecht en Isabella geweest die op 17 november 1612 de ordonnantie opt stuck van de reformatie der vonnissen wisten door te drukken. Hierin werd het hoger beroep voorgeschreven op de hoofdgerechten van Roermond, Gelre en Venlo, en in tweede instantie voor het Hof van Gelre. Ook deze ordonnantie zou later nogmaals gereviseerd en vervangen worden door het placaet aengaende de revisie van 1613, waarbij het hoofdgerecht Roermond zijn taak en invloed verloren zag gaan ten voordele van het Hof, dat nu de revisie geheel in handen kreeg. Bijgevolg betekent het plakkaat het einde van de hoofdvaart.

Eén van de meest besproken invloeden behelst het al dan niet doorwerken van de Criminele Ordonnantien (1570) van Filips II over het algemeen en in het Gelderse Land-en Stadsrecht in het bijzonder. In zijn artikel omtrent de rechtskracht van de ordonnantie op de stijl van procederen in criminele zaken van 9 juli 1570 behandelt Moorman van Kappen de adviesvraag van graaf Karel van Coblenz, gevolmachtigd minister van keizerin Maria Theresia, van 1765-1766 en de ingezonden adviezen nopens diezelfde ordonnantie. ${ }^{606}$ Hierin laat de auteur zien dat het Hof van Gelre de mening is

${ }^{603}$ Cfr. JANSSEN DE LIMPENS, Rechtsbronnen, LXXV.

${ }^{604}$ GILISSEN, Historische inleiding, 312-314.

${ }^{605}$ Cfr. JANSSEN DE LIMPENS, Rechtsbronnen, LXXV-LXXVII.

${ }^{606}$ MOORMAN VAN KAPPEN, "De rechtskracht", 327-343. 
toegedaan dat de redacteurs van het landrecht zich eveneens bediend hebben van de ordonnantie op de stijl. Het Hof stelt het als volgt: "Un examen réfléchi des règles prescriptes sur cet objet par le droit statutaire de ce pays, homologué ... en 1619, découvre assez, que ses compilateurs ont eu devant eux ladite ordonnance du 9 juillet 1570, sur quoi ils paroissent les avoir moulées en grande parties. Il y a cependant des discordances, et encore des règles dans l'ordonnance qui ne sont pas droit statutaire et vice versa. ..." 607 Het laat zien dat een groot deel van de ordonnantie in het landrecht 'gerecipieerd' zou zijn. In een bijlage bij het ingezonden advies laat het Hof zien op welke punten er overeenkomsten bestaan.

Ook één van de meest recente invloeden komt uit landsheerlijke hoek. Zo zullen ook de bepalingen van het Eeunvig Edict van 12 juli 1611 in het uiteindelijke landrecht geïntegreerd worden. Ook Maurenbrecher vermeldde dit reeds in zijn overzicht. ${ }^{608}$ Georges Martyn, die zijn proefschrift wijdde aan het Eemwig Edict, behandelt echter niet de uitwerking ervan op de later geredigeerde costumen. ${ }^{609}$

\section{Geleerd recht in strikte zin}

Onder meer bij de zojuist voornoemde Georges Martyn staat te lezen hoezeer de wetgeving zelf onder invloed heeft gestaan van het geleerde recht in brede zin. ${ }^{610} \mathrm{Er}$ is de medewerking en het advies van universitairen en rechtsgeleerden die zich behelpen met en laten inspireren door het Romeinse recht en alles wat de rechtsleer tot dan toe in boekvorm tot stand had gebracht. Desalniettemin wordt in de literatuur doorgaans aangenomen dat het 'geleerde karakter' van het lokale, Roermondse recht tot aan het begin van de zestiende eeuw zeer gering was. Zo staat bij Berkvens en Venner te lezen dat, tot de afkondiging van het Gelderse Land-en Stadsrecbt in 1620, de schepenen van het Overkwartier recht spraken volgens het grotendeels ongeschreven gewoonterecht. ${ }^{611}$ In hoeverre dit onderhevig was aan rechtsinvloeden van buitenaf, is een vraag welke nog niet onderzocht, laat staan beantwoord, is geweest. Beide auteurs wijzen evenwel op enkele aanwijzingen van externe zijde, welke een zekere Romeinsrechtelijke invloed kunnen doen vermoeden. ${ }^{612}$ Zo werd bijvoorbeeld in 1608 de verplichte schriftelijke procedure geïntroduceerd aan de hand van een

\footnotetext{
${ }^{607}$ Geciteerd naar MOORMAN VAN KAPPEN, "De rechtskracht”, 337.

${ }^{608}$ MAURENBRECHER, Rheinpreußischen Landrechte, II, 478.

${ }^{609}$ Cfr. MARTYN, Eeuwig edict.

610 MARTYN, Eeunig edict, 73-96. Ik denk in deze vooral aan de invloed van de 'rechtsgeleerde' leden van zowel de collaterale als provinciale raden. Naast inspireren en adviseren, behoorde zelfs het eigenlijke redigeren van het Eeuwig Edict tot het takenpakket van de gecommitteerden van de provinciale raden en de Geheime Raad. Bovendien is er de invloed vanuit het Zuiden. De Nederlandse instellingen en rechtsleer hebben zich immers zeer sterk onder Franse invloed ontwikkeld, een invloed die zelf een hoog rechtsgeleerd karakter genoot. (MARTYN, Eeuwig edict, 97-98.)

${ }^{611}$ Cfr. BERKVENS, VENNER en SPIJKERBOER, Gelderse Land- en Stadsrecht, XIX.

612 BERKVENS, VENNER en SPIJKERBOER, Gelderse Land- en Stadsrecht, XIX-XX. Cfr. de bevindingen van Van Caenegem, Hermesdorf en Gilissen ten aanzien van de Nederlanden, en Krynen met betrekking tot de Franse coutumiers. Cfr. supra, hoofdstuk 1, paragraaf 3, Romanisatie en humanisme.
} 
instructie van de Roermondse schepenbank, waar voordien de keuze tussen mondeling en schriftelijk bleef bestaan. ${ }^{613}$

Ook op basis van de academische opleiding van de leden van de schepenbank zou de invloed van het geleerde recht verondersteld kunnen worden. Desalniettemin is het lang wachten vooraleer de eerste, in het Romeinse recht gevormde, schepenen aan de bak komen. Zelfs in 1548 bevindt er zich onder het maximale aantal van twaalf schepenen nog geen enkele licentiaat in de beide rechten. De eerste verschijnt pas in 1575 ten tonele. Zijn naam is Michael Oeyen. De tweede heet Marcelis Koichs. Hij werd in 1591 verkozen. Tot 1620 zou hun aantal op geen enkel moment uitstijgen boven de drie. Pas in het jaar dat het Gelderse Land-en Stadsrecht werd gepubliceerd, verdubbelde hun aantal tot zes.

Ook via appelzaken bij het Hof van Gelre moet de invloed van geleerd recht beperkt zijn gebleven. Want hoewel het aantal licentiaten binnen het Hof maximaal was -naast twee raden costumier als deskundigen van het inheemse recht-, bleef de competentie van dit hof in eerste aanleg beperkt tot een aantal specifieke gevallen en werd het pas een beroepsinstantie vanaf 1613.614 De invloed van Romeinsrechtelijk geschoolde juristen op de jurisprudentie binnen het Overkwartier komt dus relatief traag op gang. Een scharniermoment in de ontwikkeling van het 'geleerde karakter' van het Gelderse Land-en Stadsrecht komt er met de komst van Hendrik Uwens in 1615. Zijn aanwezigheid betekent een definitieve ommekeer.

${ }^{613}$ BERKVENS, VENNER en SPIJKERBOER, Gelderse Land- en Stadsrecht, XIX.

${ }^{614}$ Cfr. BERKVENS, VENNER en SPIJKERBOER, Gelderse Land- en Stadsrecht, XX. 
PARAGRAAF 2

DE ANTWERPSE CONSUETUDINES COMPILATAE ALS RATIO SCRIPTA.

Centraal in deze paragraaf staat de toonaangevende rol welke de Consuetudines compilatae hebben gespeeld in het redactieproces van het Gelderse Land-en Stadsrecht. De vierde Antwerpse redactiepoging is zelfs zo bepalend geweest dat haar functie vergeleken kan worden met die welke het gemene recht in de middeleeuwen uitoefende. Zoals Lesaffer het geleerde recht omschreef als de intellectuele context waarin het eigen recht zich bewoog en een hulpmiddel om de tekortkomingen van dat laatste te bestrijden, zo kan ook de verhouding van de Consuetudines compilatae ten opzichte van het Gelderse Land- en Stadsrecht op een gelijkaardige manier getypeerd worden. ${ }^{615}$ De Consuetudines compilatae zijn een ware ratio scripta gebleken voor Tilman van Bree en zijn medewerkers. Normen, structuur, terminologie, ... het werd allemaal (vaak letterlijk) overgenomen. Waar en hoe ingrijpend deze costumiere acculturatie heeft plaatsgevonden, zal in deze tweede paragraaf aan bod komen. Hierbij zijn wat en in welke mate de belangrijkste vragende voornaamwoorden.

\section{Methode}

$\mathrm{Ik}$ heb reeds eerder aangetoond dat costumiere acculturatie een dubbel proces is. Enerzijds omvat dit de materiële receptie van vreemde, gewoonterechtelijke normen; anderzijds gaat dit meestal gepaard met een meer formele assimilatie aan de structuur, formulering en terminologie van de vreemde voorbeeldredactie. Dit laatste proces is vrij eenvoudig met het blote oog waar te nemen. Uitmaken waar er zich receptie van vreemd recht heeft voorgedaan, is beduidend moeilijker. De beschrijving van de receptie wordt immers bemoeilijkt door een aantal factoren. Centraal hierin staat de vraag in hoeverre een bepaalde rechtsregel al dan niet tot het eigen, gewoonterechtelijke arsenaal behoorde en dus het resultaat is van een 'parallelle juridisch ontwikkeling' in beide plaatsen. Dit is niet te bepalen uitsluitend op basis van het uitzicht en/of de inhoud van de regel in se. Hiertoe zijn externe bronnen nodig. Zo bestaat immers de mogelijkheid dat naast letterlijk geassimileerde artikels, ook niet-letterlijk overgenomen artikels inhoudelijk aan het Antwerpse gewoonterecht werden geassimileerd, en dus werden gerecipieerd. In dat geval kon de inhoudelijke regel op heel wat appreciatie rekenen, in tegenstelling tot de wijze waarop de norm was geformuleerd. Substantieel gaat het dus om hetzelfde artikel en bestaat er ook de mogelijkheid van materiële receptie. Anderzijds kan het hier even goed gaan om een artikel dat niet werd gerecipieerd, maar reeds lange tijd gewoonterechtelijk van kracht was binnen het Overkwartier. Uitsluitsel hieromtrent kan enkel bekomen worden aan de hand van een onderzoek naar de feitelijke rechtspraak op basis van procesdossiers of rechtspraakverzamelingen, voor zover die voor handen zijn. Een andere moeilijkheid schuilt in het feit dat ook letterlijke concordanties niet noodzakelijk materiële receptie hoeven te herbergen. Ook hier kan het louter om een formele vorm van assimilatie gaan. Een regel is reeds lange tijd in gebruik, maar men kopieert

${ }^{615}$ Cfr. LESAFFER, Inleiding tot de Europese rechtsgeschiedenis, 247. 
de Antwerpse formulering. In zulke gevallen zou ik dus ten onrechte van materiële receptie spreken. Met andere woorden, zowel met betrekking tot letterlijke als nietletterlijke assimilatie kan het zowel om Antwerps als Overkwartierlijk recht gaan. Het is bijgevolg aangewezen zeer voorzichtig om te gaan met de term 'receptie'. In wezen kan ik enkel met zekerheid spreken van (letterlijke) assimilatie aan Antwerps recht. ${ }^{616}$ Hoezeer figuren als Hendrik Uwens ook trachten te benadrukken geen vreemd recht te willen opdringen, bestaan er aanwijzingen om te geloven dat de materiële receptie niet onderschat mag worden. ${ }^{617}$ Zo bevat het Gelderse Land-en Stadsrecht verschillende titels welke zeer Antwerps van aard zijn en welke men doorgaans niet verwacht binnen de klassieke, Brabantse costume. Concreet doel ik hier op de ongebruikelijke uitwerking van de handels- en andere verbintenisrechtelijke titels binnen het Overkwartierlijke recht. Een tweede aanwijzing gaat schuil in het uitzonderlijk hoge antal artikels dat de Roermondse compilatie telt. Met haar 1990 artikels onderscheidt deze zich wederom van de klassieke redacties en meer nog van zijn eerste ontwerpen. Het eerste ontwerp van 1564 telde slechts 113 artikels in totaal. Dit kan enkel verklaard worden met behulp van de Antwerpse invloed en ik meen dan ook niets anders te kunnen concluderen dan dat naast de assimilatie ook de receptie enorm geweest moet zijn. Een andere manier om een idee te schetsen van de receptieve opstelling van de Roermondse compilatores bestaat er niet, tenminste zolang er geen versie van het ontwerp van Tilman van Bree wordt teruggevonden. Dit lijkt me echter zeer onwaarschijnlijk. ${ }^{618}$

${ }^{616}$ De werkelijke receptie kan, maar zal vermoedelijk niet hoger liggen dan het niveau waarop er Antwerps recht werd geassimileerd. Enkel wanneer er als dusdanig veel Antwerps recht op een niet-letterlijke manier werd gerecipieerd, kan de receptie de assimilatie overstijgen.

617 Meermaals benadrukt men enkel die zaken uit het Antwerpse recht over te nemen, welke conform zijn aan de eigen costumiere gebruiken. (Cfr. BERKVENS, VENNER en SPIJKERBOER, Gelderse Land- en Stadsrecht, XXXIII en XLII.) Ik stel me hierbij evenwel de vraag in hoeverre de autoriteit van Uwens, als ervaringsdeskundige, expert en kanselier, een rol heeft gespeeld bij de overtuiging dat een bepaalde, Antwerpse rechtsregel eveneens in het Overkwartier gewoonterechtelijk gold.

${ }^{618}$ Cfr. supra, hoofdstuk 2, Status quaestionis. Het vroegste ontwerp waarover ik kon beschikken is het document dat ik ben gaan aanduiden als 'versie B'. Het bevindt zich in het archief van de Staten van het Overkwartier. (MAASTRICHT, Regionaal Historisch Centrum Limburg, Staten van het Overkwartier, nr. 583.) Samen met de latere versies C (RHCL, Staten Overkwartier, nr. 584) en H (RHCL, Staten Overkwartier, nr. 589) heb ik de inhoudstafels van deze ontwerpen gereconstrueerd. Zij bevinden zich als bijlage 5 aan het einde van dit boek. De B-versie is de oudst kenbare versie tot dusver. Versie $C$ volgt hier onmiddellijk op binnen het geneseproces. De H-versie sluit nauw aan bij de moderne uitgave van Berkvens en Venner. Ik heb hen zo kunnen rangschikken aan de hand van hun onderlinge vergelijking. Ook dateren is tot op zekere hoogte mogelijk, met name door het hanteren van een terminus ante quem en een terminus post quem, afkomstig uit de wordingsgeschiedenis van de compilatie zoals ze beschreven staat in de inleiding op de uitgave van Berkvens en Venner. Zo kan er van de versies B en C gezegd worden dat zij dateren van voor het voorjaar van 1617. In die periode werd immers de titel omtrent het voogdgeding aan het ontwerp toegevoegd en deze ontbreekt nog in zowel versie $\mathrm{B}$ als versie $\mathrm{C}$. Versie $\mathrm{H}$ van zijn kant, ligt veel dichter bij de definitieve versie dan bij de B- en C-versies. Omdat de paragraaf omtrent de pandgoederen in deze versie nog steeds ontbreekt, 
Ondanks de hoge mate van waarschijnlijkheid waarmee verwacht kan worden dat er ook heel wat Antwerps recht werd gerecipieerd, zal ik me in deze paragraaf beperken tot dat waarover ik me met zekerheid uitlaten kan, namelijk de letterlijke assimilatie van het Gelderse Land- en Stadsrecht aan de Antwerpse Consuetudines compilatae. Ik duid dit aan als de 'letterlijke, normatieve assimilatie'. De gevallen van 'niet-letterlijke, normatieve assimilatie' laat ik links liggen. ${ }^{619}$ Hetzelfde geldt voor de 'terminologische assimilatie'. Deze is immers nauwelijks van belang geweest aangezien het merendeel van de Antwerpse rechtstermen in 1617 vervangen werd door termijnen in de Gelrissche taele, juist wegens het te Brabantse karakter van de Antwerpse rechtstaal. ${ }^{620}$ Assimileren behoorde op dit vlak niet tot de opties. De 'structurele assimilatie' daarentegen zal hier wel -zij het zeer kort- aan bod komen. Deze structurele assimilatie is meer van belang ten aanzien van het vraagstuk omtrent de impact van het juridisch humanisme op het costumiere redactieproces en zal bijgevolg in de eerste paragraaf van het derde hoofdstuk uitvoeriger worden behandeld.

De enige manier om deze, letterlijke, normatieve assimilatie te beschrijven, is via de identificatie van alle artikels welke afkomstig zijn van de Antwerpse Consuetudines compilatae en in het Gelderse Land- en Stadsrecht werden geïntegreerd. In concreto behelst deze onderneming een parallelle vergelijking van beide teksten. Door beiden naast elkaar te leggen en voor elk Overkwartierlijk artikel in de Consuetudines compilatae op zoek te gaan naar een letterlijke equivalent, kan een beeld worden verkregen van de mate waarin de assimilatie begrepen moet worden. Dat deze enige manier ook meteen de meest omslachtige en tijdrovende is, spreekt voor zich. Bijgevolg heeft dit onderzoek heel wat tijd in beslag genomen. Het lijkt me hier dan ook het uitgelezen moment om mijn dank te betuigen aan de heer Spijkerboer, die me met zijn voorbereidend werk al een heel eind op weg heeft gezet. Het merendeel van de honderden concordanties waren reeds door hem aan het licht gebracht. Desalniettemin bleek het geen overbodige luxe hen te onderwerpen aan een dubbele controle. In een aantal gevallen bleek Spijkerboer zich immers vergist te hebben en het gebeurde eveneens dat hij sommige concordanties over het hoofd had gezien. Vandaar dat ik ook alle resterende artikels op een corresponderend Antwerps artikel heb onderzocht. Uiteindelijk heeft dit onderzoek geresulteerd in de tabel onder bijlage 4 (Naar Antwerps model geassimileerde artikels in het Gelderse Land- en Stadsrecht).

Op het eerste gezicht zegt deze tabel weinig. Ze is te omvangrijk, het aantal artikels is te groot en bijgevolg het geheel onoverzichtelijk, wat de analyse ervan bemoeilijkt. Dat maar liefst 923.5 artikels binnen het Gelderse Land- en Stadsrecht op een totaal van

en de titel omtrent het voogdgeding al wel is toegevoegd, moet deze H-versie dus tussen het voorjaar van 1617 en juni 1618 tot stand zijn gekomen.

${ }^{619}$ Wat ik exact onder 'letterlijk' versta en wat ik als 'niet-letterlijk geassimileerd' heb gecategoriseerd, wordt verduidelijkt in bijlage 3 ('Letterlijke' assimilatie versus 'niet-letterlijke' assimilatie: voorbeelden). Cfr. infra, bijlagen, bijlage 3, Letterlijke' assimilatie versus 'niet-letterlijke' assimilatie: voorbeelden.

${ }^{620}$ Cfr. BERKVENS, VENNER en SPIJKERBOER, Gelderse Land- en Stadsrecht, XXXIX. 
1990 over een letterlijke equivalent binnen het geredigeerde, Antwerpse gewoonterecht beschikken, blijft voorlopig de meest opvallende vaststelling die ik op basis van deze concordantietabel kan maken. Dit absolute aantal komt overeen met een percentage van 47 procent. Met andere woorden, zo goed als de helft van het geredigeerde, Overkwartierlijke recht is identiek aan het Antwerpse gewoonterecht zoals het in de Consuetudines compilatae werd verzameld. Waar bijlage 4 zojuist nog als te detaillistisch werd ervaren, is dit cijfer op zijn beurt te abstract en te algemeen. De meest interessante informatie bevindt zich dan ook op de niveaus tussen het bos en de bomen, meer bepaald die van de afzonderlijke titels en hun verschillende paragrafen. Ook een voorstelling per deel maakt het mogelijk enkele vaststellingen te doen. Binnen onderstaande tabel 2.1 trekken een aantal zaken immers meteen de aandacht.

Tabel 2.1 Het assimilatieve karakter van het Gelderse Land- en Stadsrecht

\begin{tabular}{|c|c|c|c|c|}
\hline Deel & $\begin{array}{c}\text { Totaal aantal } \\
\text { artikels }\end{array}$ & $\begin{array}{c}\text { Aantal } \\
\text { geassimileerde } \\
\text { artikels }\end{array}$ & $\begin{array}{c}\text { Procentuele } \\
\text { assimilatie per } \\
\text { deel }\end{array}$ & $\begin{array}{c}\text { Procentuele assimilatie } \\
\text { binnen het geheel } \\
\text { (/1990) }\end{array}$ \\
\hline I & 331 & 195 & $58.9 \%$ & $9.8 \%$ \\
\hline II & 297 & 174 & $58.6 \%$ & $8.7 \%$ \\
\hline III & 401 & 159 & $39.7 \%$ & $8.0 \%$ \\
\hline IV & 385 & 268 & $69.6 \%$ & $13.5 \%$ \\
\hline V & 344 & 0 & $0 \%$ & $0 \%$ \\
\hline VI & 232 & 142 & $61.2 \%$ & $7.1 \%$ \\
\hline
\end{tabular}

Het Gelderse Land- en Stadsrecht blijkt vooreerst een zeer evenwichtige compilatie te zijn. Elk deel bestaat uit 200 tot 400 artikels. Toch springt de totale afwezigheid van elke concordantie in het vijfde, civielrechtelijke deel het meest in het oog. Ik heb hier geen enkel voorbeeld van letterlijke, normatieve assimilatie kunnen terugvinden. Het deel getuigt met andere woorden als geen ander van een gezonde dosis creativiteit en originaliteit. Bovendien heb ik in een eerste paragraaf reeds gewezen op de mogelijke rol van andere compilaties naast de Consuetudines compilatae. Zodadelijk zal ik nog uitvoeriger ingaan op deze uitzonderlijke positie van het Roermondse burgerlijke procesrecht.

De assimilatiegraad van nul procent in dit vijfde deel is er mede verantwoordelijk voor dat de gemiddelde assimilatiegraad van het geheel de vijftig procent niet overstijgt. Dit betekent dat de assimilatiegraad in de andere delen veel meer bedraagt dan aanvankelijk op basis van het algemene gemiddelde aangenomen wordt. Het vijfde deel buiten beschouwing gelaten, gaat het nog steeds om 923.5 geassimileerde artikels, maar nu op een totaal van slechts 1616 artikels. Bijgevolg neemt de gemiddelde assimilatiegraad toe tot 58 procent. Dit is veel. Ik heb namelijk ook het percentage aan letterlijke concordanties berekend voor twee andere voorbeelden van costumiere acculturatie, en deze bleken aanzienlijk lager te liggen. Het betrof de casussen waarbij de costumen van Lier (1570) en Bergen op Zoom (1550) aan die van Mechelen (1535) werden geaccultureerd. In het eerste geval betrof de assimilatiegraad 
35.9 procent. ${ }^{621} \mathrm{Bij}$ de redactie van Bergen op Zoom gaat het slechts om een klein vijfde van de 172 artikels. 622

Drie delen uit het Gelderse Land- en Stadsrecbt schommelen rond dit gemiddelde van bijna 60 procent. Enkel binnen de delen drie en vier wordt deze doorsnee waarde licht uit balans gebracht, meer bepaald met respectievelijk twintig en tien ten honderd. Het erfrecht en de andere manieren om goederen te verkrijgen, beperken zich tot 40 procent, waar het verbintenissenrecht bijna de kaap van 70 procent overschrijdt. De overige delen I, II en VI benaderen het gemiddelde.

Ook voorgaande tabel lijkt snel uitgeput te zijn. Het lijkt me dan ook aangewezen zich meer op het niveau van de titelstructuur te begeven. Dit zal ik voor elk deel afzonderlijk doen. Telkens wil ik laten zien waar de assimilatie het sterkst heeft plaatsgevonden en waar men het meest aan eigen tradities of op z'n minst formuleringen is blijven vasthouden.

Tot slot wil ik nog kort toelichten dat ik in deze paragraaf meermaals naar oudere tekstversies zal verwijzen. In de eerste plaats is er uiteraard het ontwerp van 1564, maar ook zal ik bij wijze van vergelijkingsmateriaal een drietal andere tussenontwerpen bij het geheel betrekken. Het gaat hier om de zogenaamde B-, C- en $\mathrm{H}$-versies. ${ }^{623} \mathrm{Zij}$ bevinden zich in het archief van de Staten van het Overkwartier en zij worden achteraan als bijlage 5 an dit proefschrift toegevoegd. ${ }^{624}$ Ook de inhoudstafel van het ontwerp van 1564 heb ik hier gemakkelijkheidshalve in opgenomen.

Deel I

... spreeckende van rechten den persoenen aengaende ...

In tegenstelling tot de Antwerpse Consuetudines compilatae, bevat het Gelderse Land-en Stadsrecht geen afzonderlijk deel dat het overheidsrecht behandelt. De inrichting van het bestuur en de organisatie van de rechtspraak binnen het Overkwartier zijn samen met het personen- en het familierecht in deel I aan de orde. Vermoedelijk mag hiervoor een verklaring gezocht worden in het feit dat de bestuurlijke en rechtelijke

${ }^{621}$ Het gaat om 174 artikels op een totaal van 485. De titels waar de assimilatie het sterkst is gebleken, zijn de volgende: titel $3 V$ an arrestementen (zeven op negen artikels), titel $6 \mathrm{Van}$ contracten, voorwaerden ende borgtochten (veertien op vijftien artikels), titel $7 V$ an bueringhen (negen op elf artikels), titel 10 Van calengieren ende naderschap (20 op 23 artikels), titel 13 Van erfscheijdinghen, servituten ende rechten de erfscheijders aengaende (47 op 52 artikels), titel 19 Van prescriptie ende verloop van tijde (één op één artikel).

${ }^{622}$ Het gaat voornamelijk om volgende titels: titel 3 ( $V$ an vrede te gevene), titel 5 ( $V$ an contracten, voirwaerden ende borchtochten), titel 6 ( $V$ an hueringe) en in minder mate titel 13 ( $V$ an onbejaerde kinderen ende andere persoonen onmachtig hunder sinnen).

623 De letters zijn het gevolg van hun positie binnen het archief van de Staten van het Overkwartier, te beginnen bij nummer 582 en de letter A tot nummer 590 en de letter I.

${ }^{224}$ Cfr. infra, bijlagen, bijlage 5, Inhoudsopgaven van vier voorontwerpen van het Gelderse Land- en Stadsrecht. Omtrent de datering van de verschillende versies, cfr. supra, hoofdstuk 2, paragraaf 2, Methode. Enkel de versies B en H zijn zo goed als volledig. Versie C mankeert zowel het burgerlijk als het crimineel procesrecht, evenals het materiële strafrecht. 
instellingen te Roermond beduidend minder waren uitgebouwd dan dit in de Antwerpse handelsmetropool het geval was. ${ }^{625}$ Zoveel andacht voor de stedelijke overheid was men binnen het Overkwartier niet gewend. Ook in het ontwerp van 1564 ontbreekt elke referentie naar de regisseurs van het juridische bedrijf. Dit verandert vanaf 1615, ongetwijfeld onder invloed van Hendrik Uwens.

Ook de positie van de desbetreffende titel binnen het geheel van de compilatie heeft men aan de kersverse kanselier te danken. Ik ben niet in staat te achterhalen waar deze titel omtrent de officiers zich aanvankelijk ophield binnen de eerste ontwerpen, maar uit de notities van Uwens blijkt alleszins dat deze titel pas later naar het begin van de compilatie is overgebracht. ${ }^{626}$ In een (niet te dateren) memorie opt beworpt van het landrecht schrijft de kanselier immers het volgende: "Ick zoude de [n] titel va [n] officiers en [de] he [n]ne eeden ierst stelle $[n]$ e $[n$ de] daer naer laeten volghe $[n]$ Van rechte gehoude $p[$ er] soene $[n]$, e $[n$ de] voirts de reste soe ick die geseght heb." 627 Vast staat ook dat deze officiers niet bij het personenrecht werden ondergebracht omdat men hen te letterlijk als personae interpreteerde. Dit blijkt immers uit het vervolg van dezelfde memorie, alwaar Uwens adviseert de procureurs bij het burgerlijk procesrecht te behandelen: "Den titel va $[n]$ procureurs offt volmachteghe en [de] voerwi[n]ders dient a part geschreven om ergherens gesteldt te worden daer het behoort. Dwelck mij dunckt dat zoude mooghe [n] wesen int beghinsel va[n] bet deel va $[n]$ rechtsvoirderinghe naer den ierste $[n]$ titel offt daeromtrent." 228 Uiteindelijk komen ze terecht binnen de achtste titel van het burgerlijk procesrecht uit deel V.

Dat er binnen deze bestuursrechtelijke titel 1.1 nauwelijks concordanties met Antwerpse artikels terug te vinden zijn, wekt weinig verbazing. Gezien het regiogebonden karakter van het onderwerp en de specifieke genese van elke instelling waar dan ook, kent ook hier deze titel een uiterst eigen en originele invulling. De bestuurlijke en rechtelijke organisatie van elke stad of regio is immers geworteld in een sterke traditie en niet in vergelijkbare instellingen binnen de Antwerpse stadsmuren. ${ }^{629}$ Dit verklaart het ontbreken van elke vorm van assimilatie, zoals kan worden vastgesteld in tabel 2.2 .

Tabel 2.2 De assimilatie aan Antwerps recht in deel I van het Gelderse Land-en Stadsrecht

\begin{tabular}{|c|c|c|c|c|c|}
\hline Titel & $\begin{array}{c}\% \\
\text { (titel) }\end{array}$ & $\mathbb{S}$ & $\begin{array}{c}\text { Totaal aantal } \\
\text { artikels }\end{array}$ & $\begin{array}{c}\text { Aantal } \\
\text { concordanties }\end{array}$ & $\%(\mathbb{S})$ \\
\hline \multirow{4}{*}{$\begin{array}{l}1.1 \text { Van officiers oft amptluyden ende } \\
\text { schepenen ende bun ampt oft officie. }\end{array}$} & \multirow{4}{*}{0.0} & 1 & 5 & 0 & 0.0 \\
\hline & & 2 & 7 & 0 & 0.0 \\
\hline & & 3 & 8 & 0 & 0.0 \\
\hline & & 4 & 6 & 0 & 0.0 \\
\hline
\end{tabular}

${ }^{625}$ Cfr. BERKVENS, VENNER en SPIJKERBOER, Gelderse Land- en Stadsrecht, X-XIV.

${ }^{626} \mathrm{Er}$ zijn ook geen voorlopige ontwerpen of inhoudstafels bewaard gebleven waar deze titel zich nog niet aan het begin van de compilatie bevond.

${ }^{627}$ MAASTRICHT, Regionaal Historisch Centrum Limburg, Staten van het Overkwartier, nr. 581: Memorien offte annotatien opt beworpt van bet landtrecht, fol. 123r.

${ }^{628}$ RHCL, Staten Overkwartier, 581, fol. 123r. In de B-versie staat deze titel op een vijfde plaats binnen het burgerlijk procesrecht. In de $\mathrm{H}$-versie zakt hij verder weg naar plaats negen. Uiteindelijk neemt de titel binnen de definitieve versie stelling als titel 8.

${ }^{629} \mathrm{Cfr}$. MONBALLYU, Zes eemwen strafrecht, 70. 


\begin{tabular}{|c|c|c|c|c|c|}
\hline \multirow{5}{*}{$\begin{array}{l}1.2 \text { Van rechten van gebylickte } \\
\text { persoenen. }\end{array}$} & \multirow{5}{*}{27.2} & 1 & 38 & 10 & 26.3 \\
\hline & & 2 & 27 & 12 & 44.4 \\
\hline & & 3 & 20 & 9 & 45.0 \\
\hline & & 4 & 14 & 0 & 0.0 \\
\hline & & 5 & 15 & 0 & 0.0 \\
\hline \multirow{6}{*}{$\begin{array}{l}1.3 \text { Van de macht, plicht ende } \\
\text { gerechticheit der alderen ende kinderen. }\end{array}$} & \multirow{6}{*}{74.2} & 1 & 8 & 7 & 87.5 \\
\hline & & 2 & 4 & 3 & 75.0 \\
\hline & & 3 & 4 & 2 & 50.0 \\
\hline & & 4 & 4 & 2 & 50.0 \\
\hline & & 5 & 6 & 6 & 100.0 \\
\hline & & 6 & 5 & 3 & 60.0 \\
\hline \multirow{6}{*}{$\begin{array}{l}1.4 V \text { an rechten van minderjaerige ende } \\
\text { andere vermomboirde personen, ende van } \\
\text { bunne momboirs ende toesienders. }\end{array}$} & \multirow{6}{*}{87.2} & 1 & 23 & 20 & 87.0 \\
\hline & & 2 & 19 & 18 & 94.7 \\
\hline & & 3 & 12 & 11 & 91.7 \\
\hline & & 4 & 49 & 49 & 100.0 \\
\hline & & 5 & 26 & 23 & 88.5 \\
\hline & & 6 & 19 & 8 & 42.1 \\
\hline 1.5 Van ongebylickte vrouven. & 100.0 & 1 & 12 & 12 & 100.0 \\
\hline
\end{tabular}

Ten aanzien van de overige, personen- en familierechtelijke titels binnen dit deel heeft men zich duidelijk wel laten inspireren door het Antwerpse model. Zo correspondeert de opeenvolging van de aanwezige titels de volle honderd procent met die van het persoonsrechtelijke, tweede deel uit de Antwerpse Consuetudines compilatae. Enkel titel 2.4 ( $V$ an bastaarden) uit de Consuetudines compilatae ontbreekt in het Gelderse Land-en Stadsrecht, tenminste als afzonderlijke titel. Oudere inhoudstafels getuigen immers dat dit aanvankelijk niet zo was. Naast de reeds vernoemde memorie, kennen ook de B- en de C-versie, een aparte titel aangaande de bastaardkinderen. Wat de laatste twee concepten (B en C) betreft, komt echter enkel de erfrechtelijke status van de onwettige kinderen aan bod (Van bastarden ende bunne versterffenisse). ${ }^{630}$ Later wordt de titel tot paragraaf 5 (Versterffenisse van bastarden) gedegradeerd binnen titel 7 (Van wettige versterfenisse of successie). ${ }^{631}$ Het grote onderscheid met het Antwerpse gewoonterecht, is dat men aan in het Overkwartier veel strenger is op het vlak van erven. ${ }^{632}$

De trend van parallelle structuren zet zich echter niet door tot op het niveau van de paragrafen. Zo tellen de Consuetudines compilatae bijvoorbeeld meer paragrafen met betrekking tot het huwelijksvermogensrecht dan het Gelderse Land-en Stadsrecbt. Dit verbaast me op het eerste gezicht, net als de uiterst lage assimilatiegraad van de titel, met name omdat het juist deze titel was welke de aanleiding vormde voor Hendrik Uwens om de Roermondse redacteurs het gebruik van de Antwerpse Consuetudines

${ }^{630}$ Het gaat hier om titel 23 (Van bastarden ende bunne versterffenisse) in de B-versie en titel 21 (Van[de] Bastarden en [de] hunne versterffenisse) in de C-versie.

${ }^{631} \mathrm{Cfr}$. versie $\mathrm{H}$, alwaar het paragraaf 2 (Wie kinderen wijt verscheyde ehe ervan sullen) van titel 17 betreft. Het keerpunt binnen dit degradatieproces situeert zich in de wijzigingsvoorstellen in de katernen 29 en 30 van RHCL, Staten Overkwartier, 585.

${ }^{632}$ Cfr. GODDING, Droit, privé, 117-118. 
compilatae aan te raden. ${ }^{633}$ Dat deze materie uiteindelijk toch zo weinig gelijkenis vertoond met het Antwerpse voorbeeld, kan verklaard worden aan de hand van twee redenen. Ten eerste -vermoedelijk tevens de meeste voorname verklaring-, heeft deze ganse titel omtrent het huwelijksvermogensrecht Hendrik Uwens, ook na de assimilatie aan Antwerps recht, nog heel wat kopzorgen bezorgd. Hij heeft de tekst nog verder uitgewerkt en voorstellen tot wijzigingen aan de redacteurs overgemaakt. ${ }^{634}$ Bovendien gaat het hier om één van de meest traditionele, costumiere rechtsfiguren, welke bovendien ook al in het ontwerp van 1564 aan bod kwam. ${ }^{635}$ Dit getuigt van een eigen traditie in deze aangelegenheden en mogelijk ligt hier eveneens een verklaring voor de discrepantie die er bestaat tussen de wijze waarop beide titels, respectievelijk in Antwerpen en Roermond, werden ingevuld. De assimilatiegraad overstijgt dan ook nauwelijks de 25 procent. Deze is zelfs nihil in de paragrafen 4 (Wat goederen men in 't scheyden des bylicxgerechticheyt ende andersints balt voor erffelicke oft onruerlick patrimoniael ofte aengestorven, gewonnen oft veroverde, ruerlicke ofte baffelicke goederen) en 5 (Schulden ende lasten van den sterffhuysen van gehylickte persoonen ende betalinghe derselver). Velen van de voorgestelde modificaties worden nog door het archief van de Staten van het Overkwartier bewaard. Desondanks blijkt uit de oude B- en C-versies met een hoge graad van waarschijnlijkheid dat ook met betrekking tot deze titel de Consuetudines compilatae, en dan titel 2.1 in het bijzonder, als uitgangspunt hebben gefungeerd. Deze titel werd echter zodanig, naar eigen inzien, herwerkt, dat assimilatie en originaliteit respectievelijk een diepte- en hoogtepunt bereikten.

Het toont nog maar eens aan dat de Consuetudines compilatae ook op persoonsrechtelijk vlak nooit veraf waren. Dit blijkt des te meer uit de overige drie titels omtrent de rechten tussen de ouders en hun kinderen (titel 1.3), de wezen en hun voogden (titel 1.4) en tot slot de rechten van ongehuwde vrouwen (titel 1.5). Het aantal geassimileerde artikels binnen deze titels bedraagt minstens 75 procent. Wat de ongehuwde vrouwen betreft, is de assimilatie zelfs compleet. Wegens het ontbreken van een vergelijkbare titel of overeenkomstige artikels in alle vroegere concepten of versies van inhoudstafels, lijkt het me acceptabel in dit geval ook van receptie te mogen spreken. Noch in de B-versie, noch in de C-versie komt het thema aan bod. Pas in de $\mathrm{H}$-versie verschijnt een titel genaamd Van ongehylichde vroumen. Het betreft

${ }^{633}$ BERKVENS, VENNER en SPIJKERBOER, Gelderse Land- en Stadsrecht, XXXIII.

${ }^{634}$ BERKVENS, VENNER en SPIJKERBOER, Gelderse Land- en Stadsrecht, XXXVII. Geen enkel ander thema heeft dan ook zoveel bescheiden nagelaten in het archief van de Staten van het Overkwartier. Hoewel de archiefbescheiden van de oudste B-versie, in het bijzonder met betrekking tot de titel omtrent het huwelijksvermogensrecht, fysiek erg beschadigd zijn en sterk te lijden hebben gehad onder de tand des tijds, barsten de marges van voorstellen tot wijzigingen. Een eerste volledige versie tref ik aan in de C-versie. De titel telt er bijna 90 artikels. Aanpassingen volgen met de katernen 1 tot en met 10 van RHCL, Staten Overkwartier, 585, evenals het eerste katern van RHCL, Staten Overkwartier, 586 en de katernen 1 en 2 van RHCL, Staten Overkwartier, 587. Geen enkele andere titel heeft zoveel modificaties ondergaan. Deze inspanningen resulteren in titel 2 (Van rechten van gebylycke personen) in versie $\mathrm{H}$. Uiteindelijk loopt het aantal artikels in de definitieve versie op tot 94. Bij dit alles heeft het Antwerpse model zeer waarschijnlijk als vertrekpunt gediend.

${ }^{635}$ Cfr. titel 7 V an hylichsbrieven und maechgescheyden. De titel telt er negen artikels. 
titel 5. De veronderstelde receptie is overigens ook van toepassing op de twee overige titels, welke voor meer dan drie kwart naar het voorbeeld van de Consuetudines compilatae werden samengesteld. Enkel met betrekking tot de paragraaf 6 van titel 1.4, omtrent de onderlinge schulden tussen voogden en wezen, en de paragrafen 3 (Verplicbtinghe der kinderen tot bun alders, ende straef der moetwillighen), 4 (Gerecbticheyt der alderen tot de goeden bij bun kinderen vercreghen) en 6 (Testamenten, bylicxvoorwaerden, contracten ende rechtsvoorderinge der kinderen) van titel 1.3 omtrent de onderlinge rechten en plichten van ouders en kinderen, grijpt men terug naar de eigen formulering, het originele recht.

Wat binnen deze thematiek echter het meest in het oog springt, is dat de titel omtrent de momborije of voogdij nauwelijks origineel is, terwijl dit doorgaans één van de meer belangrijke onderdelen vormde van de Brabantse costume. ${ }^{636}$ Bovendien kende dit

${ }^{636}$ Cfr. GODDING, Droit privé, 126: "Beaucoup d'autres coutumes, à travers les différentes phases de la codification, réserverent un titre à la tutelle." Welke rechtsfiguren binnen de Brabantse coutumiers als belangrijk beschouwd mogen worden, heb ik zelf summier onderzocht. Omdat Jacques Vanderlinden reeds in de jaren ' 50 met betrekking tot de Vlaamse costumen wist aan te tonen dat de compilatoren zich vaak lieten inspireren door wat hen door de landsheer werd aangereikt in zijn ordonnanties en herinneringsbrieven (VANDERLINDEN, "Essai sur la structure des textes coutumiers", 276-277), leek het me interessant ook de inhoudstafels van verscheidene Brabantse costumen naast elkaar te leggen. In Vlaanderen zou er immers in de tweede codificatiefase (1546-1569) een sterke nabootsingskracht zijn uitgegaan van de herinneringsbrief van Karel $\mathrm{V}$ van het jaar 1546. Hierin spoorde deze laatste de lokale overheden nogmaals aan de plaatselijke gebruiken in materie van jurisdictien, successien, zoe wel van leenen als van erfgoeden, contracten van buwelycken, testamenten, duwairen, donatien, ende andere contracten inter vivos, naederscape, preferentien, als in materie criminelle ende andere diergelycke,... te boek te stellen. Wat het oude hertogdom Brabant betreft, heb ik me beperkt tot de belangrijkste en bruikbare redactiepogingen, zoals ze werden uitgegeven in het Quartier de Brabant van het Recueil des anciennes coutumes de la Belgique. (Coutumes du pays et duché de Brabant. G. DE LONGE ed. (Recueil des anciennes coutumes de la Belgique), 7 dln., Brussel, 1869-1878.) Dit brengt de onderzoeksgroep op volgende samenstelling: Mechelen (1535), Beveren-Putte (<1553), Kasterlee (1555-1578), Herentals (1559), Kiel (1570), Lier (1570), Tienen (1570), Brussel (1606), Mol-Balen-Dessel (zeventiende eeuw), Deurne II (>1611), Geel (1619), Leuven (1622) en Zandhoven II (1664). Antwerpen heb ik wegens zijn uitzonderlijke omvang niet in rekening gebracht. De Consuetudines compilatae staan ver van het gemiddelde waar ik naar op zoek ben en zij zouden dan ook te sterk doorwegen op de uiteindelijke resultaten van het onderzoek. Deze zien er als volgt uit. Volgens hun gemiddeld procentueel aandeel binnen de eigen costume, rangschikken de voornaamste rechtsgebieden zich als volgt: goederenrecht (23 procent), administratief recht (18 procent), erfrecht (14 procent), procesrecht (tien procent), verbintenissenrecht (negen procent), personen- en familierecht (negen procent) en tot slot strafrecht (zes procent). Ik heb bovendien kunnen vaststellen dat dertien titels in meer dan de helft van de compilaties voorkomen. Dit is echter een te 'absoluut' beeld. Het kan immers gebeuren dat een bepaalde titel in tien van de dertien compilaties voorkomt, het zij slechts in uiterst beperkte mate (vb. vruchtgebruik of tochte). In dat geval zou deze titel onterecht het etiquette 'belangrijk' opgekleefd krijgen. Bovendien is de inhoudstafel van de costume van Lier (1570) en het Kiel (1570) een zo goed als perfect afkooksel van die van Mechelen (1535). Ook dit is een reden het aantal artikels per titel in de berekening te betrekken. Door de 
thema ook in het eerste ontwerp van 1564 een aanknopingspunt met de titel Wylche mundich und onmundich syn. ${ }^{637}$ Desalniettemin beschikt hier slechts iets meer dan een tiende van de artikels over een eigen, originele formulering. Deze concentreren zich voornamelijk in paragraaf 6 omtrent de onderlinge schulden tussen voogden en wezen. Met andere woorden, bijna 90 procent werd letterlijk aan de Consuetudines compilatae ontleend. Op basis van de oudere concepten ziet het er bovendien naar uit dat gans de titel werd gerecipieerd, waarna hij -zo blijkt uit het verschillende uitzicht van de definitieve versie- werd aangepast aan de eigen gebruiken waar men dit nodig achtte. ${ }^{638}$ Zo getuigt de C-versie van een identieke structuur als die van titel 2.5 uit de Consuetudines compilatae. ${ }^{639}$ Vergelijking van beide compilaties heeft echter aangetoond dat bijlange niet alle artikels uit de Consuetudines compilatae werden overgenomen. Men ging eerder selectief te werk. Kortom, men selecteert, men kopieert en men modificeert.

\section{Deel II}

... spreeckende van verscheiden gedaente oft gesteltenisse van goederen, lasten ende servituyten oft dienstbarbeiden daerop commende.

Het tweede deel van het Gelderse Land- en Stadsrecht betreft het goederenrecht. Nadat een eerste titel de verschillende types van goederen definieert, komen ook de renten,

procentuele frequentie van een titel (of het aantal keer dat een titel voorkomt, gedeeld door het totaal aantal compilaties, zijnde dertien) te vermenigvuldigen met haar procentuele, gemiddelde aandeel, bekomen we een waarde die het belang omschrijft van een welbepaald rechtsgebied binnen, in dit geval, de doorsnee Brabantse compilatie. Van zodra deze waarde het cijfer 300 overstijgt, kan men beginnen spreken van de meer voorname rechtsgebieden in Brabant: jurisdictie (1568), successie (1213), naastingsrecht (813), erfscheiding (526), contracten, opdrachten, voorwaarden en borchtochten (524), gehuwde personen (376), vermomboorde personen (371) en alles omtrent cijnzen, renten, erfpachten (354). Tenslotte is er nog het strafrecht (criminele saecken) (404) en procesrecht (arrestamenten) (319). Met de titel omtrent keuren ende breucken (251) eindigt dit strafrecht vermoedelijk nog hoger. Titels omtrent de huur (278), het testamentair erfrecht (155) en het vruchtgebruik (255), komen evenwel zeer frequent voor, maar zij werden nauwelijks uitgewerkt. Hoewel dit enigszins gelijkenissen vertoont met de opsomming in de ordonnantie van Karel V (...), zijn de verschillen van belangrijker aard. Structureel lijkt men liever de costume van Mechelen (1535) te volgen (cfr. supra, hoofdstuk 2, Status quaestionis.) en inhoudelijk is de donatio de grote afwezige en de momborije de verrassende aanwezige. Godding stelt, het zij eerder algemeen, omtrent dit alles het volgende: "La pratique coutumière n'a pas accordé la même attention à tous les domaines du droit privé. Certains, comme le mariage et la filiation, lui échappaient dansune très large mesure. D'autres sont privilégiés: le régime des biens, les incidences patrimoniales du mariage, la succession ab intestat." (GODDING, Droit privé, 7.)

${ }^{637}$ De titel telt er zeven artikels, wat veel is vergeleken met de andere titels binnen het ontwerp van 1564.

${ }^{638}$ Cfr. katernen 11 tot en met 15 van RHCL, Staten Overkwartier, 585.

${ }^{639}$ In de B-versie ontbreken echter de eerste honderd artikels, waardoor ik niet met zekerheid kan stellen dat ook deze titel identiek aan de overeenkomstige titel in de Consuetudines compilatae werd geconstrueerd. Aangezien dit wel degelijk het geval is voor de jongere C-versie, mag ik er echter van uitgaan dat dit in de B-versie vermoedelijk niet fundamenteel anders geweest is. 
het vruchtgebruik en de naburige rechten aan bod. Net zoals het derde deel, dat de manieren verzamelt waarop goederen verkregen kunnen worden, gaat dit tweede deel terug op deel III van de Consuetudines compilatae. Te Antwerpen werd evenwel geen onderscheid gemaakt tussen de goederen enerzijds en de manieren waarop deze te verkrijgen anderzijds. De ratio achter de beslissing om binnen het Gelderse Land- en Stadsrecht beide zaken op te splitsen in twee afzonderlijke delen, kan echter niet gedestilleerd worden uit de persoonlijke notities van Hendrik Uwens, noch uit de marginale glossen toegevoegd aan de bescheiden in het archief van de Staten van het Overkwartier. Het enige waar ik met zekerheid over spreken kan, is dat de ingreep behoorlijk laat in het redactieproces is doorgevoerd. Hierbij baseer ik me op een inhoudstafel welke wordt bewaard in het archief van de Staten van het Overkwartier. ${ }^{640}$ Deze leunt qua inhoud zeer nauw aan bij de definitieve tekst van Berkvens en Venner, maar telt slechts vijf delen. Het goederenrecht werd nog steeds niet opgesplitst. ${ }^{641}$

Met 58.6 procent aan geassimileerde artikels bevindt dit tweede goederenrechtelijke deel zich, net als het eerste en het laatste deel, in de spreekwoordelijke middenmoot. Tabel 2.3 geeft de spreiding weer van de geassimileerde artikels.

Tabel 2.3 De assimilatie aan Antwerps recht in deel II van het Gelderse Land- en Stadsrecht

\begin{tabular}{|c|c|c|c|c|c|}
\hline Titel & $\begin{array}{c}\% \\
\text { (titel) }\end{array}$ & $\mathbb{S}$ & $\begin{array}{l}\text { Totaal aantal } \\
\text { artikels }\end{array}$ & $\begin{array}{c}\text { Aantal } \\
\text { concordanties }\end{array}$ & $\%(\mathbb{S})$ \\
\hline $2.1 V$ an verscheidenheit van goederen. & 0.0 & 1 & 13 & 0 & 0.0 \\
\hline \multirow{4}{*}{2.2 Van renthen. } & \multirow{4}{*}{84.4} & 1 & 19 & 17 & 89.5 \\
\hline & & 2 & 12 & 11 & 91.7 \\
\hline & & 3 & 20 & 15 & 75.0 \\
\hline & & 4 & 13 & 11 & 84.6 \\
\hline \multirow{3}{*}{$\begin{array}{l}2.3 \text { Van rechtelicke vervolgh van betalinge van } \\
\text { renten. }\end{array}$} & \multirow{3}{*}{7.7} & 1 & 28 & 3 & 10.7 \\
\hline & & 2 & 5 & 0 & 0.0 \\
\hline & & 3 & 6 & 0 & 0.0 \\
\hline \multirow{5}{*}{$\begin{array}{l}2.4 \text { Van tochte ende gerichtelick vervolgh } \\
\text { derselver. }\end{array}$} & \multirow{5}{*}{40.5} & 1 & 10 & 2 & 20.0 \\
\hline & & 2 & 11 & 6 & 54.5 \\
\hline & & 3 & 8 & 8 & 100.0 \\
\hline & & 4 & 8 & 1 & 12.5 \\
\hline & & 5 & 5 & 0 & 0.0 \\
\hline \multirow{7}{*}{ 2.5V Van erffdiensten ende nabuerlicke rechten. } & \multirow{7}{*}{76.9} & 1 & 19 & 17 & 89.5 \\
\hline & & 2 & 8 & 8 & 100.0 \\
\hline & & 3 & 22 & 22 & 100.0 \\
\hline & & 4 & 8 & 8 & 100.0 \\
\hline & & 5 & 10 & 10 & 100.0 \\
\hline & & 6 & 8 & 8 & 100.0 \\
\hline & & 7 & 33 & 10 & 30.3 \\
\hline \multirow{5}{*}{$\begin{array}{l}2.6 \text { Van vervolgh tot onderhalt van nabuerlicke } \\
\text { rechten ende erffdiensten. }\end{array}$} & \multirow{5}{*}{48.4} & 1 & 7 & 7 & 100.0 \\
\hline & & 2 & 5 & 5 & 100.0 \\
\hline & & 3 & 3 & 3 & 100.0 \\
\hline & & 4 & 5 & 0 & 0.0 \\
\hline & & 5 & 11 & 0 & 0.0 \\
\hline
\end{tabular}

${ }^{640}$ RHCL, Staten Overkwartier, 581, fol. 19-28.

${ }^{641}$ Deze splitsing komt een eerste keer ter sprake in de marges van voornoemde Intitulatio. Het concrete voorstel is van de hand van Hendrik Uwens en staat neergeschreven op de ingevoegde folio 30r van RHCL, Staten Overkwartier, 581. 
Het tweede deel opent meteen met de grootste verrassing van het geheel. Hoewel ook in het derde deel van de Antwerpse Consuetudines compilatae de spits wordt afgebeten door een titel omtrent de verscheydentheyt van goeden, blijkt de Roermondse versie hiermee geen enkele letterlijke gelijkenissen te vertonen. Bovendien lijkt de titel pas zeer laat aan het geheel te zijn toegevoegd. Zowel in de oudste versies B en C, als in de meer recente $\mathrm{H}$-versie ontbreekt het thema. Ook het ontwerp van 1564 bevat slechts één artikel omtrent gewonnen und geworven guederen. Het ziet er dus naar uit dat deze titel één van de laatst doorgevoerde modificaties inhoudt. ${ }^{642}$ Dit klopt. Op basis van oriënterende gesprekken welke in oktober 1617 plaatsvonden tussen Hendrik Uwens enerzijds en de tot visitatie aangestelde raadsheren van de Geheime Raad, Willem van Grijsperre en Willem van Steenhuis, anderzijds, bleek dat een titel omtrent de verscheidenheid van goederen, hoewel deze ontbrak, toch wenselijk werd geacht. Hendrik Uwens zal er te Brussel aan werken terwijl de bevoegde commissarissen de rest van het ontwerp bestuderen. ${ }^{643}$

Naast deze eerste titel kent ook de derde titel omtrent het afdwingen van de betaling van renten weinig raakvlakken met het Antwerpse recht. Maar liefst 36 van de 39 artikels geven blijk van een maximum aan originaliteit. Ook op structureel vlak werden hier wijzigingen doorgevoerd. In tegenstelling tot Antwerpen wordt nu een onderscheid gemaakt tussen de renten en de procedure die gevolgd moet worden om de betaling van de renten te verzekeren. Eenzelfde logica wordt overigens toegepast bij de erffdiensten en nabuerlijke rechten. De opsplitsing van beide rechtsfiguren vond plaats in de leemte tussen versie $\mathrm{C}$ en versie $\mathrm{H}$. In de oudere $\mathrm{C}$-versie behoorde het gerechtelijk vervolg namelijk nog als paragraaf tot de desbetreffende titel zelf. Wat het vruchtgebruik betreft, heeft men er, vreemd genoeg en a contrario voornoemde logica, voor gekozen beide zaken als één geheel te behandelen. De reden hiervoor is me onduidelijk gebleven. ${ }^{644}$

Het valt bovendien op dat de titels aangaande het 'rechtelijk vervolg' meer origineel zijn dan die omtrent de renten en de erfdiensten en naburige rechten zelf. Naast de reeds besproken derde titel omtrent het 'gerechtelijk vervolg' van de betaling van renten is ook de laatste titel omtrent het 'gerechtelijk vervolg' van erfdiensten en naburige rechten voor de helft origineel. Dit is evenwel louter aan de paragrafen 4 (Clachte oever sijns naebuers gebreeck in 't batten, ofte besorgen van sijn landt tegens d'affdrifft van den stroem) en 5 (Clachte ende vervolch op schade bie der naebueren ende andere beesten gedaen) te wijten. Het verschil in de aard van de inhoud lijkt bijgevolg niet de oorzaak te zijn van de hogere (titels 2.2 en 2.5) en lagere (titels 2.3 en 2.6) assimilatiegraad. Ook binnen de titel omtrent het vruchtgebruik (2.4) is hier geen bevestiging voor te vinden. Hier zijn het de eerste (Waertoe ein tochtenaer gehalden is) en de laatste twee paragrafen (Tochte ende cost van batten van affdrijvende landt, mitsgaders van holtgewas ende vergenckelicke goederen tot tochte en Eindinghe van de tochte ende tochts clachte) die het meest origineel zijn en er voor

${ }^{642}$ Gans de bedrijvigheid die hiermee gepaard ging, is goed gedocumenteerd binnen het archief van de Staten van het Overkwartier. Cfr. RHCL, Staten Overkwartier, 581, fol. $40-41$ en fol. 98-108.

${ }^{643}$ BERKVENS, VENNER en SPIJKERBOER, Gelderse Land-en Stadsrecht, XLIII.

${ }^{644}$ Cfr. RHCL, Staten Overkwartier, 585. 
zorgen dat de ganse titel een assimilatiegraad bekomt van slechts 40 procent. ${ }^{645}$ Dit percentage dankt de titel aan paragraaf 3 (tochte van ein affgebrandt ofte omgevallen buys) en in mindere mate ook aan paragraaf 2 (des tochtenaers gebruick ende geniet soe doir hemselve als anderen).

Het ontbreken van een trend neemt echter niet weg dat de percentages van de titels 2.2 en 2.5 aan de zeer hoge kant liggen. Zij werden respectievelijk voor 84.4 en 76.9 procent aan het Antwerpse model geassimileerd. Absoluut gaat het hier om 54 en 83 artikels. Titel 2.5 omtrent de naburige rechten is, op paragraaf 7 aangaande hoven en landerijen na, zelfs zo goed als volledig naar het model van Antwerpen ingevuld. Gezien het weinig agrarische karakter van de handelsmetropool Antwerpen, verrast het ontbreken van een paragraaf gewijd aan landerijen en hoven niemand. Binnen het Overkwartier daarentegen is deze paragraaf er meteen vanaf versie B bij. De overige paragrafen zijn exact hetzelfde als in de Consuetudines compilatae. Ik meen te mogen veronderstellen dat in dezen receptie van Antwerps recht onvermijdelijk moet geweest zijn. Titel 2.2 omtrent de renten kent zelfs nog een hogere assimilatiegraad. De ontlening is nu echter meer gelijkmatig verspreid over de verschillende paragrafen dan dat dit het geval is in voornoemde titel 2.5 .

Deel III

... inhaldende verscheiden middelen ende manieren daerbie den eigendom oft erffelickheit van goederen vercregen wordt.

Het derde deel omvat het resterende goederenrecht dat de manieren verzamelt waarop goederen verkregen kunnen worden. Bijgevolg bevat dit deel ook erfrechtelijke titels zoals die omtrent het testament en het intestaat erfrecht. Met slechts 39.7 procent aan concordanties is de inhoud van dit deel beduidend minder aan het Antwerpse model geassimileerd dan de overige onderdelen van het Gelderse Land-en Stadsrecht. Enkel het burgerlijk procesrecht van deel V is nog origineler. Mijns inziens ligt de verklaring hiervoor deels in het feit dat rechtsfiguren als de naasting en de successio ab intestat tot de belangrijkste, costumiere rechtsfiguren behoren. ${ }^{646}$ Ook te Roermond nemen zij een aanzienlijk deel van de artikels voor hun rekening. Verder kende ook het testamentair erfrecht een hoge frequentie onder de Brabantse costumen, dit evenwel gepaard gaande met een doorgaans te beperkte uitwerking. Een andere reden voor de lage assimilatiegraad schuilt ongetwijfeld in het feit dat alle voornoemde titels, inclusief die omtrent de prescriptie en de giften, reeds in het eerste ontwerp van 1564 aan bod kwamen. ${ }^{647}$ Dit getuigt van een eigen traditie en verraadt

${ }^{645}$ De titel over het vruchtgebruik (2.4) werd voornamelijk binnen de derde (Tochte van ein affgebrandt ofte omgevallen buys, ende de costen van opmaeckinge) en minder binnen de tweede paragraaf (Des tochtenaers gebruick ende geniet soe doir hemselve als anderen) gekopieerd. Tussen versie $\mathrm{B}$ en versie $\mathrm{H}$ kent deze titel een sterke uitbreiding.

${ }^{646}$ Cfr. supra, hoofdstuk 2, paragraaf 2, Deel I.

647 Titel 3 betreft er het beschud- of naastingrecht en titel 21 behandelt er de prescriptie of verloop van tijd. Met maar liefst tien artikels behoort deze laatstgenoemde rechtsfiguur overigens tot de sterkst uitgewerkte elementen binnen het ontwerp van 1564. De giften 
uiteraard een zekere ervaring met de materie. Bijgevolg overschrijden de titels 3.2 tot en met 3.7 dan ook nergens de grens van vijftig procent.

Tabel 2.4 De assimilatie aan Antwerps recht in deel III van het Gelderse Land- en Stadsrecht

\begin{tabular}{|c|c|c|c|c|c|}
\hline Titel & $\begin{array}{c}\% \\
\text { (titel) }\end{array}$ & $\mathbb{S}$ & $\begin{array}{c}\text { Totaal aantal } \\
\text { artikels }\end{array}$ & $\begin{array}{c}\text { Aantal } \\
\text { concordanties }\end{array}$ & $\begin{array}{l}\% \\
(\$)\end{array}$ \\
\hline \multirow{2}{*}{$\begin{array}{l}3.1 \text { Van erffeniss, opdrachte, leveringe, cessie oft } \\
\text { overgifte ende verbintenisse van goederen. }\end{array}$} & \multirow[b]{2}{*}{69.2} & 1 & 25 & 14 & 56.0 \\
\hline & & 2 & 14 & 13 & 92.9 \\
\hline \multirow{3}{*}{$\begin{array}{l}3.2 \text { Van gerichtelicke clagten ter sake van } \\
\text { erffelicke ende ruerlicke goederen. }\end{array}$} & \multirow{3}{*}{37.9} & 1 & 37 & 3 & 8.1 \\
\hline & & 2 & 9 & 8 & 88.9 \\
\hline & & 3 & 12 & 11 & 91.7 \\
\hline \multirow{5}{*}{$3.3 \mathrm{~V}$ an beschudtrecht oft vernaerderinge. } & \multirow{5}{*}{36.0} & 1 & 24 & 9 & 37.5 \\
\hline & & 2 & 15 & 6 & 40.0 \\
\hline & & 3 & 11 & 4 & 36.4 \\
\hline & & 4 & 17 & 2 & 11.8 \\
\hline & & 5 & 8 & 6 & 75.0 \\
\hline \multirow{3}{*}{$\begin{array}{l}3.4 \text { Van verwijlunge oft verloep van tijdt ende } \\
\text { affdaginge. }\end{array}$} & \multirow{3}{*}{48.3} & 1 & 7 & 6 & 85.7 \\
\hline & & 2 & 10 & 5 & 50.0 \\
\hline & & 3 & 12 & 3 & 25.0 \\
\hline \multirow{3}{*}{3.5 Van ghiften. } & \multirow{3}{*}{18.5} & 1 & 14 & 1 & 7.1 \\
\hline & & 2 & 4 & 3 & 75.0 \\
\hline & & 3 & 9 & 1 & 11.1 \\
\hline \multirow{4}{*}{ 3.6 Van testamenten ende unyterste willen. } & \multirow{4}{*}{30.2} & 1 & 18 & 12 & 66.7 \\
\hline & & 2 & 15 & 1 & 6.7 \\
\hline & & 3 & 19 & 3 & 15.8 \\
\hline & & 4 & 11 & 3 & 27.3 \\
\hline \multirow{6}{*}{3.7 Van wettige versterffenisse. } & \multirow{6}{*}{4.3} & 1 & 12 & 0 & 0.0 \\
\hline & & 2 & 10 & 0 & 0.0 \\
\hline & & 3 & 6 & 0 & 0.0 \\
\hline & & 4 & 12 & 0 & 0.0 \\
\hline & & 5 & 7 & 0 & 0.0 \\
\hline & & 6 & 10 & 2 & 20.0 \\
\hline $\begin{array}{l}3.8 \text { Van aenveerdinge van versterffenisse ende } \\
\text { betalinge der scbulden. }\end{array}$ & 84.6 & / & 13 & 11 & 84.6 \\
\hline $\begin{array}{l}3.9 \text { Van inbrengen der erffgenaemen in't erff oft } \\
\text { sterffhuys. }\end{array}$ & 94.1 & I & 17 & 16 & 94.1 \\
\hline $\begin{array}{l}3.10 \text { Van scheidinge ende deilinge van } \\
\text { versterffenisse ende andere gemeine goederen. }\end{array}$ & 65.2 & I & 23 & 15 & 65.2 \\
\hline
\end{tabular}

In dit opzicht springt de eerste titel (Van erfeniss, opdrachte, leveringe, cessie oft overgifte ende verbintenisse van goederen) evenwel uit de band met een assimilatiegraad van bijna zeventig procent. Dit is in de eerste plaats te wijten aan paragraaf 2 omtrent de leveringe ende cessie oft overgevinge van gereide goederen ende uuytstaende schulden. Hoewel deze eerste titel zijn introductie reeds kent in versie B, verschijnt de term 'levering' pas te Roermond samen met de H-versie. In de B-versie daarentegen staat diezelfde titel, samen met de latere titel 3.2 (Van gerichtelicke clagten ter sake van erffelicke ende ruerlicke goederen) nog aan het begin van het nog te splitsen, goederenrechtelijke deel. Op de ingevoegde folio, waar Uwens een opdeling van dit tweede deel voorstelt, bevindt zich eveneens de opdracht beide titels naar het nieuwe derde deel te verhuizen. Ook deze tweede titel omtrent gerechtelijke klachten in verband met roerende en

daarentegen komen slechts zeer summier aan bod binnen één van de drie artikels onder de noemer Quae bona acquisita (titel 17). 
onroerende goederen, werd sterk geassimileerd en dit hoofdzakelijk in de tweede (Vervolgh van ruerlicke vercochte, vertroude, unytgeleende ende uuytgedaene goederen om te wercken) en de derde (Vervolch van verloeren ende gestoelen goederen) paragraaf. De eerste paragraaf (Clachte wegen 't besitt, gebruick ende eigendom van erffelicke goederen) daarentegen is zo goed als geheel origineel. Wat de sterk geassimileerde paragrafen 2 en 3 betreft, blijkt uit het archief van de Staten van het Overkwartier dat deze titel pas laat tot stand is gekomen. Hij verschijnt voor het eerst in versie $\mathrm{H}$.

Andere paragrafen waar de assimilatiegraad behoorlijk hoge waarden aanneemt, zijn paragraaf 2 van titel 3.5 omtrent de giften en paragraaf 1 van titel 3.6 omtrent het testamentair erfrecht. Bij de donatio gaat het om de aenveerdinge oft aenneminge van giften en bij het testament om de maniere van testamenten te maecken. ${ }^{648}$ Wat de overige paragrafen betreft, blijken deze titels uiterst origineel te zijn.

Ook de laatste drie titels werden zeer sterk naar Antwerps model geconstrueerd. Zij regelen het aanvaarden van een erfenis en de betaling van de schulden, het inbrengen van de erfgenamen in het erf- of sterfhuis en de scheiding en deling van de erfenis en andere gemeenschappelijke goederen. Deze drie titels waren tevens aanwezig in de vroegere versies $\mathrm{H}$ en C. ${ }^{649}$ In de B-versie daarentegen ontbreekt de achtste titel omtrent het aanvaarden van de erfenis en de betaling van de schulden. Desondanks lijken de drie titels duidelijk op Antwerpen terug te gaan. De kans dat er met andere woorden ook van receptie gesproken mag worden, is mijns inziens reëel.

Enigszins opvallend is ook dat men geweigerd heeft de vierde paragraaf binnen de Antwerpse titel omtrent de successio over te nemen. Deze behelst de Aenveerdinge van den sterffhuijse onder beneficie van inventaris en wordt door Gilissen bestempeld als een voorbeeld van romanisatie via provinciale wetgeving. Gilissen situeert dit in de eerste helft van de zestiende eeuw. Het Overkwartier lijkt er echter aan het begin van de zeventiende eeuw nog niet klaar voor te zijn. ${ }^{650}$

Dat de paragraaf omtrent de erfrechtelijke status van bastaarden (paragraaf 5 van titel 3.7) geheel verschillend is, strookt met de idee van Godding dat te Roermond de rechten van de bastaard beperkter zijn. Zo wordt hen bijvoorbeeld elk recht van successio ontnomen, waar bijvoorbeeld in Antwerpen het onwettig kind van de moeder erven kan. ${ }^{651}$

${ }^{648}$ Cfr. RHCL, Staten Overkwartier, 588 (katern 2) omtrent de giften; RHCL, Staten Overkwartier, 585 (katernen 23 tot en met 30) en RHCL, Staten Overkwartier, 588 (katern 3) aangaande het testament.

${ }^{649}$ Cfr. RHCL, Staten Overkwartier, 585 (katernen 31 tot en met 33).

${ }^{650}$ Gilissen ziet hierin een voorbeeld van penetratie van Romeins recht in de costume via provinciale wetgeving. Hoewel hij dit in de eerste helft van de zestiende eeuw situeert, is dit anno 1620 nog niet van toepassing op het Overkwartier. (GILISSEN, "Romeins recht en inheems Gewoonterecht", 130.)

${ }^{651}$ Cfr. GODDING, Droit privé, 117-118. 
Deel IV

... spreeckt van contracten, handelingen ende verbintenissen.

$\mathrm{Na}$ het op één na minst geassimileerde deel kom ik naadloos terecht bij het meest geassimileerde deel, met name het contract- en handelsrecht van deel IV. Met 69.7 procent bestaat geen enkel ander deel van het Gelderse Land-en Stadsrecht uit zoveel artikels, meer bepaald 268, welke letterlijk uit de Antwerpse Consuetudines compilatae werden overgenomen. De reden hiervoor is dubbel en ligt voor de hand. Enerzijds is er de aanwezigheid van het handelsrecht. Waar ik eerder heb laten zien dat titels omtrent borgtochten, contracten en huur doorgaans wel deel uitmaakten van de Brabantse costumen, kan dit niet gezegd worden van het handelsrecht. ${ }^{652}$ Anderzijds is de manier waarop deze materie in de Antwerpse Consuetudines compilatae werd uitgewerkt uniek en tevens begrijpelijk gezien de commerciële rol van een handelsmetropool als Antwerpen in de zestiende en zeventiende eeuw. Bijgevolg moet dit een enorme indruk hebben gemaakt op de samenstellers van het Gelderse Land- en Stadsrecht. Enigszins verblind door de uitmuntende kwaliteit van het Antwerpse handelsrecht en wegens het gebrek aan eigen, commerciële regelgeving, verwacht ik dan ook dat men het merendeel vanuit het Antwerpse recht gerecipieerd heeft. ${ }^{653}$ Het verbaast me dan ook des te meer dat het juist deze, eerder traditionele, titels (huur en borgtochten) zijn, die binnen het vierde deel tot de meest geassimileerde titels behoren. ${ }^{654}$ De titel omtrent de huur en de pacht is, althans wat betreft de paragrafen omtrent de huur, zo goed als volledig aan het Antwerpse model geassimileerd. Het gros van de originele artikels bevindt zich binnen de paragrafen omtrent de pacht. Het zijn de paragrafen 3 (Verpachtinge van goederen) en 5 (Van erffpachten). Dit is evident aangezien zij pas in latere instantie door Uwens werden geconcipieerd, met name op het moment dat hij zich in het kader van de homologatie van het landrecht te Brussel bevond. Beide paragrafen ontbreken dan ook in de versies B en C. Uiteindelijk zou deze materie in juni 1618 officieel door het thuisfront worden goedgekeurd en aan het geheel van de ontwerptekst worden toegevoegd. ${ }^{655}$ Mijn verbazing wordt nog groter wanneer een eerder ongebruikelijke titel als die omtrent coop ende coopmanschap tot de minst geassimileerde titels binnen deel IV blijkt te behoren en ook andere typisch handelsrechtelijke titels zoals IV.5 ( $V$ an gemeinschap van handel ende onverdeilte goederen) en IV.6 ( $V$ an bevelhebbers, factuers ende maeckelaers) niet

${ }^{652} \mathrm{Ik}$ ben me er ter dege van bewust dat ik hier tot op zekere hoogte appels met peren vergelijk. Gelre is Brabant niet, maar toch ga ik op deze manier te werk. Ik kan namelijk niet over ander vergelijkingsmateriaal beschikken. Bovendien geef ik deze vergelijking louter ter illustratie. De wijze waarop ik deze vergelijking makk, heeft geen enkel effect op de beantwoording van de centrale vraagstellingen binnen deze doctorale dissertatie.

${ }^{653}$ Het ligt bovendien voor de hand dat een stad als Roermond weinig belang stelde in het zee- en verzekeringsrecht. Deze titels werden dan ook niet gerecipieerd. Wel kan men, indien het handelsrecht aan dat van Antwerpen werd geassimileerd, zich de vraag stellen in hoeverre dit de handelsrelaties tussen beide regio's mogelijk heeft bevorderd. Dit is voer voor andersoortig onderzoek.

${ }^{654}$ De titel omtrent de borgtochten komt overigens ook aan bod in het ontwerp van 1564.

${ }^{655}$ Cfr. BERKVENS, VENNER en SPIJKERBOER, Gelderse Land- en Stadsrecht, XLVI. 
de volle honderd procent aan het Antwerpse model ontleend werden. ${ }^{656}$ Verder -zoals blijkt uit tabel 2.5- blijven de verrassingen beperkt en liggen de vaststellingen in de lijn van wat ik zojuist heb uiteengezet: hoe traditioneler de rechtsmaterie, des te lager de assimilatiegraad.

Tabel 2.5 De assimilatie aan Antwerps recht in deel IV van het Gelderse Land- en Stadsrecht

\begin{tabular}{|c|c|c|c|c|c|}
\hline Titel & $\begin{array}{c}\% \\
\text { (titel) }\end{array}$ & $\mathbb{S}$ & $\begin{array}{l}\text { Totaal aantal } \\
\text { artikels }\end{array}$ & $\begin{array}{c}\text { Aantal } \\
\text { concordanties }\end{array}$ & $\%(\mathbb{})$ \\
\hline $\begin{array}{l}4.1 \text { Van bestendige ende onbestendige oft } \\
\text { crachtloose contracten. }\end{array}$ & 52.2 & / & 23 & 12 & 52.2 \\
\hline \multirow{5}{*}{$\begin{array}{l}4.2 V \text { an schepenenbrieven, handtschriften ende } \\
\text { andere bescheiden oft schulden tot namptisatie oft } \\
\text { gerichtelicke erlegginge ende handtvullinge staende. }\end{array}$} & \multirow{5}{*}{72.5} & 1 & 6 & 3 & 50.0 \\
\hline & & 2 & 7 & 7 & 100.0 \\
\hline & & 3 & 7 & 4 & 57.1 \\
\hline & & 4 & 11 & 6 & 54.5 \\
\hline & & 5 & 9 & 9 & 100.0 \\
\hline \multirow{6}{*}{$\begin{array}{l}4.3 \text { Van coep ende coepmanschap ende wat } \\
\text { daeraen cleeft. }\end{array}$} & \multirow{6}{*}{60.8} & 1 & 8 & 1 & 12.5 \\
\hline & & 2 & 5 & 5 & 100.0 \\
\hline & & 3 & 17 & 13 & 76.5 \\
\hline & & 4 & 7 & 4 & 57.1 \\
\hline & & 5 & 6 & 1 & 16.7 \\
\hline & & 6 & 8 & 7 & 87.5 \\
\hline \multirow{5}{*}{ 4.4 V an huyre ende pacht. } & \multirow{5}{*}{73.6} & 1 & 20 & 19 & 95.0 \\
\hline & & 2 & 12 & 12 & 100.0 \\
\hline & & 3 & 13 & 0 & 0.0 \\
\hline & & 4 & 8 & 8 & 100.0 \\
\hline & & 5 & 5 & 2 & 40.0 \\
\hline \multirow{3}{*}{$\begin{array}{l}4.5 \text { Van gemeinschap van handel ende onverdeilte } \\
\text { goederen. }\end{array}$} & \multirow{3}{*}{78.6} & 1 & 5 & 2 & 40.0 \\
\hline & & 2 & 8 & 8 & 100.0 \\
\hline & & 3 & 1 & 1 & 100.0 \\
\hline \multirow{2}{*}{ 4.6 V an bevelhebbers, factuers ende maeckelaers. } & \multirow{2}{*}{71.4} & 1 & 10 & 8 & 80.0 \\
\hline & & 2 & 11 & 7 & 63.6 \\
\hline \multirow{4}{*}{ 4.7V Van panden ende pandtgoederen. } & \multirow{4}{*}{55.6} & 1 & 13 & 6 & 46.2 \\
\hline & & 2 & 12 & 10 & 83.3 \\
\hline & & 3 & 12 & 9 & 75.0 \\
\hline & & 4 & 8 & 0 & 0.0 \\
\hline \multirow{3}{*}{$4.8 V$ an borghtochten. } & \multirow{3}{*}{94.0} & 1 & 14 & 13 & 92.9 \\
\hline & & 2 & 14 & 14 & 100.0 \\
\hline & & 3 & 10 & 9 & 90.0 \\
\hline $\begin{array}{l}4.9 V \text { an betalinge, bewijsinge en compensatie oft } \\
\text { vergeldinge. }\end{array}$ & 92.0 & / & 25 & 23 & 92.0 \\
\hline $\begin{array}{l}4.10 \text { Van brieven van respijt oft unytstel van } \\
\text { betalinge. }\end{array}$ & 100.0 & / & 15 & 15 & 100.0 \\
\hline $\begin{array}{l}4.11 \text { Van brieven van cessie oft overgevinge van } \\
\text { sijn goet in plaetse van betalinge. }\end{array}$ & 90.0 & / & 10 & 9 & 90.0 \\
\hline \multirow{4}{*}{$\begin{array}{l}4.12 \text { Van preferentie oft voirdeel onder de } \\
\text { crediteuren in die betalinge. }\end{array}$} & \multirow{4}{*}{76.7} & 1 & 6 & 6 & 100.0 \\
\hline & & 2 & 12 & 10 & 83.3 \\
\hline & & 3 & 8 & 3 & 37.5 \\
\hline & & 4 & 4 & 4 & 100.0 \\
\hline
\end{tabular}

${ }^{656}$ De aanpassingen binnen titel 4.3 zijn terug te vinden in de archiefbescheiden RHCL, Staten Overkwartier, 585 (katernen 35 en 36) en RHCL, Staten Overkwartier, 586 (katern 3). Het gaat hier vooral om de paragrafen 1 (Wanneer einen coop van weerden is ende voor volcommentlick gesloten wordt gehalden, ende van wat goederen den niet en magh geschieden) en 5 (Weerschap ende verantworden voir den coeper). De wijzigingen werden tussen de versies $\mathrm{C}$ en $\mathrm{H}$ uitgevoerd. 
Aangezien er, op de documenten omtrent titel 1 (bestendige en onbestendige contracten) en titel 7 (pand en pandgoederen) na, in het archief van de Staten van het Overkwartier nauwelijks materiaal bewaard is gebleven dat een bijdrage levert tot de kennis van de genese van het vierde deel, vermoed ik dat de totstandkoming ervan met weinig discussie, oponthoud en tegenslagen verlopen is. Ik ga er van uit dat het gebrek aan ervaring in dezen aan de basis heeft gelegen van zulk een ontvankelijke opstelling en bijgevolg gewillige 'receptie'. Twee titels daarentegen lijken voor meer ophef gezorgd te hebben, althans afgaande op het aantal archiefbescheiden dat ze in het archief hebben nagelaten. Ten eerste is er titel I5.1 omtrent de bestendige en onbestendige contracten. ${ }^{657}$ Het is tevens de minst geassimileerde titel. Aanvankelijk werden slechts elf van de zestien artikels uit de overeenkomstige titel in de Consuetudines compilatae (Van geoorloofde en ongeoorloofde contracten) overgenomen. Dit blijkt onder meer uit de versies B en C. De titel $V$ an geoirloefde ende ongeoirloefde contracten telt in beide gevallen elf artikels. Uiteindelijk zou deze titel tot 23 artikels in de definitieve versie worden uitgebreid. Een gelijkaardig verhaal verklaart de assimilatiegraad van vijftig procent welke ook de zevende titel omtrent panden en pandgoederen kenmerkt. Net zoals dit bij voornoemde titel 1 het geval was, is deze lage assimilatiegraad niet zozeer het gevolg van doorgevoerde wijzigingen binnen het geassimileerde materiaal, doch, het gevolg van latere toevoegingen. Paragrafen 2 en 3 vormen de basis van de titel en werden, zoals de oudste versie B laat zien, van meet af aan onttrokken aan het Antwerpse model. Paragraaf 1 (Bewillichde panden) werd later aan het geheel toegevoegd en bijgevolg minder eenzijdig naar het voorbeeld van de Consuetudines compilatae geconcipieerd. Dat de paragraaf aanwezig is in versie $\mathrm{H}$ betekent dat hij tussen 1617 en 1618 werd toegevoegd. De vierde en laatste paragraaf (Pandtgoeden) ontbreekt in de $\mathrm{H}$-versie en dit omdat hij pas in juni 1618 werd goedgekeurd en in het geheel werd geïntegreerd. ${ }^{658}$

Tegenover deze titels met een lage assimilatiegraad staan titels als IV.9 (betaling, bewijs en compensatie), IV.10 (brieven van respijt) en IV.11 (brieven van cessie). Deze laten zich opmerken door een uitzonderlijk hoog aantal geassimileerde artikels. Dat deze titels hun oorsprong kennen in de Consuetudines compilatae, blijkt eveneens uit de oudere inhoudstafels. Zo vormen de titels IV.10 en IV.11 in de C-versie nog één gezamenlijke titel, net zoals dit te Antwerpen het geval was met titel IV.17 (Van brieven van respijt oft unijtstel van betaelinge, ende van cessie). Ook titel IV.12 omtrent de preferentie is grotendeels gebaseerd op Antwerps gewoonterecht. Het originele zit hem zo goed als uitsluitend in de toegevoegde artikels binnen de derde paragraaf ( $V$ an die privilegie personel hebben). ${ }^{659}$

657 Omtrent voorgestelde modificaties, zie RHCL, Staten Overkwartier, 581, fol. 142; RHCL, Staten Overkwartier, 586 (katern 3); RHCL, Staten Overkwartier, 585 (katernen 34 tot en met 39).

${ }^{658}$ BERKVENS, VENNER en SPIJKERBOER, Gelderse Land- en Stadsrecht, XLVI. Cfr. RHCL, Staten Overkwartier, 588 (katern 4). De titel verschijnt hier samen met de opmerking dat hij nog niet door Brussel werd gezien of geapprobeerd.

${ }^{659}$ De wijzigingen doorgevoerd in titel 4.12, werden voorgesteld in RHCL, Staten Overkwartier, 585 (katern 39). 
Tot slot wil ik er nog op wijzen dat de tweede titel, sprekende van schepenbrieven, handschriften, namptisatie of handvulling, een samensmelting is van twee aparte titels uit de B- en de C-versie, met name de titels $V$ an schepenbrieven en $V$ an namptisatie of handvulling. Beiden werden op hun beurt onttrokken aan de titels IV.2 (Van schepene brieven ende handscbriften) en IV.14 (Van handvullinge oft namptisatie) in de Consuetudines compilatae. Vooral uit de B-versie blijkt dat beide titels annvankelijk letterlijk werden overgenomen. Later zouden ze echter samengevoegd en bewerkt worden waardoor de assimilatiegraad daalt tot drie kwart. De originaliteit die zo ontstaat, schuilt in de paragrafen 1 (Schepenebrieven ende baer cracht), 3 (Versueck van namptisatie ofte gerichtlicke erlegginge ende handtvuldinge) en 4 (Exceptiën tegens 't versueck van namptisatie ende bandtvuldinge). De assimilatie blijft echter compleet ten aanzien van de paragrafen 2 (Obligatiën oft handtschrifften, ende daerinne de clausule brenger's brieffs staet, ende haer cracht) en 5 (Vonnisse tot handtvuldinge ende wijder vervolch van der saecke ten principale). Opnieuw doet de analyse van dit vierde deel naast assimilatie ook receptie veronderstellen.

Deel V

...begrijpt die maniere van borgerlicke rechtsvoorderinge oft civile procedure.

Het burgerlijk procesrecht van deel V staat in schril contrast met de overige delen binnen het Gelderse Land- en Stadsrecht. De assimilatiegraad bedraagt er immers nul procent. Geen enkel van de 344 artikels werd letterlijk uit de Antwerpse Consuetudines compilatae overgenomen. Ook de opbouw in titels is geheel verschillend en bijgevolg uiterst origineel. Gezien het feit dat ook binnen de contouren van het ontwerp van 1564 het burgerlijk procesrecht reeds een voorname plaats bekleedde, meen ik te mogen veronderstellen dat dit vijfde deel een grotendeels eigen creatie is. ${ }^{660} \mathrm{De}$ invloed van de Antwerpse Consuetudines compilatae op dit proces is -zeker in vergelijking met de overige delen- minimaal geweest. Ik heb reeds in de eerste paragraaf van dit hoofdstuk er op gewezen dat vermoedelijk de voorkeur uitging naar andere, externe compilaties, zoals bijvoorbeeld het Gulik-Bergse recht en het Landrecht van Zutphen.

Het oudste document dat deze materie behandelt en nog steeds wordt bewaard in het archief van de Staten van het Overkwartier is nummer ASO-582. ${ }^{661}$ De opbouw ligt grotendeels in de lijn van wat de B-versie ons leert. De definitieve versie ziet er uit zoals tabel 2.6 laat zien.

${ }^{660}$ Wat het ontwerp van 1564 betreft, denk ik onder meer aan titel 1 (Wie die gerichten sych halden sullen), titel 2 (Kontschafften thoe voeren), titel 3 (Kuntschappen in tegenwordicheit beider parthien thoe verhoeren), titel 4 (Welche personen nyet tuigbair), titel 8 (Van kommer und dagonge), titel 10 (Van pyndongh und pantkerongh), titel 11 (Hoeffuairt oder appellatie), etc. Cfr, infra, bijlagen, bijlage 5, Inhoudsopgaven van vier voorontwerpen van het Gelderse Land-en Stadsrecht.

${ }_{661}$ RHCL, Staten Overkwartier, 582. 
Tabel 2.6 De opbouw van deel $V$ van het Gelderse Land- en Stadsrecht

\begin{tabular}{|c|c|c|}
\hline Titel & \multicolumn{2}{|c|}{ Paragraaf } \\
\hline \multicolumn{3}{|l|}{$5.1 V$ an verscheiden manieren van borgerlicke proceduren. } \\
\hline \multicolumn{3}{|l|}{5.2 Van ordinarisse rechtsvoorderinge. } \\
\hline \multicolumn{3}{|l|}{5.3 V an onvertogen rechtsgedinge oft rechtsvoorderinge. } \\
\hline \multirow{6}{*}{$5.4 V$ an commer, besett oft arrestrecht. } & $\$ 1$ & $\begin{array}{l}\text { Wanneer ende tegens wat persoenen men arrest oft } \\
\text { commerrecht magh gebruicken }\end{array}$ \\
\hline & $\$ 2$ & $\begin{array}{l}\text { Tot wat plaetsen men d'arresten magh doen, als te weeten } \\
\text { soewel te water als te landt, ende doer wat persoonen }\end{array}$ \\
\hline & $\$ 3$ & $\begin{array}{l}\text { In welcker gestalt oft maniere men d'arresten moet doen } \\
\text { ende de brueck van 't breken van dien }\end{array}$ \\
\hline & $\int 4$ & $\begin{array}{l}\text { Vervolgh op arresten ende in wat maniere 't selve gedaen } \\
\text { magh worden }\end{array}$ \\
\hline & $\$ 5$ & $\begin{array}{l}\text { Ontset van arresten ende lichtinge derselver onder cautie } \\
\text { oft versekerheit }\end{array}$ \\
\hline & $\$ 6$ & $\begin{array}{l}\text { Vonisse op arresten ende den effect van dien, 't sij dat die } \\
\text { behoirlick oft onbehoirlick sijn gedaen ende vervolght oft } \\
\text { niet }\end{array}$ \\
\hline \multicolumn{3}{|l|}{$5.5 V$ an pandinge oft peindinge. } \\
\hline \multicolumn{3}{|l|}{5.6 Van voeghtgedinge. } \\
\hline \multirow[b]{2}{*}{ 5.7 Van gericbtelicke dagementen ende uuytblijven van partijen. } & $\$ 1$ & Gerichtlicke dagementen \\
\hline & $\$ 2$ & $\begin{array}{l}\text { Uuytblijven van partijen 't sij versuymelick ofte } \\
\text { versmaedelick. }\end{array}$ \\
\hline \multicolumn{3}{|l|}{$\begin{array}{l}5.8 \text { Van procuruers oft voorspreeckers, volmechtige ende } \\
\text { voirmunders. }\end{array}$} \\
\hline \multirow{4}{*}{$\begin{array}{l}\text { 5.9 Van 't commen van partijen voor recht, ende des aenleggers } \\
\text { aenspraecke ende versuecken. }\end{array}$} & $\$ 1$ & Aenspraeck mit die bescheiden daertoe dienende \\
\hline & $\$ 2$ & $\begin{array}{l}\text { Versueck van cautie oft versekeringe voor 't gewijsde, } \\
\text { verkiesinge van woonplaetse, ende stellinge van volmacht } \\
\text { oft voirspraeck. }\end{array}$ \\
\hline & $\$ 3$ & $\begin{array}{l}\text { Versueck van eidt de calumnia oft gefehrdt ende van } \\
\text { antwoorden bie kennen ofte ontkennen onder denselven } \\
\text { eidt, ende merckelick op schrifftelick bescheidt staende tot } \\
\text { bandvullinge }\end{array}$ \\
\hline & $\$ 4$ & Versueck op attentaet \\
\hline \multirow{3}{*}{$\begin{array}{l}5.10 \text { Van des verweerders exceptiën oft inreden ende } \\
\text { verantworden, versuecken ende wedereisch. }\end{array}$} & $\$ 1$ & Exceptiën oft inreden ende verantworden \\
\hline & $\$ 2$ & $\begin{array}{l}\text { Versueck van besichtinge van het strijdigh goet ende van } \\
\text { warhant oft wahrschap }\end{array}$ \\
\hline & $\$ 3$ & Wederheisch oft reconventie \\
\hline \multicolumn{3}{|l|}{$\begin{array}{l}5.11 V \text { an 't voorder beley oft bedinge van der sake ende } \\
\text { intitulatie oft benoeminge van schrifturen. }\end{array}$} \\
\hline \multicolumn{3}{|l|}{$5.12 V$ an konden ene verhoor deselver. } \\
\hline \multicolumn{3}{|l|}{5.13 Van brieffelicke schijn ende bescheit ende liggende konden. } \\
\hline \multicolumn{3}{|l|}{$5.14 V$ an eidt. } \\
\hline \multicolumn{3}{|l|}{$\begin{array}{l}5.15 \text { Van oepeninge van konden, straeff oft wedersegginge ende } \\
\text { verantwordinge derselver, ende sluytinge in der sake. }\end{array}$} \\
\hline \multirow{5}{*}{5.16 Van vonnissen. } & $\$ 1$ & $\begin{array}{l}\text { 't Wijsen van vonnissen 't sij eindeling oft bie } \\
\text { tusschenspreeken }\end{array}$ \\
\hline & $\$ 2$ & Costen, schade, interesten, ende vruchten van 't gewijsde \\
\hline & $\$ 3$ & $\begin{array}{l}\text { Beleeringe ende uuytspraecke van vonnisse ende revisie } \\
\text { derselver }\end{array}$ \\
\hline & $\$ 4$ & $\begin{array}{l}\text { Cantie voir de costen van de revisie ende voir d'executie } \\
\text { van 't gewijsde }\end{array}$ \\
\hline & $\$ 5$ & $\begin{array}{l}\text { Uuytspraecke van arbyters ofte segsluyden ende cracht } \\
\text { derselver }\end{array}$ \\
\hline \multirow[t]{2}{*}{$5.17 V$ an executiën oft uuytrichtinge van vonnissen. } & $\$ 1$ & $\begin{array}{l}\text { Tijdt tot voldoeninge ende uytrichtinge van vonnissen naer } \\
\text { de gesteltenisse ende aengewiesen claghte }\end{array}$ \\
\hline & $\$ 2$ & $\begin{array}{l}\text { Maniere van executie oft unytrichtinge van vonnissen van } \\
\text { schult op ruerlicke goederen }\end{array}$ \\
\hline
\end{tabular}




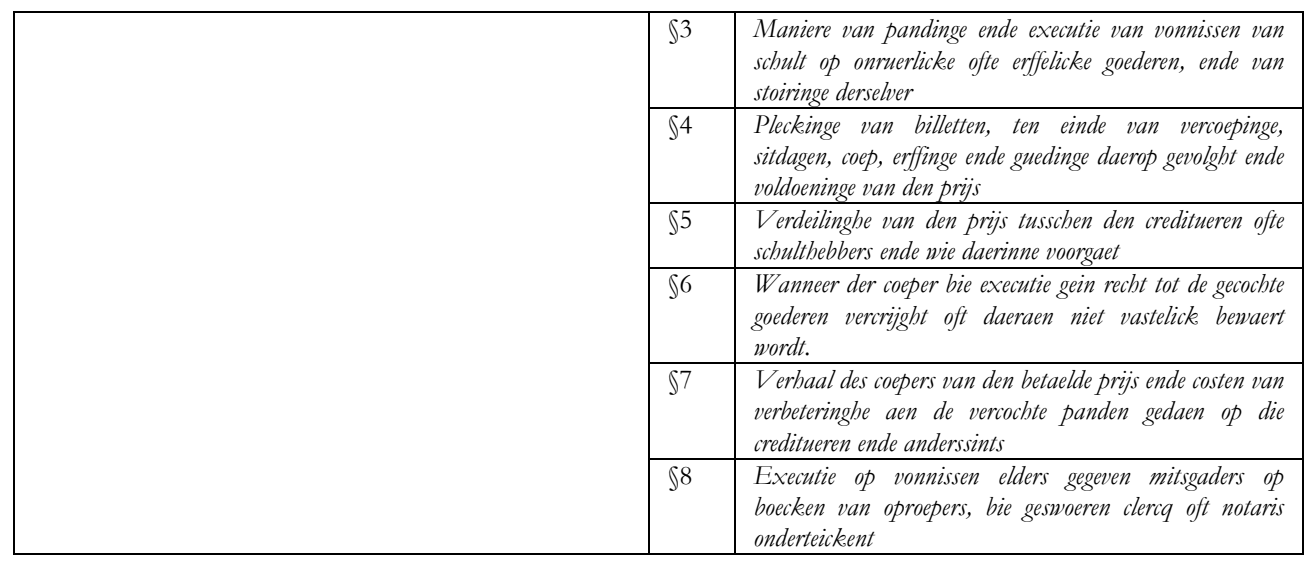

Toch mag de invloed van de Antwerpse Consuetudines compilatae niet te sterk geminimaliseerd worden. Er zijn namelijk aanwijzingen dat ook nu het Antwerpse model een zekere rol heeft gespeeld in de totstandkoming van het Roermondse burgerlijke procesrecht. Zo bestaat er een minimum aan artikels welke verraden dat angaande de inhoud van de artikels een inspirerende invloed is uitgegaan van het Antwerpse gewoonterecht. Om deze stelling kracht bij te zetten, geef ik hier het voorbeeld van het Overkwartierlijke artikel GLS V, 12, art 1 (Als partiën niet en bebben bekent, daermede die wederpartie haer solde connen behelpen, tot bewijs van haere gerechticheit, ende dat de sake in contrarie feiten ofte op bewijs gelegen is, soe worden sie ontfangen oft gewiesen ten toon om dieselve te bewijsen, 't waere bie getuygen, schijn ende bescheidt, eydt ofte anderssints, nae de gelegentheit van de sake), dat duidelijk op het Antwerpse artikel Comp V, 11, art 1 (Als ijmant eenich feijt heeft te thoonen, mach tselve doen bij getuijgen, bij schriftelijck bescheet, bekentenisse van partije, sicht oft claerbeijt van t'stuck, bij sijnen eedt, ende anderssints, gelijck de rechten dat toelaeten) werd geïnspireerd. ${ }^{662}$

Een verklaring voor het feit dat dit burgerlijk procesrecht in zulke mate gevrijwaard is gebleven van een te sterke Antwerpse invloed, schuilt in het regiospecifieke karakter van de civiele procedure. ${ }^{663}$ Dit blijkt meteen uit de eerste titel. Het deel opent met een overzicht van de vijf verschillende manieren van civiele procedure welke binnen het Overkwartier bestaan: ordinarische rechtsvordering, onvertogen rechtsvordering, commer of arrestrecht, de panding en het voogdgeding. ${ }^{.64}$ Laatstgenoemde procedure werd pas in 1617, na bevraging van de schepenbanken uit het Overkwartier, aan het ontwerp van het landrecht toegevoegd. ${ }^{665}$ Dit is net voor de derde fase van het

${ }^{662}$ Het Gelderse Land- en Stadsrecht van het Overkwartier Roermond 1620, A. M. J. A BERKVENS, G. H. A. VENNER en G. SPIJKERBOER ed. (Werken der Stichting tot Uitgaaf der Bronnen van het Oud-Vaderlandse Recht, 25), Arnhem, 1996, 296. Coutumes de la ville d'Anvers dites compilatae, IV, 640.

${ }^{663}$ Cfr. MONBALLYU, Zes eeuwen strafrecht, 350.

${ }^{664}$ Het arrestrecht krijgt veel aandacht binnen RHCL, Staten Overkwartier, 588.

${ }^{665}$ Cfr. BERKVENS, VENNER en SPIJKERBOER, Gelderse Land- en Stadsrecht, XXXIX. De reacties op de bevraging zijn bewaard gebleven in RHCL, Staten Overkwartier, 581, fol. 1-18. De 
homologatieproces, met name de visitatie van het ontwerp door de Geheime Raad. De voorlaatste procedure, de panding, daarentegen heeft wel altijd deel uitgemaakt van de ontwerptekst. Zelfs in het ontwerp van 1564 telt deze titel (Van pyndongh und pantkerongh) zes artikels. In versie B zijn dit nog steeds dezelfde zes artikels. In de Hversie daarentegen is de inhoud ervan bijna verdrievoudigd. Ook in de moderne uitgave van Berkvens en Venner telt de titel zeventien artikels.

Tot slot wil ik nog wijzen op de positie van het procesrechtelijke deel binnen het geheel van het Gelderse Land-en Stadsrecht. Dat dit geen toeval is, blijkt uit een annotatie van Hendrik Uwens bij de reeds eerder vernoemde memorie opt beworpt van het landrecht. In de kantlijn stelt de kanselier het volgende voor: "De maniere va[n] rechtsvoirderinghe zoude ik ick stellen all het naest leste deel en [de] het leste deel zoude ick stellen vande maniere va[n] rechtsvoirderinghe in criminele zaken." Zoals later in dit boek nog uitvoeriger besproken zal worden, getuigt deze uitspraak van een uiterst humanistische zin voor systematisering. ${ }^{.66} \mathrm{Het}$ is de praktische uitwerking van de twee hoofdprincipes van de Franse systematicus van het juridisch humanisme, Hugo Doneau (1527-1591). Kort samengevat impliceren deze vooreerst een strikt onderscheid tussen materieel en formeel recht en vervolgens bepleiten zij dat het formele recht steeds volgt nà het materiële recht. Beide principes werden keurig toegepast op het Gelderse Land-en Stadsrecht. Uit de laatste paragraaf van dit hoofdstuk zal blijken dat ook deze ideeën hun weg naar het Overkwartier hebben gevonden via Hendrik Uwens en zijn exemplaar van de Antwerpse Consuetudines compilatae. ${ }^{667}$

\section{Deel VI}

... spreeckende van misbruycken ende misdaden ende die maniere van die te vervolgen.

Het zesde deel van het Gelderse Land- en Stadsrecht bevat zowel het materiële als het formele strafrecht. Hoewel beide delen in de Antwerpse Consuetudines compilatae steeds gescheiden zijn gebleven, is dit te Roermond nooit anders geweest. Uit de oudere inhoudstafels en concepten, blijkt dat dit strafrecht steeds in zijn geheel aan bod is gekomen. ${ }^{668}$ Wel bestaat er binnen het zesde deel een intrinsieke scheiding tussen het materiële strafrecht enerzijds (titels 6.1 en 6.2 ) en het strafprocesrecht anderzijds (titels 6.3, 6.4, 6.5, 6.6, 6.7, 6.8 en 6.9). Ongetwijfeld werd de inspiratie hiervoor geput uit de structuur van de Antwerpse Consuetudines compilatae. Zo gelijken de namen van de titels in de oudste versie B wel erg opvallend op de titelomschrijvingen in de Consuetudines compilatae. Bovendien ontbreekt ook in het ontwerp van 1564 elke referentie naar strafbare of criminele zaken. Wederom lijkt het me acceptabel enige mate van receptie te veronderstellen op basis van bovenstaande vaststellingen.

Het ontbreken van strafrechtelijke aangelegenheden in het ontwerp van 1564 wekt enigszins verbazing gezien de traditionele rol welke doorgaans gespeeld werd door het strafrecht binnen het costumiere veld en de Brabantse costume in het

uiteindelijke toevoeging vond plaats in katern 5 van RHCL, Staten Overkwartier, 588. Hier werd de titel in de marge naast de titel omtrent de panding toegevoegd.

${ }^{666}$ Cfr. infra, hoofdstuk 2, paragraaf 4.

${ }^{667}$ Cfr. infra, hoofdstuk 2, paragraaf 4.

668 Ook aangaande het strafrecht is de oudst, beschikbare versie de B-versie. 
bijzonder. ${ }^{669}$ Dat dit te Roermond niet zo was, blijkt tevens uit de hoge mate waarin het Overkwartierlijke strafrecht aan het Antwerpse model werd geassimileerd. Het staat maar liefst tweede in lijn na het verbintenissenrecht van het vierde deel. Maar liefst 61.2 procent van alle aanwezige artikels heeft een letterlijke equivalent in de Antwerpse Consuetudines compilatae. Dit impliceert dat slechts 90 van de 232 artikels, welke het deel in totaal telt, in zekere mate een originele invulling vertonen. Onderstaande tabel 2.7 geeft de spreiding van deze concordanties weer.

Tabel 2.7 De assimilatie aan Antwerps recht in deel VI van het Gelderse Land- en Stadsrecht

\begin{tabular}{|c|c|c|c|c|c|}
\hline Titel & $\begin{array}{c}\% \\
\% \\
(\text { titel })\end{array}$ & $\mathbb{S}$ & $\begin{array}{l}\text { Totaal aantal } \\
\text { artikels }\end{array}$ & $\begin{array}{c}\text { Aantal } \\
\text { concordanties }\end{array}$ & $\%(\mathbb{S})$ \\
\hline \multirow{7}{*}{$\begin{array}{l}6.1 \text { Van misbruicken staende tot kueren ende } \\
\text { bruecken ende van vervolgh derselver. }\end{array}$} & \multirow{7}{*}{40.9} & 1 & 6 & 2 & 33.3 \\
\hline & & 2 & 8 & 5 & 62.5 \\
\hline & & 3 & 5 & 0 & 0.0 \\
\hline & & 4 & 12 & 10 & 83.3 \\
\hline & & 5 & 15 & 12 & 80.0 \\
\hline & & 6 & 11 & 0 & 0.0 \\
\hline & & 7 & 14 & 0 & 0.0 \\
\hline \multirow{7}{*}{$6.2 \mathrm{~V}$ an misdaden daer lijffstraff toestaet. } & \multirow{7}{*}{66.1} & 1 & 3 & 3 & 100.0 \\
\hline & & 2 & 8 & 8 & 100.0 \\
\hline & & 3 & 11 & 10 & 90.9 \\
\hline & & 4 & 3 & 3 & 100.0 \\
\hline & & 5 & 20 & 4 & 20.0 \\
\hline & & 6 & 6 & 6 & 100.0 \\
\hline & & 7 & 10 & 6 & 60.0 \\
\hline $\begin{array}{l}6.3 \text { Van d'aentasten, vangen ende ondervraegen } \\
\text { van de misdadigers. }\end{array}$ & 50.0 & & 14 & 7 & 50.0 \\
\hline $\begin{array}{l}6.4 V \text { an ondersueck op swaere misdaden ende } \\
\text { vervolg tegens de verloopene misdadige. }\end{array}$ & 84.2 & & 19 & 16 & 84.2 \\
\hline $\begin{array}{l}6.5 \text { Van pijnigen ende scherper examinatie oft } \\
\text { ondervraeginge der gevangenen. }\end{array}$ & 91.3 & & 23 & 21 & 91.3 \\
\hline $\begin{array}{l}\text { 6.6 Van betichtinge ende gerichtlick vervolgh der } \\
\text { gevangenen ende vonnissen daerop gegeven. }\end{array}$ & 60.0 & & 15 & 9 & 60.0 \\
\hline $\begin{array}{l}6.7 \text { Van maniere van hem te suyveren off } \\
\text { t'ontschuldighen van befaemde oft beruchte } \\
\text { misdaden. }\end{array}$ & 100.0 & & 8 & 8 & 100.0 \\
\hline 6.8 V an vredelegging tusschen twistige persoenen. & 55.6 & & 9 & 5 & 55.6 \\
\hline 6.9 Van soenen van dootslaghen. & 54.5 & & 11 & 6 & 54.5 \\
\hline
\end{tabular}

${ }^{669}$ Cfr. GILISSEN, "Rédaction des coutumes", 104-105. Hoewel het strafrecht aanvankelijk inderdaad door de gewoonte werd geregeld, zal de overheid dit rechtsgebied vanaf de twaalfde en dertiende eeuw steeds meer voor zich opeisen om de vrede binnen haar grenzen te bewaren. Alzo wordt het strafrecht in de vorm van stedelijke en landsheerlijke ordonnanties meer en meer 'gelexificeerd'. In de zestiende eeuw zorgen schriftelijke fixaties van het strafrecht, zoals de Constitutio Criminalis Carolina (1532) van Karel V en de Criminele Ordonnantiën van Filips II (1570), ervoor dat het procentuele aandeel van het strafrecht in de geredigeerde costumen vrij beperkt blijft. Wegens de voornoemde ordonnanties acht men het overbodig deze materie nogmaals te hernemen in de eigen costume. Monballyu daarentegen relativeert de inhoudelijke rol van de vorst op strafrechtelijk vlak. Hij wijst erop dat de landsheer in deze slechts sporadisch optrad en de vorstelijke ordonnanties niet meer dan hervormingsordonnantiën waren welke het bestaande strafrecht verduidelijkten of bijstuurden. Cfr. MONBALLYU, Zes eeuwen strafrecht, 37-38. 
Wat meteen in het oog springt, is dat er klaarblijkelijk een licht verschil bestaat tussen het materiële (52.3 procent) en het formele strafrecht (72.7 procent). Wat het materiële strafrecht betreft, is het logisch dat circa de helft van de artikels als origineel beschouwd kunnen worden. De oorsprong van het materiële strafrecht moet immers gezocht worden in -vaak regiogebonden- privileges, keuren of voorgeboden. Bovendien dekte deze 'strafwetgeving' slechts een klein deel van de totale strafrechtsbedeling, waardoor het grootste deel aan het oordeel van de rechters werd overgelaten, wat uiteraard het regiospecifieke karakter ervan bevorderde. Zelfs wanneer de invloed van de landsheer op het strafrecht via wetgeving gaat toenemen vanaf de zestiende eeuw, bleef dit grotendeels in handen van de strafrechters, aangezien dit wettenrecht het strafrecht slechts fragmentarisch dekte. ${ }^{670}$ Bijgevolg kenmerkt het materiële strafrecht zich door een specifiek en regiogebonden karakter en vandaar dat bijna de helft van de artikels niet letterlijk uit het Antwerpse strafrecht hoefde gekopieerd te worden. Opvallend is evenwel dat dit niet van toepassing is op het formele strafrecht. Hoewel ook het strafprocesrecht doorgaans in mindere mate volledig wettelijk geregeld was en er ook hier dus een grote vrijheid gelaten werd aan de strafrechter en zijn met de tijd mee evoluerende procedure, stel ik op basis van tabel 2.7 toch een hoge assimilatie vast. ${ }^{671}$ Dit gebrek aan originaliteit staat in schril contrast met wat ik heb kunnen vaststellen bij het Overkwartierlijk burgerlijk procesrecht, waar de assimilatie onbestaande bleek. ${ }^{672}$ Ondanks dit ruimere onderscheid tussen formeel en materieel strafrecht concentreren de concordanties en discordanties zich evenwel in zeer specifieke paragrafen.

De meest originele titel binnen het materiële strafrecht is de eerste titel welke de keuren ende breucken betreft. Dit is meestal zo.673 Ten aanzien van een drietal paragrafen is de assimilatie zelfs geheel onbestaande. Het betreft de paragrafen 3 (Beschadicheit van eins anders goet), 6 (Gevecht van twistige persoenen) en 7 (Andere brueckachtige saken ende vervolgh van bruecken). Desalniettemin heeft men zich voor de paragrafen 4 en 5 , omtrent laster, smaad en overlast aangedaan aan ambtenaren en andere individuen, toch aan het Antwerpse model gespiegeld. Zeer waarschijnlijk betreft het hier niet alleen assimilatie, maar tevens receptie. Deze conclusie trek ik omwille van het feit dat ik geen overeenkomstige titels heb kunnen terugvinden in de oudere B-versie. ${ }^{674}$ Ook de overige titel 6.2, kent enkele paragrafen welke afwijken van het zogenaamde nietoriginele karakter van het Overkwartierlijke strafrecht. Het betreft de paragrafen 5 (Dootslagers, moordenaers, verdoenders van bunselven, ofte doot gevonden) en 7 (Dieven, roovers, brandtstichters, corenbieters oft verdierders). Ook zij maken dat het materiële strafrecht meer origineel is dan het formele strafrecht. Binnen de overige paragrafen van titel 6.2 is de assimilatie opnieuw dominant.

Ook binnen de strafprocesrechtelijke titels scheert de assimilatiegraad opnieuw hoge toppen. Gezien het feit dat de strafrechtelijke procedure, op de arrestamenten na,

${ }^{670}$ MONBALLYU, Zes eeunen strafrecht, 63.

${ }^{671}$ MONBALLYU, Zes eeunen strafrecht, 349-350.

${ }^{672}$ Cfr. supra, hoofdstuk 2, paragraaf 2, Deel V.

${ }^{673}$ Dit is tevens het geval bij de compilaties van de steden Lier en Bergen op Zoom.

${ }^{674}$ RHCL, Staten Overkwartier, 583. 
weinig aandacht genoot binnen de traditionele costume, liggen deze hoge percentages in de lijn der verwachtingen. ${ }^{675}$ Conform het traditionele beeld kwam het arrestrecht ook reeds in het eerste ontwerp van 1564 aan bod. Het telt er drie artikels. Opnieuw wijst dit op een eigen traditie en bijgevolg verklaart het de lage assimilatiegraad van slechts vijftig procent van titel 6.3 (Van d'aentasten, vangen ende ondervraegen van de misdadigers). Wat de overige titels betreft, is de verleiding groot geweest zich te laten verleiden door het grondig en uitzonderlijk uitgewerkte Antwerpse strafprocesrecht. Dit is zeker gebeurd bij titels als die omtrent het onderzoek (6.4), de tortuur (6.5) en de purge of zuivering (6.7). ${ }^{676}$ Andere titels, zoals 6.3 (arresteren), 6.6 (vonnissen) en 6.9 (zoen) bevatten dan weer beduidend meer originele artikels. De frequentie waarmee deze rechtsfiguren gebezigd werden in de doorsnee Brabantse redacties, zet de veronderstelling, dat men ook binnen het Overkwartier op dit vlak een eigen traditie kende, kracht bij. ${ }^{677}$

Tot slot wil ik er nog op wijzen dat dit strafprocesrecht sinds de vroegste B-versie weinig wijzigingen heeft doorgemaakt, althans voor zover ik kan opmaken op basis van de beschikbare bescheiden in het archief van de Staten van het Overkwartier. Enkel de derde titel (Van ondersueck op swaere misdaden ende vervolg tegens de verloopene misdadige) ontbreekt in versie B. Verder is het onderscheid tussen materieel en formeel strafrecht nog niet doorgedrongen in deze fase van het redactieproces. Zo bevindt de titel omtrent de lijfstraffen zich te midden van het strafprocesrecht. Pas in de $\mathrm{H}$ versie is dit onderscheid definitief doorgevoerd. Ook voornoemde titel 6.3 is nu van de partij. Vermoedelijk gaat het hier wederom om materiële receptie van de zeventien artikels uit de Antwerpse titel VII.1 (V an ondersoeck ende vervolch van gevluchte misdaedige). Het is echter van belang te onthouden dat bij deze assimilatie niet noodzakelijk alle artikels werden overgenomen. Zo telt bijvoorbeeld de titel VII.6 (Van vrede) in de Consuetudines compilatae 27 artikels, waar de overeenkomstige titel in het Gelderse Landen Stadsrecht (titel 6.8) er slechts negen telt. ${ }^{678}$ Nogmaals, van blindelings kopiëren is nooit sprake geweest.

\footnotetext{
675 Omtrent de aandacht die de strafrechtelijke procedure genoot binnen de traditionele costume, cfr. supra, hoofdstuk 2, paragraaf 2, Deel I. Zie ook: GILISSEN, "Rédaction des coutumes", 104-105.

676 De Antwerpse titel 7.7 omtrent de oorvrede ontbreekt ook in Roermond niet. De rechtsfiguur zit vervat in de artikels 22 en 23 van titel 6.5 aangaande de pijnbank.

677 Zo heeft titel 6.3 omtrent het vangen van misdadigers zijn wortels in het ontwerp van 1564. Het betreft titel 8 (Van kommer en dagonge).

678 Ook de titel Van Soene werd van twintig tot elf artikels gereduceerd.
} 
PARAGRAAF 3

DE ANTWERPSE CONSUETUdinES COMPILATAE ALS PAARD VAN TROJE

Uit voorgaande paragraaf is gebleken dat, ondanks de waarschuwing dat ik enkel de plaatsen van assimilatie met zekerheid kan aanwijzen, er vermoedelijk ook heel wat receptie van Antwerps recht heeft plaatsgevonden. Onder meer de vergelijking met vroegere tekstversies heeft dit aangetoond. Verder is er het gesprek met de kanselier Uwens in de maand maart van het jaar 1615, alwaar men concludeerde dat het concept van Van Bree diende aangevuld te worden, met name ten aanzien van het huwelijksvermogensrecht en andere onderwerpen, welke in de ontwerptekst ontbreken. ${ }^{679}$ Men benadrukt evenwel dat wat men kopieert moet 'accorderen' met het eigen recht. Enkele dagen later is er reeds sprake van de overname van materie die conform de gewoonte en de billijkheid is. Dit laat al wat meer ruimte voor materiële receptie. Het betreft hier dus minimaal receptie van recht dat mogelijk wel materieel van kracht was, maar daarom niet formeel. Bovendien lijkt het me, gezien de uitbreiding van het gereformeerde Gelderse Land-en Stadsrecht, aanvaardbaar te stellen dat er ook heel wat nieuwe rechtsmaterie zijn weg naar het Overkwartier heeft gevonden. Bijgevolg lijkt het me niet onverantwoord om, opnieuw aan de hand van de Memorieboeken, een overzicht te geven de verschillende rechtsbronnen welke via deze costumiere acculturatie hun weg naar het Overkwartier hebben weten vinden. ${ }^{680}$ Hoofdstuk 1 heeft immers laten zien dat niet alle rechtsregels in de Consuetudines compilatae een zuivere Antwerpse en exclusief gewoonterechtelijke oorsprong kennen. Deze paragraaf hoopt dan ook een idee te geven van de potentiële gevolgen die de Consuetudines compilatae als Trojaans paard kunnen veroorzaken. Hierbij zal ik me opnieuw bedienen van de terminologie uit paragraaf 3 van hoofdstuk 1: romanisatie, lexificatie, unificatie, systematisering, verwetenschappelijking, rationalisatie, ...

${ }^{679}$ Cfr. BERKVENS, VENNER en SPIJKERBOER, Gelderse Land- en Stadsrecht, XXXIII.

680 Toch is ook hier voorzichtigheid geboden. Christopher Nessink (1695-1761), die in de achttiende eeuw het Overijselse gewoonterecht becommentarieerde, wees er in zijn voorrede immers op dat, ondanks het bestaan van zelfs letterlijk dezelfde costumiere regels in de costumen van verschillende plaatsen of regio's, dit niet noodzakelijk wil zeggen dat ook de achterliggende ratio identiek is: "Want schoon men in het verklaren van statutuire regten ofte gewoontens, wel ayn toevlugt neemt tot de regten en gewoontens van andere Provintien, en het geene door braave Mannen daar over is aangetekent, voor namentlyck zo die regten en gewoontens met die van dese Provintie over een komen; dat dog altoos met de uyterste omsigtigheyt moet geschieden, want wel de ene statuit woordelyk ende in den eersten opslag met een andere schynd over een te komen, daar dog deselve, ingezien aynde het waare ogemerk der Wetgeveren, ten eenemaal van elkeanderen verschillen." (C. NESSINK, Het landt-recht van Over-Yssel met eenige aanmerkingen en aantekeningen op het selve, door Mr. Christoffer Nessink, Campen, 1747, 'Voorreden'.) Hij waarschuwt de practici er dan ook voor om niet de commentaar van Johannes Schassert op het Veluwse gewoonterecht klakkeloos op het Overijselse recht toe te passen. (Cfr. S. J. FOCKEMA ANDREAE, "Recht en rechtsbedeling in Overijsel, gedurende het overgangstijdperk 1500-1630”, Tijdschrift voor Rechtsgeschiedenis, 17 (1941), 284. J. SCHASSERT, Commentatio ad Reformationem Velaviae, Harderwijk, 1719.) 


\section{Methode}

Om te achterhalen welke neveneffecten het gebruik van de Antwerpse Consuetudines compilatae teweeg heeft gebracht, heb ik dezelfde methode gehanteerd die ook aan de basis van het eerste hoofdstuk lag. Voor elk deel afzonderlijk zal ik eerst de aan de Consuetudines compilatae geassimileerde artikels opdelen in enerzijds artikels die teruggaan op artikels welke in de Consuetudines compilatae reeds oud waren, en dus ook deel uitmaakten van de Consuetudines impressae, waren, en anderzijds artikels die teruggaan op artikels welke nieuw waren toegevoegd tijdens de redactie van de Consuetudines compilatae. De onmiddellijke oorsprong van de eerste groep ligt dus in de Consuetudines impressae en dit zal ook hier zo worden aangegeven. De juridische basis van de tweede groep, teruggaand op de innovaties aangebracht in de Consuetudines compilatae, zal hier worden beschreven aan de hand van bijlage 2 op basis van de Memorieboeken, welke ook de basis vormde voor hoofdstuk 1. Om zowel de raadpleegbaarheid als de controleerbaarheid te vergemakkelijken, heb ik ook aan de tabel van bijlage 4 de primaire rechtsbronnen van de desbetreffende artikels nogmaals toegevoegd. Bij dit alles heb ik dezelfde indeling in categorieën behouden. Dit vergemakkelijkt eventuele vergelijkingen in de toekomst.

Alzo verdelen de artikels uit het Gelderse Land- en Stadsrecht zich, naar gelang hun origine, over drie hoofdcategorieën en vijftien subcategorieën. De eerste hoofdcategorie verzamelt de artikels welke origineel zijn. De overige twee groeperen artikels welke aan het Antwerpse recht werden geassimileerd. Deze worden door hoofdcategorie 2 en hoofdcategorie 3 opgedeeld in enerzijds artikels welke reeds in de Consuetudines impressae aanwezig waren en anderzijds artikels welke voor het eerst verschenen in de Consuetudines compilatae. De subcategorieën waarover de leden van de derde hoofdcategorie te verdelen zijn, zijn dezelfde als in hoofdstuk 1: Usus, wetgeving, Corpus Iuris Civilis, Corpus Iuris Canonici, vroegere redactiepogingen, rechtspraak, rechtsleer, extern gewoonterecht, Consuetudines compilatae, ratio en aequitas, specifieke redenen, derden, extern zee- en verzekeringsrecht en tot slot varia. ${ }^{681}$

In principe is het tevens mogelijk ook de artikels uit de hoofdcategorie 'Consuetudines impressae' over dezelfde subcategorieën te verdelen. Ook het traktaat dat stadssecretaris, Hendrik de Moy, over de gedrukte costumen schreef, geeft immers zoals de Memorieboeken- per artikel weer welke de primaire en secundaire bronnen ervan zijn. Desalniettemin heb ik van deze mogelijkheid afgezien. In de eerste plaats omdat het traktaat niet volledig is. Voor een aantal titels ontbreekt de artikelcommentaar, waardoor ik niet voor elke titel van het Gelderse Land- en Stadsrecht de bronnen van de Consuetudines impressae zou kunnen betrekken. ${ }^{682}$ Moge het een troost wezen, dat uit een kleinschalige steekproef is gebleken dat, indien ik het document wel in het onderzoek betrek, dit weinig grondige wijzigingen onder de bestaande verhoudingen tussen de primaire rechtsbronnen teweeg zou brengen. Hier komt nog bij dat voor het merendeel van de artikels uit de Consuetudines impressae naar de Consuetudines antiquae wordt verwezen als primaire rechtsbron. Rekening houden

${ }^{681}$ Cfr. supra, hoofdstuk 1, paragraaf 1, Methode.

${ }^{682}$ Het gaat hier onder meer om titel XLIII omtrent de onbejaerde kinderen en vermomboorde persoonen (101 artikels) en titel XLIV aangaande de emancipatie (3 artikels). 
met het traktaat zou bijgevolg neerkomen op enerzijds een bevestiging van de bestaande verhoudingen en anderzijds een verschuiving van het probleem naar een lager niveau, namelijk dat van de rechtsbronnen van de Consuetudines antiquae.

Ook binnen deze paragraaf zal ik in de eerste plaats elk deel afzonderlijk analyseren. Hopende dit zo overzichtelijk mogelijk te doen, heb ik ervoor geopteerd elk deel volgens het plan van een gelijkaardige structuur te beschrijven. In eerste instantie zal ik kort aangeven hoeveel van de geassimileerde artikels reeds in de Consuetudines impressae voorkwamen en hoe groot het aantal is dat ook te Antwerpen voor het eerst met de Consuetudines compilatae verschenen is. Vervolgens laat een tabel zien in welke mate deze artikels afkomstig van de Consuetudines compilatae -dus niet diegene welke reeds in de Consuetudines impressae aanwezig waren- hun oorsprong hebben in de verschillende subcategorieën welke reeds in het eerste hoofdstuk ontworpen en gedefinieerd werden. De mozaïek aan rechtsbronnen die ik op deze manier weet te construeren zal zich zonder twijfel kenmerken door dominante elementen en ondervertegenwoordigde factoren. Zij die, hetzij positief, hetzij negatief, het meest in het oog springen, zal ik uitvoeriger beschrijven. Aan het einde van elk blok komen tevens de belangrijkste, concrete voorbeelden van rechtsgeleerde, legislatieve, costumiere, jurisprudentiële en tertiaire bronnen aan bod, ongeacht het feit of deze nu ook in globo dominant waren of niet. ${ }^{683}$

$\mathrm{Na}$ deze 'partiële' beschrijving zal ik eveneens dieper ingaan op het aandeel van de verschillende categorieën op het geheel van het Gelderse Land-en Stadsrecht. Het globale palet dat hieruit te voorschijn komt, kan ik op zijn beurt gaan vergelijken met tabel 1.28 aangaande de Antwerpse Consuetudines compilatae. ${ }^{64}$ Uiteraard mag hieromtrent verwacht worden dat er sterke parallellen bestaan tussen beide tabellen. Het ene is immers een afkooksel van het andere. Dit geheel aan rechtsbronnen zal me bij wijze van conclusie in staat stellen uit te maken in hoeverre ik ook met betrekking tot het Overkwartierlijke recht van 1620 kan spreken van een mogelijke romanisatie, verwetenschappelijking, lexificatie, ... Uiteraard op voorwaarde dat er terecht van receptie gesproken mag worden.

\section{Deel I}

Het bestuurs-, personen- en familierecht van deel I kent een assimilatiegraad van 58.6 procent. Dit percentage correspondeert met 194 geassimileerde artikels op een totaal van 331. 119 hiervan of 61.3 procent kwam reeds voor in de Consuetudines impressae. Het overige deel, goed voor 75 artikels, behoorde tot de innovaties binnen de Consuetudines compilatae. Onderstaande tabel 2.8 geeft een overzicht van de mate waarin de verschillende bronnencategorieën bepalend zijn geweest voor de inhoud van de respectievelijke titels. De eerste drie rijen bevatten achtereenvolgens het totale aantal artikels per titel, het aantal onder hen welke origineel -in de zin van niet-

${ }^{683}$ Tot de 'belangrijkste' rechtsbronnen reken ik die rechtsbronnen welke aan de basis lagen van minstens twee artikels.

${ }^{684} \mathrm{Ik}$ zal enkel de posities van de verschillende bronnentypes in beide tabellen met elkaar vergelijken. Aangezien ik de percentages in beide tabellen niet op exact dezelfde wijze ben bekomen, kan ik hen niet met elkaar vergelijken. 
geassimileerd- zijn en ten derde het aantal concordanties of geassimileerde artikels. De waarden zijn hier evenals in de hiernavolgende tabellen absoluut. Al de overige rijen omvatten het procentuele aandeel van elke subcategorie binnen elke titel afzonderlijk. De percentages werden berekend op basis van het totaal aantal concordanties per titel.

Tabel 2.8 De juridische oorsprong van de geassimileerde artikels in deel I

\begin{tabular}{|l|c|c|c|c|c|c|}
\hline & Tot & $\mathbf{1}$ & $\mathbf{2}$ & $\mathbf{3}$ & $\mathbf{4}$ & $\mathbf{5}$ \\
\hline Totaal & $\mathbf{3 3 1}$ & 26 & 114 & 31 & 148 & 12 \\
\hline Origineel & $\mathbf{1 3 7}$ & 26 & 84 & 8 & 19 & 0 \\
\hline Concordanties & $\mathbf{1 9 4}$ & 0 & 30 & 23 & 129 & 12 \\
\hline & $\mathbf{0}$ & $\mathbf{0}$ & $\mathbf{0}$ & $\mathbf{0}$ & $\mathbf{0}$ & $\mathbf{0}$ \\
\hline Imp & $\mathbf{6 1 . 3}$ & 0.0 & 86.7 & 78.3 & 53.5 & 50.0 \\
\hline CICiv & $\mathbf{1 9 . 6}$ & 0.0 & 0.0 & 8.7 & 25.6 & 25.0 \\
\hline Usus & $\mathbf{9 . 3}$ & 0.0 & 6.5 & 13.0 & 10.1 & 0.0 \\
\hline S & $\mathbf{7 . 7}$ & 0.0 & 6.5 & 0.0 & 9.3 & 8.3 \\
\hline Comp & $\mathbf{5 . 7}$ & 0.0 & 3.2 & 4.3 & 4.7 & 25.0 \\
\hline RL & $\mathbf{5 . 7}$ & 0.0 & 0.0 & 8.7 & 4.7 & 25.0 \\
\hline WG & $\mathbf{3 . 6}$ & 0.0 & 6.5 & 0.0 & 3.9 & 0.0 \\
\hline 3 & $\mathbf{3 . 6}$ & 0.0 & 0.0 & 0.0 & 5.4 & 0.0 \\
\hline RS & $\mathbf{2 . 1}$ & 0.0 & 0.0 & 0.0 & 3.1 & 0.0 \\
\hline OAR & $\mathbf{2 . 1}$ & 0.0 & 6.5 & 0.0 & 1.6 & 0.0 \\
\hline eGR & $\mathbf{1 . 6}$ & 0.0 & 3.2 & 0.0 & 1.6 & 0.0 \\
\hline RA & $\mathbf{1 . 6}$ & 0.0 & 0.0 & 0.0 & 2.3 & 0.0 \\
\hline
\end{tabular}

Naast de Consuetudines impressae blijken ook het Romeinse recht evenals de Antwerpse Usus en de specifieke redenen van belang te zijn, hetzij eerder secundair. Hoewel geheel afwezig in titel 1.1 omtrent de stedelijke overheid en haar ambtenaren, zijn de Consuetudines impressae de hoofdleverancier voor alle overige titels. Naarmate het einde van het eerste deel nadert en hun belang stapsgewijs afneemt, neemt dat van het Corpus Iuris Civilis gestaag toe. ${ }^{685}$ Het Justiniaanse recht lijkt de lacune van de Consuetudines impressae op te vullen. De Antwerpse Usus van zijn kant houdt zich voornamelijk op binnen de derde en de vierde titel, respectievelijk omtrent de onderlinge rechten en plichten van ouders en kinderen en de voogdij. De overige categorieën zijn nauwelijks het vernoemen waard.

Andere, vaak alleenstaande, rechtsbronnen welke een vermelding verdienen, verdelen zich over de volgende subcategorieën: rechtsleer, wetgeving, derden, rechtspraak en extern gewoonterecht. ${ }^{686}$ De rechtsleer omvat auteurs als de Fransen Pierre Cousteau en Barthélemy de Chasseneuz, de Italiaanse commentator Bartolo da Sassoferrato, de Spanjaard Juan Garzia de Saavedra en de Nederlandse juristen Nicolas Everaerts en Joost de Damhouder. Hun invloed beperkt zich echter tot één enkel artikel. De wetgeving daarentegen concentreert zich binnen het rechtsgebied van de voogdij. Deze is voornamelijk stedelijk van aard. Er is de Antwerpse ordonnantie van 1496 die

685 Ook de assimilatiegraad van de verschillende titels evolueert op eenzelfde manier. Naarmate ik het einde van het deel nader, neemt het percentage aan geassimileerde artikels toe.

${ }^{686} \mathrm{Ik}$ zal me in dit tweede hoofdstuk beperken tot een uiterst summiere omschrijving van de waargenomen rechtsbronnen. Zij werden immers reeds uitvoerig beschreven in paragraaf 2 van hoofdstuk 1. 
de organisatie van de weeskamer regelde en de Brusselse ordonnantie op't stuck van de weeskinderen (1445). Ook binnen de categorie der derden nemen de weeskamer en haar leden, zowel de weesmeesters als de graphyarii, het voortouw. De rechtspraak van zijn kant kenmerkt zich uitsluitend door verwijzingen naar interne, Antwerpse jurisprudentie. Het externe gewoonterecht wordt op zijn beurt gedomineerd door de costumen van Gent (1563) en verscheidene Franse coutumes die door Pierre Guenoys werden verzameld in zijn Conférence des coutumes (1596). Wanneer oudere, Antwerpse redactiepogingen hun weg naar het Overkwartier vinden, betreft het bijna uitsluitend de Consuetudines antiquissimae. Slechts één maal gaat het om het Keurboeck.

Deel II

Het goederenrecht van deel II kent een assimilatiegraad van 56.9 procent. Dit percentage correspondeert met 169 geassimileerde artikels op een totaal van 297. 136 hiervan of 80.5 procent kwam reeds voor in de Consuetudines impressae. Het overige deel, goed voor 33 artikels, behoorde tot de innovaties binnen de Consuetudines compilatae. Het valt meteen op dat de Consuetudines impressae van groter belang zijn geweest ten aanzien van dit goederenrecht dan ze dat waren ten aanzien van het bestuurs-, personen- en familierecht in deel I. Dit is in de eerste plaats te wijten aan de bestuursrechtelijke titel 1.1 uit deel I, waar de Consuetudines impressae geen rol hebben gespeeld en deels ook aan de titels 1.4 (voogdij) en 1.5 (ongehuwde vrouwen) alwaar de gedruckte costuymen met moeite de kaap van vijftig procent halen. Daar wordt het Romeinse recht aanzienlijk sterker. Wat de vijfde titel betreft, dient ook de categorie van artikels op basis van andere artikels uit de Consuetudines compilatae vermeld te worden. Hoezeer het procentuele belang van de Consuetudines compilatae binnen dit tweede deel ook moge toenemen, ik moet erop wijzen dat het hier in totaal slechts 33 artikels betreft, waar dit er met betrekking tot deel I nog 75 waren. Onderstaande tabel 2.9 geeft een overzicht van de mate waarin de verschillende bronnencategorieën bepalend zijn geweest voor de inhoud van de respectievelijke titels uit het tweede deel.

Tabel 2.9 De juridische oorsprong van de geassimileerde artikels in deel II

\begin{tabular}{|l|c|c|c|c|c|c|c|}
\hline & Tot & $\mathbf{1}$ & $\mathbf{2}$ & $\mathbf{3}$ & $\mathbf{4}$ & $\mathbf{5}$ & $\mathbf{6}$ \\
\hline Totaal & $\mathbf{2 9 7}$ & 13 & 64 & 39 & 42 & 108 & 31 \\
\hline Origineel & $\mathbf{1 2 5}$ & 13 & 11 & 36 & 27 & 25 & 16 \\
\hline Concordanties & $\mathbf{1 7 2}$ & 0 & 53 & 3 & 15 & 83 & 15 \\
\hline & $\mathbf{0}$ & $\mathbf{0}$ & $\mathbf{0}$ & $\mathbf{0}$ & $\mathbf{0}$ & $\mathbf{\%}$ & $\mathbf{\%}$ \\
\hline Imp & $\mathbf{8 0 . 5}$ & 0.0 & 71.7 & 100. & 86.7 & 86.7 & 66.7 \\
\hline WG & $\mathbf{7 . 1}$ & 0.0 & 18.9 & 0.0 & 0.0 & 0.0 & 13.3 \\
\hline S & $\mathbf{5 . 3}$ & 0.0 & 13.2 & 0.0 & 0.0 & 1.2 & 6.7 \\
\hline 3 & $\mathbf{4 . 1}$ & 0.0 & 0.0 & 0.0 & 6.7 & 4.8 & 13.3 \\
\hline Usus & $\mathbf{3 . 0}$ & 0.0 & 1.9 & 0.0 & 0.0 & 4.8 & 0.0 \\
\hline OAR & $\mathbf{3 . 0}$ & 0.0 & 0.0 & 0.0 & 13.3 & 3.6 & 0.0 \\
\hline RA & $\mathbf{3 . 0}$ & 0.0 & 3.8 & 0.0 & 0.0 & 3.6 & 0.0 \\
\hline CICiv & $\mathbf{2 . 4}$ & 0.0 & 3.8 & 0.0 & 6.7 & 2.4 & 0.0 \\
\hline Comp & $\mathbf{1 . 8}$ & 0.0 & 1.9 & 0.0 & 0.0 & 2.4 & 0.0 \\
\hline eGR & $\mathbf{0 . 6}$ & 0.0 & 1.9 & 0.0 & 0.0 & 0.0 & 0.0 \\
\hline
\end{tabular}

De tabel laat zien dat er naast de Consuetudines impressae weinig ruimte wordt gelaten aan de overige types van rechtsbronnen. Door de band genomen overstijgt het 
procentuele aandeel ervan nauwelijks de vijf procent. Enkel de bronnen van legislatieve aard zijn goed voor zeven procent. Op het eerste gezicht kan de invloed van deze overige types dan ook nauwelijks onderschat worden. Dit is echter onjuist. Ook achter de Consuetudines impressae gaan immers tal van andere rechtsbronnen schuil. ${ }^{687}$

Gezien de beperkte invloed op globaal vlak, lijkt het me bijgevolg raadzaam in te zoomen op het niveau van de afzonderlijke titels. Dat deze redenering nauwelijks steek houdt, blijkt uit het minimum aan verrassingen waarmee ik geconfronteerd word. Bovendien gaat het slechts in vier gevallen om meer dan drie artikels. Er zijn de specifieke redenen in titel 2.2 (renten) en er zijn de erfscheiders als derden in de titels 2.5 en 2.6 omtrent erfdiensten en naburige rechten en het rechtelijk vervolg ervan. Ook de Usus is in titel 2.5 goed voor vier artikels. Verder bestaat titel 2.2 eveneens voor bijna twintig procent uit artikels welke een legislatieve oorsprong kennen. Het betreft in de eerste plaats plakkaten van vorstelijke origine, uitgevaardigd op 5 maart 1571 en 25 juni 1601. Eén keer komt ook het stedelijk statuut van de leveringe van 19 juni 1535 ter sprake. De enige keer wanneer extern gewoonterecht aan bod komt, betreft het de costumen van Gent (1563). Maar net als alle andere categorieën is deze, met een totaal aandeel van 0.6 procent het vermelden niet waard. Rechtsbronnen als de rechtsleer en de rechtspraak oefenen binnen dit tweede deel helemaal geen invloed uit, tenzij via de Consuetudines impressae.

Kortom, de Consuetudines impressae zijn duidelijk dominant binnen het goederenrecht. Een verklaring voor deze vaststelling kan gevonden worden in het feit dat ditzelfde goederenrecht binnen de Consuetudines compilatae, met 32.7 procent aan nieuwe artikels, tot de minst geïnnoveerde rechtsgebieden behoort. Anderzijds is er de meer bescheiden rol van de Consuetudines impressae binnen deel I van het Gelderse Land-en Stadsrecht, ondanks het feit dat deze rechtsmaterie ook binnen de Consuetudines compilatae tot de minst geïnnoveerde delen behoort. Een weinig innovatief karakter binnen de Consuetudines compilatae, garandeert bijgevolg niet noodzakelijk een dominant aandeel aan Consuetudines impressae binnen het Gelderse Land- en Stadsrecht. Mogelijk zegt dit iets over de relevantie van de innovaties binnen de Consuetudines compilatae voor het Gelderse Land- en Stadsrecht. Zo zou het hoger belang van de Consuetudines impressae voor het tweede deel van het Gelderse Land- en Stadsrecht kunnen betekenen dat de innovaties doorgevoerd in en toegevoegd aan de Consuetudines compilatae er als overbodig of misschien zelfs overdadig worden beschouwd.

Deel III

Het derde deel, sprekende van de manieren hoe goederen verkregen kunnen worden, kent een assimilatiegraad van 39.7 procent. Dit percentage correspondeert met 159 geassimileerde artikels op een totaal van 401. Op het burgerlijk procesrecht van deel $\mathrm{V}$ na, gaat het hier dan ook om het minst geassimileerde, en dus meest originele, deel binnen het Gelderse Land- en Stadsrecht. Opnieuw kwam het merendeel van de

${ }^{687}$ Cfr. GOTZEN, “De costumiere bronnen”, 109-110. SAA, Vierschaer, 21-23: DE MOY, Tractaat. 
overgenomen artikels reeds voor in de Consuetudines impressae. Het gaat hier om 57.7 procent of 92 artikels, waar de Consuetudines compilatae er 'slechts' 65 leveren. De rol van de Consuetudines impressae benadert opnieuw een niveau vergelijkbaar met dat in deel I. Het aandeel van de overige rechtsbronnen wordt in tabel 2.10 uiteengezet.

Tabel 2.10 De juridische oorsprong van de geassimileerde artikels in deel III

\begin{tabular}{|l|c|c|c|c|c|c|c|c|c|c|c|}
\hline & Tot & $\mathbf{1}$ & $\mathbf{2}$ & $\mathbf{3}$ & $\mathbf{4}$ & $\mathbf{5}$ & $\mathbf{6}$ & $\mathbf{7}$ & $\mathbf{8}$ & $\mathbf{9}$ & $\mathbf{1 0}$ \\
\hline Totaal & $\mathbf{4 0 1}$ & 39 & 58 & $\mathbf{7 5}$ & 29 & 27 & 63 & 57 & 13 & 17 & 23 \\
\hline Origineel & $\mathbf{2 4 2}$ & 12 & 36 & 48 & 15 & 22 & 43 & 55 & 2 & 1 & 8 \\
\hline Concordanties & $\mathbf{1 5 9}$ & 27 & 22 & 27 & 14 & 5 & 20 & 2 & 11 & 16 & 15 \\
\hline & $\mathbf{0}$ & $\mathbf{\%}$ & $\mathbf{\%}$ & $\mathbf{\%}$ & $\mathbf{\%}$ & $\mathbf{\%}$ & $\mathbf{\%}$ & $\mathbf{\%}$ & $\mathbf{\%}$ & $\mathbf{\%}$ & $\mathbf{\%}$ \\
\hline Imp & $\mathbf{5 7 . 7}$ & 55.5 & 59.1 & 81.5 & 50.0 & 20.0 & 45.0 & 100. & 27.3 & 87.5 & 40.0 \\
\hline Usus & $\mathbf{1 3 . 8}$ & 7.4 & 9.1 & 11.1 & 28.6 & 0.0 & 25.0 & 0.0 & 9.1 & 0.0 & 33.3 \\
\hline CICiv & $\mathbf{1 1 . 9}$ & 3.7 & 0.0 & 0.0 & 50.0 & 80.0 & 15.0 & 0.0 & 18.2 & 12.5 & 0.0 \\
\hline Comp & $\mathbf{8 . 2}$ & 18.5 & 4.6 & 0.0 & 0.0 & 0.0 & 20.0 & 0.0 & 9.1 & 0.0 & 13.3 \\
\hline OAR & $\mathbf{7 . 6}$ & 0.0 & 22.7 & 3.7 & 0.0 & 0.0 & 5.0 & 0.0 & 36.4 & 0.0 & 6.7 \\
\hline RL & $\mathbf{6 . 9}$ & 3.7 & 0.0 & 0.0 & 35.7 & 40.0 & 0.0 & 0.0 & 9.1 & 0.0 & 13.3 \\
\hline WG & $\mathbf{5 . 0}$ & 0.0 & 4.5 & 0.0 & 21.4 & 40.0 & 5.0 & 0.0 & 9.1 & 0.0 & 0.0 \\
\hline S & $\mathbf{5 . 0}$ & 18.5 & 0.0 & 3.7 & 0.0 & 0.0 & 10.0 & 0.0 & 0.0 & 0.0 & 0.0 \\
\hline RS & $\mathbf{2 . 5}$ & 3.7 & 0.0 & 0.0 & 7.1 & 0.0 & 0.0 & 0.0 & 0.0 & 0.0 & 13.3 \\
\hline eGR & $\mathbf{2 . 5}$ & 0.0 & 0.0 & 0.0 & 14.2 & 0.0 & 10.0 & 0.0 & 0.0 & 0.0 & 0.0 \\
\hline RA & $\mathbf{2 . 5}$ & 3.7 & 4.5 & 0.0 & 7.1 & 20.0 & 0.0 & 0.0 & 0.0 & 0.0 & 0.0 \\
\hline O & $\mathbf{0 . 6}$ & 0.0 & 0.0 & 0.0 & 0.0 & 0.0 & 0.0 & 0.0 & 9.1 & 0.0 & 0.0 \\
\hline Derden & $\mathbf{0 . 0}$ & 0.0 & 0.0 & 0.0 & 7.1 & 0.0 & 0.0 & 0.0 & 0.0 & 0.0 & 0.0 \\
\hline
\end{tabular}

In vergelijking met deel II is er nu meer ruimte gelaten voor andere rechtsbronnen dan de Consuetudines impressae. Zo overstijgt het aandeel van categorieën als het Romeinse recht en de Usus vlot de kaap van tien procent. Hierbij concentreert het Romeinse recht zich voornamelijk in titel 3.4 omtrent de prescriptie of het verloop van tijd en titel 3.5 inzake giften. ${ }^{688}$ Ook de Usus piekt in titel 3.4 (prescriptie), maar evenzeer in titel 3.6 (testamenten) en titel 3.10 (scheiding en deling van de erfenis en andere gemene goederen). Het aandeel van de overige rechtsbronnen blijft onder de tien procent. Toch vallen ook nu enkele specifieke concentraties op. Conform aan wat ik reeds eerder heb aangegeven, namelijk de band die er blijkt te bestaan tussen het Romeinse recht en de rechtsleer, vind ik ook nu beduidend meer rechtsgeleerde bronnen terug in de titels 3.4 (prescriptie) en 3.5 (giften), alwaar ook het Romeinse recht op prominente wijze aanwezig was. ${ }^{689}$ De groep auteurs waarnaar verwezen wordt is uiterst divers van aard en geen enkele onder hen slaagt er in de groep te domineren. ${ }^{690}$ Ook nu weer behoort Louis le Caron tot de meest opvallende figuren

${ }^{688}$ Absoluut gezien gaat het evenwel om niet meer dan zeven en vier artikels. Het feit dat deze absolute cijfers tot de hoogste waarden binnen de ganse tabel behoren, rechtvaardigt hun expliciete vermelding in de tekst.

689 Ook in andere titels komen rechtsgeleerde auteurs aan bod, het zij minder nadrukkelijk. Het gaat er om de Italianen Bartolo da Sassoferrato, Baldus de Ubaldis, Prospero Farinacci, Sebastiano Monticello en de Franse auteurs Charles Dumoulin, François Marc en Roland dela Valle.

${ }^{690}$ De groep bestaat uit de Nederlandse jurist Matthias Wesenbeeck en de Franse auteurs Pierre Coustau, Charles Dumoulin, Louis le Caron, Jean Papon, Pierre Rebuffi, François Grimaudet, Jean Favre, Bertrand d'Argentré, Pierre Guenoys en André Tiraqueau. Aan 
in het rijtje. Vier van zijn werken komen hier aan bod (Codex Henricianus, Responses du droit francois, Memorables Observations du droit françois, Coustumes de la ville, prévosté et vicomté de Paris). Titel 3.8 omtrent de anvaarding van de erfenis en de betaling van de schulden gaat in de eerste plaats terug op vroegere, Antwerpse redactiepogingen. Hierbij komen zelfs de Consuetudines impressae op een tweede plaats terecht. Zij moeten de fakkel laten aan het duo Consuetudines antiquissimae-Guldenboeck. Ook met betrekking tot het naastingrecht van titel 3.2 zijn deze compilaties -opnieuw met vier artikelsnadrukkelijk aanwezig. Ook de wetgeving behaalt een ogenschijnlijk hoog aandeel van veertig procent binnen de vijfde titel omtrent de donatio. Dit percentage is echter bedrieglijk omdat het in werkelijkheid slechts twee artikels vertegenwoordigt. Concreet gaat het om plakkaten van keizer Karel V (8 november 1541 en 14 mei 1544).

Maar ook de prominente Franse invloed die ik reeds met betrekking tot de Consuetudines compilatae had vastgesteld, laat zich hier gevoelen. Op legislatief vlak is er de Codex Henricianus samengesteld door Barnabé Brisson (1531-1591) en becommentarieerd door Louis le Caron en wat de jurisprudentie betreft, zijn er de Franse casussen uit het oeuvre van René Choppin (De privilegiis rusticorum) en opnieuw Louis le Caron (Responses du droit françois) waarnaar verwezen wordt. Maar zoals ik reeds heb gewaarschuwd, mag men, gezien het feit dat het bij titel 3.5 slechts vijf concordanties betreft, de invloed van deze bronnen niet overschatten. Ook het externe gewoonterecht waarnaar verwezen wordt, is van Franse komaf. Het betreft evenwel slechts één artikel. Van derden is er deze keer geen sprake.

Deel IV

Deel IV verzamelt het contract- en handelsrecht, dat in globo voor maar liefst 71.3 procent (259.5 artikels) aan het Antwerpse model werd geassimileerd. Hiermee plaatst het zich aan de top van de rechtsgebieden met de hoogste assimilatiegraad. Opvallend is dat niet langer de Consuetudines impressae het voortouw nemen als leverancier van de gekopieerde artikels. ${ }^{691}$ De 127.5 artikels, goed voor 49.1 procent, die ook reeds in de gedrukte costumen aanwezig waren, volstaan hier niet voor. Het zijn de innovaties binnen de Consuetudines compilatae die, met 132 artikels of 50.9 procent, de leidersrol voor zich opeisen. Dit is volledig conform de logica gezien het feit dat dit contracten vooral handelsrecht pas in de Consuetudines compilatae zijn definitieve uitwerking en voltooiing kende. Bijgevolg kwamen vele van de concorderende artikels ook pas voor het eerst in de Consuetudines compilatae voor.

Italiaanse zijde zijn er Alessandro di Tartagni, Filippo Decio, Paulo di Castro en Andrea Alciato. Het overwicht van de Franse rechtsleer is manifest.

691 De Consuetudines impressae zijn voornamelijk in de titel 6 (bevelhebbers, facteurs en makelaars), titel 7 (pand en pandgoederen) en titel 8 (borgtochten) als bron van recht terug te vinden. 
Tabel 2.11 De juridische oorsprong van de geassimileerde artikels in deel IV

\begin{tabular}{|l|c|c|c|c|c|c|c|c|c|c|c|c|c|}
\hline & $\mathbf{T o t}$ & $\mathbf{1}$ & $\mathbf{2}$ & $\mathbf{3}$ & $\mathbf{4}$ & $\mathbf{5}$ & $\mathbf{6}$ & $\mathbf{7}$ & $\mathbf{8}$ & $\mathbf{9}$ & $\mathbf{1 0}$ & $\mathbf{1 1}$ & $\mathbf{1 2}$ \\
\hline Totaal & $\mathbf{3 6 4}$ & 23 & 40 & 50 & 53 & 14 & 21 & 45 & 38 & 25 & 15 & 10 & 30 \\
\hline Origineel & $\mathbf{1 0 4 . 5}$ & 11 & 14.5 & 21 & 14 & 3 & 6 & 20 & 2 & 2 & 2 & 1 & 8 \\
\hline Concordanties & $\mathbf{2 5 9 . 5}$ & 12 & 25.5 & 29 & 39 & 11 & 15 & 25 & 36 & 23 & 13 & 9 & 22 \\
\hline & $\mathbf{0}$ & $\%$ & $\%$ & $\%$ & $\%$ & $\%$ & $\%$ & $\%$ & $\%$ & $\%$ & $\%$ & $\%$ & $\%$ \\
\hline Imp & $\mathbf{4 9 . 1}$ & 41.7 & 72.6 & 51.7 & 71.8 & 36.4 & 6.7 & 48.0 & 63.9 & 34.8 & 7.7 & 33.3 & 40.9 \\
\hline Usus & $\mathbf{1 7 . 7}$ & 33.3 & 3.9 & 13.8 & 12.8 & 36.4 & 26.7 & 32.0 & 13.9 & 26.1 & 7.7 & 0.0 & 18.2 \\
\hline Comp & $\mathbf{1 2 . 7}$ & 0.0 & 27.5 & 27.5 & 0.0 & 36.4 & 0.0 & 16.0 & 5.6 & 21.8 & 7.7 & 0.0 & 9.1 \\
\hline WG & $\mathbf{1 1 . 2}$ & 33.3 & 15.7 & 0.0 & 2.6 & 0.0 & 13.3 & 0.0 & 0.0 & 17.4 & 69.2 & 55.6 & 0.0 \\
\hline CICiv & $\mathbf{1 0 . 8}$ & 8.3 & 0.0 & 6.5 & 2.6 & 9.1 & 20.0 & 20.0 & 8.3 & 13.0 & 30.8 & 0.0 & 22.7 \\
\hline S & $\mathbf{9 . 2}$ & 8.3 & 0.0 & 0.0 & 15.4 & 18.2 & 20.0 & 12.0 & 16.7 & 0.0 & 7.7 & 11.1 & 4.6 \\
\hline RA & $\mathbf{7 . 3}$ & 0.0 & 11.8 & 17.2 & 0.0 & 9.1 & 0.0 & 12.0 & 0.0 & 26.1 & 0.0 & 0.0 & 4.6 \\
\hline RL & $\mathbf{5 . 7}$ & 8.3 & 0.0 & 6.9 & 0.0 & 0.0 & 26.7 & 4.0 & 8.3 & 0.0 & 0.0 & 0.0 & 18.2 \\
\hline 3 & $\mathbf{3 . 9}$ & 8.3 & 0.0 & 6.9 & 0.0 & 18.2 & 6.7 & 8.0 & 0.0 & 0.0 & 7.7 & 0.0 & 4.6 \\
\hline RS & $\mathbf{1 . 9}$ & 0.0 & 0.0 & 0.0 & 2.6 & 0.0 & 13.3 & 0.0 & 0.0 & 0.0 & 0.0 & 11.1 & 4.6 \\
\hline OAR & $\mathbf{1 . 2}$ & 0.0 & 0.0 & 0.0 & 0.0 & 0.0 & 0.0 & 0.0 & 2.8 & 0.0 & 0.0 & 11.1 & 4.6 \\
\hline eGR & $\mathbf{0 . 4}$ & 0.0 & 0.0 & 0.0 & 0.0 & 9.1 & 0.0 & 0.0 & 0.0 & 0.0 & 0.0 & 0.0 & 0.0 \\
\hline
\end{tabular}

De spreekwoordelijke val van de Consuetudines impressae biedt echer heel wat mogelijkheden aan de andere rechtsbronnen. Geen van hen weet zich echter op te werpen als dominante invloed en bijgevolg wordt het machtsvacuüm gelijkmatig ingevuld door vier categorieën. Hierbij gaat de meeste aandacht uit naar de Antwerpse Usus, die met 17.7 procent de tweede in lijn wordt na de Consuetudines impressae. Het kwartet wordt vervolledigd door het Romeinse recht in de titels 4.6 (bevelhebbers, facteurs en makelaars), 4.7 (panden en pandgoederen) en 4.10 (brieven van respijt), de wetgeving in de titels 4.10 (brieven van respijt) en 4.11 (brieven van cessie) en in mindere mate ook in de titels 4.1 (bestendige en onbestendige contracten) en 4.9 (betaling, bewijs en compensatie), en tot slot de artikels welke het gevolg waren van de aanwezigheid van een ander artikel binnen het geheel van de Consuetudines compilatae. Deze laatste categorie concentreert zich voornamelijk in de titels 4.2 (schepenbrieven en namptisatie) en 4.3 (koop en koopmanschap) en in mindere mate ook in de titels 4.5 (gemeenschap van handel en onverdeelde goederen) en 4.9 (betaling, bewijs en compensatie). De voornaamste legislatieve bronnen die hier ter sprake komen zijn de procesrechtelijke Albertine Ordonnantie van de Raad van Brabant (1604) inzake titel 4.10 (brieven van respijt), en de plakkaten van Karel V van 7 maart 1537 en 20 oktober 1541 met betrekking tot titel 4.11 (brieven van cessie). Ten aanzien van titel 4.9 (betaling, bewijs en compensatie) is er het plakkaat van 25 juni 1601 en wat de eerste titel betreft is er sprake van de Codex Henricianus en het reeds voornoemde plakkaat van 1541. In de zesde titel tot slot komen ook de statuten van de Italiaanse stadstaat Genua (1589) aan bod. Van de bekende zee- en verzekeringsrechtelijke ordonnanties van de jaren 1551, 1563 en 1570 is er hier geen sprake. Het zee- en verzekeringsrecht ontbreekt immers zelf in het Gelderse Land-en Stadsrecht.

Hoewel de rechtsleer in globo slechts een aandeel vertegenwoordigt van 5.7 procent, is het aandeel ervan binnen de titels 4.6 (bevelhebbers, facteurs en makelaars) en 4.12 (preferentie), respectievelijk 26.7 en 18.2 procent, toch noemenswaardig. Ten aanzien van titel 4.6 is het Matthias Wesenbeeck en zijn Paratitla in Pandectis iuris civilis (1565) die het voortouw neemt. In de tiende titel omtrent de brieven van respijt, kom ik volgende namen tegen: Benvenuto Stracca (De Mercatura seu mercatore tractatus, 1553), 
Jacques Cujas (Observationum et emendationum, 1556-1595) en Antoine Favre (Codex Fabrianus, 1606). ${ }^{692}$ Benevens deze iuris periti is er weinig opvallends waar te nemen. De derden worden veruit gedomineerd door de Antwerpse magistraat en de jurisprudentie behelst enkel voorbeelden van Antwerpse rechtspraak. De vroegere redacties en het extern gewoonterecht zijn dan weer te beperkt in aantal om er te veel woorden aan vuil te maken.

\section{Deel VI}

Het straf- en strafprocesrecht van deel VI omvat in totaal 232 artikels, waarvan er 142 letterlijk aan de Antwerpse Consuetudines compilatae werden ontleend. Dit aantal correspondeert met een percentage van 61.2 procent. Net zoals dit reeds bij het verbintenissenrecht het geval was, zijn ook nu de innovaties van de Consuetudines compilatae belangrijker als rechtsbron dan de Consuetudines impressae. Het aandeel ervan is zelfs bijna dubbel zo groot. Slechts 52 artikels, goed voor een aandeel van 38 procent, kwamen reeds voor in de Consuetudines impressae, waar 90 artikels uitsluitend teruggaan op de Consuetudines compilatae. Ook nu kan dit verklaard worden aan de hand van het feit dat het strafrecht in Consuetudines impressae helemaal niet zo goed was uitgewerkt in vergelijking met de Consuetudines compilatae. Tabel 2.12 laat zien welke categorieën van deze leemte gebruik maken om zichzelf nadrukkelijker te profileren.

Tabel 2.12 De juridische oorsprong van de geassimileerde artikels in deel VI

\begin{tabular}{|l|c|c|c|c|c|c|c|c|c|c|}
\hline & $\mathbf{T o t}$ & $\mathbf{1}$ & $\mathbf{2}$ & $\mathbf{3}$ & $\mathbf{4}$ & $\mathbf{5}$ & $\mathbf{6}$ & $\mathbf{7}$ & $\mathbf{8}$ & $\mathbf{9}$ \\
\hline Totaal & $\mathbf{2 2 2}$ & 71 & 62 & 14 & 19 & 23 & 15 & 8 & 9 & 11 \\
\hline Origineel & $\mathbf{8 0}$ & 42 & 21 & $\mathbf{7}$ & 3 & 2 & 6 & 0 & 4 & 5 \\
\hline Concordanties & $\mathbf{1 4 2}$ & 29 & 41 & $\mathbf{7}$ & 16 & 21 & 9 & 8 & 5 & 6 \\
\hline & $\mathbf{0}$ & $\mathbf{0}$ & $\mathbf{0}$ & $\mathbf{0}$ & $\mathbf{\%}$ & $\mathbf{\%}$ & $\mathbf{\%}$ & $\mathbf{\%}$ & $\mathbf{\%}$ & $\mathbf{\%}$ \\
\hline Imp & $\mathbf{3 8 . 0}$ & 6.9 & 48.8 & 14.3 & 31.3 & 19.0 & 66.7 & 100.0 & 100.0 & 50.0 \\
\hline RL & $\mathbf{1 9 . 0}$ & 27.6 & 2.4 & 14.3 & 50.0 & 42.9 & 0.0 & 0.0 & 0.0 & 0.0 \\
\hline Usus & $\mathbf{1 8 . 3}$ & 3.4 & 4.8 & 57.1 & 25.0 & 66.7 & 11.1 & 0.0 & 0.0 & 0.0 \\
\hline WG & $\mathbf{1 6 . 9}$ & 24.1 & 21.9 & 0.0 & 0.0 & 23.8 & 11.1 & 0.0 & 0.0 & 33.3 \\
\hline CICiv & $\mathbf{1 6 . 9}$ & 10.3 & 19.5 & 0.0 & 12.5 & 42.9 & 22.2 & 0.0 & 0.0 & 0.0 \\
\hline OAR & $\mathbf{1 6 . 2}$ & 41.4 & 24.4 & 0.0 & 0.0 & 0.0 & 0.0 & 0.0 & 0.0 & 16.7 \\
\hline eGR & $\mathbf{9 . 9}$ & 24.1 & 7.3 & 0.0 & 0.0 & 19.0 & 0.0 & 0.0 & 0.0 & 0.0 \\
\hline 3 & $\mathbf{6 . 3}$ & 13.8 & 9.8 & 0.0 & 0.0 & 0.0 & 0.0 & 0.0 & 0.0 & 16.7 \\
\hline Comp & $\mathbf{5 . 6}$ & 3.4 & 9.8 & 0.0 & 12.5 & 4.8 & 0.0 & 0.0 & 0.0 & 0.0 \\
\hline CiCan & $\mathbf{3 . 5}$ & 0.0 & 0.0 & 0.0 & 31.3 & 0.0 & 0.0 & 0.0 & 0.0 & 0.0 \\
\hline RA & $\mathbf{1 . 4}$ & 0.0 & 0.0 & 0.0 & 0.0 & 9.5 & 0.0 & 0.0 & 0.0 & 0.0 \\
\hline S & $\mathbf{0 . 7}$ & 0.0 & 0.0 & 14.3 & 0.0 & 0.0 & 0.0 & 0.0 & 0.0 & 0.0 \\
\hline
\end{tabular}

Meer nog dan ooit tevoren bieden de minder ontwikkelde Consuetudines impressae mogelijkheden voor de overige types van rechtsbronnen. Net zoals in deel IV wordt ook hier de lacune gelijkmatig ingevuld door andere subcategorieën. Ditmaal gaat het om zes types. De lijst wordt aangevoerd door de rechtsleer, welke overigens nooit eerder van zulk groot belang is geweest. De opinio doctorum neemt maar liefst een vijfde van de 142 concordanties voor zijn rekening. In totaal gaat het om 27 artikels, welke zich grotendeels concentreren binnen de titels 6.1 (misbruiken staande tot keuren en

${ }^{692}$ De overige namen zijn slechts goed voor één artikel: Denis Godefroy, Joachim Mynsinger von Frundeck, Bartolo da Sassoferrato, Jean Bacquet, Diego Rodrigo Alvarado en Pierre Coustau. 
breuken), 6.4 (onderzoek naar zware misdaden) en 6.5 (tortuur). De meest invloedrijke auteurs blijken, naast de reeds meermaals voornoemde Franse jurist Louis le Caron (Memorables Observations du droit françois, Somme rural en Grand Coustumier de France), de Vlaamse rechtsgeleerde Filips Wielant (Praxis rerum criminalis) en de Italiaanse auteurs Prospero Farinacci (Praxis et theorica criminalis) en Giulio Claro (Sententiarum receptarum) te zijn. De overigen beperken hun aanwezigheid tot een minimum aan artikels. ${ }^{693}$ Deze vaststellingen liggen in de lijn van de verwachtingen. Ook in het zevende strafprocesrechtelijke deel van de Consuetudines compilatae was de rechtsleer uiterst prominent aanwezig.

Eenzelfde redenering verklaart de rol van de vroegere reactiepoging, de Consuetudines antiquissimae, als inspiratiebron. Ook in deel VI van de Consuetudines compilatae, omtrent het materiële strafrecht, waren zij veruit de belangrijkste bron van nieuw toegevoegde artikels. Met een procentueel aandeel van 16.2 procent binnen het Gelderse Land-en Stadsrecht zijn de Consuetudines antiquissimae omringd door drie andere rechtsbronnen welke een vergelijkbaar aandeel voor hun rekening nemen. Met name gaat het hier om het Romeinse recht in titel 6.5 (tortuur), de Antwerpse Usus in titel 6.3 (vangen en ondervragen van misdadigers) en wederom titel 6.5 (tortuur) en ten derde de wetgeving lato sensu. Deze laatste categorie houdt zich voornamelijk op in de titels 6.1 (misbruiken staande tot keuren en breuken), 6.2 (misdaden waarvoor lijfstraffen gelden) en 6.5 (tortuur). Gerangschikt volgens afnemend belang betreft het de volgende legislatieve documenten: het Landcharter van Brabant uit 1292, de Keyserlicke statuten Ordonantien, Costumen, ende Ghewoonten, ende bysonder elcker Stadt techten, principalijck den keyserlijcken landen aengaende samengebracht door Thomas Murner in 1519, de Constitutio Criminalis Carolina van keizer Karel V (1532) en de Blijde Inkomsten van achtereenvolgens Karel V en Filips $2 .{ }^{694}$ De spreekwoordelijke tweede rang wordt afgesloten door het externe gewoonterecht. Dit is voornamelijk terug te vinden in titel 6.1 (misbruiken staande tot keuren en breuken) en titel 6.5 (tortuur), en wordt net als in de Consuetudines compilatae- volledig gedomineerd door de costumen van Utrecht (1550). Ook de costume van Mechelen (1535) is nog goed voor twee artikels. Tot slot wil ik nog wijzen op de rol van de magistraat als derde. Hij toont zich in de titels 6.1 (misbruiken staande tot keuren en breuken), 6.2 (misdaden waarvoor lijfstraffen gelden) en 6.9 (zoen).

\section{Globaliter}

Aan het einde van deze paragraaf wil ik nog kort enkele globale tendensen toelichten, welke vast te stellen zijn op basis van het cijfermateriaal in de onderstaande tabel 2.13. De tabel stelt me bovendien in staat te controleren of -zoals ik reeds in de

${ }^{693}$ Het betreft de volgende namen: Luis de Peguera uit Spanje, de Fransmannen Pierre Guenoys en Pierre Grégoire, evenals Jacopo Menocchio en Egidio Bossi, beiden afkomstig van het Italiaanse schiereiland. Antoine Favre is van Savoie afkomstig.

${ }^{694}$ Andere, concrete voorbeelden van wettenrecht welke uiterst beperkt aan bod komen, zijn het keizerlijk plakkaat van 7 oktober 1531, de Spaanse Siete Partidas, de stijlordonnantie van de Raad van Brabant uit 1604 (Albertine Ordonnantie) en de stedelijke ordonnantie van de peyskamer van Antwerpen, daterend van 12 december 1509. 
inleiding op deze paragraaf aangaf- de verhoudingen binnen tabel 2.13 in de lijn liggen van de wijze waarop dezelfde bronnencategorieën zich met betrekking tot de innovaties in de Consuetudines compilatae verhouden (cfr. tabel 2.13). Dit is immers te verwachten gezien het feit dat de Consuetudines compilatae zulk een belangrijke inspiratiebron zijn geweest voor de redacteurs van het Gelderse Land- en Stadsrecht.

Tabel 2.13 De juridische oorsprong van de geassimileerde artikels per deel

\begin{tabular}{|l|c|c|c|c|c|c|c|}
\hline & I & II & III & IV & VI & Totaal & $\begin{array}{c}\text { Totaal /923.5 } \\
\text { concordanties (\%) }\end{array}$ \\
\hline Imp & 119 & 136 & 92 & 127.5 & 54 & 528.5 & $\mathbf{5 7 . 2}$ \\
\hline Usus & 18 & 5 & 22 & 46 & 26 & 117 & $\mathbf{1 2 . 7}$ \\
\hline CICiv & 38 & 4 & 19 & 28 & 24 & 113 & $\mathbf{1 2 . 2}$ \\
\hline WG & 7 & 12 & 8 & 29 & 24 & 80 & $\mathbf{8 . 7}$ \\
\hline Comp & 11 & 3 & 13 & 33 & 8 & 68 & $\mathbf{7 . 4}$ \\
\hline RL & 11 & 0 & 11 & 15 & 27 & 64 & $\mathbf{6 . 9}$ \\
\hline S & 15 & 9 & 8 & 24 & 1 & 57 & $\mathbf{6 . 2}$ \\
\hline OAR & 4 & 5 & 12 & 3 & 23 & 47 & $\mathbf{5 . 1}$ \\
\hline 3 & 7 & 7 & 0 & 10 & 9 & 33 & 3.6 \\
\hline RA & 3 & 5 & 4 & 19 & 1 & 32 & $\mathbf{3 . 5}$ \\
\hline eGR & 3 & 1 & 4 & 1 & 14 & 23 & $\mathbf{2 . 5}$ \\
\hline RS & 4 & 0 & 4 & 5 & 0 & 13 & $\mathbf{1 . 4}$ \\
\hline O & 1 & 0 & 1 & 0 & 0 & 2 & $\mathbf{0 . 2}$ \\
\hline
\end{tabular}

Logischerwijs voeren de Consuetudines impressae de lijst aan. Ik heb reeds in de hieraan voorafgaande, 'partiële' bespreking laten zien dat zij enkel in de delen IV en VI de Consuetudines compilatae moeten laten voorgaan als voornaamste primaire rechtsbron. In deel $\mathrm{V}$ worden ze volledig buiten spel gezet door de eigen verbeelding en andere costumen van omliggende regio's. Anderzijds bleken zij nergens zo dominant als in deel II. Niet voor niets behoort het Antwerpse goederenrecht uit de Consuetudines compilatae tot de minst geïnnoveerde delen van het geheel. Dat deze relatie zeker een rol speelt, blijkt des te meer uit de Overkwartierlijke delen welke teruggaan op de meest geïnnoveerde delen van de Consuetudines compilatae, met name het handels- en contractrecht van deel IV en het straf- en strafprocesrecht van deel VI. Te Antwerpen werden beide delen in de Consuetudines compilatae immers voor circa zeventig procent geïnnoveerd. Bijgevolg neemt de rol van de Consuetudines impressae binnen de hieraan geassimileerde delen van het Gelderse Land- en Stadsrecht af. De voedingsbodem werd immers gedecimeerd.

Wat de overige, meer gangbare rechtsbronnen betreft, zijn het enerzijds het Romeinse recht en anderzijds de Antwerpse Usus, die onder de geassimileerde artikels de toon zetten. ${ }^{695}$ Dat beide rechtsbronnen in beduidend mindere mate vertegenwoordigd zijn in deel II, ligt voor de hand. De overgrote meerderheid van de concordanties wordt er door de Consuetudines impressae voor hun rekening genomen.

695 Uit de prominente aanwezigheid van romeinsrechtelijke artikels blijkt nog maar eens hoezeer de optekening van de eigen landrechten, die grotendeels tot doel had het 'eigen' recht te beschermen, de invloed van vreemde elementen, zoals bijvoorbeeld het Romeinse recht, in werkelijkheid heeft vergroot. (Cfr. KEVERLING BUISMAN, “Actoren”, 198.) 
De resterende subcategorieën schommelen binnen de marges van vijf en negen procent. Het betreft de wetgeving, de artikels als gevolg van een andere artikel uit de Consuetudines compilatae, de rechtsleer, de specifieke redenen en de vroegere redactiepogingen. Om welke bronnen het hier concreet gaat, heb ik reeds in voorgaande blokken besproken. Hier beperk ik me tot de meer globale trends. Wat de wetgeving betreft, springt meteen de vorstelijke wetgeving binnen deel IV in het oog. Centraal staan de ordonnanties van 7 maart 1537 en 8 november 1541. Maar ook elders speelt het wettenrecht afkomstig van de landsheer een prominente rol. Ik denk aan de plakkaten van 14 mei 1544, 5 maart 1571 en 25 juni 1601. Dit alles staat in schril contrast met het aandeel van de wetgevende activiteiten van het Antwerpse stadsbestuur. Deze komen zo goed als uitsluitend in deel I aan bod. Hier is vooral een invloed waarneembaar van de Antwerpse, maar tevens Brusselse, ordonnanties betreffende de voogdij. Het meest leent het strafrecht van deel VI zich tot de assimilatie aan artikels uit de Consuetudines compilatae welke afkomstig zijn van vorstelijke wetgeving. Hier heb ik naast het Landcharter van Brabant uit 1292 en de Constitutio Criminalis Carolina van 1532, ook de Keyserlijke recbten en statuten van de hand van Thomas Murner en de Blijde Inkomsten van zowel Karel V als Filips II zien verschijnen. ${ }^{696}$ Zoals ik reeds in hoofdstuk 1 heb angegeven, is dit de logica zelve. Het centrale gezag gaat deze rechtsmaterie immers meer en meer voor zich opeisen. ${ }^{677}$ De Franse invloed, waarvan Grandgagnage reeds gewag maakte, laat zich gevoelen in de delen III en IV. ${ }^{698}$ Het betreft in de eerste plaats de Codex Henricianus, samengesteld door Barnabé Brisson (1531-1591) en becommentarieerd door Louis le Caron. Ook de statuten van Genua (1589) vinden via het handelsrecht in deel IV hun weg naar het Overkwartier.

Ook wat de rechtsgeleerde opinio doctorum betreft, kom ik bij het zesde deel terecht. Verhoudingsgewijs is haar aandeel hier het sterkst, met auteurs als Filips Wielant, en Louis le Caron op kop. Ook binnen de andere delen mag laatstgenoemde steeds als de meest voorname figuur uit het pak worden beschouwd. Ten aanzien van de nieuw toegevoegde artikels in de Consuetudines compilatae was dit niet anders en bijgevolg ligt de rol van zowel le Caron als Wielant dan ook voor de hand.

De vroegere redacties brengen me terug bij het strafrecht van deel VI, alwaar ze, opnieuw omwille van dezelfde reden als bij de rechtsleer, zeer nadrukkelijk aanwezig zijn. Het gaat dan ook in de eerste plaats om de Consuetudines antiquissimae. Desalniettemin zijn ze ook in deel III prominent aanwezig, waar, naast de Consuetudines antiquissimae, plots ook heel wat ruimte is voor het Guldenboeck. We zien hoe het oudste Antwerpse recht zijn intrede doet in Overkwartierlijke middens.

Wederom vloeit ook de opvallende positie van de categorie met specifieke redenen in deel IV voort uit de rol die dit type bekleedde binnen de Consuetudines compilatae. Met name het handelsrecht is nieuw en ongewoon en spreekt de creativiteit van de redacteurs aan.

${ }^{696}$ Omtrent de afwezigheid van de Criminele Ordonnantien van Filips II, cfr. supra, hoofdstuk 1, paragraaf 2, Deel VI.

${ }^{697}$ Cfr. supra, hoofdstuk 1, paragraaf 3, Lexificatie.

698 GRANDGAGNAGE, Influence de la législation civile française, 111. 
Het residu aan rechtsbronnen slaagt er niet in de drempel der noemenswaardigheid van vier procent te halen. Ik spreek hier over de derden, de compilaties van extern gewoonterecht en de rechtspraak. Ten aanzien van de derden onthoud ik vooral de magistraat en hoe zij ontbreken in deel III. De aanwezigheid van extern gewoonterecht laat mooi de wisselwerking zien tussen Frans, Gents, Mechels en Utrechts gewoonterecht enerzijds en het Gelderse Land-en Stadsrecht anderzijds. Het is voornamelijk het Utrechtse strafrecht, wat hoofdzakelijk in deel VI opduikt, dat verantwoordelijk is voor het totaal percentage van 2.5 procent. De minuscule invloed van de rechtspraak blijft vooral intern van aard. Er zijn de turben en de verwijzingen naar concrete Antwerpse casussen. De opvallende hoeveelheid an 'redelijkheid en billijkheid' als juridische oorsprong binnen deel IV is het gevolg van het buitenproportionele percentage dat deze categorie ook in het verbintenissenrecht van de Consuetudines compilatae behaalde. Opnieuw, dit is nieuw en ongewoon en vergt rationeel denken en specifieke redenen.

Bovenstaande vaststellingen zijn in feite de logica zelve. Wie in een vijver vol kabeljauw en een beetje zalm vissen gaat, heeft veel kans kabeljauw te vangen en een kleine kans op zalm. Hetzelfde geldt voor de redacteurs van het Gelderse Land- en Stadsrecht. De onderlinge verhouding tussen de verschillende categorieën rechtsbronnen is over het algemeen een afspiegeling van de wijze waarop diezelfde categorieën zich tot elkaar verhouden met betrekking tot hun aandeel binnen het geheel van innovaties in de Consuetudines compilatae. ${ }^{999}$ Onder de drie belangrijkste, formele rechtbronnen tref ik in beide situaties dezelfde subcategorieën aan: de wetgeving, de Antwerpse Usus en het Romeinse recht. Enkel de volgorde verschilt. Zo is de wetgeving minder doorslaggevend in het Gelders Land-en Stadsrecht dan het dat is in de Consuetudines compilatae. Ook de twee belangrijkste, materiële rechtsbronnen zijn in beide rangschikkingen dezelfde: de specifieke redenen en de artikels op basis van andere artikels uit de Consuetudines compilatae. En zowel te Antwerpen als te Roermond bevindt de rechtsleer zich onderaan de eerste helft van de rangschikking. Al de overige categorieën behoren zowel ten aanzien van de innovaties in de Consuetudines compilatae als met betrekking tot de concordanties uit het Gelderse Land-en Stadsrecht tot de hekkensluiters. Het enige noemenswaardige feit is dat het externe gewoonterecht er licht op vooruit is gegaan. Meer dan waar dan ook staan de redacteurs van het Gelderse Land-en Stadsrecht open voor het lokale recht van zowel naburige als verafgelegen regio's, steden en provincies.

${ }^{699}$ Tabel 1.28 in paragraaf 3 van hoofdstuk 1 liet zien dat de verschillende rechtsbronnen zich als volgt verhouden: Wetgeving (27\%), Usus (23\%), Specifieke reden (20\%), Romeins recht $(18 \%)$, Comp (18\%), Rechtsleer (13\%), Vroegere redacties $(9 \%)$, Derden $(8 \%)$, Ratio $(7 \%)$, Extern gewoonterecht (4\%), Rechtspraak (4\%), Canoniek recht (1\%). 
PARAGRAAF 4

STRUCTURELE ASSIMILATIE: DE SYSTEMATISERINGSDRANG VAN HET JURIDISCH HUMANISME

Aan het einde van dit tweede hoofdstuk wil ik nog kort ingaan op een ander deelaspect van het costumiere acculturatiefenomeen, met name de structurele assimilatie. Hendrik Uwens heeft namelijk niet alleen een overname van materieel, Antwerps recht teweeggebracht, ook structureel werd het nieuwe Roermondse ontwerp grotendeels geboetseerd naar het model van de Antwerpse Compilatae. Doordat de systematiek, volgens dewelke deze laatstgenoemde compilatie werd opgebouwd, een directe toepassing inhield van nieuwe, humanistische principes, kwam nu ook het Gelderse Land-en Stadsrecht onder invloed te staan van de typisch humanistische systematiseringsdrang. In concreto zal deze paragraaf een beeld geven van de wijze waarop deze humanistische verworvenheden hebben doorgewerkt in beide compilaties. Hierbij begin ik bij de Antwerpse redactiepogingen om vervolgens de invloed ervan op de redactie van het Overkwartier te beschrijven.

In 1960 organiseerde John Gilissen een colloquium te Brussel met als titel La rédaction des coutumes dans le passé et le présent. Hierin kwam onder meer het codificatieproces in de Nederlanden en Frankrijk aan bod, maar tevens werd er aandacht besteed aan redactiepogingen welke elders ter wereld (Punjab, de Afrikaanse kolonies, etcetera) werden ondernomen. Bij wijze van synthese stelde Gilissen het bestaan vast van een viertal manieren waarop het lokale gewoonterecht te boek gesteld kon worden: de empirische methode, een ordening volgens een systeem, de questionnaire en een redactie aan de hand van rechtsgeleerde literatuur. ${ }^{700}$ De eerste wijze van redigeren is gebleken de meest courante te zijn onder de private, costumiere redacties. Hierin ontbreekt elke logische ordening; de samensteller rangschikt naar willekeur die costumiere regels welke híj van belang acht.

Een tweede redactietype omvat de compilaties die werden samengesteld volgens een bepaalde systematiek. Hoewel men hierbij in de eerste plaats denkt aan het plan van de Codex Justinianus, heeft men zich hiervan nauwelijks bediend. ${ }^{701}$ Een ander mogelijk

700 GILISSEN, "Rédaction des coutumes. Essai de synthèse", 50-51. Met betrekking tot Frankrijk wil ik verwijzen naar het artikel van Filhol: FILHOL, "Rédaction des coutumes", 7374. De auteur blijft echter zeer zuinig met zijn uitspraken omtrent de structurering van de Franse coutumes. Omtrent de opbouw van de middeleeuwse coutumiers in onze streken, zie: G. VAN DIEVOET, Les coutumiers, les styles, les formulaires et les 'artes notariae' (Typologie des sources du Moyen Âge occidentale. 48), Turnhout, 1986, 33-36.

701 GILISSEN, "Rédaction des coutumes", 107. Omtrent de structuur van de systematische beschrijvingen van het particuliere recht in Italië, Spanje, Frankrijk en Portugal staat bij Hölthofer in Coing's Handbuch het volgende te lezen: “Als Gliederungsschema verwendet man neben solchen, die dem gemeinen Recht entlehnt sind, wie das Institutionensystem in dreiteiliger (personae-res-actiones) oder vierteiliger (personnes, biens, moyens d'acquisition, actions) oder modifizierter Ordnung (₹. B. Loisel mit seiner Hexatomie personae-res-contractus-feuda-actiones-crimina), auch ein dem droit coutumier eigentümliches dreiteiliges Aufbauprinzip (droits royaux, seigneuraux, particuliers)." Cfr. HOLTHÖFER, "Die Literatur zum gemeinen und partikularen Recht", 228. Wat betreft de systematische 
plan of systeem, kwam aan het daglicht door een onderzoek van Vanderlinden uit 1958 met betrekking tot de beslissende factoren die bepalend zijn geweest voor de wijze waarop het gewoonterecht in het graafschap Vlaanderen van de zestiende en zeventiende eeuw werd geredigeerd. De auteur beperkte zich hierbij tot een louter formeel aspect van het costumiere redactieproces, namelijk de structuur van de compilaties. Deze kon zowel door interne als externe factoren worden beïnvloed, waarbij de laatste de belangrijkste bleken te zijn. Het gaat hier onder meer om de invloed van bijvoorbeeld vroegere redacties van andere steden of regio's, die doorwerkten via het systeem van de hoofdvaart. Maar ook de centrale overheid oefende, al dan niet bewust, een sterke structuurbepalende invloed uit. Zo bleek dat heel wat redacteurs de opsomming van te redigeren rechtsgebieden in de herinneringsbrief van Karel V aan de Raad van Vlaanderen op 30 januari 1546 over als blauwdruk voor de indeling van hun eigen compilatie. ${ }^{702}$ Vanderlinden liet eveneens zien dat, ten gevolge van de rol van centrale instellingen als de Geheime Raad en de provinciale raden in de homologatieprocedure, de centrale overheid ook op inhoudelijk vlak een niet te verwaarlozen invloed uitoefende. Interne factoren zoals vroegere tekstversies bleken dan weer minder belangrijk te zijn als structuurbepaler. Het was bijgevolg niet noodzakelijk dat een vroegere tekst als model diende voor een latere redactie. Ook de specifieke sociale situatie van een regio of stad kon een sterke invloed uitoefenen op de uiteindelijke structuur. Zo zal de costumiere redactie van een handelsstad beduidend meer overeenkomsten- of contractrecht bevatten, dan de compilatie van een eerder agrarische regio. 703 Vanderlinden wijst er evenwel op dat een volledige en letterlijke overname van een structuur onbestaande was en dat de beïnvloeding zich vaak beperkte tot een bepaalde rechtsgebied. Bovendien kon hij voor een heel aantal ook geen beïnvloeding vaststellen. Vanderlinden benadrukt evenwel het voorbereidende karakter van zijn onderzoek en met deze paragraaf hoop ik dan ook te komen tot verdere inzichten in het thema van de structurele beïnvloeding. Wat Frankrijk betreft, stellen de rechtshistorici zich eerder zwijgzaam op omtrent dit aspect van het redactieproces.

beschrijvingen van het geleerde recht: cfr. HOLTHÖFER, "Die Literatur zum gemeinen und partikularen Recht", 131-137. Ten aanzien van de structuur van de particulierrechtelijke compilaties van de Nederlanden, staat er bij Söllner in Coing's Handbuch nauwelijks iets te lezen: cfr. SÖLLNER, "Die Literatur zum gemeinen und partikularen Recht", 553-557. Söllner beperkt zich grotendeels tot gemeen- en particulierrechtelijke mengvormen als de collatio en censura, welke meermaals volgens het drie- of vierdelig Institutensysteem werden opgesteld.

702 VANDERLINDEN, "Essai sur la structure des textes coutumiers", 276. Het gaat hier om de eerder kleinschalige redacties van Nevele (stad en land), Deinze, Ronse, Machelen-Olsene, Tielt, Loo, Waasland en Oudenaarde.

${ }^{703}$ Men denke bijvoorbeeld aan de uitzonderlijke hoeveelheid handelsrecht aanwezig in de Consuetudines compilatae van de Antwerpse handelsmetropool. Zie ook: GUYON, “Annotations de la coutume de Bordeaux", 300. 
Ook elders heb ik er nauwelijks iets over kunnen terugvinden. In het Handbuch van Coing heeft men vooral aandacht voor het Institutensysteem..$^{704}$

De overige twee redactietypes, waar Gilissen in zijn synthesewerk van spreekt, zijn de redactie op basis van een questionnaire, waarbij aan de hand van vraag en antwoord het costumiere recht te boek werd gesteld, en de redactie met behulp van rechtsgeleerde werken. Beide hebben echter weinig te maken met de vier Antwerpse redacties.

Ook andere types, welke door Gilissen over het hoofd werden gezien, zijn evenwel mogelijk. Zo werden de titels binnen de tweede redactie van de costumen van Deurne $(>1611)$ alfabetisch gerangschikt. ${ }^{705}$

Het empirisme te Antwerpen

Ook het Antwerpse stadsbestuur ontving op 24 maart 1546 een eerste herinneringsbrief van keizer Karel. Hierin stonden de te redigeren themata als volgt opgesomd: zoe wel in materie van jurisdictiën, successien, zoe wel van lenen als van erfgoeden, contracten van buwelycken, testamenten, duwairen, donatien ende andere contracten inter vivos, naederscape, preferentien, als in materie criminelle ende andere diergelycke, daer inne ghy pretendeert eenige costume vander plaetse te syne, ... ${ }^{706}$ Desondanks kan ik met betrekking tot de eerste Antwerpse redactiepoging, de Consuetudines antiquissimae van 1547, alleen maar vaststellen dat de invloed zo goed als onbestaande is geweest. Dit blijkt uit onderstaande tabel 2.14 .

Tabel 2.14 De inhoudstafel van de Consuetudines antiquissimae (1547)

\begin{tabular}{|l|l|}
\hline Nr. & Naam van de titel \\
\hline 1 & Jurisdictie ende administratie van justicien ter hoogher vierscharen ende int criem \\
\hline 2 & Keuren ende bruecken der stadt van Antwerpen \\
\hline 3 & Vanden Vrede \\
\hline 4 & Arrestementen \\
\hline 5 & Administratie van justicien int civile \\
\hline 6 & Scepenen brieven, contracten, etc. \\
\hline 7 & Van calengieringe ende naederschap \\
\hline 8 & Van erven, palen, erfscheydinghe, edificien, metselrien, tymmeraigen, etc. \\
\hline 9 & Vanden poorters van Antwerpen ende vanden ouden poorters ende ingesetenen rechten \\
\hline 10 & Weeskinderen \\
\hline 11 & Aengaende gehuwede persoonen ende buwelycke voorwaerden \\
\hline 12 & Van testamenten \\
\hline 13 & Van succesien, scheydingen ende deylinghen \\
\hline 14 & Prescriptie \\
\hline
\end{tabular}

${ }^{704}$ Cfr. HOLTHÖFER, "Die Literatur zum gemeinen und partikularen Recht", 131-137 en 228. De toegenomen aandacht voor systematisering van het particulierrechtelijke materiaal vanaf het einde van de zestiende eeuw was ook Keverling Buisman opgevallen met betrekking tot de het landrecht van Drente. De herziening van 1614 blijkt zijns inziens meer blijk te geven van een systematische indeling dan een op associatie gerichte indeling, zoals dat nog in de versie van 1608 het geval was. Cfr. KEVERLING BUISMAN, Mer 't is geen lantrecht, 20.

705 Coutumes du Kiel, de Deurne et de Lierre. G. DE LONGE ed. (Coutumes de Pays et Duché de Brabant. Quartier d'Anvers. 5), Brussel, 1875.

${ }^{706}$ Coutumes de la ville d'Anvers dites Antiquissimae, I, 92-94. 
Het merendeel van de traditionele rechtsgebieden kan men ook hier terugvinden, maar de volgorde uit de herinneringsbrief werd evenwel niet nagvolgd. Ook de tweede redactiepoging, de Consuetudines antiquae (1570-1571), stond onder geen enkele invloed van welke koninklijke ordonnantie ook, zelfs niet die van de hertog van Alva daterend van 13 maart 1570, welke tien dagen later te Antwerpen werd gepubliceerd. De commissie die verantwoordelijk was voor de totstandkoming van de Consuetudines antiquae had immers de opdracht gekregen dit te doen aan de hand van de tekst van de Consuetudines antiquissimae. Gotzen stelde vast dat verwacht werd dat dit grondig gebeurde; zowel vorm als inhoud moesten aanzienlijk verbeterd worden. ${ }^{707}$ Wanneer men beide inhoudstafels echter met elkaar vergelijkt, blijkt meteen dat de Consuetudines antiquae vanop de fundamenten van de Consuetudines antiquissimae werden opgetrokken. De Consuetudines antiquae mogen dan wel beduidend omvangrijker zijn, de basisstructuur werd nauwelijks gewijzigd. De tweede kolom uit tabel 2.15 laat duidelijk zien dat het patroon van de Consuetudines antiquissimae zo goed als helemaal werd gehandhaafd. Slechts twee titels werden van plaats verwisseld.

Tabel 2.15 De inhoudstafel van de Consuetudines antiquae (1570)

\begin{tabular}{|c|c|c|}
\hline Nr. & N708 & Titel \\
\hline 1 & & Vande officiers ende beure jurisdictien \\
\hline 2 & 1 & $\begin{array}{l}\text { Aengaende de jurisdictie van criminele ende andere saecken dependerende vande } \\
\text { booger vierschaeren ons genedichsten beeren des conincx als bertoge van } \\
\text { Brabandt }\end{array}$ \\
\hline 3 & & $\begin{array}{l}\text { Aengaende apprehensien ende betichtingen int generael, midtsgaders der punitien van delicten ende } \\
\text { des dyen aencleeft }\end{array}$ \\
\hline 4 & & Punitien \\
\hline 5 & & Ander procedueren en acten, die oock ter hooger vierschaeren moeten vervolcht ende gedaen worden \\
\hline 6 & & Vande oorvrede \\
\hline 7 & & Purgien \\
\hline 8 & & Emancipatien \\
\hline 9 & & Vervolg van arresten ter vierschaeren \\
\hline 10 & & Arresten ter vierschaeren \\
\hline 11 & 2 & Ceuren ende breucken der stadt van Antwerpen \\
\hline 12 & 3 & Vanden vrede \\
\hline 13 & & Vanden soene \\
\hline 14 & & Salarien vanden soene \\
\hline 15 & 4 & Arrestementen \\
\hline 16 & & Vanden fugitiven ende insolvente persoonen ende vande preferentie in beure goeden \\
\hline 17 & 9 & Vande poorters ende ingesetenen ende beure recbten (personae) \\
\hline 18 & $(9)$ & Buyten poorters (personae) \\
\hline 19 & & Uuytscryfbrieven (actiones) \\
\hline 20 & 5 & Der justicien ende judicature int civiele aenghaende ende tgene der selver \\
\hline
\end{tabular}

707 GOTZEN, "De costumiere bronnen”, 14.

708 Deze kolom omvat het nummer dat de overeenkomstige titel droeg in de voorgaande redactiepoging. In dit geval gaat het om de Consuetudines antiquissimae. 


\begin{tabular}{|c|c|c|}
\hline & & aencleeft \\
\hline 21 & 6 & Van contracten (obligationes) \\
\hline 22 & & Erffgevinghe \\
\hline 23 & & Erffrenten \\
\hline 24 & & Afdaeginge (actiones) \\
\hline 25 & & Leveringhe (actiones) \\
\hline 26 & & Amptmans brieven (actiones) \\
\hline 27 & & Hantschriften (obligationes) \\
\hline 28 & & Wisselbrieven (obligationes) \\
\hline 29 & & Contracten van asseurantien (obligationes) \\
\hline 30 & $7(16)$ & Van calaengieringe ende naerderschap (res) \\
\hline 31 & 8 & Van erffscheydinghe, servituten, ende des daeraene cleeft (res) \\
\hline 32 & 14 & Prescriptie (res) \\
\hline 33 & 11 & Van de rechten ende costuymen geboude persoonen aengaende (personae) \\
\hline 34 & 12 & Van testamenten (res) \\
\hline 35 & 13 & Van successien, scheydinghen ende deylingen (res) \\
\hline 36 & & Lyfrenten (personae) \\
\hline 37 & & Bastaerden (personae) \\
\hline 38 & & Vande tochteneers (res) \\
\hline 39 & 15 & $\begin{array}{l}\text { Van cessie, boemen die naer doude costuymen van Antwerpen pleecht te useren } \\
\text { eer dat daer op by ordonnantien van keyserlycke maiesteyt was by provisien } \\
\text { versien (obligationes) }\end{array}$ \\
\hline
\end{tabular}

Dit alles laat nogmaals zien dat niet alleen de centrale overheid, maar ook de vroegere redactiepogingen als structuurbepalende factor kunnen fungeren. Ook deze mogelijkheid werd door Gilissen over het hoofd gezien. ${ }^{709}$ Wat de opbouw betreft van zowel de Consuetudines antiquae als de Consuetudines antiquissimae, kan ik niet anders dan vaststellen dat er nauwelijks sprake is van structurering volgens een logisch plan. Ik ben dan ook geneigd beide compilaties eerder het label empirisch op te kleven; rechtstreeks wat betreft de Consuetudines antiquae, onrechtstreeks wat de Consuetudines antiquissimae betreft. De enige vorm van logica waar de compilaties blijk van geven, is de scheiding die er wordt gemaakt tussen het publiekrecht enerzijds en het privaatrecht anderzijds. Hierbij gaat het publiekrecht steeds vooraf aan het privaatrecht. ${ }^{710}$ Hoewel men dus niet kan spreken van een systematiek zoals die bijvoorbeeld in de Institutiones werd toegepast, zouden de samenstellers evenwel onrecht aangedaan worden indien ik louter het woord 'willekeur' in de mond zou nemen. Tot op zekere hoogte werden verwante onderwerpen immers bij elkaar geplaatst.

\section{Het bumanisme te Antwerpen}

Een breuk komt er met de totstandkoming van de Consuetudines impressae in 1582. Vanaf nu wordt er beduidend meer aandacht besteed aan het logisch ordenen van het te redigeren materiaal. In de eerste plaats blijft de hoofdverdeling tussen publiekrecht (titels 1 tot en met 23) en privaatrecht (titels 24 tot en met 72) behouden. Verder dan

${ }^{709}$ GILISSEN, "Rédaction des coutumes", 50-51.

${ }^{710} \mathrm{Bij}$ de Consuetudines antiquae loopt de breuklijn tussen titel 5 en titel 6. Bij de Consuetudines antiquissimae loopt deze cesuur tussen titel 16 en titel 17. 
dit reikt de verwantschap met de vorige redactie, de Consuetudines antiquae, evenwel niet. Op de titels betreffende het straf(proces)recht (titels 12 tot en met 23) na, zijn de Consuetudines impressae niet langer gemodelleerd naar het voorbeeld van hun voorganger. De opbouw werd aanzienlijk herdacht.

Tabel 2.16 De inhoudstafel Consuetudines impressae (1582)

\begin{tabular}{|c|c|c|}
\hline Nr. & $\mathbf{N}^{711}$ & Titel \\
\hline T 1-11 & 1 & $\begin{array}{l}\text { De rechterlijke inrichting } \\
1 \text { V ande jurisdictie } \\
2 \text { Van d'officiers ende heure jurisdictie, ende eerst vanden marckgrave } \\
3 \text { V anden Amptman } \\
4 \text { Van borgemeesteren ende schepenen } \\
5 \text { V ande laken-halle } \\
6 \text { Vande weesmeesters } \\
7 \text { Vande peysmaeckers } \\
8 \text { Vande watermeulen brugghe } \\
9 \text { Vande heerlickheyt vanden Kiele } \\
10 \text { Vanden syndicalen, diemen heet seynt-schepenen } \\
11 \text { Van't consulaet vande natie van Portugael } \\
\end{array}$ \\
\hline T 12-23 & $\begin{array}{l}4 \\
\\
6 \\
7 \\
11 \\
12 \\
13 \\
14 \\
\end{array}$ & $\begin{array}{l}\text { Strafrecht en strafprocesrecht (crimina }+ \text { actiones) } \\
12 \text { Vande hooghe vierschare, ende wat saecken men aldaer handelt } \\
13 \text { Van criminele saecken, ende wyen d'apprehensie ende d'actie toecomt } \\
14 \text { Vande scherpe examinatie oft torture } \\
15 \text { Vande forme van procederen ter vierscharen ende vande betichtinghen in } \\
\text { criminele saecken } \\
16 \text { Punitien van delicten ende des dyen aencleeft } \\
17 \text { Van bannissementen ende ballingen } \\
18 \text { Vanden oorvrede } \\
19 \text { Vande purge criminele } \\
20 \text { Van keuren ende breucken } \\
21 \text { Vanden vrede } \\
22 \text { Vanden soene } \\
23 \text { Salaris in't faict vanden soene }\end{array}$ \\
\hline T 24-35 & $\begin{array}{l}9 \\
26 \\
19\end{array}$ & 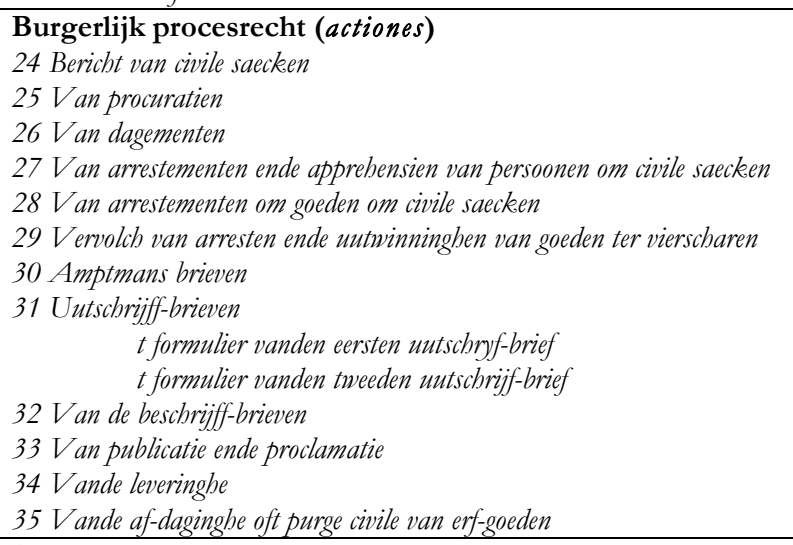 \\
\hline T 36-39 & & Personenrecht (personae) \\
\hline
\end{tabular}

711 Deze kolom omvat het nummer dat de overeenkomstige titel droeg in de voorgaande redactiepoging. In dit geval gaat het om de Consuetudines antiquae. 


\begin{tabular}{|c|c|c|}
\hline & $\begin{array}{l}17 \\
18 \\
17 \\
\end{array}$ & $\begin{array}{l}36 \text { Vanden staet ende condicie van persoonen } \\
37 \text { Vande binnen-poorters, tyy gheeedde oft gheboren } \\
38 \text { Vande buyten-poorters, t'sij gheboren oft gheeedde } \\
39 \text { Vande inghesetene }\end{array}$ \\
\hline $\mathrm{T} 40-45$ & $\begin{array}{l}8 \\
37\end{array}$ & $\begin{array}{l}\text { Familierecht (personae) } \\
40 \text { Vander issue ende pondt-penninghen } \\
41 \text { Vande recbten ghehoude persoonen aengaende } \\
\quad \text { Het Stadt Voordeel. } \\
42 \text { Van onghehoude vrouven } \\
43 \text { Van onbejaerde kinderen ende vermomboorde persoonen } \\
44 \text { Vande emancipatie } \\
45 \text { Van bastaerden }\end{array}$ \\
\hline T 46-48 & $\begin{array}{l}34 \\
35 \\
38\end{array}$ & $\begin{array}{l}\text { Erfrecht (res) } \\
46 \text { Van testamenten (res) } \\
47 \text { Van versterffenisse, scheydinghe ende deylinge (res) } \\
48 \text { Van tochteneers (res) }\end{array}$ \\
\hline T 49-56 & $\begin{array}{l}27 \\
29 \\
28\end{array}$ & $\begin{array}{l}\text { Handelsrecht (obligationes) } \\
49 V \text { ande vrij jaermercketen } \\
50 \text { Vande peerdemercten } \\
51 \text { Van coopmanschap } \\
52 \text { Van compaignie ende ghemeynschap van goeden } \\
53 \text { Van handt-schriften ende obligatien } \\
54 V \text { an contracten van asseurantien, van weddinghe ende spel } \\
55 V \text { an wissel-brieven } \\
56 V \text { an nantisatie }\end{array}$ \\
\hline T 57-67 & $\begin{array}{l}30 \\
32 \\
31\end{array}$ & $\begin{array}{l}\text { Verbintenissenrecht en goederenrecht (obligationes }+ \text { res) } \\
57 \text { Van contracten, opdrachten, hypoteken ende verbintenissen van onruerende goeden ende } \\
\text { renten (obligationes) } \\
58 \text { Van reivendicatien ende verloren goeden (res) } \\
59 \text { Van bueringhe (obligationes) } \\
60 \text { Van calengieringhe ende naederschap (res) } \\
61 \text { Van prescriptie ende verloop van tijde (res) } \\
62 \text { Van erf-scheydinge, servituten ende des daer aen cleeft (res) } \\
63 \text { Van borch-tocbten (obligationes) } \\
64 V \text { an betalinge, bewijsinghe, compensatie ende reconventie (obligationes) } \\
65 \text { Vande fugitive ende insolvente persoonen (...) } \\
66 \text { Vande preferentie vande crediteuren (obligationes) } \\
67 \text { Vande cessie (obligationes) }\end{array}$ \\
\hline T 68-72 & & $\begin{array}{l}\text { Executie van vonnissen (actiones) } \\
68 \text { Van vonnissen in civile saecken ghewesen, ende van executien } \\
69 \text { Van verjaringe van instantie, ende desisteringhe } \\
70 \text { Van provocatien } \\
71 \text { Van appellatien } \\
72 \text { Van reformatien }\end{array}$ \\
\hline
\end{tabular}

De vraag of de Consuetudines impressae kunnen worden ondergebracht in de tweede categorie van Gilissen, is niet meteen éénduidig te beantwoorden. Zo getuigt het geheel op het eerste gezicht van weinig logische inbreng. Een ruimere deelstructuur, zoals men die in de Consuetudines compilatae zal aantreffen, ontbreekt en de thematische 
groepering van inhoudelijk verwante titels wordt niet expliciet getoond. ${ }^{712}$ Hier staat tegenover dat de impliciete structuur van het geheel, in de zin van het groeperen van thematisch verwante onderwerpen, sterke gelijkenissen vertoont met de manier waarop Gaius zijn Institutiones opdeelde in de tweede eeuw na Christus. ${ }^{713}$ Van zuivere willekeur is er desalniettemin zeker geen sprake.

Het is de Franse jurist François Douaren (1509-1559) geweest, die in 1544 de ordening van de Institutiones met zijn Epistola de ratione docendi discendique iuris weer onder de aandacht van zijn tijdgenoten bracht. ${ }^{714}$ Gezien de datum van de publicatie ervan bestaat de mogelijkheid dat de commissieleden het werk hebben gelezen. De wijze waarop de verschillende titels betreffende personen, goederen en actiones bij elkaar worden gesorteerd, zet deze veronderstelling alleen maar kracht bij. Bovendien kende het Institutensysteem van Gaius nog geen vierdeling. Het bestond namelijk slechts uit drie groepen (personae, res, actiones) en bijgevolg ontbraken de obligationes als afzonderlijke groep. Dit kan de vermenging van res en obligationes in de Consuetudines impressae verklaren. ${ }^{715}$ Het handelsrecht, eveneens verbintenissenrecht, kreeg wel een afzonderlijke plaats.

Ondanks de aanwezigheid van heel wat procesrechtelijke titels in het geheel van de Consuetudines impressae zelf, werden deze nog aangevuld met een extra luik zuiver procesrecht, de zogenaamde styl ende maniere van procederen. Vanaf de vijftiende eeuw hadden de hogere jurisdicties immers hun eigen stijl van procederen, dewelke ze vaak probeerde op te leggen aan de rechtbanken die aan hen ondergeschikt waren. Ook deze stijlen werden geleidelijk opgetekend en door de vorst als wet afgekondigd. ${ }^{716}$ Op eenzelfde manier heeft ook de Antwerpse overheid haar burgerlijk procesrecht laten optekenen en dit samen met de Consuetudines impressae in 1582 laten drukken. Deze ordonnantie op de stijl en manier van procederen zal in de volgende redactiepoging van 1608 volledig worden geïntegreerd in de Consuetudines impressae tot een nieuw en harmonieus, gewoonterechterlijk geheel. De Memorieboeken verwijzen ernaar als de ordonnantie achter de gedructe costuymen.

\footnotetext{
${ }^{712}$ Deze opdeling heb ik, naar het model van Gotzen, wel expliciet voorgesteld in tabel 2.16. (Cfr. GOTZEN, “De costumiere bronnen”, 111-112.)

713 Omtrent de rol van het Institutensysteem als ordeningsprincipe van de middeleeuwse coutumiers, zie: VAN DIEVOET, Les coutumiers, 34. Van Dievoet wijst erop dat de compilatie De legibus et consuetudinibus Angliae van Henry of Bracton (ca.1210-1268) geordend is volgens de structuur van de Institutae. Samuel E. Thorne voorzag de uitgave die George E. Woodbine verzorgde van Bractons Latijnse tekst van een Engelse vertaling: DE BRACTON, H., Bracton on the laws and customs of England, S. E. THORNE en G. E. WOODBINE ed., Cambridge, 1968-1977.

Omtrent de invloed van Gaius' systematiek op het Schotse recht en ook het Nederlands Burgerlijk Wetboek, zie: WATSON, Legal transplants, 36-43.

714 STEIN, Roman Law in European History, 80-82.

${ }^{715}$ Cfr. supra, hoofdstuk 2, paragraaf 4, tabel 2.16.

716 Cfr. GILISSEN, Historische inleiding, 283. (Grote Raad van Mechelen, Raad van Brabant, Raad van Vlaanderen, etc.)
} 
Tabel 2.17 De inhoudstafel van de styl ende maniere van procederen van 1582

\begin{tabular}{|l|l|}
\hline $\mathbf{N r}$. & Titel \\
\hline 1 & Van daghementen \\
\hline 2 & Vande ordinarise rolle \\
\hline 3 & Van saecken van policie \\
\hline 4 & Vande extraordinarise saecken die voor den amptman bedingt worden \\
\hline 5 & Van de woonsdaechsche rolle \\
\hline 6 & Maendaechsche rolle \\
\hline 7 & De maniere ende forme van procederen \\
\hline 8 & Van garande \\
\hline 9 & Van reconventie \\
\hline 10 & Vanden thoon \\
\hline 11 & Van erfscheydinghen \\
\hline 12 & Van provocatien oft beroepen \\
\hline 13 & Van executie ende leveringhe \\
\hline 14 & Vande costen \\
\hline 15 & Vande greffiers \\
\hline 16 & Vande secretarissen ende heure clercken \\
\hline 17 & Vande advocaten ende procureurs \\
\hline 18 & Vande rechten ende salarisen den amptman ende sijne officiers competerende \\
\hline
\end{tabular}

Hoezeer de opbouw van de Consuetudines impressae ook geïnspireerd mag blijken door de Romeinse traditie, toch heeft de systematiseringsarbeid haar hoogtepunt nog niet bereikt. De zuiver humanistische principes aangaande structuur en logische ordening van het recht vereisen immers een vierdeling van het recht (personae, res, obligationes, actiones) en stellen dat het procesrecht steeds moet volgen op het materieel recht. ${ }^{717}$ Aan geen van beide voorwaarden werd voldaan bij de totstandkoming van de Consuetudines impressae. Het merendeel van het burgerlijk procesrecht gaat immers het civiel recht vooraf en de obligationes werden nog niet als afzonderlijk onderdeel behandeld. Ook de positie van de vijf titels civiel procesrecht aan het einde van de compilatie doen eerder onlogisch aan. Het pleit evenwel voor de compilatoren dat deze humanistische principes nog moesten worden gepubliceerd op het moment dat de eerste voltooide uitgaven van de Consuetudines impressae van de drukpers rolden.

Nadat -zoals eerder reeds vermeld- François Duaren het Institutensysteem nieuw leven ingeblazen had, zijn het de Franse humanisten François Connan (1508-1551) en Hugo Doneau (1527-1591) geweest, die het herinterpreteerden. ${ }^{718}$ Connan stelde vast dat keizer Justinianus de obligationes of het contract- of verbintenissenrecht tevens beschouwde als een 'inleiding tot de actiones', wat Connan deed besluiten dat elke act van een persoon die tot juridische procedure kon leiden, onder de hoofding actiones moest worden geressorteerd. Op die manier bevatte het deel actiones naast procesrecht, nu ook verbintenissen- of contractrecht (obligationes), evenals huwelijksvermogensrecht (vroeger onder personae), testamentair recht en erfrecht (beiden vroeger onder res).

717 Cfr. STEIN, Roman Law in European History, 80-82.

718 Wat nu volgt, is grotendeels gebaseerd op: STEIN, Roman law in European history, 80-82. 
Doneau van zijn kant ging minder radicaal te werk. Bijgevolg kende zijn ideeën tevens de grootste navolging. Hij bekritiseerde Connan en stelde vast dat de Romeinse juristen procesrecht bedoelden, wanneer zij spraken van actiones. Dit had tot gevolg dat zelfs de obligationes -zoals keizer Justinianus wel had gedaan- hier niet onder gecategoriseerd mocht worden. Alzo zorgde Doneau in de eerste plaats voor een strikte scheiding tussen materieel recht enerzijds, dat hij opdeelt in personae, res en obligationes, en procesrecht anderzijds, waaronder hij de actiones verstond of de manieren om het recht te laten gelden. Daarenboven wees Doneau erop dat het procesrecht-conform de praktijk- steeds moet volgen op het materiële recht, daar een omgekeerde volgorde -zoals in de Digesten werd toegepast- niet logisch is. Beide principes paste de Franse systematicus zelf als eerste toe in zijn Commentarii de iure civili, welke een eerste maal verschenen in de periode 1589-1597. De eerste zestien boeken bevatten louter materieel recht; de twaalf overige boeken enkel procesrecht. ${ }^{719}$

Tabel 2.18 De indeling van de Consuetudines compilatae (1608)

\begin{tabular}{|l|l|l|l|}
\hline Deel & & Inhoud & Naam \\
\hline I & Publiek & $\begin{array}{l}\text { Rechterlijke } \\
\text { inrichting }\end{array}$ & $\begin{array}{l}\text { Van der stadt, baere paelen, rechten, overbeijt, poorters ende } \\
\text { ingesetenen int gemeijn }\end{array}$ \\
\hline II & Privaat & Personae & Van rechten gehoude persoonen aengaende \\
\hline III & Privaat & Res & $\begin{array}{l}\text { Van rechten de goeden aengaende, ende bij wat manieren die } \\
\text { vercregen worden }\end{array}$ \\
\hline IV & Privaat & Obligationes & Van contracten ende verbintenissen ende des daeraen cleeft \\
\hline V & Privaat & Actiones & Van de maniere van borgerlijcke rechtvoorderinge oft civile procedure \\
\hline VI & Publiek & Strafrecht & $\begin{array}{l}\text { Van misbruijcken ende misdaeden, ende van breucken ende straffen } \\
\text { daertoe staende }\end{array}$ \\
\hline VII & Publiek & Actiones & $\begin{array}{l}\text { Van de maniere van rechtvoorderinge in straffbare ende criminele } \\
\text { saecken }\end{array}$ \\
\hline
\end{tabular}

Het volstaat te kijken naar de inhoudstafel van de Consuetudines compilatae om te concluderen dat de commissieleden van deze principes op de hoogte moeten geweest zijn. Voor het eerst ontmoet ik immers een compilatie waarbij de verschillende titels werden ondergebracht in verschillende, overkoepelende delen. De 3643 rechtsregels werden op een eerste niveau verdeeld over paragrafen, welke op hun beurt verzameld werden tot talloze titels, die in zeven grotere, thematisch verwante delen werden ondergebracht. Het eerste deel bevat de rechterlijke organisatie van de stad en omstreken. Na dit korte, publiekrechtelijke deel volgt het lokale privaatrecht. Er bestaat met andere woorden nog steeds een onderscheid tussen publiek- en privaatrecht. Het laatstgenoemde werd vervolgens -conform Doneau- in vier delen opgesplitst: personenrecht, goederenrecht, verbintenissenrecht en procesrecht.

719 Zie ook: C. A. CANNATA, "Systématique et dogmatique dans les commentarii iuris civilis de Hugo Donellus", B. SCHMIDLIN et A. DUFOUR red., Jacques Godefroy (1587-1652) et l'Humanisme juridique à Genève, Basel-Frankfurt am Main, 1991, 217-230. De meest recente bibliografische verwijzingen omtrent Hugo Doneau zijn te vinden bij: M. AVENARIUS, “'Neque is sine magna servii laude...' Historisierung der Rechtswissenschaft und Genese von System und Methode bei Donellus”, Tijdschrift voor Rechtsgeschiedenis, 74 (2006), 61-93. 
Daarenboven volgt, in tegenstelling tot de Consuetudines impressae, het procesrecht nu wèl op het materiële recht. Deze logica werd zowel op het strafrecht als het privaatrecht toegepast. De Consuetudines compilatae mogen dan ook beschouwd worden als het culminatiepunt van een evolutie waarin de zoektocht naar logische ordening voorop stond. Een apotheose dat aan het begin van de zeventiende eeuw nergens zijn gelijke kent, het hierop geïnspireerde Gelderse Land-en Stadsrecht niet te na gesproken. Tot nog toe heb ik slechts één andere compilatie kunnen identificeren, welke eveneens volgens het Institutensysteem werd geconstrueerd, zij het evenwel in combinatie met een eigen systeem. Het gaat hier om de Coutumes de Nivernais van Guy Coquille (1523-1603). ${ }^{720}$

\section{Het bumanisme te Roermond}

Dat de ordening van het Antwerpse gewoonterecht in de vierde redactie uiterst uitzonderlijk is, blijkt uit het feit dat ik tijdens mijn onderzoek nergens een gelijkaardige opbouw heb aangetroffen. ${ }^{721}$ Zelfs de indeling in delen is uitzonderlijk. Op mijn willekeurig parcours doorheen het landschap van costumiere redacties in de loop van dit onderzoek ben ik enkel met betrekking tot de costumen van Gent (1567) en Kortrijk (...) een opdeling van de titels in afzonderlijke delen tegengekomen. Ook in het geval van Gent en Kortrijk mag er overigens gesproken worden van costumiere acculturatie. ${ }^{722}$ De verklaring voor het unieke karakter van de opbouw van de Antwerpse en Roermondse compilaties is veelvuldig. De belangrijkste reden lijkt me de veelal te beperkte omvang van vele van de overige geredigeerde costumen. Deze kleinschaligheid is op zijn beurt ten dele het gevolg van de terughoudendheid waarmee de compilaties werden vervaardigd. Men beperkt zich tot het strikt noodzakelijke en laat zich hierbij maar al te graag leiden door wat expliciet gevraagd werd in de vorstelijke ordonnanties. Op deze manier beperkt men de invloed van een 'homologerende' vorst op de overige niet-geredigeerde domeinen van het recht.

Tevens van belang om het exclusieve, structurele karakter van de Consuetudines compilatae en het Gelderse Land-en Stadsrecbt te begrijpen, is de vaststelling dat een aanzienlijk deel van de costumen in de Nederlanden reeds was opgesteld alvorens Doneaus Commentaria in 1597 voor het eerst verscheen. ${ }^{723}$ De herwaardering van het Institutensysteem, wat een gevoel voor systematisch denken met zich meebracht, was

720 E. HOLTHÖFER, "Coquille (Conchyleus), Guy", M. STOLLEIS red., Juristen: ein biographisches Lexikon von der Antike bis zum 20. Jabrbundert, Munchen, 2001, 144-145.

${ }^{721}$ Cfr. VANDERLINDEN, "Essai sur la structure des textes coutumiers", 279-281: over invloed die Raad van Vlaanderen heeft uitgeoefend op oude cabier van coutumes (1547) van Kortrijk. Uiteindelijk in 1557 gehomologeerd. Invloed: vermindering aantal rubrieken $(42>18)$. Deze onderverdeeld in 4 delen (une division quadripartite) met vergelijkbaar belang: compétence et procédure, contrats, mariage, successions. Hetzelfde bij oude cahier van Gent (van 1546; gehomologeerd in 1563) Dezelfde vierdeling! (en deze is niet terug te vinden bij die coutumes die niet langs Raad van Vlaanderen zijn gepasseerd.) Gent: aantal rubrieken toegenomen $(24>28)$

722 VANDERLINDEN, "Essai sur la structure des textes coutumiers", 279-281.

${ }^{723}$ GILISSEN, “Les phases de la codification”, 37-67 en 239-268. 
nog niet tot deze regio's doorgedrongen. De redacteurs van de vroegere compilaties dachten nog niet zozeer in termen van abstraheren en systematiseren. De focus lag nog steeds op het particulaire. Het betreft hier een tegenstelling 'systeemdenken versus casuïstiek'. Men behandelde enkel die zaken die van belang leken. De rechtsboeken waren dan ook verre van exhaustief, de samenstellers verre van humanistisch geïnspireerd.

Een laatste verklarende factor voor de zeldzame, Antwerpse en Roermondse opbouw, is het feit dat het systeemdenken van Doneau nooit een monopoliepositie heeft weten te verwerven. Niet overal wist het de ordo iuris van het toneel te verdringen. Van den Bergh relativeert de invloed van Doneau als volgt: "Der schon seit jeher bekannte Beweis für den geringen Einfluss von Donellus ist, dass die Holländer am ordo legum festhielden und die Systematisierung von Donellus weder benutzten noch weiterführten. Zwar wurde der Inhalt mancher Digestentitel weiter systematisiert, ₹. B. bei einem Rechtsinstitut wie Kauf. Aber für das Privatrechtssystem als Ganzes blieben die Titelrubriken der Digesten als Ordnungsgerüst erhalten, eben auch bei Voet. Nur Vinnius scheint von Donellus -seinem dominus domini- viel übernommen zu haben, aber er gehört kaum zur eleganten Schule. Auch in Fragen der Textkritik folgte man eher Cujas als dem viel strengeren Donellus. Nur Ulrik Huber bildet hier wieder die Ausnahme. Cujacius war ebenfalls das Vorbild für die scharfe Kritik an Alciato". ${ }^{724}$ De enige humanist die, aldus Van de Bergh, naast Vinnius ook door Doneau als systematicus werd beïnvloed, is Hugo de Groot. Het verlangen het recht als geheel systematisch te ordenen, wat hij tracht te realiseren in zijn De iure belli ac pacis van 1625, heeft hij geërfd van de Franse jurist. ${ }^{725}$

Desalniettemin vond dit systeemdenken, dankzij Hendrik Uwens, zijn weg naar het Overkwartier. Wanneer ik de indeling van het Gelderse Land-en Stadsrecht bekijk, wordt meteen duidelijk dat het plan van de compilatie een variatie is van het systeem van de Consuetudines compilatae.

Tabel 2.19 De indeling van het Gelderse Land- en Stadsrecht

\begin{tabular}{|c|c|c|c|}
\hline Deel & & Inhoud & Naam \\
\hline I & Privaat & Personae & ... spreeckende van rechten den persoenen aengaende ... \\
\hline II & Privaat & Res & $\begin{array}{l}\text {... spreeckende van verscheiden gedaente oft gesteltenisse van goederen, } \\
\text { lasten ende servituyten oft dienstbarheiden daerop commende. }\end{array}$ \\
\hline III & Privaat & Res & $\begin{array}{l}\text {... inbaldende verscheiden middelen ende manieren daerbie den } \\
\text { eigendom oft erffelickheit van goederen vercregen wordt. }\end{array}$ \\
\hline IV & Privaat & Obligationes & ... spreeckt van contracten, bandelingen ende verbintenissen. \\
\hline $\mathrm{V}$ & Privaat & Actiones & $\begin{array}{l}\text {... begrijpt die maniere van borgerlicke rechtsvoorderinge oft civile } \\
\text { procedure. }\end{array}$ \\
\hline VI & Publiek & $\begin{array}{l}\text { Strafrecht en } \\
\text { strafprocesrecht }\end{array}$ & $\begin{array}{l}\text {... spreeckende van misbruycken ende misdaden ende die maniere van } \\
\text { die te vervolgen. }\end{array}$ \\
\hline
\end{tabular}

${ }^{724}$ VAN DEN BERGH, Holländische elegante Schule, 151-152. Omtrent de invloed van Doneau op de Noord-Nederlandse juristen van de zeventiende eeuw, zie: FEENSTRA, "Hugues Doneau et les juristes néerlandais", 231-248. Feenstra heeft het hier voornamelijk over de mate waarin Doneau Hugo de Groot mogelijk heeft beïnvloed.

725 VAN DEN BERGH, Holländische elegante Schule, 152. 
Beide compilaties werden duidelijk opgesteld volgens dezelfde basisprincipes. Er bestaat een duidelijk onderscheid tussen privaat- en publiekrecht; de verbintenissen werden in een afzonderlijk deel ondergebracht en het procesrecht volgt steeds op het overeenkomstige, materiële recht. Het grote verschil met de Antwerpse Consuetudines Compilatae is dat men te Roermond het goederenrecht verder heeft opgesplitst in een twee afzonderlijke delen, waarbij deel II de goederen behandelt en deel III zich concentreert op de manieren hoe goederen verkregen worden. Voor deze techniek heb ik evenwel geen theoretische verklaring of fundering kunnen terugvinden in de contemporaine rechtsgeleerde literatuur. Belangrijker is dat ook het Overkwartierlijke gewoonterecht op deze manier conform de humanistische principes van Hugo Doneau werd geconstrueerd.

Talrijker zijn de variaties op het niveau van de titels en nog meer op dat van de paragrafen. Dit is evident. Men raakt immers steeds meer aan de specifieke eigenheden van het Roermondse, costumiere recht. Men ruilt het abstracte voor het concrete. Het is hier echter niet mijn bedoeling deze individuele verschillen uitvoerig te beschrijven. Daarvoor zijn zij op deze niveaus te talrijk. Het lag louter in mijn bedoeling aan te wijzen dat men, wat het Gelderse Land- en Stadsrecht betreft, kan spreken van structurele assimilatie aan het Antwerpse, en tevens humanistische, model. Ook nu weer is Hendrik Uwens de grote gangmaker geweest van deze systematisering. Dit blijkt onder meer uit zijn aantekeningen in de kantlijn van de oudere kladversies. Meermaals heb ik in paragraaf 2 van dit hoofdstuk kunnen vaststellen hoe Uwens de structuur van de compilatie naar zijn hand weet te zetten. Hij adviseert titels te verplaatsen en delen op te splitsen.

Rest me enkel nog de vraag hoe deze kennis zijn intrede heeft gedaan in het Antwerpse redactieproces. Omdat we enkel over de uiteindelijke eindtekst van de Consuetudines compilatae beschikken en niet over kladversies uit de periode 1592-1608, ben niet in de mogelijkheid gesteld na te gaan of deze ordening zijn intrede, inderdaad, kort na het verschijnen van Doneaus werk in 1597 heeft gedaan. Bijgevolg kan ik niet met zekerheid zeggen of deze indeling het gevolg is van een geleidelijk proces op weg naar meer logische ordening, dan wel als plotse cesuur met het verleden werd doorgevoerd na de kennisname van de principes van Doneau. In het voordeel van de 'cesuurtheorie' pleiten het contrast met de Impressae, het unieke karakter van de indeling en de treffende gelijkenis met het systeem ontwikkeld door Doneau. Bovendien is reeds uit het eerste hoofdstuk gebleken en zal nogmaals blijken uit hoofdstuk 3, dat de redacteurs een sterke affiniteit vertoonden met de Franse rechtsleer. Daarenboven bleek men ten zeerste up to date te zijn van wat nieuw was op rechtsgeleerd vlak. Wat de hypothese van de cesuur tegenspreekt, is hetgeen ik de genese van het Gelderse Land- en Stadsrecht laat zien. De overgeleverde bronnen getuigen immers van een geleidelijke overgang naar het Antwerpse systeem. In het geval van Roermond is dit misschien meer vanzelfsprekend dan dat dit het geval is voor Antwerpen. Het aanvaarden van vreemde elementen vraagt immers tijd. Te veel te snel veranderen kan zeer nefast worden voor datgene wat je beoogt. Het resulteert maar al te vaak in weerstand, zoals keizer Jozef II (1741-1790) later nog par excellence 
JURIDISCH HUMANISME EN COSTUMIERE ACCUlturatie

zou illustreren. We gaan er dan ook van uit dat Uwens bewust voor de geleidelijke aanpak heeft geopteerd. 


\section{CONCLUSIE BIJ HOOFDSTUK 2}

Met dit tweede hoofdstuk heb ik getracht een eerste beschrijving te geven van een 'nieuw' fenomeen, dat ik ben gaan aanduiden als costumiere acculturatie. De essentie ervan bestaat uit de éénzijdige beïnvloeding tussen twee verschillende costumiere compilaties, waarbij de ene wordt geconstrueerd naar het voorbeeld van de andere. Ik heb er hierbij op gewezen dat dit verschijnsel helemaal niet zo ongebruikelijk is als de vaststelling dat het tot nog toe nauwelijks geïdentificeerd en beschreven werd op het eerste gezicht doet vermoeden. Met een comparatieve analyse van enkele Brabantse compilaties heb ik namelijk tal van andere voorbeelden van costumiere acculturatie aan het licht gebracht, waarbij een kapitale rol is weggelegd voor de costumen van Mechelen van 1535. Een pleidooi voor meer wetenschappelijk onderzoek inzake de rol die dit fenomeen gespeeld heeft binnen de unificatie van het gewoonterecht in de Zuidelijke (en Noordelijke) Nederlanden is hier dan ook niet misplaatst.

Zelf heb ik me beperkt tot de tandem Antwerpen-Roermond met de Antwerpse advocaat en latere kanselier van het Hof van Gelre, Hendrik Uwens, aan het stuur. Hoewel dit hoofdstuk in de eerste plaats een zuiver descriptieve benadering van het fenomeen voor ogen had, stelt het me eveneens in staat een aantal conclusies te trekken met betrekking tot de karakteristieken van de costumiere acculturatie als verschijnsel. Het aanwenden van een compilatie van een kwalitatief, hoger niveau bij de redactie van het eigen, lokale gewoonterecht, brengt namelijk een aantal implicaties met zich mee. Doordat de Antwerpse Consuetudines compilatae als een soort van ideaaltype werden beschouwd, waaraan het Gelderse Land-en Stadsrecht geassimileerd werd, gaat eerstgenoemde compilatie de rol van ratio scripta vervullen, die vergelijkbaar is met positie van het Justiniaanse recht binnen de middeleeuwse rechtscultuur. Bijgevolg werden maar liefst 923.5 artikels, goed voor 47 procent van het totale aantal artikels in de Roermondse compilatie, aan het Antwerpse voorbeeld geassimileerd. Deze assimilatie kent met een percentage van zeventig procent een hoogtepunt binnen het verbintenissenrecht. Drie andere rechtsgebieden vertonen een assimilatiegraad die rond de zestig procent schommelt. Het betreft het personen-, goederen- en strafprocesrecht. Het derde deel, aangaande de wijze waarop goederen verworven konden worden, werd voor niet meer dan veertig procent naar het model van de Antwerpse Consuetudines compilatae geconstrueerd. Enkel het burgerlijk procesrecht van het Overkwartier blijkt geheel vrij te zijn van elke Antwerpse invloed. Geen enkel artikel uit het vijfde deel vertoont namelijk gelijkenissen met de civiele, procesrechtelijke artikels uit de Antwerpse Consuetudines compilatae. Belangrijk hierbij is evenwel dat ik enkel de zogenaamde 'letterlijke, normatieve assimilatie' in rekening heb gebracht. Normen die niet letterlijk gekopieerd werden, maar dus inhoudelijk mogelijk wel overeenkomsten vertonen met het Antwerpse voorbeeld, werden buiten beschouwing gelaten. Dit impliceert dat de invloed die de vierde, Antwerpse redactiepoging op het Overkwartierlijke gewoonterecht heeft uitgeoefend, in theorie nog groter geacht kan worden dan louter op basis van de letterlijk geassimileerde artikels vermoed wordt. 
De vraag in hoeverre het hierbij om een daadwerkelijke receptie van 'vreemd' recht gaat, is moeilijker te beantwoorden. Het beschikbare bronnenmateriaal geeft immers niet aan waar dit wel en waar dit niet het geval is geweest. Bijgevolg blijft de kans bestaan dat men louter de Antwerpse formulering heeft overgenomen om een reeds in voege zijnde, eigen rechtsnorm te omschrijven. In zulke gevallen blijft de Antwerpse invloed op het eigen recht uiteraard beperkt tot een louter vormelijk niveau. Gezien de uitzonderlijke omvang van het Gelderse Land-en Stadsrecht anno 1620 en gezien de aanwezigheid van doorgaans minder courante rechtsgebieden in de compilatie, meen ik er van uit te mogen gaan dat de impact van de Antwerpse ratio scripta op de Roermondse redacteurs verre van onverwaarloosbaar te noemen is, integendeel. Bijgevolg lijkt het me bovendien gerechtvaardigd in dezen te spreken van de Antwerpse Consuetudines compilatae als een Paard van Troje. Het advies van Hendrik Uwens om zich te laten inspireren door voornoemde Antwerpse compilatie, heeft tot gevolg gehad dat deze Consuetudines compilatae als een Trojaans paard op het Overkwartierlijke gewoonterecht hebben ingewerkt. Het fenomeen van costumiere acculturatie resulteert immers in een situatie waarbij tal van rechtsbronnen behorende tot het lappendeken waaruit de juridische bronnen van de Antwerpse Consuetudines compilatae bestonden, hun weg naar het Overkwartier hebben gevonden. Logischerwijs zetten gelijkaardige rechtsbronnen de toon.

Costumiere acculturatie werkt echter niet alleen op inhoudelijk niveau. Naast deze 'normatieve assimilatie' is de 'structurele assimilatie' minstens zo opvallend. Net zoals bij de Antwerpse Consuetudines compilatae, is het Gelderse Land-en Stadsrecht op een gelijkaardige manier opgebouwd, conform de humanistische interpretatie van Institutensysteem zoals het door Hugo Doneau werd uitgedacht. Het enige structurele verschil tussen beide compilaties schuilt in het feit dat de Overkwartierlijke compilatie een opdeling van het goederenrecht kent in zuiver goederenrecht en een deel omtrent de manier waarop goederen verkregen worden. Te Antwerpen wordt deze materie gezamenlijk in eenzelfde deel behandeld. Desalniettemin getuigt de structuur van beide redacties van de doorwerking van de verworvenheden van het juridisch humanisme tot op het niveau van het lokale, particuliere recht in de Nederlanden. Ik heb laten zien hoe te Antwerpen de overgang heeft plaatsgevonden van empirisch geordend gewoonterecht naar een compilatie waarbinnen de artikels werden gerangschikt volgens een logische systematiek. Door toedoen van Hendrik Uwens zal men te Roemond op een gelijkaardige, humanistische manier te werk gaan. Andere sporen van het juridisch humanisme zullen in een volgend hoofdstuk nader onderzocht worden. 


\section{HOOFDSTUK 3 \\ DE ALLEGATIES VAN DE ANTWERPSE MEMORIEN OP DE COSTUMEN: SPOREN VAN JURIDISCH HUMANISME?}

“... De heren pantagruwelaars van vroeger hebben bevestigd wat ik zeg en niet alleen voor mogelijk verklaard, dat een vroun een kind krijgt in de elfde maand na de dood van haar echtgenoot, maar ook dat dit kind legitiem is: Hippocrates, in het boek De alimento, Plinius, in boek VII, caput V, Plautus, in Cistellaria, Marcus Varro, in de satire getiteld Het testament, waarin bij zich met betrekking biertoe beroept op Aristoteles, Censorinus, in bet boek. De die natali, Aristoteles, in boek. VII, capita III en IV van De natura animalium, Gellius in boek. III, caput XVI, Servius, in Ecloga, in zijn uiteenzetting over de versregel van Vergilius 'Matri longa decem' etc. en nog talloze andere gekken, bij wie nog moeten worden opgeteld de juristen: ff De suis et legitimis heredibus, lege intesto (wet 3 par. 13) en in Authenticae, De restitutionibus et ea quae parit in undecimo mese post mortem viri. Bovendien bebben ze er hun linkmiegelse wet Gallus, ff De liberis et posthumis heredibus instituendis vel exheredandis, en in bet zevende boek ff De statu hominum, mee weten te bezwadderen, en nog een paar andere, die ik 't nu even niet wagg te noemen. Met die wetten in de hand kunnen weduwen, twee maanden na de dood van bun man, naar hartelust en met heel bun ziel en raligheid van bil gaan.' ${ }^{26}$

In zijn Gargantua steekt Rabelais meermaals de draak met het juridische bedrijf en dit in zijn vele facetten. Ook het oeverloos refereren naar rechtsgeleerde auteurs en Romeinsrechtelijke passages uit het Corpus Iuris, zoals het in die tijd in rechtswetenschappelijke kringen gebruikelijk was, ontsnapt niet aan het satirische oordeel van de auteur. Zo maakt Rabelais ook in bovenstaand citaat deze methode door middel van overdrijving tot voorwerp van spot. In een maatschappij die in de eerste plaats leefde volgens de dogma's van de Kerk, was zulk een dwepen met de auctoritates echter uiterst vanzelfsprekend. Hoewel vanaf de dertiende eeuw de scholastieke beweging ook een plaats wist toe te kennen aan de menselijke ratio, bleef

${ }^{726}$ F. RABELAIS, Gargantua en Pantagruel, Amsterdam, 1999, 49-50. 
het dogma de eerste bron van kennis en waarheid. Zo goed als in elke wetenschapstak nam dit autoriteitsargument een uiterst voorname plaats in. ${ }^{727}$ Ook in de rechtswetenschap krijgt men te maken met een bartolistische methode die zich onder meer kenmerkt door een raisonnement à tiroir, waarbij pro- en contra-argumenten mekaar opvolgen in een ogenschijnlijke wanorde (un apparent désordre), al dan niet besloten met een oordeel van de peritus iuris van dienst. ${ }^{728}$ Ook de auteurs van de Memorieboeken hebben massaal naar dit argumentum ab auctoritate teruggegrepen.

Deze methode draagt in essentie iets middeleeuws in zich en het lijkt dan ook op het eerste gezicht onverenigbaar met het hanteren van deze allegaties als criteria voor het aantonen van humanistische invloeden met betrekking tot de compilatores van de Consuetudines compilatae. Desalniettemin kan de aard van de geallegeerde werken wel degelijk een idee geven van de mate waarin de samenstellers door het juridisch humanisme beïnvloed werden. Des te meer vertegenwoordigers van deze rechtsgeleerde school geallegeerd werden, des te aannemelijker wordt de stelling dat de verworvenheden van het juridisch humanisme, via de meestal hoger opgeleide commissieleden, tot het niveau van de geredigeerde costumen wisten door te dringen. In dit hoofdstuk zal ik bijgevolg trachten aan de hand van de allegatiepolitiek van de compilatoren een beeld te reconstrueren van de intellectuele achtergrond van waaruit de commissieleden opereerden. Het aandeel van zogenaamde 'humanistische' werken binnen dit geheel, zal bepalend zijn voor de mate waarin mijn premisse geaccepteerd kan worden. Anderzijds getuigt een gevarieerd geheel van werken, net als de annwezigheid van auteurs uit de klassieke oudheid, van een ontvoogde, en dus humanistische, opstelling. Waar Gotzen deze sysifusarbeid nog uit de weg ging, omdat 'zulks zou neerkomen op het opstellen van een lijst van al wat de Nederlanden, Frankrijk en subsidiair zelfs romanistisch Italië, aan invloedrijke rechtschrijvers hebben opgeleverd', ga ik me er hier wel aan wagen. ${ }^{729}$ Bovendien zal ik aantonen dat Gotzens uitspraak best wel wat nuancering kan gebruiken.

Ook in de vorige hoofdstukken heb ik reeds een antal keer de doorwerking van het juridisch humanisme kunnen waarnemen. Ik denk bijvoorbeeld aan de kritische en ontvoogde wijze waarop men met het ooit zo onaantastbaar geachte, Romeinse recht omgaat. Ik denk aan de 'autoritatieve degradatie' welke dit Justiniaanse recht niet alleen ten aanzien van de legislatie en de lokale gewoonte, maar tevens ten overstaan van de individuele ratio doormaakt. Er is niet langer één Waarheid. Men zoekt nu zelf naar het 'beste recht'. De redelijkheid en billijkheid zijn duidelijk aan een opmars bezig en dit ten nadele van de autoriteit van het Romeinse recht inclusief hun middeleeuwse, dogmatisch ingestelde, commentatoren. Hoofdstuk 2 liet op zijn beurt zien dat ook het gewoonterecht van een andere stad of regio als ratio scripta beschouwd en aangewend kon worden. Men breekt als het ware uit zijn eigen kortzichtige systeem. Men opent de ogen en deuren voor nieuwigheden en vreemde

${ }^{727}$ VERVAART, Nicolaas Everaerts, 52-53.

${ }^{728}$ C. DUGAS DE LA BOISSONNY, Barthélémy de Chasseneuz (1480-1541), Grenoble, 1977, 63.

${ }^{729}$ GOTZEN, “De costumiere bronnen”, 201. 
elementen, waar men zich vroeger beperkte tot het 'absolute', Romeinse recht. Zoals tevens bij Lesaffer te lezen staat, heb ik ook aan de hand van vorige hoofdstukken kunnen zien dat de rechtsgeleerdheid een eclectisch pad ingeslagen. ${ }^{730}$ Het meest visuele spoor van een humanistische ingesteldheid, blijkt echter de structuur te zijn volgens dewelke zowel de Antwerpse Consuetudines compilatae, als het Gelderse Land-en Stadsrecht opgesteld werden. Deze manifestatie van de typisch humanistische drang tot systematiseren en logische ordening is één van de meest voor de hand liggende criteria om de invloed van het juridisch humanisme aan te wijzen.

Wat de inhoud betreft, liggen de zaken er complexer bij. Men kan immers niet echt spreken van het bestaan van specifiek humanistische rechtsregels of principes. ${ }^{731}$ Ook de eigenschappen die in de literatuur doorgaans worden toegeschreven aan het juridisch humanisme, zijn moeilijk in verband te brengen met het costumiere recht. Ik denk aan de historisering van de Codex, de palingenesia in de Digesten, het achterhalen van interpolaties, het lezen van Griekse werken, tekstkritiek en historisch besef. ${ }^{732}$ Andere, meer concrete aanpakken zijn terug te vinden bij de studies van Maw en Van Nifterik over het humanistische karakter van respectievelijk de Nederlandse jurist Wigle van Aytta en zijn Spaanse collega Fernando Vazquez de Menchaca. ${ }^{733}$ Maw gaat eerst na hoezeer Viglius nog gelijkt op zijn middeleeuwse voorgangers. Dit doet ze door te kijken in hoeverre hij gebruik maakt van de scholastieke quaestio. Ook de mate waarin hij refereert naar middeleeuwse auteurs en zijn houding ten overstaan van het Romeinse recht -erkent Wigle van Aytta de actuele waarde van het Romeinse recht?fungeren als criterium. Bovendien vraagt Maw zich af of Viglius een voorstander is van het 'interpreteren' van het Corpus Iuris Civilis en welk belang hij hecht aan de bartolisten voor de rechtspraktijk. Vervolgens onderzoekt Maw hoe modern Viglius is. Volgende criteria zijn hierbij van belang: Viglius' visie met betrekking tot orde en systematiek; Viglius' wijze van doceren; verwijzingen naar klassieke literatuur;

${ }^{730}$ LESAFFER, Inleiding tot de Europese rechtsgeschiedenis, 322.

${ }^{731}$ Integendeel, Osler betreurt juist het ontbreken van sporen van een traditioneel humanisme in de zin van aandacht voor de mens en de herontdekking van het individu. Meer nog, de auteur wijst op de inhoud van het strafrecht, waarbij tortuur nog steeds een belangrijke ondervragingstechniek is en de doodstraf de zwaarste straf. Hij vraagt zich af in hoeverre deze zaken als 'humaan' kunnen beschouwd worden en benadrukt terecht dat men te pas en te onpas de term humanisme in de mond neemt. Hij kan niet anders dan besluiten dat zulk een 'menselijk' juridisch humanisme nooit bestaan heeft. De Renaissance van het recht speelde zich in de elfde eeuw af, maar de humanisering ervan volgde pas in de twintigste eeuw, aldus Osler. (D. J. OSLER, Images of legal humanism, 2001.

http://www.pum.umontreal.ca/revues/surfaces/vol9/osler.htm)

732 Cfr. OSLER, Images of legal humanism, 2001. VAN DEN BERGH, Geleerd recht, 51-71. LESAFFER, Inleiding tot de Europese rechtsgeschiedenis, 315-325. KOSCHAKER, Europa en het Romeinse recht, 105-123. STEIN, Roman Law in European History, 75-82. BELLOMO, Common Legal Past of Europe, 203-210.

${ }^{733}$ R. J. C. MAW, Humanism and legal education during the reception of Roman law in Germany: a case study, Michigan, 1976. G. P. VAN NIFTERIK, Vorst tussen volk en wet: over volkssoevereiniteit en rechtsstatelijkheid in het werk van Fernando Vázquez de Menchaca (1512-1569), Deventer-Rotterdam, 1999. 
referenties naar humanistische tijdgenoten; een andere manier van becommentariëren, waarbij meer belang wordt gehecht aan een correcte terminologie; de erkenning dat ook auteurs fouten kunnen maken en dus geen onbetwistbare autoriteiten zijn. Zulk een opbouw doet uiteraard een compromis als besluit vermoeden en Maw stelt dan ook vast dat de overgang van bartolisten naar humanisten geen plotse breuk inhield. Binnen de humane wetenschappen was het humanisme dominant geweest, maar binnen de rechtswetenschap bleef het beperkt tot een 'invloed': “..., bumanism did not overtbrow scholasticism, it "merely supplemented and modified" the medieval traditions of the disciplines without affecting their content or substance." 734 Ook Van Nifterik gaat onder meer naar de bronnen kijken van Fernando Vazquez de Menchaca om uit te maken in hoeverre hij als juridisch humanist beschouwd kan worden. Tevens komt de academische opleiding van Vazquez de Menchaca aan de traditioneel georiënteerde Universiteiten van Valladolid van Salamanca ter sprake. Andere criteria die hij hanteert zijn de drie kenmerken die Kelley toeschreef aan de term legal humanism, zijnde: filologie (tekstkritiek), historie (de in tijd beperkte dimensie van het Romeinse recht) en filosofie (teruggrijpen naar antieke filosofische auteurs). ${ }^{735}$ Verder onderzoekt hij de mate waarin autoriteiten in twijfel worden getrokken en het type onderwijs men 'belijdt'. Uiteindelijk stelt hij vast dat Vazquez aan geen enkele van de vijf hoofdpunten voldoet, waarin Van den Bergh de kritiek van de humanisten op de middeleeuwse rechtswetenschap samenvat (terugkeer ad fontes, kennis van het Grieks, autoriteiten betwijfelen, hervormingsdrang op onderwijsvlak en hang naar systematisering). ${ }^{736}$ Vergelijkbare criteria zijn terug te vinden bij het vergelijkend onderzoek van Canoy-Olthoff en Nève omtrent het privaatrechtelijk onderwijs te Leiden (juridisch humanisme) en enkele Duitse universiteiten (Usus modernus Pandektarum) aan de hand van dissertaties uit de periode 1650-1750. Verwijzingen naar niet-juridische, klassieke auteurs en interesse voor filologische problemen, de klassieke Oudheid en tekstkritische problemen, worden als sporen van humanisme beschouwd. De Usus modernus Pandektarum laat zich daarentegen kenmerken door

\footnotetext{
734 MAW, Humanism and legal education, 118. De reden hiervoor vindt Maw bij Kristeller terug. Humanisten waren namelijk specialisten in poëzie, geschiedenis, grammatica, rethorica en de studie van de Griekse en Latijnse literatuur, maar anderzijds waren het amateurs wat betreft de theologie, de geneeskunde en het juridische bedrijf. Desalniettemin worden ook zij tijdens hun universitaire opleiding aan de Artesfaculteit blootgesteld aan het humanistische gedachtengoed, waarna zij doorstromen naar de hogere faculteiten zoals die van geneeskunde, theologie en rechtsgeleerdheid. (MAW, Humanism and legal education, 188-199) Bovendien kan men niet om de vaststelling heen dat leerlingen van Alciato leerstoelen verwierven in rechtenfaculteiten over gans Europa. Wat de Leuvense rechtenfaculteit betreft, denk ik in de eerste plaats aan Gabriel Van der Muyden. Hierbij wil ik evenel opmerken dat de invloed van deze zogenaamde 'humanisten' niet altijd gegarandeerd is. Kijk bijvoorbeeld maar naar de beperkte navolging die de humanistische, systematicus Hugo Doneau kennen zou, wanneer hij doceren ging aan de Leidse universiteit. (Cfr. VAN DEN BERGH, Holländische elegante Schule, 151-152.)

735 Cfr. VAN NIFTERIK, Vorst tussen volk en wet, 26, noot 55.

736 VAN DEN BERGH, Geleerd recht, 57-64.
} 
verwijzingen naar het particuliere recht en de middeleeuwse rechtswetenschap, waarbij men veel aandacht heeft voor de behandeling van controversen. ${ }^{737}$

Naast de houding ten overstaan van het Romeinse recht en vreemde invloeden (hoofdstuk 1) en de drang tot systematisering (hoofdstuk 2) blijkt, van al deze criteria welke de studies van Maw en Van Nifterik me aanreiken, het werken met allegaties een derde instrument dat het beschikbare bronnenmateriaal aanbiedt en wat tevens ingezet kan worden ter beantwoording van de centrale vraag naar de invloed van het humanisme op de redactie van het gewoonterecht. Wat het werken met allegaties betreft, is het proefschrift van Wijffels omtrent de allegaties in de dossiers van de Grote Raad van Mechelen uit de periode circa 1460 tot 1580 op zijn minst baanbrekend geweest. ${ }^{738} \mathrm{Ik}$ heb er op methodologisch vlak dan ook heel wat aan te danken. Tevens heeft Wijffels laten zien dat zulke allegaties in dienst kunnen worden gesteld van een onderzoek naar de affiniteit van de compilatores met de nova methodus. ${ }^{739}$ $\mathrm{Er}$ is de wijze waarop het aantal middeleeuwse auteurs zich verhoudt ten overstaan van het moderne collegae. Maar ook het aantal verwijzingingen naar klassieke auteurs is samen met de andacht die men heeft voor contemporaine, zowel juridische als niet-juridische, schrijvers van belang voor de mate waarin er gesproken kan worden van humanistische invloeden.

Dit derde hoofdstuk staat bijgevolg in het teken van de rechtsgeleerde literatuur waarop de redacteurs van de Consuetudines compilatae zich hebben gebaseerd. In een eerste paragraaf zal ik toelichten hoe ik tot de totale onderzoeksgroep van relevante allegaties ben gekomen. De paragraaf wordt afgesloten met een overzicht van alle auteurs en werken die in de Memorien op de Costumen aan bod zijn gekomen en dus vermoedelijk door de compilatores werden geraadpleegd. Een tweede paragraaf

737 A. M. M. CANOY-OLTHOFF en P. L. NEVE, Holländische elegan₹ gegenüber deutschem Usus Modernus Pandectarum?, Nijmegen, 1990, 4. Voor Van den Bergh daarentegen is de aanwezigheid van verwijzingen naar middeleeuwse auteurs niet houdbaar als criterium om de invloed van de Usus Modernus Pandektarum aan te tonen. De reden hiervoor is dat "bis zum Ende hat alles gelehrte Recht an die mittelalterliche Rechtswissenschaft angeknüpft." (VAN DEN BERGH, Holländische elegante Schule, 94.) Ook Brants had dit reeds in 1917 door. (BRANTS, La Faculté de droit, 15-16. Zie ook: T. J. VEEN, P. C. KOP, Zestig juristen: bijdragen tot een beeld van de geschiedenis der Nederlandse rechtswetenschap, Zwolle, 1987, 108.) Van den Bergh heeft in deze gelijk. Wel kan mijns inziens de verhouding van het aantal 'middeleeuwse' verwijzingen tot het aantal 'humanistische' referenties iets zeggen over de mate waarin een tekst beïnvloed werd door het humanistische gedachtegoed.

738 A. WIJFFELS, Qui millies allegatur: les allégations du droit savant dans les dossiers du Grand Conseil de Malines (causes septentrionales, ca. 1460-1580) (Rechtshistorische studies 11), Leiden, 1985. Andere, inhoudelijk gerelateerde, studies waarbinnen de allegaties naar rechtsgeleerde auteurs een centrale rol spelen en hier nog ter sprake zullen komen, zijn de volgende: DUGAS DE LA BOISSONNY, Barthélémy de Chasseneuz. CANOY-OLTHOFF en NEVE, Holländische eleganz gegenüber deutschem Usus Modernus Pandectarum? F. S. CARNEY, The Politics of Johannes Althusius. An abridged translation of the Third Edition of Politica Methodice Digesta, atque exemplis sacris et profanis illustrata, Londen, 1964.

${ }^{739}$ WIJFFELS, Qui millies allegatur, I, 18. 
interpreteert deze cijfers in het licht van de vraag naar het humanistische karakter van de leden van de Antwerpse commissie. Wat is het andeel van de middeleeuwse auteurs? Hoe nadrukkelijk wordt er verwezen naar contemporaine, humanitisch georiënteerde, rechtsgeleerden? Tref ik vooral de kenmerkende genres van de mos gallicus aan? En hoe zit het met de hang naar de klassieke oudheid?

Op deze manier zal ik een bijdrage leveren aan een lacune in de hedendaagse geschiedenis, met name de doorwerking van het juridisch humanisme tot op het niveau van de geredigeerde costumen. Recentelijk heeft Warembourg in Frankrijk hieromtrent baanbrekend werk verricht. In zijn doctorale dissertatie betreffende Guy Coquille et le droit français komt ook de rol van het juridisch humanisme met betrekking tot het Franse droit commun coutumier en de Coutume de Nivernais in het bijzonder uitgebreid aan bod. ${ }^{70}$ In de Nederlanden spreekt de omvang van de paragraaf die Lesaffer aan dit thema wijdde in zijn recentelijk uitgebrachte Inleiding tot de Europese rechtsgescbiedenis boekdelen. Het laat nog maar eens zien hoe innoverend dit onderzoek is.

${ }^{740}$ WAREMBOURG, Guy Coquille. 


\section{PARAGRAAF 1}

DE GEALLEGEERDE AUTEURS EN WERKEN IN DE ANTWERPSE MEMORIEN OP DE COSTUMEN

Hoezeer het ook onverenigbaar moge klinken met een onderzoek naar sporen van een beweging die bekend staat om haar ontvoogdingsdrang, met name het humanisme, zal ik toch, teneinde de invloed van deze beweging op het costumiere redactieproces aan te tonen, gebruik maken van de allegaties in de Memorieboeken naar rechtsgeleerde auctores annex auctoritates. De bruikbaarheid van zulke referenties in het rechtshistorische bedrijf werd reeds in het verleden met succes aangetoond. Zo baseerde Wijffels zijn zoektocht naar de mate waarin er aan de Grote Raad van Mechelen Romeins recht werd gerecipieerd op de rechtsgeleerde allegaten, waarnaar werd verwezen in de procesdossiers uit de periode van circa 1460 tot $1580 .{ }^{741}$ Naar gelang hun aard deelde hij deze allegaties op in drie groepen. Ten eerste waren er de rechtstreekse verwijzingen naar het Corpus Iuris Civilis, inclusief de 'doctrinale' allegaties van het type Bartolo da Sassoferrato ad L ...ff..., welke steeds verwijzen naar de opinio doctorum omtrent de gemeenrechtelijke regel. Een tweede groep verzamelde gelijkaardige allegaties, maar dan naar het Corpus Iuris Canonici. Ook nu werden de overeenkomstige 'doctrinele' allegaties van het type de Covarubias in Cap ... X ... tot deze groep gerekend. De derde en laatste categorie groepeert dat wat Wijffels omschrijft als la doctrine monographique. Deze laatste groep omvat verwijzingen naar allerhande rechtsgeleerde werken zoals traktaten, singulariae, decisiones, coutumiers, etcetera. De groep onderscheidt zich van de twee voorgaande categorieën doordat er nergens expliciet verwezen wordt naar het Corpus Iuris.

De belangrijkste conclusies waartoe Wijffels met zijn doctorale dissertatie is gekomen, kunnen als volgt worden samengevat. Wat de eerste groep betreft, behoorden, naast de 14.5 procent aan abstracte, doctrinale omschrijvingen als doctores, scribentes, legiste, theoria, etcetera, auteurs als Bartolo da Sassoferrato, Baldus de Ubaldus, Giasone del Maino en Paulo di Castro tot de meest populaire rechtsgeleerden. In tweede instantie verdienen ook Alessandro di Tartagni en Angelus de Ubaldus een vermelding. Wat uitsluitend de Codex betreft, mag het belang van auteurs als Cynus de Pistoia (12701336) en Bartolomeo de Saliceto niet onderschat worden.

Ten aanzien van het canonieke recht laat Wijffels ook nu weer, naast de twintig procent niet-gespecifieerde doctrine, een beperkte diversiteit aan auteurs zien. Tot de meest frequent geallegeerde iuris periti behoren auteurs als Nicolo de Tudeschi alias

741 Zijn werk ligt in de lijn van wat men eerder met de computer had trachten te bewerkstelligen, maar waarbij de verhoopte resultaten niet werden behaald. Cfr. WIJFFELS, Qui millies allegatur, I, 17. De methodologische obstakels werden uiteengezet in J. T. DE SMIDT, "Komputer und die Rezeption des gelehrten Rechts", J. T. DE SMIDT red. Miscellanea Consilii Magni (Verzamelen en bewerken van de jurisprudentie van de Grote Raad. Nieuwe reeks. N4), Amsterdam, 1980, 153-158 en A. J. DE GROOT, "Datenverarbeitung bei der Rezeptionsgeschichte", J. T. DE SMIDT red. Miscellanea Consilii Magni (Verzamelen en bewerken van de jurisprudentie van de Grote Raad. Nieuwe reeks. N${ }^{\circ}$ ), Amsterdam, 1980, 159-169. 
Panormitanus, Innocentius IV (1195-1254) en Felinus Sandeus (1444-1503). Daarnaast hebben ook Giovanni d'Andrea en Alessandro di Tartagni een noemenswaardige rol gespeeld.

Wat de 'monografische doctrine' betreft, identificeert Wijffels 78 verschillende auteurs, waarvan er zeventien minstens tien maal werden geallegeerd. ${ }^{742}$ Deze lijst wordt aangevoerd door het Speculum van Guilielmo Duranti en de Consilia van Alessandro di Tartagni. Samen zijn zij goed voor maar liefst één derde van alle allegaties uit de onderzoeksgroep. Verder verdienen ook Guy de la Pape, Ludovico Pontano de Roma, Baldus de Ubaldis, Bartolo da Sassoferrato, Barthélémy de Chasseneuz en Nicolas Everaerts vernoemd te worden. Het feit dat sommige auteurs slechts met betrekking tot één casus worden aangevoerd, wijst erop hoe relatief het aandeel ervan binnen de groep kan zijn. Een gelijkaardige relativering is gewenst met betrekking tot het belang van de nummer twee uit de lijst, Alessandro di Tartagni. Maar liefst zeventig procent van alle allegaties naar zijn Consilia is immers afkomstig van één en dezelfde advocaat. Desalniettemin blijft hij, ook na deze correctie, op een vergelijkbaar niveau als dat van Baldus de Ubaldis en Bartolo da Sassoferrato. Wat eveneens opvalt binnen deze groep is de dominante positie van het genre der Consilia, evenals de manifeste aanwezigheid van contemporaine auteurs. ${ }^{743}$ Deze laatste vaststelling ligt enigszins voor de hand, aangezien deze literatuur -op de Consilia nazich na 1500 pas volop gaan ontwikkelen is, terwijl er -op de Instituten na- minder aandacht besteed werd an het becommentariëren van het Corpus Iuris Civilis. ${ }^{744}$ Wijffels besluit: "L'image globale de la doctrine monographique n'infirme donc pas l'observation générale qui caractérise la doctrine citée en connexion avec le CICiv et le CICan: l'importance du Speculum et des consilia médiévaux (ainsi que de quelque autres ouvrages) renforce au contraire la constatation que la doctrine du XVIe siècle ne perce que très modestement avant 1580, et ne représente sur l'ensemble qu'une fraction mineure des allégations." 745 Ook globaal gezien stelt de auteur een overwicht vast van werken van de mos italicus, wat -aldus Wijffels- de voorkeur voor de Italiaanse rechtswetenschap binnen de Nederlandse praktijk lijkt te bevestigen. Aan het juridisch humanisme kent hij een zeer kleine rol toe. De enkele allegaties naar auteurs als Andrea Alciato zijn voor hem representatief voor het beperkte gebruik van humanistische literatuur. ${ }^{746}$

Ander vergelijkingsmateriaal bestaat uit onder meer de biografische studie van de hand van Dugas de la Boissony over de Franse rechtsgeleerde Barthélémy de

${ }^{742}$ De 28 voornaamste auteurs worden door Wijffels opgesomd: WIJFFELS, Qui millies allegatur, I, 204.

${ }^{743}$ Het aandeel van de overige genres, zoals dat van de rechtspraakverzamelingen, traktaten en (becommentarieerde) costumiere compilaties blijft evenwel beperkt.

744 WIJFFELS, Qui millies allegatur, I, 207.

745 WIJFFELS, Qui millies allegatur, I, 207.

746 WIJFFELS, Qui millies allegatur, I, 166. Verdere bespreking van de geallegeerde werken en hun verspreiding, cfr. WIJFFELS, Qui millies allegatur, I, 207-282. Wijffels maakt evenwel geen onderscheid tussen de rechtsgeleerde aard van de auteur enerzijds en de oriëntatie van zijn werken anderzijds. Bij Wijffels zijn bijgevolg alle werken van een auteur, die doorgaans als humanist aanzien wordt, per definitie eveneens humanistisch van aard. 
Chasseneuz, en de inleiding van Carney op de (verkorte) vertaling van de derde druk van de Politica van Johannes Althusius. ${ }^{747}$ Dugas stelt echter enkel vast; tot analyse komt hij niet, althans wat de allegaties betreft. Het is een louter descriptief aangeven van de bronnen waarop de Chasseneuz zich beroept in zijn rechtsgeleerde activiteiten. In zulke condities kan er van vergelijken niet onmiddellijk sprake zijn, ware het niet dat ik zelf tot een korte analyse overgegaan ben. Ik heb me laten verleiden tot het opstellen van een top tien van auteurs die het meest frequent door de Chasseneuz werden geallegeerd. Uiterst interessant hierbij is dat de Chasseneuz zowel een (eerder praktijk-georiënteerde) commentaar op de Coutumes de Bourgogne (1517) heeft geschreven, evenals een humanistisch werk, de Catalogus gloriae mundi (1529) genaamd. Er bestaat dan ook een duidelijk verschil tussen beide paletten aan geallegeerde auteurs. Zo is dat van de Catalogus veel ruimer, rijker en overschreidt het aanzienlijk de grenzen van het zuiver juridische. De Catalogus laat de Chasseneuz toe zijn kennis te etaleren en een zeer breed spectrum van intellectuelen uit heden en verleden te vermelden. Auteurs tekenend voor een humanistische geest zijn namen van klassieke schrijvers zoals bijvoorbeeld Aristoteles en Cicero. Zelfs naar de pioniers van het juridisch humanisme, met name Andrea Alciato, Ulrich Zäsi en Guillaume Budé, wordt reeds in dit werk, dat dateert van 1532, teruggegrepen. De commentaar op het Bourgondische gewoonterecht ligt qua onderwerp dan weer veel dichter bij de aard van de grondtekst van de Memorieboeken, met name het costumiere recht van Antwerpen. Beide zijn commentaren bij een costumiere basistekst. Vergelijken is dus toegestaan. Ik vraag me dan ook af welke raakvlakken er al dan niet zullen bestaan tussen beide juridische bases. Elk voordeel heeft zijn nadeel en hier staat dan ook tegenover dat de commentaar van de Chasseneuz dateert van 1532, waar de Memorien op de Antwerpse costumen bijna tachtig jaar ouder zijn. Het aanbod van juridische literatuur is met andere woorden aanzienlijk uitgebreid. In dit opzicht blijkt de Politica van Johannes Althusius, waarvan de allegaties door Carney besproken werden, beter geschikt als vergelijkingsmateriaal. De eerste uitgave ervan verscheen immers in 1603. Thematisch daarentegen liggen beide werken dan weer ver uit elkaar. Althusius beschouwt staatstheoretische aangelegenheden, iets wat eerder neigt naar het publiekrechtelijke domein van de rechtswetenschap.

In tegenstelling tot Dugas de la Boissony, waagt Carney zich wel aan een korte bespreking van de geallegeerde auteurs. Hierbij deelt hij ze thematisch op in een negental categorieën, waaronder politicologen, juristen, calvinistische theologen, katholieke theologen, historici, klassieke auteurs, etcetera. Vooral zijn negende categorie Wie ontbreekt er? heeft inspirerend op mijn aanpak ingewerkt. Ook ik zal steeds trachten aan te geven welke auteurs en welke werken niet aan bod zijn gekomen, hoewel ze, hun plaats in de rechtsgeschiedenis in acht genomen, evenwel verwacht konden worden. Wat de resultaten betreft, blijft Carney echter zeer summier. Ten aanzien van het Corpus Iuris Civilis en de romanisten die het becommentariëerden, wijst hij op de belangrijke rol van Bartolo da Sassoferrato,

${ }^{747}$ DUGAS DE LA BOISSONNY, Barthelemy de Chasseneur. CARNEY, The Politics of Johannes Althusius, xxviii-xxxiii. 
Paulo di Castro en Andreas Gaill. Ten aanzien van het canonieke recht stelt hij een aanzienlijk aantal referenties vast naar canonisten als Nicolo di Tudeschi en Diego Covarubias y Leyva. Maar ook costumiere rechtssytemen worden geregeld vermeld. In dit opzicht wijst hij op auteurs als Henry Rosenthal en Peter Heige voor het contemporaine Heilige Roomse Rijk en François Hotman en Charles Dumoulin voor het Frankrijk van 1600. Ontbrekende namen zijn voor Carney de middeleeuwse publicisten, samen met de Engelse auteurs.

\section{Methode}

Onontbeerlijk bij een onderzoek aan de hand van rechtsgeleerde allegaties is de samenstelling van een onderzoekgroep van relevante allegaties. ${ }^{748}$ Er dient met andere woorden een selectie gemaakt te worden in functie van de onderzoeksvraag. Zo beperk ik me in deze studie tot de zogenaamde 'doctrinale' allegaties. Ik ben immers op zoek naar het intellectuele klimaat dat de commissieleden als geheel kenmerkt. Enkel allegaties waarbij sprake is van een peritus iuris kan bijdragen tot de beeldvorming van dit klimaat. Zuivere allegaties naar het Corpus Iuris zijn in dit opzicht van geen enkel belang. In mijn onderzoek is dan ook de expliciete vermelding van de naam van de geallegeerde auteur een vereiste opdat de allegatie in de onderzoekgroep kan opgenomen worden. Enkel zulke 'nominale allegaties' zullen in de onderzoeksgroep worden toegelaten. De enige uitzondering die ik op deze regel heb toegestaan, is wanneer de auteur abstract omschreven wordt als auctor, en het evident is om welke auteur en welk werk het gaat, en het bovendien duidelijk is dat men naar de mening van de auteur verwijst. ${ }^{79}$ Over gans de Memorieboeken gezien doet zich dit slechts drie maal voor, meer bepaald ten aanzien van Pierre Guenoys zoals onder meer met betrekking tot artikel 2.1.76: “...accordat expresse consuet. Paris. art 225 tit de communaulte des biens in conferentijs fol 555 verso sub finem ubi Auctor in hanc sententiam, quod videlicet Maritus delinquendo non preiudicat parti uxoris, allegat Barth. in L si quis $C$ unde vi, eleganter et Joes Garzias in tractatu de expensis et meliorationibus cap. $13 \mathrm{nu}$ 19..."750 Andere abstracte omschrijvingen zoals doctores en scribentes zijn wegens hun anoniem karakter onbruikbaar en bijgevolg irrelevant voor het onderzoek. ${ }^{751}$ Deze

\footnotetext{
${ }^{748}$ In het verleden drukte Kantorowicz het verschil tussen een allegatie en een citaat als volgt uit: "Die Allegationen, also die Verweise auf die Rechtsquellen, sind keine Zitate, d. h. wörtliche oder annähernd wörtliche Wiedergaben einer Stelle; sie enthalten lediglich die zur Auffindung der gemeinten Stelle erforderlichen Angaben." (H. KANTOROWICZ, "Die Allegationen im späteren Mittelalter", Archiv fïr Urkundenforschung, 13 (1933), 16.)

${ }^{749}$ Laatstgenoemde voorwaarde verklaart waarom sommige anominale allegaties, ondanks het feit dat het duidelijk is om wie het gaat, toch niet werden meegerekend. Dit is meermaals het geval geweest bij auteurs als Louis le Caron, Pierre Guenoys en Marcus Antonius Bellonius. Men verwijst er immers naar de inhoud van hun werken en niet naar de opinio doctorum. Mogelijk is dit ook de reden waarom hun naam niet expliciet werd vermeld.

${ }^{750}$ De andere gevallen betreffen de artikels 2.1.92 en 5.10.14.

${ }^{751}$ Ten eerste zijn er de doctores, vaak afgekort weergegeven als $d d$. Op deze verkorte manier komen zij voor met betrekking tot de volgende artikels: 1.1.15, 2.1.12, 2.1.112/113/114, 2.2.24, 2.5.80/81, 2.5.90/91/92 (2x), 2.5.198, 2.5.199/200, 3.1.1, 3.5.1, 3.5.88, 3.7.1/2, 3.10.1, 3.11.1/2, 3.11.4/5/6, 3.11.16, 3.13.9, 3.13.35, 3.13.49, 3.13.53, 3.13.67, 3.13.69/70, 3.14.100,
} 
allegaties worden dan ook buiten beschouwing gelaten. Omtrent de samenstelling van de onderzoeksgroep wil ik nog een tweetal opmerkingen maken. Zo beperkt het uit te kammen gebied zich niet langer -zoals in hoofdstuk 1 het geval was- tot uitsluitend de nieuw toegevoegde artikels in de Consuetudines compilatae. In dit derde hoofdstuk komen de ganse Memorieboeken aan bod. Ook de allegaties welke vermeld worden ten aanzien van oude artikels uit de Consuetudines impressae die behouden blijven, komen hier aan bod. Ook deze referenties weerspiegelen immers het gedachtegoed van de commissieleden. Een tweede opmerking, en tevens een tweede verschil qua aanpak met hoofdstuk 1, is dat me ook niet langer beperk tot de primaire rechtsbronnen. Het maakt niet langer uit in welke rol een bepaalde opinio doctorum wordt angewend. Het feit dat er beroep op gedaan wordt, volstaat.

Voor het onderzoek is de identificatie van de geallegeerde auteur echter niet voldoende. Ik ben immers op zoek naar humanistische invloeden en aangezien sommige auteurs zowel humanistische als eerder middeleeuwse werken voortgebracht hebben, is het van belang te focussen op de werken en niet de persoon van de auteur. Zo kan men de Chasseneuz op basis van zijn Catalogus als een rasechte humanist bestempelen, waar zijn commentaar op de Bourgondische coutumes nog niet van zulk een ingesteldheid blijk geeft. ${ }^{752}$ Dit is niet abnormaal, gezien de tijd waarin hij werkzaam was en waarin het juridisch humanisme zich nog ten volle ontplooien moest. Ook Alciato schreef, net als vele andere tijdgenoten, zowel traditionele als humanistische werken. 753

Zowel de identificatie van de persoon als het werk is met andere woorden een vereiste. Dat deze opgave niet altijd even vanzelfsprekend was, blijkt uit de door mij gevolgde identificatieprocedure. In de eerste plaats werd ik geconfronteerd met het feit dat de Memorieboeken bestonden uit bijna 2500 handgeschreven folio's, wat inhield dat er vooreerst een aanzienlijke hoeveelheid paleografische hindernissen genomen diende te worden, alvorens ik kon overgaan tot de daadwerkelijke identificatie van de

4.7.12, 4.9.6, 4.11.276/277/278/279, 4.12.18, 4.13.38/39, 4.16.24, 5.10.39/40/41, 5.10.74, $5.11 .12,5.11 .21 / 22,5.17 .100 / 101,6.1 .37,6.2 .5,6.2 .18,6.3 .10 / 11,6.3 .13,6.3 .23,7.2 .5,7.3 .1$, 7.3.27 (2x). Andere verschijningsvormen zijn doctores (3.13.23, 3.13.68, 4.10.13/14/15/16, 4.13.38/39), doctorum (3.4.3, 4.6.17), et alii dd (4.6.19, 4.12.5, 4.12.22), et aliis qui de mercatore et ... scripserunt (5.11.42), scribentes Hispani (2.1.142), theologi qui casus conscienti[a]e tractarunt (3.3.18) en de voldoende dubbelzinnige uitdrukking gloss, waarbij men nu weer de glossator (...et ibi glossator) zoals ten aanzien van de artikels 5.4.25/26 bedoelt, en een andere keer de glosse als marginale opmerking zoals bij artikel 2.5 .82 (...gloss[ae] Barth[oli] et alij in L 1 C de alend[is] liber [is] ac parentibus ...). Tot slot werden ook de pragmatici $(2.1 .173 / 174,4.3 .72 / 73)$ en de pragmatic antiquiores (5.15.17.) tot deze groep gerekend, net als 'de anderen' in letterlijke zin: et alii (1.1.3, 3.13.33/34, 4.18.52, 5.8.6, 5.11.21/22 (2x), 5.11.47, 6.3.8), et aliorum (2.1.227/228), et alii ibidem allegati (2.1.11), et alii quos allegant Gabriel et Turretus (3.13.23) en et alii quos allegant $(4.1 .9 / 10(3 \mathrm{x}))$.

752 DUGAS DE LA BOISSONNY, Barthélémy de Chasseneur.

753 P.-E. VIARD, André Alciat, 1492-1550, Parijs, 1926. 
geallegeerde werken. ${ }^{754}$ Het startpunt hierbij was in vele gevallen de homepage van de online zoekmachine Google, een afgekorte persoonsnaam en een fragmentarische titel van het werk waarnaar verwezen werd. Op deze manier, en dan vooral dankzij de mogelijkheid van wildcard-operatoren, stelde het internet me in staat er achter te komen waar ik juist mee te maken had. Verdere verificatie gebeurde vervolgens aan de hand van de vele online beschikbare bibliotheekcatalogi, waarbij die van het Max Planck Instituut in Frankfurt am Main een voorname plaats innam omwille van de unieke uitgebreidheid van de collectie. De voorlopige resultaten, op deze -misschien minder orthodoxe- manier verworven, werden vervolgens getoetst aan de hand van meer courante en traditioneel-wetenschappelijke naslagwerken zoals in de eerste plaats Coings standaardwerk Handbuch der Quellen und Literatur der neueren europäischen Privatrechtsgeschichte. ${ }^{755}$ Wat de eigen contreien betreft, mag Dekkers' Bibliotheca Belgica Juridica hier niet ontbreken. ${ }^{756}$ Hoezeer deze werken in wetenschappelijke kringen ook geapprecieerd mogen worden, ook zij zijn niet volmaakt. Niet alle geallegeerde werken konden er namelijk in teruggevonden worden. ${ }^{757}$ Gelukkig kon ik voor sommige auteurs ook over individuele biografieën beschikken, waarin leven en werk uitgebreid beschreven stonden. ${ }^{758}$ Andere iuris periti en hun werken konden teruggevonden worden in biografische encyclopedieën. ${ }^{759}$ Desondanks bleek deze methode niet te volstaan. Onidentificeerbare auteurs deden lacunes ontstaan, wat me ertoe aanzette volgens een meer willekeurige aanpak aan de slag te gaan. Allerhande bibliotheekcatalogi van zowel oude verdwenen, als nog bestaande bibliotheken

754 Ter identificatie van bronnen zijn volgende werken zeer behulpzaam gebleken: KANTOROWICZ, "Die Allegationen im späteren Mittelalter", 15-29. J. BERLIOZ et alii, Identifier sources et citations (L'atelier du Médiéviste. 1), Turnhout, 1994.

755 H. COING, Handbuch der Quellen und Literatur der neueren europäischen Privatrechtsgeschichte (Max-Planck-Institut für Europäische Rechtsgeschichte), 3 dln., Munchen, 1973-1980.

756 DEKKERS, Bibliotheca Belgica Juridica.

757 Zo is er bijvoorbeeld nergens sprake van de commentaar van Etienne Ranchin op de Decisiones van Guy de la Pape. In dat geval heb ik een beroep gedaan op meer monografische werken, zoals bijvoorbeeld de biografie die Chabrand wijdde aan Guy de la Pape. (L. CHABRAND, Étude sur Gui Pape, (1404?-1477), Parijs, 1912.)

758 Hun aantal blijft evenwel beperkt: Andrea Alciato, Etienne Bertrand, Barthélémy de Chasseneuz, Giulio Claro, Charles Dumoulin, Andreas Gaill, Joachim Mynsinger von Frndeck, Guy de la Pape, André Tiraqueau, ... Hun biografen staan vermeld bij het overzicht van geallegeerde auteurs in paragraaf 2 van dit hoofdstuk. Cfr. infra, hoofdstuk 3, paragraaf 1 , Overzicht van geallegeerde rechtsgeleerden.

${ }^{759}$ Hierbij denk ik voornamelijk aan de volgende encyclopedieën: Biographie nationale de Belgique, 44 dln., Brussel, 1866-1986. Nieuw Nederlandsch biografisch woordenboek, 10 dln., Leiden, 1911 1937. Novissimo Digesto Italiano, 27 dln., Turijn, 1957-1987. Neue deutsche Biographie, 22 dln., Berlijn, 1953-2005. Dictionnaire de biographie française, 19 dln., Parijs, 1933-2001. De Dictionnaire bistorique des juristes français (XIIe-XXe siècle), een product van het 'Centre Chevrier' van l'Université de Bourgogne te Dijon in samenwerking met het 'Centre Toulousain d'Histoire du Droit et des Idées Politiques' van l'Université des sciences sociales de Toulouse, heb ik evenwel niet kunnen raadplegen. (Cfr. Dictionnaire historique des juristes français (XIIe-XXe siècle), $5 \mathrm{dln}$., Parijs, 2006.) 
werden doorzocht, net als alle mogelijk bibliografische overzichten die betrekking hadden op rechtsgeleerde literatuur daterend van voor 1608.760 Noemenswaardig in dit opzicht is onder meer Osler en zijn Catalogue of books printed on the continent of Europe from the beginning of printing to 1600 in the Max-Planck-Institut für Europäische Rechtsgeschichte, zowel als zijn Catalogue of books printed in Spain, Portugal and the Southern and Northern Netherlands from the beginning of printing to 1800 in the Max-Planck-Institut für Europäische Rechtsgeschichte. 761 Maar ook vergelijkbare studies van onder meer Wijffels en Dugas de la Boissony bleken uiterst behulpzaam te zijn in dit opzicht. ${ }^{762}$ Beiden zijn immers voorzien van een uitstekend overzicht van allegaties welke aangetroffen werden in de door hen onderzochte werken. Tot slot wil ik voor een meer exhaustieve behandeling van dit arsenaal aan identificatiehulpmiddelen verwijzen naar de bibliografie van dit boek.

De door mij gekozen werkwijze liep echter niet altijd over rozen. De onzorgvuldige aanpak van de auteurs van de Memorieboeken en hun niet altijd even gedetailleerde omschrijvingen in combinatie met de relatieve onbekendheid van sommige rechtsgeleerden, maakte dat hun identificatie vaak heel wat meer voeten in de aarde had dan aanvankelijk verwacht. Meermaals dreigde de zoektocht om te slaan in een bron van frustatie, wat op zijn beurt de historische sensatie des te groter maakte van zodra de identificatie -tegen alle verwachtingen in- dan toch nog geschiedde. Spontaan denk ik hierbij terug aan de allegaties bij de artikels 4.1.9/10 en 6.3.27, waarin respectievelijk naar iuris periti als Jean d'Arrerac en Johan Schneidewin werd verwezen. ${ }^{763}$ De obscuriteit van d'Arrerac en de nonchalante wijze waarop er naar

\footnotetext{
${ }^{760}$ Bij laatstgenoemde soort denk ik onder meer aan volgende werken: R. DOUCET, Les bibliothèques parisiennes au XVTe siecle, Parijs, 1956. R. FEENSTRA, "Ouvrages de droit romain dans les catalogues des anciens Pays-Bas Septentrionaux (XIIIe-XVIe siècle)", Tijdschrift voor Rechtsgeschiedenis, 28 (1960), 439-530. L. T. MAES, La bibliothèque du Grand Conseil à Malines, Mechelen, 1949. P. P. SCHMIDT, Oude drukken in de bibliotheek van de Hoge Raad der Nederlanden: catalogus, Zwolle, 1988.

${ }^{761}$ D. J. OSLER, Bibliographica Iuridica 1. Catalogue of books printed on the continent of Europe from the beginning of printing to 1600 in the library of the Max-Planck-Institut für Europäische Rechtsgeschichte, Frankfurt am Main (Ius Commune Sonderheft 130), Frankfurt am Main, 2000. D. J. OSLER, Bibliographica Iuridica 2. Catalogue of books printed in Spain, Portugal and the Southern and Northern Netherlands from the beginning of printing to 1800 in the library of the Max-Planck-Institut für Europäische Rechtsgeschichte, Frankfurt am Main (Ius Commune Sonderheft 131), Frankfurt am Main, 2000. Beide catalogen kwamen tot stand in het voorbereidende werk op de Census of 16th Century Legal Imprints van Douglas Osler. Hierin beoogt deze laatste een overzicht te geven van alle gedrukte, juridische werken van het zestiende-eeuwse, continentale Europa. (Cfr. D. J. OSLER, "Towards a legal-historical Bibliography: A Census of $16^{\text {th }}$ Century Legal Imprints", Ius Commune: Zeitschrift für Europäische Rechtsgeschichte, 15 (1988) 231-242.)

762 DUGAS DE LA BOISSONNY, Barthélémy de Chasseneur. WIJFFELS, Qui millies allegatur.

${ }^{763}$ Cfr. Memorien op de Costumen met betrekking tot de artikels 4.1.9/10: “...et sequitur Jo[ann]es Arraratius consiliarius parlamenti Burdegalensis in tractatu de la philosophi [a]e civile...". Schneidewin is terug te vinden in verband met artikel 6.3.27: “...ut nemesi seu paraphrasi constit [utio] Crimin[alis] Caroli quinti cap 135 quam citat Sneyduin [us] instit [utio] de hered[is] qua[e] ab intest. defer. $n^{\circ} 15 \ldots$.
} 
Schneidewin werd verwezen, maakte dat hun identificatie niet over één nacht ijs liep. Dat de redacteurs vaak onvoldoende specifiek hun allegaties neerschreven, leidde in een aantal gevallen tot heel wat verwarring, waarbij juristen verschenen die vaak even snel weer verdwenen. Dit was bijvoorbeeld het geval met betrekking tot artikel 2.1.142: ...ut inter c [a] eteros de Hispanis testatur Palatius ruinus in repetit [io] cap. per vestras $\mathbb{I}$ 66 I de donat [ionibus] inter vir et uxor... In eerste instantie dacht ik onmiddellijk aan de Italiaanse jurist Carlo Ruini (1456-1530). Materiële controle aan de hand van de titel van het werk wees echter al gauw uit dat het hier enkel om de Spanjaard Juan Lopez de Palacios Rubeus de Ribero kon gaan. Ook het bestaan van familiebanden tussen verschillende rechtsgeleerden, dwong me tot het uitvoeren van een materiële controle. Ik denk bijvoorbeeld aan vader Mariano Sozzini Senior (1397-1467) en zijn zoon Bartolomeo Sozzini (1436-1507) die op zijn beurt de oom was van Mariano Sozzini Junior (1482-1556). Allen bouwden zij een carrière uit als gerespecteerd jurist. Het is dan ook niet meteen duidelijk op wie men doelt, wanneer de Memorieboeken enkel melding maken van Mariani Socini zoals in artikel 1.16.1: “..., ubi de ijs qui aperte incolatum profitentur est decisio Mariani Socini ad cap ult col 7 versic 6 principaliter quero $x$ de foro compet [enti]...". Ook nu bood enkel de titel van het werk uitsluitsel. Hetzelfde geldt voor te ver doorgedreven afkortingen of pseudoniemen die weliswaar zeer gebruikelijk en even herkenbaar waren in de zeventiende eeuw, maar die vandaag de dag minder voor de hand liggen (Martino de Azpilcueta alias Doctor Navarrus, Louis le Caron alias Charondas, Raffaele da Cuma alias Raffaele Raimondi, Charles Dumoulin alias Caspar Caballinus a Cingulo, Guilielmo Duranti alias Speculator, Johann Schneidewin alias Oenitomus, Nicolo de Tudeschi alias abbas Panormitanus of abbas Siculus of abbas modernus of abbas recentior.). Bovendien leidde de vaak onzorgvuldige aanpak van de scribenten tot onduidelijkheden. Zo ontstond er heel wat twijfel aangaande de artikels 3.13.21 en 3.13.23 alwaar sprake is van respectievelijk preside Gerardi en preses Chirardi. ${ }^{764}$ Gaat het hier misschien om de Antwerpse burgemeester Gerardi, verkozen in 1592 en 1612, die -samen met Karel Gabri- een Vertoog over de heryiening der Costuymen van Antwerpen schreef? ${ }^{765}$ Of gaat het hier toch -zoals eerst aangenomen- om Nicolaes Everaerts, de president van de Grote Raad van Mechelen?766 Het gebeurde eveneens dat bepaalde auteurs met de verkeerde voornaam werden geallegeerd. Zo is er ten aanzien van artikel 3.14 .46 sprake van Ioannes Collerus alwaar Matthias Coler bedoeld wordt. Althans zo bleek uit de materiële controle van de verwijzing. Nog meer gecompliceerd wordt het allemaal van zodra ook er gemorst wordt met courante -officieus conventionele- aanduidingen. Zo is het algemeen aanvaard dat, wanneer er sprake is van Angelus, men verwijst naar het oeuvre van Angelus de Ubaldis. Dit is echter niet het geval ten aanzien van de artikels 4.13.38/39 in de Memorieboeken. Hoewel er enkel sprake is van Angelus (“...ubi allegant

\footnotetext{
${ }^{764}$ Cfr. Memorien op de Costumen met betrekking tot de artikels 3.13 .2 (...et traditis a preside Gerardi cons[ilia] 129 nu sexto et seqq...) en 3.13 .23 (...Preses Chirardi cons[ilio] 26 nu $8^{\circ}$ et cons[ilio] 15 nи $\left.29^{\circ} \ldots\right)$.

${ }^{765}$ Cfr. DEKKERS, Bibliotheca Belgica Juridica, 59.

766 Beiden hadden immers juridische werken geschreven. Cfr. DEKKERS, Bibliotheca Belgica Juridica, 53 en 59.
} 
Angel[us] in $\int$ sed hodie n[ovella] inst. de satisd[atione tutorum vel curatorum]...."), bleek uit de materiële controle dat de auteurs niet op Angelus de Ubaldus doelden, maar wel verwezen naar de opinie van Angelus Aretinus, tevens bekend als Angelus Gambiglione. ${ }^{767}$ Zulk een ontbreken aan geschreven conventies omtrent de wijze van allegeren naar personen maakte dat ik de allegatie -conform de ongeschreven regelaanvankelijk toeschreef aan Angelus de Ubaldus. In een aantal gevallen is het echter onmogelijk gebleken te achterhalen naar wie men exact refereren wilde.768 Vaak zorgde een teveel aan mogelijkheden ervoor dat mijn queeste eindigde in een doodlopende straat. Zulk een probleem deed zich onder meer voor ten aanzien van de persoon omschreven als Curtius met betrekking tot artikel 5.8.6: "Est 12 in impressis et pro eo est antiqua sententia vanden 16 decemb[er] 1445 in lib pergameno fol 3 suntque iuris communis glossa in $C$ fin $X$ de foro compet[enti] ad verbum compelli Bart[olus] Castrens[is] Fulgoss[ius] Curtius et alii in $L 2 \int$ legatis ff de indic[iiis] per cap fin $X$ de dilat[ionibus] late Pecquius in tract [atu] de iure sistend[i] cap 5 nu 11 versic. ex quo." Doorheen de tijd hebben zich namelijk verschillende dragers van deze naam zich binnen de rechtswetenschap verdienstelijk gemaakt. Er zijn de zestiende-eeuwse Italianen Rochus Curtius (Rocco Corte) en Franciscus Curtius (de Curte, Corte), maar ook de naam van de te Brugge geboren Jacobus de Korte (Jacobus Curtius, 1510-1567) ${ }^{769}$ werd tot Curtius verlatiniseerd. De informatie in de Memorieboeken is bijgevolg te beperkt om uit te maken om wie het exact gaat. Ook het feit dat er eveneens in het traktaat van Pieter Peck naar Curtius wordt verwezen, helpt ons niet verder. Of toch? Omwille van het feit dat het hier juist om één allegatie gaat die van de tweede rang is, is het verder ook niet van belang om wie het gaat. Zo houdt dit onopgelost probleem geen repercussies in voor het verdere verloop van het onderzoek. Uiteindelijk zijn we voor een zevental referenties niet in staat gebleken de identiteit van de auteur te onthullen.

Ook het tweede luik van de allegatie werd vaak -meer nog zelfs dan het eerste- te onzorgvuldig of onvoldoende specifiek weergegeven. Ik denk in de eerste plaats aan de 'onvolledige allegaties' of die waarbij de naam van het werk geheel ontbreekt, zoals het geval is bij Philip Bugnyon. ${ }^{770}$ Zulke allegaties kunnen niet langer tot de

\footnotetext{
${ }^{767}$ Het betreft hier namelijk een allegatie van de zogenaamde tweede rang. Hierbij verwijst men naar een auteur x, in dit geval Giulio Claro, die op zijn beurt refereert naar een tweede auteur y, in dit geval Angelus Gambiglione. Dat het in dit geval om een tweederangse allegatie gaat, en dat het Angelus Aretinus betrof, bleek uit de editie van 1739 van Claro's Opera omnia, sive practica civilis atque criminalis. ("Et hanc cautelam tradit Ang[elus] Areti in $\int$ bodie, num 1 inst[itutio] de satisdatio.") (Cfr. G. CLARO, Opera omnia sive practica civilis et criminalis, Genève, 1739.)

768 Voor een volledig overzicht van onidentificeerbare allegaties, cfr. infra, hoofdstuk 3, paragraaf 1, Overzicht van geallegeerde rechtsgeleerden.

769 Omtrent Rochus Curtius, cfr. HOLTHÖFER, "Die Literatur zum gemeinen und partikularen Recht", 441. Omtrent Franciscus Curtius, cfr. HOLTHÖFER, "Die Literatur zum gemeinen und partikularen Recht", 441. Omtrent Jacobus Curtius, cfr. DEKKERS, Bibliotheca Belgica Juridica, 39. Het voornaamste werk van laatstgenoemde is de Institutionum iuris civilis libri IV (1536).

${ }^{770}$ Cfr. 1.1.14: “...que tam bic quam in Gallijs exoleverunt vel potius nunquam recept [a]e fuerunt, ut apud Bugnon et alios." Vermoedelijk gaat het om zijn meest bekende Tractatus legum abrogatarum, een
} 
onderzoeksgroep gerekend worden en ik heb hen dan ook buiten beschouwing gelaten. Van zodra het allegaties betrof, die verwezen naar de commentaar van een bepaalde jurist bij een specifieke regel uit het Corpus Iuris Civilis of het Corpus Iuris Canonici, werd ik in zekere zin met een gelijkaardig probleem geconfronteerd. Zolang het juridisch oeuvre van de desbetreffende rechtsgeleerde beperkt en/of specifiek is gebleven, was het mogelijk aan de hand van de identificatie van de lex, waarnaar werd verwezen, te achterhalen welke commentaar het betrof. Ter illustratie wil ik wijzen op de allegatie naar Wigle van Aytta en zijn commentaar bij de Digestentitel ff si certum petatur. ${ }^{771}$ Naast een uitvoerige commentaar op de tien titels van de Institutiones en een Griekse vertaling van hetzelfde werk heeft Viglius weinig juridische werken geproduceerd. ${ }^{772}$ Het is evident -zelfs zonder materiële controle- dat het hier om deze commentaar gaat. Een nog sprekender voorbeeld is terug te vinden bij de Leuvense humanist-jurist, Gabriel Van der Muyden, die onder andere ten aanzien van artikel 4.9.11 als volgt geallegeerd werd: “...L nemo potest $35 \mathrm{~L}$ adeo morte socii 59 ibi mudeus ff pro socio sed usus tam hic quam alibi contrarium observat et...". Het betreft de opinie van Van der Muyden bij de leges D.17.2.35 en D.17.2.59pr uit de Digestentitel pro socio (D.17.2). Eén van Mudaeus' voornaamste werken is zijn Commentaria ad titulos Digestorum: pro socio, de contrahenda emptione, de actionibus empti et venditi, de pignoribus et bypothecis. ${ }^{773}$ Het staat buiten kijf dat ik hier met hetzelfde werk te maken heb. Moeilijker werd het echter van zodra vooraanstaande, middeleeuwse commentatoren, zoals Bartolo da Sassoferrato en Baldus de Ubaldis, aan de orde waren. De commentaren welke van hun hand verschenen zijn, zijn immers zo talrijk dat het zo goed als onmogelijk is uit te maken op welke commentaar de redacteurs zich hebben gebaseerd. Omdat de materiële controle van al deze allegaties me te ver zou leiden, heb ik er van afgezien op zoek te gaan naar elke individuele commentaar waarnaar mogelijk verwezen werd. Bovendien bestaat de kans erin dat de commissieleden een Opera omnia ter beschikken hadden. Hun allegaties heb ik dan ook samengevat weergegeven onder de noemer 'commentaren van x bij het Corpus Iuris Civilis of het Corpus Iuris Canonici'. Maar ook nu weer speelde de vaak onzorgvuldige aanpak van de scribenten me parten. Neem nu de commentaar bij artikel 3.13.41: Est desumptus ex usu et arresto curiae Paris[iensis] apud Charond[as] respons[iones] Gallic[ae] lib. nono respons[io] 9a et iterum in memorabilibus dicto verbo fideicommiss[is] fol 120 versiculo et seq. ubi allegat tex. in lege cum pater $77 \int$ hereditatem $4^{\circ}$ ff ad legem falcidiam. Op het einde staat te lezen dat het artikel ook teruggaat op wat ik in de Memorables observations du droit français van Louis le Caron kan terugvinden bij het voornoemde woord fideicommissis op folio 120 verso en volgende, alwaar de wet cum pater, paragraaf vier beginnende met hereditatem uit de Digestentitel Ad legem falcidiam wordt geallegeerd. De onzorgvuldigheid laat zich op verschillende manieren gevoelen. Ten eerste is er onder deze titel niet zulk een lex terug te vinden. De wet blijkt afkomstig te zijn van de Digestentitel De legibus 2 en

rechtsvergelijkend werk van het type censura daterend van de tweede helft van de zestiende eeuw. (Cfr. HOLTHÖFER, "Die Literatur zum gemeinen und partikularen Recht", 226-227.)

771 4.1.11/12/13.

772 DEKKERS, Bibliotheca Belgica Juridica, 7.

${ }^{773}$ DEKKERS, Bibliotheca Belgica Juridica, 120. 
men wil bijgevolg verwijzen naar D.31.77.4. Hier komt nog bij dat materiële controle heeft uitgewezen dat le Caron niet naar D.31.77.4 allegeert, maar wel naar de voorlaatste lex van dezelfde titel ( L cum pater $77 \int$ pen [ultima] $D$. de leg[ibus] 2), namelijk D.31.77.32. Een vergelijkbaar probleem stelt zich bij artikel 2.1.126, alwaar verwezen wordt naar het commentaar van Pierre Rebuffi bij de wet $L$ inter stipulandum $\int$ divortium ff de verb[orum] obligat[ionibus]. Deze lex blijkt echter niet voor te komen in de -zo aangegeven- Digestentitel De verborum obligationibus. Bovendien schreef Rebuffi enkel een commentaar op de Digestentitel De verborum significatione, met name Commentaria in tit. Dig. De verborum et rerum significatione, die wel een wet bevat beginnende met divortium (D.50.16.101.1). Vergelijkbare onzorgvuldigheden deden zich voor ten aanzien van het Corpus Iuris Canonici. Bij de artikels 3.11.4/5/6 werd als volgt verwezen naar Baldus: "..., nec excipiunt minores d[octores] in c constitutus $p$ de in integrum restitutionibus Baldus in cap cum non liceat $x$ de privilegiis,...". Materiële controle wees echter uit dat deze rubriek (de privilegiis) uit het Liber Extra van Gregorius IX niet zulk een capittel (cum non liceat) bevatte. Het capittel (Quum non liceat) is enkel in de rubriek De praescriptionibus terug te vinden. Ook de verschillende onderdelen van het Corpus Iuris Civilis worden niet altijd even zorgvuldig aangeduid. Zo komt het voor dat men naar een Digestentitel verwijst, hoewel men een Codextitel bedoelt, en vice versa. Dit is zo het geval bij artikel 3.3.18. Men spreekt over Alberico de Rosciate bij $L$ si fundum ff qui potior [es] in pign[ore vel hypotheca habeantur]. De Digestentitel Qui potiores in pignore vel bypotheca babeantur et de his qui in priorum creditorum locum succedunt (D.20.4) heeft echter geen lex die begint met de woorden si fundum; de Codextitel Qui potiores in pignore habeantur (C.8.17) daarentegen wel. Bovendien worden nummers van artikels of folio's waarnaar verwezen wordt geregeld foutief neergeschreven. Ook het vergeten van één minuscuul woord als bijvoorbeeld si kan ervoor zorgen dat de referentie onbruikbaar wordt, omdat men plots naar een heel andere of zelfs onbestaande regel verwijst dan oorspronkelijk de bedoeling was. De nonchalance van de toenmalige scribentes resulteert dan ook maar al te vaak in verwarring bij de hedendaagse onderzoeker en dwingt deze laatste in een aantal gevallen de strijd te staken en te berusten in zijn onvermogen.

Gezien problematische gevallen zoals hierboven beschreven, opperde Wijffels dan ook dat materiële controle in principe ten allen tijde vereist is. ${ }^{774}$ Met betrekking tot de allegaties naar de monografische doctrine heeft hij deze dan ook daadwerkelijk uitgevoerd. Zulk een titanenarbeid bleek hier niet haalbaar. Het tijdsbestek waarbinnen ik het onderzoek beoog te voltooien, laat zulk een diepgaande studie niet toe. Toch ben ik er van overtuigd dat ook mijn resultaten desalniettemin even betrouwbaar zijn. Wat het merendeel van de allegaties betrof, was het immers duidelijk om welk werk het ging. Daar waar wel discussie mogelijk was, ben ik overigens wel tot materiële controle overgegaan. Op die manier kan het overzicht van

774 Wat de allegaties naar monografische werken betreft, is Wijffels in staat geweest deze materiële controle door te voeren. De talloze verwijzingen naar het Corpus Iuris en de commentaren hierop heeft hij daarentegen slechts formeel kunnen controleren. Hun aantal was immers te groot en de bronnen vaak niet voldoende toegankelijk. Cfr. WIJFFELS, Qui millies allegatur, I, 65-68. 
de door mij geïdentificeerde auteurs niets anders zijn dan een quasi perfecte kopie van het geheel waarnaar door de commissieleden werd gerefereerd. Rekening houdend met de auteurs en de hiermee corresponderende werken, welke wegens overmacht niet geïdentificeerd konden worden, komt het uiteindelijke antal auteurs in de onderzoeksgroep op 144, waarnaar in totaal 725 maal gerefereerd werd. Slechts zeven auteurs zijn erin geslaagd totaal anoniem te blijven (Cassidorus, Curtius, Iuveninus, Picus, Thanarius, Montanus, Oroscius). ${ }^{775}$ Bovendien vertegenwoordigen zij elk slechts één allegatie, waardoor de foutmarge op haar beurt aanvaardbaar is gebleven.

Een pak drastischer zijn de ingrepen die nu volgen. Deze zullen namelijk tot gevolg hebben dat maar liefst 122 allegaties uit de onderzoeksgroep verbannen worden. Het is namelijk zo dat onder de identificeerbare allegaties zich tal van allegaties bevinden die voor onze vraagstelling niet van belang zijn. Deze irrelevantie veroordeelt hen er dan ook toe a priori buiten beschouwing gelaten te worden. Naast de anominale allegaties -in de zin van 'naamloos'- gaat het hier om twee types. ${ }^{776}$ Een eerste groep wordt gevormd door het geheel van allegaties die ogenschijnlijk rechtsgeleerd van aard zijn, maar waar het in werkelijkheid niet om de mening van de auteur gaat. Deze allegaties verwijzen daarentegen rechtstreeks naar een wet, vonnis of gewoonterechtelijke regel, zonder toegevoegde analyse, waar deze analyse echter essentieel is om iets als rechtsgeleerd te kunnen omschrijven. ${ }^{777}$ Bijgevolg zeggen deze allegaties niets over de rechtswetenschappelijke stroming die de auteurs aanhangen. Wanneer deze juristen dan ook in rekening gebracht zouden worden, bestaat het gevaar erin dat onze robotfoto gemanipuleerd wordt in foutieve zin. Ik zal gevallen als deze, samen met de criteria ter eliminatie ervan en die ter demarcatie van de informatie die wel relevant is, verduidelijken aan de hand van enkele concrete voorbeelden. In eerste instantie is er de groep waarbij verwezen wordt naar de jurisprudentiële precedenten. Dit is veruit de grootste groep. Bij deze gevallen wordt er steeds expliciet verwezen naar een welbepaalde rechtzaak of uitspraak van een welbepaald hof, zoals het geval is ten aanzien van artikel 2.5 .156 (...et in eam sententiam 17 aprilis 1564 iudicatum in parlamento Parisiensi[s] testatur Papon in arrestis Gallia[e] lib 15 tit 5 art 13...) en artikel 2.1.76 (5 julli 1568 in camera imperiali judicatum contra episcopum Leodiensem testatur Gaill observat lib 2 obser[vatio] 86 nu 14...). Maar ook de meer abstractere verwijzingen naar de rechtspraktijk kunnen niet langer geduld worden. Voorbeelden hiervan vind ik terug met betrekking tot artikel 2.1.101 (...ut pluribus

\footnotetext{
775 Cfr. infra, hoofdstuk 3, paragraaf 1, Overzicht van geallegeerde rechtsgeleerden.

776 Tot de anominale allegaties behoren eveneens die naamloze allegaties naar le Carons Codex Henricianus (o.a. bij de artikels 1.12.20, 1.12.26, 1.12.27/28, 1.13.3, 1.13.4, 1.13.6, 1.13.9/10/11, 2.2.15, 3.13.47/48, 4.1.4, 4.7.35, 4.7.38/39, 4.7.41, 5.10.79), Papons commentaar bij de Coutumes de Bourbon (3.11.20), Guenoys' Conference des coutumes en Bellonius' Rota Genua. Men verwijst hier immers louter naar de rechtsbron en niet naar de opinio van de rechtsgeleerde hieromtrent. Wat Guenoys en Bellonius betreft, is het aantal naamloze allegaties dermate groot dat het onmogelijk is hen hier allemaal op te sommen.

777 Cfr. GILISSEN, Historische inleiding, 271.
} 
arrestis comprobatum esse notat Le Guenois ad conferentias consuet[udines] Galliae fol 661 ad [[itte]ram L....), artikel 3.13.27 (Est etiam novus ex arrestis diversarum curiarum apud Mynsing[er] centi 4a obser[vatione] 22 Guido Papae decisione 295 et 299 Boer[ius] decisione 104 Papon lib 16 tit $4^{\circ}$ art $1^{\circ}$ et lib $20^{\circ}$ tit 7 art 7 Charondas respons[iones] Gallic[ae] lib $2^{\circ}$ resp[onsione] 60 et iterum in memorabilibus verbo fideicommissi [s] fol 189.) en artikel 3.12 .10 (Est quoq[ue] novus in hac revisione ex iure scripto et arrestis Galliae citatis a Papone lib $11^{\circ}$ arrestorum tit $1^{\circ}$ articulo 8. 10. et undecimo...). Geen enkel van vorige allegaties werd in rekening gebracht. Wanneer deze verwijzingen naar de praktijk wederom té abstract werden, heb ik ze terug tot de onderzoeksgroep gerekend. Zulke situaties deden zich voor ten aanzien van de artikels 2.5 .17 (...ex praxi Hispania de qua Jo[ann]es Garcias in tract [atu] de expensis et meliorat [ionibus] cap 611 et 13...) en 4.1 .5 (...ex usu cui consentit praxis Gallia[e] testa Imbert[us] in enchirid[ion] in verbo contractus...). In totaal werden er 51 van zulke 'jurisprudentiële' allegaties geschrapt. ${ }^{778}$ In tweede -zij het zeer bescheideninstantie binnen dit eerste type zijn er de gevallen waarbij rechtstreeks verwezen werd naar de inhoud van een bepaald legislatief document (ordonnantie, statuut, ...). Het gaat hier in globo slechts om twee gevallen. Zo staat bij artikel 4.14.13 het volgende te lezen: ...et ita observat generaliter in Galliis ex constitutione Parisiis facta a [nno] 1503 art 10 quam allegat Le Guenoys in conferentiis consuet[udines] fol 385 ad litteram $G$... Het tweede voorbeeld is terug te vinden ten aanzien van artikel 6.2.35: ... et ita observant etiam in regno Neapolitano ut testatur Afflict[us] ad constitut[iones] eiusdem regni tit de dotariis constit[utio] incip [it] mulier qu[a]e dotarium nu. 28. Wat de gewoonterechtelijke referenties betreft, dient er expliciet verwezen te worden naar het materiële recht van een andere stad of regio, opdat ik de allegatie buiten beschouwing kan en moet laten. Dit is het geval bij de artikels 4.17.12/13/14/15 (Sunt desumpti partim ex d ordinatione curia art 475 et 484 partim ex iure scripto et sequuntur passim consuet[udo] Gallia[e] Paris art 111 Calays tit 12 articul[o] 225 Melun cap 23 art 322 et similes plenius et accuratius Estampes cap 13 art 166 Montagis cap 18 art 10 Orleans tit 19 art 424 Bery tit 9 art 21 et 22 Bourbon cap 9 art 68 et 69 vide Le Guenois in conferentiis fol 386 et seqq ...) en artikel 2.5.93/94 (...et sequuntur consuet[udines] Gallia[e] du Guenois fol 690 et 695 verso nominatum Sedan[um] tit 8 art 143 et Tornac [um] tit 22 art 5...). Alzo heb ik in totaal 55 uitzonderingen kunnen vaststellen die afwijken van dit eerste selectiecriterium. Ze hadden tot gevolg dat Francisco Vivio, Jean Chenu en Matteo d'Afflitto voorgoed de groep zouden verlaten. ${ }^{779}$ Ook

${ }^{778}$ Deze komen voor in de Memorieboeken ten aanzien van de artikels 2.1.75 (Chenu), 2.1.76 (Gaill), 2.1.101 (Guenoys), 2.1.203 (Guenoys), 2.4.18 (Papon), 2.5.138 (Guenoys), 2.5.172 (Guenoys), 3.3.18 (Vivio), 3.12.10 (Papon), 3.12 .13 (Papon), 3.13.3 (Guenoys), 3.13.27 (Mynsinger, Pape, Bohier, Papon, le Caron 1, le Caron 2), 3.13.29/30 (le Caron), 3.13.35 (Papon), 3.13.41 (le Caron 1, le Caron 2), 3.13.45/46 (le Caron, Favre), 3.14.15 (Choppin, Dumoulin, le Caron 1, le Caron 2, Bacquet, Guenoys), 3.14 .73 (Papon), 3.14.78 (le Caron), 3.14.96 (Choppin, Papon, le Caron 1, le Caron 2, Dumoulin, Grass), 3.14.122 (Choppin, le Caron), 4.1.6 (Gaill), 4.13.5 (Guenoys), 4.13.7/8 (d'Afflitto, Choppin), 4.16.30/31/32/33 (le Caron), 4.17.23/24 (Guenoys), 4.18.54 (Papon), 4.18.76 (Maynard), 6.2.13/14 (Bohier, Claro), 6.3.8 (Peguerra), 6.3.27 (Favre).

${ }^{779}$ Het betreft hier de volgende werken: Vivio's Decisiones Regni Neapolitani ... in S. Regia Audientia Terrae Bari, Capitanatae, Apuliae et Comitatus Mosilii (1592-1597), goed voor één 
René Choppin en Charles Dumoulin moesten ten gevolge van deze ingreep één van hun werken inleveren. ${ }^{780}$

Het tweede type allegaties dat niet langer tot onze onderzoeksgroep gerekend kan worden, is datgene dat de 'allegaties van tweede rang' groepeert. Deze zijn tweevoudig van aard; enerzijds zijn er de 'refererende allegaties van tweede rang', anderzijds de 'becommentariërende allegaties van tweede rang'. In het eerste geval worden die referenties bedoeld waarbij verwezen wordt naar een bepaalde jurist $\mathrm{x}$ die op zijn beurt (in de geallegeerde studie) verwijst naar het werk van een ander auteur y. Het werk van auteur y geldt dan als een tweederangse allegatie, en kan niet langer in de onderzoeksgroep geduld worden. ${ }^{781}$ Dit 'refereren in tweede rang' kan zowel zeer openlijk gebeuren, als op een meer verdoken manier. In het eerste geval wordt letterlijk toegegeven dat de allegatie naar auteur y afkomstig is van auteur $\mathrm{x}$, zoals bijvoorbeeld gebeurt is ten aanzien van artikel 3.1.6: ..., Pecqius loco citato allegans gloss [ae] in $L^{1 a} \mathrm{C}$ si advers[us] transact[ionem vel divisionem minor restitui velit], Bart[olus] et Angelus in L si sit legatum $\int$ ult [ima] cum seq. in fine ff de leg[ibus] $1^{\circ}$ ex quo videtur quod ... Materiële controle wees uit dat Pieter Peck niet alleen refereerde naar de glosse, maar eveneens naar Bartolo da Sassoferrato en Angelus de Ubaldis. Een gelijkaardige situatie krijg ik bij artikel 3.4.3 te zien: ... ut apud Choppin[us] de morib[us] paris[iensis] lib 2 tit $6 n^{\circ} 16$ Afflict[us] Chassan[eus] Molin[aeus] et alios quos ibi allegati... Bij artikel 5.8.6 wordt de tweede rang echter niet zo expliciet aangegeven: Est 12 in impressis et pro eo est antiqua sententia vanden 16 decemb [er] 1445 in lib pergameno fol 3 suntque iuris communis glossa in C fin $X$ de foro compet[enti] ad verbum compelli Bart[olus] Castrens [is] Fulgoss[ius] Curtius et alii in $L$ $2 \int$ legatis ff de iudic [iis] per cap fin $X$ de dilat [ionibus] late Pecquius in tract[atu] de iure sistend[i] cap 5 nu 11 versic ex quo. Uit beide voorbeelden blijkt dat deze allegaties niet op dezelfde hoogte geplaatst kunnen worden als die van de eerste rang. Het is immers duidelijk dat de redacteurs zich zoals in het eerste geval van Pieter Peck bediend hebben en niet van Bartolo da Sassoferrato of Angelus de Ubaldis. Het feit dat de redacteurs hen ook niet altijd even uitvoerig weergegeven hebben, maar hun reeks vaak afkortte tot et alios bevestigt alleen maar de ondergeschikte rol die zij vervullen. In totaal gaat het om 66 gevallen, waarbij de openlijke gevallen aanzienlijk minder talrijk waren dan die waar de redacteurs in zekere zin tot plagiarissen vervallen. ${ }^{782} \mathrm{Dit}$ heeft me ertoe gedwongen elke situatie waarin er een vermoeden bestond van

allegatie; Chenu's Cent notables et singuliers questions de droit, décidées par arrests mémorables des cours souveraines de France (1602), goed voor één allegatie; d'Afflitto's Decisiones S. R. Consilii Neapolitani (1499), goed voor één allegatie, en de Singularis Lectura super omnibus sacris Constitutionibus Regnorum utriusque Siciliae citra et ultra (1517) van dezelfde auteur, goed voor één allegatie.

${ }^{780}$ Het betreft hier de volgende werken: Choppins De privilegiis rusticorum (1575), goed voor vier allegaties en Dumoulins Tractatus analyticus variarum iuris quaestionum, goed voor één allegatie.

781 Ook Wijffels vermoedde het bestaan van tweederangse allegaties, maar stelde er zich verder geen vragen bij: "Les deux tiers de la doctrine monographique se composent d'ouvrages cités moins de cinq fois, et dont plusieurs ne le sont qu'exceptionellement." (WIJFFELS, Qui millies allegatur, I, 202-203.)

${ }^{782}$ Deze gevallen worden in het overzicht van iuris periti in voetnoot aangeduid. 
tweederangse allegaties materieel te controleren. Deze tijdrovende bezigheid leidde er evenwel toe dat een groot aantal werken van het toneel verdwenen: drie van André Tiraqueau, twee van Andrea Alciato en één van Wigle van Aytta, Bartolomeo Caepolla, René Choppin en Antonio Padilla y Meneses. ${ }^{783}$ Dat op deze manier juridische werken uit de onderzoeksgroep verdwenen, kon nog drastischere gevolgen hebben, namelijk dat ook de auteur voorgoed verdween. Dit heeft zich voorgedaan bij Paulo di Castro, Cicero, Raffael Fulgosius, Antonio Gabrieli, Angelo Gambiglione, Gregorio Lopez, Luca da Penne, Benedetto Barzi da Piombino, Mariano Sozzini en de onidentificeerbare Curtius. ${ }^{784} \mathrm{Bij}$ de becommentariërende allegaties van tweede rang daarentegen gaat het om een verwijzing naar een commentaar (annotationes of additiones) van auteur $\mathrm{x}$ op het werk van auteur $\mathrm{y}$. In dit geval behoort auteur $\mathrm{y}$ tot de tweede rang en bijgevolg niet langer tot de onderzoeksgroep. Dit is het geval bij volgende werken: Giovanni d'Andrea's Additiones ad speculum Guillelmi Durantis (1346), de Annotationes van Dumoulin op Consilia van Alessandro di Tartagni, de Annotationes van Dumoulin op delen van oeuvre Decio's oeuvre, Follerio bij het Tractatus docti et insignes, de ordine indiciorum (vulgo speculum aureum, et lumen advocatorum) van Roberto Maranta, de Apostillae van di Tartagni op de Commentaren van Bartolo da Sassoferrato en de Commentaar van Etienne Ranchin bij de decisiones van Guy de la Pape. ${ }^{785}$ Ook le Carons Somme rural, ou le Grand coustumier general de practique civil et canon: composé par M. Jean Bouteiller... Reven, corrigé sur l'exemplaire manuscript, illustré de commentaires \& annotations, enrichies de plusieurs ordonnances royaux, arrests des cours couveraines, singulieres antiquitez \& notables decisions du droict romain, \& autres observations. Par Louys Charondas le Caron... Ensemble trois indices des titres ou rubriques, chapitres \& matieres traictees tant en ladite somme, qu'es commentaires \& annotations, diens Grand Coustumier de France, contenant tout le droit françois et practique judiciaire, pour plaider ès cours de parlement, prévosté et vicomté de Paris et autres juridictions de ce royaume. (Par Jacques d'Ableiges.) Reveu et corrigé sur l'exemplaire escrit à la main et ancienne impression... par L. Charondas le Caron.... evenals zijn Code du Roy Henry III, Roy de France et de Pologne, redigé en ordre par Barnabé Brisson, depuis augmenté des édits du Roy Henry IV, avec la conférence des ordonnances, et rapporté aux ancien Code de Théodose et de Justinien, et aux Basiliques, et illustrés des Conciles de l'Eglise, Lois des Romains et autre peuples, Histoires, Antiquier, Arrêts, Observations et

${ }^{783} \mathrm{Bij}$ Tiraqueau gaat het om zijn Ex Commentariis in Pictonum Consuetudines (1513), Tractatus de iure constitui possessorii (1549) en Tractatus le mort saisit le vif (1550). Alciato van zijn kant verliest zijn De verborum significatione (1530) en Responsa (1561) en van Aytta zijn Commentaria in decem titulos Institutionum iuris civilis (1534). Van Caepolla, Choppin en Padilla y Meneses verdwijnen respectievelijk de volgende werken: Commentaria in tit. ff de verborum significatione (1460-1464), De domanio Franciae libri tres (1574) en Ad titulum Cod. de transactionibus (C.2.4) (1566).

784 Ook Matteo d'Afflitto en Guilielmo Duranti wisten ten gevolge van andere selectiecriteria geen geldige allegaties te behouden. Hun oeuvre zou bijgevolg niet langer in rekening gebracht worden.

785 Omtrent d'Andrea en Duranti, cfr. 5.3.23/24. Omtrent Dumoulin en di Tartagni, cfr. 3.13 .49 , 3.13.54/55, 3.13.56/57/58, 3.13.65, 3.13.67, 4.13.38/39, 4.15.7 en 5.17.9. Omtrent Dumoulin en Decio, cfr. 2.1.181/182/183, 2.1.227/228, 3.14.97 en 3.14.101/102/103. Omtrent Follerio en Maranta, cfr. 4.9.35/36/37. Omtrent di Tartagni en Bartolo da Sassoferrato, cfr. 7.3.1. Omtrent Ranchin en de la Pape, cfr. 4.13.33. 
Annotations kan men enigszins in deze categorie plaatsen, hoewel noch d'Ableiges, Bouteiller of Brisson in de Memorieboeken met naam noch toenaam genoemd worden. Uiteindelijk was ik het aan de kritische methode verschuldigd zestien becommentariërende allegaties van de tweede rang te schrappen. Op deze manier verlieten Roberto Maranta, samen met Phanutius di Fanuzzi en Guilielmo Duranti de onderzoeksgroep. Wanneer men echter uitdrukkelijk verwijst naar de mening van beide auteurs, dan heb ik hen ook allebei in rekening gebracht. Dit was het geval bij Guy de la Pape en Etienne Ranchin in artikel 4.13.33: Est 4 in impressis etiam ex usu et accordat consuet [udo] Gandens[is] rub 17 art $1^{\circ}$ text in $L$ fin $\int$ et cum antiquitas $C$ de iudic[iis] pres[idens] Everardi cons[ilio] 137 Guido Papa quaest[io] 26 et ibi Ranchin late Minsing[er] observ[atione] 96 cent. 4. Zowel de decisiones van de la Pape als de commentaar van Ranchin erop komen hier expliciet aan bod.

Deze methodologische inleiding wil ik afsluiten met een drietal opmerkingen. De eerste betreft het voorkomen van zogenaamde 'meervoudige allegaties'. Ook deze kunnen twee gedaantes aannemen. Zo gebeurt het dat met betrekking tot eenzelfde artikel meermaals verwezen wordt naar eenzelfde juridisch werk in dezelfde argumentatie. Dit is bij wijze van voorbeeld het geval met Andrea Fachineo ten aanzien van artikel 3.13.23.786 In zulke gevallen heb ik de studie slechts één maal doorgerekend, tenzij er naar twee verschillende passages in het werk verwezen werd, wat te zien is bij artikel 3.13.50, waar Antoine Favre tot twee maal toe geallegeerd werd. ${ }^{787}$ De tweede soort omvat die gevallen waarbij de naam van de auteur slechts

\footnotetext{
${ }^{786}$ Cfr. 3.13.23: “... pro contraria tamen est textus in L titia 13 ff de inoffic[ioso] testamento $L 2^{a}$ et L nec fideicommissa $36 \mathrm{ff}$ de leg[ibus] 3 gl[ossae] in Auth. ex caussa $C$ de liberis pr[a]eteritis [vel exhereditas] preses Chirardi cons[ilio] 26 nu $8^{\circ}$ et cons[ilio] 15 nu $29^{\circ}$ eleganter Fachineus lib $4^{\circ}$ controvers[iarum] iuris cap 11 et alii quos allegant Gabrielius et Turretus ubi i [bi] et posteriorem quidem opinionem ut magis aequiam et iure consentaneam approbavit magistratus, tum quia textus qui pro ea allegantur videntur clariores et irrefragabiles, tum quia favor liberorum concurrit, et sane si aliter capis frustra erunt constitutiones et leges quibus tam diserte cantum est liberos honorabili instittutionis titulo vocandos esse ad hereditatem nec ex heredandos nisi ex iusta caussa, nam semper in potestate parentum erit illas illudere addita clausula codicillari, cuius vi liberis sub specie fideicommissimi atq[ue] ita indirecte auferetur, quod directo et aperta voluntate auferri ïs sine instituti titi non licuit, plus valebit presumpta testatoris voluntas ex hac clausula quam aperto eam declarasset, ut pluribus dedunt et nota Fachines loco i[bi] citato habentq[ue] maiorem inspect [ionem] nostris moribus, quod notarii etiam non iussi [?] eiusmodi clausulam nunc foere adbibere soleant, tanquam ex usu, ut proinde, et ex mille testatoribus vix unus effectum eius intelligat, nulla certa presumptio voluntatis ex illius adiectione elici possit."

787 Cfr. 3.13.50: “...allegans arrestum curiae Tholosanae Anth. Faber in tract[atu] de erroribus pragmati decade 11 errore $6^{\circ}$ et sane cum generaliter verum sit Trebellianicam de iure civili probibere posse, novel[la] constit [utio] $1^{a}$ cap $2^{\circ}$ versic. haec autem dicimus, et liberi primi gradus concurrente utraq[ue] quarta ad Trebellianicam veniant, non iure filiationis sed tanquam extranei, non videmus quare iis quoq[ue] hoc casu non possit immo multo magis non debeat probiberi, et eo constituto sequitur imputationem etiam iis imponi et invingi posse, si enim quod maius est licet in totum probiberi quod est ne Trebellianica detrabatur multo magis quod minus ut pote quod fructuus imputentur ut multis ostendit et confirmat Anthon[ius] Faber loco i[bi] citato errore $5^{\circ}$ ubi respondet quoq[ue] ad d legem iubemus, illam videlicet locum habuiss[e] de iure civili cum una tantum quarta detraberetur, nec extendi posse ad bunc casum, cum ex iure
} 
één maal werd vermeld, maar waarbij deze wel door meerdere werken van zijn hand vergezeld wordt. Ter illustratie wil ik hier verwijzen naar de Memorien op de Costumen omtrent artikel 3.12.8/9: Sunt etiam novi in hac revisione ex ordinationibus Galliae de anno 1539 et 1549 quas habes in Codice Henriciano lib $6^{\circ}$ tit $4^{\circ}$ articulo $4^{\circ}$ et 5 ibi Charondas idem Charondas in memorabilibus verbo donation fol 62 versiculo... Zowel le Carons Memorables observations du droit français als zijn commentaar bij de Codex Henricianus van Brisson (1531-1591) komen hier aan bod. Het spreekt voor zich dat in zulke gevallen beide werken in rekening worden gebracht.

Een tweede opmerking betreft de verwijzingen bij naam naar de oorspronkelijke wetgever zelf. Ik denk hierbij aan de éénmalige vermelding van de Romeinse keizer Trajanus met betrekking tot de artikels 7.4.34/35: ...et ut d[ominus] Traianus Assiduo Severo rescripsit satius est impunitum relinquere facimus nocentis quam innocentem damnare $L$ absentem $\int$ ff de p[o]enis. Aangezien het hier helemaal niet om de mening van een welbepaalde rechtsgeleerde gaat, maar wel louter om een verwijzing naar keizer Trajanus als wetgever, zullen zulke allegaties uiteraard buiten beschouwing gelaten worden. Hetzelfde geldt voor de talloze keren dat de naam van keizer Karel V wordt vermeld aangaande één van zijn plakkaten of die van stadssecretaris Asseliers met betrekking tot de turbenonderzoeken. ${ }^{788}$

Tot slot wil ik nog wijzen op de uitzonderlijke positie van de verwijzingen naar nietjuridische literatuur in de Memorieboeken. Normaliter zou men geneigd zijn ook deze groep buiten beschouwing te laten, omwille van hun niet-rechtsgeleerd karakter, ware het niet zo dat het hier meestal om Romeinse auteurs gaat zoals Gaius Suetonius Tranquillus en Aulus Gellius. ${ }^{789}$ In deze hoedanigheid zijn zulke verwijzingen uiteraard een waardemeter voor de graad van humanisme onder de commissieleden,

canonico duae quartae concurrunt, ne videlicet privilegia duplicentur, quod si tamen curiae magis placeat contraria opinio quamvis minus recepta, qua videlicet Trebellianica filiis probiberi non possit, aut quod fructus in eam imputentur poterit bic articulus poni affirmati[o]ne per modum extensionis ad precedentem hoc modo dwelck oock plaetse beeft al waert oock dat den testateur etc[etera] et clausula finalis poterit iudici aut etiam reformari quod arbitrii curae sit sed placeat saltem aliquid certi statuere."

${ }^{788}$ Ter illustratie citeer ik hier de Memorieboeken aangaande de artikels 3.14.64 (Est novus additus in hac revisione ex duobus placcatis Caroli Imper[atoris] van[de] 8 novemb[er] 1541 et 14 maii 1544 accordat consuet[udo] Arthesi[a]e tit 111 art 111 Lille tit 14 art 176 et ali[a]e consuet[udo] Galli[a]e passim) en 4.2.6 (Est 5 et 8 in impressis cum quibus consentit $1^{u s}$ et iiius [lees: tertius] in antiquis tit van handtscriften et turba non registrata vanden 26 Augusti 1575 onder die vanden secretaris Asseliers nu 30 nisi quod in impressis addita sit clausula, oft dat den naem et usus ita observat).

${ }^{789}$ Beide auteurs kwamen één maal aan bod en dit ten aanzien van het artikel 5.8.37: “..., maer oock tegens recht volgende den gemeynen regel, minor in maiorem non habet imperium sane moribus Romanorum tantum abfuisse ut maior magistratus a minore auxilium aut executionem petere deberet ut etiam multa $p[0]$ ena constituta[e] sint in eos qui talia admitterent et maiores magistratus pignoribus captis immo et apprehensione minorum se tueri et vindicari potuerint si minor maiorem apud se compellare pateretur de quo non habes egregium exemplum apud Suetonium in iulio cap 17 late Gellius lib 13 noct [es] Attic[ae] cap 12 et seqq..." Cicero kwam enkel als tweederangse allegatie aan bod. Met betrekking tot de artikels 4.10.3/4/5 verwijzen de Memorieboeken naar het oeuvre van Matthias Wesenbeeck die op zijn beurt de Oratio pro Roscio van Cicero citeert: “...vide Wesenbec[ius] in paratit[lia], ubi citat Ciceronem in orat [io] pro Rescio..." 
wat hun aanwezigheid in de onderzoeksgroep rechtvaardigt. De twee overige, nietjuridische werken zijn het politiektheoretische Les six livres de la République (1576) van Jean Bodin en de brieven van de Franse historicus Etienne Pasquier.

Wat is nu het gevolg van al deze methodologische ingrepen? Wijffels wees er reeds op dat hierdoor het gevaar bestaat het uiteindelijke beeld te sterk te manipuleren. Inderdaad, het kan niet ontkend worden dat in totaal maar liefst 126 allegaties hun plaats in de oorspronkelijke onderzoeksgroep hebben verloren door mijn toedoen en dat op deze manier het totale aantal allegaties in de poule aanzienlijk werd gereduceerd, meer bepaald van 725 tot 599. Desalniettemin ben ik de mening toegedaan dat deze ingrepen in functie van de onderzoeksvraag gerechtvaardigd zijn. Meer nog, zij zijn noodzakelijk. Juist wanneer ik zou nalaten het kaf van het koren te scheiden, zouden de uiteindelijke vaststellingen en de hieruit volgende conclusies incorrect en dus onaanvaardbaar zijn. Ik ben er dan ook van overtuigd dat men aan de hand van deze relevante allegaties uit onze 'gezuiverde' onderzoeksgroep op zoek moet gaan naar een antwoord op de vraag naar het eventueel doorwerken van humanistische invloeden op de redactie van het Antwerpse gewoonterecht. Hieronder volgt het overzicht van iuris periti en hun werken.

Overzicht van geallegeerde rechtsgeleerden

Deze lijst geeft een alfabetisch overzicht van alle rechtsgeleerde auteurs en hun werken waarnaar in de Memorien op de Costumen werd gerefereerd. Het overzicht bevat niet alleen die allegaties welke de uiteindelijke onderzoeksgroep uitmaken, ook die auteurs en werken welke uit de onderzoeksgroep verdwenen zijn ten gevolge van onze selectiecriteria komen hierin voor. Deze laatste zijn kenbaar aan het cijfers 0 dat aan het werk voorafgaat of -in het geval dat de auteur in zijn geheel weggeselecteerd werd- aan het feit dat hun naam niet in het vet is weergegeven. De aard van de specifieke selectiecriteria wordt steeds in voetnoot toegelicht. Auteurs waarvan het onduidelijk gebleven is om wie het exact gaat, komen niet in de lijst voor. Het betreft hier personen die omschreven worden als Cassidorus (allegatie zonder titel), Curtius (bij 1, 2, 20), Iuveninus (in tractatu anno 1543), Montanus (in tractatu de feudis lib 1 cap 4), Oroscius (bij D.2.4.2), Picus (bij D.35.2.91), Thanarius (allegatie zonder titel). ${ }^{790}$ Enkel de allegaties naar Iuveninus, Montanus, Oroscius, Picus en Thanarius werden in de onderzoeksgroep opgenomen. De overigen hebben de selectiecriteria niet overleefd.

Ik heb er voor geopteerd elke auteur weer te geven met zijn originele naam en dus niet de vaak gebruikte, gelatiniseerde versie. Deze laatste en andere naamvarianten

790 Omtrent Cassidorus, cfr. 3.11.4/5/6. Omtrent Curtius, cfr. 5.8.6. Omtrent Iuveninus, cfr. 3.3.5/6/7. Omtrent Montanus, cfr. 1.1.14. Zie ook: SÖLLNER, "Die Literatur zum gemeinen und partikularen Recht", 587. Zie ook: W. M. C. REGT, "Montanus, Paulus", Nieun Nederlandsch biografisch Woordenboek, X, Amsterdam en Antwerpen, 1974, 645. Mogelijk gaat het om Johannes Farrarius Montanus. (Cfr. WIJFFELS, Qui millies allegatur, I, 205.) Hij schreef een Collectanea in usus feudorum. Omtrent Oroscius, cfr. 5.4.5. Omtrent Picus, cfr. 3.13.33/34. Omtrent Thanarius, cfr. 4.1.9/10. 
worden tussen haakjes weergegeven, gevolgd door de geboorte- en sterftedatum van de auteur evenals zijn geografische herkomst. De geallegeerde werken heb ik steeds per auteur gerangschikt naar het aantal allegaties dat zij representeren. Dit aantal gaat vooraf aan de naam van het werk, gevolgd door het aantal allegaties dat dit werk zou vertegenwoordigen indien ik de selectiecriteria niet in acht zou nemen. Dit laatste aantal staat steeds tussen haakjes. Het totale aantal allegaties per auteur gaat vooraf aan de naam van de auteur. In voetnoot wordt steeds verwezen naar het artikel waaraan de auteur in de Memorieboeken werd gerelateerd. Aan de hand van bijlage 1 (Referentielijst artikelcommentaar Memorieboeken) kan de exacte plaats in diezelfde Memorieboeken op een vlotte manier worden teruggevonden. Tussen de haakjes die volgen op de naam van het werk staat het jaar waarin het werk vermoedelijk werd geschreven. In het geval van middeleeuwse werken waarvan deze datum ongekend is, wordt er soms verwezen naar het jaar waarin het werk voor het eerst werd gepubliceerd. Dit heb dan ook steeds zo aangegeven in voetnoot. Veelal is het echter onmogelijk gebleken een jaartal te vinden, zowel betreffende de publicaties als de geboorte- en sterftedata van de auteurs. In zulke gevallen ontbreken deze gegevens bij de desbetreffende auteur. Wanneer de titel van het werk in de Memorieboeken ontbreekt, wordt dit in de lijst als 'allegatie zonder titel' aangeduid. In voetnoot kan dit soms nader verklaard worden.

1

D’Accolti, Francisco (Franciscus de Accoltis, Aretinus, Princeps subtilitatem; +1486 ; ita) ${ }^{791}$

$1 \quad$ Consilia seu responsa iuris. (ca.1482) $)^{792}$

0 (3) D’AfFlitTo, Matteo (Mattheus de Afflictis; 1448-1523; ita) 793

0 (1) Decisiones S. R. Consilii Neapolitani. (1499) 794

O (1) Singularis lectura super omnibus sacris Constitutionibus Regnorum utriusque Siciliae citra et ultra. $(1517)^{795}$

0 (1) allegatie zonder titel..$^{796}$

791 Cfr. P. WEIMAR, "Die legistische Literatur der Glossatorenzeit", H. COING red., Handbuch der Quellen und Literatur der Neueren europäischen Privatrechtsgeschichte, I, Munchen, 1973, 221.

792 7.1.17. Max-Planck-Institut. Online-Katalog der Bibliothek, 2006.

793 Cfr. ASCHERI, "Rechtsprechungs- und konsiliensammlungen", 1179. Holthöfer spreekt van 1443 als geboortedatum. (HOLTHÖFER, "Die Literatur zum gemeinen und partikularen Recht", 247.)

794 Volgende allegatie werd niet meegerekend wegens haar niet-rechtsgeleerd karakter (rechtspraak): 4.13.7/8. (Cfr. ASCHERI, "Rechtsprechungs- und konsiliensammlungen", 1179.)

795 Volgende allegatie werd niet meegerekend wegens haar niet-rechtsgeleerd karakter (wetgeving): 6.2.35. (Cfr. HOLTHÖFER, "Die Literatur zum gemeinen und partikularen Recht", 247.)

796 3.4.3 (tweederangse allegatie door René Choppin). 
6 (9) AlCiATo, Andrea (Andreas Alciatus; 1492-1550; ita) ${ }^{797}$

1 (2) De verborum obligationibus. (1519) $)^{798}$

1 (1) Commentaria ... in rubricas iuris canonici. (1538) 799

1 (1) Tractatus de praesumptionibus, cum annotationibus et argumentis Ioannis Nicolai Arelatani; index praeterea copiosissimus in fine adiectus (1551) 800

1 (1) Dispunctiones. (1518) 801

1 (1) allegatie zonder titel ${ }^{802}$

1 (1) allegatie zonder titel 803

0 (1) De verborum significatione libri quatuor. In tractatum eius argumenti veterum iureconsultorum commentaria. $(1530)^{804}$

0 (1) Responsa. (1561) $)^{805}$

1 Alvarado, Diego Rodrigo (Alvaradus, Didacus Rodericus; ca. 1550; spa ${ }^{806}$

$1 \quad$ Tractatus de coniecturata mente defuncti ad methodum redigenda. $(<1599)^{807}$

1 ANCARano, Pietro (Petrus Ancharanus; ca.1330-1416; ita) ${ }^{808}$

1 Consilia sive iuris responsa. (s.d.) $)^{809}$

797 TROJE, "Die Literatur des gemeinen Rechts unter dem Einfluss des Humanismus", 632633. VIARD, André Alciat. J. OTTO, “Alciatus, Andreas", M. STOLLEIS red., Juristen: ein biographisches Lexikon von der Antike bis zum 20. Jahrbundert, Munchen, 2001, 27-29.

798 3.12.8/9 (tweederangse allegatie door Louis le Caron), 3.12.10. OTTO, "Alciatus, Andreas", 28.

799 3.12.10. HOLTHÖFER, "Die Literatur zum gemeinen und partikularen Recht", 180. Hoewel Viard zich niet bezighoudt met het canoniekrechtelijk werk van Alciato, gaat het zeer waarschijnlijk om dit werk.

800 2.5.96. TROJE, "Die Literatur des gemeinen Rechts unter dem Einfluss des Humanismus", 694.

801 4.18.52. VIARD, André Alciat, 255.

802 3.13.35. Men verwijst naar de mening van Alciato in verband met het Digestenartikel D.35.2.91.

803 4.18.76. Men verwijst naar de mening van Alciato in verband met het Digestenartikel D.42.8.24.

804 1.1.3 (tweederangse allegatie door Pierre Rebuffi). HOLTHÖFER, "Die Literatur zum gemeinen und partikularen Recht", 212. Zie ook: TROJE, "Die Literatur des gemeinen Rechts unter dem Einfluss des Humanismus", 701.

8051.16 .1 (tweederangse allegatie door Jacopo Menocchio). ASCHERI, "Rechtsprechungsund konsiliensammlungen", 1213.

806 "Alvarado, Diego Rodrigo", Indice Biogräfico de Espana, Portugal e Iberoamérica, V. H. MEDIAVILLA red., 3 $3^{\text {de }}$ editie, VIII, Munchen, 2000, 174.

807 4.13.9. Max-Planck-Institut für Europäische Rechtsgeschichte. Online-Katalog der Bibliothek, 2006 (http://sunrise.mpier.uni-frankfurt.de/webOPAC/).

808 P. G. CARON, "Pietro d'Ancharano", Novissimo Digesto Italiano, I, Turijn, 1974, 615.

809 3.13.28. OSLER, Bibliographica Iuridica 1, 419. 
2 (3) D'ANDREA, Giovanni (Johannes Andreae, Fons canonum; ca.1270-1348; ita) $)^{810}$

1 (2) Novella in Decretales Gregorii IX. (1338) 811

1 (1) Additiones ad speculum Guillelmi Durantis. (1346) 812

5 D'ARgENTRE, Bertrand (Bertrandus Argentreus; 1519-1590; fra) ${ }^{813}$

$5 \quad$ Coustumes générales du pays et duché de Bretagne, revues et corrigées sur l'original des commissaires reformateurs, de l'an mil cinc cens trente neuf. Adiectae sunt $C l$. et Pr. U. perquam eruditae ex iure civili et foro notae. $(1568)^{814}$

1 D'ARRERAC, Jean (Johannes Arraratius, d'Arresrac; ca.1624; fra) 815

1 La philosophie civile et d'estat, divisée en l'irénarchie et la polémarchie. (1598)816

2 AYerve De AYORA, Antonio, (Ayerbe de Ayora; 1535/55-1596/1623; spa)

2 Tractatus de partitionibus bonorum, communium inter maritum et uxorem et filios, et beredes eorum. $(1586)^{817}$

1 (2) VAN AYTTA, Wigle (Viglius Zuichemus ab Aytta; 1507-1577; ned) $)^{818}$

1 (1) Praelectio in titul. ff Si certum petatur. (s.d.) ${ }^{819}$

810 P. LANDAU, "Johannes Andreae", M. STOLLEIS red., Juristen: ein biographisches Lexikon von der Antike bis zum 20. Jabrbundert, Munchen, 2001, 337-339.

811 2.4.19, 7.3.24/25 (tweederangse allegatie door Pierre Grégoire). N. HORN, "Die legistische Literatur der Kommentatoren und der Ausbreitung des gelehrten Rechts", H. COING red., Handbuch der Quellen und Literatur der Neueren europäischen Privatrechtsgeschichte, I, Munchen, 1973, 378. LANDAU, "Johannes Andreae", 338.

812 5.3.23/24. K. W. NÖRR, "Die kanonistische Literatur", H. COING red., Handbuch der Quellen und Literatur der Neueren europäischen Privatrechtsgeschicbte, I, Munchen, 1973, 394-395. LANDAU, "Johannes Andreae", 338.

813 J. BALTEAU, "Bertrand d'Argentré", Dictionnaire de biographie franscaise, III, Parijs, 1939, 572-574. M.-Y. CREPIN, "Argentré Bertrand d", P. ARABEYRE, J.-L. HALPERIN en J. KRYNEN red., Dictionnaire historique des juristes francais (XIIe-XXe siècle), Parijs, 2007, 17-18. 814 3.10.1, 3.11.4/5/6, 3.11.20, 4.13.1/2, 4.13.12/13/14/15. HOLTHÖFER, "Die Literatur zum gemeinen und partikularen Recht", 279.

815 G. D. GUYON, “Arrérac Jean d", P. ARABEYRE, J.-L. HALPERIN en J. KRYNEN red., Dictionnaire historique des juristes français (XIIe-XXe siècle), Parijs, 2007, 20-21. M. PREVOST, "Jean d'Arresrac ou d'Arrérac", Dictionnaire de biographie française, IV, Parijs, 1948, 1084-1085.

816 4.1.9/10. G. D. GUYON, "Recherches sur la méthode jurisprudentielle criminelle du Parlement de Bordeaux", J. POUMAREDE, en J. THOMAS red., Les Parlements de Province an XVIe siècle, Toulouse, 1996, 308 noot 117.

817 2.1.3 2.1.4. HOLTHÖFER, "Die Literatur zum gemeinen und partikularen Recht", 348.

818 BRITZ, Code de l'ancien droit Belgique, I, 77-81. T. J. VeEN, "Viglius (Zuichemius) ab Aytta (1507-1577)", T. J. VEEN en P. C. KOP red., Zestig juristen: bijdragen tot een beeld van de geschiedenis der Nederlandse rechtswetenschap, Zwolle, 1987, 104-109. R. FEENSTRA, "Aytta, Wigle van (Viglius Zuichemus ab Aytta)", M. STOLLEIS red., Juristen: ein biographisches Lexikon von der Antike bis zum 20. Jahrbundert, Munchen, 2001, 51-52. 
0 (1) Commentaria in decem titulos Institutionum iuris civilis, quibus omnia pene testamentorum iura eleganter et dilucide explicantur. (1534) 820

2 DE AzPIlCuETA, Martino (Doctor Navarrus; 1493-1586; spa) 821

2 Enchiridion sive manuale confessariorum, et poenitentium. (1557) ${ }^{822}$

8 (10) BACQUET, Jean (Johannes Bacquetius; ca.1520-1597, fra) ${ }^{823}$

8 (10) Les cuvres de Jean Bacquet des droicts du domaine de la couronne de France. (1601)824

1 DE BAEZA, Gaspar (Gasparus Baetius; 1540-1565/67; spa) ${ }^{825}$

1 De decima tutori Hispanico jure praestanda (ad Leg. II Tit. VII, Lib. III. Fori Legum), in quo supra octoginta buius legis limitationes, ampliationes et declarationes continentur. $(1567)^{826}$

0 (1) BArzi DA Piombino, Benedetto (Barza, de Barzis, de Plumbino; veertiende eeuw; ita) ${ }^{827}$

0 (1) Commentaria in II librum. (s.d.) $)^{828}$

2 BENOÎT, Guillaume (Guilielmus Benedictus; 1455-1516; fra) ${ }^{829}$

819 4.1.11/12/13. DEKKERS, Bibliotheca Belgica Juridica, 7. Het werk werd voor het eerst gepubliceerd in 1582. (Cfr. DEKKERS, Humanisme en de rechtswetenschap, 71.)

820 3.13.54/55 (tweederangse allegatie door Andreas Gaill). SÖLLNER, "Die Literatur zum gemeinen und partikularen Recht", 525.

821 C. BERGFELD, "Katholische Moraltheologie und Naturrechtslehre", H. COING red., Handbuch der Quellen und Literatur der Neueren europäischen Privatrechtsgeschichte, II/1, Munchen, 1977, 1029.

822 1.14.35, 4.1.9/10. BERGFELD, "Katholische Moraltheologie und Naturrechtslehre", 1029.

823 G. LEYTE, "Bacquet Jean", P. ARABEYRE, J.-L. HALPERIN en J. KRYNEN red., Dictionnaire historique des juristes français (XIIe-XXe siècle), Parijs, 2007, 33. P. VAUCELLES, "Jehan Bacquet", Dictionnaire de biographie française, IV, Parijs, 1948, 1122.

824 2.4.5, 2.4.7, 2.4.8, 2.4.11, 2.4.12/13, 2.4.14, 4.12.4, 4.13.9. HOLTHÖFER, "Die Literatur zum gemeinen und partikularen Recht", 464. Dit bevat onder meer de Trois premiers traictez des droicts du domaine de la Couronne de France avec l'establissement et jurisdiction de la Chambre du Trésor (1577) en het Quatriesme traicté des droicts du domaine de la Couronne de France concernant les francs-fiefs, nouveaux acquets, anoblissements et amortissements.

Volgende allegaties werden niet meegerekend wegens hun niet-rechtsgeleerd karakter (rechtspraak): 2.4.10, 3.14.15.

${ }^{825}$ HOLTHÖFER, "Die Literatur zum gemeinen und partikularen Recht", 366.

826 2.5.161. HOLTHÖFER, "Die Literatur zum gemeinen und partikularen Recht”, 302.

${ }^{827}$ BELLONI, Professori giuristi a Padova, 173-176.

828 2.1.39/40/41/42 (tweederangse allegatie door Réne Choppin). BELLONI, Professori giuristi a Padova, 175 .

${ }^{829}$ P. ARABEYRE, "Benoît (Benedicti) Guillaume”, P. ARABEYRE, J.-L. HALPERIN en J. KRYNEN red., Dictionnaire historique des juristes français (XIIe-XXe siècle), Parijs, 2007, 65-67. P. ARABEYRE, Les idées politiques à Toulouse à la veille de la Réforme. Recherches autour de l'cuvre de 
Repetitio in cap. Raynutius, de testamentis extra de testamentis: maiore quam hactenus, fide recognita emendata. $(1523)^{830}$

BERO, Agustin (Augustinus Beroius; 1474-1554; ita) 831

Quaestiones familiares pragmaticis percommodae. $(1550)^{832}$

BERTRAND, Etienne (Stephanus Bertrandus; 1434-1516; fra) ${ }^{833}$ Consiliorum sive responsorum. (1499-1515) 834

1 BINSFELD, Peter (Petrus Binsfeldius; 1545/46-1598; hrr) ${ }^{835}$

1 Commentarius theologicus et iuridicus in titulum iuris canonici de usuris. (1593) 836

1 BodIN, Jean (Johannes Bodinus; 1530-1596; fra) ${ }^{837}$

$1 \quad$ Les six livres de la république. (1576) 838

5 (7) DE BOHIER, Nicolas (Nicolaus Boerius, Boyer; 1469-1539; fra) ${ }^{839}$

4 (6) Decisiones supremi senatus Burdegalensis. (1544) $)^{840}$

Guillaume Benoît (1455-1516), Toulouse, 2004. Cfr. P. OURLIAC, "Le Palais et l'Ecole vers 1500: témoignage de Guillaume Benoît, canoniste", Revue internationale d'bistoire de la profession d'avocat, 4 (1992), 77-92.

830 3.13.63/64, 7.4.2. Cfr. ARABEYRE, Les idées politiques à Toulouse, 135-210.

831 “Bero, Agostino", Novissimo Digesto Italiano, I, Turijn, 1974, 376.

832 7.3.1. HOLTHÖFER, “Die Literatur zum gemeinen und partikularen Recht”, 410.

833 P. ARABEYRE, "Bertrand Etienne”, P. ARABEYRE, J.-L. HALPERIN en J. KRYNEN red., Dictionnaire historique des juristes français (XIIe-XXe siècle), Parijs, 2007, 79. P. OURLIAC, Etienne Bertrand: droit romain et pratique méridionale au XVe siècle, Parijs, 1937.

834 5.11.51/52/53. WALTER, "Rechtsprechungs- und konsiliensammlungen", 1269.

835 H. RIES, "Binsfeld, Peter", Neue deutsche Biographie, II, Berlijn, 1971 (nadruk van 1955), 248249.

836 4.1.9/10. Max-Planck-Institut. Online-Katalog der Bibliothek, 2006.

837 D. QUAGLIONI, “Bodin Jean”, P. ARABEYRE, J.-L. HALPERIN en J. KRYNEN red., Dictionnaire historique des juristes français (XIIe-XXe siècle), Parijs, 2007, 92-94. U. SPECK, "Bodin, Jean", M. STOLLEIS red., Juristen: ein biographisches Lexikon von der Antike bis zum 20. Jabrbundert, Munchen, 2001, 90-92.

838 5.17.9. TROJE, "Die Literatur des gemeinen Rechts unter dem Einfluss des Humanismus", 708. Troje spreekt hier van 1578 in plaats van 1576.

${ }^{839}$ G. D. GUYON, "Bohier (Boyer, Boerius) Nicolas”, P. ARABEYRE, J.-L. HALPERIN en J. KRYNEN red., Dictionnaire historique des juristes français (XIIe-XXe siècle), Parijs, 2007, 95-97. G. D. GUYON, "Un arrêtiste Bordelais: Nicolas Boerius (1469-1539)", Annales de la faculté de Droit, des sciences sociales et politiques et de la Faculté des Sciences Economiques, de Bordeaux I, 1 (1976), 17-44. Cfr. M. PREVOST, "Nicolas de Bohier", Dictionnaire de biographie française, VI, Parijs, $1954,782$.

$840 \quad 2.4 .8, \quad 4.13 .38 / 39, \quad 4.18 .23, \quad 7.4 .39$. WALTER, "Rechtsprechungs- und konsiliensammlungen", 1256. 
1 (1) Consuetudinis inclite civitatis et septene Biturigum. (1512) 841

2 Bossi, Egidio (Aegidius Bossius; 1487-1546; ita) ${ }^{842}$

2 Tractatus varii qui omnem fere criminalem materiam excellenti doctrina complectuntur et in quibus plurima ad fiscum et ad principis autoritatem ac potestatem necnon ad vectigalium conductiones, remissionesque pensionum pertinentia diligentissime explicantur ... ab omnibus erroribus novissime emendatum. 843

1 BOTTRIGARI, Jacopo (Jacobus Buttrigarius; ca.1274-1348; ita) ${ }^{844}$

$1 \quad$ Lectura super Codice. (s.d.) $)^{845}$

1 DI Boverio, Enrico (Henricus de Boverius; zestiende eeuw; ita) ${ }^{846}$

1 Singularia ..., noviter cum suis numeris et repertorio impressa. (s.d.) $)^{847}$

0 (1) Bugnyon, Philibert (Philibertus Bugnonius; ca.1530-1587; fra) ${ }^{848}$

0 (1) allegatie zonder titel ${ }^{849}$

1 (2) CAEpolla, Bartolomeo (Bartholomaeus Veronensis (da Verona), Cipolla, Cepola, Cepolla, Cevola, Zevola; 1420-1477; ita) ${ }^{850}$

1 (1) Cautelae. (1459-1466) 851

0 (1) Commentaria in tit. ff de verborum significatione. (1460-1464) 852

3 Cagnoli, Girolamo (Hieronymus Cagnolus; 1492-1551; ita) 853

\footnotetext{
Volgende allegaties werden niet meegerekend wegens hun niet-rechtsgeleerd karakter (rechtspraak): 3.13 .27 (tweederangse allegatie door Louis le Caron), 6.2.13/14 (tweederangse allegatie door Giulio Claro).

841 2.1.44. HOLTHÖFER, "Die Literatur zum gemeinen und partikularen Recht”, 277.

${ }^{842}$ CARNEY, The Politics of Johannes Althusius, 211. "Bossi, Egidio", Novissimo Digesto Italiano, II, Turijn, 1974, 558.

843 7.3.1, 7.3.27. "Bossi, Egidio", 558.

${ }^{844}$ HORN, "Die legistische Literatur der Kommentatoren”, 270.

845 4.13.38/39. Max-Planck-Institut. Online-Katalog der Bibliothek, 2006. Zie ook: HORN, "Die legistische Literatur der Kommentatoren”, 270.

846 Catalogo in linea dell'Università degli Studi di Milano, 2006 (http://opac.unimi.it).

847 5.11.51/52/53. Catalogo in linea dell'Università degli Studi di Milano, 2006. Vermoedelijk is dit werk opgenomen in de Singularia Doctorum waarvan sprake is bij Holthöfer in het Handbuch van Coing. (HOLTHÖFER, "Die Literatur zum gemeinen und partikularen Recht”, 419).

848 A. LAINGUI, "Bugnyon Philibert", P. ARABEYRE, J.-L. HALPERIN en J. KRYNEN red., Dictionnaire bistorique des juristes français (XIIe-XXe siècle), Parijs, 2007, 145-146. R. D’AMAT, "Philibert Bugnyon”, Dictionnaire de biographie française, VII, Parijs, 1956, 637-638.

849 1.1.14.

850 "Cepolla, Bartolomeo”, Novissimo Digesto Italiano, III, Turijn, 1974, 116.

851 4.13.38/39. "Cepolla, Bartolomeo", 116.

852 1.1.3 (tweederangse allegatie door Pierre Rebuffi). "Cepolla, Bartolomeo", 116.

${ }^{853}$ HOLTHÖFER, "Die Literatur zum gemeinen und partikularen Recht”, 156.
} 
Commentaria doctissima in primam et secundam Digesti Veteris et Codicis partem, maximeque in quattuor ordinarias ut appellant lecturas matutinas. (1549)854

74 (87) LE CARON, Louis (Charondas; 1536-1614, fra) ${ }^{855}$

17 (26) Responses du droit françois, confirmées par arrests de cours souveraines de France, \& rapportées aux loix Romaines ... Oewvre exactement renouvellé en ceste dernière édition, outre les précédentes. (s.d.) $)^{856}$

21 (23) Coustumes de la ville, prévosté et vicomté de Paris, on droict civil Parisien. Avec les commentaires de...(1582) 857

17 (19) Memorables Observations du droit francois, rapporté au civil et canonique, illustrées des arrests des Cours souveraines de France, auquel livre sont représentées plusieurs antiquités romaines et françaises, non encore bien observées. (1601) 858

7 (7) Somme rural, ou le Grand coustumier general de practique civil et canon: composé par M. Jean BOUTEILLER... Reveu, corrigé sur l'exemplaire manuscript, illustré de commentaires \& annotations, enrichies de plusieurs ordonnances royaux, arrests des cours couveraines, singulieres antiquitez \& notables decisions du droict romain, \& autres observations. Par Louys Charondas le Caron... Ensemble trois indices des titres ou rubriques, chapitres \& matieres traictees tant en ladite somme, qu'es commentaires \& annotations. $(1603)^{859}$

854 3.10.1, 6.3.3/4/5, 6.3.23. HOLTHÖFER, "Die Literatur zum gemeinen und partikularen Recht”, 156. Zie ook: HOLTHÖFER, "Die Literatur zum gemeinen und partikularen Recht”, $159 / 161 / 165$.

${ }^{855}$ G. LEYTE, "Le Caron Louis", P. ARABEYRE, J.-L. HALPERIN en J. KRYNEN red., Dictionnaire historique des juristes français (XIIe-XXe siècle), Parijs, 2007, 479-480. R. ORESTANO, "le Caron, Louis", Novissimo Digesto Italiano, IX, Turijn, 1975, 574. D. R. KELLEY, "Louis le Caron philosopher", E. P. MAHONEY red., Philosophy and Humanism: Renaissance Essays in Honor of Paul Oskar Kristeller, Leiden, 1976, 30. G. LEYTE, "Charondas et le droit français", Naissance du droit français II (Droits: revue française de théorie juridique 39), Parijs, 2004, 17.

856 2.1.17, 2.1.181, 2.5.82, 3.4.53, 3.5.91, 3.11.19, 3.12.8/9, 3.13.35, 3.13.49, 3.13.50, 3.13.60, 4.12.18, 4.13.4, 4.18.16, 5.10.50, 5.17.9, 7.1.17. Max-Planck-Institut. Online-Katalog der Bibliothek, 2006.

Volgende allegaties werden niet meegerekend wegens hun niet-rechtsgeleerd karakter (rechtspraak): 3.13.27, 3.13.29/30, 3.13.41, 3.13.45/46, 3.14.15, 3.14 .78 (tweederangse allegatie door Pierre Guenoys), 3.14.96, 3.14.122/123, 4.16.30/31/32/33.

857 2.1.15, 2.1.46, 3.2.32, 3.2.33, 3.3.13, 3.3.18, 3.3.19, 3.5.88, 3.5.91, 3.7.5/6/7/8/9/10, 3.7.11, 3.11.17, 3.11.19, 3.14.78, 3.14.81, 3.14.83, 3.14.90/91, 3.14.100, 3.14.101/102/103, 4.7.26, 4.14.13. HOLTHÖFER, "Die Literatur zum gemeinen und partikularen Recht", 290.

Volgende allegaties werden niet meegerekend wegens hun niet-rechtsgeleerd karakter (rechtspraak): 3.14.15, 3.14.96.

858 3.12.8/9, 3.13.24, 3.13.26, 3.13.28, 3.13.33/34, 3.13.42, 3.13.44, 3.13.49, 3.13.50, 4.18.16, $4.18 .49 / 50 / 51, \quad 4.18 .73, \quad 5.10 .33 / 34, \quad 5.10 .37 / 38, \quad 5.10 .42 / 43 / 44 / 45 / 46, \quad 6.1 .43, \quad 6.1 .44$. HOLTHÖFER, "Die Literatur zum gemeinen und partikularen Recht”, 297.

Volgende allegaties werden niet meegerekend wegens hun niet-rechtsgeleerd karakter (rechtspraak): 3.13.27, 3.13.41.

$8595.10 .33 / 34,5.10 .37 / 38,5.10 .42 / 43 / 44 / 45 / 46,6.1 .40,6.1 .43,6.1 .44,6.1 .45$. LEYTE, "Charondas et le droit français", 19. Zie ook: GILISSEN, Historische inleiding, 276. HORN, “Die legistische Literatur der Kommentatoren”, 282. 
7 (7) Le Code du Roy Henry III, Roy de France et de Pologne, redigé en ordre par Barnabé BRISSON, depuis augmenté des édits du Roy Henry IV, avec la conférence des ordonnances, et rapporté aux ancien Code de Théodose et de Justinien, et aux Basiliques, et illustrés des Conciles de l'Eglise, Lois des Romains et autre peuples, bistoires, antiquiez, arrêts, observations et annotations. $(1601)^{860}$

3 (3) [Le] grand coustumier de France, contenant tout le droit françois et practique judiciaire, pour plaider ès cours de parlement, prévosté et vicomté de Paris et autres juridictions de ce royaume. (Par Jacques D'ABLEIGES.) Reveu et corrigé sur l'exemplaire escrit à la main et ancienne impression... par L. Charondas le Caron... (1598) 861

2 (2) Pandectes ou Digestes du droit françois. (1593) 862

0 (4) Di CASTRO, Paulo (Paulus Castrensis; 1360/62-1441; ita) ${ }^{863}$

0 (2) Consilia. (s.d.) $)^{864}$

0 (2) allegatie zonder titel ${ }^{865}$

3 CaValCaNI, Borgnino (Borgninus Cavalcanus; 1530-1607; ita)

2 Decisiones Fori Fivizanensis aliorumque locorum. (1581) $)^{866}$

$1 \quad$ Tractatus de tutore et curatore ac usufructu mulieri relicto. (1571) 867

5 (6) De Chasseneuz, Barthélemy (Bartholomaeus de Chassenaeus; 14801541; fra) ${ }^{868}$

860 1.13.5, 1.13.7, 3.12.8/9, 3.12.13, 4.1.6, 5.10.73, 5.10.79. HOLTHÖFER, "Die Literatur zum gemeinen und partikularen Recht", 269. Brisson's oorspronkelijke werk dateert van 1587. De bewerking ervan door le Caron verscheen voor het eerst in 1601. In de Memorieboeken wordt tevens veelvuldig naar dit werk verwezen, zonder te verwijzen naar de opinie van le Caron. Men refereert uitsluitend naar de opgenomen wetgeving. Deze allegaties werden hier dan ook niet in rekening gebracht. Het betreft de artikels 1.12.20, 1.12.26, 1.12.27/28, 1.13.3, 1.13.4, 1.13.6, 1.13.9/10/11, 2.2.15, 3.13.47/48, 4.1.4, 4.7.35, 4.7.38/39, 4.7.41, 5.10.79.

861 6.1.39, 6.1.43, 6.1.44. LEYTE, "Charondas et le droit français", 19. Zie ook: GILISSEN, Historische inleiding, 276. HORN, "Die legistische Literatur der Kommentatoren", 282.

862 4.13.38/39, 7.1.17. HOLTHÖFER, "Die Literatur zum gemeinen und partikularen Recht", 300.

${ }^{803}$ P. WEIMAR, "Paulus de Castro", M. STOLLEIS red., Juristen: ein biographisches Lexikon von der Antike bis zum 20. Jahrbundert, Munchen, 2001, 489. A. BELLONI, Professori giuristi a Padova nel secolo XV, Frankfurt am Main, 1986, 283-292.

864 2.1.36/37 (tweederangse allegatie door René Choppin), 3.12.8/9 (tweederangse allegatie door Louis le Caron). HORN, "Die legistische Literatur der Kommentatoren”, 340.

865 2.1.39/40/41/42 (tweederangse allegatie door René Choppin), 5.8.6 (tweederangse allegatie door Pieter Peck). HORN, "Die legistische Literatur der Kommentatoren", 327. Men verwijst naar de mening van di Castro bij onder andere de Digestenregel D.24.3.22.4.

866 4.12.18, 4.18.16. ASCHERI, "Rechtsprechungs- und konsiliensammlungen", 1180.

867 4.18.10. HOLTHÖFER, "Die Literatur zum gemeinen und partikularen Recht", 340.

${ }^{868}$ C. DUGAS DE LA BOISSONNY, "Chasseneuz (Chasseneux) Barthélemy de", P. ARABEYRE, J.-L. HALPERIN en J. KRYNEN red., Dictionnaire historique des juristes francais (XIIe-XXe siècle), Parijs, 2007, 183-184. DUGAS DE LA BOISSONNY, Barthélémy de Chasseneur. 
4 (4) Commentaria in Consuetudines Ducatus Burgundiae principaliter et totius fere Galliae consecutive. (1517) 869

1 (1) Consilia D. Bartholomaei à Chasseneo Burgundi iurisconsulti praestantissimi. (1531) ${ }^{870}$

0 (1) allegatie zonder titel 871

0 (1) CHENU, Jean (1559-1627; fra) ${ }^{872}$

0 (1) Cent notables et singuliers questions de droit, décidées par arrests mémorables des cours souveraines de France. Partie d'iceux prononcez en robbes rouges: contenant les moyens et raisons decisives. $(1602)^{873}$

9 (14) CHOPPIN, René (Renatus Choppinus; 1537-1606; fra) ${ }^{874}$

5 (5) De legibus Andium municipalibus libri tres cum praevio tractatu de summis Gallicarum consuetudinum regulis. $(1600-1601)^{875}$

4 (4) De civilibus Parisiorum moribus ac institutis libri tres. (1596) 876

0 (4) De privilegiis rusticorum, libri tres. $(1575)^{877}$

0 (1) De domanio Franciae libri tres. $(1574)^{878}$

0 (1) CICERO, Marcus Tullius (106 v.c.-43 v.c.; rom) ${ }^{879}$

0 (1) Oratio pro Rescio. 880

13 (14) Claro, Giulio (Julius Clarus; 1525-1575; ita) 881

869 2.4.12, 2.5.43, 3.4.53, 4.18.16. HOLTHÖFER, "Die Literatur zum gemeinen und partikularen Recht", 281.

870 2.2.24. DUGAS DE LA BOISSONNY, Barthélémy de Chasseneuz, VII. Walter spreekt in het Handbuch van Coing ten onrechte van 1581. (WALTER, "Rechtsprechungs- und konsiliensammlungen", 1269.)

8713.4 .3 (tweederangse allegatie door René Choppin).

872 M. PREVOST, “Jean Chenu”, Dictionnaire de biographie française, VIII, Parijs, 1959, 995-996.

873 Volgende allegatie werd niet meegerekend wegens haar niet-rechtsgeleerd karakter (rechtspraak): 2.1.75. WALTER, "Rechtsprechungs- und konsiliensammlungen", 1257.

874 A. FRIGERIO, “Choppin René”, P. ARABEYRE, J.-L. HALPERIN en J. KRYNEN red., Dictionnaire historique des juristes français (XIIe-XXe siècle), Parijs, 2007, 190-191. M. PREVOST, "René Choppin", Dictionnaire de biographie française, VIII, Parijs, 1959, 1252-1253.

875 2.1.17, 2.4.18, 3.3.19, 3.11.20, 4.18.16. HOLTHÖFER, "Die Literatur zum gemeinen und partikularen Recht", 274.

876 2.1.36, 2.1.39, 3.3.18, 3.4.3. HOLTHÖFER, "Die Literatur zum gemeinen und partikularen Recht”, 290.

${ }^{877}$ HOLTHÖFER, “Die Literatur zum gemeinen und partikularen Recht”, 334.

Volgende allegaties werden niet meegerekend wegens hun niet-rechtsgeleerd karakter (rechtspraak): 3.14.15, 3.14.96, 3.14.122/123, 4.13.7/8.

878 3.14.15 (tweederangse allegatie door Pierre Guenoys). PREVOST, "René Choppin”, 1253.

${ }^{879}$ O. BEHRENDS, "Cicero, Marcus Tullius", M. STOLLEIS red., Juristen: ein biographisches Lexikon von der Antike bis zum 20. Jahrbundert, Munchen, 2001, 131-133.

880 4.10.3/4/5 (tweederangse allegatie door Matthias Wesenbeck).

${ }^{881}$ E. VON MOELLER, Julius Clarus aus Alessandria, der Kriminalist des 16. Jabrbunderts, der Rat Philipps II. 1525-1575 (Strafrechtliche Abhandlungen 136), Breslau, 1977. Beide geallegeerde 
9 (10) Sententiarum receptarum liber quintus, in quo diversorum criminum materia XX $\iint$. diligenter explicatur. (1568) 882

4 (4) Tractatus quatuor. Ex suis VII libris sententiarum receptarum quorum I est de Testamentis, II de Donationibus, III de Iure emphyteotico, IIII de Feudis. (1565) ${ }^{883}$

2 COLER, Matthias (Mattheus Colerus; 1530-1587; hrr) 884

2 Tractatus de processibus executivis ad Practicam fori Saxonici applicatus. (1572) 885

1 (2) DA Costa, Manoel (Emanuel Costa, Acosta; 1505/15-1563/64; spa) 886

1 (2) Omnia quae quidem extant in ius canonicum et civile opera. (1576) 887

5 Cousteau, Pierre (Petrus Costalius, Castalius, Costal; ca.1550; fra) ${ }^{888}$

5 Adversariorum ex Pandectis Justiniani Imperatoris. Liber prior ad quinque et viginti antecedentes libros. (1554) 889

9 (13) DE Covarubias y LeYva, Diego (Didacus Covarruvias; 1512-1577; spa) ${ }^{890}$

3 (7) In Gregorii Noni titulum de testamentis (X.3.26) commentarii. (1554) $)^{891}$

5 (5) Variarum ex iure pontificio, regio et caesareo resolutionum libri tres. (1552) 892

werken zijn terug te vinden in Claro's (Opera omnia, sive) Practica civilis atque criminalis. (Cfr. HOLTHÖFER, "Die Literatur zum gemeinen und partikularen Recht", 398.)

882 1.14.35, 4.13.38/39, 6.2.27, 7.1.12, 7.1.15, 7.1.16, 7.1.17, 7.2.12, 7.3.1. VON MOELLER, Julius Clarus, 228-229. HOLTHÖFER, "Die Literatur zum gemeinen und partikularen Recht", 398.

Volgende allegatie werd niet meegerekend wegens haar niet-rechtsgeleerd karakter (rechtspraak): 6.2.13/14.

883 3.12.10, 3.13.14/15, 3.13.49, 3.13.50. VON MOELLER, Julius Clarus, 227.

884 SÖLLNER, "Die Literatur zum gemeinen und partikularen Recht", 580. E. WOLF, "Colerus, Matthias", Neue deutsche Biographie, III, Berlijn, 1971 (nadruk van 1957), 320.

885 3.14.46, 4.17.16. HOLTHÖFER, "Die Literatur zum gemeinen und partikularen Recht", 608.

${ }^{886}$ HOLTHÖFER, “Die Literatur zum gemeinen und partikularen Recht”, 485.

887 3.13.49 (tweederangse allegatie door Michaël Grass), 3.13.50. HOLTHÖFER, "Die Literatur zum gemeinen und partikularen Recht", 485.

${ }^{888}$ P. HAMON, "Pierre Coustau", Dictionnaire de biographie française, IX, Parijs, 1961, 1089. HOLTHÖFER, "Die Literatur zum gemeinen und partikularen Recht", 191/470.

889 2.1.12, 3.11.16, 3.11.17, 4.6.17, 4.15.19/20. HOLTHÖFER, "Die Literatur zum gemeinen und partikularen Recht", 191.

${ }^{890}$ K. SEELMANN, "Covarubias (Covarruvias) y Leyva, Diego de”, M. STOLLEIS red., Juristen: ein biographisches Lexikon von der Antike bis zum 20. Jabrhundert, Munchen, 2001, 148-149.

891 3.13.31/32, 3.13.33/34, 3.13.49 (tweederangse allegatie door Michaël Grass), 3.13.50 (tweederangse allegatie door Michaël Grass), 3.13.51, 3.13 .52 (tweederangse allegatie door Michaël Grass), 3.13.69/70 (tweederangse allegatie door Michaël Grass). HOLTHÖFER, "Die Literatur zum gemeinen und partikularen Recht", 381. Het gaat hier om één van zijn vele canoniekrechtelijke werken die werden verzameld in zijn Opera omnia canonica van 1573. (Cfr. SEELMANN, "Covarubias (Covarruvias) y Leyva, Diego de”, 148.) 
1 (1) Practicarum quaestionum liber singularis. (1556) $)^{893}$

1 (2) Cravetta, Aimone (Aymo Cravetta; 1504-1569; ita) 894

1 (2) Consilia. (1543) 895

1 DE CREMA, Francisco (Franciscus Cremensis; vijftiende eeuw; ita) ${ }^{896}$

$1 \quad$ Singularia iuris. (s.d.) ${ }^{897}$

2 CUJAS, Jacques (Jacobus Cuiacius; 1522-1590; fra) 898

2 Observationum et emendationum. Liber I et II (1556) liber III (1557) liber I-IV (1559) liber $V$ (1562) libri VI-VIII (1564) libri IX-XI (1570) libri XII-XIV (1573) libri XV-XVII (1577) libri XVIII-XX (1579) libri XXI- XXIV (1585) libri XXV-XXVIII (1595). ${ }^{899}$

1 DA CumA, Raffaele (Raphael Cumanus, Raffaele Raimondi; +1427, ita) 900

1 Commentaria in prima parte Digesti novi. (s.d.) ${ }^{901}$

1 DE Cun, Guillaume (Guilelmus de Cuneo, de Cugno, du Cun; +1336; fra) ${ }^{902}$

$1 \quad$ Lectura super Digesti veteris. $(1315-1316)^{903}$

892 2.5.90, 3.4.53, 4.1.9/10, 5.17.9, 6.3.9. HOLTHÖFER, "Die Literatur zum gemeinen und partikularen Recht", 416.

893 1.14.35. HOLTHÖFER, "Die Literatur zum gemeinen und partikularen Recht", 416.

${ }^{894}$ HOLTHÖFER, "Die Literatur zum gemeinen und partikularen Recht”, 442.

895 4.18.10, 5.11.46 (tweederangse allegatie door Jacopo Menocchio). ASCHERI, "Rechtsprechungs- und konsiliensammlungen", 1212.

896 I Rotuli dei lettori, legisti et artisti dello Studio Bolognese dal 1384 al 1799, U. DALLARI ed., I, Bologna, 1888-1919, 33 en 36.

897 4.9.35/36/37. Max-Planck-Institut. Online-Katalog der Bibliothek, 2006. Dit werk is eveneens opgenomen in de Singularia omnium clarissimorum doctorum (1560). Cfr. HOLTHÖFER, "Die Literatur zum gemeinen und partikularen Recht", 419.

898 L. WINKEL, "Cujas (Cujacius) Jacques", P. ARABEYRE, J.-L. HALPERIN en J. KRYNEN red., Dictionnaire historique des juristes français (XIIe-XXe siècle), Parijs, 2007, 220-222. J. OTTO, "Cujas (Cujacius), Jacques", M. STOLLEIS red., Juristen: ein biographisches Lexikon von der Antike bis zum 20. Jabrbundert, Munchen, 2001, 152-153. Zie ook: P. MESNARD, "La place de Cujas dans la querelle de l'humanisme juridique", Revue historique du droit français et étranger, 27 (1950), 521-537.

899 3.13.50, 4.18.2. TROJE, "Die Literatur des gemeinen Rechts unter dem Einfluss des Humanismus", 683.

900 Max-Planck-Institut. Online-Katalog der Bibliothek, 2006.

901 4.18.76. Max-Planck-Institut. Online-Katalog der Bibliothek, 2006.

902 J. KRYNEN, "Cun (Cunh, Cugno, Cunho, de Cuneo) Guillaume de”, P. ARABEYRE, J.-L. HALPERIN en J. KRYNEN red., Dictionnaire bistorique des juristes français (XIIe-XXe siècle), Parijs, 2007, 223-225. HORN, "Die legistische Literatur der Kommentatoren", 278.

903 4.13.38/39. KRYNEN, “Cun (Cunh, Cugno, Cunho, de Cuneo) Guillaume de”, 224. 
DE DAMHOuder, Joost (Jodocus, Judocus Damhouderius; 1507-1581; ned) $)^{904}$

1 Praxis rerum civilium, praetoribus, propraetoribus, consulibus, proconsulibus, magistratibus, reliquisque idgenus iustitiariis, apprime utilis et necessaria, cum nonnullibus inconibus materiae subiectae convenientibus. $(1567)^{905}$

4 (9) Decio, Filippo (Philippus Decius, Dezio; 1454-1535; ita)906

2 (3) Consilia seu responsa. (1512)

1 (4) Annotationes van Charles Dumoulin bij de Consilia van Filippo Decio. $(1553)^{908}$

1 (1) De regulis iuris, sive Lectura super tit. de regulis iuris Dig. (1521) $)^{909}$

0 (1) Dumoulins commentaar bij Decio's Scripta super sexto Codicis. (1514) 910

1 DE DENARIIS, Odofredus $(+1265 \text {; ita })^{911}$

1 Lectura Digesti veteris. (s.d.) ${ }^{912}$

32 (39) Dumoulin, Charles (Carolus Molinaeus; 1500-1566; fra) ${ }^{913}$

8 (9) Prima pars Commentariorum in Consuetudines Parisienses. (1539) Secunda pars commentariorum analyticorum in Consuetudines Parisienses. $(1558)^{914}$

${ }^{904}$ BRITZ, Code de l'ancien droit Belgique, I, 86-89. R. FEENSTRA, "Damhouder, Joos de", M. STOLLEIS red., Juristen: ein biographisches Lexikon von der Antike bis zum 20. Jabrbundert, Munchen, 2001, 158-159.

905 2.5.138. SÖLLNER, "Die Literatur zum gemeinen und partikularen Recht”, 608.

906 E. HOLTHÖFER, "Decio (Decius), Filippo”, M. STOLLEIS red., Juristen: ein biographisches Lexikon von der Antike bis zum 20. Jahrbundert, Munchen, 2001, 172-173.

907 2.1.6, 2.1.112, 3.12.8/9 (tweederangse allegatie door Louis le Caron). ASCHERI, "Rechtsprechungs- und konsiliensammlungen", 1211.

908 2.1.181 (tweederangse allegatie door Annotationes van Charles Dumoulin bij Filippo Decio), 2.1.227 (tweederangse allegatie door Annotationes van Charles Dumoulin bij Filippo Decio), 2.2.9/10/11, 3.14 .101 (tweederangse allegatie door Annotationes van Charles Dumoulin bij Filippo Decio). J.-L. THIREAU, Charles de Moulin (1500-1566): étude sur les sources, la méthode, les idées politiques et économiques d'un juriste de la renaissance, Genève, 1980, 34-35. De allegatie in verband met de artikels 2.2.9/10/11 werd hier ondergebracht omdat men expliciet naar de opinie van Decio verwijst en niet naar die van Dumoulin.

909 6.3.23. HOLTHÖFER, "Die Literatur zum gemeinen und partikularen Recht", 211. De eerste uitgave dateert van 1521, maar het werk werd reeds voordien geschreven en als manuscript verspreid.

910 3.14.97 (tweederangse allegatie door Annotationes van Charles Dumoulin bij Filippo Decio). HOLTHÖFER, "Die Literatur zum gemeinen und partikularen Recht", 160.

911 WEIMAR, "Die legistische Literatur der Glossatorenzeit", 133.

912 5.4.5. WEIMAR, "Die legistische Literatur der Glossatorenzeit", 176.

913 THIREAU, Charles du Moulin. J.-L. THIREAU, "Du Moulin (Du Molin, Dumoulin, Molinaeus) Charles", P. ARABEYRE, J.-L. HALPERIN en J. KRYNEN red., Dictionnaire bistorique des juristes français (XIIe-XXe siècle), Parijs, 2007, 276-278. J. OTTO, "DuMoulin (Molinaeus), Charles", M. STOLLEIS red., Juristen: ein biographisches Lexikon von der Antike bis zum 20. Jahrbundert, Munchen, 2001, 188-189. 
7 (8) Annotationes van Dumoulin op Consilia van Alessandro di Tartagni. (1543)

4 (5) Tractatus de usuris. (1542) 916

4 (4) Annotationes van Dumoulin op Filippo Decio. (1553) 917

2 (3) Caroli Molinaei Parisiensis I.U.D. consultissimi Franciae et Germaniae I. C. et in supremo Parisiorum senatu antiqui advocati consilia et responsa iuris analytica. (1560) ${ }^{918}$

2 (2) Nova et analytica explanatio rubricae et l. I et II de verborum obligationibus. (1561)919

2 (2) Extricatio labyrinthi dividui et individui. (1562) ${ }^{920}$

1 (1) Intellectus novus et analyticus leg. Si partem. (1561)921

1 (1) Le Coutumier du pays et duché de Bourbonnais, annoté de plusieurs décisions et arrêts. $(1572)^{922}$

1 (1) Coustumes des duché, baillage et prévosté d'Orléans avec la conférence de la Coutume de Paris ... avec les notes de ... (1609) $)^{923}$

0 (1) Tractatus analyticus variarum iuris quaestionum. (s.d.) ${ }^{924}$

0 (2) allegatie zonder titel ${ }^{925}$

0 (2) DurANTI, Guilelmo (Guilielmus Durantis, Speculator; ca.1237-1296; ita) ${ }^{926}$

0 (2) Speculum indicale. (1271-1276) ${ }^{927}$

914 1.1.14, 2.4.10 (tweederangse allegatie door Louis le Caron), 2.4.15/16, 2.4.17, 2.5.157, 3.4.53, 3.13.28, 3.14.31/32/33/34, 4.6 .17 (tweederangse allegatie door Pierre Guenoys). HOLTHÖFER, "Die Literatur zum gemeinen und partikularen Recht", 289.

915 3.13.49, 3.13.54/55 (tweederangse allegatie door Andreas Gaill), 3.13.56/57/58, 3.13.65, 3.13.67, 4.13.38/39, 4.15.7, 5.17.9. THIREAU, Charles du Moulin, 32 en 34, noot 94.

916 3.11.16 (tweederangse allegatie door Pierre Guenoys), 3.11.17, 4.1.5, 4.1.11/12/13, 5.8.23. THIREAU, Charles du Moulin, 34.

917 2.1.181/182/183, 2.1.227/228, 3.14.97, 3.14.101/102/103. THIREAU, Charles du Moulin, 34-35.

918 3.12.10, 3.12.13. WALTER, “Rechtsprechungs- und konsiliensammlungen”, 1269.

Volgende allegatie werd niet meegerekend wegens haar niet-rechtsgeleerd karakter (rechtspraak): 3.14.96.

919 3.13.69/70, 5.10.75/76/77/78. THIREAU, Charles du Moulin, 41, noot 136. In tegenstelling tot Thireau spreekt Otto van 1562. (OTTO, "DuMoulin (Molinaeus), Charles", 189.)

920 3.14.89, 4.13.38/39. HOLTHÖFER, "Die Literatur zum gemeinen und partikularen Recht", 370.

921 3.2.17/18. THIREAU, Charles du Moulin, 46, noot 162.

922 3.14.62. HOLTHÖFER, "Die Literatur zum gemeinen und partikularen Recht", 279.

923 3.13.28. HOLTHÖFER, "Die Literatur zum gemeinen und partikularen Recht", 289.

924 HOLTHÖFER, "Die Literatur zum gemeinen und partikularen Recht”, 414.

Volgende allegatie werd niet meegerekend wegens haar niet-rechtsgeleerd karakter (rechtspraak): 3.14.15.

925 3.4.3 (tweederangse allegatie door René Choppin), 3.14.59/60 (tweederangse allegatie door Pierre Guenoys).

926 J. MÜLLER, "Durantis, Guilelmus d. Ä. (Speculator)", M. STOLLEIS red., Juristen: ein biographisches Lexikon von der Antike bis zum 20. Jahrbundert, Munchen, 2001, 191.

927 3.3.18 (tweederangse allegatie door René Choppin), 5.3.23/24 (tweederangse allegatie door Annotationes van Johannes Andreae op het Speculum van Duranti). NÖRR, "Die kanonistische Literatur", 394. 
1 DURET, Jean (Johannes Duretus; ca.1540-1616 of 1620; fra) ${ }^{928}$

1 Alliance des lois romaines avec le droit françois, contenu aux ordonnances des rois, arrêts des cours souveraines et coustumes provinciales. $(1600)^{929}$

8 (10) EveraERTs, Nicolas (Nicolaus Everardus, Everts, a Middelburgo; 14621532; ned) ${ }^{930}$

8 (10) Consilia sive responsa juris. (1554) ${ }^{931}$

9 FACHINEO, Andreo (Andreus Fachineus; +1607; ita) 932

9 Controversiarum iuris libri novem. (1595) ${ }^{933}$

0 (1) DI FAnUZZI/FAnUCCI, Phanutio (Phanutius de Phanutiis/Phanuciis; ca.1550; ita) $)^{934}$

0 (1) verwijzing naar di Fanuzzi die vermeld wordt in Tractatus de inventario heredis van Sebastiano Monticello. Vermoedelijk wordt hier verwezen naar dier eigen Tractatus de inventario heredis. (1571) ${ }^{935}$

4 FarinacCI, Prospero (Prosperus Farinacius; 1554-1618; ita) ${ }^{936}$

$4 \quad$ Praxis et theorica criminalis. $(1581-1614)^{937}$

8 (10) FaVRE, Antoine (Antonius Faber; 1557-1624; fra) ${ }^{938}$

928 J. VENDRAND-VOYER, "Duret Jean", P. ARABEYRE, J.-L. HALPERIN en J. KRYNEN red., Dictionnaire historique des juristes français (XIIe-XXe siècle), Parijs, 2007, 296. P. FAURE, "Jean Duret”, Dictionnaire de biographie française, XII, Parijs, 1970, 752-753.

929 7.8.1. HOLTHÖFER, “Die Literatur zum gemeinen und partikularen Recht”, 298.

930 BRITZ, Code de l'ancien droit Belgique, I, 67-69. Lovanium docet, 60-63. C. M. G. VAN RAA, "Nicolaas Everaerts (1461 of 1462-1532)", Zestig juristen. Bijdragen tot een beeld van de geschiedenis van de Nederlandse rechtswetenschap, T. J. VEEN en P. C. KOP red., Zwolle, 1987, 97-103.

VERVAART, Nicolaas Everaerts.

931 1.1.15 (tweederangse allegatie door Andreas Gaill), 2.1.97, 2.1.181, 2.2.24, 3.1.10, 3.13.21, 3.13.23 (tweederangse allegatie door Fabio Torretti), 3.14.15, 4.13.12/13/14/15, 4.13.33. DEKKERS, Bibliotheca Belgica Juridica, 53. De eerste uitgave van het werk dateert van 1554.

932 HOLTHÖFER, "Die Literatur zum gemeinen und partikularen Recht", 411.

933 3.11.4/5/6, 3.13.23, 3.13.49, 3.13.50, 3.13.52, 4.13.38/39, 6.1.25/26, 7.3.26, 7.3.30. HOLTHÖFER, "Die Literatur zum gemeinen und partikularen Recht", 411.

934 HOLTHÖFER, "Die Literatur zum gemeinen und partikularen Recht”, 389.

935 3.14.42 (tweederangse allegatie door Defensio van Sebastiano Monticello tegen di Fanuzzi). Cfr. HOLTHÖFER, "Die Literatur zum gemeinen und partikularen Recht”, 389.

936 A. MAZZACANE, "Farinacci, Prospero", M. STOLLEIS red., Juristen: ein biographisches Lexikon von der Antike bis zum 20. Jahrhundert, Munchen, 2001, 206-207.

937 6.1.25/26, 6.3.6/7, 6.3.8, 7.3.16/17/18/19/20. MAZZACANE, "Farinacci, Prospero", 206.

938 J. OTTO, "Favre (Faber), Antoine", M. STOLLEIS red., Juristen: ein biographisches Lexikon von der Antike bis zum 20. Jabrbundert, Munchen, 2001, 207-208. L. CHEVALIER, "Le président Faber et la jurisprudence du Sénat de Savoie de 1585-1605", Tijdschrift voor 
3 (4) Codex Fabrianus definitionum forensium et rerum in sacro Sabaudiae Senatu tractatarum, ad ordinem titulorum codicis Iustinianei, quantum fieri potunt ad usum accomodatus, et in novem libros distributus ... (1606)939

5 (5) De erroribus pragmaticorum et interpretum iuris chiliadis pars prima ad quarta. $(1598)^{940}$

0 (1) allegatie zonder titel 941

4 (6) Favre, Jean (Johannes Faber, Faure, Fabri, de Runciis; ca.1275-1340; fra) ${ }^{942}$

2 (3) Breviarium super Codicem. (ca.1325-1330)943

2 (3) Opus super Institutionibus. (ca.1335-1340) 944

1 FELITI, Ettore (Hector Felicius, 1589-1623; ita) ${ }^{945}$

1 allegatie zonder titel ${ }^{946}$

Rechtsgeschiedenis, 20 (1952), 263-289 en 456-478. B. BARBICHE, “Antoine Favre”, Dictionnaire de biographie française, XIII, Parijs, 1975, 857-862.

$939 \quad 3.13 .71 / 72, \quad 5.11 .51 / 52 / 53, \quad 6.1 .41 / 42$. ASCHERI, "Rechtsprechungs- und konsiliensammlungen", 1183. WALTER, "Rechtsprechungs- und konsiliensammlungen", 1257.

Volgende allegatie werd niet meegerekend wegens haar niet-rechtsgeleerd karakter (rechtspraak): 3.13.45/46.

940 3.13.49, 3.13.501 $3.13 .50^{2}, 3.14 .75$, 4.1.6. HOLTHÖFER, "Die Literatur zum gemeinen und partikularen Recht", 195. TROJE, "Die Literatur des gemeinen Rechts unter dem Einfluss des Humanismus", 684.

941 6.3.27. Men verwijst naar de mening van Favre bij de Digestenregel D.50.17.108. De allegatie werd echter niet meegerekend wegens haar niet-rechtsgeleerd karakter (rechtspraak).

942 K. WEIDENFELD, "Faure (Fabri) Jean", P. ARABEYRE, J.-L. HALPERIN en J. KRYNEN red., Dictionnaire historique des juristes francais (XIIe-XXe siècle), Parijs, 2007, 321-322. P. FOURNIER, "Jean Faure, légiste", Histoire littéraire de la France, XXXV, Parijs, 1921, 556580. A. J. BOYÉ, "Notes sur Jean Faure", Etudes d'bistoire du droit privé offertes à Pierre Petot, Parijs, 1959, 28-38. Cfr. HORN, "Die legistische Literatur der Kommentatoren", 282. Jean Favre wordt in de Memorieboeken steeds als 'Faber' aangeduid. Enkel met betrekking tot artikel 3.11.19 spreken de Memorien op de Costumen van 'Io. Faber'. Wanneer het daarentegen om Antoine Favre gaat, schrijft men ook steeds de voornaam 'Anthon.' neer. Bijgevolg heb ik alle allegaties naar 'Faber' bij Jean Favre ondergebracht. Dat het hier steeds om commentaren bij legi van de Codex of Instituten gaat, is een reden te meer om dit zo te doen. Jean Favre staat er, als bartolistisch commentator, om bekend het Corpus Iuris te becommentariëren. Antoine Favre daarentegen wordt in de Memorieboeken uitsluitend met zijn jurisprudentiële Codex Fabrianus aangewend.

943 1.14.31, 3.11.19, 4.18.71. WEIDENFELD, "Faure (Fabri) Jean”, 321. FOURNIER, "Jean Faure, légiste", 561-580.

944 2.5.64, 3.4.67/68 (tweederangse allegatie door Pierre Guenoys), 5.11.46 (tweederangse allegatie door Jacopo Menocchio). FOURNIER, “Jean Faure, légiste”, 561-580.

945 HOLTHÖFER, "Die Literatur zum gemeinen und partikularen Recht", 446.

946 6.3.23. Men verwijst naar de mening van Feliti bij de canoniekrechtelijke regel Greg. 5, 12, 6. 
DE FERRARIIS, Johannes Petrus (+1416/1421; hrr $)^{947}$

1 Practica nova judicialis. (1473) 948

FEU, Jean (Johannes Ignaeus; 1477-1549; fra) ${ }^{949}$

Prima (secunda) pars Commentariorum in tit. de Sillaniano et Claudiano Senatusconsulto, et quorum testamenta aperiantur libro vigesimonono, I-II. (1539)950

1 Follerio, Pietro (Petrus Follerius; 1515/35->1588; ita) ${ }^{951}$

1 Commentaar bij traktaat van Roberto Maranta (+ca.1540): Tractatus docti et insignes, de ordine indiciorum (vulgo speculum aureum, et lumen advocatorum). (1566) $)^{952}$

1 FORSTER, Valentin (Valentinus Forsterus; 1530-1608; hrr) ${ }^{953}$

1 De successionibus quae ab intestato deferuntur, libri quinque; de liberorum iure, quod in aliis rebus praeter successiones babent; de usufructu quem parentes consequuntur in bonis liberorum adventitiis. (1566) $)^{954}$

1 (2) FulgosiUs, Raffael (1367-1427; ita $)^{955}$

1 (1) In primam Pandectarum partem commentariorum. (s.d.) 956

0 (1) allegatie zonder titel ${ }^{957}$

0 (1) GABRIELI, Antonio (Antonius Gabrielius; +1555; ita) 958

0 (1) Communes conclusiones et opiniones. (1570)

4 (6) GAILL, Andreas (Geil, Geyll, Geihl, Gayll; 1526-1587; hrr) ${ }^{960}$

947 NÖRR, "Die kanonistische Literatur", 395.

948 5.11.18/19/20. Het werk werd omstreeks 1414 geschreven. De eerste uitgave dateert van 1473. NÖRR, "Die kanonistische Literatur", 395.

949 P. ARABEYRE, "Feu (Ignaeus) Jean”, P. ARABEYRE, J.-L. HALPERIN en J. KRYNEN

red., Dictionnaire historique des juristes français (XIIe-XXe siècle), Parijs, 2007, 329. Y. DESTAINGES, "Jean Feu", Dictionnaire de biographie française, XIII, Parijs, 1975, 1211-1212. Zie ook: HOLTHÖFER, "Die Literatur zum gemeinen und partikularen Recht”, 112.

950 4.13.38/39. HOLTHÖFER, “Die Literatur zum gemeinen und partikularen Recht”, 383.

951 HOLTHÖFER, "Die Literatur zum gemeinen und partikularen Recht", 446.

952 4.9.35/36/37. HOLTHÖFER, "Die Literatur zum gemeinen und partikularen Recht", 397.

953 SÖLLNER, "Die Literatur zum gemeinen und partikularen Recht", 605.

954 2.4.17. SÖLLNER, "Die Literatur zum gemeinen und partikularen Recht”, 605.

955 HORN, "Die legistische Literatur der Kommentatoren”, 270.

956 5.4.5. Nederlandse Centrale Catalogus, 1998-2007.

(http://picarta.pica.nl/DB=2.4/LNG=NE/). Zie ook: HORN, "Die legistische Literatur der Kommentatoren", 327.

957 5.8.6 (tweederangse allegatie door Pieter Peck). De allegatie verwijst naar de mening van Fulgosius bij het een wet uit de Digesten.

958 HOLTHÖFER, "Die Literatur zum gemeinen und partikularen Recht”, 421.

959 3.13.23 (tweederangse allegatie door Andreo Fachineo). HOLTHÖFER, "Die Literatur zum gemeinen und partikularen Recht", 421. 
4 (6) Practicarum observationum, tam ad processum indiciarium, praesertim imperialis camerae, quam ad causarum decisiones pertinentium, libri duo. (1578)961

0 (1) Gambiglione, Angelo (Angelo Aretinus; vijftiende eeuw; ita) 962 $^{962}$

0 (1) Lectura Institutionum. (s.d.) ${ }^{963}$

2 GARZiA DE SAAvEdRA, Juan (Johannes Garcias de Saavedra, García de Saavedra; 1530/40-1587/97; spa $)^{964}$

2 De expensis et meliorationibus liber unus. (1578) ${ }^{965}$

1 GELLIUS, Aulus (130-180; rom) ${ }^{966}$

$1 \quad$ Noctes Atticae. (ca.175) 967

13 (14) GoDEFroy, Denis (Dionysius Gothofredus; 1549-1622; fra) 968

11 (11) allegatie zonder titel ${ }^{969}$

2 (2) allegatie zonder titel ${ }^{970}$

960 J. OTTO, "Gaill, Andreas", M. STOLLEIS red., Juristen: ein biographisches Lexikon von der Antike bis zum 20. Jabrbundert, Munchen, 2001, 228-229. O. VON SCHLIESSER, "Gail(1), Andreas", Neue deutsche Biographie, VI, Berlijn, 1971 (nadruk van 1964), 38-39. K. VON KEMPIS, Andreas Gaill (1526-1587): zum Leben und Werk eines Juristen der frühen Neuzeit. (Rechtshistorische Reihe 65), Frankfurt am Main, 1988.

961 1.1.15， 2.1.224，3.13.54/55, 6.1.51. H. GEHRKE, "Rechtsprechungs- und Konsiliensammlungen. Deutsches Reich", H. COING red., Handbuch der Quellen und Literatur der Neueren europäischen Privatrechtsgeschichte, II/2, Munchen, 1976, 1363.

Volgende allegaties werden niet meegerekend wegens hun niet-rechtsgeleerd karakter (rechtspraak): 2.1.76, 4.1.6.

962 HORN, "Die legistische Literatur der Kommentatoren”, 221.

963 4.13.38/39 (tweederangse allegatie door Giulio Claro). HORN, "Die legistische Literatur der Kommentatoren”, 221.

964 HOLTHÖFER, "Die Literatur zum gemeinen und partikularen Recht”, 349.

965 2.1.76, 2.5.17. HOLTHÖFER, "Die Literatur zum gemeinen und partikularen Recht”, 349.

966 "Gellius, Aulus", Grote Winkler Prins Encyclopedie, 9de uitg., IX, Amsterdam en Antwerpen, $1991,515$.

967 5.8.37. "Gellius, Aulus", Grote Winkler Prins Encyclopedie, 515.

968 A. DUFOUR, "Godefroy (Gothofredus) Jacques", P. ARABEYRE, J.-L. HALPERIN en J. KRYNEN red., Dictionnaire historique des juristes français (XIIe-XXe siècle), Parijs, 2007, 376-377. E. HOLTHÖFER, "Godefroy (Gothofredus), Jacques", M. STOLLEIS red., Juristen: ein biographisches Lexikon von der Antike bis zum 20. Jabrhundert, Munchen, 2001, 248-250. T. DE MOREMBERT, "Denis Godefroy", Dictionnaire de biographie française, XVI, Parijs, 1985, 437 438.

969 2.5.118, 3.13.14/15, 3.13.50, 3.14.78, 4.6.17, 4.6.19, 4.18.52, 5.11.18/19/20, 5.11.47, 5.13.8, 7.3.9/10. De allegaties verwijzen naar de mening van Godefroy bij respectievelijk de volgende leges uit het Corpus Iuris Civilis: D.26.7.15, C.6.23.21pr, D.36.1.3pr, C.6.30.22.4, C.4.44.2 en C.4.44.8, C.4.44.2, D.42.5.37, titel D.9.2, titel C.4.1, C.4.34.2, D.48.18.1pr. Zie ook: HOLTHÖFER, "Die Literatur zum gemeinen und partikularen Recht”, 151-152. 
0 (1) allegatie zonder titel ${ }^{971}$

4 GomeZ, Antonio (Antonio Gomezius; 1501-<1572; spa) ${ }^{972}$

3 Opus praeclarum et commentum super Legibus Tauri. (1552) ${ }^{973}$

1 Variarum resolutionum iuris civilis commnis et regii libri tres. Primus: ultimarum voluntatum materiam continet. Secundus: contractuum. Tertius: delictorum. (1552) $)^{974}$

1 GosIA, Martinus (+1158/1166; ita) $)^{975}$

$1 \quad$ allegatie zonder titel ${ }^{976}$

6 (7) GRASS, Michael (Michaelus Grassus; 1541-1595; hrr) 977

6 (7) Receptarum sententiarum volumina duo. (s.d.) $)^{978}$

4 Gregoire, Pierre (Petrus Gregorius Tholosanus; 1540-1597; fra) ${ }^{979}$

4 Syntagma iuris universi, atque legum pene omnium gentium, et rerum publicarum praecipuarum in tres partes Digestum. (1582) 980

1 GRIMAUDET, François (Franciscus Grimaldetius; 1520-1580; fra) ${ }^{981}$

$1 \quad$ Paraphrase du droict de retraict lignager. (1564)

970 3.13.14/15, 5.11.21/22. De allegaties verwijzen naar de mening van Godefroy bij wetten uit het Authenticum. Het is me echter onduidelijk gebleven om welke leges het exact gaat. 971 4.12.9.

972 N. REICHARDT, “Gómez, Antonio", M. STOLLEIS red., Juristen: ein biographisches Lexikon von der Antike bis zum 20. Jabrbundert, Munchen, 2001, 252-253. HOLTHÖFER, "Die Literatur zum gemeinen und partikularen Recht", 415.

973 2.1.142, 3.13.65, 3.13.67. HOLTHÖFER, "Die Literatur zum gemeinen und partikularen Recht", 305.

974 3.13.65. HOLTHÖFER, "Die Literatur zum gemeinen und partikularen Recht”, 415.

975 P. WEIMAR, "Martinus Gosia”, Lexikon des Mittelalters, VI, Munchen, 1993, 351.

976 4.13.38/39. De allegatie verwijst naar de mening van Gosia bij de Codextitel C.3.1.

977 SÖLLNER, "Die Literatur zum gemeinen und partikularen Recht", 602.

978 3.13.33/34, 3.13.49, 3.13.50, 3.13.51, 3.13.52, 3.13.69/70. Max-Planck-Institut. Online-Katalog der Bibliothek, 2006. Zie ook: SÖLLNER, "Die Literatur zum gemeinen und partikularen Recht", 602.

Volgende allegatie werd niet meegerekend wegens haar niet-rechtsgeleerd karakter (rechtspraak): 3.14.96.

979 D. QUAGLIONI, “Grégoire Pierre”, P. ARABEYRE, J.-L. HALPERIN en J. KRYNEN red., Dictionnaire historique des juristes français (XIIe-XXe siècle), Parijs, 2007, 384-385. L. PIGEAUD, "Pierre Grégoire", Dictionnaire de biographie française, XVI, Parijs, 1985, 1143-1144. 980 3.13.63/64, 7.3.24/25, 7.3.26, 7.3.27. TROJE, "Die Literatur des gemeinen Rechts unter dem Einfluss des Humanismus", 752. HOLTHÖFER, "Die Literatur zum gemeinen und partikularen Recht”, 206.

981 S. SOLEIL, "Grimaudet François", P. ARABEYRE, J.-L. HALPERIN en J. KRYNEN red., Dictionnaire historique des juristes français (XIIe-XXe siècle), Parijs, 2007, 385-386. L. PIGEAUD, "François Grimaudet", Dictionnaire de biographie française, XVI, Parijs, 1985, 1247 1248. 
44 (53) GuENOYs, Pierre (Guenois; 1520-ca.1600; fra) 983

43 (52) La conférence des coutumes tant générales, que locales et particulieres du royaume de France, distribuée en deux parties, contenant l'barmonie et différence d'icelles: avec une briefue explication tirée des loix Romaines et canoniques, anciens docteurs, et modernes, ensemble des ordonnances et arrests des cours souveraines, plus des indices fort amples tant de titres que des principales matières, et annotations, Part. I-II. (1596) ${ }^{984}$

1 (1) La Conférence des ordonnances royals distribuée en XII livres à l'imitation et selon l'ordre $d u$ Code de l'empereur Justinien, avec plusieurs annotations et observations servans pour l'intelligence d'icelles. Vol. I, II. (1593)

1 GUTIERREZ, Juan (Johannes Guterius; 1535-1618; spa) ${ }^{986}$

1 Tractatus de iuramento confirmatorio et aliis in iure variis resolutionibus ... ex tertia eius authoris recognitione. (s.d.) $)^{987}$

1 Hotman, François (Franciscus Hotomannus; 1524-1590; fra) ${ }^{988}$

1 Quaestionum illustrium liber. (1573)

9 IMBERT, Jean (Johannes Imbertus; 1494-1560; fra) ${ }^{990}$

982 3.11.17. HOLTHÖFER, "Die Literatur zum gemeinen und partikularen Recht", 357.

983 J. KRYNEN, "Guénois (Guénoys) Pierre", P. ARABEYRE, J.-L. HALPERIN en J. KRYNEN red., Dictionnaire historique des juristes francais (XIIe-XXe siècle), Parijs, 2007, 387. D. REUILLARD, "Pierre Guenois", Dictionnaire de biographie francaise, XVI, Parijs, 1985, 14461447.

984 2.1.76, 2.1.92, 2.5.34/35, 2.5.123, 3.4.37, 3.4.51/52, 3.4.53, 3.4.67/68, 3.4.69, 3.4.89, 3.7.20, $3.8 .63 / 64,3.11 .4 / 5 / 6,3.11 .12,3.11 .19,3.11 .20,3.13 .2,3.13 .19,3.13 .61,3.13 .73,3.14 .27$, 3.14.31/32/33/34, 3.14.42, 3.14.59/60, 3.14.66/67, 3.14.75, 3.14.78, 3.14.100, 3.14.105, 4.7.3, $4.7 .4, \quad 4.7 .12, \quad 4.7 .19 / 20 / 21 / 22, \quad 4.9 .38, \quad 4.13 .1 / 2, \quad 4.13 .4, \quad 4.13 .12 / 13 / 14 / 15, \quad 4.14 .5$, 4.16.73/74/75/76/77, 4.17.2/3, 4.17.16, 4.17.17, 6.1.41/42. HOLTHÖFER, "Die Literatur zum gemeinen und partikularen Recht", 272.

Volgende allegatie werd niet meegerekend wegens haar niet-rechtsgeleerd karakter (wetgeving): 4.14.13.

Volgende allegaties werden niet meegerekend wegens hun niet-rechtsgeleerd karakter (rechtspraak): 2.1.101, 2.1.203, 2.5.138, 2.5.172, 3.13.3, 3.14.15, 4.13.5, 4.17.23/24.

985 5.4.25/26. HOLTHÖFER, "Die Literatur zum gemeinen und partikularen Recht", 266.

986 HOLTHÖFER, "Die Literatur zum gemeinen und partikularen Recht", 488.

987 4.1.6. OSLER, Bibliographica Iuridica 2, 34. OSLER, Bibliographica Iuridica 1, 245.

988 A. LECA, "Hotman François", P. ARABEYRE, J.-L. HALPERIN en J. KRYNEN red., Dictionnaire historique des juristes francais (XIIe-XXe siècle), Parijs, 2007, 409-411. E. BLOCAILLE, Etude sur Francois Hotman : La Franco-Gallia, Dijon, 1902. D. R. KELLEY, Francois Hotman. A Revolutionary Ordeal, Princeton, 1973. T. DE MOREMBERT, "François Hotman", Dictionnaire de biographie française, XVII, Parijs, 1989, 1309-1310. J. OTTO, "Hotman (Hotomannus), François", M. STOLLEIS red., Juristen: ein biographisches Lexikon von der Antike bis zum 20. Jabrbundert, Munchen, 2001, 303-304.

989 3.13.50. HOLTHÖFER, "Die Literatur zum gemeinen und partikularen Recht", 415. 
Institutiones forenses. (1535) 991

4 Enchiridion iuris scripti Galliae moribus et consuetudine frequentiore usitati, itemque abrogati, omnibus causidicis et ceteris indicialis Galliae praxis studiosis apprime necessarium et utile. (1556) 992

1 INTRIGLIOLI, Niccolo (Nicolaus Intrigliolius; 1562-1604; ita) ${ }^{993}$

1 De substitutionibus tractatus. (1591)

1 LABbe De Montveron, Gabriel (Gabrielus Labbaeus, Labeus; +1615; fra) ${ }^{995}$

$1 \quad$ Les coustumes générales des pays et duché de Berry avec les annotations de Gabriel Labbé, Sr. de Montveron. (1579) 996

LAPO DE CAStiglionchio (IL VECCHIO), Giovanni (Lapus de Castellione; +1381; ita) $)^{997}$

$1 \quad$ Allegationes iuris. (s.d.) ${ }^{998}$

1 DE LEEUW, Albert (Elbertus Leoninus; 1519/20-1598; ned) ${ }^{999}$

1 Centuria consiliorum clarissimi ... in quibus multae illustres et singulares controversiae ... discutiuntur et explicantur; quae his qui in foro versantur ad decisionem quaestionum quotidie emergentium sunt utilissimae. (1584)1000

DE LEYS, Leonard (Leonardus Lessius; 1554-1623; ned) ${ }^{1001}$

\footnotetext{
990 A. D'INNOCENZO, "Imbert Jean”, P. ARABEYRE, J.-L. HALPERIN en J. KRYNEN red., Dictionnaire historique des juristes français (XIIe-XXe siècle), Parijs, 2007, 417. HOLTHÖFER, "Die Literatur zum gemeinen und partikularen Recht", 403.

991 5.3.23/24, 5.10.33/34, 5.10.37/38, 5.10.42/43/44/45/46, 7.4.2. HOLTHÖFER, "Die Literatur zum gemeinen und partikularen Recht”, 403.

992 2.1.11, 2.1.126, 3.14.15, 4.1.5. HOLTHÖFER, "Die Literatur zum gemeinen und partikularen Recht”, 297.

993 HOLTHÖFER, "Die Literatur zum gemeinen und partikularen Recht”, 449.

994 3.13.45/46. HOLTHÖFER, "Die Literatur zum gemeinen und partikularen Recht”, 385.

995 J. VENDRAND-VOYER, "Labbé de Montveron Gabriel", P. ARABEYRE, J.-L. HALPERIN en J. KRYNEN red., Dictionnaire historique des juristes français (XIIe-XXe siècle), Parijs, 2007, 442. HOLTHÖFER, "Die Literatur zum gemeinen und partikularen Recht", 277. 996 3.11.20. HOLTHÖFER, "Die Literatur zum gemeinen und partikularen Recht", 277.

997 “Lapo de Castiglionchio (il vecchio), Giovanni”, Novissimo Digesto Italiano, IX, Turijn, 1975, 450.

998 3.13.65. OSLER, Bibliographica Iuridica 1, 301.

999 BRITZ, Code de l'ancien droit Belgique, I, 90-92. J. ROELINK, Een honderdtal brieven wit de correspondentie van Elbertus Leoninus. Uitgegeven met inleiding en toelichting, Nijkerk, 1946. SÖLLNER, "Die Literatur zum gemeinen und partikularen Recht", 593.

1000 2.1.126. U. WAGNER, "Rechtsprechungs- und Konsiliensammlungen. Niederlande", H. COING red., Handbuch der Quellen und Literatur der Neueren europäischen Privatrechtsgeschichte, II/2, Munchen, 1976, 1428.
} 
1 De iustitia et iure ceterisque virtutibus cardinalibus libri quatuor, ad secundam secundae D. Thomae a quaest. 47 usque ad quaest 171, cum appendice de Monte Pietatis. $(1605)^{1002}$

0 (1) LOPEZ, Gregorio (1496-1560; spa) 1003

0 (1) Las Siete Partidas del Sabio Rey Alfonso et Nono nuevamente glosadas por Gregorio López: (1555)1004

2 Lopez de PAlacios RubeOs DE RIBERO, Juan (ca.1447-1524; spa) 1005

2 Repetitio rubr. et cap. per vestras Decretalium de donationibus inter virum et uxorum (4.20.7). (1503) $)^{1006}$

1 MAgoni, Girolamo (Hieronimus Magonius; 1530-1596; ita) ${ }^{1007}$

1 Decisiones Rotae Florentinae et Lucensis. (1588) ${ }^{1008}$

3 DEL MAINO, Giasone (Jason de Maynus; 1435-1519; ita) ${ }^{1009}$

1 Commentaria in Digestum vetus. (s.d.) $)^{1010}$

$1 \quad$ Commentaria in Digestum novum. (s.d.) ${ }^{1011}$

1 Commentaria in Codicem. (s.d.) $)^{1012}$

0 (1) MARANTA, Roberto (+ca.1540; ita) $)^{1013}$

1001 SCHERNER, "Die Wissenschaft des Handelsrechts", 809. Zie ook: K. VAN SULL, Leonardus Lessius, Wetteren, 1923.

1002 4.1.9/10. SCHERNER, "Die Wissenschaft des Handelsrechts", 824. BERGFELD, "Katholische Moraltheologie und Naturrechtslehre", 1025.

1003 HOLTHÖFER, "Die Literatur zum gemeinen und partikularen Recht", 302. Zie ook: F. ROSS, "López de Tovar, Gregorio", M. STOLLEIS red., Juristen: ein biographisches Lexikon von der Antike bis zum 20. Jahrbundert, Munchen, 2001, 400-401.

1004 4.1.6 (tweederangse allegatie door Juan Gutierrez). HOLTHÖFER, "Die Literatur zum gemeinen und partikularen Recht”, 302.

1005 HOLTHÖFER, "Die Literatur zum gemeinen und partikularen Recht”, 347.

1006 2.1.126, 2.1.142. HOLTHÖFER, "Die Literatur zum gemeinen und partikularen Recht", 347.

1007 "Magoni, Girolamo", Indice Biografico Italiano, T. NAPPO red., 4de editie, VI, Munchen, 2007,2503

1008 4.9.25. ASCHERI, "Rechtsprechungs- und konsiliensammlungen”, 1181.

1009 P. WEIMAR, “Jason de Mayno”, M. STOLLEIS red., Juristen: ein biographisches Lexikon von der Antike bis zum 20. Jahrbundert, Munchen, 2001, 330-331. HORN, "Die legistische Literatur der Kommentatoren", 275. Zijn verschillende opera exegetica in Corpus Iuris Civilis zijn overzichtelijk weergegeven door Belloni: BELLONI, Professori giuristi a Padova, 221-227.

1010 4.12.22. BELLONI, Professori giuristi a Padova, 223.

1011 4.18.16. BELLONI, Professori giuristi a Padova, 224.

1012 4.18.76. BELLONI, Professori giuristi a Padova, 224-225.

1013 HOLTHÖFER, "Die Literatur zum gemeinen und partikularen Recht”, 397. 
0 (1) Tractatus docti et insignes, de ordine indiciorum (vulgo speculum aureum, et lumen advocatorum). (1566) 1014

2 MARC, François (Franciscus Marcus; +1522/1523; fra) ${ }^{1015}$

2 Decisiones aureae in Delphinatus Senatu discussae. (1532) 1016

$1 \quad$ MARION, Simon (1540-1605; fra) ${ }^{1017}$

1 Plaidoyez: (1594)1018

DE MARSILI, Ippolito (Hippolytus de Marsiliis, de Marsigli; 1450-1529; ita) 1019

1 Commentaria super titulis ff. ad L. Cor. De sica. et ad L. Pompe. De parici. et ad L. Corne. De falsis. (s.d.) ${ }^{1020}$

$1 \quad$ Singularia seu notabilia ex utroque iure edita. (1501) 1021

2 MAsuer, Jean (Johannes Masuerus, Maseur, Mansuer; ca.1370-ca.1452; fra $)^{1022}$

$2 \quad$ Practica forensis. $(<1446)^{1023}$

1 (2) DE MAYNARD, Géraud (Gerardus Maynard; 1537-1607; fra) ${ }^{1024}$

1014 4.9.35/36/37 (tweederangse allegatie door Additiones van Pietro Follerio op het traktaat van Roberto Maranta). HOLTHÖFER, "Die Literatur zum gemeinen und partikularen Recht", 397.

1015 P. ARABEYRE, "Marc (Marcus, Marchi) François”, P. ARABEYRE, J.-L. HALPERIN en J. KRYNEN red., Dictionnaire historique des juristes français (XIIe-XXe siècle), Parijs, 2007, 535. CARNEY, The Politics of Johannes Althusius, 215.

1016 3.14.42, 7.3.1. WALTER, "Rechtsprechungs- und konsiliensammlungen", 1256. De datum verwijst naar de eerste uitgave van het werk.

1017 M.-F. RENOUX-ZAGAME, "Marion Simon”, P. ARABEYRE, J.-L. HALPERIN en J. KRYNEN red., Dictionnaire historique des juristes français (XIIe-XXe siècle), Parijs, 2007, 540. "Marion, Simon", Index Biographique Français, T. NAPPO red., 3de editie, V, Munchen, 2004, 2896. Cfr. M. POPOFF, Prosopographie des gens du Parlement de Paris (1266-1753), Parijs, 1996, 701-702. F. OLIVIER-MARTIN, Les manuscrits de Simon Marion et la coutume de Paris au XVIe siècle (Travaux juridiques et économiques de la faculté de droit de l'Université de Rennes), Rennes, 1922.

1018 RENOUX-ZAGAME, "Marion Simon", 540. 3.13.17/18. OSLER, Bibliographica Iuridica 1, 323.

1019 HOLTHÖFER, "Die Literatur zum gemeinen und partikularen Recht”, 452.

1020 6.3.23. OSLER, Bibliographica Iuridica 1, 324.

1021 7.4.39. HOLTHÖFER, "Die Literatur zum gemeinen und partikularen Recht", 421.

1022 J. VENDRAND-VOYER, "Masuer (Mazuer, Masuyer) Jean”, P. ARABEYRE, J.-L. HALPERIN en J. KRYNEN red., Dictionnaire bistorique des juristes français (XIIe-XXe siècle), Parijs, 2007, 546-547. ARABEYRE, Les idées politiques à Toulouse, 186. Verder in het boek situeert Arabeyre het overlijden evenwel in 1450. (ARABEYRE, Les idées politiques à Toulouse, 368 , noot 535.)

1023 2.5.64, 5.10.79. OSLER, Bibliographica Iuridica 1, 330. 
1 (2) Notables et singulières questions du droict escrit décises ou préjugées par arrests mémorables de la Cour souveraine de Tholose. (1603)1025

1 DE MEDINA, Bartolomeo (1527-1581; spa) $)^{1026}$

$1 \quad$ Summa de casos consciencie. (1580) 1027

14 MeNocCHIO, Jacopo (Jacobus Menochius; 1532-1607; ita) ${ }^{1028}$

13 De arbitrariis indicum quaestionibus et causis. (1569)1029

1 De praesumptionibus, coniecturis, signis, et indiciis commentaria. (1587)1030

2 DE MOLINA, Luis (Ludovicus Molina; 1535-1600; spa) ${ }^{1031}$

2 De iustitia et iure opera omnia. (1593) ${ }^{1032}$

1 DE Molina Morales, Luis (Ludovicus Molina Morales; 1510/301573/87; spa) $)^{1033}$

1 De Hispanorum primogenitorum origine ac natura libri quattuor. (1573)1034

2 Monticello, Sebastiano (Sebastianus Monticulus; tweede helft zestiende eeuw; ita) ${ }^{1035}$

$2 \quad$ Tractatus de inventario heredis. (1571) 1036

1024 J. POUMARÈDE, "Maynard Géraud de", P. ARABEYRE, J.-L. HALPERIN en J. KRYNEN red., Dictionnaire historique des juristes français (XIIe-XXe siècle), Parijs, 2007, 553-554. J. POUMARÈDE, "Les arrêtistes toulousains", J. POUMARÈDE, en J. THOMAS red., Les Parlements de Province au XVTe siècle, Toulouse, 1996, 380, noot 54.

1025 2.1.181. POUMARÈDE, "Les arrêtistes toulousains", 376. J.-M. SCHOLZ, "Rechtsprechungs- und Konsiliensammlungen. Spanien", H. COING red., Handbuch der Quellen und Literatur der Neueren europäischen Privatrechtsgeschichte, II/2, Munchen, 1976, 1286, noot 2.

Volgende allegatie werd niet meegerekend wegens haar niet-rechtsgeleerd karakter (rechtspraak): 4.18.76.

1026 "Medina, Bartholomew", The Catholic Encyclopedia, X, New York, 1911, 143-144.

1027 4.1.9/10. BERGFELD, "Katholische Moraltheologie und Naturrechtslehre", 1029.

1028 E. HOLTHÖFER, "Menocchio (Menochius), Jacopo", M. STOLLEIS red., Juristen: ein biographisches Lexikon von der Antike bis zum 20. Jabrbundert, Munchen, 2001, 436.

$10291.14 .17,1.16 .1,1.16 .4,5.10 .75 / 76 / 77 / 78,5.11 .45,5.11 .46,6.2 .28,6.2 .30,6.3 .6 / 7,6.3 .27$, 7.3.22, 7.3.26, 7.3.27. HOLTHÖFER, "Die Literatur zum gemeinen und partikularen Recht", 363.

1030 7.3.5. HOLTHÖFER, "Die Literatur zum gemeinen und partikularen Recht", 326.

1031 F. ROSS, "Molina, Luis de", M. STOLLEIS red., Juristen: ein biographisches Lexikon von der Antike bis zum 20. Jahrbundert, Munchen, 2001, 449-450. F. B. COSTELLO, The political philosophy of Luis de Molina, S. J. (1535-1600) (Bibliotheca Instituti Historici S. I. Vol. XXXVIII), Rome, 1974.

1032 2.2.15, 4.1.9/10. BERGFELD, "Katholische Moraltheologie und Naturrechtslehre", 1027.

1033 HOLTHÖFER, "Die Literatur zum gemeinen und partikularen Recht", 394.

1034 3.13.50. HOLTHÖFER, "Die Literatur zum gemeinen und partikularen Recht", 394.

1035 HOLTHÖFER, "Die Literatur zum gemeinen und partikularen Recht”, 453. 
3 (4) VAN DER MUYDEN, Gabriël (Gabrielus Mudaeus; 1500-1560; ned) 1037

3 (3) Commentarii ad titulos Digestorum: pro socio, de contrahenda emptione, de actionibus empti et venditi, de pignoribus et bypothecis. (1563)1038

0 (1) allegatie zonder titel ${ }^{1039}$

10 (11) MYNSINGER VON FRUNDECK, Joachim (Mynsingerus a Frundeck, Münsinger, Minsinger, Dentatus; 1514-1588; hrr) ${ }^{1040}$

9 (10) Singularium observationum indicii imperialis camerae (uti vocant) centuriae quatuor. $(1563)^{1041}$

$1 \quad$ allegatie zonder titel ${ }^{1042}$

2 Negusanzio de Fano, Antonio (Antonius Negusantius de Fano; 14651528; ita) ${ }^{1043}$

2 Tractatus perutilis de pignoribus et hypothecis. (1535) 1044

2 PaCe da Beriga, Giulio (Julius Pacius; 1550-1635; ita) ${ }^{1045}$

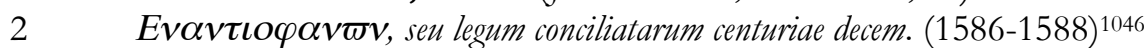

3 (4) De Padilla y Meneses, Antonio (1530/40-ca.1598; spa) $)^{1047}$

1036 3.14.42, 4.18.16. HOLTHÖFER, "Die Literatur zum gemeinen und partikularen Recht", 453.

1037 BRITZ, Code de l'ancien droit Belgique, I, 81-84. M. AHSMANN, "Mudaeus (Van der Muyden), Gabriel", M. STOLLEIS red., Juristen: ein biographisches Lexikon von der Antike bis zum 20. Jabrhundert, Munchen, 2001, 457-458.

1038 4.9.10, 4.9.11, 4.12.5. DEKKERS, Bibliotheca Belgica Juridica, 120.

1039 5.8.11 (tweederangse allegatie door Pieter Peck). De allegatie verwijst naar de mening van Van der Muyden bij een regel uit het Corpus Iuris Civilis. Het is me echter onduidelijk gebleven om welke regel het exact gaat.

1040 J. OTTO, "Mynsinger von Frundeck, Joachim", M. STOLLEIS red., Juristen: ein biographisches Lexikon von der Antike bis zum 20. Jahrbundert, Munchen, 2001, 462. W. SELLERT, "Mynsinger von Frundeck, Joachim", Neue deutsche Biographie, XVIII, Berlijn, 1997, 671-673. S. SCHUMANN, Joachim Mynsinger von Frundeck (1514-1588) (Wolfenbütteler Forschungen Band 23), Wiesbaden, 1983.

1041 3.11.16, 3.13.14/15, 4.6.19, 4.13.33, 5.10.11, 5.10.12, 5.11.18/19/20, 5.11.21/22, 5.15.17. GEHRKE, "Rechtsprechungs- und Konsiliensammlungen”, 1362.

Volgende allegatie werd niet meegerekend wegens haar niet-rechtsgeleerd karakter (rechtspraak): 3.13.27.

1042 5.11.18/19/20. De allegatie verwijst naar de mening van Mynsinger von Frundeck bij de canoniekrechtelijke regel X.2.20.43.

1043 HOLTHÖFER, "Die Literatur zum gemeinen und partikularen Recht”, 355.

1044 4.18.14, 4.18.16. HOLTHÖFER, "Die Literatur zum gemeinen und partikularen Recht", 355.

1045 HOLTHÖFER, "Die Literatur zum gemeinen und partikularen Recht”, 455.

1046 5.11.47, 2.4.10. TROJE, "Die Literatur des gemeinen Rechts unter dem Einfluss des Humanismus", 684.

1047 HOLTHÖFER, “Die Literatur zum gemeinen und partikularen Recht”, 491. 
3 (3) allegatie zonder titel ${ }^{1048}$

0 (1) Ad titulum Cod. de transactionibus (C.2.4). (1566) ${ }^{1049}$

2 PaleotTI, Gabriele (Gabrielus Palaeotus; 1522-1597; ita) ${ }^{1050}$

2 De nothis spuriisque filiis. (1550) 1051

4 (6) DE LA PAPE, Guy (Guido Papa; 1402-1487; fra) $)^{1052}$

3 (5) Decisiones grationopolitanae. (1444-1461)1053

1 (1) Singularia. (1516) 1054

44 (55) Papon, Jean (Johannes Paponius; 1507-1590; fra) ${ }^{1055}$

29 (39) Recueil d'arrests notables des courts souveraines de France. Ordonnez par tiltres, en vingtquatre livres. (1556) ${ }^{1056}$

1048 3.13.42, 3.13.43, 3.13.50. Deze allegaties verwijzen naar de mening van de Padilla y Meneses bij de regel Auth res quae nu 39 C communia de legatis et fideicommissis. Het is me onduidelijk gebleven om welk werk het hier exact gaat. Mogelijk verwijst men naar het traktaat Ad titulum Cod. de fideicommissis Commentarius (C.6.42). (Cfr. HOLTHÖFER, "Die Literatur zum gemeinen und partikularen Recht”, 392.)

1049 4.1.6 (tweederangse allegatie door Juan Gutierrez). HOLTHÖFER, "Die Literatur zum gemeinen und partikularen Recht", 372 .

${ }^{1050}$ HOLTHÖFER, "Die Literatur zum gemeinen und partikularen Recht", 455.

1051 2.4.23, 2.4.24. HOLTHÖFER, "Die Literatur zum gemeinen und partikularen Recht", 338.

1052 G. GIORDANENGO, "Pape (Papa ou Pape) Gui”, P. ARABEYRE, J.-L. HALPERIN en J. KRYNEN red., Dictionnaire historique des juristes français (XIIe-XXe siècle), Parijs, 2007, 606-607. CHABRAND, Etude sur Gui Pape. Giordanengo plaatst het overlijden van de la Pape in 1477. (GIORDANENGO, "Pape (Papa ou Pape) Gui", 606.)

1053 2.4.4, 3.13.67, 4.13.33 (tweederangse allegatie door Joachim Mynsinger en tweederangse allegatie door commentaar van Etienne Ranchin bij Guy de la Pape), 4.13.38/39. WALTER, "Rechtsprechungs- und konsiliensammlungen", 1255. CHABRAND, Etude sur Gui Pape, 4258.

Volgende allegatie werd niet meegerekend wegens haar niet-rechtsgeleerd karakter (rechtspraak): 3.13 .27 (tweederangse allegatie door Louis le Caron).

1054 5.3.23/24. CHABRAND, Etude sur Gui Pape, 60-61.

1055 L. PFISTER, "Papon Jean", P. ARABEYRE, J.-L. HALPERIN en J. KRYNEN red., Dictionnaire historique des juristes français (XIIe-XXe siècle), Parijs, 2007, 607-609. HOLTHÖFER, "Die Literatur zum gemeinen und partikularen Recht", 480. R. MARTINAGE, "Jean Papon (1507-1590), le mal aimé?”, A. DEPERCHIN, N. DERASSE en B. DUBOIS red., Figures de Justice. Etudes en l'bonneur de Jean-Pierre Royer, Rijsel, 2004, 247-257.

1056 2.1.11, 2.1.31, 2.1.61, 2.1.76 (tweederangse allegatie door Pierre Guenoys), 2.1.173, 2.4.8, $2.4 .14,2.5 .19,2.5 .72,2.5 .156,2.5 .161 / 162,2.5 .182,3.11 .17,3.11 .20,3.13 .49,3.13 .60$, 3.13.69/70, 3.14.15, 4.1.5, 4.1.6, 4.6.17, 4.7.3, 4.13.38/39, 5.10.50, 5.10.52/53/54/55, 5.11.45, 5.11.49/50, 6.2.13/14, 6.2.18, 6.3.19. WALTER, "Rechtsprechungs- und konsiliensammlungen", 1256.

Volgende allegaties werden niet meegerekend wegens hun niet-rechtsgeleerd karakter (rechtspraak): 2.4.18, 2.5.156, 3.12.10, 3.12.13, 3.13.27, 3.13.35, 3.14.73, 3.14.96, 4.18.54. 
8 (8) $\quad$ Trias judiciel du second notaire. (1575)1057

5 (5) Secrets du troisième et dernière notaire. (1578)1058

1 (1) Instrument du premier notaire. (1576) 1059

1 (2) In Burbonicas Consuetudines commentaria. (1550)1060

1 PASQUIER, Etienne (Stephanus Paschasius; 1529-1615; fra) ${ }^{1061}$

1 Epistolis. (1586) 1062

13 Peck, Pieter (Petrus Peckius Senior, Pecquis, Pecq, Pecks, von Beck, Pieter; 1529-1589; ned) ${ }^{1063}$

7 Tractatus de iure sistendi, et manuum injectione, quam vulgo arrestationum vocant. $(1564)^{1064}$

$5 \quad$ Tractatus de testamentis conjugum, in quinque libros distinctus. (1585) ${ }^{1065}$

1 De sacrosantis et catholicis Christi ecclesiis reparandis ac reficiendis, liber unus. (1573)1066

4 (5) De Peguera, Luis (Ludovicus a Peguera; ca.1550-1611/32; spa) ${ }^{1067}$

4 (5) Liber quaestionum criminalium ... in Sacro Regio Criminali Concilio Cathaloniae pro maiori earum parte decisarum, authore Don Ludovico a Peguera ... (1585) ${ }^{1068}$

$1057 \quad 2.5 .72, \quad 2.5 .73, \quad 2.5 .83, \quad 2.5 .93, \quad 2.5 .161, \quad 5.10 .52 / 53 / 54 / 55, \quad 5.11 .49 / 50, \quad 7.1 .15$. HOLTHÖFER, "Die Literatur zum gemeinen und partikularen Recht", 408.

1058 2.4.4, 2.4.8, 2.4.14, 2.4.18, 4.1.11/12/13. HOLTHÖFER, "Die Literatur zum gemeinen und partikularen Recht", 408.

1059 7.2.22. HOLTHÖFER, "Die Literatur zum gemeinen und partikularen Recht", 408.

1060 2.1.142. HOLTHÖFER, "Die Literatur zum gemeinen und partikularen Recht”, 279.

Volgende allegatie werd niet meegerekend wegens haar niet-rechtsgeleerd karakter (gewoonterecht): 3.11.20.

1061 M.-F. RENOUX-ZAGAME, "Pasquier Etienne", P. ARABEYRE, J.-L. HALPERIN en J. KRYNEN red., Dictionnaire historique des juristes français (XIIe-XXe siècle), Parijs, 2007, 611-613. L. FEUGERE, Essai sur la vie et les ouvrages d'Etienne Pasquier, Parijs, 1848. Zie ook: P. BOUTEILLER, "Un historien du XVIe siècle: Etienne Pasquier", Bibliothèque d'humanisme et renaissance, 6 (1945), 357-392. P. BOUTEILLER, Recherches sur la vie et la carrière d'Etienne Pasquier: historien et humaniste, Parijs, 1989.

1062 3.13.17/18. RENOUX-ZAGAME, "Pasquier Etienne", 612. Cfr. E. PASQUIER, Les oeuvres d'Estienne Pasquier : contenant ses recherces de la France; son plaidoyé pour $M$. le duc de Lorraine ... ; ses lettres, ses oeuvres meslées ; et les lettres de Nicolas Pasquier, fils d'Estienne, 2 dln., Amsterdam, 1723.

1063 BRITZ, Code de l'ancien droit Belgique, I, 95-98. Lovanium docet, 77-80. "Peck (Petrus)", Nieun Nederlandsch biografisch woordenboek, IX, Leiden, 778-780. SCHERNER, "Die Wissenschaft des Handelsrechts", 850.

1064 5.4.7, 5.8.1, 5.8.6, 5.8.11, 5.8.25, 7.2.5, 7.2.13. DEKKERS, Bibliotheca Belgica Juridica, 131. Lovanium docet, 79.

1065 2.1.9, 2.1.10, 3.1.1, 3.1.6, 3.1.13. SÖLLNER, "Die Literatur zum gemeinen und partikularen Recht", 603. Lovanium docet, 80. DEKKERS, Bibliotheca Belgica Juridica, 131.

1066 3.5.25. DEKKERS, Bibliotheca Belgica Juridica, 131. "Peck (Petrus)", Nieun Nederlandsch biografisch woordenboek, 779. Lovanium docet, 79.

1067 HOLTHÖFER, "Die Literatur zum gemeinen und partikularen Recht”, 491. 
Pellegrini/Peregrino, Marc-Antonio (Marcus Antonius

Pellegrinus/Peregrinus; 1530-1616; ita) ${ }^{1069}$

1 Consilia sive responsa. (1600-1623) ${ }^{1070}$

0 (1) DA PENNE, Luca (Lucas de Penna; +>1382; ita) ${ }^{1071}$

0 (1) Lectura super tribus libris codicis. (s.d.) ${ }^{1072}$

3 PINHEL, Aries (Arias Pinelus; 1505/15-1580/1600; por) ${ }^{1073}$

2 Commentaria ad constitutiones Cod[icis] de bonis maternis [=C.6.60]. (1557) ${ }^{1074}$

$1 \quad$ allegatie zonder titel ${ }^{1075}$

1 PISTORIS, Hartmann (Hartmannus Pistoris; 1543-1601; hrr) 1076

1 Quaestiones iuris tam Romani quam Saxonici, I-IV. (1579-1593)1077

$1 \quad$ Pithou, Pierre (Petrus Pithoeus; 1538-1596; fra) ${ }^{1078}$

$1 \quad$ Coutumes du bailliage de Troyes en Champagne avec quelques annotations. (1600)1079

1 DE PlateA, Johannes (+ca.1427; ita) $)^{1080}$

$1 \quad$ Lectura in Tres Libri. ${ }^{1081}$

1068 1.14.35, 6.1.25/26, 6.1.39, 6.3.8, 6.3.23. SCHOLZ, "Rechtsprechungs- und Konsiliensammlungen”, 1305.

${ }^{1069}$ HOLTHÖFER, "Die Literatur zum gemeinen und partikularen Recht”, 456.

1070 4.1.9/10. ASCHERI, "Rechtsprechungs- und konsiliensammlungen”, 1216.

1071 Cfr. HORN, "Die legistische Literatur der Kommentatoren”, 275.

1072 6.2.13/14 (tweederangse allegatie door Giulio Claro). HORN, "Die legistische Literatur der Kommentatoren”, 327.

1073 HOLTHÖFER, "Die Literatur zum gemeinen und partikularen Recht”, 491.

1074 3.1.9, 3.1.14/15/16. HOLTHÖFER, "Die Literatur zum gemeinen und partikularen Recht", 348.

1075 3.11.4/5/6. De allegatie verwijst naar de mening van Pinhel bij een regel uit het Corpus Iuris. Het is me echter onduidelijk gebleven om welke regel het exact gaat.

1076 SÖLLNER, "Die Literatur zum gemeinen und partikularen Recht", 579.

1077 5.10.12. SÖLLNER, "Die Literatur zum gemeinen und partikularen Recht", 579.

1078 B. BASDEVANT-GAUDEMET, "Pithou Pierre”, P. ARABEYRE, J.-L. HALPERIN en J. KRYNEN red., Dictionnaire historique des juristes français (XIIe-XXe siècle), Parijs, 2007, 627-629. HOLTHÖFER, "Die Literatur zum gemeinen und partikularen Recht", 295. L. MONTAZEL, "Pithou (Pithoeus), Pierre", M. STOLLEIS red., Juristen: ein biographisches Lexikon von der Antike bis zum 20. Jahrbundert, Munchen, 2001, 499-500.

1079 3.13.33/34. HOLTHÖFER, "Die Literatur zum gemeinen und partikularen Recht", 295.

1080 Cfr. R. FEENSTRA, "Johannes de Platea, Bologneser Professor aus dem Anfang des 15. Jh.: Die Überlieferung seiner Schriften, mit kurzen Beiträgen über Henricus de Piro, Arnoldus Westphal und Johannes de Gradibus," Europäisches Rechtsdenken in Geschicbte und Gegenwart: Festschrift für Helmut Coing zum 70. Geburtstag. Munchen, 1982. 39-62.

1081 6.2.13/14. OSLER, Bibliographica Iuridica 1, 426. 
3 Pontano de Roma, Ludovico (Ludovicus Pontanus Romanus, de Ponte; 1409-1439; ita) ${ }^{1082}$

$2 \quad$ Consilia. (s.d.) 1083

$1 \quad$ Singularia. (s.d.) 1084

1 RANCHIN, Etienne (Stephanus Ranchinus; ca.1510-ca.1587; fra) ${ }^{1085}$

1 Commentaar op de Decisiones van Guy de la Pape. (1575)1086

1 REBELLO, Fernando (Fernandus Rebellius; 1547-1608; por) ${ }^{1087}$

1 Opus de obligationibus iustitiae, religionis et caritatis. (1608)1088

13 (14) REBufFi, Pierre (Petrus Rebuffus, Rebuf; 1487-1557; fra) ${ }^{1089}$

8 (9) Commentarii in constitutiones seu ordinationes regias non solum iuris studiosis verumetiam pragmaticis utilissimi, in quibus facilis ad praxim curiarum Franciae via et iurium intellectus explicatur qui in tractatus in sequenti pagina distribuuntur. Tomi tres. (1554$1555)^{1090}$

4 (4) In tit. Dig. De verborum et rerum significatione commentaria. (1576) 1091

1 (1) Tractatus exceptionum atque actionum. (s.d.) $)^{1092}$

1 (3) DE Rosciate, Alberico (Albericus de Rosate; ca.1290-1360; ita) 1093

1082 "Pontano de Roma, Ludovico", Indice Biografico Italiano, T. NAPPO red., VIII, 4de editie, Munchen, 2007, 3379.

1083 3.10.1, 4.10.1/2. OSLER, Bibliographica Iuridica 1, 429.

1084 1.14.31. Dit werk is opgenomen in Singularia omnium clarissimorum doctorum (1560). Cfr. HOLTHÖFER, "Die Literatur zum gemeinen und partikularen Recht", 419.

1085 P. ARABEYRE, "Ranchin Etienne”, P. ARABEYRE, J.-L. HALPERIN en J. KRYNEN red., Dictionnaire historique des juristes francais (XIIe-XXe siècle), Parijs, 2007, 651. M. LESCUYER, "Guillaume Ranchin (1559-1605), érudit protestant et gallican: sa bibliothèque et sa famille", Bulletin de la Société de l'histoire du protestantisme français, 145 (1999), 323-358 en 509-571. Zie ook: CHABRAND, Etude sur Gui Pape, 53. HOLTHÖFER, "Die Literatur zum gemeinen und partikularen Recht", 146.

1086 4.13.33. CHABRAND, Etude sur Gui Pape, 53. Men verwijst naar Guy de la Pape die door Etienne Ranchin geciteerd wordt, maar men verwijst evenzeer naar Etienne Ranchin zelf. 1087 "Rebello, Fernando", Indice Biografico de Espana, Portugal e Iberoamérica, VIII, V. H. MEDIAVILLA red., 3 ${ }^{\text {de }}$ editie, Munchen, 2000, 2863.

1088 4.1.9/10. BERGFELD, "Katholische Moraltheologie und Naturrechtslehre”, 1027.

1089 C. ZENDRI, "Rebuffi (Rebuffe, Rebuffus) Pierre", P. ARABEYRE, J.-L. HALPERIN en J. KRYNEN red., Dictionnaire historique des juristes français (XIIe-XXe siècle), Parijs, 2007, 656-657. E. HOLTHÖFER, "Rebuffi (Rebuffus), Pierre", M. STOLLEIS red., Juristen: ein biographisches Lexikon von der Antike bis zum 20. Jabrbundert, Munchen, 2001, 528-529. HOLTHÖFER, "Die Literatur zum gemeinen und partikularen Recht", 135-136 en 212.

1090 2.5.72, 4.6.17, 4.12.5, 4.14.12, 5.8.1 (tweederangse allegatie door Pieter Peck), 5.9.29/30, 5.10.74, 5.10.79, 7.4.2. HOLTHÖFER, "Die Literatur zum gemeinen und partikularen Recht", 266.

1091 1.1.3, 1.1.4 2.1.126, 6.3.10/11. HOLTHÖFER, "Rebuffi (Rebuffus), Pierre", 529.

1092 3.11.18. HOLTHÖFER, "Die Literatur zum gemeinen und partikularen Recht", 407. 
1 (3) allegatie zonder titel ${ }^{1094}$

3 DE SAliceTo, Bartolomeo (Bartholomaeus a Saliceto; +1411; ita) 1095

2 Commentariorum Bartholomei a Saliceto in Justiniani Codicis. (s.d.) $)^{1096}$

$1 \quad$ Commentaria in Digestum vetus accuratissima. (s.d.) ${ }^{1097}$

3 (3) SANNAZARI DELla RIPA, Johannes Franciscus (a Sancto Nazario a Ripa; ca.1480-1535; ita) ${ }^{1098}$

1 (1) Commentaria in primam Codicis partem. (1538) 1099

1 (1) Commentaria in secundam Digesti Veteris partem. (1538) $)^{1100}$

1 (1) Commentaria in primam et secundam Digesti Novi partem. (1538) 1101

2 Sarmiento de Mendoza, Francisco (Franciscus Sarmientis; 1525/351595; spa $)^{1102}$

2 Selectarum interpretationum libri tres. $(1571)^{1103}$

13 (20) DA SAssoferrato, Bartolo (Bartolo da Sassoferrato de Saxoferrato; 13131357; ita) ${ }^{1104}$

13 (20) Bartolo da Sassoferrato's commentaren op het Corpus Iuris Civilis. ${ }^{1105}$

1093 HORN, "Die legistische Literatur der Kommentatoren", 272.

1094 3.3.18 (tweederangse allegatie door René Choppin), 3.5.25 (tweederangse allegatie door Pieter Peck), 4.18.52. De allegaties verwijzen naar de mening van de Rosciate bij respectievelijk de volgende wetten uit het Corpus Iuris Civilis: C.8.17.3, D.14.2.1 en D.14.2.2pr, D.50.1.10.

1095 HORN, "Die legistische Literatur der Kommentatoren”, 274.

1096 2.5.57, 4.18.16. HORN, "Die legistische Literatur der Kommentatoren”, 327.

1097 4.3.15. HORN, "Die legistische Literatur der Kommentatoren", 327.

1098 HOLTHÖFER, "Die Literatur zum gemeinen und partikularen Recht”, 159.

We hebben hier voor Johannes Franciscus gekozen omdat de andere mogelijkheid, Polydorus a Ripa (+1613) op basis van de huidige bibliotheekcatalogi niet meteen om zijn commentaren op het Corpus Iuris Civilis bekend was en omdat Franciscus a Ripa daarentegen wel vaak om zijn commentaren werd geallegeerd.

1099 2.1.103. HOLTHÖFER, “Die Literatur zum gemeinen und partikularen Recht”, 161.

1100 4.12.5. HOLTHÖFER, "Die Literatur zum gemeinen und partikularen Recht", 159.

1101 4.18.59. HOLTHÖFER, "Die Literatur zum gemeinen und partikularen Recht”, 159.

1102 HOLTHÖFER, "Die Literatur zum gemeinen und partikularen Recht", 493.

1103 3.11.4/5/6, 4.1.9/10. TROJE, "Die Literatur des gemeinen Rechts unter dem Einfluss des Humanismus", 683.

1104 HORN, "Die legistische Literatur der Kommentatoren”, 274.

1105 1.1.4 (tweederangse allegatie door Pierre Rebuffi), 1.14 .17 (tweederangse allegatie door Jacopo Menocchio), 2.1.6 (tweederangse allegatie door Filippo Decio), 2.1.76 (tweederangse allegatie door Pierre Guenoys), 2.2.24, 2.4.19, 2.5.57, 2.5.82, 2.5.90, 3.1.6 (tweederangse allegatie door Pieter Peck), 3.2.17/18, 3.11.16, 3.13.33/34, 4.12.4, 4.13.38/39, 4.18.52, 4.18.59, 5.8.6 (tweederangse allegatie door Pieter Peck), 5.11.51/52/53, 7.3.1 (tweederangse allegatie door Annotationes van Alexander de Tartagni bij Bartolo da Sassoferrato). Cfr. HORN, "Die legistische Literatur der Kommentatoren”, 327. 
SCHNEIDEWIN, Johann (Johannes Schneidewinus, Schneidewein; 15191568; hrr) ${ }^{1106}$

In IV libros Institutionum iuris civilis commentarius. (1553)1107

SIMONCELLI, Ottavio (Octavius Simoncellus; +1620; ita) 1108

0 (1) SozZINI, Mariano (Marianus Socinus Senior; 1397-1467; ita) 1110

0 (1) Lectura in Decretales of Tractatus de foro competendi. (s.d.) $)^{1111}$

2 (3) STRACCA, Benvenuto (Benevenutus Straccha; 1509-1578; ita) 1112

1 (1) Tractatus de contractibus mercatorum (in: Tractatus de mercatura seu mercatore). $(1553)^{1113}$

1 (1) Tractatus de adiecto. (1553) $)^{1114}$

0 (1) allegatie zonder titel ${ }^{1115}$

1 SUÁREZ, Rodrigo (Rodericus Suarius; 1440/60-1500/20; spa) ${ }^{1116}$

1 Subtilissima lectura legis quoniam in prioribus Cod. de inofficioso testamento (C.3.28.29) et leges post rem indicatam Dig. de re indicata (D.42.1.56). (1536) $)^{1117}$

1 SuEtoniUs (Gaius Suetonius Tranquillus; 69-122; rom) ${ }^{1118}$

1106 SÖLLNER, "Die Literatur zum gemeinen und partikularen Recht", 517 en 533. TROJE, "Die Literatur des gemeinen Rechts unter dem Einfluss des Humanismus", 780.

1107 6.3.27. SÖLLNER, "Die Literatur zum gemeinen und partikularen Recht”, 533. TROJE, "Die Literatur des gemeinen Rechts unter dem Einfluss des Humanismus", 780.

${ }^{1108}$ HOLTHÖFER, "Die Literatur zum gemeinen und partikularen Recht", 460.

1109 2.5.11, 2.5.124, 2.5.128. HOLTHÖFER, "Die Literatur zum gemeinen und partikularen Recht”, 336.

1110 J. A. TEDESCHI, "Notes toward a genealogy of the Sozzini family", J. A. TEDESCHI red., Italian reformation studies in honor of Laelius Socinus, Firenze, 1965, 282-287.

1111 1.16.1 (tweederangse allegatie door Jacopo Menocchio). Cfr. J. F. VON SCHULTE, Die Geschichte der Quellen und Literatur des canonischen Rechts von Gratian bis auf die Gegenwart, 3 dln., Stuttgart, 1875-1880.

1112 C. BERGFELD, "Stracca, Benvenuto", M. STOLLEIS red., Juristen: ein biographisches Lexikon von der Antike bis zum 20. Jabrbundert, Munchen, 2001, 605-606. HOLTHÖFER, "Die Literatur zum gemeinen und partikularen Recht", 461.

1113 4.13.12/13/14/15. HOLTHÖFER, "Die Literatur zum gemeinen und partikularen Recht”, 385-387. SCHERNER, "Die Wissenschaft des Handelsrechts”, 864.

1114 4.18.2. Dit traktaat wordt pas later in het verzamelwerk De Mercatura seu mercatore Tractatus opgenomen en uitgegeven. SCHERNER, "Die Wissenschaft des Handelsrechts", 836.

1115 5.11.42.

1116 HOLTHÖFER, "Die Literatur zum gemeinen und partikularen Recht”, 494.

1117 3.14.46. HOLTHÖFER, "Die Literatur zum gemeinen und partikularen Recht", 386.

1118 "Suetonius", Grote Winkler Prins Encyclopedie, 9de uitg., XXII, Amsterdam en Antwerpen, 1993, 131. 
2 Sordi Da Casale, Giovanni Pietro Johannes Petrus Surdus, Giampietro Surdi; +1598; ita) ${ }^{1120}$

2 Decisiones Sacri Mantuani Senatus. $(1597)^{1121}$

7 (16) DI TARTAgNI, Alessandro (Alexander Tartagni, de Imola; 1424-1477; ita) ${ }^{1122}$

4 (13) Consilia. (s.d.) $)^{1123}$

2 (2) Tartagni's commentaren op Corpus Iuris Civilis. ${ }^{1124}$

1 (1) Apostillae van di Tartagni op de Commentaren van Bartolo da Sassoferrato. (s.d.) $)^{1125}$

1 Tesauro Da Fossano, Antonino (Antoninus Thesaurus; 1526->1590; ita) ${ }^{1126}$

$1 \quad$ Novae decisiones S. Senatus Pedemontani ... additionibus illustratae per Gasparem Antonium thesaurum. (1590) $)^{1127}$

1 ThomING, Jakob (Jacobus Thomingius; 1518-1576; hrr) ${ }^{1128}$

1 Decisiones quaestionum illustrium. (1579) 1129

2 (5) TIRAQUEAU, André (Andreas Tiraquellus; 1488-1558; fra) ${ }^{1130}$

1119 5.8.37. "Suetonius", Grote Winkler Prins Encyclopedie, 131.

${ }^{1120}$ HOLTHÖFER, "Die Literatur zum gemeinen und partikularen Recht”, 461.

$1121 \quad 4.15 .23 / 24, \quad 5.10 .75 / 76 / 77 / 78$. ASCHERI, "Rechtsprechungs- und konsiliensammlungen", 1182.

1122 HORN, "Die legistische Literatur der Kommentatoren”, 273.

1123 3.12.8/9 (tweederangse allegatie door Louis le Caron), 3.13 .49 (tweederangse allegatie door Annotationes van Charles Dumoulin bij Consilia van Alessandro di Tartagni), 3.13.54 (tweederangse allegatie door Annotationes van Charles Dumoulin bij Consilia van Alessandro di Tartagni), 3.13.56/57/581, 3.13.56/57/58² (tweederangse allegatie door Annotationes van Charles Dumoulin bij Consilia van Alessandro di Tartagni), 3.13 .65 (tweederangse allegatie door Annotationes van Charles Dumoulin bij Consilia van Alessandro di Tartagni), 3.13.67 (tweederangse allegatie door Annotationes van Charles Dumoulin bij Consilia van Alessandro di Tartagni), 3.14.82, 4.13 .38 (tweederangse allegatie door Annotationes van Charles Dumoulin bij Consilia van Alessandro di Tartagni), 4.15 .7 (tweederangse allegatie door Annotationes van Charles Dumoulin bij Consilia van Alessandro di Tartagni), 4.18.10, 5.11.51/52/53, 5.17.9 (tweederangse allegatie door Annotationes van Charles Dumoulin bij Consilia van Alessandro di Tartagni). HORN, "Die legistische Literatur der Kommentatoren", 340.

1124 4.12.5, 4.18.16. HORN, "Die legistische Literatur der Kommentatoren”, 327.

1125 7.3.1. HORN, "Die legistische Literatur der Kommentatoren”, 332.

1126 ASCHERI, "Rechtsprechungs- und konsiliensammlungen", 1182.

1127 4.13.38/39. ASCHERI, "Rechtsprechungs- und konsiliensammlungen", 1182.

1128 CARNEY, The Politics of Johannes Althusius, 218.

1129 4.9.35/36/37. GEHRKE, "Rechtsprechungs- und Konsiliensammlungen”, 1363. 
1 (1) De utroque retractu, municipali et conventionali, commentarii duo. (1541)1131

1 (1) Tractatus in tit. de indicio in rebus exiguis ferendo. (1562) ${ }^{1132}$

0 (1) Commentariis in Pictonum Consuetudines. (1543) $\quad$ 1133

0 (1) De iure constitui possessorii tractatus. (1549)1134

0 (1) Tractatus le mort saisit le vif, hoc est (de) translatione possessionis ex defuncto in superstitum. (1550) 1135

1 TorretTI, Fabio (Fabius Torrectus, Turretus; +1595; ita) ${ }^{1136}$

$1 \quad$ Tractatus de codicillaris clausulae effectibus et defectibus. (1596)1137

1 (2) DE TudeschI, Nicolo (Nicolaus de Tedeschis, de Tudeschis, abbas Panormitanus, abbas Siculus, abbas modernus, abbas recentior, Lucerna iuris pontificii; 1386-1445; ita $)^{1138}$

1 (1) Consilia, iurisque responsa ac quaestiones. (s.d.) $)^{1139}$

0 (1) In quinque libros Decretalium commentaria. (s.d.) $)^{1140}$

5 (6) DE UBALDIS, Angelus (1328-1404; ita) ${ }^{1141}$

3 (4) allegatie zonder titel ${ }^{1142}$

1130 J.-M. AUGUSTIN, "Tiraqueau André", P. ARABEYRE, J.-L. HALPERIN en J. KRYNEN red., Dictionnaire historique des juristes français (XIIe-XXe siècle), Parijs, 2007, 742-743. J. BREJON, Un jurisconsulte de la Renaissance André Tiraqueau (1488-1558). Parijs, 1937. Cfr. J. OTTO, "Tiraqueau (Tiraquellus), André", M. STOLLEIS red., Juristen: ein biographisches Lexikon von der Antike bis zum 20. Jabrbundert, Munchen, 2001, 631.

1131 4.1.6. HOLTHÖFER, "Die Literatur zum gemeinen und partikularen Recht", 357.

1132 5.10.52/53/54/55. BRÉJON, Un jurisconsulte de la Renaissance André Tiraqueau, 397.

11332.1 .36 (tweederangse allegatie door René Choppin). OTTO, "Tiraqueau (Tiraquellus), André", 631.

1134 3.12.8/9 (tweederangse allegatie door Louis le Caron). HOLTHÖFER, "Die Literatur zum gemeinen und partikularen Recht", 351.

1135 3.14.81 (tweederangse allegatie door Louis le Caron). HOLTHÖFER, "Die Literatur zum gemeinen und partikularen Recht", 388.

1136 HOLTHÖFER, "Die Literatur zum gemeinen und partikularen Recht", 355.

1137 3.13.23. HOLTHÖFER, "Die Literatur zum gemeinen und partikularen Recht", 383.

1138 P. LANDAU, "Nikolaus de Tudeschis (Panormitanus)", M. STOLLEIS red., Juristen: ein biographisches Lexikon von der Antike bis zum 20. Jabrbundert, Munchen, 2001, 470-471. Zie ook: K. W. NÖRR, Kirche und Konzil bei Nicolaus de Tudeschis (Panormitanus) (Forschungen zur kirchlichen Rechtsgeschichte und zum Kirchenrecht. Band 4), Keulen, 1964.

1139 2.4.19. WIJFFELS, Qui millies allegatur, I, XXIII.

1140 7.3.24/25 (tweederangse allegatie door Pierre Grégoire). NÖRR, "Die kanonistische Literatur", 368/381.

1141 P. WEIMAR, "Baldus de Ubaldis", M. STOLLEIS red., Juristen: ein biographisches Lexikon von der Antike bis zum 20. Jabrbundert, Munchen, 2001, 58. HORN, "Die legistische Literatur der Kommentatoren", 273.

1142 2.5.57, 3.1.6 (tweederangse allegatie door Pieter Peck), 3.5.25, 5.11.51/52/53. De allegaties verwijzen naar de mening van Angelus de Ubaldis bij respectievelijk de volgende regels uit het Corpus Iuris Civilis: C.8.55.7pr , D.50.7.18, D.14.2.1 en D.14.2.2pr, C.4.1.3. 
2 (2) Consilia seu responsa. (s.d.) $)^{1143}$

14 (17) DE UBALDIS, Baldus (1327-1400; ita) $)^{1144}$

9 (11) Baldus de Ubaldis' commentaren op het Corpus Iuris Civilis. ${ }^{1145}$

2 (3) allegatie zonder titel ${ }^{1146}$

2 (2) Consilia. (s.d.) $)^{1147}$

1 (1) allegatie zonder titel ${ }^{1148}$

1 DE VALENCIA, Gregorio (Gregorius de Valentia, Valentinus, Valentianus; 1549-1603; spa) ${ }^{1149}$

1 Commentariorum theologicorum tomi quatuor, in quibus omnes materiae, quae continentur in Summa theologica Divi Thomae Aquinatis, ordine explicantur. (1591-1597)1150

1 DU VAL, Nicolas (Nicolaus Valla; ca.1568; fra) ${ }^{1151}$

$1 \quad$ De rebus dubiis et quaestionibus in iure controversis tractatus sex. (1567)1152

2 DELA VALLE, Roland (Rolandus a Valle; zestiende eeuw; fra) ${ }^{1153}$

$2 \quad$ Consilia sive responsa. (1562) 1154

2 VASQUEZ DE MENCHACA, Fernando (1512-1569; spa) $)^{1155}$

2 De succesionum creatione, progressu, effectuque et resolutione tractatus. (1559)1156

1143 4.13.12/13/14/15, 4.15.23/24. OSLER, Bibliographica Iuridica 1, 566.

1144 WEIMAR, "Baldus de Ubaldis", 58-59. HORN, "Die legistische Literatur der Kommentatoren", 273.

1145 2.1.6 (tweederangse allegatie door Filippo Decio), 2.2.9, 2.5.57, 2.5.72, 2.5.193, 3.2.17/18, 4.1.11/12/13, 4.18.16, 4.18.59, 4.18.76, 5.11.51/52/53 (tweederangse allegatie door Alessandro di Tartagni). HORN, "Die legistische Literatur der Kommentatoren", 327.

1146 3.13.14/15, 4.18.76, 5.15.17 (tweederangse allegatie door Joachim Mynsinger). De allegaties verwijzen naar de mening van Baldus de Ubaldis bij een aantal verschillende wetten uit het Authenticum.

1147 2.5.63, 2.5.64. HORN, "Die legistische Literatur der Kommentatoren", 340.

1148 3.11.4/5/6. De allegatie verwijst naar de mening van Baldus de Ubaldis bij een canoniekrechtelijke regel uit het Liber Extra. (Cfr. NÖRR, "Die kanonistische Literatur", 381.)

1149 W. HENTRICH, Gregor von Valencia und der Molinismus. Innsbruck, 1928.

1150 4.1.9/10. BERGFELD, "Katholische Moraltheologie und Naturrechtslehre", 1025.

1151 P. ARABEYRE, "Duval (Du Val, Valla) Nicolas", P. ARABEYRE, J.-L. HALPERIN en J. KRYNEN red., Dictionnaire historique des juristes français (XIIe-XXe siècle), Parijs, 2007, 303. POPOFF, Prosopographie des gens du Parlement de Paris, 923.

1152 3.14.122/123. ARABEYRE, "Duval (Du Val, Valla) Nicolas", 303. OSLER, Bibliographica Iuridica 1, 578 .

1153 CARNEY, The Politics of Johannes Althusius, 218.

1154 3.13.50, 6.3.23. ASCHERI, "Rechtsprechungs- und konsiliensammlungen", 1214.

1155 K. SEELMANN, "Vazquez de Menchaca, Fernando", M. STOLLEIS red., Juristen: ein biographisches Lexikon von der Antike bis zum 20. Jabrhundert, Munchen, 2001, 647-648. VAN NIFTERIK, Vorst tussen volk en wet. 
0 (1) Vivio DA L'AQUILA, Francisco (Franciscus Vivius; ca.1532-1616; ita) ${ }^{1157}$

0 (1) Decisiones Regni Neapolitani ... in S. Regia Audientia Terrae Bari, Capitanatae, Apuliae et Comitatus Mosilii. Libri I-II (1592-1602) Libri III-IV (1598-1610).1158

12 WeSENBEECK, Matthias (Matthaeus Wesenbecius, van Wesembeke; 1531 1586; ned) ${ }^{1159}$

9 Paratitla in Pandectas iuris civilis. (1565)1160

3 Tractatus et responsa, quae vulgo consilia iuris appellantur. (1575-1577)1161

18 WiELANT, Filips (Philippus Wielandius; 1441-1520; ned) ${ }^{1162}$

12 Corte instructie in materie civile. (1508-1519)1163

$6 \quad$ Corte instructie in materie criminele. (1510-1519) 1164

De 144 individuele auteurs, die hierboven alfabetisch werden gerangschikt, zijn goed voor 725 allegaties, ware het niet zo dat onze selectiecriteria dit aantal herleid hebben tot 599. Hierbij verdwenen niet alleen welbepaalde werken uit de onderzoeksgroep, ook auteurs moesten soms voorgoed het toneel verlaten. Dit is onder meer het geval geweest bij Matteo d'Afflitto, Philibert Bugnyon, Paulo di Castro, Jean Chenu, Marcus Tullius Cicero, Guilielmo Duranti, Phanutio di Fanuzzi, Antonio Gabrieli, Gregorio Lopez, Roberto Maranta, Luca da Penne, Benedetto Barzi da Piombino, Mariano Sozzini en Francisco Vivio da l'Aquila. Dit ingrijpen resulteert in een uiteindelijke onderzoeksgroep van 130 auteurs en 599 relevante allegaties. Gemiddeld betekent dit 4.6 allegaties per rechtsgeleerde.

1156 2.4.10, 3.13.50. HOLTHÖFER, "Die Literatur zum gemeinen und partikularen Recht", 379.

1157 ASCHERI, "Rechtsprechungs- und konsiliensammlungen”, 1182.

1158 ASCHERI, "Rechtsprechungs- und konsiliensammlungen", 1182.

Volgende allegatie werd niet meegerekend wegens haar niet-rechtsgeleerd karakter (rechtspraak): 3.3.18.

1159 BRITZ, Code de l'ancien droit Belgique, I, 103-106. M. AHSMANN, "Wesenbeck, Matthaeus", M. STOLLEIS red., Juristen: ein biographisches Lexikon von der Antike bis zum 20. Jabrbundert, Munchen, 2001, 669-670. Cfr. Lovanium docet, 68.

11602.5 .143 , 3.5.88, 3.11.15, 4.10.3/4/5, 4.15.17, 5.2.4, 5.11.47, 6.3.2, 6.3.16. TROJE, "Die Literatur des gemeinen Rechts unter dem Einfluss des Humanismus", 779.

1161 1.1.15, 3.13.29/30, 4.18.76. GEHRKE, "Rechtsprechungs- und Konsiliensammlungen", 1385.

1162 R. OPSOMMER, “Wielant, Filips”, M. STOLLEIS red., Juristen: ein biographisches Lexikon von der Antike bis zum 20. Jahrbundert, Munchen, 2001, 671-672. BRITZ, Code de l'ancien droit Belgique, I, 61-67. DEKKERS, Bibliotheca Belgica Juridica, 191-192.

$11635.10 .74,5.10 .75 / 76 / 77 / 78,5.11 .1 / 2,5.11 .28 / 29,5.11 .30 / 31,5.11 .37,5.11 .38,5.11 .40 / 41$, 5.11.42, 5.11.43, 5.11.44, 5.11.49/50. OPSOMMER, "Wielant, Filips", 671.

1164 7.1.7/8/9/10/11, 7.2.6/7, 7.3.4, 7.3.7, 7.3.14/15, 7.3.28/29. OPSOMMER, "Wielant, Filips", 671. 
De vraag blijft echter in hoeverre men een overzicht, zoals hier voorgesteld, blindelings kan vertrouwen. Elke allegatie is immers onlosmakelijk verbonden aan wat Wijffels omschrijft als l'appréciation. Stemt men in met de mening van de geallegeerde auteur of zet men er zich juist tegenaf? ${ }^{1165}$ Omtrent de artikels 5.3.23/24 is duidelijk te zien dat men het niet altijd eens is met de overtuiging van de geallegeerde rechtsgeleerde: Sunt desumpti ex articulo $5^{\circ}$ et $6^{\circ}$ in impressis tit van procuratien et 22 inde voors[chreven] ordonnantien vanden jaere 1564 nisi quod in hac revisione additum sit vande curateurs vande goeden ex usu et quod revocationem sine illa sint expresse sine per mortem aut mutationem status eius qui procuratorium dedit est contra ius Io. Andr $[e] a[e]$ ad speculat tit de procurat $\int$ ratione Guid. Pap singul 164 Imbert in instit. forens. lib $1^{\circ}$ capite 30 in glossa verbi constituere sed usus tam hic quam in galliis aliter observat... Vaak wordt de mening van de peritus iuris ook gedeeltelijk aangepast, zoals te zien is met betrekking tot artikel 4.18.10: Est desumptus ex iis qua[e] respond Alex cons 108 nu $1^{\circ}$ Cravett cons 129 lib $1^{\circ}$ Cavalcan in tract de tutor et curat nu 243 nisi quod cum illi satis generaliter loquantur magistratui visum sit addere duplicem limitationem ut videlicet id non obtineat nisi in subsidium et in casu quo pecunia pupillaris apud tutorem fuit tempore emptionis. Dit roept uiteraard de vraag op of de aangehaalde auteurs wel representatief zijn voor de rechtswetenschappelijke positie van de commissieleden. In principe zou dus elke allegatie op zijn 'appreciatie' gecontroleerd moeten worden. Of toch niet? Is het niet belangrijker dàt men refereert in plaats van de wijze waarop? Van zodra een bepaald auteur immers waardig wordt geacht in de redenering of discussie opgenomen te worden, erkent men zijn autoritatieve waarde. Auteurs als deze kunnen bijgevolg niet zomaar aan de kant worden gezet en moeten mijns inziens in rekening worden gebracht, ook al is hun mening omtrent de desbetreffende kwestie contrair aan wat de commissieleden uiteindelijk overeen zijn gekomen. Enkel op deze manier meen ik op een verantwoorde manier een blauwdruk te kunnen reconstrueren van de rechtswetenschappelijke bagage van de redacteurs en de invloedssferen omschrijven die deze intellectuele achtergrond vorm hebben gegeven. ${ }^{1166}$ Ik ben er dan ook van overtuigd dat bovenstaande lijst een betrouwbaar overzicht laat zien van de auteurs en werken die van belang waren voor de commissieleden en bij de totstandkoming van de Consuetudines compilatae.

1165 WIJFFELS, Qui millies allegatur, I, 18.

1166 Bovendien werd het merendeel van de auteurs aangehaald ter bevestiging van de eigen ideeën, en in mindere mate om de tegenstellingen ervan met de rechtsleer te illustreren. 
PARAGRAAF 2

DE ROL VAN DE VERSCHILLENDE, RECHTSGELEERDE GENRES MET BETREKKING TOT DE REDACTIE VAN HET ANTWERPSE GEWOONTERECHT

Om de bespreking van de geallegeerde literatuur zowel vlot als overzichtelijk te laten verlopen, zal ik dit thematisch aanpakken. De 599 relevante referenties zullen verdeeld worden over een achttal duidelijk van elkaar te onderscheiden categorieën. ${ }^{1167}$ Een eerste categorie groepeert de allegaties naar werken aangaande het particuliere recht. Hieronder wordt zowel het lokale gewoonterecht als elke vorm van wetgeving, afkomstig van eender welk niveau, verstaan. In tweede instantie zijn er de verwijzingen naar de monografische literatuur, gevolgd door die naar de commentaren bij het geleerde recht of het ius commune als combinatie van het Corpus Iuris Civilis en het Corpus Iuris Canonici. Vervolgens worden de referenties naar de zogenaamde Decisiones of rechtspraakverzamelingen en pleidooien apart genomen. De vijfde en voorlaatste categorie is die van de adviserende literatuur, namelijk de Consilia. De laatste groep omvat de verwijzingen naar het oeuvre van de Salamantinos van de Spaanse Laatscholastiek, de moraalfilosofen van de Secunda Scholastica. De categorie 'Overige' omvat enerzijds klassieke auteurs en anderzijds contemporaine niet-juridische auteurs. Onder het logo 'Onduidelijk' worden die werken verstaan waarvan het me onduidelijk is gebleven in welke categorie zij ondergebracht moeten worden. Tabel 3.1 en figuur 3.1 tonen de onderlinge verhoudingen tussen de verschillende groepen.

Tabel 3.1 Aantal allegaties per literatuurtype

\begin{tabular}{|l|l|}
\hline Literatuurtype & Aantal allegaties \\
\hline Monografische werken & 183 \\
\hline Particulier recht & 167 \\
\hline Geleerd recht & 136 \\
\hline Decisiones & 67 \\
\hline Consilia & 35 \\
\hline Secunda Scholastica & 8 \\
\hline Overige $^{1168}$ & 4 \\
\hline Onduidelijk $^{1169}$ & 4 \\
\hline
\end{tabular}

Vervolgens zal ik deze categorieën ieder afzonderlijk meer uitvoerig bespreken. Begonnen wordt met de meest omvangrijke groep. Hierbij gaat mijn aandacht voornamelijk uit naar wat opvallend is binnen elke groep. Bovendien zal ik oog hebben voor de manier waarop de positie, die het genre vervult binnen de Memorieboeken, geïnterpreteerd moet worden in het kader van de evolutie van het belang van datzelfde genre doorheen de tijd. Vanzelfsprekend zal de meeste aandacht

1167 Ik ben me er ter dege van bewust, dat de cijfers waarover ik beschikken kan, te beperkt zijn om nieuwe trends met zekerheid aan te tonen. Wel acht ik hen voldoende groot om reeds bestaande trends al dan niet te bevestigen.

1168 Het betreft Jean Bodin, Aulus Gellius, Etienne Pasquier en Gaius Suetonius Tranquillus.

${ }^{1169}$ Het betreft Prospero Farinacci. 
echter uitgaan naar de centrale vraag van dit hoofdstuk, namelijk het aandeel van humanistisch geïnspireerde werken. Steeds zal gekeken worden naar de auteurs welke men kan verwachten, welke er daadwerkelijk zijn en welke ontbreken. Wat het juridisch humanisme betreft, moet evenwel opgemerkt worden dat niet elke categorie zich hiertoe even goed leent. Het spreekt voor zich dat humanistische invloeden makkelijker aantoonbaar zijn aan de hand van werken uit de monografische categorie en vooral met behulp van de commentaren op het ius commune. Het is immers in de eerste plaats in deze categorieën geweest dat het juridisch humanisme zijn verworvenheden heeft laten gelden.1170 $\mathrm{Zij}$ zijn de echte waardemeters. Desalniettemin bieden ook de overige groepen heel wat mogelijkheden. Ik denk hierbij aan een al dan niet anwezige systematische aanpak bij bijvoorbeeld de commentaren op buitensteedse, costumiere en legislatieve compilaties. Daarenboven is elke blijk van ontvoogding, waarbij het Corpus Iuris Civilis niet langer als enige en onaantastbare autoriteit wordt beschouwd, een indicatie van de doorwerking van de novus methodus. In die zin draagt ook de geallegeerde, laatscholastieke literatuur evenals de nadrukkelijke aanwezigheid van vreemd gewoonterecht iets humanistisch in zich. ${ }^{1171}$

Bij de bespreking van de 599 allegaties zal ik me in de eerste plaats concentreren op de werken en pas in tweede instantie op de auteurs. Wat betreft de mate waarin een werk als humanistisch beschouwd kan worden, volg ik grotendeels de karakterisering welke terug te vinden is in het Handbuch der Quellen und Literatur der neueren Europäischen Privatrechtsgeschichte van Helmut Coing. ${ }^{172}$ In sommige gevallen kan ik eveneens gebruik maken van biografische literatuur omtrent de auteur in kwestie. In een zeer beperkt aantal gevallen heb ik me er toch toe laten verleiden, aan de hand van enkele zeer eenvoudige signalen, zelf een oordeel te vellen. Maar ook hier reikt het resultaat niet verder dan het niveau van 'indicatie' en 'conjectuur'. Desondanks mag de waarde of betekenis niet onderschat worden van de vaststelling dat een bepaalde auteur bijvoorbeeld in zijn werk veelvoudig naar klassieke auteurs verwijst en meermaals Griekse woorden in zijn tekst integreert.

Anderzijds is er het gebruik van het voorvoegsel 'eleganter' bij het verwijzen naar welbepaalde rechtsgeleerde auteurs in de Memorieboeken. Het is namelijk zo dat in een aantal gevallen de naam van de geallegeerde auteur voorafgegaan wordt door het voorvoegsel eleganter of sterker nog elegantissime. Bij wijze van voorbeeld geef ik hier de commentaar weer bij de artikels 2.4.15/16: Ex novel[la] 89 cap 3 circa princip[e] versic. ita tamen, et d novel[la] 74 cap 2 versic. omnino enim suis existentibus, eleganter Molin[aeus] loco ibbi] cit[ato] ad art 10 n[umero] 41. Bij tal van andere auteurs is dit evenwel niet het geval. Omdat het bovendien gebruikelijk is het juridisch humanisme in de Nederlanden van de zeventiende eeuw te omschrijven als de Hollandse 'elegante' school en omdat ook Feenstra en Waal gewag maken van 'elegante' auteurs wanneer

1170 LESAFFER, Inleiding tot de Europese rechtsgeschiedenis, 323. TROJE, "Die Literatur des gemeinen Rechts unter dem Einfluss des Humanismus", 634-635.

1171 Omtrent de rol van de buitensteedse, costumiere compilaties, cfr. supra, hoofdstuk 1, paragraaf 3, V roegere en buitensteedse compilaties.

1172 COING, Handbuch der Quellen und Literatur. 
zij het hebben over humanistisch geïnspireerde iuris periti, ben ik me gaan afvragen in hoeverre ook de redacteurs van de Memorieboeken eenzelfde terminologie gehanteerd hebben om te verwijzen naar humanistische rechtsgeleerden. ${ }^{1173}$ Bovendien wordt de term 'elegans' in het woordenboek van Van Wageningen en Muller omschreven als 'zuiver van vorm en logisch van gedachtegang', een vertaling die duidelijk aan de verworvenheden van het juridisch humanisme herinnert. ${ }^{1174} \mathrm{Om}$ te achterhalen of de redacteurs daadwerkelijk deze term op een consequente manier hebben aangewend om de vertegenwoordigers van de novus methodus mee aan te duiden, heb ik hen afgezonderd van de overige auteurs en aan een analyse onderworpen. De groep bestaat uit 23 verschillende rechtsgeleerden: Bartolo da Sassoferrato (+1357, ita), Rodrigo Suarez (+1500/1520, spa), Giovanni Francisco Sannazari della Ripa (+1535, ita), Andrea Alciato (+1550, ita), Jean Imbert (+1560, fra), Gaspar da Baeza $(+1565 / 67$, spa), Charles Dumoulin (+1566, fra), Nicolas du Val (+1568, fra), Fernando Vasquez de Menchaca (+1569, spa), Giulio Claro (+1575, ita), Jakob Thoming (+1576, hrr), Diego Covarubias y Leyva (+1577, spa), Juan Garzia de Saavedra (+1587/97, spa), Pieter Peck $(+1589$, ned), Bertrand d'Argentré $(+1590$, fra), Jean Papon $(+1590$, fra), Jean Bacquet $(+1597$, fra), Pierre Guenoys (+ca.1600, fra), René Choppin $(+1606$, fra), Andreo Fachineo $(+1607$, ita), Louis le Caron $(+1614$, fra) en Prospero Farinacci $(+1618$, ita). Op basis van dit overzicht kom ik tot een aantal vaststellingen welke zowel voor als tegen de hypothese pleiten. Dat men de term enkel gebruikt met betrekking tot humanistisch geïnspireerde auteurs wordt bevestigd door het feit dat binnen deze groep zo goed als alle doorwinterde, middeleeuwse auteurs ontbreken. Slechts drie onder hen kunnen als dusdanig omschreven worden (Bartolo da Sassoferrato, Gionvanni Francisco Sannazari della Ripa en Gaspar da Baeza). Daarenboven overlijden negentien van hen na 1550 en ligt de mediaan van de overlijdensdata op 1576, wat toch bijzonder laat is. Ook de herkomst van de auteurs blijkt te bevestigen dat het voornamelijk om aanhangers van de novus methodus gaat. Tien van hen zijn afkomstig van Frankrijk, de bakermat van het juridisch humanisme; slechts in zes gevallen gaat het om Italianen. De groep wordt vervolledigd met vijf Spanjaarden, één auteur uit de Nederlanden en één uit het Heilige Roomse Rijk. Naast pro's bestaan er echter ook contra's voor mijn vooronderstelling. Zo mankeert het voorvoegsel bij notoire humanistische auteurs als François Hotman en Jacques Cujas. Ook andere auteurs die aan het einde van de zestiende eeuw bedrijvig waren, worden niet noodzakelijk als 'elegant' omschreven. Ik denk bijvoorbeeld aan Denis Godefroy of Antoine Favre. Uiteraard is er ook de vaststelling dat middeleeuwse auteurs als Bartolus, da Baeza en Sannazari della Ripa het voorvoegsel wel kregen toegemeten. Hieraan dient toegevoegd te worden dat de vele allegaties naar Bartolus slechts zeer uitzonderlijk worden voorafgegaan door de

1173 Cfr. R. FEENSTRA en C. J. D. WAAL, Seventeenth-century Leyden law professors and their influence on the development of the civil law: a study of Bronchorst, Vinnius and Voet (Verhandelingen der Koninklijke Nederlandse Akademie van Wetenschappen, Afdeeling Letterkunde. dl. 90), Amsterdam, 1975, 11.

1174 "Elegans", Van Wageningen en Muller Latijnsch Woordenboek, Groningen en Den Haag, 1929, 313. 
term eleganter. Dit gebrek aan consequentie waarmee door de redacteurs van de Memorieboeken met de term wordt omgegaan, heeft me doen besluiten het al dan niet aanwezig zijn van de term niet te gebruiken ter aanduiding van humanistische invloeden aangaande de desbetreffende auteur.

Figuur 3.1 Procentueel aantal allegaties per literatuurtype

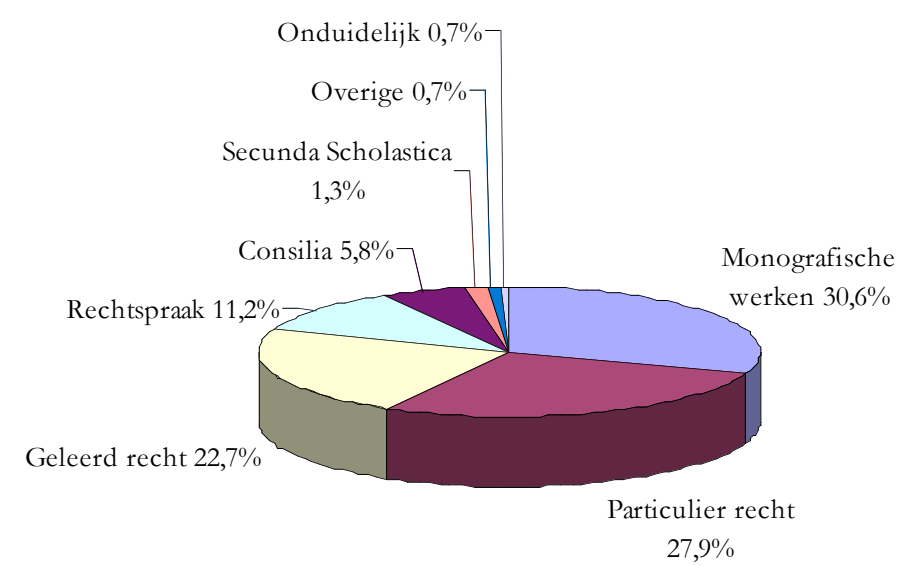

Dat de commentaren op het particuliere recht hoog scoren, strookt met wat de logica doet vermoeden. Dit onderzoek behelst immers de redactie van het gewoonterecht. ${ }^{1175}$ Het is dan ook geen verrassing vast te stellen dat deze categorie van costumiere en legislatieve rechtsleer zulk een hoog percentage van het totale aantal allegaties voor haar rekening neemt. Het gaat maar liefst om 28 procent of bijna één derde van de ganse onderzoeksgroep. Wat niet meteen uit de figuur blijkt, maar wel uit tabel 3.2, is het magere aandeel dat de legislatieve rechtsleer binnen deze groep inneemt. Dit is op het eerste zicht strijdig met de dominante rol die de

1175 Uiteraard blijft het uitermate belangrijk om welk type van 'grondtekst' het gaat. Wanneer het zoals hier om een costumiere compilatie gaat, mag men een sterk aandeel verwachten van gelijkaardige werken en commentaren, welke verwant zijn met het particulierrechtelijke onderwerp van de grontekst. Het blijft dan ook maar zeer de vraag of het verantwoord is om mijn vaststellingen te vergelijken met andere studies waarin allegaties centraal staan -denk aan Wijffels-, wanneer de grondtekst niet van dezelfde aard is. Zo concentreert Wijffels zich op procesdossiers, waar tot het domein van de jurisprudentie behoort. Waar een auteur als Ascheri zich op baseert bij het opstellen van haar autoritatieve hiërarchie, waar ik straks nog naar zal verwijzen, is niet meteen duidelijk. 
wetgeving gespeeld heeft als primaire bron van de Consuetudines compilatae. ${ }^{1176}$ Deze vaststelling is echter evident. In het eerste hoofdstuk gaat het namelijk hoofdzakelijk om zowel stedelijke als interne, vorstelijke wetgeving. In dit tweede hoofdstuk gaat het daarentegen om de mening van rechtsgeleerde auteurs omtrent legislatieve documenten. Daar er aan het begin van de zeventiende eeuw in de Nederlanden nog geen sprake kon zijn van het bestaan van een genre als de legislatieve rechtsleer, ligt haar ondervertegenwoordiging binnen deze figuur dan ook voor de hand. Ook hier kom ik later nog uitvoerig op terug.

Toch vormt de categorie van het particuliere recht niet de grootste groep. Met maar liefst dertig procent wordt de lijst namelijk aangevoerd door de categorie die de monografische literatuur omvat. Dit wekt al beduidend meer verbazing, althans in het licht van wat Ascheri over Italië vertelt in het Handbuch van Coing. Deze auteur stelt namelijk dat men, althans tot de zestiende eeuw, meer autoriteit toekende aan juridische adviezen, de zogenaamde Consilia, dan aan monografische literatuur zoals commentaren en traktaten. Vanaf de zeventiende eeuw nemen dan weer de rechtspraakverzamelingen de koppositie over in de autoritatieve hiërarchie. ${ }^{1177}$ Hun objectiviteit staat immers in schril contrast met de subjectiviteit van de in opdracht geproduceerde adviezen en eigenhandig geschreven traktaten. Ascheri lijkt de enige te zijn in Coings Handbuch die dieper ingaat op de wijze waarop de verschillende genres zich onderling verhouden inzake het gezag dat ze uitstralen. Over de positie van het particuliere en het geleerde recht laat de auteur zich echter niet uit. Wel leggen de overige auteurs, ten aanzien van de andere landen, steeds de nadruk op het feit dat het de rechtspraakverzamelingen zijn, die in de zeventiende en achttiende eeuw de spreekwoordelijke fakkel overnemen. ${ }^{1178}$

Wat de Memorien op de Costumen betreft, bevindt men zich aan het begin van de zeventiende eeuw en ik krijg een totaal ander beeld te zien. Zo zijn het hier nu net de monografieën die het vaakst aangehaald worden, waar de Consilia en de Decisiones de hekken sluiten. Respectievelijk halen beide laatstgenoemde genres nauwelijks zes en tien procent. De Consilia zijn over het algemeen te subjectief en de buitenlandse Consilia in het bijzonder mogelijk over hun hoogtepunt heen. De Consilia van eigen bodem en de Decisiones staan aan de voorhand ervan. Met tien procent hebben de rechtspraakverzamelingen duidelijk hun opmars ingezet. Conform het klassieke beeld beleven zij, ook in de Nederlanden, hun bloei in de achttiende eeuw. De Consilia kennen die, althans in onze contreien, in de zeventiende eeuw. ${ }^{1179}$ Dat men in de

${ }^{1176}$ Cfr. supra, hoofdstuk 1, paragrafen 2 en 3.

1177 ASCHERI, "Rechtsprechungs- und konsiliensammlungen", 1199. Meer over belang van de zogenaamde decisiones in Italië, cfr. ASCHERI, "Rechtsprechungs- und konsiliensammlungen", 1118-1130.

1178 Cfr. HOLTHÖFER, "Die Literatur zum gemeinen und partikularen Recht", 145-146; WALTER, "Rechtsprechungs- und konsiliensammlungen", 1228; SCHOLZ, "Rechtsprechungs- und Konsiliensammlungen", 1277-1278 en 1311; SCHOLZ, "Rechtsprechungs- und Konsiliensammlungen”, 1323.

1179 WAGNER, "Rechtsprechungs- und Konsiliensammlungen", 1403-1404 en 1418. De procentuele verdeling van het totale aantal consilia-uitgaven ziet er als volgt uit: tien procent 
Nederlanden ook nu weer achterophinkt, blijkt uit het feit dat er zelfs nog in de negentiende eeuw een rechtspraakverzameling verschijnt, waar dit nergens anders meer het geval is. ${ }^{1180}$

De enorme aandacht die wordt besteed aan zowel de commentaren op het geleerde recht als de monografische, juridische literatuur moet mijns inziens geïnterpreteerd worden als een gevolg van het feit dat men de neus op de Italiaanse en Franse rechtswereld heeft gericht. Rekening houdend met de traditionele vertraging verschijnen hier de genres die tijdens de zestiende eeuw in Zuid-Europa hun bloei kende. Zo staat er bij Holthöfer te lezen dat "wie in Spanien und vor allem in Italien seit der Mitte des 16. Jabrbunderts der grosse Traktat und die forensische Literatur, so sind es in Frankreich wäbrend des ganzen 16. und auch nog zum Beginn des 17. Jabrbunderts der gemeinrechtliche Kommentar und die anderen, vorbildlosen literarischen Neubildungen des Mos gallicus wie ₹. B. die Observatio die Leifformen juristischer Literatur gewesen."1181

Deze dominante positie van de monografische literatuur lijkt op het eerste gezicht te stroken met wat Wijffels vaststelde, namelijk een sterke toename van de monografische literatuur tijdens de zestiende eeuw. ${ }^{1182}$ Wijffels rekende echter de Consilia tot deze categorie, en bij nader inzien blijkt het deze aanwas van monografische werken grotendeels het gevolg te zijn van de sterke dominantie van deze Consilia binnen de groep. Een genre waaraan ik daarentegen een aparte plaats heb toegekend. Dat ikzelf hier met een overwegend monografisch gekleurd palet geconfronteerd word, kan op zijn beurt geïnterpreteerd worden als een gevolg van humanistische invloeden. De moderne, humanistische traditie kenmerkt zich immers met een uitgesproken voorkeur voor het monografische genre, meer concreet dat van de traktaten. ${ }^{1183}$

Rest ons enkel nog de rol gespeeld door het geleerde recht. 23 procent van de allegaties zijn verwijzingen naar commentaren bij het geleerde recht in strikte zin. Dit is enigszins logisch, gezien de receptie van het Romeinse recht en haar subsidiaire functie, maar ook het feit dat de redacteurs gewoonten vaak afwogen aan al dan niet overeenkomstige Romeinse wetten speelt hierin een rol.1184 In dat geval kom ik in een situatie terecht zoals die van Guy Coquille en het Franse recht, waarover Warembourg zich als volgt uitlaat: "Il ne s'agit pas, chez. Coquille, de faire prévaloir les

verscheen voor 1600; een kwart verscheen in de periode 1600-1650; het merendeel (35 procent) werd gedrukt in de tweede helft van de zeventiende eeuw; vijftien procent zag het daglicht tussen 1700 en 1750 en nog eens vijftien procent werd in de periode 1750-1800 gepubliceerd. (Cfr. WAGNER, "Rechtsprechungs- und Konsiliensammlungen", 1419.) Omtrent de evolutie van de consilia in de Nederlanden, cfr. WAGNER, "Rechtsprechungsund Konsiliensammlungen", 1417-1430.

1180 Dit afwijkend beeld kan mijns inziens bovendien niet gecorrigeerd worden, indien ik wél ruimte gelaten zou hebben voor de (niet-rechtsgeleerde) allegaties van zuiver jurisprudentiële en legislatieve aard. Daarvoor was de ingreep niet drastisch genoeg.

1181 Cfr. HOLTHÖFER, “Die Literatur zum gemeinen und partikularen Recht”, 145.

1182 WIJFFELS, Qui millies allegatur, I, 203.

1183 LESAFFER, Inleiding tot de Europese rechtsgeschiedenis, 323. TROJE, "Die Literatur des gemeinen Rechts unter dem Einfluss des Humanismus", 634-635.

${ }_{1184}$ Cfr. supra, hoofdstuk 1, paragraaf 3, Romanisatie en humanisme. 
solutions romaines, mais de mettre au service du droit français les dispositions et les concepts savants utiles à ce dernier. Autrement dit, la cause finale de l'utilisation du droit romain n'est plus le droit romain lui-même, mais le droit français."1185 Opnieuw gaat het om een vorm van ontvoogding, eigen aan de geest van het juridisch humanisme.

\section{Monografieën}

De grootste groep is meteen ook de minst uniforme. De term monografische literatuur verzamelt immers tal van verschillende rechtsgeleerde genres. De grootste gemene deler die hen verenigt, is het thematisch uitgangspunt van waaruit zij tot stand zijn gekomen. Niet een of andere type rechtsbron ligt aan de basis van het werk, wel eine in einer Mehrzahl solcher Stellen lokalisierte Rechtsmaterie. ${ }^{1186}$ Hoewel dit in principe evenzeer gezegd kan worden van een genre als dat van de Consilia, heb ik er toch voor geopteerd hen als een afzonderlijke categorie te behandelen, daar de Consilia ook in Coings Handbuch afzonderlijk aan bod komen. Zoals het overzicht laat zien, heb ik deze categorie verder opgedeeld in een vijftal subcategorieën. In eerste instantie zijn er de traktaten, vervolgens het subgenre van de Quaestiones, gevolgd door dat van de Singulariae. Daarnaast bestaat er een groep met procesrechtelijke studies, vaak ook omschreven als Practica, en een groep die ik ben gaan aanduiden als die van de Additiones. Bij deze laatste gaat het om werken waarbij een zekere auteur x een commentaar heeft geschreven op een werk van een andere auteur y. De 'onduidelijke' werken bevatten het niet-juridische, politiektheoretische Les six livres de la République (1576) van Jean Bodin en de Praxis et theorica criminalis (1581-1624) van Andrea Farinacci. Deze laatste wordt door Mazzacane immers omschreven als een strafrechtelijke encyclopedie. ${ }^{1187}$

Een aantal van deze genres zijn echte 'randtypes' en hadden evenzeer in een andere hoofdcategorie kunnen thuishoren. Zo sluiten de Practica ook nauw aan bij het particuliere recht. Ze beschrijven immers maar al te vaak het lokale procesrecht. De Quaestiones-verzamelingen op hun beurt bevinden zich, als Sammlung von Problemerörterungen eines oder mehrerer Rechtsgebiete, dan weer op de grens tussen enerzijds de monografische literatuur en anderzijds de verzamelingen van Decisiones en de Consilia, grosso modo balancerend op het slappe koord tussen theorie en praktijk. ${ }^{1188}$ De ratio achter de door mezelf gemaakte keuzes met betrekking tot deze indeling, is dat ik in dezen Coing ben gevolgd, zoals hij te werk is gegaan in zijn Handbuch, slechts

1185 WAREMBOURG, Guy Coquille, 29. Een gelijkaardige vaststelling heb ik kunnen doen in het eerste hoofdstuk van dit boek, waar ik dieper ingegaan ben op de houding welke de samenstellers van de Consuetudines compilatae hebben aangenomen ten overstaan van het Romeinse recht, zoals deze blijkt uit de Memorien op de Costumen. Cfr. supra, hoofdstuk 1, paragraaf 3, Romanisatie en bumanisme.

${ }^{1186}$ HOLTHÖFER, "Die Literatur zum gemeinen und partikularen Recht”, 314.

1187 MAZZACANE, "Farinacci, Prospero", 206.

${ }^{1188}$ Cfr. HOLTHÖFER, "Die Literatur zum gemeinen und partikularen Recht”, 319-320. Hoe deze Quaestiones zich exact van genres als de traktaten, consilia en rechtspraakverzamelingen onderscheiden, staat te lezen bij Holthöfer in Coings Handbuch: HOLTHÖFER, "Die Literatur zum gemeinen und partikularen Recht”, 320. 
één uitzondering niet te na gesproken. Enkel wat betreft de Singulariae, aan wie bij Coing een aparte categorie werd toegekend, heb ik anders gehandeld.1189 $\mathrm{Ik}$ heb hen bij de monografische werken ondergebracht. Tabel 3.2 geeft een overzicht van de waardeverhoudingen binnen deze eerste hoofdcategorie.

Tabel 3.2 Aantal allegaties per subcategorie binnen de monografische literatuur

\begin{tabular}{|c|c|c|c|c|}
\hline $\begin{array}{l}\text { Type } \\
\text { monografie }\end{array}$ & $\begin{array}{l}\text { Aantal } \\
\text { allegaties }\end{array}$ & $\begin{array}{lll}\begin{array}{l}\text { Procentueel } \\
\text { totaal }\end{array} & \text { aandeel } & \text { op } \\
\end{array}$ & Land & $\begin{array}{l}\text { Aantal } \\
\text { allegaties }\end{array}$ \\
\hline \multirow[t]{6}{*}{ Traktaten } & \multirow[t]{6}{*}{82} & \multirow[t]{6}{*}{$13.7 \%$ van totaal } & Frankrijk & 32 \\
\hline & & & Italië & 32 \\
\hline & & & Spanje & 9 \\
\hline & & & Nederlanden & 6 \\
\hline & & & Duitsland & 1 \\
\hline & & & Onbekend & $2^{1190}$ \\
\hline \multirow[t]{4}{*}{ Procesrecht } & \multirow[t]{4}{*}{50} & \multirow[t]{4}{*}{$8.3 \%$ van totaal } & Nederlanden & 26 \\
\hline & & & Italië & 13 \\
\hline & & & Frankrijk & 8 \\
\hline & & & Duitsland & 3 \\
\hline Quaestiones & 19 & $3.2 \%$ van totaal & & \\
\hline Additiones & 16 & $2.7 \%$ van totaal & & \\
\hline Singulariae & 11 & $1.8 \%$ van totaal & & \\
\hline Onduidelijk & 5 & $0.8 \%$ van totaal & & \\
\hline
\end{tabular}

Uit de tabel blijkt dat deze groep voornamelijk bestaat uit de zogenaamde tractati.1191 Net als de commentaren bij het gemene recht kunnen ook zij bij de overgang van de laatmiddeleeuwse naar moderne tijd aanknopen bij een lange traditie. Reeds in de Glossatorentijd kondigt het genre zich aan, maar het is evenwel pas later dat het zijn hoogdagen kent. ${ }^{1192}$ Het is succesvol bij de commentatoren (traktaten van het oude type), maar nog meer onder de humanistisch geïnspireerde juristen (traktaten van jonge type), althans volgens Lesaffer. ${ }^{1193}$ Vandaar dat ik niet zozeer verwonderd ben door het sterke overwicht van zowel Italiaanse als Franse auteurs in deze subgroep. Samen zijn ze goed voor maar liefst 76 procent van alle allegaties naar traktaten. De meest toonaangevende traktaten binnen deze groep, zoals die van Jacopo Menocchio (De arbitrariis iudicum quaestionibus et causis, 1569, dertien allegaties), Jean Bacquet (Les oeuvres de Jean Bacquet des droicts du domaine de la couronne de France, 1601, acht allegaties), Charles Dumoulin (Tractatus de usuris, 1542, vier allegaties; Extricatio labyrinthi dividui et individui, 1562, twee allegaties) en Jean Papon (Instrument du premier notaire, 1576, één allegaties; Trias judiciel du second notaire, 1575, acht allegaties; Secrets du troisième et dernière notaire, 1578, vijf allegaties), dateren evenwel allemaal van de tweede helft van de

${ }^{1189}$ Cfr. HOLTHÖFER, "Die Literatur zum gemeinen und partikularen Recht”, 418e.v.

${ }^{1190}$ Het betreft hier het tractatus de feudis van 'Montanus' (cfr. Memorieboeken bij artikel 1.1.14) en het tractatus anno 1543 van 'Iuveninus' (cfr. Memorieboeken bij de artikels 3.3.5/6/7).

1191 Omtrent de wijze waarop de traktaten de link vormen tussen de middeleeuwse en moderne rechtswetenschap: cfr. HORN, "Die legistische Literatur der Kommentatoren”, 341. 1192 Cfr. HORN, "Die legistische Literatur der Kommentatoren", 341-348.

1193 LESAFFER, Inleiding tot de Europese rechtsgeschiedenis, 323. 
zestiende eeuw. Bovendien blijkt uit tabel 3.3 dat maar liefst 86 procent van alle allegaties naar traktaten, zijnde 64 op 73 allegaties, verwijzen naar traktaten die gepubliceerd werden na 1550 . Het laat zien in welke mate het genre zijn bloei kent in de zestiende (en zeventiende eeuw), althans in Italië en Frankrijk.

Tabel 3.3 Aantal allegaties in functie van de publicatiedatum van de traktaten ${ }^{1194}$

\begin{tabular}{|c|c|c|c|c|c|c|c|c|}
\hline$<1530$ & $1531-$ & $1541-$ & $1551-$ & $1561-$ & $1571-$ & $1581-$ & $1591-$ & $1601-$ \\
& 1540 & 1550 & 1560 & 1570 & 1580 & 1590 & 1600 & 1610 \\
\hline 0 & 2 & 7 & 5 & $\mathbf{1 8}$ & $\mathbf{2 3}$ & 8 & 2 & 8 \\
\hline
\end{tabular}

De overige landen, waaronder ook de Nederlanden, blijken minder in deze traditie te staan, tenminste op het moment dat de Memorien op de Costumen tot stand kwamen. Enkel Pieter Peck (1529-1589) speelt hier een noemenswaardige rol, met zijn Tractatus de testamentis conjugum, in quinque libros distinctus (1585). Het werk is goed voor vijf allegaties. Over de beperkte rol van de middeleeuwse traktaten binnen deze categorie kom ik later nog terug. ${ }^{1195}$

De onderwerpgebondenheid, de grootste gemene deler van het genre welke elk traktaat -net als de overige monografische subgenres- kenmerkt, impliceert dat de allegaties naar deze werken zich concentreren in zeer specifieke titels van de Consuetudines compilatae. Wat de traktaten betreft, denk ik bijvoorbeeld aan Bacquets Les auvres de Jean Bacquet des droicts du domaine de la couronne de France in titel 2.4 (Van onwettige kinderen oft bastaerden), Simoncelli's Tractatus de decretis caeterisque solemnitatibus in contractibus minorum in titel 2.5 (Van minderjaerige ende andere vermomboirde persoonen, ende van henne momboirs) en Pecks Tractatus de testamentis conjugum, in quinque libros distinctus aangaande de titels 2.1 ( $V$ an gehoude persoonen) en 3.1 (Van verscheydentheyt van goeden). Ook de drie traktaten van Jean Papon omtrent het notariaat concentreren zich rond een aantal specifieke titels, met name titel 2.4 ( $V$ an onwettige kinderen oft bastaerden), 2.5 ( $V$ an minderjaerige ende andere vermomboirde persoonen, ende van benne momboirs), en het burgerlijk procesrecht in de titels 5.10 ( $V$ an de maniere ende forme van procederen) en 5.11 (Van den thoon). Dat dit niet noodzakelijk het geval hoeft te zijn, tonen de reeds vermelde traktaten van Jacopo Menocchio en Charles Dumoulin. Zij komen verspreid over de ganse Memorieboeken aan bod. ${ }^{1196}$ Wat betreft de werken die slechts één of twee maal werden geallegeerd, kan ik niet tot gelijkaardige conclusies komen. Het lage aantal allegaties laat immers niet toe concentraties vast te stellen. Dat zij daarenboven gezamenlijk te talrijk en individueel te zeldzaam zijn, heeft tot gevolg dat zij hier niet één voor één toegelicht zullen worden. Te onthouden is dat de nadruk op de Franse en Italiaanse auteurs van de tweede helft van de zestiende eeuw ligt,

\footnotetext{
${ }^{1194}$ Het totaal aantal allegaties binnen deze tabel is slechts 73 omdat ik niet van elk traktaat de ontstaansdatum heb kunnen achterhalen.

1195 Cfr. infra, hoofdstuk 3, paragraaf 2, Monografië̈n.

1196 Ook onder de groep van werken waarnaar minder dan drie maal werd gerefereerd, ligt de nadruk op het monografische genre.
} 
waarbij de eerstgenoemden gemiddeld een hoger aantal allegaties voor hun rekening nemen. ${ }^{1197}$

Een tweede frequent geraadpleegd genre onder de monografische werken is dat van de procesrechtelijke werken. Het civiel procesrecht van de Nederlanden en Frankrijk wordt in de Memorieboeken gerepresenteerd door de Practica van respectievelijk Filips Wielant (Corte instructie in materie civile, circa 1508) en Jean Imbert (Institutiones forenses, 1535), respectievelijk goed voor twaalf en vijf referenties. Diezelfde Wielant nam met zijn Corte instructie in materie criminale (ca. 1510) ook het strafprocesrecht voor zijn rekening (zes allegaties). Hoewel het genre grote populariteit genoot in de Nederlanden, is dit enigszins opvallend gezien het feit dat Wielants oeuvre nog niet in druk verschenen was op het ogenblik dat de Antwerpse commissieleden actief waren. ${ }^{1198}$ De redacteurs moeten dus over een handgeschreven versie hebben kunnen beschikken, daar waar het plagiaat van Joost de Damhouder doorgaans meer succes kende. ${ }^{1199}$ Men wist blijkbaar duidelijk waar de mosterd in eerste instantie gehaald moest worden. ${ }^{1200}$ Desalniettemin wordt ook de Damhouder zelf één maal geallegeerd met zijn Praxis rerum civilium (1567). Ook Pieter Pecks Tractatus de iure sistendi (1564, zeven allegaties) en het Tractatus exceptionum atque actionum van de Franse jurist Pierre Rebuffi (zestiende eeuw, één allegatie) behoren tot deze procesrechtelijke groep, net als de middeleeuwse vertegenwoordigers van het genre Jean Masuer (Practica forensis, <1450) en Johannes Petrus de Ferrariis (Practica nova judicialis,

${ }^{1197}$ Hoewel de plaats en tijd me hier ontbreekt dieper in te gaan op alle mogelijke traktaten die hier verwacht konden worden, wil ik toch een aantal auteurs van Nederlandse origine aanstippen wier afwezigheid hier enigszins opvallend is. Ik denk bijvoorbeeld aan een persoon als Cornelis Nieustad (1549-1606) uit den Briel, die in 1594 een traktaat publiceerde over huwelijksvoorwaarden (Tractatus de pactis antenuptialibus rerum judicatarum observationes). (Cfr. DEKKERS, Bibliotheca Juridica Belgica, 123.) Ook auteurs als Nicolaus Vigelius (1529-1600) en Jakob Reyvaert (1535-1568) lijken me in deze noemenswaardig. (Cfr. SÖLLNER, "Die Literatur zum gemeinen und partikularen Recht", 579-605.) Andere namen die hier, op basis van Söllner, vermelding verdienen zijn die van Johan Tack (1535-1578), Joost de Damhouder (1507-1581), Paul Van den Berghe (1530-1587), Pieter van der Aa (1530-1594), Pierre Goudelin (1550-1619). Op basis van Dekkers kunnen hier nog Jean Wamese (1524-1590), Paul van Merel (1558-1607), Hendrik de Hondt (1531-1610), Joachim Hopper (1523-1576) en Jan Baes (1548-1596) aan toegevoegd worden. (Cfr. DEKKERS, Bibliotheca Juridica Belgica.) 1198 Cfr. SÖLLNER, "Die Literatur zum gemeinen und partikularen Recht", 578.

1199 Zo is er in het traktaat van Hendrik de Moy over de Consuetudines impressae enkel sprake van de Damhouder en niet van Wielant. (Cfr. SAA, Vierschaer, 21-23: DE MOY, Tractaat.)

1200 Storme relativeert het plagiaat van de Damhouder en wijst op de meerwaarde die de Damhouder aan de Practyke Civile van Wielant toevoegde. (M. STORME, "Practique judiciare ès causes civiles.' Un manuel de procedure dans les Pays-Bas du XVIe siècle", A. DEPERCHIN, N. DERASSE en B. DUBOIS red., Figures de Justice. Etudes en l'honneur de JeanPierre Royer, Rijsel, 2004, 259-260.) 
1473). ${ }^{1201}$ Laatst vernoemde auteurs kwamen in de Memorieboeken respectievelijk twee en één keer aan bod. Het succes van de Nederlandse auteurs is ongetwijfeld te verklaren door het feit dat hun procesrechtelijke werken de procedure van eigen bodem beschrijven. De nauwe band met het studieobject van de Antwerpse commissieleden maakt het raadplegen van deze werken voor de hand liggend. In die zin had ik trouwens dit genre eveneens kunnen ressorteren onder de noemer van het particuliere recht, ware het niet dat zij bij Coing onderbracht werden bij de monografische literatuur. Op basis van datzelfde Handbuch had ik hier overigens auteurs als Guillaume Hanneton (De ordine ac forma judiciorum, ad usum forensem accomodata praxis, 1543) of Paulus van Merel (Synopsis praxeos civilis, ofte Maniere van procederen in de Provintien van Hollandt, Zeelandt en West-V rieslandt, belangende civile zaken, 1592) verwacht. ${ }^{1202}$

Zeker zo belangrijk is ook het feit dat met de Consuetudines compilatae voor het eerst een compilatie tot stand is gekomen waarin de Ordonnantie op de Styl ende Maniere van procederen in het geheel werd geïntegreerd, waar deze bij de Consuetudines impressae nog als appendix aan het geheel afzonderlijk was toegevoegd. De integratie ervan verklaart de nadrukkelijke aanwezigheid van voornoemde processualisten. Onderstaande tabel 3.4 laat duidelijk zien dat deze allegaties voor het overgrote deel voorkomen in de delen vijf en zeven, welke het civiel en crimineel procesrecht omvatten. Binnen beide delen ligt dan weer de nadruk op titels als 5.8 ( $V$ an arresteringe ende aentastinge van persoonen om civile saecken), 5.10 ( $V$ an de maniere ende forme van procederen), 5.11 ( $V$ an den thoon), 7.1 (Van ondersoeck ende vervolch van gevluchte misdaedige), 7.2 ( $V$ an tvangen ende bewaeren der misdadige, ende beschrijvinge van bunne goeden) en 7.3 ( $V$ an gevangenen t'ondervraegen ende ter scherper examinatien te brengen oft pijningen).

Tabel 3.4 Aantal allegaties naar Practica per deel

\begin{tabular}{|c|c|c|c|c|c|c|}
\hline I & II & III & IV & V & VI & VII \\
\hline 1 & 2 & 6 & 2 & $\mathbf{2 3}$ & 1 & $\mathbf{1 5}$ \\
\hline
\end{tabular}

Wat betreft de geallegeerde werken van de Italiaanse jurist Giulio Claro, liggen de kaarten wat moeilijker. Enerzijds behoren beide werken tot zijn Opera omnia die bij Coing omschreven wordt als Opera omnia, sive Practica civilis atque criminalis. Bovendien komt het merendeel van de allegaties naar het vijfde boek van Claro (Sententiarum receptarum liber quintus, 1568) voor in het zevende strafprocesrechtelijke deel. Daarenboven categoriseert ook Holthöfer het werk onder de civielprocesrechtelijke monografieën. ${ }^{1203}$ Daarom en ondanks het feit dat de allegaties naar de eerste vier boeken van Claro (Tractatus quatuor, 1565) voornamelijk in het derde deel -meer

1201 Ten gevolge van mijn selectiecriteria is het middeleeuwse, civiele procesrecht, zoals Duranti's Speculum judiciale, hier uit de boot gevallen. Het betrof namelijk uitsluitend tweederangse allegaties.

1202 Cfr. SÖLLNER, "Die Literatur zum gemeinen und partikularen Recht”, 608-609. Cfr. DEKKERS, Bibliotheca Belgica Juridica, 75 en 115-116.

1203 HOLTHÖFER, "Die Literatur zum gemeinen und partikularen Recht”, 398. 
specifiek aangaande de testamenten- voorkomen, heb ik er voor geopteerd het volledige oeuvre hier bij de procesrechtelijke monografieën onder te brengen.

Wat het Heilige Roomse Rijk betreft is het genre van de Practica vertegenwoordigd met werken van Matthias Coler en Johannes Petrus de Ferrariis. Hun invloed blijft evenwel zeer beperkt, namelijk slechts drie allegaties in totaal. Spanje van zijn kant lijkt dan weer nauwelijks een procesrechtelijke traditie te hebben, tenminste geen met internationale uitstraling. Enkel de weggeselecteerde Roberto Maranta zou wel kunnen, maar mag in dit opzicht niet vermeld worden.

Het derde monografische subgenre is dat van de Quaestiones. Een genre met een dubbel karakter, aangezien het balanceert op de grens tussen theoretische en casuïstisch-forensische literatuur. In wezen gaat het hier immers om verzamelingen van probleembesprekingen met betrekking tot één of meerdere rechtsgebieden, aldus Holthöfer. ${ }^{1204}$ Formeel gezien gaat het om een afgeleid product van zowel de Consiliaals de Decisiones-verzamelingen. Op enkele alleenstaande middeleeuwse voorlopers na, breekt dit genre dan ook pas echt door vanaf het midden van de zestiende eeuw, wanneer beide voorbeelden reeds algemeen vertegenwoordigd zijn. ${ }^{1205}$ Belangrijk voor de queeste van dit hoofdstuk is dat dit genre zich, zoals de traktaten van het jonge type, bijna uitsluitend bezighouden met de novus methodus. Ik kom hier later nog op terug. ${ }^{1206}$ Dat deze Quaestiones-verzamelingen eender welk rechtsgebied kunnen omvatten, verklaart ongetwijfeld haar alomtegenwoordigheid. Dit is te zien aan de hand van tabel 3.5. De piek in deel III is te wijten aan het veelvuldig allegeren -vier maal- naar Andreo Fachineo in titel 3.13.

Tabel 3.5 Aantal allegaties naar Quaestiones per deel

\begin{tabular}{|c|c|c|c|c|c|c|}
\hline I & II & III & IV & V & VI & VII \\
\hline 1 & 1 & 8 & 2 & 2 & 2 & 3 \\
\hline
\end{tabular}

Hoewel Söllner nadrukkelijk wijst op het succes van het genre binnen de Duitse landen en de rol die de Quaestiones-verzamelingen hebben gespeeld in de voorgeschiedenis van de constituties van het keurvorstendom Saksen en dat zij op deze manier tevens in het ontstaan van het Ius Commune Saxonum een belangrijke rol hebben gespeeld, blijken de Duitse vertegenwoordigers van het genre weinig indruk gemaakt te hebben op de Antwerpse commissieleden. Enkel de Quaestiones iuris tam Romani quam Saxonici van Hartmann Pistoris werd één maal geallegeerd. Met betrekking tot de Nederlanden kan ik er alleen maar op wijzen dat het eerste noemenswaardige feit binnen dit genre plaatst heeft in 1653 met het verschijnen van Arnoldus Vinnius' Selectae iuris quaestiones. 1207

Wat Antwerpen betreft, is het Quaestiones-genre in de eerste plaats een SpaansItaliaanse aangelegenheid. Men heeft zich namelijk hoofdzakelijk bediend van Diego

1204 HOLTHÖFER, “Die Literatur zum gemeinen und partikularen Recht”, 320.

1205 Cfr. HORN, "Die legistische Literatur der Kommentatoren”, 345 en 348.

1206 HOLTHÖFER, "Die Literatur zum gemeinen und partikularen Recht”, 320.

1207 Cfr. SÖLLNER, "Die Literatur zum gemeinen und partikularen Recht”, 579. 
Covarubias y Leyva (V ariarum ex iure pontificio, regio et caesareo resolutionum libri tres, 1552 en Practicarum quaestionum liber singularis, 1556) en Andreo Fachineo (Controversiarum iuris libri novem, 1595). Samen zijn zij goed voor maar liefst vijftien allegaties (zes plus negen). Verder zijn er nog éénmalige verwijzingen naar de Quaestiones van de Italiaanse jurist Agustin Berò en de Spanjaard Antonio Gomez. Ook Frankrijk speelt hier niet echt mee. De ene allegatie naar François Hotman, één van de voormannen van de mos gallicus, bevestigt alleen maar hoezeer ik hier te maken heb met een 'modern' genre. Alle werken dateren immers van de tweede helft van de zestiende eeuw.

In eenzelfde grootte-orde vind ik het type van de Additiones terug. Zoals reeds eerder aangegeven gaat het hier om commentaren bij een willekeurig rechtswetenschappelijk werk van een collega-jurist, inclusief adviezen- en rechtspraakverzamelingen. Struktureel is het genre dus sterk verwant met de commentaren op het gemene en het particuliere recht met dit verschil dat de brontekst niet langer van gemeenrechtelijke of costumiere aard is. Deze genres komen later nog uitvoerig aan bod. De wortels van deze Additiones of Annotationes liggen in de middeleeuwen. Ik denk hierbij bijvoorbeeld aan de annotaties van Giovanni d'Andrea bij het dertiende-eeuwse Speculum van Guilielmo Duranti, waarnaar ook hier één maal werd verwezen. Ook in de moderne tijd blijft het genre succes kennen, zowel ten tijde van de mos gallicus als binnen de natuurrechtelijke literatuur. ${ }^{1208}$ Getuigen hiervan, die eveneens in de Memorieboeken werden geallegeerd, zijn de commentaar van Pietro Follerio bij het Tractatus docti et insignes, de ordine iudiciorum (1566) van Roberto Maranta, de annotaties van Etienne Ranchin bij de Decisiones grationopolitanae (1441-1461) van Guy de la Pape en de Apostillae van Alessandro di Tartagni bij de commentaren van Bartolo da Sassoferrato op het geleerde recht. Elk werden zij één keer aangehaald. Maar de meest opvallende figuur in deze context is ongetwijfeld Charles Dumoulin. Zijn commentaren bij de Consilia van enerzijds Alessandro di Tartagni en anderzijds die van Filippo Decio, werden respectievelijk maar liefst zeven en vier keer geallegeerd. Nog opvallender is misschien dat de commissieleden hem hoger als commentator lijken in te schatten dan als expert van het Franse gewoonterecht, zoals hij vandaag de dag doorgaans wordt omschreven. Elf of meer dan één derde van de referenties naar Dumoulin verwijzen naar hem als annotator, waar er slechts tien refereren naar één van zijn gewoonterechtelijke commentaren. Ten aanzien van de Antwerpse Consuetudines compilatae moet zijn belang als gewoonterechtkenner dus gerelativeerd worden. Ik zal hier bij de bespreking van het particuliere recht nog uitvoerig op terugkomen. Rest mij enkel te zeggen dat deze allegaties naar Dumoulin zich concentreren in de titels omtrent het huwelijks- en erfrecht (titels 2.1, 3.13 en 3.14).

Een laatste genre dat hier vermelding verdient, is dat van de Singulariae, door Holthöfer ook als Sentenzen-sammlungen omschreven. ${ }^{1209} \mathrm{Zij}$ bestaan uit

1208 Meer hierover, zie: HOLTHÖFER, "Die Literatur zum gemeinen und partikularen Recht", 427.

1209 HOLTHÖFER, "Die Literatur zum gemeinen und partikularen Recht”, 418. 
hoofdprincipes, meestal in een mededelende of vragende zin weergegeven, die vervolgens aan de hand van een behoorlijk knappe verantwoording verklaard of beantwoord worden. Het verschil met de Quaestiones zit hem in het elementaire, summiere karakter van de Singulariae. Men beoogt geen nieuwe vragen te stellen of nieuwe antwoorden te geven op oude vraagstukken; men wil enkel maar samenvatten wat reeds 'voorbedacht' is. ${ }^{1210}$ Hoewel het genre zijn bloeitijd kende in de zestiende eeuw, lijkt het hier niet echt indrukwekkende potten te kunnen breken wat betreft het gezag dat er van uitgaat. In totaal is het slechts goed voor 1.8 procent van alle aangetroffen allegaties. Holthöfer wijst er verder op dat het een typisch Italiaans genre is, en in mindere mate ook Spaans. Desalniettemin wist het zich over gans West-Europa te verspreiden. Ook ten aanzien van de Antwerpse Consuetudines compilatae blijken vier van de zes auteurs van het middeleeuwse, Italische schiereiland afkomstig te zijn: Enrico di Boverio, Francisco di Crema, Ippolito Marsili en Ludovico Pontano. Spanjaarden heb ik hier evenwel niet mogen aantreffen. Hier staat dan weer iemand als de zestiende-eeuwse Michael Grass uit het Heilige Roomse Rijk tegenover. Zijn Receptarum Sententiarum Volumina Duo spant binnen dit genre de kroon en is goed voor maar liefst zes allegaties. Guy de la Pape is met zijn Singularia uit de vijftiende eeuw de enige auteur van Frans origine.

Het feit dat alle overige Singularia, net zoals dat van de la Pape, slechts één maal werden geallegeerd, deed ons echter vermoeden dat hoogstwaarschijnlijk één van de verscheidene verzameledities van het genre werden benut. ${ }^{1211}$ Het voorkomen van relatief onbekende auteurs als Enrico di Boverio, die zelfs in het Handbuch van Coing uitsluitend in verband met één van de gecompileerde Singularia wordt vernoemd, zet deze veronderstelling alleen maar kracht bij. ${ }^{1212}$ Exact aangeven om welk verzamelwerk het gaat, is -omwille van het uitgebreide anbod- heel wat moeilijker uit te maken. Op basis van Coings Handbuch is het bovendien onmogelijk een werk aan te duiden dat alle namen in zich verzamelt. Vermoedelijk kon de commissie over twee verschillende compilaties beschikken. ${ }^{1213}$

Uiteindelijk zou men in totaal minstens elf keer naar dit genre binnen de rechtsliteratuur refereren. In de loop van de zeventiende eeuw moet het echter aan belang inboeten. Enkel het verwante literatuurtype van het rechtslexicon weet zich te handhaven. ${ }^{1214}$

${ }^{1210}$ HOLTHÖFER, “Die Literatur zum gemeinen und partikularen Recht”, 418.

1211 Cfr. VERVAART, Nicolaas Everaerts, 89-90.

1212 Cfr. HOLTHÖFER, "Die Literatur zum gemeinen und partikularen Recht", 419-420.

1213 HOLTHÖFER, "Die Literatur zum gemeinen und partikularen Recht”, 419-420.

1214 Cfr. HOLTHÖFER, "Die Literatur zum gemeinen und partikularen Recht", 419. De oudste en beroemdste humanistische voorbeelden van dit genre, van de hand van Aelius Antonius Nebrija, Barnabas Brisson en Pardoux Duprat, worden in de Memorieboeken evenwel nergens vernoemd en dit ondanks het feit dat zij alledrie van voor het einde van zestiende eeuw dateren. Anderzijds kwamen zij voornamelijk voor in Frankrijk alwaar ze in dienst stonden van de zogenaamde fixering van het droit français. Desalniettemin had ik, gezien de influx van rechtsgeleerde werken vanuit Frankrijk bij de Antwerpse redactoren, sporen van dit genre mogen verwachten. 
De centrale vraag blijft echter in hoeverre de werken die hierboven beschreven werden enige invloed van het juridisch humanisme verraden. Wat het omvangrijkste subgenre betreft, dat van de traktaten, heb ik me laten leiden door het onderscheid dat Holthöfer maakt tussen een drietal traktaattypes, waarvan er één tot de middeleeuwse traditie wordt gerekend en de twee ovrige tot die van de nova methodus. De grens tussen oud en nieuw ligt, volgens Holthöfer, in de grote traktatenverzamelingen van Lyon $(1535,1549)$ en Venetië $(1584) .1215$ Wat hierin terug te vinden is, kan beschouwd worden als old school. Tot het midden van de zestiende eeuw verandert er immers nauwelijks iets binnen het literatuurtype. Vanaf 1550 kondigt het jonge type zich echter aan. Als uitdrukking van de nieuwe humanistische rechtswetenschap bevat het alle algemene kenmerken waar deze nieuwe methode voor staat: "Den freieren, keinem formalen Schema mehr verbafteten Stil der Darstellung, den Vervicht auf die Vollständigkeit des Kontroversenberichts, die Ersetzung bartolistischer Autoritäten durch die literarischen des klassischen Altertums, den Versuch, unmittelbar aus den Quellen zu argumentieren, scbliesslich die Mebrbeit der zur Auswabl stehenden bistorischen Quellenhorizonte." 216 Dit eerste jonge type deelt zich verder op in twee subgenres, namelijk de disputatio en de observatio, waarbij de laatstgenoemde zich van de eerstgenoemde onderscheidt doordat hij tot stand komt in een private omgeving, waar de eerstgenoemde aan het rechtenonderwijs gerelateerd is. ${ }^{1217}$ Hoewel Söllner er op wijst dat deze disputatio in onze streken een belangrijk rol heeft gespeeld, is daar in de Memorieboeken bitter weinig van te merken. Wanneer dit eerste jonge type nu aanknoopt bij bestaande rechtsbronnen, dan gaat het steeds om het overgeleverde gemene recht of het antieke Romeinse recht. Het derde traktaattype -het tweede van jonge aard dus- is in zekere zin een uitloper van het oude traktaat, daar het er een lichtgewijzigde vorm van is. Doordat de jonge gemeenrechtelijke commentaren niet langer oog hadden voor de toepassing van het recht in de contemporaine rechtspraktijk, was er een vacuüm ontstaan, waar het nieuwe, jonge Traktat der Usus modernus handig gebruik van zou maken. Het neemt de voornaamste verworvenheden over van de nova methodus, maar behoudt hierbij de aandacht voor de toenmalige rechtspraktijk. ${ }^{1218}$ Met deze focus op de praxis maakt het genre zich onontbeerlijk.

1215 Cfr. HOLTHÖFER, "Die Literatur zum gemeinen und partikularen Recht”, 324: Volumen tractatuum ex variis iuris interpretibus collectorum I-IX (1535), Volumen tractatuum ex variis iuris interpretibus collectorum I-XVII (1549) en Tractatus universi iuris, duce et auspice Gregorio XIII Pontifice Maximo in unum congesti, XVIII materias XXV voluminibus comprehendentes I-XXVII (1584). Cfr. M. H. H. ENGELS, Register van auteurs met hun werken zoals die voorkomen in de grote verzameling van het recht: Oceanus Iuris - Venetiis 1584-1584, Leeuwarden, 1999.

1216 HOLTHÖFER, "Die Literatur zum gemeinen und partikularen Recht", 317.

1217 Meer omtrent de disputatio in de Nederlanden, zie: SÖLLNER, "Die Literatur zum gemeinen und partikularen Recht", 575-576. Troje gaat dieper in op de Observatio als vlaggeschip van de humanistische rechtswetenschap: TROJE, "Die Literatur des gemeinen Rechts unter dem Einfluss des Humanismus", 671-689.

1218 Er übernabm nun von der nova methodus, deren Gebrauch sich manches seiner Exemplare in den Zusätzen zum Werktitel ausdrücklich rühmen, nur den ungebundenen Darstellungsstil und die Aufnabme der antiken Klassiker in den Zitatenschatz, nicht dagegen den Ausschluss der gelehrten Tradition des Mittelalters, zu der als weiteres Argumentationsmaterial nun die bumanistische Jurisprudenz. und vor allem die 
Belangrijk hierbij is het feit dat men steeds meer lokaal recht en forensische literatuur in het geheel gaat betrekken. Hoewel in wezen de thematiek vergelijkbaar is met die van het oude traktaattype, gaat men dus meer en meer oog hebben voor particulierrechtelijke materie. Het genre kent een verspreiding over gans gemeenrechtelijk Europa, ondanks het feit dat het zich voornamelijk concentreert in Zuid-Europa. ${ }^{1219}$

Aan de hand van het al dan niet voorkomen in de Venetiaanse verzameling Tractatus universi iuris van $1584 \mathrm{kan}$ ik nu in principe de geallegeerde traktaten opdelen over de categorieën 'oud' en 'nieuw'. Omdat ik het exhaustieve karakter van de traktatenverzameling betwijfel, heb ik ervoor geopteerd enkel aan te geven welke traktaten er daadwerkelijk in voorkomen en bijgevolg, aldus Holthöfer, als middeleeuws mogen beschouwd worden. Het betreft hier de volgende werken: Tractatus de praesumptionibus (1551) van Andrea Alciato, Tractatus de tutore et curatore ac usufructu mulieri relicto (1571) van Borgnino Cavalcani, Tractatus de expensis et meliorationibus (1578) van Juan Garzia de Saavedra, Tractatus de inventario heredis (1571) van Sebastiano Monticello, Tractatus perutilis de pignoribus et hypothecis (1535) van Antonio Negusanzio de Fano, Tractatus de notbis spuriisque filiis (1550) van Gabriele Paleotti, Tractatus de testamentis conjugum (1585) van Pieter Peck, Tractatus de decretis caeterisque solemnitatibus in contractibus minorum (1574) van Ottavio Simoncelli, De rebus dubiis et quaestionibus in iure controversis tractatus sex van Nicolas du Val en de traktaten Tractatus de contractibus Mercatorum (1553) en Tractatus de adiecto (1553) van Benvenuto Stracca. Dat ik het uitputtende karaklter van de verzameling betwijfel, impliceert dat traktaten die er niet in voorkomen, niet noodzakelijk als humanistisch hoeven beschouwd te worden. De mogelijkheid bestaat namelijk dat zij door de samenstellers van de verzameling over het hoofd gezien werden. Bij wijze van volledigheid geef ik de 21 traktaten, waar het hier om gaat, in voetnoot weer. ${ }^{1220}$ Uiteindelijk werden elf

partikularrechtliche und forensische Literatur binzukommt. Oft werden sachlich einschlägige Decisionen nun sogar im vollständigen Originalwortlaut -z. T. in Erst veröffentlichung-als Anbang mit abgedruckt und bei neuauflagen des Traktats durch neuere ergänøt; (HOLTHÖFER, "Die Literatur zum gemeinen und partikularen Recht”, 317-318.)

Ook Söllner wijst erop dat het traktaat zeer mooi laat zien hoe middeleeuwse denk- en voorstellingsvormen onder invloed van het juridisch humanisme plaats moeten maken voor meer vrijere varianten. (SÖLLNER, "Die Literatur zum gemeinen und partikularen Recht", 573-574.)

${ }^{1219}$ HOLTHÖFER, "Die Literatur zum gemeinen und partikularen Recht”, 316-318.

1220 Dispunctiones (1518) van Andrea Alciato, Tractatus de coniecturata mente defuncti ad methodum redigenda (<1599) van Diego Rodrigo Alvarado, Tractatus de partitionibus bonorum, communium inter maritum et uxorem et filios, et heredes eorum (1586) van Antonio Ayerve de Ayora, Les cuvres de Jean Bacquet des droicts du domaine de la couronne de France (1601) van Jean Bacquet, Tractatus varii $(<1546)$ van Egidio Bossi, Tractatus de usuris (1542) en Extricatio labyrinthi dividui et individui (1562) van Charles Dumoulin, Tractatus de successionibus quae ab intestato deferuntur (1566) van Valentin Forster, Paraphrase du droict de retraict lignager (1564) van François Grimaudet, Tractatus de iuramento confirmatorio et aliis in iure variis resolutionibus $(<1618)$ van Juan Gutierrez, De substitutionibus tractatus (1591) van Niccolo Intriglioli, De arbitrariis iudicum quaestionibus et causis (1587) van Jacopo Menocchio, De Hispanorum primogenitorum origine ac natura libri quattuor (1573) 
van de 32 traktaten in totaal als middeleeuws bestempeld. De overige 22 behoren mogelijk tot de groep van de traktaten van het nieuwe type.

Wat de Singulariae betreft, is het uiterst moeilijk gebleken te achterhalen in welke mate er hier sprake kan zijn van humanistische invloeden. Er bestaat immers te weinig literatuur over de (vaak al te obscure) auteurs. Wel staat vast dat binnen de Memorieboeken de nadruk ligt op de zestiende-eeuwse, Duitse jurist Michael Grass. De overige allegaties verwijzen daarentegen allemaal naar middeleeuwse auteurs. Ook het genre op zich wordt niet expliciet als een produkt van het juridisch humanisme omschreven. Dit is wel het geval wat betreft het literatuurtype der Quaestiones. Hier gaat het immers om een modern genre dat pas echt doorbreekt in de tweede helft van de zestiende eeuw. Bovendien houdt het zich bijna uitsluitend bezig met de Usus modernus. ${ }^{1221}$ Alle negentien allegaties naar de Quaestiones kunnen dan ook zonder twijfel tot het humanistische kamp gerekend worden. Ook uit ons overzicht blijkt overigens dat alle werken waarnaar deze referenties verwijzen dateren van de periode na 1550. Ook de auteurs ervan worden doorgaans geassocieerd met het juridisch humanisme. Ik denk hierbij in de eerste plaats aan iemand als de Spaanse jurist Diego Covarubias y Leyva. Hoewel hij tevens als vertegenwoordiger van de Spaanse Laatscholastiek beschouwd kan worden, heb ik ervoor geopteerd hem hier onder te brengen. ${ }^{1222}$ De werken waarmee hij in de Memorieboeken werd geallegeerd, hebben me tot deze beslissing aangezet. Omwille van zijn enorme geleerdheid, zijn vele Griekse en antieke citaten en zijn onderzoek op numismatisch vlak, plaatst Seelmann hem in der Nähe des juristischen Humanismus. ${ }^{1223}$ Ook Andreo Fachineo mag zonder twijfel als humanistisch geïnsprireerd jurist bestempeld worden. Hij wordt immers met een werk geallegeerd dat behoort tot de typisch humanistische categorie van de Quaestionis. Samen zijn beide auteurs goed voor maar liefst vijftien van de negentien allegaties. Naast hen wil ik nog wijzen op de aanwezigheid van personen als de Franse jurist-humanist, François Hotman, de Spanjaarden Agustin Berò en Antonio Gomez, en Hartmann Pistoris uit het Heilige Roomse Rijk. Zij vervolledigen de rij. Gezien hun plaats in de tijd en het typisch humanistische karakter van het genre van de Quaestionis, heb ik deze werken als sporen van juridisch humanisme beschouwd.

Wat de Annotationes betreft, kan ik me alleen maar baseren op de auteur zelf in plaats van het werk in kwestie. ${ }^{1224}$ Op deze manier lijkt alles evenwichtig verdeeld. Enerzijds tref ik twee allegaties aan naar overduidelijk middeleeuwse juristen, namelijk Giovanni

van Luis de Molina Morales, Trias judiciel du second notaire (1575), Instrument du premier notaire (1576) en Secrets du troisième et dernière notaire (1578) van Jean Papon, De utroque retractu, municipali et conventionali (1541) van André Tiraqueau, Tractatus de codicillaris clausulae effectibus et defectibus (1596) van Fabio Torretti en De succesionum creatione, progressu, effectuque et resolutione tractatus (1559) van Fernando Vasquez de Menchaca.

${ }^{1221}$ HOLTHÖFER, "Die Literatur zum gemeinen und partikularen Recht”, 320.

1222 Omtrent de de kritiek van de Spaanse, laatscholastieke auteurs als echo van de humanisten uit Frankrijk, zie: BELLOMO, Common Legal Past of Europe, 230.

1223 SEELMANN, "Covarubias (Covarruvias) y Leyva, Diego de", 149. Ook hij wijst op Covarubias' aandacht voor laatscholastieke themata.

1224 De beschikbare literatuur laat in dezen te wensen over. 
d'Andrea en Alessandro di Tartagni; anderzijds gaat het om twee referenties naar juristen die werkzaam waren in de tweede helft van de zestiende eeuw, met name de Italiaan Pietro Follerio en de Fransman Etienne Ranchin.

Rest me enkel nog de procesrechtelijke werken. Wat de Practica betreft, kan ik alleen maar stellen dat dit een genre is dat zich, net als de Singulariae, niet gemakkelijk leent tot het aanduiden van sporen van juridisch humanisme. Uiteraard bevat het een aantal auteurs die geassocieerd kunnen worden met de nieuwe wind die er doorheen rechtswetenschappelijke middens waaide in de zestiende eeuw. Ik denk opnieuw aan de Leuvense hoogleraar, Pieter Peck, maar ook aan de Franse juristen Jean Imbert en Pierre Rebuffi. Toch blijft hun aandeel beperkt. Bovendien situeert de belangrijkste figuur in deze groep, namelijk Wielant, zich nog volop in de middeleeuwen. ${ }^{1225}$ Daarenboven komt het procesrechtelijke traktaat van Pieter Peck (Tractatus de iure sistendi, 1564) tevens voor in de Venetiaanse traktatenverzameling, waarvan de inhoud door Holthöfer als middeleeuws werd bestempeld en publiceerde Rebuffi zijn Tractatus exceptionum atque actionum reeds in 1535.

\section{Particulier recht}

Een tweede groep van rechtsgeleerde werken waarnaar gedurende het redactieproces van de Antwerpse Consuetudines compilatae frequent werd teruggegrepen, omvat de vertegenwoordigers van de nog jonge particuliere rechtsleer. Deze groepeert naast de commentaren bij het reeds geredigeerde gewoonterecht en de overzichten van vorstelijke wetgeving, eveneens het literaire genre van de Collationes en Censurae. In beide gevallen gaat het om vergelijkende commentaren waarbij het gewoonterecht wordt vergeleken met het geleerde recht. Het verschil zit hem hierin dat men bij de Collatio vertrekt vanuit de gewoonterechtelijke tekst, waar men bij de Censura het ius commune als basis hanteert. Omwille van de rol die hier weggelegd is voor het particuliere recht werden beide literatuurtypes in deze tweede categorie ondergebracht (en dus niet in de categorie van het geleerde recht).

Dat ditzelfde particuliere recht hier een tweede plaats inneemt, is vanzelfsprekend. Het gaat hier immers om de redactie van het Antwerpse gewoonterecht. Bovendien is het evident dat de costumiere rechtsleer -zoals in tabel 3.7 is te zien- dominant is binnen deze groep. Maar liefst 75 procent van de allegaties naar particulierrechtelijke commentaren is afkomstig van costumierrechtelijke werken. De impact van de legislatieve rechtsleer is zo goed als te verwaarlozen. Ook ten aanzien van het totale aantal allegaties in de onderzoeksgroep representeert deze subcategorie, net als die van de Collationes en Censurae overigens, slechts drie procent van het geheel. De gewoonterechtelijke commentaren van hun kant zijn goed voor niet minder dan een vijfde van alle relevante allegaties in Memorieboeken.

1225 Een korte introductie in de civiele procedure zoals uiteengezet bij Wielant en de Damhouder is te vinden bij Storme: STORME, "Un manuel de procedure dans les Pays-Bas du XVIe siècle", 259-263. 
Tabel 3.7 Aantal allegaties per subcategorie binnen de particulierrechtelijke literatuur

\begin{tabular}{|c|c|c|c|c|c|}
\hline \multirow[t]{8}{*}{ Gewoonterecht } & \multirow[t]{8}{*}{126} & \multirow[t]{7}{*}{ Frankrijk } & \multirow[t]{7}{*}{125} & le Caron & 50 \\
\hline & & & & Guenoys & 43 \\
\hline & & & & Dumoulin & 10 \\
\hline & & & & Choppin & 9 \\
\hline & & & & d'Argentré & 5 \\
\hline & & & & de Chasseneuz & 4 \\
\hline & & & & Anderen $^{1226}$ & 4 \\
\hline & & Spanje & 1 & & \\
\hline Collatio/Censura & 22 & Frankrijk & 22 & & \\
\hline Wetgeving & 20 & Frankrijk & 16 & & \\
\hline & & Spanje & 4 & & \\
\hline
\end{tabular}

De discrepantie tussen het aandeel van de legislatieve rechtsleer en haar costumiere evenknie is frappant. ${ }^{1227}$ In tegenstelling tot het aandeel dat de wetgeving inneemt als zuivere rechtsbron, zijn de rechtswetenschappelijke commentaren op de legislatieve bronnen hier heel wat minder prominent aanwezig. Daar waar de stedelijke en vorstelijke wetgeving één van de hoekstenen vormde waarop de Consuetudines compilatae werden gebouwd, wordt er hier slechts negentien maal verwezen naar de opmerkingen van juristen bij deze wetgeving. Dit is evenwel een logische vaststelling. De vorst, zeker in de Nederlanden, had nog maar net het begin van zijn opmars als bron van alle recht achter de rug. Frankrijk stond in dezen al een pak verder. Het land was reeds sinds langere tijd een sterke monarchie, waar de Zeventien Provinciën eerder een aaneenschakeling waren van op onafhankelijkheid berustte vorstendommen, die enkel hun lokale soeverein erkende. In de landen van 's herwaarts over was het dan ook wachten tot 1484 vooraleer een eerste algemene ordonnantie werd uitgevaardigd. ${ }^{1228}$ Wegens het ontbreken van systematische, vorstelijke wetgeving, ontbrak tevens de voedingsbodem voor compilaties van landsheerlijke

1226 Het gaat hier om Nicolas de Bohier, Jean Papon, Pierre Pithou en Gabriel Labbé de Montveron.

1227 Ook omtrent dit legislatieve genre kan ik dezelfde opmerkingen maken als welke ik bij de rechtspraak heb gemaakt. Zo verteert ook dit genre niet altijd even gemakkelijk de toelatingscriteria, aangezien er vaak naar de wetgeving in se werd verwezen in plaats van de opinio doctorum aangaande deze legislatieve regelgeving. Dit verklaart onder meer de afwezigheid van de Italiaanse jurist Matteo d'Afflitto en zijn Singularis Lectura super omnibus sacris Constitutionibus Regnorum utriusque Siciliae citra et ultra uit 1517 in onze lijst van geallegeerde werken. Maar veel meer nog wordt er in de Memorieboeken naar de Franse wetgeving gerefereerd, zoals ze is weergegeven in de commentaar van Louis le Caron op Brissons Codex Henricianus. Dit geldt in mindere mate ook voor de compilatie van Pierre Rebuffi (Commentarii in constitutiones seu ordinationes regias).

1228 Toch betrof het hier slechts ordonnanties welke het domein van de gewoonte vermeden. Ze waren niet meer dan een antwoord op noden die zich in elk vorstendom lieten voelen. Zuivere wetgeving vanuit een machtsgevoel dit te mogen doen was dit niet. Dit verandert met Karel V. (Cfr. GRANDGAGNAGE, Influence de la législation civile française, 2-4.) 
ordonnanties en plakkaten. Bijgevolg bleef ook het ontstaan van een legislatieve rechtsleer van eigen bodem noodgedwongen uit.

Juist doordat Frankrijk op een langere legislatieve traditie kon terugplooiien, bestond er reeds in de zestiende eeuw een vruchtbare bodem voor het ontstaan van de eerste overzichten van vorstelijke, wetgevende activiteiten. Mijlpalen binnen dit nieuwe genre waren enerzijds de compilatie van Pierre Rebuffi, Ordonnances, loix, statuts et édicts royaulx (1547), en anderzijds die van Barnabé Brisson (1531-1591), beter bekend als de Codex Henricianus (1583) en later met succes becommentarieerd door Louis le Caron. Ook het overzicht van Pierre Guenoys, met de naam La conférence des ordonnances (1593), verdient in dit opzicht vermeld te worden. Al deze compilaties kennen, zoals ook hier is gebleken, een grote verspreiding en autoriteit, ondanks het feit dat het hier steeds gaat om private compilaties.

Spanje van zijn kant, dat eveneens een sterke monarchale traditie kende, laat een vergelijkbare ontwikkeling zien. De dynamische spanning tussen gewoonte en wet maakt dat beide rechtsbronnen reeds vroeg met elkaar verstrengeld geraken. De eerste wetgeving, in wezen een combinatie van geredigeerd wetten- en gewoonterecht, verschijnt vanaf de dertiende eeuw. Voorbeelden van zulke compilaties van particulier recht zijn terug te vinden in de Fuero Real (1252-1255) en de Libro de leyes of Siete Partidas (1263) van koning Alfonso de Wijze (1226-1284).1229 Meer zuivere wetgeving ontstaat met de beslissingen van de Spaanse 'Cortès'. ${ }^{1230}$ Deze vergaderingen zijn vergelijkbaar met de Statenvergaderingen zoals die in de Nederlanden bestonden. Het merendeel van deze Cortès werd uiteindelijk verzameld in de Nueva Recopilación van 1567.1231 Al deze compilaties werden al gauw becommentarieerd, en dit respectievelijk door Gaspar de Baeza (Fuero Real), Gregorio Lopez (Siete Partidas), Antonio Gomez (Siete Partidas, Leyes de Toro) en Juan Gutierrez (Siete Partidas, Nueva Recopilación). ${ }^{1232}$

Italië daarentegen is op dit ogenblik en in dit opzicht nog te sterk verdeeld. Toch kennen ook de vele deeluitmakende (stads)staten hun eigen compilaties van lokaal recht. Desalniettemin is het wachten tot de vijftiende eeuw vooraleer de eerste, belangrijke compilaties verschijnen. Eén van de standaardwerken, waarmee het genre een doorbraak wist te forceren, is de Singularis lectura super omnibus sacris Constitutionibus Regnorum utriusque Siciliae citra et ultra (1517) van Matteo d'Afflitto. Een werk dat ook in de Memorieboeken wordt vermeld, doch evenzeer door onze selectiecriteria uit de onderzoeksgroep werd geëlimineerd. Het Heilige Roomse Rijk van zijn kant lijkt voorlopig nog een sterk centraal gezag te ontbreken. Van noemenswaardige compilaties van vorstelijke wetgeving kan er dan ook geen sprake zijn. Daarvoor is het wachten tot de zeventiende eeuw. ${ }^{1233}$

Ook in de Nederlanden is het een kwestie van tijd. Dat er voor de zeventiende eeuw nog geen sprake kan zijn van legislatieve rechtsleer is een logisch gevolg van het feit

${ }^{1229}$ BELLOMO, Common Legal Past of Europe, 100. VANDERLINDEN, Concept de code, 23-24.

1230 VANDERLINDEN, Concept de code, 26-27.

1231 VANDERLINDEN, Concept de code, 30-31.

1232 Cfr. HOLTHÖFER, “Die Literatur zum gemeinen und partikularen Recht”, 302-307.

1233 Cfr. HOLTHÖFER, “Die Literatur zum gemeinen und partikularen Recht”, 215. 
dat het te becommentariëren object nog steeds ontbreekt. Van zodra er echter wel sprake kan zijn van legislatieve activiteiten, dan blijken deze zowel kwantiteit als kwaliteit te ontbreken: "Combien faible est leur nombre, et même, il faut le dire, leur importance absolue, à côté de toutes ces ordonnances françaises que nous avons eu l'occasion de citer, et qui contiennent des règlements étendus sur presque toutes les matières de la jurisprudence! ... En Belgique, au contraire on ne trouve guère que des dispositions de détail: de matière de droit traitée dans son ensemble, il n'en est presque aucune."1234 Hun aantal was dus net als hun inhoud beperkt, wat hen minder aantrekkelijk maakte als te becommentariëren wetgeving. Wel konden de compilatores van de Consuetudines compilatae gebruik maken van de Keyserlicke statuten Ordonantien, Costumen, ende Ghewoonten, ende bysonder elcker Stadt techten, principalijck den keyserlijcken landen aengaende (1519), samengebracht door Thomas Murner (1475-1537).1235 Maar echte, officiële, rechtsgeleerde commentaren op (compilaties van) vorstelijke wetgeving bestonden in deze contreien nog niet. Deze verschijnen pas halverwege de zeventiende eeuw, wanneer Antoon Anselmo (15891668), advocaat en schepen te Antwerpen, verschillende werken uitgaf waarin hij de belangrijkste wetgeving verzamelde (Placcaetboeken van Brabant, 1648, en Codex Belgicus, 1649), analyseerde (Tribonianus Belgicus, 1662) of becommentarieerde (Commentaria ad perpetuum edictum, 1652). ${ }^{1236}$ Ook zijn stadsgenoot, Frans van der Zype (1580-1650), had in 1635 reeds een synthese gemaakt van het 'Belgische' recht, de Notitia juris belgici. Deze Zypaeus bestudeerde vooral de verordeningen van de zestiende en zeventiende eeuw, welke grotendeels verantwoordelijk waren voor de unificatie van het 'Belgische' recht, aldus Gilissen. ${ }^{1237}$

De nadruk binnen de Memorieboeken ligt bijgevolg op de reeds voor handen zijnde Franse en Spaanse compilaties. Wat Spanje betreft, wil ik hier wijzen op de drie allegaties naar Antonio Gomez en zijn commentaar bij de Spaanse Leges Tauri van 1505: Ad Leges Tauri Commentaria (1552). ${ }^{1238}$ Toch zijn het ook nu weer de Franse

1234 GRANDGAGNAGE, Influence de la législation civile française, 106-110. Dit is het grote verschil met de Franse ordonnanties. Deze laatste zijn veel uitvoeriger en meer allesomvattend. In de Nederlanden daarentegen treft men vooral regionale detailordonnanties aan. Lange tijd wordt het traditionele gebouw van costumiere en romeinsrechtelijke bouwstenen overeind gehouden en enkel wanneer het echt nodig is, worden er legislatieve reparaties aan uitgevoerd. Het gebouw blijft intact. Bovendien nam de vorst zelden het initiatief en waren de ordonnanties een antwoord op de desiderata van de lokale autoriteiten, aldus Grandgagnage.

1235 Cfr. supra, hoofdstuk 1, paragraaf 2, Deel VI. Omtrent Murner, cfr. A. ERLER, Thomas Murner als Jurist (Frankfurter wissenschaftliche Beiträge. rechts- und wirtschaftswissenschaftliche Reihe. Band 13), Frankfurt am Main, 1956. KISCH, Studien zur bumanistischen Jurisprudeñ, 251-257.

${ }^{1236}$ Cfr. DEKKERS, Bibliotheca Belgica Juridica, 4-5.

1237 Cfr. GILISSEN, Historische inleiding, 360. Cfr. DEKKERS, Bibliotheca Belgica Juridica, 198.

1238 Ook de ene verwijzing naar de commentaar van Gregorio Lopez op de Siete Partidas heb ik hier ondergebracht. Hoewel het in wezen een verzameling van wetten- en gewoonterecht betreft, werd de tekst officieel als the general law of the kingdom afgekondigd. (Cfr. BELLOMO, Common legal past of Europe, 100.) Ook Vanderlinden omschrijft deze tekst als legislatief. 
juristen die de grootste indruk nagelaten hebben bij de Antwerpse commissie. Dit laat zich voelen in het aantal allegaties naar personen als Pierre Rebuffi en Louis le Caron. De Commentarii in constitutiones seu ordinationes regias van eerstgenoemde verzamelt de wetgeving van de Franse koningen Lodewijk de Heilige tot Hendrik II en werd negen maal geallegeerd. Het werk dateert van 1554-1555. Aanvullend hierop hanteerden de commissieleden le Carons commentaar bij Le Code du Roy Henry III -beter bekend als de Codex Henricianus- van Barnabé Brisson, welke in een latere uitgave van 1587 eveneens de wetgeving van Hendrik IV bevat. ${ }^{1239}$ Het werk is goed voor zeven referenties. Samen vertegenwoordigen zij zestien van de negentien allegaties. ${ }^{1240} \mathrm{Dat}$ er zulk een noemenswaardige invloed was uitgegaan van de Franse koninklijke ordonnanties, behoorde reeds lange tijd tot het collectieve geheugen van de rechtshistorici. Grandgagnage heeft het aangetoond: la plupart des changemens qui ont été introduits dans l'ancien droit Belgique émanaient des ordonnances françaises. 1241

Dat ik hier nu te maken heb met een relatief jong genre, impliceert eveneens dat er nauwelijks auteurs ontbreken die men hier a priori zou mogen verwachten. Dit simpelweg omdat ze nog niet bestonden. Toch lijkt er, gezien de hang naar Franse auteurs van de commissieleden, één grote afwezige -of beter 'ondergewaardeerde'- te zijn, met name Pierre Guenoys. Zijn Conférence des ordonnances royales distribuée en XII livres a l'imitation et selon l'ordre du Code de l'empereur Justinien, voor het eerst uitgegeven in 1593, komt in de Memorieboeken slechts één maal aan bod, waar zijn Conférence des coutumes het meest geallegeerde werk uit ons overzicht is. Bovendien kende het werk een enorme verspreiding doorheen gans Europa, gezien haar aanwezigheid in het merendeel van de hedendaagse wetenschappelijke bibliotheken. Wat de verklaring voor haar bescheiden aandeel is, daar heb ik nog steeds het raden naar. De enige reden, die ik kan bedenken, is de algemene ondervertegenwoordiging van de legislatieve rechtsleer in de Memorien op de Costumen. Is het genre te jong of genoot het

(VANDERLINDEN, Concept de code, 92) Op deze manier loopt het totale aantal Spaanse allegaties op tot vier.

${ }^{1239}$ Cfr. E. HOLTHÖFER, "Brissonius (Brisson), Barnabas (Barnabé)", M. STOLLEIS red., Juristen: ein biographisches Lexikon von der Antike bis zum 20. Jahrhundert, Munchen, 2001, 104. M. SUEL, "Le président Brisson et la codification", Droits: revue française de théorie juridique, 24 (1996), 31-44.

1240 De commissieleden laten zich opnieuw van hun efficiëntste kant zien. Ze hanteren verzamelwerken in plaats van werken die de wetgeving afzonderlijk per koning groeperen, waarvan een overzicht te zien is op HOLTHÖFER, "Die Literatur zum gemeinen und partikularen Recht”, 267-272. Op basis van deze opsomming lijkt Philibert Bugnyon de grote afwezige. Hij schreef maar liefst vier commentaren op Franse, wetgevende documenten. In de Memorieboeken daarentegen wordt slechts één maal naar de auteur gerefereerd. Bovendien betreft het een tweederangse allegatie. Om welk werk het gaat, is niet op te maken op basis van de beschikbare informatie in de Memorieboeken.

1241 GRANDGAGNAGE, Influence de la législation civile française, 110-113. Ondanks de veelvuldige oorlogen tussen keizer Karel V en de Franse koning Frans I, zag de Habsburgse landsheer er niet van af de Franse wetgeving te copiëren. Blijkbaar prevaleerde het gezonde verstand over de vete. Bij Grandgagnage staat letterlijk te lezen dat plus d'une fois l'ordonnance de François Ier servit textuellement de modèle à l'ordonnance de Charles-Quint. 
te weinig aanzien? Vermoedelijk was het minder relevant voor het Antwerpse gewoonterecht en volstonden dus ook de compilaties van Rebuffi en le Caron.

Uiteindelijk gaat het hier slechts om drie procent van alle allegaties van de onderzoeksgroep, terwijl de costumiere rechtsleer maar liefst een vijfde voor haar rekening neemt. De belangrijkste vaststelling hierbij is dat 125 van de 126 allegaties naar commentaren op het Franse gewoonterecht verwijzen. Spanje, het Heilige Roomse Rijk en de Italiaanse staten blijken in dit opzicht verwaarloosbaar. Dat men zijn blik op de zuiderburen richt, ligt in principe voor de hand. Enkel in Frankrijk was het redactieproces immers reeds in zulk een vergevorderd stadium aanbeland, dat men niet alleen reeds een eerste réformation des coutumes had zien geschieden, maar bovendien was er reeds een aanzienlijke hoeveelheid commentaren verschenen op de genotuleerde costumen van de verschillende regio's. Het genre kende in de eerste helft van de zestiende eeuw een doorbraak met het verschijnen van belangrijke commentaren onder meer van de hand van juristen als Nicolas de Bohier, Barthélémy de Chasseneuz, André Tiraqueau en vooral Charles Dumoulin. Zij brachten de particulierrechtelijke literatuur tot op een wetenschappelijk niveau en zorgden ervoor dat het in de loop van de tweede helft van diezelfde eeuw als een aan de gemeenrechtelijke commentaren gelijkwaardig geworden produkt van de wetenschappelijke literatuur beschouwd kon worden. Een volgende generatie die hierop voortbouwde, omvat de commentaren van auteurs als Bertrand d'Argentré en Guy Coquille. ${ }^{1242}$

Ook in Spanje en zelfs Italië verschijnen op dit ogenblik de eerste produkten van de costumiere rechtsleer. Omdat hun belang ten aanzien van de Antwerpse costumen zo goed als nihil blijkt te zijn, ga ik hier niet dieper op in. ${ }^{1243}$ Wat het Heilige Roomse Rijk en de Nederlanden betreft, is het wachten tot het einde van de zestiende eeuw. Het toetreden van beide regio's tot de groep van landen waar de particulierrechtelijke rechtsleer op een vergelijkbaar niveau is gekomen als dat van de gemeenrechtelijke commentaren, markeert eveneens het hoogtepunt van het genre. In de Zuid- en West-Europese stamlanden komt er circa 1630 een einde aan die bloeitijd. In de Nederlanden en het Heilige Roomse Rijk daarentegen blijft het genre tot en met de ganse zeventiende eeuw zijn kracht behouden. ${ }^{1244}$

Omwille van hun belang voor de Antwerpse Consuetudines compilatae, zal ik me concentreren op het Franse luik binnen de Europese, costumiere rechtsleer. Wat de voornoemde voortrekkers uit de aanvangsperiode van het genre met elkaar verbindt, is het feit dat zij zich in de eerste plaats concentreerden op de coutumes van afzonderlijke steden of regio's binnen het Franse koninkrijk. Enkel Nicolas de Bohier, Pyrrhus Angleberme (ca.1470-1521) en Jean Sainson (zestiende eeuw) brachten al in de eerste helft van de zestiende eeuw de costumen van drie verschillende regio's

${ }^{1242}$ Cfr. HOLTHÖFER, “Die Literatur zum gemeinen und partikularen Recht”, 214.

1243 Ook Italië en Spanje kennen een vergelijkbare traditie. Doch, zij spelen hier geen doorslaggevende rol. Cfr. HOLTHÖFER, "Die Literatur zum gemeinen und partikularen Recht", 214-215.

1244 Omtrent dit historisch overzicht, cfr. HOLTHÖFER, "Die Literatur zum gemeinen und partikularen Recht”, 214-215. 
(Berry, Tours en Orléans) bij elkaar. ${ }^{1245}$ Tot de tweede helft van de zestiende eeuw zou dit echter een uitzondering blijven. Het is pas vanaf het ogenblik dat Louis le Caron het bestaan van een onderliggend, gemeenschappelijk droit français oppert, dat men meer consequent de vele diverse coutumes naast elkaar gaat leggen met de bedoeling zo te komen tot de abstracte, rationele basis van algemene principes geldig voor gans Frankrijk, welke onder dit oppervlak van lokale particulariteiten verscholen zit. ${ }^{1246}$ Deze comparatistische traditie gaat op zoek naar de grootste gemene deler, en het is Charles Dumoulin die als eerste aan de slag gaat. Na zijn Grand coustumier general, gepubliceerd in 1567 volgden verschillende gelijkaardige werken van onder meer Pierre Guenoys (La conférence des coutumes, 1596), Guy Coquille (Institutions au Droit des Français, 1607), Pierre de l'Hommeau (Les maximes générales de Droit français, 1605) en Antoine Loisel (Institutes coustumières, 1607).1247 Wat het zo te destilleren droit commun coutumier nu juist inhield, en in welke mate dit zou mogen fungeren als subsidiair recht in concurrentie met het Romeinse recht, zou nog gedurende lange tijd de Franse costumiere rechtsgeleerden parten spelen. Ook de vraag of het droit commun coutumier wel het recht heeft zich te profileren als het droit commun van het Franse volk, zal hen blijven boeien.

Enkel in Frankrijk kon men dus reeds spreken van het bestaan van een costumiere rechtsleer. Doorgaans wordt in de huidige literatuur de gewezen advocaat van het Parijse parlement, Charles Dumoulin, hierin als grote voorganger aangeduid. Hoewel zijn boeken op de index van verboden boeken terecht zouden komen, voornamelijk wegens zijn aversie ten aanzien van de macht van de Kerk in de staat, wist hij zich op te werpen tot de pater familias van de Franse costumiere rechtsleer. Weinig verbaasd was ik dan ook vast te stellen dat hij ook in de Memorien op de Costumen tot de vier meest geallegeerde auteurs behoorde. Naast de reeds vermelde traktaten, werden verschillende van zijn gewoonterechtelijke commentaren aangehaald (o.a. die bij de coutumes van Parijs, Bourbon, Orleans), waaronder die op het Parijse gewoonterecht de voornaamste was en welke tevens zijn grote doorbraak betekende. Tegenover Dumoulin staat een andere protagonist van de Franse costumiere rechtsleer, Bertrand d'Argentré. Deze Bretoen becommentarieerde het gewoonterecht van Bretagne in zijn Coustumes générales du pays et duché de Bretagne (1568). Daar waar Dumoulin lak had aan de tegenstrijdigheden in de geschreven gewoonterechten, en opperde er een droit coutumier commun voor het ganse rijk uit af te leiden, is d'Argentré een verdediger van het leenstelsel en voorstander van het gewestelijk particularisme gebleken. Net zoals de commentaar van d'Argentré werden die van Choppin, omtrent de costumen van

1245 Consuetudines generales Bituricensis, Turonensis, ac Aurelianensis praesidatuum (1520).

1246 In deze zoektocht naar meer abstracte uitdrukkingsvormen en minder particularismen, weerklinkt het geluid van het juridisch humanisme. Het casuïstieke maakt plaats voor het abstracte systeem. Bovendien is men overtuigd van het bestaan van een juridisch systeem dat volledig losstaat van het ius commune. Ook deze opstelling getuigt van een zekere ontvoogdingsdrang.

1247 Cfr. HOLTHÖFER, "Die Literatur zum gemeinen und partikularen Recht”, 300. Omtrent Pierre de l'Hommeau, zie: M. REULOS, "L'importance des praticiens dans l'humanisme juridique”, in Pédagogues et juristes (De Pétrarqua à Descartes. 4), Parijs, 1963, 130-131. 
Anjou, en de Chasseneuz, omtrent de costumen van Bourgondië, meermaals door de commissieleden geraadpleegd. ${ }^{1248}$

Toch dient bij dit alles opgemerkt te worden dat de allegaties naar de gewoonterechtelijke commentaren van Dumoulin slechts een kwart representeren van het aantal referenties naar zijn totale oeuvre. Ik kan me niet van de indruk ontdoen dat Dumoulin duidelijk niet in de eerste plaats als gewoonterechtelijk expert wordt geapprecieerd. Voor de leden van de commissie blijken eerder auteurs als Louis le Caron en Pierre Guenoys meer gewicht in de schaal te leggen. De tien allegaties naar het costumiere oeuvre van Dumoulin staan in schril contrast met de respectievelijk vijftig en 43 referenties naar de gewoonterechtelijke werken van voornoemde le Caron en Guenoys. Is dit louter toeval of kan er meer achter gezocht worden? Speelt het feit dat Dumoulin op de index pronkt een rol? Of staan zijn ambities om een geünificeerd Frans recht zonder Romeinsrechtelijke invloed op te stellen het gebruik van zijn oeuvre in de weg? ${ }^{\text {1249 }}$ Dat men pertinent auteurs met een voorkeur voor de hervormde kerk weigert, is zeker niet het geval. Dat blijkt zeer duidelijk uit ons overzicht van geallegeerde auteurs. Hoezeer het geven van een verklaring een moeilijke kwestie blijkt te zijn, kan ik er niet omheen dat het zo lijkt dat men Dumoulin uit de weg wil gaan. Deze tweederangspositie die aan hem wordt toegekend, wordt nogmaals bevestigd wanneer de commissieleden de keuze hebben tussen twee overzichten van alle Franse coutumes. Enerzijds is er de Grand coutumier général de la France et des Gaules van Dumoulin uit 1567, anderzijds de Conférence des coutumes tant générales, que locales et particulieres du royaume de France uit 1596 van de hand van Pierre Guenoys. ${ }^{1250}$ Het is een veeg teken dat ik nergens de Grand Coutumier van Dumoulin in de Memorieboeken kan terugvinden, waar de Conférence des coutumes van Guenoys goed is voor maar liefst 43 allegaties. Deze lieutenant particulier au siège et ressort $d^{\prime} Y$ ssoudin et Berry is in de historiografie steeds een duistere figuur geweest. ${ }^{1251}$ Desalniettemin opteren de Antwerpse redacteurs voor zijn overzicht van het Franse gewoonterecht en verwijzen zij maar liefst 43 maal naar zijn rechtsgeleerde opinie. Bovendien heeft het een niet te onderschatten rol gespeeld als primaire maar vooral

1248 Andere gelijkaardige werken, maar dan met minder dan drie allegaties op hun conto, zijn de gewoonterechtelijke commentaren van Gabriel Labbé de Montveron (Berry), Jean Papon (Bourbon), Pierre Pithou (Troyes et Champagne) en André Tiraqueau (Pictonum).

1249 Cfr. LESAFFER, Inleiding tot de Europese rechtsgeschiedenis, 323: de protestante auteurs François Hotman, Charles Dumoulin en later ook Antoine Loysel wilden een droit français tot stand brengen, dat vrij van Romeinsrechtelijke invloed was en dat volledig gebaseerd was op de eigen, Franse coutumes.

1250 Naast de verzamelde coutumes van Berry, Tours en Orléans door Nicolas de Bohier, Pyrrhus d'Angleberme en Jean Sainson, waren op het moment van de werkzaamheden van de commissie enkel deze werken nog maar verschenen, althans op basis van de opsomming van Holthöfer in Coings Handbuch: HOLTHÖFER, "Die Literatur zum gemeinen und partikularen Recht", 272.

1251 Met deze titel staat Pierre Guenoys vermeld op de titelpagina van zijn Conférence des ordonnances. Cfr. P. GUENOYS, La Conférence des ordonnances royals distribuée en XII livres à l'imitation et selon l'ordre du Code de l'empereur Justinien, avec plusieurs annotations et observations servans pour l'intelligence d'icelles, Lyon, 1593. 
als secundaire rechtsbron van de Antwerpse Consuetudines compilatae. ${ }^{1252}$ Dat dit vreemd in de oren kan klinken, is niet zo verbazingwekkend. De naam en faam die een jurist uit het verleden vandaag de dag verwerft, is vaak het gevolg van de aandacht die hij vandaag krijgt toebedeeld in de historiografie, waar dit echter evenredig zou moeten zijn met zijn werkelijk belang in het verleden. Vaak lijkt een historisch persoon belangrijker te worden van zodra er een biografie aan hem wordt gewijd. In wezen moet het andersom zijn: zijn belang moet het al dan niet schrijven van een biografie bepalen. Zo blijken op basis van onze bevindingen le Caron en Guenoys biografie-waardig materiaal. Geen van beiden heeft echter tot nog toe een met hun werkelijk belang voor de rechtswetenschap corresponderend aandeel in de geschiedschrijving verworven. ${ }^{1253}$ Steeds werd hen in de literatuur de tweede, misschien wel derde, viool toegewezen. Bovendien lijkt Guenoys meer succes geoogst te hebben met zijn Conference des ordonnances royaux, althans dat leid ik af uit de huidige verspreiding en beschikbaarheid van beide werken. ${ }^{1254}$ In de Memorieboeken zijn de rollen echter omgekeerd. Daar moet de Conférence des ordonnances royaux de duimen leggen voor de Conférence des coutumes.

Dé gewoonterechtkenner bij uitstek blijkt echter Louis le Caron te zijn, althans voor de redacteurs van de Antwerpse Consuetudines compilatae. Hij wordt maar liefst zeventig maal geallegeerd wat correspondeert met 11.6 procent van het totale aantal referenties. Hij is dan ook veruit de meest geallegeerde auteur van het hele gezelschap. Vijftig van deze allegaties verwijzen naar gewoonterechtelijke werken van zijn hand. Nog eens zeventien andere naar een collatio, de Mémorables observations $d u$ droit francois, rapporté au civil et canonique, illustrées des arrests des Cours souveraines de France, en zeven naar een legislatieve commentaar, de reeds aangehaalde Codex Henricianus. Dat dit voor ons enigszins vreemd lijkt, maar het daarom niet per se hoeft te zijn, volgt uit het feit dat in de historiografie nooit dezelfde aandacht aan le Caron werd besteed als dat bijvoorbeeld het geval was bij iemand zoals Dumoulin. ${ }^{1255}$ Dit impliceert echter niet dat le Caron ook in werkelijkheid een jurist van de tweede lijn was. Welke plaats hij exact verdient in de geschiedenis van de costumiere rechtsleer, kan ik op basis van deze gegevens niet bepalen. Daarvoor moet er immers nog heel wat onderzoek geschieden. Maar de vaststellingen gedaan met betrekking tot het Antwerpse gewoonterecht, doen in ieder geval vermoeden dat zijn betekenis niet langer onderschat mag worden. Een belangrijke invloed, kwantitatief uitgedrukt in 21

${ }^{1252}$ Cfr. supra, hoofdstuk 1 , paragraaf 2.

1253 Ook Rials, die verscheidene lessen aan le Caron wijdde, betreurt de bescheidenheid van de literatuur over de Franse jurist. (Cfr. S. RIALS, "Veritas iuris. La vérité du droit écrit. Critique philologique humaniste et culture juridique moderne de la forme", Droits: revue française de théorie juridique, 26 (1997), 155 noot ii.

1254 Deze indruk heb ik gevormd op basis van de talloze elektronische bibliotheekcatalogi welke ik doorheen het ganse onderzoek heb geraadpleegd.

1255 Zo verbaast het me tevens dat de auteur geen afzonderlijk lemma kreeg toegewezen in Stolleis' biografisch overzicht van de grootste juristen doorheen de tijd. Een recent artikel omtrent le Caron werd in 2004 door Leyte geschreven: LEYTE, "Charondas et le droit français". 
allegaties, ging uit van zijn commentaar bij het Parijse gewoonterecht. Verder speelden zijn Responses du droit françois, confirmées par arrests de cours souveraines de France, \& rapportées aux loix Romaines en zijn annotaties bij gewoonterechtelijke overzichten zoals de Somme rural van Jean Bouteiller (1393-1396) en de Grand Coutumier de France van Jacques d'Ableiges (ca.1470-1521) een aanzienlijk rol.

Ook le Carons Mémorables observations du droit françois werd zeventien maal geallegeerd. Dit laatste werk is van het type van de Collatio, een vergelijkende commentaar, waarbij het lokale gewoonterecht wordt vergeleken met het Romeinse recht. Het is echter ook mogelijk dat men vanuit het gemene recht vertrekt. In dat geval spreekt men van Censurae. ${ }^{1256}$ Voorbeelden van dit tweede type zijn in de Memorieboeken terug te vinden bij Jean Imbert (Enchiridion iuris scripti Galliae moribus et consuetudine frequentiore usitati, itemque abrogati, omnibus causidicis et ceteris indicialis Galliae praxis studiosis apprime necessarium et utile, 1556) en Jean Duret (Alliance des lois romaines avec le droit françois, contenu aux ordonnances des rois, arrêts des cours souveraines et coustumes provincials, 1600). Beide genres maken hun opwachting vanaf halverwege de zestiende eeuw. ${ }^{1257}$ Spanje groeit uit tot het land van de Collationes en Frankrijk tot dat van de Censurae. Het gaat duidelijk om landen waar een vruchtbare bodem voor handen is ter vergelijking. Het gaat immers om gebieden van het pays du droit écrit. Juist daarom was er ook nood aan een comparatieve commentaar. In de Nederlanden en het Heilige Roomse Rijk blijft de Collatio uiterst zeldzaam. Ook wat betreft het verschijnen van een eerste vertegenwoordiger van de Censura-traditie is het wachten tot halverwege de zeventiende eeuw. ${ }^{1258}$ De focus op Frankrijk in deze categorie ligt dan ook voor de hand. De negatie van Spanje bezorgt ons meer kopzorgen aangezien de reden ervoor onduidelijk blijft. Omwille van hun aparte (vergelijkende) karakter heb ik beide types in één subcategorie samengevoegd, welke goed is voor een totaal van 22 allegaties. Ook nu weer neemt le Caron het voortouw.

Uit diezelfde Memorien op de Costumen blijkt echter eveneens dat er van de Parijse coutumes niet alleen binnen de Franse landsgrenzen een ongeëvenaarde invloed is uitgegaan, maar dat zij -althans de commentaren erop- ook op niet-Frans gewoonterecht hun stempel hebben weten te drukken. ${ }^{1259}$ Dumoulin noemde ze al

1256 Omtrent de Censurae en de Collationes in Frankrijk, Spanje, Portugal en Italië, cfr. HOLTHÖFER, "Die Literatur zum gemeinen und partikularen Recht”, 224-227. Omtrent de Censurae en de Collationes in het Heilige Roomse Rijk en de Nederlanden, cfr. SÖLLNER, "Die Literatur zum gemeinen und partikularen Recht", 555-557.

${ }^{1257}$ Cfr. HOLTHÖFER, "Die Literatur zum gemeinen und partikularen Recht", 224e.v. Eerst verschijnen de Censurae (Baro, Imbert, Bugnyon), vervolgens de Collationes (le Caron). Cfr. HOLTHÖFER, "Die Literatur zum gemeinen und partikularen Recht”, 297

1258 Een eerste voorbeeld van eigen bodem verschijnt in 1610 van de hand van Paul Buys (+1617): Commentarii breves in universas Pandectas Dni Justiniani, cum differentiis juris canonici et consuetudinum Germaniae, Galliae et Belgicae, ad usum hujus seculi compositi. Cfr. DEKKERS, Bibiliotheca Belgica Juridica, 31. Zie ook: HOLTHÖFER, "Die Literatur zum gemeinen und partikularen Recht", 227.

1259 Omtrent de invloed van de Parijse costumen, cfr. HOLTHÖFER, "Die Literatur zum gemeinen und partikularen Recht", 218. In hoeverre zij ook inhoudelijk invloed hebben 
het caput omnium totius Galliae, Belgicae consuetudinum en ook in de hervormingsperiode van 1555-1581 zou blijken hoezeer de gewoonten van Parijs werden gefavoriseerd. ${ }^{1260}$ Christofle de Thou (1508-1582), toenmalig president van het parlement van Parijs, leidde deze reformatie en slaagde erin rechtsregels te introduceren (in andere compilaties), die hij putte uit de rechtspraak van het Parijse rechtscollege. Het merendeel hiervan werd aan het costumiere recht van Parijs ontleend, ondanks het feit dat een aantal van deze regels een Romeinsrechtelijke oorsprong kende. ${ }^{1261}$ Ook de Antwerpse commissieleden hebben zich in de eerste plaats laten inspireren door de commentatoren van het Parijse gewoonterecht. Die van Dumoulin en Choppin werden reeds vermeld, maar waar deze samen slechts goed zijn voor dertien allegaties, grijpt de commissie maar liefst zeventien maal terug naar de mening van le Caron, zoals die verwoord werd in zijn Coustumes de la ville, prévosté et vicomté de Paris, ou droict civil Parisien. In totaal gaat het dus om dertig allegaties. Geen enkele andere stad of regio doet beter.

De Grand coutumier général van Dumoulin is echter niet het enige werk dat, mijns inziens, hier ontbreekt. Ook andere, reeds ter sprake gekomen, gewoonterechtelijke experts als Antoine Loisel (1536-1617), Guy Coquille (1523-1603) en Pierre de l'Hommeau zijn hier, evenwel tevergeefs, te verwachten. ${ }^{1262}$ Mogelijk waren de commissieleden niet zozeer opgezet met de unificerende ambities waarvan hun comparatistische werken blijk geven. ${ }^{1263}$ Nergens wordt er, ondanks de naam en faam van Coquille zelf, in de Memorieboeken verwezen naar zijn commentaar op de coutumes van Nevers. Toch werden deze vermoedelijk al in 1605 geschreven. ${ }^{1264}$ Een verklaring kan gezocht worden in het feit dat Coquilles oeuvre pas halverwege de zeventiende eeuw werd uitgebracht (1646-1650). ${ }^{1265}$ Vermoedelijk is dit ook de reden voor het ontbreken in de Memorieboeken van allegaties naar zijn meest origineel en interessant werk, de Institutions au droit des François, ou Nouvelle Conférence des Coutumes de France (circa 1607), aangaande het Franse gewoonterecht. Ook dit is -net als Loisels Institutes coustumiers- een poging om uit de honderden verschillende Franse coutumes, gesteund door de praktijk -vooral die van Parijs- en in samenhang met Romeins recht een droit

uitgeoefend staat in hoofdstuk 1 te lezen. Cfr. supra, hoofdstuk 1, paragraaf 2 en paragraaf 3, $\checkmark$ roegere en buitensteedse compilaties.

1260 Geciteerd naar KOSCHAKER, Europa en het Romeinse recht, 120.

1261 Cfr. GILISSEN, Historische inleiding, 279.

1262 De geboorte- en sterftedatum van Pierre de l'Hommeau heb ik nergens kunnen terugvinden.

1263 Zo hoopte Loisel met deze verzameling van rechtspreuken, bepalingen en beginselen (Institutes coustumières) immers bij te dragen tot de éénmaking van het Franse recht, waarbij men zich onderwerpt aan la conformité, raison et équité d'une seule loy et coustume... sous l'auctorité du roi. (Geciteerd naar GILISSEN, Historische inleiding, 356.)

1264 Cfr. WAREMBOURG, Guy Coquille.

1265 Anderzijds bewijzen de verwijzingen naar het onuitgegeven oeuvre van Filips Wielant dat een werk niet noodzakelijk gedrukt hoeft te zijn opdat het geraadpleegd wordt door de Antwerpse commissieleden en het enig gezag wist te verwerven. Uiteraard besef ik zeer goed dat men (geografisch) dichter bij Wielant stond dan de Franse auteurs en dat Coquille veel recenter was en dus mogelijk nog ver van hun bed. 
civil commun van Frankrijk te construeren. ${ }^{1266}$ De 'comparatisten' vullen een nood aan die eerst in Frankrijk voelbaar was, met name om al het recht dat binnen één land in gebruik was weer te geven, zonder rekening te houden met de herkomst ervan. ${ }^{1267}$ Een nood die te Antwerpen in 1608 nergens gevoeld werd. Het argument dat deze werken pas in het eerste decennium van de zeventiende eeuw werden gepubliceerd, houdt geen steek. Door het gebruik van de Ordonnantie van Rouen als primaire rechtsbron heb ik reeds kunnen zien hoezeer up-to-date de commissieleden wel niet waren. De ordonnantie, ook bekend als de Guidon de la Mer, dateert immers van 1607.1268 Later zal ik hier, met de allegaties naar de Codex Fabrianus van Antoine Favre (1557-1624), welke pas in 1606 voor het eerst gedrukt werd, nogmaals op gewezen worden.

In de Nederlanden was dit alles nog niet aan de orde. Zelfs de eenvoudige commentaren op de costumen van een welbepaalde stad of regio bleven uit, laat staan dat er reeds sprake was van vergelijkende commentaren. Het is zelfs wachten tot de tweede helft van de zeventiende eeuw vooraleer ik de eerste uitingen van costumiere geleerdheid zie verschijnen. Het gaat hier om commentaren bij de redacties van het gewoonterecht van steden als Brussel (De Condé, 1657; Van Christynen, 1689), Mechelen (Van Christynen, 1625) of Gent (Knobbaert, 1677). Zij verschenen dus pas na het voltooien van de Consuetudines compilatae ten tonele. ${ }^{1269}$

Wat Antwerpen zelf betreft, kan men zich dan weer afvragen waarom er bijvoorbeeld nooit verwezen werd naar de handgeschreven commentaar op de Consuetudines impressae van stadssecretaris Hendrik de Moy (1534-1610), het Tractaat over de Costuymen. ${ }^{1270}$ En dit ondanks zijn uitdrukkelijke opzet toekomstige commissies te hulp te komen: "Het welck mede sal moghe[n] diene[n] tot v[er]lichtinghe van[de] ghene[n] die naermaels sek [er] worden geco[m] mitteert om de gedructe costuyme $[n]$ te helpe $[n]$ revidere $[n]$ e [nde] herscrave $[n] . " 1271$ Ik denk ook aan zijn eigenhandig geschreven Tractaet der officieren der stadt Antwerpen waarvan nergens sprake is in de Memorieboeken, terwijl er in zijn

1266 KOSCHAKER, Europa en het Romeinse recht, 100. HOLTHÖFER, "Coquille (Conchyleus), Guy", 144. In zijn Institutions au droit des François bespreekt Coquille twee mogelijke posities van het provinciale gewoonterecht. Ten eerste is er die waarbij lokale gewoonten primeren en het Romeinse recht fungeert als subsidiair recht van de eerste lijn. Het droit commun coutumier staat hierbij onderaan de autoritatieve ladder. (Cfr. Baron, Imbert, Bugnyon, Mornac, Automne). De tweede visie is die van Coquille zelf, evenals auteurs als le Caron, Loisel, de l'Hommeau. Zij bepleiten het afleiden van algemene principes uit de verschillende provinciale coutumes welke op hun beurt dienst moeten doen als subsidiair recht, daar waar het lokale gewoonterecht lacunes vertoont. Het Romeinse recht is nu niet meer dan a subsidiary law of last resort, aldus Stein. (Cfr. STEIN, Roman law in European history, 85.)

${ }^{1267}$ HOLTHÖFER, “Coquille (Conchyleus), Guy”, 144.

${ }^{1268}$ Cfr. supra, hoofdstuk 1, paragraaf 2, Deel IV, Zee- en assurantierecht.

${ }^{1269}$ Cfr. GILISSEN, Historische inleiding, 357-362. GILISSEN, Historische inleiding, 360, noot 44. Ook Goudelin's (1550-1609) De iure novissimo werd pas in 1620 uitgegeven. (Cfr. SÖLLNER, "Die Literatur zum gemeinen und partikularen Recht", 567.)

1270 SAA, Vierschaer, 21-23: DE MOY, Tractaat.

1271 SAA, Vierschaer, 21: DE MOY, Tractaat, fol. 1r. 
commentaar bij de Impressae zo vaak naar verwezen wordt. ${ }^{1272}$ De twee overige commentaren die aan deze derde redactiepoging werden gewijd, dateren van veel latere datum, net zoals de handgeschreven commentaar van Antoon Anselmo (15891668), welke bovendien verloren geraakt is, en een anoniem handschrift uit de achttiende eeuw. ${ }^{1273}$ Ook de annotaties van Karel Gabri, zowel als die van Potier bij de Antwerpse costumen dateren van respectievelijk 1639 en 1717.1274 In het spoor van de rest van de Zuidelijke en Noordelijke Nederlanden komt de costumiere rechtsleer ook in Antwerpen te laat op gang opdat er een beroep op kon worden gedaan.

Hoe zit het nu met de elementaire vraagstelling van dit hoofdstuk? Is het mogelijk deze categorie aan te wenden ter beantwoording van de vraag in hoeverre het juridisch humanisme zijn invloed heeft laten gelden bij de redactie van het Antwerpse gewoonterecht? Zeker, louter de aanwezigheid van de categorie en haar omvang bevestigen reeds mijn hypothese. Het bestaan ervan in se getuigt immers van de typisch humanistische 'ontvoogding' van de moderne rechtsgeleerden. Men rukt zich los van het traditionele middeleeuwse ius commune-keurslijf en men opent de ogen voor andere juridische systemen buiten dat van het Corpus Iuris. Zoals ook al in het eerste hoofdstuk te zien was, hebben de commissieleden te Antwerpen oog voor heel wat vreemde rechtsstelsels. Samen met de andere categorieën hier besproken, en met de verschillende rechtsbronnen waarvan sprake was in het eerste hoofdstuk, getuigt deze categorie van het eclectische karakter van de moderne rechtsleer zoals Lesaffer er in zijn boek over spreekt. ${ }^{1275}$

Anderzijds lijkt in de aanwending van deze categorie het risico schuil te gaan in een petitio principii te vervallen. Aantonen dat gewoonterechtelijke compilaties de invloed zijn ondergaan van de verworvenheden van het juridisch humanisme op basis van (allegaties naar) vergelijkbare werken die een vergelijkbare invloed zijn ondergaan, zou immers neerkomen op een cirkelredenering. Datgene wat bewezen moet worden, wordt reeds verondersteld. Toch gaat deze vlieger hier niet op. Het betreft hier immers specifiek de Antwerpse compilatores. De mate waarin er verwezen wordt naar niet-Antwerpse, humanistisch geïnspireerde particulierrechtelijke commentaren kan ons dan wel degelijk iets vertellen over de mate waarin de Antwerpse compilatores door de nova methodus werden beïnvloed. Methodologisch zijn er dan ook geen bezwaren meer. Bijgevolg is het mogelijk om, aan de hand van wat Holthöfer in Coings Handbuch vertelt, tot een overzicht te komen waarbij de verschillende costumierrechtelijke commentaren worden verdeeld naar gelang hun

${ }^{1272}$ Cfr. DEKKERS, Bibliotheca Belgica Juridica, 119. Men kan zich de vraag stellen, wat zijn deelname aan de commissie impliceerde voor het al dan expliciet refereren naar zijn oeuvre.

1273 Cfr. GOTZEN, "De costumiere bronnen", 198-199. Zie ook: DEKKERS, Bibliotheca Belgica Juridica, 4-5.

1274 Cfr. POHLMANN, "Bibliographie der Gesetzgebung”, 497-498. Zie ook: DEKKERS, Bibliotheca Belgica Juridica, 59 en 137.

1275 LESAFFER, Inleiding tot de Europese rechtsgeschiedenis, 322. 
rechtswetenschappelijke oriëntatie. ${ }^{1276}$ Het plaatst de middeleeuws aandoende commentaren tegenover hun moderne tegenpolen. Zo wijst Holthöfer erop dat de laatmiddeleeuwse commentaartraditie ook ten aanzien van het particuliere recht tot ver in de zestiende eeuw heeft standgehouden. Enkel in Frankrijk duiken reeds in de eerste helft van diezelfde eeuw de eerste, humanistisch beïnvloede, commentaarvormen op. Holthöfer vermeldt Charles Dumoulin en Pierre Rebuffi als voorbeeld. Ze gaan de concurrentie aan met hun middeleeuwse collegae, zoals er zijn Nicolas de Bohier en Barthélémy de Chasseneuz. In de tweede helft van de zestiende eeuw komt er een definitief einde aan de middeleeuwse commentaarvorm in Frankrijk. In de overige landen zoals Spanje en Italië blijft het wachten tot het einde van de zestiende eeuw. Gregorio Lopez en Juan Gutierrez uit Spanje en de Italiaan Aymo Cravetta blijven immers op laatmiddeleeuwse wijze te werk gaan. Op basis van de diverse humanistische commentaarvormen, en de hiermee corresponderende auteurs die door Holthöfer ten tonele worden gevoerd, kan ik het overzicht aan gewoonterechtelijke commentaren opsplitsen zoals dat in tabel 3.8 te zien is. ${ }^{1277}$ Jean Papon en zijn commentaar op de costumen van Bourbon (1550) is nog niet in deze tabel verwerkt omwille van het feit dat ik er niet in geslaagd dit werk al dan niet als hetzij middeleeuws, hetzij humanistisch van aard te kwalificeren.

Tabel 3.8 Middeleeunse versus humanistische costumierrechtelijke commentaren

\begin{tabular}{|l|l|l|l|}
\hline \multicolumn{1}{|c|}{ Middeleeuws } & $\mathbf{5}$ & \multicolumn{1}{|c|}{ Humanistisch } & $\mathbf{1 2 0}$ \\
\hline Nicolas de Bohier & 1 & Bertrand d'Argentré & 5 \\
\hline Barthélémy de Chasseneuz & 4 & Gaspar de Baeza & 1 \\
\hline & & Louis le Caron & 50 \\
\hline & & Réné Choppin & 9 \\
\hline & & Charles Dumoulin & 10 \\
\hline & & Pierre Guenoys & 43 \\
\hline & & Gabriel Labbé de Montveron & 1 \\
\hline & & Pierre Pithou & 1 \\
\hline
\end{tabular}

Het ligt voor de hand dat het jeugdige karakter van het genre grotendeels verantwoordelijk is voor het overwicht van de moderne commentaarvormen. Toch kan ik er niet omheen dat er een heleboel middeleeuwse commentaren bestaan die men links heeft laten liggen. Ik denk bijvoorbeeld aan die van André Tiraqueau. ${ }^{1278}$ Aan humanistische zijde kom ik opnieuw terecht bij Guy Coquille en zijn Coutumes de Nivernais. Voor zover ik weet, is deze compilatie-commentaar de enige die, naast de Antwerpse Consuetudines compilatae en het Gelderse Land-en Stadsrecht, eveneens volgens het Justiniaanse Institutensysteem, weliswaar in combinatie met een eigen systeem, werd opgebouwd. ${ }^{1279}$ Desalniettemin is er ook hier in de Memorieboeken geen sprake van.

1276 HOLTHÖFER, “Die Literatur zum gemeinen und partikularen Recht”, 213-223.

1277 Cfr. HOLTHÖFER, "Die Literatur zum gemeinen und partikularen Recht”, 218-222.

1278 Ik denk an Tiraqueau's commentaar bij de costumen van Poitou uit 1543. Cfr. OTTO, "Tiraqueau (Tiraquellus), André", 631.

${ }^{1279}$ Cfr. supra, hoofdstuk 2, paragraaf 4. 
Ook wat betreft de legislatieve compilaties en de hierop verschenen commentaren spreekt het overwicht van humanistisch georiënteerde werken voor zich. Holthöfer omschrijft Rebuffi's Commentarii in constitutiones seu ordinationes regias ... qui in tractatus in sequenti pagina distribunntur (1554-1555) als één van de meesterwerken van de grote exegetische commentaren van het vroeg-humanisme. ${ }^{1280}$ In het lexicon van Stolleis stelt Holthöfer het volgende: 'Die 'Ordonnances, loix, statuts et edicts royaux' (1547 u.ö.) enthalten, systematisch geordnet und mit Rechtsprechungszitaten versehen, die Gesetze aus der Zeit Ludwigs des Heiligen bis zu Rebuffi's Gegenwart, ...”.1281 Ook de commentaar van Louis le Caron bij de Codex Henricianus, evenals Pierre Guenoys' Conférence des ordonnances kunnen als staaltjes van juridisch humanisme beschouwd worden. ${ }^{1282}$ Enkel Antonio Gomez en zijn commentaar bij de Leyes de Toro (1552) behoort nog tot de laatmiddeleeuwse traditie. ${ }^{1283}$ Kwantitatief komt dit alles neer op wat in tabel 3.9 te zien is.

Tabel 3.9 Middeleeunse versus humanistische legislatieve commentaren

\begin{tabular}{|c|l|l|l|}
\hline \multicolumn{1}{|c|}{ Middeleeuws } & $\mathbf{3}$ & \multicolumn{1}{|c|}{ Humanistisch } & $\mathbf{1 6}$ \\
\hline Antonio Gomez & 3 & Pierre Rebuffi & 8 \\
\hline & & Louis le Caron & 7 \\
\hline & & Pierre Guenoys & 1 \\
\hline
\end{tabular}

Ondanks het overwicht van humanistische geïnspireerde commentaren, blijkt dit humanisme evenwel niet in de eerste plaats uit de logisch-systematische opbouw ervan. Het jeugdige karakter van het genre lijkt een doordachte opbouw vooralsnog in de weg te staan. Als het van Immel afhangt, is dit een zeer logische constatatie: "So nimmt es nicht wunder, dass die Gesetzgebung des Ancien Régime bis ins 18.Jabrubundert binein

${ }^{1280}$ HOLTHÖFER, "Die Literatur zum gemeinen und partikularen Recht”, 219.

${ }^{1281}$ HOLTHÖFER, "Rebuffi (Rebuffus), Pierre”, 528.

$1282 \mathrm{Zo}$ is de Codex Henricianus, welke le Caron becommentarieerde en waarnaar meermaals werd verwezen in de Memorieboeken, oorspronkelijk het werk van Barnabé Brisson (1531-1591), één van de protagonisten van de Franse mos gallicus, meer bepaald de antiquarische richting. Dat Brisson bovendien tijdens zijn studies in contact is gekomen met zowel Doneau (te Orleans) als Duaren (te Bourges), doet me verwachten dat Brisson toch wel een neus voor systematiek moet ontwikkeld hebben. ${ }^{1282}$ Bovendien vind ik in de uitvoerige titel van le Carons bewerking van het werk een aantal vleugjes humanisme terug: Le Code du Roy Henry III, Roy de France et de Pologne, redigé en ordre par Barnabé Brisson, depuis augmenté des édits du Roy Henry $I V$, avec la conférence des ordonnances, et rapporté aux ancien Code de Théodose et de Justinien, et aux Basiliques, et illustrés des Conciles de l'Eglise, Lois des Romains et autre peuples, Histoires, Antiquiez, Arrêts, Observations et Annotations. Zo is er de typische terminologie van tekstkritische, humanistische genres als de Observatio en de gelijkaardige Adnotatio. ${ }^{1282}$ Verder is er ook de aandacht die besteed wordt aan Histoires en Antiquiez. Le Caron van zijn kant verkoos als pseudoniem de naam van een Grieks wetgever vermoedelijk daterend uit de zesde eeuw voor Christus.

1283 HOLTHÖFER, “Die Literatur zum gemeinen und partikularen Recht”, 218. 
einer Systematik entbehrt."1284 Tot zeker in de achttiende eeuw bestaan er enkel kompilatorisch in plaats van systematisch opgebouwde compilaties van wetgeving. Zodra ik wel gewag kan maken van enige systematische ordening, dan is deze, buiten de chronologische overzichten gerekend, a-logisch. Ik denk onder meer aan La Conférence des ordonnances royals van Pierre Guenoys distribuée en XII livres à l'imitation et selon l'ordre $d u$ Code de l'empereur Justinien. Ook de in de Memorieboeken geallegeerde, vergelijkende (particulierrechtelijke) literatuur, zoals tot stand gekomen in de genres van de Collatio en Censura, kent nog geen logische ordening. ${ }^{1285}$ Desalniettemin gaat het hier om een nieuw, modern type als opvolger van de middeleeuwse differentiae die de verschillen tussen het Romeinse en het canonieke recht aangaven. De centrale rol die het particuliere gewoonterecht binnen deze nieuwe genres krijgt toebedeeld, getuigt in zekere zin van de moderne, ontvoogde geest.

\section{Geleerd recht}

Deze groep omvat de commentaren die werden geschreven op het utrumque ius, namelijk het Corpus Iuris Civilis en het Corpus Iuris Canonici. Hierbij is het mogelijk dat beide corpora in hun geheel werden becommentarieerd, maar even goed kon men zich beperken tot één of meerdere afzonderlijke titels uit het geleerde recht. Als moeder van alle rechtsgeleerde literatuurtypes heeft ze steeds haar mannetje weten staan tegen het jonge opkomende geweld van tal van nieuwe genres. Om deze plek aan het rechtsgeleerde firmament als kwintessens van de rechtswetenschap te behouden, is het genre meermaals van look moeten veranderen. Zulk een gedaanteverwisseling houdt in dat de wijze waarop het geleerde recht werd benaderd -lees onderzoeksmethode- door de eeuwen heen vaak aangepast werd. Op deze manier kregen de verschillende rechtswetenschappelijke scholen hun typische vorm (van Glossatoren over Commentatoren tot Humanisten, etcetera). Belangrijk in het kader van dit onderzoek is de overgang van de laatmiddeleeuwse variant, de bartolistische traditie, naar het moderne equivalent ervan, welke de invloed van het humanisme had ondergaan. Omdat de verworvenheden van deze nova methodus zich nu juist het best manifesteerden in hun toepassing op de teksten van het Corpus Iuris, leent deze categorie zich als geen andere tot een opdeling in stereotiepe vakjes, waarbij oud tegenover nieuw wordt gepositioneerd. ${ }^{1286}$

1284 G. IMMEL, “Typologie der Gesetzgbung des Privatrechts und Prozessrechts", H. COING red., Handbuch der Quellen und Literatur der Neueren europäischen Privatrechtsgeschichte, II/2, Munchen, 1976, 94.

1285 Cfr. HOLTHÖFER, "Die Literatur zum gemeinen und partikularen Recht", 223-227. Omtrent de weergave van het particuliere Mischrecht volgens het Institutensysteem binnen de grenzen van het Helige Roomse Rijk en de Nederlanden, cfr. SÖLLNER, "Die Literatur zum gemeinen und partikularen Recht", 555-557.

${ }^{1286}$ Hierbij wil ik benadrukken dat de invloed van het juridisch humanisme zich niet beperkt tot de commentaren op het Corpus Iuris. Ook andere literatuurtypes spelen een belangrijke rol. Ik denk aan tekstuitgaven, tekstkritische werken als de observatio en adnotatio, tal van nieuwsoortige monografieën, onderwijsliteratuur, juridische argumentenleer, juridische systemen, verklarende commentaren en lexica. Troje bespreekt hen elk afzonderlijk in Coing's 
Dit brengt me bij Holthöfer die in Coings Handbuch de commentaren bij het geleerde recht opdeelde in een groep van het jonge type versus een groep van het oude type. Ook ik zal ditzelfde onderscheid evenals de overeenkomstige onderverdeling aanhouden. Waar het oude type naar de bartolistische traditie van de Commentatoren verwijst, laat het nieuwe type zich met het juridisch humanisme identificeren. Dit laatste type kenmerkt zich, althans volgens Holthöfer, door het gebruik van een nieuwe grondtekst, gecombineerd met een nieuwe vorm. De brontekst gaat opnieuw fungeren als naakt aanknopingspunt voor de commentatoren van deze nieuwe methode en men probeert deze opnieuw samenhangend en leesbaar te interpreteren als logisch geheel, waar bartolisten zich eerder op specifieke onderwerpen concentreerden en zich hierbij vaak lieten afleiden door de reeds verschenen commentaren op het onderwerp. Wat betreft de inhoud, ziet men af van het oeverloos weergeven en citeren van de meningen van de doctores en het zoeken naar oplossingen voor hun discussies. ${ }^{1287}$ Holthöfer wijst er eveneens op dat onder de medegedeelde referenties het aandeel van de middeleeuwse auteurs terugloopt tot occasionele citaten van Bartolo da Sassoferrato en Baldus de Ubaldis. Van een volledige breuk met het middeleeuwse erfgoed mag dan ook geen sprake zijn. ${ }^{1288}$ Dat de humanistisch geïnspireerde juristen niet om het werk van hun middeleeuwse voorgangers heen konden en het positieve ervan wisten te appreciëren, daar wordt in tegenstelling tot vroeger niet langer aan getwijfeld. ${ }^{1289}$ In dat opzicht is het juridisch humanisme minder extreem dan het algemene humanisme. Ook mijn onderzoek zal dit blijvende belang van de protagonisten van de bartolistische traditie niet tegenspreken. Louter de aanwezigheid van referenties naar middeleeuwse auteurs volstaat dan ook niet langer als criterium om een werk als middeleeuws te bestempelen. ${ }^{1290}$ Enkel de wijze waarop het aantal allegaties naar middeleeuwse en humanistische werken zich onderling verhoudt, kan als maatstaf fungeren voor het aanduiden van het humanistisch gehalte van een bepaald werk of dier auteur. Volgens deze idee ben ik dan ook in tabel 3.10 aan de slag gegaan.

Vooraleer verder te gaan, wil ik er nog op wijzen dat het niet altijd even evident is geweest, de verschillende geallegeerde werken onder te brengen in beide categorieën van oud versus jong, zoals Holthöfer dat heeft gedaan. Zo heb ik een aantal werken, die in het Handbuch van Coing onder de categorie van de monografieën werden geressorteerd, desondanks toch hier bij de commentaren op het geleerde recht ondergebracht. Het gaat hier om commentaren bij titels uit het Corpus Iuris welke, juist doordat ze thematisch gezien zo beperkt zijn, sterk neigen naar het literatuurtype van de tractati. Ik heb er echter voor geopteerd hen hier aan bod te laten komen. Dit had evenwel tot gevolg dat ik via een andere weg op zoek moest gaan naar een antwoord op de vraag in hoeverre deze werken als humanistisch mogen beschouwd worden. Zo

Handbuch: TROJE, "Die Literatur des gemeinen Rechts unter dem Einfluss des Humanismus", 615-798.

1287 Cfr. HOLTHÖFER, “Die Literatur zum gemeinen und partikularen Recht”, 115.

1288 Waarop Holthöfer zich baseert, is me niet meteen duidelijk geworden.

${ }^{1289}$ Cfr, supra, hoofdstuk 3, Inleiding.

1290 Cfr. VAN DEN BERGH, Holländische elegante Schule, 94. 
ben ik voor auteurs als Wigle van Aytta (Praelectio in titul. ff Si certum petatur) en Andrea Alciato (De verborum obligationinus, 1519) moeten uitwijken naar andere literatuur, welke me in staat stelde de van hen geallegeerde werken respectievelijk als middeleeuws en humanistisch te typeren. ${ }^{1291}$ Vergelijkbaar is de situatie van Rodrigo Suarez, zij het dat ik hem op deze manier als middeleeuws bestempeld heb. Ook hij werd met zijn Subtilissima lectura legis quoniam in prioribus Cod. de inofficioso testamento (C.3.28.29) et leges post rem iudicatam Dig. de re iudicata (D.42.1.56) van 1536 bij Coing onder de monografieën ondergebracht. ${ }^{1292}$ Soms is het echter onmogelijk gebleken uitlatingen terug te vinden over het humanistische karakter van een welbepaald werk. In enkele van die gevallen heb ik het risico genomen deductief te werk te gaan en, vertrekkende vanuit het label dat de auteur doorgaans krijgt opgekleefd in de literatuur, meer bepaald in Coings Handbuch, deze lijn door te trekken naar het geallegeerde werk in kwestie. Deze kunstgreep heb ik toegepast op de commentaren van Jean le Feu, Antonio de Padilla y Meneses en Aries Pinhel. ${ }^{1293}$ In Coing worden deze auteurs in de eerste plaats als bartolistisch aanzien. ${ }^{1294}$ Ook Guillaume Benoit heb ik op basis van zijn plaats in de tijd tot het kamp van de middeleeuwse commentatoren gerekend. Arabeyre daarentegen ziet graag de eerste tekenen van een humanistische ingesteldheid in de bibliotheek van de auteur en de door hem geraadpleegde bronnen. Bijgevolg typeert hij Benoît als een voorloper van de grote, Franse juristen van de zestiende eeuw. ${ }^{1295}$

Alzo blijft de subcategorie van de twijfelgevallen slechts twee types bevatten. Enerzijds zijn er de onidentificeerbare auteurs, zoals Picus en Oroscius. Anderzijds heb ik binnen deze categorie onderdak gegeven aan de zogenaamde overgangsfiguren. De literatuur blijft zwijgzaam wat betreft het desbetreffende werk en ten aanzien van de auteurs ervan, is ze vaak maar al te vaag en/of tweeledig. Het gaat om bartolisten tenminste als commentatoren van het geleerde recht- waarbij de eerste sporen van juridisch humanisme zichtbaar worden. Juist omwille van deze dubbelzinnige situatie kunnen ze in geen van beide categorieën ondergebracht worden. In hun balanceren op het slappe koord tussen de mos italicus en de mos gallicus ligt juist hun bestaansreden. Een knoop doorhakken zou dus onverantwoord zijn. De auteurs waar het hier over gaat zijn Pierre Rebuffi en Charles Dumoulin. ${ }^{1296}$ Tot slot wil ik nog even dieper

1291 Omtrent Wigle van Aytta, cfr. DEKKERS, Humanisme en de rechtswetenschap, 71. (Zie ook: T. J. VEEN, "Viglius (Zuichemius) ab Aytta (1507-1577)", T. J. VEEN, P. C. KOP red., Zestig juristen: bijdragen tot een beeld van de geschiedenis der Nederlandse rechtswetenschap, Zwolle, 1987, 104109.)

Omtrent Andrea Alciato, cfr. infra, hoofdstuk 3, paragraaf 3, Geleerd recht.

1292 HOLTHÖFER, "Die Literatur zum gemeinen und partikularen Recht", 386.

1293 Dit heb ik zo beoordeeld, ondanks Canoy-Olthoff en Nève, die hem een vroege vertegenwoordiger van de Usus Modernus noemen. (CANOY-OLTHOFF en NEVE, Holländische elegan₹, gegenüber deutschem Usus Modernus Pandectarum?, 10.)

1294 HOLTHÖFER, "Die Literatur zum gemeinen und partikularen Recht”, 111.

1295 ARABEYRE, Les idées politiques à Toulouse, 187-208.

1296 Dat ik met de commentaren van Rebuffi en Tiraqueau te maken heb met overgangswerken, blijkt uit onder meer uit het oordeel van Holthöfer: “..., André Tiraqueau (1480-1558) und Pierre Rebuffi (1487-1557), baben nur einige Einzelrepetitionen bintergelassen, die 
ingaan op de positie van de Spaanse rechtsgeleerde, Diego Covarubias y Leyva. Hoewel hij vaak wordt omschreven als de Spaanse Bartolus, blijkt zijn plaats binnen het juridisch humanisme onaantastbaar. ${ }^{1297}$ De toenaam blijkt eerder het gevolg te zijn van het feit dat hij in Spanje, als grootste jurist die het land ooit heeft gekend, een vergelijkbare status verworven heeft als Bartolo da Sassoferrato binnen de rest van West-Europa. De reden moet dus niet gezocht worden in een middeleeuwse aanpak. Integendeel, Covarubias y Leyva is één van de leidende figuren van de Spaanse Secunda Scholastica, een moraalfilosofische beweging waarvan de kritische ingesteldheid maar al te vaak als een echo weerklinkt van het juridisch humanisme. Zo werden de teksten van Justinianus ook door hen niet langer als onaantastbaar, compleet en perfect beschouwd. Neen, de tekortkomingen kwamen aan het licht en de hele

überdies ibrem Aufbau und dem erschöpfenden Charakter ibrer Darstellung nach noch dem Typus des älteren gemeinrechtlichen Kommentars gehören und nur durch die Originalität ibrer Denkansätze dessen gewohnten Rabmen sprengen und bumanistiche Einflüsse verraten." (HOLTHÖFER, "Die Literatur zum gemeinen und partikularen Recht", 148) Ook Rials benadrukt de dubbele positie van Tiraqueau. (Cfr. RIALS, "Veritas iuris", 158-159 noot xiii.) Bij Holthöfer staat eveneens staat te lezen hoe met Dumoulin en Douaren voor de eerste maal de band van de commentaar met de ganse ordo iuris opgegeven wordt en door een behandeling van de broninhoud, waarbij men titels afzonderlijk bestudeerd, vervangen wordt. Wat Dumoulin betreft, komt dit vooral tot uiting in zijn Codex-commentaar. De werken die hier centraal staan, komen bij Holthöfer evenwel niet aan bod. Desalniettemin toont dit de invloed van de nieuwe geest aan. Later bevestigt Holthöfer de dubbele aard van Rebuffi nogmaals in het lexicon van Stolleis: "Rebuffi gebört zusammen mit seinem Weggenossen André Tiraqueau, der wie er selbst noch der Bartolistenschule zuqurechnen ist, und den Frübhumanisten Budé und Baron qu jenen in letəten Drittel des 15. Jahrbunderts geborenen Juristen, mit denen die Rechtswissenschaft in Frankreich wieder europaïsche Bedeutung erlangt hat. Mit Tiraqueau und DuMoulin, die im Unterschied zu ihm selbst reine Praktiker waren und zur gleichen Zeit wie er in Paris gewirkt haben, zählt er zu den dogmengeschichtlich ergiebigsten Juristen des 16. Jahrbunderts und hat, wie diese, zur Fortbildung des gelehrten Rechts mehr beigetragen als mancher Humanist." (HOLTHÖFER, "Rebuffi (Rebuffus), Pierre", 528.) In hetzelfde biografisch overzicht omschrijft Otto André Tiraqueau dan weer als ein bumanistisch gebildeter Jurist. (OTTO, "Tiraqueau (Tiraquellus), André", 631.) Tiraqueau-biograaf, Jacques Bréjon, van zijn kant, noemt hem un Bartoliste convaincu. (BREJON, Un jurisconsulte de la Renaissance André Tiraqueau, 367.) Koschaker typeerde Dumoulin dan weer als overtuigd bartolist. (KOSCHAKER, Europa en het Romeinse recht, 121.) Uit de biografie van de hand van Thireau blijkt dan weer de genegenheid die Dumoulin voor de novus methodus koesterde. (THIREAU, Charles de Moulin, 128-209.) Thireau besluit als volgt: "La richesse de l'oeuvre juridique de Du Moulin, le succès durable de beaucoup de ses théories juridiques, proviendront pour une large part de cette fidélité à des méthodes éprouvées, mais rénovées par l'bumanisme et utilisées, sous l'influence de ce mouvement, avec une très grande liberté qui explique l'originalité profonde des solutions adoptéespar lui." (THIREAU, Charles de Moulin, 209.) Hoe dan ook, de meningsverschillen omtrent de wetenschappelijke positie van deze drie auteurs, lijkt me het mooiste bewijs voor hun typering als 'overgangsfiguren'.

1297 Volgens Holthöfer gehört er zu den Autoren, in denen bereits bumanistische Einflüsse spürbar werden. (HOLTHÖFER, "Die Literatur zum gemeinen und partikularen Recht", 112.) Ook Seelmann plaatst hem, omwille van de vele, antieke citaten en zijn numismatisch onderzoek, in der Nähe des juristischen Humanismus. (SEELMANN, "Covarubias (Covarruvias) y Leyva, Diego de", 149.) 
organisatie ervan werd ook door de Spaanse moraalfilosofen als chaotisch beschouwd. De laatscholastieke auteurs op hun beurt gingen vanaf nu op zoek naar het beste recht met behulp van de eigen ratio, in tegenstelling tot een blindelings vertrouwen in de Justiniaanse teksten. Deze ratio stelde hen immers in staat het recht te interpreteren dat, door toedoen van God, verscholen lag in de natuur. ${ }^{1298}$ Hoewel Covarubias y Leyva doorgaans beschouwd wordt als één van de protagonisten van deze nieuwe school, heb ik hem desondanks in deze categorie ondergebracht. In de Memorieboeken wordt hij immers in de eerste plaats met zijn commentaren op het geleerde recht geallegeerd en niet met zijn laatscholastieke oeuvre.

Een tweede slotopmerking betreft de ene allegatie naar Joachim Mynsinger von Frundeck en zijn opinie ten aanzien van een kerkrechtelijke canon. ${ }^{1299}$ Gezien het feit dat Mynsinger mijns inziens geen enkele commentaar op eender welke canoniekrechtelijke titel heeft voortgebracht, kan de positie van deze allegatie binnen deze categorie niet langer gerechtvaardigd worden. Zeer waarschijnlijk gaat het om een opmerking afkomstig uit zijn Singularium observationum iudicii imperialis camerae, maar omdat ik hier geen zekerheid over heb kunnen verkrijgen, zal ik vanaf nu deze allegatie buiten beschouwing laten. Uiteindelijk ziet de verdeling er uit zoals te zien is in tabel 3.10.

Tabel 3.10 De commentaren bij het geleerde recht in functie van het aantal allegaties en de verschillende rechtsgeleerde stromingen 1300

\begin{tabular}{|c|c|c|c|c|c|c|}
\hline \multirow{12}{*}{$\begin{array}{c}\text { Coprus Iuris Civilis } \\
118\end{array}$} & \multirow[t]{6}{*}{ Oud } & \multirow[t]{6}{*}{64} & Glossatoren & 2 & & \\
\hline & & & \multirow{5}{*}{ Commentatoren } & \multirow[t]{5}{*}{61} & ita & 48 \\
\hline & & & & & fra & 6 \\
\hline & & & & & spa & 4 \\
\hline & & & & & por & 3 \\
\hline & & & & & ned & 1 \\
\hline & Twiifel & 9 & & & & \\
\hline & \multirow{5}{*}{ Nieuw } & \multirow[t]{5}{*}{45} & & & fra & 25 \\
\hline & & & & & ned & 12 \\
\hline & & & & & ita & 5 \\
\hline & & & & & $\mathrm{spa}$ & 2 \\
\hline & & & & & hrr & 1 \\
\hline \multirow{2}{*}{$\begin{array}{c}\text { Corpus Iuris } \\
\text { Canonici } \\
12\end{array}$} & Oud & 6 & & & & \\
\hline & Nieuw & 6 & & & & \\
\hline \multirow{2}{*}{$\begin{array}{c}\text { Utrumque Ius } \\
5\end{array}$} & Oud & 1 & & & & \\
\hline & Nieuw & 4 & & & & \\
\hline
\end{tabular}

Antwerpen bevestigt. De middeleeuwers blijven prominent aanwezig, zowel ten aanzien van het Romeinse als het Canonieke recht. Wat betreft het Corpus Iuris Civilis

1298 Cfr. BELLOMO, Common Legal Past of Europe, HOLTHÖFER, "Die Literatur zum gemeinen und partikularen Recht", 229-230.

1299 Cfr. Memorien op de Costumen met betrekking tot de artikels 5.11.18/19/20.

1300 De subcategorie 'twijfel' bevat zowel zij van wie ik niet hebben kunnen achterhalen of zij al dan middeleeuws van aard waren, evenals zij die ik als overgangsfiguren heb beschouwd. 
zijn het zelfs de Commentatoren die grosso modo de groep anvoeren. Van de Glossatoren is nog nauwelijks sprake. Enkel naar de verdiensten van Martinus Gosia, één van de twaalfde-eeuwse Quattuor Doctores, en Odofredus de Denariis, een dertiende-eeuws jurist te Bologna, werd een enkele keer verwezen. Conform de traditionele opvatting binnen de rechtsgeschiedenis is het tijdvak van de Commentatoren er één dat zich in de eerste plaats in Italië afspeelt. In maar liefst 48 gevallen of zeker twee derde gaat het hier om auteurs afkomstig van de Italische laars: Bartolo da Sassoferrato (13 allegaties), Baldus de Ubaldis (11 allegaties), Girolamo Cagnoli (3 allegaties), Johannes Franciscus Sannazari della Ripa (3 allegaties), Giasone del Maino (3 allegaties), Bartolomeo de Saliceto (3 allegaties), Angelus de Ubaldis (3 allegaties), Alessandro di Tartagni (2 allegaties), Jacopo Bottrigari (1 allegatie), Filippo Decio (1 allegatie), Raffael Fulgosius (1 allegatie), Raffaele da Cuma (1 allegatie), Joannes de Platea (1 allegatie), Ippolyto de Marsili (1 allegatie) en Alberico de Rosciate (1 allegatie). Hoofdrolspelers blijven overduidelijk Bartolo da Sassoferrato en Baldus de Ubaldis. Respectievelijk werden zij dertien en elf maal geallegeerd. Zoals ook Lesaffer reeds opmerkte: hun verworvenheden worden niet miskend. ${ }^{1301}$ Desalniettemin kan ik, rekening houdend met de zwakke posities van traditionele hoogvliegers als Angelus de Ubaldis, Giasone del Maino en Alessandro di Tartagni, alleen maar vaststellen dat een aantal zekerheden verdwenen zijn. Zelfs Sannazari della Ripa, Cagnoli en de Saliceto plaatsen zich, elk goed voor drie allegaties, op een vergelijkbaar niveau. ${ }^{1302} \mathrm{Er}$ lijkt zich een uitzuivering te hebben voorgedaan, waarbij het kaf van het koren word gescheiden.

Tegenover deze Italiaanse overmacht staan landen als Frankrijk en Spanje, welke in dit opzicht nauwelijks het vermelden waard zijn. Spanje is met Rodrigo Suarez en Antonio de Padilla y Meneses goed voor vier allegaties in totaal en wat betreft Frankrijk, tref ik, naast de vier referenties naar het oeuvre van Jean Favre, overigens der bedeutende Kommentator aus dem Beginn des 14. Jabrbunderts, enkel de Lectura Digesti veteris van Guillaume de Cun aan, evenals de commentaar van Jean le Feu bij de Digestentitel De Sillaniano et Claudiano Senatusconsulto van 1539.1303 In totaal gaat het om zes Franse allegaties. Favre en de Cun bevinden zich in het zog en onder de invloed van de School van Orléans welke hen op weg zette naar een bedeutender wissenschaftlicher Lehrbetrieb, aldus Horn. ${ }^{1304}$ De School zelf en haar pioneers (Jacques de Révigny, Pierre de Belleperche, Jean Pyrrhus d'Angleberme,...) in het bijzonder komen in de Memorieboeken verder niet aan bod, evenmin als Cinus de Pistoia (12701336/37), die de nieuwe ideeën naar Italië overbracht. ${ }^{1305}$

${ }^{1301}$ LESAFFER, Inleiding tot de Europese rechtsgeschiedenis, 322.

1302 Holthöfer omschrijft Cagnoli als één van die letz̨ten grösseren Gesamtkommentare zu Digesten und Codex, die nog der Bartolistischen Tradition verplichtet sind. (HOLTHÖFER, "Die Literatur zum gemeinen und partikularen Recht", 111.)

1303 Omtrent Jean Favre, cfr. HORN, "Die legistische Literatur der Kommentatoren”, 278.

1304 HORN, "Die legistische Literatur der Kommentatoren”, 278.

1305 Hét literatuurgenre van de school zijn de zusammenhängende grosse exegetische Werke (Kommentare) zu den Quellen, die erstmals die für die Kommentatorenschule später kennzeichnende intensive Problembehandlung und Argumentationstechnik, Praxisnähe und grössere Unbefangenheit gegenüber der 
Het staat buiten kijf dat de oude commentaren in de eerste plaats een Italiaanse aangelegenheid zijn en ook in het Antwerpen van het einde van de zestiende eeuw worden zij nog steeds geapprecieerd. Het verbaast me bovendien niet dat ik me, van zodra ik me verplaats naar de groep van de jonge commentaren, ook geografisch moet heroriënteren. Conform de traditionele opvatting speelt het juridisch humanisme zich met name hoofdzakelijk in Frankrijk af, t.t.z. hier kent het zijn belangrijkste wetenschappelijke doorbraken. Via de universiteit van Bourges kom ik terecht bij de generatie van Jacques Cujas, François Hotman en Hugo Doneau. Zij komen in de Memorieboeken echter nauwelijks of -in het geval van Doneau- zelfs niet ter sprake. Als commentator van het geleerde recht, komt zelfs uitsluitend -zij het zeer summier- Jacques Cujas aan bod. ${ }^{1306}$ Naar zijn tekstkritische Observationum et emendationum libri XXVIII (1556-1595), overigens één van de mijlpalen binnen het uitgesproken humanistische genre van de Observatio, wordt twee maal gerefereerd. Uit diezelfde periode dateert de Adversariorum ex Pandectis Justiniani Imperatoris (1554) van een meer obscure figuur als Pierre Cousteau. ${ }^{307}$ Desalniettemin verwijzen de commissieleden niet minder dan vijf maal naar deze commentaar van het jonge type. De echte nadruk ligt, wat Antwerpen betreft, op een volgende generatie sterkhouders. Denis Godefroy en Antoine Favre zijn namelijk goed voor respectievelijk dertien en vijf allegaties. Ten aanzien van Godefroy is het nog niet duidelijk van welk werk men zich heeft bediend. ${ }^{1308}$ Wat Favre betreft, gaat het om zijn tekstkritische De erroribus pragmaticorum et interpretum iuris chiliadis pars prima ad quarta (1598). Ook hier gaat het eveneens om een uitgesproken humanistisch werk. Tot dezelfde generatie behoort Pierre Grégoire, na voornoemde twee auteurs ongetwijfeld de belangrijkste gemeenrechtelijke auteur van zijn tijd. In zijn Syntagma iuris universi (1580), een werk waarin trouwens beide rechten aan bod komen, zal hij als eerste de taak op zich nemen das gesamte zu seiner Zeit geltende Recht systematisch darzustellen, wobei er die gajanische Trichotomie personae-res-actiones als Gliederungsschema verwendet. ${ }^{1309}$ Dat het tot één van de sterkst verspreide boeken van zijn tijd behoorde, blijkt ook uit de vier allegaties ernaar die ik in de Memorieboeken terugvinden kan. Aangezien ik op deze manier bij de subcategorie van het utrumque ius ben aanbeland, wil ik eveneens wijzen op de bescheiden aanwezigheid van de Spaanse jurist Manoel da Costa en zijn middeleeuws aandoende Omnia quae quidem extant in ius canonicum et civile opera (1576). Het werk is goed voor één allegatie. De enige moderne, tekstkritische commentaar van Spaanse

\footnotetext{
Autorität der Glosse aufweisen, aldus Horn. (HORN, "Die legistische Literatur der Kommentatoren", 278.)

1306 Van Hugo Doneau is er in de Memorieboeken geen sprake. Hotman wordt enkel met zijn Quaestionum illustrium liber (1573) vernoemd. Dit kwam reeds in het luik betreffende de Quaestiones aan bod. Cfr. supra, hoofdstuk 3, paragraaf 2, Monografieën.

1307 Cfr. HAMON, "Pierre Coustau", 1089.

1308 Vermoedelijk gaat het om Godefroy's Littera Gothefrediana. Cfr. TROJE, "Die Literatur des gemeinen Rechts unter dem Einfluss des Humanismus", 651.) Omtrent het leven werk van Godefroy, cfr. HOLTHÖFER, "Godefroy (Gothofredus), Jacques”, 248-250. Zie ook: MOREMBERT, "Denis Godefroy”, 437-438.

1309 HOLTHÖFER, “Die Literatur zum gemeinen und partikularen Recht”, 151.
} 
bodem, die ook in de Memorieboeken aan bod komt, is van de hand van Francisco Sarmiento de Mendoza. ${ }^{1310}$ Naar zijn Selectarum interpretationum libri tres (1571) wordt tot twee maal toe verwezen.

De Franse overmacht, wat betreft humanistisch geïnspireerde werken, wordt in zijn voortrekkersrol geruggesteund door enkele auteurs van Nederlandse bodem. Er is Gabriel Van der Muyden, die volgens de traditionele visie het juridisch humanisme vanuit Bourges aan de Oude Universiteit van Leuven introduceerde. Zijn Commentarii ad titulos Digestorum: pro socio, de contrahenda emptione, de actionibus empti et venditi, de pignoribus et hypothecis (1563) wordt drie maal aangehaald. Een belangrijkere invloed negen allegaties- ging echter uit van de Paratitla in Pandectis iuris civilis (1565) van Matthias Wesenbeeck. Een werk dat ook voor het onderwijs zeer belangrijk is geweest. ${ }^{1311}$ De nadrukkelijke aanwezigheid ervan kan wijzen op de rol die het onderwijs onrechtstreeks speelt bij de redactie van het Antwerpse gewoonterecht. Iedereen draagt immers bagage met zich mee.

Hoezeer het juridisch humanisme doorgaans ook met Frankrijk geassocieerd wordt, toch komen ook in het Italië van de zestiende eeuw commentaren van het nieuwe type tot stand. ${ }^{1312}$ Overigens, de founding father van de nova methodus, Andrea Alciato, was afkomstig van het Italische schiereiland. Hij was het die vanaf 1518 op tekstkritisch vlak voor een doorbraak zorgde met werken als Paradoxa (1518), Dispunctiones (1518), Praetermissa (1518) en Parerga (1529-1536). Ook zijn De verborum significatione van 1530 getuigt van deze nieuwe geest, aldus zijn biograaf Viard: "La recherche historique pour elle-même, le souci de mieux connaitre le droit romain tel qu'il fut appliqué sous Justinien et avant lui, ressortent, avec évidence, de travaux tels que le commentaire sur le titre De verborum significatione, les Paradoxa, Dispunctiones, Praetermissa et Parerga."'1313 Zelfs zijn allereerste werk, Annotationes in tres posteriores libros Codicis Iustiniani (1515), vertrekt vanuit eenzelfde optiek: diepgaande kennis van de klassieke talen en antieke cultuur in Verbindung mit der Jurispruden : $^{1314}$ In de Memorien op de Costumen is er -althans als commentaar op het geleerde recht- enkel sprake van zijn commentaar bij de titel De verborum obligationibus uit 1519. Ook dit werk heb ik niet in het Handbuch van Coing kunnen terugvinden. De vraag blijft dus in hoeverre zijn positie binnen deze categorie van 'jonge commentaren' gerechtvaardigd is? We zullen deze stelling op basis van andere argumenten verantwoorden. Gezien het tijdstip waarop een aantal van zijn lezingen aan de Universiteit van Avignon werden gepubliceerd in een werk als $D e$ verborum obligationibus, namelijk 1519, kan ik met zekerheid stellen dat het ook hier om een humanistisch beïnvloed werk gaat. In 1518 had hij immers reeds de Paradoxa uitgebracht, een werk dat hem op slag wereldberoemd maakte, en waarin hij blijk gaf

1310 TROJE, “Die Literatur des gemeinen Rechts unter dem Einfluss des Humanismus”, 683.

1311 CANOY-OLTHOFF en NEVE, Holländische elegan₹ gegenüber deutschem Usus Modernus Pandectarum?, noot 107.

1312 Cfr. HOLTHÖFER, "Die Literatur zum gemeinen und partikularen Recht”, 141-145.

1313 VIARD, André Alciat, 137. Hoewel Alciato's commentaar op de Digestentitel De verborum significatione bij Coing gerangschikt staat onder de Nicht-systematische Elementarliteratur, behoort het werk tot de eerste manifestaties van de nieuwe geest.

1314 OTTO, "Alciatus, Andreas", 28. 
van zijn superioriteit wat betreft de verklaring van juridische teksten met behulp van filologische hulpmiddelen. Desalniettemin wordt hij hier slechts één maal met dit specifiek werk aangehaald. Verder zijn er nog twee andere ongeïdentificeerde allegaties naar Alciato in de Memorieboeken terug te vinden.

Benevens de commentaren van Alciato is het echter armoe troef wat betreft de Italiaanse commentatoren van het jonge type. De Memorieboeken laten overtuigend zien dat de uitstraling en invloed ervan duidelijk te wensen overlaat. De twee enige andere allegaties naar een modern auteur van het Italisch schiereiland verwijzen naar

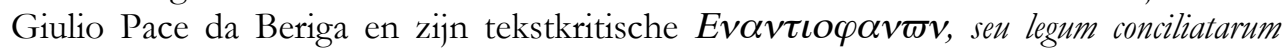
centuriae decem (1586-1588).

Rest mij enkel nog te wijzen op de al even ondervertegenwoordigde commentaren afkomstig van auteurs uit het Heilige Roomse Rijk. Wanneer men de grotendeels te Wittenberg werkzame, Matthias Wesenbeeck tot de Nederlanden rekent, dan blijft er enkel Johann Schneidewin over. Hij publiceerde in 1553 een commentaar, In IV libros Institutionum iuris civilis commentarius, bij de vier boeken van de Institutiones. Ook dit werk, waarnaar de commissieleden slechts één maal hebben verwezen, staat in de traditie van het juridisch humanisme.

Ondanks het feit dat bijna veertig procent van de allegaties binnen deze categorie afkomstig is van werken welke doorgaans als commentaren van het jonge type worden beschouwd, moet ik me er evenzeer rekenschap van geven dat net iets meer dan de helft van de allegaties verwijst naar middeleeuwse auteurs. Bovendien ontbreken een aantal toch wel zeer uitgesproken humanistische auteurs van Nederlands origine. ${ }^{1315} \mathrm{Ik}$ denk aan iemand als de Bruggeling Jacob Reyvaert (15351568), leerling van Van der Muyden en later docent volgens de humanistische methode aan de jonge universiteit van Dowaai. Verder dient hier ook melding gemaakt te worden van figuren als Joachim Hopper (1527-1576) en Jean Tack (15351578). Beiden doceerden aan de Oude Universiteit van Leuven en schreven commentaren op het Corpus Iuris volgens de nieuwe stijl. ${ }^{1316}$ Het lijkt een vergeten generatie.

Gezien de beperkte relevantie van de commentaren geschreven op het canonieke recht ten aanzien van de Antwerpse Consuetudines compilatae, zal ik hier ook niet al te uitvoerig op deze materie ingaan. De cijfers zijn bovendien te beperkt om er zelfs eventuele trends uit af te leiden, zeker wat betreft het evenwicht tussen middeleeuwse en moderne auteurs. Ik wil me dan ook beperken tot het aangeven van een aantal vaststellingen. In de eerste plaats wil ik wijzen op de voorname positie van Diego

1315 Teneinde het geheel hier niet onnodig te overladen, beperk ik me tot de Nederlandse regio.

1316 Cfr. Lovanium docet, 67-72; VAN DEN BERGH, Geleerd recht, 71. Ook Troje en Söllner plaatsen beide figuren bij de exponenten van het juridisch humanisme in de Nederlanden. (Cfr. TROJE, "Die Literatur des gemeinen Rechts unter dem Einfluss des Humanismus", 678; SÖLLNER, "Die Literatur zum gemeinen und partikularen Recht in Deutschland, Österreich, den Niederlanden und der Schweiz", 545.) Omtrent de werken die beide auteurs hebben geproduceerd, cfr. DEKKERS, Bibliotheca Belgica Juridica, 83-84 en 168-169. 
Covarubias y Leyva binnen de groep. Rechtstreeks is hij goed voor niet meer dan drie allegaties, maar onrechtstreeks -als tweederangsallegatie- wordt zijn canoniekrechtelijk oeuvre niet minder dan zeven maal aangesproken. We hebben hier immers te maken met vermoedelijk de belangrijkste Spaanse jurist tout court. Zoals reeds eerder aangegeven, levert het hem de toenaam van Spaanse Bartolo da Sassoferrato op. Als 21 -jarige schopte hij het reeds tot professor Canoniek recht aan de Universiteit van Salamanca, waar hij eveneens in contact komt met de Spaanse Laatscholastiek. Ook Covarubias y Leyva zelf zal uitgebreid ingaan op staats- en volkenrechtelijke thema's, net als privaatrechtelijke aangelegenheden zoals verjaring, erfrecht, etcetera. Ook in de Memorieboeken is het ten aanzien van dat laatste thema, meer bepaald in titel 3.13 over testamenten, dat zijn oeuvre wordt geraadpleegd.

Het is overigens opvallend in hoeverre de allegaties naar kerkrechtelijke commentaren zich in de titels over het (testamentair) erfrecht concentreren. Vier van hen komen voor in titel 3.13, waar al de overige allegaties willekeurig verspreid liggen over andere titels. Dit ligt echter voor de hand gezien de invloed welke de Kerk heeft uitgeoefend bij de renaissance van het testament. Samen met de Romeinen en hun recht was het principe in verval geraakt. Het is pas met de herontdekking van het Romeinse recht en de opname van een titel over testamenten in de Decretalen van paus Gregorius IX (1234) dat zij voorgoed opnieuw ten tonele verschijnen. ${ }^{1317}$ Doordat het canonieke recht zulk een decisieve rol heeft gespeeld bij de remonte van het testament, ligt het voor de hand dat de kerkrechtelijke commentaren zich in titel 3.13 concentreren.

De overige commentaren worden niet meer dan één of twee maal geallegeerd. De nadruk ligt hierbij op Italiaanse auteurs (Giovanni d'Andrea, Andrea Alciato, Ettore Feliti en Baldus de Ubaldis). Afzonderlijk representeren zij ieder één allegatie. De rangen worden gesloten door de Franse jurist Guillaume Benoit, die twee maal wordt geallegeerd en Peter Binsfeld, afkomstig van het Heilige Roomse Rijk. Zijn Commentarius theologicus et iuridicus in titulum iuris canonici de usuris (1593) werd slechts één maal geraadpleegd. Juan López de Palacios Rubeos de Ribero maakt het Spaanse overwicht compleet. 1318 Twee maal wordt er in de Memorieboeken naar zijn Repetitio rubr. Et cap per vestras Decretalium de donationibus inter virum et uxorum (1503) verwezen.

\section{Rechtspraak}

Deze categorie omvat de rechtspraakverzamelingen of de zogenaamde Decisiones. In deze collecties staan de beslissingen van welbepaalde, voornamelijk hogere, gerechtshoven centraal. Deze worden bovendien gekenmerkt door een ontvankelijke houding ten overstaan van het geleerde ius commune. Maar ook aan de motivatie, die aan de basis ligt van de besluitvorming, wordt hier aandacht besteed. ${ }^{1319}$ Reeds in

1317 Cfr. supra, hoofdstuk 1, paragraaf 2, Deel III, Erfrecht. Zie ook: GODDING, Droit privé, 377e.v.

1318 Dit ligt in de lijn van de woorden van Holthöfer, die in Coing's Handbuch de voorkeur van de Spaanse juristen voor canoniekrechtelijke bronnen aanstipt. Cfr. HOLTHÖFER, "Die Literatur zum gemeinen und partikularen Recht", 111.

1319 Ook binnen dit genre bestaan verschillende subcategorieën. Om de overzichtelijkheid van dit luik te vrijwaren, heb ik er voor geopteerd al deze licht verschillende types onder dezelfde 
vijftiende eeuw eigenen zij zich -volgens het voorbeeld van de rechtspraakverzamelingen van de (kerkrechtelijke) Rota Romana- een eigen plaats toe binnen de (wereldlijke) rechtswetenschappelijke literatuur. ${ }^{1320}$ Het is namelijk belangrijk voor de procesvoerende partijen te weten op welke manier er bij de besluitvorming werd geredeneerd en welke autoriteiten hierbij door de rechtbank in kwestie werden gevolgd. Een eeuw later was ten aanzien van het genre een algemeen positieve beoordeling tot stand gekomen, voornamelijk omwille van het objectieve karakter ervan, waarbij op een onpartijdige manier gezocht wordt naar de juridische waarheid. Ook de educatieve waarde van de verzamelingen werd sterk geapprecieerd. Jonge praktizijnen leren er het gangbare recht in, wat aan de juridische faculteit maar al te vaak werd genegeerd. ${ }^{1321}$ Deze houding zou in de zeventiende eeuw uitmonden in een situatie waarbij het genre, wat betreft autoritatieve waarde, het hoogste aanzien bereikt. Desalniettemin kende het genre, althans te Italië, op dat ogenblik nog niet de grootste verspreiding. ${ }^{1322}$ Walter komt, met betrekking tot de Franse decisiones, tot de volgende vaststellingen. Op basis van hun eerste verschijningsdatum plaatst hij de bloeiperiode van de arretisten tussen 1600 en $1750 .{ }^{1323}$ Scholz stelt met betrekking tot de Spaanse Decisiones dat zij hun bloei kennen in de periode 1580-1650 uitlopend naar 1700. Die van het adviserende literatuurtype plaatst hij dan weer wat later dan normaal, namelijk van 1550 tot $1650 .{ }^{1324}$ Rest me enkel nog het Heilige Roomse Rijk. Absoluut gezien heeft men hier de meeste rechtsprechungssammlungen voortgebracht, waarvan het merendeel in de achttiende eeuw (een tiende in de zestiende eeuw en een derde in de zeventiende eeuw). Opnieuw krijg ik een afspiegeling van het klassieke beeld te zien. Dit werd nog maar eens treffend omschreven door Gehrke: "Über die Hälfte der Werke mit privaten Gelebrtengutachten erschien im 16. und 17. Jahrbundert, während die Sammlungen aus den Bereichen der Gerichte und Universitäten als kollegialisch zusammengesetzter Institutionen überwiegend aus dem 18. Jabrhundert stammen. Hierin spiegelt sich die in der Rechtsentwicklung des betrachteten Zeitraums allgemein erkennbare Umbewertung juristischer Autoritäten wider, die der Meinung einzelner Rechtsgelehrter -auch in ibrer

noemer te behandelen. Meer detaillistische uiteenzettingen hieromtrent zijn terug te vinden in het Handbuch van Coing: Ascheri met betrekking tot de Italiaanse staten (ASCHERI, "Rechtsprechungs- und konsiliensammlungen", 1161-1178), Walter met betrekking tot Frankrijk (WALTER, "Rechtsprechungs- und konsiliensammlungen", 1244-1255), Gehrke met betrekking tot het Heilige Roomse Rijk (GEHRKE, "Rechtsprechungs- und Konsiliensammlungen”, 1351-1362), Wagner met betrekking tot de Nederlanden (WAGNER, "Rechtsprechungs- und Konsiliensammlungen", 1407-1413.), Scholz met betrekking tot Spanje (SCHOLZ, "Rechtsprechungs- und Konsiliensammlungen", 1291-1305.) en Portugal (SCHOLZ, "Rechtsprechungs- und Konsiliensammlungen”, 1328-1335.)

1320 Reeds vanaf de veertiende eeuw werden de besluiten van de Romeinse Rota gepubliceerd. (Cfr. STEIN, Roman Law in European History, 93.)

1321 DAUCHY en DEMARS-SION, Les recueils d'arrêts, 12.

1322 Cfr. ASCHERI, "Rechtsprechungs- und konsiliensammlungen”, 1118-1120.

1323 WALTER, "Rechtsprechungs- und konsiliensammlungen”, 1228.

1324 SCHOLZ, "Rechtsprechungs- und Konsiliensammlungen", 1277-1278 en 1311. Te Portugal kennen de rechtspraakverzamelingen hun hoogtepunt tijdens de periode 1580-1650. (SCHOLZ, "Rechtsprechungs- und Konsiliensammlungen", 1323.) 
Zusammenfassung als 'communis opinio doctorum'- eine abnehmende und der in kollegialer Beratung zustandegekommenen Rechtsauffassung von Sprüchkörpern eine zunehmende Bedeutung beimisst."1325

Tabel 3.11 geeft nu een overzicht van de wijze waarop deze verschillende 'producenten' van decisiones zich onderling verhouden binnen het geheel van de Memorieboeken. Dat het hier uitsluitend om 'buitenlandse' jurisprudentie gaat, was te verwachten. Het is namelijk zo dat in de zestiende eeuw slechts zeer uitzonderlijk naar de rechtspraak van de eigen, provinciale of centrale hoven wordt verwezen. Men verwijst enkel naar de jurisprudentie van buitenlandse hoven. ${ }^{1326}$ Bovendien werden er voor 1626 geen rechtspraakverzamelingen van eigen bodem gepubliceerd. ${ }^{1327}$

Tabel 3.11 De geografische herkomst van de geallegeerde rechtspraakverzamelingen in functie het aantal allegaties

\begin{tabular}{|l|l|l|}
\hline Land van herkomst & Aantal allegaties & Jaar van publicatie \\
\hline Frankrijk & 40 & $1461,1532,1544,1556,1603$ \\
\hline Duitsland & 14 & $1563,1578,1579$ \\
\hline Italië (Fivizzano, Firenze en Luca, Mantua) & $5(2,1,2)$ & $1581,1588,1597$ \\
\hline Savoie-Piemont & $4(3,1)$ & 1606,1590 \\
\hline Spanje (Cathalonië) & 4 & 1585 \\
\hline
\end{tabular}

Net zoals bij de categorie van het particuliere recht verdient ook hier Frankrijk de meeste aandacht. Maar liefst zestig procent van de 67 jurisprudentiële allegaties is afkomstig van Franse arretisten. Hierbij spant het Recueil d'arrests notables des courts souveraines de France (1556) van Jean Papon de kroon. Het werk verzamelt tal van uitspraken van diverse souvereine hoven binnen het Franse koninkrijk. Hoewel het heel wat kritiek van contemporaine auteurs als Cujas, d'Argentré, Dumoulin en Coquille had te verduren, bleek het, zowel in binnen- en buitenland, een enorm succes te kennen. ${ }^{1328}$ Dat zijn invloed verder reikte dan het Franse koninkrijk alleen bleek onder meer uit de Practica criminalis van de Milanese jurist Giulio Claro, die constant naar de Franse arresten uit het Recueil van Papon verwees, maar blijkt evenzeer uit de Memorien op de Costumen. Ook de Antwerpse commissieleden verwezen niet minder dan dertig maal naar de commentaar van Jean Papon. Maar ook andere verzamelingen van uitspraken van Franse rechtscolleges komen hier aan bod. Zo denk ik aan de vroege collecties van bijvoorbeeld Guy de la Pape (Decisiones grationopolitanae, 1444-1461) en Nicolas de Bohier (Decisiones supremi senatus Burdegalensis, 1544). Zij brachten de beslissingen bij elkaar van respectievelijk het parlement van

1325 GEHRKE, "Rechtsprechungs- und Konsiliensammlungen”, 1345-1346. Omtrent de betekenis van de consilia in het Heilige Roomse Rijk, cfr. GEHRKE, "Rechtsprechungs- und Konsiliensammlungen", 1375-1380.

${ }^{1326}$ Cfr. supra, hoofdstuk 1, paragraaf 2. Zie ook: GODDING, "Recueils de jurisprudence", 14-15.

1327 Cfr. infra, hoofdstuk 3, paragraaf 2, Rechtspraak.

1328 Omtrent deze double mouvement de méfiance et référence au travail de Papon, cfr. R. MARTINAGE, “Jean Papon (1507-1590), le mal aimé?”, A. DEPERCHIN, N. DERASSE en B. DUBOIS red., Figures de Justice. Etudes en l'honneur de Jean-Pierre Royer, Rijsel, 2004, 247-257. 
Grenoble en dat van Bordeaux. Het overwicht van deze auteurs binnen het Franse luik verbaast me in die zin niet, dat de compilaties van de la Pape, Papon en de Bohier tot de meest herdukte compilaties van dit genre in Frankrijk behoren. De la Papes Decisiones grationopolitanae werd 25 maal heruitgegeven, het Recueil van Papon negentien maal en de Decisiones van de Bohier zestien keer. ${ }^{1329}$ De compilaties van besluitvorming afkomstig van de gerechtshoven van de Dauphiné en Toulouse, respectievelijk van de hand van François Marc en Géraud de Maynard, oefenden op het Antwerpse gewoonterecht een veel meer bescheiden invloed uit. ${ }^{1330}$ Gezamelijk vertegenwoordigen zij slechts een drietal allegaties. Ook de Plaidoyez, van Simon Marion behoort met één allegatie tot dit weinig invloedrijke segment van de rechtspraakverzamelingen. ${ }^{1331}$

Op basis van wat er in Coings Handbuch te lezen staat, lijkt het me geoorloofd gewag te maken van een aantal andere Franse auteurs die eveneens, op basis van hun toenmalige verspreiding -lees aantal herdukken-, in de Memorien op de Costumen verwacht hadden mogen worden. Het betreft hier het Recueil d'aucuns notables arrests donnez en la cour de parlement de Paris (1602) van George Louet, de Actions notables et plaidoyez. (1603) van Loys Servin en het Aurelii rerum iudicatarum libri IV (1596) van Anne Robert. Respectievelijk werden deze werken zestien, dertien en dertien keer heruitgegeven. ${ }^{1332}$

Het Franse succesverhaal verbaast me geenszins gezien het feit dat men in dit koninkrijk als eerste begonnen is met het tot stand brengen van jurisprudentiële collecties. Dat dit reeds vroeg kon geschieden is mogelijk dankzij de lange én grote traditie van centrale gerechtshoven, de zogenaamde parlementen, in Frankrijk. Nadat in 1302 het parlement van Parijs was ontsproten uit de vroegere curia regis, doet zich in de vijftiende eeuw een echte vlaag aan creaties van provinciale gerechtshoven voor: Toulouse (1420), Grenoble (1457), Bordeaux (1462), Dijon (1477), Aix-en-Provence (1501), Rouen (1515) en Rennes (1561).1333 Van zodra deze hoven enkele decennia actief geweest zijn en hun activiteiten dus voldoende materiaal ter compilatie hebben voortgebracht, kennen ook de eerste rechtspraakverzamelingen hun ontstaan. Vaak gaan deze zij aan zij met de carrière van één van zijn leden. Het grote aantal parlementen in Frankrijk en de relatief vroegtijdige creatie ervan, maakt de ontwikkeling van het Decisiones-genre reeds aan het begin van de zestiende eeuw

${ }^{1329}$ WALTER, “Rechtsprechungs- und konsiliensammlungen”, 1228.

1330 Net als in de Memorieboeken haalden deze werken ook in eigen kamp niet eenzelfde niveau als dat van de reeds vernoemde Decisiones van de la Pape en Papon. Zo bleef het aantal herdukken van Marc beperkt tot elf. Over de Maynard en Marion wordt er bij Walter met geen woord gerept. (WALTER, "Rechtsprechungs- und konsiliensammlungen”, 1228.)

1331 Omtrent het genre der Plaidoyez, cfr. WALTER, "Rechtsprechungs- und konsiliensammlungen", 1247.

1332 Cfr. WALTER, “Rechtsprechungs- und konsiliensammlungen”, 1228, noot 5.

1333 Cfr. J. POUMAREDE en J. THOMAS, "Introduction", J. POUMAREDE, en J. THOMAS red., Les Parlements de Province au XVTe siècle, Toulouse, 1996, 14-15. Later volgen er nog meer. Cfr. WALTER, "Rechtsprechungs- und konsiliensammlungen”, 1229-1230. 
mogelijk. Op die manier is haar sterke invloed op de Antwerpse commissieleden te verklaren.

Andere landen kennen een meer bescheiden en/of jongere jurisprudentiële traditie. Wat het Heilige Roomse Rijk betreft, is enkel het in 1495 te Spiers opgerichte Reichskammergericht het vermelden waard. Ook nu verschijnen de eerste compilaties van besluitvorming pas een zevental decennia later. Ik kom hier later nog op terug. De Nederlanden kennen een vergelijkbare evolutie. Alleen is hier de kloof nog groter. Naast de verschillende provinciale hoven (Raad van Vlaanderen, Raad van Brabant, ...) beschikte men er vanaf 1504 definitief over een centraal hof, de Grote Raad van Mechelen genaamd. Het werd in het leven geroepen nadat zijn Bourgondische voorloper, het Parlement van Mechelen, dat in 1463 door Karel de Stoute naar Frans model was ingericht, in 1477, met de komst van Maria van Bourgondië, terug werd opgedoekt. Desalniettemin moet men tot aan het begin van de zeventiende eeuw geduld uitoefenen alvorens Paul Van Christynens (1543-1631) Practicarum quaestionum ... in supremis Belgarum curiis actarum et observationum decisiones (1626), een eerste verzameling uitspraken van de Grote Raad van Mechelen in zes delen, het daglicht ziet. ${ }^{1334}$ Wat de Raad van Brabant betreft, is het zelfs wachten tot 1670 alvorens Pieter Stockmans (1608-1671) zijn Decisionum curiae Brabantiae sequicenturia publiceert. Wat de Noordelijke Nederlanden betreft, verschijnt ook hier pas in 1617 een eerste verzameling van uitspraken van het Hof van Holland en Zeeland (Curiae Hollandiae, Zelandiae et West-Frisiae decisiones) van de hand van Cornelis Mathiasz van Nieustad (1549-1606). ${ }^{1335}$ Data als deze verklaren uiteraard de afwezigheid van deze auteurs onder de geallegeerde iuris periti. Desondanks wisten de precedenten een, zij het beperkte, rol te spelen als decisief element ter voltooiing van de Consuetudines compilatae. In het eerste hoofdstuk van dit boek kon ik reeds een aantal keren lezen, hoe naar de autochtone jurisprudentie teruggegrepen werd als primaire rechtsbron. Ik denk hierbij aan de verscheidene verwijzingen naar de Antwerpse turbenboeken, maar evenzeer aan de referenties naar zeer concrete casussen zoals die zich hebben afgespeeld voor onder andere de Raad van Brabant.

Naast Frankrijk vormde het hertogdom Savoie gedurende het ancien régime een onafhankelijke staat tussen Frankrijk en Italië. Dat dit samen met Piemont gebeurde, is het gevolg van de vereniging van beide vorstendommen sinds 1563 onder de hertogen van het huis van Savoie. Ik heb in ons overzicht dan ook een aparte subcategorie toegekend aan deze regio. Het is immers zo dat het vorstendom pas in 1792 door Frankrijk veroverd werd en pas in 1860 definitief in het koninkrijk geïntegreerd werd. Vanaf 1559 kende het een centraal gerechtshof, met name de Senaat van Savoie te Chambéry. Terwijl Antonino Tesauro da Fossano de Piemontese decisiones verzamelde, welke hier slechts één maal geallegeerd werden, gaat de grootste aandacht in dit opzicht uit naar de besluitvorming van de Senaat van Savoie te Chambéry, welke in 1559 zijn ontstaan kende. Het is Antoine Favre geweest die als

1334 GODDING, "Recueils de jurisprudence", 14-15. In 1773 worden pas de verzamelingen van Cuvelier en de Grysperre, welke tot dan toe slechts als manuscript bestonden, te Rijsel uitgegeven. Cfr. GODDING, "Recueils de jurisprudence", 22.

1335 Cfr. GILISSEN, Historische inleiding, 389. 
gevolg van zijn arbeid in de gedaante van Eerste Président van het hof te Chambéry, als eerste de decisiones ervan zou samenbrengen. Favre, een overtuigd juridisch humanist, die later in de eerste plaats befaamd zou blijven om zijn interpolatiekritiek, publiceerde deze Codex Fabrianus in 1606. Hoewel men, gezien het belang dat er in de literatuur aan wordt toegeschreven, enigszins teleurgesteld zou kunnen zijn over het aandeel dat het werk hier vertegenwoordigt, is het toch opvallend dat het werk hier tout court anwezig is. Het werd immers pas twee jaar voor het voltooien van de Consuetudines compilatae in Lyon voor het eerst gedrukt. Anders staat het feit dát men er daadwerkelijk over kan beschikken de exhaustieve toepassing ervan niet langer in de weg.

Zoals reeds eerder aangehaald, zag ook het Heilige Roomse Rijk in 1495 zijn eerste centrale gerechtshof ontstaan, waarbij uitdrukkelijk een subsidiaire rol weggelegd werd voor het Romeinse recht. Dit Reichskammergericht motiveerde zijn beslissingen echter niet en deze situatie zette een aantal leden ervan aan de ratio achter de besluitvorming van het hof te verduidelijken. Tot de standaardwerken binnen dit genre, dat bij Coing ook als de Kameralistik aangeduid wordt, worden de Singularium observationum iudicii imperialis camerae (1563) van de arrestograaf Joachim Mynsinger von Frundeck en de Practicarum observationum (1578) van Andreas Gaill gerekend. ${ }^{1336}$ Beiden zijn te Spiers werkzaam geweest, Mynsinger als rechter (1548-1556) en Gaill als bijzitter (1558-1568). ${ }^{1337}$ Het was Mynsingers bedoeling de reputatie van het hof te verbeteren door te tonen dat, hoewel het hof nooit de redenering achter zijn beslissing op papier zette, ditzelfde hof evenwel de beste auteurs van het ius commune in acht nam bij de besluitvorming. ${ }^{1338}$ Gehrke spreekt in Coings Handbuch van Abhandlungen auf der Grundlage der Judikatur einzelner oder mehrever Gerichte (observationes forenses). ${ }^{1339}$ Hierbij worden rechtsvragen en -problemen, die steeds weer in de rechtspraktijk opduiken en wier beoordeling moeilijk en omstreden is, in afzonderlijke, vaak zeer korte uiteenzettingen bewezen, besproken en beoordeeld. De werken gelijken op die van het type van de quaestiones forenses, waarvan de in de Memorieboeken één maal geallegeerde Decisiones quaestionum illustrium (1579) van Jakob Thoming een voorbeeld is. ${ }^{1340}$ Het enige verschil schuilt in het ontbreken van een casusbeschrijving bij dit type van de observationes. De betekenis van werken als deze voor het rechtsleven van hun tijd, blijkt onder meer uit het feit dat zij tot die titels behoren die de grootste oplages halen. ${ }^{1341}$ Ook in Antwerpen ging er van beide werken een invloed uit die kwantitatief uitgedrukt kan worden in een totaal van dertien allegaties. Dit verbaast mij niet. Beide compilaties werden immers meermaals

1336 Omtrent de mate waarin Gaill Mynsinger von Frundeck heeft geplagieerd, cfr. SCHUMANN, Joachim Mynsinger von Frundeck, 58.

1337 Biografische details omtrent beide juristen zijn te vinden bij Schumann en von Kempis: SCHUMANN, Joachim Mynsinger von Frundeck; VON KEMPIS, Andreas Gaill.

1338 Cfr. STEIN, Roman Law in European History, 93.

1339 GEHRKE, "Rechtsprechungs- und Konsiliensammlungen", 1360.

1340 Cfr. GEHRKE, “Rechtsprechungs- und Konsiliensammlungen”, 1359.

1341 Cfr. GEHRKE, "Rechtsprechungs- und Konsiliensammlungen”, 1359-1360. Het type van de observationes forenses correspondeert met een vierde van alle rechtspraakverzamelingen. 
herdukt en kenden een enorme verspreiding doorheen gans Europa. Zo volgden er tot aan het einde van de zeventiende eeuw meer dan twintig uitgaven van de collectie van Mynsinger von Frundeck. ${ }^{1342}$

De invloed die uitgaat van de Spaanse rechtspraak is dan weer miniem. Niet meer dan vier allegaties gaan terug op het Iberisch schiereiland. De beslissingen van het crimineel gerechtshof in Cathalonië (Senatus Regius Cathaloniae, 1585), dewelke Luis de Peguera verzamelde, spelen een rol die nauwelijks te vergelijken is met die van de compilaties van de Franse (en Duitse) 'vonniscollectioneurs'. Bovendien concentreren deze allegaties zich in het zesde, strafrechtelijke deel van de Consuetudines compilatae, wat op zich logisch is, gezien het feit dat het hier een crimineel hof betreft. Dat het hier om de beslissingen van dít hof gaat, ligt evenzeer voor de hand aangezien het op z'n eentje goed is voor maar liefst vijftien verschillende rechtspraakverzamelingen. Het brengt het hof op een eenzame hoogte. ${ }^{1343}$ De compilatie van Peguera uit 1585 is overigens de tweede in lijn, nadat het pad werd geëffend door de Observantiarum Sacri Regii Cathaloniae Senatus (1580) van Miguel Ferrer en Segismundo Pujol. ${ }^{1344}$ Het feit dat het merendeel van de verzamelingen pas in de zeventiende eeuw tot stand kwamen, lag ongetwijfeld mee aan de basis van hun ondervertegenwoordiging binnen deze categorie. ${ }^{1345}$

Ook de Italiaanse collegae wisten op het eerste zicht geen noemenswaardige potten te breken. Een drietal verschillende Italiaanse hoven werden spaarzaam aangesproken. Het gaat hier om auteurs als Borgnino Cavalcani, Girolamo Magoni en Giovanni Pietro Sordi. Respectievelijk verzamelden zij de besluitvorming van de hoven van Fivizzano, Firenze en Luca, en Mantua. Samen komen zij echter niet verder dan vijf allegaties. ${ }^{1346}$ Wat de Italiaanse jurisprudentie betreft, is er één werk dat extra aandacht verdient, met name de Decisiones Rotae Genuensis de mercatura (1581) van Marcus Antonius Bellonus. ${ }^{1347}$ Omwille van het criterium der naamsvermelding viel dit werk uit de boot en de auteur komt dan ook niet voor in onze algemene lijst van iuris periti. Desalniettemin was het goed voor vijf allegaties, uiteraard met betrekking tot het vierde (handelsrechtelijke) deel van de Consuetudines compilatae. Bovendien wist Genua via haar 'statuten' een nog veel grotere invloed uit te oefenen. ${ }^{1348}$

Trouwens, het aandeel van de auteurs uit dit jurisprudentiële genre had aanzienlijk groter kunnen zijn, ware het niet dat deze categorie zich er uitstekend toe leende door onze toelatingscriteria gedecimeerd te worden. Vaak beoogde men -bij wijze van voorbeeld- louter een verwijzing naar een bepaalde casus uit de gecompileerde collectie, zonder daarbij oog te hebben voor de mening van de samensteller

1342 Cfr. OTTO, "Mynsinger von Frundeck, Joachim”, 462.

1343 Cfr. SCHOLZ, "Rechtsprechungs- und Konsiliensammlungen”, 1286.

1344 SCHOLZ, "Rechtsprechungs- und Konsiliensammlungen”, 1305.

1345 SCHOLZ, "Rechtsprechungs- und Konsiliensammlungen", 1277-1278.

1346 Ascheri rekent ook Agustin Bero tot deze categorie. (ASCHERI, "Rechtsprechungs- und konsiliensammlungen", 1180.) Ik daarentegen heb zijn Quaestiones familiares pragmaticis percommodae (1550) reeds bij de Quaestiones behandeld.

1347 ASCHERI, "Rechtsprechungs- und konsiliensammlungen”, 1153 en 1181.

1348 Cfr. supra, hoofdstuk 1, paragraaf 2, Deel IV. 
hieromtrent. Op deze manier verlieten een aantal auteurs de onderzoeksgroep. Dit deed zich onder meer voor bij de eerste rechtspraakverzameling van Italiaanse bodem, namelijk de Napolitaanse decisiones van Matteo d'Afflitto en die van Francisco Vivio da l'Aquila ten aanzien van hetzelfde hof. ${ }^{1349}$ Beide auteurs komen hier dan ook niet meer aan te pas. Wat Frankrijk betreft, geldt hetzelfde voor de Cent notables et singuliers questions de droit, décidées par arrests mémorables des cours souveraines de France (1602) van Jean Chenu.

Zoals ik met dit onderzoek tracht aan te tonen, hoeft het feit dat het hier een eerder praktisch genre betreft geen obstakel te zijn voor humanistische invloeden. Het juridisch humanisme reikt immers verder dan alleen het geleerde recht. Desalniettemin lijkt voorlopig de ordening van het materiaal het enige onmiddellijk hanteerbare criterium ter identificatie van sporen van de nova methodus. Kijken naar de persoon van de geallegeerde jurist in kwestie en zijn leeftijd, lijkt me niet veelzeggend gezien het jonge karakter van de meeste werken (Cfr. tabel 3.11) en de Kameralistik in het algemeen. Ik zal me hier dan ook beperken tot de structuur van de verschillende collecties. Van zodra er immers sprake is van een logisch systeem dat aan de basis van de ordening ligt, kan er bijgevolg ook gesproken worden van humanistische invloeden. Dit karakter wordt des te meer uitgesproken, des te meer logica in het systeem verwerkt is. Ik heb er reeds meermaals op gewezen dat in dit opzicht het Institutensysteem met zijn trichotomie (personae-res-actiones), evenals de herwerkte vierdeling van Doneau (personae-res-actiones-obligationes), één van de meest concrete verschijningsvormen is. Wat het genre van de rechtspraakcompilaties betreft, is dit echter een grote teleurstelling. ${ }^{1350} \mathrm{Ik}$ heb immers te maken met een jong, en dus nog onvoldoende ontwikkeld, genre. Doorgaans volgt het structureren van het materiaal op het verzamelen ervan. In Frankrijk bijvoorbeeld, dat ook nu weer de kroon spant, werd twee derde van de werken van deze arretisten in de periode 1600-1750 gepubliceerd. ${ }^{1351}$ De bloeiperiode ervan valt dan ook na de voltooiing van de Consuetudines compilatae. Slechts vijftien procent dateert van de periode ervoor. Het verbaast me dan ook nauwelijks logisch gestructureerde compilaties onder de geallegeerde werken aan te treffen. Het is immers te verwachten dat een onvolwassen genre als dit nog niet echt getuigt van een goed doordachte ordening en systematiek.

Dit is ook werkelijk het geval voor de toonaangevende werken in de Memorieboeken. Bij deze bespreking ga ik me bijgevolg beperken tot de meest invloedrijke collecties ten aanzien van de Antwerpse Consuetudines compilatae, zijnde die van Papon, Mynsinger von Frundeck, Gaill, Favre en Peguera. Jean Papon ordende zijn Recueil van arresten par tiltres, en XIIII livres, waarbij hij zich baseerde op de compilaties van Aufrerii, de la Pape, Bohier, Dumoulin, Rebuffi, Luc, Imbert et autres ho $[\mathrm{m}] \mathrm{mes}$ de bonne doctrine, desquelz. i'ai prins les plus notables arrestz, et y ay adiousté plus grand nombre

1349 De decisiones van d'Aflitto vormen de eerste compilatie van een seculier hof in Italië. (STEIN, Roman Law in European History, 93.)

1350 Dauchy spreekt enkel van thematische, alfabetische of chronologische indelingen. (DAUCHY en DEMARS-SION, Les recueils d'arrêts, 17.)

1351 Cfr. WALTER, “Rechtsprechungs- und konsiliensammlungen”, 1228-1229. 
d'autres... ${ }^{1352}$ De volgorde waarop hij al dit verzamelde materiaal weergaf, deed ons echter sterk terugdenken aan de vrij willekeurige ratio die ook aan de basis lag van de a-systematisch geordende Consuetudines antiquae en vele andere costumiere redacties van het eerste uur. ${ }^{1353}$ Ondanks het ontbreken van elke lógische ordening heb ik -op basis van de uitgave van het werk van 1559- toch de indruk dat Jean Papon niet geheel ongevoelig is gebleven voor de verlokkingen van het humanisme. Het werk mag dan wel geschreven zijn in het 'vulgaire' Frans, toch is op de achterzijde een gedicht in het Grieks aan te treffen en is de ganse proloog doorspekt van de antieke, mythologische figuren. Bovendien verzorgde Papon vertalingen van een aantal Griekse en Latijnse werken. ${ }^{1354}$ Ook de persoon van Joachim Mynsinger von Frundeck kan in se als humanist worden beschouwd. ${ }^{1355}$ Hij was een leerling van Zäsi en zou de grondlegger worden van de Kameralistik, de tak binnen de Duitse rechtswetenschap die zich concentreerde op de rechtspraak van het Rijkskamergerecht te Spiers. Toch schuilt dit humanisme niet meteen in de structuur van zijn Singularium observationum Iudicii Imperialis Camerae. Otto spreekt van unsystematuisch bei Gericht angelegte kurze Aufzeichnungen en ook Schumann wijst erop dat Mynsingers verdienste op juridisch vlak in de eerste plaats verscholen ligt in zijn rol als Begründer der kameralistischen Jurispruden::1356 Ook Andreas Gaill speelde een belangrijke rol binnen deze tak van de Duitse rechtswetenschap. Uitspraken over zijn al dan niet humanistische aard blijken schaars. Hoewel hij te Leuven Gabriel Van der Muyden en Pieter Peck als leermeesters aan het Studium Generale kende, laat von Kempis de vraag in hoeverre Van der Muyden met zijn nieuwe aanpak op Gaill indruk heeft kunnen maken in het midden. ${ }^{1357}$

1352 J. PAPON, Recueil d'arrestz, notables des courts souveraines de France, ordonnez par tiltres, en vingtquatre livres, Lyon, 1559, 16.

1353 Verder heb ik in de beschikbare literatuur weinig kunnen terugvinden omtrent de persoon en het werk van Jean Papon. Hij ontbreekt in Stolleis' Lexicon en de Franse Dictionnaire de biographie Française is nog niet aan de letter P. Wel komt hij uitvoeriger aan bod in de bijdrage van Martinage aan Les recueils d'arrêts et dictionnaires de jurisprudence van Dauchy en Demars-Sion: R. MARTINAGE, "Les arrêts en matière pénale dans les ouvrages juridiques du XVIe siècle", S. DAUCHY, en V. DEMARS-SION red., Les recueils d'arrêts et dictionaires de jurisprudence (XVTeXVIIIe siècles) (Collection bibliographie. II), Parijs, 2005, 219-251.

1354 Het betreft hier onder meer werken van Marcus Tullius Cicero en Demosthenes. (Cfr. PAPON, Recueil d'arrestz. notables des courts souveraines de France.)

1355 Cfr. SCHUMANN, Joachim Mynsinger von Frundeck, 193: Hij kent een strenge humanistische opvoeding, waarbij een belangrijke rol gespeeld wordt door vooraanstaande humanisten als Viglius (Padua) en Zäsi (Freiburg), met wie hij nauwe persoonlijke contacten onderhield. Verder getuigen ook zijn gedichten van deze humanistische invloed. Schumann besluit: "Nicht zuletz̨t haben wir einen 'Gebildeten' angetroffen, mit einer Bildung, deren Wurzeln weit in die bumanistischen Tradition zurückreichen.” (SCHUMANN, Joachim Mynsinger von Frundeck, 197.)

1356 OTTO, "Mynsinger von Frundeck, Joachim", 462. SCHUMANN, Joachim Mynsinger von Frundeck, 196.

1357 VON KEMPIS, Andreas Gaill, 16-17: "Inwieweit Mudaeus mit seiner neuartigen Methodik Eindruck auf seine Schüler und insbesondere auf Andreas machen konnte, mag offenbleiben. Den Bedürnissen der juristischen Praxis wird sie nicht unbedingt genügt haben. So ist ibr Einfluss auf das 
Niet elke rechtspraakverzameling ontbeert echter een systeem, ware het niet dat de logica erin achterwege blijft. Zelfs doorwinterde humanisten als Antoine Favre kwamen niet verder dan een opbouw van hun compilatie volgens de ordo iuris zoals hij die in de Codex Justinianus aantrof. Favre zei hieromtrent tot niets beters in staat te zijn: Id vero nec melius nec aptius a me praestari posse credidi, quam si ex ordine titulorum Codicis Iustinianei Placita disponerem... ${ }^{1358}$ Desalniettemin heb ik zulk een ordening steeds als onlogisch beschouwd en getuigt ze evenmin van een humanistische geest. Desondanks uit deze zich op een andere manier bij Antoine Favre. In zijn Codex Fabrianus tracht hij immers vele particuliere gevallen onder te brengen bij meer abstracte principes die ervan aan de basis liggen. Deze drang de stap te maken van particulier naar algemeen, is een typisch kenmerk van de humanistische wetenschap: minder Justiniaanse casuïstiek, meer systematisering.

Hier staat het middeleeuwse karakter van de Spaanse Decisiones -en dus ook de compilatie van Peguera- tegenover, aldus Scholz: "Im Ergebnis ist der Aufbau der einzelnen Abschnitte der Decisionensammlungen auf ein Schema zurückzufübren, wie es bereits die schulphilosophische Bildung des Mittelalters kannte und in der 'quaestio disputata' der Glossatoren und den 'quaestiones de facto' der Kommentatoren ibren ausdruck fand: casus-quaestio-Argumente pro et contra-solutio oder decisio." De oorzaak hiervan ziet hij in het rechtenonderwijs dat in Spanje tot in het midden van de zeventiende eeuw middeleeuws georiënteerd zal blijven. ${ }^{1359}$

Van de minder invloedrijke compilaties heb ik wat betreft de structuur enkel een aantal geïsoleerde opmerking kunnen terugvinden. Zo wijst Poumarède ten aanzien van de décisions toulousaines van Géraud de Maynard op l'absence de plan; sans aucun ordre logique. ${ }^{1360}$ Wat betreft Nicolas de Bohier en zijn rechtspraakverzameling van het parlement van Bordeaux, is bij Guyon het volgende te lezen: "Chez Nicolas Bobier, il n'est pas possible de trouver de plan véritable. Les matières se suivent en désordre ou selon un ordre qui échappe à toute logique, encore que l'on puisse trouver des groupes de décisions se rapportant à des sujets communs." "1361 Ook wat betreft de compilatie van Guy de la Pape verwacht ik, gezien zijn plaats in de tijd, geen logische ordening, systematiek of andere humanistische invloeden. De la Pape overleed reeds in 1487. Enkel van de meest omvangrijke collectie decisiones, die van François Marc met maar liefst 2800 uitspraken, heb ik hieromtrent geen enkele uitspraak kunnen terugvinden. ${ }^{1362}$

juristische Werk, von Andreas, wie noch zu zeigen sein wird, nicht allzu gross, wenn Gaill seinen Löwener Professor auch wiederholt als 'praeceptor meus honorandae memoriae' und ähnlich bezeichnete."

1358 Geciteerd naar: CHEVALIER, "Le président Faber", 275. Zie ook: OTTO, "Favre (Faber), Antoine", 207.

1359 SCHOLZ, "Rechtsprechungs- und Konsiliensammlungen", 1301.

1360 POUMARÈDE, "Les arrêtistes toulousains", 385. Zie ook: GUYON, "Recherches sur la méthode jurisprudentielle criminelle du Parlement de Bordeaux", 285-309.

1361 GUYON, "Recherches sur la méthode jurisprudentielle criminelle du Parlement de Bordeaux", 108.

1362 Omtrent de verzameling van François Marc, cfr. WALTER, "Rechtsprechungs- und konsiliensammlungen", 1254. 
Bij wijze van voorlopig besluit lijkt het me verantwoord te stellen dat het juridisch humanisme niet onmiddellijk langs deze weg zijn invloed uitoefende en bijgevolg bepalend was voor het uiteindelijke uitzicht van de costumiere compilaties in de Nederlanden. Wegens de kinderschoenen waarin het genre zich circa 1600 bevindt, ontbreken systematisch geordende rechtspraakverzamelingen. Anderzijds kan ik er niet omheen dat men voornamelijk auteurs allegeert welke enige affiniteit vertonen met het humanistische gedachtengoed. Papon, Mynsinger von Frundeck, Favre, ... allen flirten zij met de appetijtelijkheden van de Renaissance. Enkel de Spaanse arretisten à la Peguera blijven geworteld in de middeleeuwse traditie.

\section{Consilia}

Deze vijfde categorie groepeert alle vertegenwoordigers van het literatuurtype van de zogenaamde Consilia. Hierbij gaat het om verzamelingen van juridische adviezen welke de wetenschappelijke mening weergeven van een rechtsgeleerde aangaande een rechtsvraag uit de praktijk. Het genre verbindt dus de juridische geleerdheid van de universiteit met de forensische praktijk van de balie en op deze manier verwerft de juridische wetenschap onmiddellijke invloed op de rechtspraktijk, waarbij de duurzame gelding van het geleerde recht wordt verzekerd, aldus Horn. ${ }^{1363}$ Ook betekent dit dat, net zoals bij de band tussen de houding van de commissieleden en hun academische opleiding, er van een gelijkaardige gateway sprake kan zijn ten aanzien van de Consilia. Het genre vormt voor de professoren immers een uitgelezen mogelijkheid om hun rechtsgeleerde positie, hun wetenschappelijke uitgangspunten, verworvenheden en denkwijzen ingang te doen vinden in de onmiddellijke praktijk.

De Consilia-literatuur kan dan ook aan het begin van de moderne tijd anknopen bij een reeds lange middeleeuwse traditie, meer bepaald sinds de oprichting van de eerste rechtenfaculteiten. Het eerste gekende consilium is dat van Johannes Bassianus en dateert van de twaalfde eeuw. Het bevindt zich momenteel in het Trinity College te Cambridge. ${ }^{1364}$ Onder de commentatoren wordt deze traditie met succes voortgezet en tijdens de late middeleeuwen beleeft zij haar hoogtepunt. Naast de commentaren bij het geleerde recht en de traktaten vormen de Consilia het derde, grote genre van de Commentatoren. ${ }^{1365}$ Consilia worden nu als het ware aan de lopende band gefabriceerd. ${ }^{1366}$ Ook qua kwaliteit en betekenis voor de praxis van het juridische bedrijf vormden zij zeer waarschijnlijk het belangrijkste genre van dat moment en ze blijven dit tot in de nabloei van de Commentatorentijd. Horn wijst hieromtrent op de Consilia van Mariano Socini, Giasone del Maino en Filippo Decio. Ascheri spreekt, met betrekking tot de bloei die het genre kent in de zestiende eeuw, zowaar van een Konsiliatorenzeit. ${ }^{1367} \mathrm{Na} 1600$ moet het literatuurtype, met het verschijnen van de eerste

${ }^{1363}$ HORN, "Die legistische Literatur der Kommentatoren", 340.

1364 Cfr. WEIMAR, "Die legistische Literatur der Glossatorenzeit”, 243 en 249-250. HORN, "Die legistische Literatur der Kommentatoren”, 337.

1365 LESAFFER, Inleiding tot de Europese rechtsgeschiedenis, 234-235.

1366 Cfr. HORN, "Die legistische Literatur der Kommentatoren", 336.

1367 HORN, "Die legistische Literatur der Kommentatoren", 336. ASCHERI, "Rechtsprechungs- und konsiliensammlungen", 1202. 
rechtspraakverzamelingen, desalniettemin aan belang inboeten. ${ }^{1368}$ De verzamelingen van decisiones nemen immers de elementaire functie van het consilium over, namelijk het aanbieden van een oplossing voor controversiële casussen. Dat zij hierbij door de tijdgenoten als objectiever recht werden beschouwd, is te wijten aan het feit dat de adviezen van hun kant steeds tegen betaling werden besteld 'in functie van' de betalende partij. Deze lagere betrouwbaarheidsgraad maakt dat de adviezenverzamelingen stilaan de duimen moeten leggen voor het genre van de Decisiones. ${ }^{1369}$

In de Nederlanden kent het genre een gelijkaardige evolutie, zij het met de nodige vertraging. Het is immers wachten tot halverwege de zestiende eeuw alvorens er met de Consilia sive Responsa iuris van Nicolas Everaerts in 1554 een eerste adviezenverzamelingen van Nederlandse bodem verschijnt. Toch zal het genre pas tijdens de tweede helft van de zeventiende eeuw een gelijkaardige bloei kennen als dat het geval was in het Italië van de zestiende eeuw. Daar was het genre in deze periode reeds op zijn retour, welke ook in de Nederlanden volgde op de bloei, zij het opnieuw een pak later. De verklaring is eenvoudig. De oorzaak van het verval, namelijk het verschijnen van de -meer betrouwbar geachte- rechtspraakverzamelingen, vond eveneens veel later plaats. Een andere mogelijke verklaring is het relatief laat verschijnen van de voedingsbodem voor de creatie van Consilia, namelijk een academisch platform. In de Nederlanden werd immers pas in 1425 het eerste Studium Generale binnen de Bourgondische Nederlanden opgericht. Het brengt met zich mee dat de eerste adviserende literatuur van eigen bodem pas vanaf de tweede helft van de vijftiende kán verschijnen. Bovendien blijft Leuven tot 1562 de enige universiteit in de landen van 's herwaarts over. Het recruteringsveld blijft dan ook beperkt. Bijgevolg blijft ook in de Memorieboeken het genre van de Consilia een uitgesproken Italiaanse aangelegenheid. Voor elke collectie adviezen die er in de Nederlanden is verschenen, rolden er in Italië immers tien van de drukpers. ${ }^{1370}$ Hoewel de verhoudingen niet hetzelfde zijn, wordt het Italiaanse overwicht toch ook door onze cijfers in tabel 3.12 bevestigd. 1371

1368 Cfr. ASCHERI, "Rechtsprechungs- und konsiliensammlungen”, 1202.

1369 Men kan zich hierbij de vraag stellen of op deze manier de academische wereld aan invloed op de praktijk moet inboeten? We hebben immers voordien de aandacht gevestigd op de Consilia als rechtsreeks doorgeefluik van nieuwe trends.

1370 ASCHERI, "Rechtsprechungs- und konsiliensammlungen", 1198. WAGNER, "Rechtsprechungs- und Konsiliensammlungen", 1418.

1371 Hierbij is enige voorzichtigheid geboden. Vervaart, die in zijn onderzoek betreffende de Topica van Everaerts over een totaal van 5000 tot 6000 allegaties beschikken kon, acht deze aantallen te beperkt om precieze uitspraken te doen. Hooguit zijn deze waarden in staat bestaande trends al dan niet te bevestigen. Hierbij verwijst Vervaart naar het onderzoek van Wijffels omtrent de allegaties in de procesdossiers van de Grote Raad van Mechelen. Dit onderzoek stoelt op een totaal van maar liefst 10600 allegaties. Wat Vervaart echter fout doet, is dat hij de absolute waarden uit beide studies met elkaar vergelijkt, daar waar het totale aantal allegaties bij Wijffels zo goed als dubbel zo groot is. Het is bijgevolg enkel toegestaan de volgorde of relatieve verhoudingen van de auteurs met elkaar te vergelijken. (VERVAART, Nicolaas Everaerts, 120-124.) 
Tabel 3.12 De geografische herkomst van de Consilia in functie van het aantal allegaties

\begin{tabular}{|l|l|}
\hline Land van herkomst & Aantal allegaties \\
\hline Italië & 17 \\
\hline Nederlanden & 12 \\
\hline Frankrijk & 6 \\
\hline
\end{tabular}

De dominante rol van de Italiaanse auteurs binnen deze categorie is het logische gevolg van de Italiaanse oorsprong van het genre en het feit dat het genre aldaar zijn grootste bloei kent ten tijde van de Commentatoren, terwijl de andere landen in dat opzicht achterophinken. Ook Lesaffer bestempelde het genre als één van de drie typische, literaire manifestaties van de middeleeuwse rechtswetenschap. ${ }^{1372}$ Dit blijkt ook overtuigend uit de vaststelling dat maar liefst acht van de tien Italiaanse auteurs met zekerheid tot de bartolistische traditie gerekend mogen worden. De nadruk hierbij ligt op de collectie consilia van Alessandro di Tartagni, waarnaar vier maal werd gerefereerd. Hier komt bij dat ook nog eens negen maal werd gerefereerd naar de commentaar van Charles Dumoulin op dit werk. Filippo Decio, Ludovico Pontano de Roma, evenals Angelus en Baldus de Ubaldis werden twee maal geallegeerd. De overigen slechts één maal: Francisco d'Accolti, Pietro Ancarano, Aimone Cravetta, Marc-Antonio Pellegrini en Nicolo Tudeschi. Het gaat hier dus duidelijk om een grote en zeer verscheiden groep waardoor hun individueel aandeel in zekere zin beperkt blijft.

Dit is niet van toepassing op de adviserende literatuur afkomstig van de Nederlanden. De adviezen van Nicolas Everaerts werden maar liefst acht maal geconsulteerd en op deze manier ontpopt hij zich tot de voornaamste Consilia-auteur van allemaal, althans in de ogen van de Antwerpse commissieleden. Zijn aanwezigheid hier verbaast uiteraard niemand, gezien de herkomst van de man, zijn gezag als jurist en de aandacht die hij als eerste aan het lokale recht besteedde. ${ }^{1373}$ De twee overige juristen van eigen bodem die tot dan toe een verzameling van hun consilia hadden gepubliceerd, met name Albert de Leeuw, beter bekend als Leoninus, en Matthias Wesenbeeck, werden heel wat minder geraadpleegd. Respectievelijk greep men slechts één en drie maal terug naar de opinie van dit duo. Een verklaring voor hun

Wat de Memorieboeken betreft, ben ik niet verder dan 600 relevante allegaties gekomen. Desalniettemin blijkt uit alle drie de studies dat het aandeel van het genre der Consilia beperkt is gebleven. Bij Vervaart en Wijffels is de adviserende literatuur respectievelijk goed voor drie en anderhalf procent. (VERVAART, Nicolaas Everaerts, 121.) Te Antwerpen heb ik een aandeel 5.8 van vastgesteld. Dit percentage ligt enigszins in de lijn van wat Vervaart en Wijffels hebben geconstateerd. Dit is echter niet langer het geval van zodra ik de meest populaire consilia-auteurs binnen de drie verschillende studies met elkaar vergelijk. Bij Wijffels gaat het om Alessandro di Tartagni en Ludovico Pontano de Roma. Bij Vervaart zie ik zo goed als dezelfde namen verschijnen: Alessandro di Tartagni, Ludovico Pontano de Roma en Pietro Ancarano. Wat de Antwerpse commissieleden daarentegen betreft, liggende kaarten lichtelijk verschillend. Di Tartagni is nog goed te praten, maar de populairste consilia blijken die van de hand van Everaerts te zijn. Ook Matthias Wesenbeeck verdient hier vermeld te worden.

1372 LESAFFER, Inleiding tot de Europese rechtsgeschiedenis, 234-235.

1373 Cfr. BRANTS, La Faculté de droit, 9. 
ondervertegenwoordigde positie binnen deze groep ligt mogelijk in hun flirten met de hervormde ideeën wat deze individuen kenmerkt. ${ }^{1374}$

Rest me enkel nog in te gaan op de zes allegaties naar Franse consiliatoren. ${ }^{1375}$ Hier gaat het om twee allegaties naar zowel Charles Dumoulin als Roland dela Valle en slechts één naar Etienne Bertrand enerzijds en Barthélémy de Chasseneuz anderzijds. In combinatie met de totale afwezigheid van representanten van het genre afkomstig van het Heilige Roomse Rijk, lijkt dit logisch. Het is immers reeds gebleken dat beide landen vroeg, maar vooral over een zeer invloedrijke traditie van rechtspraakverzamelingen konden beschikken. Waar Italië en de Nederlanden op datzelfde vlak ondermaats presteren, wordt dat tekort hier ruim gecompenseerd. De band is duidelijk. De logica zegeviert. Consilia en Decisiones gedragen zich als een zandloper. Zit hij bovenaan vol, dan is hij onderaan leeg en vice versa. Enkel de totale afwezigheid van Spanje blijkt moeilijker te verklaren.

Wat Frankrijk betreft, wil ik nog volgende opmerking maken. Er blijken bij de zuiderburen overigens sowieso opvallend weinig Consilia te vinden te zijn. De oorzaak hiervan werd eveneens nog niet onderzocht. ${ }^{1376}$ Het literaire landschap werd er tijdens de zestiende en ook nog aan het begin van de zeventiende eeuw dan ook gedomineerd door de gemeenrechtelijke commentaren. Vanaf halverwege de zestiende eeuw ziet men ook de aandacht voor het droit francais behoorlijk toenemen. Samen met die verklarende literatuur betreffende het particuliere recht en de verzamelbeschrijvingen van het Franse recht, zijn het ook hier in Frankrijk de rechtspraakverzamelingen die een eeuw later definitief het grootste gezag genieten. ${ }^{1377}$

Essentieel voor onze vraagstelling is dat ik hier te maken heb met een uitgesproken middeleeuws genre. Dit is reeds gebleken uit het aantal bartolistische auteurs onder de Italiaanse vertegenwoordigers van het genre binnen de onderzoeksgroep. Zoals in tabel 3.13 te zien is, valt ook in totaliteit hun overwicht niet te ontkennen.

Tabel 3.13 Middeleeuns versus bumanistisch georiënteerde auteurs van Consilia.

\begin{tabular}{|l|l|l|l|}
\hline \multicolumn{2}{|c|}{ Middeleeuws (25) } & \multicolumn{2}{c|}{ Humanistisch (5) } \\
\hline Nicolas Everaerts & 8 & Matthias Wesenbeeck & 3 \\
\hline Alessandro di Tartagni & 4 & Albert de Leeuw & 1 \\
\hline Filippo Decio & 2 & Marc-Antonio Pellegrini & 1 \\
\hline Ludovico Pontano de Roma & 2 & & \\
\hline Angelus de Ubaldis & 2 & & \\
\hline Baldus de Ubaldis & 2 & & \\
\hline Pietro Ancarano & 1 & & \\
\hline Francisco d'Accolti & 1 & & \\
\hline Nicolo Tudeschi & 1 & & \\
\hline
\end{tabular}

1374 Cfr. BRANTS, La Faculté de droit, 51, noot 5.

1375 In tegenstelling tot wat ik met betrekking tot de overige genres heb gedaan, zal ik hier geen opsomming geven van de verzamelingen van Consilia die hier ontbreken. Daarvoor de voorraad te massaal.

1376 Cfr. WALTER, "Rechtsprechungs- und konsiliensammlungen”, 1263.

1377 HOLTHÖFER, “Die Literatur zum gemeinen und partikularen Recht”, 145-146. 


\begin{tabular}{|l|l|l|l|}
\hline Etienne Bertrand & 1 & & \\
\hline Barthélémy de Chasseneuz & 1 & & \\
\hline
\end{tabular}

De cijfers liegen er niet om. 25 allegaties zijn afkomstig van bartolistische auteurs tegenover vijf van humanistisch geïnspireerde juristen. Betreffende vijf referenties blijft het onduidelijk de auteurs onder te brengen in zulk een nauw omschreven vakje (Dumoulin, Cravetta en dela Valle). Aan Everaerts wordt in de literatuur wel een dosis humanisme toegeschreven, maar dan heeft men het in de eerste plaats over zijn Topica (1516) en niet zijn Consilia. ${ }^{1378}$ Vandaar dat ik Everaerts tot het bartolistische kamp heb gerekend. Enkel Matthias Wesenbeeck, Albert de Leeuw en Marc-Antonio Pellegrini kunnen van humanistische trekjes beticht worden. ${ }^{1379}$

Het overwicht van bartolistische auteurs binnen deze groep mag evenwel niet geïnterpreteerd worden als een signaal van de voorkeur van de commissieleden voor de middeleeuwse rechtswetenschap. Neen, zij is louter het gevolg van het feit dat het hier een genre betreft, dat in de eerste plaats middeleeuws van aard is. Belangrijker voor mijn hypothese is het totale aandeel van de categorie binnen het geheel van de onderzoeksgroep. Dit aandeel blijft, met bijna zes procent, eerder beperkt en lijkt mijn vermoeden te bevestigen, namelijk de voorkeur van de commissieleden voor de verdiensten van de nova methodus. Anderzijds kan deze bescheiden invloed verklaard worden doordat tal van -voornamelijk buitenlandse- rechtspraakverzamelingen reeds voor handen waren, wat het gezag van de juridische adviezen heel wat schade toebrengt. Bovendien kan het belang nog verder gerelativeerd worden, namelijk door hun invloed af te meten aan de hand van het antal verschillende consilia dat werd geraadpleegd in tegenstelling tot het aantal allegaties naar vaak dezelfde raadgevingen. Toch verandert dit nauwelijks iets. In de meeste gevallen verwijst elke allegatie immers naar een verschillend consilium. Meer nog, de 36 allegaties waar het in deze categorie om gaat, refereren zelfs naar veertig verschillende adviezen. ${ }^{1380}$ Het komt immers voor dat er bij de allegatie van een auteur soms naar meerdere consilia van hem tegelijk verwezen wordt. Zoals reeds eerder aangegeven, heb ik zulke gevallen steeds als één enkele allegatie gerekend.

1378 Hetzelfde kan gezegd worden van Matthias Wesenbeeck. Het humanisme in hem uit zich in de eerste plaats in zijn Paratitla, en minder in zijn Consilia. (Cfr. DEKKERS, Humanisme en de rechtswetenschap, 236-239 en 246.)

1379 Wat Marc-Antonio Pellegrini betreft, heb ik me enkel op zijn plaats in de tijd (1530-1616) gebaseerd.

${ }^{1380}$ Nicolas Everaerts (acht allegaties naar acht verschillende consilia), Alessandro di Tartagni (vier allegaties naar zes consilia), Matthias Wesenbeeck (drie allegaties naar drie consilia) en Filippo Decio (twee allegaties naar twee consilia). Bij Paulo di Castro, Aymo Cravetta, Ludovico Pontano de Roma en Angelus de Ubaldis gaat het steeds om twee allegaties die naar twee verschillende consilia verwijzen. Bij Baldus de Ubaldis gaat het om twee allegaties en vier consilia; bij Roland dela Valle om twee allegaties en drie consilia en bij Charles Dumoulin om twee allegaties naar hetzelfde consilium. Wat de overige auteurs betreft, wordt steeds met één allegatie naar één consilium gerefereerd: Etienne Bertrand, Albert de Leeuw, Francisco d'Accolti, Pietro Ancherano en Nicolo Tudeschi. 
Secunda Scholastica

In de zestiende eeuw wordt christelijk Europa geconfronteerd met de Nieuwe Wereld. Vooral in Spanje brengt deze gewijzigde, mondiale situatie tal van nieuwe juridische vragen met zich mee, zoals bijvoorbeeld de rechtspositie van de autochtone bevolkingsgroepen van de veroverde, overzeese gebieden. Wat zijn de wederzijdse rechten en plichten van de kolonisatoren en de heidense bewoners van het Nieuwe Continent? Aan wie behoorde de eigendom van de nieuw veroverde gebieden? Enzovoort. ${ }^{1381}$ Deze problematiek kwam centraal te staan in het denken van de moraaltheologen, welke in de zestiende eeuw werkzaam waren aan de universiteit van Salamanca en er zich zowel met theologie als rechtsgeleerdheid gingen bezighouden. ${ }^{1382}$ In navolging van Francisco de Vitoria (1480-1546), de grondlegger van deze Secunda Scholastica, keren de Salamantinos terug naar het scholastieke oeuvre van Thomas van Aquino (1224-1274) en de middeleeuwse natuurrechtsleer in het bijzonder. Deze laatste kenmerkte zich door een opdeling van het recht in een veranderlijk en tijdelijk menselijk recht (ius positivum) enerzijds en een eeuwig, universeel geldend goddelijk (natuur)recht (ius naturale) anderzijds. Het scholastieke aspect schuilt in de overtuiging dat dit ius naturale de wil van God representeert en dat de mens deze natuurwet kennen kan door zijn rede, die deel had aan de goddelijke rede. Door dit universeel geldend recht te leren kennen, trachten zij tot oplossingen te komen met betrekking tot de rechtspositie van de nieuwe spelers op het mondiale toneel. Men was immers tot de conclusie gekomen dat het Romeinse recht in dezen niet langer toereikend was. De ontdekking van de Nieuwe Wereld liet namelijk blijken dat dit helemaal niet zo universeel geldend was als tot dan toe werd aangenomen. ${ }^{1383}$ Deze nieuwe tendens binnen het rechtsgeleerde veld zal zich snel over gans Europa

1381 Zie ook: E. NYS, Le droit des gens et les anciens jurisconsultes espagnols, Den Haag, 1914, 64-68. 1382 Cfr. STEIN, Roman law in European history, 94-96.

1383 Cfr. VAN DEN BERGH, Geleerd recht, 80-82. Dit gedachtegoed heeft zich in rechtstreekse lijn voortgeplant van de middeleeuwen over de laatscholastieke School van Salamanca tot het natuurrechtelijk denken van Hugo de Groot (1583-1645). In de loop van de zeventiende en de achttiende eeuw doet er zich vervolgens een secularisering voor van het natuurrecht. Het wordt zodanig losgekoppeld van de moraaltheologie dat het religieuze aspect geheel verdwijnen zal. Meer omtrent de geschiedenis van de Spaanse moraalfilosofen, cfr. F. C. J. P. COPLESTON, A History of Philosophy, I, New York, 1985. (Volume III Ockham to Suares); H. THIEME, "Natürliches Privatrecht und Spätscholastik", Zeitschrift der Savigny-Stiftung für Rechtsgeschichte. Germanistische Abteilung, 83 (1953), 230-266. H. THIEME, "Qu'est-ce que nous, les juristes, devons à la Seconde Scolastique espagnole”, P. GROSSI red., La Seconda Scolastica nella formazione el diritto privato moderno. Incontro di studio. Firenze, 16-19 ottobre 1972, Milaan, 1973, 7-21. BELLOMO, Common Legal Past of Europe, 224-232. Zie ook: J. M. DE AGUILAR, "The law of nations and the Salamanca School of Theology", The Thomist: a speculative quarterly review, 9 (1946), 186-221. H. F. KÖCK, Der Beitrag der Schule von Salamanca zur Entwicklung der Lebre von den Grundrechten (Schriften zur Rechtsgeschichte. Heft 39), Berlijn, 1987, 15-25. B. TIERNEY, “The Idea of Natural Rights. Studies on Natural Rights, Natural Law and Church Law 1150-1625”, Atlanta, 1997, 255-315. 
verspreiden en zich opwerken tot één van de dominante stromingen binnen het juridische denken. ${ }^{1384}$

Dit wordt tevens bevestigd door de Antwerpse Memorieboeken. Ook zij leveren een bewijs van de weidse verspreiding van het laatscholastieke gedachtegoed. Acht allegaties, of 1.3 procent van het totale aantal referenties, betreffen namelijk werken die doorgaans tot de voortbrengselen van de Secunda Scholastica gerekend worden. Twee auteurs die over het algemeen ook als vertegenwoordigers van de Spaanse Laatscholastiek omschreven worden, werden hier evenwel buiten beschouwing gelaten, omdat zij in de Memorien op de Costumen niet met hun laatscholastieke werken aan bod kwamen. Het betreft Diego Covarubias y Leyva en Fernando Vasquez de Menchaca, respectievelijk goed voor negen en twee allegaties. Hun werken, waarnaar verwezen wordt, werden reeds eerder besproken. ${ }^{1385}$ Met andere woorden, indien ik louter naar de persoon van de jurist zou kijken, en dus niet strikt naar het etiket dat op het geallegeerde werk kleeft, zou het aandeel van de Secunda Scholastica meer dan verdubbelen en toenemen met elf allegaties tot een totaal van negentien of een percentage van 3.2 procent. Hoe dan ook, het andeel van de Salamantinos blijft uitermate bescheiden. Hun invloed op het Antwerpse gewoonterecht beperkt zich zelfs tot slechts vier artikels, waarbij de artikels 4.1.9/10 maar liefst zes van acht allegaties voor hun rekening nemen. Artikel 4.1.9 omschrijft de regelgeving omtrent het geven van geld tot handel en gewin door een particulier aan een koopman: "Niettemin, soo wanneer een coopman te vreden waere eenige somme van penningen te aenveerden, om die in sijnen handel te bekeeren, met gelofte van, boven t'wederkeeren van de hooftpenningen, seker gewin, op den voet van de obligatie biernaer geruert, soo soude den gever van den gelde, alwaer hij geen coopman, t'selve gewin neffens sijne hooftpenningen mogen heijsschen ende genieten, als een schatschult, behoudelijck dattet gewin niet hooger en sij dan naer advenant den penninck sesthiene."1386 Artikel 4.1.10 omvat de obligatie waarvan sprake is in artikel 4.1.9: “D'obligatie daerop men sijn gelt tot handel ende gewin mach geven is dese: Ick, onderschreven, kenne mits desen onfangen te bebben van $N$. de somme van ..., om die voor hem te bekeeren in geoorloffden handel oft coopmanschappe; welcke somme mette proffijten van dijen tegens den penninck sestbiene, ick hem in den selven bandel oft coopmanschappeversekere, behoudelijck dat hij mij laet het meerder gewin dat daerop sal commen te vallen, gelove den voorschreven $\mathrm{N}$. de selve proffijten jaerlijcx goet te doen, naer advenant van den tijde dat ick dese voorschreve somme in den voorschreven handel hebben ende bouden sal, ende bem de selve somme oock weder te geven tot sijnder geliefte, naer dijen bij hem den voorschreven handel drije maenden te voorens sal hebben opgeseght."1387 Beide artikels kwamen in de plaats van het laatste artikel van titel LI (Van coopmanschap) van de Consuetudines impressae: "Item als yemandt eenen anderen geldt leent oft onder laet, $t$ 'sy ondersijn handtgheschrift oft anders, mach bespreken ende hem daer af doengeloven interest oft verloop rentsghenyse tegens den penninck sesthiene: Ende sijn alsulcke obligatien, daer by men gheloeft voor sekere somme geltsrente te betalen, van weerden, al en ware d'wtgever vanden gelde oft crediteur, noch d'ontfangher van dien gheen coopman: Ende en worden sulcke obligatien voor gheene renten ghehouden, dan alleenlijck voor

1384 BELLOMO, Common Legal Past of Europe, 225.

1385 Cfr. supra, hoofdstuk 3, paragraaf 2.

1386 Coutumes de la ville d'Anvers dites compilatae, IV, 6.

1387 Coutumes de la ville d'Anvers dites compilatae, IV, 6. 
Schatschulden, soo wanneer dat de debiteur ghelofte ghedaen heeft t'capitael metten verloope binnen sekeren bestemden tijde te betalen.". ${ }^{1388}$ Hierbij volgde men de gemeenschappelijke resolutio van de theologen en canonisten, aldus de Memorieboeken: Sunt etiam novi in hac revisione substituti in locum ar[ticu]li finalis in impressis tit van coopmanschappen qui passim lucrativos et subusurarios istos contractus admittebat contractus et placitum supra citatum ideoque necessario debuit restringi, nos hoc sumpsimus ex communi resolutione theologorum et canonistarum de qua late Ludovicus Molina in tract[atu] de iust[itia] et iure quaest[ione] 417 Covarr[uvius] 3 resolut[iones] cap 2 nu 3 et 4 et alii quos allegant, quorum sententiam etiam probat et sequitur Jo[ann]es Arraratius consiliarius parlamenti Burdegalensis in tractatu de la philosophi[a]e civile at tit quod quisque iuris citans ad hoc etiam Valentiam tomo 3 coment[ariorum] theolog[icorum] disputio 5 questio 25 puncto 2 idemque responderunt et pluribus rationibus confirmarunt novem precepui theologi Societatis Jesu. in hoc nostro Belgio, late Leonardus Lessius eiusdem Societatis Iesu theologus in tractatu de iustitia et iure lib 2 cap 25 dubit 3 Medina in summa instruct. conscient. $\int 2$ thanarius et alii quos refert, et sub certis modificationibus et limitat[ionibus] sequitur Lopes de Tove[r] lib $1^{\circ}$ cap 65 et talem contractum valere probat, post alios etiam Petrus Buffeldius in tractatu de usuris ad cap naviganti $x$ de usuris quaest[ione] 8 nec videtur obstare quod non desint qui in contrariam sententiam eunt, quos refert Rebellius Societatis Iesu theologus in tract[atu] de iustitia et iure lib 15, quaest[ione] 4 Pereg[rinus] cons[ilio] 96 nu 16 Sarment[is] lib 7 select[arum] interpret[ationum] iuris nu 7 et seqq, et alii quos allegant, nam plerique eorum saltem fatentur hac in conscientia posse subsistere adeoque si non ausuros aliquem ex tali contractu condemnari quamvis de iure canonico putant habere difficultatem ut dicit quoque Lopes de Corte loco i[bi] citato ut proinde et quod videamus hos contractus in Italia passim receptus et nominatum Luc [a] e ubi expresse statuto decisum invenies visum magistratui id etiam bic tollerare, et nisi facis preterquam quod multorum pupillorum et viduarum resperire necessum sit cum deficienti redituum emptione ut nunc fere fit neminem inveniunt cui pecuniam suam collocare tuto et sine periculo logis possunt, buenide [?] preterea ut dum pauperioris aut ogostate oppressos a levioribus usuris defendere volumus, eos gravioribus oneremus, improbissimo quoque ad rapinam et lucrum intento quod certe tollerandum non est, et propterea etiam inter canonistas convenit statutum valere quo maioribus usuris sublatis moderatores tollerantur hoc bic late Navar[rus] in manuali confessar[iorum] cap 27 nu 147 et post eum Buffeldius ubi i[bi] ad c quanto $X$ de usuris conclus [ione] 3 et 4 non obstat etiam placitum imp[eratoris] i[bi] citatum probibens ne quis lucrum habeat qui non subit periculum mercatura vel cum mercatore in eo participiat quia non tollit casum assecurationis cum alius intervenit qui periculum in se suscipit ut bic nec fuit unquam tam precise observatum quin multis sententiis probari potest obligationes de certo lucro etiam non mercatoribus factas in indicio contradictorio fuisse tolleratas usuris aut lucro tantum ad aquitabilem modum reductis idque etiam hic in curia ut no [m]i[n] atim de inter ceteros evenit in causa Augusti Sporeken, et Francisci Cortenbroeck quibus cum civitate negocium fuit ut taceamus imperatoris mentem non fuisse tollere qua ecclesia [e] aut canoniste permittunt sed vetita tantum voluisse vetare aut iis modum ponere ne in immensum abeant, denique non obstat, nec monere etiam debet quod malnere [?] plerique videantur, ne si hac tollerentur emptiones pra[e] diorum et redituum annorum negligantur et usuris aditus pate fiat pra[e]sertim gravioribus quod est fondamentum omnium illorum qui in contraria opinione sunt nam ut diximus vix est ut nunc opportunum sit pecuniam suam in reditus

1388 Coutumes de la ville d'Anvers dites impressae, II, 392. 
aut emptionem prediorum collocare et in civitate negociatoria inter mercatores inveniuntur pauci qui cum ipsi pecuniam suam collocant tam exiguo lucro aut moderatis usuris contenti sunt, ut pote qui ex cambiis et aliis legitimis negociationibus plus acquirere possunt adeoque sibi persuadeant se ex dispositione d placiti maioris exigere posse quod facient etiam acervius [?] nisi permittas honestiores cives qui mercatores non sunt pecuniam suam in hunc modum aliis ad lucrum dare ita tamen ut rationem reditus non exce $[r c]$ ant atque ita exponentur pauperiores et alii qui ad stabiliendam fidem suam aliena ope indigent gravioribus usuris quas mercatores ut diximus aliis me $[r]$ ciis sublatis inter se exercent ut proinde si omnia bene expendantur hac magis faciant ad moderationem quam augmentam usurarum nec est quod dicamus quod saltem conveniat taxam hic expressam diminuere ne hos contractus cum veris reditibus equiparemus nam ratio ubique eadem est et in reditibus id accedit quod hipothecqua etiam de iis cautum sit hac nuda obligatione adeoque mercatorum subsistant ut propterea intuitu maioris periculi et quod illi quibus pecunia hoc modo traditur etiam maius lucrum cum ea facturi sunt, aliquid pauperioribus viduis et pupillis hoc casu conce[r]cendum sit curia dividicet [?]. Onder de geallegeerde auteurs bevinden zich de volgende Salamantinos: Luis de Molina (De iustitia et iure, 1593), Gregorio de Valencia (Commentariorum theologicorum, 1591-1597), Leonard de Leys (De iustitia et iure, 1605), Bartolomeo de Medina (Summa de casos consciencie, 1580), Fernando Rebello (Opus de obligationibus iustitiae, religionis et caritatis, 1608), Martin Azpilcueta of Doctor Navarrus (Enchiridion sive manuale confessariorum, et poenitentium, 1557). Laatstgenoemde auteur vind ik eveneens terug bij artikel 1.14 .35 omtrent het ondervragen van poorters en ingezetenen en eerstgenoemde auteur wordt tevens geallegeerd met betrekking tot artikel 2.2.15 aangaande kinderen die huwen zonder hun ouders of momboors hierbij te betrekken.

De band die deze Spaanse (en Portugese) moraaltheologen met het juridisch humanisme hebben, is beperkt. Zo had bijvoorbeeld de grondlegger van de stroming, Francisco de Vitoria, die te Parijs had gestudeerd, namelijks voeling met het humanisme. ${ }^{1389}$ Ook intrinsiek vertoont de verhouding van de Secunda Scholastica met het humanisme eerder een zekere ambiguïteit. Zo getuigt ook de Spaanse laatscholastiek van een proces van ontvoogding, dat vergelijkbaar is met wat de juridische humanisten ondergaan hebben. Centraal hierin staat de erkenning van de ontoereikendheid van het Corpus Iuris Civilis, dat zijn universele ambities moet opbergen ten voordele van de eigen ratio. Hier staat echter tegenover dat deze ratio nu in dienst gesteld wordt van een ander type autoriteitsdenken, namelijk dat waarbij de dogmatische waarheid door God in de natuur gelegd werd en deze op basis van de eigen ratio achterhaald kan worden. Desalniettemin weerklinkt in de taal van de Salamantinos de echo van de conclusies van het juridisch humanisme, zoals ook Bellomo stelde: "Now, almost unexpectedly but hardly by chance, after centuries in which the laws of Justinian had been not only accepted but regarded as sacred texts, authoritative, complete, and perfect (that is, without real internal contratietates-contradictions), the content of those laws was discovered to have defects and their organisation was denounced as chaotic (a criticism that to some

1389 BELLOMO, Common Legal Past of Europe, 226. 
extent echoed the conclusions of legal humanism). A return to natura and a trust in reason to interpret that 'nature' became the guidelines of the new political and spiritual reality."1390

1390 BELLOMO, Common Legal Past of Europe, 230. Ook Villey stelde gelijkenissen vast tussen beide rechtswetenschappelijke strekkingen wanneer het de formulering betrof van het natuurrecht door de Spaanse moraaltheologen: “..., mais c'est bien plutôt la loi naturelle, et même une loi naturelle don't nos scolastiques ne craignent pas de chercher la formule plutôt dans la philosophie païenne, principalement le stoïcisme. Notre scolastique espagnole rejointà cet égard l'bumanisme." (M. VILLEY, "La promotion de la loi et du droit subjectif dans la Seconde Scholastique", P. GROSSI red., La Seconda Scolastica nella formazione el diritto privato moderno. Incontro di studio. Firenze, 16-19 ottobre 1972, Milaan, 1973, 66.) 


\section{CONCLUSIE BIJ HOOFDSTUK 3}

Zowel uit het eerste als het tweede hoofdstuk zijn elementen te voorschijn gekomen die erop wijzen dat ook de redactie van het gewoonterecht in de Nederlanden de invloed van het juridisch humanisme heeft ondergaan. Op inhoudelijk vlak denk ik hierbij aan het lappendeken van juridische bronnen die aan de basis liggen van de Antwerpse Consuetudines compilatae. Deze mozaïek van rechtsbronnen duidt op een ontvoogde instelling waarbij openheid en verscheidenheid de plaats hebben ingenomen van het dogmatische en universele karakter van het Romeinse recht binnen de middeleeuwse rechtswetenschap. Tekenend in dezen is de gewijzigde omgangsvorm met het Romeinse recht. Dit blijkt namelijk een autoritatieve degradatie ondergaan te hebben ten voordele van verschillende andere categorieën van rechtsbronnen en invloeden, zoals ik in het eerste hoofdstuk heb aangetoond. Daarenboven manifesteert de nieuwe methode van de mos gallicus zich ook op vormelijk vlak binnen het geredigeerde, Antwerpse recht. Zo bleek uit het tweede hoofdstuk dat zowel de Antwerpse Consuetudines compilatae, als het Gelderse Land-en Stadsrecht opgebouwd werden volgens de humanistische ordeningsprincipes van de Franse jurist Hugo Doneau. Beide vaststellingen zetten de hypothese dat, via de academische opleiding van de commissieleden, de verworvenheden van het juridisch humanisme ook hun weg naar het niveau van de geredigeerde costumen hebben gevonden, alleen maar kracht bij.

Bij wijze van extra argumentatie heb ik in dit derde en tevens laatste hoofdstuk de verschillende rechtswetenschappelijke allegaties in de Memorieboeken onderzocht. Zij geven immers als geheel een idee van het intellectuele klimaat waaruit de compilatores van de Antwerpse costume te werk zijn gegaan. Ook deze omgeving bleek sterk doordrongen te zijn van humanistische invloeden. Ten eerste zijn er de talrijke verwijzingen naar traktaten van het zogenaamde 'nieuwe type'. Slechts een derde van de geallegeerde traktaten, 32 in totaal, kunnen met zekerheid als middeleeuws bestempeld worden. In tweede instantie zijn er de referenties naar het typisch humanistische genre van de Quaestiones. Het genre breekt pas echt door in de tweede helft van de zestiende eeuw en ook de auteurs ervan worden doorgaans met de mos gallicus geassocieerd. Ten derde kan er gewezen worden op het overwicht van auteurs welke als vertegenwoordigers van het juridisch humanisme worden beschouwd, evenals het feit dat het merendeel van de geallegeerde iuris periti, afkomstig is van Frankrijk, de bakermat van de mos gallicus en waar de nova methodus haar eerste bloeiperiode kende. Deze kentering toont zich eveneens in de veel beperktere rol van de -veelal Italiaanse- bartolistische rechtsgeleerden, welke voordien de rechtswetenschappelijke wereld beheersten. Een vierde element is de enorme verscheidenheid aan literatuurtypes die hier aangebracht worden. Dat men zich niet langer uitsluitend laat inspireren door Romeinsrechtelijke commentaren, getuigt van een ontvoogde houding, die ruimte laat voor vreemde invloeden in plaats van de vroegere, dogmatische wijze waarop rechtsgeleerden het Justiniaanse recht aan zich lieten opdringen. Onder deze literatuurtypes tref $\mathrm{ik}$ nu onder meer costumierrechtelijke commentaren van vreemde steden of regio's, de 
rechtspraakverzamelingen van verschillende, buitensteedse rechtsbanken, allerhande monografische werken, consilia, etcetera. Het beste recht is de doelstelling en hiervoor mogen alle beschikbare hulpmiddelen aangewend worden. Ook binnen deze verschillende genres zijn de humanistisch geïnspireerde werken opvallend sterk vertegenwoordigd. In dit opzicht wil ik de bijna exclusieve dominantie van zowel humanistische, costumierrechtelijke commentaren als de humanistische, legislatieve commentaren vermelden. Maar ook binnen het genre van de commentaren op het 'geleerde recht' verwerven de gemeenrechtelijke commentaren van de nieuwe stijl een positie die evenwaardig is aan die van hun middeleeuwse soortgenoten. Bovendien vertonen ook de auteurs van de voornaamste decisiones enige affiniteit met het humanistische gedachtegoed. Allen flirten zij met de appetijtelijkheden van de Renaissance. Enkel de Spaanse arretisten blijven geworteld in de middeleeuwse traditie. Ten vijfde wil ik verwijzen naar de tweederangspositie die een typisch middeleeuws genre als dat van de consilia binnen de Memorieboeken inneemt. Een zesde en tevens laatste spoor van juridisch humanisme kan gevonden worden in de -zij het beperkte- aanwezigheid van laatscholastieke moraaltheologen van de Secunda Scholastica. Ook in de taal van de Salamantinos weerklinkt namelijk de echo van de verworvenheden van de mos gallicus. Kortom, men heeft z'n horizon sterk verbreed. Het Romeinse recht is niet langer de enige bron van redelijkheid. Uit deze ontvoogdingsdrang spreekt duidelijk de invloed van het juridisch humanisme. 


\section{ALGEMENE SLOTBESCHOUWING}

Op één jaar na is het exact vier volle eeuwen geleden dat te Antwerpen de 3643 artikels tellende Consuetudines compilatae werden voltooid. De costumiere compilatie is de apotheose van een drie kwart eeuw durend proces waarbij tot vier maal toe gepoogd werd de Antwerpse costume op zulk een manier te boek te stellen, zodat de vorstelijke homologatie van het ius proprium verworven kon worden. Het ganse, gewoonterechtelijke redactieproces in de Nederlanden vindt zijn oorsprong in de plakkaat van keizer Karel V van 7 oktober 1531, waarin hij de optekening beval van alle in gebruik zijnde costumen in de Zeventien Provinciën. Hierbij volgde hij het voorbeeld van de Franse koning Karel VII, die reeds in 1454 met de ordonnantie van Montilz-les-Tours een gelijkaardig bevel uitvaardigde. Waar dit proces in het Franse koninkrijk grotendeels voltooid was tegen het einde van de zestiende eeuw, nam dit in de landen van 's herwaarts over zo goed als het ganse oud-regime in beslag. De uitwendige geschiedenis van het costumiere redactieproces in de Nederlanden werd reeds uitvoerig en grotendeels volledig onderzocht door John Gilissen. Hij beschreef de homologatieprocedure, de talloze redactiepogingen binnen de verschillende Zeventien Provinciën, het moment waarop ze tot stand kwamen en in hoeverre zij door de vorst bekrachtigd werden. De inwendige ontwikkeling van het redactieproces behoort echter nog tot het wetenschappelijke terra incognita. Slechts zeer zelden ging in het verleden de aandacht uit naar de oorsprong van de inhoud en de vorm van de geredigeerde costumen. Met deze studie heb ik gepoogd aan deze tekortkoming tegemoet te komen. Wat zijn de vormelijke en inhoudelijke kenmerken van deze costumiere compilaties en welke invloeden kunnen hiervoor verantwoordelijk worden geacht? Deze vraag omvat het fundamentele uitgangspunt van dit proefschrift. De casus waarbij de Antwerpse Consuetudines compilatae (1608) en het Gelderse Land-en Stadsrecht (1620) via de Antwerpse advocaat en latere kanselier van het Hof van Gelre, Hendrik Uwens, op een uitzonderlijke manier aan elkaar gelinkt zijn, vormt in dit opzicht, mede dankzij de rijkdom van het beschikbare bronnenmateriaal, een ideaal studieobject om de inwerking van een aantal vorm- en inhoudsbepalende factoren op het redactieproces an te tonen en te beschrijven. Het tweespan AntwerpenRoermond, met Hendrik Uwens als trait-d'union, leent zich ertoe een niveau dieper te graven dan Gilissen en op deze manier een drietal fenomenen te beschrijven, die een belangrijke invloed uitgeoefend hebben op de totstandkoming en het uiteindelijke 
'zijn' van beide gewoonterechtelijke compilaties. Alzo komen in dit boek drie aspecten van het redactieproces aan bod: de rechtsbronnen van de innovaties binnen de Antwerpse Consuetudines compilatae, het verschijnsel van costumiere acculturatie en ten derde de invloed van het juridisch humanisme op de redactie van het gewoonterecht.

In 1610 verweet Jacques Van Uffel de redacteurs van de Consuetudines compilatae het Antwerpse gewoonterecht te hebben bezoedeld door er een farragine of mengelmoes van rechtsregels van te maken, die vaak weinig costumier van aard waren. In een eerste hoofdstuk heb ik kunnen zien dat de kritiek van Van Uffel moeilijk weerlegd kan worden. De voedingsbodem van de vierde, Antwerpse redactiepoging blijkt uiterst verscheiden en gevarieerd te zijn. Naast costumiere regels werd de compilatie geïnnoveerd aan de hand van wetgeving, het Romeinse recht, rechtsgeleerde opinies, buitensteedse jurisprudentie, gewoonterecht van andere steden en regio's, etcetera. Bovendien heb ik kunnen vaststellen dat het hier voornamelijk een daadwerkelijke receptie van 'niet-costumier' recht betrof, aangezien in het merendeel van de gevallen een expliciete bevestiging door de eigen gewoonte in de Memorieboeken ontbrak. Bijgevolg ben ik met betrekking tot het geredigeerde gewoonterecht gaan spreken van een aantal bijwerkingen van het redactieproces. Ik heb de lexificatie en romanisatie aangetoond, net als de verwetenschappelijking en technocratisering. Uiteindelijk bleek dit alles in het teken te staan van een trend tot rationalisering van het ius proprium.

Hoewel de rol van buitensteedse, costumiere compilaties als inspiratiebron voor de Antwerpse commissieleden relatief beperkt gebleven is, bestaat tevens de mogelijkheid dat deze vorm van beïnvloeding buitensporige proporties kan aannemen. In dit geval spreek ik van 'costumiere acculturatie', waarbij de ene compilatie als een soort van ratio scripta beschouwd en aangewend wordt door de samenstellers van een andere compilatie. De wijze waarop de Antwerpse Consuetudines compilatae, op aanraden van Hendrik Uwens, als model hebben gefungeerd bij de totstandkoming van het Gelderse Land-en Stadsrecht is hier een treffend voorbeeld van gebleken. Maar liefst 47 procent van de 1990 artikels uit het Gelderse Land- en Stadsrecht vertonen een letterlijke gelijkenis met artikels zoals ze in de Consuetudines compilatae kunnen aangetroffen worden. Hierbij werkt de vierde, Antwerpse redactiepoging als een Paard van Troje in op de compilatie van het Overkwartier. Via de acculturatie komt een gelijkaardig palet van rechtsbronnen aan de basis te liggen van het geredigeerde gewoonterecht in Roermond.

Deze verscheidenheid onder de juridische bronnen, welke aan de basis liggen van de Antwerpse, en dus ook Overkwartierlijke, costume, getuigt van een nieuwe, ontvoogde grondhouding, waarbij openheid naar vreemde elementen hoog in het vaandel wordt gedragen. Zulk een methode zet zich af tegen de vroegere, middeleeuwse benadering van het Romeinse recht, waarbij dit laatste een exclusieve en zelfs dogmatische rol opeiste bij de studie en analyse van het eigen, lokale recht. In zulk een autoritatieve degradatie van het Justiniaanse recht weerklinkt de echo van de mos gallicus. De universele, autoriteit van het Corpus Iuris wordt in twijfel getrokken en bekritiseerd. Er wordt ruimte gemaakt voor andere, niet-gemeenrechtelijke rechtsbronnen, die op een gelijke hoogte worden geplaatst als het Romeinse recht. 
Dit laatste wordt niet langer onvoorwaardelijk gerecipieerd. Enkel wanneer het conform de gewoonte is of voldoende redelijkheid en billijkheid in zich draagt, wordt de invloed van Rome aanvaard.

De doorwerking van de verworvenheden van de mos gallicus op het redactieproces van het costumiere recht in de Nederlanden laat zich echter niet alleen gevoelen op inhoudelijk vlak. Ook vormelijk is deze invloed aantoonbaar. Zowel de Antwerpse Consuetudines compilatae als het Gelderse Land- en Stadsrecht werden immers gestructureerd overeenkomstig de humanistische ordeningsprincipes van de Franse jurist, Hugo Doneau. Deze systematiseringsdrang, welke kenmerkend is voor de mos gallicus, kenmerkt zich door een terugkeer naar het Romeinse Institutensysteem, waarbij, in de gereviseerde versie, het recht wordt gerangschikt over vier in plaats van drie categorieën: personae, res, obligationes en tot slot actiones. Zowel in Antwerpen als te Roermond heeft men deze evolutie van empirisme naar humanisme doorgemaakt.

De doorwerking van het juridisch humanisme op het redactieproces van de costumen in de Nederlanden wordt nogmaals bevestigd door het beeld dat ik, aan de hand van een analyse van de allegaties in de Memorieboeken, geschetst heb van de intellectuele achtergrond waartegen de Antwerpse commissieleden opereerden. De mozaïek aan rechtsgeleerde werken, die op deze manier samengesteld werd, laat duidelijk zien hoezeer de compilatores van de Antwerpse costume op de hoogte waren van wat er zich rondom hen in rechtswetenschappelijke middens afspeelde. Het intellectuele klimaat toont zich namelijk als uitzonderlijk recent en sterk gevarieerd, met een enorme openheid naar alle mogelijke inspiratiebronnen toe. Ook nu weer blijkt uit verschillende elementen dat de commissieleden een grote affiniteit vertoonden met het gedachtegoed van de mos gallicus: de talrijke verwijzingen naar traktaten van het zogenaamde 'nieuwe type', de referenties naar het typisch humanistische genre van de Quaestiones, het overwicht van auteurs welke als vertegenwoordigers van het juridisch humanisme beschouwd worden evenals het feit dat het merendeel van de geallegeerde iuris periti afkomstig is van Frankrijk, de veel beperktere rol van de -veelal Italiaansebartolistische rechtsgeleerden, de enorme verscheidenheid aan literatuurtypes (Romeinsrechtelijke commentaren, costumierrechtelijke commentaren, rechtspraakverzamelingen van verschillende -voornamelijk buitensteedserechtbanken, allerhande monografische werken, consilia, etcetera), de bijna exclusieve dominantie van zowel humanistische costumierrechtelijke commentaren als de humanistische legislatieve commentaren, de evenwaardige positie van de gemeenrechtelijke commentaren van de nova methodus aan die van hun middeleeuwse soortgenoten, de affiniteit van de auteurs van de voornaamste decisiones met het humanistische gedachtegoed, de tweederangspositie die een typisch middeleeuws genre als dat van de consilia binnen de Memorieboeken inneemt, en tot slot de -zij het evenwel beperkte- aanwezigheid van laatscholastieke moraaltheologen van de Secunda Scholastica. Kortom, het staat buiten kijf dat het juridisch humanisme, via de academische opleiding van de commissieleden, tot op het niveau van het costumiere recht doorgedrongen is. 



\section{SUMMARY}

\section{LEGAL HUMANISM AND CUSTOMARY ACCULTURATION. FACTORS THAT DETERMINED BOTH FORM AND CONTENT OF THE ANTWERP CONSUETUDINES COMPILATAE (1608) AND THE GUELDERS COUNTRY AND TOWN STATUTE BOOK (1620).}

With this dissertation, the author attempts to offer an insight into the internal development of the process of recording customs in the Habsburg Netherlands, which has long remained in the shadow of its external history. He discusses the factors likely to have determined both form and content of compilations of customary law as recorded at the beginning of the seventeenth century in the Habsburg Netherlands. Basing himself on such compilations as those at Antwerp (Consuetudines compilatae) and Roermond (The Guelders Country and Town Statute Book [Het Gelderse Land-en Stadsrecbt]) of 1608 and 1620, respectively, the author reveals a number of factors which had a decisive impact on the form and content of the law of customs as recorded. In view of the special character of a case study such as the one presented here, the author does not presume to attempt an exhaustive presentation of these factors. On the contrary, his dissertation is intended to provide an exploratory first encounter with the internal history of the process of recording customs, a process initiated in the Habsburg Netherlands by Charles V in 1531.

More specifically, the book focuses on three phenomena that were decisive for this process. In the first part, the author discusses the legal basis of the recorded customary law prevailing in Antwerp in the year 1608. What legal sources formed the basis for the innovations in the Consuetudines compilatae? This question is of major relevance to the issue of whether its recorded version contains "unadulterated custom". To what extent do the customs recorded merely comprise the rules of the consuetudo? Or were recordings such as these influenced by foreign or non-customary elements? In this respect, the study calls attention to a number of phenomena, such as the legification, Romanisation, technocratisation, and scientificalisation of customary law. 
In the second part, the focus shifts according to the degree to which the recorded customs of one town or region influenced the recording process elsewhere. The main subject of the study discussed in this part is the Antwerp-Roermond case. In this connection, the author explains the phenomenon of 'customary acculturation'. The case study shows that one compilation may dramatically affect both form and content of another.

In the final part, the author demonstrates the effect of the accomplishments of legal humanism. These have proved to be traceable in relation to form and content, since both compilations reflect a purposive drive to systematise where form is concerned and an emancipatory process with regard to content. The auctoritas from Roman law is in decline, for example. 'Best law' is the new standard, irrespective of its origin. The intellectual weight of the compilers of the Consuetudines compilatae, which the author has reconstructed on the basis of the references expressed in the "Memorien op de costumen', reveals a penchant for the mos gallicus, combined with the rich diversity offered by a broad horizon. A logical order, as found in the Gaian System of the Institutes, is introduced.

On 7 October 1531, the Emperor Charles V issued an ordinance prescribing the recording of all customs in use in the Burgundian-Habsburg Netherlands. In so doing, he followed in the footsteps of the French King Charles VII, who, as early as 1454, issued the Montils-les-Tours ordinance prescribing a similar recording of local customary law. This process, intended to result in (partial) unification and (final) homologation of the countless customs observed within the boundaries of the Seventeen Provinces, did not always proceed smoothly. The town of Antwerp, for example, saw no less than four recording efforts over a period of more than sixty years (1547-1608). In Roermond, people had to wait until 1620 before The Guelders Country and Town Statute Book was compiled. Because of the exceptional way in which these two recording processes were affiliated, this customary twosome is at the core of this dissertation. The Antwerpian lawyer, Hendrik Uwens, for example, served as a trait-d'union between the two recording boards. After Uwens had collaborated from 1592 until 1608 on the compilation of the Antwerpian Consuetudines compilatae, he was appointed, in 1607, to the higher position of justice of the Grand Council of Mechelen (Grote Raad van Mechelen). From here, he made the switch-over to Roermond in 1614 to serve as chancellor of the Court of Guelders (Hof van Gelre). And so it happened that Uwens came into contact with Tilman van Bree, who at that very moment in time was responsible for recording the law of Upper Guelders (Overkwartier Roermond). Uwens advised him to make use for this task of a copy of the Antwerpian Consuetudines compilatae, which consisted of not less than 3,646 articles. Thus, a considerable amount of Antwerpian law was adopted into the Roermond compilation. As a result, the latter developed into an exceptional collection of no less than 1,990 articles. In both cases, such volume coincided with an endeavour to organise the material available logically. Conversely, this systemisation urge raises the suspicion that the accomplishments of legal humanism affected the process. This influence may be safely assumed, incidentally, given the academic education which 
many of the compilers of customs in the sixteenth and seventeenth century had enjoyed, in many cases at the Law Faculty of the University of Leuven. From the middle of the sixteenth century onwards, the professors at the Leuven Alma Mater were increasingly inspired by the legal humanism of Andrea Alciato's Bourges, which had been introduced by the legal scholar, Gabriel Van der Muyden. More specifically, there was an interest in the nova methodus for systemic and logical ordering, in which a major role was reserved for the revised, four-volume version of the Institutes (personae-res-obligationes-actiones), written by the French jurist, Hugo Doneau. Furthermore, legal humanism was also characterised by a change in attitude towards Roman Law. Whereas to bartolist commentators the auctoritas of Justinian law was inviolable, legal humanism is characterised by a drive for emancipation, in which the universal and dogmatic status of the Corpus Iuris could no longer be defended, as its imperfections were acknowledged. Such an attitude would allow more and more room for legal sources other than those of Roman Law. Stripped of the straightjacket formed by Roman Law, a quest for 'best law' was initiated.

This attitude of openness may be observed already in the first chapter of this book, in which the author's analysis of the legal basis of the innovations found in the Consuetudines compilatae forms the core. The various legal sources which formed the foundation for these innovations of the fourth Antwerpian recording attempt, are known from the Memorien op de costumen, a commentary on the Consuetudines compilatae, consisting of two thousand folios written by the compilers of the fourth recording attempt, to account for their actions. Article by article, the origin of each norm or legal rule is recorded. Apart from being influenced by the previous recording attempt, the Consuetudines impressae (1582), and local usage or usus as causa consuetudo, the patchwork of legal sources that emerged from the analysis is dominated by legislation and Roman law. The most striking conclusion in relation to the legislative sources is the dominant position of the written laws of the sovereign. Moreover, ordinances issued by the sovereign were also imposed in areas that are usually not regarded as falling within the potestas of the sovereign, exposing the extended scope of such written law and, in consequence, an increasingly firmer grip of the sovereign on local laws.

In addition to the legification of customary law, its Romanisation is one of the most important consequences of the recording process. Most susceptible, in this respect, were the law of persons, property law and criminal procedure, and to a lesser degree the law of obligations and substantive criminal law.

The role apparently played in the recording process by third parties, such as traders and "experts" of local commercial usage, has prompted the author to use the term 'technocratisation'. Their input was propably brought about by a lack of expertise on the part of the editors themselves, mainly where maritime and insurance law was concerned, but also in connection with the area of commercial law and the law of obligations in general. The say afforded to interested parties in this matter contrasts sharply with the authoritarian way in which the Antwerpian magistrate time and again managed to impose his will on the entire recording process. 
As to the influence of scholars, the prominence of the French legal literature is remarkable as is the connection between legal scholars and the Romanised articles. The French jurist, Louis le Caron, and the Flemish Filips Wielant were two of the most inspiring authors. Judicial decisions (inquisitiones per turbae, Antwerpian judgments and French collections of judicial decisions) and foreign, out-of-town, compilations of customary law, inter alia French coutumes and the customs of Ghent and Utrecht proved to be of less decisive influence. From the earlier Antwerpian recording attempts, the Consuetudines antiquissimae (1547), the first attempt, steals the show, primarily in the area of criminal law. All too often, it concerned actual reception of elements alien to local custom, which started to unravel the "unadulterated custom" myth.

The second chapter describes the phenomenon of 'customary acculturation'. The author reveals how the Antwerpian Consuetudines compilatae served as a ratio scripta in the formation of The Guelders Country and Town Statute Book. Nearly 50\% of the total number of articles in the Roermond compilation was assimilated with the Antwerpian example. A zenith was reached by the law of obligations, of which $70 \%$ was assimilated. In view of the role of commercial law in such a commercial metropolis as Antwerp was at the time -in contradistinction to the rather more modest commercial function of Upper Guelders-, this is a logical outcome. Three other legal areas, the law of persons, property law and criminal procedure, showed a degree of assimilation of around $60 \%$. 'Only' $40 \%$ of the third part of the Roermond compilation, on the manner in which property may be acquired, was assimilated with the Antwerpian model. It turns out that only civil procedure applicable in Upper Guelders has remained devoid of any Antwerpian influence. It was in large part original work. Generally speaking, therefore, the advice given by Hendrik Uwens to draw inspiration from the Antwerpian compilation earlier referred to had not fallen on deaf ears. In consequence, the Consuetudines compilatae had the effect of a Trojan horse on the customary law of Upper Guelders. Because of the phenomenon of customary acculturation, similar legal sources and influences which had lied at the root of the fourth Antwerpian recording effort, managed to seep into Upper Guelders. Furthermore, such 'normative assimilation' went hand in hand with 'structural assimilation'. Modelled on the Antwerpian Consuetudines compilatae, The Guelders Country and Town Statute Book was also largely organised according to the four-part system of the Institutes, as conceived by the French jurist, Hugo Doneau. Of relevance here are two ordering principles which were Doneau's brainchild. First of all, a strict distinction is made between substantive law, subdivided into the law of persons, property law, and the law of obligations, and procedural law. The second principle prescribes that, as happened in actual practice, substantive law must always precede procedural law. The two principles were applied in Antwerp and Roermond. The organisation of these compilations is therefore evidence of the effect of the accomplishments of legal humanism at the level of the local, private law in the Habsburg Netherlands. 
The influence of legal humanism is not only observed in the application of humanist ordering principles. The attitude towards Roman Law, as may be observed in the Memorieboeken, also reveals an attitude inspired by humanism. Thus, an authoritative degradation of Roman Law took place. Other legal sources and influences, legislation in particular, were accorded equal value. Moreover, the Justinian leges were no longer accepted without critical reflection. They were only received if rational and not contrary to custom. The effect of humanist thought is reaffirmed upon the author's analysis of the references in the Memorien op de Costumen. Also here, the influence of the nova methodus can no longer be ignored. Significant, in this respect, are the numerous references to treatises of the 'new type', references to specific humanist genres, such as the Quaestiones and the text-critical Observationes; the near-exclusive dominance of both humanist commentaries on customary law and the humanist commentaries on legislation; the equal position taken up by nova methodus commentaries of the ius commune together with the medieval commentaries on the Corpus Iuris; the authoritative presence of authors usually associated with the mos gallicus, on the one hand, and a more limited or no longer dominant role of medieval legal scholars, on the other; the second-rate status of such a typical medieval genre as the consilia; the presence of late-scholastic moral theologists of the Secunda Scholastica; and so on.

In sum, the dissertation calls attention to three aspects of the recording process in the Habsburg Netherlands at the beginning of the seventeenth century. First, the "unadulterated custom" myth has now indeed been debunked; second, the importance of the cross-influence on and by custom-recording boards must not be underestimated; and third, the accomplishments of legal humanism found their way into the domain of recorded customary law.

Translated by Louise Rayar 



\section{BIJLAGEN}



BIJLAGE 1

REFERENTIELIJST ARTIKELCOMMENTAAR MEMORIEBOEKEN.

Boek 28bis (Cfr. ANTWERPEN, Stadsarchief, Vierschaer, nr. 28bis: Memorien op de Costumen)

\begin{tabular}{|c|c|}
\hline Artikel & Pagina \\
\hline 1.1 .1 & 1 \\
\hline 1.1 .2 & 1 \\
\hline 1.1 .3 & $1-2$ \\
\hline 1.1 .4 & $2-3$ \\
\hline 1.1 .5 & 3 \\
\hline 1.1 .6 & 3 \\
\hline 1.1 .7 & $3-4$ \\
\hline 1.1 .8 & 4 \\
\hline 1.1 .9 & $4-5$ \\
\hline 1.1 .10 & 5 \\
\hline 1.1 .11 & 5 \\
\hline 1.1 .12 & $5-6$ \\
\hline 1.1 .13 & 6 \\
\hline 1.1 .14 & $6-7$ \\
\hline 1.1 .15 & 7 \\
\hline 1.2 .1 & 8 \\
\hline 1.2 .2 & $8-9$ \\
\hline 1.2 .3 & 9 \\
\hline 1.2 .4 & 9 \\
\hline 1.2 .5 & 10 \\
\hline 1.2 .6 & 10 \\
\hline 1.2 .7 & 10 \\
\hline 1.2 .8 & 10 \\
\hline 1.2 .9 & 11 \\
\hline 1.2 .10 & 11 \\
\hline 1.2 .11 & 12 \\
\hline 1.2 .12 & 12 \\
\hline 1.2 .13 & 12 \\
\hline 1.2 .14 & 12 \\
\hline 1.2 .15 & 12 \\
\hline 1.2 .16 & 12 \\
\hline 1.2 .17 & 12 \\
\hline 1.3 .1 & 13 \\
\hline 1.3 .2 & 13 \\
\hline 1.3 .3 & $13-14$ \\
\hline 1.3 .4 & 14 \\
\hline 1.3 .5 & 14 \\
\hline 1.3 .6 & $14-15$ \\
\hline 1.3 .7 & 15 \\
\hline 1.3 .8 & 15 \\
\hline 1.3 .9 & 15 \\
\hline $1.3 .10 / 11 / 12$ & 15 \\
\hline 1.3 .13 & 16 \\
\hline
\end{tabular}

\begin{tabular}{|c|c|}
\hline $1.3 .14 / 15$ & 16 \\
\hline 1.3 .16 & 16 \\
\hline 1.4 .1 & $16-17$ \\
\hline 1.4 .2 & 17 \\
\hline 1.4 .3 & 17 \\
\hline 1.4 .4 & 18 \\
\hline 1.4 .5 & 18 \\
\hline 1.4 .6 & 18 \\
\hline 1.4 .7 & 18-19 \\
\hline 1.4 .8 & 19 \\
\hline 1.4 .9 & 19 \\
\hline 1.4 .10 & 19 \\
\hline 1.4 .11 & $19-20$ \\
\hline 1.4 .12 & 20 \\
\hline 1.4 .13 & $20-21$ \\
\hline 1.4 .14 & 21 \\
\hline 1.4 .15 & 21 \\
\hline 1.4 .16 & 21 \\
\hline 1.4 .17 & 21 \\
\hline 1.4 .18 & $21-22$ \\
\hline 1.4 .19 & 22 \\
\hline 1.4 .20 & 22 \\
\hline 1.4 .21 & 22 \\
\hline 1.4 .22 & 22 \\
\hline 1.4 .23 & $22-23$ \\
\hline 1.4 .24 & 23 \\
\hline $1.5 .1 / 2 / 3$ & 23 \\
\hline 1.5 .4 & 23 \\
\hline 1.5 .5 & 23 \\
\hline 1.5 .6 & 24 \\
\hline 1.5 .7 & 24 \\
\hline $1.5 .8 / 9$ & 24 \\
\hline 1.5 .10 & 24 \\
\hline 1.5 .11 & 24 \\
\hline 1.5 .12 & 25 \\
\hline 1.5 .13 & 25 \\
\hline $1.5 .14 / 15$ & 25 \\
\hline 1.6 .1 & 25 \\
\hline 1.6 .2 & 26 \\
\hline 1.6 .3 & 26 \\
\hline $1.6 .4 / 5$ & 26 \\
\hline $1.6 .6 / 7$ & 26 \\
\hline 1.6 .8 & 26 \\
\hline 1.7 .1 & 26 \\
\hline
\end{tabular}




\begin{tabular}{|c|c|}
\hline 1.7 .2 & $26-27$ \\
\hline 1.7 .3 & 27 \\
\hline 1.7 .4 & 27 \\
\hline 1.7 .5 & 27 \\
\hline 1.7 .6 & 27 \\
\hline 1.7 .7 & 27 \\
\hline $1.7 .8 / 9$ & $27-28$ \\
\hline 1.7 .10 & 28 \\
\hline 1.7 .12 & 28 \\
\hline 1.7 .11 & 28 \\
\hline 1.7 .13 & 28 \\
\hline 1.8 .1 e.v. & 28 \\
\hline 1.9.1 e.v. & 29 \\
\hline $1.10 .1 / 2 / 3 / 4 / 5$ & 29 \\
\hline $1.10 .6 / 7$ & 29 \\
\hline 1.10 .8 & 29 \\
\hline 1.11 .1 & 30 \\
\hline $1.11 .2 / 3$ & 30 \\
\hline 1.11 .4 & 30 \\
\hline 1.11 .5 & $30-31$ \\
\hline 1.11 .6 & 31 \\
\hline 1.11 .7 & 31 \\
\hline 1.11 .8 & 31 \\
\hline 1.11 .9 & 31 \\
\hline 1.11 .10 & 31 \\
\hline $1.12 .1 / 2 / 3 / 4 / 5$ & 32 \\
\hline 1.12 .6 & 32 \\
\hline $1.12 .7 / 8$ & $32-33$ \\
\hline $1.12 .9 / 10$ & 33 \\
\hline 1.12 .11 & 34 \\
\hline 1.12 .12 & 34 \\
\hline 1.12 .13 & 34 \\
\hline $1.12 .14 / 15$ & 34 \\
\hline 1.12 .16 & 34 \\
\hline $1.12 .17 / 18$ & $34-35$ \\
\hline 1.12 .19 & 35 \\
\hline 1.12 .20 & 35 \\
\hline $1.12 .21 / 22$ & $35-36$ \\
\hline 1.12 .23 & 36 \\
\hline 1.12 .24 & 36 \\
\hline 1.12 .25 & 36 \\
\hline 1.12 .26 & 36 \\
\hline $1.12 .27 / 28$ & 37 \\
\hline 1.12 .29 & 37 \\
\hline $1.12 .30 / 31$ & 37 \\
\hline 1.13 .1 & 37 \\
\hline 1.13 .2 & 38 \\
\hline 1.13 .3 & 38 \\
\hline 1.13 .4 & 39 \\
\hline 1.13 .5 & 39 \\
\hline 1.13 .6 & 39 \\
\hline
\end{tabular}

\begin{tabular}{|c|c|}
\hline 1.13 .7 & $39-40$ \\
\hline 1.13 .8 & 40 \\
\hline $1.13 .9 / 10 / 11$ & 40 \\
\hline $1.13 .12 / 13 / 14$ & $40-41$ \\
\hline 1.14 .1 & $41-42$ \\
\hline $1.14 .2 / 3 / 4 / 5$ & 42 \\
\hline 1.14 .6 & 42 \\
\hline 1.14 .7 & 42 \\
\hline 1.14 .8 & $42-43$ \\
\hline 1.14 .9 & 43 \\
\hline $1.14 .10 / 11$ & $43-44$ \\
\hline 1.14 .12 & 44 \\
\hline $1.14 .13 / 14$ & 44 \\
\hline $1.14 .15 / 16$ & 44 \\
\hline 1.14 .17 & $44-45$ \\
\hline 1.14 .18 & 45 \\
\hline 1.14 .19 & 45 \\
\hline 1.14 .20 & 45 \\
\hline 1.14 .21 & $45-46$ \\
\hline $1.14 .22 / 23$ & 46 \\
\hline 1.14 .24 & 46 \\
\hline 1.14 .25 & $46-47$ \\
\hline 1.14 .26 & 47 \\
\hline 1.14 .27 & 47 \\
\hline $1.14 .28 / 29$ & 48 \\
\hline 1.14 .30 & 48 \\
\hline 1.14 .31 & 48 \\
\hline 1.14 .32 & 48 \\
\hline 1.14 .33 & $48-49$ \\
\hline 1.14 .34 & 49 \\
\hline $1.14 .35 / 36 / 37 / 38$ & $49-50$ \\
\hline 1.14 .39 & 50 \\
\hline 1.14 .40 & 50 \\
\hline 1.14 .41 & $50-51$ \\
\hline 1.14 .42 & 51 \\
\hline 1.14 .43 & 51 \\
\hline 1.15 .1 & $51-52$ \\
\hline $1.15 .2 / 3$ & 52 \\
\hline 1.15 .4 & 52 \\
\hline 1.15 .5 & 52 \\
\hline 1.15 .6 & 52 \\
\hline 1.15 .7 & 53 \\
\hline 1.16 .1 & $53-54$ \\
\hline $1.16 .2 / 3$ & 54 \\
\hline 1.16 .4 & $54-56$ \\
\hline $1.16 .5 / 6$ & 56 \\
\hline $1.16 .7 / 8$ & 56 \\
\hline $1.16 .9 / 10$ & 56 \\
\hline 1.16 .11 & 56 \\
\hline 1.16 .12 & $56-57$ \\
\hline 1.16 .13 & 57 \\
\hline
\end{tabular}


REFERENTIELIJST ARTIKELCOMMENTAAR MEMORIEBOEKEN

\begin{tabular}{|c|c|}
\hline $1.16 .14 / 15$ & 57 \\
\hline $2.1 .1 / 2$ & 59 \\
\hline 2.1 .3 & 59 \\
\hline 2.1 .4 & 60 \\
\hline 2.1 .5 & 60 \\
\hline 2.1 .6 & $60-61$ \\
\hline 2.1 .7 & 61 \\
\hline 2.1 .8 & 61 \\
\hline 2.1 .9 & 62 \\
\hline 2.1 .10 & 62 \\
\hline 2.1 .11 & 63 \\
\hline 2.1 .12 & 63 \\
\hline 2.1 .13 & 63-64 \\
\hline 2.1 .14 & 64 \\
\hline $2.1 .15 / 16$ & 64-65 \\
\hline 2.1 .17 & 65 \\
\hline $2.1 .18 / 19$ & $65-66$ \\
\hline 2.1 .20 & 66 \\
\hline 2.1 .21 & 66 \\
\hline $2.1 .22 / 23$ & $66-67$ \\
\hline 2.1 .24 & 67 \\
\hline 2.1 .25 & 67 \\
\hline 2.1 .26 & 67 \\
\hline 2.1 .27 & 67 \\
\hline 2.1 .28 & 68 \\
\hline 2.1 .29 & 68 \\
\hline 2.1 .30 & $68-69$ \\
\hline 2.1 .31 & 69 \\
\hline 2.1 .32 & $69-70$ \\
\hline 2.1 .33 & $70-71$ \\
\hline 2.1 .34 & 71 \\
\hline 2.1 .35 & $71-72$ \\
\hline $2.1 .36 / 37$ & 72 \\
\hline 2.1 .38 & $72-73$ \\
\hline $2.1 .39 / 40 / 41 / 42$ & 73 \\
\hline 2.1 .43 & $73-74$ \\
\hline 2.1 .44 & 74 \\
\hline 2.1 .45 & $74-75$ \\
\hline 2.1 .46 & 75 \\
\hline 2.1 .47 & 76 \\
\hline 2.1 .48 & 76 \\
\hline 2.1 .49 & $76-77$ \\
\hline $2.1 .50 / 51 / 52 / 53$ & $77-78$ \\
\hline 2.1 .54 & 78 \\
\hline $2.1 .55 / 56$ & 78 \\
\hline 2.1 .57 & 78 \\
\hline $2.1 .58 / 59$ & $78-79$ \\
\hline 2.1 .60 & 79 \\
\hline $2.1 .61-62$ & 79 \\
\hline 2.1 .63 & 79 \\
\hline 2.1 .64 & 80 \\
\hline
\end{tabular}

\begin{tabular}{|c|c|}
\hline 2.1 .65 & 80 \\
\hline 2.1 .66 & 80 \\
\hline 2.1 .67 & $80-81$ \\
\hline $2.1 .68 / 69 / 70 / 71 / 72$ & $81-82$ \\
\hline 2.1 .73 & 82 \\
\hline 2.1 .74 & 82 \\
\hline 2.1 .75 & $82-83$ \\
\hline 2.1 .76 & 83-84 \\
\hline 2.1.77 & 84 \\
\hline 2.1 .78 & $84-85$ \\
\hline 2.1 .79 & 85 \\
\hline 2.1 .80 & 85 \\
\hline 2.1 .81 & 85 \\
\hline 2.1.82 & $85-86$ \\
\hline 2.1 .83 & 86 \\
\hline 2.1 .84 & 86 \\
\hline 2.1 .85 & 86 \\
\hline $2.1 .86 / 87$ & $86-87$ \\
\hline 2.1 .88 & 87 \\
\hline 2.1 .89 & $87-88$ \\
\hline 2.1 .90 & 88 \\
\hline 2.1 .91 & 88 \\
\hline 2.1 .92 & $88-89$ \\
\hline 2.1 .93 & 89 \\
\hline 2.1 .94 & 89 \\
\hline 2.1 .95 & 89 \\
\hline 2.1 .96 & 90 \\
\hline 2.1 .97 & $90-91$ \\
\hline $2.1 .98 / 99 / 100$ & 91 \\
\hline 2.1 .101 & $91-92$ \\
\hline 2.1 .102 & 92 \\
\hline 2.1 .103 & $92-93$ \\
\hline 2.1 .104 & 93 \\
\hline 2.1 .105 & 93 \\
\hline 2.1 .106 & 93 \\
\hline $2.1 .107 / 108$ & 93-94 \\
\hline 2.1 .109 & 94 \\
\hline $2.1 .110 / 111$ & $94-95$ \\
\hline $2.1 .112 / 113 / 114$ & 95 \\
\hline 2.1 .115 & $95-96$ \\
\hline 2.1 .116 & 96 \\
\hline $2.1 .117 / 118$ & $96-97$ \\
\hline $2.1 .119 / 120$ & $97-98$ \\
\hline 2.1 .121 & 98 \\
\hline 2.1 .122 & 98 \\
\hline 2.1 .123 & $98-99$ \\
\hline $2.1 .124 / 125$ & $99-100$ \\
\hline $2.1 .126 / 127 / 128 / 129$ & 100 \\
\hline 2.1 .130 & 100 \\
\hline 2.1 .131 & $100-101$ \\
\hline 2.1 .132 & 101 \\
\hline
\end{tabular}




\begin{tabular}{|c|c|}
\hline 2.1 .133 & 101 \\
\hline 2.1 .134 & 101 \\
\hline 2.1 .135 & 101 \\
\hline 2.1 .136 & 102 \\
\hline $2.1 .137 / 138$ & 102 \\
\hline $2.1 .139 / 140$ & $102-103$ \\
\hline 2.1 .141 & 103 \\
\hline 2.1 .142 & $103-106$ \\
\hline $2.1 .143 / 144$ & 106 \\
\hline $2.1 .145 / 146$ & 106-107 \\
\hline 2.1 .147 & 107 \\
\hline $2.1 .148 / 149$ & $107-108$ \\
\hline 2.1 .150 & 108-109 \\
\hline 2.1 .151 & 109 \\
\hline $2.1 .152 / 153$ & 109 \\
\hline 2.1 .154 & $109-110$ \\
\hline 2.1 .155 & 110 \\
\hline $2.1 .156 / 157$ & 110 \\
\hline 2.1 .158 & 111 \\
\hline $2.1 .159 / 160$ & 111 \\
\hline $2.1 .161 / 162$ & $111-112$ \\
\hline 2.1 .163 & 112 \\
\hline 2.1 .164 & $112-113$ \\
\hline $2.1 .165 / 166$ & 113-114 \\
\hline 2.1 .167 & 114 \\
\hline 2.1 .168 & 114-115 \\
\hline 2.1 .169 & 115 \\
\hline 2.1 .170 & $115-116$ \\
\hline 2.1 .171 & 116 \\
\hline 2.1 .172 & 116 \\
\hline $2.1 .173 / 174$ & 117-119 \\
\hline $2.1 .175 / 176 / 177$ & 120 \\
\hline 2.1 .178 & $120-121$ \\
\hline 2.1 .179 & 121 \\
\hline 2.1 .180 & 121 \\
\hline $2.1 .181 / 182 / 183$ & $121-122$ \\
\hline $2.1 .184 / 185$ & $122-123$ \\
\hline $2.1 .186 / 187$ & 123 \\
\hline $2.1 .188 / 189 / 190$ & 123 \\
\hline 2.1 .191 & 124 \\
\hline 2.1 .192 & 124 \\
\hline 2.1 .193 & $124-125$ \\
\hline 2.1 .194 & 125 \\
\hline 2.1 .195 & $125-126$ \\
\hline $2.1 .196 / 197 / 198$ & $126-127$ \\
\hline 2.1 .199 & 127 \\
\hline 2.1 .200 & 127 \\
\hline 2.1 .201 & 127 \\
\hline 2.1 .202 & $127-128$ \\
\hline 2.1 .203 & 128 \\
\hline $2.1 .204 / 205$ & 128 \\
\hline
\end{tabular}

\begin{tabular}{|c|c|}
\hline $2.1 .206 / 207 / 208$ & $128-129$ \\
\hline 2.1.209 & 129 \\
\hline 2.1 .210 & $129-130$ \\
\hline 2.1 .211 & 130 \\
\hline 2.1 .212 & $130-131$ \\
\hline 2.1 .213 & 131 \\
\hline 2.1 .214 & 131 \\
\hline 2.1 .215 & 132 \\
\hline 2.1 .216 & $132-133$ \\
\hline $2.1 .217 / 218$ & 133 \\
\hline 2.1 .219 & 133 \\
\hline 2.1 .220 & 133 \\
\hline 2.1 .221 & $133-134$ \\
\hline $2.1 .222 / 223$ & 134 \\
\hline 2.1.224 & 134 \\
\hline 2.1 .225 & $134-135$ \\
\hline 2.1 .226 & 135 \\
\hline $2.1 .227 / 228$ & 135 \\
\hline 2.2 .1 & $136-137$ \\
\hline 2.2 .2 & 137 \\
\hline $2.2 .3 / 4$ & 137 \\
\hline $2.2 .5 / 6$ & 137 \\
\hline 2.2 .7 & 138 \\
\hline 2.2 .8 & 138 \\
\hline $2.2 .9 / 10 / 11$ & 138 \\
\hline 2.2 .12 & $138-139$ \\
\hline $2.2 .13 / 14$ & 139 \\
\hline 2.2 .15 & 139 \\
\hline 2.2 .16 & $139-140$ \\
\hline 2.2 .17 & 140 \\
\hline 2.2 .18 & 140 \\
\hline 2.2 .19 & 140 \\
\hline 2.2 .20 & $140-141$ \\
\hline 2.2 .21 & 141 \\
\hline 2.2 .22 & 141 \\
\hline 2.2 .23 & 141 \\
\hline 2.2 .24 & $141-142$ \\
\hline 2.2 .25 & 142 \\
\hline 2.2 .26 & 142 \\
\hline 2.2 .27 & $142-143$ \\
\hline 2.2 .28 & 143 \\
\hline 2.2 .29 & 143 \\
\hline 2.3 .1 & $143-144$ \\
\hline 2.3 .2 & 144 \\
\hline 2.3 .3 & 144 \\
\hline 2.3 .4 & $144-145$ \\
\hline 2.3 .5 & 145 \\
\hline 2.3 .6 & 145 \\
\hline $2.3 .7 / 8 / 9$ & $145-146$ \\
\hline 2.3 .10 & 146 \\
\hline $2.3 .11 / 12$ & 146 \\
\hline
\end{tabular}


REFERENTIELIJST ARTIKELCOMMENTAAR MEMORIEBOEKEN

\begin{tabular}{|c|c|}
\hline $2.3 .13 / 14$ & $146-147$ \\
\hline 2.3 .15 & 147 \\
\hline $2.3 .16 / 17$ & 147 \\
\hline $2.4 .1 / 2$ & $147-148$ \\
\hline 2.4 .3 & 148 \\
\hline 2.4 .4 & 148 \\
\hline 2.4 .5 & 148-149 \\
\hline 2.4 .6 & 149 \\
\hline 2.4 .7 & 149 \\
\hline 2.4 .8 & 149-150 \\
\hline 2.4 .9 & 150 \\
\hline 2.4 .10 & 150 \\
\hline 2.4 .11 & $150-151$ \\
\hline $2.4 .12 / 13$ & 151 \\
\hline 2.4 .14 & 151 \\
\hline $2.4 .15 / 16$ & $151-152$ \\
\hline 2.4 .17 & 152 \\
\hline 2.4 .18 & $152-153$ \\
\hline $2.4 .19 / 20$ & $153-154$ \\
\hline 2.4 .21 & 154 \\
\hline 2.4 .22 & 154-155 \\
\hline 2.4 .23 & 155 \\
\hline 2.4 .24 & 155 \\
\hline 2.5 .1 & 156 \\
\hline $2.5 .2 / 3$ & 156 \\
\hline $2.5 .4 / 5$ & 157 \\
\hline 2.5 .6 & 157 \\
\hline 2.5 .7 & 157 \\
\hline 2.5 .8 & $157-158$ \\
\hline 2.5 .9 & 158 \\
\hline 2.5 .10 & 158 \\
\hline $2.5 .11 / 12 / 13$ & $158-160$ \\
\hline 2.5 .14 & 160 \\
\hline $2.5 .15 / 16$ & $160-161$ \\
\hline 2.5 .17 & 161 \\
\hline 2.5 .18 & 161-162 \\
\hline $2.5 .19 / 20$ & 162 \\
\hline $2.5 .21 / 22$ & 162 \\
\hline $2.5 .23 / 24$ & $162-163$ \\
\hline 2.5 .25 & 163 \\
\hline 2.5 .26 & 163 \\
\hline 2.5 .27 & 163 \\
\hline $2.5 .28 / 29$ & $163-164$ \\
\hline 2.5 .30 & 164 \\
\hline 2.5 .31 & $164-165$ \\
\hline 2.5 .32 & 165 \\
\hline 2.5 .33 & $165-166$ \\
\hline $2.5 .34 / 35$ & $166-167$ \\
\hline $2.5 .36 / 37 / 38 / 39 / 40 / 41 / 42$ & $167-168$ \\
\hline 2.5 .43 & 168 \\
\hline $2.5 .44 / 45$ & 168 \\
\hline
\end{tabular}

\begin{tabular}{|c|c|}
\hline 2.5 .46 & $168-169$ \\
\hline 2.5 .47 & 169 \\
\hline 2.5 .48 & 169 \\
\hline 2.5 .49 & 169 \\
\hline 2.5 .50 & 169 \\
\hline 2.5 .51 & $169-170$ \\
\hline 2.5 .52 & 170 \\
\hline 2.5 .53 & 170 \\
\hline $2.5 .54 / 55$ & $170-171$ \\
\hline 2.5 .56 & 171 \\
\hline $2.5 .57 / 58 / 59$ & $171-172$ \\
\hline 2.5 .60 & 172 \\
\hline 2.5 .61 & 172 \\
\hline 2.5 .62 & $172-173$ \\
\hline 2.5 .63 & 173 \\
\hline 2.3 .64 & 173 \\
\hline 2.5 .65 & 173-174 \\
\hline $2.5 .66 / 67$ & 174 \\
\hline 2.5 .68 & 174 \\
\hline $2.5 .69 / 70$ & $174-175$ \\
\hline 2.5 .71 & 175 \\
\hline 2.5 .72 & 175 \\
\hline 2.5 .73 & $175-176$ \\
\hline $2.5 .74 / 75$ & 176 \\
\hline 2.5 .76 & 176 \\
\hline 2.5 .77 & 176-177 \\
\hline 2.5 .78 & $177-178$ \\
\hline 2.5 .79 & 178 \\
\hline $2.5 .80 / 81$ & 178 \\
\hline 2.5 .82 & $178-179$ \\
\hline 2.5 .83 & 179 \\
\hline 2.5 .84 & 179 \\
\hline 2.5 .85 & 179 \\
\hline $2.5 .86 / 87 / 88$ & $179-180$ \\
\hline 2.5 .89 & 181 \\
\hline $2.5 .90 / 91 / 92$ & 181-182 \\
\hline $2.5 .93 / 94$ & $182-183$ \\
\hline 2.5 .95 & 183 \\
\hline $2.5 .96 / 97 / 98$ & $184-185$ \\
\hline $2.5 .99 / 100$ & 185 \\
\hline 2.5 .101 & 185 \\
\hline $2.5 .102 / 103$ & 185 \\
\hline $2.5 .104 / 105$ & $185-186$ \\
\hline 2.5 .106 & 186 \\
\hline 2.5 .107 & 186 \\
\hline 2.5 .108 & $186-187$ \\
\hline $2.5 .109 / 110$ & 187 \\
\hline 2.5 .111 & 187 \\
\hline $2.5 .112 / 113$ & $187-188$ \\
\hline $2.5 .114 / 115 / 116$ & 188 \\
\hline 2.5 .117 & 188 \\
\hline
\end{tabular}




\begin{tabular}{|l|l|}
\hline $2.5 .118 / 119$ & $188-189$ \\
\hline 2.5 .120 & 189 \\
\hline 2.5 .121 & $189-190$ \\
\hline 2.5 .122 & $190-191$ \\
\hline 2.5 .123 & 191 \\
\hline 2.5 .124 & $191-192$ \\
\hline 2.5 .125 & 192 \\
\hline $2.5 .126 / 127$ & 193 \\
\hline 2.5 .128 & $193-194$ \\
\hline 2.5 .129 & 194 \\
\hline 2.5 .130 & 194 \\
\hline $2.5 .131 / 132 / 133$ & 194 \\
\hline 2.5 .134 & $194-195$ \\
\hline 2.5 .135 & 195 \\
\hline 2.5 .136 & 196 \\
\hline 2.5 .137 & 196 \\
\hline 2.5 .138 & $196-197$ \\
\hline 2.5 .139 & 197 \\
\hline $2.5 .140 / 141 / 142$ & $197-198$ \\
\hline $2.5 .143 / 144$ & 198 \\
\hline $2.5 .145 / 146 / 147 / 148$ & $198-199$ \\
\hline 2.5 .149 & 200 \\
\hline $2.5 .150 / 151$ & 200 \\
\hline $2.5 .152 / 153 / 154$ & $200-201$ \\
\hline 2.5 .155 & 201 \\
\hline 2.5 .156 & $201-202$ \\
\hline 2.5 .157 & 202 \\
\hline $2.5 .158 / 159$ & 202 \\
\hline 2.5 .160 & 203 \\
\hline $2.5 .161 / 162$ & $203-204$ \\
\hline 2.5 .163 & 204 \\
\hline $2.5 .164 / 165$ & $204-205$ \\
\hline 2.5 .166 & 205 \\
\hline 2.5 .167 & $205-206$ \\
\hline & \\
\hline & \\
\hline
\end{tabular}

\begin{tabular}{|l|l|}
\hline 2.5 .168 & 206 \\
\hline 2.5 .169 & 206 \\
\hline 2.5 .170 & $206-207$ \\
\hline 2.5 .171 & 207 \\
\hline 2.5 .172 & $207-208$ \\
\hline $2.5 .173 / 174$ & 208 \\
\hline 2.5 .175 & $208-209$ \\
\hline 2.5 .176 & 209 \\
\hline 2.5 .177 & 209 \\
\hline 2.5 .178 & 210 \\
\hline 2.5 .179 & 210 \\
\hline 2.5 .180 & 210 \\
\hline 2.5 .181 & $210-211$ \\
\hline 2.5 .182 & 211 \\
\hline 2.5 .183 & $211-212$ \\
\hline 2.5 .184 & 212 \\
\hline $2.5 .185 / 186$ & 212 \\
\hline 2.5 .187 & $212-213$ \\
\hline 2.5 .188 & 213 \\
\hline 2.5 .189 & 213 \\
\hline 2.5 .190 & $213-214$ \\
\hline 2.5 .191 & 214 \\
\hline 2.5 .192 & 214 \\
\hline $2.5 .193 / 194$ & $214-215$ \\
\hline 2.5 .195 & 215 \\
\hline $2.5 .196 / 197$ & 215 \\
\hline 2.1 .198 & 216 \\
\hline $2.1 .199 / 200$ & 216 \\
\hline 2.1 .201 & 216 \\
\hline 2.1 .202 & $216-217$ \\
\hline 2.1 .203 & 217 \\
\hline 2.1 .204 & 217 \\
\hline $2.1 .205 / 206 / 207$ & 217 \\
\hline & \\
\hline & \\
\hline
\end{tabular}

Boek 49 (Cfr. ANTWERPEN, Stadsarchief, Vierschaer, nr. 49: Memorien op de Costumen)

\begin{tabular}{|l|l|}
\hline Artikel & Pagina \\
\hline 3.1 .1 & $2-3$ \\
\hline 3.1 .2 & $3-4$ \\
\hline 3.1 .3 & 4 \\
\hline 3.1 .4 & $4-6$ \\
\hline 3.1 .5 & 6 \\
\hline 3.1 .6 & $6-7$ \\
\hline 3.1 .7 & $7-9$ \\
\hline 3.1 .8 & 9 \\
\hline 3.1 .9 & $9-10$ \\
\hline 3.1 .10 & $10-11$ \\
\hline 3.1 .11 & $11-12$ \\
\hline
\end{tabular}

\begin{tabular}{|l|l|}
\hline 3.1 .12 & 12 \\
\hline 3.1 .13 & 13 \\
\hline $3.1 .14 / 15 / 16$ & 13 \\
\hline 3.1 .17 & 13 \\
\hline 3.1 .18 & $13-14$ \\
\hline $3.2 .1 / 2$ & 15 \\
\hline $3.2 .3 / 4 / 5$ & $15-19$ \\
\hline $3.2 .6 / 7 / 8$ & $19-22$ \\
\hline 3.2 .9 & $22-23$ \\
\hline 3.2 .10 & $23-28$ \\
\hline 3.2 .11 & $28-29$ \\
\hline 3.2 .12 & $29-30$ \\
\hline
\end{tabular}


REFERENTIELIJST ARTIKELCOMMENTAAR MEMORIEBOEKEN

\begin{tabular}{|c|c|}
\hline 3.2 .13 & 30 \\
\hline 3.2 .14 & 31 \\
\hline 3.2 .15 & $31-32$ \\
\hline 3.2 .16 & 32 \\
\hline $3.2 .17 / 18$ & $32-33$ \\
\hline $3.2 .19 / 20 / 21 / 22$ & 33 \\
\hline 3.2 .23 & 33 \\
\hline 3.2 .24 & 33 \\
\hline $3.2 .25 / 26$ & $33-35$ \\
\hline 3.2 .27 & 35 \\
\hline 3.2 .28 & 35 \\
\hline 3.2 .29 & $35-36$ \\
\hline 3.2 .30 & 36 \\
\hline 3.2 .31 & $36-37$ \\
\hline 3.2 .32 & $37-38$ \\
\hline 3.2 .33 & $38-39$ \\
\hline $3.2 .34 / 35$ & 39 \\
\hline 3.2 .36 & 39 \\
\hline $3.2 .37 / 38 / 39 / 40$ & $40-41$ \\
\hline 3.3 .1 & 42 \\
\hline 3.3 .2 & $42-43$ \\
\hline 3.3 .3 & 43 \\
\hline 3.3 .4 & 43 \\
\hline $3.3 .5 / 6 / 7$ & 43-44 \\
\hline 3.3 .8 & 44 \\
\hline $3.3 .9 / 10 / 11$ & $44-45$ \\
\hline 3.3 .12 & $45-46$ \\
\hline 3.3 .13 & $46-47$ \\
\hline 3.3 .14 & 47 \\
\hline 3.3 .15 & $47-48$ \\
\hline $3.3 .16 / 17$ & $48-49$ \\
\hline 3.3 .18 & $49-50$ \\
\hline 3.3 .19 & $50-51$ \\
\hline $3.3 .20 / 21 / 22$ & 51 \\
\hline 3.3 .23 & 52 \\
\hline 3.3 .24 & 52 \\
\hline $3.3 .25 / 26$ & $52-53$ \\
\hline 3.3 .27 & 53 \\
\hline $3.3 .28 / 29$ & $53-55$ \\
\hline 3.4 .1 & 56 \\
\hline 3.4 .2 & $56-57$ \\
\hline 3.4 .3 & $57-59$ \\
\hline 3.4 .4 & 59 \\
\hline $3.4 .5 / 6$ & $59-60$ \\
\hline 3.4 .7 & 60 \\
\hline 3.4 .8 & $60-62$ \\
\hline 3.4 .9 & 62 \\
\hline 3.4 .10 & $62-64$ \\
\hline 3.4 .11 & 64-65 \\
\hline 3.4 .12 & 65 \\
\hline 3.4 .13 & 65 \\
\hline
\end{tabular}

\begin{tabular}{|c|c|}
\hline 3.4 .14 & $65-66$ \\
\hline 3.4 .15 & 66 \\
\hline 3.4 .16 & 66 \\
\hline 3.4.17 & $66-67$ \\
\hline 3.4 .18 & 67 \\
\hline $3.4 .19 / 20$ & 67 \\
\hline 3.4 .21 & 68 \\
\hline 3.4 .22 & 68 \\
\hline 3.4 .23 & $68-69$ \\
\hline 3.4 .24 & ontbreekt \\
\hline 3.4 .25 & 69 \\
\hline 3.4 .26 & $69-71$ \\
\hline 3.4 .27 & 71 \\
\hline 3.4 .28 & 71 \\
\hline $3.4 .29 / 30$ & $71-72$ \\
\hline $3.4 .31 / 32$ & $72-73$ \\
\hline 3.4 .33 & $73-74$ \\
\hline 3.4 .34 & 74 \\
\hline 3.4 .35 & 74 \\
\hline 3.4 .36 & 74 \\
\hline 3.4 .37 & $74-75$ \\
\hline 3.4 .38 & $75-76$ \\
\hline 3.4 .39 & 76 \\
\hline $3.4 .40 / 41 / 42$ & 76 \\
\hline 3.4 .43 & $76-77$ \\
\hline 3.4 .44 & 77 \\
\hline 3.4 .45 & 77 \\
\hline $3.4 .46 / 47$ & $77-78$ \\
\hline 3.4 .48 & 78 \\
\hline 3.4 .49 & 78 \\
\hline 3.4 .50 & 78 \\
\hline $3.4 .51 / 52$ & $79-80$ \\
\hline 3.4 .53 & $80-82$ \\
\hline $3.4 .54 / 55 / 56 / 57$ & 82-83 \\
\hline $3.4 .58 / 59 / 60$ & 83-84 \\
\hline 3.4 .61 & 84 \\
\hline 3.4 .62 & 84 \\
\hline 3.4 .63 & 85 \\
\hline 3.4.64 & 85-86 \\
\hline 3.4 .65 & 86 \\
\hline 3.4 .66 & 87 \\
\hline $3.4 .67 / 68$ & $87-88$ \\
\hline 3.4 .69 & $88-89$ \\
\hline 3.4 .70 & 89-90 \\
\hline 3.4 .71 & 90 \\
\hline 3.4 .72 & $90-91$ \\
\hline 3.4 .73 & $91-92$ \\
\hline 3.4 .74 & $92-93$ \\
\hline 3.4 .75 & 93 \\
\hline 3.4 .76 & 93 \\
\hline 3.4 .77 & $93-95$ \\
\hline
\end{tabular}




\begin{tabular}{|c|c|}
\hline 3.4 .78 & 95 \\
\hline 3.4 .79 & 95 \\
\hline 3.4 .80 & 96 \\
\hline $3.4 .81 / 82$ & 96 \\
\hline 3.4 .83 & 97 \\
\hline 3.4 .84 & 97 \\
\hline 3.4 .85 & 97 \\
\hline 3.4 .86 & $97-98$ \\
\hline 3.4 .87 & 98 \\
\hline 3.4 .88 & 98 \\
\hline 3.4 .89 & 99 \\
\hline 3.4 .90 & $99-100$ \\
\hline $3.4 .91 / 92$ & $100-103$ \\
\hline 3.4 .93 & 103-105 \\
\hline $3.4 .94 / 95$ & 105 \\
\hline 3.4 .96 & $\overline{105-106}$ \\
\hline 3.4 .97 & $106-107$ \\
\hline 3.4 .98 & $107-108$ \\
\hline 3.4 .99 & $108-109$ \\
\hline 3.4 .100 & 109 \\
\hline 3.4 .101 & 110 \\
\hline $3.4 .102 / 103$ & 110 \\
\hline $3.4 .104 / 105$ & $110-111$ \\
\hline 3.4 .106 & 111 \\
\hline 3.5 .1 & $112-113$ \\
\hline 3.5 .2 & $113-114$ \\
\hline $3.5 .3 / 4$ & 114 \\
\hline 3.5 .5 & $114-115$ \\
\hline 3.5 .6 & $115-116$ \\
\hline $3.5 .7 / 8 / 9 / 10$ & 116 \\
\hline $3.5 .11 / 12$ & 117 \\
\hline 3.5 .13 & 117 \\
\hline 3.5 .14 & 117 \\
\hline $3.5 .15 / 16$ & $117-118$ \\
\hline $3.5 .17 / 18$ & 118 \\
\hline 3.5 .19 & $118-119$ \\
\hline 3.5 .20 & 119 \\
\hline $3.5 .21 / 22$ & 119 \\
\hline 3.5 .23 & $119-120$ \\
\hline 3.5 .24 & 120 \\
\hline 3.5 .25 & 120 \\
\hline 3.5 .26 & $120-121$ \\
\hline 3.5 .27 & 121 \\
\hline $3.5 .28 / 29$ & 121 \\
\hline 3.5 .30 & $121-122$ \\
\hline 3.5 .31 & 122 \\
\hline 3.5 .32 & 122 \\
\hline 3.5 .33 & $122-123$ \\
\hline $3.5 .34 / 35$ & 123 \\
\hline 3.5 .36 & 123 \\
\hline $3.5 .37 / 38$ & 124 \\
\hline
\end{tabular}

\begin{tabular}{|c|c|}
\hline $3.5 .39 / 40$ & 124 \\
\hline $3.5 .41 / 42 / 43$ & 124 \\
\hline $3.5 .44 / 45$ & $124-125$ \\
\hline 3.5 .46 & 125 \\
\hline 3.5 .47 & 126 \\
\hline 3.5 .48 & 126 \\
\hline 3.5 .49 & $126-127$ \\
\hline 3.5 .50 & 127 \\
\hline 3.5 .51 & $127-128$ \\
\hline $3.5 .52 / 53$ & $128-129$ \\
\hline 3.5 .54 & 129 \\
\hline $3.5 .55 / 56$ & $129-130$ \\
\hline 3.5 .57 & 130 \\
\hline $3.5 .58 / 59$ & 130 \\
\hline 3.5 .60 & $130-131$ \\
\hline $3.5 .61 / 62$ & $131-132$ \\
\hline 3.5 .63 & 132 \\
\hline $3.5 .64 / 65$ & $132-133$ \\
\hline 3.5 .66 & 133 \\
\hline 3.5 .67 & 133-134 \\
\hline 3.5 .68 & 134 \\
\hline 3.5 .69 & 134-135 \\
\hline 3.5 .70 & 135 \\
\hline 3.5 .71 & 135 \\
\hline 3.5 .72 & 135 \\
\hline 3.5 .73 & $135-136$ \\
\hline 3.5 .74 & 136 \\
\hline $3.5 .75 / 76 / 77$ & 136 \\
\hline 3.5 .78 & 136-137 \\
\hline 3.5 .79 & 137 \\
\hline 3.5 .80 & 137 \\
\hline 3.5 .81 & 137 \\
\hline 3.5 .82 & $137-138$ \\
\hline 3.5 .83 & 138 \\
\hline 3.5 .84 & 138-139 \\
\hline $3.5 .85 / 86$ & 139 \\
\hline 3.5 .87 & 139 \\
\hline 3.5 .88 & 139-142 \\
\hline 3.5 .89 & $142-143$ \\
\hline 3.5 .90 & 143-144 \\
\hline 3.5 .91 & 144-145 \\
\hline $3.5 .92 / 93$ & 145-146 \\
\hline 3.5 .94 & 146 \\
\hline 3.5 .95 & $146-147$ \\
\hline 3.5 .96 & 147 \\
\hline 3.5 .97 & $147-148$ \\
\hline $3.5 .98 / 99$ & 148 \\
\hline 3.5 .100 & 148-149 \\
\hline 3.5 .101 & 149 \\
\hline 3.5 .102 & 149 \\
\hline 3.5 .103 & $149-150$ \\
\hline
\end{tabular}


REFERENTIELIJST ARTIKELCOMMENTAAR MEMORIEBOEKEN

\begin{tabular}{|c|c|}
\hline $3.5 .104 / 105$ & 150 \\
\hline 3.5 .106 & 150 \\
\hline $3.6 .1 / 2$ & 151 \\
\hline 3.6 .3 & 151 \\
\hline 3.6 .4 & 151 \\
\hline 3.6 .5 & $151-152$ \\
\hline 3.6 .6 & 152 \\
\hline 3.6 .7 & 152 \\
\hline $3.6 .8 / 9$ & 152 \\
\hline 3.6 .10 & 153 \\
\hline 3.6.11 & $153-154$ \\
\hline 3.6.12/13 & 155 \\
\hline 3.6.14/15 & 155 \\
\hline 3.6.16 & 155 \\
\hline 3.6.17 & $155-156$ \\
\hline 3.6.18 & 156 \\
\hline $3.6 .19 / 20$ & 156 \\
\hline 3.6.21 & 156 \\
\hline $3.7 .1 / 2$ & 157 \\
\hline 3.7 .3 & $157-158$ \\
\hline 3.7 .4 & 158 \\
\hline $3.7 .5 / 6 / 7 / 8 / 9 / 10$ & 159 \\
\hline 3.7 .11 & $159-160$ \\
\hline 3.7 .12 & 161 \\
\hline $3.7 .13 / 14$ & 161 \\
\hline 3.7 .15 & 162 \\
\hline 3.7 .16 & $162-163$ \\
\hline 3.7 .17 & $163-164$ \\
\hline 3.7 .18 & 164 \\
\hline 3.7 .19 & 164 \\
\hline 3.7 .20 & 165 \\
\hline $3.7 .21 / 22 / 23$ & 166 \\
\hline $3.7 .24 / 25$ & $166-167$ \\
\hline $3.7 .26 / 27$ & 167 \\
\hline 3.7 .28 & 168 \\
\hline 3.8 .1 & 169 \\
\hline 3.8 .2 & $169-170$ \\
\hline 3.8 .3 & 170 \\
\hline 3.8 .4 & $170-171$ \\
\hline 3.8 .5 & $171-172$ \\
\hline 3.8 .6 & $172-173$ \\
\hline 3.8 .7 & $173-175$ \\
\hline 3.8 .8 & $175-176$ \\
\hline 3.8 .9 & 176 \\
\hline 3.8 .10 & 176-177 \\
\hline 3.8 .11 & 177 \\
\hline $3.8 .12 / 13$ & 177 \\
\hline 3.8.14 & 178 \\
\hline 3.8 .15 & 178 \\
\hline 3.8 .16 & 178 \\
\hline $3.8 .17 / 18$ & 178-179 \\
\hline
\end{tabular}

\begin{tabular}{|c|c|}
\hline $3.8 .19 / 20$ & 179 \\
\hline 3.8 .21 & 180 \\
\hline 3.8 .22 & 180 \\
\hline 3.8 .23 & 180 \\
\hline $3.8 .24 / 25 / 26 / 27 / 28$ & $180-181$ \\
\hline $3.8 .29 / 30$ & 181 \\
\hline 3.8 .31 & $182-183$ \\
\hline 3.8 .32 & 183 \\
\hline 3.8 .33 & $183-184$ \\
\hline 3.8 .34 & 184 \\
\hline 3.8 .35 & 184 \\
\hline 3.8 .36 & 184 \\
\hline 3.8 .37 & 184-185 \\
\hline 3.8 .38 & 185 \\
\hline 3.8 .39 & 185-186 \\
\hline 3.8 .40 & 186 \\
\hline $3.8 .41 / 42 / 43 / 44 / 45 / 46 / 47 / 48$ & 186-187 \\
\hline 3.8 .49 & 187 \\
\hline 3.8 .50 & $187-188$ \\
\hline $3.8 .51 / 52$ & 188 \\
\hline 3.8 .53 & 188 \\
\hline 3.8 .54 & 189 \\
\hline 3.5 .55 & 189 \\
\hline 3.8 .56 & $189-190$ \\
\hline $3.8 .57 / 58$ & 190 \\
\hline 3.8 .59 & 190 \\
\hline 3.8 .60 & 190-191 \\
\hline $3.8 .61 / 62$ & 191-192 \\
\hline $3.8 .63 / 64$ & 193-194 \\
\hline 3.8 .65 & 194 \\
\hline 3.8 .66 & 194-195 \\
\hline 3.8 .67 & 195 \\
\hline 3.8 .68 & $195-196$ \\
\hline $3.8 .69 / 70$ & 196 \\
\hline 3.8 .71 & 196-197 \\
\hline 3.8 .72 & 197 \\
\hline 3.8 .73 & 197 \\
\hline 3.9 .1 & 198 \\
\hline 3.9 .2 & 198-199 \\
\hline 3.9 .3 & 199 \\
\hline $3.9 .4 / 5 / 6$ & $199-200$ \\
\hline 3.9 .7 & $200-202$ \\
\hline 3.9 .8 & 202 \\
\hline 3.9.8bis & $202-203$ \\
\hline 3.9 .9 & 203 \\
\hline 3.9 .10 & 203 \\
\hline $3.9 .11 / 12 / 13$ & $203-204$ \\
\hline 3.9.14/15 & 204-205 \\
\hline 3.9 .16 & 205 \\
\hline 3.9.17 & 206 \\
\hline 3.9 .18 & 206 \\
\hline
\end{tabular}




\begin{tabular}{|c|c|}
\hline 3.9 .19 & 206 \\
\hline 3.9 .20 & $206-207$ \\
\hline $3.9 .21 / 22$ & 207 \\
\hline 3.9 .23 & 208 \\
\hline 3.9 .24 & 208 \\
\hline 3.9 .25 & $208-209$ \\
\hline 3.9 .26 & 209 \\
\hline 3.9 .27 & $209-210$ \\
\hline 3.9 .28 & $210-213$ \\
\hline $3.9 .29 / 30$ & $214-215$ \\
\hline $3.9 .31 / 32 / 33$ & $215-216$ \\
\hline 3.9 .34 & 217 \\
\hline $3.9 .35 / 36$ & $217-218$ \\
\hline $3.9 .37 / 38$ & 218 \\
\hline 3.9 .39 & $218-219$ \\
\hline $3.9 .40 / 41$ & $219-220$ \\
\hline 3.9 .42 & 220 \\
\hline 3.9 .43 & $220-221$ \\
\hline 3.9 .44 & $221-223$ \\
\hline 3.9 .45 & 223 \\
\hline $3.9 .46 / 47$ & 224 \\
\hline $3.9 .48 / 49$ & $224-225$ \\
\hline 3.9 .50 & 225 \\
\hline 3.9 .51 & 226 \\
\hline 3.9 .52 & 226 \\
\hline $3.9 .53 / 54$ & 226 \\
\hline 3.10 .1 & $227-230$ \\
\hline 3.10 .2 & 230 \\
\hline 3.10 .3 & $230-232$ \\
\hline 3.10 .4 & 232 \\
\hline 3.10 .5 & 232 \\
\hline $3.10 .6 / 7 / 8$ & $232-233$ \\
\hline $3.10 .9 / 10$ & 233 \\
\hline 3.10 .11 & 233 \\
\hline 3.10 .12 & $233-234$ \\
\hline 3.10.12bis & 234 \\
\hline 3.10 .13 & $234-236$ \\
\hline 3.10 .14 & $236-237$ \\
\hline 3.10 .15 & $237-239$ \\
\hline 3.10 .16 & $239-240$ \\
\hline $3.10 .17 / 18$ & $240-241$ \\
\hline 3.10 .19 & $241-242$ \\
\hline $3.10 .20 / 21 / 22 / 23$ & $242-244$ \\
\hline 3.10 .24 & $244-246$ \\
\hline 3.10 .25 & $246-247$ \\
\hline 3.10 .26 & $247-248$ \\
\hline 3.10 .27 & $248-249$ \\
\hline 3.10 .28 & $249-251$ \\
\hline 3.10 .29 & 251 \\
\hline $3.10 .30 / 31 / 32$ & $251-252$ \\
\hline 3.10 .33 & 252 \\
\hline
\end{tabular}

\begin{tabular}{|c|c|}
\hline $3.10 .34 / 35$ & $252-253$ \\
\hline $3.11 .1 / 2$ & $254-256$ \\
\hline 3.11 .3 & 256 \\
\hline $3.11 .4 / 5 / 6$ & $256-260$ \\
\hline 3.11 .7 & $261-262$ \\
\hline 3.11 .8 & $262-264$ \\
\hline 3.11 .9 & 264 \\
\hline 3.11 .10 & $264-265$ \\
\hline 3.11 .11 & $265-266$ \\
\hline 3.11 .12 & 267 \\
\hline 3.11 .13 & $267-268$ \\
\hline 3.11 .14 & 268 \\
\hline 3.11 .15 & $268-269$ \\
\hline 3.11 .16 & $269-270$ \\
\hline 3.11 .17 & $270-271$ \\
\hline 3.11 .18 & $271-272$ \\
\hline 3.11 .19 & $272-277$ \\
\hline 3.11 .20 & $277-279$ \\
\hline 3.12 .1 & 280 \\
\hline $3.12 .2 / 3 / 4 / 5 / 6$ & $280-281$ \\
\hline 3.12 .7 & 281 \\
\hline $3.12 .8 / 9$ & $282-283$ \\
\hline 3.12 .10 & $283-284$ \\
\hline 3.12 .11 & $284-285$ \\
\hline 3.12 .12 & $285-286$ \\
\hline 3.12 .13 & 286 \\
\hline $3.12 .14 / 15$ & $286-287$ \\
\hline 3.12 .16 & 287 \\
\hline 3.12 .17 & $287-288$ \\
\hline 3.13 .1 & $289-290$ \\
\hline 3.13 .2 & $290-291$ \\
\hline 3.13 .3 & $291-292$ \\
\hline 3.13 .4 & 292 \\
\hline 3.13 .5 & $292-294$ \\
\hline $3.13 .6 / 7 / 8$ & 294 \\
\hline 3.13 .9 & $294-295$ \\
\hline $3.13 .10 / 11 / 12$ & $296-297$ \\
\hline 3.13 .13 & $297-298$ \\
\hline $3.13 .14 / 15$ & $298-300$ \\
\hline 3.13 .16 & $300-301$ \\
\hline $3.13 .17 / 18$ & $301-305$ \\
\hline 3.13 .19 & $305-306$ \\
\hline 3.13 .20 & 306 \\
\hline 3.13 .21 & $306-307$ \\
\hline 3.13 .22 & 308 \\
\hline 3.13 .23 & $309-312$ \\
\hline 3.13 .24 & $312-313$ \\
\hline 3.13 .25 & $313-314$ \\
\hline 3.13 .26 & 314 \\
\hline 3.13 .27 & 315 \\
\hline 3.13 .28 & $315-316$ \\
\hline
\end{tabular}


REFERENTIELIJST ARTIKELCOMMENTAAR MEMORIEBOEKEN

\begin{tabular}{|c|c|}
\hline $3.13 .29 / 30$ & $316-318$ \\
\hline $3.13 .31 / 32$ & $318-319$ \\
\hline $3.13 .33 / 34$ & $319-320$ \\
\hline 3.13 .35 & $320-321$ \\
\hline 3.13 .36 & $321-323$ \\
\hline 3.13 .37 & $323-324$ \\
\hline $3.13 .38 / 39 / 40$ & $325-326$ \\
\hline 3.13 .41 & 326 \\
\hline 3.13 .42 & $326-327$ \\
\hline 3.13 .43 & 327 \\
\hline 3.13 .44 & $327-328$ \\
\hline $3.13 .45 / 46$ & $328-329$ \\
\hline $3.13 .47 / 48$ & $329-330$ \\
\hline 3.13 .49 & $330-332$ \\
\hline 3.13 .50 & $333-337$ \\
\hline 3.13 .51 & $338-339$ \\
\hline 3.13 .52 & $339-341$ \\
\hline 3.13 .53 & 341 \\
\hline $3.13 .54 / 55$ & 342 \\
\hline $3.13 .56 / 57 / 58$ & $342-343$ \\
\hline 3.13 .59 & 343 \\
\hline 3.13 .60 & $344-345$ \\
\hline 3.13 .61 & $345-360$ \\
\hline 3.13 .62 & $346-347$ \\
\hline $3.13 .63 / 64$ & $347-348$ \\
\hline 3.13 .65 & $348-349$ \\
\hline 3.13 .66 & $349-350$ \\
\hline 3.13 .67 & $350-352$ \\
\hline 3.13 .68 & $352-353$ \\
\hline $3.13 .69 / 70$ & 354 \\
\hline $3.13 .71 / 72$ & $355-356$ \\
\hline 3.13 .73 & $356-358$ \\
\hline 3.13 .74 & 358 \\
\hline $3.13 .75 / 76$ & $359-361$ \\
\hline 3.13 .77 & $361-362$ \\
\hline 3.13 .78 & $362-363$ \\
\hline 3.13 .79 & $363-365$ \\
\hline 3.13 .80 & $365-366$ \\
\hline 3.13 .81 & 366 \\
\hline 3.13 .82 & $366-367$ \\
\hline 3.13 .83 & 367 \\
\hline 3.13 .84 & $368-369$ \\
\hline 3.13 .85 & $369-370$ \\
\hline 3.13 .86 & $370-371$ \\
\hline 3.13 .87 & $371-372$ \\
\hline $3.13 .88 / 89$ & $372-373$ \\
\hline $3.13 .90 / 91$ & $373-374$ \\
\hline 3.13 .92 & $374-375$ \\
\hline 3.14 .1 & 376 \\
\hline 3.14 .2 & 377 \\
\hline 3.14 .3 & 377 \\
\hline
\end{tabular}

\begin{tabular}{|c|c|}
\hline 3.14 .4 & 378 \\
\hline 3.14 .5 & $378-379$ \\
\hline 3.14 .6 & $379-380$ \\
\hline $3.14 .7 / 8$ & $380-381$ \\
\hline 3.14 .9 & 381 \\
\hline 3.14 .10 & $381-382$ \\
\hline 3.14 .11 & $382-383$ \\
\hline 3.14 .12 & 383 \\
\hline 3.14 .13 & 383-384 \\
\hline 3.14 .14 & 384 \\
\hline 3.14 .15 & $384-389$ \\
\hline 3.14 .16 & $389-391$ \\
\hline $3.14 .17 / 18 / 19 / 20$ & $391-393$ \\
\hline 3.14 .21 & 393-394 \\
\hline $3.14 .22 / 23 / 24$ & 394-395 \\
\hline 3.14 .25 & $395-396$ \\
\hline 3.14 .26 & $396-397$ \\
\hline 3.14 .27 & $397-398$ \\
\hline 3.14 .28 & 398 \\
\hline 3.14 .29 & 398 \\
\hline 3.14 .30 & 399 \\
\hline $3.14 .31 / 32 / 33 / 34$ & $399-401$ \\
\hline 3.14 .35 & $401-402$ \\
\hline $3.14 .36 / 37 / 38$ & $402-405$ \\
\hline 3.14 .39 & $405-406$ \\
\hline 3.14 .40 & 406 \\
\hline 3.14 .41 & 407 \\
\hline 3.14 .42 & $407-408$ \\
\hline 3.14 .43 & 409 \\
\hline 3.14 .44 & $409-410$ \\
\hline 3.14 .45 & 410 \\
\hline 3.14 .46 & $410-411$ \\
\hline $3.14 .47 / 48 / 49 / 50 / 51 / 52$ & $411-416$ \\
\hline 3.14 .53 & 416-417 \\
\hline 3.14 .54 & 417 \\
\hline $3.14 .55 / 56$ & $417-418$ \\
\hline $3.14 .57 / 58$ & $418-419$ \\
\hline $3.14 .59 / 60$ & $419-421$ \\
\hline 3.14 .61 & 421-423 \\
\hline 3.14 .62 & $423-424$ \\
\hline 3.14 .63 & 424 \\
\hline 3.14 .64 & $424-425$ \\
\hline 3.14 .65 & 425 \\
\hline $3.14 .66 / 67$ & $425-426$ \\
\hline $3.14 .68 / 69$ & $426-427$ \\
\hline 3.14 .70 & 427 \\
\hline $3.14 .71 / 72$ & $427-428$ \\
\hline 3.14 .73 & $428-429$ \\
\hline 3.14 .74 & $429-430$ \\
\hline 3.14 .75 & $430-432$ \\
\hline 3.14 .76 & 432 \\
\hline
\end{tabular}




\begin{tabular}{|l|l|}
\hline 3.14 .77 & 432 \\
\hline 3.14 .78 & 433 \\
\hline 3.14 .79 & $433-434$ \\
\hline 3.14 .80 & $434-435$ \\
\hline 3.14 .81 & $435-436$ \\
\hline 3.14 .82 & $436-437$ \\
\hline 3.14 .83 & 437 \\
\hline 3.14 .84 & 438 \\
\hline 3.14 .85 & $438-439$ \\
\hline 3.14 .86 & 439 \\
\hline 3.14 .87 & 439 \\
\hline 3.14 .88 & 440 \\
\hline 3.14 .89 & $440-444$ \\
\hline $3.14 .90 / 91$ & 444 \\
\hline $3.14 .92 / 93$ & $445-446$ \\
\hline 3.14 .94 & $446-447$ \\
\hline 3.14 .95 & $447-448$ \\
\hline 3.14 .96 & $448-449$ \\
\hline 3.14 .97 & $449-450$ \\
\hline 3.14 .98 & $450-451$ \\
\hline 3.14 .99 & 451 \\
\hline
\end{tabular}

\begin{tabular}{|l|l|}
\hline 3.14 .100 & $451-452$ \\
\hline $3.14 .101 / 102 / 103$ & $452-453$ \\
\hline 3.14 .104 & 453 \\
\hline 3.14 .105 & $453-454$ \\
\hline $3.14 .106 / 107$ & $454-455$ \\
\hline 3.14 .108 & 455 \\
\hline 3.14 .109 & 455 \\
\hline 3.14 .110 & 456 \\
\hline $3.14 .111 / 112$ & $456-457$ \\
\hline 3.14 .113 & 457 \\
\hline 3.14 .114 & 458 \\
\hline 3.14 .115 & 458 \\
\hline 3.14 .116 & 458 \\
\hline 3.14 .117 & 458 \\
\hline $3.14 .118 / 119 / 120 / 121$ & 459 \\
\hline $3.14 .122 / 123$ & $459-460$ \\
\hline $3.14 .124 / 125$ & 460 \\
\hline 3.14 .126 & $460-461$ \\
\hline $3.14 .127 / 128 / 129 / 130$ & 461 \\
\hline &
\end{tabular}

Boek 50 (Cfr. ANTWERPEN, Stadsarchief, Vierschaer, nr. 50: Memorien op de Costumen)

\begin{tabular}{|l|l|}
\hline Artikel(s) & Pagina \\
\hline $4.1 .1 / 2$ & 1 \\
\hline 4.1 .3 & $1-2$ \\
\hline 4.1 .4 & $2-3$ \\
\hline 4.1 .5 & $3-4$ \\
\hline 4.1 .6 & $4-6$ \\
\hline $4.1 .7 / 8$ & $6-7$ \\
\hline $4.1 .9 / 10$ & $7-16$ \\
\hline $4.1 .11 / 12 / 13$ & 16 \\
\hline 4.1 .14 & 17 \\
\hline $4.1 .15 / 16$ & $17-18$ \\
\hline 4.2 .1 & 19 \\
\hline 4.2 .2 & $19-20$ \\
\hline 4.2 .3 & 20 \\
\hline 4.2 .4 & $20-21$ \\
\hline 4.2 .5 & 21 \\
\hline 4.2 .6 & $21-22$ \\
\hline 4.2 .7 & 22 \\
\hline 4.2 .8 & $22-23$ \\
\hline 4.2 .9 & 23 \\
\hline $4.2 .10 / 11$ & $23-24$ \\
\hline 4.2 .12 & 24 \\
\hline $4.2 .13 / 14$ & $24-25$ \\
\hline 4.2 .15 & 25 \\
\hline & \\
\hline & \\
\hline
\end{tabular}

\begin{tabular}{|l|l|}
\hline 4.2 .16 & 25 \\
\hline 4.2 .17 & $25-26$ \\
\hline 4.3 .1 & 28 \\
\hline 4.3 .2 & $28-29$ \\
\hline $4.3 .3 / 4 / 5 / 6$ & $29-30$ \\
\hline 4.3 .7 & $30-31$ \\
\hline 4.3 .8 & $31-32$ \\
\hline $4.3 .9 / 10$ & 32 \\
\hline 4.3 .11 & $32-33$ \\
\hline 4.3 .12 & $33-34$ \\
\hline 4.3 .13 & 34 \\
\hline 4.3 .14 & $34-35$ \\
\hline 4.3 .15 & $35-36$ \\
\hline 4.3 .16 & $36-37$ \\
\hline $4.3 .17 / 18 / 19 / 20$ & $37-39$ \\
\hline $4.3 .21 / 22$ & $39-40$ \\
\hline $4.3 .23 / 24 / 25$ & 40 \\
\hline 4.3 .26 & $41-42$ \\
\hline 4.3 .27 & 42 \\
\hline 4.3 .28 & 43 \\
\hline 4.3 .29 & $43-44$ \\
\hline 4.3 .30 & 44 \\
\hline 4.3 .31 & 44 \\
\hline $4.3 .32 / 33$ & $44-46$ \\
\hline & \\
\hline
\end{tabular}




\begin{tabular}{|c|c|}
\hline 4.3 .34 & 46 \\
\hline 4.3 .35 & 46 \\
\hline 4.3 .36 & 47 \\
\hline $4.3 .37 / 38$ & 47 \\
\hline $4.3 .39 / 40$ & 48 \\
\hline 4.3 .41 & $48-49$ \\
\hline $4.3 .42 / 43 / 44$ & 49 \\
\hline 4.3 .45 & $49-50$ \\
\hline 4.3 .46 & $50-51$ \\
\hline 4.3 .47 & 51 \\
\hline 4.3 .48 & 51 \\
\hline 4.3 .49 & $51-52$ \\
\hline 4.3 .50 & 52 \\
\hline 4.3 .51 & 52 \\
\hline 4.3 .52 & 52 \\
\hline 4.3 .53 & 53 \\
\hline 4.3 .54 & $53-55$ \\
\hline 4.3 .55 & 55 \\
\hline $4.3 .56 / 57$ & 55 \\
\hline $4.3 .58 / 59$ & $55-56$ \\
\hline $4.3 .60 / 61 / 62$ & 56 \\
\hline $4.3 .63 / 64 / 65$ & 57 \\
\hline $4.3 .66 / 67$ & $57-59$ \\
\hline 4.3 .68 & $59-60$ \\
\hline 4.3 .69 & 61 \\
\hline $4.3 .70 / 71$ & 61 \\
\hline $4.3 .72 / 73$ & $61-63$ \\
\hline $4.3 .74 / 75$ & $63-65$ \\
\hline $4.3 .76 / 77$ & $65-66$ \\
\hline $4.4 .1 / 2$ & $68-69$ \\
\hline 4.4 .3 & 69 \\
\hline 4.4 .4 & 69 \\
\hline 4.4 .5 & 70 \\
\hline 4.4 .6 & $70-71$ \\
\hline 4.4 .7 & 71 \\
\hline 4.4 .8 & 71 \\
\hline 4.4 .9 & $71-72$ \\
\hline 4.4 .10 & 72 \\
\hline 4.4 .11 & 73 \\
\hline 4.4 .12 & 73 \\
\hline 4.4 .13 & 73 \\
\hline 4.4 .14 & $73-74$ \\
\hline 4.4 .15 & 74 \\
\hline $4.4 .16 / 17$ & 74 \\
\hline 4.5 .1 & $75-76$ \\
\hline $4.5 .2 / 3$ & 76 \\
\hline 4.5 .4 & 76 \\
\hline $4.5 .5 / 6$ & 76 \\
\hline 4.5 .7 & 76 \\
\hline 4.5 .8 & 76 \\
\hline 4.5 .9 & 77 \\
\hline
\end{tabular}

\begin{tabular}{|c|c|}
\hline 4.6 .1 & 78 \\
\hline 4.6 .2 & 78 \\
\hline 4.6 .3 & 78-79 \\
\hline 4.6 .4 & 79 \\
\hline 4.6 .5 & 79 \\
\hline $4.6 .6 / 7 / 8 / 9$ & $79-80$ \\
\hline $4.6 .10 / 11$ & $80-81$ \\
\hline 4.6 .12 & 81 \\
\hline $4.6 .13 / 14 / 15$ & 81 \\
\hline 4.6 .16 & 81 \\
\hline 4.6 .17 & $82-84$ \\
\hline 4.6 .18 & 84 \\
\hline 4.6 .19 & $84-85$ \\
\hline $4.6 .20 / 21 / 22 / 23$ & $85-86$ \\
\hline 4.6.23? & 86 \\
\hline 4.6 .25 & 86 \\
\hline 4.6 .26 & $87-88$ \\
\hline 4.7 .1 & 89 \\
\hline 4.7 .2 & 89 \\
\hline 4.7 .3 & $89-90$ \\
\hline 4.7 .4 & 91 \\
\hline 4.7 .5 & $91-92$ \\
\hline $4.7 .6 / 7$ & 92 \\
\hline 4.7 .8 & $92-93$ \\
\hline 4.7 .9 & 93 \\
\hline 4.7 .10 & 93 \\
\hline 4.7 .11 & 94 \\
\hline 4.7 .12 & 94-95 \\
\hline 4.7 .13 & $95-96$ \\
\hline 4.7 .14 & 96 \\
\hline 4.7 .15 & $96-97$ \\
\hline $4.7 .16 / 17$ & $97-98$ \\
\hline 4.7 .18 & 98 \\
\hline $4.7 .19 / 20 / 21 / 22$ & 98-101 \\
\hline 4.7 .23 & 101-102 \\
\hline $4.7 .24 / 25$ & $102-103$ \\
\hline 4.7 .26 & 103 \\
\hline 4.7 .27 & 104 \\
\hline 4.7 .28 & 104 \\
\hline $4.7 .29 / 30$ & 104-105 \\
\hline 4.7 .31 & 105 \\
\hline $4.7 .32 / 33$ & $105-106$ \\
\hline 4.7 .34 & 106 \\
\hline 4.7 .35 & 106-107 \\
\hline 4.7 .36 & $107-108$ \\
\hline 4.7 .37 & 108 \\
\hline $4.7 .38 / 39$ & 108-109 \\
\hline 4.7 .40 & 109 \\
\hline 4.7 .41 & 109 \\
\hline 4.7 .42 & 110 \\
\hline $4.7 .43 / 44$ & 110 \\
\hline
\end{tabular}




\begin{tabular}{|c|c|}
\hline 4.7 .45 & 111 \\
\hline 4.8 .1 & $112-114$ \\
\hline $4.8 .2 / 3 / 4$ & 114-115 \\
\hline 4.8 .5 & $115-116$ \\
\hline $4.8 .6 / 7$ & 116-118 \\
\hline 4.8 .8 & 118-119 \\
\hline 4.8 .9 & 119 \\
\hline $4.8 .10 / 11$ & $120-121$ \\
\hline 4.8 .12 & 121 \\
\hline 4.8 .13 & $121-122$ \\
\hline 4.8 .14 & 122 \\
\hline 4.8 .15 & 122 \\
\hline 4.8.16/17/18 & $122-123$ \\
\hline 4.8 .19 & $124-126$ \\
\hline 4.8 .20 & $126-128$ \\
\hline $4.8 .21 / 22$ & $128-129$ \\
\hline 4.8 .23 & $129-130$ \\
\hline 4.8 .24 & $130-131$ \\
\hline 4.8 .25 & 131 \\
\hline $4.8 .26 / 27 / 28$ & $132-133$ \\
\hline 4.8 .29 & 133 \\
\hline $4.8 .30 / 31$ & $133-134$ \\
\hline $4.8 .32 / 33$ & $134-136$ \\
\hline $4.8 .34 / 35$ & $136-137$ \\
\hline 4.8 .36 & $138-141$ \\
\hline 4.8 .37 & 141-142 \\
\hline 4.8 .38 & 142 \\
\hline $4.8 .39 / 40 / 41 / 42$ & $142-143$ \\
\hline 4.8 .43 & 143-144 \\
\hline 4.8 .44 & 144 \\
\hline $4.8 .45 / 46$ & 144-148 \\
\hline 4.8 .47 & $148-151$ \\
\hline $4.8 .48 / 49 / 50$ & $151-152$ \\
\hline 4.8 .51 & $152-153$ \\
\hline $4.8 .52 / 53 / 54$ & $153-154$ \\
\hline 4.8 .55 & 154 \\
\hline 4.8 .56 & 154 \\
\hline 4.8 .57 & $154-155$ \\
\hline 4.8 .58 & $155-156$ \\
\hline $4.8 .59 / 60$ & $156-157$ \\
\hline 4.8 .61 & 157 \\
\hline $4.8 .62 / 63 / 64$ & $157-158$ \\
\hline 4.8 .65 & 158 \\
\hline 4.8 .66 & 159 \\
\hline 4.8 .67 & $159-160$ \\
\hline 4.8 .68 & 160 \\
\hline 4.8 .69 & $160-161$ \\
\hline $4.8 .70 / 71$ & 161-162 \\
\hline 4.8 .72 & 162 \\
\hline 4.8 .73 & $162-163$ \\
\hline $4.8 .74 / 75 / 76$ & 163-165 \\
\hline
\end{tabular}

\begin{tabular}{|c|c|}
\hline 4.8 .77 & 165 \\
\hline 4.8 .78 & $165-166$ \\
\hline $4.8 .79 / 80 / 81$ & $166-168$ \\
\hline 4.8 .82 & 168 \\
\hline $4.8 .83 / 84$ & $168-169$ \\
\hline 4.8 .85 & 169 \\
\hline 4.8 .86 & $169-170$ \\
\hline $4.8 .87 / 88$ & 170 \\
\hline 4.8 .89 & $170-172$ \\
\hline 4.8 .90 & 172 \\
\hline 4.8 .91 & 173 \\
\hline 4.8 .92 & 173-174 \\
\hline 4.8 .93 & 174 \\
\hline $4.8 .94 / 95 / 96$ & 174 \\
\hline 4.8 .97 & $174-175$ \\
\hline $4.8 .98 / 99$ & 175 \\
\hline $4.8 .100 / 101$ & 175 \\
\hline 4.8 .102 & $175-176$ \\
\hline $4.8 .103 / 104$ & 176 \\
\hline $4.8 .105 / 106$ & 176-178 \\
\hline $4.8 .107 / 108 / 109$ & 178 \\
\hline 4.8 .110 & $178-179$ \\
\hline $4.8 .111 / 112$ & $179-180$ \\
\hline $4.8 .113 / 114$ & 180 \\
\hline $4.8 .115 / 116$ & 180 \\
\hline $4.8 .117 / 118 / 119$ & $180-181$ \\
\hline 4.8 .120 & 182 \\
\hline 4.8 .121 & 182 \\
\hline $4.8 .122 / 123$ & $182-183$ \\
\hline $4.8 .124 / 125 / 126$ & 183-184 \\
\hline 4.8 .127 & 184 \\
\hline $4.8 .128 / 129 / 130 / 131$ & $184-185$ \\
\hline 4.8 .132 & 185 \\
\hline 4.8 .133 & 186-187 \\
\hline 4.8 .134 & 187 \\
\hline $4.8 .135 / 136$ & 187 \\
\hline 4.8 .137 & 188 \\
\hline 4.8 .138 & $188-190$ \\
\hline $4.8 .139 / 140$ & 190-191 \\
\hline 4.8 .141 & 191 \\
\hline $4.8 .142 / 143 / 144 / 145$ & 192-198 \\
\hline 4.8 .146 & 198-199 \\
\hline 4.8 .147 & $199-200$ \\
\hline 4.8 .148 & 200 \\
\hline $4.8 .149 / 150$ & 201 \\
\hline $4.8 .151 / 152$ & 201 \\
\hline $4.8 .153 / 154 / 155$ & 202 \\
\hline $4.8 .156 / 157$ & 202 \\
\hline 4.8 .158 & 203 \\
\hline 4.8 .159 & 203 \\
\hline $4.8 .160 / 161$ & 203-204 \\
\hline
\end{tabular}




\begin{tabular}{|c|c|}
\hline $4.8 .162 / 163 / 164 / 165 / 166$ & 204 \\
\hline 4.8 .167 & $204-205$ \\
\hline $4.8 .168 / 169$ & 205 \\
\hline 4.8 .170 & 205 \\
\hline 4.8 .171 & $205-206$ \\
\hline $4.8 .172 / 173$ & 206 \\
\hline $4.8 .174 / 175 / 176$ & 206 \\
\hline 4.8 .177 & $206-207$ \\
\hline $4.8 .178 / 179$ & $207-208$ \\
\hline 4.8 .180 & 208 \\
\hline 4.8 .181 & $208-209$ \\
\hline 4.8 .182 & 210 \\
\hline 4.8 .183 & 210 \\
\hline 4.8 .184 & 210 \\
\hline $4.8 .185 / 186$ & $210-211$ \\
\hline 4.8 .187 & 212 \\
\hline 4.8 .188 & $212-215$ \\
\hline 4.8 .189 & $215-216$ \\
\hline $4.8 .190 / 191$ & 216 \\
\hline 4.8 .192 & $216-217$ \\
\hline $4.8 .193 / 194$ & $217-218$ \\
\hline $4.8 .195 / 196 / 197$ & $218-219$ \\
\hline $4.8 .198 / 199$ & $219-220$ \\
\hline $4.8 .200 / 201 / 202 / 203$ & 220 \\
\hline 4.8 .204 & 220 \\
\hline $4.8 .205 / 206 / 207$ & 221 \\
\hline 4.8 .208 & $221-222$ \\
\hline 4.9 .1 & 223 \\
\hline $4.9 .2 / 3$ & $223-224$ \\
\hline 4.9 .4 & 224 \\
\hline 4.9 .5 & 225 \\
\hline 4.9 .6 & 225 \\
\hline 4.9 .7 & $225-226$ \\
\hline 4.9 .8 & 226 \\
\hline 4.9 .9 & 226 \\
\hline 4.9 .10 & 227 \\
\hline 4.9 .11 & $227-228$ \\
\hline $4.9 .12 / 13$ & $228-229$ \\
\hline $4.9 .14 / 15$ & $229-230$ \\
\hline 4.9 .16 & 230 \\
\hline $4.9 .17 / 18$ & $230-231$ \\
\hline $4.9 .19 / 20 / 21$ & $231-232$ \\
\hline 4.9 .22 & 232 \\
\hline $4.9 .23 / 24$ & $232-234$ \\
\hline 4.9 .25 & $234-238$ \\
\hline $4.9 .26 / 27$ & $238-239$ \\
\hline 4.9 .28 & $239-240$ \\
\hline $4.9 .29 / 30$ & $241-243$ \\
\hline 4.9 .31 & $243-245$ \\
\hline 4.9 .32 & $245-246$ \\
\hline 4.9 .33 & 246 \\
\hline
\end{tabular}

\begin{tabular}{|c|c|}
\hline 4.9 .34 & 246 \\
\hline $4.9 .35 / 36 / 37$ & 247 \\
\hline 4.9 .38 & $248-250$ \\
\hline 4.9 .39 & $250-251$ \\
\hline $4.10 .1 / 2$ & $252-253$ \\
\hline $4.10 .3 / 4 / 5$ & $253-255$ \\
\hline 4.10 .6 & $255-256$ \\
\hline 4.10 .7 & 256 \\
\hline $4.10 .8 / 9 / 10$ & $256-257$ \\
\hline 4.10 .11 & 257 \\
\hline 4.10 .12 & 258 \\
\hline $4.10 .13 / 14 / 15 / 16$ & $258-259$ \\
\hline $4.10 .17 / 18$ & 259 \\
\hline 4.10 .19 & 260 \\
\hline $4.10 .20 / 21$ & $260-262$ \\
\hline 4.10 .22 & 262 \\
\hline 4.11 .1 & 263 \\
\hline $4.11 .2 / 3 / 4$ & $263-265$ \\
\hline 4.11 .5 & $265-267$ \\
\hline 4.11 .6 & 268 \\
\hline $4.11 .7 / 8$ & $268-271$ \\
\hline 4.11 .9 & $271-273$ \\
\hline 4.11 .10 & $273-274$ \\
\hline 4.11 .11 & $274-275$ \\
\hline 4.11 .12 & 275 \\
\hline 4.11 .13 & $276-277$ \\
\hline 4.11 .14 & 277 \\
\hline 4.11 .15 & 277 \\
\hline 4.11 .16 & $277-278$ \\
\hline $4.11 .17 / 18$ & $278-279$ \\
\hline $4.11 .19 / 20 / 21 / 22$ & 279 \\
\hline 4.11 .23 & $279-280$ \\
\hline 4.11 .24 & 280 \\
\hline 4.11 .25 & $280-281$ \\
\hline 4.11 .26 & $281-282$ \\
\hline 4.11 .27 & $282-283$ \\
\hline 4.11 .28 & $283-284$ \\
\hline $4.11 .29 / 30$ & $285-286$ \\
\hline $4.11 .31 / 32$ & $287-289$ \\
\hline 4.11 .33 & $289-290$ \\
\hline $4.11 .34 / 35 / 36$ & $290-291$ \\
\hline 4.11 .37 & 291 \\
\hline $4.11 .38 / 39 / 40$ & 291-294 \\
\hline $4.11 .41 / 42 / 43$ & $294-295$ \\
\hline 4.11 .44 & 295 \\
\hline $4.11 .45 / 46$ & 295 \\
\hline 4.11 .47 & $295-296$ \\
\hline 4.11 .48 & $296-297$ \\
\hline 4.11 .49 & 297 \\
\hline $4.11 .50 / 51 / 52 / 53$ & $297-298$ \\
\hline $4.11 .54 / 55$ & $298-299$ \\
\hline
\end{tabular}




\begin{tabular}{|c|c|}
\hline $4.11 .56 / 57$ & $299-300$ \\
\hline $4.11 .58 / 59$ & $300-301$ \\
\hline 4.11 .60 & $302-303$ \\
\hline 4.11 .61 & $303-304$ \\
\hline $4.11 .62 / 63$ & 304 \\
\hline 4.11 .64 & $304-305$ \\
\hline 4.11 .65 & $305-306$ \\
\hline 4.11 .66 & $306-307$ \\
\hline $4.11 .67 / 68$ & $307-309$ \\
\hline 4.11 .69 & 309 \\
\hline 4.11 .70 & $309-310$ \\
\hline $4.11 .71 / 72 / 73$ & 310 \\
\hline $4.11 .74 / 75$ & $310-311$ \\
\hline $4.11 .76 / 77$ & $311-312$ \\
\hline 4.11 .78 & 312 \\
\hline 4.11 .79 & 313 \\
\hline $4.11 .80 / 81 / 82 / 83 / 84 / 85$ & 313 \\
\hline $4.11 .86 / 87 / 88$ & 314 \\
\hline $4.11 .89 / 90$ & 314 \\
\hline $4.11 .91 / 92 / 93$ & $314-316$ \\
\hline $4.11 .94 / 95 / 96$ & 316 \\
\hline $4.11 .97 / 98$ & $316-317$ \\
\hline 4.11 .99 & $317-318$ \\
\hline 4.11 .100 & 319 \\
\hline $\begin{array}{l}\text { 4.11.101/102/103/104 } \\
/ 105 / 106 / 107-108\end{array}$ & $319-320$ \\
\hline 4.11 .109 & $320-321$ \\
\hline $4.11 .110 / 111 / 112 / 113 / 114$ & 322 \\
\hline 4.11 .115 & $322-324$ \\
\hline 4.11 .116 & $324-325$ \\
\hline 4.11 .117 & 325 \\
\hline $4.11 .118 / 119 / 120 / 121$ & $325-326$ \\
\hline 4.11 .122 & $326-327$ \\
\hline $\begin{array}{l}4.11 .123 / 124 / 125 / 126 / 127 \\
/ 128 / 129\end{array}$ & $327-329$ \\
\hline $4.11 .130 / 131$ & 329 \\
\hline $4.11 .132 / 133$ & $329-330$ \\
\hline $4.11 .134 / 135$ & 330 \\
\hline $4.11 .136 / 137 / 138 / 139 / 140$ & $330-331$ \\
\hline $\begin{array}{l}4.11 .141 / 142 / 143 / 144 / 145 \\
/ 146\end{array}$ & 331 \\
\hline 4.11 .147 & $331-332$ \\
\hline 4.11 .148 & 332 \\
\hline $4.11 .149 / 150$ & $332-333$ \\
\hline $4.11 .151 / 152$ & 333 \\
\hline $4.11 .153 / 154 / 155$ & 333 \\
\hline 4.11 .156 & $334-335$ \\
\hline 4.11 .157 & 335 \\
\hline $4.11 .158 / 159$ & $335-336$ \\
\hline $4.11 .160 / 161 / 162 / 163$ & $336-337$ \\
\hline $4.11 .164 / 165 / 166 / 167$ & $337-338$ \\
\hline
\end{tabular}

\begin{tabular}{|c|c|}
\hline $4.11 .168 / 169 / 170$ & 338 \\
\hline 4.11 .171 & 339 \\
\hline 4.11 .172 & 339 \\
\hline 4.11 .173 & 339 \\
\hline 4.11 .174 & 340 \\
\hline 4.11 .175 & $340-341$ \\
\hline $4.11 .176 / 177 / 178 / 179$ & $342-343$ \\
\hline 4.11 .180 & $343-344$ \\
\hline $4.11 .181 / 182 / 183 / 184 / 185$ & $344-347$ \\
\hline $4.11 .186 / 187$ & 347 \\
\hline 4.11 .188 & 347 \\
\hline $4.11 .189 / 190 / 191$ & $347-348$ \\
\hline $4.11 .192 / 193$ & 348 \\
\hline $4.11 .194 / 195$ & $348-349$ \\
\hline $4.11 .196 / 197$ & $349-350$ \\
\hline $4.11 .198 / 199$ & 351 \\
\hline $4.11 .200 / 201$ & 351 \\
\hline 4.11 .202 & $351-353$ \\
\hline $4.11 .203 / 204$ & $353-355$ \\
\hline $4.11 .205 / 206 / 207$ & 355 \\
\hline 4.11 .208 & 355 \\
\hline 4.11 .209 & 356 \\
\hline 4.11 .210 & 356 \\
\hline $4.11 .211 / 212$ & $357-359$ \\
\hline $4.11 .213 / 214$ & 359 \\
\hline $4.11 .215 / 216$ & 359 \\
\hline 4.11 .222 & $360-361$ \\
\hline $4.11 .223 / 224 / 225$ & $362-363$ \\
\hline $4.11 .226 / 227$ & $363-364$ \\
\hline 4.11 .228 & 365 \\
\hline $4.11 .229 / 230$ & $365-366$ \\
\hline 4.11 .231 & 366 \\
\hline $4.11 .232 / 233 / 234$ & $366-367$ \\
\hline 4.11 .235 & 367 \\
\hline $4.11 .236 / 237$ & $367-368$ \\
\hline $4.11 .238 / 239$ & $368-369$ \\
\hline 4.11 .240 & $369-370$ \\
\hline 4.11 .241 & $370-371$ \\
\hline 4.11 .242 & $371-372$ \\
\hline 4.11 .243 & 372 \\
\hline 4.11 .244 & 372 \\
\hline $4.11 .245 / 246 / 247$ & $373-374$ \\
\hline 4.11 .248 & 374 \\
\hline $4.11 .249 / 250$ & $374-375$ \\
\hline 4.11 .251 & $375-376$ \\
\hline $4.11 .252 / 253$ & 376 \\
\hline 4.11 .254 & 376 \\
\hline $4.11 .255 / 256$ & 377 \\
\hline 4.11 .257 & $377-378$ \\
\hline 4.11 .258 & 378 \\
\hline 4.11 .259 & $378-379$ \\
\hline
\end{tabular}




\begin{tabular}{|c|c|}
\hline 4.11 .260 & $379-381$ \\
\hline 4.11 .261 & $381-382$ \\
\hline 4.11 .262 & 382 \\
\hline 4.11 .263 & 382 \\
\hline $4.11 .264 / 265$ & 383 \\
\hline $4.11 .266 / 267 / 268$ & $383-384$ \\
\hline $4.11 .269 / 270 / 271$ & $384-385$ \\
\hline $4.11 .272 / 273$ & 385 \\
\hline $4.11 .274 / 275$ & $385-386$ \\
\hline $4.11 .276 / 277 / 278 / 279$ & 386 \\
\hline $4.11 .280 / 281$ & 387 \\
\hline 4.11 .282 & 387 \\
\hline $4.11 .283 / 284 / 285$ & $387-388$ \\
\hline $4.11 .286 / 287$ & 389 \\
\hline 4.11 .288 & $389-390$ \\
\hline $4.11 .289 / 290 / 291$ & $390-391$ \\
\hline 4.11 .292 & 391 \\
\hline $4.11 .293 / 294$ & $391-392$ \\
\hline $4.11 .295 / 296 / 297$ & $392-393$ \\
\hline $4.11 .298 / 299$ & 393 \\
\hline 4.11 .300 & 394 \\
\hline 4.11 .301 & 394-395 \\
\hline 4.11 .302 & 395 \\
\hline $4.11 .303 / 304$ & 395 \\
\hline $4.11 .305 / 306$ & $\begin{array}{l}395,366^{*} \\
367 * 1391\end{array}$ \\
\hline 4.11 .307 & $367 *$ \\
\hline 4.11 .308 & $367 *-368^{*}$ \\
\hline 4.11 .309 & $368^{*}$ \\
\hline 4.11 .310 & $368^{*}$ \\
\hline $4.11 .311 / 312$ & $368^{*}$ \\
\hline 4.11 .313 & $368^{*}-370^{*}$ \\
\hline 4.11 .314 & $370^{*}$ \\
\hline 4.11 .315 & $370^{*}$ \\
\hline 4.11 .316 & $370 *-371 *$ \\
\hline $\begin{array}{l}4.11 .317 / 318 / 319 / 320 \\
/ 321 / 322 / 323\end{array}$ & $371 *-373 *$ \\
\hline 4.12 .1 & $374 *$ \\
\hline 4.12 .2 & $374 *$ \\
\hline 4.12 .3 & $374 *-375^{*}$ \\
\hline 4.12 .4 & $375^{*}-376^{*}$ \\
\hline 4.12 .5 & $376^{*}-377^{*}$ \\
\hline
\end{tabular}

${ }^{1391}$ Op deze plaats in het boek verspringt de paginering van 395 naar 366 en gaat zo weer verder. Om een onderscheid te maken met vorige pagina's met paginanummers als 366 tot en met 395 werd er hier een asterisk aan toegevoegd.

\begin{tabular}{|c|c|}
\hline $4.12 .6 / 7$ & $377 *-378^{*}$ \\
\hline 4.12 .8 & $379 *$ \\
\hline 4.12 .9 & $379 *-380^{*}$ \\
\hline 4.12 .10 & $381 *-382^{*}$ \\
\hline 4.12 .11 & $382 *-383^{*}$ \\
\hline 4.12 .12 & $383^{*}-386^{*}$ \\
\hline $4.12 .13 / 14 / 15 / 16 / 17$ & $386^{*}$ \\
\hline 4.12 .18 & $386^{*}-387^{*}$ \\
\hline $4.12 .19 / 20$ & $388^{*}-392^{*}$ \\
\hline 4.12 .21 & $392^{*}-393^{*}$ \\
\hline 4.12 .22 & 393* \\
\hline 4.12 .23 & $393 *-394 *$ \\
\hline 4.12 .24 & 394* \\
\hline $4.12 .25 / 26$ & $394 *-395 *$ \\
\hline 4.12 .27 & $395 *-396$ \\
\hline $4.12 .28 / 29$ & 396 \\
\hline 4.12 .30 & $396-397$ \\
\hline $4.12 .31 / 32$ & 397 \\
\hline 4.12 .33 & 397 \\
\hline 4.12 .34 & $397-398$ \\
\hline 4.12 .35 & 398 \\
\hline $4.13 .1 / 2$ & $400-401$ \\
\hline 4.13 .3 & 401 \\
\hline 4.13.4 & 401-402 \\
\hline 4.13 .5 & $402-404$ \\
\hline 4.13 .6 & 404-405 \\
\hline $4.13 .7 / 8$ & $405-406$ \\
\hline 4.13 .9 & $406-407$ \\
\hline 4.13 .10 & 407 \\
\hline 4.13 .11 & 407 \\
\hline $4.13 .12 / 13 / 14 / 15$ & $408-411$ \\
\hline 4.13 .16 & 412 \\
\hline 4.13 .17 & 412 \\
\hline 4.13 .18 & 412-413 \\
\hline 4.13 .19 & 413 \\
\hline 4.13 .20 & 413 \\
\hline $4.13 .21 / 22$ & 413 \\
\hline 4.13 .23 & $413-414$ \\
\hline 4.13 .24 & 414 \\
\hline 4.13 .25 & 415 \\
\hline 4.13 .26 & $415-417$ \\
\hline 4.13 .27 & 417 \\
\hline $4.13 .28 / 29$ & 417 \\
\hline $4.13 .30 / 31$ & 417-418 \\
\hline 4.13 .32 & 418 \\
\hline 4.13 .33 & 418 \\
\hline 4.13 .34 & 419 \\
\hline 4.13 .35 & 419 \\
\hline 4.13 .36 & 419 \\
\hline 4.13 .37 & 419 \\
\hline $4.13 .38 / 39$ & $420-428$ \\
\hline
\end{tabular}




\begin{tabular}{|c|c|}
\hline 4.13 .40 & 428 \\
\hline $4.14 .1 / 2 / 3$ & $430-432$ \\
\hline 4.14 .4 & $432-433$ \\
\hline 4.14 .5 & 433 \\
\hline 4.14 .6 & $433-434$ \\
\hline 4.14 .7 & 434 \\
\hline $4.14 .8 / 9$ & 434 \\
\hline $4.14 .10 / 11$ & $434-435$ \\
\hline 4.14 .12 & 435 \\
\hline 4.14 .13 & $436-437$ \\
\hline $4.14 .14 / 15 / 16$ & $437-438$ \\
\hline 4.14 .17 & 438 \\
\hline $4.14 .18 / 19$ & 438 \\
\hline 4.14 .20 & $438-439$ \\
\hline 4.14 .21 & 439 \\
\hline 4.14 .22 & 439 \\
\hline $4.14 .23 / 24$ & 440 \\
\hline 4.14 .25 & 440 \\
\hline $4.15 .1 / 2 / 3$ & 442 \\
\hline 4.15 .4 & 442 \\
\hline 4.15 .5 & 443 \\
\hline 4.15 .6 & 443 \\
\hline 4.15 .7 & 443 \\
\hline 4.15 .8 & $443-445$ \\
\hline 4.15 .9 & 445 \\
\hline 4.15 .10 & $445-446$ \\
\hline 4.15 .11 & $446-447$ \\
\hline $4.15 .12 / 13$ & 447 \\
\hline 4.15 .14 & 447 \\
\hline $4.15 .15 / 16$ & $447-448$ \\
\hline 4.15 .17 & 448 \\
\hline 4.15 .18 & $448-449$ \\
\hline $4.15 .19 / 20$ & 449 \\
\hline 4.15 .21 & 449 \\
\hline 4.15 .22 & $449-450$ \\
\hline $4.15 .23 / 24$ & $450-451$ \\
\hline 4.15 .25 & 451 \\
\hline 4.15 .26 & $451-453$ \\
\hline 4.15 .27 & $453-454$ \\
\hline 4.15 .28 & $454-455$ \\
\hline 4.16 .1 & 456 \\
\hline $4.16 .2 / 3$ & $456-457$ \\
\hline 4.16 .4 & $457-458$ \\
\hline 4.16 .5 & $458-459$ \\
\hline $4.16 .6 / 7$ & 459 \\
\hline 4.16 .8 & 460 \\
\hline $4.16 .9 / 10$ & 460 \\
\hline 4.16 .11 & $461-465$ \\
\hline $4.16 .12 / 13$ & $465-466$ \\
\hline 4.16 .14 & 466 \\
\hline 4.16 .15 & 466 \\
\hline
\end{tabular}

\begin{tabular}{|c|c|}
\hline $4.16 .16 / 17$ & 467 \\
\hline $4.16 .18 / 19$ & $467-469$ \\
\hline 4.16 .20 & $469-470$ \\
\hline 4.16 .21 & 470 \\
\hline 4.16 .22 & 470 \\
\hline 4.16 .23 & 471 \\
\hline 4.16 .24 & 471 \\
\hline 4.16 .25 & 471 \\
\hline 4.16 .26 & $471-472$ \\
\hline 4.16 .27 & 472 \\
\hline 4.16 .28 & $472-473$ \\
\hline 4.16 .29 & $473-474$ \\
\hline $4.16 .30 / 31 / 32 / 33$ & $474-476$ \\
\hline 4.16 .34 & 476 \\
\hline $4.16 .35 / 36 / 37$ & $476-477$ \\
\hline 4.16 .38 & $477-478$ \\
\hline 4.16 .39 & 478 \\
\hline 4.16 .40 & $478-479$ \\
\hline 4.16 .41 & 479 \\
\hline 4.16 .42 & 480 \\
\hline $4.16 .43 / 44 / 45$ & $480-481$ \\
\hline 4.16 .46 & 482 \\
\hline $4.16 .47 / 48$ & $482-483$ \\
\hline 4.16 .49 & $483-484$ \\
\hline 4.16 .50 & 484 \\
\hline 4.16 .51 & $484-485$ \\
\hline $4.16 .52 / 53 / 54 / 55$ & 485 \\
\hline $4.16 .56 / 57$ & $486-487$ \\
\hline $4.16 .58 / 59$ & $487-488$ \\
\hline 4.16 .60 & $488-489$ \\
\hline 4.16 .61 & 489 \\
\hline 4.16 .62 & 489 \\
\hline 4.16 .63 & $489-490$ \\
\hline 4.16 .64 & $490-491$ \\
\hline 4.16 .65 & $491-492$ \\
\hline 4.16 .66 & 492 \\
\hline $4.16 .67 / 68$ & $492-493$ \\
\hline 4.16 .69 & $493-494$ \\
\hline $4.16 .70 / 71 / 72$ & $494-495$ \\
\hline $4.16 .73 / 74 / 75 / 76 / 77$ & $495-499$ \\
\hline 4.16 .78 & $499-500$ \\
\hline $4.16 .79 / 80$ & $500-501$ \\
\hline 4.16 .81 & $501-502$ \\
\hline $4.16 .82 / 83$ & $502-503$ \\
\hline $4.16 .84 / 85$ & $503-505$ \\
\hline 4.16 .86 & 505 \\
\hline 4.16 .87 & $505-506$ \\
\hline $4.16 .88 / 89 / 90 / 91$ & $506-507$ \\
\hline 4.17 .1 & 509 \\
\hline $4.17 .2 / 3$ & $509-510$ \\
\hline $4.17 .4 / 5$ & $510-511$ \\
\hline
\end{tabular}




\begin{tabular}{|c|c|}
\hline $4.17 .6 / 7 / 8 / 9$ & $511-512$ \\
\hline 4.17 .10 & 512 \\
\hline 4.17 .11 & 512 \\
\hline $4 / 17.12 / 13 / 14 / 15$ & $512-513$ \\
\hline 4.17 .16 & 514-518 \\
\hline 4.17 .17 & $518-520$ \\
\hline $4.17 .18 / 19 / 20$ & 520 \\
\hline 4.17 .21 & 520 \\
\hline 4.17 .22 & $520-521$ \\
\hline $4.17 .23 / 24$ & $521-522$ \\
\hline 4.17 .25 & $522-523$ \\
\hline 4.18 .1 & $524-525$ \\
\hline 4.18 .2 & $525-526$ \\
\hline $4.18 .3 / 4$ & 526 \\
\hline 4.18 .5 & 527 \\
\hline $4.18 .6 / 7$ & 527 \\
\hline 4.18 .8 & $527-528$ \\
\hline 4.18 .9 & 528 \\
\hline 4.18 .10 & $528-529$ \\
\hline 4.18 .11 & 529 \\
\hline 4.18 .12 & 530 \\
\hline 4.18 .13 & 530 \\
\hline 4.18 .14 & $530-531$ \\
\hline 4.18 .15 & $531-532$ \\
\hline 4.18 .16 & $532-534$ \\
\hline 4.18 .17 & 534-537 \\
\hline 4.18 .18 & $538-540$ \\
\hline 4.18 .19 & $540-542$ \\
\hline 4.18 .20 & 542 \\
\hline $4.18 .21 / 22$ & $542-544$ \\
\hline 4.18 .23 & 544 \\
\hline $4.18 .24 / 25$ & 544-548 \\
\hline 4.18 .26 & $548-549$ \\
\hline 4.18 .27 & 549 \\
\hline 4.18 .28 & 549 \\
\hline 4.18 .29 & $549-550$ \\
\hline 4.18 .30 & $550-551$ \\
\hline
\end{tabular}

\begin{tabular}{|l|l|}
\hline $4.18 .31 / 32$ & 551 \\
\hline 4.18 .33 & 551 \\
\hline 4.18 .34 & $551-552$ \\
\hline 4.18 .35 & $552-553$ \\
\hline 4.18 .36 & 553 \\
\hline 4.18 .37 & 554 \\
\hline $4.18 .38 / 39$ & 554 \\
\hline $4.18 .40 / 41$ & $554-555$ \\
\hline 4.18 .42 & 555 \\
\hline 4.18 .43 & $555-556$ \\
\hline 4.18 .44 & 556 \\
\hline 4.18 .45 & $556-560$ \\
\hline 4.18 .46 & 560 \\
\hline $4.18 .47 / 48$ & $560-561$ \\
\hline $4.18 .49 / 50 / 51$ & $561-563$ \\
\hline 4.18 .52 & $564-566$ \\
\hline 4.18 .53 & $566-568$ \\
\hline $4.18 .54 / 55$ & $568-569$ \\
\hline 4.18 .56 & $569-570$ \\
\hline 4.18 .57 & 570 \\
\hline 4.18 .58 & $570-571$ \\
\hline 4.18 .59 & $571-572$ \\
\hline $4.18 .60 / 61 / 62$ & $572-573$ \\
\hline 4.18 .63 & 573 \\
\hline $4.18 .64 / 65 / 66$ & $573-574$ \\
\hline 4.18 .67 & $574-575$ \\
\hline 4.18 .68 & 575 \\
\hline 4.18 .69 & $575-576$ \\
\hline 4.18 .70 & 576 \\
\hline 4.18 .71 & 577 \\
\hline 4.18 .72 & 577 \\
\hline 4.18 .73 & $577-578$ \\
\hline $4.18 .74 / 75$ & $578-579$ \\
\hline 4.18 .76 & $579-585$ \\
\hline $4.18 .77 / 78$ & 585 \\
\hline & \\
\hline & \\
\hline
\end{tabular}

Boek 51 (Cfr. ANTWERPEN, Stadsarchief, Vierschaer, nr. 51: Memorien op de Costumen)

\begin{tabular}{|l|l|}
\hline Artikel(s) & Pagina \\
\hline 5.1 .1 & 1 \\
\hline $5.1 .2 / 3$ & $1-3$ \\
\hline 5.1 .4 & $3-4$ \\
\hline 5.1 .5 & 4 \\
\hline $5.1 .5 \mathrm{bis}$ & $4-5$ \\
\hline 5.1 .6 & 5 \\
\hline
\end{tabular}

\begin{tabular}{|l|l|}
\hline 5.1 .7 & 5 \\
\hline 8.1 .8 & $6-6$ \\
\hline 5.1 .9 & 6 \\
\hline 5.1 .10 & 7 \\
\hline 5.1 .11 & 7 \\
\hline 5.1 .12 & 7 \\
\hline 5.1 .13 & $7-8$ \\
\hline
\end{tabular}


BiJLAGEN

\begin{tabular}{|c|c|}
\hline $5.1 .14 / 15$ & 8 \\
\hline 5.1 .16 & $8-9$ \\
\hline $5.1 .17 / 18 / 19$ & 9 \\
\hline 5.1 .20 & 9 \\
\hline 5.1 .21 & 10 \\
\hline 5.1 .22 & 10 \\
\hline 5.1 .23 & 10 \\
\hline 5.1 .24 & $10-11$ \\
\hline 5.1 .25 & $11-12$ \\
\hline $5.1 .26 / 27 / 28$ & $12-13$ \\
\hline $5.1 .29 / 30$ & $13-14$ \\
\hline 5.1 .31 & 14 \\
\hline 5.1 .32 & 14 \\
\hline $5.1 .33 / 34$ & $14-15$ \\
\hline 5.1 .35 & 15 \\
\hline 5.1 .36 & 15 \\
\hline 5.1 .37 & 15 \\
\hline 5.1 .38 & 16 \\
\hline 5.1 .39 & $17-20$ \\
\hline 5.1 .40 & $20-21$ \\
\hline $5.1 .41 / 42$ & $21-22$ \\
\hline $5.1 .43 / 44 / 45 / 46 / 47 / 48 / 49$ & $22-23$ \\
\hline 5.1 .50 & $23-24$ \\
\hline $5.1 .52 / 53 / 54$ & $24-25$ \\
\hline 5.1 .55 & 25 \\
\hline 5.1 .56 & 25 \\
\hline $5.1 .57 / 58 / 59$ & 25 \\
\hline $5.1 .60 / 61 / 62 /$ & $25-26$ \\
\hline 5.1 .63 & 26 \\
\hline 5.1 .64 & 26 \\
\hline 5.1 .65 & 26 \\
\hline $5.1 .66 / 67$ & 26 \\
\hline 5.1 .68 & 27 \\
\hline $5.1 .69 / 70$ & 27 \\
\hline 5.1 .71 & $27-28$ \\
\hline $5.1 .72 / 73$ & 28 \\
\hline 5.1 .74 & 28 \\
\hline 5.1 .75 & 29 \\
\hline 5.1 .76 & 29 \\
\hline 5.2 .1 & 30 \\
\hline 5.2 .2 & 30 \\
\hline 5.2 .3 & $30-31$ \\
\hline 5.2 .4 & $31-32$ \\
\hline 5.3 .1 & 33 \\
\hline 5.3 .2 & 33 \\
\hline 5.3 .3 & 33-34 \\
\hline 5.3 .4 & 34 \\
\hline 5.3 .5 & 34 \\
\hline 5.3 .6 & 34-35 \\
\hline 5.3 .7 & 35 \\
\hline 5.3 .8 & $35-36$ \\
\hline
\end{tabular}

\begin{tabular}{|c|c|}
\hline 5.3 .9 & 36 \\
\hline 5.3 .10 & 36 \\
\hline 5.3 .11 & 36 \\
\hline 5.3 .12 & 36 \\
\hline 5.3 .13 & 37 \\
\hline 5.3 .14 & 37 \\
\hline 5.3 .15 & 37 \\
\hline $5.3 .16 / 17 / 18$ & $37-39$ \\
\hline $5.3 .19 / 20$ & 40 \\
\hline 5.3 .21 & $40-41$ \\
\hline 5.3 .22 & $41-42$ \\
\hline $5.3 .23 / 24$ & $42-46$ \\
\hline 5.3 .25 & 46 \\
\hline 5.3 .26 & $46-47$ \\
\hline 5.3 .27 & 47 \\
\hline 5.3 .28 & $47-48$ \\
\hline 5.3 .29 & 48 \\
\hline 5.3 .30 & $48-50$ \\
\hline 5.4 .1 & 51 \\
\hline 5.4 .2 & $51-53$ \\
\hline $5.4 .3 / 4$ & $53-54$ \\
\hline 5.4 .5 & $54-55$ \\
\hline 5.4 .6 & $55-56$ \\
\hline 5.4 .7 & 56 \\
\hline 5.4 .8 & 56 \\
\hline 5.4 .9 & $56-57$ \\
\hline 5.4 .10 & 57 \\
\hline 5.4 .11 & 57 \\
\hline 5.4 .12 & 57 \\
\hline 5.4 .13 & 58 \\
\hline 5.4 .14 & 58 \\
\hline 5.4 .15 & 58 \\
\hline 5.4 .16 & 58 \\
\hline 5.4 .17 & 58-59 \\
\hline 5.4 .18 & 59 \\
\hline 5.4 .19 & 59 \\
\hline 5.4 .20 & 59 \\
\hline 5.4 .21 & $59-60$ \\
\hline 5.4 .22 & 60 \\
\hline 5.4 .23 & 60 \\
\hline 5.4 .24 & 60 \\
\hline $5.4 .25 / 26$ & $61-63$ \\
\hline $5.4 .27 / 28 / 29$ & 63 \\
\hline 5.4 .30 & 63 \\
\hline 5.4 .31 & $63-64$ \\
\hline 5.4 .32 & 64 \\
\hline 5.5 .1 & 65 \\
\hline $5.5 .2 / 3$ & 65 \\
\hline 5.5 .4 & 66 \\
\hline 5.5 .5 & 66 \\
\hline 5.5 .6 & 66 \\
\hline
\end{tabular}




\begin{tabular}{|c|c|}
\hline $5.5 .7 / 8$ & $66-67$ \\
\hline 5.6 .1 & 68 \\
\hline $5.6 .2 / 3$ & 68-69 \\
\hline $5.6 .4 / 5$ & 69 \\
\hline $5.6 .6 / 7$ & $69-70$ \\
\hline 5.6 .8 & $70-71$ \\
\hline 5.6 .9 & $71-72$ \\
\hline 5.6 .10 & 72 \\
\hline 5.6 .11 & 73 \\
\hline 5.6 .12 & 73 \\
\hline $5.6 .13 / 14$ & 74 \\
\hline 5.6 .15 & 74-75 \\
\hline 5.6 .16 & $75-76$ \\
\hline 5.6 .17 & 76 \\
\hline $5.6 .18 / 19$ & $77-78$ \\
\hline $5.6 .20 / 21$ & 78 \\
\hline 5.6 .22 & 79 \\
\hline $5.6 .23 / 24$ & $79-80$ \\
\hline 5.6 .25 & 80 \\
\hline 5.6 .26 & 80 \\
\hline $5.6 .27 / 28 / 29$ & $80-81$ \\
\hline 5.6 .30 & 81 \\
\hline 5.7 .1 & 82 \\
\hline 5.7 .2 & $82-83$ \\
\hline $5.7 .3 / 4 / 5$ & $83-84$ \\
\hline 5.7 .6 & $84-85$ \\
\hline $5.7 .7 / 8$ & $85-86$ \\
\hline 5.7 .9 & 86 \\
\hline $5.7 .10 / 11$ & $87-88$ \\
\hline 5.7 .12 & $88-89$ \\
\hline 5.7 .13 & 89 \\
\hline 5.7 .14 & $89-90$ \\
\hline 5.7 .15 & 90 \\
\hline 5.7 .16 & $90-91$ \\
\hline 5.7 .17 & $91-92$ \\
\hline $5.7 .18 / 19$ & $92-93$ \\
\hline $5.7 .20 / 21 / 22$ & $93-96$ \\
\hline $5.7 .23 / 24$ & $96-97$ \\
\hline $5.7 .25 / 26 / 27$ & $97-98$ \\
\hline 5.8 .1 & 99-101 \\
\hline 5.8 .2 & 101 \\
\hline 5.8 .3 & $101-103$ \\
\hline 5.8 .4 & 103-105 \\
\hline 5.8 .5 & 105 \\
\hline 5.8 .6 & 105-106 \\
\hline $5.8 .7 / 8$ & 106-107 \\
\hline 5.8 .9 & 107 \\
\hline 5.8 .10 & $107-108$ \\
\hline 5.8 .11 & 108 \\
\hline $5.8 .12 / 13$ & 108-110 \\
\hline 5.8 .14 & 110 \\
\hline
\end{tabular}

\begin{tabular}{|c|c|}
\hline 5.8 .15 & $111-112$ \\
\hline 5.8 .16 & 112 \\
\hline 5.8 .17 & $112-113$ \\
\hline 5.8 .18 & 113 \\
\hline 5.8 .19 & 113 \\
\hline 5.8 .20 & $113-115$ \\
\hline $5.8 .21 / 22$ & $115-116$ \\
\hline 5.8 .23 & 117 \\
\hline 5.8 .24 & 117 \\
\hline 5.8 .25 & $117-118$ \\
\hline $5.8 .26 / 27$ & 118 \\
\hline 5.8 .28 & 118 \\
\hline 5.8 .29 & $118-119$ \\
\hline $5.8 .30 / 31 / 32$ & $119-120$ \\
\hline $5.8 .33 / 34$ & 121 \\
\hline 5.8 .35 & 122 \\
\hline 5.8 .36 & 122 \\
\hline 5.8 .37 & $123-130$ \\
\hline $5.8 .38 / 39$ & 131 \\
\hline 5.8 .40 & 131 \\
\hline $5.8 .41 / 42$ & $131-133$ \\
\hline 5.8 .43 & 133 \\
\hline 5.8 .44 & $133-134$ \\
\hline $5.8 .45 / 46$ & $134-135$ \\
\hline 5.8 .47 & 135 \\
\hline $5.8 .48 / 49 / 50$ & $135-136$ \\
\hline 5.8 .51 & 136 \\
\hline $5.8 .52 / 53$ & $136-137$ \\
\hline 5.9 .1 & $138-139$ \\
\hline 5.9 .2 & $139-140$ \\
\hline 5.9 .3 & $140-141$ \\
\hline 5.9 .4 & $141-142$ \\
\hline 5.9 .5 & $142-143$ \\
\hline 5.9 .6 & 143 \\
\hline 5.9 .7 & 144 \\
\hline 5.9 .8 & $144-145$ \\
\hline 5.9 .9 & 145 \\
\hline 5.9 .10 & $145-146$ \\
\hline 5.9 .11 & 146 \\
\hline 5.9 .12 & $146-147$ \\
\hline $5.9 .13 / 14$ & $147-149$ \\
\hline 5.9 .15 & 150 \\
\hline $5.9 .16 / 17$ & $150-152$ \\
\hline 5.9.18 & $152-153$ \\
\hline 5.9 .19 & 153 \\
\hline 5.9 .20 & $153-155$ \\
\hline $5.9 .21 / 22 / 23$ & 155 \\
\hline $5.9 .24 / 25$ & 156 \\
\hline $5.9 .26 / 27 / 28$ & 156 \\
\hline $5.9 .29 / 30$ & $156-157$ \\
\hline 5.9 .31 & 158 \\
\hline
\end{tabular}




\begin{tabular}{|c|c|}
\hline $5.9 .32 / 33 / 34$ & $158-159$ \\
\hline 5.9 .35 & $159-160$ \\
\hline $5.9 .36 / 37$ & $160-162$ \\
\hline $5.9 .38 / 39 / 40 / 41$ & $162-165$ \\
\hline $5.9 .42 / 43$ & $165-166$ \\
\hline $5.9 .44 / 45$ & $166-167$ \\
\hline $5.9 .46 / 47 / 48 / 49 / 50 / 51$ & $167-168$ \\
\hline $5.9 .52 / 53$ & $168-171$ \\
\hline 5.9 .54 & 171 \\
\hline $5.9 .55 / 56$ & $171-172$ \\
\hline 5.9 .57 & 172 \\
\hline 5.9 .58 & $172-174$ \\
\hline $5.9 .59 / 60 / 61$ & $174-176$ \\
\hline 5.9 .62 & $176-177$ \\
\hline 5.9.63 & 177 \\
\hline $5.9 .64 / 65 / 66 / 67 / 68 / 69$ & $177-179$ \\
\hline 5.9 .70 & 179 \\
\hline 5.9 .71 & 180 \\
\hline $5.9 .72 / 73$ & 180 \\
\hline 5.9 .74 & $180-181$ \\
\hline $5.9 .75 / 76$ & $181-182$ \\
\hline $5.9 .77 / 78 / 79$ & 182 \\
\hline 5.9 .80 & 183 \\
\hline $5.9 .81 / 82$ & 183 \\
\hline 5.9 .83 & $183-184$ \\
\hline 5.9 .84 & $184-185$ \\
\hline 5.9 .85 & $185-186$ \\
\hline 5.9 .86 & 186 \\
\hline $5.9 .87 / 88$ & 187 \\
\hline $5.9 .89 / 90$ & $187-188$ \\
\hline 5.9 .91 & 189 \\
\hline 5.9 .92 & 189 \\
\hline 5.9 .93 & 189 \\
\hline 5.9 .94 & 189 \\
\hline 5.9 .95 & $189-190$ \\
\hline 5.10 .1 & 191 \\
\hline $5.10 .2 / 3$ & $191-192$ \\
\hline 5.10 .4 & 192 \\
\hline 5.10 .5 & $192-193$ \\
\hline 5.10 .6 & 193 \\
\hline $5.10 .7 / 8$ & 193 \\
\hline 5.10 .9 & 194 \\
\hline 5.10 .10 & 194 \\
\hline 5.10 .11 & 194-195 \\
\hline 5.10 .12 & 195-198 \\
\hline 5.10 .13 & 198 \\
\hline 5.10 .14 & $198-200$ \\
\hline 5.10 .15 & 200 \\
\hline 5.10 .16 & 200 \\
\hline 5.10 .17 & 201 \\
\hline 5.10 .18 & 201 \\
\hline
\end{tabular}

\begin{tabular}{|c|c|}
\hline 5.10 .19 & 201 \\
\hline 5.10 .20 & 201 \\
\hline 5.10 .21 & $201-202$ \\
\hline 5.10 .22 & 202 \\
\hline 5.10 .23 & 203-204 \\
\hline 5.10 .24 & $204-205$ \\
\hline 5.10 .25 & 205 \\
\hline 5.10 .26 & 205 \\
\hline 5.10 .27 & $205-206$ \\
\hline 5.10 .28 & 206 \\
\hline 5.10 .29 & $206-207$ \\
\hline $5.10 .30 / 31$ & 207 \\
\hline 5.10 .32 & 207 \\
\hline $5.10 .33 / 34$ & $207-208$ \\
\hline $5.10 .35 / 36$ & 208 \\
\hline $5.10 .37 / 38$ & $208-209$ \\
\hline $5.10 .39 / 40 / 41$ & 209 \\
\hline $5.10 .42 / 43 / 44 / 45 / 46$ & $209-211$ \\
\hline $5.10 .47 / 48$ & 211 \\
\hline 5.10 .49 & 211 \\
\hline 5.10 .50 & 212 \\
\hline 5.10 .51 & 212 \\
\hline $5.10 .52 / 53 / 54 / 55$ & $212-218$ \\
\hline $5.10 .56 / 57$ & 218-221 \\
\hline 5.10 .58 & 221 \\
\hline 5.10 .59 & 221 \\
\hline 5.10 .60 & $221-222$ \\
\hline $5.10 .61 / 62 / 63$ & 222 \\
\hline $5.10 .64 / 65$ & 222 \\
\hline 5.10 .66 & 222 \\
\hline $5.10 .67 / 68$ & 223 \\
\hline 5.10 .69 & $223-225$ \\
\hline 5.10 .70 & $225-226$ \\
\hline $5.10 .71 / 72$ & 226 \\
\hline 5.10 .73 & $227-230$ \\
\hline 5.10 .74 & $230-231$ \\
\hline $5.10 .75 / 76 / 77 / 78$ & $231-232$ \\
\hline 5.10 .79 & $232-233$ \\
\hline $5.11 .1 / 2$ & 234 \\
\hline $5.11 .3 / 4 / 5$ & $234-235$ \\
\hline 5.11 .6 & 236 \\
\hline 5.11 .7 & 236 \\
\hline 5.11 .8 & $236-237$ \\
\hline 5.11 .9 & 237 \\
\hline 5.11 .10 & $237-238$ \\
\hline 5.11 .11 & 238 \\
\hline 5.11 .12 & $238-239$ \\
\hline 5.11 .13 & 240 \\
\hline 5.11 .14 & 240 \\
\hline 5.11 .15 & $240-241$ \\
\hline 5.11 .16 & $241-242$ \\
\hline
\end{tabular}




\begin{tabular}{|c|c|}
\hline 5.11 .17 & 242 \\
\hline $5.11 .18 / 19 / 20$ & $242-243$ \\
\hline $5.11 .21 / 22$ & 243 \\
\hline 5.11 .23 & 244 \\
\hline $5.11 .24 / 25$ & 245 \\
\hline $5.11 .26 / 27$ & $245-247$ \\
\hline $5.11 .28 / 29$ & $247-248$ \\
\hline $5.11 .30 / 31$ & 248 \\
\hline 5.11 .32 & $248-249$ \\
\hline 5.11 .33 & 249 \\
\hline $5.11 .34 / 35$ & 249 \\
\hline 5.11 .36 & $249-250$ \\
\hline 5.11 .37 & 250 \\
\hline 5.11 .38 & $250-251$ \\
\hline 5.11 .39 & $251-252$ \\
\hline $5.11 .40 / 41$ & 253 \\
\hline 5.11 .42 & $253-254$ \\
\hline 5.11 .43 & 254 \\
\hline 5.11 .44 & 255 \\
\hline 5.11 .45 & 255 \\
\hline 5.11 .46 & $255-256$ \\
\hline 5.11 .47 & $256-259$ \\
\hline 5.11 .48 & 259 \\
\hline $5.11 .49 / 50$ & $259-260$ \\
\hline $5.11 .51 / 52 / 53$ & $260-261$ \\
\hline 5.11 .54 & $261-262$ \\
\hline $5.11 .55 / 56$ & $262-263$ \\
\hline 5.11 .57 & $263-264$ \\
\hline 5.11 .58 & $264-265$ \\
\hline 5.12 .1 & 266 \\
\hline 5.12 .2 & $266-267$ \\
\hline $5.12 .3 / 4$ & $267-268$ \\
\hline 5.12 .5 & 268 \\
\hline 5.12 .6 & $268-269$ \\
\hline 5.13 .1 & 270 \\
\hline $5.13 .2 / 3$ & $270-271$ \\
\hline 5.13 .4 & $271-272$ \\
\hline 5.13 .5 & 272 \\
\hline 5.13 .6 & $272-273$ \\
\hline 5.13 .7 & 273 \\
\hline 5.13 .8 & $273-274$ \\
\hline 5.13 .9 & 275 \\
\hline $5.13 .10 / 11$ & 275 \\
\hline $5.13 .12 / 13$ & $275-276$ \\
\hline 5.13 .14 & 276 \\
\hline 5.13 .15 & 277 \\
\hline 5.13 .16 & 277 \\
\hline 5.13 .17 & 277 \\
\hline $5.13 .18 / 19$ & $277-278$ \\
\hline $5.14 .1 / 2 / 3$ & $279-280$ \\
\hline 5.14 .4 & 280 \\
\hline
\end{tabular}

\begin{tabular}{|c|c|}
\hline 5.14 .5 & $280-281$ \\
\hline 5.14 .6 & $281-282$ \\
\hline 5.14 .7 & 282 \\
\hline $5.14 .8 / 9$ & 282 \\
\hline 5.14 .10 & 282 \\
\hline $5.14 .11 / 12$ & 283 \\
\hline 5.14 .13 & 283 \\
\hline $5.14 .14 / 15 / 16$ & 283 \\
\hline 5.14 .17 & 283 \\
\hline $5.14 .18 / 19$ & $283-284$ \\
\hline 5.14 .20 & 284 \\
\hline 5.15 .1 & 285 \\
\hline 5.15 .2 & 285 \\
\hline 5.15 .3 & 286 \\
\hline $5.15 .4 / 5$ & 286 \\
\hline $5.15 .6 / 7$ & 286 \\
\hline $5.15 .8 / 9 / 10$ & $286-287$ \\
\hline $5.15 .11 / 12$ & 287 \\
\hline 5.15 .13 & 287 \\
\hline 5.15 .14 & $287-288$ \\
\hline $5.15 .15 / 16$ & 288 \\
\hline 5.15 .17 & $288-289$ \\
\hline $5.15 .18 / 19 / 20$ & 289 \\
\hline 5.15 .21 & 289 \\
\hline 5.15 .22 & $289-292$ \\
\hline 5.16 .1 & 293 \\
\hline 5.16 .2 & $293-294$ \\
\hline 5.16 .3 & 294 \\
\hline $5.16 .4 / 5$ & $294-296$ \\
\hline 5.16 .6 & 296 \\
\hline 5.16 .7 & $296-298$ \\
\hline 5.16 .8 & $299-300$ \\
\hline 5.16 .9 & $300-301$ \\
\hline $5.16 .10 / 11$ & $301-302$ \\
\hline 5.16 .12 & 302 \\
\hline 5.16 .13 & 302 \\
\hline $5.16 .14 / 15$ & $302-303$ \\
\hline 5.16 .16 & 304 \\
\hline 5.16 .17 & 304-305 \\
\hline 5.17 .1 & $306-307$ \\
\hline 5.17 .2 & $307-308$ \\
\hline 5.17 .3 & 308 \\
\hline 5.17 .4 & 308 \\
\hline 5.17 .5 & $308-309$ \\
\hline 5.17 .6 & 309 \\
\hline 5.17 .7 & $309-310$ \\
\hline 5.17 .8 & 310 \\
\hline 5.17 .9 & $310-311$ \\
\hline 5.17 .10 & 312 \\
\hline 5.17 .11 & 312 \\
\hline 5.17 .12 & 312 \\
\hline
\end{tabular}




\begin{tabular}{|c|c|}
\hline $5.17 .13 / 14$ & 313 \\
\hline $5.17 .15 / 16$ & 313-314 \\
\hline $5.17 .17 / 18$ & $314-316$ \\
\hline $5.17 .19 / 20$ & $316-317$ \\
\hline 5.17 .21 & 317 \\
\hline 5.17 .22 & 318 \\
\hline 5.17 .23 & 318 \\
\hline $5.17 .24 / 25 / 26$ & 319 \\
\hline 5.17 .27 & 319 \\
\hline $5.17 .28 / 29$ & 319 \\
\hline $5.17 .30 / 31$ & $319-320$ \\
\hline $5.17 .32 / 33$ & $320-321$ \\
\hline 5.17 .34 & 321 \\
\hline $5.17 .35 / 36$ & $321-324$ \\
\hline $5.17 .37 / 38$ & 324 \\
\hline 5.17 .39 & 325 \\
\hline $5.17 .40 / 41$ & $325-326$ \\
\hline 5.17 .42 & $326-327$ \\
\hline 5.17 .43 & $327-328$ \\
\hline $5.17 .44 / 45$ & $328-331$ \\
\hline 5.17 .46 & 331 \\
\hline $5.17 .47 / 48 / 49$ & $331-332$ \\
\hline 5.17 .50 & 332 \\
\hline 5.17 .51 & $332-333$ \\
\hline 5.17 .52 & $333-334$ \\
\hline 5.17 .53 & 334-335 \\
\hline 5.17 .54 & $335-336$ \\
\hline 5.17 .55 & 336 \\
\hline 5.17 .56 & $336-337$ \\
\hline $5.17 .57 / 58$ & $337-338$ \\
\hline $5.17 .59 / 60$ & $338-339$ \\
\hline 5.17 .61 & $339-340$ \\
\hline 5.17 .62 & $340-341$ \\
\hline 5.17 .63 & $341-342$ \\
\hline $5.17 .64 / 65$ & $342-343$ \\
\hline 5.17 .66 & 343-344 \\
\hline 5.17 .67 & $344-345$ \\
\hline $5.17 .68 / 69$ & $345-346$ \\
\hline 5.17 .70 & 346-348 \\
\hline $5.17 .71 / 72$ & $348-349$ \\
\hline $5.17 .73 / 74 / 75$ & $349-350$ \\
\hline 5.17 .76 & $350-351$ \\
\hline 5.17 .77 & $351-352$ \\
\hline 5.17 .78 & $352-353$ \\
\hline 5.17 .79 & 353 \\
\hline $5.17 .80 / 81$ & $353-355$ \\
\hline 5.17 .82 & $355-356$ \\
\hline 5.17 .83 & 356 \\
\hline $5.17 .84 / 85$ & $356-357$ \\
\hline 5.17 .86 & 357 \\
\hline 5.17 .87 & $357-359$ \\
\hline
\end{tabular}

\begin{tabular}{|c|c|}
\hline $5.17 .88 / 89$ & $359-361$ \\
\hline $5.17 .90 / 91 / 92$ & $361-362$ \\
\hline $5.17 .93 / 94$ & 362 \\
\hline 5.17 .95 & $362-363$ \\
\hline 5.17 .96 & 363 \\
\hline 5.17.97/98 & $363-364$ \\
\hline 5.17 .99 & 365 \\
\hline $5.17 .100 / 101$ & $365-367$ \\
\hline 5.17 .102 & $367-368$ \\
\hline 6.1.1. & 369 \\
\hline 6.1 .2 & 370 \\
\hline $6.1 .3 / 4$ & $370-372$ \\
\hline 6.1 .5 & 372 \\
\hline 6.1 .6 & $372-373$ \\
\hline 6.1 .7 & 373 \\
\hline 6.1 .8 & $374-375$ \\
\hline $6.1 .9 / 10$ & 376 \\
\hline 6.1 .11 & $376-377$ \\
\hline $6.1 .12 / 13$ & 377 \\
\hline 6.1 .14 & 377 \\
\hline 6.1 .15 & $377-378$ \\
\hline 6.1 .16 & $379-380$ \\
\hline 6.1 .17 & 380 \\
\hline $6.1 .18 / 19$ & 381 \\
\hline 6.1 .20 & 381 \\
\hline 6.1 .21 & $381-382$ \\
\hline 6.1 .22 & 382 \\
\hline 6.1 .23 & 382 \\
\hline 6.1 .24 & $382-383$ \\
\hline $6.1 .25 / 26$ & $383-387$ \\
\hline 6.1 .27 & 387 \\
\hline 6.1 .28 & 388 \\
\hline 6.1 .29 & 388 \\
\hline 6.1 .30 & 388-389 \\
\hline 6.1 .31 & $389-390$ \\
\hline 6.1 .32 & 390 \\
\hline $6.1 .33 / 34$ & $390-391$ \\
\hline 6.1 .35 & 391 \\
\hline 6.1 .36 & $392-393$ \\
\hline 6.1 .37 & 394 \\
\hline 6.1 .38 & 395 \\
\hline 6.1 .39 & $395-396$ \\
\hline 6.1 .40 & $396-397$ \\
\hline $6.1 .41 / 42$ & $397-398$ \\
\hline 6.1 .43 & 398 \\
\hline 6.1 .44 & $398-399$ \\
\hline 6.1 .45 & 399 \\
\hline 6.1 .46 & $399-400$ \\
\hline 6.1 .47 & $400-401$ \\
\hline $6.1 .48 / 49 / 50$ & $401-402$ \\
\hline 6.1 .51 & 402 \\
\hline
\end{tabular}




\begin{tabular}{|c|c|}
\hline $6.1 .52 / 53$ & $402-403$ \\
\hline $6.1 .54 / 55$ & 403 \\
\hline 6.2 .1 & 404 \\
\hline 6.2 .2 & $405-406$ \\
\hline 6.2 .3 & $406-407$ \\
\hline 6.2 .4 & 407 \\
\hline 6.2 .5 & $407-408$ \\
\hline 6.2 .6 & 408-409 \\
\hline 6.2 .7 & 409 \\
\hline $6.2 .8 / 9$ & $409-410$ \\
\hline 6.2 .10 & $410-411$ \\
\hline 6.2 .11 & 411 \\
\hline 6.2 .12 & $411-412$ \\
\hline $6.2 .13 / 14$ & $412-415$ \\
\hline 6.2 .15 & $415-416$ \\
\hline 6.2 .16 & $416-417$ \\
\hline 6.2 .17 & $417-418$ \\
\hline 6.2 .18 & $418-419$ \\
\hline $6.2 .19 / 20$ & $419-420$ \\
\hline 6.2 .21 & 420 \\
\hline 6.2 .22 & $420-420^{*}$ \\
\hline 6.2 .23 & $420 *-421$ \\
\hline 6.2 .24 & $421-422$ \\
\hline 6.2 .25 & $422-423$ \\
\hline 6.2 .26 & 423 \\
\hline 6.2 .27 & $423-425$ \\
\hline 6.2 .28 & $425-426$ \\
\hline 6.2 .29 & 426 \\
\hline 6.2 .30 & 427 \\
\hline 6.2 .31 & 428 \\
\hline 6.2 .32 & $428-429$ \\
\hline 6.2 .33 & 429 \\
\hline 6.2 .34 & 430 \\
\hline 6.2 .35 & 431 \\
\hline 6.3 .1 & $432-433$ \\
\hline 6.3 .2 & $433-434$ \\
\hline $6.3 / 4 / 5$ & $434-435$ \\
\hline $6.3 .6 / 7$ & $435-436$ \\
\hline 6.3 .8 & $436-437$ \\
\hline 6.3 .9 & $437-438$ \\
\hline $6.3 .10 / 11$ & $438-439$ \\
\hline 6.3 .12 & $439-440$ \\
\hline 6.3 .13 & $440-442$ \\
\hline 6.3 .14 & $442-443$ \\
\hline 6.3 .15 & 443 \\
\hline 6.3 .16 & $443-446$ \\
\hline 6.3 .17 & $447-448$ \\
\hline 6.3 .18 & $448-449$ \\
\hline 6.3 .19 & $450-451$ \\
\hline $6.3 .20 / 21 / 22$ & $451-453$ \\
\hline 6.3 .23 & $453-456$ \\
\hline
\end{tabular}

\begin{tabular}{|c|c|}
\hline $6.3 .24 / 25$ & $456-457$ \\
\hline 6.3 .26 & 457 \\
\hline 6.3 .27 & $458-460$ \\
\hline 6.3 .28 & $460-462$ \\
\hline 7.1.1 & 463 \\
\hline $7.1 .2 / 3 / 4$ & $464-465$ \\
\hline 7.1 .5 & 465 \\
\hline 7.1 .6 & $465-466$ \\
\hline $7.1 .7 / 8 / 9 / 10 / 11$ & $466-467$ \\
\hline 7.1 .12 & $467-469$ \\
\hline $7.1 .13 / 14$ & $469-471$ \\
\hline 7.1 .15 & $471-474$ \\
\hline 7.1 .16 & 474 \\
\hline 7.1 .17 & $474-475$ \\
\hline 7.2 .1 & $476-477$ \\
\hline 7.2 .2 & 477 \\
\hline 7.2 .3 & $477-478$ \\
\hline 7.2 .4 & $478-480$ \\
\hline 7.2 .5 & $480-483$ \\
\hline $7.2 .6 / 7$ & $483-484$ \\
\hline $7.2 .8 / 9 / 10 / 11$ & $484-485$ \\
\hline 7.2 .12 & $485-486$ \\
\hline 7.2 .13 & $486-487$ \\
\hline $7.2 .14 / 15 / 16 / 17$ & 487 \\
\hline 7.2 .18 & $487-493$ \\
\hline 7.2 .19 & $493-494$ \\
\hline $7.2 .20 / 21$ & $494-496$ \\
\hline 7.2 .22 & $496-497$ \\
\hline $7.2 .23 / 24 / 25$ & $497-498$ \\
\hline 7.3 .1 & $500-502$ \\
\hline 7.3 .2 & 502 \\
\hline 7.3 .3 & $502-503$ \\
\hline 7.3 .4 & 503 \\
\hline 7.3 .5 & $503-504$ \\
\hline 7.3 .6 & $504-505$ \\
\hline 7.3 .7 & 505 \\
\hline 7.3 .8 & $505-506$ \\
\hline $7.3 .9 / 10$ & 507 \\
\hline 7.3 .11 & 508 \\
\hline 7.3.12 & 508 \\
\hline 7.3 .13 & 509 \\
\hline $7.3 .14 / 15$ & $509-510$ \\
\hline 7.3.16/17/18/19/20 & $510-511$ \\
\hline 7.3 .21 & 511 \\
\hline 7.3 .22 & $511-512$ \\
\hline 7.3 .23 & 512 \\
\hline $7.3 .24 / 25$ & $512-513$ \\
\hline 7.3 .26 & $514-515$ \\
\hline 7.3 .27 & $515-516$ \\
\hline $7.3 .28 / 29$ & $516-517$ \\
\hline 7.3 .30 & 517 \\
\hline
\end{tabular}


BijLAgEN

\begin{tabular}{|l|l|}
\hline 7.4 .1 & 518 \\
\hline 7.4 .2 & $518-519$ \\
\hline 7.4 .3 & 519 \\
\hline 7.4 .4 & $519-520$ \\
\hline $7.4 .5 / 6 / 7 / 8$ & $520-522$ \\
\hline 7.4 .9 & $522-523$ \\
\hline 7.4 .10 & 523 \\
\hline $7.4 .11 / 12$ & 523 \\
\hline $7.4 .13 *$ & $523-524$ \\
\hline 7.4 .14 & 524 \\
\hline 7.4 .15 & 524 \\
\hline $7.4 .16 / 17$ & $524-525$ \\
\hline 7.4 .18 & 525 \\
\hline $7.4 .19 / 20 / 21 / 22$ & $525-526$ \\
\hline $7.4 .23 / 24$ & 526 \\
\hline 7.4 .25 & $526-527$ \\
\hline $7.4 .26 / 27 / 28$ & 527 \\
\hline $7.4 .29 / 30 / 31 / 32$ & $527-528$ \\
\hline 7.4 .33 & $528-529$ \\
\hline $7.4 .34 / 35$ & $529-531$ \\
\hline $7.4 .36 / 37 / 38$ & $531-532$ \\
\hline 7.4 .39 & $532-535$ \\
\hline 7.4 .40 & 535 \\
\hline 7.4 .41 & 536 \\
\hline 7.4 .42 & $536-537$ \\
\hline 7.4 .43 & 537 \\
\hline 7.5 .1 & 539 \\
\hline $7.5 .2 / 3 / 4 / 5 / 6$ & $539-540$ \\
\hline 7.5 .7 & $540-541$ \\
\hline $7.6 .1 / 2$ & $542-543$ \\
\hline 7.6 .3 & 543 \\
\hline 7.6 .4 & $543-545$ \\
\hline 7.6 .5 & 545 \\
\hline 7.6 .6 & 545 \\
\hline 7.6 .7 & $545-546$ \\
\hline 7.6 .8 & $546-547$ \\
\hline 7.6 .9 & 547 \\
\hline & \\
\hline & \\
\hline & \\
\hline & \\
\hline
\end{tabular}

\begin{tabular}{|l|l|}
\hline $7.6 .10 / 11 \mathrm{bis} / 12 \mathrm{bis}$ & $547-548$ \\
\hline $7.6 .11 / 12$ & $548-549$ \\
\hline 7.6 .13 & $549-550$ \\
\hline 7.6 .14 & 550 \\
\hline 7.6 .15 & $550-551$ \\
\hline 7.6 .16 & 551 \\
\hline 7.6 .17 & 552 \\
\hline 7.6 .18 & 552 \\
\hline 7.6 .19 & 553 \\
\hline 7.6 .20 & $553-554$ \\
\hline 7.6 .21 & $554-555$ \\
\hline $7.6 .21 \mathrm{bis}$ & 555 \\
\hline 7.6 .22 & $555-556$ \\
\hline 7.6 .23 & 556 \\
\hline 7.7 .1 & 557 \\
\hline 7.7 .2 & 557 \\
\hline 7.7 .3 & $557-558$ \\
\hline 7.7 .4 & 558 \\
\hline $7.7 .5 / 6$ & 558 \\
\hline 7.7 .7 & 558 \\
\hline $7.7 .8 / 9$ & 559 \\
\hline $7.7 .10 / 11$ & 559 \\
\hline 7.7 .12 & $559-561$ \\
\hline 7.8 .1 & $562-563$ \\
\hline $7.8 .2 / 3 / 4 / 5$ & $563-565$ \\
\hline $7.8 .6 / 7 / 8$ & 566 \\
\hline 7.8 .9 & 566 \\
\hline 7.8 .10 & $566-567$ \\
\hline 7.8 .11 & 567 \\
\hline 7.8 .12 & 567 \\
\hline 7.8 .13 & 567 \\
\hline $7.8 .14 / 15 / 16$ & $567-568$ \\
\hline 7.8 .17 & 568 \\
\hline 7.8 .18 & $568-569$ \\
\hline 7.8 .19 & $569-570$ \\
\hline 7.8 .20 & 570 \\
\hline & \\
\hline & \\
\hline
\end{tabular}




\section{BIJLAGE 2}

\section{DE PRIMAIRE RECHTSBRONNEN VAN DE NIEUW TOEGEVOEGDE ARTIKELS IN DE ANTWERPSE CONSUETUDINES COMPILATAE (1608).}

Deel I

$V$ an der stadt, haere paelen, rechten, overheyt, poorters ende ingesetenen int gemeijn. (16 titels, 244 artikels waarvan 77.5 nieuw)

\begin{tabular}{|l|l|l|}
\hline \multicolumn{2}{|l|}{$\begin{array}{l}\text { titel } 1 \\
\text { van de stadt, haere paelen ende rechten } \mathbf{( 5 / 1 5 )}\end{array}$} \\
\hline 1.1 .5 & $\begin{array}{l}\text { OAR } \\
\text { RSi }\end{array}$ & $\begin{array}{l}\text { Consuetudines Antiquissimae } \\
\text { Turbe }\end{array}$ \\
\hline 1.1 .7 & $\mathrm{~S}$ & Specifieke reden \\
\hline 1.1 .11 & OAR & Consuetudines Antiquissimae \\
\hline 1.1 .12 & OAR & $\begin{array}{l}\text { Consuetudines Antiquissimae } \\
\text { Keurboeck }\end{array}$ \\
\hline 1.1 .13 & OAR & Specifieke reden \\
\hline
\end{tabular}



\section{titel 3}

van den Amptman, sijne clercken ende dienaeren (0/16)

\begin{tabular}{|l|l|l|}
\hline \multicolumn{3}{|l|}{ titel 4} \\
van borgemeesteren ende schepenen, ende bunne dienaeren $\mathbf{( 3 / 2 4 )}$ \\
\hline 1.4 .19 & Usus & Usus \\
\hline 1.4 .21 & Usus & Usus \\
& Comp & Consuetudines Compilatae \\
\hline 1.4 .23 & S & Specifieke reden \\
\hline
\end{tabular}

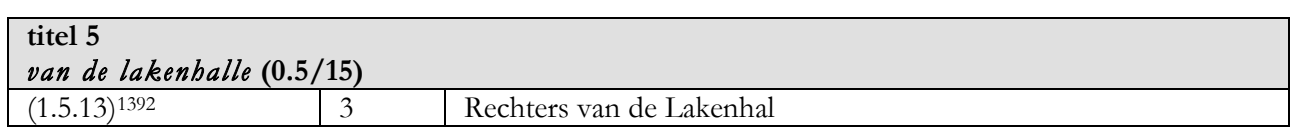

\begin{tabular}{|l|l|l|}
\hline $\begin{array}{l}\text { titel } \mathbf{6} \\
\text { van de peysmaeckers } \mathbf{( 5 / 8 )}\end{array}$ \\
\hline $1.6 .4 / 5$ & iWGs & Ordonnantie Peyskamer: 12 november 1509 \\
\hline $1.6 .6 / 7$ & iWGs & Ordonnantie: 24 oktober 1592 \\
\hline 1.6 .8 & Comp & Consuetudines Compilatae \\
\hline
\end{tabular}

\begin{tabular}{|l|l|l|}
\hline $\begin{array}{l}\text { titel } 7 \\
\text { van de weesmeesters } \mathbf{( 3 / 1 4 )}\end{array}$ \\
\hline 1.7 .4 & OAR & Consuetudines Antiquissimae \\
& iWGs & Ordonnantie Weeskamer: 28 maart 1496 \\
\hline
\end{tabular}

1392 Haakjes als deze geven aan dat het artikel slechts voor de helft geïnnoveerd werd. 


\section{titel 8}

van de rechters van de Watermeulen-brugge $(0 / 3)$

titel 9

van de beerlijckheijt van den Kiele ende de rechters aldaer (0/5)

$\begin{aligned} & \text { titel } 10 \\
& \text { van verscheijde andere rechteren binnen dese stadt }(5 / 8)\end{aligned}$
\begin{tabular}{|l|l|l|}
\hline $1.10 .1 / 2 / 3 / 4 / 5$ & Usus & Usus \\
\hline
\end{tabular}

\begin{tabular}{|c|c|c|}
\hline $\begin{array}{l}\text { titel } 11 \\
\text { van de gr }\end{array}$ & ne cl & $(9 / 10)$ \\
\hline 1.11 .1 & Usus & Usus \\
\hline $1.11 .2 / 3$ & iWGs & Ordonnantie Stijl en manier van procederen: 1582 \\
\hline & iWGs & Ordonnantie Stijl en manier van procederen: 1564 \\
\hline & iWGs & Ordonnantie Stijl en manier van procederen: 1576 \\
\hline 1.11 .5 & iWGs & Ordonnantie Stijl en manier van procederen: 1582 \\
\hline & iWGs & Ordonnantie Stijl en manier van procederen: 1564 \\
\hline 1.11 .6 & iWGs & Ordonnantie Stijl en manier van procederen: 1582 \\
\hline & iWGs & Ordonnantie Stijl en manier van procederen: 1564 \\
\hline & iWGs & Ordonnantie Stijl en manier van procederen: 1576 \\
\hline 1.11 .7 & iWGs & Ordonnantie Stijl en manier van procederen: 1582 \\
\hline & iWGs & Ordonnantie Stijl en manier van procederen: 1564 \\
\hline & iWGs & Ordonnantie Stijl en manier van procederen: 1576 \\
\hline 1.11 .8 & iWGs & Ordonnantie Stijl en manier van procederen: 1582 \\
\hline & iWGs & Ordonnantie Stijl en manier van procederen: 1564 \\
\hline & iWGs & Ordonnantie Stijl en manier van procederen: 1576 \\
\hline 1.11 .9 & iWGs & Ordonnantie Stijl en manier van procederen: 1582 \\
\hline & iWGs & Ordonnantie Stijl en manier van procederen: 1564 \\
\hline & iWGs & Ordonnantie Stijl en manier van procederen: 1576 \\
\hline 1.11 .10 & iWGs & Ordonnantie Stijl en manier van procederen: 1582 \\
\hline & iWGs & Ordonnantie Stijl en manier van procederen: 1564 \\
\hline & iWGs & Ordonnantie Stijl en manier van procederen: 1576 \\
\hline
\end{tabular}

\begin{tabular}{|l|l|l|}
\hline \multicolumn{3}{|l|}{$\begin{array}{l}\text { titel } 12 \\
\text { vande secretarissen ende }\end{array}$} \\
\hline $1.12 .1 / 2$ & Usus & Usus \\
\hline 1.12 .3 & Usus & Usus \\
\hline $1.12 .4 / 5$ & Usus & Usus \\
\hline 1.12 .6 & Usus & Usus \\
\hline $1.12 .7 / 8$ & Comp & Consuetudines Compilatae \\
\hline 1.12 .11 & iWG & Ordonnantie: 15 februari 15931393 \\
& Usus & Usus \\
\hline 1.12 .12 & iWGs & Ordonnantie Stijl en manier van procederen: 1582 \\
& iWGs & Ordonnantie Stijl en manier van procederen: 1564 \\
& iWGs & Ordonnantie Stijl en manier van procederen: 1576 \\
\hline 1.12 .13 & iWG & Ordonnantie: 15 februari 1593 \\
\hline
\end{tabular}

1393 De Memorieboeken spreken echter van 25 februari 1593 of 18 februari 1593. Materiële controle heeft echter uitgewezen dat het hier de ordonnantie van 15 februari 1593 betreft. 


\begin{tabular}{|c|c|c|}
\hline 1.12 .14 & $\begin{array}{l}\text { iWGs } \\
\text { iWGs } \\
\text { iWGs }\end{array}$ & $\begin{array}{l}\text { Ordonnantie Stijl en manier van procederen: } 1582 \\
\text { Ordonnantie Stijl en manier van procederen: } 1564 \\
\text { Ordonnantie Stijl en manier van procederen: } 1576\end{array}$ \\
\hline 1.12 .15 & Usus & Usus \\
\hline 1.12 .16 & $\begin{array}{l}\mathrm{iWGs} \\
\mathrm{iWGs} \\
\mathrm{iWGs}\end{array}$ & $\begin{array}{l}\text { Ordonnantie Stijl en manier van procederen: } 1582 \\
\text { Ordonnantie Stijl en manier van procederen: } 1564 \\
\text { Ordonnantie Stijl en manier van procederen: } 1576\end{array}$ \\
\hline 1.12 .19 & $\begin{array}{l}\mathrm{iWGs} \\
\mathrm{iWG}\end{array}$ & $\begin{array}{l}\text { Ordonnantie Stijl en manier van procederen: } 1564 \\
\text { Ordonnantie Verzwijging van de renten: } 1593\end{array}$ \\
\hline 1.12 .20 & $\begin{array}{l}\text { iWGs } \\
\text { iWGs } \\
\text { iWGs }\end{array}$ & $\begin{array}{l}\text { Ordonnantie Stijl en manier van procederen: } 1582 \\
\text { Ordonnantie Stijl en manier van procederen: } 1564 \\
\text { Ordonnantie Stijl en manier van procederen: } 1576\end{array}$ \\
\hline $1.12 .21 / 22$ & $\mathrm{~S}$ & Specifieke reden \\
\hline 1.12 .23 & $\begin{array}{l}\text { iWGs } \\
\text { iWGs } \\
\text { iWGs }\end{array}$ & $\begin{array}{l}\text { Ordonnantie Stijl en manier van procederen: } 1582 \\
\text { Ordonnantie Stijl en manier van procederen: } 1564 \\
\text { Ordonnantie Stijl en manier van procederen: } 1576\end{array}$ \\
\hline 1.12 .24 & $\begin{array}{l}\text { Usus } \\
\text { Comp }\end{array}$ & $\begin{array}{l}\text { Usus } \\
\text { Consuetudines Compilatae }\end{array}$ \\
\hline 1.12 .25 & $\begin{array}{l}\text { iWGs } \\
\text { iWGs } \\
\text { iWGs } \\
\text { iWG }\end{array}$ & $\begin{array}{l}\text { Ordonnantie Stijl en manier van procederen: } 1582 \\
\text { Ordonnantie Stijl en manier van procederen: } 1564 \\
\text { Ordonnantie Stijl en manier van procederen: } 1576 \\
\text { Ordonnantie Verzwijging van de renten: } 1593\end{array}$ \\
\hline 1.12 .26 & $\begin{array}{l}\text { iWGs } \\
\text { iWGs } \\
\text { iWGs } \\
\text { Comp } \\
\text { RL }\end{array}$ & $\begin{array}{l}\text { Ordonnantie Stijl en manier van procederen: } 1582 \\
\text { Ordonnantie Stijl en manier van procederen: } 1564 \\
\text { Ordonnantie Stijl en manier van procederen: } 1576 \\
\text { Consuetudines Compilatae } \\
\text { Glossatoren bij Digestae }\end{array}$ \\
\hline $1.12 .27 / 28$ & $\begin{array}{l}\text { Usus } \\
\text { iWG }\end{array}$ & $\begin{array}{l}\text { Usus } \\
\text { 'Ex diversis statutis' }\end{array}$ \\
\hline 1.12 .29 & $\begin{array}{l}\text { iWGs } \\
\text { iWGs } \\
\text { iWGs }\end{array}$ & $\begin{array}{l}\text { Ordonnantie Stijl en manier van procederen: } 1582 \\
\text { Ordonnantie Stijl en manier van procederen: } 1564 \\
\text { Ordonnantie Stijl en manier van procederen: } 1576\end{array}$ \\
\hline $1.12 .30 / 31$ & $\begin{array}{l}\text { iWGs } \\
\text { iWGs } \\
\text { iWGs }\end{array}$ & $\begin{array}{l}\text { Ordonnantie Stijl en manier van procederen: } 1582 \\
\text { Ordonnantie Stijl en manier van procederen: } 1564 \\
\text { Ordonnantie Stijl en manier van procederen: } 1576\end{array}$ \\
\hline
\end{tabular}

\begin{tabular}{|l|l|l|}
\hline \multicolumn{2}{|l|}{$\begin{array}{l}\text { titel 13 } \\
\text { van notarissen } \mathbf{( 1 0 / 1 4 )})\end{array}$} \\
\hline 1.13 .1 & iWGv & Ordonnantie Karel V: 7 oktober 1531 \\
\hline 1.13 .3 & iWGv & Ordonnantie Karel V: 4 oktober 1540 \\
\hline 1.13 .4 & iWGv & Ordonnantie Karel V: 4 oktober 1540 \\
& eWG & Wetgeving Frankrijk: Codex Henricianus \\
\hline 1.13 .5 & iWGv & Ordonnantie Karel V: 4 oktober 1540 \\
& $\begin{array}{l}\text { RL } \\
\text { Ciciv }\end{array}$ & $\begin{array}{l}\text { Louis le Caron (Codex Henricianus) } \\
\text { Corpus Iuris Civilis (Codex) }\end{array}$ \\
\hline 1.13 .6 & iWGv & Ordonnantie Karel V: 4 oktober 1540 \\
& Usus & Usus \\
& eWG & Wetgeving Frankrijk: Codex Henricianus \\
\hline 1.13 .7 & S & Specifieke reden \\
& Ciciv & 'Ex iure' \\
& RL & Louis le Caron (Codex Henricianus) \\
\hline 1.13 .8 & S & Specifieke reden \\
\hline $1.13 .9 / 10 / 11$ & eWG & Wetgeving Frankrijk: Codex Henricianus \\
\hline
\end{tabular}




\begin{tabular}{|c|c|c|}
\hline & Comp & Consuetudines Compilatae \\
\hline \multicolumn{3}{|c|}{$\begin{array}{l}\text { titel } 14 \\
\text { van de binnen-poorters }(6 / 43)\end{array}$} \\
\hline $1.14 .10 / 11$ & $\begin{array}{l}\text { OAR } \\
\text { OAR }\end{array}$ & $\begin{array}{l}\text { Consuetudines Antiquae } \\
\text { Consuetudines Antiquissimae }\end{array}$ \\
\hline 1.14 .18 & $\begin{array}{l}\text { Comp } \\
\text { RL } \\
\text { Ciciv }\end{array}$ & $\begin{array}{l}\text { Consuetudines Compilatae } \\
\text { Doctores bij Codex } \\
\text { Corpus Iuris Civilis (Codex) }\end{array}$ \\
\hline 1.14 .19 & Comp & Consuetudines Compilatae \\
\hline 1.14 .32 & $\begin{array}{l}\text { Comp } \\
\text { Usus }\end{array}$ & $\begin{array}{l}\text { Consuetudines Compilatae } \\
\text { Usus }\end{array}$ \\
\hline 1.14 .34 & $\mathrm{~S}$ & Specifieke reden \\
\hline
\end{tabular}

titel 15

van buijten-poorters, $t$ 'sij geboorne oft geëede (0/7)

\begin{tabular}{l}
\begin{tabular}{l} 
titel 16 \\
van ingesetenen ende inwoonders $(1 / 15)$ \\
\hline 1.16 .4 \\
\hline
\end{tabular} \\
\hline
\end{tabular}

Deel II

$V$ an rechten gehoude persoonen aengaende. (5 titels, 505 artikels waarvan 197 nieuw)

\begin{tabular}{|c|c|c|}
\hline \multicolumn{3}{|c|}{$\begin{array}{l}\text { titel } 1 \\
\text { [van gehoude persoonen] }(76.5 / 228)\end{array}$} \\
\hline 2.1 .3 & $\begin{array}{l}\text { eWG } \\
\text { RL }\end{array}$ & $\begin{array}{l}\text { Wetgeving Spanje: Nueva recopilaciòn (1567), Cortes de Madrid (1534) } \\
\text { Antonio Ayerve de Ayora (Tractatus de partitionibus bonorum, } \\
\text { communium inter maritum et uxorem et filios, et heredes eorum) }\end{array}$ \\
\hline 2.1 .4 & $\begin{array}{l}\text { eWG } \\
\text { RL } \\
\text { RA } \\
\text { Comp }\end{array}$ & $\begin{array}{l}\text { Wetgeving Spanje: Nueva recopilaciòn (1567), Cortes de Madrid (1534) } \\
\text { Antonio Ayerve de Ayora (Tractatus de partitionibus bonorum, } \\
\text { communium inter maritum et uxorem et filios, et heredes eorum) } \\
\text { Ratio van ander artikel uit Consuetudines Compilatae }\end{array}$ \\
\hline 2.1 .10 & $\begin{array}{l}\text { Ciciv } \\
\text { RL }\end{array}$ & $\begin{array}{l}\text { Corpus Iuris Civilis (Codex) } \\
\text { Pieter Peck (Tractatus de testamentis conjugum, in quinque libros } \\
\text { distinctus) }\end{array}$ \\
\hline$(2.1 .12)$ & $\begin{array}{l}\text { OAR } \\
\mathrm{S}\end{array}$ & $\begin{array}{l}\text { Consuetudines Antiquissimae } \\
\text { Specifieke reden }\end{array}$ \\
\hline 2.1 .17 & Comp & Consuetudines Compilatae \\
\hline $2.1 .18 / 19$ & Comp & Consuetudines Compilatae \\
\hline 2.1 .24 & Comp & Consuetudines Compilatae \\
\hline 2.1 .28 & $\mathrm{~S}$ & Specifieke reden \\
\hline 2.1 .43 & $\mathrm{~S}$ & Specifieke reden \\
\hline 2.1 .47 & Usus & Usus \\
\hline 2.1 .48 & $\mathrm{~S}$ & Specifieke reden \\
\hline 2.1 .49 & $\mathrm{~S}$ & Specifieke reden \\
\hline $2.1 .50 / 51 / 52 / 53$ & $\mathrm{~S}$ & Specifieke reden \\
\hline 2.1 .57 & $\begin{array}{l}\text { iWG } \\
\text { Comp }\end{array}$ & $\begin{array}{l}\text { Ordonnantie Verzwijging van de renten: } 1593 \\
\text { Consuetudines Compilatae }\end{array}$ \\
\hline $2.1 .68 / 69 / 70 / 71 / 72$ & $\mathrm{~S}$ & Specifieke reden \\
\hline
\end{tabular}


PRIMAIRE RECHTSBRONNEN CONSUETUDINES COMPILATAE

\begin{tabular}{|c|c|c|}
\hline 2.1 .74 & $\begin{array}{l}\text { Usus } \\
\text { eGR }\end{array}$ & $\begin{array}{l}\text { Usus } \\
\text { Costuymen van Gent, Coutumes de Berry, Conférence des coutumes (Pierre } \\
\text { Guenoys) }\end{array}$ \\
\hline 2.1 .75 & eGR & $\begin{array}{l}\text { Costuymen van Gent, Coutumes de Berry, Coutumes de Bourbon, Conférence } \\
\text { des coutumes (Pierre Guenoys) }\end{array}$ \\
\hline 2.1 .76 & eGR & $\begin{array}{l}\text { Costuymen van Gent, Coutumes de Berry, Conférence des coutumes (Pierre } \\
\text { Guenoys) }\end{array}$ \\
\hline 2.1 .78 & OAR & Consuetudines Antiquissimae (a contrario sensu) \\
\hline 2.1 .83 & OAR & Consuetudines Antiquissimae \\
\hline 2.1 .84 & $\begin{array}{l}\text { OAR } \\
\text { OAR }\end{array}$ & $\begin{array}{l}\text { Consuetudines Antiquae } \\
\text { Consuetudines Antiquissimae }\end{array}$ \\
\hline$(2.1 .90)$ & RA & Ratio \\
\hline $2.1 .98 / 99 / 100$ & $\begin{array}{l}\text { S } \\
\text { Ciciv }\end{array}$ & $\begin{array}{l}\text { Specifieke reden } \\
\text { Corpus Iuris Civilis (Digestae) }\end{array}$ \\
\hline 2.1 .103 & $\begin{array}{l}\text { RA } \\
\text { Comp }\end{array}$ & $\begin{array}{l}\text { Ratio } \\
\text { Consuetudines Compilatae }\end{array}$ \\
\hline $2.1 .112 / 113 / 114$ & $\begin{array}{l}\text { RA } \\
\text { Comp }\end{array}$ & $\begin{array}{l}\text { Ratio } \\
\text { Consuetudines Compilatae }\end{array}$ \\
\hline 2.1 .115 & $\mathrm{~S}$ & Specifieke reden \\
\hline 2.1 .116 & $\begin{array}{l}\text { Comp } \\
\text { Ciciv }\end{array}$ & $\begin{array}{l}\text { Consuetudines Compilatae } \\
\text { Corpus Iuris Civilis (Digestae) }\end{array}$ \\
\hline $2.1 .117 / 118$ & Comp & Consuetudines Compilatae \\
\hline $2.1 .119 / 120$ & Comp & Consuetudines Compilatae \\
\hline$(2.1 .122)$ & $\begin{array}{l}\text { Usus } \\
\text { Comp }\end{array}$ & $\begin{array}{l}\text { Usus } \\
\text { Consuetudines Compilatae }\end{array}$ \\
\hline 2.1 .133 & $\begin{array}{l}\text { OAR } \\
\text { Usus } \\
\text { Comp }\end{array}$ & $\begin{array}{l}\text { Consuetudines Antiquissimae } \\
\text { Usus } \\
\text { Consuetudines Compilatae }\end{array}$ \\
\hline $2.1 .143 / 144$ & $\mathrm{~S}$ & Specifieke reden \\
\hline $2.1 .145 / 146$ & $\begin{array}{l}\text { OAR } \\
\text { OAR } \\
\text { OAR } \\
\text { RSi } \\
\text { Comp }\end{array}$ & $\begin{array}{l}\text { Consuetudines Antiquae } \\
\text { Consuetudines Antiquissimae } \\
\text { Guldenboeck } \\
\text { Turbe } \\
\text { Consuetudines Compilatae }\end{array}$ \\
\hline $2.1 .148 / 149$ & $\begin{array}{l}\text { Usus } \\
\text { RA }\end{array}$ & $\begin{array}{l}\text { Usus } \\
\text { Aequitas }\end{array}$ \\
\hline $2.1 .156 / 157$ & Comp & Consuetudines Compilatae \\
\hline $2.1 .159 / 160$ & $\begin{array}{l}\text { Comp } \\
\mathrm{RSi}\end{array}$ & $\begin{array}{l}\text { Consuetudines Compilatae } \\
\text { Rechtspraak (Antwerpen) }\end{array}$ \\
\hline $2.1 .165 / 166$ & $\mathrm{~S}$ & Specifieke reden \\
\hline$(2.1 .168)$ & $\begin{array}{l}\text { OAR } \\
\text { OAR } \\
\text { RSi } \\
\end{array}$ & $\begin{array}{l}\text { Consuetudines Antiquissimae } \\
\text { Guldenboeck } \\
\text { Turbe }\end{array}$ \\
\hline 2.1 .172 & $\begin{array}{l}\text { Comp } \\
\text { OAR }\end{array}$ & $\begin{array}{l}\text { Consuetudines Compilatae } \\
\text { Guldenboeck. }\end{array}$ \\
\hline $2.1 .173 / 174$ & RSi & Turbe \\
\hline $2.1 .175 / 176 / 177$ & $\mathrm{~S}$ & Specifieke reden \\
\hline 2.1 .180 & $\mathrm{~S}$ & Specifieke reden \\
\hline $2.1 .184 / 185$ & $\mathrm{~S}$ & Specifieke reden \\
\hline $2.1 .188 / 189 / 190$ & $\begin{array}{l}\text { Usus } \\
\mathrm{S}\end{array}$ & $\begin{array}{l}\text { Usus } \\
\text { Specifieke reden }\end{array}$ \\
\hline 2.1 .203 & $\mathrm{~S}$ & Specifieke reden \\
\hline 2.1 .211 & Comp & Consuetudines Compilatae \\
\hline
\end{tabular}




\begin{tabular}{|l|l|l|}
\hline & OAR & Guldenboeck \\
& RSi & Turbe \\
\hline 2.1 .212 & $\mathrm{~S}$ & Specifieke reden \\
& 3 & Magistraat \\
\hline 2.1 .220 & $\mathrm{~S}$ & Specifieke reden \\
\hline 2.1 .224 & Usus & Usus \\
\hline 2.1 .226 & Usus & Usus \\
\hline $2.1 .227 / 228$ & Usus & Usus \\
\hline
\end{tabular}

\begin{tabular}{|l|l|l|}
\hline \multicolumn{3}{|l|}{$\begin{array}{l}\text { titel } 2 \\
\text { van de rechten tusschen }\end{array}$} \\
\hline$(2.2 .1)$ & Comp ouders & Conde kinderen $\mathbf{( 7 . 5 / 2 9 )}$ \\
\hline 2.2 .2 & Usus & Usus \\
\hline $2.2 .13 / 14$ & Usus & Usus \\
\hline 2.2 .15 & Comp & Consuetudines Compilatae \\
\hline 2.2 .18 & Usus & Usus \\
\hline 2.2 .24 & $\mathrm{RL}$ & Bartolo da Sassoferrato bij Codex \\
& $\mathrm{RL}$ & Doctores bij Codex \\
& Ciciv & Corpus Iuris Civilis (Codex) \\
& $\mathrm{RL}$ & Nicolaes Everaerts (Consilia) \\
& $\mathrm{RL}$ & Barthélémy de Chasseneuz (Consilia) \\
\hline 2.2 .25 & Usus & Usus \\
\hline
\end{tabular}

\begin{tabular}{|c|c|c|}
\hline \multicolumn{3}{|c|}{$\begin{array}{l}\text { titel } 3 \\
\text { van ongehoude vrouwen }(6 / 17)\end{array}$} \\
\hline 2.3 .2 & $\mathrm{~S}$ & Specifieke reden \\
\hline 2.3 .4 & Comp & Consuetudines Compilatae \\
\hline 2.3 .5 & Comp & Consuetudines Compilatae \\
\hline 2.3 .7 & $\begin{array}{l}\text { Ciciv } \\
\text { RL }\end{array}$ & 'Ex iure commmuni' \\
\hline 2.3 .8 & $\begin{array}{l}\text { Ciciv } \\
\text { RL } \\
\text { Comp }\end{array}$ & $\begin{array}{l}\text { 'Ex iure commmun' } \\
\text { Consuetudines Compilatae }\end{array}$ \\
\hline 2.3 .9 & $\begin{array}{l}\text { Ciciv } \\
\text { RL }\end{array}$ & 'Ex iure commmuni' \\
\hline
\end{tabular}




PRIMAIRE RECHTSBRONNEN CONSUETUDINES COMPILATAE

\begin{tabular}{|l|l|l|}
\hline & eGR & Europa \\
\hline $2.4 .12 / 13$ & Usus & Usus \\
\hline 2.4 .14 & Ciciv & Corpus Iuris Civilis (Novellae Constitutiones) \\
& RL & Jean Papon (Recueil d'arrests notables) \\
& RL & Jean Papon (Secrets du troisième et dernière notaire) \\
& RL & $\begin{array}{l}\text { Jean Bacquet (Les cuvres de Jean Bacquet des droicts du domaine de la } \\
\text { couronne de France) }\end{array}$ \\
\hline $2.4 .15 / 16$ & Ciciv & Corpus Iuris Civilis (Novellae Constitutiones) \\
& RL & Charles Dumoulin (Commentariorum in Consuetudines Parisienses) \\
\hline 2.4 .17 & O & Onduidelijk \\
\hline 2.4 .21 & RA & Ratio \\
\hline
\end{tabular}

\begin{tabular}{|c|c|c|}
\hline \multicolumn{3}{|c|}{$\begin{array}{l}\text { titel } 5 \\
\text { van minderjaerige ende andere vermomboirde persoonen, ende van benne momboirs }(92 / 207)\end{array}$} \\
\hline $2.5 .4 / 5$ & iWGs & Ordonnantie Weeskamer: 28 maart 1496 \\
\hline 2.5 .7 & $\begin{array}{l}\mathrm{eGR} \\
\mathrm{RSi}\end{array}$ & $\begin{array}{l}\text { Coutumes de Bretagne } \\
\text { Rechtspraak (Raad van Brabant) }\end{array}$ \\
\hline 2.5 .10 & RSe & Rechtspraak (Napels) \\
\hline 2.5 .14 & $\begin{array}{l}\text { iWGs } \\
\text { Ciciv }\end{array}$ & $\begin{array}{l}\text { Ordonnantie Weeskamer: } 28 \text { maart } 1495 \\
\text { Corpus Iuris Civilis (Codex) }\end{array}$ \\
\hline 2.5 .17 & $\begin{array}{l}\text { Ciciv } \\
\text { RL }\end{array}$ & $\begin{array}{l}\text { Corpus Iuris Civilis (Codex) } \\
\text { Juan Garzia de Saavreda (De expensis et meliorationibus liber unus) }\end{array}$ \\
\hline 2.5 .18 & Ciciv & Corpus Iuris Civilis (Digestae) \\
\hline 2.5 .30 & $\begin{array}{l}\text { Ciciv } \\
\text { iWGv }\end{array}$ & $\begin{array}{l}\text { Corpus Iuris Civilis (Codex) } \\
\text { Criminele Ordonnantiën Filips II: } 1570\end{array}$ \\
\hline $2.5 .21 / 22$ & Ciciv & Corpus Iuris Civilis (Digestae) \\
\hline $2.5 .34 / 35$ & $\begin{array}{l}\text { S } \\
\text { eGR } \\
\text { Ciciv }\end{array}$ & $\begin{array}{l}\text { Specifieke reden } \\
\text { Conférence des coutumes (Pierre Guenoys) } \\
\text { Corpus Iuris Civilis (Novellae Constitutiones) }\end{array}$ \\
\hline $\begin{array}{l}2.5 .37 / 38 / 39 / 40 / 41 \\
/ 42\end{array}$ & $\begin{array}{l}\text { Usus } \\
\text { Ciciv }\end{array}$ & $\begin{array}{l}\text { Usus } \\
\text { 'Exiure scripto' }\end{array}$ \\
\hline 2.5 .43 & OAR & Consuetudines Antiquissimae \\
\hline 2.5 .60 & 3 & Weeskamer \\
\hline 2.5 .61 & Comp & Consuetudines Compilatae \\
\hline 2.5 .63 & $\begin{array}{l}\text { Ciciv } \\
\text { RL }\end{array}$ & $\begin{array}{l}\text { Corpus Iuris Civilis (Codex) } \\
\text { Baldus de Ubaldis (Consilia) }\end{array}$ \\
\hline 2.5 .64 & Usus & Usus \\
\hline 2.5 .65 & $\mathrm{~S}$ & Specifieke reden \\
\hline $2.5 .66 / 67$ & $\begin{array}{l}\text { Ciciv } \\
\text { eGR }\end{array}$ & $\begin{array}{l}\text { Corpus Iuris Civilis (Digestae) } \\
\text { Costuymen van Zeeland, Coutumes de Bretagne }\end{array}$ \\
\hline $2.5 .69 / 70$ & Ciciv & 'Ex iure scripto' \\
\hline 2.5 .71 & $\begin{array}{l}\text { Ciciv } \\
3\end{array}$ & $\begin{array}{l}\text { Corpus Iuris Civilis (Codex, Digestae) } \\
\text { Magistraat }\end{array}$ \\
\hline 2.5 .72 & $\begin{array}{l}\text { Ciciv } \\
\text { RL }\end{array}$ & $\begin{array}{l}\text { Corpus Iuris Civilis (Digestae) } \\
\text { Baldus de Ubaldis bij Digestae }\end{array}$ \\
\hline 2.5 .73 & Ciciv & Corpus Iuris Civilis (Digestae) \\
\hline 2.5 .78 & $\mathrm{eWG}$ & Ordonnantie Brussel Weeskinderen \\
\hline $2.5 .80 / 81$ & $\begin{array}{l}\text { Ciciv } \\
\text { RL }\end{array}$ & $\begin{array}{l}\text { CIC (Digestae, Codex }) \\
\text { Doctores bij Digestae }\end{array}$ \\
\hline 2.5 .82 & Usus & Usus \\
\hline 2.5 .83 & $\begin{array}{l}\text { Usus } \\
\text { eWG }\end{array}$ & $\begin{array}{l}\text { Usus } \\
\text { Ordonnantie Brussel Weeskinderen }\end{array}$ \\
\hline 2.5 .84 & Usus & Usus \\
\hline
\end{tabular}




\begin{tabular}{|c|c|c|}
\hline & $\begin{array}{l}\text { eWG } \\
\text { Ciciv } \\
\text { RL }\end{array}$ & $\begin{array}{l}\text { Ordonnantie Brussel Weeskinderen } \\
\text { Corpus Iuris Civilis (Codex) } \\
\text { Doctores bij Codex }\end{array}$ \\
\hline 2.5 .85 & $\begin{array}{l}\text { OAR } \\
\mathrm{S}\end{array}$ & $\begin{array}{l}\text { Keurboeck } \\
\text { Specifieke reden }\end{array}$ \\
\hline $2.5 .93 / 94$ & RL & Jean Papon (Trias judiciel du second notaire) \\
\hline $2.5 .96 / 97 / 98$ & $\mathrm{~S}$ & Specifieke reden \\
\hline 2.5 .106 & 3 & Weeskamer \\
\hline 2.5 .107 & Usus & Usus \\
\hline 2.5 .108 & $\begin{array}{l}\text { Usus } \\
\mathrm{RSi} \\
\end{array}$ & $\begin{array}{l}\text { Usus } \\
\text { Rechtspraak (Antwerpen) }\end{array}$ \\
\hline $2.5 .112 / 113$ & $\begin{array}{l}3 \\
\mathrm{~S}\end{array}$ & $\begin{array}{l}\text { Graphyarii van de Weeskamer } \\
\text { Specifieke reden }\end{array}$ \\
\hline 2.5 .116 & Comp & Consuetudines Compilatae \\
\hline 2.5 .119 & $\mathrm{~S}$ & Specifieke reden \\
\hline 2.5 .123 & $\begin{array}{l}\text { Usus } \\
3\end{array}$ & $\begin{array}{l}\text { Usus } \\
\text { De consensu Cantoris }\end{array}$ \\
\hline $2.5 .126 / 127$ & eGR & Costuymen van Gent, Conférence des coutumes (Pierre Guenoys) \\
\hline 2.5 .134 & $\begin{array}{l}\text { Comp } \\
\text { Ciciv }\end{array}$ & $\begin{array}{l}\text { Consuetudines Compilatae } \\
\text { Corpus Iuris Civilis (Digestae) }\end{array}$ \\
\hline 2.5 .138 & $\begin{array}{l}\text { Ciciv } \\
\text { RL }\end{array}$ & $\begin{array}{l}\text { Corpus Iuris Civilis (Novellae Constitutiones) } \\
\text { Joost de Damhouder (Praxis rerum civilium) }\end{array}$ \\
\hline 2.5 .139 & $\begin{array}{l}\mathrm{S} \\
3 \\
\end{array}$ & $\begin{array}{l}\text { Specifieke reden } \\
\text { Magistraat }\end{array}$ \\
\hline $2.5 .140 / 141 / 142$ & $\begin{array}{l}\text { RSi } \\
\mathrm{S}\end{array}$ & $\begin{array}{l}\text { Turbe } \\
\text { Specifieke reden }\end{array}$ \\
\hline $2.5 .146 / 147 / 148$ & $\begin{array}{l}\text { Ciciv } \\
\text { RA }\end{array}$ & $\begin{array}{l}\text { Corpus Iuris Civilis (Digestae) } \\
\text { Ratio }\end{array}$ \\
\hline 2.5 .149 & $\mathrm{~S}$ & Specifieke reden \\
\hline $2.5 .150 / 151$ & $\mathrm{~S}$ & Specifieke reden \\
\hline $2.5 .152 / 153 / 154$ & $\begin{array}{l}\text { Comp } \\
\text { Ciciv }\end{array}$ & $\begin{array}{l}\text { Consuetudines Compilatae } \\
\text { Corpus Iuris Civilis (Digestae) }\end{array}$ \\
\hline 2.5 .155 & Ciciv & Corpus Iuris Civilis (Codex, Digestae) \\
\hline 2.5 .156 & $\begin{array}{l}\text { Ciciv } \\
3\end{array}$ & $\begin{array}{l}\text { Corpus Iuris Civilis (Digestae) } \\
\text { Magistraat }\end{array}$ \\
\hline 2.5 .159 & Ciciv & Corpus Iuris Civilis (Codex, Digestae) \\
\hline 2.5 .168 & $\begin{array}{l}\mathrm{eWG} \\
\text { Comp }\end{array}$ & $\begin{array}{l}\text { Ordonnantie Brugge Weeskinderen } \\
\text { Consuetudines Compilatae }\end{array}$ \\
\hline 2.5 .171 & $\begin{array}{l}\text { Ciciv } \\
\text { RA }\end{array}$ & 'In iure et ratione fundatus' \\
\hline 2.5 .172 & $\begin{array}{l}\text { Ciciv } \\
\mathrm{RL}\end{array}$ & 'Ex iure communi' \\
\hline 2.5.176 & $\begin{array}{l}\text { Comp } \\
\text { Ciciv }\end{array}$ & $\begin{array}{l}\text { Consuetudines Compilatae } \\
\text { Corpus Iuris Civilis (Digestae) }\end{array}$ \\
\hline 2.5 .177 & $\mathrm{~S}$ & Specifieke reden \\
\hline 2.5 .178 & Ciciv & Corpus Iuris Civilis (Digestae) \\
\hline 2.5 .179 & $\begin{array}{l}\text { OAR } \\
\text { Ciciv }\end{array}$ & $\begin{array}{l}\text { Consuetudines Antiquissimae } \\
\text { Corpus Iuris Civilis (Codex, Digestae) }\end{array}$ \\
\hline 2.5 .180 & Ciciv & Corpus Iuris Civilis (Codex, Digestae) \\
\hline 2.5 .181 & Ciciv & Corpus Iuris Civilis (Digestae) \\
\hline 2.5 .182 & RL & Jean Papon (Recueil d'arrests notables) \\
\hline 2.5 .183 & $\begin{array}{l}\text { Ciciv } \\
\text { Usus }\end{array}$ & $\begin{array}{l}\text { Corpus Iuris Civilis (Digestae) } \\
\text { Usus }\end{array}$ \\
\hline
\end{tabular}


PRIMAIRE RECHTSBRONNEN CONSUETUDINES COMPILATAE

\begin{tabular}{|l|l|l|}
\hline 2.5 .184 & Ciciv & Corpus Iuris Civilis (Codex, Digestae) \\
\hline $2.5 .185 / 186$ & Ciciv & Corpus Iuris Civilis (Digestae) \\
\hline 2.5 .192 & Usus & Usus \\
\hline $2.5 .196 / 197$ & Usus & Usus \\
\hline 2.5 .198 & Usus & Usus \\
& Ciciv & Corpus Iuris Civilis (Digestae) \\
& RL & Doctores bij Digestae \\
\hline $2.5 .199 / 200$ & S & Specifieke reden \\
& Ciciv & Corpus Iuris Civilis (Digestae, Codex) \\
& RL & Doctores bij Codex en Digestae \\
\hline 2.5 .204 & Comp & Consuetudines Compilatae \\
\hline
\end{tabular}

Deel III

$V$ an rechten de goeden aengaende, ende bij wat manieren die vercregen wordden. (16 titels, 779 artikels, waarvan 266 nieuw)

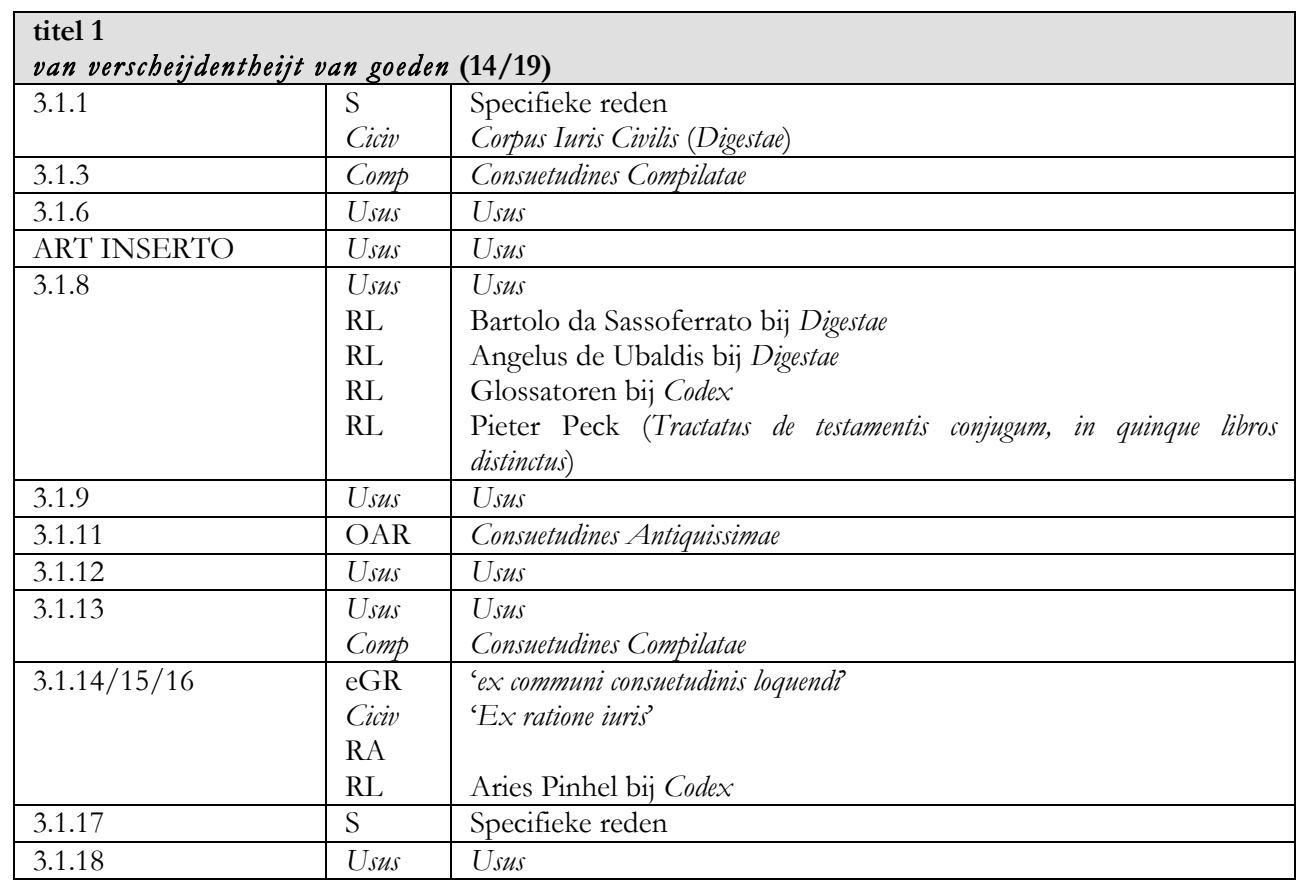

\begin{tabular}{|l|l|l|}
\hline \multicolumn{3}{|l|}{ titel 2} \\
van opdracht ende overgevingen & van goeden (16/43) \\
\hline 3.2 .12 & Comp & Consuetudines Compilatae \\
\hline 3.2 .17 & Usus & Usus \\
& Ciciv & Corpus Iuris Civilis (Digestae) \\
& RL & Bartolus bij Digestae \\
& RL & Baldus bij Codex \\
& RL & Charles Dumoulin (Intellectus novus et analyticus leg. Si partem) \\
\hline 3.2 .18 & Usus & Usus \\
\hline 3.2 .23 & RSi & Turbe \\
\hline
\end{tabular}




\begin{tabular}{|l|l|l|}
\hline & Comp & Consuetudines Compilatae \\
\hline 3.2 .24 & Comp & Consuetudines Compilatae \\
\hline 3.2 .29 & OAR & Consuetudines Impressae (a contrario sensu) \\
\hline 3.2 .31 & Comp & Consuetudines Compilatae \\
\hline 3.2 .32 & RA & Ratio van ander artikel uit Consuetudines Compilatae \\
\hline 3.2 .32 BIS & Comp & \\
\hline $3.2 .34 / 35$ & S & Specifieke reden \\
\hline $3.2 .37 / 38 / 39 / 40 / 41$ & S & Consuetudines Compilatae \\
\hline
\end{tabular}

\begin{tabular}{|c|c|c|}
\hline \multicolumn{3}{|c|}{$\begin{array}{l}\text { titel } 3 \\
\text { van vervolgh van sijn eijgen goet }(12 / 30)\end{array}$} \\
\hline 3.3 .2 & $\begin{array}{l}\text { Ciciv } \\
\text { RA } \\
\text { OAR }\end{array}$ & $\begin{array}{l}\text { 'Ex iure scripto' } \\
\text { Ratio van een ander artikel uit Consuetudines Impressae } \\
\text { Consuetudines Impressae }\end{array}$ \\
\hline $3.3 .5 / 6 / 7$ & OAR & Consuetudines Antiquissimae \\
\hline 3.3 .8 & Comp & Consuetudines Compilatae \\
\hline 3.3 .11 & $\mathrm{iWGv}$ & Blijde Inkomst Karel V, Blijde Inkomst Filips II \\
\hline 3.3 .14 & OAR & Guldenboeck (a contrario sensu) \\
\hline 3.3 .15 & OAR & Consuetudines Antiquissimae \\
\hline 3.3 .19 & $\begin{array}{l}\text { OAR } \\
\text { OAR } \\
\text { S }\end{array}$ & $\begin{array}{l}\text { Consuetudines Antiquissimae } \\
\text { Keurboeck } \\
\text { Specifieke reden }\end{array}$ \\
\hline 3.3 .22 & $\begin{array}{l}\text { OAR } \\
\text { OAR }\end{array}$ & $\begin{array}{l}\text { Keurboeck } \\
\text { Consuetudines Antiquissimae }\end{array}$ \\
\hline 3.3 .23 & RA & Aequitas \\
\hline 3.3 .27 & Usus & Usus \\
\hline
\end{tabular}

\begin{tabular}{|l|l|l|}
\hline $\begin{array}{l}\text { titel } 4 \\
\text { van vernaerderinge } \mathbf{( 1 9 . 5 / 1 0 6 )}\end{array}$ \\
\hline 3.4 .9 & Comp & Consuetudines Compilatae \\
\hline$(3.4 .10)$ & $\mathrm{S}$ & Specifieke reden \\
& RA & Ratio \\
\hline 3.4 .27 & $\mathrm{~S}$ & Specifieke reden \\
\hline $3.4 .29 / 30$ & $\mathrm{RA}$ & Ratio \\
\hline $3.4 .31 / 32$ & $\mathrm{~S}$ & Specifieke reden \\
& 3 & Magistraat \\
\hline 3.4 .34 & Comp & Consuetudines Compilatae \\
\hline 3.4 .43 & $\mathrm{iWG}$ & Statuut: 18 augustus 1592 \\
\hline $3.4 .46 / 47$ & Usus & Usus \\
\hline $3.4 .54 / 55 / 56 / 57$ & $\mathrm{~S}$ & Specifieke reden \\
\hline $3.4 .67 / 68$ & Ciciv & 'Ex ratione iuris' \\
& $\mathrm{RA}$ & \\
\hline 3.4 .69 & $\mathrm{RL}$ & Jean Favre bij Institutiones \\
\hline 3.4 .71 & Comp & Consuetudines Compilatae \\
\hline 3.4 .93 & OAR & $\begin{array}{l}\text { Consuetudines Antiquae } \\
\text { Consuetudines Antiquissimae }\end{array}$ \\
\hline & & Specifieke reden \\
\hline
\end{tabular}




PRIMAIRE RECHTSBRONNEN CONSUETUDINES COMPILATAE

\begin{tabular}{|l|l|l|}
\hline 3.5 .4 & Comp & Consuetudines Compilatae \\
\hline 3.5 .13 & 3 & Erfscheiders \\
\hline 3.5 .19 & 3 & Erfscheiders \\
& RA & Aequitas \\
\hline 3.5 .24 & 3 & Erfscheiders \\
\hline 3.5 .25 & $\begin{array}{l}\text { Usus } \\
\text { Ciciv }\end{array}$ & $\begin{array}{l}\text { Usus } \\
\text { 'Ex ratione iuris' }\end{array}$ \\
& RA & \\
\hline 3.5 .30 & S & Specifieke reden \\
\hline 3.5 .68 & 3 & Erfscheiders \\
\hline 3.5 .72 & RA & Ratio van een ander artikel uit Consuetudines Impressae \\
& OAR & \\
\hline 3.5 .74$)$ & Usus & Usus \\
\hline 3.5 .76 & Usus & Usus \\
& 3 & Erfscheiders \\
\hline 3.5 .89 & Ciciv & Corpus Iuris Civilis (Digestae) \\
\hline 3.5 .91 & RA & Ratio van ander artikel uit Consuetudines Compilatae \\
& Comp & \\
\hline $3.5 .98 / 99$ & Usus & Usus \\
& 3 & Erfscheiders \\
\hline 3.5 .100 & OAR & Consuetudines Antiquissimae \\
\hline 3.5 .103 & OAR & Consuetudines Antiquissimae \\
& Usus & Usus \\
\hline
\end{tabular}

\begin{tabular}{|l|l|l|}
\hline \multicolumn{2}{|l|}{$\begin{array}{l}\text { titel } \mathbf{6} \\
\text { van erffscheijdinge, oft }\end{array}$} \\
\hline $3.6 .8 / 9$ & 3 & Erfscheiders \\
\hline 3.6 .11 & $\mathrm{~S}$ & Specifieke reden \\
\hline $3.6 .14 / 15$ & iWGs & Ordonnantie Stijl en manier van procederen: 1582 \\
\hline 3.6 .16 & iWGs & Ordonnantie Stijl en manier van procederen: 1582 \\
& 3 & Erfscheiders \\
& Usus & Usus \\
\hline 3.6 .17 & Usus & Usus \\
\hline
\end{tabular}

\begin{tabular}{|l|l|l|}
\hline \multicolumn{2}{|l|}{$\begin{array}{l}\text { titel } 7 \\
\text { van tocht ende tochtenaers } \mathbf{( 2 / 2 8 )}\end{array}$} \\
\hline 3.7 .11 & OAR & Consuetudines Antiquissimae \\
& 3 & Magistraat \\
\hline 3.7 .12 & OAR & Consuetudines Antiquissimae \\
& Ciciv & Corpus Iuris Civilis (Digestae) \\
\hline
\end{tabular}

\begin{tabular}{|c|c|c|}
\hline \multicolumn{3}{|c|}{$\begin{array}{l}\text { titel } 8 \\
\text { van chijnsen ende renten }(23 / 73)\end{array}$} \\
\hline $3.8 .12 / 13$ & $\begin{array}{l}\text { Ciciv } \\
\text { RA }\end{array}$ & 'Ex ratione iuris' \\
\hline 3.8 .15 & eGR & Costuymen van Gent \\
\hline $3.8 .24 / 25 / 26 / 27 / 28$ & $\begin{array}{l}\mathrm{S} \\
\mathrm{iWGV}\end{array}$ & $\begin{array}{l}\text { Specifieke reden } \\
\text { Plakkaat Filips II: } 5 \text { maart } 1571\end{array}$ \\
\hline 3.8 .31 & $\begin{array}{l}\text { Usus } \\
\text { iWGv } \\
\text { iWGs }\end{array}$ & $\begin{array}{l}\text { Usus } \\
\text { Plakkaat Filips II: } 5 \text { maart } 1571 \\
\text { Statuut Levering: } 19 \text { juni } 1535\end{array}$ \\
\hline 3.8 .49 & $\begin{array}{l}\mathrm{S} \\
\mathrm{iWG}\end{array}$ & $\begin{array}{l}\text { Specifieke reden } \\
\text { Plakkaat Aartshertogen: } 25 \text { juni } 1601\end{array}$ \\
\hline
\end{tabular}




\begin{tabular}{|l|l|l|}
\hline $3.8 .51 / 52$ & iWGv & Plakkaat Aartshertogen: 25 juni 1601 \\
\hline 3.8 .53 & iWGv & Plakkaat Filips II: 5 maart 1571 \\
& iWGv & Plakkaat Aartshertogen: 25 juni 1601 \\
\hline 3.8 .54 & $\begin{array}{l}\text { iWGv } \\
\text { iWGv }\end{array}$ & $\begin{array}{l}\text { Plakkaat Filips II: } 5 \text { maart 1571 } \\
\text { Plakkaat Aartshertogen: 25 juni 1601 }\end{array}$ \\
\hline 3.8 .55 & $\begin{array}{l}\text { Usus } \\
\text { eGR }\end{array}$ & $\begin{array}{l}\text { Usus } \\
\text { Costuymen van 's Hertogenbosch }\end{array}$ \\
\hline $3.8 .57 / 58$ & Usus & Usus \\
& Consuetudines Compilatae \\
\hline 3.8 .59 & Usus & $\begin{array}{l}\text { Usus } \\
\text { Rechtspraak (Antwerpen) }\end{array}$ \\
\hline $3.8 .61 / 62$ & $\mathrm{RSi}$ & Specifieke reden \\
& Corpus Iuris Civilis (Codex) \\
\hline 3.8 .65 & Comp & Consuetudines Compilatae \\
\hline 3.8 .68 & $\mathrm{~S}$ & Specifieke reden \\
\hline 3.8 .73 & $\mathrm{iWGv}$ & Ex recenti ordinatione' \\
\hline
\end{tabular}

\begin{tabular}{|l|l|l|}
\hline \multicolumn{3}{|l|}{$\begin{array}{l}\text { titel } 9 \\
\text { van leveringe ende ander rechtelijck vervolch tot betaelinge van chijnsen ende renten }(\mathbf{1 0} / 57)\end{array}$} \\
\hline 3.9 .2 & $\begin{array}{l}\text { Usus } \\
\text { Comp }\end{array}$ & $\begin{array}{l}\text { Usus } \\
\text { Consuetudines Compilatae }\end{array}$ \\
\hline Art inserto & S & Specifieke reden \\
\hline $3.9 .14 / 15$ & S & Specifieke reden \\
\hline 3.9 .20 & S & Specifieke reden \\
\hline $3.9 .31 / 32 / 33$ & S & Specifieke reden \\
\hline 3.9 .43 & Usus & Usus \\
\hline 3.9 .52 & Usus & Usus \\
\hline $3.9 .55 / 56 / 57: 0$
\end{tabular}

3.9.55/56/57: ontbreken in Memorieboeken

\begin{tabular}{|l|l|l|}
\hline \multicolumn{1}{|l|}{$\begin{array}{l}\text { titel } 10 \\
\text { van affdaeginge ende suijveringe }\end{array}$} & San onruerende goeden $\mathbf{( 5 / 3 6 )}$ \\
\hline 3.10 .5 & $\mathrm{~S}$ & Specifieke reden \\
\hline $3.10 .12 \mathrm{bis}$ & Comp & Consuetudines Compilatae \\
\hline 3.10 .15 & OAR & Consuetudines Antiquae \\
& OAR & Consuetudines Antiquissimae \\
& iWGs & Statuut: 15181394 \\
\hline 3.10 .24 & S & Specifieke reden \\
\hline 3.10 .29 & $\mathrm{~S}$ & Specifieke reden \\
\hline
\end{tabular}

\begin{tabular}{|l|l|l|}
\hline \multicolumn{2}{|l|}{$\begin{array}{l}\text { titel 11 } \\
\text { van verloop van tijde oft prescriptie } \mathbf{( 1 1 / 2 0 )}\end{array}$} \\
\hline $3.11 .4 / 5 / 6$ & Ciciv & Corpus Iuris Civilis (Codex) \\
\hline 3.11 .7 & Ciciv & 'Exiure scripto' \\
& eGR & Conférence des coutumes (Pierre Guenoys), Coutumes de Bretagne \\
& 3 & Magistraat \\
\hline 3.11 .11 & $\mathrm{~S}$ & Specifieke reden \\
\hline 3.11 .13 & Comp & Consuetudines Compilatae \\
\hline 3.11 .15 & Usus & Usus \\
& Ciciv & Corpus Iuris Civilis (Digestae) \\
& RL & Matthias Wesenbeeck (Paratitla in Pandectas iuris civilis) \\
\hline
\end{tabular}

1394 'by de stad gemaeckt en te hove geconfirmeert opt stuck vande fugitiven' 


\begin{tabular}{|l|l|l|}
\hline 3.11 .17 & Ciciv & 'Ex iure scripto' \\
& RL & Pierre Coustau bij Digestae \\
& RL & Charles Dumoulin (Tractatus de usuris) \\
& RL & François Grimaudet (Paraphrase du droict de retraict lignager) \\
& RL & Louis le Caron (Coustumes de la ville, prévosté et vicomté de Paris) \\
& RL & Jean Papon (Recueil d'arrests notables) \\
\hline 3.11 .18 & Usus & Usus \\
& Ciciv & Corpus Iuris Civilis (Codex) \\
& RL & Pierre Rebuffi (Tractatus exceptionum atque actionum) \\
\hline 3.11 .19 & Usus & Usus \\
& Ciciv & 'Ex ratione iuris' (Codex, Digestae) \\
& RA & \\
& RL & Jean Favre bij Codex \\
& RL & Louis le Caron (Coustumes de la ville, prévosté et vicomté de Paris) \\
& eGR & Coutumes de Paris \\
\hline 3.11 .20 & Usus & Usus \\
& RL & Bertrand d'Argentré (Coutumes de Bretagne) \\
& RL & Pierre Guenoys (Conférence des coutumes) \\
\hline
\end{tabular}

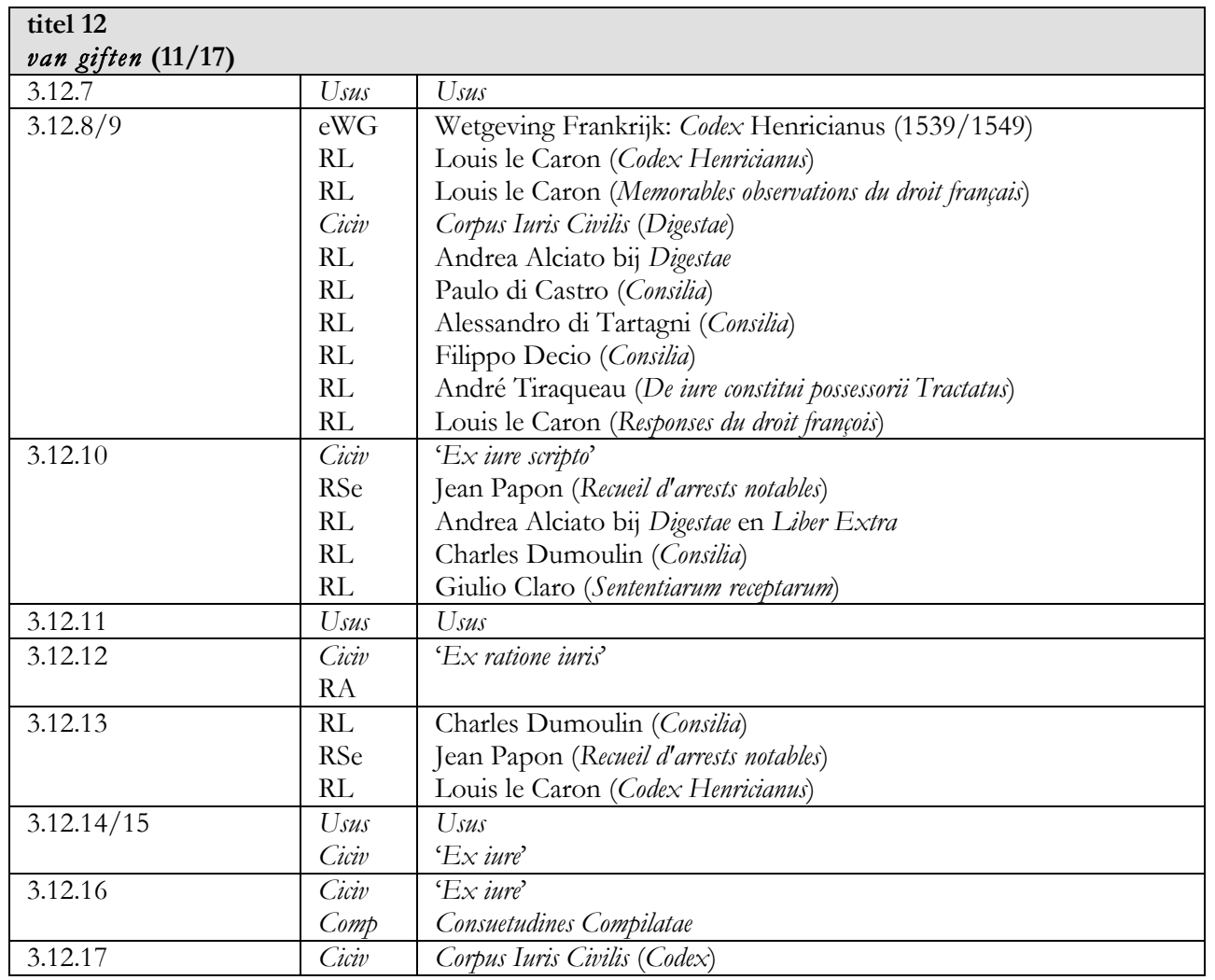

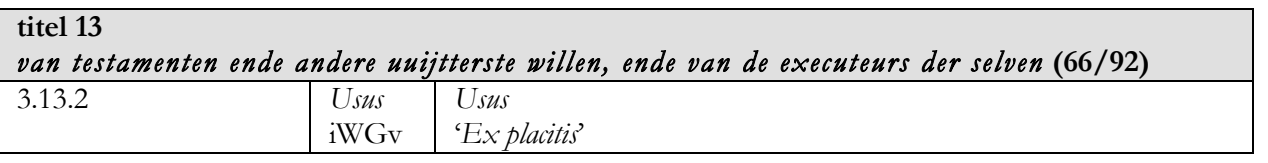


BIJLAGEN

\begin{tabular}{|c|c|c|}
\hline 3.13 .3 & $\begin{array}{l}\text { Usus } \\
\text { Comp }\end{array}$ & $\begin{array}{l}\text { Usus } \\
\text { Consuetudines Compilatae }\end{array}$ \\
\hline 3.13 .5 & $\mathrm{~S}$ & Specifieke reden \\
\hline $3.13 .6 / 7 / 8$ & $\begin{array}{l}\text { Ciciv } \\
\text { Comp }\end{array}$ & $\begin{array}{l}\text { 'Ex iure scripto' } \\
\text { Consuetudines Compilatae }\end{array}$ \\
\hline 3.13 .9 & Usus & Usus \\
\hline $3.13 .11 / 12$ & $\begin{array}{l}\text { Usus } \\
\mathrm{eGR}\end{array}$ & $\begin{array}{l}\text { Usus } \\
\text { Coutumes de Berry }\end{array}$ \\
\hline 3.13 .13 & $\begin{array}{l}\text { Usus } \\
\text { OAR }\end{array}$ & $\begin{array}{l}\text { Usus } \\
\text { Guldenboeck }\end{array}$ \\
\hline $3.13 .14 / 15$ & $\begin{array}{l}\text { Ciciv } \\
\text { RL } \\
\text { RL } \\
\text { RL } \\
\text { RL } \\
3\end{array}$ & $\begin{array}{l}\text { Corpus Iuris Civilis (Novellae Constitutiones) } \\
\text { Baldus de Ubaldis bij Authenticum } \\
\text { Denis Godefroy bij Authenticum } \\
\text { Joachim Mynsinger von Frundeck (Singularium observationum } \\
\text { iudicii imperialis camerae) } \\
\text { Giulio Claro (Sententiarum receptarum) } \\
\text { Magistraat }\end{array}$ \\
\hline $3.13 .17 / 18$ & $\mathrm{~S}$ & Specifieke reden \\
\hline 3.13 .23 & $\mathrm{~S}$ & Specifieke reden \\
\hline 3.13 .24 & $\begin{array}{l}\text { Ciciv } \\
\text { RL } \\
\text { Comp }\end{array}$ & $\begin{array}{l}\text { 'Ex iure scripto' (Institutiones, Codex) } \\
\text { Louis le Caron (Memorables observations du droit français) } \\
\text { Consuetudines Compilatae }\end{array}$ \\
\hline 3.13 .26 & Ciciv & Corpus Iuris Civilis (Authenticum, Codex) \\
\hline 3.13 .27 & $\begin{array}{l}\text { RSe } \\
\text { RSe } \\
\text { RSe } \\
\text { RSe } \\
\text { RSe } \\
\text { RL }\end{array}$ & $\begin{array}{l}\text { Joachim Mynsinger von Frundeck (Singularium observationum } \\
\text { iudicii imperialis camerae) } \\
\text { Guy de la Pape (Decisiones grationopolitanae) } \\
\text { Nicolas de Bohier (Decisiones supremi senatus Burdegalensis) } \\
\text { Jean Papon (Recueil d'arrests notables) } \\
\text { Louis le Caron (Responses du droit françois) } \\
\text { Louis le Caron (Memorables observations du droit français) }\end{array}$ \\
\hline $3.13 .29 / 30$ & Comp & Consuetudines Compilatae \\
\hline $3.13 .31 / 32$ & $\begin{array}{l}\text { Ciciv } \\
\text { RL }\end{array}$ & $\begin{array}{l}\text { Corpus Iuris Civilis (Codex) } \\
\text { Diego Covarubias y Leyva bij Liber Extra }\end{array}$ \\
\hline $3.13 .33 / 34$ & $\begin{array}{l}\text { Ciciv } \\
\text { RL } \\
\text { RL } \\
\text { RL } \\
\text { RL } \\
\text { RL } \\
\text { RL }\end{array}$ & $\begin{array}{l}\text { Corpus Iuris Civilis (Institutiones) } \\
\text { Bartolus da Sassoferrato bij Digestae } \\
\text { 'Picus' bij Digestae } \\
\text { Diego Covarubias y Leyva bij Liber Extra } \\
\text { Michael Grass (Receptarum Sententiarum) } \\
\text { Louis le Caron (Memorables observations du droit français) } \\
\text { Pierre Pithou (Coutumes de Troyes) }\end{array}$ \\
\hline 3.13 .35 & $\begin{array}{l}\text { Ciciv } \\
\text { RL }\end{array}$ & $\begin{array}{l}\text { 'Ex iure scripto' } \\
\text { Andrea Alciato bij Digestae }\end{array}$ \\
\hline 3.13 .36 & Usus & Usus \\
\hline 3.13 .37 & $\begin{array}{l}\text { Usus } \\
\text { RA }\end{array}$ & $\begin{array}{l}\text { Usus } \\
\text { Ratio }\end{array}$ \\
\hline $3.13 .38 / 39 / 40$ & $\mathrm{~S}$ & Specifieke reden \\
\hline 3.13 .41 & $\begin{array}{l}\text { Usus } \\
\text { RSe } \\
\text { RL } \\
\end{array}$ & $\begin{array}{l}\text { Usus } \\
\text { Louis le Caron (Responses du droit françois) } \\
\text { Louis le Caron (Memorables observations du droit français) }\end{array}$ \\
\hline 3.13 .42 & $\begin{array}{l}\text { Ciciv } \\
\text { RL } \\
\text { RL }\end{array}$ & $\begin{array}{l}\text { Corpus Iuris Civilis (Authenticum, Codex) } \\
\text { Antonio Padilla y Meneses bij Authenticum } \\
\text { Louis le Caron (Memorables observations du droit français) }\end{array}$ \\
\hline 3.13 .43 & Ciciv & Corpus Iuris Civilis (Novellae Constitutiones) \\
\hline
\end{tabular}


PRIMAIRE RECHTSBRONNEN CONSUETUDINES COMPILATAE

\begin{tabular}{|c|c|c|}
\hline & RL & Antonio Padilla y Meneses bij Authenticum \\
\hline 3.13 .44 & $\begin{array}{l}\text { Ciciv } \\
\text { RL }\end{array}$ & $\begin{array}{l}\text { Corpus Iuris Civilis (Novellae Constitutiones, Digestae) } \\
\text { Louis le Caron (Memorables observations du droit français) }\end{array}$ \\
\hline $3.13 .45 / 46$ & Ciciv & Corpus Iuris Civilis (Digestae, Codex) \\
\hline $3.13 .47 / 48$ & $\begin{array}{l}\text { iWGv } \\
\text { eWG }\end{array}$ & $\begin{array}{l}\text { 'Ex placatis nostrorum principium' } \\
\text { Wetgeving Frankrijk: Codex Henricianus }\end{array}$ \\
\hline 3.13 .49 & $\begin{array}{l}\text { Cican } \\
\text { RL } \\
\text { RL } \\
\text { RL } \\
\text { RL } \\
3\end{array}$ & $\begin{array}{l}\text { Corpus Iuris Civilis (Liber Extra) } \\
\text { Diego Covarubias y Leyva bij Liber Extra } \\
\text { Manoel a Casto bij Liber Extra } \\
\text { Michael Grass (Receptarum Sententiarum) } \\
\text { Giulio Claro (Sententiarum receptarum) } \\
\text { Magistraat }\end{array}$ \\
\hline 3.13 .50 & S & Specifieke reden \\
\hline 3.13 .51 & $\begin{array}{l}\text { Ciciv } \\
\text { RL } \\
\text { RL }\end{array}$ & $\begin{array}{l}\text { Corpus Iuris Civilis (Novellae Constitutiones) } \\
\text { Michael Grass (Receptarum Sententiarum) } \\
\text { Diego Covarubias y Leyva bij Liber Extra }\end{array}$ \\
\hline 3.13 .52 & S & Specifieke reden \\
\hline 3.13 .53 & $\begin{array}{l}\mathrm{RL} \\
\text { Ciciv } \\
\text { Comp }\end{array}$ & $\begin{array}{l}\text { Doctores bij Digestae } \\
\text { Corpus Iuris Civilis (Digestae) } \\
\text { Consuetudines Compilatae }\end{array}$ \\
\hline $3.13 .54 / 55$ & $\begin{array}{l}\text { RL } \\
\text { RL } \\
\text { RL }\end{array}$ & $\begin{array}{l}\text { Charles Dumoulin (Annotationes op Consilia van Alessandro di } \\
\text { Tartagni) } \\
\text { Wigle ab Aytta bij Institutiones } \\
\text { Andreas Gaill (Practicarum observationum) }\end{array}$ \\
\hline 3.13 .61 & Comp & Consuetudines Compilatae \\
\hline $3.13 .63 / 64$ & $\begin{array}{l}\text { Ciciv } \\
3\end{array}$ & $\begin{array}{l}\text { Corpus Iuris Civilis (Novellae Constitutiones, Authenticum) } \\
\text { Magistraat }\end{array}$ \\
\hline 3.13 .65 & Usus & Usus \\
\hline 3.13 .68 & S & Specifieke reden \\
\hline $3.13 .69 / 70$ & $\begin{array}{l}\text { Comp } \\
\mathrm{RL}\end{array}$ & $\begin{array}{l}\text { Consuetudines Compilatae } \\
\text { Doctores bij Digestae }\end{array}$ \\
\hline $3.13 .71 / 72$ & $\begin{array}{l}\mathrm{RL} \\
3 \\
\end{array}$ & $\begin{array}{l}\text { Antoine Favre (Codex Fabrianus) } \\
\text { Magistraat }\end{array}$ \\
\hline 3.13 .73 & $\begin{array}{l}\text { OAR } \\
\text { OAR }\end{array}$ & $\begin{array}{l}\text { Consuetudines Antiquae } \\
\text { Consuetudines Antiquissimae }\end{array}$ \\
\hline 3.13 .78 & $\begin{array}{l}\text { Usus } \\
\mathrm{eGR}\end{array}$ & $\begin{array}{l}\text { Usus } \\
\text { Conférence des coutumes (Pierre Guenoys) }\end{array}$ \\
\hline 3.13 .80 & $\begin{array}{l}\text { Ciciv } \\
\text { RA } \\
\text { Usus }\end{array}$ & $\begin{array}{l}\text { 'Ex ratione iuris' } \\
\text { Usus }\end{array}$ \\
\hline 3.13 .81 & Comp & Consuetudines Compilatae (a contrario sensu) \\
\hline 3.13 .82 & eGR & Conférence des coutumes (Pierre Guenoys) \\
\hline 3.13 .83 & eGR & Conférence des coutumes (Pierre Guenoys) \\
\hline 3.13 .84 & $\begin{array}{l}\text { eGR } \\
\text { Comp }\end{array}$ & $\begin{array}{l}\text { Conférence des coutumes (Pierre Guenoys), Coutumes de Paris } \\
\text { Consuetudines Compilatae }\end{array}$ \\
\hline 3.13 .85 & eGR & Conférence des coutumes (Pierre Guenoys) \\
\hline 3.13 .86 & $\begin{array}{l}\text { eGR } \\
3 \\
\end{array}$ & $\begin{array}{l}\text { Conférence des coutumes (Pierre Guenoys) } \\
\text { Magistraat }\end{array}$ \\
\hline 3.13 .87 & eGR & Coutumes de Chalons \\
\hline $3.13 .88 / 89$ & Comp & Consuetudines Compilatae \\
\hline
\end{tabular}




\begin{tabular}{|c|c|c|}
\hline \multicolumn{3}{|c|}{$\begin{array}{l}\text { titel } 14 \\
\text { van wettige versterffenissen, scheijdinge ende deijlinge, en des daertoe beboort }(53 / 131)\end{array}$} \\
\hline 3.14 .5 & $\begin{array}{l}\text { OAR } \\
\text { OAR }\end{array}$ & $\begin{array}{l}\text { Consuetudines Antiquae } \\
\text { Keurboeck. }\end{array}$ \\
\hline 3.14 .6 & $\begin{array}{l}\mathrm{RSi} \\
\text { Comp }\end{array}$ & $\begin{array}{l}\text { Turbe } \\
\text { Consuetudines Compilatae }\end{array}$ \\
\hline 3.14 .8 & $\begin{array}{l}\text { Usus } \\
\text { RSi }\end{array}$ & $\begin{array}{l}\text { Usus } \\
\text { Turbe }\end{array}$ \\
\hline 3.14 .10 & $\begin{array}{l}\text { Comp } \\
\text { Ciciv }\end{array}$ & $\begin{array}{l}\text { Consuetudines Compilatae } \\
\text { Corpus Iuris Civilis (Codex) }\end{array}$ \\
\hline 3.14 .42 & $\begin{array}{l}\text { OAR } \\
\text { Comp } \\
\text { RL } \\
\text { RL } \\
\text { RL }\end{array}$ & $\begin{array}{l}\text { Consuetudines Antiquissimae } \\
\text { Consuetudines Compilatae } \\
\text { François Marc (Decisiones aureae in Delphinatus Senatu discussae) } \\
\text { Phanutio di Fanuzzi bij Codex } \\
\text { Sebastiano Monticello bij Codex }\end{array}$ \\
\hline 3.14 .43 & Ciciv & 'Ex iure scripto' \\
\hline 3.14 .44 & $\begin{array}{l}\text { Ciciv } \\
\text { Usus }\end{array}$ & $\begin{array}{l}\text { Corpus Iuris Civilis (Codex, Digestae) } \\
\text { Usus }\end{array}$ \\
\hline 3.14 .53 & $\mathrm{~S}$ & Specifieke reden \\
\hline $3.14 .59 / 60$ & $\begin{array}{l}\text { OAR } \\
\text { OAR }\end{array}$ & $\begin{array}{l}\text { Consuetudines Antiquissimae } \\
\text { Guldenboeck. }\end{array}$ \\
\hline 3.14 .61 & $\mathrm{O}$ & Onduidelijk \\
\hline 3.14 .62 & $\begin{array}{l}\text { OAR } \\
\text { OAR }\end{array}$ & $\begin{array}{l}\text { Consuetudines Antiquissimae } \\
\text { Guldenboeck. }\end{array}$ \\
\hline 3.14 .64 & $\begin{array}{l}\text { iWGv } \\
\mathrm{iWGv}\end{array}$ & $\begin{array}{l}\text { Plakkaat Karel V: } 8 \text { november } 1541 \\
\text { Plakkaat Karel V: } 14 \text { mei } 1544\end{array}$ \\
\hline 3.14 .65 & $\mathrm{~V}$ & Stijl vd Raad \\
\hline $3.14 .66 / 67$ & $\begin{array}{l}\text { iWGv } \\
\text { iWGv }\end{array}$ & $\begin{array}{l}\text { Plakkaat Karel V: } 8 \text { november } 1541 \\
\text { Plakkaat Karel V: } 14 \text { mei } 1544\end{array}$ \\
\hline $3.14 .68 / 69$ & eGR & Coutumes de Berry \\
\hline 3.14 .70 & $\begin{array}{l}\text { eGR } \\
\text { Comp }\end{array}$ & $\begin{array}{l}\text { Conférence des coutumes (Pierre Guenoys) } \\
\text { Consuetudines Compilatae }\end{array}$ \\
\hline $3.14 .71 / 72$ & $\begin{array}{l}\text { iWGv } \\
\text { iWGv } \\
\text { eGR }\end{array}$ & $\begin{array}{l}\text { Plakkaat Karel V: } 8 \text { november } 1541 \\
\text { Plakkaat Karel V: } 14 \text { mei } 1544 \\
\text { Conférence des coutumes (Pierre Guenoys) }\end{array}$ \\
\hline 3.14 .73 & $\begin{array}{l}\text { iWGv } \\
\text { iWGv } \\
\text { Usus } \\
\text { eGR } \\
\text { RSe }\end{array}$ & $\begin{array}{l}\text { Plakkaat Karel V: } 8 \text { november } 1541 \\
\text { Plakkaat Karel V: } 14 \text { mei } 1544 \\
\text { Usus } \\
\text { Coutumes d'Artois } \\
\text { Jean Papon (Recueil d'arrests notables) }\end{array}$ \\
\hline 3.14 .74 & $\begin{array}{l}\text { Usus } \\
\text { Comp }\end{array}$ & $\begin{array}{l}\text { Usus } \\
\text { Consuetudines Compilatae }\end{array}$ \\
\hline 3.14 .75 & $\operatorname{Comp}$ & Consuetudines Compilatae \\
\hline 3.14 .77 & $\begin{array}{l}\text { iWGv } \\
\text { iWG } \\
\text { Ciciv }\end{array}$ & $\begin{array}{l}\text { Plakkaat Karel V: } 8 \text { november } 1541 \\
\text { Plakkaat Karel V: } 14 \text { mei } 1544 \\
\text { Corpus Iuris Civilis (Codex) }\end{array}$ \\
\hline 3.14 .78 & $\begin{array}{l}\text { RL } \\
\text { RSe } \\
\text { RL } \\
\text { RSe }\end{array}$ & $\begin{array}{l}\text { Denis Godefroy bij Codex en Digestae } \\
\text { Louis le Caron (Coustumes de la ville, prévosté et vicomté de Paris) } \\
\text { Pierre Guenoys (Conférence des coutumes) } \\
\text { Louis le Caron (Responses du droit françois) }\end{array}$ \\
\hline 3.14 .80 & $\begin{array}{l}\text { eGR } \\
\text { Comp }\end{array}$ & $\begin{array}{l}\text { Conférence des coutumes (Pierre Guenoys) } \\
\text { Consuetudines Compilatae }\end{array}$ \\
\hline 3.14 .81 & Usus & Usus \\
\hline
\end{tabular}


PRIMAIRE RECHTSBRONNEN CONSUETUDINES COMPILATAE

\begin{tabular}{|c|c|c|}
\hline 3.14 .82 & $\begin{array}{l}\text { eGR } \\
\text { Comp } \\
\text { RL }\end{array}$ & $\begin{array}{l}\text { Coutumes de Berry } \\
\text { Consuetudines Compilatae } \\
\text { Alessandro di Tartagni (Consilia) }\end{array}$ \\
\hline 3.14 .83 & $\begin{array}{l}\text { RSe } \\
\text { Comp }\end{array}$ & $\begin{array}{l}\text { Louis le Caron (Coustumes de la ville, prévosté et vicomté de Paris) } \\
\text { Consuetudines Compilatae }\end{array}$ \\
\hline 3.14 .85 & eGR & Conférence des coutumes (Pierre Guenoys) \\
\hline 3.14 .86 & eGR & Conférence des coutumes (Pierre Guenoys) \\
\hline 3.14 .87 & eGR & Conférence des coutumes (Pierre Guenoys) \\
\hline 3.14 .89 & $\mathrm{~S}$ & Specifieke reden \\
\hline $3.14 .90 / 91$ & eGR & Conférence des coutumes (Pierre Guenoys) \\
\hline $3.14 .92 / 93$ & Ciciv & Corpus Iuris Civilis (Codex) \\
\hline 3.14 .96 & Ciciv & Corpus Iuris Civilis (Codex) \\
\hline 3.14 .97 & Usus & Usus \\
\hline 3.14 .99 & Usus & Usus \\
\hline 3.14 .104 & Ciciv & Corpus Iuris Civilis (Novellae Constitutiones) \\
\hline 3.14 .116 & $\begin{array}{l}\text { OAR } \\
\text { Usus }\end{array}$ & $\begin{array}{l}\text { Guldenboeck } \\
\text { Usus }\end{array}$ \\
\hline $\begin{array}{l}3.14 .118 / 119 / 120 \\
/ 121\end{array}$ & Usus & Usus \\
\hline $3.14 .122 / 123$ & $\begin{array}{l}\text { RSe } \\
\text { RSe } \\
\text { RL }\end{array}$ & $\begin{array}{l}\text { René Choppin (De privilegiis rusticorum) } \\
\text { Louis le Caron (Responses du droit françois) } \\
\text { Nicolas du Val (De rebus dubiis et quaestionibus in iure controversis } \\
\text { tractatus sex) }\end{array}$ \\
\hline $3.14 .124 / 125$ & Comp & Consuetudines Compilatae \\
\hline 3.14 .126 & Usus & Usus \\
\hline
\end{tabular}

Deel IV

$V$ an contracten ende verbintenissen ende des daeraen cleeft. (16 titels, 1124 artikels, waarvan 823 nieuw)

\begin{tabular}{|l|l|l|}
\hline $\begin{array}{l}\text { titel } 1 \\
\text { van geoorloffde ende ongeoorloffde contracten }(\mathbf{1 1 / 1 6})\end{array}$ \\
\hline 4.1 .3 & $\mathrm{~S}$ & Specifieke reden \\
\hline 4.1 .4 & $\begin{array}{l}\text { Usus } \\
\text { eWG }\end{array}$ & $\begin{array}{l}\text { Usus } \\
\text { Wetgeving Frankrijk: Codex Henricianus }\end{array}$ \\
\hline 4.1 .5 & Usus & Usus \\
\hline 4.1 .6 & Ciciv & Corpus Iuris Civilis (Digestae) \\
\hline $4.1 .7 / 8$ & iWGv & Plakkaat Karel V: 8 november 1541 \\
\hline $4.1 .9 / 10$ & S & Specifieke reden \\
& iWGv & Plakkat Karel V: 8 november 1541 \\
& RL & Canonisten \\
& 3 & Theologen \\
\hline $4.1 .11 / 12 / 13$ & 3 & Magistraat \\
\hline
\end{tabular}

\begin{tabular}{|l|l|l|}
\hline \multicolumn{3}{|l|}{$\begin{array}{l}\text { titel } 2 \\
\text { van schepene brieven ende bantschriften }(\mathbf{5} / \mathbf{1 7})\end{array}$} \\
\hline 4.2 .2 & Comp & Consuetudines Compilatae \\
\hline 4.2 .3 & Usus & Usus \\
& Comp & Consuetudines Compilatae \\
\hline
\end{tabular}


BIJLAGEN

\begin{tabular}{|l|l|l|}
\hline 4.2 .15 & iWGv & Plakkaat Karel V: 7 maart 1537 (n.s.) ${ }^{1395}$ \\
\hline 4.2 .16 & Usus & Usus \\
\hline 4.2 .17 & Comp & Consuetudines Compilatae \\
\hline
\end{tabular}

\begin{tabular}{|c|c|c|}
\hline \multicolumn{3}{|c|}{$\begin{array}{l}\text { titel } 3 \\
\text { van wisselbrieven }(58 / 77)\end{array}$} \\
\hline 4.3 .1 & Usus & Usus \\
\hline $4.3 .3 / 4 / 5 / 6$ & $\begin{array}{l}S \\
3\end{array}$ & $\begin{array}{l}\text { Specifieke reden } \\
\text { Handelaars }\end{array}$ \\
\hline 4.3 .7 & $\mathrm{eWG}$ & Wetgeving Venetië: 14 december 1593 \\
\hline 4.3 .13 & Usus & Usus \\
\hline 4.3 .15 & $\begin{array}{l}3 \\
\text { Ciciv } \\
\text { RL }\end{array}$ & $\begin{array}{l}\text { Handelaars } \\
\text { Corpus Iuris Civilis (Codex, Digestae) } \\
\text { Bartolomeo di Saliceto bij Digestae }\end{array}$ \\
\hline 4.3 .16 & Usus & Usus \\
\hline $4.3 .17 / 18 / 19 / 20$ & Usus & Usus \\
\hline $4.3 .21 / 22$ & $\mathrm{eWG}$ & Wetgeving Genua: Statuten 1589 \\
\hline $4.3 .23 / 24 / 25$ & $\begin{array}{l}\text { Usus } \\
3\end{array}$ & $\begin{array}{l}\text { Usus } \\
\text { Handelaars }\end{array}$ \\
\hline 4.3 .26 & $\mathrm{~S}$ & Specifieke reden \\
\hline 4.3 .27 & $\begin{array}{l}\mathrm{S} \\
\mathrm{RA}\end{array}$ & $\begin{array}{l}\text { Specifieke reden } \\
\text { Ratio }\end{array}$ \\
\hline 4.3 .30 & $\begin{array}{l}\text { RA } \\
\text { Comp }\end{array}$ & Ratio van ander artikel uit Consuetudines Compilatae \\
\hline $4.3 .37 / 38$ & $\mathrm{RSi}$ & Turbe \\
\hline $4.3 .39 / 40$ & $\begin{array}{l}\text { RSi } \\
3\end{array}$ & $\begin{array}{l}\text { Turbe } \\
\text { Handelaars }\end{array}$ \\
\hline 4.3 .41 & $\begin{array}{l}\text { Usus } \\
3\end{array}$ & $\begin{array}{l}\text { Usus } \\
\text { Handelaars }\end{array}$ \\
\hline 4.3 .43 & Usus & Usus \\
\hline 4.3 .45 & Usus & Usus \\
\hline 4.3 .46 & $\begin{array}{l}\text { Ciciv } \\
\text { RA } \\
\text { eWG }\end{array}$ & $\begin{array}{l}\text { 'Ex ratione iuris' } \\
\text { Wetgeving Genua: Statuten } 1589\end{array}$ \\
\hline 4.3 .47 & $\begin{array}{l}\text { Ciciv } \\
\text { eWG }\end{array}$ & $\begin{array}{l}\text { 'Ex iure' } \\
\text { Wetgeving Genua: Statuten } 1589\end{array}$ \\
\hline 4.3 .48 & Comp & Consuetudines Compilatae \\
\hline 4.3 .49 & Usus & Usus \\
\hline 4.3 .50 & $\begin{array}{l}\text { Ciciv } \\
\text { Comp }\end{array}$ & $\begin{array}{l}\text { 'Ex iure' } \\
\text { Consuetudines Compilatae }\end{array}$ \\
\hline 4.3 .51 & Comp & Consuetudines Compilatae (a contrario sensu) \\
\hline 4.3 .53 & $\begin{array}{l}\text { Usus } \\
\text { Comp }\end{array}$ & $\begin{array}{l}\text { Usus } \\
\text { Consuetudines Compilatae }\end{array}$ \\
\hline 4.3 .54 & Usus & Usus \\
\hline $4.3 .56 / 57$ & $\begin{array}{l}\text { Usus } \\
\text { Comp }\end{array}$ & $\begin{array}{l}\text { Usus } \\
\text { Consuetudines Compilatae }\end{array}$ \\
\hline $4.3 .58 / 59$ & 3 & Handelaars \\
\hline $4.3 .60 / 61 / 62$ & $\mathrm{~S}$ & Specifieke reden \\
\hline
\end{tabular}

1395 De Memorieboeken spreken van 6 maart 1536. Materiële controle heeft echter uitgewezen dat het hier de ordonnantie van 7 maart 1537 (n.s.) betreft. 
PRIMAIRE RECHTSBRONNEN CONSUETUDINES COMPILATAE

\begin{tabular}{|l|l|l|}
\hline $4.3 .63 / 64 / 65$ & Usus & Usus \\
& 3 & Handelaars \\
\hline $4.3 .66 / 67$ & 3 & Handelaars \\
& 3 & Magistraat \\
\hline 4.3 .68 & $\mathrm{~S}$ & Specifieke reden \\
\hline 4.3 .69 & 3 & Handelaars \\
\hline $4.3 .70 / 71$ & Usus & Usus \\
\hline $4.3 .72 / 73$ & $\mathrm{~S}$ & Specifieke reden \\
\hline $4.3 .74 / 75$ & $\mathrm{~S}$ & Specifieke reden \\
\hline $4.3 .76 / 77$ & Usus & Usus \\
\hline
\end{tabular}

\section{titel 4}

van de vrije jaermerckten $(0 / 17)$

\begin{tabular}{|l|l|l|}
\hline $\begin{array}{l}\text { titel } \mathbf{5} \\
\text { van de peerdemerckten }(\mathbf{2} / \mathbf{9})\end{array}$ \\
\hline 4.5 .1$. & iWG & Privilege Jan II van Brabant: 1298 \\
\hline 4.5 .2 & 3 & Experts \\
\hline
\end{tabular}

\begin{tabular}{|c|c|c|}
\hline \multicolumn{3}{|c|}{$\begin{array}{l}\text { titel } 6 \\
\text { van coop ende coopmanschappen }(12 / 26)\end{array}$} \\
\hline 4.6 .3 & $\mathrm{~S}$ & Specifieke reden \\
\hline $4.6 .13 / 14 / 15$ & $\begin{array}{l}\text { RA } \\
\text { Comp }\end{array}$ & $\begin{array}{l}\text { Ratio } \\
\text { Consuetudines Compilatae }\end{array}$ \\
\hline 4.6 .16 & $\begin{array}{l}\text { Usus } \\
\text { Comp }\end{array}$ & $\begin{array}{l}\text { Usus } \\
\text { Consuetudines Compilatae }\end{array}$ \\
\hline 4.6 .17 & $\begin{array}{l}\text { RL } \\
\text { Ciciv } \\
3\end{array}$ & $\begin{array}{l}\text { Doctores } \\
\text { Corpus Iuris Civilis (Codex) } \\
\text { Magistraat }\end{array}$ \\
\hline 4.6 .18 & Comp & Consuetudines Compilatae \\
\hline 4.6 .19 & $\begin{array}{l}\text { Ciciv } \\
\text { RL } \\
\text { RL }\end{array}$ & $\begin{array}{l}\text { Corpus Iuris Civilis (Codex) } \\
\text { Denis Godefroy en alii doctores bij Codex } \\
\text { Joachim Mynsinger von Frundeck (Singularium observationum iudicii } \\
\text { imperialis camerae) }\end{array}$ \\
\hline $4.6 .20 / 21 / 22 / 23$ & Usus & Usus \\
\hline
\end{tabular}

\begin{tabular}{|c|c|c|}
\hline \multicolumn{3}{|c|}{$\begin{array}{l}\text { titel } 7 \\
\text { van buere }(16 / 45)\end{array}$} \\
\hline $4.7 .6 / 7$ & Comp & Consuetudines Compilatae \\
\hline $4.7 .16 / 17$ & $\mathrm{~S}$ & Specifieke reden \\
\hline 4.7 .26 & RSi & Rechtspraak \\
\hline 4.7 .27 & Usus & Usus \\
\hline 4.7 .35 & Usus & Usus \\
\hline 4.7 .36 & $\mathrm{~S}$ & Specifieke reden \\
\hline 4.7 .37 & S & Specifieke reden \\
\hline $4.7 .38 / 39$ & eWG & Wetgeving Frankrijk: Codex Henricianus \\
\hline 4.7 .41 & $\begin{array}{l}\text { eWG } \\
\text { S }\end{array}$ & $\begin{array}{l}\text { Wetgeving Frankriik: Codex Henricianus } \\
\text { Specifieke reden }\end{array}$ \\
\hline 4.7 .42 & $\mathrm{~S}$ & Specifieke reden \\
\hline $4.7 .43 / 44$ & $\begin{array}{l}\text { Usus } \\
\mathrm{S}\end{array}$ & $\begin{array}{l}\text { Usus } \\
\text { Specifieke reden }\end{array}$ \\
\hline 4.7 .45 & $\begin{array}{l}\text { Usus } \\
\text { Ciciv }\end{array}$ & $\begin{array}{l}\text { Usus } \\
\text { 'Ex iure scripto' }\end{array}$ \\
\hline
\end{tabular}




\begin{tabular}{|c|c|c|}
\hline \multicolumn{3}{|c|}{$\begin{array}{l}\text { titel } 8 \\
\text { van schipvracht }(205 / 210)\end{array}$} \\
\hline 4.8 .1 & $\mathrm{iWGv}$ & Ordonnantie Filips II: 31 oktober 1563 \\
\hline $4.8 .2 / 3 / 4$ & $\mathrm{~S}$ & Specifieke reden \\
\hline 4.8 .5 & $\begin{array}{l}\mathrm{iWGv} \\
\mathrm{iWG}\end{array}$ & $\begin{array}{l}\text { Ordonnantie Filips II: } 19 \text { juli } 1551 \\
\text { Ordonnantie Filips II: } 31 \text { oktober } 1563\end{array}$ \\
\hline $4.8 .6 / 7$ & $\begin{array}{l}\text { iWGv } \\
3\end{array}$ & $\begin{array}{l}\text { Ordonnantie Filips II: } 31 \text { oktober } 1563 \\
\text { Experts }\end{array}$ \\
\hline 4.8 .8 & $\begin{array}{l}\text { eZR } \\
\text { iWGv } \\
3 \\
3\end{array}$ & $\begin{array}{l}\text { Wisbuyse zeerechten } \\
\text { Ordonnantie Filips II: } 31 \text { oktober } 1563 \\
\text { Magistraat } \\
\text { Onderhandelaars }\end{array}$ \\
\hline 4.8 .9 & Usus & Usus \\
\hline 4.8 .10 & $\begin{array}{l}\text { Usus } \\
\mathrm{eZR}\end{array}$ & $\begin{array}{l}\text { Usus } \\
\text { Ordonnantie van Rouen/Guidon de la Mer }\end{array}$ \\
\hline 4.8 .11 & $\begin{array}{l}\text { Usus } \\
\mathrm{eZR} \\
3 \\
\end{array}$ & $\begin{array}{l}\text { Usus } \\
\text { Ordonnantie van Rouen/Guidon de la Mer } \\
\text { Handelaars }\end{array}$ \\
\hline 4.8 .12 & $\begin{array}{l}\text { Usus } \\
\mathrm{eZR}\end{array}$ & $\begin{array}{l}\text { Usus } \\
\text { Ordonnantie van Rouen/Guidon de la Mer }\end{array}$ \\
\hline 4.8 .13 & $\begin{array}{l}\text { iWGv } \\
\text { Usus } \\
3\end{array}$ & $\begin{array}{l}\text { Ordonnantie Filips II: } 31 \text { oktober } 1563 \\
\text { Usus } \\
\text { Handelaars }\end{array}$ \\
\hline 4.8 .14 & $\mathrm{iWGv}$ & Ordonnantie Filips II: 31 oktober 1563 \\
\hline 4.8 .15 & $\begin{array}{l}\mathrm{iWGv} \\
\mathrm{iWG}\end{array}$ & $\begin{array}{l}\text { Ordonnantie Filips II: } 19 \text { juli } 1551 \\
\text { Ordonnantie Filips II: } 31 \text { oktober } 1563\end{array}$ \\
\hline $4.8 .16 / 17 / 18$ & $\begin{array}{l}\text { iWGv } \\
\text { iWG } \\
\text { S }\end{array}$ & $\begin{array}{l}\text { Ordonnantie Filips II: } 19 \text { juli } 1551 \\
\text { Ordonnantie Filips II: } 31 \text { oktober } 1563 \\
\text { Specieke reden }\end{array}$ \\
\hline 4.8 .19 & $\begin{array}{l}\text { iWGv } \\
\text { Comp } \\
3\end{array}$ & $\begin{array}{l}\text { Ordonnantie Filips II: } 31 \text { oktober } 1563 \\
\text { Consuetudines Compilatae } \\
\text { Experts }\end{array}$ \\
\hline 4.8 .20 & Ciciv & 'Ex iure scripto' \\
\hline $4.8 .21 / 22$ & $\begin{array}{l}\text { Ciciv } \\
\text { Usus }\end{array}$ & $\begin{array}{l}\text { 'Ex iuris script'’ } \\
\text { Usus }\end{array}$ \\
\hline 4.8 .23 & iWGv & Ordonnantie Filips II: 19 juli 1551 \\
\hline 4.8 .24 & $\begin{array}{l}\mathrm{eZR} \\
\mathrm{iWG} \\
\end{array}$ & $\begin{array}{l}\text { Wisbuyse zeerechten } \\
\text { Ordonnantie Filips II: } 19 \text { juli } 1551\end{array}$ \\
\hline 4.8 .25 & $\begin{array}{l}\text { Usus } \\
3\end{array}$ & $\begin{array}{l}\text { Usus } \\
\text { Experts }\end{array}$ \\
\hline $4.8 .26 / 27$ & $\begin{array}{l}\text { iWGv } \\
\text { eZR }\end{array}$ & $\begin{array}{l}\text { Ordonnantie Filips II: } 31 \text { oktober } 1563 \\
\text { Wisbuyse zeerechten }\end{array}$ \\
\hline 4.8 .28 & $\begin{array}{l}3 \\
3 \\
\end{array}$ & $\begin{array}{l}\text { Experts } \\
\text { Handelaars } \\
\end{array}$ \\
\hline 4.8 .29 & Usus & Usus \\
\hline $4.8 .30 / 31$ & Usus & Usus \\
\hline $4.8 .32 / 33$ & $\begin{array}{l}\mathrm{iWGv} \\
\mathrm{iWGv}\end{array}$ & $\begin{array}{l}\text { Ordonnantie Filips II: } 19 \text { juli } 1551 \\
\text { Ordonnantie Filips II: } 31 \text { oktober } 1563\end{array}$ \\
\hline 4.8 .34 & $\begin{array}{l}\mathrm{iWGv} \\
\mathrm{iWGv} \\
\text { Comp }\end{array}$ & $\begin{array}{l}\text { Ordonnantie Filips II: } 19 \text { juli } 1551 \\
\text { Ordonnantie Filips II: } 31 \text { oktober } 1563 \\
\text { Consuetudines Compilatae }\end{array}$ \\
\hline 4.8 .35 & Usus & Usus \\
\hline
\end{tabular}


PRIMAIRE RECHTSBRONNEN CONSUETUDINES COMPILATAE

\begin{tabular}{|c|c|c|}
\hline & 3 & Experts \\
\hline 4.8 .36 & $\begin{array}{l}\mathrm{iWGv} \\
\mathrm{iWGv} \\
3\end{array}$ & $\begin{array}{l}\text { Ordonnantie Filips II: } 19 \text { juli } 1551 \\
\text { Ordonnantie Filips II: } 31 \text { oktober } 1563 \\
\text { Handelaars }\end{array}$ \\
\hline 4.8 .37 & $\begin{array}{l}\text { iWGv } \\
\text { iWG }\end{array}$ & $\begin{array}{l}\text { Ordonnantie Filips II: } 19 \text { juli } 1551 \\
\text { Ordonnantie Filips II: } 31 \text { oktober } 1563\end{array}$ \\
\hline 4.8 .38 & $\begin{array}{l}\text { Usus } \\
\text { Comp }\end{array}$ & $\begin{array}{l}\text { Usus } \\
\text { Consuetudines Compilatae }\end{array}$ \\
\hline 4.8 .43 & Usus & Usus \\
\hline 4.8 .44 & $\mathrm{~S}$ & Specifieke reden \\
\hline $4.8 .45 / 46$ & $\begin{array}{l}\mathrm{iWGv} \\
\mathrm{iWG} \\
\text { Usus }\end{array}$ & $\begin{array}{l}\text { Ordonnantie Filips II: } 31 \text { oktober } 1563 \\
\text { Ordonnantie Filips II: } 20 \text { januari } 1570 \\
\text { Usus }\end{array}$ \\
\hline 4.8 .47 & $\begin{array}{l}\text { Usus } \\
\text { Comp } \\
3 \\
\text { RA }\end{array}$ & $\begin{array}{l}\text { Usus } \\
\text { Consuetudines Compilatae } \\
\text { Experts } \\
\text { Ratio }\end{array}$ \\
\hline $4.8 .48 / 49 / 50$ & $\mathrm{iWGv}$ & Ordonnantie Filips II: 31 oktober 1563 \\
\hline 4.8 .51 & Usus & Usus \\
\hline $4.8 .52 / 53 / 54$ & $\begin{array}{l}\mathrm{iWGv} \\
\text { Usus }\end{array}$ & $\begin{array}{l}\text { Ordonnantie Filips II: } 31 \text { oktober } 1563 \\
\text { Usus }\end{array}$ \\
\hline 4.8 .55 & $\begin{array}{l}\text { eZR } \\
\text { Comp }\end{array}$ & $\begin{array}{l}\text { Wisbuyse zeerecbten } \\
\text { Consuetudines Compilatae }\end{array}$ \\
\hline 4.8 .56 & iWGv & Ordonnantie Filips II: 31 oktober 1563 \\
\hline 4.8 .57 & $\begin{array}{l}\mathrm{iWGv} \\
\text { Comp }\end{array}$ & $\begin{array}{l}\text { Ordonnantie Filips II: } 31 \text { oktober } 1563 \\
\text { Consuetudines Compilatae }\end{array}$ \\
\hline 4.8 .58 & Usus & Usus \\
\hline $4.8 .59 / 60$ & $\begin{array}{l}\text { Usus } \\
\text { Ciciv }\end{array}$ & $\begin{array}{l}\text { Usus } \\
\text { 'Ex iure scripto' }\end{array}$ \\
\hline 4.8 .61 & Usus & Usus \\
\hline $4.8 .62 / 63 / 64$ & $\begin{array}{l}\mathrm{S} \\
3 \\
\end{array}$ & $\begin{array}{l}\text { Specifieke reden } \\
\text { Experts }\end{array}$ \\
\hline 4.8 .65 & Usus & Usus \\
\hline 4.8 .66 & Usus & Usus \\
\hline 4.8 .67 & $\begin{array}{l}\text { Usus } \\
3\end{array}$ & $\begin{array}{l}\text { Usus } \\
\text { Onderhandelaars }\end{array}$ \\
\hline 4.8 .68 & $\begin{array}{l}\mathrm{iWGV} \\
\mathrm{eZR}\end{array}$ & $\begin{array}{l}\text { Ordonnantie Filips II: } 31 \text { oktober } 1563 \\
\text { Wisbuyse zeerecbten }\end{array}$ \\
\hline 4.8 .69 & Usus & Usus \\
\hline $4.8 .70 / 71$ & $\begin{array}{l}\text { iWGv } \\
\text { eZR } \\
3\end{array}$ & $\begin{array}{l}\text { Ordonnantie Filips II: } 31 \text { oktober } 1563 \\
\text { Wisbuyse zeerecbten } \\
\text { Experts }\end{array}$ \\
\hline 4.8 .72 & $\begin{array}{l}\text { Usus } \\
3 \\
\end{array}$ & $\begin{array}{l}\text { Usus } \\
\text { Experts }\end{array}$ \\
\hline 4.8 .73 & $\begin{array}{l}\text { iWGv } \\
\text { Usus } \\
3\end{array}$ & $\begin{array}{l}\text { Ordonnantie Filips II: } 19 \text { juli } 1551 \\
\text { Usus } \\
\text { Experts }\end{array}$ \\
\hline $4.8 .74 / 75 / 76$ & Usus & Usus \\
\hline 4.8 .77 & $\begin{array}{l}\mathrm{iWG} \\
\mathrm{iWGv}\end{array}$ & $\begin{array}{l}\text { Ordonnantie Filips II: } 19 \text { juli } 1551 \\
\text { Ordonnantie Filips II: } 31 \text { oktober } 1563\end{array}$ \\
\hline 4.8 .78 & $\begin{array}{l}\text { Usus } \\
3 \\
3\end{array}$ & $\begin{array}{l}\text { Usus } \\
\text { Onderhandelaars } \\
\text { Verzekeraars }\end{array}$ \\
\hline
\end{tabular}




\begin{tabular}{|c|c|c|}
\hline & 3 & Theologen \\
\hline $4.8 .79 / 80 / 81$ & $\begin{array}{l}\text { iWGv } \\
3 \\
3\end{array}$ & $\begin{array}{l}\text { Ordonnantie Filips II: } 31 \text { oktober } 1563 \\
\text { Magistraat } \\
\text { Experts }\end{array}$ \\
\hline 4.8 .82 & iWGv & Ordonnantie Filips II: 31 oktober 1563 \\
\hline $4.8 .83 / 84$ & Usus & Usus \\
\hline 4.8 .85 & $\begin{array}{l}\text { iWGv } \\
\text { eZR }\end{array}$ & $\begin{array}{l}\text { Ordonnantie Filips II: } 31 \text { oktober } 1563 \\
\text { Wisbuyse zeerechten }\end{array}$ \\
\hline 4.8 .86 & iWGv & Ordonnantie Filips II: 31 oktober 1563 \\
\hline $4.8 .87 / 88$ & $\begin{array}{l}\text { Usus } \\
\text { Comp }\end{array}$ & $\begin{array}{l}\text { Usus } \\
\text { Consuetudines Compilatae }\end{array}$ \\
\hline 4.8 .89 & $\frac{1}{\text { Usus }}$ & Usus \\
\hline 4.8 .90 & $\mathrm{iWGv}$ & Ordonnantie Filips II: 31 oktober 1563 \\
\hline 4.8 .92 & Usus & Usus \\
\hline 4.8 .93 & $\begin{array}{l}\text { Usus } \\
\text { Comp }\end{array}$ & $\begin{array}{l}\text { Usus } \\
\text { Consuetudines Compilatae }\end{array}$ \\
\hline $4.8 .94 / 95 / 96$ & $\begin{array}{l}\text { Usus } \\
3\end{array}$ & $\begin{array}{l}\text { Usus } \\
\text { Experts }\end{array}$ \\
\hline 4.8 .97 & Usus & Usus \\
\hline $4.8 .98 / 99$ & $\begin{array}{l}\text { Usus } \\
\mathrm{eZR}\end{array}$ & $\begin{array}{l}\text { Usus } \\
\text { Ordonnantie van Rouen/Guidon de la Mer }\end{array}$ \\
\hline $4.8 .100 / 101$ & $\begin{array}{l}\text { Usus } \\
\mathrm{eZR}\end{array}$ & $\begin{array}{l}\text { Usus } \\
\text { Ordonnantie van Rouen/Guidon de la Mer }\end{array}$ \\
\hline 4.8 .102 & Usus & Usus \\
\hline $4.8 .103 / 104$ & Usus & Usus \\
\hline $4.8 .105 / 106$ & Usus & Usus \\
\hline $4.8 .107 / 108 / 109$ & Usus & Usus \\
\hline 4.8 .110 & $\begin{array}{l}\text { Usus } \\
3\end{array}$ & $\begin{array}{l}\text { Usus } \\
\text { Experts }\end{array}$ \\
\hline 4.8 .111 & $\begin{array}{l}\text { Usus } \\
\text { Comp }\end{array}$ & $\begin{array}{l}\text { Usus } \\
\text { Consuetudines Compilatae }\end{array}$ \\
\hline 4.8 .112 & $\begin{array}{l}\text { Usus } \\
\text { Comp }\end{array}$ & $\begin{array}{l}\text { Usus } \\
\text { Consuetudines Compilatae }\end{array}$ \\
\hline $4.8 .113 / 114$ & $\begin{array}{l}\text { Usus } \\
\mathrm{eZR} \\
3 \\
\end{array}$ & $\begin{array}{l}\text { Usus } \\
\text { Ordonnantie van Rouen/Guidon de la Mer } \\
\text { Experts }\end{array}$ \\
\hline $4.8 .115 / 116$ & $\begin{array}{l}\text { Usus } \\
\mathrm{eZR}\end{array}$ & $\begin{array}{l}\text { Usus } \\
\text { Ordonnantie van Rouen/Guidon de la Mer }\end{array}$ \\
\hline $4.8 .117 / 118 / 119$ & $\begin{array}{l}\mathrm{iWGv} \\
\text { Usus } \\
\mathrm{eZR}\end{array}$ & $\begin{array}{l}\text { Ordonnantie Filips II: } 31 \text { oktober } 1563 \\
\text { Usus } \\
\text { Ordonnantie van Rouen/Guidon de la Mer }\end{array}$ \\
\hline 4.8 .120 & iWGv & Ordonnantie Filips II: 31 oktober 1563 \\
\hline 4.8 .121 & eZR & Wisbuyse zeerechten \\
\hline $4.8 .122 / 123$ & iWGv & Ordonnantie Filips II: 31 oktober 1563 \\
\hline $4.8 .124 / 125 / 126$ & $\begin{array}{l}\text { iWGv } \\
\text { eZR } \\
3 \\
\text { Comp }\end{array}$ & $\begin{array}{l}\text { Ordonnantie Filips II: } 31 \text { oktober } 1563 \\
\text { Wisbuyse zeerechten } \\
\text { Experts } \\
\text { Consuetudines Compilatae }\end{array}$ \\
\hline 4.8 .127 & $\begin{array}{l}\mathrm{iWGv} \\
\mathrm{iWGv}\end{array}$ & $\begin{array}{l}\text { Ordonnantie Filips II: } 19 \text { juli } 1551 \\
\text { Ordonnantie Filips II: } 31 \text { oktober } 1563\end{array}$ \\
\hline $4.8 .128 / 129 / 130 / 131$ & $\begin{array}{l}\text { Usus } \\
\text { Comp }\end{array}$ & $\begin{array}{l}\text { Usus } \\
\text { Consuetudines Compilatae }\end{array}$ \\
\hline 4.8 .132 & Usus & Usus \\
\hline
\end{tabular}




\begin{tabular}{|c|c|c|}
\hline & eZR & Ordonnantie van Rouen/Guidon de la Mer \\
\hline 4.8 .133 & $\begin{array}{l}\text { iWGv } \\
\text { iWG } \\
\text { eZR }\end{array}$ & $\begin{array}{l}\text { Ordonnantie Filips II: } 19 \text { juli } 1551 \\
\text { Ordonnantie Filips II: } 31 \text { oktober } 1563 \\
\text { Wisbuyse zeerechten }\end{array}$ \\
\hline 4.8 .134 & eZR & Wisbuyse zeerechten \\
\hline $4.8 .135 / 136$ & $\begin{array}{l}\text { iWGv } \\
\text { iWGv } \\
\text { eZR } \\
\text { Comp }\end{array}$ & $\begin{array}{l}\text { Ordonnantie Filips II: } 19 \text { juli } 1551 \\
\text { Ordonnantie Filips II: } 31 \text { oktober } 1563 \\
\text { Wisbuyse zeerechten } \\
\text { Consuetudines Compilatae }\end{array}$ \\
\hline 4.8 .137 & $\begin{array}{l}\text { iWGv } \\
\text { iWGv } \\
\text { Comp }\end{array}$ & $\begin{array}{l}\text { Ordonnantie Filips II: } 19 \text { juli } 1551 \\
\text { Ordonnantie Filips II: } 31 \text { oktober } 1563 \\
\text { Consuetudines Compilatae }\end{array}$ \\
\hline 4.8 .138 & $\begin{array}{l}\text { iWGv } \\
\text { iWGv } \\
\text { eZR } \\
\text { RA } \\
\text { Comp }\end{array}$ & $\begin{array}{l}\text { Ordonnantie Filips II: } 19 \text { juli } 1551 \\
\text { Ordonnantie Filips II: } 31 \text { oktober } 1563 \\
\text { Wisbuyse zeerechten } \\
\text { Ratio } \\
\text { Consuetudines Compilatae }\end{array}$ \\
\hline $4.8 .139 / 140$ & $\mathrm{iWGv}$ & Ordonnantie Filips II: 31 oktober 1563 \\
\hline 4.8 .141 & $\begin{array}{l}\text { Usus } \\
\text { Comp }\end{array}$ & $\begin{array}{l}\text { Usus } \\
\text { Consuetudines Compilatae }\end{array}$ \\
\hline $4.8 .142 / 143 / 144 / 145$ & $\begin{array}{l}\text { iWGv } \\
\text { Usus } \\
\text { S }\end{array}$ & $\begin{array}{l}\text { Ordonnantie Filips II: } 31 \text { oktober } 1563 \\
\text { Usus } \\
\text { Specifieke reden }\end{array}$ \\
\hline 4.8 .146 & $\mathrm{RA}$ & Ratio \\
\hline 4.8 .147 & $\begin{array}{l}\text { iWGv } \\
\text { eZR } \\
\text { Comp }\end{array}$ & $\begin{array}{l}\text { Ordonnantie Filips II: } 31 \text { oktober } 1563 \\
\text { Wisbuyse zeerecbten } \\
\text { Consuetudines Compilatae }\end{array}$ \\
\hline 4.8 .148 & iWGv & Ordonnantie Filips II: 31 oktober 1563 \\
\hline $4.8 .149 / 150$ & iWGv & Ordonnantie Filips II: 31 oktober 1563 \\
\hline $4.8 .151 / 152$ & $\begin{array}{l}\text { Usus } \\
\text { Comp }\end{array}$ & $\begin{array}{l}\text { Usus } \\
\text { Consuetudines Compilatae }\end{array}$ \\
\hline $4.8 .153 / 154 / 155$ & $\begin{array}{l}\text { Usus } \\
3\end{array}$ & $\begin{array}{l}\text { Usus } \\
\text { Ex suggestione Experts }\end{array}$ \\
\hline $4.8 .156 / 157$ & $\begin{array}{l}\text { Usus } \\
3\end{array}$ & $\begin{array}{l}\text { Usus } \\
\text { Experts } \\
\end{array}$ \\
\hline 4.8 .158 & $\mathrm{iWGv}$ & Ordonnantie Filips II: 31 oktober 1563 \\
\hline 4.8 .159 & iWGv & Ordonnantie Filips II: 31 oktober 1563 \\
\hline $4.8 .160 / 161$ & $\mathrm{iWGv}$ & Ordonnantie Filips II: 31 oktober 1563 \\
\hline $\begin{array}{l}4.8 .162 / 163 / 164 / 165 \\
/ 166\end{array}$ & $\begin{array}{l}\mathrm{iWGv} \\
\mathrm{iWG} \\
\mathrm{eZR}\end{array}$ & $\begin{array}{l}\text { Ordonnantie Filips II: } 19 \text { juli } 1551 \\
\text { Ordonnantie Filips II: } 31 \text { oktober } 1563 \\
\text { Wisbuyse zeerecbten }\end{array}$ \\
\hline 4.8 .167 & $\begin{array}{l}\mathrm{iWGv} \\
\mathrm{iWG}\end{array}$ & $\begin{array}{l}\text { Ordonnantie Filips II: } 19 \text { juli } 1551 \\
\text { Ordonnantie Filips II: } 31 \text { oktober } 1563\end{array}$ \\
\hline $4.8 .168 / 169$ & $\begin{array}{l}\text { iWGv } \\
\text { iWGv }\end{array}$ & $\begin{array}{l}\text { Ordonnantie Filips II: } 19 \text { juli } 1551 \\
\text { Ordonnantie Filips II: } 31 \text { oktober } 1563\end{array}$ \\
\hline 4.8 .170 & $\mathrm{iWGv}$ & Ordonnantie Filips II: 19 juli 1551 \\
\hline 4.8 .171 & $\begin{array}{l}\text { iWGv } \\
\mathrm{eZR}\end{array}$ & $\begin{array}{l}\text { Ordonnantie Filips II: } 31 \text { oktober } 1563 \\
\text { Wisbuyse zeerechten }\end{array}$ \\
\hline $4.8 .172 / 173$ & $\begin{array}{l}\text { iWGv } \\
\text { iWGv } \\
\text { eZR }\end{array}$ & $\begin{array}{l}\text { Ordonnantie Filips II: } 19 \text { juli } 1551 \\
\text { Ordonnantie Filips II: } 31 \text { oktober } 1563 \\
\text { Wisbuyse zeerecbten }\end{array}$ \\
\hline $4.8 .174 / 175 / 176$ & $\begin{array}{l}\mathrm{iWGv} \\
\mathrm{iWGv}\end{array}$ & $\begin{array}{l}\text { Ordonnantie Filips II: } 19 \text { juli } 1551 \\
\text { Ordonnantie Filips II: } 31 \text { oktober } 1563\end{array}$ \\
\hline
\end{tabular}




\begin{tabular}{|c|c|c|}
\hline 4.8 .177 & $\mathrm{~S}$ & Specifieke reden \\
\hline $4.8 .178 / 179$ & iWGv & Ordonnantie Filips II: 31 oktober 1563 \\
\hline 4.8.180 & iWGv & Ordonnantie Filips II: 31 oktober 1563 \\
\hline 4.8.181 & $\begin{array}{l}3 \\
3\end{array}$ & $\begin{array}{l}\text { Schippers } \\
\text { Experts }\end{array}$ \\
\hline 4.8 .182 & $\begin{array}{l}\mathrm{iWGv} \\
\mathrm{iWG}\end{array}$ & $\begin{array}{l}\text { Ordonnantie Filips II: } 19 \text { juli } 1551 \\
\text { Ordonnantie Filips II: } 31 \text { oktober } 1563\end{array}$ \\
\hline 4.8 .183 & $\begin{array}{l}\text { iWGv } \\
\text { iWG }\end{array}$ & $\begin{array}{l}\text { Ordonnantie Filips II: } 19 \text { juli } 1551 \\
\text { Ordonnantie Filips II: } 31 \text { oktober } 1563\end{array}$ \\
\hline 4.8 .184 & $\begin{array}{l}\text { iWGv } \\
\text { iWG } \\
\text { eZR }\end{array}$ & $\begin{array}{l}\text { Ordonnantie Filips II: } 19 \text { juli } 1551 \\
\text { Ordonnantie Filips II: } 31 \text { oktober } 1563 \\
\text { Wisbuyse zeerecbten }\end{array}$ \\
\hline $4.8 .185 / 186$ & $\begin{array}{l}\mathrm{iWGv} \\
3 \\
3\end{array}$ & $\begin{array}{l}\text { Ordonnantie Filips II: } 31 \text { oktober } 1563 \\
\text { Magistraat } \\
\text { Raad }\end{array}$ \\
\hline 4.8 .187 & $\begin{array}{l}\mathrm{iWGv} \\
\mathrm{eZR}\end{array}$ & $\begin{array}{l}\text { Ordonnantie Filips II: } 31 \text { oktober } 1563 \\
\text { Wisbuyse zeerechten }\end{array}$ \\
\hline 4.8 .188 & $\begin{array}{l}\text { iWGv } \\
\text { eZR } \\
\text { Comp }\end{array}$ & $\begin{array}{l}\text { Ordonnantie Filips II: } 31 \text { oktober } 1563 \\
\text { Wisbuyse zeerecbten } \\
\text { Consuetudines Compilatae }\end{array}$ \\
\hline 4.8 .189 & iWGv & Ordonnantie Filips II: 31 oktober 1563 \\
\hline $4.8 .190 / 191$ & $\begin{array}{l}\mathrm{iWGv} \\
\mathrm{eZR}\end{array}$ & $\begin{array}{l}\text { Ordonnantie Filips II: } 31 \text { oktober } 1563 \\
\text { Wisbuyse zeerechten }\end{array}$ \\
\hline 4.8 .192 & $\begin{array}{l}\text { Usus } \\
3 \\
\text { RA }\end{array}$ & $\begin{array}{l}\text { Usus } \\
\text { Onderhandelaars } \\
\text { Ratio }\end{array}$ \\
\hline 4.8 .193 & $\begin{array}{l}\text { iWGv } \\
\mathrm{eZR}\end{array}$ & $\begin{array}{l}\text { Ordonnantie Filips II: } 31 \text { oktober } 1563 \\
\text { Wisbuyse zeerechten }\end{array}$ \\
\hline 4.8 .194 & $\begin{array}{l}\text { iWGv } \\
\text { eZR } \\
\text { S }\end{array}$ & $\begin{array}{l}\text { Ordonnantie Filips II: } 31 \text { oktober } 1563 \\
\text { Wisbuyse zeerechten } \\
\text { Specifieke reden }\end{array}$ \\
\hline $4.8 .195 / 196 / 197$ & $\begin{array}{l}\mathrm{iWGv} \\
\mathrm{iWG}\end{array}$ & $\begin{array}{l}\text { Ordonnantie Filips II: } 19 \text { juli } 1551 \\
\text { Ordonnantie Filips II: } 31 \text { oktober } 1563\end{array}$ \\
\hline $4.8 .198 / 199$ & $\begin{array}{l}\mathrm{iWGv} \\
\mathrm{iWG}\end{array}$ & $\begin{array}{l}\text { Ordonnantie Filips II: } 19 \text { juli } 1551 \\
\text { Ordonnantie Filips II: } 31 \text { oktober } 1563\end{array}$ \\
\hline $4.8 .200 / 201 / 202 / 203$ & $\mathrm{iWGv}$ & Ordonnantie Filips II: 31 oktober 1563 \\
\hline 4.8 .204 & $\begin{array}{l}\text { iWGv } \\
\text { iWGv }\end{array}$ & $\begin{array}{l}\text { Ordonnantie Filips II: } 19 \text { juli } 1551 \\
\text { Ordonnantie Filips II: } 31 \text { oktober } 1563\end{array}$ \\
\hline $4.8 .205 / 206 / 207$ & $\mathrm{iWGv}$ & Ordonnantie Filips II: 31 oktober 1563 \\
\hline 4.8 .208 & $\begin{array}{l}\mathrm{iWGv} \\
\mathrm{iWG}\end{array}$ & $\begin{array}{l}\text { Ordonnantie Filips II: } 19 \text { juli } 1551 \\
\text { Ordonnantie Filips II: } 31 \text { oktober } 1563\end{array}$ \\
\hline 4.8 .209 & $\begin{array}{l}\mathrm{iWGv} \\
\mathrm{iWG} \\
\end{array}$ & $\begin{array}{l}\text { Ordonnantie Filips II: } 19 \text { juli } 1551 \\
\text { Ordonnantie Filips II: } 31 \text { oktober } 1563 \\
\end{array}$ \\
\hline 4.8 .210 & $\mathrm{~S}$ & Specifieke reden \\
\hline
\end{tabular}

\begin{tabular}{|c|c|c|}
\hline \multicolumn{3}{|c|}{$\begin{array}{l}\text { titel } 9 \\
\text { van geselschap ende gemeijnschap van goeden }(28 / 39)\end{array}$} \\
\hline 4.9 .1 & Usus & Usus \\
\hline $4.9 .2 / 3$ & $\mathrm{~S}$ & Specifieke reden \\
\hline 4.9 .6 & $\begin{array}{l}\text { RL } \\
\text { Ciciv }\end{array}$ & $\begin{array}{l}\text { Doctores bij Digestae } \\
\text { Corpus Iuris Civilis (Digestae) }\end{array}$ \\
\hline 4.9 .7 & RA & Aequitas \\
\hline 4.9 .8 & Usus & Usus \\
\hline
\end{tabular}


PRIMAIRE RECHTSBRONNEN CONSUETUDINES COMPILATAE

\begin{tabular}{|l|l|l|}
\hline 4.9 .9 & Comp & Consuetudines Compilatae \\
\hline 4.9 .10 & Usus & Usus \\
& Ciciv & 'Exiure scripto' \\
& $\mathrm{S}$ & Specifieke reden \\
\hline 4.9 .11 & Usus & Usus \\
\hline $4.9 .12 / 13$ & Ciciv & 'Ex iure scripto' \\
\hline 4.9 .14 & Ciciv & Corpus Iuris Civilis (Digestae) \\
\hline 4.9 .15 & $\mathrm{~S}$ & Specifieke reden \\
\hline $4.9 .17 / 18$ & Usus & Usus \\
& eWG & Wetgeving Genua: Statuten 1589 \\
\hline $4.9 .19 / 20 / 21$ & eWG & Wetgeving Genua: Statuten 1589 \\
& 3 & Magistraat \\
& Ciciv & Corpus Iuris Civilis (Digestae) \\
\hline 4.9 .22 & eWG & Wetgeving Genua: Statuten 1589 \\
& 3 & Magistraat \\
& Ciciv & Corpus Iuris Civilis (Codex) \\
\hline $4.9 .29 / 30$ & Usus & Usus \\
& 3 & Magistraat \\
& Comp & Consuetudines Compilatae \\
\hline 4.9 .31 & Ciciv & Corpus Iuris Civilis (Digestae) \\
& RA & Ratio van ander artikel uit Consuetudines Compilatae \\
& Usus & Usus \\
& Comp & Consuetudines Compilatae \\
& 3 & Magistraat \\
\hline 4.9 .32 & Usus & Usus \\
& eGR & Costuymen van Gent, Costuymen van Utrecht) \\
\hline 4.9 .33 & Comp & Consuetudines Compilatae \\
\hline 4.9 .34 & Comp & Consuetudines Compilatae \\
\hline $4.9 .35 / 36 / 37$ & S & Specifieke reden \\
\hline
\end{tabular}

\begin{tabular}{|c|c|c|}
\hline \multicolumn{3}{|c|}{$\begin{array}{l}\text { titel } 10 \\
\text { van bevel ende factorije }(21 / 22)\end{array}$} \\
\hline $4.10 .1 / 2$ & $\begin{array}{l}\text { Usus } \\
\text { Ciciv }\end{array}$ & $\begin{array}{l}\text { Usus } \\
\text { Corpus Iuris Civilis (Digestae) }\end{array}$ \\
\hline $4.10 .3 / 4 / 5$ & $\begin{array}{l}\mathrm{S} \\
\mathrm{RL}\end{array}$ & $\begin{array}{l}\text { Specifieke reden } \\
\text { Matthias Wesenbeeck (Paratitla in Pandectas iuris civilis) }\end{array}$ \\
\hline 4.10 .6 & $\mathrm{eWG}$ & Wetgeving Genua: Statuten 1589 \\
\hline 4.10 .7 & $\mathrm{eWG}$ & Wetgeving Genua: Statuten 1589 \\
\hline $4.10 .8 / 9$ & $\mathrm{RSi}$ & Turbe \\
\hline 4.10 .10 & Ciciv & 'Ex iure scripto' (Codex) \\
\hline 4.10 .11 & RL & 'Collutione constituties regni galliae cum iure scripto' \\
\hline 4.10 .12 & Comp & Consuetudines Compilatae \\
\hline $4.10 .13 / 14 / 15 / 16$ & $\begin{array}{l}\text { S } \\
\text { Usus } \\
\text { Ciciv } \\
\text { Comp }\end{array}$ & $\begin{array}{l}\text { Specifieke reden } \\
\text { Usus } \\
\text { 'Ex iure scripto' } \\
\text { Consuetudines Compilatae }\end{array}$ \\
\hline $4.10 .17 / 18$ & 3 & Hof \\
\hline $4.10 .20 / 21$ & Usus & Usus \\
\hline 4.10 .22 & Comp & Consuetudines Compilatae \\
\hline
\end{tabular}

titel 11

van versekeringe oft asseurantie (301.5/323)

\begin{tabular}{l|l|l}
$4.11 .2 / 3 / 4$ & iWGv & Ordonnantie Filips II: 20 januari 1570
\end{tabular} 
BIJLAGEN

\begin{tabular}{|c|c|c|}
\hline 4.11 .5 & iWGv & Ordonnantie Filips II: 20 januari 1570 \\
\hline 4.11 .6 & $\mathrm{~S}$ & Specifieke reden \\
\hline $4.11 .7 / 8$ & $\mathrm{~S}$ & Specifieke reden \\
\hline 4.11 .9 & $\begin{array}{l}\mathrm{S} \\
3\end{array}$ & $\begin{array}{l}\text { Specifieke reden } \\
\text { Verzekeraars }\end{array}$ \\
\hline 4.11 .10 & $\begin{array}{l}3 \\
3 \\
\end{array}$ & $\begin{array}{l}\text { Experts } \\
\text { Verzekeraars }\end{array}$ \\
\hline 4.11 .11 & 3 & Onderhandelaars \\
\hline 4.11 .14 & $\begin{array}{l}\text { Usus } \\
\text { Usus }\end{array}$ & $\begin{array}{l}\text { Usus } \\
\text { Gebruiken van de verzekeraars }\end{array}$ \\
\hline 4.11 .15 & Usus & Usus \\
\hline $4.11 .17 / 18$ & $\begin{array}{l}3 \\
3\end{array}$ & $\begin{array}{l}\text { Onderhandelaars } \\
\text { Verzekeraars }\end{array}$ \\
\hline $4.11 .19 / 20 / 21 / 22$ & $\begin{array}{l}\text { Usus } \\
\text { Comp }\end{array}$ & $\begin{array}{l}\text { Usus } \\
\text { Consuetudines Compilatae }\end{array}$ \\
\hline 4.11 .24 & $\begin{array}{l}\text { Usus } \\
\text { Ciciv } \\
\text { RA }\end{array}$ & $\begin{array}{l}\text { Usus } \\
\text { 'Ex ratione iuris' }\end{array}$ \\
\hline 4.11 .25 & $\mathrm{iWGv}$ & Ordonnantie Filips II: 20 januari 1570 \\
\hline 4.11 .26 & $\begin{array}{l}\text { iWGv } \\
\mathrm{eZR}\end{array}$ & $\begin{array}{l}\text { Ordonnantie Filips II: } 20 \text { januari } 1570 \\
\text { Amsterdam }\end{array}$ \\
\hline 4.11 .27 & iWGv & Ordonnantie Filips II: 20 januari 1570 \\
\hline 4.11 .28 & $\mathrm{~S}$ & Specifieke reden \\
\hline $4.11 .29 / 30$ & $\begin{array}{l}3 \\
3 \\
\end{array}$ & $\begin{array}{l}\text { Onderhandelaars } \\
\text { Verzekeraars }\end{array}$ \\
\hline $4.11 .31 / 32$ & $\begin{array}{l}\text { Usus } \\
\mathrm{S} \\
3 \\
3 \\
3\end{array}$ & $\begin{array}{l}\text { Usus } \\
\text { Specifieke reden } \\
\text { Handelaars } \\
\text { Verzekeraars } \\
\text { Magistraat }\end{array}$ \\
\hline 4.11 .33 & $\mathrm{~S}$ & Specifieke reden \\
\hline $4.11 .34 / 35 / 36$ & $\begin{array}{l}\text { Comp } \\
\text { eZR } \\
3 \\
3 \\
\end{array}$ & $\begin{array}{l}\text { Consuetudines Compilatae } \\
\text { Brugge } \\
\text { Onderhandelaars } \\
\text { Verzekeraars }\end{array}$ \\
\hline 4.11 .37 & 3 & Experts \\
\hline $4.11 .38 / 39 / 40$ & $\begin{array}{l}3 \\
\mathrm{~S}\end{array}$ & $\begin{array}{l}\text { Experts } \\
\text { Specifieke reden }\end{array}$ \\
\hline 4.11 .44 & $\begin{array}{l}\text { Usus } \\
3 \\
\text { Comp }\end{array}$ & $\begin{array}{l}\text { Usus } \\
\text { Experts } \\
\text { Consuetudines Compilatae }\end{array}$ \\
\hline $4.11 .45 / 46$ & Usus & Usus \\
\hline 4.11 .47 & $\begin{array}{l}\text { Usus } \\
3 \\
3\end{array}$ & $\begin{array}{l}\text { Usus } \\
\text { Onderhandelaars } \\
\text { Verzekeraars }\end{array}$ \\
\hline 4.11 .48 & iWGv & Ordonnantie Filips II: 20 januari 1570 \\
\hline 4.11 .49 & $\mathrm{iWGv}$ & Ordonnantie Filips II: 20 januari 1570 \\
\hline $4.11 .50 / 51 / 52 / 53$ & Usus & Usus \\
\hline $4.11 .54 / 55$ & Usus & Usus \\
\hline $4.11 .56 / 57$ & $\begin{array}{l}\text { iWGv } \\
\text { eZR }\end{array}$ & $\begin{array}{l}\text { Ordonnantie Filips II: } 20 \text { januari } 1570 \\
\text { Amsterdam }\end{array}$ \\
\hline $4.11 .58 / 59$ & $\begin{array}{l}\text { Usus } \\
\mathrm{eZR}\end{array}$ & $\begin{array}{l}\text { Usus } \\
\text { Amsterdam }\end{array}$ \\
\hline
\end{tabular}


PRIMAIRE RECHTSBRONNEN CONSUETUDINES COMPILATAE

\begin{tabular}{|c|c|c|}
\hline & $\mathrm{S}$ & Specifieke reden \\
\hline 4.11 .60 & $\begin{array}{l}\text { Comp } \\
\mathrm{S}\end{array}$ & $\begin{array}{l}\text { Consuetudines Compilatae } \\
\text { Specifieke reden }\end{array}$ \\
\hline 4.11 .61 & $\mathrm{~S}$ & Specifieke reden \\
\hline $4.11 .62 / 63$ & Usus & Usus \\
\hline 4.11 .64 & S & Specifieke reden \\
\hline 4.11 .65 & $\begin{array}{l}\text { eZR } \\
3 \\
3\end{array}$ & $\begin{array}{l}\text { Brugge } \\
\text { Magistraat } \\
\text { Experts }\end{array}$ \\
\hline $4.11 .67 / 68$ & $\begin{array}{l}3 \\
\text { eGR } \\
3\end{array}$ & $\begin{array}{l}\text { Experts } \\
\text { 'Consuetudo vicinorum locorum' } \\
\text { Onderhandelaars }\end{array}$ \\
\hline 4.11 .69 & 3 & Experts \\
\hline$(4.11 .70)$ & Comp & Consuetudines Compilatae \\
\hline $4.11 .71 / 72 / 73$ & 3 & Onderhandelaars \\
\hline $4.11 .74 / 75$ & $\begin{array}{l}\text { Usus } \\
3\end{array}$ & $\begin{array}{l}\text { Usus } \\
\text { Experts }\end{array}$ \\
\hline $4.11 .76 / 77$ & Usus & Usus \\
\hline 4.11 .78 & $\begin{array}{l}\text { Ciciv } \\
\text { RA }\end{array}$ & $\begin{array}{l}\text { 'Ex ratione iuris' } \\
\text { Ratio }\end{array}$ \\
\hline 4.11 .79 & Usus & Usus \\
\hline $\begin{array}{l}4.11 .80 / 81 / 82 / 83 / 84 \\
/ 85\end{array}$ & $\begin{array}{l}\text { Usus } \\
3\end{array}$ & $\begin{array}{l}\text { Usus } \\
\text { Experts }\end{array}$ \\
\hline $4.11 .86 / 87 / 88$ & $\begin{array}{l}\text { Usus } \\
\text { Comp }\end{array}$ & $\begin{array}{l}\text { Usus } \\
\text { Consuetudines Compilatae }\end{array}$ \\
\hline $4.11 .89 / 90$ & $\begin{array}{l}\text { RA } \\
\text { Comp }\end{array}$ & Ratio van ander artikel uit Consuetudines Compilatae \\
\hline $4.11 .91 / 92 / 93$ & $\begin{array}{l}\text { Usus } \\
\text { Comp }\end{array}$ & $\begin{array}{l}\text { Usus } \\
\text { Consuetudines Compilatae }\end{array}$ \\
\hline $4.11 .94 / 95 / 96$ & $\begin{array}{l}\text { Usus } \\
3\end{array}$ & $\begin{array}{l}\text { Usus } \\
\text { Experts }\end{array}$ \\
\hline $4.11 .97 / 98$ & $\mathrm{~S}$ & Specifieke reden \\
\hline 4.11 .99 & S & Specifieke reden \\
\hline 4.11 .100 & Usus & Usus \\
\hline $\begin{array}{l}4.11 .101 / 102 / 103 \\
/ 104 / 105 / 106 / 107 \\
/ 108\end{array}$ & $\begin{array}{l}\text { Usus } \\
\mathrm{iWGv}\end{array}$ & $\begin{array}{l}\text { Usus } \\
\text { Ordonnantie Filips II: } 20 \text { januari } 1570\end{array}$ \\
\hline 4.11 .109 & $\mathrm{O}$ & Onduidelijk \\
\hline $\begin{array}{l}4.11 .110 / 111 / 112 / 11 \\
3 / 114\end{array}$ & Usus & Usus \\
\hline 4.11 .115 & Comp & Consuetudines Compilatae \\
\hline 4.11 .116 & Comp & Consuetudines Compilatae \\
\hline 4.11 .117 & Usus & Usus \\
\hline $\begin{array}{l}4.11 .118 / 119 / 120 \\
/ 121\end{array}$ & $\begin{array}{l}\text { Usus } \\
3 \\
3\end{array}$ & $\begin{array}{l}\text { Usus } \\
\text { Handelaars } \\
\text { Verzekeraars }\end{array}$ \\
\hline 4.11 .122 & $\mathrm{iWGv}$ & Ordonnantie Filips II: 20 januari 1570 \\
\hline $\begin{array}{l}4.11 .123 / 124 / 125 \\
/ 126 / 127 / 128 / 129\end{array}$ & $\begin{array}{l}\text { Comp } \\
\mathrm{S}\end{array}$ & $\begin{array}{l}\text { Consuetudines Compilatae } \\
\text { Specifieke reden }\end{array}$ \\
\hline $4.11 .130 / 131$ & $\begin{array}{l}\text { Usus } \\
\mathrm{S}\end{array}$ & $\begin{array}{l}\text { Usus } \\
\text { Specifieke reden }\end{array}$ \\
\hline $4.11 .132 / 133$ & $\begin{array}{l}\mathrm{iWGv} \\
\text { Usus }\end{array}$ & $\begin{array}{l}\text { Ordonnantie Filips II: } 20 \text { januari } 1570 \\
\text { Usus }\end{array}$ \\
\hline
\end{tabular}


BIJLAGEN

\begin{tabular}{|c|c|c|}
\hline & eZR & Ordonnantie van Rouen/Guidon de la Mer \\
\hline $4.11 .134 / 135$ & $\begin{array}{l}\text { Usus } \\
3\end{array}$ & $\begin{array}{l}\text { Usus } \\
\text { Experts }\end{array}$ \\
\hline $\begin{array}{l}4.11 .136 / 137 / 138 \\
/ 139 / 140\end{array}$ & $\begin{array}{l}\text { Usus } \\
3\end{array}$ & $\begin{array}{l}\text { Usus } \\
\text { Experts }\end{array}$ \\
\hline $\begin{array}{l}4.11 .141 / 142 / 143 \\
/ 144 / 145 / 146\end{array}$ & $\begin{array}{l}\text { Usus } \\
3\end{array}$ & $\begin{array}{l}\text { Usus } \\
\text { Experts }\end{array}$ \\
\hline 4.11 .147 & Usus & Usus \\
\hline 4.11 .148 & $\begin{array}{l}\text { Usus } \\
\mathrm{eZR}\end{array}$ & $\begin{array}{l}\text { Usus } \\
\text { Ordonnantie van Rouen/Guidon de la Mer }\end{array}$ \\
\hline $4.11 .149 / 150$ & $\begin{array}{l}\text { iWGv } \\
\text { Comp }\end{array}$ & $\begin{array}{l}\text { Ordonnantie Filips II: } 20 \text { januari } 1570 \\
\text { Consuetudines Compilatae }\end{array}$ \\
\hline $4.11 .151 / 152$ & $\begin{array}{l}3 \\
S\end{array}$ & $\begin{array}{l}\text { Experts } \\
\text { Specifieke reden }\end{array}$ \\
\hline $4.11 .153 / 154 / 155$ & iWGv & Ordonnantie Filips II: 31 oktober 1563 \\
\hline 4.11 .156 & $\begin{array}{l}\text { iWGv } \\
\text { eZR } \\
\text { eZR } \\
\text { Comp }\end{array}$ & $\begin{array}{l}\text { Ordonnantie Filips II: } 20 \text { januari } 1570 \\
\text { Amsterdam } \\
\text { Brugge } \\
\text { Consuetudines Compilatae }\end{array}$ \\
\hline 4.11 .157 & $\begin{array}{l}\text { Usus } \\
\text { Comp }\end{array}$ & $\begin{array}{l}\text { Usus } \\
\text { Consuetudines Compilatae }\end{array}$ \\
\hline $4.11 .158 / 159$ & $\begin{array}{l}\text { Usus } \\
3\end{array}$ & $\begin{array}{l}\text { Usus } \\
\text { Verzekeraars }\end{array}$ \\
\hline $\begin{array}{l}4.11 .160 / 161 / 162 / 16 \\
3\end{array}$ & $\begin{array}{l}\text { Usus } \\
3\end{array}$ & $\begin{array}{l}\text { Usus } \\
\text { Experts }\end{array}$ \\
\hline $\begin{array}{l}4.11 .164 / 165 / 166 / 16 \\
7\end{array}$ & $\begin{array}{l}\text { Usus } \\
\mathrm{S}\end{array}$ & $\begin{array}{l}\text { Usus } \\
\text { Specifieke reden }\end{array}$ \\
\hline $4.11 .168 / 169 / 170$ & Usus & Usus \\
\hline 4.11 .171 & $\begin{array}{l}\text { Usus } \\
\text { Comp }\end{array}$ & $\begin{array}{l}\text { Usus } \\
\text { Consuetudines Compilatae }\end{array}$ \\
\hline 4.11 .172 & Usus & Usus \\
\hline 4.11 .173 & $\begin{array}{l}\text { Usus } \\
\text { Ciciv } \\
\text { RA }\end{array}$ & $\begin{array}{l}\text { Usus } \\
\text { 'Ex ratione iuris' }\end{array}$ \\
\hline 4.11 .174 & $\begin{array}{l}\text { Usus } \\
\text { Comp }\end{array}$ & $\begin{array}{l}\text { Usus } \\
\text { Consuetudines Compilatae }\end{array}$ \\
\hline 4.11 .175 & Usus & Usus \\
\hline $\begin{array}{l}4.11 .176 / 177 / 178 \\
/ 179\end{array}$ & Comp & Consuetudines Compilatae \\
\hline 4.11 .180 & $\begin{array}{l}\text { Usus } \\
\text { Comp }\end{array}$ & $\begin{array}{l}\text { Usus } \\
\text { Consuetudines Compilatae }\end{array}$ \\
\hline $\begin{array}{l}4.11 .181 / 182 / 183 \\
/ 184 / 185\end{array}$ & Usus & Usus \\
\hline $4.11 .186 / 187$ & $\begin{array}{l}\text { Usus } \\
\text { Comp }\end{array}$ & $\begin{array}{l}\text { Usus } \\
\text { Consuetudines Compilatae }\end{array}$ \\
\hline 4.11 .188 & Comp & Consuetudines Compilatae \\
\hline $4.11 .189 / 190 / 191$ & Usus & Usus \\
\hline $4.11 .192 / 193$ & Usus & Usus \\
\hline $4.11 .194 / 195$ & Usus & Usus \\
\hline $4.11 .196 / 197$ & $\begin{array}{l}\text { Usus } \\
3 \\
3\end{array}$ & $\begin{array}{l}\text { Usus } \\
\text { Handelaars } \\
\text { Verzekeraars }\end{array}$ \\
\hline $4.11 .198 / 199$ & Usus & Usus \\
\hline
\end{tabular}


PRIMAIRE RECHTSBRONNEN CONSUETUDINES COMPILATAE

\begin{tabular}{|c|c|c|}
\hline & 3 & Experts \\
\hline 4.11 .200 & Usus & Usus \\
\hline 4.11 .201 & $\begin{array}{l}\text { Usus } \\
\text { Comp }\end{array}$ & $\begin{array}{l}\text { Usus } \\
\text { Consuetudines Compilatae }\end{array}$ \\
\hline 4.11 .202 & $\begin{array}{l}\text { Usus } \\
\text { Ciciv } \\
\text { RA }\end{array}$ & $\begin{array}{l}\text { Usus } \\
\text { 'Ex ratione iuris' }\end{array}$ \\
\hline 4.11 .203 & $\begin{array}{l}\mathrm{iWGv} \\
\mathrm{eZR}\end{array}$ & $\begin{array}{l}\text { Ordonnantie Filips II: } 20 \text { januari } 1570 \\
\text { Amsterdam }\end{array}$ \\
\hline 4.11 .204 & 3 & Experts \\
\hline 4.11 .206 & RA & Ratio \\
\hline 4.11 .207 & RA & Ratio \\
\hline 4.11 .208 & $\begin{array}{l}\text { Usus } \\
\text { Comp }\end{array}$ & $\begin{array}{l}\text { Usus } \\
\text { Consuetudines Compilatae }\end{array}$ \\
\hline 4.11 .209 & Usus & Usus \\
\hline 4.11 .210 & $\begin{array}{l}3 \\
S\end{array}$ & $\begin{array}{l}\text { Experts } \\
\text { Specifieke reden }\end{array}$ \\
\hline $4.11 .211 / 212$ & $\begin{array}{l}\text { Usus } \\
3\end{array}$ & $\begin{array}{l}\text { Usus } \\
\text { Experts }\end{array}$ \\
\hline $4.11 .213 / 214$ & $\begin{array}{l}3 \\
\text { Comp }\end{array}$ & $\begin{array}{l}\text { Experts } \\
\text { Consuetudines Compilatae }\end{array}$ \\
\hline $\begin{array}{l}4.11 .215 / 216 / 217 \\
/ 218 / 219 / 220 / 221\end{array}$ & $\begin{array}{l}3 \\
S\end{array}$ & $\begin{array}{l}\text { Experts } \\
\text { Specifieke reden }\end{array}$ \\
\hline 4.11 .222 & 3 & Experts \\
\hline $4.11 .223 / 224 / 225$ & Usus & Usus \\
\hline $4.11 .226 / 227$ & $\begin{array}{l}3 \\
\text { Usus }\end{array}$ & $\begin{array}{l}\text { Experts } \\
\text { Usus }\end{array}$ \\
\hline 4.11 .228 & $\begin{array}{l}\text { Usus } \\
\text { Comp }\end{array}$ & $\begin{array}{l}\text { Usus } \\
\text { Consuetudines Compilatae }\end{array}$ \\
\hline $4.11 .229 / 230$ & $\begin{array}{l}\text { Usus } \\
3\end{array}$ & $\begin{array}{l}\text { Usus } \\
\text { Experts }\end{array}$ \\
\hline 4.11 .231 & Usus & Usus \\
\hline $4.11 .232 / 233 / 234$ & $\begin{array}{l}\text { iWGv } \\
\text { eZR }\end{array}$ & $\begin{array}{l}\text { Ordonnantie Filips II: } 20 \text { januari } 1570 \\
\text { Amsterdam }\end{array}$ \\
\hline 4.11 .235 & eZR & Amsterdam \\
\hline $4.11 .236 / 237$ & $\begin{array}{l}\text { iWGv } \\
\text { eZR }\end{array}$ & $\begin{array}{l}\text { Ordonnantie Filips II: } 20 \text { januari } 1570 \\
\text { Amsterdam }\end{array}$ \\
\hline $4.11 .238 / 239$ & $\begin{array}{l}\text { Usus } \\
3\end{array}$ & $\begin{array}{l}\text { Usus } \\
\text { Verzekeraars }\end{array}$ \\
\hline 4.11 .240 & $\begin{array}{l}\text { iWGv } \\
\text { eZR }\end{array}$ & $\begin{array}{l}\text { Ordonnantie Filips II: } 20 \text { januari } 1570 \\
\text { Amsterdam }\end{array}$ \\
\hline 4.11 .242 & $\begin{array}{l}\text { iWGv } \\
\text { eZR }\end{array}$ & $\begin{array}{l}\text { Ordonnantie Filips II: } 20 \text { januari } 1570 \\
\text { Amsterdam }\end{array}$ \\
\hline 4.11 .243 & iWGv & Ordonnantie Filips II: 20 januari 1570 \\
\hline 4.11 .244 & $\begin{array}{l}3 \\
\mathrm{RA} \\
\text { Comp } \\
\end{array}$ & $\begin{array}{l}\text { Experts } \\
\text { Ratio } \\
\text { Consuetudines Compilatae }\end{array}$ \\
\hline 4.11 .248 & Comp & Consuetudines Compilatae \\
\hline $4.11 .249 / 250$ & $\begin{array}{l}\text { Usus } \\
3 \\
3 \\
\end{array}$ & $\begin{array}{l}\text { Usus } \\
\text { Handelaars } \\
\text { Verzekeraars } \\
\end{array}$ \\
\hline 4.11 .251 & Comp & Consuetudines Compilatae \\
\hline $4.11 .252 / 253$ & Usus & Usus \\
\hline
\end{tabular}


BIJLAGEN

\begin{tabular}{|c|c|c|}
\hline 4.11 .254 & Comp & Consuetudines Compilatae \\
\hline $4.11 .255 / 256$ & $\mathrm{~S}$ & Specifieke reden \\
\hline 4.11 .257 & Comp & Consuetudines Compilatae \\
\hline 4.11 .258 & $\begin{array}{l}\text { Usus } \\
\text { Comp }\end{array}$ & $\begin{array}{l}\text { Usus } \\
\text { Consuetudines Compilatae }\end{array}$ \\
\hline 4.11 .259 & 3 & Experts \\
\hline 4.11 .260 & $\mathrm{~S}$ & Specifieke reden \\
\hline 4.11 .261 & $\begin{array}{l}\text { Comp } \\
\mathrm{S}\end{array}$ & $\begin{array}{l}\text { Consuetudines Compilatae } \\
\text { Specifieke reden }\end{array}$ \\
\hline 4.11 .262 & $\begin{array}{l}\mathrm{RA} \\
\text { Usus }\end{array}$ & $\begin{array}{l}\text { Ratio } \\
\text { Usus }\end{array}$ \\
\hline 4.11 .263 & $\begin{array}{l}\text { Comp } \\
\text { eZR }\end{array}$ & $\begin{array}{l}\text { Consuetudines Compilatae } \\
\text { Ordonnantie van Rouen/Guidon de la Mer }\end{array}$ \\
\hline $4.11 .264 / 265$ & $\begin{array}{l}\text { Usus } \\
3 \\
3\end{array}$ & $\begin{array}{l}\text { Usus } \\
\text { Handelaars } \\
\text { Verzekeraars }\end{array}$ \\
\hline $4.11 .266 / 267 / 268$ & $\begin{array}{l}\text { Usus } \\
3 \\
\text { Comp }\end{array}$ & $\begin{array}{l}\text { Usus } \\
\text { Experts } \\
\text { Consuetudines Compilatae }\end{array}$ \\
\hline $4.11 .269 / 270 / 271$ & $\begin{array}{l}\text { Usus } \\
3\end{array}$ & $\begin{array}{l}\text { Usus } \\
\text { Experts }\end{array}$ \\
\hline $4.11 .272 / 273$ & $\begin{array}{l}\text { Usus } \\
3\end{array}$ & $\begin{array}{l}\text { Usus } \\
\text { Experts }\end{array}$ \\
\hline $4.11 .280 / 281$ & Comp & Consuetudines Compilatae \\
\hline 4.11 .282 & $\mathrm{iWGv}$ & Ordonnantie Filips II: 20 januari 1570 \\
\hline $4.11 .283 / 284 / 285$ & iWGv & Ordonnantie Filips II: 20 januari 1570 \\
\hline $4.11 .286 / 287$ & $\begin{array}{l}\text { iWGv } \\
\mathrm{iWGv}\end{array}$ & $\begin{array}{l}\text { Ordonnantie Filips II: } 31 \text { oktober } 1563 \\
\text { Ordonnantie Filips II: } 20 \text { januari } 1570\end{array}$ \\
\hline 4.11 .288 & $\begin{array}{l}\text { iWGv } \\
\text { Comp }\end{array}$ & $\begin{array}{l}\text { Ordonnantie Filips II: } 31 \text { oktober } 1563 \\
\text { Consuetudines Compilatae }\end{array}$ \\
\hline $4.11 .289 / 290 / 291$ & $\begin{array}{l}\text { Comp } \\
3 \\
3 \\
\end{array}$ & $\begin{array}{l}\text { Consuetudines Compilatae } \\
\text { Handelaars } \\
\text { Verzekeraars }\end{array}$ \\
\hline 4.11 .292 & $\begin{array}{l}\text { Usus } \\
\text { Comp }\end{array}$ & $\begin{array}{l}\text { Usus } \\
\text { Consuetudines Compilatae }\end{array}$ \\
\hline $4.11 .293 / 294$ & $\begin{array}{l}\text { Usus } \\
\text { Comp }\end{array}$ & $\begin{array}{l}\text { Usus } \\
\text { Consuetudines Compilatae }\end{array}$ \\
\hline $4.11 .295 / 296 / 297$ & $\begin{array}{l}\text { Usus } \\
3 \\
\mathrm{~S} \\
\end{array}$ & $\begin{array}{l}\text { Usus } \\
\text { Experts } \\
\text { Specifieke reden } \\
\end{array}$ \\
\hline $4.11 .298 / 299$ & $\begin{array}{l}\text { RA } \\
\text { Comp }\end{array}$ & Ratio van ander artikel uit Consuetudines Compilatae \\
\hline 4.11 .300 & $\begin{array}{l}\text { Usus } \\
\text { RA } \\
\text { Comp }\end{array}$ & $\begin{array}{l}\text { Usus } \\
\text { Ratio van ander artikel uit Consuetudines Compilatae }\end{array}$ \\
\hline 4.11 .301 & $\begin{array}{l}\text { Usus } \\
\text { Comp }\end{array}$ & $\begin{array}{l}\text { Usus } \\
\text { Consuetudines Compilatae }\end{array}$ \\
\hline 4.11 .302 & Usus & Usus \\
\hline $4.11 .303 / 304$ & $\begin{array}{l}\text { Usus } \\
\text { RA } \\
\text { Comp }\end{array}$ & $\begin{array}{l}\text { Usus } \\
\text { Ratio van ander artikel uit Consuetudines Compilatae }\end{array}$ \\
\hline $4.11 .305 / 306$ & $\begin{array}{l}\text { Usus } \\
\text { Comp }\end{array}$ & $\begin{array}{l}\text { Usus } \\
\text { Consuetudines Compilatae }\end{array}$ \\
\hline
\end{tabular}


PRIMAIRE RECHTSBRONNEN CONSUETUDINES COMPILATAE

\begin{tabular}{|c|c|c|}
\hline 4.11 .307 & $\begin{array}{l}\text { Usus } \\
\text { eZR } \\
\mathrm{S}\end{array}$ & $\begin{array}{l}\text { Usus } \\
\text { Brugge } \\
\text { Specifieke reden }\end{array}$ \\
\hline 4.11 .308 & $\begin{array}{l}\text { Usus } \\
\text { RA } \\
\text { Comp }\end{array}$ & $\begin{array}{l}\text { Usus } \\
\text { Ratio van ander artikel uit Consuetudines Compilatae }\end{array}$ \\
\hline $4.11 .309 / 310$ & $\begin{array}{l}\text { Usus } \\
\text { Comp }\end{array}$ & $\begin{array}{l}\text { Usus } \\
\text { Consuetudines Compilatae }\end{array}$ \\
\hline $4.11 .311 / 312$ & $\begin{array}{l}\text { Usus } \\
\text { Comp }\end{array}$ & $\begin{array}{l}\text { Usus } \\
\text { Consuetudines Compilatae }\end{array}$ \\
\hline 4.11 .313 & iWGv & Ordonnantie Filips II: 20 januari 1570 \\
\hline 4.11 .314 & $\begin{array}{l}\text { Usus } \\
\text { Comp }\end{array}$ & $\begin{array}{l}\text { Usus } \\
\text { Consuetudines Compilatae }\end{array}$ \\
\hline 4.11 .315 & $\begin{array}{l}\text { iWGv } \\
\text { iWGv } \\
\text { eZR }\end{array}$ & $\begin{array}{l}\text { Ordonnantie Filips II: } 31 \text { oktober } 1563 \\
\text { Ordonnantie Filips II: } 20 \text { januari } 1570 \\
\text { Amsterdam }\end{array}$ \\
\hline $\begin{array}{l}4.11 .317 / 318 / 319 \\
/ 320 / 321 / 322 / 323\end{array}$ & $\begin{array}{l}\text { S } \\
\text { Usus } \\
\text { eZR }\end{array}$ & $\begin{array}{l}\text { Specifieke reden } \\
\text { Usus } \\
\text { Ordonnantie van Rouen/Guidon de la Mer }\end{array}$ \\
\hline
\end{tabular}

\begin{tabular}{|c|c|c|}
\hline \multicolumn{3}{|c|}{$\begin{array}{l}\text { titel } 12 \\
\text { van pantschappe }(14 / 36)\end{array}$} \\
\hline 4.12 .2 & $\begin{array}{l}\text { Usus } \\
\text { Comp }\end{array}$ & $\begin{array}{l}\text { Usus } \\
\text { Consuetudines Compilatae }\end{array}$ \\
\hline 4.12 .4 & $\begin{array}{l}\text { Ciciv } \\
\text { RA } \\
\text { Ciciv } \\
\text { RL }\end{array}$ & $\begin{array}{l}\text { 'Ex ratione iuris' } \\
\text { Corpus Iuris Civilis (Digestae) } \\
\text { Bartolo da Sassoferrato bij Digestae }\end{array}$ \\
\hline 4.12 .5 & $\begin{array}{l}\text { Usus } \\
\text { Ciciv } \\
\text { RL } \\
\text { RL } \\
\text { RL }\end{array}$ & $\begin{array}{l}\text { Usus } \\
\text { Corpus Iuris Civilis (Digestae) } \\
\text { Alessandro di Tartagni en alii doctores bij Digestae } \\
\text { Giovanni Sannazari della Ripa bij Digestae } \\
\text { Gabriel van der Muyden (Commentarii ad titulos Digestorum: pro socio, } \\
\text { de contrahenda emptione, de actionibus empti et venditi, de pignoribus et } \\
\text { bypothecis) } \\
\text { Pierre Rebuffi (Commentarii in constitutiones seu ordinationes regias) } \\
\text { Rechtspraak (Antwerpen) }\end{array}$ \\
\hline $4.12 .6 / 7$ & Usus & Usus \\
\hline 4.12 .8 & Ciciv & Corpus Iuris Civilis (Digestae) \\
\hline 4.12 .9 & Usus & Usus \\
\hline $4.12 .19 / 20$ & $\begin{array}{l}\text { OAR } \\
3 \\
\text { Ciciv } \\
\text { S } \\
\end{array}$ & $\begin{array}{l}\text { Consuetudines Impressae } \\
\text { Magistraat } \\
\text { Corpus Iuris Civilis (Digestae) } \\
\text { Specifieke reden }\end{array}$ \\
\hline 4.12 .21 & $\begin{array}{l}\text { Usus } \\
\text { RA } \\
\text { Comp }\end{array}$ & $\begin{array}{l}\text { Usus } \\
\text { Ratio van ander artikel uit Consuetudines Compilatae }\end{array}$ \\
\hline 4.12 .24 & Comp & Consuetudines Compilatae \\
\hline $4.12 .25 / 26$ & $\begin{array}{l}\text { Usus } \\
\text { Comp }\end{array}$ & $\begin{array}{l}\text { Usus } \\
\text { Consuetudines Compilatae }\end{array}$ \\
\hline 4.12 .33 & $\begin{array}{l}\text { Usus } \\
\text { Ciciv } \\
\text { RA }\end{array}$ & $\begin{array}{l}\text { Usus } \\
\text { 'Ex ratione iuris' }\end{array}$ \\
\hline
\end{tabular}




\begin{tabular}{|c|c|c|}
\hline & $\mathrm{S}$ & Specifieke reden \\
\hline \multicolumn{3}{|c|}{$\begin{array}{l}\text { titel } 13 \\
\text { van borchtocbten }(13 / 40)\end{array}$} \\
\hline $4.13 .1 / 2$ & $\begin{array}{l}\text { Usus } \\
\text { Ciciv }\end{array}$ & $\begin{array}{l}\text { Usus } \\
\text { Corpus Iuris Civilis (Digestae, Codex, Institutiones) }\end{array}$ \\
\hline 4.13 .4 & $\begin{array}{l}\text { OAR } \\
\text { Usus }\end{array}$ & $\begin{array}{l}\text { Consuetudines impressae } \\
\text { Usus }\end{array}$ \\
\hline 4.13 .6 & $\mathrm{~S}$ & Specifieke reden \\
\hline 4.13 .9 & $\begin{array}{l}\text { Usus } \\
\text { Comp } \\
\text { Ciciv } \\
\text { RL } \\
\text { RL }\end{array}$ & $\begin{array}{l}\text { Usus } \\
\text { Consuetudines Compilatae } \\
\text { Corpus Iuris Civilis (Digestae) } \\
\text { Jean Bacquet (Les cuvres de Jean Bacquet des droicts du domaine de la } \\
\text { couronne de France) } \\
\text { Diego Alvarado (Tractatus de coniecturata mente defuncti ad methodum } \\
\text { redigenda) }\end{array}$ \\
\hline $4.13 .12 / 13 / 14 / 15$ & $\mathrm{~S}$ & Specifieke reden \\
\hline 4.13 .35 & $\begin{array}{l}\text { Comp } \\
\text { Usus }\end{array}$ & $\begin{array}{l}\text { Consuetudines Compilatae } \\
\text { Usus }\end{array}$ \\
\hline $4.13 .38 / 39$ & RL & Doctores bij Digestae \\
\hline 4.13 .40 & Comp & Consuetudines Compilatae \\
\hline
\end{tabular}

\begin{tabular}{|c|c|c|}
\hline \multicolumn{3}{|c|}{$\begin{array}{l}\text { titel } 14 \\
\text { van handvullinge oft namptisatie }(6 / 25)\end{array}$} \\
\hline 4.14 .6 & S & $\begin{array}{l}\text { Specifieke reden } \\
\text { Consuetudines Compilatae }\end{array}$ \\
\hline 4.14 .12 & $\begin{array}{l}\text { iWGs } \\
\text { Comp }\end{array}$ & $\begin{array}{l}\text { Ordonnantie Stijl en manier van procederen: } 1582 \\
\text { Consuetudines Compilatae }\end{array}$ \\
\hline 4.14 .21 & $\begin{array}{l}\text { RA } \\
\text { Comp } \\
\text { iWGs }\end{array}$ & $\begin{array}{l}\text { Ratio van ander artikel uit Consuetudines Compilatae } \\
\text { Consuetudines Compilatae } \\
\text { Ordonnantie Stijl en manier van procederen: } 1582\end{array}$ \\
\hline $4.14 .23 / 24$ & $\begin{array}{l}\text { iWGs } \\
\text { RA } \\
\text { Comp }\end{array}$ & $\begin{array}{l}\text { Ordonnantie Stijl en manier van procederen: } 1582 \\
\text { Ratio van ander artikel uit Consuetudines Compilatae }\end{array}$ \\
\hline 4.14 .25 & Comp & Consuetudines Compilatae \\
\hline
\end{tabular}

\begin{tabular}{|l|l|l|}
\hline \multicolumn{3}{|l|}{$\begin{array}{l}\text { titel 15 } \\
\text { van betaelinge, bewijsinge, compensatie, etc. (17/28) }\end{array}$} \\
\hline $4.15 .1 / 2$ & iWGv & Plakkaat Aartshertogen: 25 juni 1605 \\
\hline 4.15 .3 & iWGv & Plakkaat Aartshertogen: 25 juni 1605 \\
\hline 4.15 .7 & Usus & Usus \\
\hline 4.15 .9 & S & Specifieke reden \\
\hline 4.15 .10 & Usus & Usus \\
\hline $4.15 .12 / 13$ & RA & Ratio van ander artikel uit Consuetudines Compilatae \\
& Comp & \\
\hline 4.15 .14 & Usus & Gebruiken van de handelaars \\
\hline $4.15 .15 / 16$ & Ciciv & 'Ex ratione iuris' \\
& RA & \\
& Usus & Usus \\
\hline $4.15 .19 / 20$ & Usus & Usus \\
& Ciciv & 'Ex ratione iuris' (Digestae) \\
& RA & Pierre Coustau bij Digestae \\
& RL & Pis \\
\end{tabular}


PRIMAIRE RECHTSBRONNEN CONSUETUDINES COMPILATAE

\begin{tabular}{|l|l|l|}
\hline 4.15 .22 & Comp & Consuetudines Compilatae \\
\hline 4.15 .25 & $\begin{array}{l}\text { RA } \\
\text { Comp }\end{array}$ & Ratio van ander artikel uit Consuetudines Compilatae \\
\hline 4.15 .27 & $\begin{array}{l}\text { RA } \\
\text { Comp }\end{array}$ & Ratio van ander artikel uit Consuetudines Compilatae \\
\hline 4.15 .28 & S & Specifieke reden \\
\hline
\end{tabular}

\begin{tabular}{|c|c|c|}
\hline \multicolumn{3}{|c|}{$\begin{array}{l}\text { titel } 16 \\
\text { van gebroken schuldenaers }(54 / 91)\end{array}$} \\
\hline 4.16 .5 & S & Specifieke reden \\
\hline $4.16 .6 / 7$ & $\begin{array}{l}\mathrm{S} \\
\mathrm{eWG} \\
3\end{array}$ & $\begin{array}{l}\text { Specifieke reden } \\
\text { Wetgeving Genua: Statuten } 1589 \\
\text { Magistraat }\end{array}$ \\
\hline 4.16 .8 & OAR & Guldenboeck \\
\hline $4.16 .9 / 10$ & $\begin{array}{l}\mathrm{iWGv} \\
\mathrm{iWGV}\end{array}$ & $\begin{array}{l}\text { Ordonnantie Karel V: } 7 \text { oktober } 1531 \\
\text { Ordonnantie Karel V: } 4 \text { oktober } 1540\end{array}$ \\
\hline 4.16 .11 & $\mathrm{~S}$ & Specifieke reden \\
\hline $4.16 .18 / 19$ & $\begin{array}{l}\text { eWG } \\
3\end{array}$ & $\begin{array}{l}\text { Wetgeving Genua: Statuten } 1589 \\
\text { Magistraat }\end{array}$ \\
\hline 4.16 .22 & $\begin{array}{l}\text { OAR } \\
\text { OAR }\end{array}$ & $\begin{array}{l}\text { Consuetudines Antiquae } \\
\text { Consuetudines Antiquissimae }\end{array}$ \\
\hline 4.16 .24 & $\begin{array}{l}\text { Ciciv } \\
\mathrm{RL}\end{array}$ & $\begin{array}{l}\text { Corpus Iuris Civilis (Digestae) } \\
\text { Doctores bij Digestae }\end{array}$ \\
\hline 4.16 .25 & OAR & Guldenboeck. \\
\hline 4.16 .27 & Ciciv & Corpus Iuris Civilis (Digestae) \\
\hline 4.16 .29 & $\begin{array}{l}\text { Ciciv } \\
\text { eWG }\end{array}$ & $\begin{array}{l}\text { 'Ex iure scripto' } \\
\text { Wetgeving Genua: Statuten } 1589\end{array}$ \\
\hline $4.16 .30 / 31$ & OAR & Consuetudines Antiquissimae \\
\hline $4.16 .32 / 33$ & $\begin{array}{l}\text { OAR } \\
3\end{array}$ & $\begin{array}{l}\text { Consuetudines Antiquissimae } \\
\text { Magistraat }\end{array}$ \\
\hline 4.16 .34 & Usus & Usus \\
\hline $4.16 .35 / 36 / 37$ & $\begin{array}{l}\text { Usus } \\
3 \\
\text { Usus }\end{array}$ & $\begin{array}{l}\text { Usus } \\
\text { Handelaars } \\
\text { Gebruiken van de Beurs van Antwerpen }\end{array}$ \\
\hline 4.16 .38 & iWGv & 'Ex mente placitorum' \\
\hline 4.16 .40 & $\begin{array}{l}\text { eWG } \\
3\end{array}$ & $\begin{array}{l}\text { Wetgeving Genua: Statuten } 1589 \\
\text { Magistraat }\end{array}$ \\
\hline 4.16 .41 & Usus & Usus \\
\hline 4.16 .42 & Usus & Usus \\
\hline $4.16 .43 / 44 / 45$ & $\begin{array}{l}\text { Usus } \\
\text { RA } \\
\text { Comp }\end{array}$ & $\begin{array}{l}\text { Usus } \\
\text { Ratio van ander artikel uit Consuetudines Compilatae }\end{array}$ \\
\hline 4.16 .46 & iWGs & Statuut Fugitiven: 1515 \\
\hline $4.16 .47 / 48$ & $\begin{array}{l}\text { iWGs } \\
\text { iWGV }\end{array}$ & $\begin{array}{l}\text { Statuut Fugitiven: } 1515 \\
\text { Ordonnantie Karel V: } 7 \text { oktober } 1531\end{array}$ \\
\hline 4.16 .49 & $\begin{array}{l}\text { RA } \\
\text { Comp }\end{array}$ & Ratio van ander artikel uit Consuetudines Compilatae \\
\hline 4.16 .50 & RA & Ratio \\
\hline 4.16 .51 & $\mathrm{~S}$ & Specifieke reden \\
\hline 4.16 .62 & Usus & Usus \\
\hline 4.16 .63 & $\begin{array}{l}\text { Usus } \\
\mathrm{RS} \\
\text { Comp }\end{array}$ & $\begin{array}{l}\text { Usus } \\
\text { Rechtspraak (Raad van Brabant) } \\
\text { Consuetudines Compilatae }\end{array}$ \\
\hline
\end{tabular}




\begin{tabular}{|l|l|l|}
\hline 4.16 .65 & Usus & Usus \\
& RS & Rechtspraak (Raad van Brabant) \\
\hline $4.16 .67 / 68$ & 3 & Handelaars \\
& S & Specifieke reden \\
\hline $4.16 .73 / 74 / 75 / 76 / 77$ & RA & Ratio \\
& Comp & Consuetudines Compilatae \\
& 3 & Magistraat \\
& Usus & Usus \\
\hline $4.16 .79 / 80$ & RA & Ratio \\
\hline $4.16 .84 / 85$ & S & Specifieke reden \\
& 3 & Magistraat \\
\hline 4.16 .87 & iWGs & Statuut: 1518 \\
\hline $4.16 .88 / 89 / 90 / 91$ & S & Specifieke reden \\
\hline
\end{tabular}

\begin{tabular}{|c|c|c|}
\hline \multicolumn{3}{|c|}{$\begin{array}{l}\text { titel } 17 \\
\text { van brieven van respijt oft unijtstel van betaelinge, ende van cessie }(21 / 25\end{array}$} \\
\hline $4.17 .2 / 3$ & $\begin{array}{l}\mathrm{S} \\
3\end{array}$ & $\begin{array}{l}\text { Specifieke reden } \\
\text { Magistraat }\end{array}$ \\
\hline $4.17 .4 / 5$ & iWGp & Albertine Ordonnantie: 13 april 1604 \\
\hline $4.17 .6 / 7 / 8 / 9$ & iWGp & Albertine Ordonnantie: 13 april 1604 \\
\hline 4.17 .10 & Comp & Consuetudines Compilatae \\
\hline 4.17 .11 & Usus & Usus \\
\hline $4.17 .12 / 13 / 14 / 15$ & $\begin{array}{l}\text { iWGp } \\
\text { Ciciv }\end{array}$ & $\begin{array}{l}\text { Albertine Ordonnantie: } 13 \text { april } 1604 \\
\text { 'Ex iure scripto' }\end{array}$ \\
\hline $4.17 .18 / 19 / 20$ & $\begin{array}{l}\text { iWGv } \\
\text { iWGv }\end{array}$ & $\begin{array}{l}\text { Plakkaat Karel V: } 7 \text { maart } 1537 \text { (n.s.) }{ }^{1396} \\
\text { Plakkaat Karel V: } 8 \text { november } 1541\end{array}$ \\
\hline 4.17 .22 & $\begin{array}{l}\text { iWGv } \\
\text { OAR }\end{array}$ & $\begin{array}{l}\text { Plakkaat Karel V: } 8 \text { november } 1541 \\
\text { Consuetudines Antiquissimae }\end{array}$ \\
\hline $4.17 .23 / 24$ & iWGv & Plakkaat Karel V: 7 maart 1537 (n.s.) \\
\hline 4.17 .25 & $\begin{array}{l}\mathrm{S} \\
\mathrm{RSi}\end{array}$ & $\begin{array}{l}\text { Specifieke reden } \\
\text { Turbe }\end{array}$ \\
\hline
\end{tabular}

\begin{tabular}{|l|l|l|}
\hline \multicolumn{3}{|l|}{$\begin{array}{l}\text { titel 18 } \\
\text { van voordeel oft preferentie onder }\end{array}$} \\
\hline 4.18 .2 & $\mathrm{RL}$ & Benvenuto Stracca (De Mercatura seu mercatore Tractatus) \\
& $\mathrm{RL}$ & Jacques Cujas (Observationum et emendationum) \\
\hline $4.18 .3 / 4$ & $\begin{array}{l}\text { Usus } \\
\mathrm{RSi}\end{array}$ & $\begin{array}{l}\text { Usus } \\
\text { Rechtspraak (Antwerpen) }\end{array}$ \\
\hline 4.18 .5 & Comp & Consuetudines Compilatae \\
\hline $4.18 .6 / 7$ & $\mathrm{eWG}$ & Wetgeving Genua: Statuten 1589 \\
\hline 4.18 .8 & $\mathrm{RA}$ & Aequitas \\
\hline 4.18 .9 & Ciciv & Corpus Iuris Civilis (Codex, Digestae) \\
\hline 4.18 .10 & $\mathrm{RL}$ & $\begin{array}{l}\text { Alessandro di Tartagni (Consilia) } \\
\text { Aimone Cravetta (Consilia) }\end{array}$ \\
& $\mathrm{RL}$ & $\begin{array}{l}\text { Borgnino Cavalcani (Tractatus de tutore et curatore ac usufructu mulieri } \\
\text { relicto) } \\
\text { Magistraat }\end{array}$ \\
\hline 4.18 .11 & $\mathrm{RL}$ & Consuetudines Compilatae \\
\hline 4.18 .13 & 3 & Ratio van ander artikel uit Consuetudines Compilatae \\
& Comp \\
\hline
\end{tabular}

${ }^{1396}$ De Memorieboeken spreken, conform de oude jaarstijl, van 1536. 
PRIMAIRE RECHTSBRONNEN CONSUETUDINES COMPILATAE

\begin{tabular}{|c|c|c|}
\hline & Usus & Usus \\
\hline 4.18 .14 & $\begin{array}{l}\text { Ciciv } \\
\text { RL } \\
\text { OAR }\end{array}$ & $\begin{array}{l}\text { Corpus Iuris Civilis (Codex) } \\
\text { Antonio Negusanzio de Fano (Tractatus perutilis de pignoribus et } \\
\text { bypothecis) } \\
\text { Consuetudines Antiquissimae }\end{array}$ \\
\hline 4.18 .18 & $\mathrm{O}$ & Onduidelijk \\
\hline 4.18 .19 & $\begin{array}{l}\text { Usus } \\
\text { RSp } \\
\text { OAR }\end{array}$ & $\begin{array}{l}\text { Usus } \\
\text { Rechtspraak (Grote Raad van Mechelen, Raad van Vlaanderen, } \\
\text { Raad van Brabant) } \\
\text { Procuratieboek }{ }^{1397}\end{array}$ \\
\hline$(4.18 .20)$ & Ciciv & 'Reliqua sunt etiam notorii iuris' \\
\hline 4.18 .34 & Comp & Consuetudines Compilatae \\
\hline 4.18 .35 & $\begin{array}{l}\text { iWG } \\
\text { Comp }\end{array}$ & $\begin{array}{l}\text { 'Nieune ordonnantie van 1593' } \\
\text { Consuetudines Compilatae }\end{array}$ \\
\hline 4.18 .36 & $\begin{array}{l}\text { Ciciv } \\
\text { RA }\end{array}$ & $\begin{array}{l}\text { 'In iure et ratione fundatus' } \\
\text { Ratio }\end{array}$ \\
\hline $4.18 .38 / 39$ & $\mathrm{~S}$ & Specifieke reden \\
\hline 4.18 .44 & $\begin{array}{l}\text { RA } \\
\text { Comp }\end{array}$ & Ratio van ander artikel uit Consuetudines Compilatae \\
\hline 4.18 .45 & $\begin{array}{l}\text { Usus } \\
\text { RA }\end{array}$ & $\begin{array}{l}\text { Usus } \\
\text { Ratio }\end{array}$ \\
\hline 4.18 .48 & Comp & Consuetudines Compilatae \\
\hline 4.18 .53 & $\mathrm{~S}$ & Specifieke reden \\
\hline 4.18 .57 & $\mathrm{~S}$ & Specifieke reden \\
\hline 4.18 .58 & RA & Ratio \\
\hline 4.18 .59 & $\begin{array}{l}\text { Ciciv } \\
\text { RL } \\
\text { RL } \\
\text { RL }\end{array}$ & $\begin{array}{l}\text { Corpus Iuris Civilis (Digestae) } \\
\text { Giovanni Sannazari della Ripa bij Digestae } \\
\text { Baldus de Ubaldis bij Codex } \\
\text { Bartolo da Sassoferrato bij Digestae }\end{array}$ \\
\hline $4.18 .64 / 65 / 66$ & $\begin{array}{l}\mathrm{S} \\
3\end{array}$ & $\begin{array}{l}\text { Specifieke reden } \\
\text { Magistraat }\end{array}$ \\
\hline 4.18 .69 & $\mathrm{~V}$ & 'Ex certificatione schabinali' \\
\hline 4.18 .71 & $\begin{array}{l}\text { Ciciv } \\
\text { RL }\end{array}$ & $\begin{array}{l}\text { Corpus Iuris Civilis (Codex) } \\
\text { Jean Favre bij Codex }\end{array}$ \\
\hline 4.18 .72 & Ciciv & Corpus Iuris Civilis (Digestae) \\
\hline 4.18 .73 & Usus & Usus \\
\hline $4.18 .74 / 75$ & Usus & Usus \\
\hline 4.18 .76 & $\begin{array}{l}\text { Usus } \\
\text { iWGs } \\
\text { iWGs } \\
\text { RL } \\
\text { RL }\end{array}$ & $\begin{array}{l}\text { Usus } \\
\text { Statuut Fugitiven: } 1515 \\
\text { Statuut Fugitiven: } 1518 \\
\text { Matthias Wesenbeeck (Consilia) } \\
\text { Géraud de Maynard (Notables et singulières questions du droict escrit } \\
\text { décises ou préjugées par arrests mémorables de la Cour souveraine de Tholose) }\end{array}$ \\
\hline $4.18 .77 / 78$ & $\begin{array}{l}\text { Ciciv } \\
\mathrm{S}\end{array}$ & $\begin{array}{l}\text { 'Ex iure scripto' } \\
\text { Specifieke reden }\end{array}$ \\
\hline
\end{tabular}

1397 ANTWERPEN, Stadsarchief, Vierschaer, nrs. 1433-1449. 
Deel V

$V$ an de maniere van borgerlijcke rechtvoorderinge oft civile procedure. (17 titels, 691 artikels, waarvan 310 nieuw)

\begin{tabular}{|c|c|c|}
\hline 5.1 .1 & $\mathrm{~V}$ & Varia: noch primaire, noch secundaire bronnen \\
\hline 5.1 .4 & Usus & Usus \\
\hline $\begin{array}{l}\text { Art insert tussen } \\
{[5.1 .5] \text { en [5.1.6] }}\end{array}$ & $\mathrm{S}$ & Specifieke reden \\
\hline 5.1 .22 & $\begin{array}{l}\text { iWGs } \\
\text { iWGs }\end{array}$ & $\begin{array}{l}\text { Ordonnantie Stijl en manier van procederen: } 1582 \\
\text { Ordonnantie Stijl en manier van procederen: } 1564\end{array}$ \\
\hline 5.1 .23 & iWGs & Ordonnantie Stijl en manier van procederen: 1582 \\
\hline $5.1 .29 / 30$ & $\mathrm{~S}$ & Specifieke reden \\
\hline 5.1 .31 & iWGs & Ordonnantie Stijl en manier van procederen: 1582 \\
\hline 5.1 .32 & $\begin{array}{l}\text { iWGs } \\
\text { Usus }\end{array}$ & $\begin{array}{l}\text { Ordonnantie Stijl en manier van procederen: } 1582 \\
\text { Usus }\end{array}$ \\
\hline $5.1 .33 / 34$ & iWGs & Ordonnantie Stijl en manier van procederen: 1582 \\
\hline 5.1 .35 & iWGs & Ordonnantie Stijl en manier van procederen: 1582 \\
\hline 5.1 .36 & $\begin{array}{l}\mathrm{iWGs} \\
\mathrm{iWG}\end{array}$ & $\begin{array}{l}\text { Ordonnantie Stijl en manier van procederen: } 1582 \\
\text { Ordonnantie: } 1 \text { oktober } 1601\end{array}$ \\
\hline 5.1 .37 & iWGs & Ordonnantie Stijl en manier van procederen: 1582 \\
\hline 5.1 .38 & $\begin{array}{l}\text { iWGs } \\
\text { iWGs } \\
3\end{array}$ & $\begin{array}{l}\text { Ordonnantie Stijl en manier van procederen: } 1582 \\
\text { Ordonnantie Stijl en manier van procederen: } 1564 \\
\text { Magistraat }\end{array}$ \\
\hline 5.1 .39 & $\begin{array}{l}\mathrm{iWGs} \\
\mathrm{iWGs}\end{array}$ & $\begin{array}{l}\text { Ordonnantie Stijl en manier van procederen: } 1582 \\
\text { Ordonnantie Stijl en manier van procederen: } 1564\end{array}$ \\
\hline 5.1 .40 & $\begin{array}{l}\text { RSi } \\
\text { iWG } \\
\text { eGR }\end{array}$ & $\begin{array}{l}\text { Rechtspraak (Antwerpen) } \\
\text { 'Explerisque statutis' } \\
\text { Costuymen van Brussel, Costuymen van Mechelen }\end{array}$ \\
\hline $5.1 .41 / 42$ & iWGs & Ordonnantie Stijl en manier van procederen: 1582 \\
\hline $\begin{array}{l}5.1 .43 / 44 / 45 / 46 / 47 \\
/ 48 / 49\end{array}$ & Comp & Consuetudines Compilatae \\
\hline 5.1 .50 & $\begin{array}{l}\text { iWGs } \\
\text { Comp }\end{array}$ & $\begin{array}{l}\text { Ordonnantie Stijl en manier van procederen: } 1582 \\
\text { Consuetudines Compilatae }\end{array}$ \\
\hline 5.1 .51 & $\begin{array}{l}\text { RSi } \\
\text { Comp }\end{array}$ & $\begin{array}{l}\text { Rechtspraak (Antwerpen) } \\
\text { Consuetudines Compilatae }\end{array}$ \\
\hline $5.1 .52 / 53 / 54$ & iWGs & Ordonnantie Stijl en manier van procederen: 1582 \\
\hline 5.1 .55 & iWGs & Ordonnantie: 24 oktober 1592 \\
\hline 5.1 .56 & iWGs & Ordonnantie Stijl en manier van procederen: 1582 \\
\hline $5.1 .57 / 58 / 59$ & iWGs & Ordonnantie Stijl en manier van procederen: 1582 \\
\hline $5.1 .60 / 61 / 62$ & iWGs & Ordonnantie Stijl en manier van procederen: 1582 \\
\hline 5.1 .63 & iWGs & Ordonnantie Stijl en manier van procederen: 1582 \\
\hline 5.1 .64 & iWGs & Ordonnantie Stijl en manier van procederen: 1582 \\
\hline 5.1 .68 & iWGs & Ordonnantie Stijl en manier van procederen: 1582 \\
\hline $5.1 .69 / 70$ & $\begin{array}{l}\text { Usus } \\
\text { Comp }\end{array}$ & $\begin{array}{l}\text { Usus } \\
\text { Consuetudines Compilatae }\end{array}$ \\
\hline 5.1 .71 & $\begin{array}{l}\text { Usus } \\
\text { iWGp } \\
\text { S }\end{array}$ & $\begin{array}{l}\text { Usus } \\
\text { Albertine Ordonnantie: } 13 \text { april } 1604 \\
\text { Specifieke reden }\end{array}$ \\
\hline $5.1 .72 / 73$ & iWGs & Ordonnantie: 24 oktober 1592 \\
\hline 5.1 .74 & iWGs & Ordonnantie: 24 oktober 1592 \\
\hline
\end{tabular}


PRIMAIRE RECHTSBRONNEN CONSUETUDINES COMPILATAE

\begin{tabular}{|l|l|l|}
\hline 5.1 .75 & Usus & Usus \\
& $\mathrm{S}$ & Specifieke reden \\
\hline 5.1 .76 & iWGs & Ordonnantie Stijl en manier van procederen: 1582 \\
& iWGs & Ordonnantie Stijl en manier van procederen: 1564 \\
& Comp & Consuetudines Compilatae \\
\hline
\end{tabular}

\begin{tabular}{|l|l|l|}
\hline $\begin{array}{l}\text { titel } 2 \\
\text { van aenleggeren ende verweerderen }\end{array}$ & $(3 / 4)$ \\
\hline 5.2 .1 & S & Specifieke reden \\
\hline 5.2 .2 & Comp & Consuetudines Compilatae \\
\hline 5.2 .4 & $\begin{array}{l}\text { iWGs } \\
\text { Ciciv }\end{array}$ & $\begin{array}{l}\text { Ordonnantie Stijl en manier van procederen: } 1582 \\
\text { 'Ex iure scripto' }\end{array}$ \\
\hline
\end{tabular}

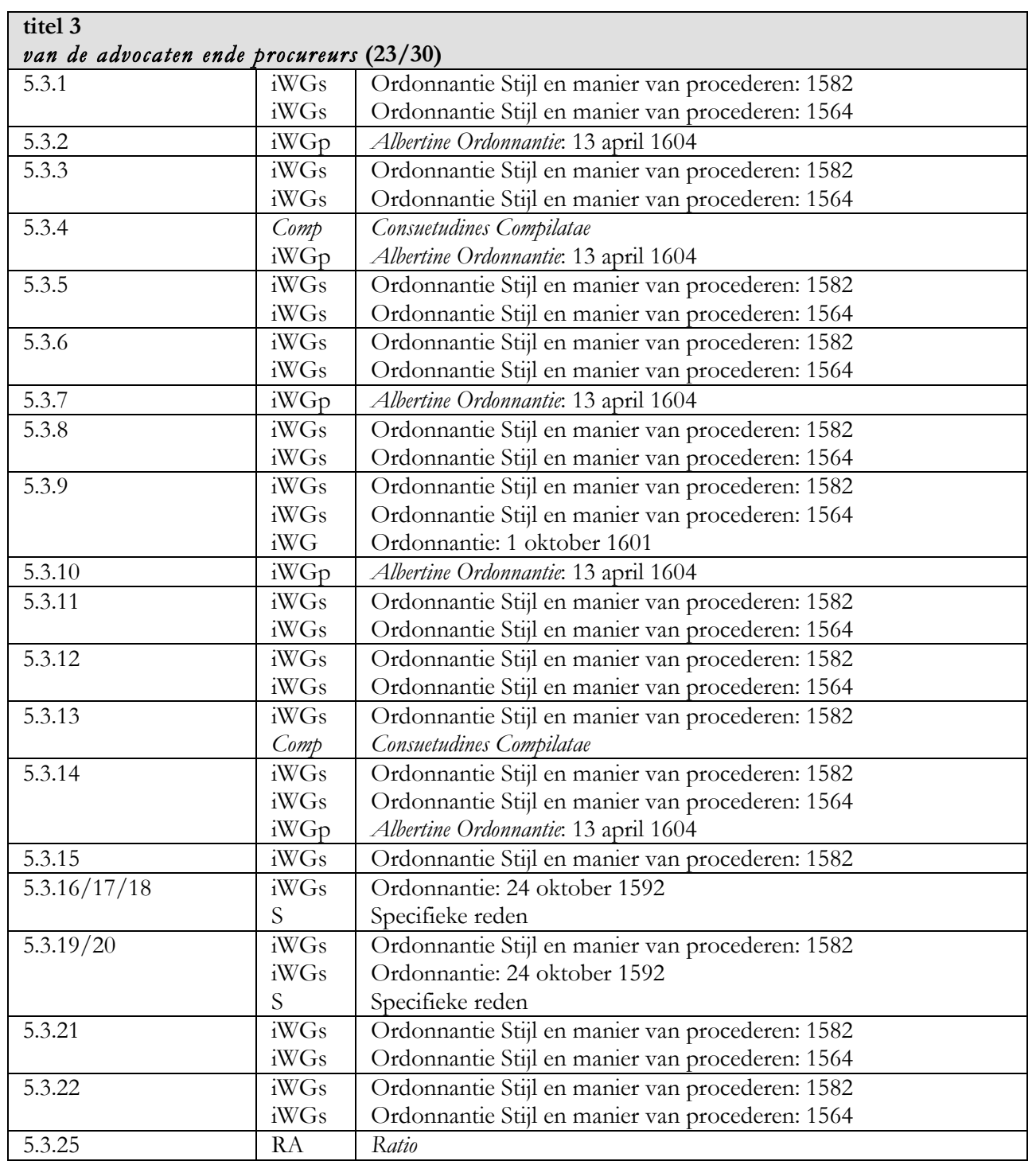






titel 5

van beschrijffbrieven $(0 / 8)$

\begin{tabular}{|c|c|c|}
\hline $\begin{array}{l}\text { titel } 6 \\
\text { van } u \text { u }\end{array}$ & /30) & \\
\hline $5.6 .6 / 7$ & OAR & Consuetudines Antiquissimae \\
\hline
\end{tabular}

\begin{tabular}{|l|}
\hline titel 7 \\
van ammans brieven $(0 / 33)$ \\
\hline
\end{tabular}

\begin{tabular}{|l|l|l|}
\hline $\begin{array}{l}\text { titel } \mathbf{8} \\
\text { van arresteringe ende }\end{array}$ & \multicolumn{2}{l|}{ aentastinge van persoonen om civile saecken $(6 / 57)$} \\
\hline 5.8 .3 & $\mathrm{~S}$ & Specifieke reden \\
\hline $\begin{array}{l}3 \text { articulos omissos positos } \\
\text { ad finem tituli }\end{array}$ & $\mathrm{S}$ & Specifieke reden \\
\hline 5.8 .42 & $\mathrm{RA}$ & $\begin{array}{l}\text { Ratio } \\
\text { Specifieke reden }\end{array}$ \\
\hline 5.8 .47 & $\mathrm{~S}$ & $\begin{array}{l}\text { Usus } \\
\text { Consuetudines Compilatae }\end{array}$ \\
\hline
\end{tabular}

\begin{tabular}{|l|l|l|}
\hline \multicolumn{2}{|l|}{$\begin{array}{l}\text { titel } 9 \\
\text { van arresten van goeden ende vervolch der selver } \mathbf{( 1 8 / 9 5 )}\end{array}$} \\
\hline 5.9 .6 & Comp & Consuetudines Compilatae \\
\hline 5.9 .11 & RA \\
Comp & Ratio van ander artikel uit Consuetudines Compilatae \\
\hline $5.9 .13 / 14$ & S & Specifieke reden \\
\hline 5.9 .57 & Comp & Consuetudines Compilatae \\
\hline 5.9 .62 & Comp & Consuetudines Compilatae \\
\hline $5.9 .64 / 65 / 66 / 67 / 68$ & S & Specifieke reden \\
\hline
\end{tabular}


PRIMAIRE RECHTSBRONNEN CONSUETUDINES COMPILATAE

\begin{tabular}{|l|l|l|}
\hline$/ 69$ & 3 & Amptman \\
\hline 5.9 .83 & $\mathrm{~S}$ & Specifieke reden \\
\hline 5.9 .84 & $\mathrm{~S}$ & Specifieke reden \\
\hline 5.9 .85 & $\mathrm{~S}$ & Specifieke reden \\
\hline $5.9 .89 / 90$ & $\mathrm{O}$ & Onduidelijk \\
\hline 5.9 .93 & Comp & Consuetudines Compilatae \\
\hline
\end{tabular}

\begin{tabular}{|c|c|c|}
\hline \multicolumn{3}{|c|}{$\begin{array}{l}\text { titel } 10 \\
\text { van de maniere ende forme van procederen }(72 / 79)\end{array}$} \\
\hline 5.10 .1 & $\begin{array}{l}\text { iWGs } \\
\text { iWGs }\end{array}$ & $\begin{array}{l}\text { Ordonnantie Stijl en manier van procederen: } 1582 \\
\text { Ordonnantie Stijl en manier van procederen: } 1564\end{array}$ \\
\hline $5.10 .2 / 3$ & $\begin{array}{l}\mathrm{iWGv} \\
3\end{array}$ & $\begin{array}{l}\text { Criminele ordonnantiën Filips II: } 1570 \\
\text { Magistraat }\end{array}$ \\
\hline 5.10 .4 & $\begin{array}{l}\text { Comp } \\
\mathrm{S}\end{array}$ & $\begin{array}{l}\text { Consuetudines Compilatae } \\
\text { Specifieke reden }\end{array}$ \\
\hline 5.10 .5 & $\begin{array}{l}\mathrm{iWGs} \\
\mathrm{iWGs}\end{array}$ & $\begin{array}{l}\text { Ordonnantie Stijl en manier van procederen: } 1582 \\
\text { Ordonnantie Stijl en manier van procederen: } 1564\end{array}$ \\
\hline 5.10 .6 & $\begin{array}{l}\text { iWGs } \\
\text { iWGs } \\
\text { S } \\
\text { RA }\end{array}$ & $\begin{array}{l}\text { Ordonnantie Stijl en manier van procederen: } 1582 \\
\text { Ordonnantie Stijl en manier van procederen: } 1564 \\
\text { Specifieke reden } \\
\text { Ratio }\end{array}$ \\
\hline $5.10 .7 / 8$ & iWGs & Ordonnantie: 24 oktober 1592 \\
\hline 5.10 .9 & $\begin{array}{l}\text { iWGs } \\
\text { iWGs }\end{array}$ & $\begin{array}{l}\text { Ordonnantie Stijl en manier van procederen: } 1582 \\
\text { Ordonnantie Stijl en manier van procederen: } 1564\end{array}$ \\
\hline 5.10 .10 & Comp & Consuetudines Compilatae \\
\hline 5.10 .11 & $\begin{array}{l}\text { iWGs } \\
\text { iWGs } \\
\text { Ciciv } \\
\text { RL }\end{array}$ & $\begin{array}{l}\text { Ordonnantie Stijl en manier van procederen: } 1582 \\
\text { Ordonnantie Stijl en manier van procederen: } 1564 \\
\text { Corpus Iuris Civilis (Digestae) } \\
\text { Joachim Mynsinger von Frundeck (Singularium observationum iudicii } \\
\text { imperialis camerae) }\end{array}$ \\
\hline 5.10 .12 & $\begin{array}{l}\text { iWGs } \\
\text { iWGs } \\
3 \\
\text { Ciciv }\end{array}$ & $\begin{array}{l}\text { Ordonnantie Stijl en manier van procederen: } 1582 \\
\text { Ordonnantie Stijl en manier van procederen: } 1564 \\
\text { Magistraat } \\
\text { Corpus Iuris Civilis (Digestae, Novellae Constitutiones) }\end{array}$ \\
\hline 5.10 .13 & Comp & Consuetudines Compilatae \\
\hline 5.10 .14 & iWGp & Albertine Ordonnantie: 13 april 1604 \\
\hline 5.10 .15 & $\begin{array}{l}\text { iWGs } \\
\text { iWGs }\end{array}$ & $\begin{array}{l}\text { Ordonnantie Stijl en manier van procederen: } 1582 \\
\text { Ordonnantie Stijl en manier van procederen: } 1564\end{array}$ \\
\hline 5.10 .17 & $\begin{array}{l}\text { iWGs } \\
\text { iWGs }\end{array}$ & $\begin{array}{l}\text { Ordonnantie Stijl en manier van procederen: } 1582 \\
\text { Ordonnantie Stijl en manier van procederen: } 1564\end{array}$ \\
\hline 5.10 .18 & $\begin{array}{l}\mathrm{iWGs} \\
\mathrm{iWGs}\end{array}$ & $\begin{array}{l}\text { Ordonnantie Stijl en manier van procederen: } 1582 \\
\text { Ordonnantie Stijl en manier van procederen: } 1564\end{array}$ \\
\hline 5.10 .21 & $\begin{array}{l}\text { iWGs } \\
\text { iWGs }\end{array}$ & $\begin{array}{l}\text { Ordonnantie Stijl en manier van procederen: } 1582 \\
\text { Ordonnantie Stijl en manier van procederen: } 1564\end{array}$ \\
\hline 5.10 .22 & $\begin{array}{l}\text { iWGs } \\
\text { iWGs } \\
\text { S }\end{array}$ & $\begin{array}{l}\text { Ordonnantie Stijl en manier van procederen: } 1582 \\
\text { Ordonnantie Stijl en manier van procederen: } 1564 \\
\text { Specifieke reden }\end{array}$ \\
\hline 5.10 .23 & iWGs & Ordonnantie: 24 oktober 1592 \\
\hline 5.10 .24 & $\begin{array}{l}\text { iWGs } \\
\text { Usus }\end{array}$ & $\begin{array}{l}\text { Ordonnantie Stijl en manier van procederen: } 1564 \\
\text { Usus }\end{array}$ \\
\hline 5.10 .25 & iWGs & Ordonnantie: 24 oktober 1592 \\
\hline 5.10 .26 & $\begin{array}{l}\text { iWGs } \\
\text { iWGs }\end{array}$ & $\begin{array}{l}\text { Ordonnantie Stijl en manier van procederen: } 1582 \\
\text { Ordonnantie Stijl en manier van procederen: } 1564\end{array}$ \\
\hline
\end{tabular}




\begin{tabular}{|c|c|c|}
\hline 5.10 .27 & iWGp & Albertine Ordonnantie: 13 april 1604 \\
\hline 5.10 .28 & $\begin{array}{l}\text { iWGs } \\
\text { iWGs } \\
\text { Comp }\end{array}$ & $\begin{array}{l}\text { Ordonnantie Stijl en manier van procederen: } 1582 \\
\text { Ordonnantie Stijl en manier van procederen: } 1564 \\
\text { Consuetudines Compilatae }\end{array}$ \\
\hline 5.10 .29 & $\begin{array}{l}\mathrm{iWGs} \\
\mathrm{iWGs}\end{array}$ & $\begin{array}{l}\text { Ordonnantie Stijl en manier van procederen: } 1582 \\
\text { Ordonnantie Stijl en manier van procederen: } 1564\end{array}$ \\
\hline $5.10 .30 / 31$ & $\begin{array}{l}\text { iWGs } \\
\text { iWGs }\end{array}$ & $\begin{array}{l}\text { Ordonnantie Stijl en manier van procederen: } 1582 \\
\text { Ordonnantie Stijl en manier van procederen: } 1564\end{array}$ \\
\hline 5.10 .32 & iWGp & Albertine Ordonnantie: 13 april 1604 \\
\hline $5.10 .33 / 34$ & $\begin{array}{l}\text { iWGs } \\
\text { iWGs } \\
\text { S } \\
\text { RL } \\
\text { RL }\end{array}$ & $\begin{array}{l}\text { Ordonnantie Stijl en manier van procederen: } 1582 \\
\text { Ordonnantie Stijl en manier van procederen: } 1564 \\
\text { Specifieke reden } \\
\text { Jean Imbert (Institutiones forenses) } \\
\text { Louis le Caron (Annotationes op Somme rural van Jean Boutillier) }\end{array}$ \\
\hline $5.10 .35 / 36$ & $\begin{array}{l}\text { iWGs } \\
\text { iWGs } \\
\text { iWGp }\end{array}$ & $\begin{array}{l}\text { Ordonnantie Stijl en manier van procederen: } 1582 \\
\text { Ordonnantie Stijl en manier van procederen: } 1564 \\
\text { Albertine Ordonnantie: } 13 \text { april } 1604\end{array}$ \\
\hline $5.10 .37 / 38$ & $\begin{array}{l}\text { RL } \\
\text { RL }\end{array}$ & $\begin{array}{l}\text { Jean Imbert (Institutiones forenses) } \\
\text { Louis le Caron (Annotationes op Somme rural van Jean Boutillier) }\end{array}$ \\
\hline $5.10 .39 / 40 / 41$ & $\begin{array}{l}\text { iWGs } \\
\text { iWGs } \\
\text { iWGp }\end{array}$ & $\begin{array}{l}\text { Ordonnantie Stijl en manier van procederen: } 1582 \\
\text { Ordonnantie Stijl en manier van procederen: } 1564 \\
\text { Albertine Ordonnantie: } 13 \text { april } 1604\end{array}$ \\
\hline $5.10 .42 / 43 / 44 / 45 / 46$ & $\begin{array}{l}\text { RL } \\
\text { RL }\end{array}$ & $\begin{array}{l}\text { Jean Imbert (Institutiones forenses) } \\
\text { Louis le Caron (Annotationes op Somme rural van Jean Boutillier) }\end{array}$ \\
\hline $5.10 .47 / 48$ & $\begin{array}{l}\text { iWGs } \\
\text { iWGs } \\
\text { iWGp }\end{array}$ & $\begin{array}{l}\text { Ordonnantie Stijl en manier van procederen: } 1582 \\
\text { Ordonnantie Stijl en manier van procederen: } 1564 \\
\text { Albertine Ordonnantie: } 13 \text { april } 1604\end{array}$ \\
\hline 5.10 .49 & iWGp & Albertine Ordonnantie: 13 april 1604 \\
\hline 5.10 .50 & $\begin{array}{l}\mathrm{RL} \\
\mathrm{RL}\end{array}$ & $\begin{array}{l}\text { Jean Papon (Recueil d'arrests notables) } \\
\text { Louis le Caron (Responses du droit françois) }\end{array}$ \\
\hline 5.10 .51 & iWGs & Ordonnantie: 24 oktober 1592 \\
\hline $5.10 .52 / 53 / 54 / 55$ & $\begin{array}{l}\mathrm{iWGs} \\
\mathrm{S}\end{array}$ & $\begin{array}{l}\text { Ordonnantie Stijl en manier van procederen: } 1564 \\
\text { Specifieke reden }\end{array}$ \\
\hline $5.10 .56 / 57$ & $\begin{array}{l}\mathrm{iWGs} \\
\mathrm{iWGs} \\
\end{array}$ & $\begin{array}{l}\text { Ordonnantie Stijl en manier van procederen: } 1582 \\
\text { Ordonnantie Stijl en manier van procederen: } 1564\end{array}$ \\
\hline 5.10 .58 & Comp & Consuetudines Compilatae \\
\hline 5.10 .59 & iWGs & Ordonnantie: 24 oktober 1592 \\
\hline 5.10 .60 & iWGp & Albertine Ordonnantie: 13 april 1604 \\
\hline $5.10 .64 / 65$ & RA & Ratio \\
\hline $5.10 .67 / 68$ & $\begin{array}{l}\text { iWGs } \\
\text { iWGs } \\
\text { iWGs }\end{array}$ & $\begin{array}{l}\text { Ordonnantie Stijl en manier van procederen: } 1582 \\
\text { Ordonnantie Stijl en manier van procederen: } 1564 \\
\text { Ordonnantie: } 24 \text { oktober } 1592\end{array}$ \\
\hline 5.10 .69 & $\begin{array}{l}\text { Usus } \\
\mathrm{V}\end{array}$ & $\begin{array}{l}\text { Usus } \\
\text { Stijl van de Raad } \\
\end{array}$ \\
\hline 5.10 .70 & $\begin{array}{l}\text { iWGs } \\
\text { iWGs }\end{array}$ & $\begin{array}{l}\text { Ordonnantie: } 24 \text { oktober } 1592 \\
\text { Ordonnantie Stijl en manier van procederen: } 1564\end{array}$ \\
\hline $5.10 .71 / 72$ & iWGs & Ordonnantie: 24 oktober 1592 \\
\hline 5.10 .73 & $\mathrm{~S}$ & Specifieke reden \\
\hline 5.10 .74 & Comp & Consuetudines Compilatae \\
\hline $5.10 .75 / 76 / 77 / 78$ & $\begin{array}{l}\text { RL } \\
\text { RL } \\
\text { RL } \\
\text { RL }\end{array}$ & $\begin{array}{l}\text { Filips Wielant (Practycke civile) } \\
\text { Charles Dumoulin bij Digestae } \\
\text { Jacopo Menocchio (De arbitrariis iudicum quaestionibus et causis) } \\
\text { Giovanni Pietro Sordi di Casale (Decisiones S. Mantuani Senatus) }\end{array}$ \\
\hline
\end{tabular}




\begin{tabular}{|l|l|l|}
\hline 5.10 .79 & $\begin{array}{l}\text { RL } \\
\text { eWG }\end{array}$ & $\begin{array}{l}\text { Louis le Caron (Codex Henricianus) } \\
\text { Wetgeving Frankrijk: Codex Henricianus }\end{array}$ \\
\hline
\end{tabular}

\begin{tabular}{|c|c|c|}
\hline \multicolumn{3}{|c|}{$\begin{array}{l}\text { titel } 11 \\
\text { van den thoon }(60 / 60)\end{array}$} \\
\hline $5.11 .1 / 2$ & RL & Filips Wielant (Practycke civile) \\
\hline $5.11 .3 / 4 / 5$ & $\begin{array}{l}\text { iWGs } \\
\text { iWGs } \\
\text { Comp }\end{array}$ & $\begin{array}{l}\text { Ordonnantie Stijl en manier van procederen: } 1582 \\
\text { Ordonnantie Stijl en manier van procederen: } 1564 \\
\text { Consuetudines Compilatae }\end{array}$ \\
\hline 5.11 .6 & $\begin{array}{l}\text { iWGs } \\
\text { iWGs }\end{array}$ & $\begin{array}{l}\text { Ordonnantie Stijl en manier van procederen: } 1582 \\
\text { Ordonnantie Stijl en manier van procederen: } 1564\end{array}$ \\
\hline 5.11 .7 & $\begin{array}{l}\mathrm{iWGs} \\
\text { Usus }\end{array}$ & $\begin{array}{l}\text { Ordonnantie Stijl en manier van procederen: } 1582 \\
\text { Usus }\end{array}$ \\
\hline 5.11 .8 & $\begin{array}{l}\text { iWGs } \\
\text { Usus } \\
\text { Comp }\end{array}$ & $\begin{array}{l}\text { Ordonnantie Stijl en manier van procederen: } 1582 \\
\text { Usus } \\
\text { Consuetudines Compilatae }\end{array}$ \\
\hline 5.11 .9 & $\begin{array}{l}\text { iWGs } \\
\text { Usus }\end{array}$ & $\begin{array}{l}\text { Ordonnantie Stijl en manier van procederen: } 1582 \\
\text { Usus }\end{array}$ \\
\hline 5.11 .10 & $\begin{array}{l}\text { iWGs } \\
\text { iWGs } \\
\text { Comp }\end{array}$ & $\begin{array}{l}\text { Ordonnantie Stijl en manier van procederen: } 1582 \\
\text { Ordonnantie Stijl en manier van procederen: } 1564 \\
\text { Consuetudines Compilatae }\end{array}$ \\
\hline 5.11 .11 & Usus & Usus \\
\hline 5.11 .12 & $\begin{array}{l}\text { iWGs } \\
\text { Comp }\end{array}$ & $\begin{array}{l}\text { Ordonnantie Stijl en manier van procederen: } 1582 \\
\text { Consuetudines Compilatae }\end{array}$ \\
\hline 5.11 .13 & iWGp & Albertine Ordonnantie: 13 april 1604 \\
\hline 5.11 .14 & $\mathrm{~S}$ & Specifieke reden \\
\hline 5.11 .15 & $\begin{array}{l}\text { iWGs } \\
\text { Comp }\end{array}$ & $\begin{array}{l}\text { Ordonnantie: } 24 \text { oktober } 1592 \\
\text { Consuetudines Compilatae }\end{array}$ \\
\hline 5.11 .16 & $\begin{array}{l}\text { Usus } \\
\text { Comp }\end{array}$ & $\begin{array}{l}\text { Usus } \\
\text { Consuetudines Compilatae }\end{array}$ \\
\hline 5.11 .17 & $\begin{array}{l}\text { iWGs } \\
\text { Comp }\end{array}$ & $\begin{array}{l}\text { Ordonnantie Stijl en manier van procederen: } 1582 \\
\text { Consuetudines Compilatae }\end{array}$ \\
\hline $5.11 .18 / 19 / 20$ & $\mathrm{~S}$ & Specifieke reden \\
\hline $5.11 .21 / 22$ & $\begin{array}{l}\text { Cican } \\
\text { RL } \\
\text { RL } \\
\text { RL }\end{array}$ & $\begin{array}{l}\text { Corpus Iuris Canonici (Liber Extra) } \\
\text { Doctores bij Liber Extra } \\
\text { Denis Godefroy bij Liber Extra } \\
\text { Joachim Mynsinger von Frundeck bij Liber Extra }\end{array}$ \\
\hline 5.11 .23 & $\begin{array}{l}\text { iWGs } \\
\text { S }\end{array}$ & $\begin{array}{l}\text { Ordonnantie: } 24 \text { oktober } 1592 \\
\text { Specifieke reden }\end{array}$ \\
\hline 5.11 .24 & $\begin{array}{l}\text { iWGs } \\
\text { iWGs } \\
\text { iWGs }\end{array}$ & $\begin{array}{l}\text { Ordonnantie Stijl en manier van procederen: } 1582 \\
\text { Ordonnantie Stijl en manier van procederen: } 1564 \\
\text { Ordonnantie: } 24 \text { oktober } 1592\end{array}$ \\
\hline 5.11 .25 & $\begin{array}{l}\mathrm{iWGs} \\
\mathrm{iWG}\end{array}$ & $\begin{array}{l}\text { Ordonnantie Stijl en manier van procederen: } 1582 \\
\text { Ordonnantie Stijl en manier van procederen: } 1564\end{array}$ \\
\hline $5.11 .26 / 27$ & $\begin{array}{l}\text { iWGs } \\
\text { iWGs }\end{array}$ & $\begin{array}{l}\text { Ordonnantie Stijl en manier van procederen: } 1582 \\
\text { Ordonnantie Stijl en manier van procederen: } 1564\end{array}$ \\
\hline $5.11 .28 / 29$ & $\begin{array}{l}\text { iWGs } \\
\text { iWGs } \\
\text { Ciciv } \\
\text { RL }\end{array}$ & $\begin{array}{l}\text { Ordonnantie Stijl en manier van procederen: } 1582 \\
\text { Ordonnantie Stijl en manier van procederen: } 1564 \\
\text { 'Ex iure' } \\
\text { Filips Wielant (Practycke civile) }\end{array}$ \\
\hline $5.11 .30 / 31$ & RL & Filips Wielant (Practycke civile) \\
\hline 5.11 .32 & $\begin{array}{l}\mathrm{iWGs} \\
\mathrm{iWGs}\end{array}$ & $\begin{array}{l}\text { Ordonnantie Stijl en manier van procederen: } 1582 \\
\text { Ordonnantie Stijl en manier van procederen: } 1564\end{array}$ \\
\hline
\end{tabular}




\begin{tabular}{|c|c|c|}
\hline & Usus & Usus \\
\hline 5.11 .33 & $\begin{array}{l}\text { iWGs } \\
\text { Usus }\end{array}$ & $\begin{array}{l}\text { Ordonnantie: } 24 \text { oktober } 1592 \\
\text { Usus }\end{array}$ \\
\hline $5.11 .34 / 35$ & $\begin{array}{l}\text { iWGs } \\
\text { iWGs } \\
\text { iWGs }\end{array}$ & $\begin{array}{l}\text { Ordonnantie Stijl en manier van procederen: } 1582 \\
\text { Ordonnantie Stijl en manier van procederen: } 1564 \\
\text { Ordonnantie: } 24 \text { oktober } 1592\end{array}$ \\
\hline 5.11 .36 & $\begin{array}{l}\text { iWGs } \\
\text { iWGs }\end{array}$ & $\begin{array}{l}\text { Ordonnantie Stijl en manier van procederen: } 1582 \\
\text { Ordonnantie Stijl en manier van procederen: } 1564\end{array}$ \\
\hline 5.11 .37 & RL & Filips Wielant (Practycke civile) \\
\hline 5.11 .38 & $\begin{array}{l}\text { iWGs } \\
\text { Comp } \\
\text { RL } \\
\text { Ciciv }\end{array}$ & $\begin{array}{l}\text { Ordonnantie: } 24 \text { oktober } 1592 \\
\text { Consuetudines Compilatae } \\
\text { Filips Wielant (Practycke civile) } \\
\text { Corpus Iuris Civilis (Digestae) }\end{array}$ \\
\hline 5.11 .39 & $\mathrm{~S}$ & Specifieke reden \\
\hline $5.11 .40 / 41$ & RL & Filips Wielant (Practycke civile) \\
\hline 5.11 .42 & $\begin{array}{l}\mathrm{RL} \\
\mathrm{RL}\end{array}$ & $\begin{array}{l}\text { Filips Wielant (Practycke civile) } \\
\text { Benvenuto Stracca (De Mercatura seu mercatore Tractatus) }\end{array}$ \\
\hline 5.11 .43 & RL & Filips Wielant (Practycke civile) \\
\hline 5.11 .44 & RL & Filips Wielant (Practycke civile) \\
\hline 5.11 .45 & $\begin{array}{l}\text { RL } \\
\text { RL } \\
\text { RL }\end{array}$ & $\begin{array}{l}\text { Jean Favre bij Institutiones } \\
\text { Jacopo Menocchio (De arbitrariis iudicum quaestionibus et causis) } \\
\text { Jean Papon (Recueil d'arrests notables) }\end{array}$ \\
\hline 5.11 .46 & Ciciv & Corpus Iuris Civilis (Digestae) \\
\hline 5.11 .47 & $\mathrm{~S}$ & Specifieke reden \\
\hline 5.11 .48 & $\mathrm{~S}$ & Specifieke reden \\
\hline $5.11 .49 / 50$ & $\begin{array}{l}\text { Ciciv } \\
\text { RL }\end{array}$ & $\begin{array}{l}\text { 'Uterque est iuris scripti') } \\
\text { Filips Wielant (Practycke civile) }\end{array}$ \\
\hline $5.11 .51 / 52 / 53$ & $\begin{array}{l}\text { Ciciv } \\
\text { RL } \\
\text { RL } \\
\text { RL } \\
\text { RL } \\
\text { RL } \\
\text { RL } \\
\text { RL } \\
\end{array}$ & $\begin{array}{l}\text { 'Sunt etiam iuris scripti’ } \\
\text { Bartolo da Sassoferrato bij Digestae } \\
\text { Angelus de Ubaldis bij Digestae } \\
\text { Baldus de Ubaldis bij Codex } \\
\text { Alessandro di Tartagni (Consilia) } \\
\text { Enrico di Boverio (Singularia) } \\
\text { Etienne Betrand (Consilia) } \\
\text { Antoine Favre (Codex Fabrianus) }\end{array}$ \\
\hline 5.11 .54 & Ciciv & Corpus Iuris Civilis (Codex) \\
\hline $5.11 .55 / 56$ & $\begin{array}{l}\text { iWGs } \\
\text { iWGs }\end{array}$ & $\begin{array}{l}\text { Ordonnantie Stijl en manier van procederen: } 1582 \\
\text { Ordonnantie Stijl en manier van procederen: } 1564\end{array}$ \\
\hline 5.11 .57 & $\begin{array}{l}\text { iWGs } \\
\text { iWGs }\end{array}$ & $\begin{array}{l}\text { Ordonnantie Stijl en manier van procederen: } 1582 \\
\text { Ordonnantie Stijl en manier van procederen: } 1564\end{array}$ \\
\hline 5.11 .58 & $\mathrm{~S}$ & Specifieke reden \\
\hline $5.11 .59 / 60$ & $\begin{array}{l}\text { iWGs } \\
\text { iWGs }\end{array}$ & $\begin{array}{l}\text { Ordonnantie Stijl en manier van procederen: } 1582 \\
\text { Ordonnantie Stijl en manier van procederen: } 1564\end{array}$ \\
\hline
\end{tabular}

\begin{tabular}{|l|l|l|}
\hline titel 12 \\
vant veriaeren ende affgaen oft desisteren van den processe (1/6) \\
\hline 5.12 .6 & $\mathrm{~S}$ & Specifieke reden \\
& 3 & Magistraat \\
\hline
\end{tabular}

\begin{tabular}{|l|l|l|}
\hline \multicolumn{3}{|l|}{$\begin{array}{l}\text { titel } 13 \\
\text { van vonnissen, ende taxatie oft begroottinge van de costen (10/19) }\end{array}$} \\
\hline 5.13 .9 & RA & Ratio \\
\hline $5.13 .10 / 11$ & Usus & Usus \\
\hline
\end{tabular}




\begin{tabular}{|l|l|l|}
\hline $5.13 .12 / 13$ & $\begin{array}{l}\text { RA } \\
\text { Cicis }\end{array}$ & $\begin{array}{l}\text { Ratio } \\
\text { Corpus Iuris Civilis (Digestae) }\end{array}$ \\
\hline 5.13 .15 & iWGs & Ordonnantie Stijl en manier van procederen: 1582 \\
& iWGs & Ordonnantie Stijl en manier van procederen: 1564 \\
\hline 5.13 .16 & iWGs & Ordonnantie Stijl en manier van procederen: 1582 \\
& iWGs & Ordonnantie Stijl en manier van procederen: 1564 \\
& Usus & Usus \\
\hline 5.13 .17 & iWGs & Ordonnantie Stijl en manier van procederen: 1582 \\
& iWGs & Ordonnantie Stijl en manier van procederen: 1564 \\
\hline 5.13 .18 & iWGs & Ordonnantie Stijl en manier van procederen: 1582 \\
& iWGs & Ordonnantie Stijl en manier van procederen: 1564 \\
\hline 5.13 .19 & iWGs & Ordonnantie Stijl en manier van procederen: 1582 \\
& iWGs & Ordonnantie Stijl en manier van procederen: 1564 \\
& Usus & Usus \\
\hline
\end{tabular}

\begin{tabular}{|l|l|l|}
\hline \multicolumn{2}{|l|}{$\begin{array}{l}\text { titel } 14 \\
\text { van provocatien oft beroepen } \mathbf{( 5 / 2 0 )}\end{array}$} \\
\hline 5.14 .4 & iWGs & Ordonnantie Stijl en manier van procederen: 1582 \\
& iWGs & Ordonnantie Stijl en manier van procederen: 1564 \\
\hline 5.14 .5 & iWGs & Ordonnantie Stijl en manier van procederen: 1582 \\
& iWGs & Ordonnantie Stijl en manier van procederen: 1564 \\
& Comp & Consuetudines Compilatae \\
\hline 5.14 .17 & iWGs & Ordonnantie Stijl en manier van procederen: 1582 \\
& iWGs & Ordonnantie Stijl en manier van procederen: 1564 \\
\hline $5.14 .18 / 19$ & iWGs & Ordonnantie Stijl en manier van procederen: 1582 \\
& iWGs & Ordonnantie Stijl en manier van procederen: 1564 \\
\hline
\end{tabular}

\begin{tabular}{|l|l|l|}
\hline \multicolumn{3}{|l|}{$\begin{array}{l}\text { titel } \mathbf{1 5} \\
\text { van appellation ende leeringe van vonnissen } \mathbf{( 8 / 2 2 )}\end{array}$} \\
\hline 5.15 .3 & iWGp & Albertine Ordonnantie: 13 april 1604 \\
\hline $5.15 .11 / 12$ & iWGp & Albertine Ordonnantie: 13 april 1604 \\
\hline 5.15 .13 & Ciciv & 'Ex iure scripto' \\
\hline 5.15 .14 & iWGp & Albertine Ordonnantie: 13 april 1604 \\
\hline 5.15 .17 & Ciciv & Corpus Iuris Civilis (Codex) \\
\hline 5.15 .21 & iWGp & Albertine Ordonnantie: 13 april 1604 \\
\hline 5.15 .22 & iWGp & Albertine Ordonnantie: 13 april 1604 \\
\hline
\end{tabular}

\begin{tabular}{|l|l|l|}
\hline $\begin{array}{l}\text { titel } 16 \\
\text { van } \text { reformation } \mathbf{( 3 / 1 7 )}\end{array}$ \\
\hline $5.16 .10 / 11$ & $\mathrm{iWGp}$ & Albertine Ordonnantie: 13 april 1604 \\
\hline 5.16 .16 & $\mathrm{iWGp}$ & Albertine Ordonnantie: 13 april 1604 \\
\hline
\end{tabular}

\begin{tabular}{|l|l|l|}
\hline \multicolumn{1}{|l|}{$\begin{array}{l}\text { titel } 17 \\
\text { van executie oft pandinge (37/102) }\end{array}$} \\
\hline 5.17 .2 & OAR & Consuetudines Antiquissimae \\
\hline 5.17 .7 & 3 & Amptman \\
\hline 5.17 .9 & $\mathrm{RL}$ & $\begin{array}{l}\text { Charles Dumoulin (Annotationes op Consilia van Alessandro di } \\
\text { Tartagni) }\end{array}$ \\
& $\mathrm{RL}$ & Jean Bodin (Les six livres de la République) \\
& $\mathrm{RL}$ & $\begin{array}{l}\text { Diego Covarubias y Leyva (Variarum ex iure pontificio, regio et caesareo } \\
\text { resolutionum) }\end{array}$ \\
& $\mathrm{RSe}$ & $\begin{array}{l}\text { Louis le Caron (Responses du droit françois) } \\
\text { Rechtspraak (Antwerpen) }\end{array}$ \\
\hline
\end{tabular}


BIJLAGEN

\begin{tabular}{|c|c|c|}
\hline 5.17 .22 & $\begin{array}{l}\text { Usus } \\
\text { RA }\end{array}$ & $\begin{array}{l}\text { Usus } \\
\text { Ratio }\end{array}$ \\
\hline 5.17 .23 & $\begin{array}{l}\text { iWG } \\
\text { Usus }\end{array}$ & $\begin{array}{l}\text { 'Ex diversis statutis' } \\
\text { Usus }\end{array}$ \\
\hline 5.17 .34 & $\begin{array}{l}\text { RA } \\
\text { Comp }\end{array}$ & Ratio van ander artikel uit Consuetudines Compilatae \\
\hline $5.17 .35 / 36$ & Comp & Consuetudines Compilatae \\
\hline 5.17 .54 & $\begin{array}{l}\text { iWGs } \\
\text { RA } \\
\text { Comp }\end{array}$ & $\begin{array}{l}\text { Ordonnantie Stijl en manier van procederen: } 1582 \\
\text { Ratio van ander artikel uit Consuetudines Compilatae }\end{array}$ \\
\hline 5.17 .57 & $\begin{array}{l}\text { iWGs } \\
\text { OAR } \\
3\end{array}$ & $\begin{array}{l}\text { Ordonnantie Stijl en manier van procederen: } 1582 \\
\text { Consuetudines Antiquissimae } \\
\text { Amptman }\end{array}$ \\
\hline 5.17 .58 & $\begin{array}{l}\text { iWGs } \\
\text { Ciciv } \\
\text { RA } \\
\text { Usus }\end{array}$ & $\begin{array}{l}\text { Ordonnantie Stijl en manier van procederen: } 1582 \\
\text { 'Ex ratione iuris' } \\
\text { Usus }\end{array}$ \\
\hline 5.17 .62 & $\mathrm{~S}$ & Specifieke reden \\
\hline 5.17 .63 & $\mathrm{~S}$ & Specifieke reden \\
\hline 5.17 .67 & $\begin{array}{l}\text { Comp } \\
\text { iWG }\end{array}$ & $\begin{array}{l}\text { Consuetudines Compilatae } \\
\text { 'Nieuw ontwerp van de ordonnantie van 1543' }\end{array}$ \\
\hline $5.17 .68 / 69$ & $\begin{array}{l}\text { iWG } \\
\text { Comp } \\
\text { Usus }\end{array}$ & $\begin{array}{l}\text { 'Nieuw ontwerp van de ordonnantie van 1543' } \\
\text { Consuetudines Compilatae } \\
\text { Usus }\end{array}$ \\
\hline 5.17 .70 & $\begin{array}{l}\mathrm{iWGs} \\
\text { Usus }\end{array}$ & $\begin{array}{l}\text { Ordonnantie Stijl en manier van procederen: } 1582 \\
\text { Usus }\end{array}$ \\
\hline 5.17 .71 & $\begin{array}{l}\text { Usus } \\
\mathrm{S}\end{array}$ & $\begin{array}{l}\text { Usus } \\
\text { Specifieke reden }\end{array}$ \\
\hline 5.17 .72 & $\mathrm{~S}$ & Specifieke reden \\
\hline $5.17 .73 / 74 / 75$ & Comp & Consuetudines Compilatae \\
\hline 5.17 .76 & $\begin{array}{l}\text { iWG } \\
\text { Comp }\end{array}$ & $\begin{array}{l}\text { 'Ex diversis statutis' } \\
\text { Consuetudines Compilatae }\end{array}$ \\
\hline 5.17 .83 & $\begin{array}{l}\text { iWGs } \\
\text { OAR }\end{array}$ & $\begin{array}{l}\text { Ordonnantie Stijl en manier van procederen: } 1582 \\
\text { Consuetudines Antiquissimae }\end{array}$ \\
\hline $5.17 .84 / 85$ & iWGs & Ordonnantie Stijl en manier van procederen: 1582 \\
\hline 5.17 .86 & $\mathrm{~S}$ & Specifieke reden \\
\hline 5.17 .87 & $\begin{array}{l}\text { Usus } \\
\mathrm{V}\end{array}$ & $\begin{array}{l}\text { Usus } \\
\text { Usus vd Raad }\end{array}$ \\
\hline $5.17 .88 / 89$ & $\begin{array}{l}\text { Usus } \\
\mathrm{S}\end{array}$ & $\begin{array}{l}\text { Usus } \\
\text { Specifieke reden }\end{array}$ \\
\hline $5.17 .90 / 91$ & iWGs & Ordonnantie Stijl en manier van procederen: 1582 \\
\hline 5.17 .92 & $\begin{array}{l}\text { iWGs } \\
\text { Ciciv } \\
\text { RA }\end{array}$ & $\begin{array}{l}\text { Ordonnantie Stijl en manier van procederen: } 1582 \\
\text { 'Ex ratione iuris' }\end{array}$ \\
\hline 5.17 .95 & Usus & Usus \\
\hline $5.17 .100 / 101$ & $\begin{array}{l}\mathrm{S} \\
3 \\
\mathrm{RSi}\end{array}$ & $\begin{array}{l}\text { Specifieke reden } \\
\text { Magistraat } \\
\text { Rechtspraak (Antwerpen) }\end{array}$ \\
\hline 5.17 .102 & Usus & Usus \\
\hline
\end{tabular}


Deel VI

$V$ an misbruijcken ende misdaeden, ende van breucken ende straffen daertoe staende. (3 titels, 118 artikels, waarvan 82 nieuw)

\begin{tabular}{|c|c|c|}
\hline \multicolumn{3}{|c|}{$\begin{array}{l}\text { titel } 1 \\
\text { van keuren ende breucken, ende van misbruijcken daertoe de keuren ende breucken staen }(48 / 55\end{array}$} \\
\hline 6.1 .5 & $\mathrm{~S}$ & Specifieke reden \\
\hline 6.1 .6 & OAR & Consuetudines Antiquissimae \\
\hline 6.1 .7 & $\begin{array}{l}\text { RA } \\
\text { Comp }\end{array}$ & Ratio van ander artikel uit Consuetudines Compilatae \\
\hline 6.1 .8 & OAR & Consuetudines Antiquissimae \\
\hline $6.1 .9 / 10$ & $\begin{array}{l}\text { OAR } \\
\text { OAR } \\
\text { Usus }\end{array}$ & $\begin{array}{l}\text { Consuetudines Antiquissimae } \\
\text { Oude specificatie 'keuren ende breucken van Antwerpen' } \\
\text { Usus }\end{array}$ \\
\hline 6.1 .11 & OAR & Consuetudines Antiquissimae \\
\hline $6.1 .12 / 13$ & $\begin{array}{l}\text { OAR } \\
\text { OAR }\end{array}$ & $\begin{array}{l}\text { Consuetudines Antiquissimae } \\
\text { Keurboeck. }\end{array}$ \\
\hline 6.1 .14 & $\begin{array}{l}\text { OAR } \\
\text { OAR }\end{array}$ & $\begin{array}{l}\text { Consuetudines Antiquissimae } \\
\text { Oude specificatie 'keuren ende breucken van Antwerpen' }\end{array}$ \\
\hline 6.1 .15 & $\begin{array}{l}\text { OAR } \\
\text { OAR }\end{array}$ & $\begin{array}{l}\text { Consuetudines Antiquissimae } \\
\text { Oude specificatie 'keuren ende breucken van Antwerpen' }\end{array}$ \\
\hline 6.1 .16 & OAR & Consuetudines Antiquissimae \\
\hline 6.1 .17 & $\mathrm{~S}$ & Specifieke reden \\
\hline $6.1 .18 / 19$ & $\begin{array}{l}\text { OAR } \\
\text { OAR }\end{array}$ & $\begin{array}{l}\text { Consuetudines Antiquissimae } \\
\text { Oude specificatie 'keuren ende breucken van Antwerpen' }\end{array}$ \\
\hline 6.1 .20 & $\begin{array}{l}\text { OAR } \\
\text { OAR } \\
\text { Comp }\end{array}$ & $\begin{array}{l}\text { Consuetudines Antiquissimae } \\
\text { Oude specificatie 'keuren ende breucken van Antwerpen' } \\
\text { Consuetudines Compilatae }\end{array}$ \\
\hline 6.1 .21 & $\begin{array}{l}\text { OAR } \\
\text { OAR }\end{array}$ & $\begin{array}{l}\text { Consuetudines Antiquissimae } \\
\text { Oude specificatie 'keuren ende breucken van Antwerpen' }\end{array}$ \\
\hline 6.1 .22 & $\begin{array}{l}\text { OAR } \\
\text { OAR }\end{array}$ & $\begin{array}{l}\text { Consuetudines Antiquissimae } \\
\text { Oude specificatie 'keuren ende breucken van Antwerpen' }\end{array}$ \\
\hline 6.1 .23 & Comp & Consuetudines Compilatae \\
\hline 6.1 .24 & OAR & Consuetudines Antiquissimae \\
\hline $6.1 .25 / 26$ & $\begin{array}{l}\mathrm{S} \\
\mathrm{RL}\end{array}$ & $\begin{array}{l}\text { Specifieke reden } \\
\text { Luis de Peguera (Liber quaestionum criminalium) }\end{array}$ \\
\hline 6.1 .28 & Usus & Usus \\
\hline 6.1 .29 & OAR & Consuetudines Antiquissimae \\
\hline 6.1 .30 & $\begin{array}{l}\text { iWGs } \\
\text { Comp }\end{array}$ & $\begin{array}{l}\text { Ordonnantie Peyskamer: } 12 \text { november } 1509 \\
\text { Consuetudines Compilatae }\end{array}$ \\
\hline 6.1 .31 & $\begin{array}{l}\text { OAR } \\
\text { iWGV } \\
\text { eGR }\end{array}$ & $\begin{array}{l}\text { Consuetudines Antiquissimae } \\
\text { Landcharter van Brabant: } 1292 \\
\text { Costuymen van Mechelen }\end{array}$ \\
\hline 6.1 .32 & OAR & Consuetudines Antiquissimae \\
\hline $6.1 .33 / 34$ & $\begin{array}{l}\text { OAR } \\
3\end{array}$ & $\begin{array}{l}\text { Consuetudines Antiquissimae } \\
\text { Magistraat }\end{array}$ \\
\hline 6.1 .35 & OAR & Consuetudines Antiquissimae \\
\hline 6.1 .36 & $\begin{array}{l}\text { OAR } \\
\text { iWGv } \\
\text { eGR }\end{array}$ & $\begin{array}{l}\text { Consuetudines Antiquissimae } \\
\text { Landcharter van Brabant: } 1292 \\
\text { Conférence des coutumes (Pierre Guenoys), Costuymen van Mechelen }\end{array}$ \\
\hline 6.1 .37 & $\begin{array}{l}\text { Usus } \\
\text { Comp }\end{array}$ & $\begin{array}{l}\text { Usus } \\
\text { Consuetudines Compilatae }\end{array}$ \\
\hline
\end{tabular}




\begin{tabular}{|c|c|c|}
\hline 6.1 .38 & $\begin{array}{l}\text { OAR } \\
\text { OAR } \\
\text { OAR }\end{array}$ & $\begin{array}{l}\text { Consuetudines Antiquissimae } \\
\text { Oude specificatie 'Keuren ende breucken van Antwerpen'n } \\
\text { Keurboeck. }\end{array}$ \\
\hline 6.1 .39 & $\begin{array}{l}\text { Ciciv } \\
\text { RL } \\
\text { RL }\end{array}$ & $\begin{array}{l}\text { 'Ex iure scripto' } \\
\text { Luis de Peguera (Liber quaestionum criminalium) } \\
\text { Louis le Caron (Annotationes op Grand Coutumier de France van } \\
\text { Jacques d'Ableiges) }\end{array}$ \\
\hline 6.1 .40 & eWG & Wetgeving Spanje: Siete partidas (1263) \\
\hline $6.1 .41 / 42$ & $\begin{array}{l}\text { Ciciv } \\
\text { RL } \\
\text { RL }\end{array}$ & $\begin{array}{l}\text { Corpus Iuris Civilis (Codex, Digestae) } \\
\text { Antoine Favre (Codex Fabrianus) } \\
\text { Pierre Guenoys (Conférence des coutumes) }\end{array}$ \\
\hline 6.1 .43 & $\begin{array}{l}\text { RL } \\
\text { RL } \\
\text { RL }\end{array}$ & $\begin{array}{l}\text { Louis le Caron (Annotationes op Grand Coutumier de France van } \\
\text { Jacques d'Ableiges) } \\
\text { Louis le Caron (Memorables observations du droit français) } \\
\text { Louis le Caron (Annotationes op Somme rural van Jean Boutillier) }\end{array}$ \\
\hline 6.1 .44 & $\begin{array}{l}\text { RL } \\
\text { RL } \\
\text { RL }\end{array}$ & $\begin{array}{l}\text { Louis le Caron (Annotationes op Grand Coutumier de France van } \\
\text { Jacques d'Ableiges) } \\
\text { Louis le Caron (Memorables observations du droit français) } \\
\text { Louis le Caron (Annotationes op Somme rural van Jean Boutillier) }\end{array}$ \\
\hline 6.1 .45 & RL & Louis le Caron (Annotationes op Somme rural van Jean Boutillier) \\
\hline 6.1 .46 & eGR & Costuymen van Utrecht, Coutumes de Bretagne \\
\hline 6.1 .47 & $\begin{array}{l}\text { OAR } \\
\text { OAR }\end{array}$ & $\begin{array}{l}\text { Consuetudines Antiquissimae } \\
\text { Oude specificatie 'keuren ende breucken van Antwerpen' }\end{array}$ \\
\hline $6.1 .48 / 49 / 50$ & OAR & Consuetudines Antiquissimae \\
\hline 6.1 .51 & $\begin{array}{l}\text { OAR } \\
\text { OAR } \\
\text { OAR } \\
\text { iWG }\end{array}$ & $\begin{array}{l}\text { Consuetudines Antiquissimae } \\
\text { Oude specificatie 'keuren ende breucken van Antwerpen' } \\
\text { Keurboeck. } \\
\text { Privilege Jan III van Brabant: } 1335\end{array}$ \\
\hline $6.1 .52 / 53$ & eGR & Costuymen van Utrecht \\
\hline
\end{tabular}

\begin{tabular}{|c|c|c|}
\hline \multicolumn{3}{|c|}{$\begin{array}{l}\text { titel } 2 \\
\text { van bannissementen ende saecken daertoe den ban oft arbitraele straffe staet }(25 / 35)\end{array}$} \\
\hline 6.2 .4 & eGR & Costuymen van Gent \\
\hline 6.2 .5 & Usus & Usus \\
\hline 6.2 .10 & OAR & Consuetudines Antiquissimae \\
\hline 6.2 .12 & $\begin{array}{l}\text { OAR } \\
\text { OAR }\end{array}$ & $\begin{array}{l}\text { Consuetudines Antiquae } \\
\text { Consuetudines Antiquissimae }\end{array}$ \\
\hline $6.2 .13 / 14$ & $\begin{array}{l}\text { iWGv } \\
3\end{array}$ & $\begin{array}{l}\text { Ordonnantie Karel V: } 7 \text { oktober } 1531 \\
\text { Magistraat }\end{array}$ \\
\hline 6.2 .16 & Comp & Consuetudines Compilatae \\
\hline 6.2 .18 & Ciciv & Corpus Iuris Civilis (Authenticum, Novellae Constitutiones) \\
\hline $6.2 .19 / 20$ & $\begin{array}{l}3 \\
\text { eWG } \\
\text { Usus }\end{array}$ & $\begin{array}{l}\text { Magistraat } \\
\text { Nieuwe ordonnantie van Holland opde policye } \\
\text { Usus }\end{array}$ \\
\hline 6.2 .21 & OAR & Consuetudines Antiquissimae \\
\hline 6.2 .22 & OAR & Consuetudines Antiquissimae \\
\hline 6.2 .23 & $\begin{array}{l}\text { OAR } \\
\text { Ciciv } \\
\text { OAR }\end{array}$ & $\begin{array}{l}\text { Consuetudines Antiquissimae } \\
\text { Corpus Iuris Civilis (Digestae) } \\
\text { Keurboeck }\end{array}$ \\
\hline 6.2 .24 & OAR & Consuetudines Antiquissimae \\
\hline 6.2 .25 & $\begin{array}{l}\text { OAR } \\
\text { Ciciv }\end{array}$ & $\begin{array}{l}\text { Consuetudines Antiquissimae } \\
\text { Corpus Iuris Civilis (Digestae) }\end{array}$ \\
\hline 6.2 .26 & OAR & Consuetudines Antiquissimae \\
\hline
\end{tabular}


PRIMAIRE RECHTSBRONNEN CONSUETUDINES COMPILATAE

\begin{tabular}{|l|l|l|}
\hline 6.2 .27 & $\begin{array}{l}\text { iWGv } \\
\text { Comp }\end{array}$ & $\begin{array}{l}\text { Ordonnantie Karel V: Constitutio Criminalis Carolina (1532) } \\
\text { Consuetudines Compilatae }\end{array}$ \\
\hline 6.2 .28 & iWGv & 'Ex dicti statutis Carolinis' \\
\hline 6.2 .29 & iWGv & 'Ex dicti statutis Carolinis' \\
\hline 6.2 .30 & iWGv & Ordonnantie Karel V: Constitutio Criminalis Carolina (1532) \\
& iWGv & Institutiones imperiales (Thomas Murner, 1519) \\
\hline 6.2 .31 & OAR & Consuetudines Antiquissimae \\
& Ciciv & Corpus Iuris Civilis (Digestae) \\
& Comp & Consuetudines Compilatae \\
\hline 6.2 .32 & iWGv & Ordonnantie Karel V: Constitutio Criminalis Carolina (1532) \\
& Ciciv & Corpus Iuris Civilis (Codex, Digestae) \\
& Comp & Consuetudines Compilatae \\
\hline 6.2 .33 & OAR & Consuetudines Antiquissimae \\
& RA & Ratio \\
\hline 6.2 .34 & OAR & Consuetudines Antiquissimae \\
& iWGv & Institutiones imperiales (Thomas Murner, 1519) \\
& Ciciv & Corpus Iuris Civilis (Digestae) \\
\hline 6.2 .35 & S & Specifieke reden \\
& iWGv & Criminele Ordonnantiën Filips II: 1570 \\
& iWGv & Blijde Inkomst \\
\hline
\end{tabular}

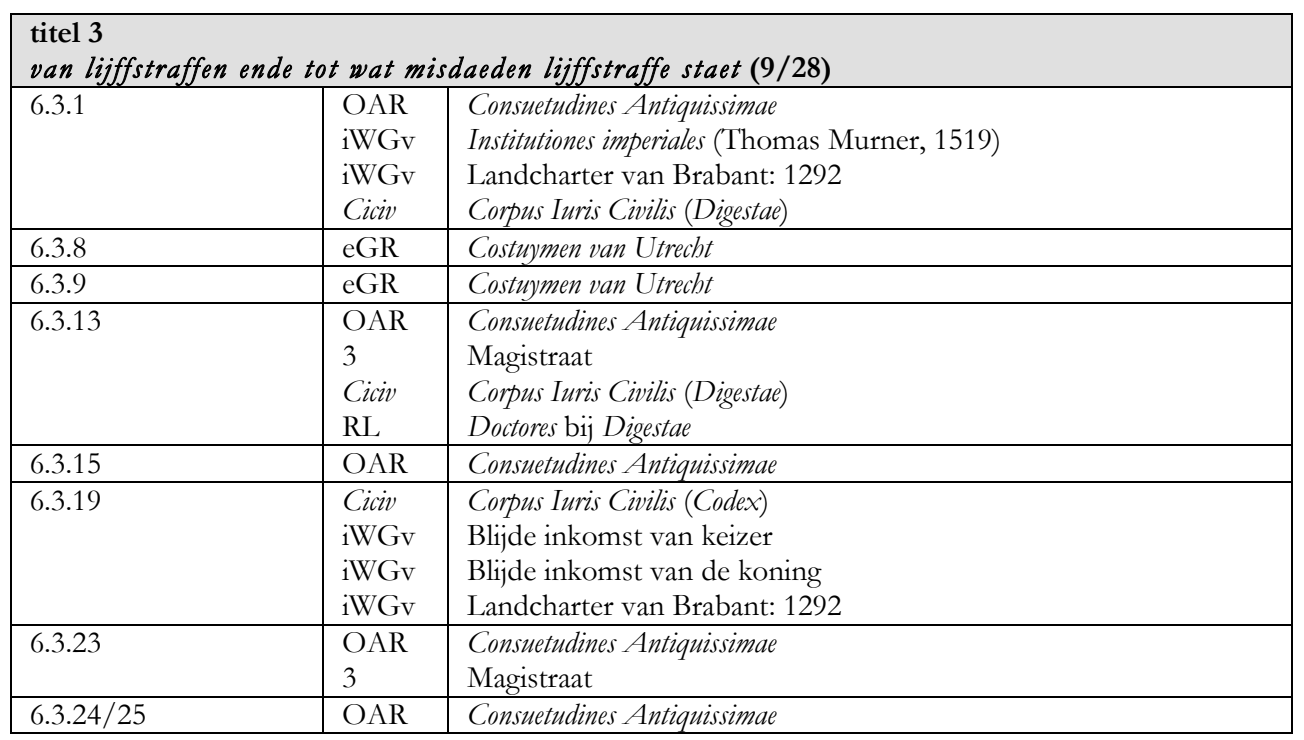

\section{Deel VII}

$V$ an de maniere van rechtvoordering in straffbare ende criminele saecken. (8 titels, 182 artikels, waarvan 46 nieuw)

\begin{tabular}{|l|l|l|}
\hline $\begin{array}{l}\text { titel } 1 \\
\text { van ondersoeck ende vervolch van }\end{array}$ gevlucbte misdaedige (11/17) \\
\hline $7.1 .7 / 8 / 9 / 10 / 11$ & $\begin{array}{l}\text { RL } \\
\text { Cican }\end{array}$ & $\begin{array}{l}\text { Filips Wielant (Practycke criminele) } \\
\text { Corpus Iuris Civilis (Liber Extra) }\end{array}$ \\
\hline 7.1 .12 & Usus & Usus \\
\hline
\end{tabular}




\begin{tabular}{|l|l|l|}
\hline $7.1 .13 / 14$ & Usus & Usus \\
& Comp & Consuetudines Compilatae \\
\hline 7.1 .15 & Usus & Usus \\
& RL & Giulio Claro (Sententiarum receptarum) \\
\hline 7.1 .16 & Ciciv & Corpus Iuris Civilis (Codex, Digestae) \\
& RL & Giulio Claro (Sententiarum receptarum) \\
\hline 7.1 .17 & Ciciv & Corpus Iuris Civilis (Codex, Digestae) \\
& RL & Louis le Caron (Pandectes ou Digestes du droit françois) \\
& RL & Louis le Caron (Responses du droit francois) \\
\hline
\end{tabular}

\begin{tabular}{|l|l|l|}
\hline \multicolumn{3}{|l|}{$\begin{array}{l}\text { titel } 2 \\
\text { van tvangen ende bewaeren der }\end{array}$ misdadige, ende beschrijvinge van bunne goeden $(\mathbf{6 / 2 5 )}$} \\
\hline $7.2 .8 / 9 / 10 / 11$ & Usus & Usus \\
\hline 7.2 .12 & OAR & Consuetudines Antiquissimae \\
\hline 7.2 .22 & Usus & Usus \\
& RA & Aequitas \\
& Ciciv & Corpus Iuris Civilis (Digestae) \\
\hline
\end{tabular}

\begin{tabular}{|c|c|c|}
\hline \multicolumn{3}{|c|}{$\begin{array}{l}\text { titel } 3 \\
\text { van gevangenen t'ondervraegen ende ter scherper examinatien te brengen oft pijningen }(22 / 30)\end{array}$} \\
\hline 7.3 .2 & Usus & Usus \\
\hline 7.3 .3 & $\mathrm{~S}$ & Specifieke reden \\
\hline 7.3 .4 & RL & Filips Wielant (Practycke criminele) \\
\hline 7.3 .5 & Usus & Usus \\
\hline 7.3.6 & Usus & Usus \\
\hline 7.3 .7 & Usus & Usus \\
\hline 7.3 .11 & $\begin{array}{l}\text { Usus } \\
\text { Ciciv } \\
\text { RA }\end{array}$ & $\begin{array}{l}\text { Usus } \\
\text { 'Ex ratione iuris' }\end{array}$ \\
\hline 7.3 .12 & Usus & Usus \\
\hline $7.3 .14 / 15$ & Usus & Usus \\
\hline 7.3.16/17/18/19/20 & $\begin{array}{l}\text { Usus } \\
\text { Ciciv } \\
\text { RL } \\
\text { iWGv } \\
\text { RL }\end{array}$ & $\begin{array}{l}\text { Usus } \\
\text { 'Ex iure commun' } \\
\text { Institutiones imperiales (Thomas Murner, 1519) } \\
\text { Prospero Farinacci (Praxis et theorica criminalis) }\end{array}$ \\
\hline 7.3 .21 & $\begin{array}{l}\text { Usus } \\
\text { Comp }\end{array}$ & $\begin{array}{l}\text { Usus } \\
\text { Consuetudines Compilatae }\end{array}$ \\
\hline 7.3 .22 & $\begin{array}{l}\text { Usus } \\
\text { eGR }\end{array}$ & $\begin{array}{l}\text { Usus } \\
\text { Costuymen van Utrecht }\end{array}$ \\
\hline 7.3 .23 & $\begin{array}{l}\text { Usus } \\
\text { eGR } \\
\text { Ciciv }\end{array}$ & $\begin{array}{l}\text { Usus } \\
\text { Costuymen van Utrecbt } \\
\text { Corpus Iuris Civilis (Digestae) }\end{array}$ \\
\hline 7.3 .26 & $\begin{array}{l}\text { eGR } \\
\text { RL } \\
\text { RA } \\
\text { Ciciv } \\
\text { RL } \\
\end{array}$ & $\begin{array}{l}\text { Costuymen van Utrecht } \\
\text { Pierre Grégoire (Syntagma iuris universi) } \\
\text { Ratio } \\
\text { Corpus Iuris Civilis (Digestae) } \\
\text { Jacopo Menocchio (De arbitrariis iudicum quaestionibus et causis) }\end{array}$ \\
\hline 7.3 .27 & $\begin{array}{l}\text { Ciciv } \\
\text { RL } \\
\text { RL }\end{array}$ & $\begin{array}{l}\text { Corpus Iuris Civilis (Digestae) } \\
\text { Doctores bij Digestae } \\
\text { Egidio Bossi (Tractatus varii) }\end{array}$ \\
\hline $7.3 .28 / 29$ & RL & Filips Wielant (Practycke criminele) \\
\hline 7.3 .30 & Usus & Usus \\
\hline
\end{tabular}


PRIMAIRE RECHTSBRONNEN CONSUETUDINES COMPILATAE

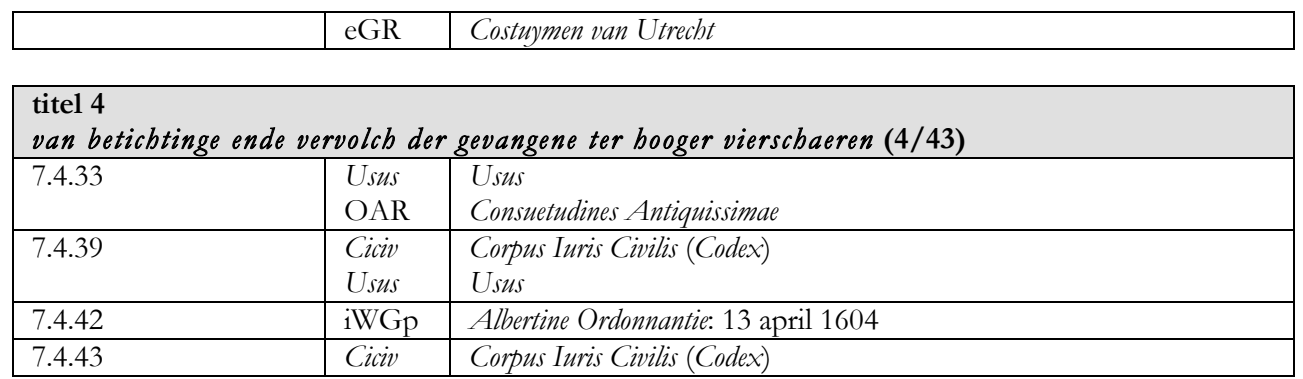

\section{titel 5}

van purge oft suijveringe van misdaeden $(0 / 8)$

titel 6

van vrede $(0 / 27)$

titel 7

van oorvrede $(0 / 12)$

\begin{tabular}{|c|c|c|}
\hline \multicolumn{3}{|c|}{$\begin{array}{l}\text { titel } 8 \\
\text { van den soene }(3 / 20)\end{array}$} \\
\hline 7.8 .1 & $\begin{array}{l}\text { iWGv } \\
\mathrm{iWGV}\end{array}$ & $\begin{array}{l}\text { Blijde inkomst Karel V } \\
\text { Blijde inkomst Filips II }\end{array}$ \\
\hline 7.8 .18 & $\begin{array}{l}\text { iWGs } \\
3\end{array}$ & $\begin{array}{l}\text { Ordonnantie Peyskamer: } 12 \text { november } 1509 \\
\text { Magistraat }\end{array}$ \\
\hline 7.8 .20 & OAR & Consuetudines Antiquissimae \\
\hline
\end{tabular}

In totaal gaat het hier om 3643 artikels waarvan er 1801.5 nieuw werden toegevoegd. 

BIJLAGE 3

\section{'LETTERLIJKE' ASSIMILATIE VERSUS 'NIET-LETTERLIJKE' ASSIMILATIE: VOORBEELDEN}

Deze bijlage geeft, aan de hand van voorbeelden, een verduidelijking van de criteria volgens dewelke ik een onderscheid heb gemaakt tussen 'letterlijk' en 'niet-letterlijk' geassimileerde artikels in het Gelderse Land-en Stadsrecht.

Voorbeelden van letterlijke, normatieve assimilatie zijn er bij de vleet. Ter illustratie geef ik hier de concordantie weer tussen de artikels GLS, I, 2, §1, art 17 en Comp, II, 1, art 20. Het Roermondse artikel luidt als volgt: "Desgelicx, soe wanneer mann ende vrouw, bij hunne bylicxe voorwaerde yet hebben versien, gegeven ofte gelaeten van hunne eygene goederen tot profijte van eenen anderen, moghen desniettegenstaende 't zelve breken oft veranderen, ten waere dat denselven daeruuyt eenich onwederroepelick recht waere vercreghen, bij maniere oft recht van volcomene ghifte, volgende 't geene onder den titel van ghiffte wordt gesaght."'1398 De Antwerpse equivalent ervan luidt als volgt: "Desgelijcx, soo wanneer man ende wijff bij henne houwelijcxe voor-waerden ijet hebben versien ofte gelaeten van bun eijgen goet tot proffijte van eenen anderen, mogen dijennijettegenstaende $t^{\prime}$ selve wel breken oft veranderen, ten waere dat den selven daervuijt onwederroepelijek recht hadde [waere geboren oft] vercregen bij maniere ende titel van giften."1399 Hierbij heb ik geen rekening gehouden met de mogelijke verschillen inzake Brabantse en Roermondse terminologie. Niet-letterlijke, normatieve assimilatie ontstaat pas van zodra de zinsbouw verschillend is. Een voorbeeld hiervan is terug te vinden bij de artikels GLS, III, 1, $\$ 1$, art 5 en Comp, III, 2, art 7. Het eerste luidt als volgt: "Insgelicx als op einige goederen in der manieren voors. renthen sijn vercocht ende bevestight, oft dat die voor andere schulden gerichtlick sijn verbonden, oft pandtschapswijse aen jemandt verschreven, soe sijn dieselve goederen tot versekerheit van alsulcke renthen, schulden ende pandtschappen, terstondt verpandt ende verplicht, sonder dat daertoe daetelicke overleveringe der goederen van nooden is."1400 De Antwerpse equivalent ervan luidt als volgt: "Insgelijcx, soo wanneer op eenige goeden renten sijn verleden, oft dat die voor andere schulden rechtelijck voor schepenen sijn verbonden, soo is alsulcke schult oft rente terstont bepant oft beseth, alwaert dat de selve goeden, diemen voor schepenen van Antwerpen heeft verbonden, niet en waren gelegen binnen de stadt oft vrijheijt, maer int quartier, als voore." 1401

Lichte (syntactische) verschillen werden uiteraard over het hoofd gezien. Ik denk bijvoorbeeld aan de artikels GLS I, 3, \4, art 2 (Vader ende moeder worden verstaen hunne kinderen alsulcken gelt oft goet gegunt oft gegeven te hebben, om bun eygen profijt daermit te doen, soe wanneer sij hun daermit laeten handelen op hunnen eygen naem, sonder hun daervan in hunnen leven reeckeninge, bewijs ende veroeveringhe ofte profijt geheyst te hebben, al waer 't oock dat van hunnen meyninge anders niet en bleeke $e^{1402}$ ) en Comp II, 2, art 18 (Ende worden vader ende moeder verstaen benne kinderen alsulcken gelt oft goet gegunt te hebben, om daermede hun eijgen proffijte te

1398 Gelderse Land- en stadsrecht, BERKVENS, VENNER en SPIJKERBOER, 24.

1399 Coutumes de la ville d'Anvers dites Compilatae, III, 90.

1400 Gelderse Land- en stadsrecht, BERKVENS, VENNER en SPIJKERBOER, 121.

1401 Coutumes de la ville d'Anvers dites Compilatae, III, 308.

1402 Gelderse Land-en Stadsrecht, BERKVENS, VENNER en SPIJKERBOER, 44. 
doene, soo wanneer sij bun daermede laten handelen op hunnen eijgen naeme, sonder hun daervan in bun leven rekeninge, bewijs ende proffijte geheijst te hebben, alwaert oock dat van henne neiringe anders niet en bleke $\left.e^{1403}\right)$. Vergelijkbaar is de situatie met betrekking tot de artikels GLS III, 1, $\mathbb{\$} 1$, art 4a (Soe haest als einighe opdracht, ende verhandelinge in der manieren voors. is gedaen ende bekendt, Soe is ende wordt den cooper oft vercrijger volcommen heer ende meister darvan:... ${ }^{1404}$ ) en Comp III, 2, art 6 (Soo geringe als eenich opdracht, vertieringe, maeekinghe, overgevinge oft vertijdinge van renten voor schepenen, als voore, behoorelijck verleden ende bekent is, soo is ende wort den cooper ende vercrijger heer ende meester van de opgedragene goeden oft renten, soo wel aengaende het besith oft possessie daerinne de vercooper was, als d'erffelijckheijt ${ }^{405}$ ), de artikels GLS III, 1, \$1, art 5 (Insgelicx als op einige goederen in der manieren voors. renthen sijn vercocht ende bevestight, oft dat die voor andere schulden gerichtlick sijn verbonden, oft pandtschapswijse aen jemandt verschreven, soe sijn dieselve goederen tot versekerheit van alsulcke renthen, schulden ende pandtschappen, terstondt verpandt ende verplicht, sonder dat daertoe daetelicke overleveringe der goederen van nooden is ${ }^{1406}$ ) en Comp III, 2, art 7 (Insgelijcx, soo wanneer op eenige goeden renten sijn verleden, oft dat die voor andere schulden rechtelijck voor schepenen sijn verbonden, soo is alsulcke schult oft rente terstont bepant oft beseth, alwaert dat de selve goeden, diemen voor schepenen van Antwerpen heeft verbonden, niet en waren gelegen binnen de stadt oft vrijheijt, maer int quartier, als voore ${ }^{1407}$ ), en de artikels GLS III, 1, $\$ 1$, art 6 (Ende oft aen jemandt einige opdrachten, verhandelingen ofte verbintenissen van buysen, ofte onruerende goederen, anders waere gedaen, dan gesacht is, die en solde daermit geen erffrecht ofte pandtschap vercrijgen, dan alleenlick personeele actie oft gerechticheit, tegens den vercooper ofte bekenner, om hem behoorlick te doen voltrecken sijne verbintenisse ofte opdracht ${ }^{408}$ ) en Comp III, 2, art 9 (Ende ofter eenige opdrachten, mangelingen ofte verbintenissen van huijsen oft onrurende goeden ende renten, erffelijcke oft lijfftocht renten, oft oock scheijdingen ende deijlingen van sterffhuijsen binnen dese stadt oft vrijheijt van Antwerpen gelegen. elders oft anderssints dan voor schepenen van Antwerpen waeren gedaen oft verleden, daerdoor en is, noch en wort vercregen eenich recht van erffelijckheijt oft pandtschappe, maer wel alleenelijck actie personeel tegens den verlijder, tot voldoeninge van sijne gelofte, ende om van nieuws voor schepenen van Antwerpen alsulcke verlijdinge te doen $\left.{ }^{1409}\right)$. Zij werden als 'letterlijk geassimileerd' beschouwd.

Anders is het wanneer zich een situatie voordoet zoals bij de artikels GLS I, 4, \$6, art 3 (Maer als een oft eenige van de momboirs bun alleen den handel oft bewindt der weesen oft vermomboirde persoonen goederen onderwonden hebben, sonder dat d'andere bun des hebben gemoyt oft daertoe last gegeven, laetende alleenlick de medemomboir oft momboirs daermit gewerden, soe sijn die andere momboirs die de handelinge der goederen niet en bebben gehat, derwegen end van de t'achterheit daeruuyt spruytende, niet gehalden oft pandtbaer, dan in subsidium, oft tot onderstandt ende behulp, bij gebrecke van verhael op de andere ${ }^{1410}$ ) en Comp II, 5, art 175 (Soo wanneer den

1403 Coutumes de la ville d'Anvers dites compilatae, III, 198.

1404 Gelderse Land-en Stadsrecht, BERKVENS, VENNER en SPIJKERBOER, 121.

1405 Coutumes de la ville d'Anvers dites compilatae, III, 308.

1406 Gelderse Land-en Stadsrecht, BERKVENS, VENNER en SPIJKERBOER, 121.

1407 Coutumes de la ville d'Anvers dites compilatae, III, 308.

1408 Gelderse Land-en Stadsrecht, BERKVENS, VENNER en SPIJKERBOER, 122.

${ }^{1409}$ Coutumes de la ville d'Anvers dites compilatae, III, 308-309.

1410 Gelderse Land-en Stadsrecht, BERKVENS, VENNER en SPIJKERBOER, 67. 
eenen momboor der weesen oft vermomboorde goeden niet en heeft behandelt oft hem die onderwonden, maer die bij sijnen medemomboor alleen laeten behandelen, ende dat die d'onderwint gehadt heeft ten tijde van de eijn-dinge van de momboordije machtich is om sijne t'achterheijt te betaelen, soo en is de gene, die d'onderwint niet en heeft gehadt, niet aensprekelijck noch gehouden voort gene den anderen beeft gedaen $\left.{ }^{1411}\right)$. Hoewel men zich hoogstwaarschijnlijk door het Antwerpse model heeft laten inspireren, kan ik niet langer van letterlijke assimilatie spreken. Daarvoor zijn de linguïstische en grammaticale verschillen te groot. De acculturatie is vermoedelijk dus nog groter. Want, vergelijkbaar met laatstgenoemde voorbeeld zijn de artikels GLS II, 2, \$4, art 6 (Welverstaende dat der verlijder van de rente, ende sijne erffgenaemen, het onderpandt van de rente wel moeghen vercoopen, ende anderen opdraegen, vermeldende van de rente daerop unytgaende, ende dat soelange het onderpant bie die coopers, oft andere, op den last word beseten, sie niet gehalden sijn 't verloop van de rente jaerlicx te betaelen: Ten waere dat daervan noch op die besitters van 't onderpant noch op 't selve pandt gein verhael en waere ${ }^{1412}$ ) en Comp III, 8, art 71 (Den verlijder van eenige renten die den pant niet meer en bebben, maer daervan wettelijck is gescheijden tot proffijt van derde persoonen, en is niet gehouden $t^{\prime}$ verloop van de selve rente jaerelijcx te betaelen ten waere dat, den pant ende leste besitter geproeft sijnde, bevonden werde niet genoechsaem te sijn, om daerop sijn verhael te hebben ${ }^{1413}$ ), de artikels GLS IV, 3, \4, art 6 (Niettemin opdat noch der beveelgever, noch der factuer in gein onverwachten oft onvermeinden interesten bie langh stillswijgen, oft ooghluycken van d'ein oft d'ander en vallen, soe is dergeene, die aen den anderen vanwegen 't geene voirs. is verstaet ten achter te sijn, gehalden tot bewaringe van sijn gerechticheit van schade ende interesten, (insoevern bie daervan gein geloefte en beeft) sijn t'achterheit binnen vier maenden bie brieven te voorderen, ende soe bie daervan niet en wordt voldaen, noch geloefte en becompt, binnen vier maenden darnae te protesteeren, ende binnen andere vier maenden sijn t'achterheit mit den interesten van deselve mit recht te eisschen, ende te vervolgen; 't sij voir recht ofte goede mannen ten beiden sijden te kiesen, oftwel hem ondertusschen versien van behoirlicke beloefte ${ }^{1414}$ ) en Comp IV, 6, art 23 (Dies moet eenen committent oft facteur, soo verre bij geene geloften van interest en heeft met brieven oft anderssints, partije daeraff terstont waerschouwen, ende, om sijne gerechticheijt totten selven interest te behouden, binnen s'jaers naerdijen de schult is geboren, ter saecken van dijen protesteren, ende binnen sesse weken daernaer sijn recht vervolgen, $t^{\prime}$ sij voor de weth oft voor goede mannen ter weder sijde te kiesen, oft wel ondertusschen hem versien van behoorelijcke gelofte; ende oft hij d'een ende d'ander niet en dede, soude verstaen worden van den heijsch van den interest hem verdraegen te hebben ${ }^{1415}$ ), de artikels GLS IV, 3, \5, art 6 (Die ein perdt voir suyver ende rein vercoept, is gehalden te verantwoorden voir alle die gebreken die aen 't peerdt worden bevonden, binnen den tijdt van einen maendt, naer den coep, maer heeft hie sulcx niet toegesaght, en is wegen die gebreken van het vercocht peerdt niet gehalden, behalven van de gebreken dempicheit, oft aenborsticheit, ruyicheit, oft snuyvicheit, wie insgelicx van den worm die hem binnen den tijdt van ses weken openbaeren ten waere dat der coeper die gebreken geweten, ende verswegen hadde ${ }^{1416}$ ) en Comp IV, 5, art 9 (Die een peert vercoopt en is niet gehouden van eenich

1411 Coutumes de la ville d'Anvers dites compilatae, III, 284.

1412 Gelderse Land-en Stadsrecht, BERKVENS, VENNER en SPIJKERBOER, 84.

1413 Coutumes de la ville d'Anvers dites compilatae, III, 462.

1414 Gelderse Land-en Stadsrecht, BERKVENS, VENNER en SPIJKERBOER, 211.

1415 Coutumes de la ville d'Anvers dites compilatae, IV, 76.

1416 Gelderse Land- en Stadsrecht, BERKVENS, VENNER en SPIJKERBOER, 212. 
gebreck d'welck tselve peert soude mogen hebben, behalvens van dempicheijt binnen acht daegen, ende van snotheijt ende van woom binnen sesse weken naer den coop, ten waere men eenich peert suijver ende net vercocht, in welcken gevalle men gehouden is verantwoorden van alle gebreken die bij weerderinge aen de peerden wordden bevonden ${ }^{1417}$ ), en de artikels GLS IV, 12, \$2, art 9 (Voirts bebben voirdeel van betalinge ende recht van stilswijgende pandtschap, den prince weghen die t'achterbeit van sijne rechten ende schulden, maer niet van de penen ofte bruecken, ende die weesen ende andere vermomboirde persoenen, voir die t'achterbeit van bunne momboirs, ende de kinders aen bunne alders, wegen de bandelinge oft onderwindt van bunne goederen, sonder dat tusschen den prince, weesen ende kinderen, als sie $t^{\prime}$ 'saemen aen eine persoon ten acbteren sijn, ander oirdre wordt gehalden, dan dat voirgaet ende ierst betaelt wordt, die d'altste gerechticheit heeft ${ }^{418}$ ) en Comp IV, 18, art 18 (Daernaer worden naer elcx ouderdom geprefereert de vroune ende baere kinderen ter saeeken van haere bouwelijcxe goeden, de weesen voor bunne tachterbeijt aen bunne momboors, ende den prince ter saecken van de tachterheijt van sijne rechten ende schulden, ende niet van penen oft breucken $\left.{ }^{1419}\right)$.

Een voorbeeld van een half letterlijk geassimileerd artikel is te vinden bij de artikels GLS IV , 2, \$2, art 7 (Desgelijcx staet tot gericbtlicke erlegginge ende handtvuldinge de gebeiscbte schuldt, die compt van achterstendige renten, tinsen, buishueren ende verschenen pacbten, enckelen arbeitsloon, temmelicke verteerde costen, beckers, brouwers, vleeschouwers, ende tepperskerven, als die maer van den tijdt van drie naeste jaeren voir den eisch gefordert worden, ende daervan blickt, oft dat die niet ontkendt en worden, mits stellende genouchsame cautie oft versekeringe voor 't lichten van de gelaghte penningen ${ }^{1420}$ ) en Comp IV, 14, art 1 (Alle claere bantschriften, wissel ende asseurantie brieven, schepenen bekentenissen, saecken van acbterstellige bueren, renten ende verschenen pacbten, enckelen aerbeijtsloon, tamelijcke verteerde costen, backers, brouvers, vleeschounvers ende taveniers kerven, staen tot namptisatie onder seker ${ }^{1421}$ ).

\footnotetext{
1417 Coutumes de la ville d'Anvers dites compilatae, IV, 60.

1418 Gelderse Land- en Stadsrecht, BERKVENS, VENNER en SPIJKERBOER, 254.

1419 Coutumes de la ville d'Anvers dites compilatae, IV, 442.

1420 Gelderse Land-en Stadsrecht, BERKVENS, VENNER en SPIJKERBOER, 200.

1421 Coutumes de la ville d'Anvers dites compilatae, IV, 364.
} 


\section{BIJLAGE 4}

\section{NAAR ANTWERPS MODEL GEASSIMILEERDE ARTIKELS IN HET GELDERSE LAND- EN STADSRECHT}

De tabel geeft alle artikels weer welke zowel in de Antwerpse Consuetudines compilatae als het Gelderse Land-en Stadsrecht voorkomen. De gelijkenis is (quasi) identiek. De eerste drie kolommen hebben betrekking op de artikels van het Gelderse Land- en Stadsrecht, zoals de vier volgende kolommen verwijzen naar de plaats van de overeenkomstige artikels in de Antwerpse Consuetudines compilatae. Kolom 'P' verwijst naar de paragraaf, kolom ' $\mathrm{T}$ ' naar de titel, kolom $\mathrm{D}$ naar het deel en kolom 'A' geeft het artikelnummer weer. De laatste kolom geeft de primaire rechtsbronnen weer zoals ze in de Memorien op de costuymen werden weergegeven en in bijlage 2 werden opgesomd. De gehanteerde afkortingen komen overeen met die welke werden gebruikt in de eerste paragraaf van het eerste hoofdstuk omtrent de methode van dit hoofdstuk.

\begin{tabular}{|c|c|c|c|c|c|c|c|}
\hline Roermond & $\mathbf{P}$ & A & Antwerpen & D & $\mathbf{T}$ & $\mathbf{A}$ & Rechtsbronnen \\
\hline \multicolumn{8}{|l|}{ TITEL 1.1} \\
\hline 5 artikels & 1 & & 0 concordanties & & & & \\
\hline 7 artikels & 2 & & 0 concordanties & & & & \\
\hline 8 artikels & 3 & & 0 concordanties & & & & \\
\hline 6 eden & 4 & & 0 concordanties & & & & \\
\hline \multicolumn{8}{|l|}{ TITEL 1.2} \\
\hline \multirow{9}{*}{38 artikels } & 1 & 1 & \multirow{9}{*}{9 concordanties } & II & 5 & 2 & $\operatorname{Imp}$ \\
\hline & 1 & 2 & & II & 5 & 4 & iWG \\
\hline & 1 & 3 & & II & 5 & 5 & iWG \\
\hline & 1 & 8 & & II & 1 & 1 & $\operatorname{Imp}$ \\
\hline & 1 & 9 & & II & 1 & 2 & $\operatorname{Imp}$ \\
\hline & 1 & 13 & & II & 1 & 8 & $\operatorname{Imp}$ \\
\hline & 1 & 14 & & II & 1 & 9 & $\operatorname{Imp}$ \\
\hline & 1 & 16 & & II & 1 & 11 & $\operatorname{Imp}$ \\
\hline & 1 & 17 & & II & 1 & 12 & Imp, OAR, S \\
\hline \multirow[t]{11}{*}{27 artikels } & 2 & 1 & \multirow[t]{11}{*}{12 concordanties } & II & 1 & $21,22,23$ & $\operatorname{Imp}$ \\
\hline & 2 & 2 & & II & 1 & $21,22,23$ & $\operatorname{Imp}$ \\
\hline & 2 & 3 & & II & 1 & 26 & $\operatorname{Imp}$ \\
\hline & 2 & 8 & & II & 1 & 30 & $\operatorname{Imp}$ \\
\hline & 2 & 13 & & II & 1 & 44 & $\operatorname{Imp}$ \\
\hline & 2 & 14 & & II & 1 & 45 & $\operatorname{Imp}$ \\
\hline & 2 & 15 & & II & 1 & 60 & $\operatorname{Imp}$ \\
\hline & 2 & 16 & & II & 1 & 61 & $\operatorname{Imp}$ \\
\hline & 2 & 17 & & II & 1 & 62 & $\operatorname{Imp}$ \\
\hline & 2 & 19 & & II & 1 & 67,78 & $\operatorname{Imp}, \mathrm{S}$ \\
\hline & 2 & 20 & & II & 1 & 74,76 & Usus, eGR \\
\hline
\end{tabular}


BiJLAGEN

\begin{tabular}{|c|c|c|c|c|c|c|c|}
\hline & 2 & 21 & & II & 1 & 92 & $\operatorname{Imp}$ \\
\hline \multirow{9}{*}{20 artikels } & 3 & 1 & \multirow{9}{*}{9 concordanties } & II & 1 & 124 & $\operatorname{Imp}$ \\
\hline & 3 & 2 & & II & 1 & 125 & $\operatorname{Imp}$ \\
\hline & 3 & 3 & & II & 1 & 126 & $\operatorname{Imp}$ \\
\hline & 3 & 4 & & II & 1 & 127 & $\operatorname{Imp}$ \\
\hline & 3 & 5 & & II & 1 & 128 & $\operatorname{Imp}$ \\
\hline & 3 & 6 & & II & 1 & 130 & $\operatorname{Imp}$ \\
\hline & 3 & 7 & & II & 1 & 131 & $\operatorname{Imp}$ \\
\hline & 3 & 8 & & II & 1 & 133 & OAR, Usus, Comp \\
\hline & 3 & 10 & & II & 1 & 121 & $\operatorname{Imp}$ \\
\hline 14 artikels & 4 & & 0 concordanties & & & & \\
\hline 15 artikels & 5 & & 0 concordanties & & & & \\
\hline \multicolumn{8}{|l|}{ TITEL 1.3} \\
\hline \multirow{7}{*}{8 artikels } & 1 & 1 & \multirow{7}{*}{7 concordanties } & II & 2 & 1 & $\operatorname{Imp}$, Comp \\
\hline & 1 & 2 & & II & 2 & 2 & Usus \\
\hline & 1 & 3 & & II & 2 & 3 & $\operatorname{Imp}$ \\
\hline & 1 & 4 & & II & 2 & 4 & $\operatorname{Imp}$ \\
\hline & 1 & 5 & & II & 2 & 5 & $\operatorname{Imp}$ \\
\hline & 1 & 6 & & II & 2 & 6 & $\operatorname{Imp}$ \\
\hline & 1 & 7 & & II & 2 & 7 & $\operatorname{Imp}$ \\
\hline \multirow{3}{*}{4 artikels } & 2 & 1 & \multirow{3}{*}{3 concordanties } & II & 2 & $8,9 \mathrm{a}$ & $\operatorname{Imp}$ \\
\hline & 2 & 2 & & II & 2 & $9 \mathrm{~b}$ & $\operatorname{Imp}$ \\
\hline & 2 & 4 & & II & 2 & 10,11 & $\operatorname{Imp}$ \\
\hline \multirow{2}{*}{4 artikels } & 3 & 1 & \multirow{2}{*}{2 concordanties } & II & 2 & 12 & $\operatorname{Imp}$ \\
\hline & 3 & 4 & & II & 2 & 29 & $\operatorname{Imp}$ \\
\hline \multirow{2}{*}{4 artikels } & 4 & 1 & \multirow{2}{*}{2 concordanties } & II & 2 & 16,17 & $\operatorname{Imp}$ \\
\hline & 4 & 2 & & II & 2 & 18 & Usus \\
\hline \multirow{6}{*}{6 artikels } & 5 & 1 & \multirow{6}{*}{6 concordanties } & II & 2 & 20 & $\operatorname{Imp}$ \\
\hline & 5 & 2 & & II & 2 & 21 & $\operatorname{Imp}$ \\
\hline & 5 & $3 a$ & & II & 2 & 22 & $\operatorname{Imp}$ \\
\hline & 5 & 4 & & II & 2 & 24 & Ciciv, RL \\
\hline & 5 & 5 & & II & 2 & 24 & Ciciv, RL \\
\hline & 5 & 6 & & II & 2 & 25 & Usus \\
\hline \multirow{3}{*}{5 artikels } & 6 & 1 & \multirow{3}{*}{3 concordanties } & II & 2 & 26 & $\operatorname{Imp}$ \\
\hline & 6 & 2 & & II & 2 & 27 & $\operatorname{Imp}$ \\
\hline & 6 & 5 & & II & 2 & 28 & $\operatorname{Imp}$ \\
\hline \multicolumn{8}{|l|}{ TITEL 1.4} \\
\hline \multirow[t]{7}{*}{23 artikels } & 1 & 1 & \multirow[t]{7}{*}{20 concordanties } & II & 5 & 1 & $\operatorname{Imp}$ \\
\hline & 1 & 5 & & II & 5 & 8 & $\operatorname{Imp}$ \\
\hline & 1 & 6 & & II & 5 & 9 & $\operatorname{Imp}$ \\
\hline & 1 & 7 & & II & 5 & 10 & RSe \\
\hline & 1 & 8 & & II & 5 & 15 & $\operatorname{Imp}$ \\
\hline & 1 & 9 & & II & 5 & 16 & $\operatorname{Imp}$ \\
\hline & 1 & 10 & & II & 5 & 17 & Ciciv, RL \\
\hline
\end{tabular}


GEASSIMILEERDE ARTIKELS IN HET GELDERSE LAND- EN STADSRECHT

\begin{tabular}{|c|c|c|c|c|c|c|c|}
\hline & 1 & 11 & & II & 5 & 18 & Ciciv \\
\hline & 1 & 12 & & II & 5 & 19 & $\operatorname{Imp}$ \\
\hline & 1 & 13 & & II & 5 & 20 & Ciciv, iWGv \\
\hline & 1 & 14 & & II & 5 & 21 & Ciciv \\
\hline & 1 & 15 & & II & 5 & 22 & Ciciv \\
\hline & 1 & 16 & & II & 5 & 23 & $\operatorname{Imp}$ \\
\hline & 1 & 17 & & II & 5 & 24 & $\operatorname{Imp}$ \\
\hline & 1 & 18 & & II & 5 & 25 & $\operatorname{Imp}$ \\
\hline & 1 & 19 & & II & 5 & 26 & $\operatorname{Imp}$ \\
\hline & 1 & 20 & & II & 5 & 27 & $\operatorname{Imp}$ \\
\hline & 1 & 21 & & II & 5 & 28 & $\operatorname{Imp}$ \\
\hline & 1 & 22 & & II & 5 & 29 & $\operatorname{Imp}$ \\
\hline & 1 & 23 & & II & 5 & 30 & $\operatorname{Imp}$ \\
\hline \multirow{18}{*}{19 artikels } & 2 & 1 & \multirow{18}{*}{18 concordanties } & II & 5 & 31 & $\operatorname{Imp}$ \\
\hline & 2 & 2 & & II & 5 & 33 & $\operatorname{Imp}$ \\
\hline & 2 & 3 & & II & 5 & 37 & Usus, Ciciv \\
\hline & 2 & 4 & & II & 5 & 38 & Usus, Ciciv \\
\hline & 2 & 6 & & II & 5 & 39 & Usus, Ciciv \\
\hline & 2 & 7 & & II & 5 & 40 & Usus, Ciciv \\
\hline & 2 & 8 & & II & 5 & 42 & Usus, Ciciv \\
\hline & 2 & 9 & & II & 5 & 43 & OAR \\
\hline & 2 & 10 & & II & 5 & 44,45 & $\operatorname{Imp}$ \\
\hline & 2 & 11 & & II & 5 & 46 & $\operatorname{Imp}$ \\
\hline & 2 & 12 & & II & 5 & 47 & $\operatorname{Imp}$ \\
\hline & 2 & 13 & & II & 5 & 48 & $\operatorname{Imp}$ \\
\hline & 2 & 14 & & II & 5 & 49 & $\operatorname{Imp}$ \\
\hline & 2 & 15 & & II & 5 & 50,51 & $\operatorname{Imp}$ \\
\hline & 2 & 16 & & II & 5 & 54 & $\operatorname{Imp}$ \\
\hline & 2 & 17 & & II & 5 & 58 & $\operatorname{Imp}$ \\
\hline & 2 & 18 & & II & 5 & 59 & $\operatorname{Imp}$ \\
\hline & 2 & 19 & & II & 5 & 62 & $\operatorname{Imp}$ \\
\hline \multirow{11}{*}{12 artikels } & 3 & 1 & \multirow{11}{*}{11 concordanties } & II & 5 & 68 & $\operatorname{Imp}$ \\
\hline & 3 & 2 & & II & 5 & 69 & Ciciv \\
\hline & 3 & 3 & & II & 5 & 70 & Ciciv \\
\hline & 3 & 4 & & II & 5 & 71 & Ciciv, 3 \\
\hline & 3 & 5 & & II & 5 & 73 & Ciciv \\
\hline & 3 & 7 & & II & 5 & 52 & $\operatorname{Imp}$ \\
\hline & 3 & 8 & & II & 5 & 53 & $\operatorname{Imp}$ \\
\hline & 3 & 9 & & II & 5 & 74 & $\operatorname{Imp}$ \\
\hline & 3 & 10 & & II & 5 & 75 & $\operatorname{Imp}$ \\
\hline & 3 & 11 & & II & 5 & 76 & $\operatorname{Imp}$ \\
\hline & 3 & 12 & & II & 5 & 77 & $\operatorname{Imp}$ \\
\hline \multirow[t]{2}{*}{49 artikels } & 4 & 1 & \multirow[t]{2}{*}{49 concordanties } & II & 5 & 78 & $\mathrm{eWG}$ \\
\hline & 4 & 2 & & II & 5 & 79 & $\operatorname{Imp}$ \\
\hline
\end{tabular}




\section{BiJLAGEN}

\begin{tabular}{|l|l|}
\hline 4 & 3 \\
\hline 4 & 4 \\
\hline 4 & 5 \\
\hline 4 & 6 \\
\hline 4 & 7 \\
\hline 4 & 8 \\
\hline 4 & 9 \\
\hline 4 & 10 \\
\hline 4 & $11 \mathrm{a}$ \\
\hline 4 & 12 \\
\hline 4 & 13 \\
\hline 4 & 14 \\
\hline 4 & 15 \\
\hline 4 & 16 \\
\hline 4 & 17 \\
\hline 4 & 18 \\
\hline 4 & 19 \\
\hline 4 & 20 \\
\hline 4 & 21 \\
\hline 4 & 22 \\
\hline 4 & 23 \\
\hline 4 & 24 \\
\hline 4 & 25 \\
\hline 4 & 26 \\
\hline 4 & 27 \\
\hline 4 & 28 \\
\hline 4 & 29 \\
\hline 4 & 30 \\
\hline 4 & 31 \\
\hline 4 & 32 \\
\hline 4 & 33 \\
\hline 4 & 34 \\
\hline 4 & 35 \\
\hline 4 & 36 \\
\hline 4 & 37 \\
\hline 4 & 38 \\
\hline 4 & 39 \\
\hline 4 & 40 \\
\hline 4 & 41 \\
\hline 4 & 42 \\
\hline 4 & 43 \\
\hline 4 & 44 \\
\hline 4 & 45 \\
\hline 4 & 46 \\
\hline & \\
\hline 4
\end{tabular}

\begin{tabular}{|c|c|c|c|}
\hline II & 5 & 80 & Ciciv, RL \\
\hline II & 5 & 81 & Ciciv, RL \\
\hline II & 5 & 82 & Usus \\
\hline II & 5 & 83 & Usus, eWG \\
\hline II & 5 & 83 & Usus, eWG \\
\hline II & 5 & 84 & Usus, eWG, Ciciv, RL \\
\hline II & 5 & 85 & OAR, S \\
\hline II & 5 & 86 & $\operatorname{Imp}$ \\
\hline II & 5 & 87 & $\operatorname{Imp}$ \\
\hline II & 5 & 88 & $\operatorname{Imp}$ \\
\hline II & 5 & 95 & $\operatorname{Imp}$ \\
\hline II & 5 & 96 & S \\
\hline II & 5 & 97 & $\mathrm{~S}$ \\
\hline II & 5 & 103 & $\operatorname{Imp}$ \\
\hline II & 5 & 104 & $\operatorname{Imp}$ \\
\hline II & 5 & 105 & $\operatorname{Imp}$ \\
\hline II & 5 & 106 & 3 \\
\hline II & 5 & 107 & Usus \\
\hline II & 5 & 108 & Usus, RSi \\
\hline II & 5 & 109 & $\operatorname{Imp}$ \\
\hline II & 5 & 110 & $\operatorname{Imp}$ \\
\hline II & 5 & 111 & $\operatorname{Imp}$ \\
\hline II & 5 & 112 & $3, S$ \\
\hline II & 5 & 113 & $3, \mathrm{~S}$ \\
\hline II & 5 & 114 & $\operatorname{Imp}$ \\
\hline II & 5 & 115 & $\operatorname{Imp}$ \\
\hline II & 5 & 116 & Comp \\
\hline II & 5 & 118 & $\operatorname{Imp}$ \\
\hline II & 5 & 119 & $\operatorname{Imp}$ \\
\hline II & 5 & 120 & $\operatorname{Im} p$ \\
\hline II & 5 & 122 & $\operatorname{Im} p$ \\
\hline II & 5 & 123 & Usus, 3 \\
\hline II & 5 & 124 & $\operatorname{Imp}$ \\
\hline II & 5 & 125 & $\operatorname{Imp}$ \\
\hline II & 5 & 126 & eGR \\
\hline II & 5 & 127 & eGR \\
\hline II & 5 & 128 & $\operatorname{Imp}$ \\
\hline II & 5 & 129 & $\operatorname{Imp}$ \\
\hline II & 5 & 130 & $\operatorname{Imp}$ \\
\hline II & 5 & 134 & Comp, Ciciv \\
\hline II & 5 & 135 & $\operatorname{Imp}$ \\
\hline II & 5 & 136 & $\operatorname{Imp}$ \\
\hline II & 5 & 137 & $\operatorname{Imp}$ \\
\hline II & 5 & 138 & Ciciv, RL \\
\hline
\end{tabular}


GEASSIMILEERDE ARTIKELS IN HET GELDERSE LAND- EN STADSRECHT




BiJLAGEN

\begin{tabular}{|c|c|c|c|c|c|c|c|}
\hline & & 10 & & II & 3 & 9 & Ciciv, RL \\
\hline & & 11 & & II & 3 & 11 & $\operatorname{Imp}$ \\
\hline & & 12 & & II & 3 & 12 & $\operatorname{Imp}$ \\
\hline \multicolumn{8}{|l|}{ TITEL 2.1} \\
\hline 13 artikels & & & 0 concordanties & & & & \\
\hline \multicolumn{8}{|l|}{ TITEL 2.2} \\
\hline \multirow{17}{*}{19 artikels } & 1 & 1 & \multirow{17}{*}{17 concordanties } & III & 8 & 1 & $\operatorname{Imp}$ \\
\hline & 1 & 2 & & III & 8 & 2 & $\operatorname{Imp}$ \\
\hline & 1 & 3 & & III & 8 & 3 & $\operatorname{Imp}$ \\
\hline & 1 & 4 & & III & 8 & 4 & $\operatorname{Imp}$ \\
\hline & 1 & 5 & & III & 8 & 7,8 & $\operatorname{Imp}$ \\
\hline & 1 & 6 & & III & 8 & 8 & $\operatorname{Imp}$ \\
\hline & 1 & 7 & & III & 8 & 10 & $\operatorname{Imp}$ \\
\hline & 1 & 8 & & III & 8 & 11 & $\operatorname{Imp}$ \\
\hline & 1 & 9 & & III & 8 & 12 & Ciciv, RA \\
\hline & 1 & 10 & & III & 8 & 13 & Ciciv, RA \\
\hline & 1 & 11 & & III & 8 & 14 & $\operatorname{Imp}$ \\
\hline & 1 & 13 & & III & 8 & 15 & eGR \\
\hline & 1 & 14 & & III & 8 & 16 & $\operatorname{Imp}$ \\
\hline & 1 & 16 & & III & 8 & 17 & $\operatorname{Imp}$ \\
\hline & 1 & 17 & & III & 8 & 18 & $\operatorname{Imp}$ \\
\hline & 1 & 18 & & III & 8 & 19 & $\operatorname{Imp}$ \\
\hline & 1 & 19 & & III & 8 & 20 & $\operatorname{Imp}$ \\
\hline \multirow{11}{*}{12 artikels } & 2 & 1 & \multirow{11}{*}{11 concordanties } & III & 8 & 23 & $\operatorname{Imp}$ \\
\hline & 2 & 2 & & III & 8 & 24 & $\mathrm{~S}, \mathrm{iWG}$ \\
\hline & 2 & 3 & & III & 8 & 25 & S, iWGv \\
\hline & 2 & 4 & & III & 8 & 26 & $\mathrm{~S}, \mathrm{iWGv}$ \\
\hline & 2 & 6 & & III & 8 & 27 & $\mathrm{~S}, \mathrm{iWGv}$ \\
\hline & 2 & 7 & & III & 8 & 28 & $\mathrm{~S}, \mathrm{iWG}$ \\
\hline & 2 & 8 & & III & 8 & 29 & $\operatorname{Imp}$ \\
\hline & 2 & 9 & & III & 8 & 30 & $\operatorname{Imp}$ \\
\hline & 2 & 10 & & III & 8 & 31 & Usus, iWGv, iWGs \\
\hline & 2 & 11 & & III & 8 & 32 & $\operatorname{Imp}$ \\
\hline & 2 & 12 & & III & 8 & 33 & $\operatorname{Imp}$ \\
\hline \multirow[t]{10}{*}{20 artikels } & 3 & 1 & \multirow[t]{10}{*}{15 concordanties } & III & 8 & 34 & $\operatorname{Imp}$ \\
\hline & 3 & 2 & & III & 8 & 35 & $\operatorname{Imp}$ \\
\hline & 3 & 3 & & III & 8 & 36 & $\operatorname{Imp}$ \\
\hline & 3 & 5 & & III & 8 & 38 & $\operatorname{Imp}$ \\
\hline & 3 & 6 & & III & 8 & 39 & $\operatorname{Imp}$ \\
\hline & 3 & 7 & & III & 8 & 40 & $\operatorname{Imp}$ \\
\hline & 3 & 11 & & III & 8 & 43 & $\operatorname{Imp}$ \\
\hline & 3 & 12 & & III & 8 & 44 & $\operatorname{Imp}$ \\
\hline & 3 & 13 & & III & 8 & 45 & $\operatorname{Imp}$ \\
\hline & 3 & 14 & & III & 8 & 46 & $\operatorname{Imp}$ \\
\hline
\end{tabular}


GEASSIMILEERDE ARTIKELS IN HET GELDERSE LAND- EN STADSRECHT




BiJLAGEN

\begin{tabular}{|c|c|c|c|c|c|c|c|}
\hline & 1 & 6 & & III & 5 & 15 & $\operatorname{Imp}$ \\
\hline & 1 & 7 & & III & 5 & 17 & $\operatorname{Imp}$ \\
\hline & 1 & 8 & & III & 5 & 18 & $\operatorname{Imp}$ \\
\hline & 1 & 9 & & III & 5 & 20 & $\operatorname{Imp}$ \\
\hline & 1 & 10 & & III & 5 & 21 & $\operatorname{Imp}$ \\
\hline & 1 & 11 & & III & 5 & 22 & $\operatorname{Imp}$ \\
\hline & 1 & 14 & & III & 5 & 23 & $\operatorname{Imp}$ \\
\hline & 1 & 15 & & III & 5 & 24 & 3 \\
\hline & 1 & 16 & & III & 5 & 25 & Usus, Ciciv, RA \\
\hline & 1 & 17 & & III & 5 & 84 & $\operatorname{Imp}$ \\
\hline & 1 & 18 & & III & 5 & 85 & $\operatorname{Imp}$ \\
\hline & 1 & 19 & & III & 5 & 87 & $\operatorname{Imp}$ \\
\hline \multirow{8}{*}{8 artikels } & 2 & 1 & \multirow{8}{*}{8 concordanties } & III & 5 & 26 & $\operatorname{Imp}$ \\
\hline & 2 & 2 & & III & 5 & 27 & $\operatorname{Imp}$ \\
\hline & 2 & 3 & & III & 5 & 28 & $\operatorname{Imp}$ \\
\hline & 2 & 4 & & III & 5 & 29 & $\operatorname{Imp}$ \\
\hline & 2 & 5 & & III & 5 & 30 & $\mathrm{~S}$ \\
\hline & 2 & 6 & & III & 5 & 31 & $\operatorname{Imp}$ \\
\hline & 2 & 7 & & III & 5 & 32 & $\operatorname{Imp}$ \\
\hline & 2 & 8 & & III & 5 & 33 & $\operatorname{Imp}$ \\
\hline \multirow{22}{*}{22 artikels } & 3 & 1 & \multirow{22}{*}{22 concordanties } & III & 5 & 34 & $\operatorname{Imp}$ \\
\hline & 3 & 2 & & III & 5 & 35 & $\operatorname{Imp}$ \\
\hline & 3 & 3 & & III & 5 & 36 & $\operatorname{Imp}$ \\
\hline & 3 & 4 & & III & 5 & 37 & $\operatorname{Imp}$ \\
\hline & 3 & 5 & & III & 5 & 38 & $\operatorname{Imp}$ \\
\hline & 3 & 6 & & III & 5 & 39 & $\operatorname{Imp}$ \\
\hline & 3 & 7 & & III & 5 & 41 & $\operatorname{Imp}$ \\
\hline & 3 & 8 & & III & 5 & 42 & $\operatorname{Imp}$ \\
\hline & 3 & 9 & & III & 5 & 43 & $\operatorname{Imp}$ \\
\hline & 3 & 10 & & III & 5 & 44 & $\operatorname{Imp}$ \\
\hline & 3 & 11 & & III & 5 & 45,46 & $\operatorname{Imp}$ \\
\hline & 3 & 12 & & III & 5 & 47 & $\operatorname{Imp}$ \\
\hline & 3 & 13 & & III & 5 & 48 & $\operatorname{Imp}$ \\
\hline & 3 & 14 & & III & 5 & 49 & $\operatorname{Imp}$ \\
\hline & 3 & 15 & & III & 5 & 50 & $\operatorname{Imp}$ \\
\hline & 3 & 16 & & III & 5 & 51 & $\operatorname{Imp}$ \\
\hline & 3 & 17 & & III & 5 & 52 & $\operatorname{Imp}$ \\
\hline & 3 & 18 & & III & 5 & 53 & $\operatorname{Imp}$ \\
\hline & 3 & 19 & & III & 5 & 54 & $\operatorname{Imp}$ \\
\hline & 3 & 20 & & III & 5 & $55 \mathrm{a}$ & $\operatorname{Imp}$ \\
\hline & 3 & 21 & & III & 5 & 56 & $\operatorname{Imp}$ \\
\hline & 3 & 22 & & III & 5 & 57 & $\operatorname{Imp}$ \\
\hline \multirow[t]{2}{*}{8 artikels } & 4 & 1 & \multirow[t]{2}{*}{8 concordanties } & III & 5 & 60 & $\operatorname{Imp}$ \\
\hline & 4 & 2 & & III & 5 & 61 & $\operatorname{Imp}$ \\
\hline
\end{tabular}


GEASSIMILEERDE ARTIKELS IN HET GELDERSE LAND- EN STADSRECHT

\begin{tabular}{|c|c|c|c|c|c|c|c|}
\hline & 4 & 3 & & III & 5 & 62 & $\operatorname{Imp}$ \\
\hline & 4 & 4 & & III & 5 & 63 & $\operatorname{Imp}$ \\
\hline & 4 & 5 & & III & 5 & 64 & $\operatorname{Imp}$ \\
\hline & 4 & 6 & & III & 5 & 65 & $\operatorname{Imp}$ \\
\hline & 4 & 7 & & III & 5 & 66 & $\operatorname{Imp}$ \\
\hline & 4 & 8 & & III & 5 & 69 & $\operatorname{Imp}$ \\
\hline \multirow{10}{*}{10 artikels } & 5 & 1 & \multirow{10}{*}{10 concordanties } & III & 5 & 71 & $\operatorname{Imp}$ \\
\hline & 5 & 2 & & III & 5 & 72 & RA, OAR \\
\hline & 5 & 3 & & III & 5 & 75 & $\operatorname{Imp}$ \\
\hline & 5 & 4 & & III & 5 & 77 & $\operatorname{Imp}$ \\
\hline & 5 & 5 & & III & 5 & 78 & $\operatorname{Imp}$ \\
\hline & 5 & 6 & & III & 5 & 79 & $\operatorname{Imp}$ \\
\hline & 5 & 7 & & III & 5 & 80 & $\operatorname{Imp}$ \\
\hline & 5 & 8 & & III & 5 & 81 & $\operatorname{Imp}$ \\
\hline & 5 & 9 & & III & 5 & 82 & $\operatorname{Imp}$ \\
\hline & 5 & 10 & & III & 5 & 83 & $\operatorname{Imp}$ \\
\hline \multirow{8}{*}{8 artikels } & 6 & 1 & \multirow{8}{*}{8 concordanties } & III & 5 & 88 & $\operatorname{Imp}$ \\
\hline & 6 & 2 & & III & 5 & 89 & Ciciv \\
\hline & 6 & 3 & & III & 5 & 90 & $\operatorname{Imp}$ \\
\hline & 6 & 4 & & III & 5 & 91 & RA, Comp \\
\hline & 6 & 5 & & III & 5 & 92 & $\operatorname{Imp}$ \\
\hline & 6 & 6 & & III & 5 & 94 & $\operatorname{Imp}$ \\
\hline & 6 & 7 & & III & 5 & 95 & $\operatorname{Imp}$ \\
\hline & 6 & 8 & & III & 5 & 96 & $\operatorname{Imp}$ \\
\hline \multirow{10}{*}{33 artikels } & 7 & 1 & \multirow{10}{*}{10 concordanties } & III & 5 & 97 & $\operatorname{Imp}$ \\
\hline & 7 & 2 & & III & 5 & 98 & Usus, 3 \\
\hline & 7 & 3 & & III & 5 & 99 & Usus, 3 \\
\hline & 7 & 4 & & III & 5 & 100 & OAR \\
\hline & 7 & 6 & & III & 5 & 101 & $\operatorname{Imp}$ \\
\hline & 7 & 7 & & III & 5 & 102 & $\operatorname{Imp}$ \\
\hline & 7 & 8 & & III & 5 & 103 & OAR, Usus \\
\hline & 7 & 11 & & III & 5 & 104 & $\operatorname{Imp}$ \\
\hline & 7 & 13 & & III & 5 & 105 & $\operatorname{Imp}$ \\
\hline & 7 & 14 & & III & 5 & 106 & $\operatorname{Imp}$ \\
\hline \multicolumn{8}{|l|}{ TITEL 2.6} \\
\hline \multirow{7}{*}{7 artikels } & 1 & 1 & \multirow{7}{*}{7 concordanties } & III & 6 & 1 & $\operatorname{Imp}$ \\
\hline & 1 & 2 & & III & 6 & 2 & $\operatorname{Imp}$ \\
\hline & 1 & 3 & & III & 6 & 3 & $\operatorname{Imp}$ \\
\hline & 1 & 4 & & III & 6 & 4 & $\operatorname{Imp}$ \\
\hline & 1 & 5 & & III & 6 & 5 & $\operatorname{Imp}$ \\
\hline & 1 & 6 & & III & 6 & 6 & $\operatorname{Imp}$ \\
\hline & 1 & 7 & & III & 6 & 6 & $\operatorname{Imp}$ \\
\hline \multirow[t]{2}{*}{5 artikels } & 2 & 1 & \multirow[t]{2}{*}{5 concordanties } & III & 6 & 7 & $\operatorname{Imp}$ \\
\hline & 2 & 2 & & III & 6 & 8 & 3 \\
\hline
\end{tabular}


BiJLAGEN

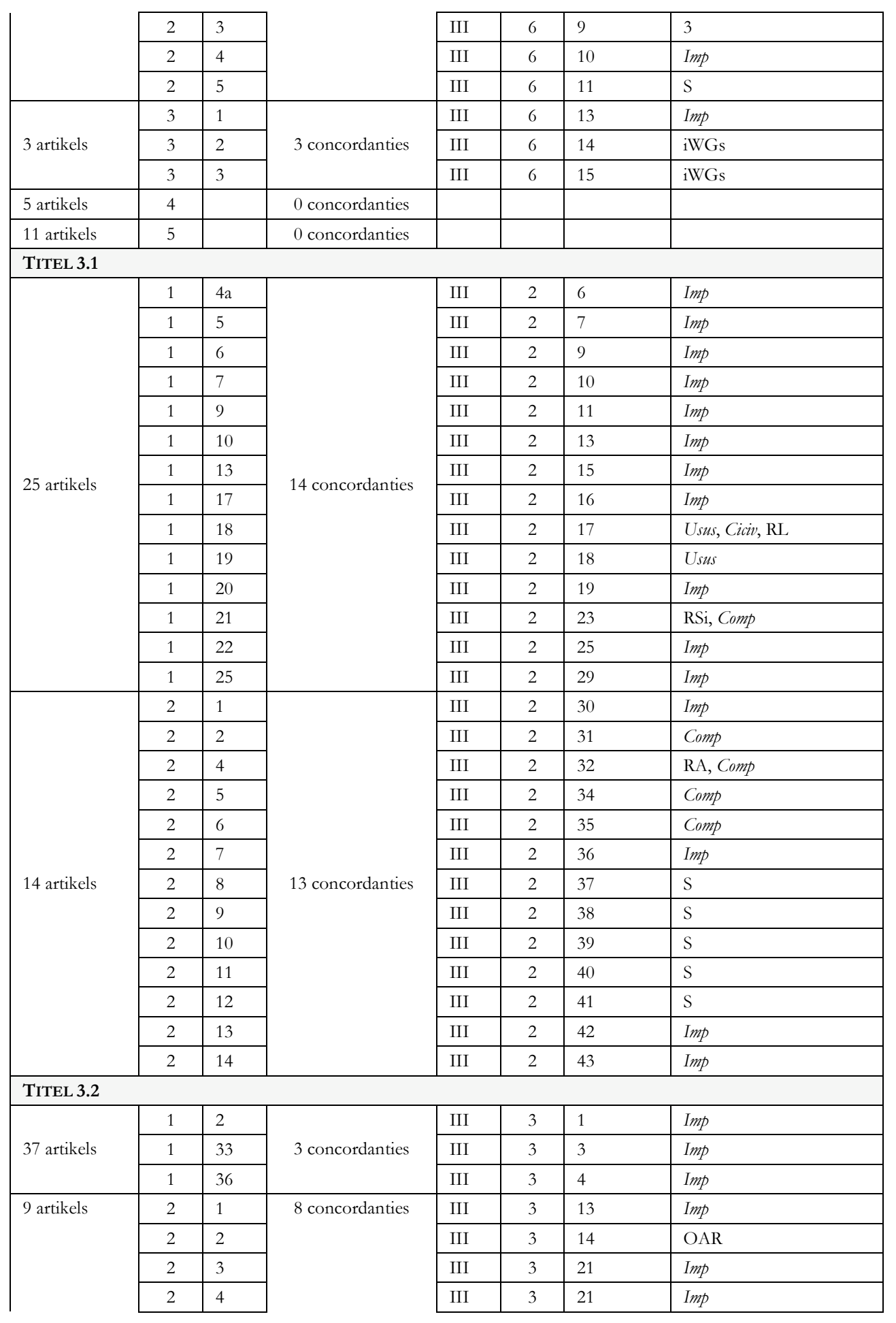


GEASSIMILEERDE ARTIKELS IN HET GELDERSE LAND- EN STADSRECHT

\begin{tabular}{|c|c|c|c|c|c|c|c|}
\hline & 2 & 5 & & III & 3 & 22 & OAR \\
\hline & 2 & 6 & & III & 3 & 23 & RA \\
\hline & 2 & 7 & & III & 3 & 24 & $\operatorname{Imp}$ \\
\hline & 2 & 9 & & III & 3 & 25 & $\operatorname{Imp}$ \\
\hline \multirow{11}{*}{12 artikels } & 3 & 1 & \multirow{11}{*}{11 concordanties } & III & 3 & 26 & $\operatorname{Imp}$ \\
\hline & 3 & 2 & & III & 3 & $26,27 a$ & Imp, Usus \\
\hline & 3 & 4 & & III & 3 & $27 \mathrm{~b}$ & Usus \\
\hline & 3 & 5 & & III & 3 & 28 & $\operatorname{Imp}$ \\
\hline & 3 & 6 & & III & 3 & 5 & OAR \\
\hline & 3 & 7 & & III & 3 & 6 & OAR \\
\hline & 3 & 8 & & III & 3 & 7 & OAR \\
\hline & 3 & 9 & & III & 3 & 8 & Comp \\
\hline & 3 & 10 & & III & 3 & 9 & $\operatorname{Imp}$ \\
\hline & 3 & 11 & & III & 3 & 10 & $\operatorname{Imp}$ \\
\hline & 3 & 12 & & III & 3 & 11 & $\mathrm{iWGV}$ \\
\hline \multicolumn{8}{|l|}{ TITEL 3.3} \\
\hline \multirow{9}{*}{24 artikels } & 1 & 1 & \multirow{9}{*}{9 concordanties } & III & 4 & 2 & $\operatorname{Imp}$ \\
\hline & 1 & 2 & & III & 4 & 3 & $\operatorname{Imp}$ \\
\hline & 1 & 5 & & III & 4 & 8 & $\operatorname{Imp}$ \\
\hline & 1 & 6 & & III & 4 & 12 & $\operatorname{Imp}$ \\
\hline & 1 & 7 & & III & 4 & 19 & $\operatorname{Imp}$ \\
\hline & 1 & 14 & & III & 4 & 13 & $\operatorname{Imp}$ \\
\hline & 1 & 15 & & III & 4 & 17 & $\operatorname{Imp}$ \\
\hline & 1 & 16 & & III & 4 & 18 & $\operatorname{Imp}$ \\
\hline & 1 & 24 & & III & 4 & 71 & OAR \\
\hline \multirow{6}{*}{15 artikels } & 2 & 4 & \multirow{6}{*}{6 concordanties } & III & 4 & 44 & $\operatorname{Imp}$ \\
\hline & 2 & 6 & & III & 4 & 36 & $\operatorname{Imp}$ \\
\hline & 2 & 8 & & III & 4 & 37 & $\operatorname{Imp}$ \\
\hline & 2 & 9 & & III & 4 & 37 & $\operatorname{Imp}$ \\
\hline & 2 & 12 & & III & 4 & 38 & $\operatorname{Imp}$ \\
\hline & 2 & 13 & & III & 4 & 40 & $\operatorname{Imp}$ \\
\hline \multirow{4}{*}{11 artikels } & 3 & 1 & \multirow{4}{*}{4 concordanties } & III & 4 & 45 & $\operatorname{Imp}$ \\
\hline & 3 & 2 & & III & 4 & 46 & Usus \\
\hline & 3 & 3 & & III & 4 & 46 & Usus \\
\hline & 3 & 4 & & III & 4 & 47 & Usus \\
\hline \multirow{2}{*}{17 artikels } & 4 & 7 & \multirow{2}{*}{2 concordanties } & III & 4 & 91,92 & $\operatorname{Imp}$ \\
\hline & 4 & 8 & & III & 4 & 93 & $S$ \\
\hline \multirow{6}{*}{8 artikels } & 5 & 1 & \multirow{6}{*}{6 concordanties } & III & 4 & 94 & $\operatorname{Imp}$ \\
\hline & 5 & 2 & & III & 4 & 95 & $\operatorname{Imp}$ \\
\hline & 5 & 3 & & III & 4 & 96 & $\operatorname{Imp}$ \\
\hline & 5 & 6 & & III & 4 & 98 & $\operatorname{Imp}$ \\
\hline & 5 & 7 & & III & 4 & 100 & $\operatorname{Imp}$ \\
\hline & 5 & 8 & & III & 4 & 106 & $\operatorname{Imp}$ \\
\hline
\end{tabular}


BiJLAGEN

\begin{tabular}{|c|c|c|c|c|c|c|c|}
\hline \multirow{6}{*}{7 artikels } & 1 & 1 & \multirow{6}{*}{6 concordanties } & III & 11 & 1 & $\operatorname{Imp}$ \\
\hline & 1 & 2 & & III & 11 & 3 & $\operatorname{Imp}$ \\
\hline & 1 & 3 & & III & 11 & 4 & Ciciv \\
\hline & 1 & 4 & & III & 11 & 5 & Ciciv \\
\hline & 1 & 5 & & III & 11 & 6 & Ciciv \\
\hline & 1 & 6 & & III & 11 & 2 & $\operatorname{Imp}$ \\
\hline \multirow{5}{*}{10 artikels } & 2 & 5 & \multirow{5}{*}{5 concordanties } & III & 11 & 14,15 & Imp, Usus, Ciciv, RL \\
\hline & 2 & 6 & & III & 11 & 16,17 & Imp, Ciciv, RL \\
\hline & 2 & 7 & & III & 11 & 18 & Usus, Ciciv, RL \\
\hline & 2 & 8 & & III & 11 & 19 & Usus, Ciciv, RL, RA, eGR \\
\hline & 2 & 10 & & III & 11 & 20 & Usus, RL \\
\hline \multirow{3}{*}{12 artikels } & 3 & 1 & \multirow{3}{*}{3 concordanties } & III & 11 & 7 & Ciciv, eGR, 3 \\
\hline & 3 & 2 & & III & 11 & 8 & $\operatorname{Imp}$ \\
\hline & 3 & 7 & & III & 11 & 12 & $\operatorname{Imp}$ \\
\hline \multicolumn{8}{|l|}{ TITEL 3.5} \\
\hline 14 artikels & 1 & 1 & 1 concordantie & III & 12 & 1 & $\operatorname{Imp}$ \\
\hline \multirow{3}{*}{4 artikels } & 2 & 1 & \multirow{3}{*}{3 concordanties } & III & 12 & 8 & eWG, RL, Ciciv \\
\hline & 2 & 2 & & III & 12 & 9 & eWG, RL, Ciciv \\
\hline & 2 & 3 & & III & 12 & 12 & Ciciv, RA \\
\hline 9 artikels & 3 & 2 & 1 concordantie & III & 12 & 17 & Ciciv \\
\hline \multicolumn{8}{|l|}{ TITEL 3.6} \\
\hline \multirow{12}{*}{18 artikels } & 1 & 1 & \multirow{12}{*}{12 concordanties } & III & 13 & 1 & $\operatorname{Imp}$ \\
\hline & 1 & 4 & & III & 13 & 2 & Usus, iWGv \\
\hline & 1 & 6 & & III & 13 & 3 & Usus, Comp \\
\hline & 1 & 7 & & III & 13 & 4 & $\operatorname{Imp}$ \\
\hline & 1 & 8 & & III & 13 & 5 & S \\
\hline & 1 & 9 & & III & 13 & 6 & Ciciv, Comp \\
\hline & 1 & 10 & & III & 13 & 7 & Ciciv, Comp \\
\hline & 1 & 11 & & III & 13 & 8 & Ciciv, Comp \\
\hline & 1 & 12 & & III & 13 & 10 & $\operatorname{Imp}$ \\
\hline & 1 & 13 & & III & 13 & 11 & Usus, eGR \\
\hline & 1 & 14 & & III & 13 & 12 & Usus, eGR \\
\hline & 1 & 15 & & III & 13 & 13 & Usus, OAR \\
\hline 15 artikels & 2 & 7 & 2 concordanties & III & 13 & 21 & $\operatorname{Imp}$ \\
\hline \multirow{3}{*}{19 artikels } & 3 & 3 & \multirow{3}{*}{3 concordanties } & III & 13 & 56 & $\operatorname{Imp}$ \\
\hline & 3 & 4 & & III & 13 & 57 & $\operatorname{Imp}$ \\
\hline & 3 & 5 & & III & 13 & 58 & $\operatorname{Imp}$ \\
\hline \multirow{3}{*}{11 artikels } & 4 & 3 & \multirow{3}{*}{3 concordanties } & III & 13 & 66 & $\operatorname{Imp}$ \\
\hline & 4 & 4 & & III & 13 & 67 & $\operatorname{Imp}$ \\
\hline & 4 & 7 & & III & 13 & 68 & S \\
\hline \multicolumn{8}{|l|}{ TITEL 3.7} \\
\hline 12 artikels & 1 & & 0 concordanties & & & & \\
\hline 10 artikels & 2 & & 0 concordanties & & & & \\
\hline 6 artikels & 3 & & 0 concordanties & & & & \\
\hline
\end{tabular}


GEASSIMILEERDE ARTIKELS IN HET GELDERSE LAND- EN STADSRECHT

\begin{tabular}{|c|c|c|c|c|c|c|c|}
\hline 12 artikels & 4 & & 0 concordanties & & & & \\
\hline 7 artikels & 5 & & 0 concordanties & & & & \\
\hline \multirow{2}{*}{10 artikels } & 6 & 3 & \multirow{2}{*}{2 concordanties } & III & 14 & 31 & $\operatorname{Imp}$ \\
\hline & 6 & 4 & & III & 14 & 32 & $\operatorname{Imp}$ \\
\hline \multicolumn{8}{|l|}{ Titel 3.8} \\
\hline \multirow{11}{*}{13 artikels } & & 2 & \multirow{11}{*}{11 concordanties } & III & 14 & 41 & $\operatorname{Imp}$ \\
\hline & & 3 & & III & 14 & 42 & OAR, Comp, RL \\
\hline & & 4 & & III & 14 & 43 & Ciciv \\
\hline & & 5 & & III & 14 & 44 & Ciciv, Usus \\
\hline & & 6 & & III & 14 & 45 & $\operatorname{Imp}$ \\
\hline & & 7 & & III & 14 & 55 & $\operatorname{Imp}$ \\
\hline & & 8 & & III & 14 & 59 & OAR \\
\hline & & 9 & & III & 14 & 60 & OAR \\
\hline & & 10 & & III & 14 & 61 & $\mathrm{O}$ \\
\hline & & 11 & & III & 14 & 62 & OAR \\
\hline & & 13 & & III & 14 & 64 & iWGv \\
\hline \multicolumn{8}{|l|}{ TITEL 3.9} \\
\hline \multirow{16}{*}{17 artikels } & & 1 & \multirow{16}{*}{16 concordanties } & III & 14 & 95 & $\operatorname{Imp}$ \\
\hline & & 2 & & III & 14 & 96 & Ciciv \\
\hline & & 3 & & III & 14 & 100 & $\operatorname{Imp}$ \\
\hline & & 4 & & III & 14 & 101 & $\operatorname{Imp}$ \\
\hline & & 5 & & III & 14 & 102 & $\operatorname{Imp}$ \\
\hline & & 6 & & III & 14 & 104 & Ciciv \\
\hline & & 7 & & III & 14 & 105 & $\operatorname{Imp}$ \\
\hline & & 9 & & III & 14 & 106 & $\operatorname{Imp}$ \\
\hline & & 10 & & III & 14 & 107 & $\operatorname{Imp}$ \\
\hline & & 11 & & III & 14 & 108 & $\operatorname{Imp}$ \\
\hline & & 12 & & III & 14 & 109 & $\operatorname{Imp}$ \\
\hline & & 13 & & III & 14 & 110 & $\operatorname{Imp}$ \\
\hline & & 14 & & III & 14 & 111 & $\operatorname{Imp}$ \\
\hline & & 15 & & III & 14 & 112 & $\operatorname{Imp}$ \\
\hline & & 16 & & III & 14 & 113 & $\operatorname{Imp}$ \\
\hline & & 17 & & III & 14 & 114 & $\operatorname{Imp}$ \\
\hline \multicolumn{8}{|l|}{ TITEL 3.10} \\
\hline \multirow[t]{10}{*}{23 artikels } & & 1 & \multirow[t]{10}{*}{15 concordanties } & III & 14 & 116 & OAR, Usus \\
\hline & & 3 & & III & 14 & 117 & $\operatorname{Imp}$ \\
\hline & & 4 & & III & 14 & 119 & Usus \\
\hline & & 5 & & III & 14 & 120 & Usus \\
\hline & & 6 & & III & 14 & 121 & Usus \\
\hline & & 7 & & III & 14 & 122 & RSe, RL \\
\hline & & 8 & & III & 14 & 123 & RSe, RL \\
\hline & & 9 & & III & 14 & 124 & Comp \\
\hline & & 10 & & III & 14 & 125 & Comp \\
\hline & & 11 & & III & 14 & 126 & Usus \\
\hline
\end{tabular}


BIJLAGEN

\begin{tabular}{|c|c|c|c|c|c|c|c|}
\hline & & 12 & & III & 14 & 127 & $\operatorname{Imp}$ \\
\hline & & 13 & & III & 14 & 128 & $\operatorname{Imp}$ \\
\hline & & 14 & & III & 14 & 129 & $\operatorname{Imp}$ \\
\hline & & 15 & & III & 14 & 130 & $\operatorname{Imp}$ \\
\hline & & 16 & & III & 14 & 131 & $\operatorname{Imp}$ \\
\hline \multicolumn{8}{|l|}{ TITEL 4.1} \\
\hline \multirow{12}{*}{23 artikels } & & 1 & \multirow{12}{*}{12 concordanties } & IV & 1 & 1 & $\operatorname{Imp}$ \\
\hline & & 2 & & IV & 1 & 2 & $\operatorname{Imp}$ \\
\hline & & 5 & & IV & 1 & 4 & Usus, eWG \\
\hline & & 6 & & IV & 1 & 4 & Usus, eWG \\
\hline & & 7 & & IV & 1 & 5 & Usus \\
\hline & & 8 & & IV & 1 & 6 & Ciciv \\
\hline & & 10 & & IV & 1 & 7 & iWGv \\
\hline & & 11 & & IV & 1 & 9 & $\mathrm{~S}, \mathrm{iWGv}, \mathrm{RL}, 3$ \\
\hline & & 13 & & IV & 1 & 11 & Usus \\
\hline & & 14 & & IV & 1 & 14 & $\operatorname{Imp}$ \\
\hline & & 15 & & IV & 1 & 15 & $\operatorname{Imp}$ \\
\hline & & 16 & & IV & 1 & 16 & $\operatorname{Imp}$ \\
\hline \multicolumn{8}{|l|}{$\begin{array}{l}\text { TITEL } 4.2 \\
\end{array}$} \\
\hline \multirow{3}{*}{6 artikels } & 1 & 1 & \multirow{3}{*}{3 concordanties } & IV & 2 & 3 & Usus, Comp \\
\hline & 1 & 5 & & IV & 2 & 2 & Comp \\
\hline & 1 & 6 & & IV & 2 & (7) en 12 & $\operatorname{Imp}$ \\
\hline \multirow{6}{*}{7 artikels } & 2 & 2 & \multirow{6}{*}{5.5 concordanties } & IV & 2 & 6 & $\operatorname{Imp}$ \\
\hline & 2 & 3 & & IV & 2 & 7 & $\operatorname{Imp}$ \\
\hline & 2 & 4 & & IV & 2 & 8 & $\operatorname{Imp}$ \\
\hline & 2 & 5 & & IV & 2 & 9 & $\operatorname{Imp}$ \\
\hline & 2 & 6 & & IV & 2 & 10 & $\operatorname{Imp}$ \\
\hline & 2 & $7^{1422}$ & & IV & 14 & 1 & $\operatorname{Imp}$ \\
\hline \multirow{3}{*}{7 artikels } & 3 & 1 & \multirow{3}{*}{3 concordanties } & IV & 14 & 16 & $\operatorname{Imp}$ \\
\hline & 3 & 2 & & IV & 14 & 8 & $\operatorname{Imp}$ \\
\hline & 3 & 3 & & IV & 14 & 9 & $\operatorname{Imp}$ \\
\hline \multirow{5}{*}{11 artikels } & 4 & 4 & \multirow{5}{*}{5 concordanties } & IV & 14 & 3 & $\operatorname{Imp}$ \\
\hline & 4 & 5 & & IV & 14 & 7 & $\operatorname{Imp}$ \\
\hline & 4 & 6 & & IV & 14 & 4 & $\operatorname{Imp}$ \\
\hline & 4 & 10 & & IV & 14 & 12 & iWGs, Comp \\
\hline & 4 & 11 & & IV & 14 & 15 & $\operatorname{Imp}$ \\
\hline \multirow[t]{6}{*}{9 artikels } & 5 & 1 & \multirow[t]{6}{*}{9 concordanties } & IV & 14 & 17 & $\operatorname{Imp}$ \\
\hline & 5 & 2 & & IV & 14 & 18 & $\operatorname{Imp}$ \\
\hline & 5 & 3 & & IV & 14 & 19 & $\operatorname{Imp}$ \\
\hline & 5 & 4 & & IV & 14 & 20 & $\operatorname{Imp}$ \\
\hline & 5 & 5 & & IV & 14 & 21 & RA, iWGs, Comp \\
\hline & 5 & 6 & & IV & 14 & 22 & $\operatorname{Imp}$ \\
\hline
\end{tabular}

1422 Slechts half. 
GEASSIMILEERDE ARTIKELS IN HET GELDERSE LAND- EN STADSRECHT

\begin{tabular}{|c|c|c|c|c|c|c|c|}
\hline & & & & & & & \\
\hline & 5 & 7 & & IV & 14 & 23 & iWGs, RA, Comp \\
\hline & 5 & 8 & & IV & 14 & 24 & iWGs, RA, Comp \\
\hline & 5 & 9 & & IV & 14 & 25 & Comp \\
\hline \multicolumn{8}{|l|}{ TITEL 4.3} \\
\hline 8 artikels & 1 & 1 & 1 concordantie & IV & 6 & 2 & $\operatorname{Imp}$ \\
\hline \multirow{5}{*}{5 artikels } & 2 & 1 & \multirow{5}{*}{5 concordanties } & IV & 6 & 16 & Usus, Comp \\
\hline & 2 & 2 & & IV & 6 & 17 & 3, Ciciv, RL \\
\hline & 2 & 3 & & IV & 6 & 18 & Comp \\
\hline & 2 & 4 & & IV & 6 & 18 & $\operatorname{Comp}$ \\
\hline & 2 & 5 & & IV & 6 & 19 & Ciciv, RL \\
\hline \multirow{13}{*}{17 artikels } & 3 & 1 & \multirow{13}{*}{13 concordanties } & IV & 6 & 4 & $\operatorname{Imp}$ \\
\hline & 3 & 6 & & IV & 6 & 5 & $\operatorname{Imp}$ \\
\hline & 3 & 7 & & IV & 6 & 5 & $\operatorname{Imp}$ \\
\hline & 3 & 8 & & IV & 6 & 6 & $\operatorname{Imp}$ \\
\hline & 3 & 9 & & IV & 6 & 7 & $\operatorname{Imp}$ \\
\hline & 3 & 10 & & IV & 6 & 10 & $\operatorname{Imp}$ \\
\hline & 3 & 11 & & IV & 6 & 11 & $\operatorname{Imp}$ \\
\hline & 3 & 12 & & IV & 6 & 12 & $\operatorname{Imp}$ \\
\hline & 3 & 13 & & IV & 6 & 13 & $\mathrm{RA}$, Comp \\
\hline & 3 & 14 & & IV & 6 & 13 & RA, Comp \\
\hline & 3 & 15 & & IV & 6 & 14 & $\mathrm{RA}$, Comp \\
\hline & 3 & 16 & & IV & 6 & 14 & $\mathrm{RA}$, Comp \\
\hline & 3 & 17 & & IV & 6 & 15 & RA, Comp \\
\hline \multirow{3}{*}{7 artikels } & 4 & 2 & \multirow{3}{*}{3 concordanties } & IV & 6 & 20 & Usus \\
\hline & 4 & 4 & & IV & 6 & 21 & Usus \\
\hline & 4 & 5 & & IV & 6 & 22 & Usus \\
\hline 6 artikels & & & 0 concordanties & & & & \\
\hline \multirow{7}{*}{8 artikels } & 6 & 1 & \multirow{7}{*}{7 concordanties } & IV & 4 & 5 & $\operatorname{Imp}$ \\
\hline & 6 & 2 & & IV & 4 & 6 & $\operatorname{Imp}$ \\
\hline & 6 & 3 & & IV & 4 & 6 & $\operatorname{Imp}$ \\
\hline & 6 & 4 & & IV & 4 & 7 & $\operatorname{Imp}$ \\
\hline & 6 & 5 & & IV & 4 & 13 & $\operatorname{Imp}$ \\
\hline & 6 & 6 & & IV & 4 & 13 & $\operatorname{Imp}$ \\
\hline & 6 & 8 & & IV & 4 & 14 & $\operatorname{Imp}$ \\
\hline \multicolumn{8}{|l|}{ TITEL 4.4} \\
\hline \multirow[t]{9}{*}{20 artikels } & 1 & 1 & \multirow[t]{9}{*}{19 concordanties } & IV & 7 & 1 & $\operatorname{Imp}$ \\
\hline & 1 & 2 & & IV & 7 & 11 & $\operatorname{Imp}$ \\
\hline & 1 & 3 & & IV & 7 & 2 & $\operatorname{Imp}$ \\
\hline & 1 & 4 & & IV & 7 & 3 & $\operatorname{Imp}$ \\
\hline & 1 & 5 & & IV & 7 & 3 & $\operatorname{Imp}$ \\
\hline & 1 & 6 & & IV & 7 & 4 & $\operatorname{Imp}$ \\
\hline & 1 & 8 & & IV & 7 & 8 & $\operatorname{Imp}$ \\
\hline & 1 & 9 & & IV & 7 & 12 & $\operatorname{Imp}$ \\
\hline & 1 & 10 & & IV & 7 & 13 & $\operatorname{Imp}$ \\
\hline
\end{tabular}


BiJLAGEN

\begin{tabular}{|c|c|c|c|c|c|c|c|}
\hline & 1 & 11 & & IV & 7 & 14 & $\operatorname{Imp}$ \\
\hline & 1 & 12 & & IV & 7 & 15 & $\operatorname{Imp}$ \\
\hline & 1 & 13 & & IV & 7 & 15 & $\operatorname{Imp}$ \\
\hline & 1 & 14 & & IV & 7 & 17 & $\mathrm{~S}$ \\
\hline & 1 & 15 & & IV & 7 & 18 & $\operatorname{Imp}$ \\
\hline & 1 & 16 & & IV & 7 & 18 & $\operatorname{Imp}$ \\
\hline & 1 & 17 & & IV & 7 & 19 & $\operatorname{Imp}$ \\
\hline & 1 & 18 & & IV & 7 & 20 & $\operatorname{Imp}$ \\
\hline & 1 & 19 & & IV & 7 & 21 & $\operatorname{Imp}$ \\
\hline & 1 & 20 & & IV & 7 & 22 & $\operatorname{Imp}$ \\
\hline \multirow{12}{*}{12 artikels } & 2 & 1 & \multirow{12}{*}{12 concordanties } & IV & 7 & 23 & $\operatorname{Imp}$ \\
\hline & 2 & 2 & & IV & 7 & 24 & $\operatorname{Imp}$ \\
\hline & 2 & 3 & & IV & 7 & 25 & $\operatorname{Imp}$ \\
\hline & 2 & 4 & & IV & 7 & 26 & $\mathrm{RSi}$ \\
\hline & 2 & 5 & & IV & 7 & 27 & Usus \\
\hline & 2 & 6 & & IV & 7 & 28 & $\operatorname{Imp}$ \\
\hline & 2 & 7 & & IV & 7 & 29 & $\operatorname{Imp}$ \\
\hline & 2 & 8 & & IV & 7 & 30 & $\operatorname{Imp}$ \\
\hline & 2 & 9 & & IV & 7 & 32 & $\operatorname{Imp}$ \\
\hline & 2 & 10 & & IV & 7 & 31 & $\operatorname{Imp}$ \\
\hline & 2 & 11 & & IV & 7 & 33 & $\operatorname{Imp}$ \\
\hline & 2 & 12 & & IV & 7 & 34 & $\operatorname{Imp}$ \\
\hline 13 artikels & 3 & & 0 concordanties & IV & & & \\
\hline \multirow{8}{*}{8 artikels } & 4 & 1 & \multirow{8}{*}{8 concordanties } & IV & 7 & 35 & Usus \\
\hline & 4 & 2 & & IV & 7 & 36 & $\mathrm{~S}$ \\
\hline & 4 & 3 & & IV & 7 & 36,37 & $\mathrm{~S}$ \\
\hline & 4 & 4 & & IV & 7 & 39 & $\mathrm{eWG}$ \\
\hline & 4 & 5 & & IV & 7 & 42 & $\mathrm{~S}$ \\
\hline & 4 & 6 & & IV & 7 & 43 & Usus, $\mathrm{S}$ \\
\hline & 4 & 7 & & IV & 7 & 44 & Usus, $\mathrm{S}$ \\
\hline & 4 & 8 & & IV & 7 & 45 & Usus, Ciciv \\
\hline \multicolumn{8}{|l|}{ TITEL 4.5} \\
\hline \multirow{2}{*}{5 artikels } & 1 & 1 & \multirow{2}{*}{2 concordanties } & IV & 9 & 4 & $\operatorname{Imp}$ \\
\hline & 1 & 5 & & IV & 9 & 25,27 & $\operatorname{Imp}$ \\
\hline \multirow{8}{*}{8 artikels } & 2 & 1 & \multirow{8}{*}{8 concordanties } & IV & 9 & 28 & $\operatorname{Imp}$ \\
\hline & 2 & 2 & & IV & 9 & 29 & Usus, 3, Comp \\
\hline & 2 & 3 & & IV & 9 & 30 & Usus, 3, Comp \\
\hline & 2 & 4 & & IV & 9 & 31 & Ciciv, RA, Comp, Usus \\
\hline & 2 & 5 & & IV & 9 & 32 & Usus, eGR \\
\hline & 2 & 6 & & IV & 9 & 33 & Comp \\
\hline & 2 & 7 & & IV & 9 & 35 & $\mathrm{~S}$ \\
\hline & 2 & 8 & & IV & 9 & 36 & $\mathrm{~S}$ \\
\hline 1 artikel & 3 & 1 & 1 concordantie & IV & 9 & 39 & $\operatorname{Imp}$ \\
\hline \multicolumn{8}{|l|}{ TITEL 4.6} \\
\hline
\end{tabular}


GEASSIMILEERDE ARTIKELS IN HET GELDERSE LAND- EN STADSRECHT

\begin{tabular}{|c|c|c|c|c|c|c|c|}
\hline \multirow{8}{*}{10 artikels } & 1 & 1 & \multirow{8}{*}{8 concordanties } & IV & 10 & 1 & Usus, Ciciv \\
\hline & 1 & 2 & & IV & 10 & 2 & Usus, Ciciv \\
\hline & 1 & 4 & & IV & 10 & 3 & $\mathrm{~S}, \mathrm{RL}$ \\
\hline & 1 & 5 & & IV & 10 & 4 & $\mathrm{~S}, \mathrm{RL}$ \\
\hline & 1 & 6 & & IV & 10 & 5 & $\mathrm{~S}, \mathrm{RL}$ \\
\hline & 1 & 7 & & IV & 10 & 6 & eWG \\
\hline & 1 & 9 & & IV & 10 & 7 & eWG \\
\hline & 1 & 10 & & IV & 10 & 17 & 3 \\
\hline \multirow{7}{*}{11 artikels } & 2 & 1 & \multirow{7}{*}{7 concordanties } & IV & 10 & 8 & $\mathrm{RSi}$ \\
\hline & 2 & 2 & & IV & 10 & 9 & $\mathrm{RSi}$ \\
\hline & 2 & 3 & & IV & 10 & 10 & Ciciv \\
\hline & 2 & 8 & & IV & 10 & 11 & RL \\
\hline & 2 & 9 & & IV & 10 & 20 & Usus \\
\hline & 2 & 10 & & IV & 10 & 21 & Usus \\
\hline & 2 & 11 & & IV & 10 & 19 & $\operatorname{Imp}$ \\
\hline \multicolumn{8}{|l|}{ TITEL 4.7} \\
\hline \multirow{6}{*}{13 artikels } & 1 & 8 & \multirow{6}{*}{6 concordanties } & IV & 12 & 4 & RA, Ciciv, RL \\
\hline & 1 & 9 & & IV & 12 & 6 & Usus \\
\hline & 1 & 10 & & IV & 12 & 6 & Usus \\
\hline & 1 & 11 & & IV & 12 & 7 & Usus \\
\hline & 1 & 12 & & IV & 12 & 8 & Ciciv \\
\hline & 1 & 13 & & IV & 12 & 9 & Usus \\
\hline \multirow{10}{*}{12 artikels } & 2 & 1 & \multirow{10}{*}{10 concordanties } & IV & 12 & 18 & $\operatorname{Imp}$ \\
\hline & 2 & 2 & & IV & 12 & 19 & OAR, 3, Ciciv, S \\
\hline & 2 & 3 & & IV & 12 & 20 & OAR, 3, Ciciv, S \\
\hline & 2 & 4 & & IV & 12 & 21 & Usus, RA, Comp \\
\hline & 2 & 5 & & IV & 12 & 22 & $\operatorname{Imp}$ \\
\hline & 2 & 6 & & IV & 12 & 23 & $\operatorname{Imp}$ \\
\hline & 2 & 7 & & IV & 12 & 24 & Comp \\
\hline & 2 & 8 & & IV & 12 & 25 & Usus, Comp \\
\hline & 2 & 11 & & IV & 12 & 26 & Usus, Comp \\
\hline & 2 & 12 & & IV & 12 & 27 & $\operatorname{Imp}$ \\
\hline \multirow{9}{*}{12 artikels } & 3 & 1 & \multirow{9}{*}{9 concordanties } & IV & 12 & 28 & $\operatorname{Imp}$ \\
\hline & 3 & 2 & & IV & 12 & 29 & $\operatorname{Imp}$ \\
\hline & 3 & 3 & & IV & 12 & 30 & $\operatorname{Imp}$ \\
\hline & 3 & 4 & & IV & 12 & 31 & $\operatorname{Imp}$ \\
\hline & 3 & 5 & & IV & 12 & 32 & $\operatorname{Imp}$ \\
\hline & 3 & 6 & & IV & 12 & 33 & Usus, Ciciv, S, RA \\
\hline & 3 & 7 & & IV & 12 & 34 & $\operatorname{Imp}$ \\
\hline & 3 & 8 & & IV & 12 & 35 & $\operatorname{Imp}$ \\
\hline & 3 & 9 & & IV & 12 & 36 & $\operatorname{Imp}$ \\
\hline 8 artikels & 4 & & 0 concordanties & IV & & & \\
\hline \multicolumn{8}{|l|}{ TITEL 4.8} \\
\hline 14 artikels & 1 & 1 & 13 concordanties & IV & 13 & 1 & Usus, C \\
\hline
\end{tabular}


BiJLAGEN

\begin{tabular}{|c|c|c|c|c|c|c|c|}
\hline & 1 & 2 & & IV & 13 & 2 & Usus, C \\
\hline & 1 & 3 & & IV & 13 & 3 & $\operatorname{Imp}$ \\
\hline & 1 & 5 & & IV & 13 & 7 & $\operatorname{Imp}$ \\
\hline & 1 & 6 & & IV & 13 & 8 & $\operatorname{Imp}$ \\
\hline & 1 & 7 & & IV & 13 & 9 & Usus, Comp, RL, Ciciv \\
\hline & 1 & 8 & & IV & 13 & 10 & $\operatorname{Imp}$ \\
\hline & 1 & 9 & & IV & 13 & 11 & $\operatorname{Imp}$ \\
\hline & 1 & 10 & & IV & 13 & 12 & $\mathrm{~S}$ \\
\hline & 1 & 11 & & IV & 13 & 13 & $\mathrm{~S}$ \\
\hline & 1 & 12 & & IV & 13 & 14 & $\mathrm{~S}$ \\
\hline & 1 & 13 & & IV & 13 & 14 & $\mathrm{~S}$ \\
\hline & 1 & 14 & & IV & 13 & 15 & $\mathrm{~S}$ \\
\hline \multirow{14}{*}{14 artikels } & 2 & 1 & \multirow{14}{*}{14 concordanties } & IV & 13 & 16 & $\operatorname{Imp}$ \\
\hline & 2 & 2 & & IV & 13 & 18 & $\operatorname{Imp}$ \\
\hline & 2 & 3 & & IV & 13 & 21 & $\operatorname{Imp}$ \\
\hline & 2 & 4 & & IV & 13 & 22 & $\operatorname{Imp}$ \\
\hline & 2 & 5 & & IV & 13 & 23 & $\operatorname{Imp}$ \\
\hline & 2 & 6 & & IV & 13 & 24 & $\operatorname{Imp}$ \\
\hline & 2 & 7 & & IV & 13 & 25 & $\operatorname{Imp}$ \\
\hline & 2 & 8 & & IV & 13 & 26 & $\operatorname{Imp}$ \\
\hline & 2 & 9 & & IV & 13 & 27 & $\operatorname{Imp}$ \\
\hline & 2 & 10 & & IV & 13 & 28 & $\operatorname{Imp}$ \\
\hline & 2 & 11 & & IV & 13 & 29 & $\operatorname{Imp}$ \\
\hline & 2 & 12 & & IV & 13 & 30 & $\operatorname{Imp}$ \\
\hline & 2 & 13 & & IV & 13 & 32 & $\operatorname{Imp}$ \\
\hline & 2 & 14 & & IV & 13 & 33 & $\operatorname{Imp}$ \\
\hline \multirow{9}{*}{10 artikels } & 3 & 1 & \multirow{9}{*}{9 concordanties } & IV & 13 & 34 & $\operatorname{Imp}$ \\
\hline & 3 & 2 & & IV & 13 & 35 & Comp, Usus \\
\hline & 3 & 3 & & IV & 13 & 36 & $\operatorname{Imp}$ \\
\hline & 3 & 4 & & IV & 13 & 37 & $\operatorname{Imp}$ \\
\hline & 3 & 5 & & IV & 13 & 38 & $\mathrm{RL}$ \\
\hline & 3 & 6 & & IV & 13 & 39 & $\mathrm{RL}$ \\
\hline & 3 & 8 & & IV & 13 & 4 & OAR, Usus \\
\hline & 3 & 9 & & IV & 13 & 5 & $\operatorname{Imp}$ \\
\hline & 3 & 10 & & IV & 13 & 6 & S \\
\hline \multicolumn{8}{|l|}{ TITEL 4.9} \\
\hline \multirow[t]{8}{*}{25 artikels } & & 1 & \multirow[t]{8}{*}{23 concordanties } & IV & 15 & 1 & iWGv \\
\hline & & 2 & & IV & 15 & 1 & iWGv \\
\hline & & 3 & & IV & 15 & 2 & iWGv \\
\hline & & 4 & & IV & 15 & 3 & iWGv \\
\hline & & 7 & & IV & 15 & 7 & Usus \\
\hline & & 8 & & IV & 15 & 8 & $\operatorname{Imp}$ \\
\hline & & 9 & & IV & 15 & 10 & Usus \\
\hline & & 10 & & IV & 15 & 11 & $\operatorname{Imp}$ \\
\hline
\end{tabular}


GEASSIMILEERDE ARTIKELS IN HET GELDERSE LAND- EN STADSRECHT

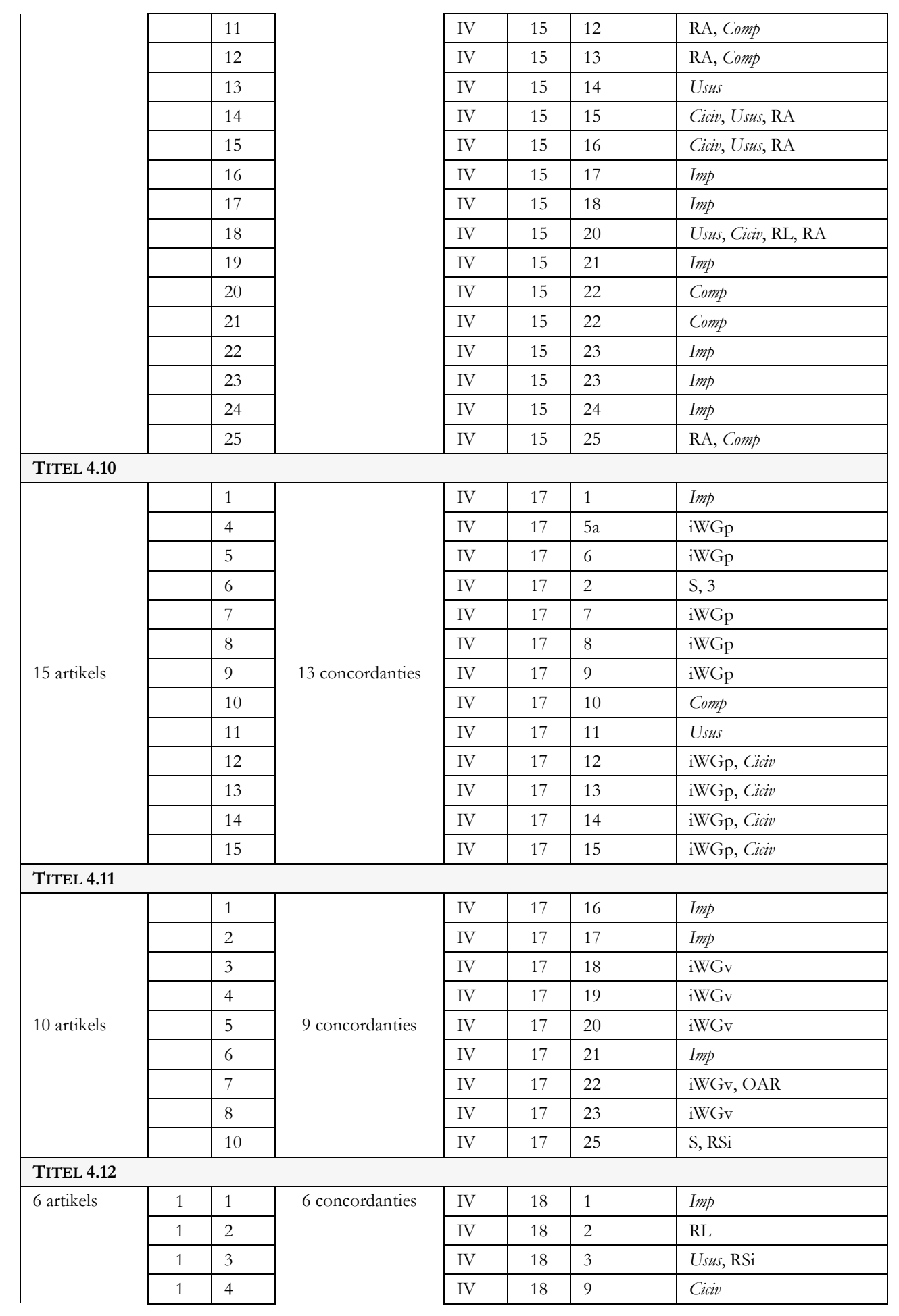


BijLAGEN

\begin{tabular}{|c|c|c|c|c|c|c|c|}
\hline & 1 & 5 & & IV & 18 & 10 & RL, 3 \\
\hline & 1 & 6 & & IV & 18 & 11 & Comp \\
\hline \multirow{9}{*}{12 artikels } & 2 & 1 & \multirow{9}{*}{9 concordanties } & IV & 18 & 12 & $\operatorname{Imp}$ \\
\hline & 2 & 2 & & IV & 18 & 13 & RA, Comp, Usus \\
\hline & 2 & 3 & & IV & 18 & 14 & Ciciv, OAR, RL \\
\hline & 2 & 6 & & IV & 18 & 15 & $\operatorname{Imp}$ \\
\hline & 2 & 7 & & IV & 18 & 16 & $\operatorname{Imp}$ \\
\hline & 2 & 8 & & IV & 18 & 16 & $\operatorname{Imp}$ \\
\hline & 2 & 10 & & IV & 18 & 20 & Ciciv \\
\hline & 2 & 11 & & IV & 18 & 52 & $\operatorname{Imp}$ \\
\hline & 2 & 12 & & IV & 18 & 53 & $\mathrm{~S}$ \\
\hline \multirow{3}{*}{8 artikels } & 3 & 1 & \multirow{3}{*}{3 concordanties } & IV & 18 & 54 & $\operatorname{Imp}$ \\
\hline & 3 & 2 & & IV & 18 & 17 en 54 & $\operatorname{Imp}$ \\
\hline & 3 & 3 & & IV & 18 & 55 & $\operatorname{Imp}$ \\
\hline \multirow{4}{*}{4 artikels } & 4 & 1 & \multirow{4}{*}{4 concordanties } & IV & 18 & 71 & Ciciv, RL \\
\hline & 4 & 2 & & IV & 18 & 72 & Ciciv \\
\hline & 4 & 3 & & IV & 18 & 73 & Usus \\
\hline & 4 & 4 & & IV & 18 & 74 & Usus \\
\hline \multicolumn{8}{|l|}{ TITEL 5.1} \\
\hline 1 artikel & & & 0 concordanties & & & & \\
\hline \multicolumn{8}{|l|}{ TITEL 5.2} \\
\hline 9 artikels & & & 0 concordanties & & & & \\
\hline \multicolumn{8}{|l|}{ TITEL 5.3} \\
\hline 6 artikels & & & 0 concordanties & & & & \\
\hline \multicolumn{8}{|l|}{ TITEL 5.4} \\
\hline 49 artikels & & & 0 concordanties & & & & \\
\hline \multicolumn{8}{|l|}{ TITEL 5.5} \\
\hline 17 artikels & & & 0 concordanties & & & & \\
\hline \multicolumn{8}{|l|}{ TITEL 5.6} \\
\hline 3 artikels & & & 0 concordanties & & & & \\
\hline \multicolumn{8}{|l|}{ TITEL 5.7} \\
\hline 34 artikels & & & 0 concordanties & & & & \\
\hline \multicolumn{8}{|l|}{ TITEL 5.8} \\
\hline 18 artikels & & & 0 concordanties & & & & \\
\hline \multicolumn{8}{|l|}{ TITEL 5.9} \\
\hline 36 artikels & & & 0 concordanties & & & & \\
\hline \multicolumn{8}{|l|}{ TITEL 5.10} \\
\hline 16 artikels & & & 0 concordanties & & & & \\
\hline \multicolumn{8}{|l|}{ TITEL 5.11} \\
\hline 18 artikels & & & 0 concordanties & & & & \\
\hline \multicolumn{8}{|l|}{ TITEL 5.12} \\
\hline 24 artikels & & & 0 concordanties & & & & \\
\hline \multicolumn{8}{|l|}{ TITEL 5.13} \\
\hline 11 artikels & & & 0 concordanties & & & & \\
\hline
\end{tabular}


GEASSIMILEERDE ARTIKELS IN HET GELDERSE LAND- EN STADSRECHT

\begin{tabular}{|c|c|c|c|c|c|c|c|}
\hline \multicolumn{8}{|c|}{ TITEL 5.14} \\
\hline 6 artikels & & & 0 concordanties & & & & \\
\hline \multicolumn{8}{|l|}{ TITEL 5.15} \\
\hline 5 artikels & & & 0 concordanties & & & & \\
\hline \multicolumn{8}{|l|}{ TITEL 5.16} \\
\hline 34 artikels & & & 0 concordanties & & & & \\
\hline \multicolumn{8}{|l|}{ TITEL 5.17} \\
\hline 57 artikels & & & 0 concordanties & & & & \\
\hline \multicolumn{8}{|l|}{ TITEL 6.1} \\
\hline \multirow{2}{*}{6 artikels } & 1 & 1 & \multirow{2}{*}{2 concordanties } & VI & 2 & 13 & iWGv, 3 \\
\hline & 1 & 2 & & VI & 2 & 13 & iWGv, 3 \\
\hline \multirow{5}{*}{8 artikels } & 2 & 1 & \multirow{5}{*}{5 concordanties } & VI & 1 & 31 & OAR, iWGv, eGR \\
\hline & 2 & 2 & & VI & 1 & 31 & OAR, iWGv, eGR \\
\hline & 2 & 3 & & VI & 1 & 32 & OAR \\
\hline & 2 & 4 & & VI & 1 & 33 & OAR, 3 \\
\hline & 2 & 5 & & VI & 1 & 34 & OAR, 3 \\
\hline 5 artikels & 3 & & 0 concordanties & VI & & & \\
\hline \multirow{10}{*}{12 artikels } & 4 & 1 & \multirow{10}{*}{10 concordanties } & VI & 1 & 48 & OAR \\
\hline & 5 & 2 & & VI & 1 & 48 & OAR \\
\hline & 5 & 3 & & $\mathrm{VI}$ & 1 & 49 & OAR \\
\hline & 5 & 4 & & VI & 1 & 50 & OAR \\
\hline & 5 & 5 & & VI & 1 & 50 & OAR \\
\hline & 5 & 8 & & $\mathrm{VI}$ & 1 & 52 & eGR \\
\hline & 5 & 9 & & VI & 1 & 53 & eGR \\
\hline & 5 & 10 & & VI & 1 & 53 & eGR \\
\hline & 5 & 11 & & VI & 1 & 54 & $\operatorname{Imp}$ \\
\hline & 5 & 12 & & VI & 1 & 55 & $\operatorname{Imp}$ \\
\hline \multirow{12}{*}{15 artikels } & 5 & 1 & \multirow{12}{*}{12 concordanties } & VI & 1 & 36 & OAR, iWGv, eGR \\
\hline & 6 & 2 & & VI & 1 & 36 & OAR, iWGv, eGR \\
\hline & 6 & 3 & & VI & 1 & 37 & Usus, Comp \\
\hline & 6 & 4 & & VI & 1 & 39 & Ciciv, RL \\
\hline & 6 & 5 & & VI & 1 & 40 & eWG \\
\hline & 6 & 6 & & VI & 1 & 41 & Ciciv, RL \\
\hline & 6 & 7 & & VI & 1 & 42 & Ciciv, RL \\
\hline & 6 & 8 & & VI & 1 & 43 & $\mathrm{RL}$ \\
\hline & 6 & 12 & & VI & 1 & 44 & $\mathrm{RL}$ \\
\hline & 6 & 13 & & $\mathrm{VI}$ & 1 & 44 & $\mathrm{RL}$ \\
\hline & 6 & 14 & & VI & 1 & 45 & $\mathrm{RL}$ \\
\hline & 6 & 15 & & VI & 1 & 45 & $\mathrm{RL}$ \\
\hline 11 artikels & 6 & & 0 concordanties & VI & & & \\
\hline 14 artikels & 7 & & 0 concordanties & VI & & & \\
\hline \multicolumn{8}{|l|}{ TITEL 6.2} \\
\hline 1 inleiding & & & 1 concordantie & VI & 3 & 1 & OAR, iWGv, Ciciv \\
\hline 3 artikels & 1 & 1 & 3 concordanties & VI & 3 & 3 & $\operatorname{Imp}$ \\
\hline
\end{tabular}


BiJLAGEN

\begin{tabular}{|c|c|c|c|c|c|c|c|}
\hline & 1 & 2 & & VI & 3 & 4 & $\operatorname{Imp}$ \\
\hline & 1 & 3 & & VI & 3 & 5 & $\operatorname{Imp}$ \\
\hline \multirow{8}{*}{8 artikels } & 2 & 1 & \multirow{8}{*}{8 concordanties } & VI & 3 & 6 & $\operatorname{Imp}$ \\
\hline & 2 & 2 & & VI & 3 & 6 & $\operatorname{Imp}$ \\
\hline & 2 & 3 & & VI & 3 & 7 & $\operatorname{Imp}$ \\
\hline & 2 & 4 & & VI & 3 & 8 & eGR \\
\hline & 2 & 5 & & VI & 3 & 9 & eGR \\
\hline & 2 & 6 & & VI & 3 & 9 & eGR \\
\hline & 2 & 7 & & VI & 3 & 10 & $\operatorname{Imp}$ \\
\hline & 2 & 8 & & VI & 3 & 11 & $\operatorname{Imp}$ \\
\hline \multirow{10}{*}{11 artikels } & 3 & 1 & \multirow{10}{*}{10 concordanties } & VI & 3 & 18 & $\operatorname{Imp}$ \\
\hline & 3 & 2 & & VI & 3 & 19 & Ciciv, iWGv \\
\hline & 3 & 3 & & VI & 2 & 22 & OAR \\
\hline & 3 & 4 & & VI & 2 & 25 & OAR, Ciciv \\
\hline & 3 & 5 & & VI & 2 & 15 & $\operatorname{Imp}$ \\
\hline & 3 & 6 & & VI & 2 & 17 & $\operatorname{Imp}$ \\
\hline & 3 & 7 & & VI & 2 & 18 & Ciciv \\
\hline & 3 & 8 & & VI & 2 & 19 & 3, Usus, eWG \\
\hline & 3 & 9 & & VI & 2 & 20 & 3, Usus, eWG \\
\hline & 3 & 10 & & VI & 2 & 21 & OAR \\
\hline \multirow{3}{*}{3 artikels } & 4 & 1 & \multirow{3}{*}{3 concordanties } & VI & 3 & 20 & $\operatorname{Imp}$ \\
\hline & 4 & 2 & & VI & 3 & 21 & $\operatorname{Imp}$ \\
\hline & 4 & 3 & & VI & 3 & 22 & $\operatorname{Imp}$ \\
\hline \multirow{4}{*}{20 artikels } & 5 & 1 & \multirow{4}{*}{4 concordanties } & VI & 3 & 23 en 26 & OAR, 3, Imp \\
\hline & 5 & 2 & & VI & 3 & 24 & OAR \\
\hline & 5 & 3 & & VI & 3 & 25 & OAR \\
\hline & 5 & 18 & & VI & 3 & 27 & $\operatorname{Imp}$ \\
\hline \multirow{6}{*}{6 artikels } & 6 & 1 & \multirow{6}{*}{6 concordanties } & VI & 2 & $27,28,29$ & iWGv, Comp \\
\hline & 6 & 2 & & VI & 2 & $27,28,29$ & iWGv, Comp \\
\hline & 6 & 3 & & VI & 2 & 30 & iWGv \\
\hline & 6 & 4 & & VI & 2 & 31 & OAR, Ciciv, Comp \\
\hline & 6 & 5 & & VI & 2 & 32 & iWGv, Ciciv, Comp \\
\hline & 6 & 6 & & VI & 2 & 33 & OAR \\
\hline \multirow{6}{*}{10 artikels } & 7 & 1 & \multirow{6}{*}{6 concordanties } & $\mathrm{VI}$ & 3 & 12 & $\operatorname{Imp}$ \\
\hline & 7 & 2 & & VI & 3 & 13 & OAR, 3, Ciciv, RL \\
\hline & 7 & 3 & & VI & 3 & 16 & $\operatorname{Imp}$ \\
\hline & 7 & 4 & & VI & 3 & 17 & $\operatorname{Imp}$ \\
\hline & 7 & 5 & & VI & 3 & 17 & $\operatorname{Imp}$ \\
\hline & 7 & 6 & & VI & 2 & 34 & OAR, iWGv, Ciciv \\
\hline \multicolumn{8}{|l|}{ TITEL 6.3} \\
\hline \multirow[t]{4}{*}{14 artikels } & & 7 & \multirow[t]{4}{*}{7 concordanties } & VII & 3 & 1 & $\operatorname{Imp}$ \\
\hline & & 8 & & VII & 3 & 2 & Usus \\
\hline & & 10 & & VII & 3 & 3 & $\mathrm{~S}$ \\
\hline & & 11 & & VII & 3 & 4 & $\mathrm{RL}$ \\
\hline
\end{tabular}


GEASSIMILEERDE ARTIKELS IN HET GELDERSE LAND- EN STADSRECHT




BijLAGEN

\begin{tabular}{|c|c|c|c|c|c|c|}
\hline & 2 & & VII & 4 & 3 & $\operatorname{Imp}$ \\
\hline & 3 & & VII & 4 & 4 & $\operatorname{Imp}$ \\
\hline & 4 & & VII & 4 & 5 & $\operatorname{Imp}$ \\
\hline & 8 & & VII & 4 & 39 & Ciciv, Usus \\
\hline & 9 & & VII & 4 & 40 & $\operatorname{Im} p$ \\
\hline & 10 & & VII & 4 & 41 & $\operatorname{Imp}$ \\
\hline & 11 & & VII & 4 & 42 & iWGp \\
\hline & 15 & & VII & 4 & 43 & Ciciv \\
\hline \multicolumn{7}{|l|}{ TITEL 6.7} \\
\hline \multirow{8}{*}{8 artikels } & 1 & \multirow{8}{*}{8 concordanties } & VII & 5 & 1 & $\operatorname{Imp}$ \\
\hline & 2 & & VII & 5 & 2 & $\operatorname{Imp}$ \\
\hline & 3 & & VII & 5 & 3 & $\operatorname{Imp}$ \\
\hline & 4 & & VII & 5 & 4 & $\operatorname{Imp}$ \\
\hline & 5 & & VII & 5 & 5 & $\operatorname{Imp}$ \\
\hline & 6 & & VII & 5 & 6 & $\operatorname{Imp}$ \\
\hline & 7 & & VII & 5 & 7 & $\operatorname{Imp}$ \\
\hline & 8 & & VII & 5 & 8 & $\operatorname{Imp}$ \\
\hline \multicolumn{7}{|l|}{ TITEL 6.8} \\
\hline \multirow{5}{*}{9 artikels } & 1 & \multirow{5}{*}{5 concordanties } & VII & 6 & 1 & $\operatorname{Imp}$ \\
\hline & 3 & & VII & 6 & 4 & $\operatorname{Imp}$ \\
\hline & 4 & & VII & 6 & 23 & $\operatorname{Imp}$ \\
\hline & 8 & & VII & 6 & 9 & $\operatorname{Imp}$ \\
\hline & 9 & & VII & 6 & 24 & $\operatorname{Imp}$ \\
\hline \multicolumn{7}{|l|}{ TITEL 6.9} \\
\hline \multirow{6}{*}{11 artikels } & 1 & \multirow{6}{*}{6 concordanties } & VII & 8 & 1 & iWGv \\
\hline & 7 & & VII & 8 & 6 & $\operatorname{Imp}$ \\
\hline & 8 & & VII & 8 & 7 & $\operatorname{Imp}$ \\
\hline & 9 & & VII & 8 & 8 & $\operatorname{Imp}$ \\
\hline & 10 & & VII & 8 & 18 & iWGs, 3 \\
\hline & 11 & & VII & 8 & 20 & OAR \\
\hline
\end{tabular}


BIJLAGE 5

INHOUDSOPGAVEN VAN VIER VOORONTWERPEN VAN HET GELDERSE LANDEN STADSRECHT ${ }^{1423}$

Inhoudstafel ontwerp 15641424

1 Wie die gerichten sych balden sullen $\quad 11$

2 Kontschafften thoe voeren 3

3 Kuntschappen in tegenwordicheit beider parthien thoe verhoeren 2

4 Welche personen nyet tuigbair 3

5 In welchen saichen die kynder weder yren alderen und die alderen weder yre kynderen
getuigeniss geven und auch nyet geven moegen

$6 V$ an beschudt. Wie beschudt gedaen werden sall und wer es beschudden mach 1

7 Van hylichsbrieven und maechgescheyden 9

8 Van kommer und dagonge 3

9 Van burgen und weerburgen 9

10 Van pyndongh und pantkerongh 6

11 Hoeffuairt oder appellatie 1

12 Wyevyll scholtiss und schepenen sdachs, als si ordelen thoe hoefft bringen, vuer yre
terongh hebben sullen

13 Wilch vuer noetbewyss geacht und gehalden wurdt 11

14 Geine erffueder verfallen, ter tuchter of tuchtersche sie irst doet 3

$15 V$ an testamenten. Watt gueder in testament ewegh gemaicht moegen werden und watt gueder nyet

16 Van gewonnen und geworven guederen 1

17 Quae bona acquisita 3

18 Van bastarden 1

19 Van cloesterluiden und gheistelicheit $\quad 7$

20 Wylche mundich und onmundich syn

21 Prescription 10

22 Ordenongh van den landtschriever 3

23 Ordenongh van den voerspreeckeren 3

Voorontwerp versie B (<voorjaar 1617)1425

1a [Rechten van gehylickde persoenen] 22

2 Van officiers schepenen en [de] bun officie 17

$\begin{array}{ll}\text { Scholtis eydt } & 1 \\ \text { Schepen eydt } & 1 \\ \text { Gerichts scryver eydt } & 1\end{array}$

${ }^{1423} \mathrm{Na}$ elke titel of paragraaf heb ik steeds het aantal artikels weergegeven. Wanneer dit aantal onduidelijk was, heb ik dit aangegeven met een vraagteken?

1424 Rechtsbronnen van het Gelders Overkwartier van Roermond: Ontwerp Landrecht 1564. K. J. T JANSSEN DE LIMPENS ed. (Werken der Vereeneging tot uitgaaf der bronnen van het oudvaderlandsche recht. Derde reeks. No. 20), Utrecht, 1965, 440-458.

1425 RHCL, Staten Overkwartier, nr. 583. 


\section{BIJLAGEN}

Gerichts boden eydt

1b Rechten huwelijkese personen ${ }^{1426}$

3 Van bylicx gerechticheit sonder vurwhaerden

$\$ 1 V$ an contracten van gebylickde persoenen $\quad 5$

$\$ 2$ Ghyften ende testamenten van gehylickde persoenen $\quad 5$

\$3 Tscheyden van [de] bylick ende bylicxsche gerechticheit 9

4 Sterffhuys van gehylickde persoenen ende betaelinge van schulden 23

5 [V an minderjarige ende andere vermomboirde persoenen ende van hunne mombours] ${ }^{1427} \quad 14$

Den eydt die de momboirs schuldich syn te doen is, soobyer nae volght 1

[S5] Vande verantwoordinge van momboiren ende voldoeninge vande weesen $\quad 17$

6 Van opdracht en [de] overgevinghe van schepengoederen 18

$\$ 1$ Overgevinghe vertydinghe oft cessie van gereyde guederen ende schulden $\quad 10$

7 Van vervolch van syn eygen goet

$\$ 1$ Ende ierst van besidt van dyen $\quad 4$

$\$ 2$ Hoemen syn gestoelen goet mach aenvheerden 8

$\$ 3$ Wanneer men syn geleent oft verbuert goet wederom mach aenvbeerden oft nyet 5

$\$ 4$ Verloren goet ende vervolch daer van 4

8 Van renthen

$\$ 1$ Geldt en [de] koeren renthen 13

\$2 Betaelinghe van jairlicxe verloopen $\quad 12$

$\$ 3$ Quytinghe en [de] ontlastinge van renten $\quad 29$

$\$ 4 V$ an rechtelyck vervolch totte betalinge van chynssen ende renthen $\quad 10$

$\$ 5 V$ an vercoopinghe vanden untgewonnen landt $\quad 6$

\$6 Verdeylinghe vande $[n]$ cooppenninghen $\quad 7$

9 Van beschuetrecht

$\$ 1$ Tyt en [de] maniere van beschudt $\quad 25$

10 Van naebeurrechten ende servituten 17

$\$ 1$ Van eyghen muyren $\quad 8$

$\$ 2$ Van gemeijn muyren $\quad 22$

$\$ 3$ Lijcteeckenen van gemeynen oft eygen muyren 8

\$4 Van gemeijn putten ende waterloopen 4

$\$ 5$ Van gemeijne privaten heymelycke gemacken ende gengh 6

$\$ 6 V$ an leuven ende bancken $\quad 3$

$\$ 7 V$ an servituten ofte erffdiensten van huijseren $\quad 8$

\$8 Servituyten van erffdiensten van hoven ende landen 9

$\int$ Weegen $\quad 17$

$\int W$ aterschap [?] off leydinghe $\quad 7$

$\$ 9 V$ an erffscheydingen ofte maniere van vervolch tot onderbalt
van naebuyrlicke rechten

$11[\text { V an tochte }]^{1428}-23$

$12 \mathrm{~V}$ an hylicxe en [de] andere lyfftochte 3

13 Van verloop van tijde oft prescriptie $\quad 21$

14 Van pandtschappen 3

1426 Materiële controle heeft uitgewezen dat het hier een jongere, licht herwerkte versie van titel 1a aangaande de rechten van gehuwde personen betreft.

1427 Van deze titel ontbreken de eerste honderd artikels. Het aantal artikels van deze titel, zoals het hier werd weergegeven, omvat enkel de aanwezige artikels.

${ }^{1428}$ De eerste vier lijnen van deze titel ontbreken. 
15 Van ghiften

16 Van testamenten

$\$ 1$ Wij testamenten maecken mach

$\$ 2$ Wederroepinghe van unyterste wille

$\$ 3 V$ an oirsaecken daerom die elderen ibre kynder, ende ter contrarie die kynder ibre elderen onterfven moegen, soe verre, die ten rechte bewesen ende waer gemaeckt werden

$18 V$ an wettighe erffinge oft versterffenisse in affgaende struyck

$\$ 1$ Wie kynderen unyt verscheydene ehe erven sullen

$19 V$ an die eijnkindtschap van kynderen, van [de] iersten, tweeden oft anderen bedde 11

$20 \mathrm{~V}$ ande erffuinghe ende successie in opgaende struyck off linie 5

$21 V$ an erffinghe $[n]$ oft versterffnissen in syden vallen 5

22 Gemeyne regelen van erffvinghe ofte successie 11

23 Van bastarden ende bunne versterffenisse $\quad 7$

\1 Inbringen van guederen int sterffhuys $\quad 17$

24 Scheydinghe ende deylinge vander sterfhuys ende andere gemeyne guederen 23

$25 V$ an geoirloefde ende ongeoirloefde contracten 11

26 Van schepenbrieven en [de] handtscriften 15

27 Van neamptisatie ofte handtvullinghe 25

28 Van coop, ende coopmanschappe 41

$\$ 1$ Van vercoopen op wederloess $\quad 6$

29 Van vrije jaermerckden $\quad 7$

30 Van buyre $\quad 8$

$\$ 1$ Wat der buyrlinck mach doen oft nyet doen $\quad 10$

$\$ 2$ Recht ofte actie van [de] verbuyrder tot betaelinghe $\quad 23$

$\$ 3$ Loon van dienstboden en [de] vermeldinghe van dienst 8

31 Van gemeenschap end onverdeilte goederen 9

$32 \mathrm{~V}$ an beveel en $[$ de] factorien

$\$ 1$ Ende ierst van tgene den beveelhebber toestaat te doen $\quad 7$

$\$ 2$ Wanneer ende hoeverre den beveelgever voir stuck vanden beveelhebber gehalden is 10

$\$ 3$ Eynde van theveel ende verhael van [de] beveelhebber 3

$33 V$ an onbeweglicke onderpanden oft andere panden 8

$\$ 1$ Van stilswygende panden $\quad 10$

$\$ 2$ Voirdeel onder die pandthebbers en [de] wiemen dat pandt mach vercoopen 9

$34 \mathrm{~V}$ an borchtochten

$\$ 1$ Ende ierst van goetwillige borchtochten wie die gestelt en [de] ontslaegen worden 16

$\$ 2$ Gerichtlycke borchtochten ende wie die moet stellen $\quad 7$

$\$ 3$ Welcker gestalt die gerichtlicke borghen gestelt ende ontslaegen werden $\quad 17$

$35 V$ an betaelinghe bewysinghe ende compensatie etc. 20

$36 V$ an brieven van respyt oft unytstel van betaelinge ende cessie
$\$ 1$ Ende ierst van respyt

$\$ 2$ Van cessie $\quad 10$

$37 V$ an voerdeyl oft preferentie onder die crediteuren

$\$ 1$ Ende ierst vandeghene die bun eygen goet vervolgen 18

$\$ 2$ Gemeijne regels in cas van preferentie $\quad 4$ 
38 Van verscheyde rechtlicke proceduren oft rechtsvoorderinghe ${ }^{1429}$ $\$ 1$ Ordinarisse rechtsvoorderinge

$39 V$ an commerrecht oft arresten 32

$40 \mathrm{~V}$ an peyndinge 6

$41 \mathrm{~V}$ an dagementen

42 V an voirspreeckers ofte procureurs ende volmechtige

Des voirspreckers ofte procureurs eydt

$V$ urmunders eydt

$43 \mathrm{~V}$ andes clegers mijt blijven

44 Vandes gedaechdes uuytblyven offt [...]

$45 V$ an comparitie van partijen ende aenspraecke $[n]$

$\$ 1 V$ an onkennen ende kennen

$46 V$ an meerderheysch dan den claeger compt

$47 V$ an eydt van calumnie en [de] kennen oft onkennen onder den selven eedt 8

Forma juramenti calumnie 1

$48 V$ an executien ende andtwordt

49 Van reconventie 3

50 Van konde [?] ende verhoor derselve $\quad 20$

$\int 1$ Der tuygen eedt 1

$51 V$ an briefflicke schyn ende bescheidt en [de] liggende houden 8

52 Van stellinge der saecke ten eydt 5

$53 V$ an openinghe van thoenstraeff ende verandtworden van dien ende slutinghe inder zake 4

54 Van onvertoghen recht 4

55 Van vonnisse 14

56 Van executie 26

$57 V$ ande maniere van rechtvoirderinghe in straffbare offt criminele saecken en [de] van lyff ende andere straeffe $[n]$ ende bruecken derselver $\quad 16$

$\$ 1 V$ an aentasten ende vangen der misdaedigers $\quad 5$

$\$ 2 V$ an gevangenen te ondervraege ende ter banck te breughen offt pijnighen 28

$\$ 3 V$ an betichdinghe, en [de] vervolgh der gevanghene $n]$ voyr tgericht 13

$\$ 4 V$ an lijffstraffen ende van misdaeden daer toe lijffstraff staet, arbitrale correctie, ende andere bruecken 84

58 Van purghe off suyvering van misdaden $\quad 8$

59 Van vrede $\quad 7$

60 Van soene 9

Voorontwerp versie $C(<$ voorjaar 1617)1430

[1 Van officiers schepenen ende bun officie] ?

$2 V$ an hylicx gerechteycheydt en [de] eerst ter zake van bylyxe verscrijvinghe off vurwaerden 22

$\int V$ an bylicx gerechticheit sonder voyrwaerde

${ }^{1429}$ In tegenstelling tot de voorgaande titels kenmerken de hiernavolgende titels zich door een groot aantal marginale, voorstellen tot wijzigen.

1430 RHCL, Staten Overkwartier, nr. 584. Deze inhoudsopgave omvat enkel het materiële en procesrechtelijke, civiele recht. Het straf- en strafprocesrecht ontbreekt in dit voorontwerp. 
3 Van contracten van gebylickde personen en [de] schulden

Ghiften en [de] testamenten van gehylickte personen

Tscheyden van [de] bylick en [de] bylick, gerechticheit en [de] betalinghe van schulden

$4 V$ an minderjarige en [de] andere vermomboirde persoenen ende van bunne mombours

$\$ 1$ Ende ierst hoe lange die minderjaricheit duert, ende wat minderjarigen vermoegen te doen

$\$ 2$ Mombors van minderjarige personen

Den eydt die de momboirs schuldich sijn te doen ${ }^{1431}$

$\$ 3$ Besorgh last en [de] onderwyndt van [de] momboirs

$\int 4$ Reckeninge van momb [oirs]

$\$ 5 V$ ande verandtwoirdinghe van momboiren en [de] voldoeninge van $[$ de $]$ weesen

5 Van opdracht en [de] overgevinge van schepengoederen

$\$ 1$ Overgevinge. Vertijdinge oft cessie van gereyde guedere [n] en [de] schulden

6 Van renthen

$\$ 1$ Gelt en $[$ de] koeren renthen

$\$ 2$ Betalinge vande jaerlicxe verloopen

$\$ 3$ Quijttinge en [de] ontlasting van renthen

$\$ 4 V$ an rechtlick vervolgh tot betalinge van chijnssen ende renten

$\$ 5 V$ an vercoopinge vanden uuytgewonnen pandt

$\$ 6$ Verdeijlinge vande coopenningen

7 Van pandtschappen

$8 \mathrm{~V}$ an beschudtrecht

$\$ 1$ Tijt en [de] maniere van beschudt

9 Van naebuere rechten en [de] servitute $[n]$

$\$ 1$ Eijghen muijren

$\$ 2$ Gemeijn muijren

$\$ 3$ Lijcteckenen van gemeijnen oft eygen muijren

$\$ 4$ Gemeijne putten ende waterloopen

$\$ 5$ Leuven en bancken

\$6 Servituten, off erffdiensten van buijseren

$\$ 7$ Servituten van erffdiensten, van hoven en lande

$\$ 8 V$ an erffscheijdingen offt maniere van vervolch tot onderhalt van nabuerlycke rechten

$10 V$ an bylicxe ende andere lijfftochte

$11 V$ an verloop van tijde offt praescriptie

$12 \mathrm{~V}$ an ghifften

$13 \mathrm{~V}$ an oirsaecken daerom die elderen ibre kinder ende ter contrarie die kynder ihre elderen onterven mogen soe van die ten recht beweesen ende waer gemaeck.t werden $\quad 10$

$14 \mathrm{~V}$ an testamenten

$\$ 1$ Wie testamenten maecken mach $\quad 11$

$\$ 2$ Wederroepinge van unijtersten wille $\quad 5$

15 Van wettighe ervinghe $[n]$ offt versterffenisse in affgaende struijck

16 Wie kinderen mijt verscheijden ehe erven sullen 7

$17 V$ an die eijnkindtschap van kinderen vande ierste, tweede, ofte andere Bedde 10

18 Vande ervinghe ende successie in opgaende struyck 5

19 Van ervinghe offt versterffenissen in sijden vallen 5

20 Gemeijn regelen van erffinge oft successie 11

1431 De eed zelf ontbreekt. 


\section{BIJLAGEN}

$21 V$ an [de] bastarden en [de] hunne versteffenisse 8

22 Besit off possessie vande verstorvene guederen 2

$\$ 1$ Aenverdinghe van[de] sterffhiijse en [de] betalinghe vande schulden 11

$\$ 2$ Inbringen van goederen int sterfbuys $\quad 17$

23 Scheijdinge ende deijlinge van [de] sterffhuyse en [de] andere gemeine guedere [n] 15

$24 V$ an georloffde ende ongeorloffde contracte $[n] \quad 11$

25 Van schepenbrieven ende handtschriften $\quad 15$

26 Van namptisatie offt handtvullinge $\quad 25$

27 Van coop ende coopmanschap $\quad 40$

\$1 Van vercoopen op wederloos 6

28 Van vrije jaermerckden $\quad 7$

29 Van huijre $\quad 8$

$\$ 1$ Wat der huijrling mach doen off niet doen 10

$\$ 2$ Recht en [de] actie va [n] verbuerder tot betaelinghe $\quad 23$

$\$ 3$ Lohn van dienstboeden en [de] vermeedinge van dienst 8

$30 \mathrm{~V}$ an gemeinschap ende verdeilte [lees: onverdeilte] goederen 9

$31 \mathrm{~V}$ an beveel en [de] factoiren

$\$ 1$ Ende ierst van tgeene den beveelhebber toestaet te doen $\quad 7$

$\$ 2$ Wanneer en [de] hoeverre den beveelgever voor tstuck vande bevellhebber gehalden is 10

$\$ 3$ Eijnde van theveel en [de] verhael van [de] beveelhebber 3

$32 \mathrm{~V}$ an onbeweglicke onderpanden oft andere panden 8

$\begin{array}{ll}\$ 1 \text { Van stijlswijgende panden } & 10 \\ \$ 2 \text { Voerdeel onder die pandthebbers en [de] wie men dat pandt mach vercoopen } & 9\end{array}$

33 Van borchtochten

$\$ 1$ Ende ierst van goetwillige borchtochten wie die gestelt ende ontslagen worden $\quad 16$

$\$ 2$ Gerichtelycke borchtochte en [de] wie die moet stellen 17

$\$ 3$ Welcker gestalt die gerichtelicke borgh gestelt en [de] onslagen werden $\quad 17$

$34 V$ an betaelinghe bewijssinghe ende compensatie etc. 20

$35 V$ an brieven van respijt oft unijtstell van betalinge en [de] van cessie
\[ 1 \text { Ende ierst van respyt } \]

$\$ 2$ Van cessie $\quad 10$

$36 \mathrm{~V}$ an voerdeel oft preferentie onder die crediteuren

$\$ 1$ Ende ierst vande gheene die hun eygen goet vervolgen $\quad 18$

$\$ 2$ Gemeyn regels in cas van preferentie $\quad 4$

Voorontwerp versie D (voorjaar 1617-juni 1618)1432

1 Van officiers oft amptluyden ende schepenen ende bun ampt oft offitie ?

2 Van rechten van gehylycke personen ?

$3 V$ ande rechten tusschen die elders ende kindere $[n]$

$4 V$ an minderjarighe ende andere vermomboirde persoenen ende van henne mombours oft toesienders

$\$ 1$ Hoe lange die minderjaericheyt duert, ende wat minderjarigen vermoghen te doen oft nyet ?

$5 V$ an ongehylichde vrouwen 13

6 Van renthen 17

${ }^{1432}$ RHCL, Staten Overkwartier, nr. 589. 
$\$ 1$ Betalinghe van verloopen van renthen met wat gelde en [de] tot wat prijs die te doen is

$\$ 2$ Quijttinge en [de] ontlastinge van renten ende mit wat gelde ende [... weerde van tgelt is die is te doen

$\$ 3$ Verlaetinghe oft vertijdinghe vanden pandt voordie renten

$7 \mathrm{~V}$ an richtelicke aenclachte ende vervolgh tot betalinghe van renten

$\$ 1$ Vervolgh opden pandt

$8 \mathrm{~V}$ an tochte ende rechtelyck vervolgh derzelver

$\$ 1$ Waertoe eenen tochtenaer gehouden is 37

9 Van nabure rechten en [de] servitute oft erffdiensten 9

$\$ 1$ Gebuerlijcke rechten besunder in stede $\quad 19$

\$2 Eijghen muijren $\quad 8$

$\$ 3$ Gemein muijren $\quad 22$

\4 Lyckteckenen van gemein oft eijgen muijren $\quad 8$

\5 Gemeijne putten waterloepen heymelijcke gemaecke[n] ende ganghen $\quad 10$

$\$ 6$ Servituten oft erffdiensten van buyseren $\quad 8$

$\$ 7$ Nabuerlijcke rechte besonder van hoven en [de] landerien ende erffdiensten oft servytuten derselver

$10 \mathrm{~V}$ an erffscheidingen offt manier[ $[\mathrm{e}]$ van vervolgh tot onderhalt van nabuerlycke rechten en [de] erffdiensten

$11 V$ an opdrachten leveringhe overgeven ende rechtel[ijck] vervolgh van goederen

$12 \mathrm{~V}$ an rechtelycke clachte ende vervolgh op erffelycke ende onruerlycke goederen

$\$ 1$ Clachte ter sake van tbesit gebruyck ende eygendom van onerffelijcke goederen 34

$\$ 2$ Vervolch van ruerlycke vercochte vertrouwde unytgeleende ende unytgedaene goederen om te wercken.

$\$ 3$ Vervolgh van verlooren ende gestoole goederen $\quad 12$

$13 \mathrm{~V}$ an beschudtrecht oft vernaerderinghe

$\$ 1$ By wyn ende waerop beschud gedaen mach worden, ende de naesten daertoe $\quad 38$

$\$ 2$ Tyt ende maniere van beschudt $\quad 27$

$\$ 3[\ldots] \quad 6$

14 Van verloop van tijde oft prescriptie 33

15 Van ghifften

\$1 In wat gestalt dat giften gedaen moeten worden om bestendich te rijn $\quad 18$

$\$ 2$ Wederroepinghe van ghifften

16 Titel van testamen [t]en ende unijterste wille

$\$ 1$ Maniere van testamenten te maecken $\quad 18$

$\$ 2$ Wie testamente $[n]$ maken mach ende van wat goeden 14

$\$ 3$ Testamenten vande ouders tusschen de kinders ende rechtelycken oorsaecken van onterffinghe te weder zijde

\4 Voltreckinghe ende wederroepin[ghe] van testamenten offt muytersten wille $\quad 11$

$17 V$ an wettighe successie oft versterffenisse

$\$ 1$ Versterffenisse in affgaende stam

$\$ 2$ Wie kinderen nijt verscheyde ehe ervan sullen

$\$ 3 V$ an dyenkindtschap van kinderen van verscheyde bedde $\quad 10$

$\$ 4$ Versterffenisse in opgaende stam

$\$ 5$ Versterffenissen in sijden vallen $\quad 15$

$\$ 6$ Gemein regelen van verstervenisse $\quad 10$

$18 \mathrm{~V}$ an aenveerdinghe van versterffenisse betalinghe der schulden en [de] scheydinghe

derzelver ende andere gemeyne goederen 


\section{BIJLAGEN}

$\$ 1$ Anveerdinghe der sterffhuyse ende betalinghe der schulden $\quad 12$

19 Van inbringen der erffenaemen int erff offt sterffhuys

20 Scheydinghe ende deylinge van versterffenisse ende andere gemeyne goederen 23

21 Van geoorlooffde ende ongheoorlooffde contracten $\quad 15$

$22 V$ an schepenen brieven handtschriften ende andere bescheyden oft schulden tot namtisatie oft gerechtelycke legginge ende hantvullinghe staende 40

23 Van coop ende coopmanschap ende dat daeraen cleeft 12

$\$ 1$ Voldoeninghe tot coop staende en [de] wye vanden coop daer in voer gaet $\quad 15$

$\$ 2$ Betalinghe vanden prijs en [de] interst offt proffijct vande cooppenningen $\quad 7$

$\$ 3$ Waerschap ende verandtwoerden voorden cooper 6

$\$ 4$ V rije jaermerckte $\quad 8$

$24 V$ an huijre pachten dienstbode ende werckluijde

$\$ 1$ Waertoe een gerecht $[\ldots]$

$\$ 2 V$ an dienstboden en [de] aenneminghe van werck $\quad 7$

$25 V$ an gemeinscap van handel ende onverdeilde goederen 14

$26 V$ an beveel en [de] factoire
\[ 1 \text { Waertoe een bev [e]elhebber gehouden is } \]

27 Van panden

$\$ 2$ Waertoe een beveelgever gehouden is ?

$\$ 1$ Bewillighde panden $\quad 8$

\$2 Stilswygende panden $\quad 12$

$28 \mathrm{~V}$ an borchtochten

$\$ 3$ Voerdeel onder die pandthebbers en [de] wiemen die panden mach v[er]coopen 9

$\$ 1$ Goetwillighe borchtochten $\quad 17$

$\$ 2$ Gerichtelicke borchtochte ende wie die moet stellen 6

$\$ 3$ Hoe die gerichtelicke borchtochte gesteldt werden $\quad 8$

\$4 Ontlastinge van gerichtelijcke borchtochte $\quad 7$

29 Van betaelinghe bewijesinge ende compensatie etc. 24

$30 \mathrm{~V}$ an brieven van respijt oft tot uuytstel van betalinge $\quad 15$

$31 V$ an brieven van cessie offt tot overgevinghe van alle sijn goet in plaetse van betaelinghe 9

32 Van preferentie offt voordeel onder die crediteuren inde betalinghe

$\$ 1$ Ende ierst vande gheene die hun eyghen goet vervolghen $\quad 24$

$\$ 2$ Gemein regels vande preferentie oft voordeel van [de] crediteuren

Vierde deel V an rechtlicke proceduren oft rechtsvoorderinghe

33 Iersten titul $V$ an verscheyden manieren van borghelycke proceduren 3

34 Tweeden titul V an ordinarisse rechtsvoorderinghe 9

35 Onvertoghen recht 4

36 V an commer, beset, offt arrestrecht ?

37 Van peindonghe oft pandonghe 17

38 Sesten titul Van voeghtgedinghe 3

39 Sevenste titel $V$ an rechtelycke dagementen ende nyet commen offt uuytblieven van partien

$\$ 1$ Rechtelycke dagementen 6

$\$ 2$ Uuytblieven van partien tsij versuymelyck oft versmaedelyck 28

40 Achtsten titel $V$ ant commen van partien voor recht ende des aenleggers aenspraecke ende verzuijcken

$\$ 1$ Aenspraecke mit den bescheyden daertoe dienende $\quad 34$

$41 V$ an voirspreeckers ofte procureurs volmechtighe en [de] voermunders 17

42 Van $[. .] \quad$.

43 Van konden ende verhoor derselver $\quad 24$ 
$44 V$ an brieffelicke schijn ende bescheidt en [de] liggende conden 11

45 Vanden eedt 6

$46 V$ an openinghe straeff oft wederseggen ende verantworden van thoon ende slutinge inder zake 5

47 Van vonnisse 34

48 Van executie offt voltreckinge van vonnissen ?

$49 \mathrm{~V}$ an misbruijcken staen [de] tot keuren ende breucken ende van tvervolgh derselver $\quad 67$

50 Van misdaden daer lijfstraeff toestaet $\quad 56$

$51 V$ an d'aentasten vanghen ende ondervraeghen vande tegenwordighe misdadighe 14

$52 \mathrm{~V}$ an ondersuyck opde misdaden ende vervolgh tegens de verloopenden misdadighe 19

53 Van pieneghen ende scherper examinatie der gevangenen 23

54 Van betichdinghe ende rechtelick vervolgh der ghevanghenen $\quad 15$

$55 V$ an suyverungh ofte ontschuldegengh van misdaden 8

$56 V$ an vrede leghingh tusschen twistighe persoenen 9

57 Van soenen van dootslaghen 11 



\section{INDEX OP PERSOONSNAMEN}

Ableiges, Jacques d', 129, 179, 312, 376

Accolti, Francesco d', 315, 403-404

Afflitto, Matteo d', 309, 315, 348, 369, 398

Albrecht en Isabella (aartshertogen), 5, 14, 57, 142, 145, 210, 233

Alciato, Andrea, 15, 16, 17, 178, 298-299, 301, 311, 316, 352, 365, 384, 389-391, 419

Alfonso X (koning van Castilië-Léon), 98, 369

Althusius, Johannes, 299

Alvarado, Diego Rodrigo, 179, 316

Alvarez de Toledo, Fernando, 5, 8, 278

Ancarano, Pietro, 316, 403, 404

Andrea, Giovanni d', 298, 311, 317, 362, 367,391

Angleberme, Jean Pyrrhus d', 372, 387

Anselmo, Antonio, 202, 205-206, 370, 379

Aquino, Thomas van, 406

Argentré, Bertrand d', 178, 198, 317, 352, 368, 372-373, 380, 393

Aristoteles, 299

Arrerac, Jean d', 303, 317

Asseliers, Jan, 313

Ayerve de Ayora, Antonio, 96, 178, 317

Aytta, Wigle van, 19, 178, 293, 306, 311, 317, 384

Azpilcueta, Martino de, 304, 318, 409

Bacquet, Jean, 96, 178, 318, 352, 357-358

Baeza, Gaspar de, 318, 352, 369, 380

Barzi da Piombino, Benedetto, 311, 318, 348

Bassianus, Johannes, 401

Belleperche, Pierre de, 387

Belloni, Marcus Antonius, 116, 397

Benoît, Guillaume, 318, 384, 391
Bero, Augustin, 319, 362, 366

Bertrand, Etienne, 178, 319, 404-405

Biesval, Benedictus, 207

Binsfeld, Peter, 319, 391

Bree, Tilman van, 6, 12, 13, 22, 225, 227, 236-237, 261

Bodin, Jean, 178, 181, 314, 319, 356

Bohier, Nicolas de, 198, 319, 372, 380, 393, 394, 398, 400

Bossi, Egidio, 135, 178, 320

Bottrigari, Jacopo, 320, 387

Bouteiller, Jean, 79, 126, 129, 179, 311312, 376

Boverio, Henrico di, 178, 320, 363

Brisson, Barnabé, 90, 98, 142, 179, 268, 273, 311-313, 369, 371

Budé, Guillaume, 16, 299

Bugnyon, Philip, 305, 320, 348

Caepolla, Bartolomeo, 311, 320

Cagnoli, Girolamo, 320, 387

Caron, Louis le, 79, 90, 96, 98, 102-103, 108, 126, 129, 142, 177-182, 188, 212-213, 267-268, 271, 273, 304, 306-307, 311, 313, 321, 352, 368-369, 371-377, 380-381, 420 Castro, Paulo di, 178, 297, 300, 311, 322, 348

Cavalcani, Borgnino, 178, 322, 365, 397

Chasseneuz, Barthélémy de, 178, 264, 298, 299, 301, 322, 368, 372, 374, 380, 404-405 Chenu, Jean, 309, 323, 348, 398

Choppin, René, 102, 268, 310, 311, 323, 352, 368, 373, 377, 380

Christyn, Jean-Baptist, 208

Christynen, Paul van, 378, 395 
Cicero, Marcus Tullius, 16, 18, 299, 311, 323, 348

Claro, Giulio, 103, 135, 178, 180, 271, 323, 352, 360, 393

Coblenz, Karel van, 233

Coler, Matthias, 304, 324, 361

Connan, François, 283-284

Coquille, Guy, 63, 285, 296, 355, 372-373, 377, 380, 393

Corte, Franciscus de, 305

Corte, Jacobus de, 305

Corte, Rocco, 305

Costa, Manoel da, 179, 324, 388

Cousteau, Pierre, 178, 264, 324, 388

Covarubias y Leyva, Diego, 103, 178, 180,

300, 324, 352, 362, 366, 385-386, 391, 407

Cravetta, Aimone, 178, 325, 380, 403, 405

Crema, Francisco de, 325, 363

Creyarts, Gerard, 12

Cujas, Jacques, 16, 17, 178, 270, 325, 352, 388, 393

Cuma, Rafaela da, 304, 325, 387

Cun, Guillaume de, 325, 387

Damhouder, Joost de, 179, 181, 264, 326, 359

Decio, Filippo, 16, 178, 311, 326, 362, 387, 401, 403-404

Denariis, Odofredus de, 326, 387

Doneau, Hugo, 17, 257, 283-287, 290, 388, 398, 411, 415, 419-420

Douaren, François, 282

Dulcken, Matheus van, 12

Dumoulin, Charles, 96, 108, 126, 177-180, 212, 300, 304, 310-311, 326-327, 352, 357358, 362, 368, 372-377, 380, 384, 393, 398, 403-405

Duranti, Guilielmo, 298, 304, 312, 327, 348, 362

Duret, Jean, 328, 376

Duysentdaelders, Nicolas, 207

Everaerts, Nicolas, 179, 181, 187, 264, 298, 304, 328, 402-405

Fachineo, Andrea, 135, 312, 328, 352, 361-362, 366

Fanuzzi, Phanutio di, 178, 312, 328, 348
Farinacci, Prospero, 135, 177-178, 180 181, 271, 328, 352

Farnese, Alexander (hertog van Parma), 10

Favre, Antoine, 178, 180, 270, 312, 328329, 351, 378, 388, 395-396, 398, 400-401 Favre, Jean, 178, 329, 387

Feliti, Ettore, 329, 391

Ferrariis, Johannes Petrus de, 330, 359, 361

Ferrer, Miguel, 397

Ferretti, Giulio, 117

Feu, Jean le, 330, 384, 387

Filips II (koning van Spanje), 106, 113, 116, 128, 130-131, 134-135, 144-145, 192, 210, 233, 271, 273

Follerio, Pietro, 311, 330, 362, 367

Forster, Valentin, 330

Fulgosius, Raffael, 311, 330, 387

Gabri, Karel, 9, 206, 304, 379

Gabrieli, Antonio, 311, 330, 348

Gaill, Andreas, 300, 330, 396, 398-399

Gaius, 17, 282

Gambiglione, Angelus, 305, 311, 331

Garzia de Saavedra, Juan, 179, 264, 331, 352, 365

Gellius, Aulus, 313, 331

Gerardi, Gillis, 304

Godefroy, Denis, 178, 180, 331, 352, 388

Gomez, Antonio, 332, 362, 366, 369-370, 381

Gosia, Martinus, 332, 387

Grass, Michael, 103, 178, 332, 363, 366

Grégoire, Pierre, 135, 177, 178, 332, 388

Gregorius IX (paus), 102, 307, 391

Grimaudet, François, 178, 332

Grijsperre, Willem van, 247

Groot, Hugo de, 286

Guenoys, Pierre, 99, 104-105, 108, 178, 196, 198, 214, 265, 300, 333, 352, 368, $369,371,373-375,380-382$

Gutierrez, Juan, 333, 369, 380

Hanneton, Guillaume, 360

Heige, Peter, 300

Hendrik II (koning van Frankrijk), 371

Hendrik III (koning van Frankrijk), 74, 90

Hendrik IV (koning van Frankrijk), 371 
Hommeau, Pierre de l', 373, 377

Hopper, Joachim, 18, 390

Hotman, François, 16, 17, 300, 333, 352, $362,366,388$

Huygens, Johan Baptist Joseph, 205

Imbert, Jean, 78, 126, 177, 178, 179, 212, 333, 349, 352, 359, 367, 376, 398

Innocentius IV (paus), 298

Intriglioli, Niccolo, 334

Jan I(hertog van Brabant), 120

Jan II (hertog van Brabant), 135

Justinianus (keizer), 16, 19, 283-284, 385

Karel V (keizer), 2, 5-7, 74, 89, 101, 104, 123, 130, 135, 144, 193, 210, 268-269, 271, 273, 276, 313, 413

Karel VII (koning van Frankrijk), 3, 413

Karel de Stoute (hertog van Bourgondië), 395

Kern van Vroenhoven, Johan, 229

King, Alexander, 117

Koichs, Marcelis, 235

Labbé de Montveron, Gabriel, 334, 380

Lapo de Castiglionchio, Giovanni, 334

Leeuw, Elbert de, 18, 334, 405

Leys, Leonard de, 334, 409

Lodewijk de Heilige (koning van

Frankrijk), 371

Loisel, Antoine, 373, 377

Lopez, Gregorio, 311, 335, 348, 369, 380

Lopez de Palacios Rubeus de Ribero, Juan, 304, 335, 391

Louet, George, 394

Maino, Giasone del, 16, 297, 335, 387, 401

Magoni, Girolamo, 335, 397

Mallery, Philips van, 9

Maranta, Roberto, 311-312, 335-336, 348, 361, 362

Marc, François, 102, 336, 394, 400

Maria (hertogin van Bourgondië), 4, 395

Maria Theresia (keizerin), 233

Marion, Simon, 336, 394

Marsili, Ippolito de, 336, 363, 387

Masuer, Jean, 336, 359

Maynard, Géraud de, 336, 394, 400
Medina, Bartolomeo de, 336-337, 409

Menocchio, Jacopo, 126, 135, 177-178, 180, 337, 357-358

Merel, Paulus van, 360

Moeits, Peter, 12

Molina, Luis de, 337, 409

Monticello, Sebastiano, 179, 337, 365

Moy, Hendrik de, 58, 80, 205, 262, 378

Murner, Thomas, 130, 135, 144, 271, 273, 370

Muyden, Gabriel van der, 14, 17, 19, 179, 181, 306, 338, 389, 390, 399

Mynsinger von Frundeck, Joachim, 178, 180, 338, 386, 396-399, 401

Negusanzio de Fano, Antonio, 338, 365

Nieustad, Cornelis Mathiasz van, 395

Oeyen, Michael, 235

Pace de Beriga, Giulio, 338, 390

Padilla y Meneses, Antonio, 103, 178, 183, 311, 338, 384, 387

Paleotti, Gabriele, 339, 365

Pape, Guy de la, 298, 311-312, 339, 362 363, 393-394, 400

Papon, Jean, 96, 102, 178, 179, 212, 339, 352, 357-358, 380, 393-394, 398-399, 401

Pasquier, Etienne, 314, 340

Peck, Pieter, 18, 96, 109, 117, 178, 181, 305, 310, 340, 352, 358-359, 365, 367, 399 Peguera, Luis de, 179, 340, 397-398, 400401

Pellegrini, Marc-Antonio, 341, 403-405

Penne, Luca da, 311, 341, 348

Pinhel, Aries, 108-109, 178, 341, 384

Pistoia, Cynus de, 297, 387

Pistoris, Hartmann, 341, 361, 366

Pithou, Pierre, 178, 341, 380

Pius V (paus), 106

Platea, Johannes de, 341, 387

Pontano de Roma, Ludovico, 298, 342, 363, 403, 404

Pujol, Segismundo, 397

Ranchin, Etienne, 312,342, 362, 367

Rebello, Fernando, 342, 409

Rebuffi, Pierre, 178, 307, 342, 359, 367, 369, 371-372, 380, 381, 384, 398 
Révigny, Jacques de, 387

Reyvaert, Jacob, 390

Robert, Anne, 394

Rooseboom, Gerhard, 207

Rosciate, Alberico de, 307, 342-343, 387

Rosenthal, Henry, 300

Ruini, Carlo, 304

Saliceto, Bartolomeo di, 179, 297, 343, 387

Sainson, Jean, 372

Sandeus, Felinus, 298

Sannazari della Ripa, Giovanni Francesco, 178, 343, 352, 387

Santarem, Piedro de, 117

Sarmiento de Mendoza, Francisco, 343, 389

Sassoferrato, Bartolo da, 75, 178, 180, 213, 264, 297-299, 306, 310, 311, 343, 352, $362,383,385,387,391$

Schneidewin, Johannes, 303, 304, 344, 390

Servin, Louis, 394

Simoncelli, Ottavio, 344, 358, 365

Sordi da Casale, Giovanni Pietro, 78, 126, 345, 397

Sozzini, Bartolomeo, 304

Sozinni junior, Mariano, 304, 311

Sozinni senior, Mariano, 304, 311, 344, 348

Steenhuis, Willem van, 247

Stockmans, Pieter, 205, 395

Stracca, Benvenuto, 116, 178, 269, 344, 365

Suarez, Rodrigo, 344, 352, 384, 387

Suetonius, Gaius Tranquillus, 313, 344345

Tack, Johan, 18, 390

Tartagni, Alessandro di, 178, 180, 213, 297, 298, 311, 345, 362, 367, 387, 403-404

Tesauro da Fossano, Antonio, 345, 395
Thoming, Jacob, 345, 352, 396

Thou, Christofle de, 4, 63, 377

Tiraqueau, André, 178, 311, 345-346, 372, 380

Torretti, Fabio, 346

Trajanus, Marcus Ulpius (keizer), 313

Tudeschi, Nicolo de, 297, 300, 304, 346, 403-404

Ubaldis, Angelus de, 178, 304, 310, 346347, 387, 404

Ubaldis, Baldus de, 178, 180, 213, 298, 306, 347, 383, 387, 391, 403-404

Uffel, Jacques van, 58-61, 84, 136, 138, 175-176, 185-186, 191, 193, 202, 212-214, 414

Uffel, Severinus van, 59

Uwens, Hendrik, 6, 11-13, 22, 218, 224, $227,233,235,237,241-243,246-247,249$, $251,257,261,275,286-290,413-414$

Val, Nicolas du, 178, 347, 352, 365

Valencia, Gregorio de, 347, 409

Valle, Roland dela, 347, 404-405

Vazquez de Menchaca, Fernando, 96, 179, 293-294, 347, 352, 407

Vendeville, Jean, 18

Vigilus (paus), 16

Vinnius, Arnoldus, 286, 361

Vivio de l'Aquila, Francisco, 309, 348, 398

Wames, Jean, 18, 204, 205

Wielant, Filips, 76, 126, 130, 135, 177-179, 181, 208, 212-213, 271, 273, 348, 359, 367, 420

Wesenbeeck, Matthias, 18, 178, 181, 183, 269, 348, 389-390, 403-405

Weytsen, Quintin, 117

Zäsi, Ullrich, 16, 299, 399

Zype, Frans van der, 370 


\section{CURRICULUM VitaE}

Bram Van Hofstraeten werd geboren op 11 juni 1978 te Herentals. In 2002 behaalde hij met grote onderscheiding de graad van 'licentiaat in de geschiedenis' aan de Katholieke Universiteit van Leuven. Zijn licentiaatsverhandeling bestond uit een prosopografische studie van de Brusselse seculiere clerus tijdens de vijftiende en zestiende eeuw. Vervolgens verbleef hij enige tijd in het Franse Poitiers alwaar hij zich aan het Centre d'Etudes Supérieures de Civilisation Médiévale verder verdiepte in de middeleeuwse kerkgeschiedenis. Van 2003 tot 2007 was hij als junior onderzoeker verbonden aan de Faculteit der Rechtsgeleerdheid van de Universiteit Maastricht. Sinds april 2007 is hij werkzaam als docent aan de Faculteit der Cultuur- en Maatschappijwetenschappen van dezelfde Maastrichtse universiteit. 